
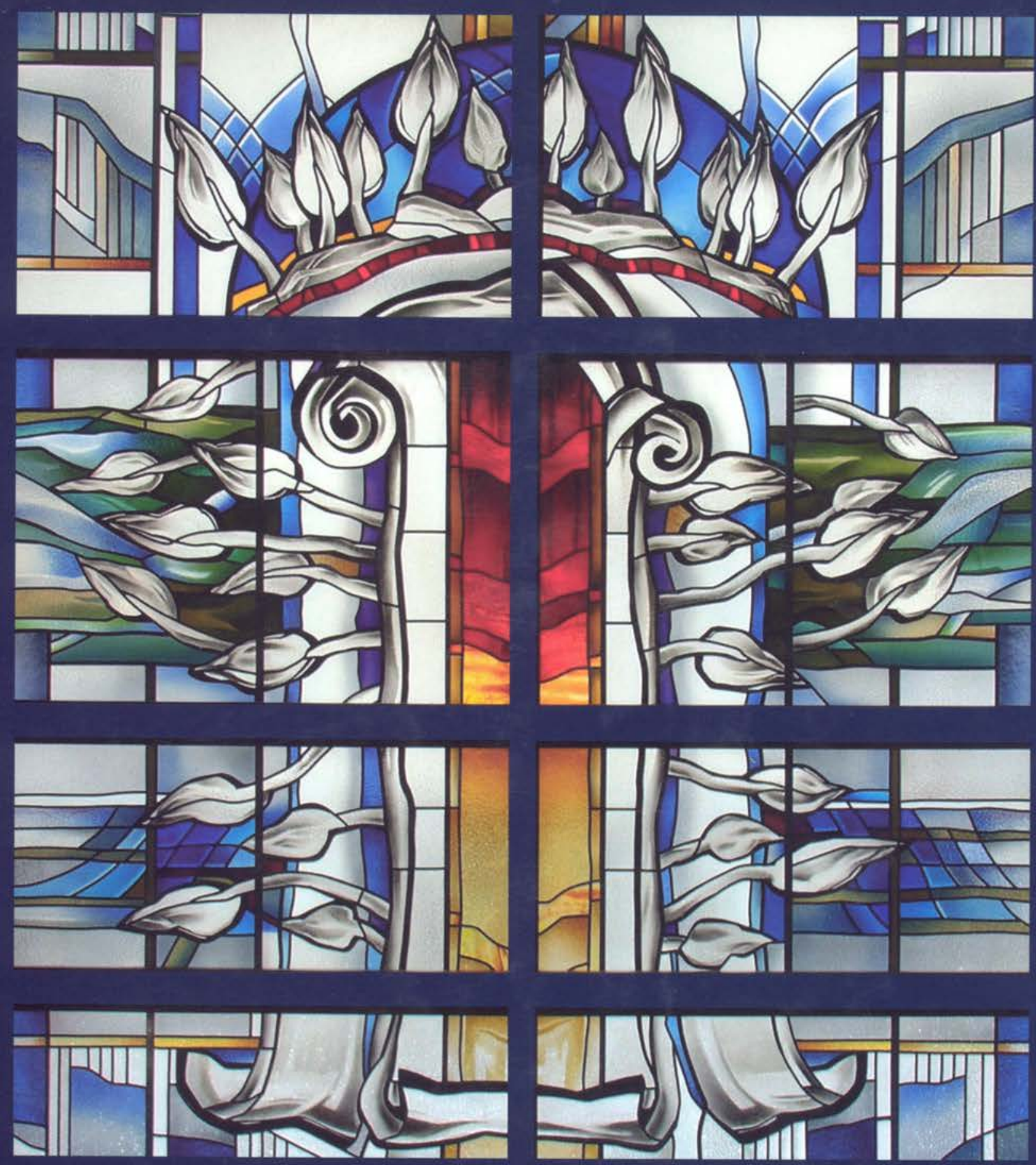

Algimantas Nakas

VILNIAUS GEDIMINO TECHNIKOS UNIVERSITETO
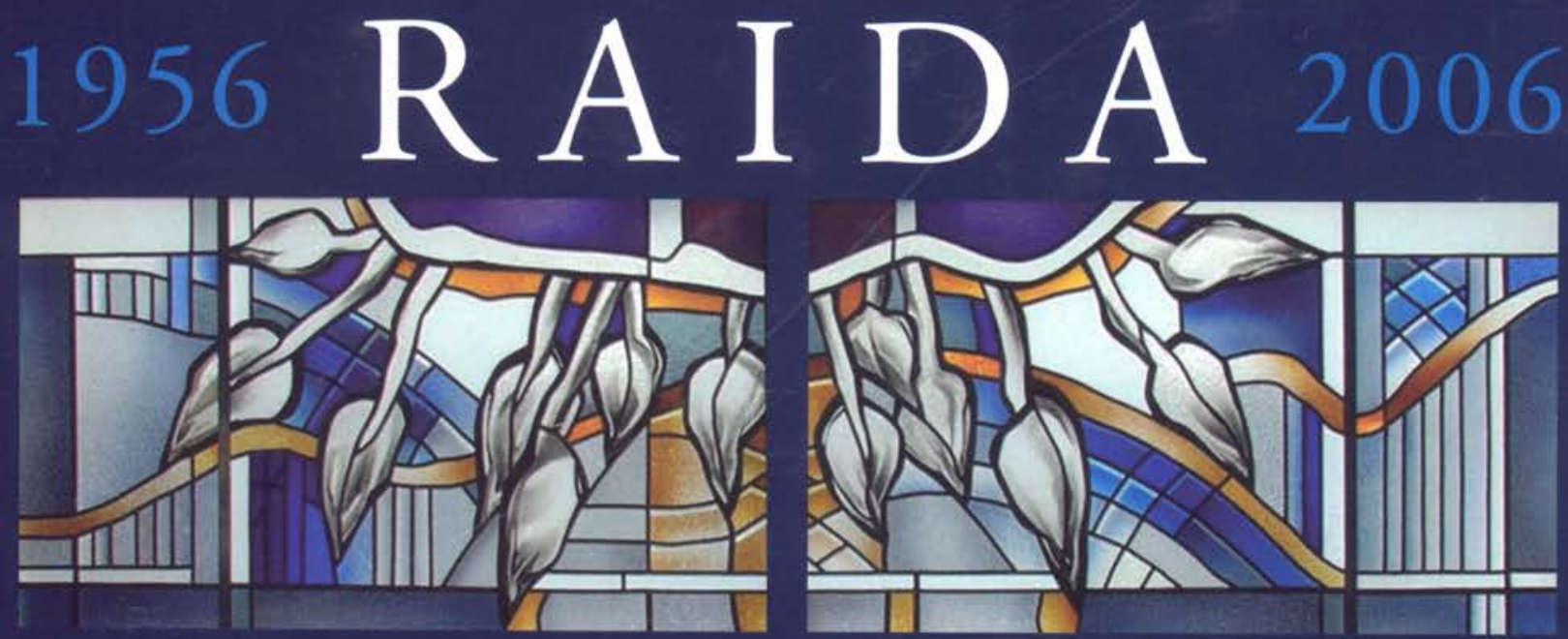


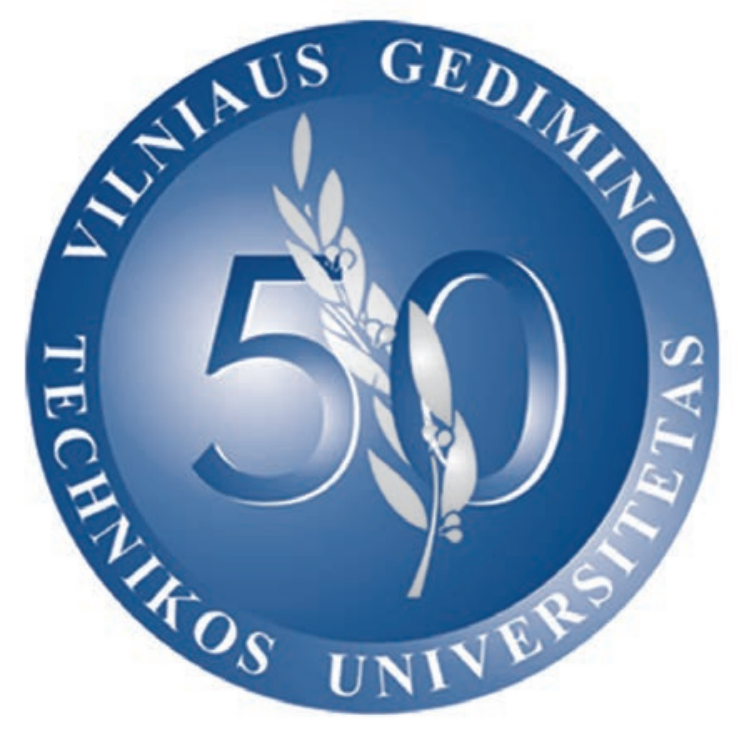




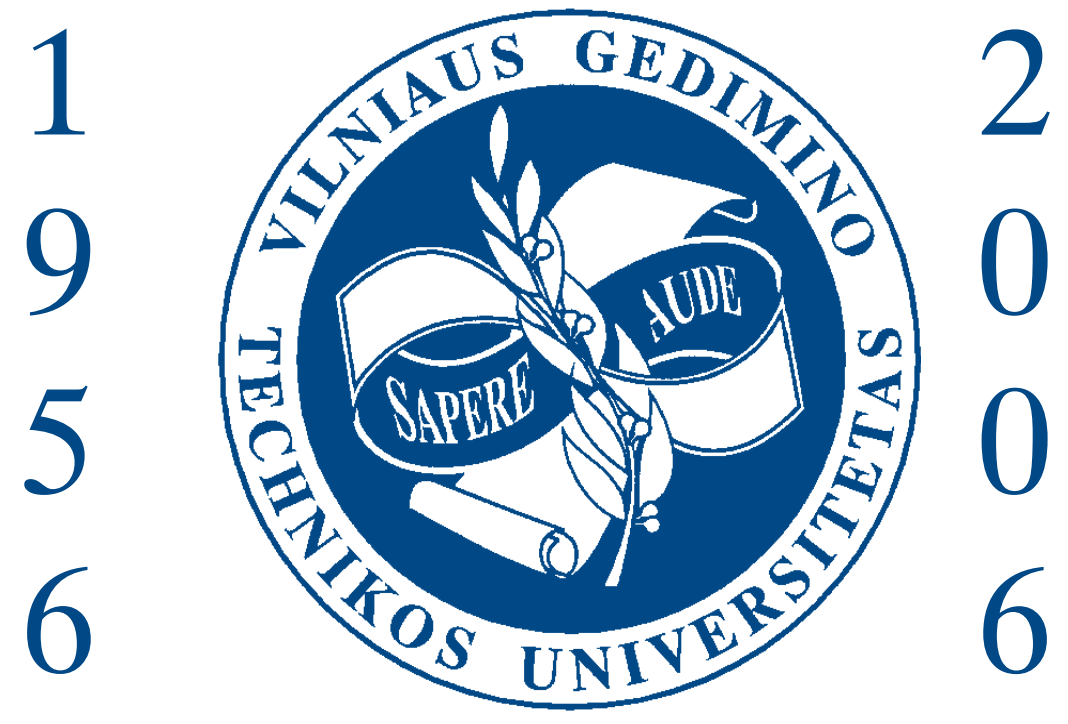


Algimantas Nakas

VILNIAUS GEDIMINO TECHNIKOS UNIVERSITETO

1956 R A I D A 2006

MONOGRAFIJA

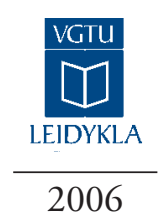




\section{Algimantas Nakas}

Vilniaus Gedimino technikos universiteto raida. 1956-2006.

Vilnius: Technika, 2006. 510 p., iliustr.

Monografija skirta Vilniaus aukštosios technikos mokyklos 50-mečiui pažymèti. Pradejusi veiklą kaip Kauno politechnikos instituto Vakarinio fakulteto Vilniaus skyrius, vèliau ji tapo KPI Vilniaus vakariniu fakultetu, KPI Vilniaus filialu, Vilniaus inžineriniu statybos institutu, Vilniaus technikos universitetu ir pagaliau 1996 m. - Vilniaus Gedimino technikos universitetu. Monografijoje apžvelgiami svarbiausi VGTU raidos momentai, analizuojami mokyklos struktūros, studijų ir mokslo tiriamųjų darbų organizavimo pokyčiai, pedagoginio ir mokslinio personalo kvalifikacijos kèlimo, absolventų perspektyvų ir kiti klausimai.

Monografija skirta akademinei visuomenei, mokslotyros ir kitiems tikslams.

VGTU leidyklos „Technika“

1248 mokslo literatūros knyga

Recenzavo: prof. habil. dr. Algirdas Ažubalis, Generolo Jono Žemaičio Lietuvos karo akademija prof. dr. Algimantas Mačiulis, Lietuvos dailès akademija doc. dr. Juozas Nagevičius, Vilniaus Gedimino technikos universitetas

ISBN 9955-28-038-7

(C) Algimantas Nakas, 2006

(C) VGTU leidykla „Technika“, 2006 m. 
REKTORIAUS ŽODIS

19

PRATARMÉ

123

TECHNIKOS

IR TECHNIKOS MOKSLŲ

RAIDA LIETUVOJE

126

II TECHNIKOS

STUDIJŲ PRADŽIA

VILNIUJE

152

III KAUNO

POLITECHNIKOS

INSTITUTO

VILNIAUS FILIALAS

176

IV VILNIAUS

INŽINERINIS

STATYBOS

INSTITUTAS

$/ 130$

V VILNIAUS

TECHNIKOS

UNIVERSITETAS

1242

VI VILNIAUS

GEDIMINO

TECHNIKOS

UNIVERSITETAS

1272

Literatūra ir šaltiniai

1488

Pavardžiu rodykle

1492 

REKTORIAUS

ŽODIS
Jubiliejai ne tik švenčiami. Rengiantis jubiliejams suvedami ir nueito kelio rezultatai. Žmogui svarbūs šeimos, visų pirma vaikų laimëjimai, jo paties sèkmè darbe, statusas visuomenëje ir pan., o įstaigai, gamybinei organizacijai reikšmingi produkcijos ir paslaugų mastai. Universitetas tokiu atveju pirmiausia skaičiuoja, kiek ir kokių absolventų išleido, kiek parengè mokslininkų, kokia jo mokslinè produkcija ir t. t. Visais atvejais minimi svarbūs žmonès, nes tik nuoširdžiu jų triūsu pasiekiami šie rezultatai.

Mūsų aukštosios mokyklos nueitą 50-ies metų kelią ir laimẻjimus išsamiai nušviečia Jūsų rankose laikoma doc. A. Nako knyga. Joje metodiškai, pasitelkiant gausią archyvinę medžiagą ir iliustruojant įdomiomis nuotraukomis, pateikti per ši laikotarpi îvykę esminiai îvykiai. Visi jie tarpusavyje susieti, todèl turime išsamią mūsų mokyklos plètros studiją.

Žmogų, švenčiantị jubiliejų, nuoširdžiai sveikiname, džiaugiamès jo pasiektais rezultatais, linkime ilgų gyvenimo metų ir dar didesnių laimejjimų, o minint organizacijos sukaktį visų pirma linkima nemažinti plètros tempų. Kokių linkëjimų noretųsi išgirsti Vilniaus Gedimino technikos universiteto 50-mečio proga? Koki universitetą norètume matyti tiek artimoje, tiek tolesneje ateityje?

Esame Europos Sąjungoje, kartu su ja kuriame bendrą studijų ir mokslo erdvę. Tai reiškia, kad gerokai prasiplečia veiklos galimybès, bet, kita vertus, labai išauga reikalavimai darbo kokybei. Apibendrinamasis šios kokybès rodiklis - universiteto konkurencingumas tiek šalyje, tiek užsienyje. Ateis laikas, kai reikès kovoti dèl kiekvieno stojančiojo. Konkurencingumas - tai ir yra pagrindinis reikalavimas bei sąlyga ateities vizijoms kurti. Ko reikia, kad universitetas būtų konkurencingas? Jis turi būti šiuolaikiškas. Esminè universiteto funkcionavimo sąlyga - pažangios studijos ir pažangus mokslas. Pirmiausia, kiekvienas fakultetas turi dirbti moderniame, specialiai suprojektuotame ir studijų procesui bei moksliniams tyrimams pritaikytame pastate, idealiu atveju esančiame Studentų miestelyje. Antra, kiekviename tokiame pastate turi būti sumontuota visa būtina moderni studijų ir mokslinių tyrimų ịranga. Trečia, ši įranga susieta su moderniomis mokymo ir mokslinių tyrimų technologijomis. Ketvirta, šias technologijas taiko profesionalūs, darbingi, puikiai užsienio kalbų mokantys ir todẻl labai gerai mokami dèstytojai. Penkta, produktyviam kūrybiniam darbui sąlygas sudaro demokratiška ir autonomiška universiteto vidaus aplinka.

Tokiu keliu mes norime eiti, tokiu keliu mes einame. Deja, tempai daugiausia priklauso ne tik nuo mūsų noro, bet ir nuo išorès sąlygų. Šiandieną reikalavimai universitetams keliami neatsižvelgiant ị jų galimybes. Kad ir kaip būtų, galiausiai visada laimi sveikas protas, todèl $\mathfrak{i}$ ateitị mes žvelgiame su optimizmu.

Sąlygos tam yra.

VGTU rektorius

prof. habil. dr. Romualdas Ginevičius

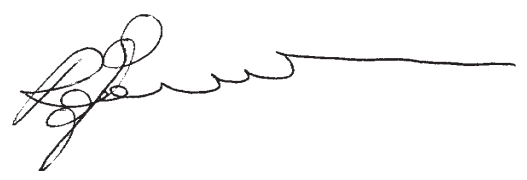




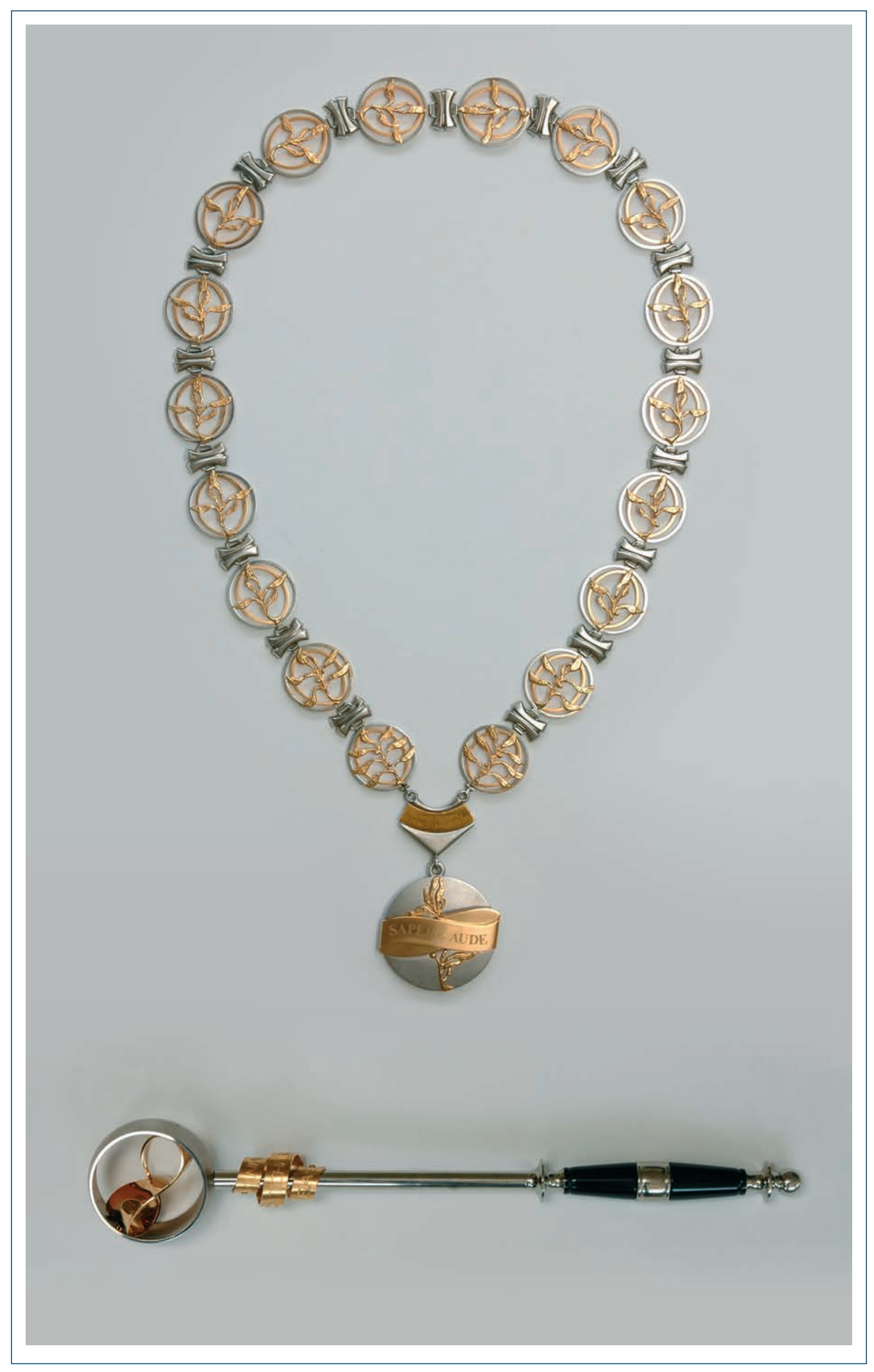


KAZIMIERAS BARŠAUSKAS

\author{
KPI REKTORIUS
}

1950-1964 METAIS

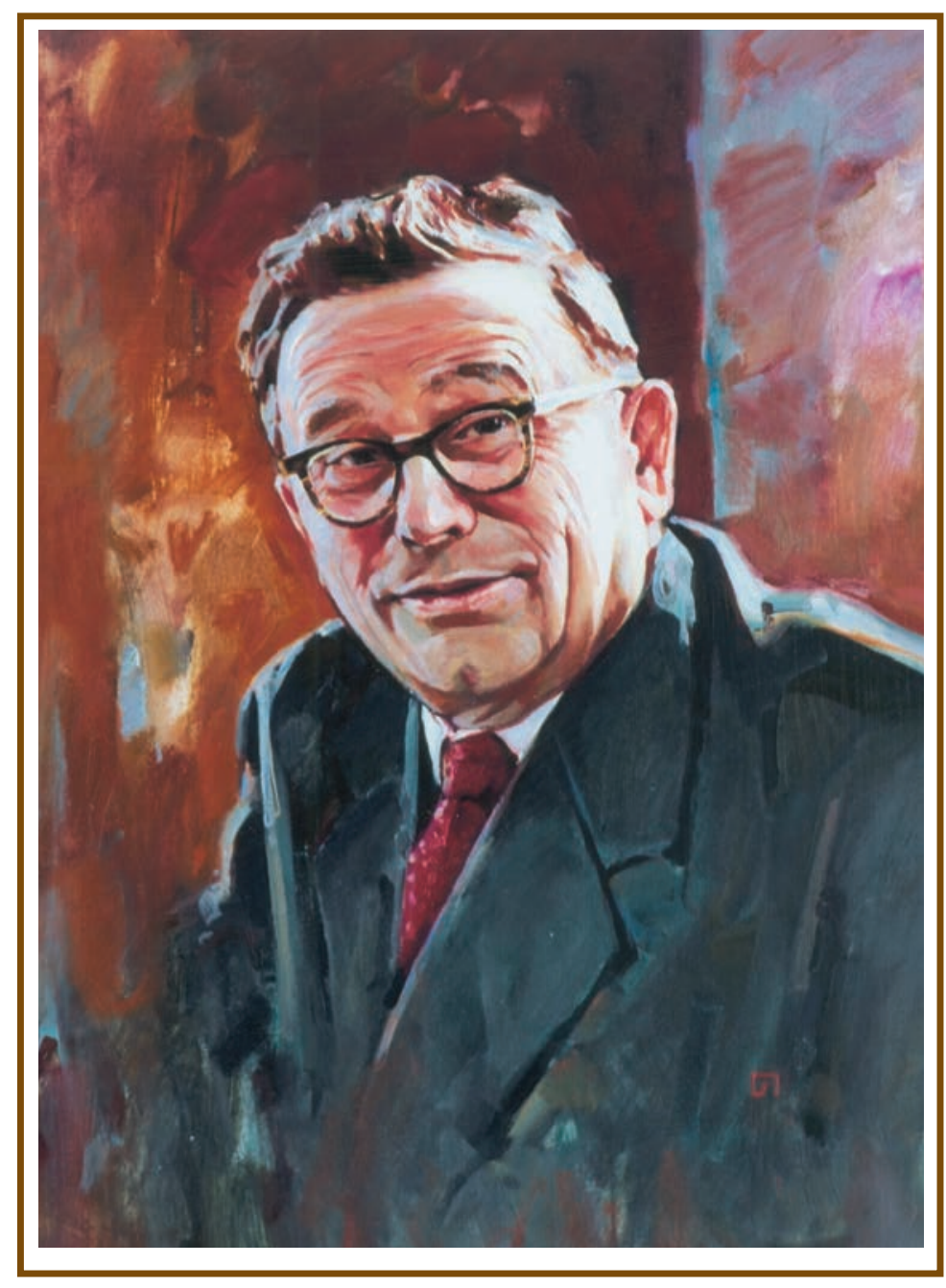

Gimè 1904 m. gegužès 3 d. Gižuose, Vilkaviškio rajone. 1930 m. baige Vytauto Didžiojo universiteto Gamtos-matematikos fakulteto Fizikos-matematikos skyrių. Buvo pakviestas dirbti į Fizikos katedrą.

1936 m. K. Baršauskas buvo komandiruotas stažuotis ị Vokietiją pas ižymųji J. Geigerị. Jo paskatintas èmé tirti kosminius spindulius. 1938 m. K. Baršauskas apgynè fizikos-matematikos mokslų daktaro disertaciją. $1940 \mathrm{~m}$. jam buvo suteiktas profesoriaus mokslinis vardas. Nuo $1941 \mathrm{~m}$. jis buvo universiteto Fizikos katedros vedeju, parengè ir išleido du fizikos vadovèlius moksleiviams.

1947m. K. Baršauskas buvo paskirtas Kauno universiteto Technologijos fakulteto dekanu, o kiek vèliau - Elektrotechnikos fakulteto dekanu.

1950 m. K. Baršauskas buvo paskirtas Kauno politechnikos instituto direktoriumi (rektoriumi). 1956 m. jis buvo išrinktas Lietuvos mokslų akademijos tikruoju nariu.

K. Baršauskas publikavo per 60 mokslinių straipsnių, 21 jo vadovaujamas mokslininkas apgyne mokslo kandidato disertaciją, jis oponavo net 36 disertantų darbams.

K. Baršauskas dirbo KPI rektoriumi iki mirties - 1964 m. gegužès 24 d. Jo vardu pavadinta KTU (buvusio KPI) Ultragarso laboratorija, VGTU Fizikos katedros srautiné auditorija. 
MARIJONAS

MARTYNAITIS

KPI REKTORIUS

1964-1983 METAIS

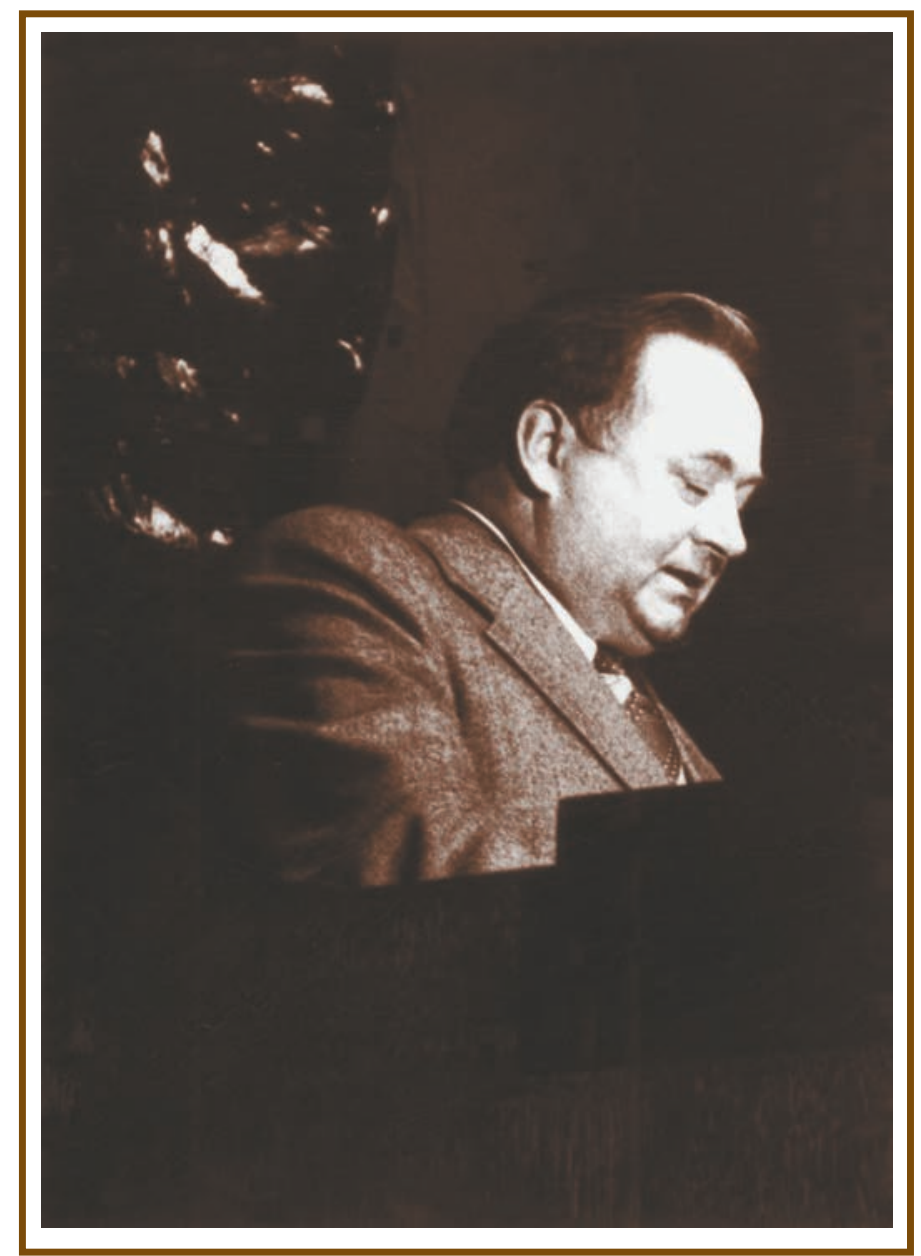

Gimè 1922 m. balandžio 3 d. Kaune. 1950 m. baige Kauno universiteto Chemines technologijos fakultetą ir gavo inžinieriaus silikatininko diplomą. Buvo paliktas dirbti Silikatų technologijos katedroje. 1955 m. apgyne kandidatinę disertaciją iš rišamųjų medžiagų technologijos.

1956-1964 m. M. Martynaitis buvo Kauno politechnikos instituto mokymo reikalų prorektoriumi, o 1964-1983 m. KPI rektoriumi (nuo 1966 m. - profesorius), 1983 m. tapo Silikatų technologijos katedros profesoriumi konsultantu, o vèliau išejo ị rentą.

M. Martynaitis paraše darbų iš rišamųjų medžiagų technologijos. Kartu su kitais už mokslinius darbus gavo 1960 m. respublikinę premiją. Parenge darbų aukštojo mokslo istorijos ir aukštosios mokyklos darbo metodikos klausimais.

M. Martynaitis parenge ir $1974 \mathrm{~m}$. išleido mokymo priemonę „Mineralinès rišamosios medžiagos“. Jis yra vadovèlių „Bendroji silikatų technologija“ (1963), „Bendrosios silikatų technologijos laboratoriniai darbai“ (1967) bendraautoris. 1979 m. parenge ir išleido monografiją „Kauno A. Sniečkaus politechnikos institutas“. 


\section{ALEKSANDRAS ČYRAS}

VISI REKTORIUS 1969-1990 METAIS

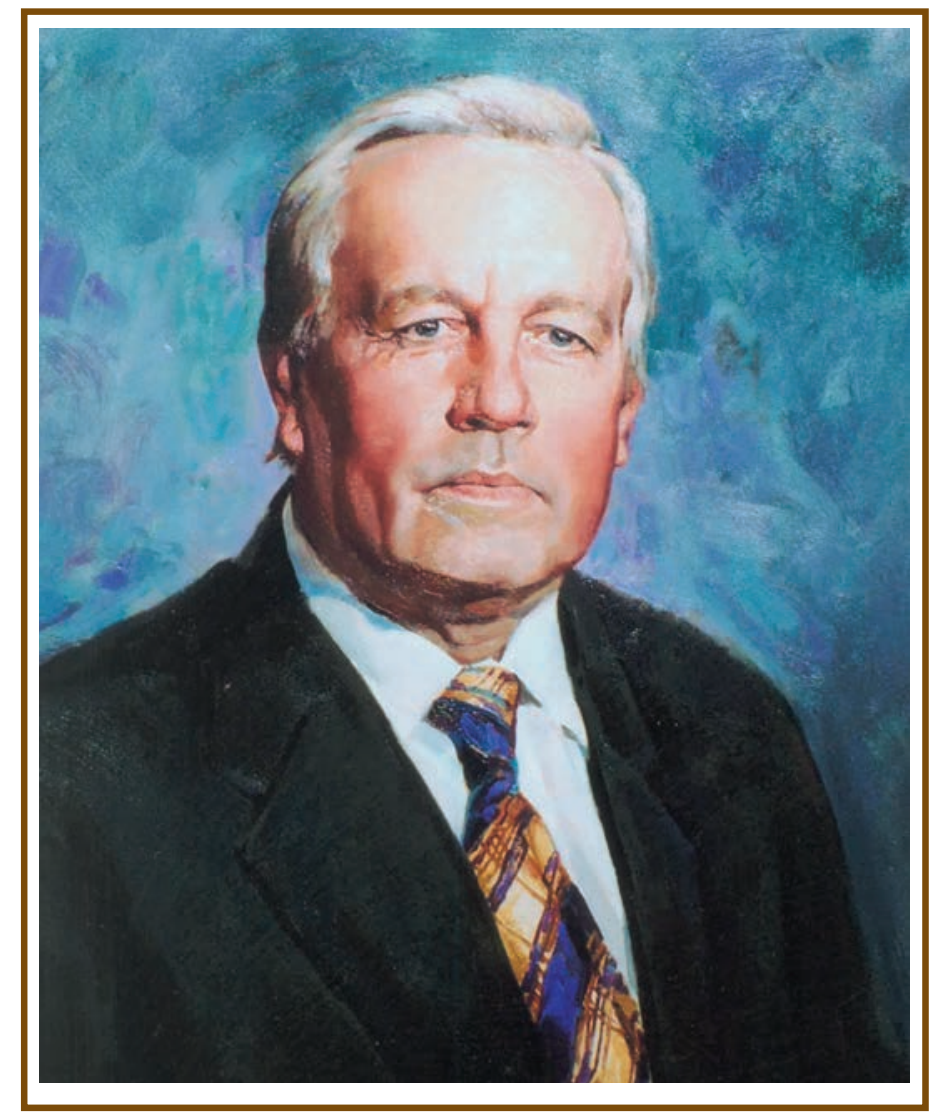

Gime 1927 m. kovo 15 d. Merkineje. 1950 m. su pagyrimu baigé Kauno universiteto Statybos fakultetą ir liko jame dirbti. Pirmasis Lietuvoje èmé taikyti optinius įtempimų tyrimo metodus. $1954 \mathrm{~m}$. apgynè daktaro disertaciją. Nuo 1958 m. pradejo dirbti pirmuoju etatiniu destytoju KPI Vilniaus skyriuje. 1960 m. šis skyrius tapo Vakariniu fakultetu, o A. Čyras buvo paskirtas jo dekanu. Nuo $1961 \mathrm{~m}$., vietoj vakarinio fakulteto ịsteigus KPI Vilniaus filialą su dieniniu ir vakariniu skyriais, jis dirbo KPI Vilniaus filialo prorektoriumi. 1965 m. Aleksandras Čyras apgynè habilituoto daktaro disertaciją „Matematinio programavimo metodai skaičiuojant tampriai plastines vienmates sistemas“. 1969 m. daugiausia profesoriaus A. Čyro pastangomis buvo įsteigtas Vilniaus inžinerinis statybos institutas. Šio instituto rektoriumi A. Čyras dirbo iki 1990 metų.

A. Čyras - sąjunginès B. Galiorkino ir Lietuvos valstybinès premiju laureatas, Lietuvos nusipelnęs statybininkas, Lietuvos nusipelnęs mokslo veikëjas.

1980 m. A. Čyras išrinktas Lietuvos MA nariu-korespondentu, o nuo 1985 m. - akademiku.

Aleksandras Čyras - daugelio mokslinių darbų, monografijų, vadovelių autorius. Jo sukurti statybinių konstrukcijų optimizavimo metodai gerai žinomi daugelyje pasaulio šalių. Jo monografijos anglų kalba yra išleistos Didžiojoje Britanijoje, Vokietijoje ir Lenkijoje. 1985 m. jis išrinktas Veimaro aukštosios statybos ir architektūros mokyklos Garbès daktaru, o 1994 m. - Lenkijos moksly̨ akademijos užsienio nariu.

A. Čyras labai ryžtingai ir atkakliai studijose diegè kompiuterinius skaičiavimus. Jis daug prisidejjo prie Vilniaus inžinerinio statybos instituto materialinès bazès stiprinimo, ypač prie naujų mokymui ir mokslui skirtu pastatų statybos.

A. Čyras - 1993 metų Lietuvos valstybinès premijos laureatas. 1996 m. jis apdovanotas Lietuvos Didžiojo kunigaikščio Gedimino III laipsnio ordinu.

A. Čyras mirè $2001 \mathrm{~m}$. rugsëjo $29 \mathrm{~d}$. Vilniuje. 
EDMUNDAS

KAZIMIERAS

ZAVADSKAS

VGTU (VISI, VTU)

REKTORIUS

1990-2002 METAIS

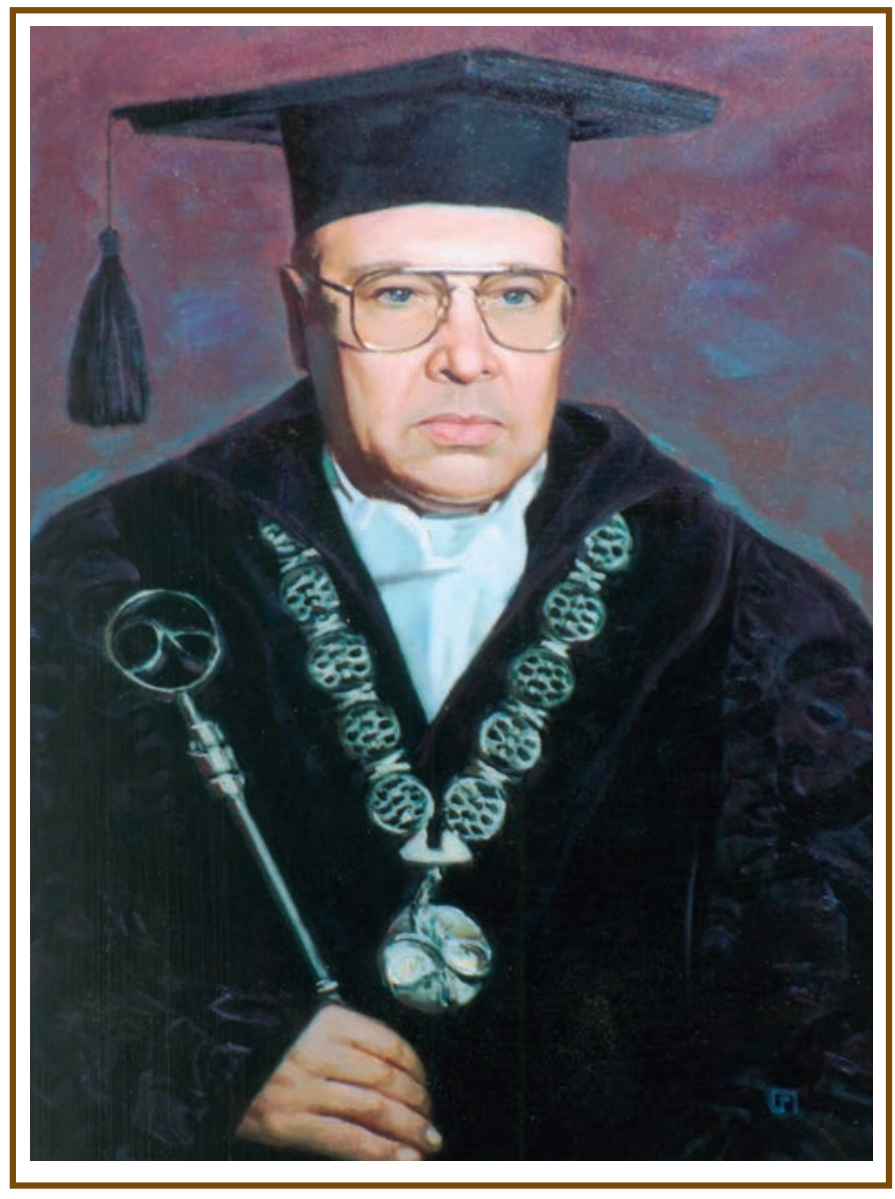

Gime 1944 m. gegužès 12 d. Vilniuje. 1967 m. baigè Kauno politechnikos instituto Vilniaus filialą ir gavo inžinieriaus statybininko diplomą. Buvo paliktas dirbti filiale. 1970 m. ìstojo ị aspirantūrą ir per trejus metus parenge kandidatinę disertaciją. Paskui dirbo pedagoginị darbą Statybos darbų technologijos katedroje.

1980-1981 m. E. K. Zavadskas stažavosi Leipcigo aukštojoje technikos mokykloje, Vokietijoje. 1987 m. Maskvoje apgyne daktaro (dabar habilituoto) daktaro disertaciją. Nuo 1988 m. - profesorius, Statybos darbų technologijos katedros vedejas.

1990 m. vasario 7 d. E. K. Zavadskas demokratiškai buvo išrinktas Vilniaus inžinerinio statybos instituto rektoriumi. Jo iniciatyva ir atkakliomis pastangomis institutas buvo pertvarkytas į Technikos universitetą, pavadintas LDK Gedimino vardu.

1991 m. E. K. Zavadskas išrinktas Lietuvos mokslų akademijos nariu ekspertu, o 1994 m. - nariu korespondentu. Jis yra Ukrainos technologinès kibernetikos akademijos, Rusijos architektūros ir statybos akademijos, Rusijos inžinierių akademijos ir kt. užsienio nariu, yra išrinktas Europos mokslo, menų ir profesijų akademijos Garbès nariu. Jam suteiktas Poznanès technologijos universiteto bei Peterburgo A. Gerceno pedagoginio universiteto Garbès daktarų vardai.

Dideli E. K. Zavadsko mokslo laimējimai. Jis sukūrè sprendimų paramos sistemų teorinius pagrindus, paskelbe apie tūkstantị mokslinių ir publicistinių straipsnių, paraše ir išleido per šimtą knygų statybos, vadybos ir edukologijos klausimais lietuvių, anglų, vokiečių ir kt. kalbomis. E. K. Zavadsko darbai cituojami tarptautiniuose prestižiniuose leidiniuose. Jis išugde per 20 doktorantų, sukūrè mokslinę mokyklą.

E. K. Zavadskas - dviejų Lietuvos nacionalinių mokslo premijų laureatas, turi daug įvairiausių kitų apdovanojimų, visuomeninių pareigų. rektorius.

Nuo 2002 m. prof. habil. dr. E. K. Zavadskas - pirmasis VGTU pro- 


\section{ROMUALDAS GINEVIČIUS}

VGTU REKTORIUS

NUO 2002 METU

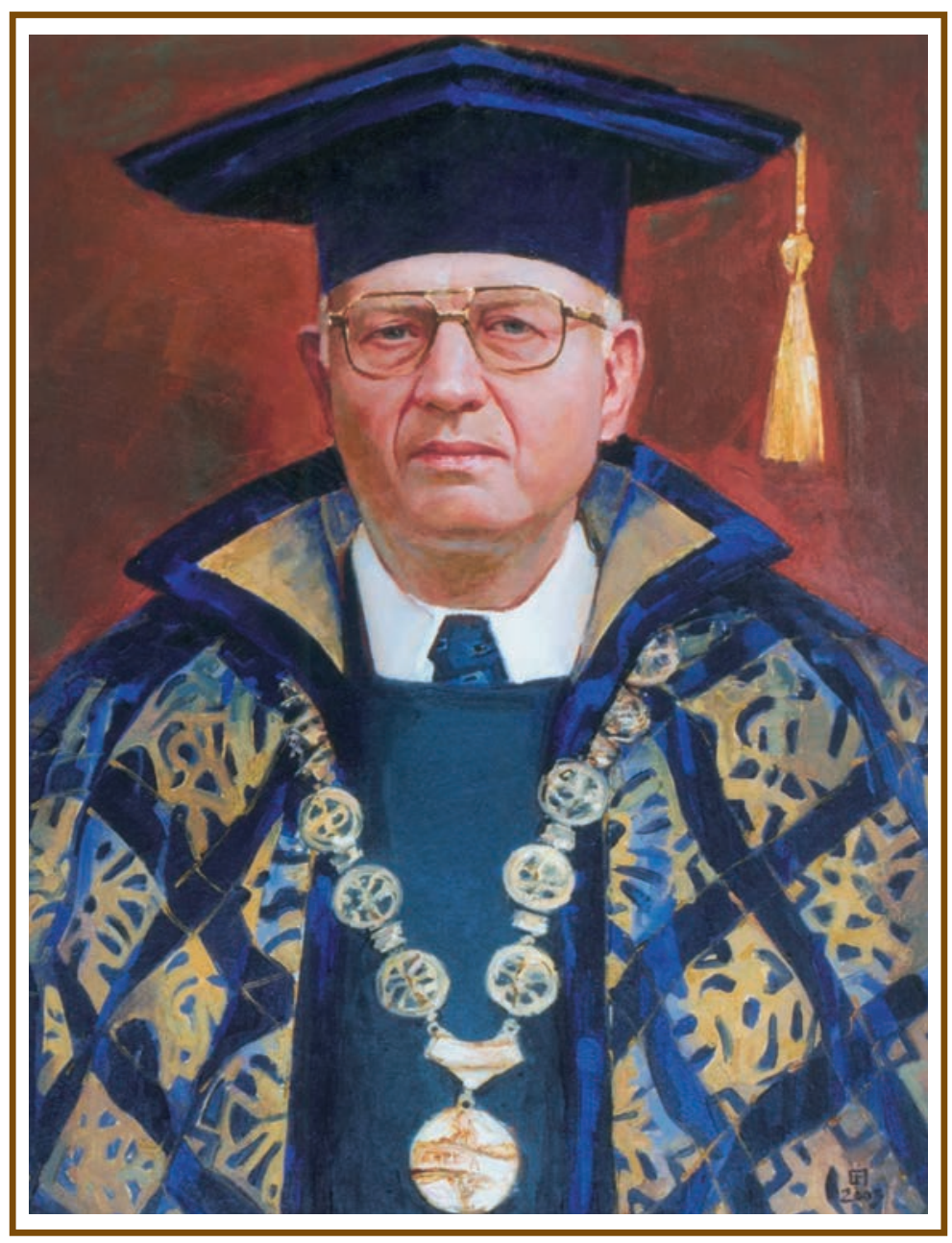

Gimè 1946 m. rugsëjo 9 d. Varénos rajono Valkininkų miestelyje.

1969 m., baigęs KPI Vilniaus filialą ir gavęs inžinieriaus ekonomisto diplomą, R. Ginevičius ịstojo ị aspirantūrą. $1975 \mathrm{~m}$. sékmingai apgyné disertaciją „Namų statybos kombinatų srautinių-technologinių linijų funkcionavimo patikimumo klausimai (Lietuvos NSK pavyzdžiu)“.

Nuo 1975 m. iki 1980 m. R. Ginevičius dirbo Statybos ekonomikos fakulteto prodekanu, po to 10 ménesių stažavosi Vokietijoje.

1990-1993 m. buvo VGTU Ekonomikos katedros vedëju.

Nuo 1993 m. - Verslo administravimo fakulteto dekanas.

$1997 \mathrm{~m}$. apgyne habilituoto daktaro disertaciją.

Nuo 1999 m. - profesorius. Yra Tarptautines informatikos akademijos narys, Šiaures informatikos akademijos (Vokietija) viceprezidentas.

2001 m. išrinktas Vilniaus Gedimino technikos universiteto Senato pirmininku ir İmoniu ekonomikos ir vadybos katedros vedeju.

2002 m. išrinktas Vilniaus Gedimino technikos universiteto rektoriumi, paskirtas šalies Privatizavimo komisijos pirmininku.

Rektoriaus R. Ginevičiaus mokslinè veikla - rinkos ekonomikos klausimai, organizacijos teorija. Yra dešimties knygų, monografijų, vadovelių ir daugiau kaip 250 mokslinių straipsnių autorius. Yra ịvairių tarptautinių asociacijų, draugijų narys.

2002 m. R. Ginevičiui suteiktas Kijevo nacionalinio aviacijos universiteto Garbès daktaro vardas. Jis yra įvairių šalių akademijų užsienio narys.

2006 m. R. Ginevičius apdovanotas DLK Gedimino ordinu, perrinktas rektoriumi antrai kadencijai, išrinktas Lietuvos universitetų rektorių konferencijos prezidentu. 
Per 50 savo veiklos metų Vilniaus aukštoji technikos mokykla nuolat ženge pažangos keliu, augo kiekybiškai ir kokybiškai. Tapusi Vilniaus Gedimino technikos universitetu, dabar ji turi keliolika tūkstančių studentų ir pagal dydį yra trečiasis universitetas šalyje. VGTU pirmauja pagal absolventų įsidarbinimą, pasieke puikių mokslo laimëjimų, kurie periodiškai vertinami nacionalinèmis mokslo premijomis. Gražiu laimëjimu pasiekta tokiose srityse, kaip tarptautinès studijos, dalyvavimas įvairiose tarptautinèse programose, architektų kūrybos darbai ir t. t.

Sumanymas parašyti mokyklos raidos knygą kilo rengiant VGTU (VISI) istorijos muziejaus ekspozicijas, paaiškejjus, kad neturime detalios, susistemintos mūsų universiteto veiklos medžiagos. Sovietmečiu išleistuose leidinukuose tik lakoniškai pristatyta Inžinerinio statybos instituto struktūra, pedagoginis, mokslinis ir ūkinis personalas, pateikta kai kurių studijas ir mokslą apibūdinančių rodiklių. Kiek daugiau jų yra leidinyje, išleistame VISI 10-mečiui paminèti.

Padètis pagerëjo Nepriklausomybès metais. 1996 m., minint mokyklos 40-ąsias metines, buvo parengtas ir išleistas leidinys „Vilniaus technikos universitetas. 1956-1996“ (sudarytojas A. Nakas), 2000 m. - „Dešimt Vilniaus Gedimino technikos universiteto reformos ir kūrybos metu“" (sudarytojas A. V. Valiulis), 2001 m. - E. K. Zavadsko ir A. V. Valiulio „Universitetas plètros ir tobulëjimo kelyje“. Buvo išleista ir kitų leidinių, kuriuose nušviesti svarbiausi aprašomųju laikotarpių įvykiai.

Reikšmingą darbą pradejjo prof. E. K. Zavadskas ir dr. V. Lujanienè, ėmę sistemingai leisti VGTU metraštị „Metai ir dienos“. Spausdinamoji medžiaga jau dabar naudinga, o ateityje bus ypač vertinga rašant naują VGTU istorijos leidinį.

Šiame leidinyje, be abejo, nepavyko išvengti netikslumų, subjektyvumo. Kai kurie vertinimai gal per ankstyvi - juk sakoma, kad istorija rašoma po 100 metų. Vis delto surinkta ir kiek įmanoma susisteminta medžiaga, tikimès, padès universiteto veiklą išsamiau išnagrinèti ir apibendrinti.

Dẻkoju visiems, padëjusiems parengti šị leidinị, ir ypač Rasai Karnilaitei, Jolantai Šiugždaitei, Aleksui Jauniui, Astai Rudminaitei, Astai Verbickienei, Jevgenijai Petkuvienei, Ritai Malikenienei, Juliui Norkevičiui.

Esu dekingas VGTU rektoriui prof. Romualdui Ginevičiui ir pirmajam prorektoriui prof. Edmundui Kazimierui Zavadskui už nuoširdų ir pozityvų istorinių tyrinejimų vertinimą ir tam teikiamas sąlygas.

Ypač dẻkoju savo žmonai Vitalijai Nakienei, prisidëjusiai prie knygos rengimo, parodžiusiai didelę kantrybę, nes teko paaukoti kelerių metų šeimos atostogas, savaitgalius ir kasdienius vakarus.

Dèkoju visiems, kurie pataré, pasakojo prisiminimus, rūpinosi nuotraukomis ir kt. Dar kartą visiems - nuoširdžiai ačiū.

\section{AUTORIUS}

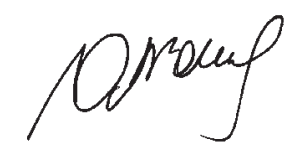






\section{TECHNIKOS}

\section{IR TECHNIKOS MOKSLŲ}

RAIDA LIETUVOJE

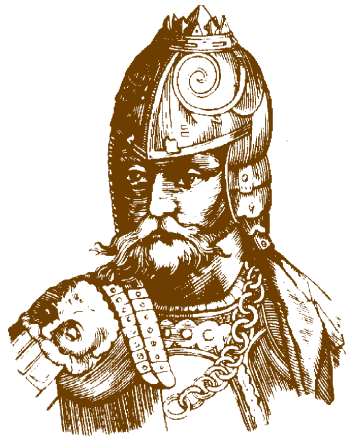

Lietuvos Didysis kunigaikštis Gediminas

\section{Gedimino kvietimas}

„Todèl mes prašome, kad jūs miestuose, kaimuose ir vietovese, kur tiktai kuriam iš jūsiškių pasitaikys pamokslauti, šitai žmonèms praneštumète, o taip pat [tai kad] jei būtu kokiu nors riterių ir ginklanešių, mes jiems skirtume pajamų ir žemès, kiek jie noretų. Pirkliams, kalviams, račiams, balistininkams, kurpiams, bet kokios srities amatininkams su žmonomis, vaikais ir galvijais suteikiame savo žemëje [teisę] laisvai ateiti be jokios rinkliavos arba mokesčio ir bet kokio kliuvimo.

Nors kryžiuočiai dèl šio aukščiau minèto reikalo [ir] sudegino mūsu ižeidimui mūsiškį antspaudą (matyt, [tuo tikslu, kad [darbą] Dievo pradètą, sužlugdytu ir žmonems akis apdumtu), tačiau mes ši rašta pažymime tuo pačiu antspaudu, kaip kad liepème pažymèti ponui didžiai mylimam apaštališkajam tèvui, garantuodami [jo] patikimumą ir apsaugą, [nes] pirmiau geležis vašku taps ir vanduo ị plieną pavirs, negu iš mūsų išejusi žodi atšauksime“.

Gedimino laiškas Saksonijos

domininkonams. 13230526

Iš A. Bumblausko „Senosios Lietuvos istorija 1009-1795“, p. 73
Viršuje dešinëje -

M. E. Andriolis.

Gediminas stato Vilniaus pili. 1882

\section{Technikos ir technikos mokslu raidos Lietuvoje apžvalga iki XX a. pradžios}

İvairius įrankius produktui pagaminti senų senoveje pasidarydavo patys produkto vartotojai. Nuo natūrinio ūkio amatai atsiskyre tada, kai amatininkas už savo darbą gautą atlyginimą galëjo pragyventi. Tuomet amatininkas gamini parduodavo tiesiogiai vartotojui arba jo tarpininkui - pirkliui. Amatu plètote Lietuvos miestuose ypač paspartëjo LDK Gedimino laikais.

Nuo 1323 m. Lietuvos Didysis kunigaikštis Gediminas, siekdamas sustiprinti krašto ekonomiką, kviete iš Vakarų Europos i Lietuvą amatininkus ir pirklius. $1324 \mathrm{~m}$. jis paraše kreipimąsi į Vokietijos miestus, kuriuo kviete juos igyvendinti jo parengtą ekonominę programą. Gediminas suvoké, kad, norint sustabdyti nuolatinius kryžiuočiu puldinejjimus, būtina priimti krikščionybę. Karai su kryžiuočiais sekino ir šiaip jau nelabai stiprias ekonomines jegas. Lietuva, valdoma diplomatinių gabumų turinčio Gedimino, nors ir nepriemè krikšto, daugelį metu gyveno palyginti ramiai.

Atvykdami į Lietuvą, amatininkai atveždavo žinių apie naujausią to meto technikos įrangą, mokydavo technologinių dalykų, taigi plètojo pažangią įvairių medžiagų, daiktų, karybos priemoniu gamybą.

Gediminas atvykusiems amatininkams teike ivvairiu privilegiju ir tuo viliojo gerus savojo amato specialistus. Tai turëjo didelę reikšmę krašto ekonomikai. Gedimino politine veikla lèmé, kad Lietuva suartejo su Vakaru Europos katalikiškaja kultūra. Suintensyvëjo miestu pletra, padidèjo karinè krašto galia, spartesnè buvo feodalinès visuomenès raida.

Lietuvos valstybès sostinę Vilnių Gediminas ivvairiai puoselejo, ir dar jo valdymo laikais miestas tapo dideliu Vidurio ir Rytu Europos politiniu ir ekonominiu centru. Istorikas Alvydas Nikžentaitis rašè: „Savo ipediniams Gediminas paliko ne tik politines veiklos programa, bet ir galinga valstybe, kuri

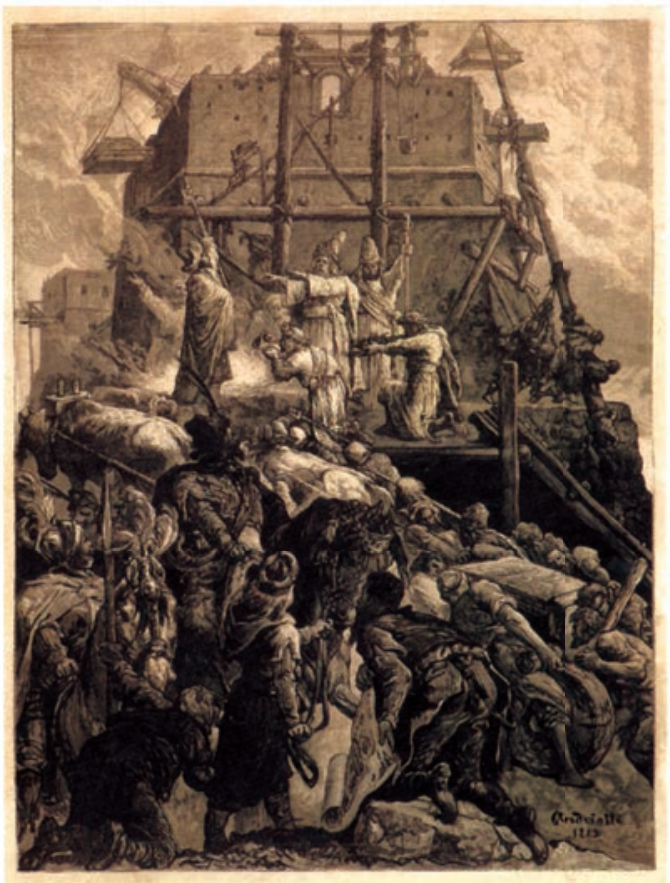

sugebejo sustabdyti Vokiečiu ordino agresija $\dot{z}$ Rytus" [1.1, p. 109].

$\mathrm{XV}$ a., įsigalint šaunamiesiems ugnies ginklams, Lietuvoje daugèjo specialistų, gebančių išlieti geležies kamuolius, apytikriai nustatyti tokių sviedinių skriejimo nuotolius.

Architektūros istorikas Stasys Abramauskas rašè, kad XV a. Lietuvoje inžineriniai darbai pasieke gana aukštą lygi, ypač gynybineje statyboje. Pavyzdžiui, perstatant Trakų salos pili, kai reikejo atlikti pamatu klojimo darbus, vandens lygis ežere buvo pažemintas, o baigus statybą ežeras vèl užtvindytas iki ankstesnio lygio. Vilniuje buvo atlikti labai didelès apimties žemès darbai Vilnelès vagai pakreipti prie Aukštutinès pilies kanalo $[1.2$, p. 2].

1495 m. Lietuvos Didysis kunigaikštis Aleksandras, paskutinis Lietuvos valdovas, mūsų kraštą valdęs atskirai nuo Lenkijos, patvirtino Vilniaus auksakalių cecho statutą. Sis cechas laikomas pirmuoju Vilniuje ir Lietuvoje, o šią datą siūloma laikyti pramonès 
vystymosi pradžia Lietuvoje. Cechų daugëjo, jie vis labiau specializavosi.

Norint tapti amatininku, reikëjo daug ko išmokti. Mokiniais i cechą priimdavo jaunuolius, kurie turëjo mokslą išeiti pas cecho meistrą. Paskui mokinys tapdavo pameistriu ir vykdavo į kelionę po užsienio miestus. Čia dirbdavo pas tų miestų meistrus ir apgynęs „šedevrą" (diplominị darbą), gaudavo meistro mokslo baigimo pažymejjimą. Tuometinëje visuomenèje meistrai ir buvo geriausi technikos žinovai.

XVI a. šalies technikos pletra daugiausia buvo susijusi su karybos reikmèmis. Šios veiklos sritys - tai fortifikacinè statyba, šaudybos technika, kartografija. Žinomi geri to meto specialistai: A. Andras - požemių statytojas, Annus ir M. Enkingeris - Vilniaus įtvirtinimų statytojai, U. Hozijus, J. Skidelis, J. Bretfusas - tų įtvirtinimų įrenginių statybos vadovai ir t. t. Pagal U. Hozijaus projektą Vilniuje buvo pastatytas arkinis tiltas per Neri.

Ginklų dirbtuvès gamino ginklus ir šarvus. Daugiausia garsejjo geležies gamyklos Vilniuje, Valkininkuose, Plateliuose. Bet vystesi ir kitos ūkio šakos. Vilniuje $1524 \mathrm{~m}$. buvo įsteigta pirmoji Lietuvoje popieriaus gamykla, o 1547 m. - pirmoji stiklo dirbtuvè. Vilniuje gamino ne tik geležì, kanuoles, popierių ir stiklą, bet ir plytas, čerpes, kalkes, medinius vandentiekio vamzdžius, veikè pinigų kalykla, patrankų liejykla, lentpjūvès, kalvès ir kt. Gamyba vis sudetingëjo, naudoti tobulesnius įrenginius ir taikyti gamybos būdus galëjo tik nemažai žinių turintys amatininkai. Tiksliųjų mokslų, kurie yra technikos mokslų pagrindas, paklausa èmé sparčiai augti. Mokslas skatino technikos plètrą, o technikos laimejjimai sudarè galimybių mokslo pažangai pletoti. Šiame procese ypač reikšmingas vaidmuo teko Vilniaus universitetui.

Kai 1579 m. Vilniuje buvo įsteigta pirmoji Lietuvoje aukštoji mokykla - Alma academia et universitas Vilnensis societatis Jezu-jos pirmuoju rektoriumi (1579-1584) paskirtas teologas ir rašytojas lenkas Petras Skarga-Paveneckis. Akademijoje tebuvo du fakultetai - Teologijos ir Filosofijos. Filosofijos fakultete buvo dvi katedros: Filosofijos ir Matematikos. Yra žinių, kad jau nuo 1579 metų Jezuitų akademijoje imta déstyti fiziką, elementariąą matematiką, teorinę astronomiją, kiek ir technikos dalykų. Matematikos profesorius Andrius Milevskis dèstè (be kitų dalykų) saulès laikrodžio konstravimą, Simonas Beretas parenge paskaitas apie astronomijos prietaisų konstrukcijas ir jų naudojimą.

Lietuvos ir Lenkijos valstybès dažnai kariavo, daugiausia su Maskva, todèl krašte XVI a. buvo pletojama fortifikacija ir balistika, geodezija ir kartografija. Tai verte daugiau skirti demesio matematikai, gamtos mokslams, technikai.

Nuo 1584 iki 1587 m. buvęs Akademijos rektoriumi Povilas Bokša (1552-1627) esą projektavęs pastatus, prižiūrèdavęs statybas, skaitęs architektūros paskaitas.

Akademijos profesorius Osvaldas Krygeris (1598-1665) déste matematiką ir dirbo technikos darbus, ejo kariuomenès inžinieriaus pareigas. Jis parašè artilerijos veikalą „Patrankų sviedinių kelio nustatymas“, kuriame nagrinejo naujus, praktine patirtimi paremtus trajektorijų apskaičiavimo būdus.

Lotyniškas žodis ingenium reiškia talentą, mintį, mokejjimą. Viduramžių pabaigoje inžinieriais pradeti vadinti fortifikacijos, o vèliau ir kitų technikos sričių specialistai. Prieš pat mirtį O. Krygeris vadovavo Dancigo tvirtovès stiprinimo darbams. Nuo 1632 m. Akademijoje dèstydamas bendruosius mechanikos ir matematikos kursus, i juos įterpdavęs architektūros ir statybos pagrindų.

Akademijoje mokèsi nuo Raseinių kilęs Kazimieras Semenavičius, artilerijos inžinierius, daugiapakopių raketų kūrëjas. $1650 \mathrm{~m}$. Amsterdame jis išleido knygos „Didysis artilerijos menas" pirmąą dalį (Artis Magnae Artilleriae Pars Prima), kurioje aprašè raketų

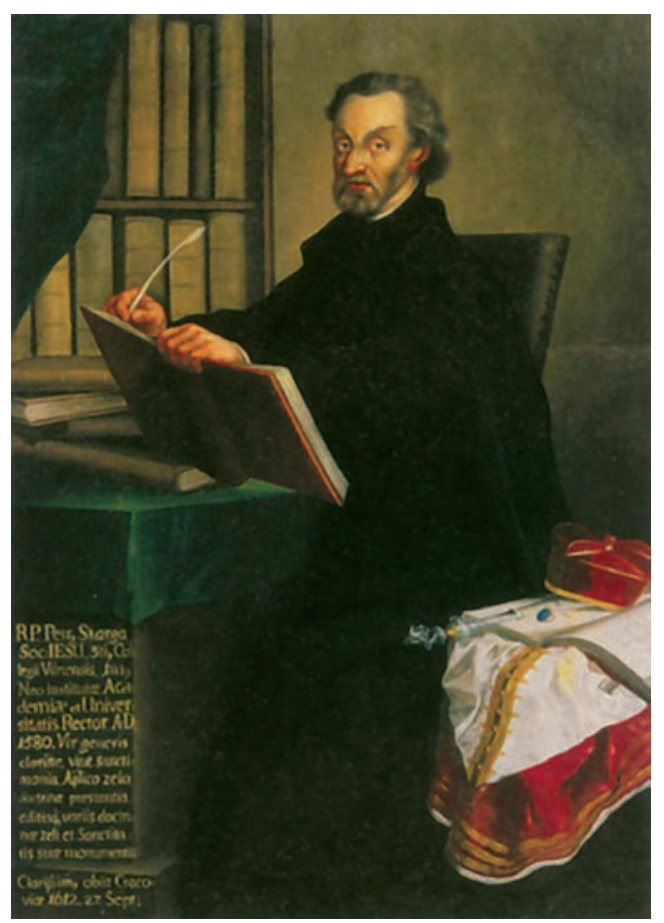

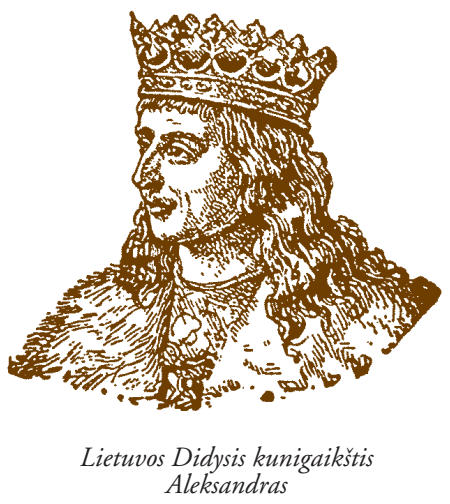

Nežinomas dailininkas. Petras Skarga. XVII a. 
TECHNIKOS

IR TECHNIKOS MOKSLŲ

RAIDA LIETUVOJE
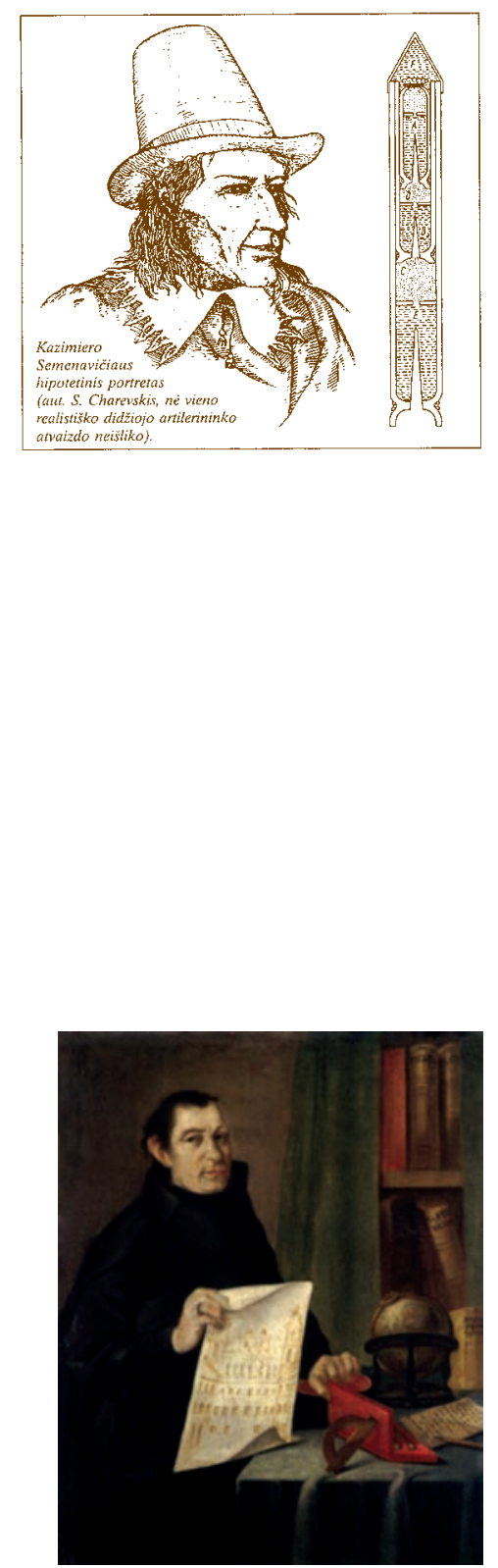

T. Žebrauskas

Observatorijos jikürejas ir

pirmasis direktorius konstrukciją, kurą, gamybą, raketų stabilizaciją, daugiapakopes raketas, sprogmenis ir kt. Knygą sudaro 305 puslapiai teksto, 206 brežiniai, daug lentelių. Daugiau nei 100 metų šis darbas Europoje buvo laikomas klasikiniu. Knyga išversta ị prancūzų, vokiečių, anglų, rusų ir lenkų kalbas.

Apie K. Semenavičiu žinome nedaug. Manoma, kad jis gimęs apie $1600 \mathrm{~m}$. Save vadino Eques Lithuanus (Lietuvos bajoras). Mire Olandijoje apie $1654 \mathrm{~m}$.

Lietuvos technikos istorijoje žinomas Frydrikas Getkantas (1602-1666), gimęs Ragainëje. Nuo 1621 m. studijavo Karaliaučiaus universitete. Tapo karo inžinieriumi. Projektavo ir state uostus, tvirtoves, sudare Lietuvos ir Lenkijos tvirtovių planus, tobulino artilerijos pabūklus. Švedijoje yra jo 1648 m. sudarytas Vilniaus tvirtoves planas, Kauno, Tauragès ir Virbalio miestų planai. Mire Lvove.

Karinis veikalas „Architektura Militaris“ („Karine statyba“) išgarsino Europoje Juozą Narūną-Naronovičių (Naronskị) (1610-1678). Šis matematikas, geodezininkas, statybininkas gime Kèdainiuose. Baigè Kèdainių Radvilų mokyklą. Studijavo Vilniaus ir Karaliaučiaus universitetuose. Gyvendamas Mažojoje Lietuvoje, state kanalus ir dvarų rūmus, dare geodezines nuotraukas, inventorizavo pastatus. J. Narūną remé Boguslavas Radvila.

Lietuvos ir Lenkijos valstybę valdant Vazu dinastijai (1588-1668), kai vyko daug valstybę nualinusių karu, Vilniuje kilo maras ir badas, cechų organizacija pakriko, neaugo gamyba, mažai buvo skiriama demesio ir mokslams.

XVIII a. viduryje inžinerijos darbais pasižymëjo matematikos profesorius T. Žebrauskas (1714-1758), kuris renge taikomosios matematikos veikalus, deste taikomąją matematiką, architektūrą ir kt.

Tik XVIII a. pabaigoje, prasidejus sparčiam kapitalizmo vystymuisi, mokslo pažanga buvo ryški ir Europoje, ir Lietuvoje.

Vilniaus akademijoje (nuo $1781 \mathrm{~m}$. LDK vyriausiojoje mokykloje) vykdant 1773-1782 metu reformas, ju antrajame projekte buvo teigiama, kad reikia „...gilintis i gamtos mokslus ne tik protui apšviesti, bet ir praktinei veiklai “. Išryškëjo būdingas naujiems laikams bruožas - pasitelkti gamtos mokslus gamybai [1.3, p. 113].

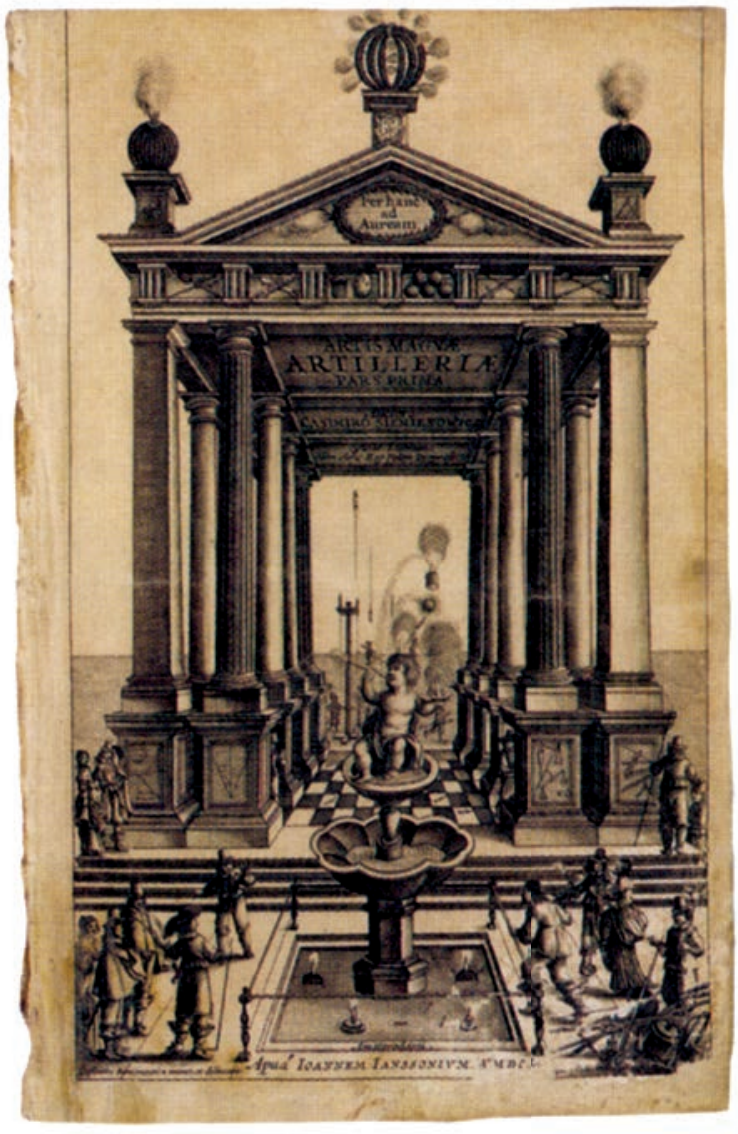

Reikšmingas įvykis buvo I. Niutono klasikines mechanikos, L. Eilerio, R. Huko ir kt. darbų dèstymas. Jų darbus citavo Fizikos kolegijoje matematiką dèstęs Pranciškus Norvaiša (1742-1819).

P. Norvaišos mokinys Tadas Kundzičius (1747-1829) nuo $1780 \mathrm{~m}$. destè taikomąą matematiką, o šio kurso dalį sudare mechanika, kurioje jau minima statika ir dinamika. T. Kundzičius dar deste hidrostatiką, civilinę architektūrą, fortifikaciją ir kt. Pirmojoje civilines architektūros kurso dalyje buvo studijuojamos statybinès medžiagos, antrojoje - statybinès konstrukcijos.

Technikos laimëjimus populiarino profesorius Juozas Mickevičius (1743-1817). Jis įkūre Eksperimentinès fizikos katedrą ir kabinetą, konstravo prietaisus darbui palengvinti. Be to, mokè įtaisyti žaibolaidžius, racionaliai statyti dūmtraukius ir kt.

1780 m. rektoriaus M. Počobuto įsakymu buvo įsteigta Taikomosios matematikos katedra, kurios skaitomų dalykų sąraše - kietųjų kūnų ir skysčių mechanika.

$1793 \mathrm{~m}$. profesoriumi paskyrus Lauryną Gucevičiu (1753-1798), pradejo veikti Architektūros katedra. Jo sudarytoje destymo programoje ryški medžiagu atsparumo ir statikos dalykų svarba. Pastatai turi būti ne tik patogūs ir gražūs, bet ir stiprūs bei pigūs. 
L. Gucevičius pabrèže būtinumą mokèti projektuoti pastatu pamatus, atsižvelgiant i pastato masę ir vietą, taigi įvertinti apkrovas ir gruntų savybes, išmokti naudoti tinkamiausias medžiagas. Jis plètojo ne tik architektūrinę, bet ir inžinerinę veiklą. Matyt, naudodamas skrysčius, sukonstravo keltuvą medžiagoms kelti ir poliakalę poliams ị gruntą kalti.

XIX a. pradžioje mokslas sparčiai žengia pažangos keliu. Pirmiausia pažymetini su Lietuva susijusio fiziko ir chemiko vokiečio Teodoro Grotuso (1785-1822) darbai, reikšmingi mokslo ir technikos raidai.

Studijavęs Leipcigo universitete, Paryžiaus politechnikos mokykloje bei Neapolyje, T. Grotusas pirmasis pasaulyje sukūre ir paskelbe elektrolizes teoriją, atrado fotorescencijos dèsnị, kapiliarinį elektrizacijos reiškini, atliko pionieriškus darbus grandininių reakcijų srityje, sukūre pirmąjį chemini fotometrą ir kt.

Pasaulinio garso mokslininkas T. Grotusas nuo 1808 m. daugiausia gyveno Gedučiuose (Pakruojo r.), kur mirè ir yra palaidotas.

1816 m. pirmą kartą studentams pradètas skaityti specialus konstrukciju skaičiavimo kursas. Kaip mokslo šaka išryškejja statybine mechanika.

Matyt, Vilniaus universitete atidžiai buvo sekama mokslo ir technikos pažanga, todèl turbūt neatsitiktinai jau $1817 \mathrm{~m}$. Vilniaus universiteto auklettinis, filosofijos moksly daktaras Valerijonas Gurskis (1790-1874) stažavosi Vakarų Europoje. Paryžiaus karališkoje politechnikos mokykloje jis klause racionaliosios mechanikos paskaitu, kurias skaite izzymusis Puasonas. Ten jis tobulino ir hidrotechnikos žinias, kuri tuomet buvo vadinama hidrauline architektūra.

Nuo 1812 m. būsimiems architektams ir statybininkams Vilniaus universitete V. Gurskis skaite praktinę mechaniką, o M. Polinskis-Pelka (1783-1848) - analizinę mechaniką. Nuo $1826 \mathrm{~m}$. V. Gurskis skaitè dar inžineriją, t. y. mokslą apie kelių, tiltų, kanalų ir šliuzų statybą.

Kaip ir L. Gucevičius, V. Gurskis daug projektavo, vadovavo įvairių objektų statybai. Jis sutvarke Vilnelès krantus ties Bekešo kalnu, Botanikos sode prie Pilies kalno pagal jo projektą buvo pastatytas kabamasis grandininis tiltas pèstiesiems per Vilnelę. Atrodo, jo fragmentas matyti K. Račinsko 1831 metu litografijoje.

Architektūros katedra gyvavo iki $1832 \mathrm{~m}$. gegužès. Tuo metu inžineriniais gebejjimais joje garsejo adjunktas architektas Fulgentas Rimgaila (1805-1873). Jis veliau dirbo tiesiant Paryžiaus-Strasburgo geležinkeli, sèkmingai dalyvavo konkurse (1850) Londono parodų rūmams projektuoti, tobulino matematinès mechanikos ir statybinių konstrukcijų žinias Berlyne.

Po to, kai 1832 m. gegužès 1 d. Rusijos caras Aleksandras I uždare Vilniaus universitetą, atsargiai buvo keliama mintis ji atgaivinti. Miesto generalgubernatorius $\mathrm{V}$. Nazimovas norejo sugyventi su vietos dvarininkais ir kūre aukštosios realinès mokyklos įsteigimo planą. Joje turëjo būti agronomijos, mechanikos ir architektūros-geodezijos skyriai. $1859 \mathrm{~m}$. sausio $26 \mathrm{~d}$. projektą svarste gubernijos seimelis, bet iš to nieko neišejo.

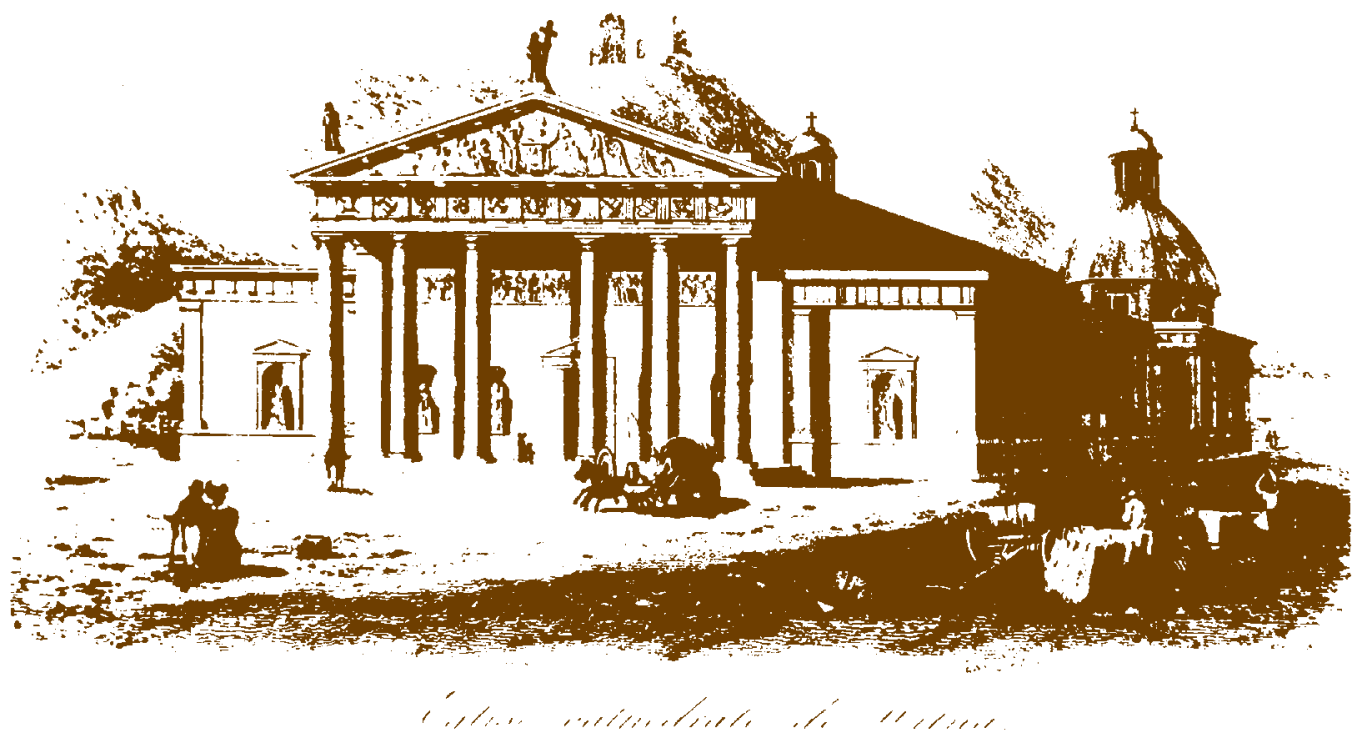

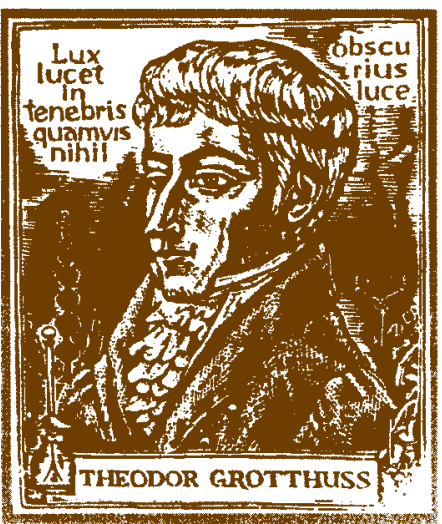

T. Grotusas

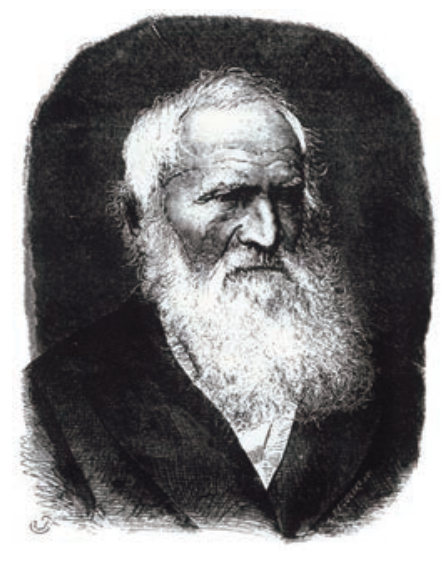

V. Gurskis 
TECHNIKOS

IR TECHNIKOS MOKSLŲ

RAIDA LIETUVOJE

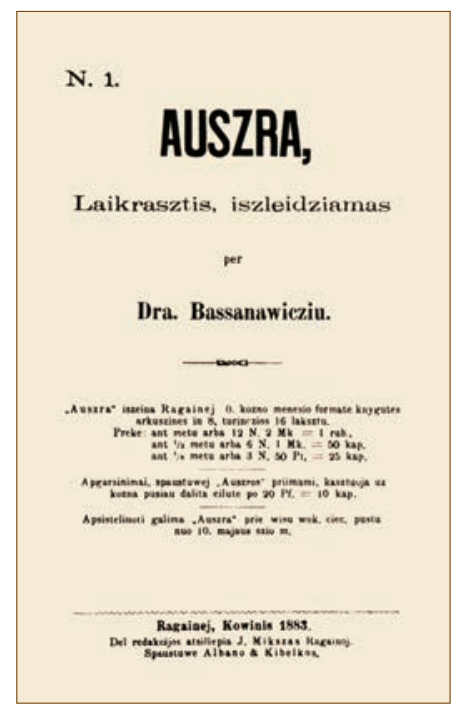

Pirmoji Lietuvių mokslo draugijos valdyba.

Viršutineje eilëje (iš kaires): Antanas Smetona, Petras Vileišis, Jonas Basanavičius (pirm.), Povilas Matulionis, Antanas Vileišis; apatineje eilëje: Juozas Tumas-Vaižgantas, Jonas Vileišis, Stasys Matulaitis, Juozas Bagdonavičius
Rusiškąji Vilniaus universitetą ịkūrti planavo M. Muravjovas-Korikas, bet ir šis planas nebuvo igyvendintas.

Po $1863 \mathrm{~m}$. sukilimo prasidejo labai intensyvi krašto rusifikacija. Tai sukèle dideli lietuvių pasipriešinimą, o kartu labai sustiprëjo lietuvių tautiškasis judèjimas. Uždraudus lietuviškąją spaudą, lietuviškos knygos buvo spausdinamos svetur ir slapta gabenamos i Lietuvą. Lietuvišketti ème dar galutinai nesulenkejusi inteligentijos dalis. Vèl buvo siekiama atkurti Vilniaus universitetą. Bet caro valdžia buvo kurčia šiam Lietuvos gyventojų troškimui. 1874-1880 m. Lietuvos dvarininkija ir visuomene buvo surinkusi nemažą sumą pinigų, kad Vilniuje būtų ịsteigtas Technikos institutas, bet rusų vyriausybe ir šiam pasiūlymui nepritare $[1.4$, p. 211]. Buvo rašoma, kad Vilniui aukštoji mokykla nereikalinga.

$1883 \mathrm{~m}$. Jono Basanavičiaus iniciatyva buvo įsteigtas lietuviškas laikraštis „Aušra“, kuris skatino meilę savajai kalbai, smerkẻ lenkinimą ir rusinimą, sieke lietuviškos spaudos laisves.

1889 m. Vincas Kudirka ėme leisti laikraštị „Varpas“, suvaidinusị svarbų vaidmenị tautiškajame sąjūdyje. „Aušra“ daugiausia raše kultūros klausimais, o „Varpas“ skyre demesị ir ekonomikai. Jame buvo rašoma, $\mathrm{kad}$ „tauta galés greičiau išsivaduoti iš svetimos globos tik ekonomiškai ir kultūišskai sustiprejusi " $[1.5$, p. 504]. Nors ir buvo spausdinama užsienyje, Lietuvoje labai gausejo lietuvišku knygų. 1904 m. gegužès 7 d. daugiausia inžinieriaus Petro Vileišio pastangomis caras paskelbe lietuviškos spaudos laisvę. Suaktyvèjo Lietuvoje kultūros draugijų veikla.

Amžiaus pradžioje vell buvo keliamas universiteto atkūrimo klausimas, buvo rašomi atsišaukimai, svarstoma spaudoje. Tačiau Rusijos valdžia teige, kad ,...provincija nera dar pribrendusi universitetams" [1.4, p. 212].

$1900 \mathrm{~m}$. Vilniaus žemès ūkio draugija, kurios nariai buvo daugiausia stambūs žemvaldžiai, rūpinosi Aukštosios žemès ūkio mokyklos Vilniuje įsteigimu. Tam buvo sudaryta komisija, kuri $1901 \mathrm{~m}$. pasiūlè kurti ne minètą mokyklą, o Politechnikumą (t. y. Politechnikos institutą) su žemès ūkio, miškininkystès, chemijos ir mechanikos skyriais. Bet nesuradus lešų reikalas žlugo [1.6, p. 184].

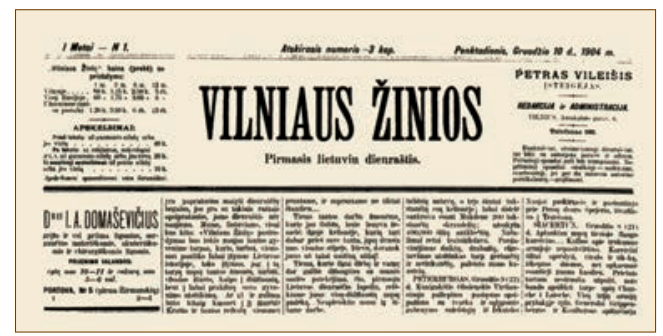

„Vilniaus žiniose“ - pirmojo lietuvių dienraščio, leidžiamo inžinieriaus Petro Vileišio, 1905 m. gruodžio 20 d. numeryje [1.7, p. 1] buvo paskelbta deklaracija, kviečianti atkurti universitetą Vilniuje. Deklaracijoje, be kita ko, rašoma: „Apačioje pasirašiusieji apsiimame visomis spekomis ir visokiais keliais ginti reikala isteigimo Vilniuje liuoso universiteto ir neissiskirti, kol tas užmanymas neivyks". Bet tiek iš deklaracijos, tiek ir iš ten pat spausdinto atsišaukimo nematyti, koks tai turejo būti universitetas, kokius konkrečius uždavinius jis turëjo spręsti.

Vilniaus universiteto atkūrimą svarstant vèlesniais metais, jau yra užuominų apie technikos mokslų reikalingumą. 1907 m. laikraštyje „Viltis“ rašyta apie Vilniaus miesto dūmos iškeltą aukštosios mokyklos idejjąir teigta, kad pradžioje gerai būtų ir politechnika. Tačiau, deja, čia pat pareikšta, kad lietuviai inžinieriai reikalingi mažiausiai $[1.8$, p. 1$]$.

Labai didelę reikšmę lietuviškajam atgimimui turejo Lietuviu mokslo draugijos ịkūrimas. Jos tikslas buvo tirti lietuvių tautą, jos kilmę, kultūrą, tautos formavimosi problemas, jos dislokaciją teritorijoje. Draugijoje buvo analizuojami technikos, ūkio atkūrimo ir ugdymo klausimai.

1907 m. kovo 25 d. (pagal naują kalendorių - balandžio 7 d.) Vilniuje įvyko LMD steigiamasis susirinkimas. Valdybos pirmininku tapo Jonas Basanavičius, nariais - A. Smetona, P. Matulionis, P. ir J. Vileišiai ir kt.

Nors draugijos veikloje vyravo humanitarai, i ją įstojo ir technikos inteligentijos atstovu. Žinoma, kad 1911 m. LMD susirinkime narių teisemis dalyvavo inžinieriai

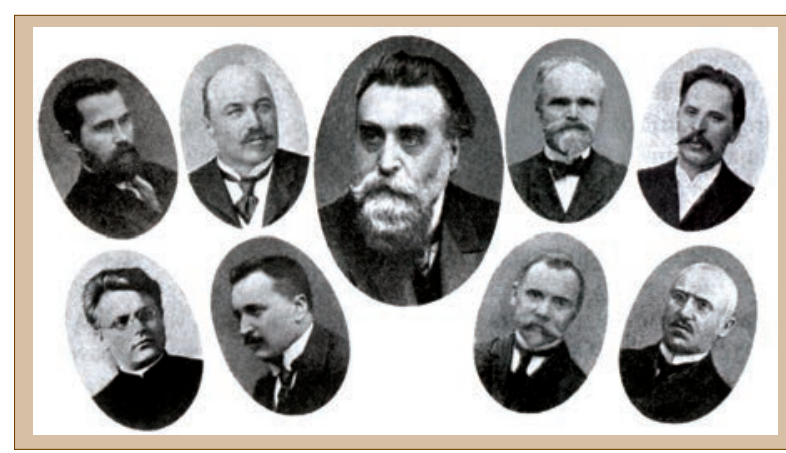


P. Vileišis, Pr. Jodelè, J. Skripkus, S. Kairys, J. Mašiotas [1.9, p. 82]. Vèlesniuose draugijos susirinkimuose buvo skaitomi pranešimai, kuriuose nagrinetos ir Lietuvos ūkio problemos.

1918 m. Lietuvių mokslo draugijoje buvo 846 nariai. Buvo palaikomi ryšiai su užsienio mokslininkais ir mokslo draugijomis. LMD turëjo savo biblioteką, rankraščiu skyrių. Sustiprejusi Lietuvių mokslo draugija buvo reikšminga atgimstančiai tautos kultūrai.

1918 m. vasario 16 d. paskelbus Lietuvos nepriklausomybę, kilo būtinybe sparčiai vystyti šalies ūkị. Buvusioji pramone buvo beveik sunaikinta karo ir okupaciju. Jai atstatyti ir transportui reikejo savų specialistų. Daug lietuvių inžinierių, architektų, technikų buvo išsiblaškę po Rusijos platybes. Reikèjo juos kviesti į tèvynę, rūpintis specialistų rengimu Lietuvoje, suburti juos bendrai veiklai. Tą uždavinị èmè spręsti inžinieriai, susirinkę Vilniuje 1918 metų rudenį.

1918 m. rugsèjo 4 d. buvo ịkurta Lietuvos techniku draugija. Steigiamajame susirinkime dalyvavo 15 inžinierių: Jonas Mašiotas (išrinktas valdybos pirmininku), Steponas Kairys, Jurgis Čiurlys (valdybos nariai), Jonas Šimoliūnas (vicepirmininkas), Kazys Vasiliauskas (sekretorius), Tadas Šulcas (iždininkas), Benediktas Tamoševičius, Adolfas Sruoga, Valdemaras Čarneckis, Juozas Skripkus, Valerijonas Verbickas, Stasys Eidrigevičius, Balys Sližys, Petras Pundzevičius, Konstantinas Šakenis [1.10, p. 41].

Vienas pagrindiniu Lietuvos techniku draugijos tiksly̨ buvo „... padeti i vairioms technikos ir pramonès šakoms pletotis, Lietuvai po karo atsistatyti, detis prie krašto natūraliniu turty tyrinejimo" $[1.11$, p. 86].

Lietuvos technikų draugijon susibūrę inžinieriai sudarinèjo „...planus ateičiai, svarsté, kokia būtu geresne mokykla inžinieriams: Inžinieriu institutas, Politechnika ar Technikos fakultetas Vilniaus universitete? " [1.10, p. 41].

İžymus Lietuvos valstybès veikëjas profesorius Jonas Šimoliūnas (1878-1965) užrašuose, kuriuos paskelbe dr. Jurgis Gimbutas, apie Lietuvos valstybès kūrimąsi 1918 metais, rašé: ,...darbuateityje buvo kalnai, o jiems prityrusiu darbininku be galo maža. Inžinieriai, susitikdami tarp savesskaičiavo, kiekjujau yra Vilniuje, ir pavardemis tepriskaitydavo apie 15, o galimu sulaukti iš Rusijos ir Europos sunku buvo priskaityti iki šimto. Stažnotu techniku specialistu bemaž visai nebuvo. Gi valstybès kūrimosi pradžioje reikëjo inžinieriu ir architektu bent 500, o stažnoty techniku ir kitu prityrusiu specialistu bent 100. Geriausia būtu tokiusparuošti cia pat, savo mokyklose, su salygomis, kuriose, mokslus baige, privales dirbti savistoviai, nebus atitrūkę nuo šalies gyvenimo. Iš teivynëje baigusiuju kai kuriu specialybiu tam tikrus asmenis (reikia) siusti i užsienípasitobulinti, kad jie vel grižtu tevynen dirbti tarp savuju, myletu savo šali, bütu patriotai. Tai normalu, naudinga, gražu; prie to reikia ir eiti “ [1.11, p. 40].

Lietuvos valstybes Taryba $1918 \mathrm{~m}$. lapkričio $11 \mathrm{~d}$. sudare pirmają Lietuvos vyriausybę, kurios ministru pirmininku buvo paskirtas A. Voldemaras. Śi vyriausybe் „...vienu svarbiausiu darbu laike Vilniaus universiteto organizavima. Tam reikalui buvo sudaryta atitinkama komisija atlikti paruošiamuosius darbus. Buvo nutarta 1919 m. sausio 1 d. Vilniaus universiteta atidaryti " [1.4, p. 213].

1918 m. gruodžio 5 d. Lietuvos valstybes tarybos priimtajame Vilniaus universiteto statute buvo numatyta, kad Vilniaus universitete bus 4 fakultetai - Teologijos, Socialiniu mokslų, Gamtos-matematikos ir Medicinos. Bet tai nebuvo realizuota dèl artejančios bolševikų kariuomenès, o Lietuvos vyriausybè pasitraukè į Kauną. Lenkų okupacija, prasidejusi 1919 m. balandžio 19 d., nutrauke ir Sovietų valdžios ketinimus atkurti universitetą Vilniuje. Pažymetina, kad nepaisant krašto techninio atsilikimo, praūžusio pasaulinio karo sugriovimų, nebuvo planuojama rengti inžinierius nei Nepriklausomos Lietuvos, nei Sovietų vyriausybès. Bet lapkričio pabaigoje vokiečiai ème trauktis iš Rusijos ir gruodžio pabaigoje rusai jau buvo prie Vilniaus, todèl susidare grèsminga padetis. Universiteto reikalai nebuvo aktualiausi. Reikëjo ginti Lietuvą, organizuoti kariuomenę. Pirmojo ministro pirmininko Augustino Voldemaro manymas, kad tuo metu Lietuvai tereikëjo tik milicijos, nes taikingos demokratiškos šalies niekas neįsimanysiąs pulti, pasirodè esantis iliuzija, kuri netrukus buvo sutrypta.

1919 m. sausio 5-6 d. rusu bolševiku pajegos užèmé Vilnių. Kiek velliau Vilniuje okupantus rusus pakeite lenkai.

Dar bolševikams esant Vilniuje, Lietuvių mokslo draugija Vilniuje įsteige Aukštuosius mokslo kursus, o 1920 m. tokius kursus Kaune organizavo 1919 m. ịsteigtoji Aukštųjų mokslų draugija [1.12, p. 86]. Aukštieji kursai Kaune buvo atidaryti 1920 m. sausio 27 d. Šie kursai suvaidino didelį vaidmenị kuriant Lietuvos universitetą.

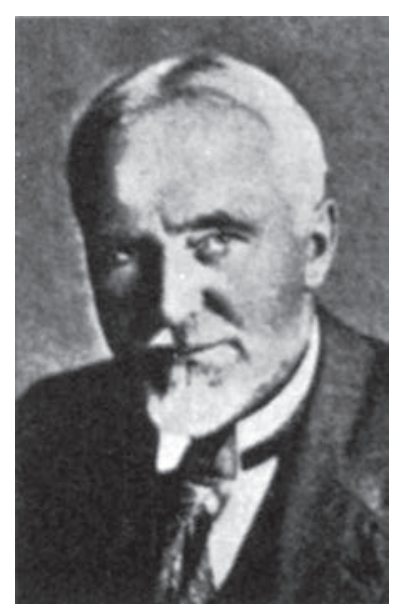

J. Mašiotas

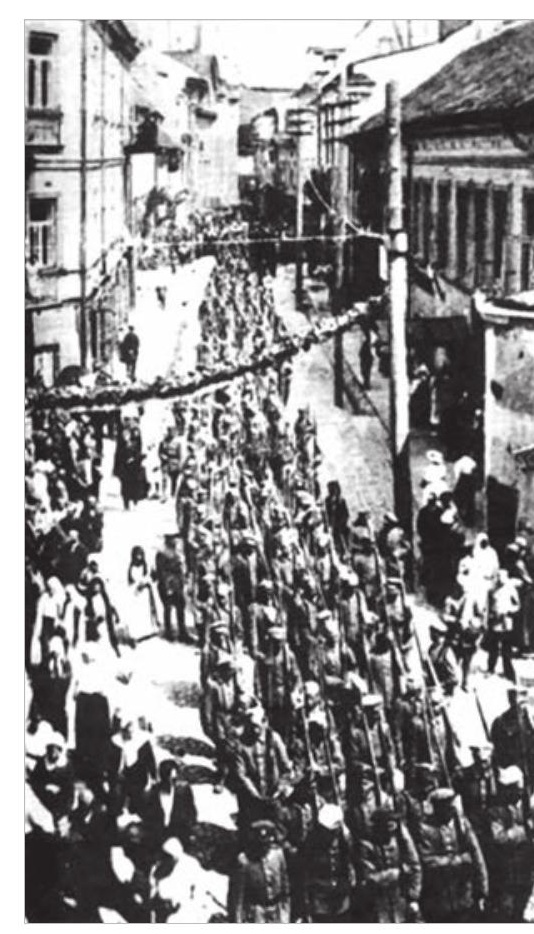

Lenkijos armija Vilniuje $1919 \mathrm{~m}$. 
TECHNIKOS

IR TECHNIKOS MOKSLU

RAIDA LIETUVOJE

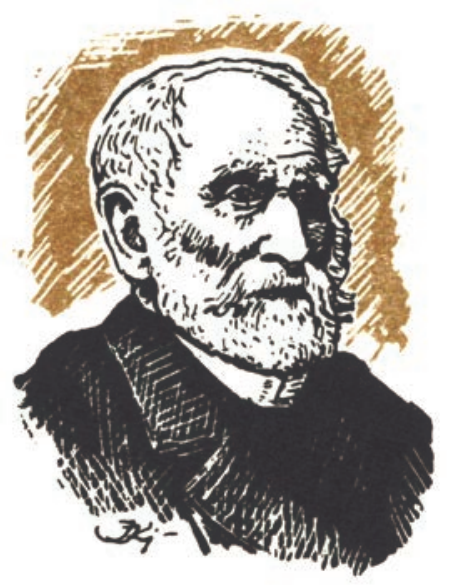

S. Kerbedis

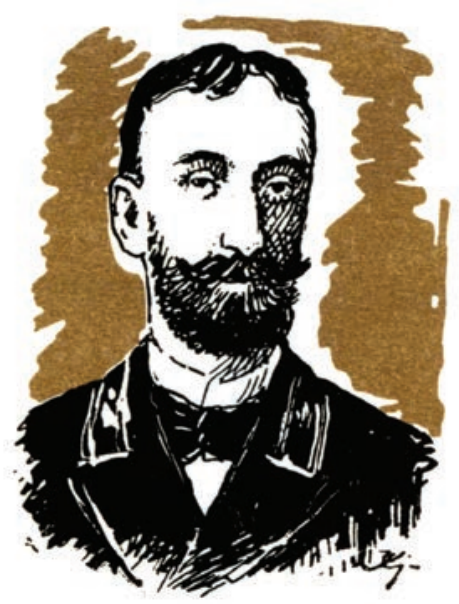

F. Jasinskis
Steigti technikos mokslų studijas Vilniuje buvo sena Lietuvos inteligentijos svajone. Ji buvo realizuota $1956 \mathrm{~m}$., kai Lietuvos sostinëje buvo atidarytas Kauno politechnikos instituto vakarinis skyrius, ilgainiui išaugęs į Vilniaus Gedimino technikos universitetą.

\section{Aukštuju technikos mokslų siekiai XIX a. ir XX a. pradžioje}

XIX a. pradžioje didelè mokslo ir technikos pletra neaplenkè ir Lietuvos. Jau minèjome reikšmingus Vilniaus universiteto dèstytojų inžinerinius darbus. Didẻjo ir inžinerijos disciplinų svarba studijų procese, augo krašto jaunimo susidomejimas technikos mokslais. Tuo pat metu Rusija vis daugiau intensyvino rusinimo politiką, siekdama visus Lietuvos gyventojus asimiliuoti. Tokia politika tapo totaline po 1831 metų sukilimo. Jau $1832 \mathrm{~m}$. caras uždare Vilniaus universitetą. Lietuviai aukštųjų mokslų siekti galëjo tik Rusijos gilumos miestuose. Bet tokių lietuvaičių buvo nepaprastai mažai. Beveik 90 metų lietuviai studijuoti galëjo tik svetur. Pagrindines lietuvių inžinierių „kalves“ buvo Peterburgo susisiekimo kelių inžinierių korpuso (PKI), Peterburgo technologijos, Peterburgo elektrotechnikos, Peterburgo civilinių inžinieriu institutai, Kijevo, Charkovo bei Rygos politechnikos institutai ir kt.

Susisiekimo kelių inžinierių korpuso institutas Peterburge buvo atidarytas $1810 \mathrm{~m}$. Tai buvo pirmoji Rusijos imperijos techninio profilio aukštoji mokykla. Jos paskirtis buvo rengti Rusijos armijai kelių inžinierius. Mokymo programos buvo sudarytos prancūzu identiškos mokyklos pavyzdžiu. Institute destè ir daug prancūzų. Dirbo jame ir ǐžymūs Peterburgo universiteto bei Moksly akademijos mokslininkai. Taigi instituto mokymo lygis buvo labai aukštas [1.13, p. 15].

Peterburgo susisiekimo kelių inžinierių institute studijavo keletas iš Lietuvos kilusių jaunuolių. Vienas žymiausių - Stanislovas Kerbedis.

S. Kerbedis (1810-1899) gimè prie Panevežio esančioje Naudvario gyvenvieteje. Jis su pagyrimu baigè Panevežio pijorų mokyklą, toliau mokesi Kauno ir Varšuvos gimnazijose, o veliau dvejus metus studijavo Vilniaus universitete. Paskui įstojo į Peterburgo susisiekimo kelių inžinierių institutą. Studijuodamas praktiką atliko Lietuvoje, statant Ventos - Dubysos kanalą bei atliekant Ventos upés vagos reguliavimo darbus.

$1828 \mathrm{~m}$. S. Kerbedis baige PKI ir buvo pakviestas šiame institute desstyti. Déste taikomosios mechanikos kursą. Metus laiko tobulinosi užsienyje. Pabuvojo Austrijoje, Anglijoje, Belgijoje, Vokietijoje, Olandijoje, Prancūzijoje ir Šveicarijoje. Ten išstudijavo mechanikos įmonių, geležinkelių, hidrotechnikos ịrenginiu projektavimo ir statybos klausimus, susipažino su naujovemis, aukštųjų mokyklų veikla.

Pirmasis S. Kerbedžio statybos darbas Peterburgo Šv. Stanislovo cerkve. Bet išgarsëjo jis, kai parenge tilto per Nevą projektą.

Tiltą per Nevą Peterburge S. Kerbedis suprojektavo iš ketaus, septynių arkinių 32$48 \mathrm{~m}$ pločio tarpatramių. Aštuntasis tarpatramis buvo numatytas $21 \mathrm{~m}$, bet atveriamas. Tiltas buvo pastatytas $1850 \mathrm{~m}$. ir sèkmingai

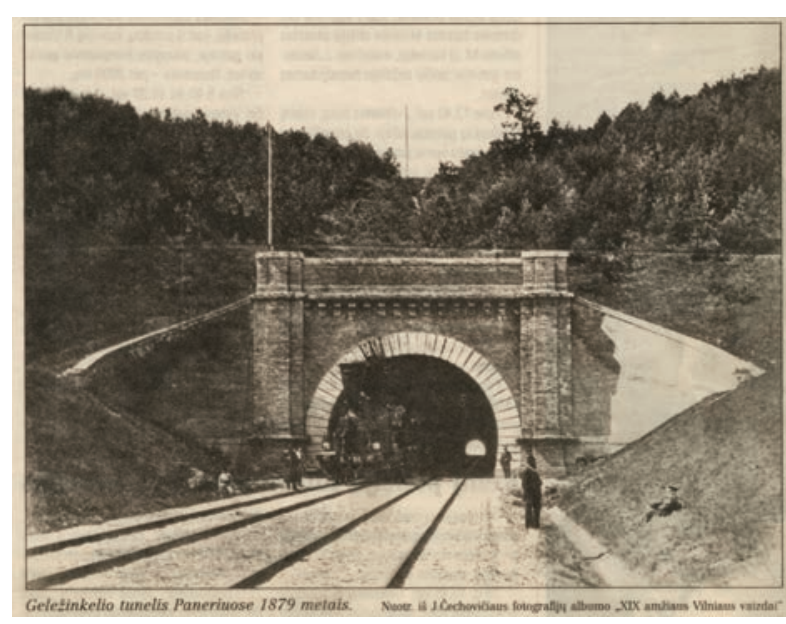


eksploatuojamas iki Antrojo pasaulinio karo. S. Kerbedis gavo daug apdovanojimų, buvo priimtas Peterburgo mokslų akademijos nariu, gavo generolo-majoro karinị laipsnị.

S. Kerbedis daugiausia state tiltus. Kai kurie šaltiniai teigia, kad jis projektavo ir state abiejų Lietuvos geležinkelio tunelius - Vilniaus ir Kauno. Bet yra žinoma, kad Kauno tuneli projektavo prancūzai. Galima manyti, kad S. Kerbedis dalyvavo vertinant projektinius sprendimus, domejjosi tunelių statybos eiga ir kokybe.

İspūdingas S. Kerbedžio suprojektuotas ir pastatytas tiltas buvo Varšuvoje $1864 \mathrm{~m}$. $475 \mathrm{~m}$ ilgio tiltas per Vislą varšuviečiu buvo vadinamas Kerbedžio tiltu. Susprogdintas per Antrąji pasaulinị karą.

Daug metų S. Kerbedis buvo PKI Taikomosios mechanikos katedros profesoriumi. Projektuodamas bei statydamas jis dirbo ir mokslinị tiriamąjị darbą. S. Kerbedis nustatè, kad kniedèms išmuštos skylès sumažina plieno tempiamajji stiprị apie $15 \%$. Jis rado, kad naudingiau kniedžių skyles išgręžti, o ne išmušti. Nagrinëjo kesoninių atramu stiprumo ir ju įrengimo klausimus.

S. Kerbedis kurị laiką dirbo Rusijos susisiekimo kelių ministru. Nuo $1891 \mathrm{~m}$. gyveno Varšuvoje, ten ir palaidotas [1.14, p. 79-83].

Lietuva didžiuojasi šiuo pasaulinio garso statybų inžinieriumi. Panevežio gimnazijoje įrengta jo ekspozicija, Panevežyje ir Vilniuje jo vardu pavadintos gatves. Bet S. Kerbedis nebuvo Lietuvos patriotas, liko svetimas tautiniam atgimimui, nepajege išsivaduoti iš sulenkẻjimo ir surusëjimo.

Feliksas Jasinskis (1856-1899) - lenku inžinierius, taip pat PKI absolventas. Jị minime todèl, kad nuo $1878 \mathrm{~m}$. F. Jasinskis buvo Vilniaus geležinkelio ruožo viršininkas, o nuo 1880 m. - Vilniaus miesto inžinierius, palikęs Lietuvos sostinëje ryškų pedsaką. Jis parenge projektą ir pastate akmeninę Vilneles upès krantinę, sureguliavo Vilnelès vagą, miesto dalyje irrenge vandentiekị ir kanalizaciją, vykde didelès miesto gyvulių skerdyklos statybą.

Nuo 1888 m. F. Jasinskis dirbo Peterburge. Projektavo geležinkelius, tiltus. Pasaulinị garsą turi F. Jasinskio moksliniai darbai, kuriuos jis pradejo $1892 \mathrm{~m}$. Nuo $1895 \mathrm{~m}$. deste PKI, taip pat kitose aukštosiose Peterburgo mokyklose.

Ypač reikšmingi F. Jasinskio atlikti gniuždomujjų strypų stiprumo išilginiam išlinkiui tyrimai. Jis nustate formulę, pagal kurią ap- skaičiuojamas gniuždomojo strypo atsparumas kritinei jegai. Paskelbe 40 mokslinių darbų. Susirgo džiova ir mire Peterburge, palaidotas Varšuvoje [1.14, p. 104-108].

Žymiausias Lietuvoje Peterburgo susisiekimo kelių instituto aukletinis neabejotinai yra Petras Vileišis (1854-1926). Jis buvo ne tik žymus statybos inžinierius, bet ir vienas didžiausių tautinio atgimimo veikëjų.

P. Vileišis gimè $1851 \mathrm{~m}$. sausio $25 \mathrm{~d}$. Panevėžio apskrities Skrebotiškio parapijos Medinių kaime. $1870 \mathrm{~m}$. baigęs gimnaziją, ìstojo į Peterburgo universitetą studijuoti matematikos. Gavęs matematiko diplomą, $1876 \mathrm{~m}$. ịstojo į PKI, kurị baige $1880 \mathrm{~m}$.

Iki $1885 \mathrm{~m}$. projektavo ir state Rusijoje geležinkelius. Vèliau pagarsëjo kaip tiltų kesoninių pamatų specialistas. Nuo $1898 \mathrm{~m}$. sukūre tiltų kesono darbų rangovinę firmą ir state tik tiltus.

1897 m. P. Vileišis ịsteige Vilniuje geležies dirbtuves. Čia buvo gaminamos plieniniu tiltų santvaros, kiti metalo dirbiniai. Tikslus P. Vileišio pastatytų tiltų skaičius nèra nustatytas. Bet jų, matyti, daugiau kaip šimtas.

P. Vileišis buvo didelis tautos patriotas. Jis suprato, kad Lietuvai kelią i gražesnę ateitị gali užtikrinti mokykla ir kultūra. Dar 18751876 m., nepaisant lietuviškos spaudos draudimo, jis išleido kelias lietuviškas knygeles. Tam jis skyre savo studentiškas lèšas. O kai, pasiekus profesinių aukštumų, jo uždarbis buvo jau didelis, savo pinigus jis skyre taip pat lietuviškajai leidybai. P. Vileišis išleido per 100 populiaraus turinio knygelių. Vienas

Petro Vileišio

gyvenimo ir veiklos geografija

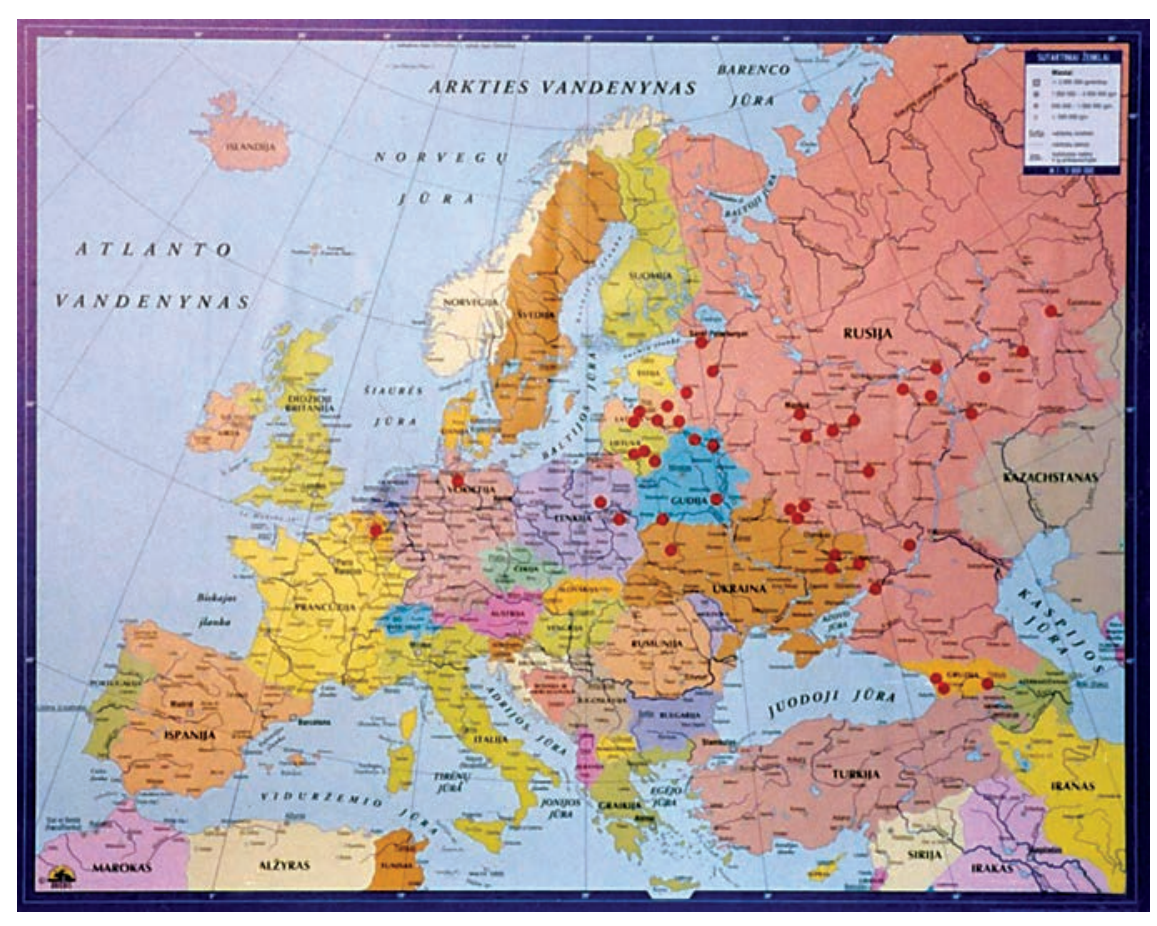


TECHNIKOS

IR TECHNIKOS MOKSLŲ

RAIDA LIETUVOJE

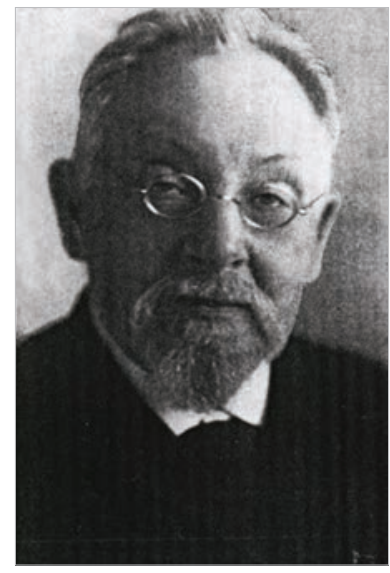

P. Čchavičius

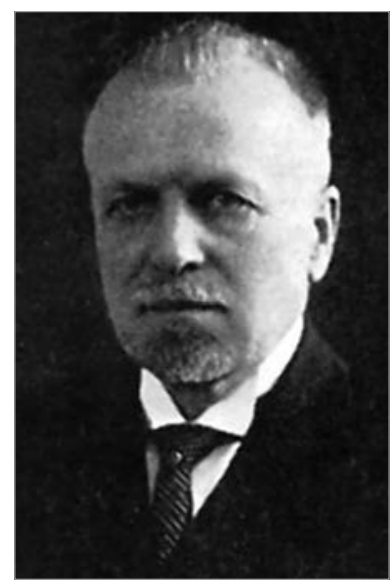

S. Grinkevičius parašè pats, kitas išvertè. Pasakojama, kad P. Vileišio pinigai labai prisidejjo prie lietuviškosios spaudos draudimo panaikinimo.

1921 m. Petras Vileišis galutinai grịzo ị Lietuvą. Kurị laiką buvo susisiekimo ministru. Mire 1926 m. rugpjūčio 12 d., palaidotas Vilniuje [1.15, p. 6-107].

Povilas Čechavičius (1858-1935) gimè Vilniuje, gimnaziją baige Balstogèje, o paskui studijavo Peterburgo kelių institute, kuri baige $1881 \mathrm{~m}$. Kurị laiką dirbo hidrotechnikos darbus Rusijoje, vèliau - Odesoje, kur suprojektavo ir pastate daug Odesos uosto statinių. $1908 \mathrm{~m}$. P. Čechavičius buvo išrinktas Kijevo politechnikos instituto ekstraordinariniu, o $1910 \mathrm{~m}$. - ordinariniu profesoriumi.

1913 m. P. Čechavičių, kaip žymų uostų statybos specialistą, pakviete dirbti olandu firma „Akkerman et Van Haren“ padeti pritaikyti Ravelio (Talino) uostą karo reikalams. 1920 m. P. Čechavičius persikèlè į Belgiją, o 1922 m. grị̌zo į Lietuvą. Čia buvo pakviestas į Lietuvos universiteto Hidrotechnikos katedrą eiti ekstraordinarinio profesoriaus pareigas. $1930 \mathrm{~m}$. pakeltas ị ordinarinius profesorius.

P. Čechavičius dèstè „,Vandens kelių“ ir „Hidrotechnikos įrengimu“ kursus. Būdavo kviečiamas kaip specialistas svarstyti hidrotechnikos projektų, turejo spausdintu darbų: «Молы из плавучих гигантских массивов», ,,Bendros žinios apie vandentiekius“ ir „Uostų kursas“.

Nuo 1933 m. rugsèjo 1 d. dèl ligos išëjo i pensiją. Mire $1935 \mathrm{~m}$. sausio $10 \mathrm{~d}$. Kaune [1.16, p. 59-60].

Peterburgo Susisiekimo kelių instituto auklètinis buvo ir Jonas Kiškinas (18841975). Šis kelių inžinierius gimè rugsèjo $1 \mathrm{~d}$. Kursko gubernijos Fatežo mieste. 1903 m. baige Kursko gimnaziją ir įstojo ị PKI, kurị baige $1910 \mathrm{~m}$. Vèliau dirbo Lietuvoje geležinkelio tarnyboje: Šeštokuose, Rudiškyje, Virbalyje. Véliau dirbo Rusijoje, Latvijoje. Nuo 1920 m. tapo Lietuvos Respublikos geležinkelių kelių tarnybos Technikos skyriaus viršininku. Nuo 1926 m. sausio 1 d. pakviestas eiti Keliu valdybos Sauskeliu tarnybos viršininko pareigas.

Nuo 1924 m. dirbo ir pedagoginį darbą Kauno aukštesniojoje technikos mokyk- loje. Nuo 1940 m. spalio 21 d. priimtas ị Kauno valstybinį universitetą docentu. Nuo $1944 \mathrm{~m}$. rugpjūčio $1 \mathrm{~d}$. buvo paskirtas KU Kelių katedros vedëju.

Docento J. Kiškino pastangomis ir jam vadovaujant pokario metais atkurta Keliu katedros veikla, pradetti rengti plataus profilio sauskelių inžinieriai. J. Kiškinas yra pirmojo lietuviškojo gelžbetoninių konstrukciju vadovelio autorius - „Gelžbetonis“ išleistas $1930 \mathrm{~m}$.

1944 m. pateikè disertacinį darbą daktaro laipsniui ịgyti - „Pabègių ūkis geležinkeliuose ir gelžbetoninių konstrukcijų reikšme“".

Nuo 1961 m. J. Kiškinas išejo i pensiją. Mire 1975 m. [1.17, p. 109-111].

Peterburgo Technologijos instituto žinomiausi absolventai lietuviai buvo V. Mošinskis, J. Čiurlys, J. ir A. Graurogkai, T. Šulcas. Kaip statybų inžinieriai, statybinių konstrukciju specialistai garsiausi Lietuvoje buvo Peterburgo technologijos institutą baigę Silvestras Grinkevičius ir Pranciškus Markūnas.

Silvestras Grinkevičius (1871-1941) gimé sausio $27 \mathrm{~d}$. Panevěžio apskrities Piniavos valsčiaus Vaivadų kaime. Dvidešimt vienerių metų baigè realinę mokyklą Velikije Luki mieste, o 1898 m. - Petrapilio technologijos institutą. 1899-1906 m. S. Grinkevičius tarnavo Saratovo geležinkelių valdyboje, nuo 1907 m. buvo Kozlovo mieste tiltų ir geležinkelių dirbtuvių viršininkas, o 1908-1917 m. vèl dirbo Saratove. 1918 m. S. Grinkevičius pradejjo destyti Astrachanès politechnikos institute. Lietuvai paskelbus nepriklausomybę, grį̌o ị Tèvynę. Sugrįžęs iš Rusijos prityręs geležinkelių specialistas S. Grinkevičius jau 1918 m. liepą skiriamas Lietuvos geležinkelių direktoriumi, o nuo spalio kartu buvo ir Lietuvos susisiekimo ministro pavaduotoju. 1923 m. pradžioje S. Grinkevičius pradëjo dirbti Lietuvos universiteto Technikos fakulteto Tiltų ir geležinių konstrukcijų katedros docentu. 1928 m. jam buvo suteiktas ekstraordinarinio profesoriaus mokslinis vardas.

S. Grinkevičius išleido vadoveli „Mediniai tiltai“, žinyną „Pastatams skaičiuoti daviniai“, vadovèli „Geležinès konstrukcijos“. 1933 m. jis buvo išrinktas Vytauto Didžiojo universiteto Technikos fakulteto dekanu (1933-1937), 1934 m. jam suteiktas ordinarinio profesoriaus mokslinis vardas.

1940 m. S. Grinkevičius išèjo ị pensiją, o 1941 m. spalio 31 d. mire, palaidotas Kaune [1.18, p. 34-35]. 
Pranciškus Markūnas (1873-1964) laikomas gelžbetoninių konstrukcijų naudojimo Lietuvoje patriarchu. Jis gimé sausio 1 d. Butkiškyje (Anykščiu r.), esančiame netoli Andrioniškio, kur baigè pradžios mokyklą. Paskui mokessi Panevežio realinëje mokykloje, o 7-ąją klasę baigè Balstogèje. $1893-1898$ m. studijavo Peterburgo technologijos institute ir gavo inžinieriaus technologo diplomą.

Baigęs institutą P. Markūnas dirbo Ukrainoje metalo gamykloje, o nuo 1909 metu Saratove, kur pradejo dirbti gelžbetonio darbus, èmè projektuoti tiltus.

1919 m. P. Markūnas grịžo į Lietuvą. Vilniuje įsidarbino P. Vileišio mechanikos gamykloje. Kai lenkai Vilnių okupavo, persikèle į Kauną. Dirbdamas statybos bendrovejje projektavo pastatu ir statiniu gelžbetonines bei kitas konstrukcijas. Per 20 metu P. Markūnas suprojektavo keliasdešimt tiltų per daugumą svarbiausių Lietuvos upių: $\mathrm{Ne}-$ muną, Šventąją, Nevežiz Šešupę, Miniją, Mūšą ir kt. Kartu su žymiausiais Lietuvos architektais suprojektavo daugeli pastatų, vykdè jų statybos priežiūrą.

1923-1941 m. P. Markūnas déstè Vytauto Didžiojo universitete, ejo privatdocento pareigas Tiltų katedroje. Po karo P. Markūnas dirbo projektuotoju „Lietstatprojekte“, o vèliau „Pramprojekte“. P. Markūnas pirmasis Lietuvoje 1950-1956 m. suprojektavo ir panaudojo Kauno statybose plonasienes kevalines gelžbetonines stogo konstrukcijas, buvo Kauno universiteto valstybinių egzaminų komisijos nariu, disertacijų oponentu, įvairių ekspertizių komisijose.
Pranciškus Markūnas Lietuvos statybų raidoje laikomas vienu žymiausių statybos konstruktoriu [1.19, p. 45-60].

Vytautas Mošinskis (1876-1955) gimè Naciūnuose (Kèdainių aps.). 1906 m. baigè Peterburgo technologijos institutą. Nuo 1918 m. destè Charkovo technologijos institute. Į Lietuvą sugrįžo 1919 m. Nuo 1924 m. Lietuvos universitete buvo Mechanines technologijos katedros vedejju. 1930 m. tapo ekstraordinariniu profesoriumi. Teigiama, kad V. Mošinskis buvo labai kruopštus, gerai išmane dèstomus dalykus. Déstè ir Aukštesniojoje technikos mokykloje [1.20, p. 305].

V. Mošinskis buvo vienas didžiausių entuziastų kuriant suverenią aukšstą̧̨̨ technikos mokyklą - Politechniką.

Julius Graurogkas (1885-1968) gimè Telšiuose. Mokesi Šiaulių gimnazijoje, 1915 m. baige Peterburgo technologijos institutą. Dirbo Rusijoje, o 1920 m. grižzo ị Lietuvą. Vilniuje įkūre technikos mokyklą, bet, sostinę okupavus lenkams, persikèlè $i$ Kauną ir čia taip pat įkūre technikos mokyklą. Buvo jos direktoriumi iki $1940 \mathrm{~m}$. Nuo 1922 m. deste ir Lietuvos universitete. 1941-1944 m. J. Graurogkas buvo VDU rektoriumi. Po karo kurị laiką dèste Pabaltijo universitete, o nuo $1949 \mathrm{~m}$. gyveno JAV [1.21, p. 8-9].

Vasaris Gorodeckis (1873-1940) gimé Palukniuose (Raseinių aps.). 1898 m. baigè Charkovo technologijos institutą. Dirbo metalo apdirbimo pramonès įmonèse Ukrainoje, o 1914-1915 m. destė Peterburgo politechnikos institute. İ Lietuvą grįžo 1923 m. ir destè Lietuvos universitete Variklių katedroje.

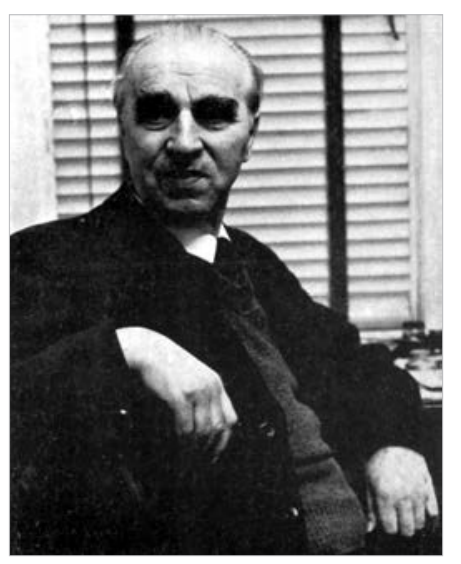

J. Graurogkas

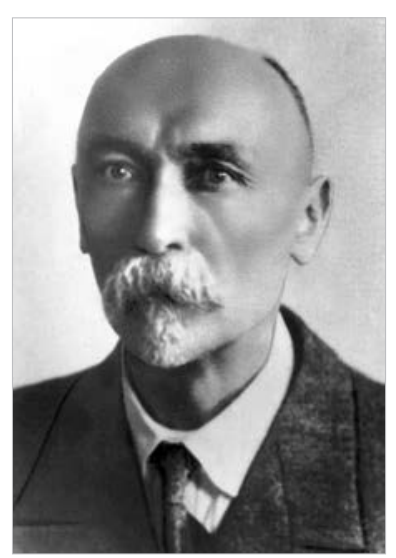

P. Markūnas

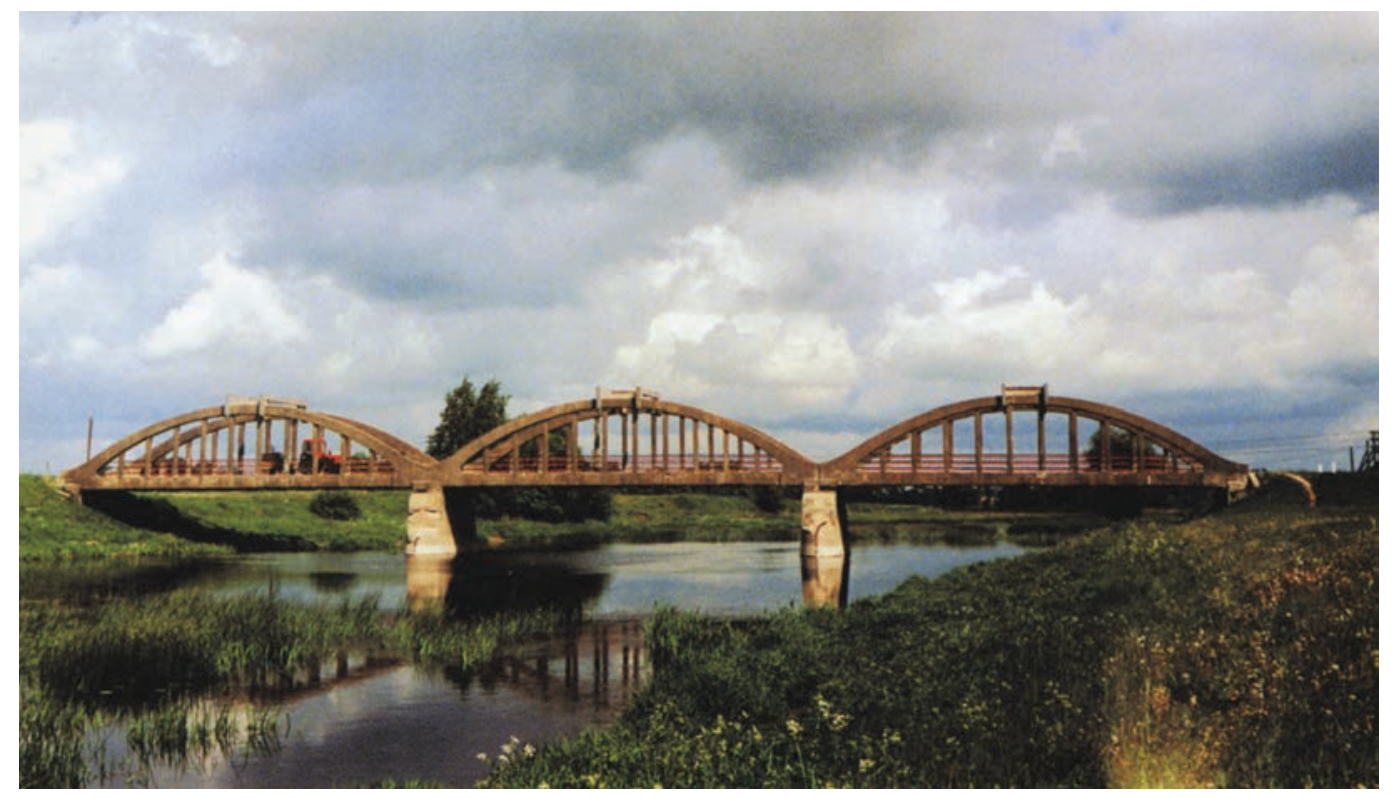


TECHNIKOS

IR TECHNIKOS MOKSLU

RAIDA LIETUVOJE

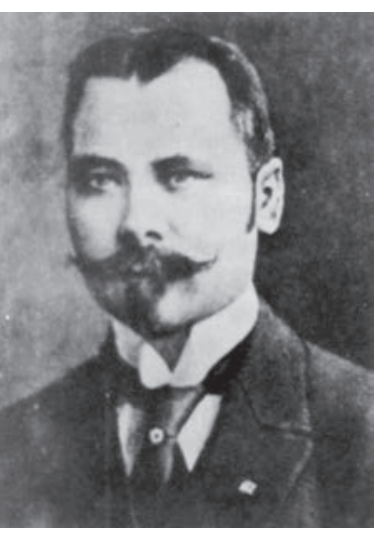

J. Šimoliūnas
1930 m. jam suteiktas docento mokslinis vardas, jis tapo Taikomosios mechanikos katedros vedeju. 1935 m. išspausdino „Techninę termodinamiką".

Jurgis Čiurlys (1881-1959) gimé Itkonių kaime, netoli Kupiškio. 1900 m. baige Šiaulių gimnaziją. $1913 \mathrm{~m}$. baige Peterburgo technologijos institutą ir, atvykęs į Vilnių, dirbo kanalizacijos statybos darbus. Per Pirmajį pasaulinį karą dirbo Tuloje. I Lietuvą sugrįžęs 1918 m., dirbo Susisiekimo ministerijos padaliniuose. Nuo $1935 \mathrm{~m}$. buvo Lietuvos energijos komiteto pirmininkas. Nuo 1922 m. destè Lietuvos universitete įvairius mašinų kursus. 1942-1944 m. buvo VDU ekstraordinarinis profesorius. Po karo pasitraukè į Vakarus. Nuo 1947 m. gyveno JAV. Išleido destomiems kursams šiuos leidinius: „Mašinų detalès“ (1931), „Keliamosios mašinos“ (1932), „Mašinų teorija“"(1940, 2 dalys) [1.22, p. 207].
Jeronimas Šliogeris (1871-1936) gimè Bružių kaime prie Smilgių. 1891 m. baigè Panevėžio realinę gimnaziją, o $1900 \mathrm{~m}$. - Peterburgo elektrotechnikos institutą. Dirbo Peterburge, o 1920 m. grižo ị Lietuvą, dirbo elektros akcinèse bendrovese. Nuo $1922 \mathrm{~m}$. desste Lietuvos universitete. $1923 \mathrm{~m}$. gavo docento mokslinį vardą, nuo $1936 \mathrm{~m}$. - ordinarinis profesorius. 1923-1936 m. buvo Elektrotechnikos katedros vedeju [1.23, p. 52-53].

Tadas Šulcas (1880-1940) gimè Palèvenyje prie Kupiškio. Baigęs Liepojos gimnaziją 1902 m., studijavo Rygos politechnikos institute, o $1913 \mathrm{~m}$. baige Peterburgo technologijos instituto Mechanikos skyrių. 1918 m. sugrižo į Lietuvą, dirbo Kaune, vèliau Vilniuje, o jị okupavus - Kauno aukštesniojoje technikos mokykloje. Nuo $1927 \mathrm{~m}$. dèste Lietuvos universitete. $1930 \mathrm{~m}$. gavo docento, o $1938 \mathrm{~m}$. - ekstraordinarinio profesoriaus mokslinį vardą. Parengè daug publikaciju įvairiais technikos klausimais [1.23, p. 103].

\section{Technikos mokslai Aukštuosiuose kursuose 1920-1922 metais}

Atkūrus Lietuvos valstybę 1918 metais, èmé trūkti įvairių specialistų: administravimo, medicinos, finansų, teisès, švietimo, technikos, žemès ūkio ir kt. Padètį kiek gerino grį̌tantys inteligentai iš Rusijos ir kitu kraštų, bet tai problemos nesprende. Kilo būtinybe kuo greičiau imti ugdyti specialistus savajame krašte. Pradeta rūpintis Vilniaus universiteto atkūrimu, bet ši procesą sutrukde bolševikų, paskui ir lenkų okupacijos.

1919 m. rudenị Kaune ịkurtai Aukštųju mokslų draugijai buvo iškeltas uždavinys „....steigti ir remti ivairias aukštuju mokslu istaigas, organizuoti aukštuju mokslu paskaitas, leisti mokslo knygas ir laikraščius, šlpti aukštuosius mokslus einančia studentija, tačiau praktiškai vienintele ir svarbiausia jos užduotis buvo įkurti ir išlaikyti Aukštuosius kursus" [1.24, p. 77].

Aukštuosiuose kursuose turëjo veikti Humanitarinių mokslų, Teisių, Gamtos, Fizikosmatematikos, Medicinos ir Technikos skyriai. Darbo sąlygos Aukštuosiuose kursuose buvo labai sunkios, nebuvo galimybių vesti praktinius užsiemimus, trūko studijų literatūros, o lietuviškos literatūros išvis nebuvo.
Greitai paaiškejo, kad netobulos buvo studiju programos, bloga padetis lietuviškos terminijos klausimais. Netrūko tik entuziazmo. Kursus lankè keli šimtai klausytojų, tarp kurių vyravo lietuviai ir žydai: studijavo 362 lietuviai ir 152 žydai.

Technikos skyriaus mokslo planus parenge skyriaus vadovas Jonas Šimoliūnas drauge su Kazimieru Vasiliausku. Juos rengè remdamiesi Rygos politechnikos instituto planu. Technikos skyriaus veiklą sunkino desstytojų, patalpu trūkumas, laboratorinès įrangos neturejjimas. Ypač stigo lešųu.

J. Šimoliūno teigimu, „Destytojai ne tik negaudavo atlyginimo, bet ir patys dejosi prie šalpos, stodami $j$ specialiai organizuota Aukštuju mokslu draugija kursams globoti ir remti żymiais nario mokesčiais..." [1.25, p. 63]. Anot Z. Žemaičio, "Lektoriams buvo mokamas tik elgetiškas valandinis atlyginimas -75 auksinai už valanda. Beveik visi lektoriai turëjo nuolatini darba kitose istaigose, o kursuose deste laisvalaikiu, po darbo valandu, nes paskaitos vykdavo nuo 17 iki 22 valandos. Lektorius vidutiniškai per menesi uždirbdavo apie 1000 auksinu. Keletas lektoriu dirbo vien 
tik aukštuosiuose kursuose ir uždirbdavo 2500 auksinu" $[1.25$, p. 31].

V. Terleckas knygoje „Pinigai Lietuvoje 1915-1944“, išleistoje 1992 m., rašo apie tai, kokiu galimybių teike tokie atlyginimai. 1922 m. vidutinis mènesinis Kauno darbininkų darbo užmokestis buvo apie 1300-1400 auksinu, o vien išlaidos maistui ir butui sudare 1220 auksinų. Infliacija tuo metu buvo labai didele, nebuvo įmanoma nei taupyti, nei kredituoti. Labai mažą atlyginimą gaudavo ir Aukštųjų kursų pagalbinis personalas - per ménesį tik 500 auksinu $[1.27$, p. 31].

Aukštųjų kursų klausytojai buvo skirstomi $\mathfrak{i}$ tikruosius ir laisvuosius. Tikraisiais buvo laikomi tie, kurie turejo brandos atestatą. Technikos skyriuje 1920 m. sausį tokiu klausytojų buvo 40 iš 78 . İdomu pažymèti, kad tarp visų klausytojų buvo 44 lietuviai ir net 33 žydai. Mokèsi 75 vyrai ir tik 3 moterys [1.26, p. 32].

Technikos skyriuje buvo trys poskyriai: statybos, mechanikos ir technologijos.

Jonas Šimoliūnas savo užrašuose, kuriuos paskelbẻ J. Gimbutas, rašè, kad „...pirmieji destytojai buvo šie asmenys:

1. J. Šimoliūnas - Žemès darbai, statyba, keliai, uostai, masyviniai tiltai; jis taip pat buvo AK ūkvedžiu.

2. K. Vasiliauskas - mechanika, medžiagu atsparumas, statybine statika.

3. V. Verbickis - paišyba, architektūros formos, ventiliacija, šildymas.

4. T. Šulcas - techniné braižyba, garo katilai, laivu statyba.
5. Z. Žemaitis-aukštoji matematika; jis buvo $A K$ vadovas pirmaisiais metais.

6. V. Čepinskis - fizika ir chemija.

7. J. Vabalas-Gudaitis - psichotechnika, laboratoriniai tyrimai; jis buvo AK vadovas antraisiais metais.

8. J. Čiurlys - braižyba, mašinu detales.

9. J. Mašiotas - technine atsakomybe ir samatos " $[1.25$, p. 61].

Antraisiais kursų veikimo metais lektorių padaugejo. J. Graurogkas dèste braižomosios ir analizinés geometrijų disciplinas, P. Jankauskas - mechaniką, S. Dirmantas - geodeziją, M. Songaila - architektūros formas, P. Jodele - statybinių medžiagų technologiją ir mineralogiją.

Per ketverius metus buvo numatyta parengti plataus profilio inžinierius. Visi technikos skyriaus klausytojai, be bendruju disciplinų, tokių kaip aukštoji matematika, fizika, chemija, braižyba ir kt., turëjo išklausyti ir grynai statybos profilio specialybems reikalingas disciplinas. Buvo siekiama, kad bet kurio profilio inžinieriai išmanytų ir statybų reikalus.

Pirmajame ir antrajame kurse visi Technikos skyriaus klausytojai mokèsi pagal tuos pačius mokymo planus, t. y. bendrai. Disciplinos ir ju apimtys turejo skirtis tik nuo trečiųjų metų. Užbaigus ketverių metų studijas, buvo numatyta, kad klausytojai ne mažiau kaip metus turëjo dirbti pagal igytą specialybę.

Aukštųjų kursų klausytojai daugiausia buvo valstybinių ìstaigu tarnautojai, mokytojai, karininkai. Studentų, kurie niekur

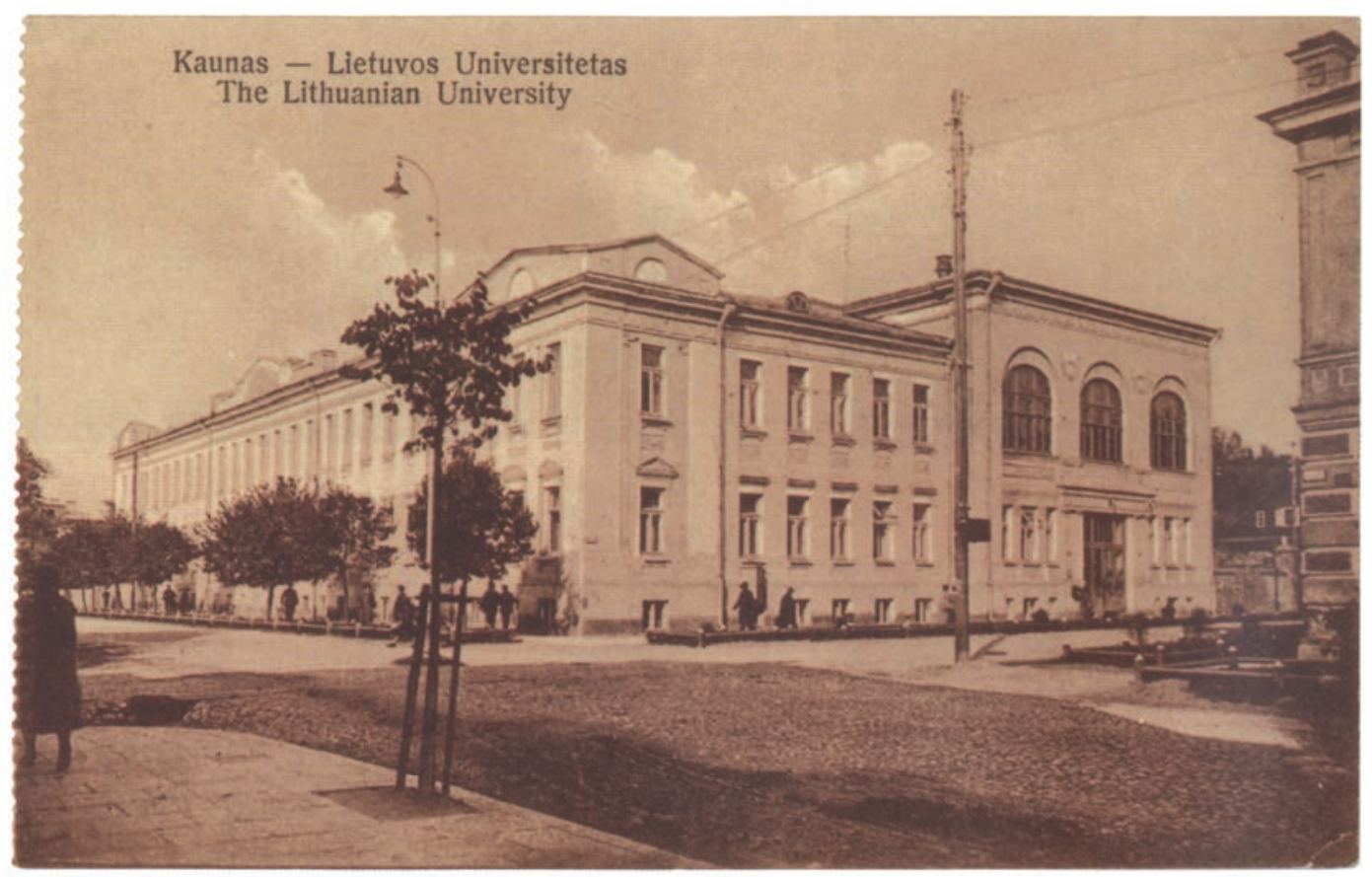

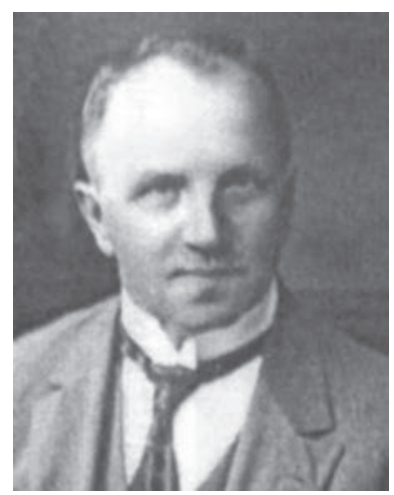

K. Vasiliauskas 
TECHNIKOS

IR TECHNIKOS MOKSLU

RAIDA LIETUVOJE

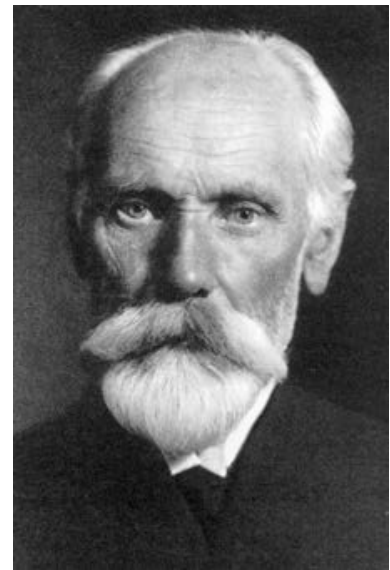

P. Jodele

nedirbo, o tik studijavo kursuose, buvo labai nedaug.

Kursus aukomis paremé Amerikos lietuviai, švedų draugija. Antraisiais metais subsidiju mokslo priemonems įsigyti skyre ir vyriausybè.

Didžiausi nuopelnai, organizuojant Lietuvos aukštųjų kursų Technikos skyrių, neabejotinai tenka Jonui Šimoliūnui ir Kazimierui Vasiliauskui.

Aukštujju kursų Technikos skyriaus vedejjas Jonas Šimoliūnas, anot J. Gimbuto, buvo nepaprastai darbštus ir ištvermingas, siekdamas užsibrežto tikslo. "Jo gyvenimas ir darbai, pasiryžimai, pasiaukojimo dvasia ir patriotizmas buvo artimi ir büdingi jo kartos lietuviu veikejjams" $[1.25$, p. 7].

\section{Technikos fakulteto veikla 1922-1940 metais}

Lietuvos universitetas Kaune buvo iškilmingai atidarytas $1922 \mathrm{~m}$. vasario $16 \mathrm{~d}$. Netrukus buvo patvirtintas universiteto statutas ir jau kovo 6 d. prasidejo studijos. Veiklą pradejo 6 fakultetai: Teologijos-filosofijos, $\mathrm{Hu}-$ manitarinių mokslų, Teisių, Matematikosgamtos, Medicinos ir Technikos. Visiems fakultetams buvo suteikta autonomija.

Universiteto rektoriumi buvo išrinktas profesorius Jonas Šimkus (1873-1944). Rektoriaus, universiteto Tarybos ir Senato bei fakultetų tarybų didžiausias rūpestis - komplektuoti mokslo personalą, organizuoti universiteto katedrų mokslinị ir pedagogini darbą. $1922 \mathrm{~m}$. pavasarị pedagoginị personalą sudare 53 asmenys, o rudens semestre dirbo jau 102 etatiniai darbuotojai, studijavo 1168 klausytojai.

Technikos studijas pradëjo 50 studentu ir 4 laisvieji klausytojai, bet rudens semestre technikos mokslus studijavo jau 162 klausytojai.

$1923 \mathrm{~m}$. buvo įsteigta universiteto biblioteka. Jos fondai buvo kuklūs: pradèta nuo 40 knygų. Trūko patalpų, laboratorijų, dalis dèstytojų neturëjo jokios pedagoginés patirties. Nedaug studentu gavo stipendijas, todèl per $50 \%$ jų dirbo įvairiose ịstaigose ir žinybose tarnautojais.

Technikos fakultetą planavo keturių skyrių: Statybos, Mechanikos, Chemijos ir Elek-
J. Šimoliūnas savo atsiminimuose rašè, kad Aukštųjų kursų Technikos skyriaus "Lektoriai ir studentai dirbo rimtai, dare gera pažanga ir spëjo taip užsirekomenduoti, kad jau 1921 m. gale visuomeneje ir valdžioje buvo plačiai kalbama, kad Aukštieji kursai jau esa pribrende virsti valdišku Lietuvos universitetu. Kursu vadovybei valdžios buvo patarta susirasti Kaune tinkamiausias rūmus universitetui..." [1.25, p. 61].

Rūmų remonto rūpesčiai, gavus būsimam universitetui 2-iejų aukštų pastatą Donelaičio ir Mickevičiaus gatvių kampe, teko daugiausia Technikos skyriaus statybininkams J. Šimoliūnui ir V. Verbickiui. Darbai buvo atlikti gerai ir laiku.

Aukštieji kursai veike tik dvejus metus. Tai buvo pirmoji aukštoji mokykla Lietuvoje, kurioje imta rengti inžinierius. Šitaip sukurtas pagrindas įsteigti Kauno universitetą. trotechnikos. Darbą pradëjo šios katedros: Mechanikos, Elektrotechnikos, Statybos ir statybos medžiagų technologijos, Architektūros, Geodezijos, Statybos mechanikos, Hidrotechnikos, Kelių, Tiltų, Varikliu, Mechanizmų ir dirbamųjų mašinų, Mechaninès technologijos, Telefonijos, telegrafijos ir radijo telegrafijos, Organines chemijos technologijos, Neorganines chemijos technologijos ir Pritaikomosios fizines chemijos $[1.28$, p. 23].

Technikos fakulteto dekanu buvo išrinktas ordinarinis profesorius Pranas Jodelè. Pirmųjų desstytojų būrys buvo nedidelis - visi, dirbę Aukštuosiuose kursuose: J. Šimkus (pirmasis universiteto rektorius), P. Jodele, P. Jankauskas, K. Vasiliauskas, M. Songaila, S. Dirmantas, J. Šimoliūnas, V. Verbickis. Pradžioje buvo vedami tik pirmojo, antrojo ir penktojo semestrų užsiemmimai. Klausytojai universitete buvo trijų kategoriju - studentai, laisvieji klausytojai ir hospitantai.

Studentais priimdavo baigusius gimnaziją ar jai prilygstančią vidurinę mokyklą. Laisvaisiais klausytojais, jei būdavo laisvų vietų, galëjo būti ir neturintys brandos atestato. Hospitantai išklausydavo keletą pasirinktų disciplinų ir paskui gaudavo tik pažymëjimą.

Studijos Technikos fakultete truko 5 metus. Universiteto veiklos pradžioje nemaža dalis studentų buvo tarnautojai, o dauguma 
studentų buvo išlaikomi tèvų ar giminių. Studentų socialinès sąlygos buvo labai sunkios. Buvo didinamas mokestis už mokslą. Pradžioje jis buvo 100 Lt, o 1927 m. - jau 200 Lt. Stipendijas gaudavo mažiau kaip $3 \%$ studentų. Nebuvo bendrabučių, o kambarių nuoma vis brango. Dẻl sunkių studijų sąlygu dažnas studijavo ilgai, kartais iki 15 metų. Nustatyta, kad Technikos fakulteto absolventai mokèsi vidutiniškai 9 metus [1.26, p. 175].

Pagal pirmąji Technikos fakulteto studentų mokymo planą, galiojusi nuo 1922 metų, buvo numatyta rengti mechanikos bei statybos inžinierius ir inžinierius technologus. Pirmajame kurse visi studentai mokèsi pagal vienodą programą. Specializuojama buvo nuo trečiojo semestro.

Technikos fakulteto mokymosi planai buvo keičiami 1927 ir 1932 m. Šie mokymo planai galiojo iki sovietinès okupacijos $1940 \mathrm{~m}$.

Apžvelgus prieškario inžinierių rengimo studijas, matyti, kad visi buvę mokymo planai daug laiko skyré fundamentaliesiems mokslams. 1922 m. plane pirmajame ir antrajame semestruose numatytas toks fundamentaliujuc disciplinų savaitinių valandų skaičius:

- $\quad$ analitinei geometrijai 3 val. paskaitų +1 val. pratimų;

- diferencialinei skaičiuotei $4+1$;

- integralinei skaičiuotei $4+1$;

- $\quad$ fizikai $4+2$;

- $\quad$ neorganinei chemijai $4+2$.

Būsimiesiems inžinieriams fundamentaliąsias disciplinas dèstè Matematikos-gamtos fakulteto katedros. Trūko specialiujų disciplinų dèstytojų. Matyt, todèl fundamentaliosioms disciplinoms buvo skirta daug akademinių valandų, bet ilgainiui padetis keitèsi.
1930 m. Vytauto Didžiojo vardu pavadinto universiteto Statute Technikos fakultete numatyti du skyriai: Statybos ir Technologijos. Statybos skyriuje buvo rengiami statybos inžinieriai, o Technologijos - mechanikos, elektrotechnikos ir cheminès technologijos inžinieriai.

Visų specialybių pirmojo kurso studentai per savaitę turejo 41 valandą paskaitų, vyresnių kursų studentai jų turejo įvairiai, bet ne daugiau kaip 39 valandas. Kai studentas parašydavo kontrolinius darbus, atlikdavo laboratorinius darbus ir gaudavo įskaitą, susitardavo su kursą dèstančiu dèstytoju dèl egzamino laikymo. Ne sesijinè egzaminų sistema taikyta daugumai disciplinų. Egzaminui dažniausiai bilietų nenaudojo. Kad būtų perkeltas į aukštesnị kursą, studentas turëjo ívykdyti nustatytą atsiskaitymo minimumą. Buvo nurodyti dalykai, kurių egzaminų neišlaikęs studentas nebūdavo perkeliamas ît aukštesnį kursą.

Studijas sunkino literatūros stoka, ypač lietuviškų vadovèlių. İsigyti knygų užsienio kalbomis buvo neįmanoma dèl brangumo. Problemų ir déstytojams, ir studentams kèle lietuviškosios techninès terminologijos stygius.

1932 m. pradejo galioti nauji Technikos fakulteto mokymo planai, kuriuose dominuoja inžinerijos dalykai, nors kai kurių disciplinų dèstymo reikalingumas visoms specialybėms, šiandienos samprata, keltų abejonių.

Nepaisant minètų abejonių, reikia pabrèžti, kad prieškario VDU parengtų inžinierių kompetencija buvo aukšta, daugelis jų, karo metais emigravę i Vakarų valstybes, toliau sẻkmingai dirbo inžinerinius darbus, pagarsëjo moksliniais tyrimais.

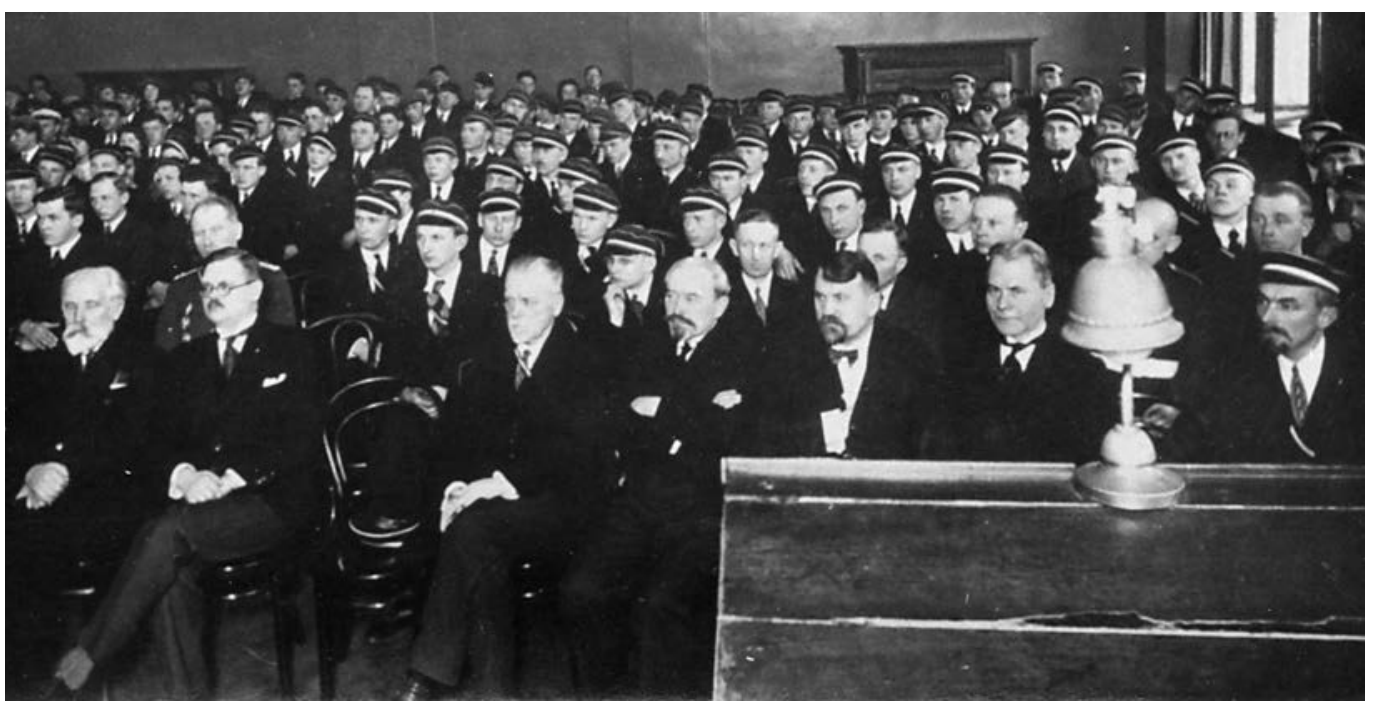

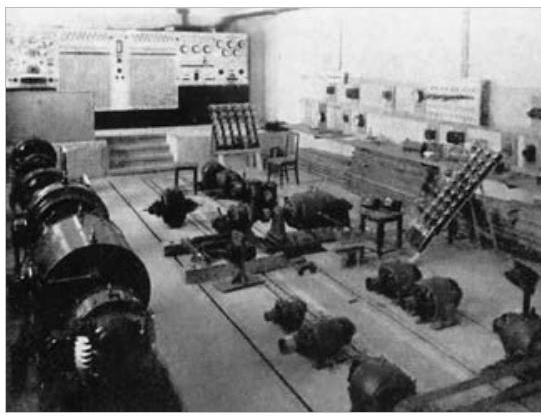

Elektrotechnikos laboratorijos mašinu sale $(1930 \mathrm{~m}$.)
VDU profesūra „Plieno“ korporacijos susirinkime.

Iš kairés:

P. Jodelè, J. Jankevičius,

S. Grinkevičius, J. Čiurlys, T. Šulcas, J. Šimoliūnas, S. Kolupaila 
TECHNIKOS

IR TECHNIKOS MOKSLŲ RAIDA LIETUVOJE

\section{VDU Technikos fakulteto} profesūra $1932 \mathrm{~m}$.

Iš kaires:

pirmoje eileje - prof. J. Šliogeris, prof. P. Jankauskas, prof. J. Simkus, prof. Pr. Jodelé, prof. K. Vasiliauskas (dekanas), doc. J. Simoliūnas; antroje eileje - prof. S. Kolupaila vyr. asist. V. Verbickis, doc. J. Jankevičius, doc. V. Gorodeckis, doc. T. Šulcas, doc. J. Ciurlys, prof. M. Songaila; trečioje ir ketvirtoje eilèje - vyr. asist. J. Gabrys, prof. S. Dirmantas, jaun. labor. M. Baublys, privatdoc. F. Dobkevičius, vyr. asist. M. Spiridavičius, doc. J. Mašiotas, vyr. lab. J. Jankauskas, privatdoc. P. Markūnas, jaun. labor. V. Maciūnas, prof. S. Grinkevičius, vyr. labor. J. Vidmantas, vyr. asist. L. Gimbutas, jaun. labor. J. Sivickas, jaun. asist. K. Kriščiukaitis

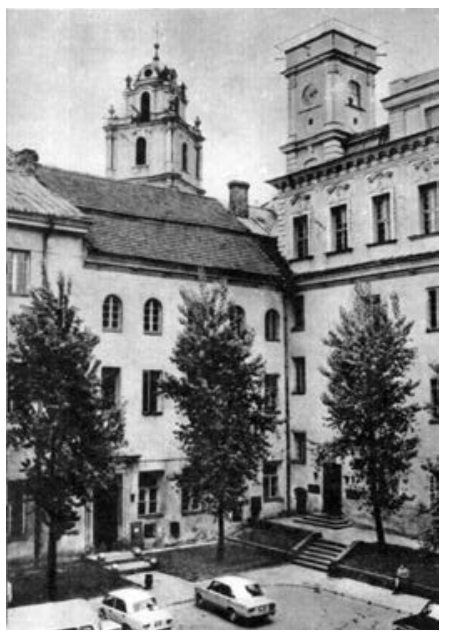

Vilniaus universitetas

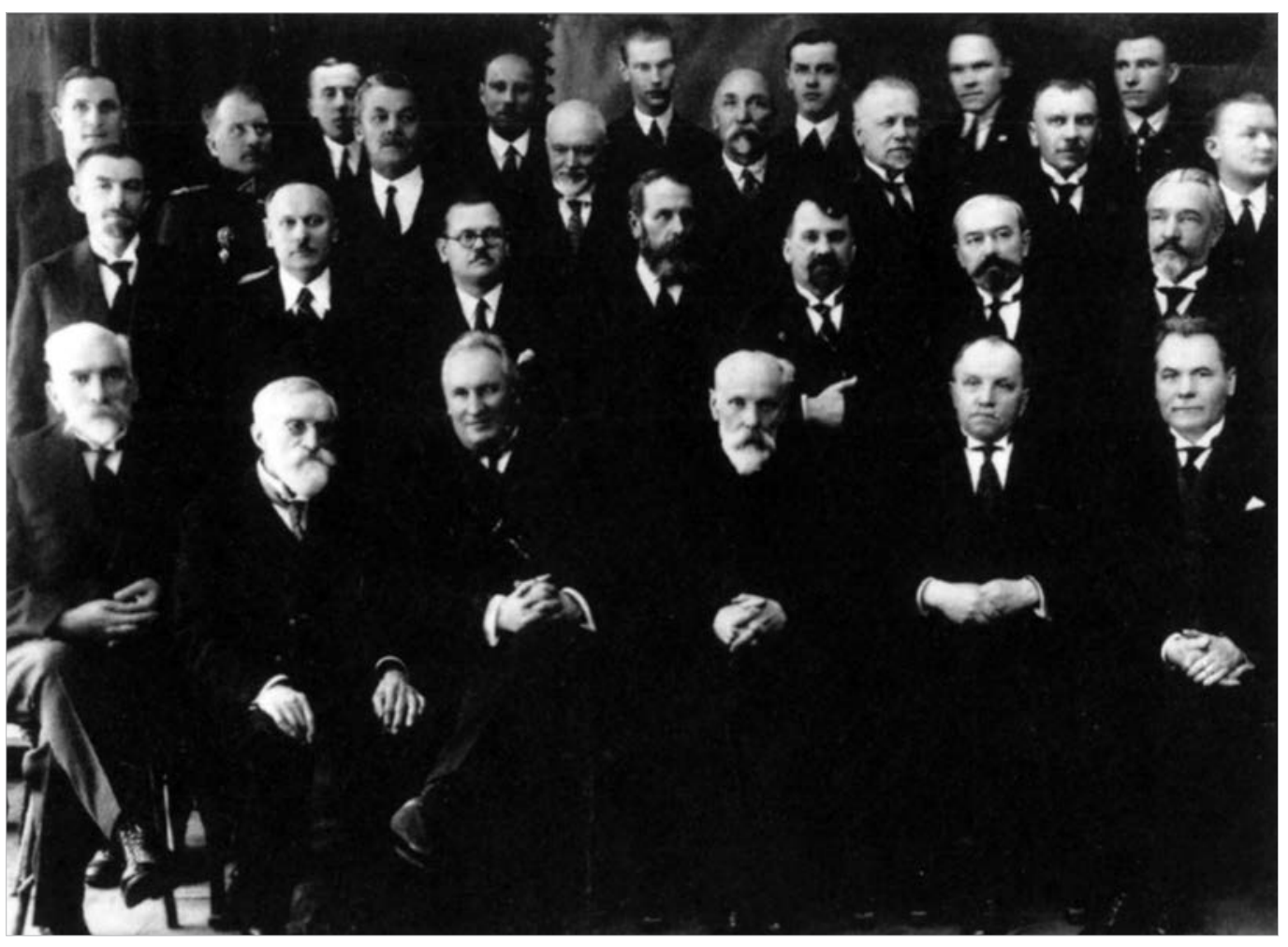

Aukštieji technikos mokslai Vilniuje 1919-1939 metais

Kai 1918 m. vasario 16 d. lietuvių tauta paskelbé nepriklausomybę ir èmé kurti savo valstybę, vienas svarbiausiu darbų buvo lietuviškojo universiteto įsteigimas istorineje Lietuvos sostineje. $1918 \mathrm{~m}$. gruodžio $5 \mathrm{~d}$. Valstybès taryba priemé Vilniaus universiteto statutą ir numate, kad 1919 m. sausio $1 \mathrm{~d}$. universitetas bus atidarytas. Bet okupaciné vokiečių kariuomene traukèsi, į Lietuvą isiverže bolševikai. Jie 1919 m. sausio 5 d. užèmé Vilnių, o 1919 m. vasario $20 \mathrm{~d}$. paskelbe Lietuvos ir Baltarusijos sovietinę respubliką. Šios konglomeratinès respublikos vyriausybès pirmininkas Vincas MickevičiusKapsukas 1919 m. kovo 13 d. išleido dekreta „Dèl Darbo universiteto Vilniuje atidarymo“. Jo veiklą buvo numatyta pradeti rudeni.

Suorganizuotoji Lietuvos kariuomenè išvadavo didžiąją Lietuvos teritorijos dalị nuo bolševiku ir artinosi prie Vilniaus. Bet 1919 m. Vilniu užème lenkai. Lenkijos diktatorius Juzefas Pilsudskis 1919 m. rugpjūčio 28 d. išleido ịsaką apie Vilniaus universiteto ¡ikūrima, pavadinant ji Stepono Batoro vardu. Taip norèta pabrežti, kad ,... tai lenku universitetas, lenku karaliaus ikurtas, tadsusijessu lenkiška dvasia ir tradicija" $[1.29$, p. 201]. Buvo suformuoti 6 fakultetai: Humanitarinių mok- slų, Teologijos, Teisès ir visuomenés mokslų, Matematikos ir gamtos mokslų, Medicinos ir Dailess. Buvo dèstoma lenkų kalba.

1920 m. vasarą bolševikai vel užèmé Vilnių. Liepos $12 \mathrm{~d}$. Rusija pripažino Lietuvos nepriklausomybę, o liepos $15 \mathrm{~d}$. lietuvių kariuomene įžengè į Vilnių. Iš laikinosios sostinès įstaigos kèlèsi į senąją sostinę. Bet Vilniaus universiteto atgaivinti nesuspeta, nes spalio 9 d. lenkų kariauna, generolui L. Želigovskiui vaidinant sukilimą, vèl užèmé Vilnių. $1921 \mathrm{~m}$. sausio viduryje lenkiško universiteto visi 6 fakultetai pradejo mokslo metus.

$\mathrm{Su}$ technikos mokslais sąsaju buvo tik Dailes fakultete. Jame buvo 4 specialybès: tapybos, skulptūros, dekoratyvinès dailes ir architektūros. Pastarosios specialybès studentams buvo destomi ir kai kurie technikos dalykai. Veike 3 architektūros specialybès katedros: Architektūrinio projektavimo, Statybos ir Liaudies architektūros.

Architektūros studijos truko ketverius metus. Po kiekvieno kurso buvo laikomi keliamieji egzaminai. Architektūros destymo metodika buvo grindžiama Vakarų Europos aukštųju mokyklų pavyzdžiu, naudotasi ir ankstesnių laikų destymo universitete patirtimi. Bet ilgainiui visas architektūros kurso 


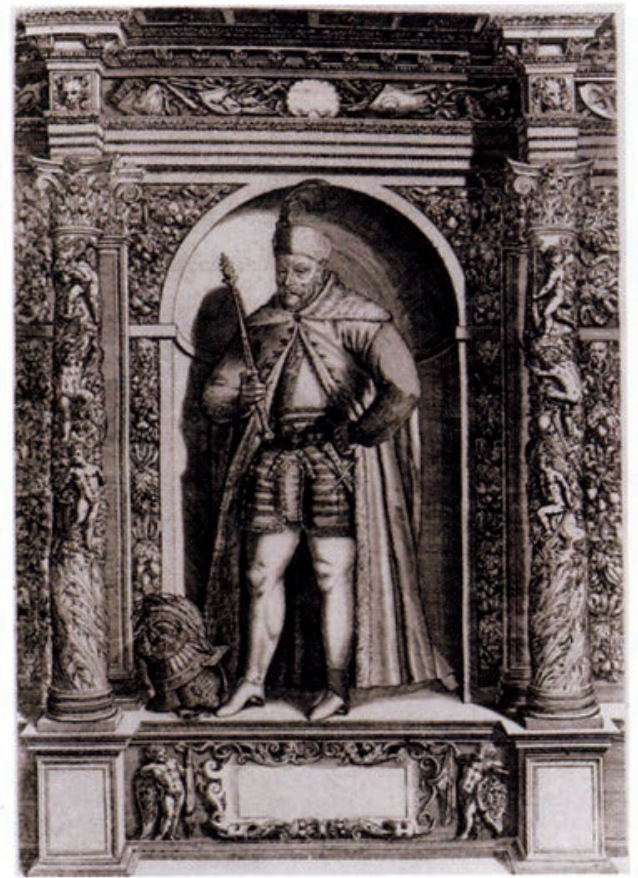

dèstymas virto architektūros paminklų matavimu ir fiksavimu. Architektūros studentai, negaudami reikiamų inžinerijos dalykų žinių, buvo rengiami silpnai. 1928-1929 mokslo metais išleista paskutine lenkiško Vilniaus universiteto architektų laida. Dalis studentu perkelti i Varšuvą, dalis - i Krokuvą. Vilniuje buvo palikta architektūrinio interjero specialybe, bet „... interjery projektai buvo rengiami abstrakciai, nesuteikus studentams statybos bei konstrukciju pagrindu. 1939 m. rugsejo 1 d. kilus Vokietijos ir Lenkijos karui, architektūros destymas Vilniuje buvo nutrauktas. Tais pačiais metais Vilnius gražintas Lietuvai" [1.30, p. 79].

Stepono Batoro universitetas buvo ne tik lenkiška, bet ir lenkinimo ịstaiga, siekusi vykdyti imperialistinius Lenkijos planus $[1.30$, p. 7$]$.
Steponas Batoras Iś J. Schrencko vad. Didvyriu knygos. 1601

\section{Pirmosios sovietų ir vokiečiu okupacijos metais (1940-1944)}

1939 m. rugsëjo $1 \mathrm{~d}$. hitlerinès Vokietijos kariauna ịsiveržè į Lenkiją. Jau spalio 5 d. Lenkija buvo palaužta. Kaip vèliau paaiškẻjo, 1939 m. rugpjūtị Sovietų Sąjunga su Vokietija sudare susitarimus ne tik dèl viena kitos nepuolimo, bet ir pasidalijo užkariauti numatytas nepriklausomy valstybių teritorijas. Stalinas gavo mandatą igyvendinti savo svajonę - okupuoti Lietuvą, Latviją ir Estiją.

1939 m. rudenį, Lenkijos ir Vokietijos karo metu Lietuvoje buvo jaučiamas didelis nerimas. Dar pavasarį Lietuva neteko Klaipedos krašto. Raudonoji armija, pasinaudojusi vokiečiu ir lenkų karu, okupavo dali Lenkijos bei jos okupuotą Vilniaus kraštą.

Sovietų sąjunga, kad esą apsaugotų savo sienas, reikalavo iš Lietuvos pasirašyti savitarpio pagalbos sutartį, pagal kurią Lietuvoje turetu būti dislokuoti Raudonosios armijos

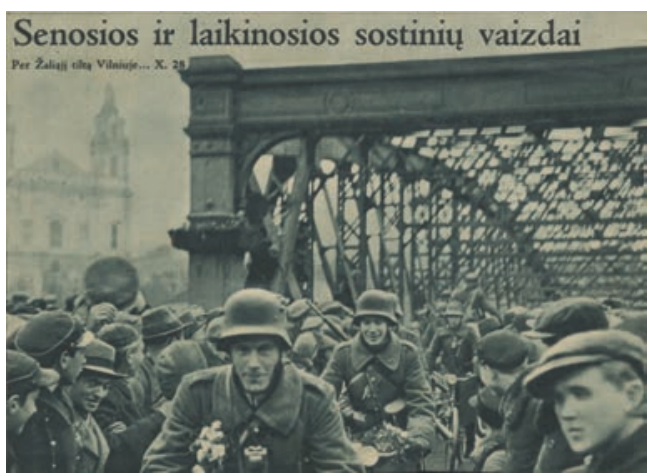

daliniai. Prastame tarptautinès padèties kontekste Lietuvos vadovams atrode, kad nieko neliko, kaip sutikti su visomis sąlygomis. Ta sutartimi buvo atgautas Vilniaus kraštas. Spalio 27 d. ị Vilnių įžengè Lietuvos kariuomené. Bet jau po paros savaičių i Lietuvą riedejo sovietinès armijos technika. 20000 raudonarmiečių buvo išdesstyti Alytuje, Prienuose, Gaižiūnų poligone prie Jonavos ir Naujojoje Vilnioje.

Kai Lietuva atgavo Vilnių, nepaisant nuojautos dèl galimos sovietines okupacijos, $i$ sostinę kèlèsi kai kurios krašto įstaigos. Imta svarstyti universiteto grąžinimo į Vilnių iš tremties Kaune klausimą. Didžiausias entuziastas Vilniaus universiteto klausimu buvo profesorius Zigmas Žemaitis. Jis siūlè pasirūpinti Vilniaus universiteto patalpomis ir turtu, kèle minti, kad kai kuriuos VDU fakultetus teksią perkelti į Vilnių [1.32, p. 238].

Laikinuoju Stepono Batoro universiteto valdytoju buvo paskirtas prof. Ignas Končius. Lenkiškam universitetui buvo leista baigti rudens semestrą sena tvarka, o naujaji semestrą turejo pradèti jau lietuviškas universitetas.

1940 m. sausio 15 d. įvyko naujo VU rektoriaus rinkimai. Juo tapo prof. Mykolas Biržiška. Atgaivintas lietuviškas universitetas Vilniuje èmé dirbti pagal VDU statutą. I Vilniu persikèle du VDU fakultetai su savo studentais ir profesūra.

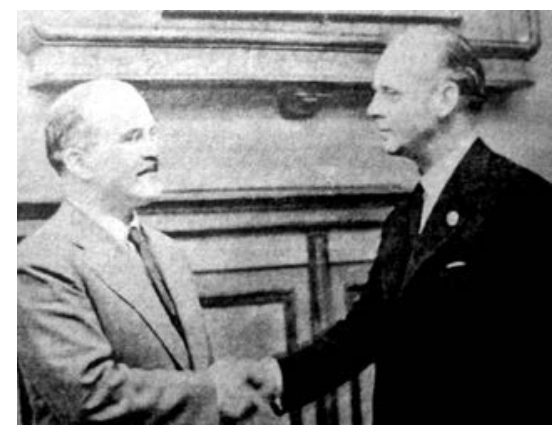

Molotovas ir Ribentropas. 1939 mety rugpjūčio 23-oji. Juoda diena žmonijos istorijoje. Diena, kai tituluoti nusikalteliai nusprendè karpyti Europos žemélapí, ištisoms tautoms primeté savo valiq

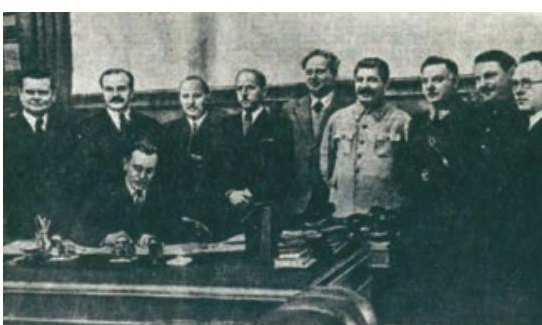

Lietuvos užsienio reikalu ministras pasirašo "pagalbos" sutarti su TSRS

Lietuvos kariuomemé $1939 \mathrm{~m}$. ižengia $j$ Vilnix 


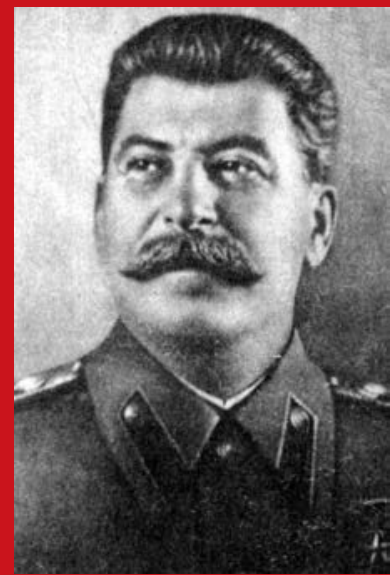

Kraugerio J. Stalino rankos suteptos milijonu žmoniu krauju
Dešinëje viř̌uje:

Tokiais traukiniais

žmonés buvo vežami i Sibira
Buvo svarstomos galimybès perkelti iš Kauno į Vilniu ir kitus fakultetus. Tomis galimybemis domejosi ir VDU Technikos fakultetas.

1939 m. rudens pabaigoje į Vilnių buvo komandiruoti profesoriai Vytautas Mošinskis ir Jonas Šimoliūnas, kad įvertintų Technikos fakulteto perkèlimo ị Vilnių galimybes. Jie apžiūrèjo buvusios maršalo Juzefo Pilsudskio technikos mokyklos patalpas ir jų tinkamumą Technikos fakultetui.

Lapkričio $8 \mathrm{~d}$. Technikos fakulteto tarybos posedyje buvo pažymeta, kad ,...nors Technikos mokykla ir neblogai ìrengta, tačiau fakultetas sutilpti negaletu, nes jos plotas tera maždaug 7400 kv. metrų. Fakulteto ìstaigoms, braižykloms ir auditorijoms reikia nors 40000 kv. metru. Praplèsti rümus bütu sunku, nes sklypas yra Antakalnio šlaituose" [1.33, p. 102].

Technikos fakulteto vadovai nutare, kad inžinierius toliau rengti tikslinga Kaune, nes jam perkelti reikètų didelių išlaidų, Lietuvos pramoné sukoncentruota Kaune, o tai naudinga veikiančiam fakultetui.

Džiaugsmas, kuri patyrẻ krašto gyventojai, atgavus Vilnių, nebuvo didelis. Karas Europoje, Raudonosios armijos dislokacija Lietuvoje pranašavo valstybès nepriklausomybès praradimą.

Dar prieš Raudonajai armijai užimant Lietuvą, 1939-1940 mokslo metais buvo numatyta VDU reforma: vietoj Technikos fakulteto planavo ikurti Statybos ir Technologijos fakultetus. Bet ši reforma įvykdyta jau netekus valstybingumo.

1940 m. birželio 15 d. Sovietų sąjunga okupavo Lietuvą. Universitete buvo ivesta sovietine tvarka, mokymo planuose ivvestas marksizmo-leninizmo kursas. Buvo uždraustos studentu organizacijos, veiklą pradejo komjaunimas. Naujasis $1940 \mathrm{~m}$. universiteto statutas neige universiteto autonomiją, panaikino Vytauto Didžiojo vardą, o pavadino Kauno universitetu.

Ypač šlykštų veidą bolševizmas parode 1941 metų birželyje. Birželio 14-ajją iš Lietuvos buvo ištremta per trisdešimt tūkstančiu žmonių. Tarp ištremtųjų ar areštuotųju buvo ir destytojų, ir studentų.

Kai 1941 m. birželio 22 d. Vokietija pradèjo karą su Sovietų Sąjunga, netrukus
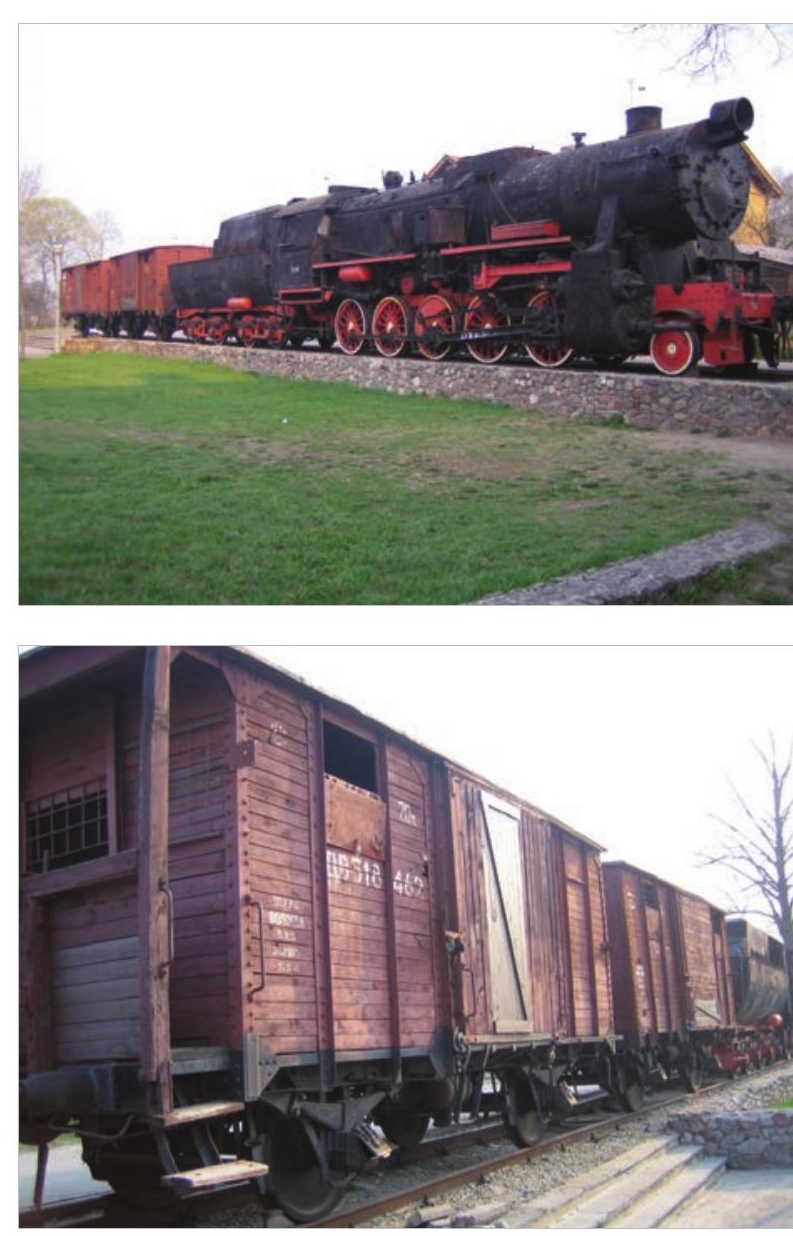

Lietuvoje prasidejo Lietuvos aktyvistų fronto organizuotas sukilimas Lietuvai išlaisvinti. Jame vadovaujantị vaidmenị vaidino VDU technikos fakultetu personalo nariai, sukilime dalyvavo dalis šių fakultetų studentų. Keliasdešimt sukilelių žuvo kovoje su besitraukiančia sovietine armada.

Okupaciné vokiečiu kariuomenè užèmé daug universiteto patalpų, greitai atsirado trintis tarp vokiečių ir lietuvių valdžių. Lietuviškoji valdžia buvo išvaikyta.

Jau 1941 m. rudenį vokiečių valdžia èmé spausti ir universitetą - uždare fakultetus, atemé patalpas, kitais būdais varžè veiklą, ypač karpe lèšas. Vokiečių reikalavimu iš universiteto buvo pašalinti žydų tautybes studentai ir desstytojai, atleisti kairiųjų pažiūrų pedagogai ir darbuotojai. Visa tai paveike universiteto darbą. Teko koreguoti mokymo planus, atsižvelgiant ị patalpų ir personalo pasikeitimus.

Krašte siaubą kèle prasidëjęs žydų genocidas. Kilo okupantų smurtas ir prieš lietuvius, daug kur kabëjo užrašai „Tik reicho vokiečiams".

Bet ir tomis tragiškomis aplinkybèmis universitetas tęsé savo darbą. Buvo skaitomos paskaitos, vyko pratybos, diplomantai gyne atliktus baigiamuosius darbus [1.34, p. 25]. 
$1942 \mathrm{~m}$. antrojoje puseje įtampai tarp lietuvių ir vokiečių padidejjus, vokiečiai ème grasinti, kad universitetus uždarys. Lietuviai išsisukinëjo nuo darbų Vokietijoje, nestojo ị SS legioną. I lietuvius inteligentus vokiečiai èmé žiūreti kaip ị antivokiškos veiklos organizatorius. Prasidejjo inteligentų suemimai. 1943 m. kovo 17 d. Vilniaus ir Kauno universitetai buvo uždaryti, bet studentams buvo leista baigti diplominius projektus, o mokslo personalui - vykdyti patvirtintus mokslinius darbus. Tačiau paskaitos ir pratybos aukštesniuose kursuose vyko įvairiose patalpose neoficialiai. Pavyzdžiui, Statybos fakulteto Hidrologijos katedra persikèle i t prof. Jono Šimoliūno namus, savo namuose deste kursą prof. Steponas Kolupaila ir t. t.

Vokiečiu okupacijos laikotarpiu technikos fakultetai išleido 261 inžinierių. 84 absolventai igijo statybos inžinieriaus, 17 - architekto, 19 - hidrotechnikohidromelioratoriaus, 9 - geodezininko, 77 - mechanikos inžinieriaus, 28 - elektrotechnikos inžinieriaus ir 27 - chemijos inžinieriaus diplomus [1.35, p. 63].

Nuo 1944 m. birželio, prie Lietuvos artèjant sovietinei armijai, daug lietuvių, tarp ju ir technikos fakultetų déstytojų, èmé trauktis ị Vokietiją, nenoredami pakliūti ị bolševiku rankas.

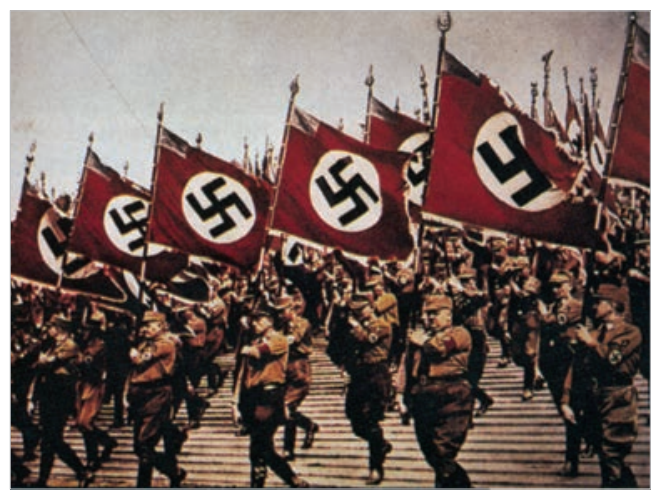

Taip atëjo

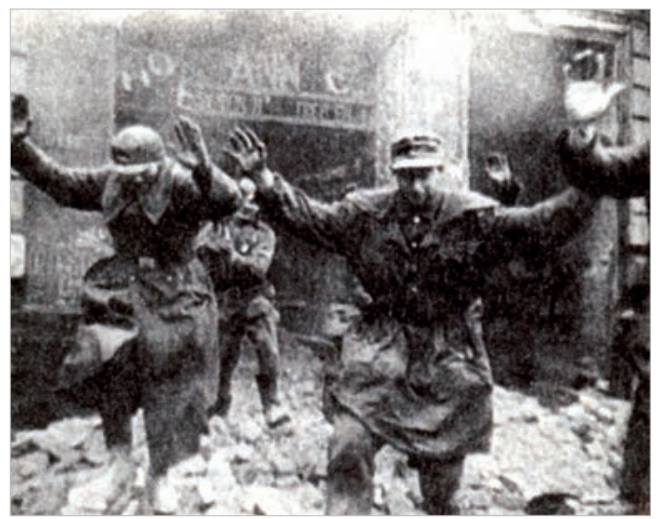

Taip baige

Liepos 9 dieną Vilnių apsupo Raudonosios armijos pulkai, o liepos $13 \mathrm{~d}$. Vilnius jau buvo rusų karių rankose. Kauną sovietai užèmé rugpjūčio 1 dieną. Prasidejjo antroji sovietinè okupacija.

\section{Po Antrojo pasaulinio karo. 1944-1950 metai}

Prasidëjusi 1944 m. rudenị antroji sovietine okupacija atneše kraštui daug skausmo, didelių vargų ir nelaimių. Prasidëjo gyventojų represijos, dalis gyventojų išejo į miškus ir ème kovoti prieš okupantus ginklu.

1944 m. lapkričio 13 d. LTSR liaudies komisaru taryba prièmé nutarimą „Dèl Lietuvos TSR aukštųjų mokyklų veikimo atnaujinimo". Kauno universitete buvo numatyti 4 fakultetai: Istorijos-filosofijos, Medicinos, Statybos ir Technologijos.

Technologijos fakultete pradejo veiklą Mechanikos, Chemijos ir Elektrotechnikos skyriai, o Statybos fakultete-Architektūros, Statybos, Geodezijos, Hidrotechnikos ir melioracijos bei Kelių.

Dar tų pačiu metų spalị valdžia, matyt, laikinai pataikaudama gyventojams, Kauno universitetą pavadino naujai - Kauno valstybiniu Vytauto Didžiojo universitetu [1.36, p. 20]. Rektoriumi buvo paskirtas prof. Antanas Purenas, Technologijos fakulteto dekanu - prof. Juozas Indriūnas, Statybos fakulteto dekanu - doc. Jonas Kiškinas. Pastarąji netrukus pakeite doc. A. Bistrickas.

Pirmieji pokario metai buvo labai sunkūs. Nebuvo šildomos patalpos, trūko elektros energijos, baldų, mokomosios literatūros. Destytojai buvo siunčiami studijuoti marksizmą-leninizmą. Vyko dažnos konferencijos ideologijos klausimais, rusu ir sovietu mokslininkų prioritetų pažinimo klausimais. Dalis destytojų buvo aštriai kritikuojami už apolitiškumą, keliaklupsčiavimą prieš Vakarų mokslą ir techniką, nepakankamą rusų ir sovietinio mokslo iškèlimą [1.37, p. 30].

Valdžia nepripažino diplomų, baigusių universitetą vokiečiu okupacijos metais. Prof. M. Kosčiauskas raše: „Soviety okupacijos metais šiu mūsu diplomu nepripažino.

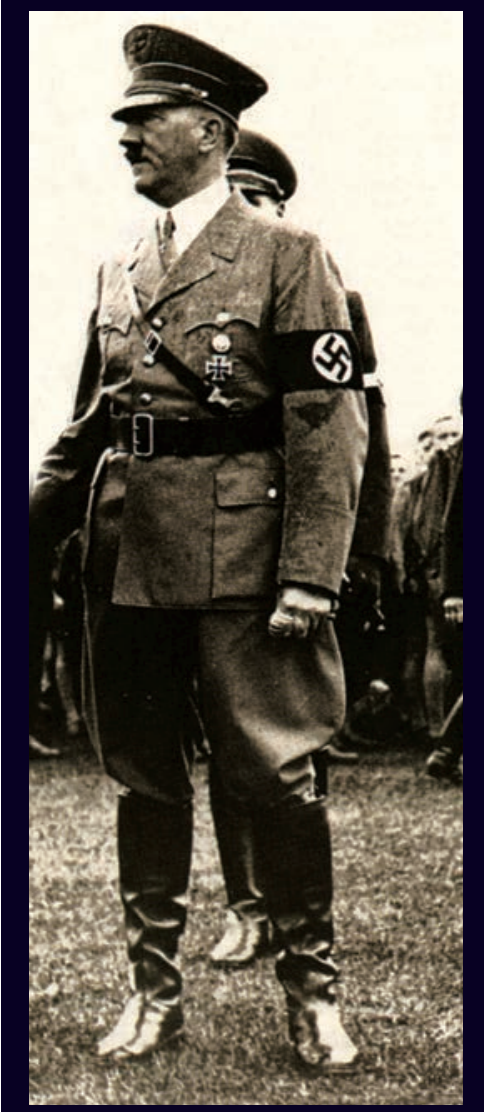

Hitleris - žmonijos pabaisa 


\section{TECHNIKOS}

IR TECHNIKOS MOKSLŲ RAIDA LIETUVOJE

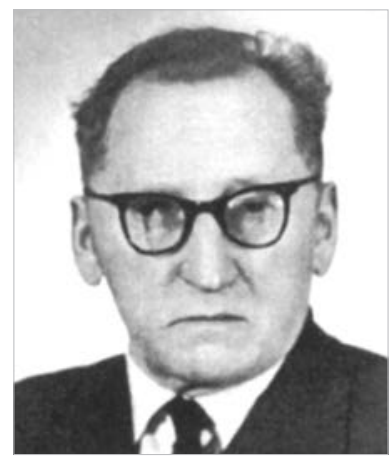

A. Bistrickas
Negana to, reikejo laikyti papildomus egzaminus ir naujai ginti diplominius projektus. Anksčiau gauta diploma reikejo atiduoti Universiteto kadru skyriui ir vietoj jo gauti sovietu inžinieriaus diploma.

Tokie reikalavimai mus siutino. Buvo tokiu, ypač dirbusiu gamyboje, kurie atsisake savo diploma "iteisinti“" ir todel gaudavo mažesni, kaip nebaige aukštojo mokslo, atlyginima. Man ir kitiems, dirbantiems Universitete, reikejo pasirinkti, ar, „iteisinti “ diploma irpasilikti dirbti Universitete, ar atsisakyti ,iteisinimo" ir netekti darbo Universitete. Pasirinkau, kaip visi dirbe Universitete, pirmaji varianta" $[1.38$, p. 76-77].

Bet daug déstytojų buvo atleisti iš universiteto dèl politinių motyvų, daugelį represavo. Partokratai teige, kad nežinantys marksizmoleninizmo, nepritariantys komunistu partijos politikai negali parengti gerų specialistu. Stalino valdymo laikais universitete vyravo siaubinga ịtarinejjimų ir nepasitikejjimo atmosfera.

1946 m. liepos 22 d. TSRS aukštojo mokslo ministro įsakymu Statybos fakulteto Architektūros skyrius buvo perorganizuotas ị Architektūros fakultetą. Jame buvo Architektūros kompozicijos, Miestų planavimo ir architektūros istorijos, Tapybos ir skulptūros bei Piešimo katedros. Tais pačiais metais Technologijos fakultete buvo įkurta Braižomosios geometrijos katedra, o nuo $1947 \mathrm{~m}$. rudens Architektūros fakultete pradèjo veiklą Statybos technikos katedra.

1945 m. pavasario semestre Technologijos fakultete studijavo 176 jaunuoliai ir 34 merginos, o Statybos fakultete -157 jaunuoliai ir 18 merginų. Toliau studentų gerokai daugejo. Paskutiniais Kauno universiteto gyvavimo metais technikos fakultetuose studijavo 1478 jaunuoliai ir 381 mergina: Statybos fakultete -484 studentai ( 20 merginu), Architektūros fakultete - 202 (49 merginos), Elektrotechnikos fakultete - 321 (8 merginos), Mechanikos - 400 (26 merginos), Chemines technologijos - 452 (278 merginos) $[1.35$, p. 82].

Per penkerius metus buvo išleisti 385 inžinieriai. Statybos fakultetą baige 155, Architektūros - 46; 75 absolventai igijo mechanikos specialybę, 62 - cheminès technologijos, 47 - elektrotechnikos.

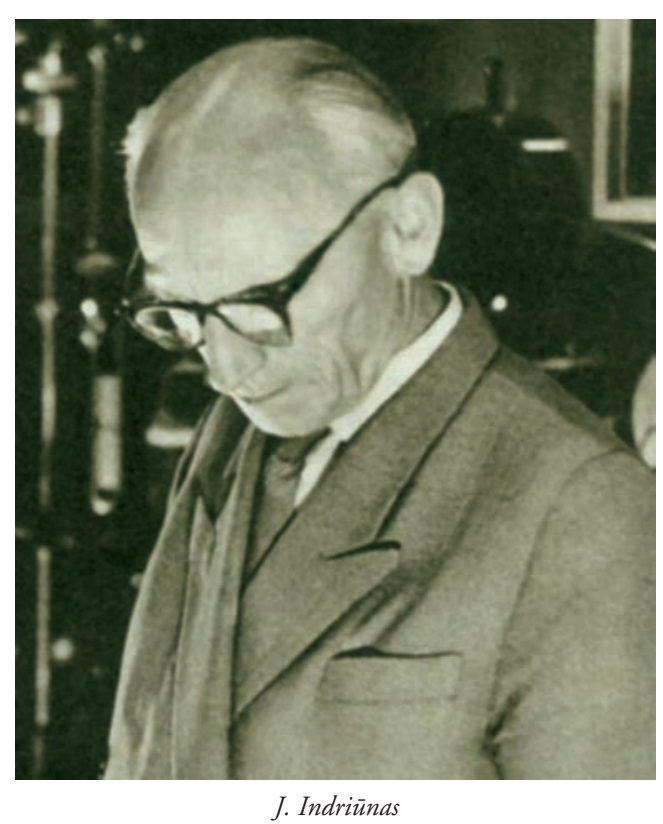

Technikos fakultetų dekanais dirbo: Statybos fakulteto - J. Kiškinas (1944 m. vasara), doc. A. Bistrickas (1944-1945), doc. S. Vabalevičius (1945-1946 ir 1947-1949), doc. S. Stulginskis (1946 m. balandi-rugsejij), M. Stonis (1946-1947), B. Petrulis (19491950); Technologijos fakulteto - prof. J. Indriūnas (1944-1946), prof. K. Baršauskas (1946-1947); Architektūros fakulteto - doc. S. Stulginskis (1946-1949) ir doc. S. Sčesnulevičius (1949-1950); Mechanikos fakulteto - doc. N. Milenskis (1947-1950); Elektrotechnikos fakulteto - prof. K. Baršauskas (1947-1950).

1947 m. ịkurtas Statybinių medžiagu fakultetas veike tik rudeni, o paskui reorganizuotas ị Chemines technologijos fakultetą. Fakulteto dekanu pradžioje buvo doc. J. Vidmantas, o nuo 1949 m. iki KPI įsteigimo - doc. A. Novodvorskis.

Kasmet po truputị buvo stiprinama universiteto technikos fakultetų materialinè bazè. Nors universitetui buvo perduodami kai kurie pastatai, patalpų labai trūko, jos nebuvo pritaikytos akademiniam procesui. Laboratorine ịranga buvo pasenusi, o nauju aparatu, prietaisu, įrenginiu gauti buvo sunku arba net neimanoma. Tik po kelerių metu padetis emé gereti. Tuomet ir suintensyvejo mokslinis darbas, apginta daugiau disertacijų.

Visoje Lietuvoje vyravo nyki nuotaika. Lietuvoje siautejo NKVD, rajonų centrų aikštese ant grindinio nuolat guldydavo okupantams pasipriešinusius žuvusius ir išrengtus partizanus. Universitete dèstytojus ir studentus terorizavo partorgai, komsorgai. 
Dažnas reiškinys pokariu buvo areštai tiesiog auditorijose. 1949 m. areštuotas ir nuteistas 10-iai metų Statybos fakulteto dekanas S. Stulginskis. Kalte - priklausymas N. Rericho draugijai.

Sovietine valdžia su nepasitikejjimu stebëjo universitetų darbą. Vienas svarbiausių Kauno universiteto uždarymo motyvų ir buvo siekimas likviduoti, anot partorgo V. Kuzminskio, ideologinès reakcijos centrą [1.36, p. 73].

\section{Technikos moksliniai tyrimai iki KPI isteigimo}

Technika grindžiama gamtos mokslais. Pažinimo procesas ir gamtos, ir technikos moksluose adekvatus. Kai kas mokslu laike tik su praktika nesusijusi mokslą, priešino mokslą ir techniką. Bet technika įsiskverbia ir i mokslą, ir i praktiką. Grynasis pažinimo mokslas teigiamai veikia ị praktiką orientuotus mokslus. Senoveje tikruoju mokslu buvo laikoma tik metafizika, o pastaraisiais amžiais gamtos ir technikos mokslams suteiktas mokslo statusas. Technikos mokslai tapo gamtos mokslų stimuliatoriumi, o gamtos mokslai skatina technikos pažangą.

Mokslinių tyrimų pradžia Lietuvoje susijusi su Lietuvos universiteto veiklos pradžia. Jau 1923 m. rugsèji rektorius Vincas Čepinskis per imatrikuliacijos aktą sake, kad "universitetas, kuris neprisideda prie mokslo dauginimo darbo, neturi teises vadintis universitetu ir yra ne daugiau kaip aukštesnioji mokykla. <...> universiteto uždavinys yra padaryti is jaunimo tyrinètojus ir mastytojus, išvystant kuo labiau abstraktaus mastymo gabumą.<...> kiekvienas vidutiniško gabumo studentas gali dalyvauti tyrinejimo darbe ir gali prisideti prie mokslo padauginimo. Tiesa, tiktai išimtinio gabumo žmonés iš tu studentu tyrinètoju taps tikrais mokslininkais, bet dauguma is ju taps gerais specialistais su mokslinio mastymo ipročiais" [1.39, p. 225-226].

Lietuvos universiteto Technikos fakultetas stokojo moksliniam darbui patalpų, laboratorijų, prietaisų, įrengimų ar aparatūros, trūko literatūros, bet ir tomis sunkiomis sąlygomis pradeti moksliniai tyrimai. Bet darbuotojų su moksliniais laipsniais fakultete nebuvo, todèl tie tyrimai nebuvo baigiami disertacijomis, o turejo tik praktinę reikšmę.

Vienas labiausiai patyrusių Technikos fakulteto mokslininkų buvo profesorius
Pranas Jodele. Jis, dar dirbdamas Kijevo politechnikos institute, 1907 m. paskelbè savo pirmąjị mokslinį darbą apie portlandcemenčio struktūrą ir jo kietejimo procesus. Ten 1912 m. buvo išrinktas ekstraordinariniu profesoriumi. Grižzęs ì Lietuvą vykdè geologinius tyrimus. $1934-1935$ m. paskelbè 8 mokslinius straipsnius apie betono savybes, smèlio ir žvyro naudojimą statybos skiediniams, cemento gamybą ir kt. temomis. Jo vadovaujamas 1947 m. disertaciją „Pagreitinta karbonatinių padermių analize ir jos panaudojimas Karpènų klinčių tyrimui“" apgynè J. Mituzas [1.40, p. 9-12].

Kijevo politechnikos institute, $1906 \mathrm{~m}$. apgynęs disertaciją ir vèliau tapęs ordinariniu profesoriumi, Povilas Čechavičius mokslinès produkcijos Kaune jau nebesukūrè.

Daug tyrimų hidrologijos, hidrometrijos ir kitais klausimais atliko Steponas Kolupaila, buvęs Maskvos matavimo instituto profesorius. Jis patikslino formules upių vandens debitams nustatyti. Prof. S. Kolupaila daug nuveike, tobulindamas hidrometrinius instrumentus, paskelbè daug mokslinių straipsnių [1.41, p. 399-418].

Pirmasis medžiagų atsparumo ir statybinès mechanikos tyrimus Lietuvoje pradejo Kazimieras Vasiliauskas. 1939 m. VDU tarybai buvo pateikta 15 jo darbų, atliktų nuo 1924 m. iki 1939 m., kuriuos įvertinus jam buvo suteiktas inžinerijos daktaro laipsnis [1.34, p. 99].

Pirmasis inžinerijos daktaro laipsnị Vytauto Didžiojo universitete gavo Juozas Indriūnas, apgynęs disertaciją „Vilnų plaukeliai lankstomi pavargsta" Technikos fakulteto taryboje 1936 m. [1.35, p. 45].

Tais pačiais metais pirmasis lietuvis, apgynęs disertaciją iš gelžbetonio konstrukcijų, buvo Jonas Kuodis. 1936 m. Vienoje jis apgyne disertaciją „Gelžbetonine sija su aukštos kokybés plienu“. Jam buvo suteiktas technikos daktaro laipsnis [1.42, p. 190].

1938 m. Juozas Gabrys Latvijos universitete Rygoje apgyne disertaciją „Betoninès ir gelžbetoninès trijų šarnyrų arkos" [1.42, p. 191].

1939 m. inžinieriaus daktaro laipsnị gavo Vladas Jakovickis, apgynęs disertaciją „Atbulų užsidegimų Marx’o lygintuvo kameroje atsiradimo klausimu“.

Inžinierius Adolfas Damušis 1940 m. apgynè disertaciją „Geležies-aliuminio denginių santykio įtaka i portlandcemento susitraukimą".

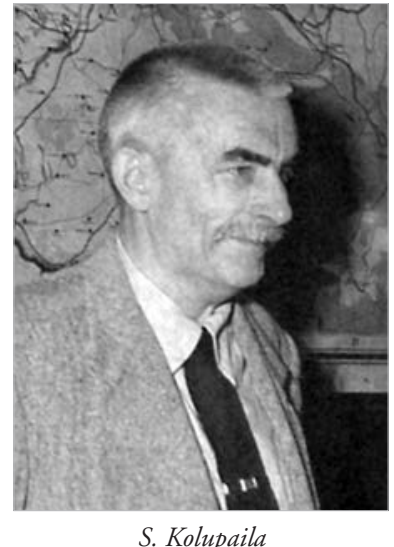

S. Kolupaila
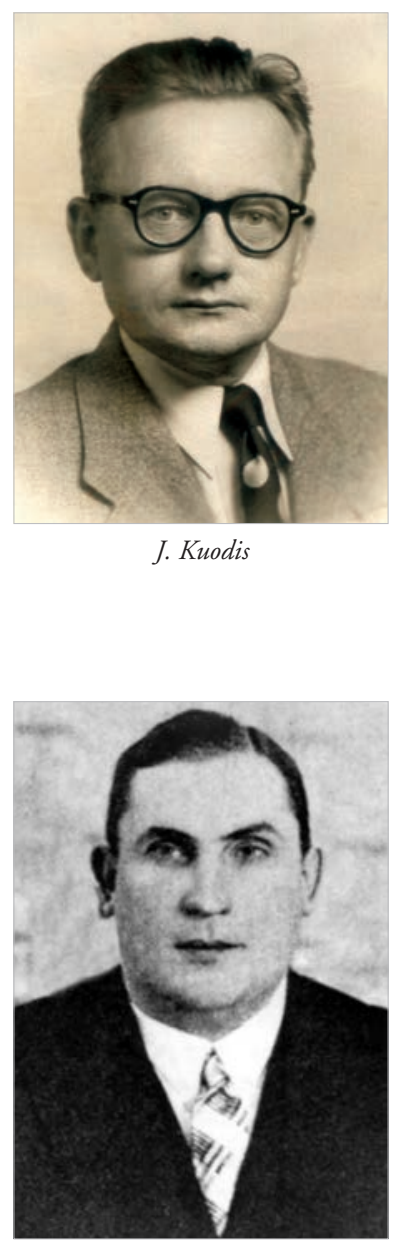

J. Gabrys 
TECHNIKOS

IR TECHNIKOS MOKSLŲ

RAIDA LIETUVOJE

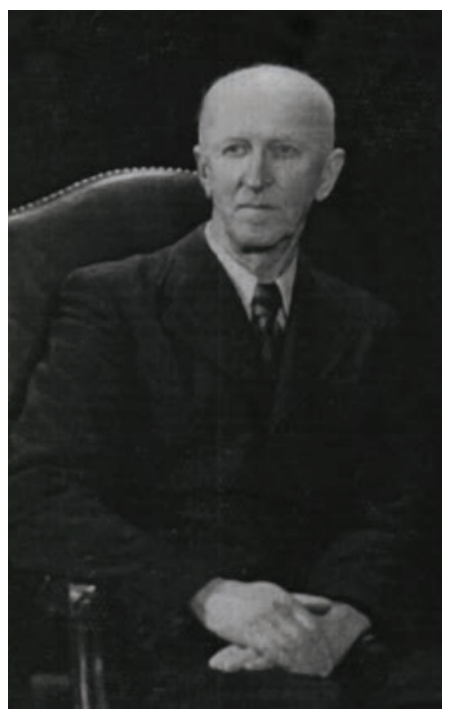

J. Kiškinas

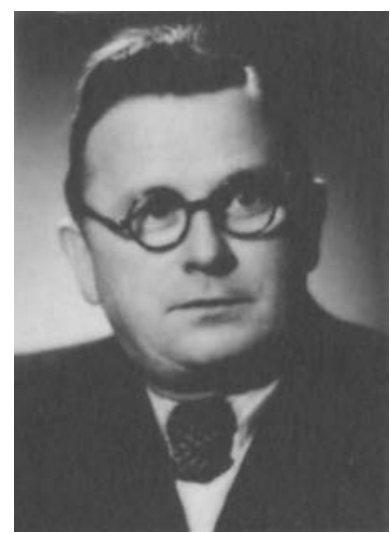

K. Baršauskas

Tai bene ir visas mokslininkų reikšmingesnių darbų derlius iki Antrojo pasaulinio karo pradžios.

Apskritai mokslinių tyrimo darbų tarpukario Lietuvoje praktiškai niekas neremè. Moksle reiškèsi iniciatyvūs desstytojai. Kita vertus, daug problemų kèle pats studiju procesas. Reikejjo daug ko: lietuviškų vadovèlių, sukurti technikos terminus, steigti laboratorijas ir t. t. Tuometinei profesūrai tai buvo pagrindiniai klausimai.

Po karo mokslinius laipsnius ir vardus turëjo tvirtinti Maskvos valdininkai. Ne visi, gavę prieš karą daktaro laipsnį, buvo patvirtinti. Kai 1946 m. Kauno universitetas igijo teisę rengti disertaciju gynimus, technikos fakultetuose èmè gausèti mokslo daktarų.

\section{Kauno politechnikos instituto ìsteigimo ir veiklos iki 1956 metu štrichai}

Kauno politechnikos institutas (KPI) buvo įsteigtas reorganizavus Kauno universitetą. $1950 \mathrm{~m}$. spalio $31 \mathrm{~d}$. TSRS aukštojo mokslo ministro ịsakymu vietoj Kauno universiteto buvo įsteigiami Kauno politechnikos ir Kauno medicinos institutai. Gruodžio 15 d. Maskva patvirtino KPI struktūrą, o gruodžio $30 \mathrm{~d}$. instituto direktoriumi, vèl gi ne be Maskvos įsakymo, tapo profesorius Kazimieras Baršauskas.

Kauno politechnikos institutas savo veiklą pradëjo turedamas 5 fakultetus: Cheminès technologijos, Elektrotechnikos, Mechanikos, Statybos ir Hidrotechnikos.

Statybos fakultetas buvo seniausias, ikurtas dar $1940 \mathrm{~m}$. liepos $27 \mathrm{~d}$. Jo 8 katedros turëjo rengti 3 specialybių inžinierius: architektūros, pramonès ir civilinès statybos bei žemès ūkio statybos.

Cheminès technologijos, Elektrotechnikos ir Mechanikos fakultetai buvo įkurti 1947 m. gruodžio 9 d.

Cheminès technologijos fakulteto $8 \mathrm{ka}-$ tedros turëjo rengti 4 specialybių inžinierius: organinių medžiagų technologijos, maisto produktų technologijos, silikatų technologijos ir durpininkystes.

Elektrotechnikos fakultete buvo 6 katedros, kurios turëjo rengti 2 specialybių inžinie-
Pirmasis technikos kandidato laipsni gavo Jonas Kiškinas. $1947 \mathrm{~m}$. jis apgyne disertaciją "Gelžbetoninių konstrukcijų tinkamumo geležinkelio viršutinei daliai teorinis tyrimas".

Vèlesniais metais technikos moksly kandidatais tapo J. Vidmantas, J. Čeičys, A. Novodvorskis, A. Rozenbliumas, J. Mikuckis, L. Kumpikas, K. Bieliūnas, L. Gastila, R. Pesys ir A. Matukonis. Dar aštuoni Kauno universiteto atstovai tapo matematikos, fizikos arba chemijos mokslų kandidatais [1.28, p. 119-120].

Moksliniai darbai pokariu buvo sunkiai vykdomi. Trūko įrenginių, medžiagų, pagalbinio personalo. Nebuvo ir kvalifikuoty mokslo darbų vadovų, labai didelis buvo destytojų pedagoginis krūvis, maži atlyginimai. Be to, tuometinemis aplinkybèmis slège psichologinè aplinka: kolegų ar studentų areštai, tremimai. Apie kūrybai reikalingą aplinką tebuvo galima tik pasvajoti. rius: pramonés įmonių elektrinių įrengimų ir elektros stočių bei sistemų.

Mechanikos fakultete buvo 8 katedros, kurios turëjo rengti 4 specialybių inžinierius: mašinu gamybos technologijos, pluoštinių medžiagų mechaninès technologijos, pramonés šiluminés technikos ir automobilių.

Hidrotechnikos fakultetas praktiškai ikurtas tuo pat metu, kaip ir pats institutas $-1950 \mathrm{~m}$. gruodžio $15 \mathrm{~d}$. Šiame fakultete buvo 6 katedros, kurios turejo rengti 3 specialybių inžinierius: hidrotechninès statybos, vandentiekio ir kanalizacijos, automagistralių ir miesto kelių [1.28, p. 129].

Kauno politechnikos institutas pradejo veiklą 1951 m. sausio 1 d., turedamas 1859 studentus (spalio $1 \mathrm{~d}$. duomenimis). Visi jie studijavo stacionare (veliau pavadintame dieniniu skyriumi). Institute dirbo 246 destytojai, kurių $16 \%$ turejjo mokslinius vardus ir laipsnius [1.35, 119]. Fakultetų dekanais pradëjo dirbti: Statybos - Stasys Sčesnulevičius, Cheminès technologijos-Jonas Venskevičius, Elektrotechnikos - Jonas Matulionis, Mechanikos - Nikolajus Milenskis ir Hidrotechnikos - Stasys Vabalevičius. Ant šiųžmonių pečiu gule didžiausi organizaciniai sunkumai.

Statybos fakultetas dirbo buvusioje miesto Rotušeje, kuri jam buvo perduota 1946 m. 
ir buvusiuose Vyskupijos rūmuose, kur jau dirbo buvęs Architektūros fakultetas.

Cheminès technologijos fakultetas dirbo buvusiuose Tyrimų laboratorijos rūmuose, Elektrotechnikos fakultetas - universiteto Pirmuosiuose rūmuose, Mechanikos fakultetas - Antruosiuose rūmuose.

KPI direktoratas (vèliau rektoratas) ir Hidrotechnikos fakultetas įsikūre buvusiuose Žemès banko rūmuose. Toliau jie buvo vadinami KPI centriniais rūmais.

$1951 \mathrm{~m}$. Kauno politechnikos institutą baigè 236 absolventai. Palyginti su nepriklausomybès metais parengtais 300 inžinierių, baigusiųjų institutą skaičius įspūdingas. Bet reikia atsiminti, kad tūkstančiai tarpukario darbuotojų buvo atleisti dèl priešiškos veiklos ar nelojalumo valdžiai, daug buvo represuota. Specialistų labai trūko, todèl buvo sparčiai didinamas studijuojančiųjų kontingentas.

Issteigtame Politechnikos institute dirbo 61 komunistų partijos narys, tik 29 lietuviai. Tačiau aktyvių komunistų buvo nedaug.

Kasmet studentų skaičius augo: $1951 \mathrm{~m}$. 2283, 1952 m. - 2300, 1953 m. - 2506, bet stacionare buvo tik 2456, o 50 - vakarinèse studijose.

KPI Vakarinis fakultetas veiklą pradejo 1953 m. rugsëjo 1 d. Jo veiklą administravo Mechanikos fakultetas, nes jame buvo tik mechanikos specialybès.

1953 metai daugelio žmonių įsimenami pirmiausia kaip Stalino mirties metai. Tuo metu Lietuvos ekonomikos reikalus tvarke daugiausia atvykèliai rusakalbiai. Daugumos pramonès įmonių direktoriai, vyriausieji inžinieriai, transporto, ryšių įmonių vadovai neturejo net aukštojo mokslo diplomų, dažnai tai buvo „...perejjūnai, nevykèliai, avantiūristai" [1.43, p. 31]. Respublikos pramonei dirbti geriau, o to reikalavo Maskva, buvo reikalingi kvalifikuoti specialistai. Viskas atskirose gamybos baruose imdavo keistis i gerąją pusę, kai perëjūnus pakeisdavo respublikos aukštųjų mokyklų absolventai. Tiesa, norint užimti vadovaujančiuosius postus pramonëje, statyboje ir kitur, tekdavo stoti $i$ partiją. Bet daugelis partinių tetapdavo „ridikèliais“. Tokių dauguma buvo ir aukštosiose mokyklose. Gyvenimo raida tai įrodè.

Po Stalino mirties kagébisto L. Berijos deklaruota politika apie tautiškumo prioritetus respublikose, siekiant įsitvirtinti valdžioje, buvo priimta žmonių su nepasitikejjimu. Bet vis dèlto per 3000 minètų perejūnų, o ir gal ne tik jie, paliko Lietuvą. Tas procesas buvo trumpalaikis. Beriją nušovè, o nacionalinè politika vèl buvo pasiūlyta lenininè-stalinine. Tačiau kvietimas ir nutarimai „ugdyti vietinius vadovaujančiuosius kadrus "buvo taikomas Lietuvoje su nemažu entuziazmu.

1953 m. perèmęs valdžią Nikita Chruščiovas èmési reformų. Jau 1954 m. pradžioje TSKP CK nutarimu buvo numatyta plèsti respublikinių ir rajoninių organų teises ir atsakomybę. Daug naujo buvo siekiama igyvendinti pramonëje, statyboje, žemès ūkyje ir kitur. Bet, žinoma, jokiu būdu nebuvo atsisakoma socialistinių gamybinių santykių. Ir toliau buvo deklaruojama apie stambaus, centralizuoto liaudies ūkio pranašumus.

Dešimtmetis pokario metų Lietuvai atnešè daug kančių ir praradimų. Pradèti areštai ir masiniai tremimai 1940-1941 m. buvo tęsiami ir po karo. Partizaniniame kare prieš okupantus žuvo per 20000 šalies patriotų. „Sukolchozinimas“ sumaitojo Lietuvos žemès ūkį. Karo sunaikinti fabrikai ir gamyklos letai ir sunkiai kèlesi iš griuvèsių. Trūko transporto, prasti buvo keliai. İ Lietuvą plūdo svetimtaučiai, ypač ị Vilnių ir Vilniaus kraštą, Klaipedą ir tuos miestus ir rajonus, kuriuose kūresi ar buvo atgaivintos pramonès įmonès. Rusų-slavų ekspansija į mūsų šalį buvo labai intensyvi. Anot R. Grigo, „Rusiškasis bolševizmas buvo numatęs ne tik masines lietuviu deportacijas, kolonistu perkelima $i$ Lietuvą. Likusius lietuvius noreta asimiliuoti. Drakoniški planai liko neigyvendinti dèl daugelio priežasčiu: aktyvios rezistencines kovos, masinio lietuviu tautos priešinimosi, paties rusiškojo bolševizmo evoliucijos formuojant, „žmogiškesni veida", laisvojo pasaulio opinijos ir kt. "[1.41, p. 109].

Pramonès augimą lydinti rusifikacija kèle pavojų lietuviškajam identitetui. Būtent tai vienijo lietuvių tautą, stiprino vidines dvasines jejgas atsispirti okupantui ir, kaip rašè B. Raila, „...nepaisant iki minimumo sumažéjusiu gyvuju lietuviškuju pajegu, rusu kolonistu ir tükstančiu sargybiniu iš "plačiosios tevynes" infiltravimo, Dievo garbinimo ir visu kitu žmogaus laisviu ikalinimo, visu gyvenimo sričiu pajungimo ir persunkimo okupacines funkcijos ir sovietizacijos pareigai atlikti, - lietuviu tautos nugarkaulis nebuvo sulaužytas... Ne fizinem jëgom, ne medžiaginem priemonem ji atlaike, bet savo büdo ir dvasios kokybe, lietuviškos garbés jautimu, savo vertybes pasitikejimu, pasiaukojimu, rizika ir atkaklumu pasinaudoti kiekviena proga ir rasti kokia nors išeiti padetyje be išeities"[1.42, p. 154].

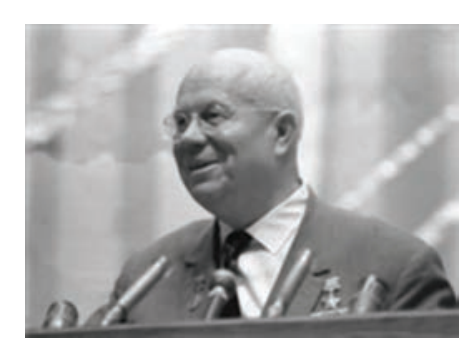

N. Chruščiovas

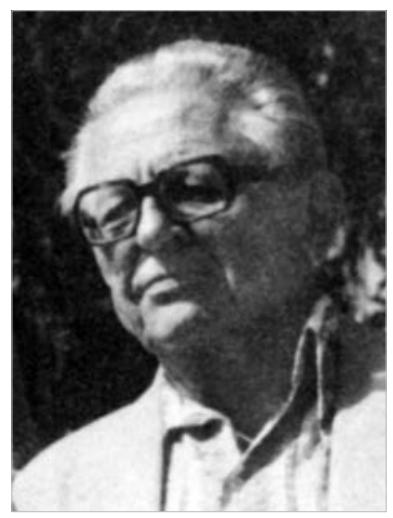

B. Raila 
TECHNIKOS

IR TECHNIKOS MOKSLU

RAIDA LIETUVOJE mas iš Kauno, lietuviško pedagoginio instituto funkcionavimas Vilniuje nuo pat jo atgavimo dienos nulemè tai, kad Vilniuje tolydžio stiprëjo lietuviškosios tendencijos, o čia nusédantys specialistai didino lietuviu procentą amžinajame mūsu mieste.

Kita vertus, visi specialistai, kurie buvo reikalingi gamybai-pramonei ir žemès ükiui, buvo rengiami Kaune, kurio lietuviškumas niekam nekele abejoniu nei tada, nei dabar. Vadinasi, tie darbuotojai, nuo kuriu veiklos priklause ne vien gamybos kokybe, bet ir darbo kolektyvu tautine dvasia, buvo brandinami lietuviškai ir lietuviškoje aplinkoje. Pasisklaide po visa Lietuva jie neabejotinai stabde Lietuvos nutautinimo procesa, o isiliedami $i$ Vilniu ir Klaipeda, kur nelietuviu procentas buvo labai didelis, gerino ju gyventoju sudeti lietuviu naudai. Kai iš Kauno politechnikos instituto Vilniaus filialo išango savarankiška aukštoji technikos mokykla Vilniuje, rusiškoji Vilniaus pramones potencija galutinai buvo palaužta. Tokie dalykai neivyksta per viena diena. Tam reikia dešimtmeči ir, be to, nepaliaujamai veikiančio socialinio mechanizmo. Toki mechanizma natūraliai reguliavo specialistu parengimo tinklas. Kas ir kodel jị sukūre toki pirmaisiais pokario metais, šiandien gal sunkoka paaiškinti, bet kad jis padejo išsangoti lietuviu tautos atsparuma, dabar mes nesunkiai galime matyti, pasilygine su latviais. Rygoje 75 procentai studenty politechnikos institute mokesi rusiškai, o universitete - 50 procentu. Neatsitiktinai Ryga, Liepoja, Daugpilis surusejo, o Lietuvoje, kur inžinieriai buvo Kaune rengiami tik lietuviškai, sulietuvejo Vilnius, atsilaike nuo kitataučin invazijos Klaipeda ir Šiauliai, neužsiteř̌e naujai kuriami pramonès centrai-Alytus, Marijampole, Utena " $[1.43$, p. 240-241].

Panašiai tuometines aplinkybes vertina akademikas Jonas Kubilius, ilgus metus buvęs Vilniaus universiteto rektoriumi:

„Augančiai Vilniaus pramonei reikëjo inžinieriu. Todel prireike juos rengti vietoje. Paprasčiausia bütu buveprie Vilniaus universiteto isteigti viena kita techninio profilio fakulteta. Deja, dideleje centralizuotoje valstybeje veike kitos nuostatos. Visi buvo guldomi i Prokrusto lova. Universitetuose büdavo leidžiama rengti tik tiksliuju, gamtos ir humanitariniu moksly atstovus. Net ir $\dot{z}$ medicina buvo kreivai žiürima. Ji buvo tik Vilniaus, Tartu, Lvovo ir kažkuriame Sibiro universitete. Todel Vilniuje teko isteigti Kauno politechnikos instituto filialq" [1.43, p. 288]. 


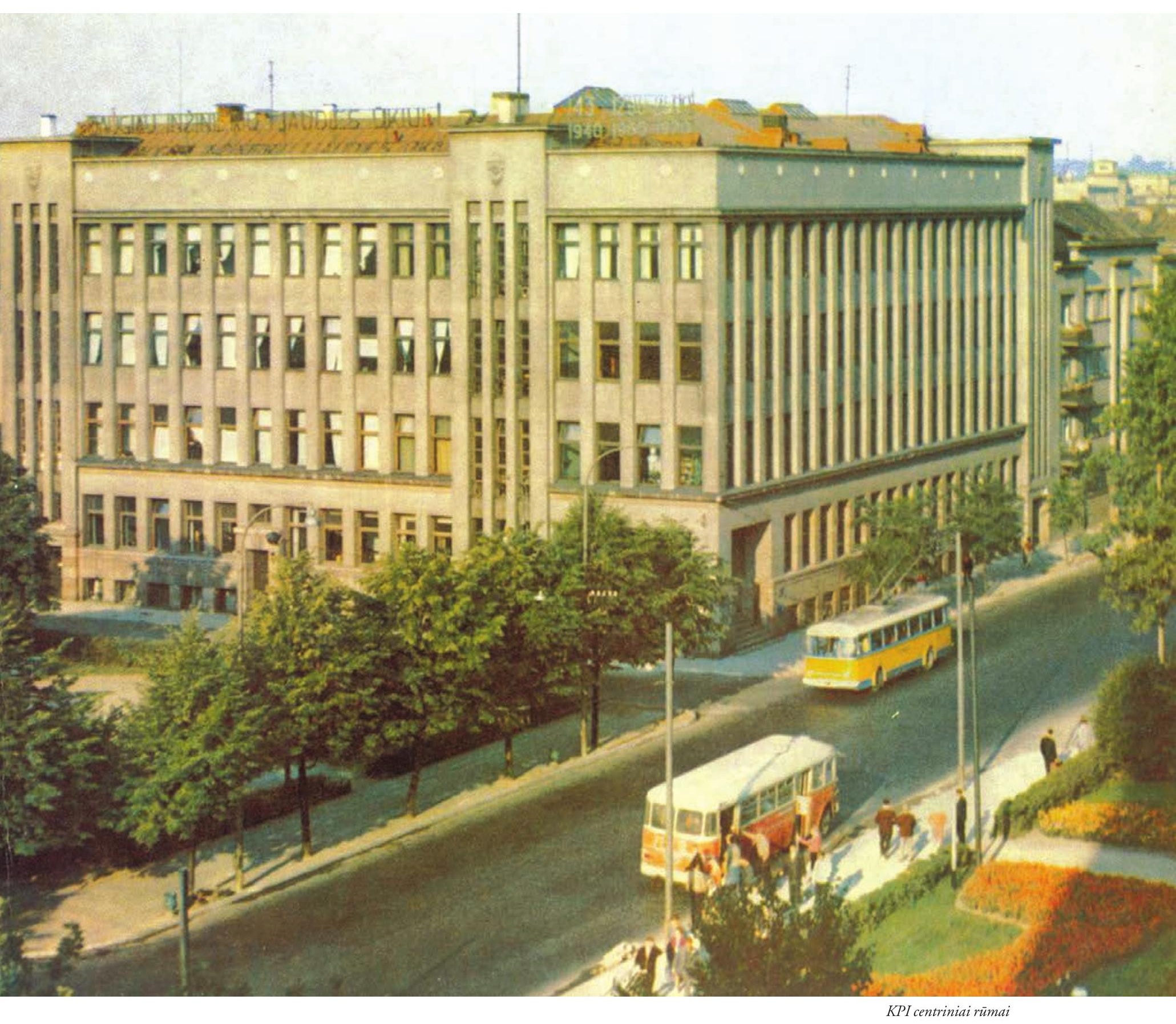

Vakariniai skyriai buvo isteigti Vilniuje 1956 m., Klaipedoje ir Šiauliuose 1959 m., Panevėžyje - 1961 m. 1956 m. KPI studijavo 3606 studentai dieniniame skyriuje, 372 - vakariniame skyriuje, iš to skaičiaus 75 - KPI Vakarinio fakulteto Vilniaus skyriuje.

Tik 1956 m. Kauno politechnikos institutui buvo suteikta teise priimti ginti disertacijas. Technikos mokslų kandidatų institute kasmet daugëjo. Jie ème pildyti ir KPI Vilniaus skyriaus pedagogu gretas. 



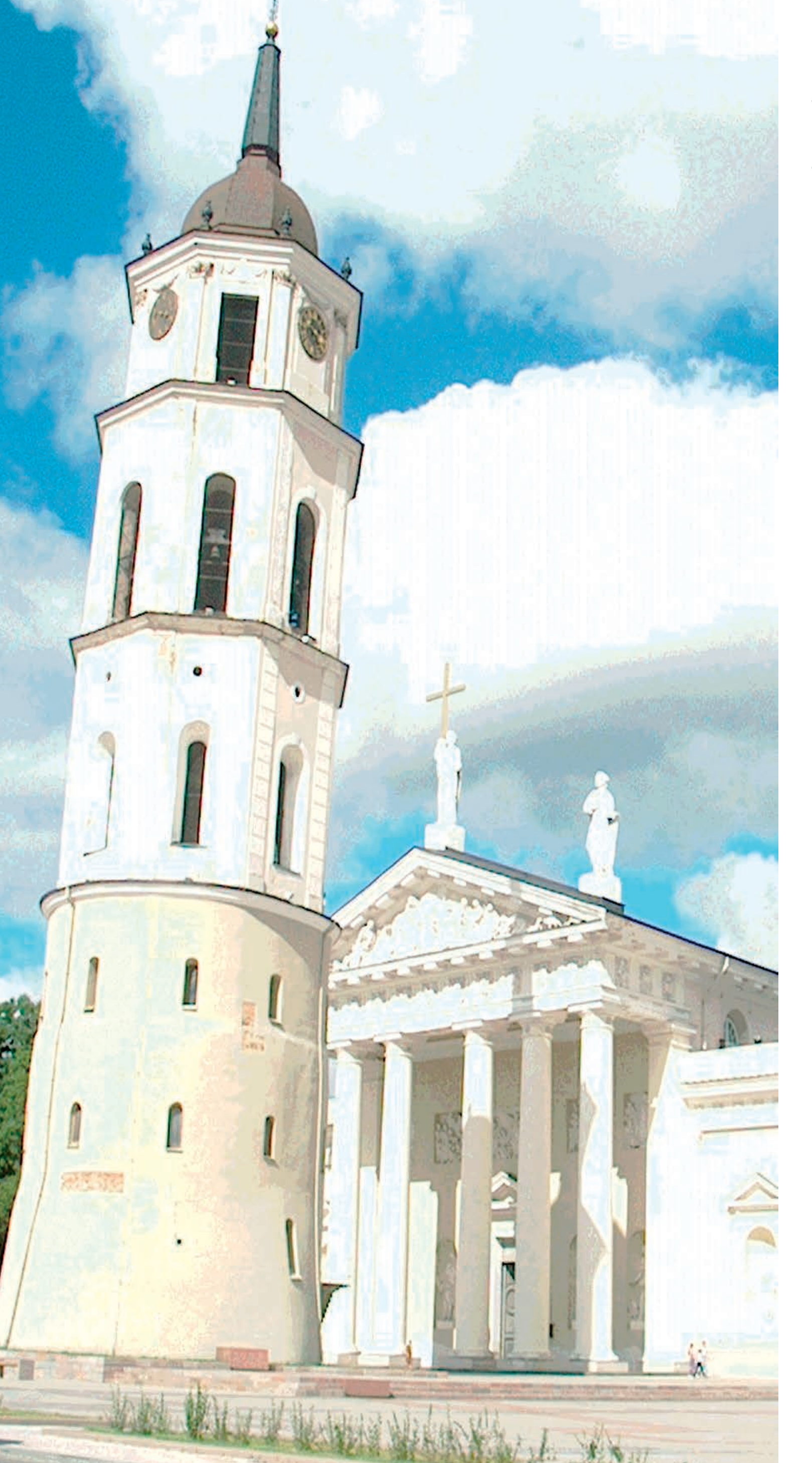




\title{
TECHNIKOS
}

\section{STUDIJŲ PRADŽIA}

\section{VILNIUJE}

\author{
Pramonès raidos Vilniuje iki 1956 metu apžvalga
}

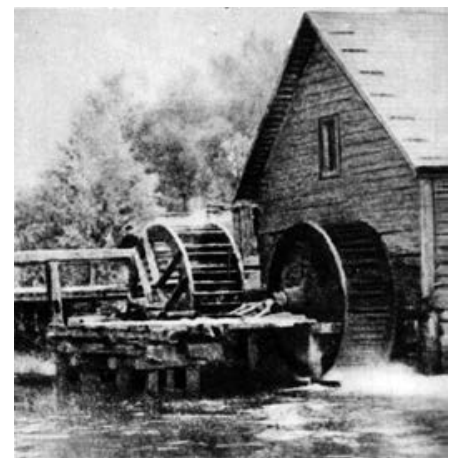

1495 m. Lietuvos Didysis kunigaikštis Aleksandras patvirtino Vilniaus auksakalių cecho statutą. Šis cechas laikomas pirmuoju ir Vilniuje, ir visoje Lietuvoje.

Bègant laikui cechų skaičius didèjo. Dažniausia jie buvo smulkūs. Vieni pradedavo veikti, o kai kurie nustodavo veikę. Buvo žemès ūkio produktų perdirbimo cechų, veike odos ir kailiu, metalo apdirbimo, audimo ir siuvimo bei kitos paskirties cechai. Žinoma, kad $1540 \mathrm{~m}$. Vilniuje jau veike patrankų liejykla, stovejjusi netoli Šv. Jurgio bažnyčios, Vilniaus vaivados Radvilos užmiesčio žemeje Vilniuje iš importuotos salietros, sieros ir vietinių anglių gamino paraką.

1533-1558 m. dokumentuose minima Pavilnio popieriaus dirbtuve. $1547 \mathrm{~m}$. Žygimantas Augustas leido įsteigti prie Vilniaus stiklo dirbtuvę.

Visos minetos gamyklos naudojo ne tik rankų darbą, bet ir vandens arba arklių varomas mašinas. Tokios įmonés sudare manufaktūriness pramonès pradžią [2.1, p. 31-44].

Vilniaus miesto gyventoju skaičius iki XIX a. didejo lètai. XVI a. Vilniuje gyveno 25000 žmonių, o XIX a. pradžioje - tik 31000 [2.2, p. 29].

Po III Žečpospolitos padalijimo, įvykusio 1795 m., mūsų senoji sostine tapo Rusijos Vilniaus gubernijos centru. Vilniaus ekonominé pletra dabar jau priklausé nuo Rusijos ekonomines politikos.

$\mathrm{Ne}$ visiškai patikimais duomenimis, $1825 \mathrm{~m}$. Vilniuje buvo 106 fabrikai ir gamyklos [2.1, p. 57]. Vilnius XIX a. pirmoje puseje buvo svarbiausias amatų centras Lietuvoje.

Kolonizatoriai visuomet siekia vietinius gyventojus laikyti tamsoje, t. y. varžyti ju švietimą, kultūrą ir tam tikslui dažniausiai naudojama degtinè. Todèl neatsitiktinai iki XIX a. vidurio Lietuvoje tarp kitų pramones imonių dominavo spirito varyklos. Ne išimtis buvo ir Vilniaus miestas. $1811 \mathrm{~m}$. Vilniuje buvo 183 spirito varyklos. Vèliau jų skaičius mažèjo, nes pigesnį spiritą atsiveždavo iš kitur [2.1, p. 63].

Žinoma, kad tuomet Vilniuje veikè tabako ir cigarų fabrikas, žvakių dirbtuves, drobès ir gelumbès audyklos, skrybèliu ir kepurių, odos ir kailių, sagų dirbtuves. Vilniaus mieste ir apskrityje buvo statybiniu medžiagu gamybos įmonių: plytinių, kalkinių. Prie Vilniaus - Kučkuriškèse - veike popieriaus gaminimo įmonè, o kiek vèliau èmè veikti tokia įmone Naujuosiuose Verkiuose. İsteigta keletas spaustuvių, medžio apdirbimo įmonių, veikè malūnai.

Vilniuje buvo susikoncentravę aukso ir sidabro dirbinių amatai. To meto šaltiniuose minimos audinių dažyklos, lako bei žibintų dirbtuves ir kt. [2.1, p. 66-73].

Pramonés pletrai didelę įtaką dare transporto pletra, ypač Lietuvos teritorijoje $1862 \mathrm{~m}$. baigus tiesti Peterburgo-Varšuvos geležinkelį. Kol nebuvo geležinkelio, transportuoti prekes sausumos keliais buvo brangu ir sudetinga, o vandens keliais Lietuva negalejo labai pasigirti.

Po $1863 \mathrm{~m}$. sukilimo prieš caro valdžią daug kas buvo reformuota. Verslininkai sukauptas lèšas èmé intensyviau investuoti i pramonę. Išsiplete bankų ir kredito įstaigu veikla. Buvo įkuriamos dideles gamybos įmonès sujungiant kapitalus.

XIX a. antroje puseje pramonè Vilniuje smarkiai augo. Netoli Vilniaus buvo įkurta Kairenų vielos ir vinių gamybos įmone, „Patentuotų vinių rusų-vokiečių įmoné“, vèliau žinoma kaip E. Poselio dalgiu fabrikas Naujojoje Vilnioje, issteigtos stambios mechaninès remonto dirbtuvès Vilniuje geležinkeliui prižiūrèti. Veike saldainių ir šokolado gamybos ¿̇monès, trikotažo fabrikai, didelès siuvyklos, kailių dirbinių i̇monés, Lentvario vielos ir viniu gamykla. Prie Vilniaus gamino čerpes, koklius.

Naujojoje Vilnioje buvo ịsteigta A. Mozerio nerinių ir mechaninio siuvinejjimo 
i̇monè. Vilniuje įsikūrè rankdarbių dirbtuvé, kojinių mezgimo, mezgimo, stambios odu apdirbimo įmonés, avalynès ir aulų gamybos dirbtuvès. Dirbo karamelès bei kakavos fabrikas, jau mechanizuotos kepyklos, aliejaus, muilo dirbtuves.

XIX a. pabaigoje stambiausiomis ir labiausiai mechanizuotomis tapo Vilniaus alaus gamybos akcinès bendrovès „Šopenas“ imone ir I. Lipskio akcinès bendroves alaus darykla. Vilnius buvo stambus salyklo gamybos centras. Veike gyvulių skerdyklos, dešru gamybos įmonés, didelè tabako dirbiniu gamybos įmoné, net 42 poligrafijos įmonès [2.3, p. 147]. Nustatyta, kad Vilniuje nagrinëjamo laikotarpio pabaigoje pramoninio pobūdžio amatais vertesi beveik 16 tūkst. Vilniaus miesto gyventojų [2.1, p. 218].

$\mathrm{XX}$ a. pradžioje pramoné Vilniuje toliau vystesi.

1900 m. Vilniuje inžinierius Petras Vileišis įsteige mechaninę gamyklą, kuri gamino metalinius bakus, cisternas, garo katilus, įvairias metalo konstrukcijas.

Pramonès kilimas Lietuvoje ypač ryškus nuo 1908 metu, nors Rusijoje buvo juntami krizès reiškiniai. Sparčiai vystèsi maisto, miško, medžio apdirbimo bei popieriaus pramoné, didejo metalo apdirbimo ir mašinu gamybos pramonés produkcija.

Pirmojo pasaulinio karo išvakarese Vilniuje gyveno beveik 215 tūkstančiu gyventojų, mieste buvo 17 tūkstančių amatininkų. Vyko gamybos koncentracija, įmonés stambëjo, didejo jų mechanizavimo lygis.

Lietuvos pramonésmarkiai nukentëjo karo metais, politinių permainų laikotarpiais. Vil- nius okupuotas lenku, jis tapo Lenkijos provincija ir jo pletra suletejo. Tuo metu Vilniuje èmè veikti radijo aparatų gamykla „Elektrit“, linų apdirbimo fabrikas „Rallopol“, faneros fabrikas „Dykta“, Grigiškių kartono fabrikas, kai kurios smulkios dirbtuves.

Vilniaus miesto pramonę gerokai sunaikino Antrasis pasaulinis karas. Vilniaus pramone pokario metais praktiškai buvo kuriama iš naujo.

1946 m. pradejjo veikti Vilniaus konservų gamykla, Vilniaus odos galanterijos fabrikas. 1948 m. pradejjo darbą Vilniaus elektros matavimo technikos gamykla (nuo 1974 m. - elektros skaitiklių). 1953 m. èmé veikti Vilniaus suvirinimo įrengimų gamykla. Stalino laikais buvo pastatytas ir pradejo veikti „Elfos“ elektrotechnikos, „Žalgirio“ staklių, dažymo aparatų gamyklos, „Lelijos“ siuvimo fabrikas.

Iki 1956 m. Lietuvos sostineje jau dirbo „Pergalès“ konditerijos fabrikas, Duonos kombinatas, Pieno kombinatas, Silikatinių plytų bei Gelžbetonio gamyklos ir kt. [2.2, p. 35-36].

Taigi Vilnius vystesi vis daugiau kaip pramonés miestas, kuriam labai trūko darbininkų, aukštos kvalifikacijos specialistų. Didejo kitataučių migracija iš TSRS gilumos. Ją sulaikyti ir padèti lietuvinti mūsų sostinę buvo įmanoma tik keičiant atsibasčiusius į Lietuvą „kadrus“ savo šalyje išugdytais žmonemis, pirmiausia - pramonés ir statybų vadovus. Sprendžiant šią problemą ryškus ir KPI Vilniaus filialo, vèliau Vilniaus inžinerinio statybos instituto ir pagaliau Vilniaus Gedimino technikos universiteto indelis.
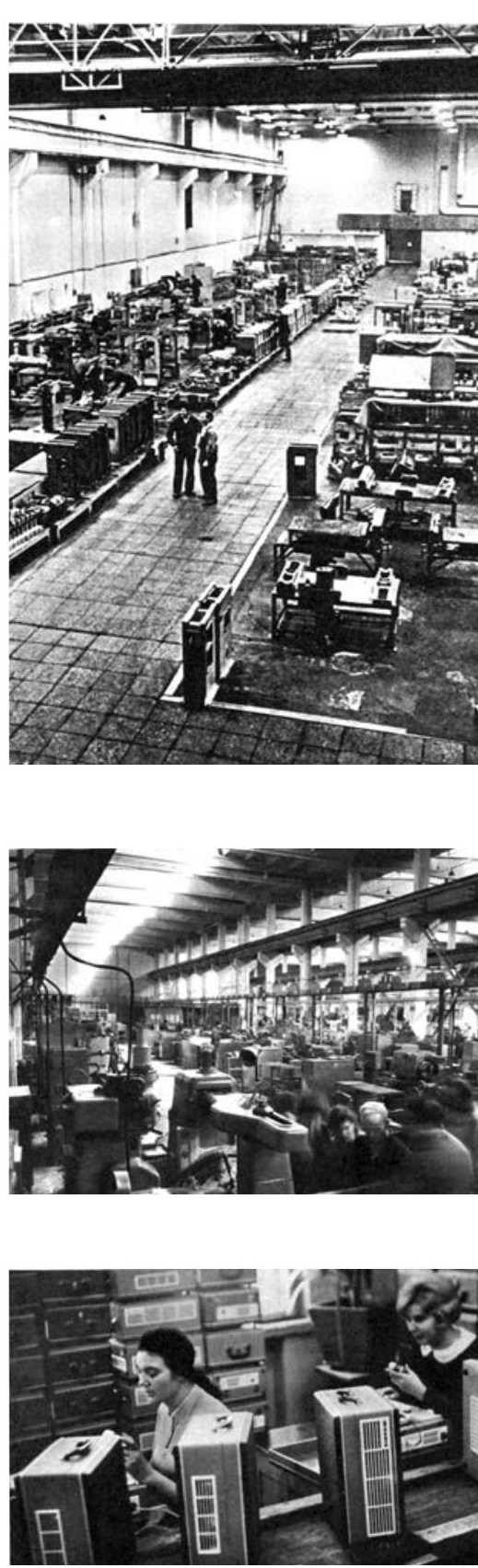

\section{KPI Vakarinio fakulteto Vilniaus skyriaus kūrimo aplinkybès}

Sparčiai auganti Vilniaus pramonè, augančios statybų apimtys Lietuvos sostineje didino kvalifikuotų specialistų paklausą. Per pokario dešimtmetį Vilnius netapo lietuvišku miestu. Lietuviai tesudare apie $30 \%$ sostinès gyventojų. Rusų buvo per $30 \%$, lenkų apie $20 \%$, kitu tautybiu - taip pat $20 \%$. Siai situacijai gerinti į Vilnių buvo būtina siųsti kuo daugiau specialistų lietuvių, rengti specialistus vietoje, pritraukiant studijuoti jaunimą iš visos Lietuvos.

Taigi inžinerijos studijas organizuoti Vilniuje buvo vis labiau aktualu. Prireike Vil- niuje steigti inžinerijos studijas. Šią misiją turëjo atlikti Kauno politechnikos institutas, kurio rektorius prof. Kazimieras Baršauskas buvo vienas didžiausių inžinerijos studiju sostineje steigimo iniciatorių.

1955 m. lapkričio 14 d. KPI direkcijos posedyje buvo svarstytas instituto struktūros pakeitimu projektas. Buvo numatoma palikti 5 esamus fakultetus ir sukurti šeštą - Lengvosios pramonés fakultetą, į kurị įeitų Tekstilès technologijos, Braižomosios geometrijos katedros bei naujai steigiama Gaminių iš audinių ir odos technologijos katedra. Pokyčiai taip 
TECHNIKOS

STUDIJŲ PRADŽIA

VILNIUJE

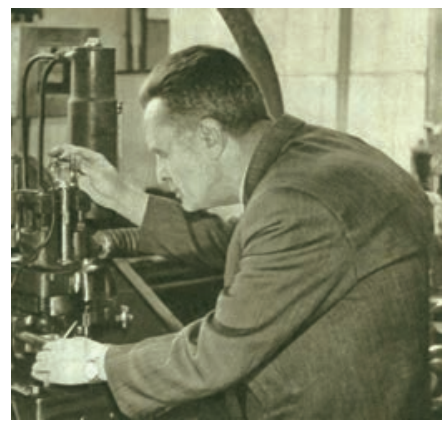

N. Milenskis

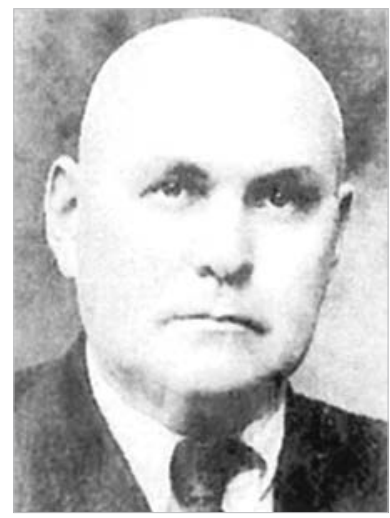

P. Baskutis pat buvo numatyti Mechanikos ir Chemines technologijos fakultetuose, o Hidrotechnikos ir Statybos fakultetuose pakeitimų projekte nenumatyta [2.4, p. 18].

Po dviejų savaičių, lapkričio 28 d., posèdyje vèl kalbèta apie KPI ir jo fakultetu struktūros keitimus. Buvo siūlyta Hidrotechnikos fakultetą pavadinti Komunalinès ir kelių statybos fakultetu, Inžinerinès geologijos katedrą pavadinti Pagrindų ir pamatų katedra ir kt. [2.4, p. 22].

Bet projektuojamoje KPI struktūroje dar nieko neužsimenama apie studijų organizavimą Vilniuje ar kituose miestuose.

Tačiau neabejotina, neformalūs pasitarimai dèl technikos mokslų studijų organizavimo Vilniuje jau vyko. Tai liudija $1956 \mathrm{~m}$. kovo 7 d. direkcijos posedžio protokolas, kai jau sprendžiami labai konkretūs KPI vakarinio fakulteto Vilniaus filialo įkūrimo klausimai $[2.5$, p. $6,6 \mathrm{v}, 7]$.

Tame posedyje KPI direktorius prof. K. Baršauskas praneša, kad Vakarinio fakulteto filialui Vilniuje patalpas suteiks universitetas. K. Baršauskas sake, kad siūloma Vilniuje rengti statybos, mašinu statybos technologijos ir pramones įmonių elektriniu įrengimų specialistus. Statybos specialybès priemimo kontingentą sudarytų 50 žmonių, o ị kitas dvi specialybes - po 25 žmones. Taigi Vilniaus filiale, kaip tuomet direktorius vadino KPI Vakarinio fakulteto Vilniaus skyrių, studijuotu 100 žmonių.

KPI Vakarinį fakultetą kuruojantis Mechanikos fakulteto dekanas doc. N. Milenskis kalbëjo dèl numatytų specialybių, paskaitu organizavimo, desstytoju apkrovimo ir etatų. Jis teige, kad destymo klausimais teks susitarti su Vilniaus universitetu. Kartu N. Milenskis pabrèžè, kad artimiausiu metu reikia paskirti filialo vedejją ir skirti sekretorès mašininkès etatą.

Direkcijos posedyje buvo nutarta pavesti N. Milenskiui iki kovo 14 d. parengti Vilniaus filialo steigimo priemoniu planą.

Apie Vakarinio fakulteto filialo Vilniuje organizavimą kalbèta tų pačių metu gegužès 7 d. posedyje. Vykstančiam į Maskvą KPI direktoriaus pavaduotojui doc. P. Baskučiui buvo pavesta informuoti sąjunginę aukštojo mokslo ministeriją apie atliktus darbus filialo steigimo klausimu [2.5, p. 33v].
1956 m. birželi Vilniaus filialo (taip vadintas Vilniaus skyrius) klausimas tampa vienu prioritetinių KPI veikloje.

Birželio $1 \mathrm{~d}$. įvykusiame KPI Mokslinès tarybos posedyje apie KPI Vakarinio fakulteto Vilniaus skyriaus organizavimo problemas kalbëjo doc. N. Milenskis.

Doc. P. Baskutis informavo, kad Aukštojo mokslo ministerijoje filialo steigimo klausimu isakymo projektą rengia drg. Nikonovas ir kad tas įsakymas greit būsiąs gautas.

Direktorius prof. K. Baršauskas pranešè, kad filialo įkūrimu yra rūpinamasi, jau išskirtos patalpos, bus priimami norinčiųju studijuoti Vilniuje pareiškimai. Direktorius sakè, kad numatyti dèstytojų ir pagalbinio personalo etatai, ir pažymëjo, jog už tinkamą filialo veiklos organizavimą atsakingas Mechanikos fakulteto dekanas [2.6, p. 98].

Iš pateiktos medžiagos matyti, kad direktorius nebuvo patenkintas dekano N. Milenskio veikla filialo kūrimo klausimais. Nesunku suvokti, kad K. Baršauskui Vilniaus filialo reikalas labiau rūpejo nei Vakarinį fakultetą kuruojančiam dekanui. Šiaip ar taip ant docento Nikolajaus Milenskio pečiu gule dauguma Vilniaus skyriaus kūrimo rūpesčių.

Nikolajus Milenskis (1907-1990) gimè Marijampoleje. Kaip ir K. Baršauskas, baige Marijampoles realinę gimnaziją, kurioje pirmenybé buvo atiduodama gamtos mokslams. Studijavo Vytauto Didžiojo universitete, kurị baige 1943 metais. Po Antrojo pasaulinio karo pradëjo dirbti Kauno universiteto Technologijos fakulteto Mechanikos skyriuje.

Kai 1947 m. sausio 1 d. K. Baršauskas buvo paskirtas Kauno universiteto Technologijos fakulteto dekanu, N. Milenskis tapo vienu iš prodekanų. İstojęs į $\mathrm{VKP}(\mathrm{b})$, tapo aktyviu partijos veikëju. 1947 m. gruodžio $9 \mathrm{~d}$. jis buvo paskirtas naujai įsteigto Mechanikos fakulteto dekanu.

N. Milenskis stalinizmo siautejimo metais universitete garsejo „principingumu“, dažnai apkaltindavo destytojus paskaitų ar politvalandų nepakankamu idejjiniu lygiu, mokslinių darbų apolitiškumu, nepakankamu rusų mokslininkų vertinimu ir pan. [2.7, p. 65, 68]. Bet K. Baršauską N. Milenskis rèmé. Kai 1951 m. sausio 2 d. pradejo veikti Kauno politechnikos institutas, direktoriumi paskyre prof. K. Baršauską, o fakultetų dekanais tapo J. Matulionis, S. Sčesnulevičius, J. Venskevičius, S. Vabalevičius ir N. Milenskis. Anot J. Stražnicko, „Šiais žmonemis direktorius 
galëjo pasikliauti. N. Milenskį pažinojo dar nuo Marijampolés realinés gimnazijos laikü" [2.8, p. 249].

N. Milenskis Mechanikos fakulteto dekanu buvo iki $1966 \mathrm{~m}$. liepos $1 \mathrm{~d}$. Jis daug metų vadovavo ir Šilumines energetikos katedrai. $1953 \mathrm{~m}$. rugsëjo $1 \mathrm{~d}$. KPI buvo įsteigtas Vakarinis fakultetas. Jị administravo Mechanikos fakulteto dekanatas, nes iš pradžiu jame buvo tik mechanikos specialybès. Po trejų metų, kuriant KPI Vakarinio fakulteto Vilniaus skyriu, dekanui N. Milenskiui ir teko atlikti skyriaus steigimo ir veiklos pradžios organizacinius darbus [2.9, p. 129].

1956 m. birželio $2 \mathrm{~d}$. vykusiame direkcijos posedyje direktorius prof. K. Baršauskas pasiūle pavesti rūpintis filialo Vilniuje organizavimu ne tik Mechanikos fakulteto dekanui, bet ir abiem fakulteto prodekanams. Prof. K. Baršauskas nurode, kad jie turi susitikti su Vilniaus universiteto Fizikos-chemijos instituto vadovu, taip pat su rektoriumi J. Bulavu bei Ministru Tarybos pirmininko pavaduotoju K. Preikšu.

Posèdyje N. Milenskis prašè skirti susisiekimo su Vilniumi priemonę bei tgaliojančiu veikti dokumentu. Bibliotekos direktoré S. Užkuraite prašè spręsti literatūros tiekimo filialui reikalą.

Klausimo svarstymą apibendrinęs K. Baršauskas sake prireikus skirsiantis automobili, o reikalingi iggaliojimai būsią duoti. Direktorius praše apie pareiškimų studijuoti Vilniuje priemimą nuo liepos $1 \mathrm{~d}$. paskelbti Vilniaus spaudoje [2.5, p. 48v].

KPI vakarinio fakulteto Vilniaus skyriaus organizavimo klausimu kalbèta ir birželio 18 d. posédyje. Nerimauta dèl negaunamo iš Maskvos įsakymo apie filialo įsteigimą. Nutarta tuo klausimu skambinti i Maskvą. Tai turëjo padaryti P. Baskutis.

Pagaliau 1956 m. birželio 23 d. ị Kauno politechnikos institutą atëjo laiškas su TSRS aukštojo mokslo ministerijos įsakymu Nr. 498, pasirašytu TSRS aukštojo mokslo ministro pavaduotojo V. Stoletovo birželio 13 d. İsakymas pavadintas „Apie Kauno politechnikos instituto vakarinio skyriaus organizavimą Vilniaus mieste" [2.10, p. 11]. Isakyme sakoma:

"Pletojant vakarini ir neakivaizdini mokyma isakau:

1. Vilniaus V. Kapsuko valstybinio universiteto bazeje organizuoti Vilniaus mieste Kauno politechnikos instituto vakarini skyriu pramonines ir civilines statybos, mašinu gamybos technologijos ir pramones imoniu elektros įrengimu specialistams rengti.

2. Nustatyti priemimo plana i I kursa Kauno politechnikos instituto Vilniaus vakarini skyriu 1956/57 mokslo metams 100 žmoniu.

3. Kauno politechnikos instituto direktoriui drg. Baršauskui organizuoti studentu priemima $i$ Vilniaus vakarinio skyriaus I kursa. ir pradeti studijas nuo $1956 \mathrm{~m}$. rugsejo $1 d$.

4. Padaryti atitinkamus pakeitimus Kauno politechnikos instituto Statute“.

Gavus iš Maskvos įsakymą apie Vilniaus skyriaus įsteigimą, rūpesčių nesumažejo, bet formalumai buvo atlikti. Direkcijos posedžiuose buvo aptariami įvairūs ūkiniai ir kito naujojo skyriaus klausimai.

Rugpjūčio 14 d. įsakymu direktorius K. Baršauskas paskyre komisiją KPI Vakarinio fakulteto Vilniaus skyriaus stojantiesiems egzaminuoti. Komisiją sudare: lietuviu kalbos - vyr. dèst. J. Pikčilingis; rusų kalbos - dest. O. Kaskievič; matematikos - pirmininkas vyr. desst. K. Grincevičius, nariai vyr. dest. P. Golokvoščius, asist. P. Žemaitis, vyr. dèst. P. Rumšas; fizikos - pirmininkas vyr. desst. J.Viščiakas, nariai doc. H. Jonaitis, vyr. dest. A. Bilkyte, asist. A. Želvys; chemijos - pirmininkas vyr. dest. J. Kudaba, nariai doc. P. Buckus, asist. R. Stonyte, vyr. dest. E. Ramanauskas; braižybos - pirmininkas doc. T. Sadauskas, nariai doc. J. Vaitys, asist. A. Bogušauskas; svetimųju kalbų - vokiečių kalbos - vyr. desst. I. Vladimiroviené, anglų kalbos - vyr. dèst. R. Aprijarskyté, prancūzy kalbos - vyr. dèst. R. Ramūnienè.

Absoliuti dauguma egzaminų komisijos narių buvo iš Vilniaus universiteto. Studenty priemimo komisija turëjo dirbti rugpjūčio $22 \mathrm{~d}$. Jos darbe jau dalyvavo ir paskirtas KPI Vakarinio fakulteto Vilniaus skyriaus vedeju vyr. dest. Jeronimas Kudaba.

J. Kudaba gime 1909 m. spalio 1 d. Sankt Peterburge. $1918 \mathrm{~m}$. su tevais persikele ị Omsko guberniją, o 1922 m. šeima grį̌̌o i Lietuvą. Kurị laiką jis mokèsi Tverečiaus mokykloje. Nuo 1924 m. gyveno ir mokèsi Vilniuje, tapo Vytauto Didžiojo gimnazijos moksleiviu. Gimnaziją baige $1931 \mathrm{~m}$. ir įstojo į Stepono Batoro universiteto Chemijos skyrių. Universitetą baige 1937 m. ir gavo chemijos srities filosofijos magistro laipsni. Tais pačiais metais pradejo dirbti asistentu universiteto Neorganines chemijos katedroje. Nuo 1938 metų dar ir mokytojavo Vytauto

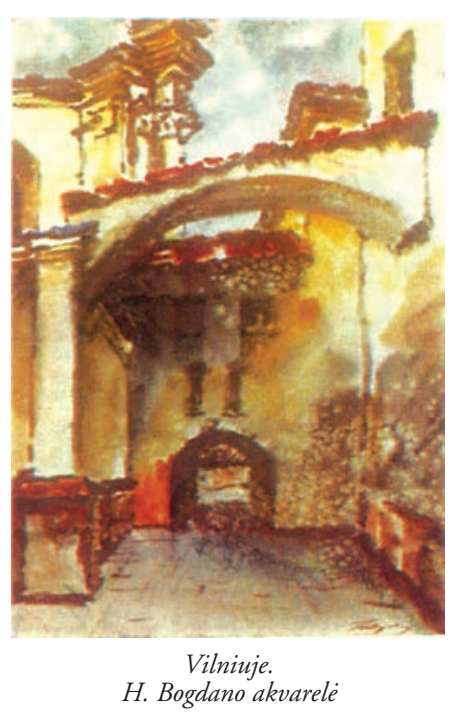


TECHNIKOS

STUDIJŲ PRADŽIA

VILNIUJE

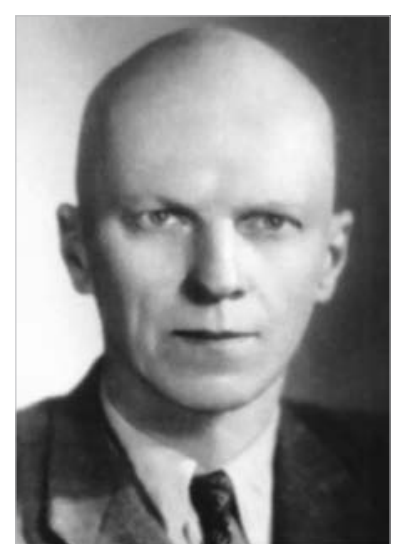

J. Kudaba
VU Chemijos fakulteto rūmai, kuriuose pradejo veikla KPI vakarinio fakulteto Vilniaus skyrius
Didžiojo berniukų ir „Birutès" mergaičių gimnazijose. Déste chemiją, fiziką, matematiką.

Universitete J. Kudaba vede būsimiems agronomams laboratorinius darbus iki pat Stepono Batoro universiteto uždarymo 1939 m. gruodžio $31 \mathrm{~d}$. Be to, gruodžio pradžioje Lietuvos valdžios paskirtasis Stepono Batoro universiteto valdytoju prof. I. Končius prièmè J. Kudabą laisvai samdomu likviduojamo Stepono Batoro universiteto Chemijos instituto turto prižiūrètoju nuo $1940 \mathrm{~m}$. sausio $1 \mathrm{~d}$., už tai buvo mokamas $200 \mathrm{Lt}$ atlyginimas. Nuo rugsèjo 1 d. J. Kudabą vèl paskyre dirbti jaunesniuoju asistentu, dabar - Technikinès chemijos katedroje, kurioje dirbo iki $1942 \mathrm{~m}$. gegužès $1 \mathrm{~d}$.

Nuo 1939 m. iki 1944 m. J. Kudaba dar dirbo chemiku Vilniaus odu ir avalynès fabrikuose.

Po karo, nuo 1944 m. rugpjūčio 1 d., vèl èmé dirbti Vilniaus universiteto Chemijos fakulteto Technikines chemijos katedroje. Jis buvo paskirtas vyr. destytoju ir katedros vedeju. Tuo pat metu iki $1946 \mathrm{~m}$. liepos $1 \mathrm{~d}$. jis buvo ir fakulteto prodekanu.

J. Kudaba buvo Vilniaus universiteto Polimeru chemijos katedros vedejju 1944 1953 m. ir 1960-1967 m., o Bendrosios chemijos katedros vedeju 1956-1960 m.

1955 m. Jeronimas Kudaba tapo chemijos mokslų kandidatu. Nuo 1956 m. buvo paskirtas Chemijos fakulteto dekanu (dirbo iki 1959 m.) ir KPI Vakarinio fakulteto Vilniaus skyriaus vedeju [2.11, p. 1-89].

Jeronimui Kudabai teko sunkiausia našta pradiniu skyriaus veiklos etepu. Skyriaus studentams paskaitos buvo skaitomos Chemijos fakulteto patalpose Naugarduko gatveje, o kiek vèliau ir VU rūmuose Čiurlionio gatvejje.

Jeronimui Kudabai teko įdèti daug triūso, išmonès, kad KPI Vakarinio fakulteto skyrius galètų tureti nors minimalias darbo sąlygas. Nebuvo bibliotekos, laboratoriju, etatiniu dėstytojų. Šią spragą teko užpildyti KPI dèstytojams, kurie reguliariai važinëjo iš Kauno i Vilnių. Dalis déstytojų atejo iš kitų Vilniaus aukštujų mokyklų arba tai buvo specialistai, dirbantys Vilniaus įstaigose ir įmonèse.

KPI Vilniaus vakarinio skyriaus studentu mokymo planai buvo identiški tos pačios spe- cialybės dieninio skyriaus studentų mokymo planams. Studentu užsiemimai vyko keturis vakarus po 4 valandas. Po sunkios darbo dienos iki 22 valandos trukdavę užsièmimai labai vargino studentus. Ne vienas neišlaikydavo tokio krūvio. Tarp „vakariniokų“ buvo daug grįzusių iš tremties, daugelis buvo vyresnio amžiaus, turëjo šeimas. Visa tai kèle rimtų problemų ir skyriaus vedëjui. Šias pareigas Jeronimas Kudaba ejo iki 1959 metų, kol ji pakeite docentas Aleksandras Čyras, su kurio vardu susijusi ilga tolesne Vilniaus aukštosios technikos mokyklos epocha. Jeronimui Kudabai 1959 m. buvo suteiktas docento mokslinis vardas. 1960-1967 m. jis vadovavo Vilniaus universiteto Polimeru chemijos katedrai, desste dar kurį laiką ir KPI Vilniaus filiale.

Doc. J. Kudaba buvo našus mokslininkas, daugiausia dirbo baltymų modifikavimo srityje. Paraše knygelių apie chemini pluoštą, polimerus, naftą, gamtines dujas. Parenge keletą mokomųju priemonių.

Kauno politechnikos instituto vadovai gerai vertino doc. Jeronimo Kudabos darbą KPI Vakarinio fakulteto Vilniaus skyriuje. Tai matyti iš KPI rektoriaus prof. dr. K. Baršausko ịsakymo Nr. 130, paskelbto $1961 \mathrm{~m}$. lapkričio 4 d. Jame sakoma:

„Dirbdamas Kauno Politechnikos institute ir büdamas KPI Vilniaus filialo dekanu nuo 1956 metu, docentas KUDABA JERONIMAS ineše nemaža indeli z aukštojo mokslo vystymasi ir aktyviai prisidejo prie aukštai kvalifikuotu inžinerinin kadru paruošimo mūsu respublikoje.

Docentas J. KUDABA pasireiše kaip geras pedagogas ir pažangus jaunimo aukletojas, pelnytai užsitarnavo dideli autoriteta déstytoju ir studentu tarpe.

Už sékminga pedagogine bei moksline veikla Kauno Politechnikos institute darbavimosi metu docentui KUDABAI JERONIMUI reiškiu padikq" [2.11, p. 146].

Mirè Jeronimas Kudaba 1992 m.

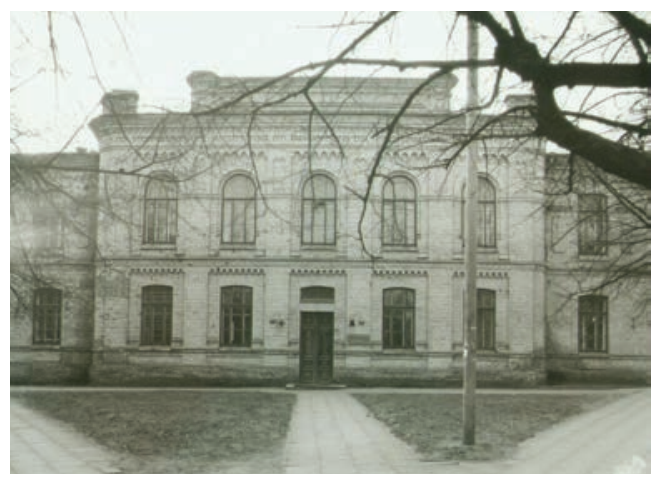


TSRS aukštojo mokslo ministerija buvo nustačiusi planą priimti į I kursą KPI Vilniaus skyriuje 100 žmonių. Matyt, dèl organizacinių sunkumų $1956 \mathrm{~m}$. rugsèjo $1 \mathrm{~d}$. studijas KPI Vakarinio fakulteto Vilniaus skyriuje pradejo 75 studentai. Trys akademinès grupes buvo šių specialybių:

1. Mašinų gamybos technologijos,

2. Pramones ir civilines statybos,

3. Pramonés įmonių elektrinių irrenginių.

Vakarinio skyriaus studentų studijos buvo numatytos šešerių metų, o mokymo planai nedaug skyrèsi nuo dieninio skyriaus mokymo planų. Bet paskaitos ar praktiniai darbai per savaitę turëjo neviršyti 16 valandų. Užsièmimai vykdavo pirmadieniais-ketvirtadieniais po 4 val. kasdieną. I vakarinị skyrių buvo leidžiama priimti tik gamybininkus, t. y. dirbančius pagal būsimą specialybę, bet iš tikruju priimdavo ir kitokius darbus dirbančius žmones. Vakariniame skyriuje pagal specialybę studijavo patyrę gamybininkai, jau solidaus amžiaus, bet dèl ịvairių aplinkybių anksčiau neigiję aukštojo mokslo diplomo.

Rengiant aukštos kvalifikacijos specialistą, jo būsimai kompetencijai didžiausią reikšmę turi studijų turinys. Siekiama, kad baigęs aukštąji mokslą išmanytų ne tik praktinius dalykus, bet remdamasis gautomis žiniomis, gebetų savarankiškai mąstyti, moketų turimas žinias taikyti konkretiems sprendimams priimti. Sudarant studiju turinį keliamas uždavinys išugdyti būsimą specialistą kaip tyrinètoją, analitiką, išpletoti jo abstraktaus mąstymo gabumus. Šiems tikslams spręsti pasitelkiami mokymo planai.

Mokymo planuose numatomos viso studiju laikotarpio disciplinos, nurodoma, kuriuose semestruose jos destomos, kiek valandu skiriama paskaitoms, pratyboms, laboratoriniams ir praktiniams darbams, kursiniams darbams ir kursiniams projektams, seminarams. Mokymo planuose nustatoma, kada ir kokių disciplinų laikomi egzaminai ar įskaitos.

Pagal mokymo planus sudaromas mokymo proceso grafikas. Jame numatomas laikas, skirtas teoriniam ir praktiniam mokymui, tarp ju mokomajai, gamybinei bei diplominei praktikai. Mokymo proceso grafike planuojamas ir studentų atostogų laikas.
Visais laikais visose mokyklose mokymo planai kinta. Atsižvelgiama į mokslo ir technikos pažangą. İ mokymo planus įtraukiamos naujos disciplinos, planuojama kita disciplinos mokymo trukmé, dažniausiai pasikeičia tos disciplinos mokymo (darbo) programa.

1956 m. pradejęs veikti KPI Vakarinio fakulteto Vilniaus skyrius dirbo pagal standartinius TSRS aukštojo mokslo ministerijos sudarytus mokymo planus. Suprantama, taip dirbo ir visi KPI fakultetai. Vakarinio mokymo studentai studijavo 11 semestrų, o 12-asis semestras buvo skirtas ikidiplominei praktikai ir diplominiam projektui parengti bei apginti.

1956-1957 mokslo metu visi skyriaus studentai studijavo tuos pačius dalykus. Pirmajame semestre reikèjo išlaikyti 3 egzaminus: aukštosios matematikos, braižomosios geometrijos ir TSKP istorijos. Reikëjo gauti chemijos, užsienio kalbos ir braižomosios geometrijos įskaitas, atlikti chemijos laboratorinius darbus. Antrajame semestre buvo laikomi aukštosios matematikos, chemijos ir fizikos disciplinu egzaminai, aukštosios matematikos, chemijos, fizikos, braižybos ir užsienio kalbos įskaitos. Studentai dar kartą privalëjo atlikti chemijos bei kitus laboratorinius darbus.

Nuo antrojo kurso atskirų specialybių studijų turinys jau kiek nevienodas. Trečiajame semestre visi studijavo aukštąją matematiką, fiziką, TSKP istoriją, užsienio kalbą ir braižybą, bet mokymo plane buvo numatyta ir skirtingų dalykų. Mašinų gamybos technologijos ir pramones įmonių elektrinių įrengimų specialybès studentai studijavo metalų technologiją, pramones ir civilines statybos specialybès studentai - geodeziją. Ketvirtajame semestre visi tęse aukštosios matematikos, fizikos ir užsienio kalbos studijas, o trečiajame semestre - atitinkamai metalų technologijos ir geodezijos dalykus. Bet vietoj TSKP istorijos visi studijavo politinę ekonomiją ir teorinę mechaniką. Be viso to, mašinų gamybos technologijos studentai turëjo braižybos, o PCS - geodezijos praktinius darbus.

Per pirmuosius du studiju kursus studentai studijavo inžinerijos dalykus labai menkai. Jie tesudare $6,6 \%$ bendro užsièmimų laiko. Didžiausia studijų laiko dalis teko fundamentiniams dalykams. Jie sudare $64 \%$ bendro laiko. $14,6 \%$ paskaitų laiko teko užsienio 
TECHNIKOS

STUDIJŲ PRADŽIA

VILNIUJE čiajame semestre jų buvo net per 300, o 11 semestre - apie 200 valandu. Tokia tendencija būdinga ir kitoms specialybèms. Tai susiję su poreikiu skirti vis daugiau laiko kursiniams darbams ir projektams parengti.

Didžiausias paskaitų krūvis teko būsimiesiems statybų inžinieriams. Galima manyti, kad intensyviausių studijų modelị statybininkams lèmé tuometinis turimas pedagogu kontingentas.

Per visą vakarinio mokymo studentų studijų laiką ketvirtị akademinių užsiemimų sudare fundamentiniai mokslai, apie $5 \%$ laiko skirta užsienio kalbai, net $12 \%$ - politikos mokslams, o inžinerijos dalykai, ypač svarbūs būsimajai karjerai, nesudare ir $60 \%$ laiko. Reikia pažymėti, kad tarpukariu Vytauto Didžiojo universiteto Technikos fakultete inžinerijos dalykams buvo skirta ne mažiau kaip $80 \%$ bendro akademinių užsièmimų laiko. Todèl neatsitiktinai daug VDU absolventų, Antrojo pasaulinio karo metais nublokštų ì Vakarus, greitai įsidarbindavo pagal profesini pasirengimą ir užsirekomenduodavo kaip kompetentingi savosios srities specialistai. Galima pamineti Vytautą Izbicką, Juozą Danį-Daniliauską, Adolfą Damuší, Jeronimą Dabrilą, Joną Kuodị, Joną Vasį-Vasiliauską, Jurgị Gimbutą ir t. t. Vieni ju pasižymejo praktiniais inžineriniais darbais, kiti destè prestižiniuose universitetuose. Kai kurie pelne JAV apdovanojimus, vadinamuosius „avardsus “, už geriausius metu inžinerinius projektus ir kt. Geram profesiniam VDU

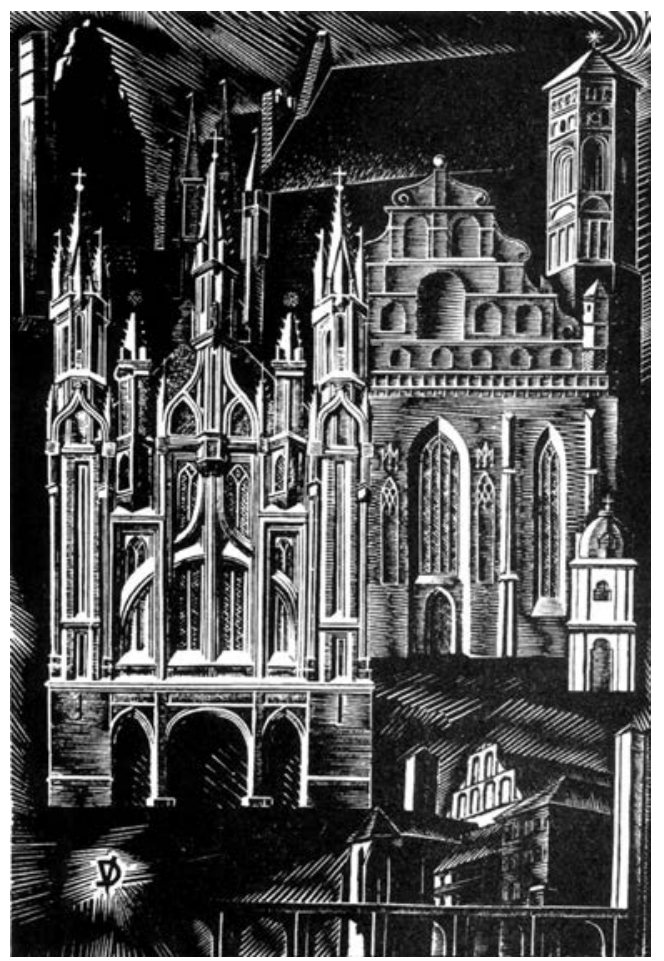


Bendras valandu skaičius semestre

\begin{tabular}{|c|c|c|c|c|c|c|c|c|c|c|c|c|}
\hline \multirow{2}{*}{ Specialybe } & \multicolumn{11}{|c|}{ Semestras } & \multirow{2}{*}{$\begin{array}{c}\text { Is viso } \\
\text { valandy }\end{array}$} \\
\hline & 1 & 2 & 3 & 4 & 5 & 6 & 7 & 8 & 9 & 10 & 11 & \\
\hline $\begin{array}{c}\text { Mašinu gamybos } \\
\text { technologija }\end{array}$ & 288 & 258 & 306 & 288 & 288 & 256 & 288 & 240 & 284 & 240 & 212 & 2948 \\
\hline PCS & 288 & 258 & 288 & 272 & 288 & 256 & 288 & 240 & 378 & 232 & 203 & 3019 \\
\hline $\begin{array}{c}\text { Pramonés imoniy } \\
\text { elektriniai } \\
\text { irenginiai }\end{array}$ & 288 & 258 & 306 & 272 & 288 & 256 & 270 & 224 & 364 & 208 & 196 & 2930 \\
\hline
\end{tabular}

absolventų pasirengimui neabejotinai didelę svarbą turëjo daugumos jų praktinè veikla studijų metu.

Retas baigdavo studijas per penkerius metus, nes beveik visi dirbo, ir dažniausiai pagal būsimą specialybę. Toks studijų modelis suteikè realiu galimybių, baigus universitetą, greitai imti dirbti konkretu praktini darbą. Bet nereikia manyti, kad lietuviams emigrantams tai buvo lengva. Teko derintis prie naujų standartų, naujos kalbos, naujų gyvenimo sąlygų. Bet svarbiausias veiksnys, anot J. Danio, buvo "profesinis išsilavinimas ir profesinis subrendimas, kuris buvo pakankamai aukšto lygio, kad prilygtu kitu kraštu statomiems reikalavimams" [2.12, p. 1].

\section{Vakarinio fakulteto Vilniaus skyriaus bendras valandu skaičius}

\begin{tabular}{|l|c|c|c|}
\hline \multirow{2}{*}{$\begin{array}{l}\text { Dalyku } \\
\text { grupès }\end{array}$} & \multicolumn{3}{|c|}{ Valandos ir akademiniu užsiemimu \% } \\
\cline { 2 - 4 } & $\begin{array}{c}\text { Specialybe } \\
\text { mašinu } \\
\text { gamybos } \\
\text { technologija }\end{array}$ & PCS & $\begin{array}{c}\text { pramones } \\
\text { imoniu } \\
\text { elektriniai } \\
\text { irenginiai }\end{array}$ \\
\hline $\begin{array}{l}\text { Funda- } \\
\text { mentiniai } \\
\text { mokslai }\end{array}$ & 782 & 766 & 766 \\
\cline { 2 - 4 } & $26,5 \%$ & $25,4 \%$ & $26,1 \%$ \\
\hline \multirow{2}{*}{$\begin{array}{l}\text { Inžineriniai } \\
\text { dalykai }\end{array}$} & 1652 & 1755 & 1649 \\
\cline { 2 - 4 } & $56,0 \%$ & $58,1 \%$ & $56,2 \%$ \\
\hline \multirow{2}{*}{$\begin{array}{l}\text { Užsienio } \\
\text { kalba }\end{array}$} & 152 & 152 & 152 \\
\cline { 2 - 4 } & $5,2 \%$ & $5,0 \%$ & $5,2 \%$ \\
\hline \multirow{2}{*}{$\begin{array}{l}\text { Politiniai } \\
\text { dalykai }\end{array}$} & 362 & 346 & 366 \\
\cline { 2 - 4 } & $12,3 \%$ & $11,5 \%$ & $12,5 \%$ \\
\hline \multirow{2}{*}{ IŠ VISO } & 2948 & 3019 & 2930 \\
\cline { 2 - 4 } & $100 \%$ & $100 \%$ & $100 \%$ \\
\hline
\end{tabular}

Ilgainiui mokymo planai buvo keičiami, siekiama juos patobulinti. Bet jie ir toliau stokojo kryptingumo profesiniam meistriškumui siekti. Inžinerinems disciplinoms skiriamo laiko nepadaugejo. Žinoma, kad profesinių žinių stoka varžo specialisto savarankiškumą, mąstymo kritiškumą ir gilumą. Tuomet sunku tiketis, kad toks specialistas ivveiks kylančias problemas, gebes kaupti patirti, sèkmingai dirbs kintančiomis sąlygomis. Jis nebus organizuotas ir iniciatyvus. Taigi profesinès žinios yra esminis ir galbūt vienintelis inžinieriaus kompetentingumo rodiklis. Sovietinè vakarine inžinierių rengimo forma daugelį metų buvo kur kas silpnesnè nei dieninio mokymo modelis.

\section{Pirmosios absolventu laidos desstytojai}

Kai buvo nutarta įsteigti sostineje KPI Vakarinio fakulteto Vilniaus skyrių, iškilo patalpų ir desstytojų problema. Ne be KPI vadovo profesoriaus $\mathrm{K}$. Baršausko talento spręsti ịvairius klausimus buvo susilaukta geranoriškos Vilniaus universiteto paramos. Matyt, VU ir KPI vadovai Juozas Bulavas ir Kazimieras Baršauskas gerai sutare, nes universitetas suteike skyriui patalpas, daug jo fundamentaliųjų mokslų katedrų desstytojų èmé dirbti antraeilininkais KPI Vilniaus skyriuje.
Juozas Bulavas $1956 \mathrm{~m}$. balandị Maskvos buvo patvirtintas rektoriumi ir iškart èmèsi „atlietuvinti“ Vilniaus universitetą. Jau iki spalio $1 \mathrm{~d}$. iš universiteto konkursų būdu buvo atleista 11 rusų, 9 lietuviai, 4 žydai, 1 lenkas ir 1 azerbaidžanietis. $\mathrm{O}$ iš viso konkursais, etatu mažinimu dèl sumažejusios darbo apimties ,išsluota apie 122 nekvalifikuotus ateivius" [2.14, p. 290-291]. Nesunku suvokti, kad rektorius J. Bulavas KPI Vakarinio fakulteto Vilniaus skyriaus

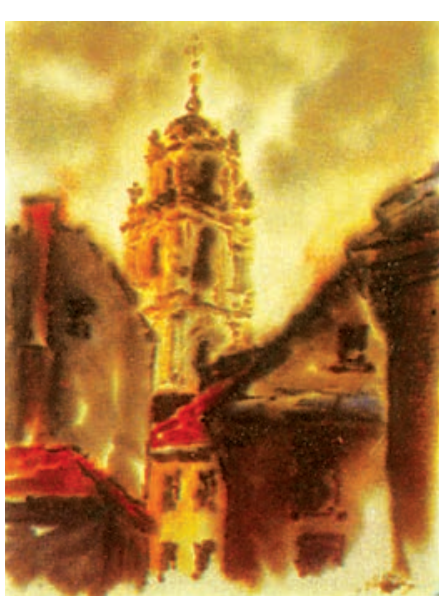

Vilnius. H. Bogdano akvarele

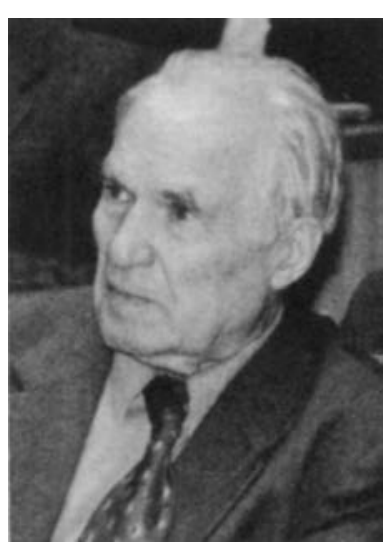

J. Bulavas 
TECHNIKOS

STUDIJŲ PRADŽIA

VILNIUJE

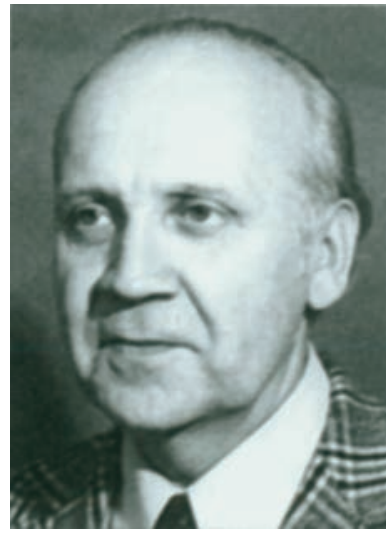

E. Budreika

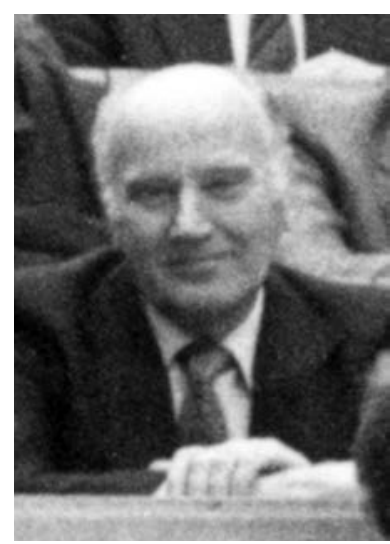

A. Raudeliūnas

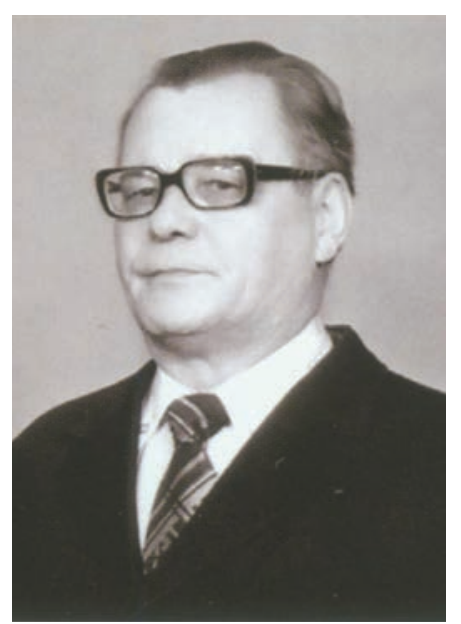

P. Rumšas steigimą laikè Vilniaus lietuvinimo proceso dalimi. Tuo klausimu J. Bulavo K. Baršauskui greičiausiai neteko įtikinèti. O Vilniaus universiteto parama sostineje kuriamai technikos mokyklai buvo labai svarbi. Bet rektoriavo J. Bulavas neilgai. $1958 \mathrm{~m}$. vasarą ji apkaltino įvairiausiais nusikaltimais: užterše universitetą politiniais priešais, nesidomejo politiniu studentų auklejjimu, taikstėsi su buržuazinio nacionalizmo ideologija ir t. t. Jis buvo iš rektoriaus pareigu atleistas. VU rektoriumi tapo Jonas Kubilius, taip pat rèmęs aukštosios technikos mokyklos Vilniuje plètrą [2.14, p. 292, 296].

Visada įdomu, kas buvo pirmieji. Jiems būna sunkiausia. Juos lydi daugybę įvairiausių problemų, spręstinų kūrimosi ir darbo klausimu. Tad kas gi buvo pirmieji Vilniaus vakarinio skyriaus destytojai, kuriuos galima laikyti būsimojo technikos universiteto pedagogu pirmtakais?

1956-1957 mokslo metais Vilniaus skyriuje dirbo iš viso tik 10 destytojų: A. Raudeliūnas, P. Rumšas, M. Priluckaja, R. Stonyte, E. Budreika, I. Vladimiroviene, R. Sereiskyte, N. Nikolajeva, A. Bilkyte ir G. Vasionis. Daugelis jų buvo Vilniaus aukštųju mokyklų desstytojai.

Matematikos docentas A. Raudeliūnas žinomas kaip akademiko Vytauto Statulevičiaus mokinys. Jo vadovaujamas vykde vadinamųjų Markovo grandinių tyrimus, Vilniaus universitete dèste aukštąą algebrą ir algebrinę skaičiu teoriją. 1965-1974 m. buvo Vilniaus universiteto Matematikos ir mechanikos fakulteto dekanu. Nuo $1971 \mathrm{~m}$. A. Raudeliūnas dirbo universiteto Taikomosios matematikos katedroje, skaite matematinę analizę ir tikimybiu teoriją fizikams $[2.15$, p. 57,383$]$. KPI vakarinio fakulteto Vilniaus skyriuje A. Raudeliūnas skaitè paskaitas arba vede pratybas visų trijų specialybių skyriaus studentams.

Aukštosios matematikos paskaitas skaitè ir pratybas vede dar vienas VU matematikas - P. Rumšas, 1954-1960 m. dirbęs Vilniaus universiteto Geometrijos katedroje, o nuo $1960 \mathrm{~m}$. - Matematinès analizès katedroje. VU jis desste matematinę analizę ir matematikos dèstymo metodiką. Vykde lietuviškų matematikos vadovelių ir matematikos terminų istorijos tyrimus [2.14, p. 208-209], yra matematikos vadovèlių aukštosioms mokykloms bendraautoris. Pažymètinas tris kartus išleistas „Trumpas aukštosios matematikos kursas", išspausdintas 1963, 1969 ir 1976 metais [2.16, p. 56-57].

Mašinų gamybos technologijos specialybès studentams bendrosios chemijos, o paskui ir chemijos paskaitas skaite bei laboratorinius darbus vede M. Priluckaja.

Lietuvai tamsiais okupacijos ir stalininio teroro metais $1944 \mathrm{~m}$. rugpjūtį M. Priluckajos vyras $\operatorname{VKP}(\mathrm{b})$ CK buvo atsiųstas i Lietuvą eiti Lietuvos komunistu partijos sekretoriaus pareigas. Gruodžio menesi i Lietuvą atsikrauste ir jo šeima. Marija Priluckaja nuo 1945 m. sausio įdarbinama partijos Vilniaus miesto komiteto Pramones skyriaus instruktore. Nuo rugsëjo $1 \mathrm{~d}$. ima direktoriauti Vilniaus 6-ojoje mergaičiu gimnazijoje. Po trejų metų atleidžiama ir ima desstyti chemiją Vilniaus geležinkelių technikume. Nuo 1950 m. skiriamas Vilniaus tarybinès prekybos technikumo direktore, bet jau po poros ménesiu pereina i Vilniaus universiteto Organinès chemijos katedrą. Nuo $1956 \mathrm{~m}$. rugsejo $1 \mathrm{~d}$. pradejo dirbti KPI Vakarinio fakulteto Vilniaus skyriuje atraeilininke [2.17, p. 1-84]. 1959 m. ji tapo chemijos mokslų kandidate, o 1960 m. - docente.

Pramonés ir civilinès statybos specialybes studentams bedrosios chemijos ir chemijos dalykų paskaitas skaite ir laboratorinius darbus vede R. Stonyte. Ši chemikè organike kartu su kitais VU Organinès chemijos katedros mokslininkais tyre biologiškai svarbių medžiagų fizikines ir chemines savybes [2.15, p. 224-225].

Braižomosios geometrijos paskaitas visų trijų specialybių studentams skaite ir pratybas vedè žinomas architektūros istorikas inžinierius architektas docentas Eduardas Budreika. Jis 1944-1947 m. buvo Šiaulių miesto vyriausiuoju architektu. Paskui visą laiką dirbo Vilniaus dailes institute (dabar akademija). 1951-1961 m. E. Budreika buvo VDI Architektūros kompozicijos ir projektavimo katedros vedeju. $1965 \mathrm{~m}$. jis tapo habilituotu architektūros mokslų daktaru, dar po metų - profesoriumi. Paraše porą knygų apie Lauryną Gucevičių, apie sovietinès Lietuvos architektūrą ir kt. [2.18, p. 298-299; 2.6, p. 244].

Germanistè Irina Vladimirovienè dèste vokiečiu kalbą. Senajame universitete ji dirbo jau nuo 1947 m. 1958 m. kartu su 
E. Vengriene ir R. Topper parenge ir išleido Vokiečių kalbos gramatiką [2.15, p. 39].

Anglų kalbą dèste Lëja Sereiskytè. Déste tik vienerius mokslo metus, nes jau nuo 1957 m. persikèle gyventi i Lenkiją.

TSKP istoriją visų trijų specialybių studentams deste Nina Nikolajeva. Stalino laikais visa šios partijos istorija tilpo i „Trumpą VKP(b) istorijos kursą“. Kai 1953 m. rugsejo mènesi komunistų partijos pirmuoju sekretoriumi buvo išrinktas Nikita Chruščiovas, sovietinèje imperijoje prasidejo tam tikros permainos. Keitesi ir TSKP istorijos turinys. Studentai daugiausia laiko turëjo skirti XX TSKP suvažiavimo nutarimams apsvarstyti. KPI Vakarinio fakulteto Vilniaus skyriaus studentams įkyriai kale į galvas, kad jie, „tape aukštai kvalifikuotais inžinieriais, savo žiniomis, savo patyrimu ir pasiaukojančiu darbu prisides prie didingos komunizmo statybos mūsu šalyje“ [2.20, p. 2].

Tačiau 1956 metai įejo i pasaulio istoriją ne kaip „didingos komunizmo statybos“ metai, bet kaip sovietinés imperijos žiauraus susidorojimo su Vengrijos Respublika, bandžiusia išsivaduoti iš komunistinio lagerio gniaužtų, metai. Vengrijos ịvykiai turèjo stiprų rezonansą ir Lietuvoje, taip pat ir aukštosiose mokyklose.

Chruščiovinis atlydys buvo suteikęs daug vilčių, kad sovietijoje, o kartu ir Lietuvoje imanomos pozityvios permainos. Po truputi buvo eliminuojamas iš gyvenimo Stalinas, paleidžiama nemažai iš kalejimų ir konclagerių politinių kalinių, dalis jų reabilituojami. Ima grįžti iš Sibiro tremtiniai, įmonese ir įstaigose pradèta „apsivalyti“ nuo neraštingų ateivių, jose ryškiai silpnëja partinès organizacijos itaka. Bet krašto demokratejimas truko neilgai. Stalinistų įtaka vèl padidejo, kai sovietiniai tankai sutrype Vengrijos revoliuciją.

Pavasario semestre KPI Vakarinio fakulteto Vilniaus skyriuje visų trijų specialybiu studentams toliau buvo destoma aukštoji matematika, chemija, užsienio kalba ir TSKP istorija, ir du nauji dalykai: fizika ir braižyba. Pirmųjų minètų dalykų déstytojai buvo tie patys, kaip ir rudens semestre. Fizikos paskaitas skaite ir laboratorinius darbus vede Aldona Bilkytė, o braižybą dèste Eduardas Budreika ir Gintautas Vasionis.

Aldona Bilkytè-Kazlauskienè 1964 m. tapo fizikos ir matematikos mokslų kandidate, apgynusi disertaciją „Tirpiklio ir temperatūros poveikis karotino ir vitamino A elektroniniams spektrams“. Déstydama KPI VF
Vilniaus skyriuje, pagrindines pareigas ëjo Vilniaus universitete (dirbo 1953-1993 m.). Nuo 1970 m. - docente. Paskelbè mokslinių straipsnių molekulinès spektroskopijos klausimais, išleido metodinių leidinių ir kt. [2.21, p. 39].

Gintautas Vasionis 1954 m. baigè KPI Mechanikos fakultetą ir gavo mašinų gamybos inžinieriaus diplomą. Dirbo vyriausiuoju mechaniku Vilniaus specializuotoje mechanizuotų darbų valdyboje, nuo 1956 m. - Vilniaus grąžtų gamykloje. Nuo 1957 m. vasari pradejo destyti KPI VF Vilniaus skyriuje kaip valandinis déstytojas.

Nuo 1956-1957 mokslo metų pradžios sovietinèse aukštosiose mokyklose įsigalejo naujas destytojų skaičiaus nustatymo principas - pagal vidutinį studentų skaičių, tenkantį vienam dèstytojui. Iki tol aukštųjų mokyklų destytojų darbo matas buvo pagal mokslo planus atidirbtas valandu skaičius. Reforma turejo įtakos Vilniaus skyriaus dèstytojų darbui, nors visi jie ejo tik antraeiles pareigas. Dèl to sumažejo atlyginimai.

KPI VF Vilniaus skyriaus būsimiems pirmosios laidos absolventams aukštesniuose kursuose paskaitas skaite dèstytojai iš Vilniaus universiteto, Pedagoginio instituto ir specialistai iš Vilniaus gamybinių įmonių, projektavimo bei statybos organizacijų. Déste ir KPI dèstytojai, važinëjantys iš Kauno į Vilnių.

Dèstytojų gretos kasmet didejjo. Nuo 1956 m. rudens iki 1962 m. pavasario semestrų imtinai būsimiesiems visų trijų specialybiu pirmosios laidos absolventams vien paskaitas skaitè 61 desstytojas. Todel toliau minésime ir aptarsime tik paskaitas skaičiusius dèstytojus, kurie savo darbais paliko ryškesnius pèdsakus skyriaus, fakulteto ir pagaliau KPI Vilniaus filialo veikloje.

Antrame kurse destęs fiziką Alfonsas Misiukas-Misiūnas Vilniaus universitete èjo pagrindines docento pareigas. Jis priklause Bendrosios fizikos katedrai jau nuo 1944 m. Vadovaujamas įžymaus fiziko P. Brazdžiūno A. Misiūnas parengè ir 1949 m. apgyne fizikos ir matematikos mokslų kandidato disertaciją „Cu-Al kieto tirpalo elektrinè varža“. Nuo 1951 m. - docentas. Ilgainiui jis tapo Astronomijos ir plazmos fizikos katedros vedeju (1971-1974), Astronomijos ir kvantinès elektronikos katedros vedeju (1974-1978). Jo mokslinių tyrimų sritis buvo eksperimentine spektroskopija. Dar 1937 m. apdovanotas Lietuvos Respublikos 4-ojo laipsnio Gedimino ordinu [2.21, p. 29].

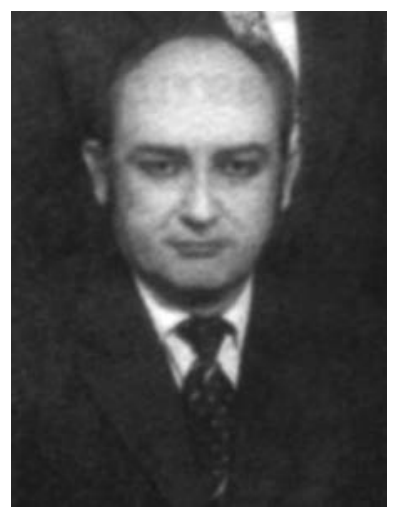

G. Vasionis

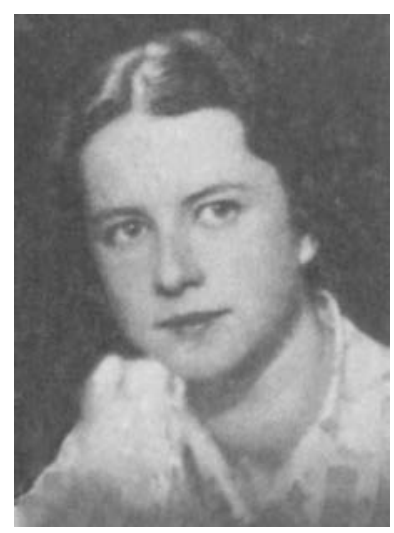

I. Vladimiroviené

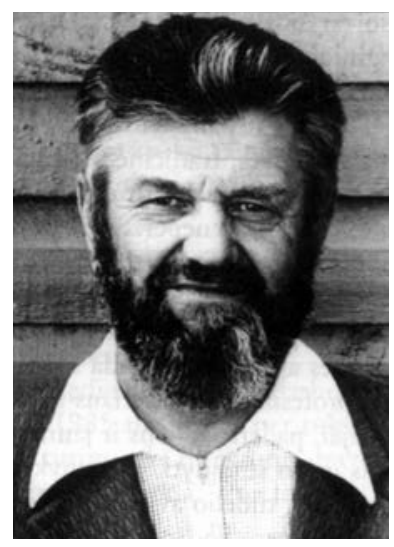

A. Speičys 
TECHNIKOS

STUDIJŲ PRADŽIA

VILNIUJE

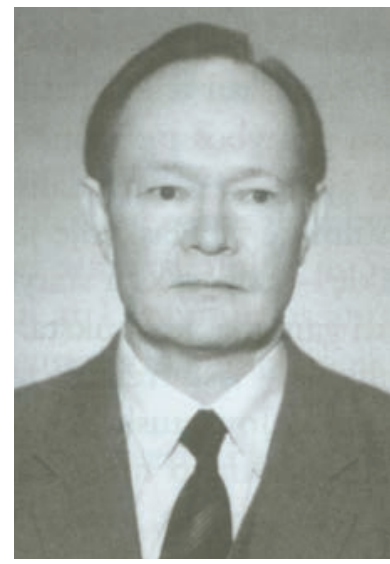

A. Jovarauskas

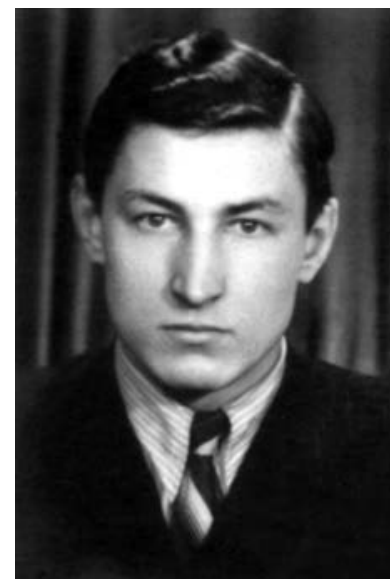

A. V. Gap̌̌ys

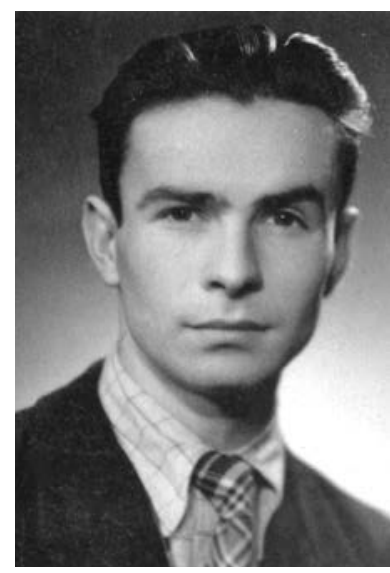

A. Kuzmickas
Nuo 1957-1958 mokslo metų rudens semestro mašinų gamybos technologijos specialybés studentams metalų technologiją dèste Anatolijus Speičys, vienas žymiausių tuo metu gamybos vadovu.

A. Speičys buvo baigęs KPI, 1955-1957 metais dirbo Vilniaus grąžtu gamyklos vadovu, paskuio porą metų - Liaudies ūkio tarybos Mašinu gamybos valdybos viršininku. Vèliau buvo Ślifavimo staklių gamyklos, Eksperimentinio metalo pjovimo stakliu mokslinio tiriamojo instituto Vilniaus filialo direktoriumi ir t. t. A. Speičys garsëjo ne tik kaip geras specialistas, talentingas gamybos organizatorius, bet ir tiems laikams svariais patriotiškais veiksmais. Jis skatino jaunus specialistus lietuvius stoti i partiją, kad vadovaujančiųjų gamybos vietų neužimtų „,ivanai“, leido Baltijos laivų statyklos lěšmis statyti Klaipedoje kultūros rūmus, agitavo baigusiuosius KPI važiuoti į Vilnių - lietuvinti mūsų sostinę. Kalbama, kad A. Speičio paskaitų kontekste buvo atpažistamos jo tikrosios politines ir tautinès nuostatos [2.22, p. 40, 52, 56, 68, 249-250].

Tuo pat metu TSKP istoriją dèste Vilniaus universiteto Visuomenés mokslu (1953-1990) katedros vedejas Konstantinas Navickas. Vilniaus universiteto to meto, kaip dabar vadintume, politologai buvo neatsiejami su totalitarine ideologija, daugelis ju aršiai „kovojo“ su keliaklupsčiautojais prieš Vakarų kultūrą, sovietinių laimèjimų menkintojais. Tai ju paslaugomis universitete buvo susidorota su daugeliu iškilių Lietuvos mokslo ižymybių.

Nuo 1958 m. pavasario KPI Vakarinio fakulteto Vilniaus skyriuje teorines mechanikos kurso paskaitas skaitè Aleksandras Čyras. Su jo vardu siejamos ilgainiui vykusios mokyklos permainos.

A. Cyras su pagyrimu $1950 \mathrm{~m}$. baige Vytauto Didžiojo universiteto Statybos fakultetą. Studijavo aspirantūroje ir $1954 \mathrm{~m}$. apgyne disertaciją technikos mokslų kandidato laipsniui gauti. Dirbo KPI Statybines mechanikos katedroje. $1958 \mathrm{~m}$. pavasarị èmé dirbti ir neetatiniu destytoju KPI Vilniaus skyriuje. Nuo $1958 \mathrm{~m}$. rugsejo $1 \mathrm{~d}$. jau perkeltas ị Vilniaus skyrių. A. Čyras - pirmasis etatinis destytojas KPI Vakarinio fakulteto Vilniaus skyriuje, ejęs pagrindines pareigas.
Nuo rudens ėmè skaityti medžiagų atsparumo kursą. 1960 m. rugpjūčio 1 d., ịsteigus KPI Vilniaus fakultetą, A. Čyras buvo paskirtas šio fakulteto dekanu [2.23, p. 49, 59].

Nuo 1959 m. pavasario Teorinę mechaniką dèste Borisas Voronkovas, žinomo šio dalyko vadovelio (1961 m.) autorius.

Nuo 1958-1959 mokslo metų rudens semestro Vilniaus skyriuje bendrąją elektrotechniką èmé desstyti Albinas Jovarauskas. A. Jovarauskas, baigęs KPI Elektronikos fakultetą, dirbo „Inkaro“ fabrike inžinieriumi elektriku, paskui - Elektros suvirinimo gamykloje. Vèliau dirbo Plano komisijos Mašinų ir prietaisu pramonés skyriaus vedëju. Jis priskiriamas daug nusipelniusių Lietuvos pramonei žmonių kategorijai. A. Jovarauskas daug nusipelnè plètodamas mašinų ir prietaisų gamybos pramonę Lietuvoje. Tai jis sugebejo įtikinti Maskvą, kad Lietuva gamintų ypač tikslią ir brangią produkciją - tai mūsų kraštui buvo naudinga. Reikšmingesnei A. Jovarausko karjerai, matyti, kenke tai, kad žmonos tévai buvo tremtiniai [2.22, p. 70].

Mašinų mechanizmų teoriją dèste inžinieriai Algimantas Gapšys ir Antanas Kuzmickas. Pastarasis dèste dar ir mašinų detalių kursą.

Algimantas Gap̌̌ys 1950 m. baigè KPI. Porą metų dirbo Kauno motoru remonto gamyklos inžinieriumi technologu. 1955$1959 \mathrm{~m}$. dèste KPI Mechanikos fakultete ir dirbo fakulteto prodekanu, nuo $1959 \mathrm{~m}$. iki 1961 m. - Šlifavimo staklių gamykloje.

A. Gapšys nuo 1959 m. iki 1980 m. kaip antraeilininkas deste mašinų ir mechanizmų teoriją. $1961 \mathrm{~m}$. buvo paskirtas naujai issteigto Metalo pjovimo staklių mokslinio tyrimo instituto filialo vyr. inžinieriumi, o nuo 1967 m. iki 1997 m. dirbo jo ir eksperimentines gamyklos „Precizika“ direktoriumi.

Antanas Kuzmickas - inžinierius mechanikas, $1950 \mathrm{~m}$. baigęs KPI, kurị laiką ten dèste. 1958-1978 m. dirbo Šlifavimo staklių gamyklos vyr. inžinieriumi. Yra vadovélių, mokomųjų priemonių autorius. Daug metų buvo VISI (vèliau - VGTU) Mašinų gamybos katedros docentu. Jis dèste mašinų detalių ir metalo pjovimo staklių dalykus.

Būsimiesiems statybų inžinieriams statybinių medžiagų kursą nuo $1958 \mathrm{~m}$. skaitè Ipolitas Nickus, iš pradžių dirbęs antraeilininku, ilgainiui daug metų susiejo savo darbinę veiklą tik su VGTU. I. Nickus 1952 m. baigè KPI Cheminès technologijos fakulteto silikatų technologijos specialybę. Baige aspirantūrą Sverdlovske ir 1956 m. apgyne 
technikos mokslų kandidato disertaciją. Dirbo Pramonès gamybos katedros vedeju Vilniaus aukštojoje partinëje mokykloje, o nuo 1961 m. - KPI Vilniaus filiale.

Dar vienas įsimintinas skyriaus déstytojas - Pranas Vaičys, destęs tuomet elektrotechniką pramonés ir civilines statybos specialybès studentams. P. Vaičys 1951 m. baige KPI Elektrotechnikos fakultetą. Pradžioje dirbo „Pašto děžuteje“ Nr. 6, paskui - Vilniaus šiluminèje elektrinëje. 1959 m. kaip antraeilininkas ème destyti KPI Vakarinio fakulteto Vilniaus skyriuje, o nuo $1960 \mathrm{~m}$. dirbo etatiniu vyr. destytoju.

Patyrę gamybininkai ir destytojai dèstè pramoninès ir civilinès statybos specialybès studentams. Pirmiausia tai Vytautas Kriščiūnas ir Stasys Vabalevičius.

Vytautas Kriščiūnas 1938 m. baige Vytauto Didžiojo universitetą ir gavo statybos inžinieriaus diplomą. Daug metų dirbo projektavimo darbus, buvo projektavimo instituto vyriausiuoju konstruktoriumi, kurị laiką - statybos ministro pavaduotoju. Nuo 1951 m. deste Vilniaus dailes institute. 1957 m. apgyne technikos mokslų kandidato disertaciją, pradejjo dèstyti valandininku KPI Vakarinio fakulteto Vilniaus skyriuje. 1959 m. V. Kriščiūną išrinko VDI Statybos ir inžinerinès matematikos katedros vedëju, bet jau 1960 m. V. Kriščiūnas šių pareigu atsisake ir perëjo dirbti į tik ką issteigtą KPI Vilniaus vakarinį fakultetą bei tapo Statybos katedros vedeju [2.24, p. 12-44].

Stasys Vabalevičius 1936 m. baigè Prahos aukštąją technikos mokyklą ir igijo in- žinieriaus hidrotechniko išsilavinimą. Daug prisidejo prie Lietuvos vandentiekio pletotes. Po karo buvo Kauno universiteto Sanitarijos katedros vedeju, Statybos fakulteto dekanu. Išleido vadovèli „Vandentiekis ir kanalizacija“"(1954 m.). Nuo 1955 m. buvo Statybos ir architektūros reikalų komiteto pirmininku, nuo 1956 m. - LMA nariu korespondentu. Pagarsèjo drąsa pradèti Trakų ir Biržų pilių regeneraciją, eliminavo iš pareigų nemokšas ateivius. Buvo apkaltintas nacionalizmu, šovinizmu ir atleistas iš pirmininko pareigų. Nuo 1962 m. - KPI profesorius [2.25, p. 29-31].

Čia aptareme iškiliausius destytojus, dirbusius KPI Vakarinio fakulteto Vilniaus skyriuje ir vèliau - Vilniaus vakariniame fakultete. Be jų, minetini skaitę paskaitas: Vladas Vitkauskas - geodezijos, Karajakovskis - matematikos, Gulbinas - bendrosios šiluminès technikos, Edmundas Laucevičius - anglu kalbos, Ancevičius ir Šustavičius - politinès ekonomijos, Bytautas ir Č. Gerliakas - architektūros, V. Pranaitis - inžinerinès geologijos, A. Kudzys - statybinių konstrukciju ir kt. Pastarieji du daug nuveike Vilniaus aukštosios technikos mokyklos labui, bet apie tai - kituose skyriuose.

Taigi iš pateiktos medžiagos matyti, kad dauguma KPI Vakarinio skyriaus destytojų buvo kompetentingi savo srities specialistai, turintys praktinio darbo patyrimą. Daugelis ju jau turejo mokslinius laipsnius ir mokslinius vardus arba renge disertacijas, todèl, galima manyti, jų paskaitų mokslingumas buvo deramo lygio.

\section{KPI Vakarinio fakulteto Vilniaus skyriaus performavimas $i$ Vilniaus vakarini fakulteta}

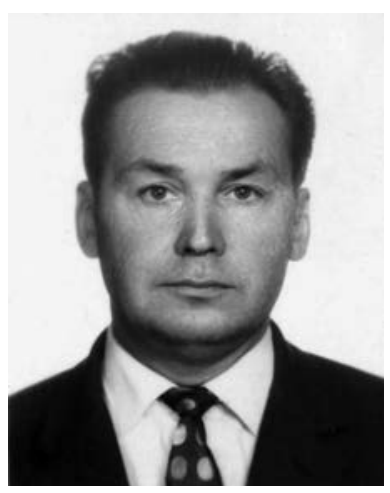

I. Nickus

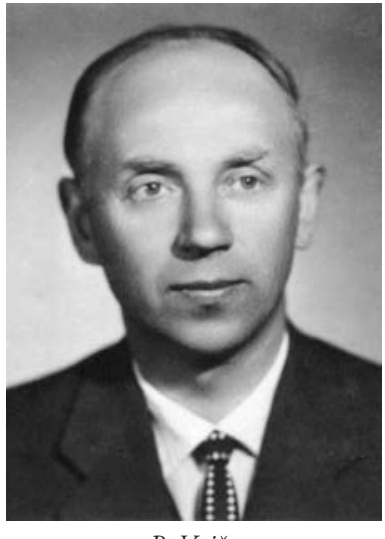

P. Vaičys

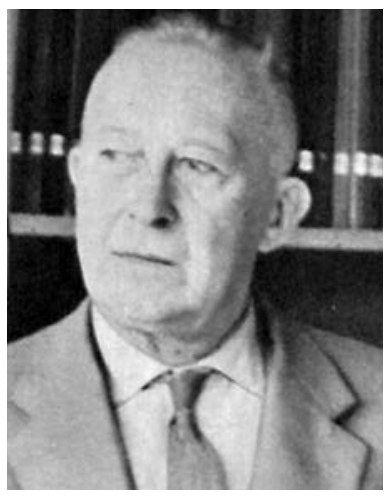

S. Vabalevičius

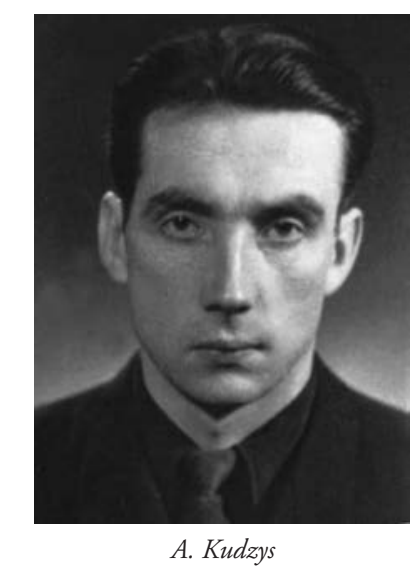

A. Kudzys
1960 m. sausio 5 d. KPI direkcijos posedyje buvo svarstomas perspektyvinis 15 metu veiklos planas. Pagrindinị pranešimą skaite mokymo reikalų direktoriaus pavaduotojas doc. M. Martynaitis. Jis, remdamasis iš fakultetu gauta medžiaga, teigè, kad yra ịvairių nuomonių dèl KPI pobūdžio, dèl politechnikumo prijungimo ir savo gamyklos, dèl instituto miestelio statybos ir kt.

M. Martynaitis sake, kad tikslinga steigti inžinierių tobulinimo, Vilniaus vakarinị, Klaipedos ir Šiaulių trejų metų bendruosius inžinerijos fakultetus. Jo manymu, ì vakarinị ir neakivaizdinị skyrius reiketu priimineti visus, išlaikiusius egzaminus, ir t. t. [2.26, p. 164].

İdomu pažymeti, kad vasario $15 \mathrm{~d}$. direkcijos posedyje prof. $\mathrm{K}$. Baršauskas praneše apie tai, kad architektūros specialybę norima perduoti Dailes institutui, bet KPI direkcija su tuo nesutinkanti [2.27, p. 177v].

Kovo $21 \mathrm{~d}$. posèdyje vèl kalbèta apie vakarinių skyrių darbą. Direktorius prof. K. Baršauskas informavo posedžio dalyvius, kad Vilniaus vakariniam skyriui žadami Pedagoginio instituto rūmai, kad siūloma steigti Kaune 
TECHNIKOS

STUDIJŲ PRADŽIA

VILNIUJE

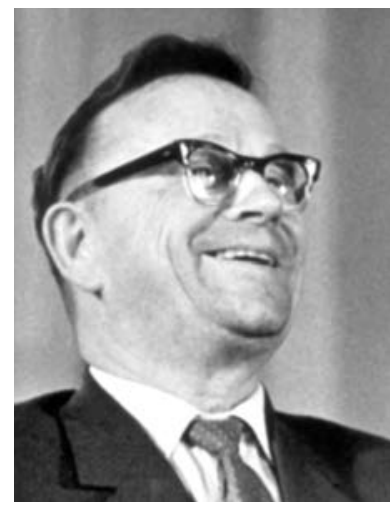

K. Baršauskas

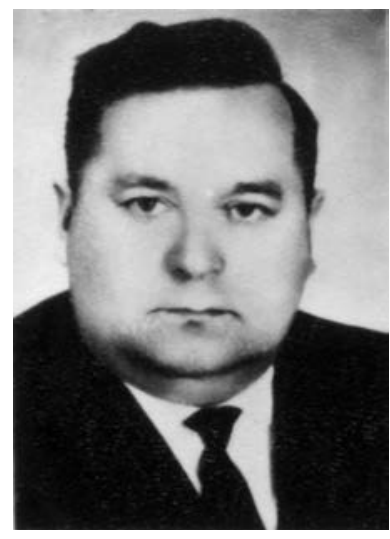

M. Martynaitis bendrąjį inžinerijos fakultetą, kuris gal steigtinas Vilniuje, o gal, be to, ir Šiauliuose.

Kovo $25 \mathrm{~d}$. KPI tarybos posedyje direktoriaus pavaduotojas doc. M. Martynaitis praneše, kad perduodamuose Vilniaus skyriui Vilniaus pedagoginio instituto rūmuose yra 80 klasių, kurių dalị būtų galima panaudoti bendrabučiui [taigi jau ruošiamasi steigti dienines studijas - aut. past.], ir išreiške nuomonę, kad Vilniuje steigtinas Bendrasis inžinerijos fakultetas, o esamas Vakarinis skyrius turètų būti pavadintas fakultetu (čia mokymo dalies vedeja M. Žitnikoviené patikslino, kad Vilniaus skyrius taip oficialiai ir vadinamas), o prie to fakulteto galètų būti bendrasis mokslo skyrius.

M. Martynaitis sakè, kad Vilniaus fakultete issteigtinos 4 katedros: Visuomeninių moksly ir kalbų (4 personalo nariai), Mechanikos (5 nariai), Elektrotechnikos su matematika ir fizika (4 nariai) ir Statybos (4 nariai), kurioms atatinkami fakultetai turi numatyti vedëjus.

Doc. N. Milenskis siūlè atitinkamą Vilniaus fakulteto katedrą pavadinti Taikomosios mechanikos katedra [2.28, p. 183-184].

KPI vadovų demesys vakarinių skyrių darbui vis didejo. Tai rodo, kad vos ne kiekviename direkcijos posedyje buvo kalbama vakarinių studijų klausimais. Stebina tik, kad tuose posedžiuose nedalyvavo vakarinių skyrių vedëjai, tarp jų ir J. Kudaba.

Kauno politechnikos instituto vakariniu skyriu veikla ir perspektyvos buvo svarstomos $1960 \mathrm{~m}$. kovo $25 \mathrm{~d}$. instituto Mokslines tarybos posedyje, ị kurị jau buvo pakviesti ne tik visu KPI vakarinių skyriu vedejai, bet ir neseniai isteigto LTSR Ministru Tarybos Valstybinio aukštojo ir specialiojo vidurinio mokslo komiteto Aukštụjų mokyklų valdybos viršininkas Henrikas Zabulis.

Pranešimą skaite KPI mokymo reikalų direktoriaus pavaduotojas doc. Marijonas Martynaitis. Jis pranešé, kad keturiuose miestuose veikiančiuose KPI vakariniuose skyriuose studijuoja 1224 studentai, o pagal priemimo kontingentus turètu mokytis 1385 . Esąs didelis nubyrëjimas - vien priimtųjų nuo $1959 \mathrm{~m}$. rugsejo $1 \mathrm{~d}$. į I kursą nubyrejo $6 \%$.

Prelegentas pažymëjo, kad didelis skaičius - net 80 žmonių - dirba ne pagal specialybę. Žemas pažangumas: apie $50 \%$ studentu gauna nepatenkinamus pažymius. Svarstymo dieną apie 250 studentų turi skolų.

Doc. M. Martynaitis išdèstè tokios nenormalios padèties priežastis: 1 . sunku studijas derinti su darbu; 2. neišnaudojamos visos teikiamos lengvatos; 3 . dalis destytoju neatitinka reikiamų kvalifikacijų; 4. studiju procese trūksta paskaitų ir seminarų; 5. vakarinių skyrių desstytojai stokoja metodinès paramos; 6. silpna materialinè baze, nèra braižyklų.

Pranešime pažymèta, kad „Per mažai rüpinamasi Vilniaus skyriumi, kuris išaugo i dideli kolektyva". M. Martynaitis pabreže, kad Vilniaus skyrius greitu laiku dar gerokai išaugs, ir jị reikia performuoti į Vakarinị fakultetą su Bendruoju inžinerijos skyriumi, įsteigti 4 katedras: Visuomeninių mokslų ir kalbu, Taikomosios mechanikos, Statybos ir Elektrotechnikos. Jis sake, kad „Yra vilties gauti Vilniaus skyriui dabartinius Pedagoginio instituto rümus. Ten bus pakankamai auditoriju, braižyklu, teks isteigti bibliotekos filiala, bus vietos bendrabuciui, galima bus pagalvoti apie apmokyma pamainomis" "* $^{\circ}$.

Doc. M. Martynaitis informavo Tarybos narius, kad Vilniaus vakariniame skyriuje numatoma įsteigti metalotyros laboratoriją ir kt.

Dalyvavęs Mokslinès tarybos posedyje Vilniaus vakarinio skyriaus vedejas J. Kudaba kalbëjo apie žemą studentų pažangumą ir nurodè tokias priežastis: „Lietuviu grupems nera konkurso, o i gamyba ëjo tie, kurie savo laiku, būdami silpniau už kitus pasiruoše, negalëo ¿ aukštaja mokykla istoti; nera laboratoriju; saltos, tamsios ir išmetytos patalpos; nera specialios bibliotekos, o esamose bibliotekose nera techniškos literatūros; jauni, nepatyre, ǐsskyrus kelis, destytojai; $j u$ valandinis darbas; stoka vaizdiniu priemoniu; nesuvienodinti bendru disciplinu mokymo plana".

Direktorius K. Baršauskas pritare siūlymui Vilniuje vakarini skyriu performuoti i vakarini fakultetą su 4 katedromis ir 20 etatinių darbuotojų. Jis „pabrěže didele dr. Kudabos pagalba institutui, organizuojant Vilniuje vakarini skyriu" [2.29, p. 213-215].

Bet Mokslines tarybos posedžio nutarimas svarstytu klausimu kiek minorinis. Pateikiame šio nutarimo dalis, susijusias su KPI Vakarinio fakulteto Vilniaus darbu:

* Čia ir toliau cituojamu dokumentu kalba netaisyta 
„Vakariniu skyriu veikloje yra nemažai trūkumu. Vakarininose skyriuose, išskyrus Kauno, dalis destytoju neturi reikiamo pedagoginio patyrimo, todel kai kurie ǔsiemimai pravedami nepakankamu lygiu. Nepaisant to, kad Vilniaus skyriuje is dangelio disciplinu jau yra reikiamas apkrovimas etatiniams destytojams sukomplektuoti, daugelis destytoju dirba už valandini atlyginima ir todel negali mokomajam procesui skirti tiek demesio, kiek jam skiria etatiniai destytojai. Mechanikos, Statybos ir Elektrotechnikos fakultetu dekanatai, Vilniaus vakarinio skyriaus vedejas, profiliuojančios katedros ir destytojai neskiria pakankamai demesio tam, kad studenty mokymasis būtu labiau suderintas su ju gamybiniu darbu: dar labai mažai yra realiu diplominiu ir kursiniu projektu užduočiu, tiesiogiai susiety su tomis imonemis, kuriose dirba studentai. Vakariniuose skyriuose žemas akademinis pažangumas <...>

Šiu trūkumu priežastis yra ta, kad atitinkamu fakultetu dekanai, skyriu vedejai, katedru vedëjai per mažai rüpinasi vakariniu skyriu studentu mokymusi. Instituto katedros teikia pernelyg maža metodine pagalba kituose miestuose esančiu skyriu atitinkamu disciplinu destytojams.

Vakariniu skyriu darbą labai apsunkina ju nepatenkinama materialine baze. Jau šz rudeni Mechanikos ir Statybos fakultetai nepajegs aprüpinti vakariniu skyriu studentu savo žinioje turimomis auditorijomis. Vilniaus skyriaus studentai naudojasi Vilniaus universiteto triju fakultetu, esanči skirtinguose miesto rajonuose, auditorijomis. Skyriuje visai nera braižyklu. Imoniu ir technikumu laboratorijos, kuriomis naudojasi Vilniaus, Klaipedos ir Šiauliu skyriai, nera pilnai sukomplektuotos, ir todel jose šiuo metu negali büti atlikti visi programu numatyti laboratoriniai darbai ".

Nutarime sakoma:

„8. Ipareigoti vakariniu skyriu vedejus ir fizikos, neorganines chemijos, statybines mechanikos, šiluminiu varikliu, metalu technologijos, inžineriniu konstrukciju, statybos darbu organizavimo, pramones imoniu elektros i̇rengimu, radiotechnikos, mašinu gamybos technologijos, odos ir tekstiles gaminiu technologijos katedru vedëus iki s. m. balandžio 10 d. sudaryti sarašus jirengimu ir prietaisu, kuriais reikia papildyti atitinkamu Vilniaus, Klaipedos ir Siauliu mokyklu bei imoniu laboratorijas, kad jose galima būtu pravesti visus programy nustatytus laboratorinius darbus, ir pateikti pasiūlymus dèl KPI laboratoriju steigimo vakariniuose skyriuose.

9. Prašyti LTSR MT Aukštojo ir specialiojo vidurinio mokslo komiteta:

a) nuo nauju mokslo metu performuoti Vilniaus vakarini skyrim $\dot{i}$ vakarini fakultetg. ir isteigti prie jo bendrainžinerini skyriu;

b) Vilniaus vakariniame fakultete isteigti 4 katedras: visuomeniniu mokslu, taikomosios mechanikos, elektrotechnikos ir statybos;

c) išskirti Vilniaus vakariniam fakultetui senas Vilniaus Pedagoginio instituto patalpas (Gorkio g-veje);

$<\ldots>$

g) pradedant šiais metais, parüpinti per Vilniaus miesto vykdomaji komiteta butus destytojams, perkeliamiems iš Kauno" [2.29, p. 216].

Nutarimo preambuleje pažymèta, kad KPI vakariniuose skyriuose studijuoja 1224 studentai: Kaune - 698, Vilniuje - 391, Klaipedoje -75 ir Šiauliuose -60 .

Kaip matyti, nutarime tiesiogiai pabrěžti Vilniaus vakarinio skyriaus vedejjo darbo trūkumai. Tai jau buvo jo pakeitimo preliudija. Šiame posedyje dalyvavo ir pirmasis Vilniaus skyriaus etatinis destytojas docentas Aleksandras Čyras. Jis kalbejo apie Vilniaus vakarinio fakulteto Mechanikos katedros pavadinimo patikslinimą. Daugelis nesunkiai suvoke, kad kalba būsimasis to fakulteto dekanas.

1960 m. balandžio 18 d. KPI direkcijos posedyje direktoriaus pavaduotojas ūkio ir administracijos reikalams Henrikas Petrusevičius supažindino posedžio dalyvius su parengtu Ministrų Tarybos nutarimo projektu, kuriame pasakyta ir apie Vilniaus skyriaus reikalus: "perduoti Kauno politechnikos institutui Vilniaus pedagoginio instituto rūmus $<\ldots>$, ipareigoti Vilniaus, Šiauliu ir Klaipedos vykdomuosius komitetus aprūpinti instituto filialu personala butais" [2.30, p. 193v].

Negalima nepaminèti reikšmingo indèlio, kuriant KPI vakarinį Vilniaus skyrių, fakultetą ir galop filialą, puikaus KPI ūkio ir finansu administratoriaus, direktoriaus pavaduotojo Henriko Petrusevičiaus (19161996). Šis nuostabus žmogus nuoširdžiai rūpinosi sostinëje besikuriančios aukštosios technikos mokyklos reikalais. H. Petrusevičius studijavo VDU Teisių fakulteto ekonomikos skyriuje. Jam buvo būdingas begalinis pareigingumas, labai aukšta, inteligentiška bendravimo su bendradarbiais ir kitais žmonèmis kultūra. Šis sumanus, talentingas labai sunkaus baro vadovas visų 


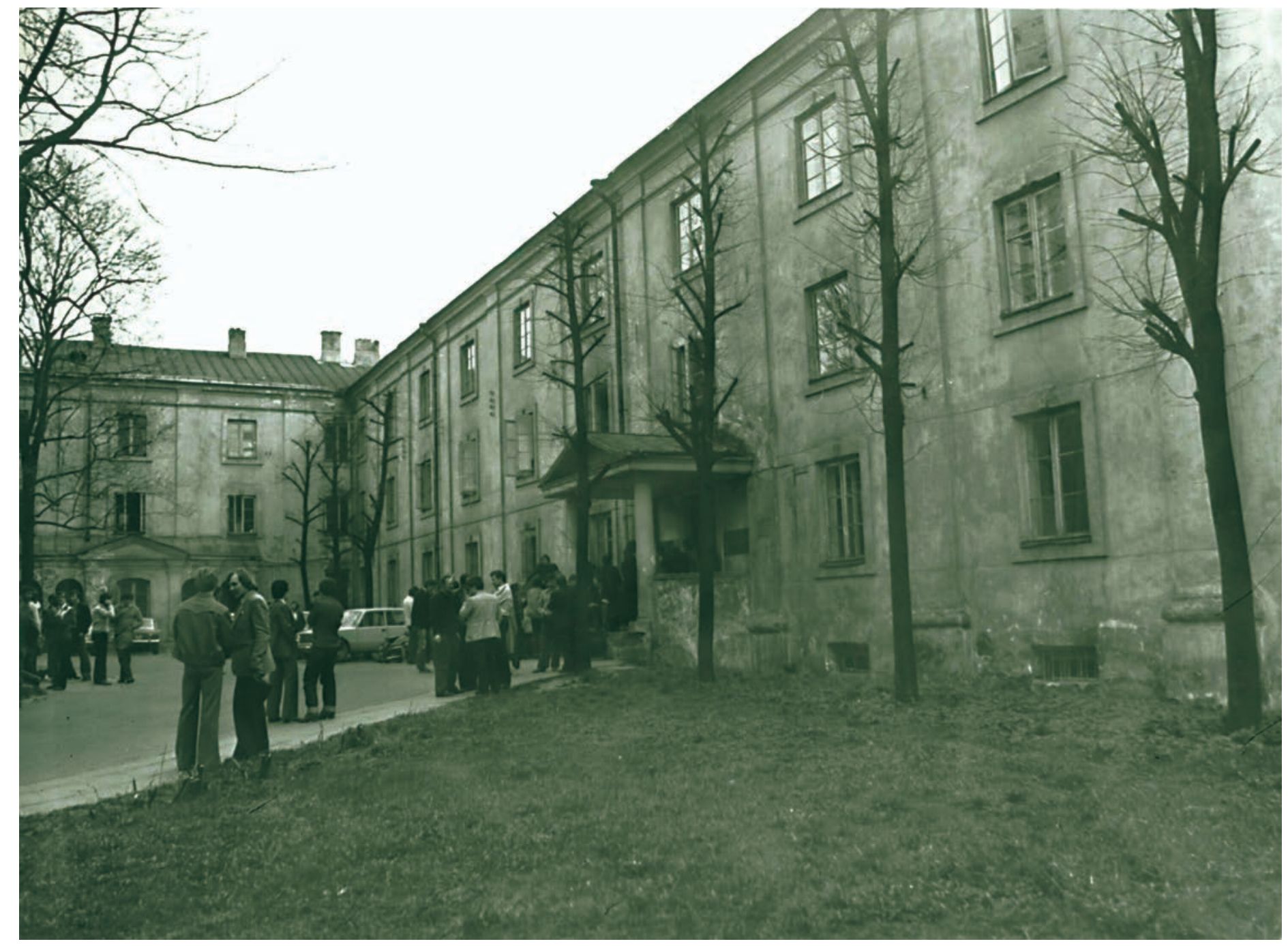




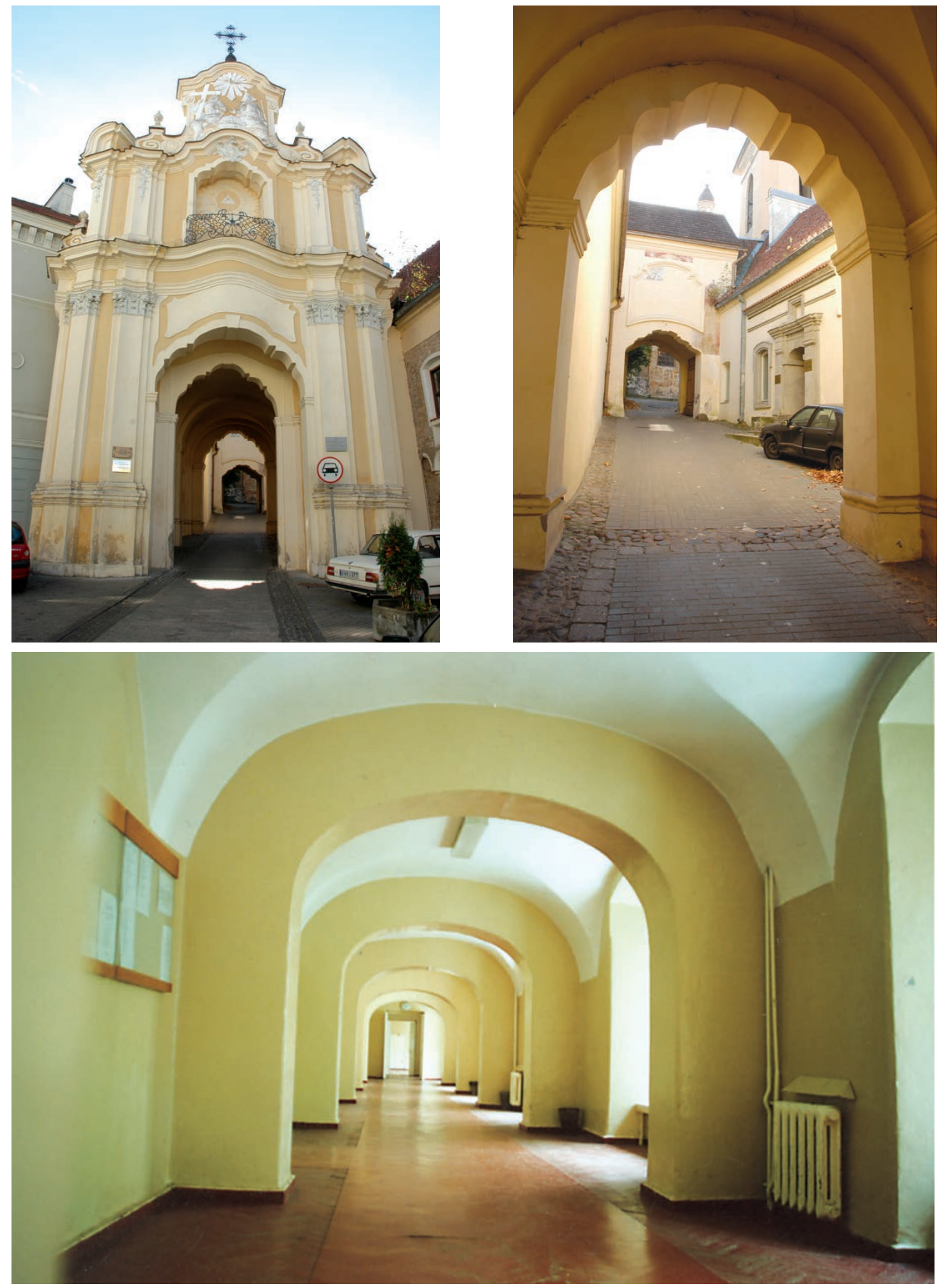


TECHNIKOS

STUDIJŲ PRADŽIA

VILNIUJE su vakariniam skyriui duotu priemimo kontingento paskirstymo projektu. Juo remiantis Kauno vakariniame skyriuje turejo studijuoti 210 , Vilniaus vakariniame skyriuje - 155, Šiaulių - 75 ir Klaipèdos - 100 žmonių [2.31, p. 3].

Nuo 1960 m. liepos 1 d. KPI Vakarinio fakulteto Vilniaus skyrius buvo perorganizuotas ị KPI Vilniaus vakarinị fakultetą [2.32, p. 57]. Fakulteto dekanu buvo paskirtas technikos mokslų kandidatas docentas Aleksandras Čyras.

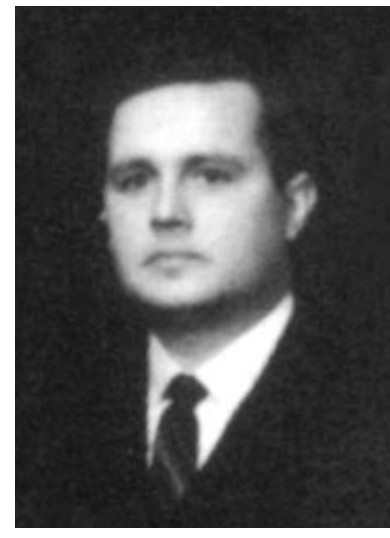

Vakarinio fakulteto dekanas A. Cyras

ji pažinojusių buvo aukštai vertinamas ir didžiai gerbiamas. Tik sovietinei santvarkai netinkama autobiografija neleido $\mathrm{H}$. Petrusevičiui pasiekti daug reikšmingesnès karjeros pakopu.

1960 m. gegužès $16 \mathrm{~d}$. KPI direkcijos posedyje buvo svarstomi naujo priemimo klausimai. Doc. M. Martynaitis supažindino

\section{KPI Vakarinio fakulteto veikla 1960-1961 mokslo metais}

Iki 1959-1960 mokslo metų pradžios KPI Vakarinio fakulteto Vilniaus skyriuje studijavo mašinu gamybos technologijos, pramonès ir civilines statybos bei pramonès įmonių elektrifikacijos specialybiu studentai. Nuo 1959-1960 mokslo mety pradèti rengti radijo aparatūros konstravimo ir technologijos inžinieriai. Kasmet ryškiai augo Vilniaus skyriaus studentu skaičius: $1956 \mathrm{~m} .-75$; $1957 \mathrm{~m} .-188$; 1958 m. - 289; 1959 m. - 396.

1960 m. vasarą Vilniaus vakariniam fakultetui buvo nustatyta priimti studijuoti ì pirmąji kursą 155 asmenis. Pažymetina, kad priemimo kontingentą paskirste jau ne Sąjungine aukštojo mokslo ministerija, o 1959 m. įsteigtas LTSR Aukštojo ir specialiojo vidurinio mokslo komitetas. Tai buvo pozityvus žingsnis, leidęs sumažinti Maskvos įtaką, pasireiškusią noru rusifikuoti studijas, krašto nacionalinių interesų nepaisymu.

Lietuvos aukštąsias mokyklas iki 1959 m. tiesiogiai valde Maskva - TSRS Aukštojo mokslo ministerija. Matyt, respublikos valdžioje buvo žmonių, supratusių, kad, norint vykdyti palankią krašto interesams aukštojo mokslo politiką, reikia į savo rankas perimti iš Maskvos nors vadžias. Botagas, žinoma, liktu Maskvoje. Bet tai teikè ir nemažai geresnių galimybių.

Dar 1956 m. Lietuvos KP CK ir Lietuvos TSR Ministrų Taryba iškele klausimą sąunginei valdžiai dèl Aukštojo mokslo valdybos prie LTSR MT sukūrimo. Chruščioviškojo atšilimo laikotarpiu buvo galima tiketis pozityvaus sprendimo. Tuo klausimu įdomi KPI direktorato narių pozicija. Apie tai randame informacijos KPI direkcijos 1957 m. sausio
$2 \mathrm{~d}$. posèdžio protokole, kai buvo svarstytas rengimasis priimti atvykstančius į Lietuvą TSRS aukštojo mokslo ministrų V. Jeliutiną ir TSKP CK atstovą Kiriliną. Jie numate susipažinti vietoje su Lietuvos aukštosiomis mokyklomis ir planavo aptarti su vietos valdžia pasiūlymą įkurti Lietuvos aukštojo mokslo valdybą.

KPI direktorius prof. K. Baršauskas nurode parengti medžiagą apie mokymo planus, specialybes, kontingentus ir priemimo taisykles, mokslinių laipsnių ir vardų suteikimo tvarką, informaciją apie instituto Mokslinès tarybos teisiu prapletimą, gamybinių praktikų bazes, vadovèlius, bendrabučiu statybą, jaunųjų specialistų skyrimą ir t. t. Tais klausimais kalbëjo dauguma posedž̌io dalyvių.

Hidrotechnikos fakulteto dekanas doc. Vytautas Klimavičius, visada teikęs prioritetus savojo krašto interesams, sakè, kad jei specialistai būtų „...ruošiami pagrinde savo respublikai, reiketu kitokiu, skirtingu nuo tipiniu, mokymo planu, nes inžinieriu profiliai tuo atveju turètu büti platesni, reiketu juesti geležinkeliu eksploatacijos specialybę".

Statybos fakulteto dekanas doc. Stasys Sčesnulevičius taip pat reiške interesą praplesti instituto teises. Jis kalbëjo apie kraštui reikalingas naujas specialybes, teisę priimti ginti disertacijas ir t. t.

Elektrotechnikos fakulteto dekanas doc. Jonas Matulionis siūlè radistų kontingentą mažinti, o didinti pramonès įmonių elektrinių įrengimų specialybès studentų skaičių, rengti inžinierius pedagogus.

Direktorius profesorius Kazimieras Baršauskas pabrěze politechninio mokymo mokyklose svarbą, būtinumą tureti respublikoje 
organą, kuris rūpintųsi gamybinès praktikos bazemis.

Ir kiti prelegentai kalbëjo rūpimais klausimais, o dauguma pabreže tai, kad Vilniuje būtų ìsteigtas „organas, kuris rūpintusi Lietuvos aukštuju mokyklu reikalais, kad jis nebūtu vien tarpininkas tarp Maskvos ir Vilniaus". Pabrěžta, kad institutas pirmiausia turi tenkinti respublikos poreikius, o i kitas respublikas siųstų tik „tam tikra ruošiamu specialistu procentą".

Bet buvo ir tokių kalbetojų, kuriems priimtinesnis atrode tiesioginis Maskvos valdymas. İdomus keletu požiūrių šių kalbètojų sąrašas.

Prieš respublikos aukštojo mokslo valdybos sukūrimą buvo nusiteikę Nikolajus Milenskis, katedrų vedejai: pulkininkas Borisas Gilduninas, Galina Liulčenko, Ivanas Trušinas. Prieš buvo ir direktoriaus pavaduotojas Marijonas Martynaitis bei instituto partinio biuro sekretorius Kazimieras Lengvinas. Visi jie turëjo ivvairių motyvų, apeliavo i „su respublikine priklausomybe susijusi pavoju, kad institutas gali susiaureti, tuo tarpu kai jis, ruošdamas specialistus ne vien savo respublikai, turèty ir toliau plestis “ [2.33, p. 43-45v].

Tokia instituto pletra, kokios vylèsi dalis kalbètojų, reiške totalinị instituto rusinimą, nes daugetuc rusakalbių grupių, $\mathrm{i}$ jas vis daugiau atvyktų studijuoti iš kitų respublikų, neabejotinai atsirastų daugiau ir rusakalbiu dèstytojų.

Dauguma posedžio dalyvių, kartu su direktoriumi prof. K. Baršausku, buvo kitos nuomonès. Jie rèmè respublikini aukštojo mokslo valdymą, tam reikalingos instancijos įsteigimą.

Praejjus daugiau nei dvejiems metams, Lietuvos TSR Aukštojo ir specialiojo vidurinio mokslo komitetas buvo įsteigtas. Komiteto (vèliau ministerijos) ilgamečiai vadovai suvaidino pozityvų vaidmenį, ugdant Vilniaus aukštąją technikos mokyklą.

Nuo 1959 m. rugsejo pradëjo veikti dar du periferiniai KPI vakariniai skyriai: Klaipedoje ir Šiauliuose. İdomu pažymèti, kad visi trys - Vilniaus, Klaipedos ir Šiaulių - KPI skyriai ilgainiui išaugo ị naujus Lietuvos universitetus.

KPI Vilniaus vakariniame fakultete buvo isteigtos trys katedros: Statybos, Elektrotechnikos ir Taikomosios mechanikos. Nuo 1960 m. birželio 20 d. vedejais atitinkamai buvo paskirti Vytautas Kriščiūnas, Stanislovas Marazas ir Borisas Liaudis.
Formuoti visų katedrų pedagogini personalą nebuvo lengvas darbas. Tai rodo $1960 \mathrm{~m}$. liepos $1 \mathrm{~d}$. KPI tarybos posèdžio medžiaga. Šiame posedyje ịvyko rinkimai katedrų pedagogų vakantinèms vietoms užimti.

Vilniaus vakarinio fakulteto etatinèms vietoms užimti konkursui buvo pateiktos 9 kandidatūros. Net keturioms etatinems vietoms užimti kandidatų nerasta, būtent: aukštosios matematikos antrajai daliai dèstyti - vyr. dèstytojo; braižomajai geometrijai ir braižybai déstyti - asistento; mechanikos disciplinoms destyti - vyr. dèstytojo ir asistento.

Konkurse etatinems vietoms užimti dalyvavo: Taikomosios mechanikos katedros vedejo, docento vietai - Borisas Liaudis; Elektrotechnikos katedros vedejo, docento vietai - Stanislovas Marazas; Statybos katedros vedëjo, docento vietai užimti - Vytautas Kriščiūnas; aukštajai matematikai dèstyti, vyr. destytojo vietai užimti - Vytautas Tulevičius; fizikai destyti, vyr. destytojo vietai užimti Hinda Gutmaniene; teorinei mechanikai dèstyti, docento vietai užimti - Antanas Rusteika; elektrotechnikos disciplinoms dèstyti, vyr. déstytojo vietai užimti - Pranas Vaičys; statybos disciplinoms déstyti, docento vietai užimti - Antanas Kudzys.

Tame KPI tarybos posedyje etatinèms vietoms užimti buvo renkami dar 11 asmenų dirbti Kaune. Bet Tarybos narių didžiausio dèmesio sulauke tik Vilniaus skyriaus kandidatai. Kai konkursinès komisijos pirmininkas doc. M. Martynaitis praneše kiekvieno kandidato asmeninius duomenis ir motyvuotą konkursinès komisijos išvadą, klausimų bei pastabų pateike Tarybos nariai daugiausia Vilniaus kandidatams.

B. Liaudi „egzaminavo“ prof. J. Janickis, doc. S. Vabalevičius, doc. L. Kumpikas ir prof. J. Indriūnas. A. Rusteiką klausinëjo doc. J. Macevičius, doc. L. Kumpikas, doc. J. Mikuckis. P. Vaiči klausinëjo doc. J. Kaunas, o H. Gutmanienę - prof. J. Indriūnas ir doc. S. Vabalevičius.

H. Gutmanienè susilaukè ypatingo dèmesio. Ją neigiamai charakterizavo prof. M. Kaveckis, bet teigiamai - prof. J. Janickis.

Balsų skaičiavimo komisijos pirmininkas prof. A. Žmuidzinavičius praneše slapto balsavimo rezultatus. Štai kaip buvo įvertinti kandidatai dirbti Vilniaus skyriuje: B. Liaudis: sutinku - 26, nesutinku - 7; negaliojantys biuleteniai - 2; S. Marazas: $30-2-3$; V. Kriščiūnas: $31-1-3$; L. Janulionis: $30-0-5$; V. Tulevičius: $32-1-2$;

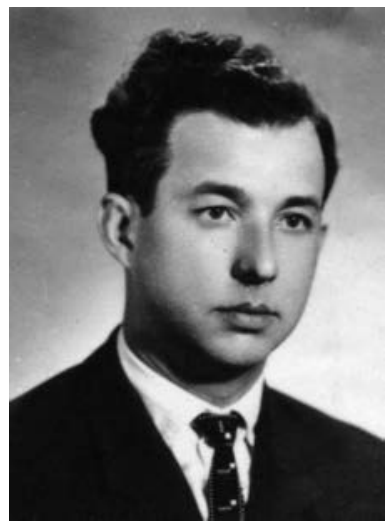

S. Marazas

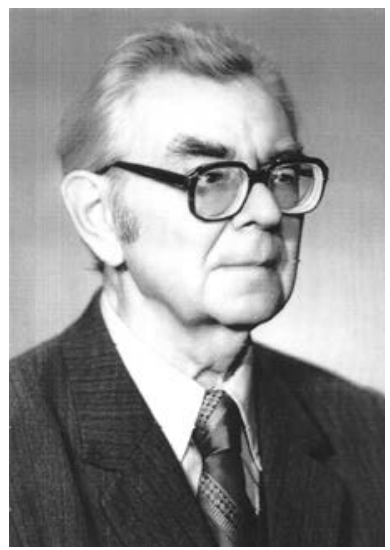

V. Kriščiūnas 
TECHNIKOS

STUDIJŲ PRADŽIA

VILNIUJE pasiūle energinga, darbštu ir talentinga Aleksandra Cyra skirti KPI vakarinio fakulteto dekanu, bet ir padejo jam formuoti sio fakulteto katedras, rüpinosi gauti mokymui reikalingy patalpu ir kt.

$1960 \mathrm{~m}$. birželio 13 d. vardiniu proga mane Kaune sveikino kurso draugai. Cia A. Cyras pasisake esas kviečiamas vadovauti KPI Vilniaus vakariniam fakultetui ir pakviete mane persikelti $i$ Vilniu. Kita dienq abu atejome pas M. Martynaiti, kuriam A. Cyras pristate mane kaip būsima fakulteto dèstytoja. Veliau jie aptare fakultetui reikalingu destytojy. specialybes ir ju konkurso salygas. Mane nustebino M. Martynaičio operatyvumas ir tai, kad jis asmeniškai pažinojo KPI destytojus ir ju dalykinius privalumus bei trūkumus. <...>

KPI vakarinis fakultetas 1960 metais isikūrè buvusinose Bazilijonu vienuolyno rūmuose. Skurdome krosnimis kürenamose, o dažniausiai šaltose auditorijose. Tačiau blogiausia buvo tai, kad neturejome laboratoriju ir mokymo kabinetu, be kuriu buvo neimanoma rengti inžinieriuu. Mane pradžioje nustebino o veliau ir maloniai nuteike tas faktas, kad destytojams nereikëjo skaityti paskaitu rusu kalba, nors kai kuriose studentu grupese lietuviu buvo labai mažai. Tuo metu, kai Kauno aukštosiose mokyklose buvo steigiamos vis naujos studentu grupes destomaja rusu kalba, KPI Vilniaus fakulteto rusai, lenkai, žydai ir kitu tautybiu studentai aktyviai mokesi lietuviu kalbos. Man buvo keistoka stebeti, kai šie studentai, klausydami lietuviškai kalbančio destytojo paskaitu, jo mintis užrašydavo gimtaja kalba. Egzaminu metu šie studentai pageidavo leisti jiems atsakineti rusiškai".

Fakulteto veiklą administravo dekanas A. Čyras bei periodiškai vykstantis katedrų vedèju posedis.

Fakultetas, kai vadovavimą iš J. Kudabos priemė A. Čyras, ème skirti demesị moksliniam darbui. Trūko lěšų patalpoms tvarkyti, elementariai laboratorinei ịrangai, todèl aktualu buvo skatinti ūkiskaitinius mokslinius darbus. 1960 m. lapkričio 15 d. katedros vedeju posedyje nutarta $1961 \mathrm{~m}$. sudaryti ūkiskaitinių sutarčių, kurių suma 65000 rublių. Dekanas A. Čyras įpareigojo Statybos katedrą skubiai rūpintis laboratorinès įrangos gavimu medžiagų atsparumo, statybinių medžiagų ir konstrukcijų studentų laboratoriniams darbams ir destytoju moksliniams tyrimams vykdyti.

Katedrų vedejų posedžiuose daugiausia demesio buvo skiriama akademiniams 
reikalams. Studiju procese pasitaikydavo rimtų trūkumų: kai kurie destytojai antraeilininkai praleisdavo paskaitas ar pratybas, laiku nepristatydavo įskaitu ar egzaminu žiniaraščių, vèluodavo pateikti kursiniams darbams ir projektams užduotis ir kt. Trūko auditorijose ir braižyklose baldų, prastas buvo patalpų apšvietimas. Bet energingasis A. Čyras labai greitai sudrausmino tiek pažeidžiančius nustatytą tvarką destytojus, tiek visą kitą fakulteto personalą. Kai fakultete įsivyravo drausmè ir pareigingumas, fakulteto veikla kasdien ryškiai gerejo. Tai gerai prisimena to meto destytojai ir darbuotojai.

Dar 1960 m. kovo 25 d. KPI tarybos posedyje svarstant instituto vakarinių skyrių veiklą ir perspektyvas buvo kalbeta apie bendrojo inžinerijos skyriaus steigimą KPI Vilniaus vakariniame fakultete. Sis klausimas buvo svarstomas $1961 \mathrm{~m}$. sausio $13 \mathrm{~d}$. KPI Vilniaus vakarinio fakulteto katedru vedeju posedyje. Iš posedžio protokolo matyti, kuriems fakulteto darbuotojams teko šio skyriaus organizavimo darbas. Bendras skyriaus organizavimo darbas buvo paskirtas V. Valaičiui. Atskiru disciplinu akademini krūvị apskaičiuoti ir dèstymą organizuoti buvo pavesta: TSKP istorijos - N. Nikolajevai, matematikos - L. Janulioniui, fizikos - H. Gutmanienei, braižomosios geometrijos - V. Tulevičiui, braižybos V. Klimavičiui, chemijos - J. Kudabai, metalų technologijos - B. Liaudžiui, teorinès mechanikos - A. Rusteikai [2.36].

Vaidotas Valaitis 1951 m. baige Kauno politechnikos institutą ir gavo mašinų gamybos technologijos specialybes inžinieriaus diplomą. Dirbo Kauno turbinų gamykloje „Pergale“". Nuo 1957 m. buvo perkeltas ị Liaudies ūkio tarybos Mašinu gamybos valdybą eiti Gamybos skyriaus viršininko pareigas. Jau nuo $1953 \mathrm{~m}$. kaip valandininkas dèstè metalų technologijos ir metalotyros kursus KPI Mechanikos fakultete. Nuo 1959 m. rugsèjo dirbo valandiniu destytoju KPI Vilniaus skyriuje. $1962 \mathrm{~m}$., nors ir neturejo mokslinio laipsnio, buvo išrinktas docentu KPI Vilniaus filiale. Bet šis mokslinis vardas nebuvo patvirtintas, o perspektyvusis V. Valaitis dèl netinkamo elgesio ilgainiui buvo priverstas palikti aukštąją mokyklą [2.37, p. 2-86].

Tame pačiame KPI tarybos posedyje kalbèta apie laboratorijų steigimą Vilniaus fakultete, vadovelių rengimą, katedros pavadinimo keitimą ir kt.
İdomus VGTU istorijai momentas pažymètas $1961 \mathrm{~m}$. kovo $13 \mathrm{~d}$. KPI direkcijos posedyje, kai svarstytas sveikatingumo stovyklų klausimas. Čia pirmą kartą užfiksuota, kad KPI rengiasi skirti lěšu suomiško tipo namukams statyti sklype prie Aukštadvario [2.32, p. 20v, 21].

Reikšmingi pokalbiai, susiję su Vilniaus vakariniu fakultetu, vyko KPI direkcijos gegužès $8 \mathrm{~d}$. poseddyje.

Rektorius (šis postas taip pavadintas balandžio $24 \mathrm{~d}$. posèdyje) prof. K. Baršauskas pranešè, kad Vilniaus vakarinị fakultetą numatoma išplesti $\mathfrak{i}$ instituto filialą su 3 fakultetais: Mechanikos, Elektrotechnikos ir Statybos. Doc. M. Martynaitis išvardijo specialybes ir nurode kontingentus, kuriuos visam ar tik įdarbinimo laikui teks perduoti Vilniaus fakultetui. Posèdyje kalbèta apie fakultetų dydį, mokslinę bazę, specialiojo rengimo organizavimą.

Gegužes $22 \mathrm{~d}$. posedyje, svarstant KPI statuto projektą, vèl daug demesio buvo skirta Vilniaus fakultetui. Posedyje dalyvavo ir dekanas A. Čyras. Jis siūle patikslinti būsimųjų fakultetų pavadinimus. M. Martynaitis teige, kad Vilniaus vakarinis fakultetas bus išplèstas ị filialą nuo 1962-1963 mokslo metų, kad bus du fakultetai - Metalų apdirbimo ir Bendrainžinerinis. Svarstant būsimojo Vilniaus filialo reikalus, rektorius $\mathrm{K}$. Baršauskas siūle apsvarstyti, kokias specialybes teks perduoti Vilniui. Mokslo reikalų prorektorius M. Martynaitis nurode, kad struktūros klausimus pagal nuostatus sprendžia Aukštojo mokslo komitetas. Jis išreiškè nuomonę, kad Vilniaus filialui reikia skirti prodekano etatą. Prorektorius H. Petrusevičius kalbëjo apie būtinumą filialui tureti buhalterio ir techniko etatus, o dekanas A. Čyras pabrežè, kad reikia ịsteigti pavaduotojo ūkio reikalams pareigybę. Jis pasidžiauge, kad KPI Vilniaus vakariniam fakultetui atiduoti dar vieneri rūmai - J. Basanavičiaus g. 28. Posedyje M. Martynaitis informavo, kad i stacionarą (dienines studijas) $1961 \mathrm{~m}$. Vilniui reikès perduoti šiuos kontingentus: radijo aparatūros specialybès -50 žmonių, garso technikos -25 , metalu apdirbimo spaudimu - 25, suvirinimo įrangos technikos - 25, PCS - 25 (rusų grupe). Iš viso 150 žmonių. A. Čyras pareiškè, kad gerai būtų, jei radijo aparatūros specialybe būtų palikta Kaune, o PCS grupè būtų lietuviška. Jis sakè, kad Vilniuje nutarta priemimą į stacionarą ir vakarinị skyrių

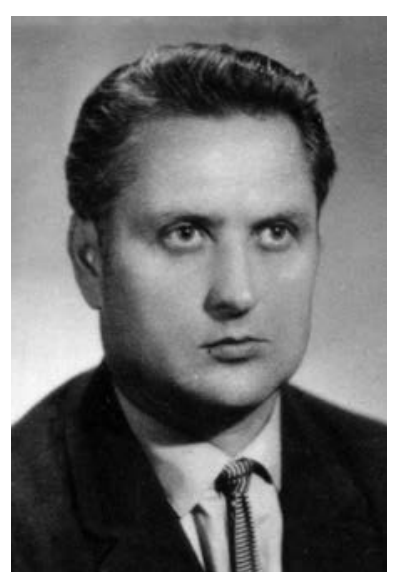

V. Valaitis

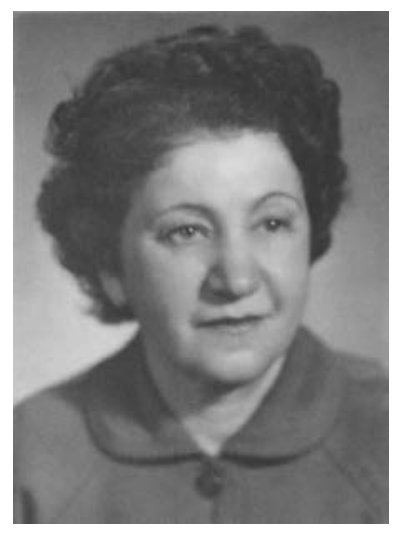

H. Gutmaniene

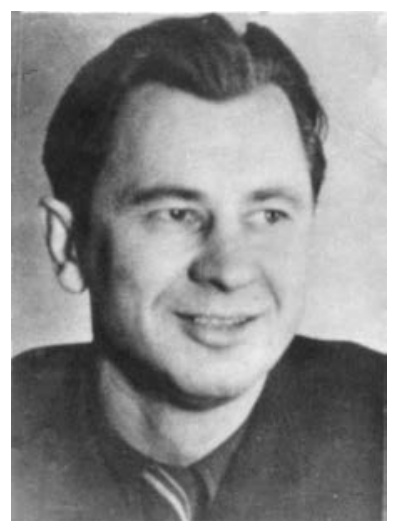

A. Rusteika 
TECHNIKOS

STUDIJŲ PRADŽIA

VILNIUJE studentų perkèlimo ị Vilnių, nes tai esą bus tik bereikalingas dubliavimas.

Statybos fakulteto atstovai, matyt, jaute, kad Hidrotechnikos fakulteto pavadinimo pakeitimas į Inžinerinès statybos fakultetą diskredituoja esamą Statybos fakultetą, nes „atrodytu, kad čia bütu ne inžinerine, o kažkokia kita statyba ". Jie jaute, kad naujasis Hidrotechnikos fakulteto pavadinimas silpnintu jų priešinimąsi perkelti statybos specialybes i Vilnių.

PCS specialybès perkèlimui ị Vilnių prieštaravo KPI partorgas A. Jurele, e. doc. p. V. Ražaitis, doc. Pesys. Bet tašką diskusijai padejo rektorius K. Baršauskas, pasakęs, kad "toks yra direktyviniu organu reikalavimas, kuri reikia juykdyti". Kokių organų keliami ir kokie reikalavimai dokumentuose, nenurodyta. Galima manyti, kad K. Baršauskas taip išsprende problemą, kurios statute pasiūlytam sprendimo variantui širdyje pats pritare.

Po rektoriaus kalbos doc. A. Čyras su patosu pareiške, kad „Vilniaus filialo kolektyvas su šz filiala liečiančiu rektorato siülomu projektu sutinka“. Jis sake, kad statybos specialybès labai reikalingos filialui, turinčiam Statybos katedrą, kurios destytojams reikalingas akademinis krūvis. O dubliuojasi ir kitos specialybes, pvz., radijo aparatūros konstravimo, skaičiavimo mašinų, bet kažin kodèl dubliavimo klausimą kelia tik statybininkai [2.40, p. $94-95 \mathrm{v}]$.

KPI taryba pritare Statuto projektui. Taigi jau 1961 m. gegužę A. Čyras pasieke, kad statybos inžinierių rengimo centru ilgainiui taptų Vilnius. Visi šie prieštaravimai tik stabde procesą, bet negalëjo jo nei sulaikyti, nei pakeisti. Ilgainiui Vilniaus filialas tapo būtent Vilniaus inžineriniu statybos institutu. Bet iki to momento praejo beveik dešimtmetis. Po menesio KPI taryba vèl svarstè Vilniaus filialo reikalus. Dabar jau prieštaraujančiuju Ui Vilniaus filialo kūrimui ir jo tolesnei plètrai atsirado daugiau. Doc. B. Pečiūra (doc. Liulčenkos vyras) pranešè, kad kai kurie dèstytojai manantys esa netikslinga Vilniuje steigti stacionarą, t. y. dienines studijas, nes tuo tik skaldomos lěšos ir jegos, ir siūle tai apsvarstyti Taryboje. Šis politines ekonomijos dèstytojas, žinoma, neįžiūrëjo kitų reikmių plètoti lietuviškas studijas sostinèje.

Prof. K. Baršauskas, tiesiogiai niekada neprieštaravęs Vilniaus filialo steigimui ir, mūsų manymu, turintis jau minètą asmeninę motyvaciją, pareiškè, kad „už stacionaro Vil- 
niuje steigima pasisako Vyriausybe ir Liaudies ükio taryba [dar vienas veiksnys - aut. past.], nes reikalinga atsižvelgti $i$ poreikius, ir kad tuo tarpu ten perkeliama is duoto kontingento tik 150 PCS specialybes studentu. Turintiems priešinga nuomone siülau pareikšti ją ir savo sumetimus LKP CK, Vyriausybei “.

Tai nepaveikè B. Pečiūros. Jis griežtai teigè, kad stacionare inžinieriai būtų rengiami tik Kaune, abejojo, kad 150 žmoniu Kaune trūksta patalpų, reikalavo neplètoti Vilniaus vakarinio fakulteto.

Mokymo reikalų prorektorius M. Martynaitis informavo, kad „rektoratas kovojo prieš stacionaro steigima Vilniuje, sieke išvengti dubliavimo ir daug šiuo atžvilgiu atsieke, kad $i$ Vilniu bus perkeltos rusu grupes, kad apkrovimo sumažinimo nera ko bijoti, ir ispejo, kad balsuoti siuo klausimu netiktu, nes buvo juo išreikšta partijos CK ir Vyriausybes nuomone, bet atskiri Tarybos nariai gali tam tikra tvarka savo nuomone pareikšti " [2.40, p. 103-104]. Doc. S. Sčesnulevičius kalbejo apie Statybos fakulteto nusistatymą neduoti
Vilniui profilinès specialybès - PCS, nes dèl to specialybe dubliuosis. Bijoma ne apkrovimo sumažinimo, o fakulteto likvidavimo. Prof. J. Janickis pareiškè, kad jei Vilniuje bus insteigtas stacionaras, tragedijos nereiketų daryti, bet priekaišstavo rektoratui, kad apie ši reikalą Taryboje anksčiau nebuvo plačiau pareferuota. Reziumuodamas karštą diskusiją ir atsakydamas į Tarybos narių priekaištus, prof. K. Baršauskas primine, kad Vilniaus filialo klausimas buvo svarstomas rektorato posedžiuose, kad jis turëjo būti svarstomas katedrų vedejju posedžiuose, kad tuo klausimu buvo daug diskutuota, aiškintasi Vilniuje. Pabrězee, kad, turint Vyriausybès sudarytos komisijos sprendimą, netinka prieštarauti keliant aukščiau savo interesus, juo labiau, kad dubliavimo stengiamasi vengti, kad Vilniuje reikia išnaudoti dieną esančias tuščias patalpas.

KPI taryba nutare pritarti rektorato siūlymams [2.40, p. 104-104v]. Lemiamą reikšmę Tarybos apsisprendimui neabejotinai turejo rektoriaus K. Baršausko nuomone.

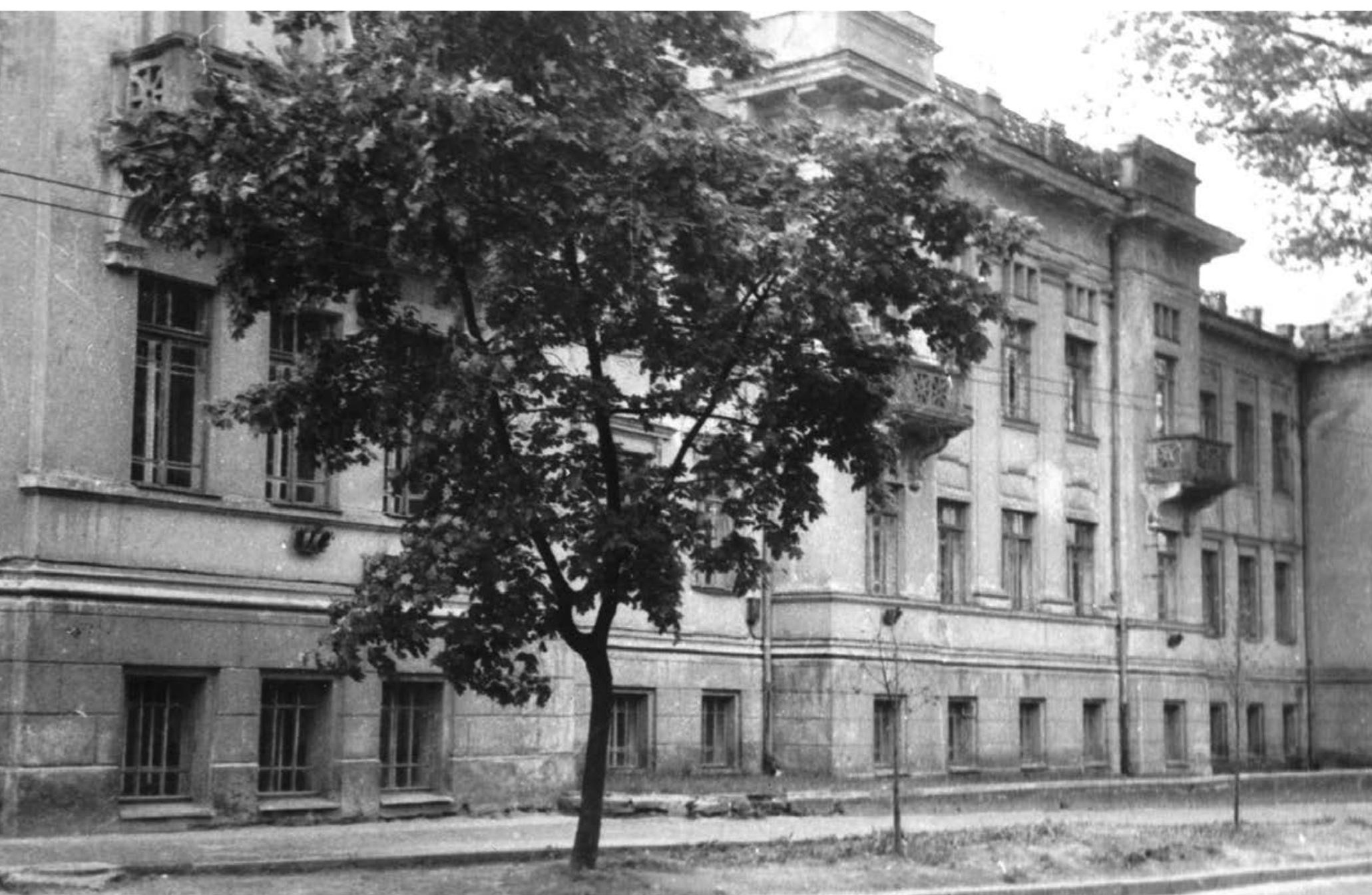





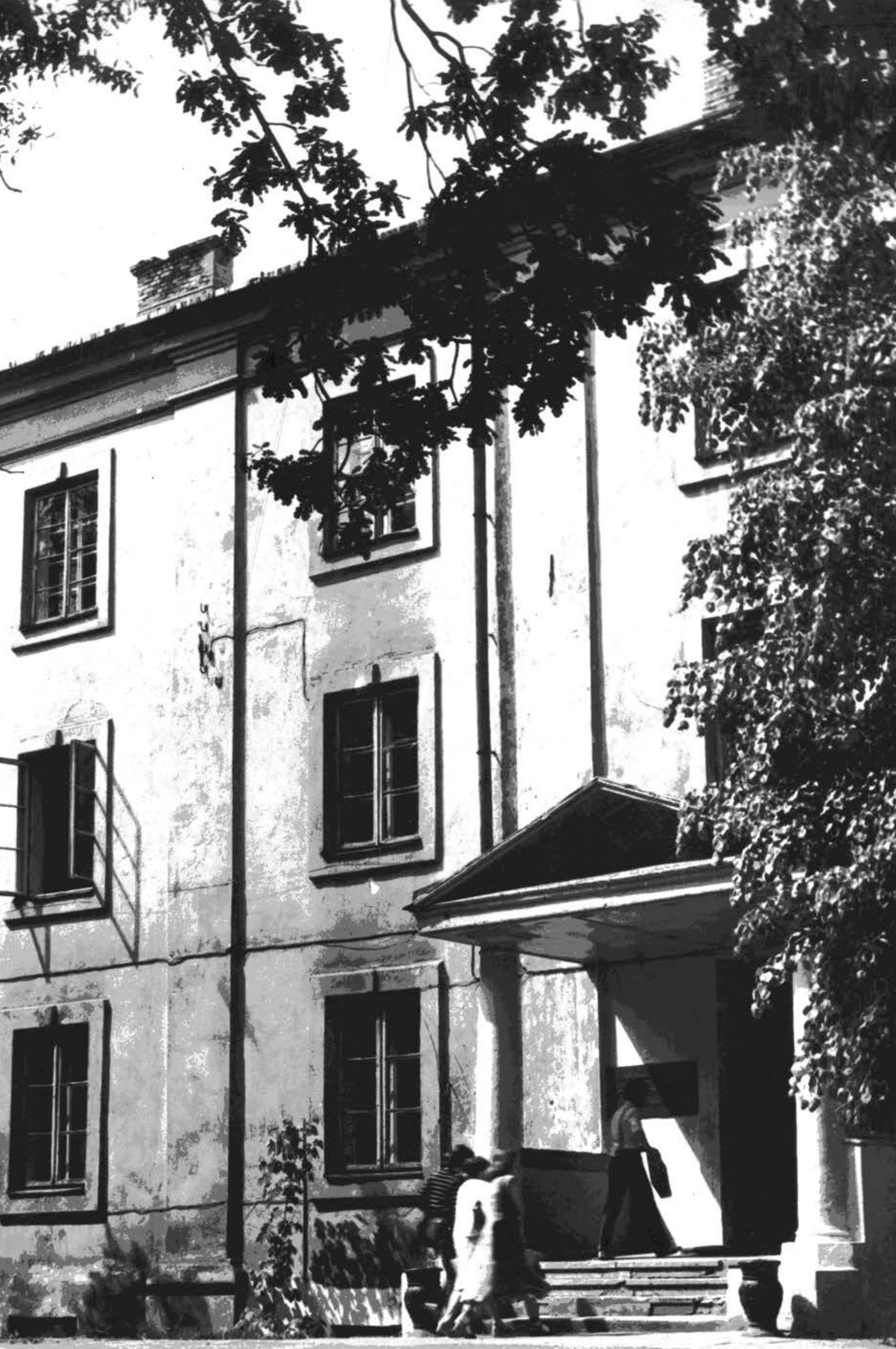
and

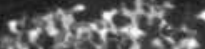
(1.0.0.

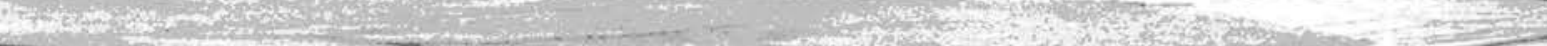

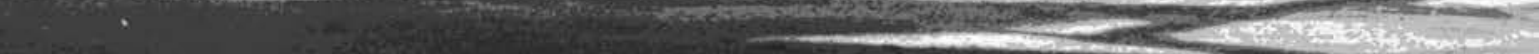




\title{
KAUNO
}

\section{POLITECHNIKOS INSTITUTO}

\section{VILNIAUS FILIALAS}

\author{
Filialo įsteigimas ir pradinè struktūra
}

Nors po Stalino mirties 1953 m. Sovietu Sąungoje vyko tam tikras gyvenimo liberalizavimas, bet reikšmingai niekas nesikeitè. Tebeveikè lageriai, siaubą tebekèle KGB, nebuvo jokių demokratejimo požymių. Sovietiniai tankai užgniaužè Rytų Berlyno, Vengrijos bandymus ištrūkti iš geležinio Maskvos glèbio. Tačiau vèliau, kai N. Chruščiovas emè demaskuoti (tik iš dalies) Stalino kultą, propaguoti taikųji sambūrį su Vakarais, prasidejo Vakarų ir Rytų santykių atlydys. Bet tai truko neilgai.

1960 m. rusai raketa numuše JAV žvalgybinį lèktuvą ir suemé pilotą $H$. Pauersą. Nuo to momento JAV ir TSRS santykiai ème blogeti. $1961 \mathrm{~m}$. JAV kubiečiu emigrantų jegomis pabande nuversti komunistinį F. Kastro režimą. Tai nepavyko, bet jau 1962 m. rudeni TSRS nutare įkurti Kuboje savo raketų bazę su atominiais užtaisais. Pasaulis atsidūre realiame atominio karo pavojuje, nes JAV prezidentas Kenedis pareiške, kad su tuo nesitaikstys ir pareikalavo raketas išvežti. Chruščiovas nusileido, bet pasaulis pirmą kartą pajuto realų pasaulinio atominio karo dvelkimą. Dabar yra žinoma, kad jau $1961 \mathrm{~m}$. TSRS turejo tiek atominių bombų, kad jomis galejo dukart sunaikinti pasauli, o JAV - net penkeriopai daugiau, t. y. galëjo sunaikinti pasaulį dešimt kartų!

Štai tokiomis žmonių nerimo dèl ateities sąlygomis vis dèlto augo, tvirtejo Kauno politechnikos instituto padalinys Vilniuje.

$1961 \mathrm{~m}$. liepos 4 d. Lietuvos TSR Ministru Tarybos nutarime Nr. 397 „Dèl medžiagines technines bazess sukürimo inžinieriu kadrams Lietuvos Tarybu Socialistineje Respublikoje ruošti “ pažymèta, kad „Pagrindine inžinieriu kadru dali ruošia Kauno politechnikos institutas, kuris per 10 savo gyvenimo metu išaugo ir tapo stambia mokslo istaiga su vakariniais skyriais Vilniuje, Klaipedoje ir Šiauliuose. Institutas jau paruošé daugiau kaip 5300 inžinieriu, kurie sékmingai dirba <...>“.
Toliau nutarime sakoma, kad „<...> Vilniaus, Klaipedos ir Šiaulių skyriai neturi savo mokymo ir laboratorinés bazes inžinierių kadrams ruošti, o Panevėžyje dar neatidarytas instituto skyrius". Buvo nutarta (minime Vilniaus filialui svarbius punktus):

„1. Iki 1961 m. rugpjūūio 1 d. isteigti Vilniuje Kauno politechnikos instituto filiala su dieniniu, vakariniu ir bendratechniniu skyriais;

2. Ipareigoti Lietuvos geležinkelio valdyba, Miestu statybos projektavimo institutui issikeilus $i$ nauja pastata K. Požélos $g$. [dabar - A. Goštauto - A. N.], suteikti Kauno politechnikos instituto Vilniaus filialui ilgalaikes nuomos tvarka to instituto patustinamas patalpas Mindaugo g. Nr. 14 (plotas - $1350 \mathrm{~m}^{2}$ )" [3.1, p. 1-2].

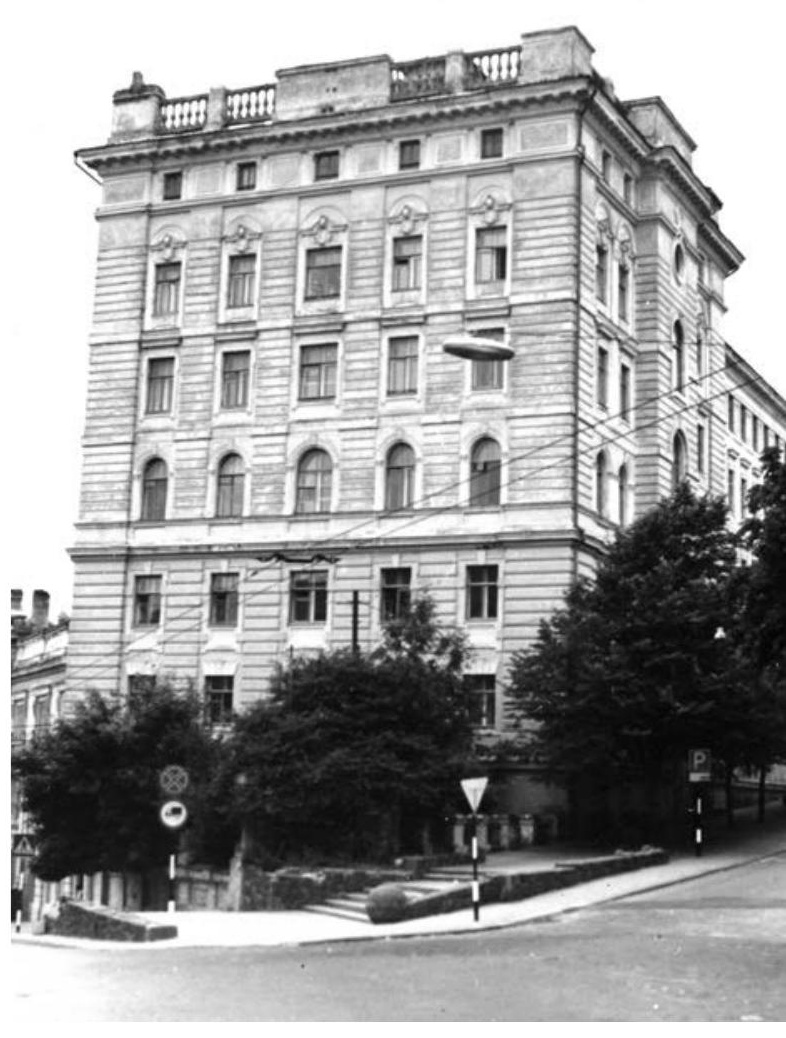

Geležinkelininku rümai, kuriu IV aukšte jsiküre KPI VF, buvo vadinami KPI VF antraisiais rümais 


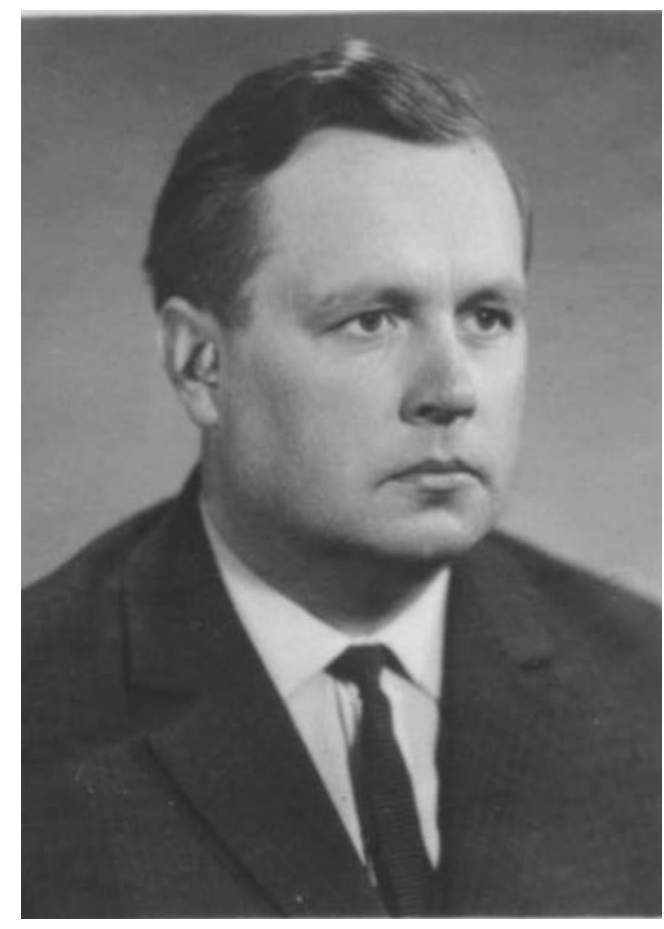

Vietoj fakulteto įsteigus filialą, docentas Aleksandras Čyras 1961 m. lapkričio 2 d. buvo paskirtas Kauno politechnikos instituto prorektoriumi Vilniaus filialo reikalams. Tuo metu Kaune daugelis mané, kad suverenios aukštosios technikos mokyklos ịkūrimas Vilniuje jau nebe toli. 34 metu Aleksandras Čyras buvo pilnas jëgų, energingas, gerai suprato, kaip reikia veikti valdžios koridoriuose ir kabinetuose. İžymaus Kazimiero Vasiliausko mokinys, pagarsëjęs kaip labai gabus ir perspektyvus mokslininkas bei organizatorius, jau neslepe ketinimų įkurti technikos institutą Vilniuje.

Kauno politechnikos instituto Vilniaus filialas $1961 \mathrm{~m}$. rugsëjo $1 \mathrm{~d}$. pradëjo mokslo metus turedamas 986 studentus, 150 iš jų dieninio skyriaus, daugiausia vilniečių.

Filiale buvo suformuotos 5 katedros: vietoje Taikomosios mechanikos katedros - Mechanikos ir matematikos (vedëjas A. Čyras) bei Metalu apdirbimo (vedejas B. Liaudis), o toliau veike Elektrotechnikos (vedëjas S. Marazas) ir Statybos katedros (vedejjas V. Kriščiūnas). Naujai ịkurta Marksizmo-leninizmo katedra (vedejjas A. Marcelis).

Nors filialo darbo sąlygos buvo sunkios, ši Vilniaus mokykla augo ne tik kiekybiškai; stiprejo pedagogu kolektyvas, nes déstyti i filialą atejo ir mokslininkai, ir patyrę gamybininkai. Tiesa, katedru personalo struktūra buvo įvairialypé, nes jose buvo ivvairių dalykų déstytojų, bet tai tebuvo „augimo sunkumaı". Ilgainiui katedros griežtai specializavosi, vis labiau stiprejo jų mokslinis potencialas.

Kas gi dirbo îsteigtojo filialo katedrose, kuriose, jau esant dieninems studijoms, reikejo vis daugiau etatinių destytojų?

Mechanikos ir matematikos katedroje buvo 10 desstytojų: technikos mokslų kandidatas (toliau t. m. k.) A. Čyras, t. m. k. A. Rusteika, vyr. dest. L. Janulionis, asist. A. Šeputis, vyr. dèst. A. Miliušas, vyr. dest. T. Bilkis, vyr. dest. V. Gurskis, dest. O. Glemžiené, dèst. S. Zaskevičiūte, dèst. A. Sabonienè.

Metaly apdirbimo katedroje dirbo 8 dèstytojai: t. m. k. B. Liaudis, vyr. dest. Z. Klimavičius, vyr. desst. A. Kuzmickas (0,5 etato), vyr. dest. A. Gapšys (0,5 etato), vyr. dest. Mašanauskiene, t. m. k. J. Charitas, asist. Paškevičienè, vyr. dest. V. Klimavičius.

Elektrotechnikos katedroje dirbo 6 desstytojai: t. m. k. S. Marazas, vyr. dest. P. Vaičys, vyr. desst. P. Breive, vyr. dèst. H. Gutmanienè, asist. A. Šatas, asist. P. Jurenas.

Statybos katedroje dirbo 7 dèstytojai: t. m. k. V. Kriščiūnas, t. m. k. A. Kudzys, vyr. dèst. V. Tulevičius, vyr. dèst. V. Pranaitis $(0,5$ etato), chemijos m. k. I. Nickus, ch. m. k. M. Priluckaja, asist. A. Raudeliūnienè.

Marksizmo-leninizmo katedroje dirbo 5 destytojai: istorijos m. k. A. Marcelis, ist. m. k. N. Nikolajeva, vyr. dest. J. Bacevičius, vyr. dèst. O. Petraškevičius, asist. Z. Jarašiūnaitè (Barkauskienè).

KPI Vilniaus filialo vadovas toliau stiprino savo įstaigos suverenitetą. Jis pateike rektoriui K. Baršauskui siūlymų dèl instituto statuto projekto - įtraukti konkrečius punktus apie KPI Vilniaus filialą, būtent:

1. Vilniaus filialas su Mechaninès technologijos fakultetu, Radioelektronikos fakultetu ir Inžineriniu fakultetu.

2. Vilniaus filialas yra struktūrinis instituto vienetas, suorganizuotas inžinerinių kadru rengimo apimtims padidinti bei priartinti specialistų rengimą prie gamybinès bazés ir studentu gyvenamosios vietos.

3. Filialo veikla nustatoma LTSR valstybinio aukštojo ir specialiojo vidurinio mokslo komiteto patvirtintais nuostatais.

4. Vilniaus filialo prorektoriaus veikla nusakoma filialo nuostatais. Jis atskaitingas rektoriui už visą mokomąją, mokslinę ir auklejamąją Vilniaus filialo veiklą.

Nesunku matyti, kad A. Čyras šiais pasiūlymais ir toliau sieke stiprinti filialo savarankiškumą, pabrěžè, kad filialo veikla nustatoma 
KAUNO

POLITECHNIKOS

INSTITUTO

VILNIAUS FILIALAS

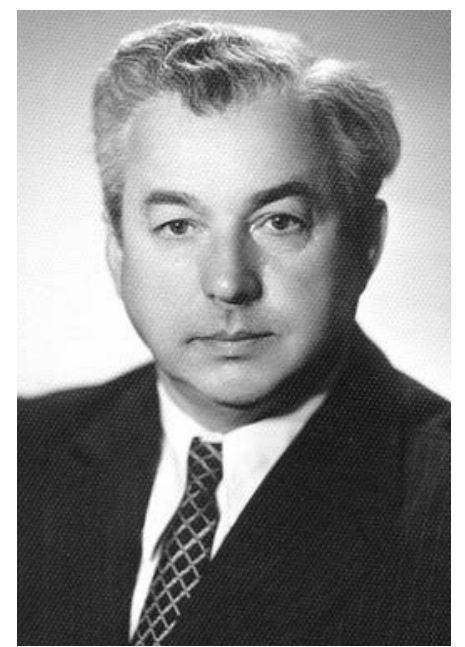

KPI Vilniaus filialo dekanas doc. S. Marazas

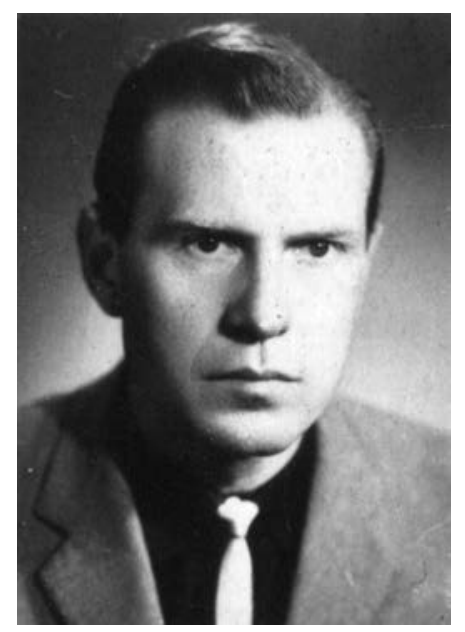

KPI Vilniaus filialo prodekanas L. Janulionis ne tik KPI statutu, bet ir Aukštojo ir specialiojo vidurinio mokslo komiteto patvirtintais nuostatais.

$1961 \mathrm{~m}$. pabaigoje to paties komiteto įsakymu nuo $1962 \mathrm{~m}$. sausio $1 \mathrm{~d}$. KPI Vilniaus filialo administracinè, finansinè ir ūkinè veikla performuota savarankiško balanso pagrindu, su einamąja sąskaita banke, filialui buvo suteiktos juridinio asmens teises. Tame pačiame įsakyme patvirtinti filialo nuostatai, nustatyti administracijos valdymo ir administracijos ūkio personalo skaičiai, personalo atlyginimai nustatyti tokie pat, kaip KPI centro personalo.

Patvirtintieji filialo nuostatai ịteisino filialo Mokslinę tarybą, nustate dekanų rinkimo tvarką ir kt.

KPI Vilniaus filialo Mokslinè taryba turejo svarstyti filialo mokomojo-metodinio, mokslinio, ūkinio ir administracinio darbo organizavimo ir kitus klausimus. De jure ji turejo kontroliuoti administracijos veiklą. Bet LTSR MT valstybinio aukštojo ir specialiojo vidurinio mokslo komiteto patvirtinti nuostatai faktiškai absoliučią valdžią filiale suteike prorektoriui. Štai kai kurios šių nuostatu pastraipos: „Filialo mokymo, mokslo ir auklejamajam procesui bei ükinei veiklai vadovauja prorektorius <...>. Už visa filialo darba pilnai atsako prorektorius filialo reikalams..." [3.2, p. 36-37]. Apie Mokslinę tarybą tepasakyta, kad dekanai renkami Mokslineje taryboje ir tvirtinami KPI rektoriaus.

İ pirmąją KPI Vilniaus filialo Mokslinę tarybą buvo įtraukti: Aleksandras Čyras, Vytautas Kriščiūnas, Borisas Liaudis, Stanislovas Marazas, Albertas Marcelis, Antanas Aksamitas, Donatas Kostiukevičius, Antanas Kudzys, Leonas Janulionis, Judelis Charitas, Ipolitas Nickus, Antanas Rusteika ir Marija Priluckaja [1962 0223 MT protokolas].

Paskyrus A. Čyrą KPI Vilniaus filialo reikalų prorektoriumi, $1961 \mathrm{~m}$. lapkričio $22 \mathrm{~d}$. KPI Vilniaus filialo Mokslinès tarybos posedyje buvo renkamas filialo dekanas. Dar rugsèjo $29 \mathrm{~d}$. vykusiame vadinamajame KPI Vilniaus filialo aktyvo pasitarime, kuriame dalyvavo ir KPI rektorius prof. K. Baršauskas, buvo aptarta būsimojo filialo dekano kandidatūra.

Filialo dekanas doc. A. Čyras pasiūlè skirti dekano pareigoms filialo Elektrotech- nikos katedros vedëją, technikos mokslų kandidatą, e. doc. p. Stanislovą Marazą. A. Čyrui pritare partinès organizacijos sekretorius B. Liaudis.

Filialo Mokslinè taryba vienbalsiai išrinko S. Marazą filialo dekanu. KPI Vilniaus filialo prodekanais buvo paskirti vyr. destytojas Leonas Janulionis ir e. doc. p. Antanas Kudzys.

Tiek A. Čyrui, tiek S. Marazui, L. Janulioniui bei A. Kudziui tai buvo labai sunkaus darbo periodas. Nuo 1961-1962 mokslo metų pradejjęs veikti dieninis skyrius kèle daug naujų rūpesčių: filialas stokojo nuolatinių desstytojų, trūko auditorijų, braižyklų, laboratorijų, mokomojo inventoriaus, reikëjo spręsti stipendijų, bendrabučiu klausimus. Dalis dèstytojų važinëjo iš Kauno, todèl nelengva buvo derinti užsièmimų tvarkaraštị. Nelengva buvo rasti destyti tinkamų specialistų iš dirbančiųjų Vilniaus įstaigose ir ịmonèse. Šie mokslo metai dar buvo ypatingi tuo, kad 1962 m. turëjo baigti studijas pirmoji diplomantu laida.

Nepaisant visų sunkumų, studijų procesas buvo gana sklandus. Dauguma filialo vadovų buvo jauni, energingi ir turintys sveikų ambicijų išugdyti filialą i gero lygio aukštąą mokyklą, kuri taptų technikos mokslų šventove Lietuvos sostinëje.

Filialo Mokslinè taryba metu pabaigoje keturiems filialo etatiniams pedagogams, turintiems mokslų kandidato laipsnị ir einantiems docento pareigas, suteike docento mokslinius vardus. Bet be Maskvos patvirtinimo šis pripažinimas dar ne kažin ką reiškè. Docentais jie visi buvo patvirtinti veliau. Tai Borisas Liaudis, Stanislovas Marazas, Antanas Kudzys ir Antanas Rusteika. Iki jų filiale docento mokslinius vardus turejo tik 4 etatiniai darbuotojai - A. Čyras, V. Kriščiūnas, M. Priluckaja ir I. Nickus.

1961-1962 mokslo metais KPI Vilniaus filiale buvo rengiami radioelektronikos ir elektros pramonès, mechaninès technologijos ir statybos bei inžinerinès elektronikos inžinieriai. Taigi destyti numatytoms disciplinoms reikejjo daug įvairių specialybių desstytojų. Bendrojo techninio pobūdžio dalykams dėstyti paramą teike KPI centras. Bet dauguma déstytojų sudare vilniečiai, kuriais nuolat pasipilde pedagogu gretos.

Nors Marksizmo-leninizmo katedros destytojai paskaitose ir seminaruose išsijuosę deklaravo socializmo privalumus, tarybinį patriotizmą, proletarinị internacionalizmą, „demaskuodavo“ buržuazinę nacionalistinę 
ideologiją, pasirode, kad studentai menkai ugde savyje tas propaguojamas savybes. Katedrai šiais klausimais talkino partine ir komjaunimo organizacijos. Bet ir to nepakako. Todèl filialo Mokslinè taryba taip pat periodiškai svarste panašius klausimus. Tuo buvo pabrežiama politinio auklejjamojo darbo akademinèse grupese svarba ir būtinybe ji stiprinti. Bet gyvenimas rode ką kita. Niekas nuoširdžiai netikejo jau stipriai įkyrejusiomis dogmomis.

Sausio $20 \mathrm{~d}$. KPI filialo prorektoriaus Vilniaus Aleksandro Čyro pavaduotoju administracijos ir ūkio reikalams buvo paskirtas Vilhelmas Eitminavičius (1929-1963). Jis $1957 \mathrm{~m}$. buvo baigęs KPI Statybos fakultetą ir iki perejjimo ị KPI Vilniaus filialą dirbo Vilniaus statybos tresto 4-ojoje statybos valdyboje. Šiame darbe jis tedirbo pusmeti. Ji pakeite Jonas Kaunelis, šias pareigas eję̧s iki 1965 m. pabaigos, o ji pakeitè Jonas Žemkus.

Augo ir visų kitų administracijos ir ūkio tarnybų gretos. Buvo ikurta KPI Vilniaus filialo buhalterija, priimti etatiniai darbuotojai tiekimo, kadru, įvairiems ūkio reikalams. Tai sudarè sąlygas didesniam filialo savarankišskumui. Iki tol atlyginimus destytojams ir darbuotojams mokedavo bei kitas finansines operacijas vykde tik KPI centras. Suprantama, tai labai sunkino administracijos darbą, dèl smulkmenų tekdavo važinèti ị Kauną.

Pirmąja vyriausiąja buhaltere Vilniaus filiale nuo kovo menesio pradejo dirbti Stase Zaparackiené. Specialiųjų mokslų ji nebuvo baigusi, bet turejo dideli praktinio buhalterinio darbo patyrimą. 1947-1957 m. dirbo Joniškio rajono organizacijose. Kai vyrą perkèle į Vilnių dirbti LKP CK, persikèle ir S. Zaparackiene. İsidarbinti iš karto vyriausiąja buhaltere, matyt, padëjo darbinè vyro padetis. LKP CK funkcionierių kabinetuose filialo reikalais dažnai lankèsi A. Čyras. Ilgainiui Vilniaus aukštojoje technikos mokykloje gana dažnai buvo įdarbintos nomenklatūros antrosios puses. Tai buvo viena priemoniu pasiekti kai kurių reikalingu rezultatu filialo labui. Toks gyvenimas! A. Čyras turejo prisitaikyti prie tokių aplinkybiu arba pasmerkti filialą tik pasyviai vegetacijai.

KPI Vakarinio fakulteto Vilniaus skyrius pradžioje bibliotekos neturejo. Studentai naudojosi miesto bibliotekomis, daugiausia Respublikinès mokslinès-techninès bibliotekos fondais. Kiek vèliau tiek skyriaus, paskui fakulteto studiju reikmes tenkino KPI bibliotekos skaitykla, kurioje dirbo viena darbuotoja. Skaitykla teturejo kelis šimtus įvairių vadovelių [3.3, p. 166].

Nuo 1962 m. kovo 5 d. pradejjo darbą KPI Vilniaus filialo biblioteka. Ji ịsikūre Basanavičiaus gatvëje esančiuose filialo rūmuose. Bibliotekos fondą sudare tik apie 2000 egzempliorių leidinių iš statybos, architektūros, meno, automobilių transporto, elektrotechnikos, mechanikos ir kitų sričių. Knygos buvo perduotos iš KPI bibliotekos fondų. Buvo pradèti kurti knygų ir periodinių leidinių abecelinis ir sisteminis katalogai.

Bibliotekos inventorius buvo labai prastas: medines kilnojamosios lentynos, kelios sekcijos, trys rašomieji stalai, numeratorius knygoms numeruoti, keletas kataloginių blokų tarnybiniam katalogui ir bibliografinei kartotekai laikyti. Bet knygų fondas kasmet augo, buvo išskiriama vis daugiau lešų fondui komplektuoti. Vis labiau suvokiama, kad mokykla prasideda nuo knygos.

Bibliotekos vedeju nuo pat jos ịkūrimo pradžios dirbo Algirdas Baliulis, nuo $1961 \mathrm{~m}$. dirbęs Aukštojo ir specialiojo vidurinio mokslo komiteto Mokymo-metodinio komiteto bibliotekos vedëju. Jis, $1958 \mathrm{~m}$. baigęs Vilniaus valstybinio universiteto Istorijos-filologijos fakultete bibliotekininkystes specialybę, kurị laiką dirbo Vilkijos rajoninëje bibliotekoje, paskui - Valstybinio statybos ir architektūros reikalų komiteto bibliotekos vedëju, dar veliau - inspektoriumi architektu.

I KPI Vilniaus filialo vedejo pareigas A. Baliulis buvo perkeltas Aukštojo ir specialiojo vidurinio mokslo komiteto pirmininko îsakymu ir ejo tas pareigas iki $1969 \mathrm{~m}$. birželio $20 \mathrm{~d}$.

Jau 1963 m. bibliotekos knygų fondas padidëjo iki 11294 egzempliorių. Bibliotekoje dirbo 2 darbuotojai. Didžiausią skaitytoju dali sudare studentai.

Pirmuosiuose rūmuose biblioteka veikè iki 1966 metu, o paskui buvo perkelta ị pastatą Senamiestyje - Giedrio g. 5 (dabar Šv. Ignoto) [3.4, p. 1-33].

1962 m. balandžio $10 \mathrm{~d}$. Lietuvos TSR Ministrų Taryba priemè nutarimą Nr. 297, kuris ịpareigojo KPI Vilniaus filiale ịsteigti trečiąji fakultetą-Inžinerinį ekonominị. Bet iki jo įsteigimo praèjo dar per dvejus metus.

Ir vis delto pagrindinis filialo vadovo demesys buvo skirtas studijoms ir mokslui. A. Čyras nuosekliai ir atkakliai sieke priimti pedagoginiam darbui jau susiformavusius mokslininkus arba patyrusius gamybininkus.

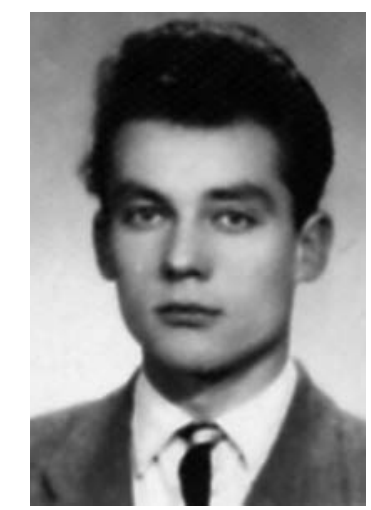

KPI Vilniaus filialo bibliotekos direktorius 1962-1969 m. A. Baliulis

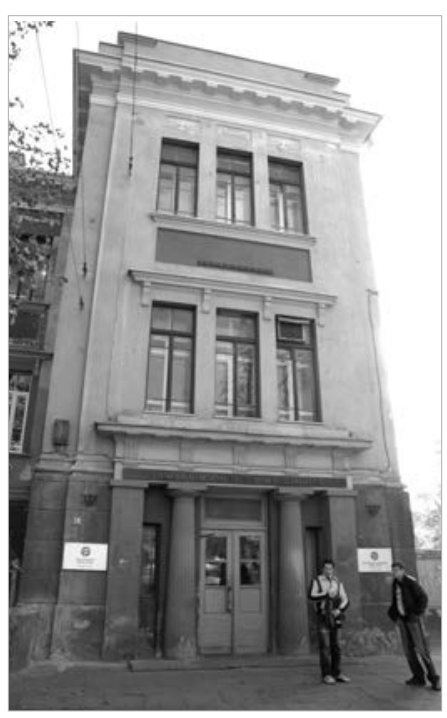

1962-1969 m. KPI Vilniaus filialo biblioteka buvo pirmuosiuose rūmuose II aukšte 
KAUNO

POLITECHNIKOS

INSTITUTO

VILNIAUS FILIALAS
Viršuje dešinëje -

Diplomini darba gina Albertas Inta (nuotrauka iš kino juostos)

KPI rektorius prof. K. Baršauskas iteikia diplomus pirmiesiems filialo diplomantams
Tokia pedagogu korpuso sudetis geriausiai atitiko studiju proceso reikalavimus. Nuo $1962 \mathrm{~m}$. rugsëjo turëjo gerokai išaugti studijuojančiųjų skaičiai, todèl turëjo padaugèti ir pedagoginio, ir pagalbinio personalo etatu. Reikalingu pedagogų paieška buvo kasdienis prorektoriaus A. Cyro rūpestis. Tam jis skyre labai daug laiko ir energijos, lankesi gamybos imonèse, projektavimo organizacijose, mokslo institutuose ir t. t.

\section{Pirmoji absolventu laida}

$1962 \mathrm{~m}$. pavasaris jaudino filialo darbuotojus dèl dar vieno labai svarbaus dalyko. Diplominius darbus intensyviai renge pirmieji filialo diplomantai. Diplominiu darbų rengimo eigą svarste katedros, Moksline taryba.

Statybos katedra turejjo 21 diplomantą, Metalo apdirbimo katedra - 26 ir Elektrotechnikos katedra - 30. Diplominiu darbu gynimui priimti buvo sudarytos Valstybinès egzaminu komisijos (VEK). Ju sudetys labai solidžios, taigi pirmosios filialo produkcijos kokybe buvo vertinta tikrai reikliai ir profesionaliai.

Statybininkų VEK sudare: pirmininkas Statybos ir architektūros reikalų komiteto pirmininkas A. Aksomitas; nariai: A. Čyras, V. Kriščiūnas, A. Kudzys, A. Rusteika, G. Izraelis, E. Chlomauskas, J. Šileika.

Mechanikų VEK sudare: pirmininkas Eksperimentinio metalo pjovimo stakliu

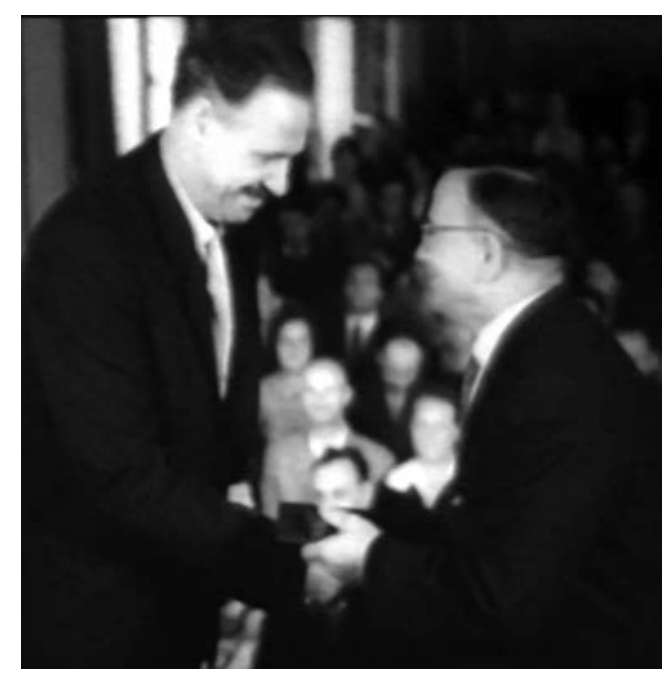

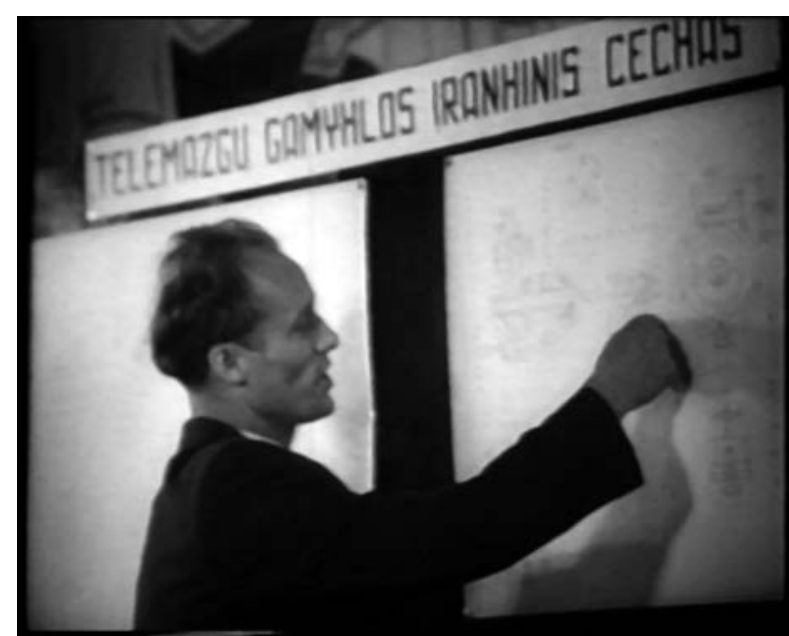

mokslinio tiriamojo instituto Vilniaus filialo direktorius A. Speičys; nariai: A. Čyras, B. Liaudis, A. Martinaitis, J. Charitas, K. Paškevičius, A. Gap̌̌ys, A. Kuzmickas, Z. Brazauskas.

Elektrotechniku VEK sudare: pirmininkas - LŪT Energetikos valdybos viršininkas J. Nekrašas; nariai: S. Marazas, P. Vaičys, V. Česonis, A. Martinaitis, A. Seilius, V. Raudonikis.

KPI Vilniaus filialo dekano S. Marazo ịsakymu diplominius darbus buvo leista ginti šiems pirmiesiems filialo diplomantams:

\section{Pramones imoniu elektriniu irengimu specialybe}

1. Vaduokliui Broniui, 2. Školler Vladimirui, 3. Ožechovui Volfui, 4. Keturkai Albinui, 5. Šemetai Stanislovui, 6. Juršui Vladui, 7. Lanaitei Sarai, 8. Liatukui Vytautui, 9. Ramanauskui Jonui, 10. Urbonui Petrui, 11. Pimpei Eugenijui, 12. Totoriui Feliksui, 13. Urbanovič Galinai, 14. Juodžiui Vytautui, 15. Jančiui Mindaugui, 16. Eriugros Vitalijui, 17. Ivanovui Danieliui, 18. Kulbiui Vladui, 19. Vereščiak Rimui, 20. Bieliavičiui Pranui, 21. Kalveliui Juozui, 22. Rakauskui Vytautui, 23. Steponavičiui Broniui, 24. Strumskiui Antanui, 25. Skrodeniui Vaclovui, 26. Strogui Dmitrijui, 27. Steckiui Vitoldui, 28. Šifrin Borisui, 29. Taruliui Broniui, 30. Vasiljevui Anatolijui.

\section{Mašinu gamybos technologijos specialybej}

1. Katkevičiui Kazimierui, 2. Tamašauskui Mečiui, 3. Šablauskui Zenonui, 
4. Semaško Petrui, 5. Zmejauskui Antanui, 6. Tamošiūnui Vladui, 7. Kukauskui Jonui, 8. Grinblatui Dovydui, 9. Račeliui Kaziui, 10. Lukaševič Leonorai, 11. Mickevičiui Karoliui, 12. Intai Albertui, 13. Benkovič Borisui, 14. Žilinskui Vladimirui, 15. Grečionok Eugenijui, 16. Dorfman Michailui, 17. Šleifmanui Viktorui, 18. Matusevič Eduardui, 19. Orlovai Žanai, 20. Segal Basei, 21. Rusakovui Pavelui, 22. Vasiljevui Michailui, 23. Osipovai Galinai, 24. Vitui Maratui, 25. Vladeslavlevui Aleksandrui, 26. Vostrenkovui Semionui.

\section{Pramones ir civilinés statybos specialybe}

1. Jasinkaitei (Pavalkienei) Zitai, 2. Andriušiui Pranui, 3. Baronui Petrui, 4. Budykinai Alai, 5. Černevičiui Jonui, 6. Dovydenienei Nijolei, 7. Bogvilai Večeslavui, 8. Kantarovskui Ruvimui, 9. Kuliešiui Vaclovui, 10. Fišui Dovydui, 11. Janušoniui Broniui, 12. Jakimavičiui Eugenijui, 13. Mimui Kaziui, 14. Mikšiui Adolfui, 15. Rožkovui Eugenijui, 16. Rybalko Vladimirui, 17. Stundžiui Broniui, 18. Sriubšai Kazimierui, 19. Tinovskajai Eugenijai, 20. Tamulynui Jovitui, 21. Žvirinskiui Henrikui.

Visi šie 77 diplomantai ir veliau dar statybininkè E. Vapšienè sèkmingai parenge ir apgyne diplominius darbus ir tapo pirmąja KPI Vilniaus filialo inžinierių laida.

\section{Filialo materialinès bazès pokyčiai}

Vilniaus filialo plètra turëjo didelę perspektyvą, todèl daug darbo reikëjo ne vien kasdienos uždaviniams spręsti, bet ir pasirūpinti netolima ateitimi. Nei studiju proceso plesti, nei mokslo darbų vykdyti nebuvo imanoma be reikiamų patalpų. O ir turimosios nebuvo pritaikytos aukštosios mokyklos reikmèms.

Aprašomuoju metu darbas vyko trijuose rūmuose. Centriniuose rūmuose (Gorkio gatve 73, dabar Aušros Vartų g. 7A) įsikūre filialo administracija ir būsimasis Prietaisu gamybos fakultetas, pirmuosiuose rūmuose (Basanavičiaus g. 28) - būsimasis Mechaninès technologijos fakultetas, antruosiuose rūmuose (Mindaugo g. 14) buvo įrengtos statybos specialybiu katedros, auditorijos ir braižyklos. Bet problemų buvo daug.

Buvusiuose unitu vienuolyno, o veliau Vilniaus pedagoginio instituto rūmuose įsikūrusio KPI Vilniaus filialo patalpos buvo šildomos krosnimis ir normaliai apšildyti didžiulius koridorius ir buvusias "celes“ buvo neįmanoma. Todèl filialo vadovybè pirmiausia èmèsi energingai spręsti centrinio šildymo sistemos įrengimo klausimą.

1962 m. KPI Vilniaus filialas centriniuose rūmuose turejo 12 auditorijų $\left(850 \mathrm{~m}^{2}\right)$ ir 7 laboratorijas $\left(810 \mathrm{~m}^{2}\right)$. Sie rūmai, priklausę Pedagoginiam institutui, iš dalies buvo pradeti rekonstruoti

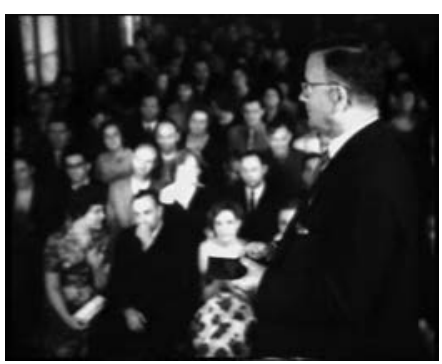

Rektorius K. Baršauskas sveikina pirmaja filialo laida

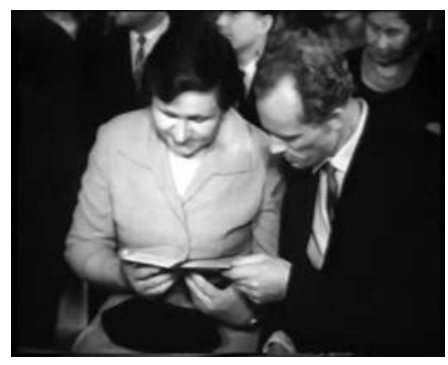

Puiku, kai diplomas jau rankose

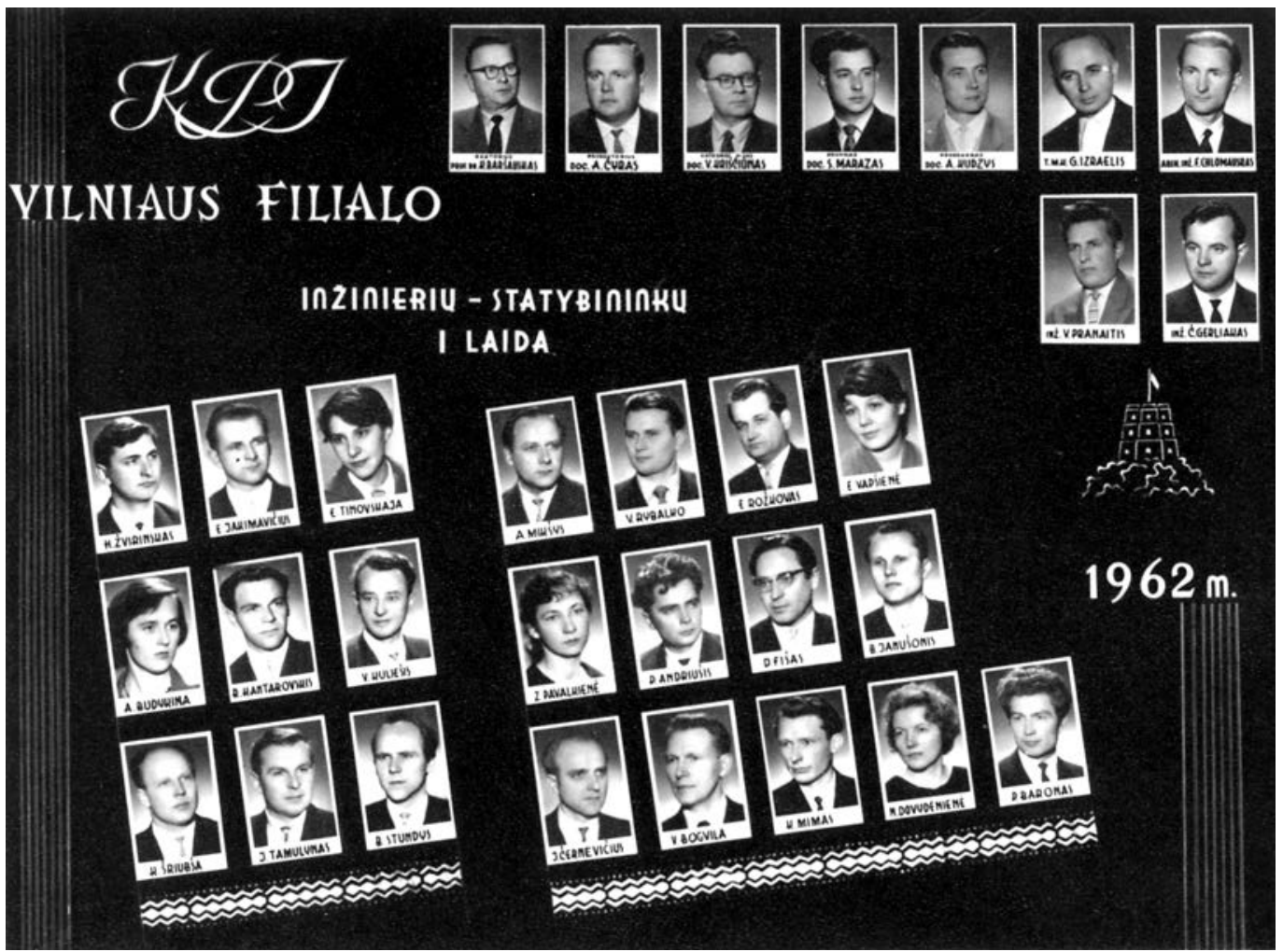


KAUNO

POLITECHNIKOS

INSTITUTO

VILNIAUS FILIALAS ir pritaikomi technikos studijoms, dalis patalpu buvo kapitaliai remontuojama. Buvo sutvarkytas elektros apšvietimas, védinimo sistema, dalis patalpų gavo teisę naudoti dujas.

Ir kituose filialo rūmuose buvo vykdomi remonto darbai. Pirmuosiuose rūmuose (Basanavičiaus g. 28) turèta 11 auditoriju $\left(740 \mathrm{~m}^{2}\right)$ ir 6 laboratorijas $\left(520 \mathrm{~m}^{2}\right)$, antruosiuose rūmuose (Mindaugo g. 14) -8 auditorijas $\left(390 \mathrm{~m}^{2}\right)$ ir 6 laboratorijas $\left(470 \mathrm{~m}^{2}\right)$. Bendras auditorijų, braižyklų ir laboratoriju fondas sudare $3780 \mathrm{~m}^{2}$. Taigi eksploatuoti nepritaikytas patalpas, jas remontuoti socialistinio deficito sąlygomis buvo tikrai sunku. Tai buvo pagrindinis ūkio darbuotojų rūpestis.

Ir vis dèlto filialas $1962 \mathrm{~m}$. jau turëjo įsteigęs keletą laboratoriju, kuriuose vyko ne tik studijų procesas, o ir moksliniai tyrimai. Medžiagų atsparumo ir statybinių konstrukciju bandymo laboratorija turejo naujausio tipo mašinas. Jos buvo naudojamos ir moksliniams darbams. Chemijos laboratorija turejo įrangą statybinèms medžiagoms tirti. Fizikos laboratorijoje veike trys skyriai: 1 . Mechanikos ir molekulinès fizikos; 2. Optikos; 3. Elektros ir magnetizmo. Gerai irengta buvo Elektrotechnikos laboratorija su šešiais skyriais: 1 . Bendrosios elektrotechnikos darbų; 2 . Teorines elektrotechnikos; 3. Elektrinių matavimų; 4. Elektros mašinų; 5. Elektrotechninių medžiagų; 6. Elektros energijos tiekimo. Intensyviai buvo įrenginëjamos Elektros mašinu ir pavarų, Radiotechnikos, Elektroninių ir joninių prietaisų laboratorijos. Tris įrengtas laboratorijas, nuosekliai papildomas naujais irenginiais, aparatais ir prietaisais, jau turëjo mechanikai: 1. Metalo technologijos; 2. Metalotyros; 3. Automobilių.

Buvo daug dirbama įrengiant dar 4 laboratorijas: 1 . Metalo pjovimo stakliu; 2 . Techninių matavimu; 3. Metalo pjovimo ir mašinų teorijos; 4. Mašinų detalių.

\section{Mokslinį darba plètojant}

KPI Vilniaus filialo prorektoriaus docento Aleksandro Čyro energingai vadovaujamą filialą nuolat papildydavo gabūs žmonès. Daugelis jų net ir sunkiausiomis sąlygomis, esant labai dideliam užimtumui vakarais, dieną turëjo galimybes vykdyti mokslinius tyrimus, rengti mokomąsias priemones, rašyti vadovelius. Buvo atliekami dar negausūs ūkiskaitiniai darbai. Apie tai rašoma KPI Vilniaus filialo mokslinès tarybos posedžio, ivykusio 1961-12-20, protokole [3.5, p. 7-8]. Taikomosios mechanikos katedra, o jai skilus - Metalų apdirbimo katedra vykdè sutartị su „Žalgirio“ gamykla. Darbo vadovu buvo katedros vedejas B. Liaudis. Kitam ükiskaitiniam darbui vadovavo e. doc. p. A. Kudzys. Sutartis buvo sudaryta su Vilniaus gelžbetoninių atramų gamykla.

Apie filialo mokslinius darbus KPI laikraštyje filialo prodekanas A. Kudzys raše: „Mūsu dèstytojai nuolat lankosi pramonés imonese ir konsultuoja gamybininkus... Statybos katedros darbuotojai (docentai Kriščiūnas ir Kudzys, t. m. kand. Izraelis), naudojant elektrotermini armatūros itempimo metoda, paruoše nauja gelžbetoniniu stiebu gamybos technologija, pagal kuria stiebai Vilniaus atramu gamykloje jau gaminami. Tai vien tik sioje gamykloje leis kasmet sutaupyti 200000 rub., 320 tonu metalo. Gamykloje pagal Statybos katedros kolektyvo paruosta projekta. pirma karta mūsu respublikoje veikia pilnai suremontuotos šutinimo kameros, kuriose gelžbetoniniu stiebu sutinimo procesas trunka tik 15-16 val.

Metalo apdirbimo katedros kolektyvas, vadovaujamas doc. Liaudžio, drauge su "Žalgirio" stakliu gamyklos darbuotojais ištyre ir nustate didelio stiprumo špyžiaus gamybos būdus.

Filialo chemikai, vadovaujami doc. Nickaus, padeda "Raudonosios auśros" stiklo fabrikui isisavinti stiklo karoliuku, reikalingu elektrografiniu būdu ryškinant dauginamus brězinius, gamybq" [3.6, p. 1].

Mokslo darbai buvo vykdomi ir kitose laboratorijose. Jau 1961 - 1962 mokslo metų pavasario semestre veike gerai ịrengta Elektrotechnikos laboratorija. Ją įrengti ir aprūpinti reikalingais prietaisais, aparatais ir įrenginiais padejo Vilniaus pramonès įmonès: Televizijos mazgų, Suvirinimo aparatų ir kitos gamyklos. Šioje laboratorijoje jau imta vykdyti mokslinius tyrimus. Elektrotechnikos katedros etatiniai destytojai -S. Marazas, M. Paulauskas, P. Vaičys, K. Kunigèlis tyre transformatorines alyvos, dielektrikų savybes ir kt. [3.7, p. 12].

Filialo mokslininkai paskelbe daug straipsnių tiek visasąjunginëje, tiek respublikinëje 
mokslinëje-techninëje spaudoje, skaite pranešimus mokslinèse konferencijose. $V y r$. dètytojas P. Vaičys sukonstravo ir pagamino universalų megometrą, kuris buvo eksponuojamas Liaudies ūkio pasiekimų parodoje Maskvoje. Doc. A. Kudzio vadovaujami mokslininkai už darbą apie elektroterminio metodo pritaikymą gelžbetoninių elektros liniju atramų gamybai gavo 1500 rub. Vyriausybes premiją.

Bet apskritai filialo katedrose mokslinis darbas buvo pletojamas silpnai. Katedry laboratorine bazè buvo skurdi. Negavusi poliarizacijos aparato, Mechanikos katedra negalëjo atlikti planuoto darbo eksperimentu taikant fototamprumo metodą, negavus reikalingos aparatūros liko nebaigtas vibracijos ir ultragarso įtakos silikatų kristalinimui tyrimas ir t. t.

1962 m. tik vienas filialo mokslininkas vadovavo vieninteliam aspirantui, būtent doc. A. Čyras - neakivaizdiniam aspirantui H. Gyliui.

Bet 1962 m. gegužès 9 d. KPI Vilniaus filialo mokslinès tarybos posedyje buvo pristatytas 1962-1970 m. daktaro disertaciju (habilitaciju) rengimo planas. Šiame plane jau buvo numatyta, kad daktaro disertacijas gins: A. Kudzys - 1967 m., A. Čyras 1968 m., I. Nickus - 1969 m., V. Krišsčiūnas - 1969 m., B. Liaudis - $1970 \mathrm{~m}$. ir A. Rusteika - 1969 m. Užmojai buvo gražūs, bet planus realizavo tik A. Čyras ir A. Kudzys.

\section{Filialo studentu džiaugsmai ir rūpesčiai}

Gausejjant dieninio skyriaus studentų, KPI Vilniaus filialas emè igyti vis solidesnès aukštosios mokyklos bruožų. Tam didelę reikšmę turejjo faktas, kad 1962 m. išleista pirmoji absolventų laida. Inžinierių diplomus gavo 26 mašinu gamybos, 30 pramonès imonių elektrifikavimo bei 22 pramonès ir civilinès statybos absolventai.

Vilniaus filialas pagrịstai didžiavosi tuo, kad, palyginti su "metropolija“ - Kauno politechnikos institutu, filiale diplominiai darbai buvo ginami ne instituto rūmuose, o gamybinèse organizacijose. Mašinų gamybos diplomantai gynè savo darbus Eksperimentinio mokslinio tiriamojo metalo pjovimo staklių instituto Vilniaus filiale ir Šlifavimo staklių gamykloje, elektrikai - specialiajame konstrukcijų biure prie „Elfos“ gamyklos, o statybininkai - projektavimo institute „Lietprojektas“.

Diplominių darbu gynimuose dalyvavo daug tų ịstaigų specialistų. Jie pateikdavo daugybę klausimų diplomantams. Dauguma diplominių darbų recenzentų taip pat buvo gamybininkai, dažniausiai patyrę tam tikros srities specialistai.

Pirmosios laidos diplominių darbų gynimas įrode, kad KPI Vilniaus filialas kvalifikuotai rengia inžinierius. Filialo mokslinè taryba tai pabrěže viename savo posèdžių, bet ir pažymejjo, kas taisytina studijų procese.

KPI Vilniaus filiale 1962 m. studenty laisvalaikis pastebimai pagerejo. Buvo organizuojami poilsio vakarai, susitikimai su kitų aukštujjų mokyklų studentais, literatūriniai vakarai, ème burtis meno saviveiklos rateliai.

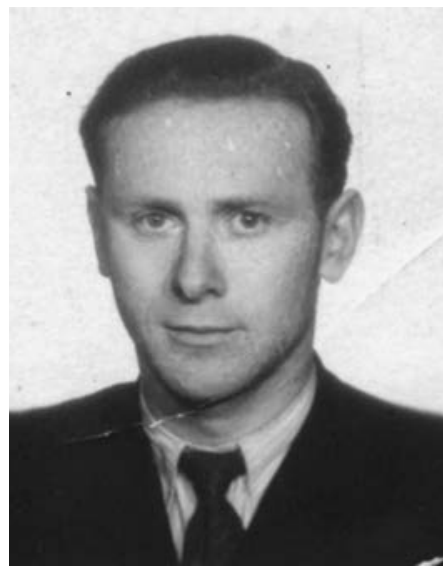

H. Gylys
Doc. A. Kudzys 1961 m. gavo vyriausybès premija už elektroterminio metodo pritaikyma gelžbetoniu atramy gamybai

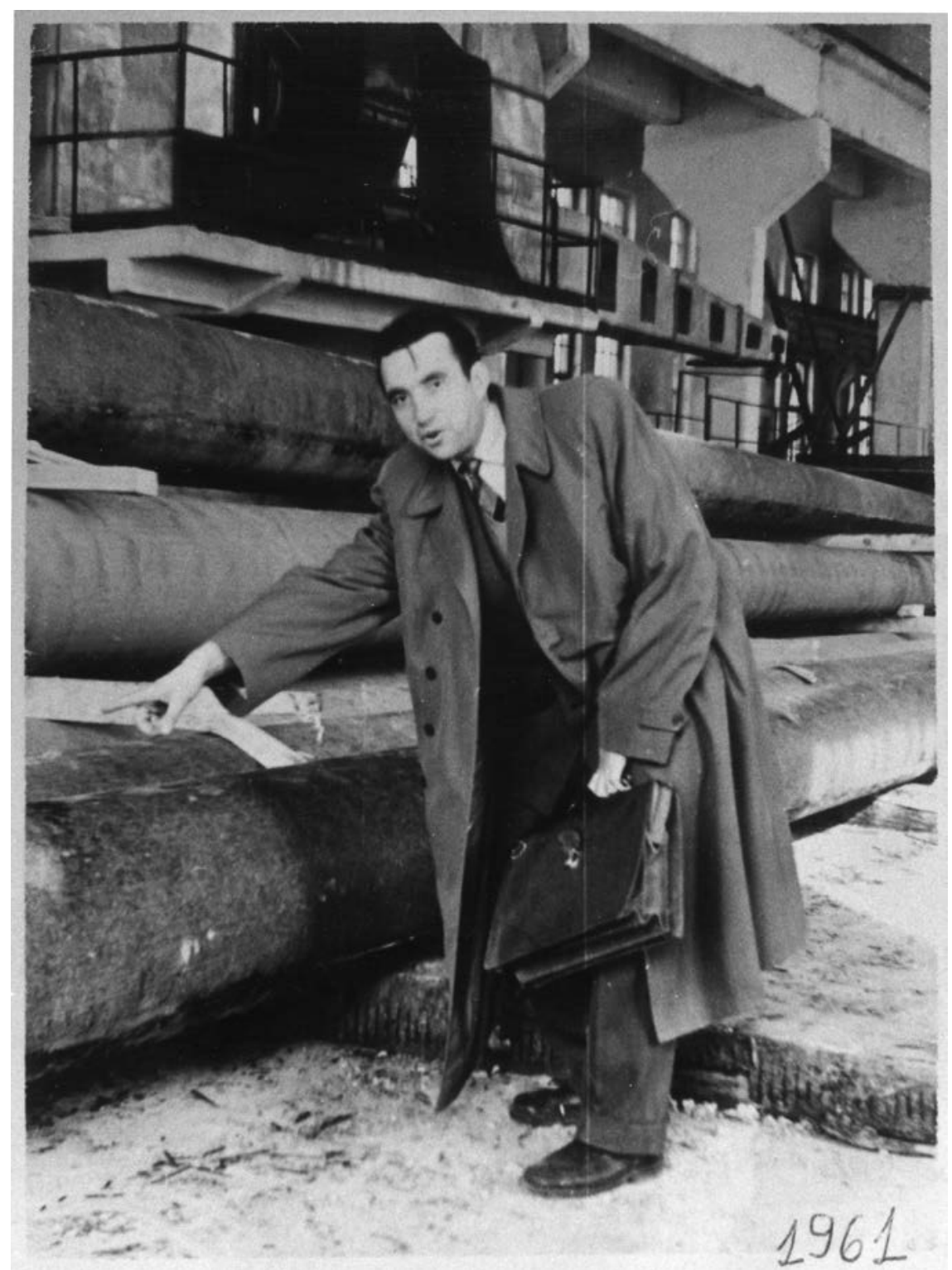


KAUNO

POLITECHNIKOS

INSTITUTO

VILNIAUS FILIALAS

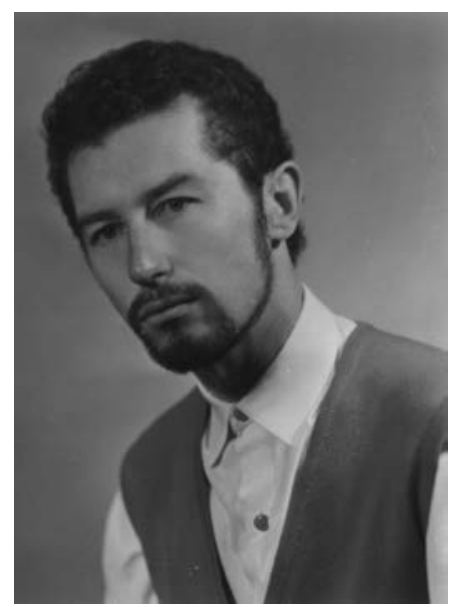

A. Gineitis

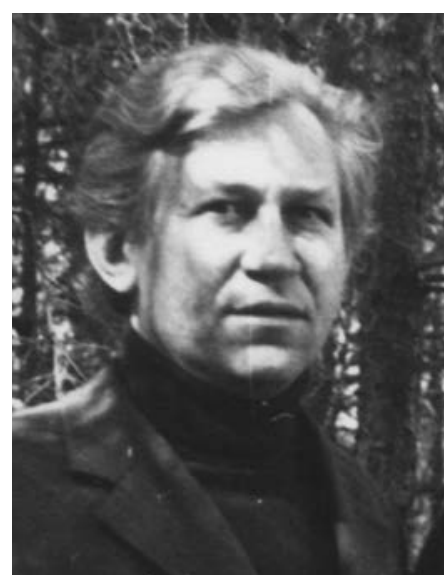

J. Mykolaitis
Dešinëje - KPI filialo ansamblio šokëjai Latvijoje
Iš KPI laikraštyje 1962 m. išspausdinto straipsnio epizodo matyti, kokios buvo tikrosios, o ne propagandinès studentu galimybès "tapti visapusiškai išsilavinusiu tarybiniu žmogum “. ZZavi vis delto to meto entuziastai, net sunkiausiomis aplinkybemis gebeję kurti meno kolektyvus, rengti vakarus, koncertus.

Filiale dar nebuvo studentų visuomeninių organizaciju - nei komjaunimo, nei profsąjungos. Tačiau didžiausią susirūpinimą filialo vadovams kèlè ne studentų laisvalaikis, o jų mokymosi klausimai.

KPI Vilniaus filialo mokslinè taryba dažnai svarstè studijų reikalus. Svarstant 1961-1962 m. egzaminų rezultatus buvo nustatyta, kad stacionaro I kurso ir žemesniųjų vakarinio skyriaus studentų egzaminų rezultatai blogi. Paaiškeejo, kokia yra pažangumo dinamika atskiruose vakariniuose kursuose. I kurse egzaminu neišlaike $49 \%$, II kurse $45 \%$, III kurse - $35 \%$, IV kurse - $24 \%$, V kurse $-14 \%$ ir VI kurse $-9 \%$ studentu. Taigi prasčiausiai atrodo pirmieji kursai. Daugiausia įsiskolinimų buvo iš aukštosios matematikos, braižomosios geometrijos ir medžiagu atsparumo.

Siekiant "priartinti aukštaja mokykla prie gamybos “, dar 1959 m. TSRS buvo nutarta taikyti naują studijų tvarką. Ta tvarka buvo idiegta ir Kauno politechnikos institute bei

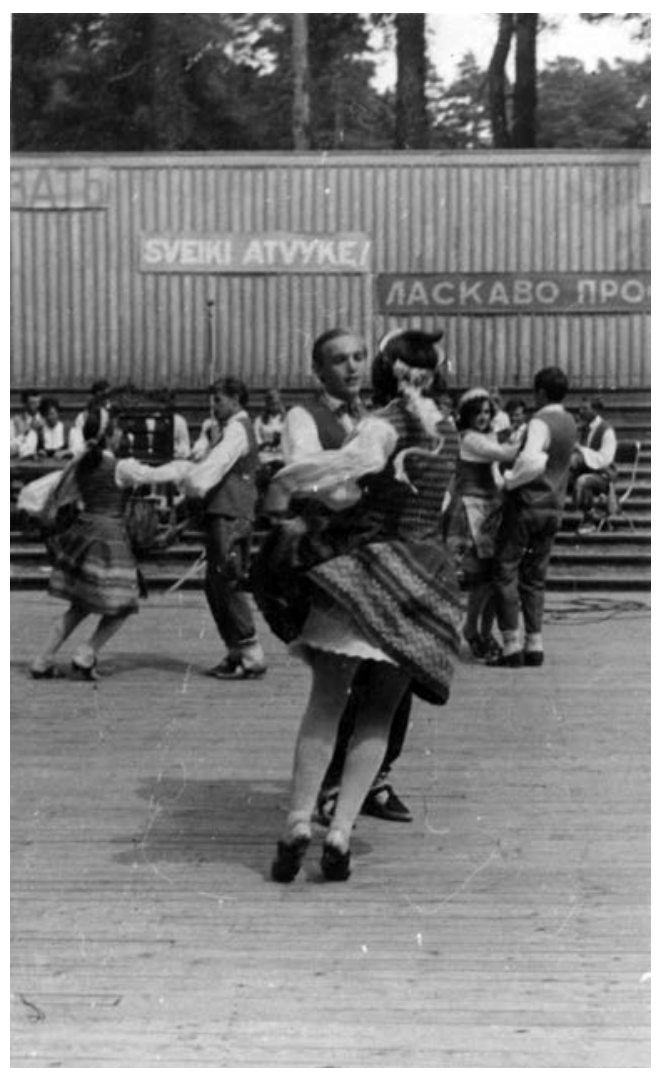


jo Vilniaus filiale. Naujai įstojusieji ị KPI dieninį skyrių turëjo dvejus metus dirbti gamyboje: dieną dirbti, vakare - studijuoti. Buvo numatyta, kad studentams mokes atlyginimą ir per dvejus metus jie ịveiks 1,5 metu ankstesnès tvarkos numatytą dieninio mokymo kursą. Po dvejų metų studentai jau studijuotų normaliai ir tolesnés studijos truktu 3,5 metų. Iprastinių studiju metu praktikų buvo numatyta atsisakyti ir palikti tik ikidiplominę praktiką. Studentai, kurie turëjo gamybini stažą, turëjo studijuoti 5 metus, kiti - 5,5 metu [3.9, p. 1].

Pirmojo kurso studentai privalëjo įsidarbinti tokiose darbo vietose, kurios būty artimos būsimajai specialybei. Bet susipažinus su pirmakursių įdarbinimu, paaiškejo, kad daugiausia taip nèra. Tarkim, Televizijos mazgu gamykloje dirbo 13 studentu, tačiau dèl blogų darbo sąlygų, priverstinio dykinejimo ir mažo uždarbio dalis išejo ir ìsidarbino kitur. Dauguma neturëjo nuolatinès darbo vietos, dirbo pagalbiniais darbininkais, kur būsima specialybe net nekvepejjo. Mènesinis darbo užmokestis tebuvo apie 22-23 rublius. Studentams neduodavo išeiginių dienų, dažnai tekdavo dirbti viršvalandžius. „Meistras Samsonovas stengiasi visaip trukdyti studentams sažiningai dirbti ir reikalauja, kad jie dirbty kuo daugiau ir taip, kad kaip nors gamini "prastumtu pro kontrolieriu“ $[3.10$, p. 1]. Būdavo ir tokių, kurie neblogai uždirbdavo, pavyzdžiui, Suvirinimo įrengimu gamykloje - po 60-70 rubliu per mènesi, bet ju mokslo pažangumas buvo blogas: iš 33 studentu - 22 dvejetai.

1962 m. KPI Vilniaus filiale įvykusiame pasitarime studiju klausimais dalyvavęs Aukštojo ir specialiojo vidurinio mokslo komiteto pirmininkas V. Kuzminskis kviete padetį taisyti. Esą „negali būti tokiu faktu, kad studentas, noredamas uždirbti 100 ir daugiau rubliu, dirba viršvalandžius naktineje pamainoje, o veliau miega paskaitose ir jas praleidžia" $[3.10$, p. 1]. Bet pirmininkas V. Kuzminskis nepateikè receptų, kaip uždirbti tą 100 rublių ir nemiegoti paskaitose.

Taigi „aukštosios mokyklos priartinimas prie gamybos" buvo viena iš nepavykusių voliuntaristo N. Chruščiovo reformų. Tai irode realus gyvenimas. Nelengvos buvo ir "tikrųju" vakarinioku studijos. Apie tai KPI laikraštyje deste vienas iš diplomantų: ,... ar sunku yra studijuoti, neatsitraukiant nuo gamybos? Be abejo, sunku. Norint sèkmingai mokytis, būtina racionaliai išnaudoti laika: jokiu büdu nepraleisti paskaitu, vesti smulkius užrašus, dalyvauti seminaruose ir praktikos darbuose, o ypač svarbu laiku gauti iskaitas ir išlaikyti egzaminus. Studijuojantiems neatsitraukiant nuo gamybos, akademinis isiskolinimas yra pražūtingas. Be to, reikia tinkamai sutvarkyti savo asmenini gyvenima, kad ne viena minute nenueitu veltui... Tačiau svarbiausias priekaistas institutui yra tas, kad dar pasitaiko destytoju, kurie visai neturi gamybinio patyrimo, kuriu destymas yra abstraktus <... " [3.11, p. 3].

Vakarinès studijos iš studentų reikalauja ypač didelio pasiryžimo, valios, geros sveikatos. Sunkiai atidirbus darbo dieną (nuo 1960 m. - 7 valandu) gamyklose, statybose ar įstaigose, auditorijoje nelengva susikaupti, suprasti ir įsisąmoninti dèstomą dalyką. Tenka daug padirbeti ir namuose: skaityti vadovèlius, užrašus, spręsti uždavinius, rengti kursinius projektus, rašyti referatus ir kt. Laisvalaikio beveik ir nelieka. Taigi gautas vakarinių studiju diplomas nusipelno ypatingos pagarbos ir pripažinimo. Šiaip ar taip, vakarinių studiju absolventų praktinè parengtis, palyginti su dieniniu skyriu studentais, visada buvo geresne. Tai bene vienintelis vakariniu studiju privalumas.

1962 m. KPI Vilniaus filialas pelnytai šventè reikšmingą pergalę: sèkmingai baigè mokslus ir inžinieriaus diplomus gavo pirmieji 78 absolventai. Filialo vadovas, KPI prorektorius doc. A. Čyras raše, kad „Pirmosios inžinieriu laidos diplominiai darbai - filialo mokomojo proceso veidrodis. Šiam labai atsakingam egzaminui kolektyvas ruošesi labai atidžiai <...>, gynimas parode, kad diplomantai paruošti gerai. Apie diplominiu darbu kokybe kalba ir tai, kad is 21 statybininko diplominio darbo Valstybineje egzaminu komisijoje jvertinti labai gerai 10, gerai - 10 ir tik vienas darbas-patenkinamai" [3.12, p. 2].

\section{Pirmieji filialo fakultetai}

1961-1962 mokslo metu pabaigoje KPI Vilniaus filiale dirbo 47 etatiniai ir 62 valandiniai destytojai. 14 jų turejo mokslų kandidato laipsni. Jau kitais mokslo metais buvo numatyta etatinių destytojų skaičių reikšmingai padidinti, nes labai daugejo studentų. 
KAUNO

POLITECHNIKOS

INSTITUTO

VILNIAUS FILIALAS

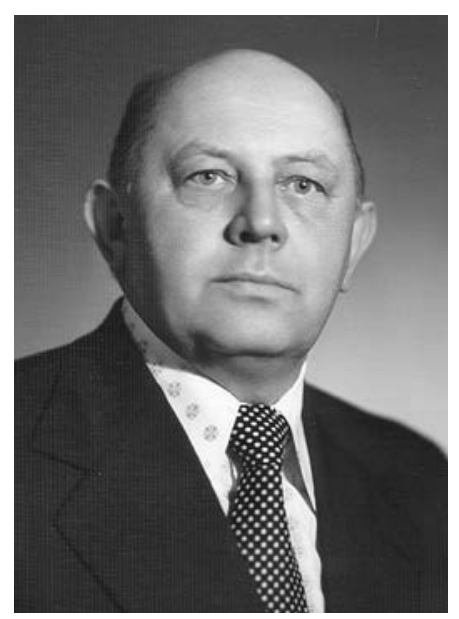

B. Liaudis

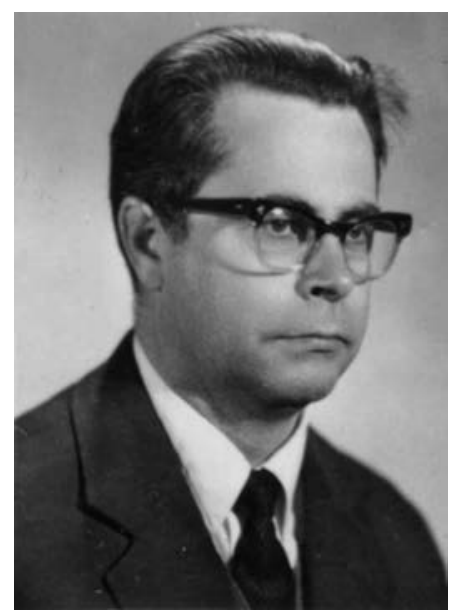

M. Paulauskas
Nuo 1962 m. liepos 1 d. KPI Vilniaus filiale buvo ịsteigti 2 fakultetai: Mechaninès technologijos ir Prietaisu gamybos. Mechaninès technologijos fakulteto dekanu buvo paskirtas Borisas Liaudis, Prietaisu gamybos fakulteto - Stanislovas Marazas.

Borisas Liaudis $1950 \mathrm{~m}$. baige Dnieprodzeržinsko metalurgijos institutą. Dirbo gamybininku, o vèliau instituto moksliniu bendradarbiu, TSRS Liaudies ūkio tarybos moksliniu sekretoriumi. 1954 m. parenge ir apgyne technikos mokslų kandidato disertaciją. Nuo $1960 \mathrm{~m}$. deste KPI Vilniaus vakariniame fakultete, vèliau KPI Vilniaus filiale. $1962 \mathrm{~m}$. tapo docentu ir Mechaninès technologijos fakulteto dekanu.

Stanislovas Marazas - KPI Elektrotechnikos fakulteto dekanas 1963-1973 m. Elektros mašinų katedros vedejas 1967-1972 m. Mažo galingumo elektros mašinų žinybinès laboratorijos, ikurtos $1961 \mathrm{~m}$., vienas iš moksliniu vadovu. Tyre ir renge vienfazių asinchroninių mažo galingumo elektros mašinu automatizuoto skaičiavimo ir optimalaus projektavimo metodiką ir kūre naujo tipo mažo galingumo variklius.

Tuo pat metu buvo reformuota Mechanikos-matematikos katedra. Ji skilo i dvi - Matematikos ir Mechanikos - katedras. Matematikos katedra buvo priskirta Prietaisu gamybos fakultetui, o Mechanikos katedra-Mechanines technologijos fakultetui. Pastarajam fakultetui buvo priskirta ir nuo 19620701 naujai įsteigta Mašinų teorijos katedra.

Naujus 1962-1963 mokslo metus KPI Vilniaus filialas pradejo turedamas 7 katedras ir 3 metodines komisijas, kurios faktiškai atliko katedru vaidmeni.

1962-1963 mokslo metais KPI Vilniaus filialo studentų skaičius perženge tūkstantį. Dieniniame filialo skyriuje studijavo 524 studentai, vakariniame skyriuje - 1182 studentai. Taigi iš viso studijavo 1706 jaunuoliai ir merginos. Prietaisu gamybos fakultete studijavo 726 studentai: 288 dieniniame ir 438 vakariniame skyriuose. Dieniniame skyriuje buvo 3 specialybès: 1) radijo aparatūros gamybos technologija ir konstravimas; 2) skaičiavimo mašinos ir prietaisai; 3) elektros pavaros ir gamybinių mechanizmu automatizacija. Prietaisu gamybos fakultete
1962-1963 mokslo metais dirbo 81 etatinis dèstytojas ir 61 destytojas-valandininkas. Jie buvo pakviesti iš įvairių ìmonių bei organizaciju kaip aukštai kvalifikuoti specialistai. Fakultete veike 6 laboratorijos ir užsienio kalbų kabinetas, pradetos komplektuoti ir įrengti Elektros mašinų ir pavarų bei Siųstuvų ir imtuvų laboratorijos.

Mechaninès technologijos fakultete studijavo 870 studentų: 236 dieniniame ir 614 vakariniame skyriuose. Dieniniame skyriuje buvo 5 specialybes: 1) metalo apdirbimas spaudimu; 2) suvirinimo technologija ir ìrengimai; 3) pramonine ir civiline statyba; 4) gelžbetoninių dirbinių technologija (iš Kauno) ir 5) mašinų statybos ir plastmasių technologija (iš Kauno). Vakariniame skyriuje buvo 3 specialybès: 1) mašinu gamybos technologija; 2) automobilių transportas; 3) pramoninè ir civiline statyba. Prie Mechanines technologijos fakulteto vakarinio skyriaus buvo priskirtas Bendratechninis skyrius, kuriame studijavo 130 studentu. Mechanines technologijos fakultete 1962-1963 mokslo metais dirbo 39 etatiniai destytojai, kurių 9 turejo mokslinius laipsnius ir 29 destytojaivalandininkai - patyrę specialistai iš gamybinių organizacijų.

Fakultete veike 2 laboratorijos: Medžiagų atsparumo bei Metalo technologijos ir metalotyros. Buvo pradeta kurti Automobiliu laboratorija. Veikè statybos bei piešimo kabinetai. Dalį laboratorinių darbų studentai

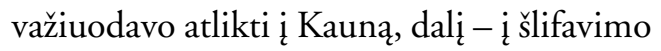
staklių, grąžtu gamyklų laboratorijas.

Prietaisu gamybos fakultete veike Elektrotechnikos ir Matematikos katedros bei Fizikos ir Chemijos metodines komisijos. Elektrotechnikos katedroje dirbo: vedejas doc. t. m. k. S. Marazas, e. doc. p., t. m. k. M. Paulauskas, vyr. dèst. P. Vaičys, asistentai T. Žemaitis ir K. Kunigelis. Matematikos katedrą sudare: vedejas - e. doc. p., fiz.mat. m. k. R. Uždavinys, vyr. dèst. L. Janulionis (kartu ir vienas fakulteto prodekanų), vyr. dèst. A. Miliušas, vyr. dèst. A. Šeputis, vyr. dest. T. Bilkis, asist. V. Gurskis, asist. J. Stankevičius. Puse etato dar dirbo V. Toleikyte, I. Ambraziejūnaite ir E. Degutyté. Matematikos katedros vedeju išrinktas Romualdas Uždavinys 1955 m. baigè Vilniaus universiteto Fizikos-matematikos fakultetą. Paskui studijavo Lietuvos moksly akademijos Fizikos ir matematikos institute aspirantūroje bei tuo pačiu metu mokytojavo. Jau nuo $1956 \mathrm{~m}$. buvo priimtas eiti 
ne pagrindines pareigas i $\mathrm{VU}$ Bendrosios matematikos katedrą. Nuo 1958 m. dirbo minettojo instituto jaunesniuoju moksliniu bendradarbiu. $1962 \mathrm{~m}$. apgyne disertaciją ir gavo fizikos-matematikos mokslų kandidato laipsnic. 1964 m. tapo docentu. KPI Vilniaus filiale katedros vedeju R. Uždavinys dirbo iki 1967 m. Kai buvo išrinktas Vilniaus universiteto Skaičiavimo matematikos katedros vedejju, filiale jis dar kurị laiką dirbo valandiniu destytoju.

Filiale jau nuo pat KPI Vakarinio fakulteto Vilniaus skyriaus įsteigimo labai daug dèmesio buvo skiriama aukštajai matematikai. Buvo manoma, kad „...tvirtas aukštosios matematikos žiniu isisavinimas ne tik padeda geriau suprasti specialiasias technines disciplinas aukstesniuose kursuose, bet ir žymiai sutvirtina büsimo inžinieriaus techniniu žiniu bagaža, leidžia spręsti pačias sudetingiausias sizu dienu mokslo ir technikos problemas" [3.13, p. 1].

Išskirtinị demesị matematikos dalykams skyrè ir filialo vadovas doc. Aleksandras Čyras. Jis akcentavo būtinybę išugdyti būsimojo inžinieriaus mokejjimą taikyti matematikos metodus praktiniams uždaviniams spręsti. Jo iniciatyva kaip atskiri dalykai buvo įvesti matematinès skaičiavimo mašinosir programavimas. Dar tais metais Matematikos katedros vedejjas R. Uždavinys teige, kad „ateis laikas, kad programavimą turès žinoti kiekvienas, kaip dabar daugybos lentelę “ [3.14, p. 14].

Matematinių skaičiavimo mašinų ir programavimo dalykui išdesstyti buvo skirta 60 akademinių valandų dieninio skyriaus studentams ir 22 akademines valandos - vakarinio skyriaus studentams. Ši naują dalyką katedra buvo pasiūliusi parengti jaunoms specialistems E. Degutytei ir V. Toleikytei. Tačiau žinoma, kad dalyką deste A. L. Telksnys.

Adolfas Laimutis Telksnys - ižymus informatikos specialistas, ilgainiui tapęs habilituotu daktaru, profesoriumi, Lietuvos mokslu akademijos tikruoju nariu akademiku. KPI Vilniaus filialo vadovas A. Čyras buvo matematinio programavimo metodu taikymo konstrukciju tyrimams pradininkas ir didelis entuziastas, todel neatsitiktinai jis labai vertino šį dalyką ir siekè, kad jị desstytų aukščiausios kategorijos specialistai. Reikia pažymèti, kad vèliau, jau VISI, prof. A. L. Telksnys buvo instituto tarybos nariu.

Fizikos metodinę komisiją sudarè: pirmininke, vyr. dest. H. Gutmaniené, vyr. dèst. P. Breive, asistentai A. Šatas, P. Jurènas, R. Banienè. B. Naruševičiene, E. Charitienè. Puse etato dirbo L. Bastytè.

Chemijos metodinę komisiją sudarè: pirmininkas doc. t. m. k. I. Nickus, doc. ch. m. k. M. Priluckaja, vyr. dest. R. Likšienè, asistentai A. Raudeliūnienè, P. Vosylius, D. Slankauskiené.

Hinda Gutmaniene $1937 \mathrm{~m}$. baige Vytauto Didžiojo universiteto Gamtos-matematikos fakultetą ir gavo fiziko diplomą. Mokytojavo Kauno mokyklose, o prasidejus karui atsidūre Kazachstane. Mokytojavo Alma Atos, o veliau - Zavodonskovsko vidurinèse mokyklose. 1945 m. grižo ị Lietuvą. Nuo 1946 m. pradejo dirbti Vilniaus valstybinio universiteto Bendrosios fizikos katedroje. Nuo 1960 m. dirbo KPI Vilniaus filiale vyr. dèstytoja. $1963 \mathrm{~m}$. rugsëjo-lapkričio mènesiais ejo Fizikos katedros vedëjos pareigas. Nuo 1972 m. sausio išèjo i i pensiją.

Ipolitas Nickus 1952 m. baigè Kauno politechnikos instituto Cheminess technologijos fakultetą ir, igijęs silikatų technologijos inžinieriaus specialybę, emé dirbti KPI Fizikines chemijos katedroje vyr. laborantu, kiek vèliau - asistentu. Nuo 1953 m. trejus metus buvo Uralo politechnikos instituto (Sverdlovske) aspirantu. $1956 \mathrm{~m}$. apgyne disertacinį darbą ir tapo technikos mokslų kandidatu, po kelerių metu - docentu. Nuo 1961 m. ème dirbti KPI Vilniaus filiale, buvo katedros vedeju, Vietos komiteto pirmininku.

1963 m. birželio 24 d. vietoj Fizikos ir Chemijos metodinių komisijų buvo įsteigtos Bendrosios fizikos ir Chemijos katedros. Bendrosios fizikos katedros vedejo pareigas laikinai ejjo H. Gutmaniené, o Chemijos katedros vedëju buvo išrinktas I. Nickus.

Mechanines technologijos fakultete veike Metaly apdirbimo, Mechanikos, Statybos ir Mašinų teorijos katedros bei Užsienio kalbų ir Techninès braižybos metodinès komisijos. Metalų apdirbimo katedrą sudarè: vedejjas doc. t. m. k. B. Liaudis, e. doc. p. V. Valaitis, vyr. desst. L. Klimavičius ir asistent. J. Ališauskaite. Mechanikos katedrą sudare: vedejas - doc. t. m. k. A. Čyras, doc. t. m. k. A. Rusteika, e. doc. p. E. Maksimavičius, vyr. dèst. V. Kulakauskas. Puse etato dirbo V. Jemeljanovas. Statybos katedrą sudare: vedejjas - doc. t. m. k. V. Kriščiūnas, doc. t. m. k. A. Kudzys, vyr. dest. V. Tulevičius, asist. R. Vadlūga. Puse etato dirbo V. Pranaitis ir G. Izraelis.

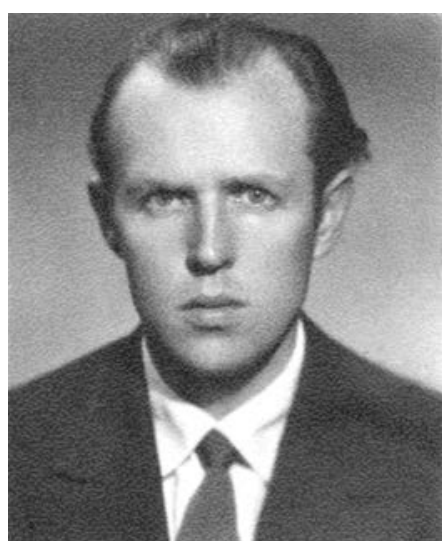

R. Uždavinys

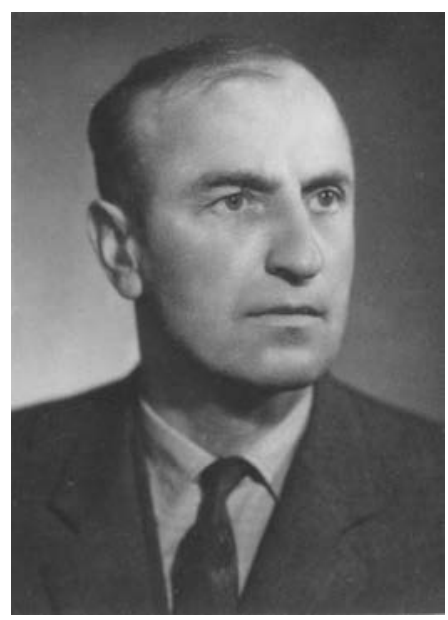

A. Miliušas 
KAUNO

POLITECHNIKOS

INSTITUTO

VILNIAUS FILIALAS

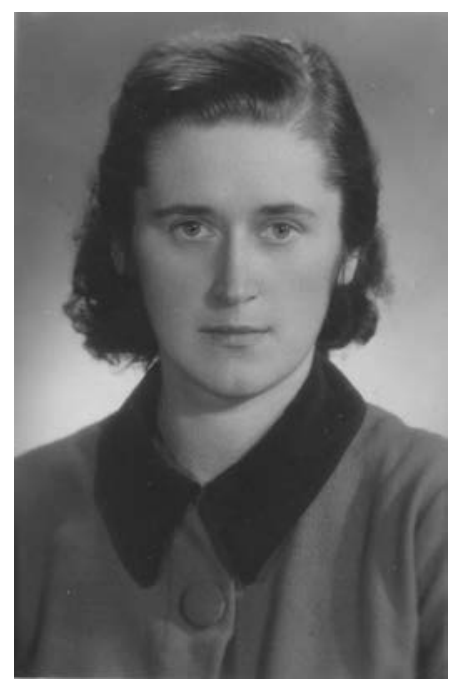

A. Raudeliūnienè

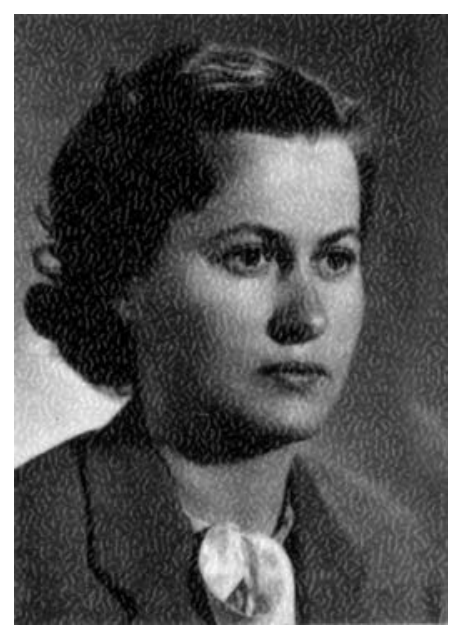

A. Glemžiené

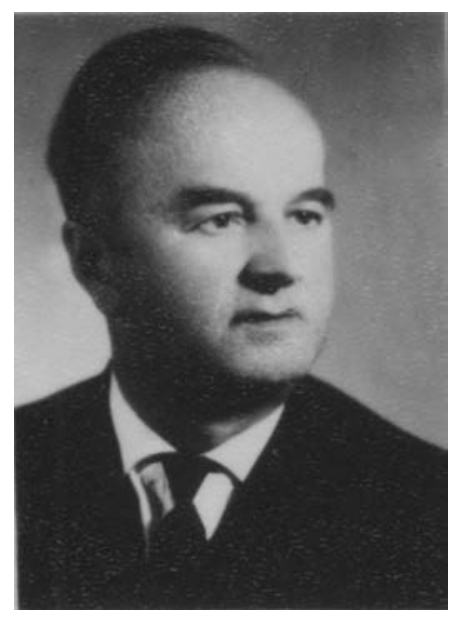

A. Martinaitis
Mašinų teorijos katedrą sudare: vedèjas - doc. t. m. k. D. Maciulevičius, doc. t. m. k. R. Jonušas, vyr. dèst. ek. m. k. A. Martinaitis, e. doc. p. K. Paškevičius, asist. J. M. Nemira. Puse etato dirbo A. Gap̌̌ys ir A. Kuzmickas.

Daumantas Maciulevičius 1951 m. baige Kauno politechnikos instituto Mechanikos fakultetą ir gavo mašinų gamybos inžinieriaus diplomą. Dirbo gamybininku, o $1952 \mathrm{~m}$. įstojo į LTSR MA Fizikos-technikos instituto aspirantūrą. Nuo $1953 \mathrm{~m}$. buvo komandiruotas į TSRS MA Mašinų mokslo institutą Maskvoje, kur parenge ir apgyne disertaciją. Gavo technikos mokslų kandidato laipsnị. Nuo 1956 m. dirbo minetame Fizikostechnikos institute, paskui - Energetikos ir elektronikos institute, o nuo 1962 m. - KPI Vilniaus filiale.

Užsienio kalbų metodinę komisiją sudarè: pirmininkè vyr. dest. A. Glemžienè ir asistentai A. Saboniene, R. Saugeniené, E. Adomenienè, M. Kybartiene, A. Kryžanauskaité, B. Laukaitiené, A. Žitkute bei K. Rukšènas.

Techninès braižybos metodinę komisiją sudare: pirmininkas - doc. t. m. k. J. Charitas, vyr. desstytojai V. Klimavičius, S. Taunys, B. Paškevičius ir asist. V. Šimonis.

Aldona Glemžienè 1959 m. baige Vilniaus valstybinį pedagoginį institutą ir gavo anglu kalbos specialisto diplomą. Dirbo Lietuvos žemès ūkio akademijoje, nuo 1960 m. - KPI Vilniaus filialo vyr. destytoja. Nuo $1963 \mathrm{~m}$. buvo Kalbų katedros vedeja.

Judelis Charitas nuo 1938 iki $1941 \mathrm{~m}$. studijavo statybą Vytauto Didžiojo universitete. Karo metais kartu su tevais buvo evakuotas į TSRS gilumą. $1945 \mathrm{~m}$. baige Tomsko geležinkeliu transporto institutą. Grįžęs į Lietuvą 1945-1948 m. dirbo LTSR Ministrų Tarybos Transporto ir ryšių skyriaus viršininko padejejju. Nuo 1948 m. studijavo Leningrado elektrotechnikos, signalizacijos ir ryšiu institute, braižomosios geometrijos specialybès aspirantūroje. $1951 \mathrm{~m}$. apgynè disertaciją ir dirbo Vilniaus geležinkeliu transporto technikumo desstytoju bei ejo ne pagrindines vyr. destytojo pareigas KPI Braižomosios geometrijos katedroje. Nuo $1953 \mathrm{~m}$. buvo perkeltas į Baltarusijos geležinkelių transporto institutą, kur iki $1961 \mathrm{~m}$. dirbo Braižomosios geometrijos ir grafikos katedros vedẻju. Paskui atvyko į Vilnių ir buvo KPI Vilniaus filialo docentu.

Metodinių komisijų vietoje (1963 06 24) buvo ịkurtos Kalbų ir Braižybos katedros. Buvę šiu komisijų pirmininkai tapo katedrų vedejjais.

Vadinamosioms bendrosioms katedroms (ne fakultetinems) buvo priskirta Marksizmo-leninizmo katedra, kurią sudare: vedejas - A. Marcelis ir nariai N. Nikolajeva, S. Lazutka, Adelšina, Z. Barkauskiene, O. Petraškevičius, J. Bacevičius ir A. S. Babičas. KPI Vilniaus filialo praejusių mokslo metu ataskaitoje buvo tvirtinama, kad „visos katedros destytoju darbo rezultate studentai visumoje giliai ir kryptingai jisisavino marksizmo-leninizmo teorija, TSKP XXII suvažiavimo medžiaga“. Bet ten pažymèta, kad „dalis (nors ir nežymi) studentu nepajegia arba nenori kūrybingai isisavinti marksizmo-leninizmo teorijos. Dar ne visiems studentams marksizmasleninizmas tapo ju pasaulezżiūros pagrindu. Pas kai kuriuos studentus pasitaiko nesveiku nuotaiku, buržuazines nacionalistines ideologijos pasireiškimu“. Ataskaitoje dejuojama, kad „kai kurie studentai ima, nors ir pridengtai, ginti neteisingas pažiūras, reiškia nepasitikejima komunizmo statyba, partijos politika, ypač nacionaliniu klausimu" [3.15, p. 5].

Archyviniuose dokumentuose neradome medžiagos, kad KPI Vakarinio fakulteto Vilniaus skyriaus studentai būtų kažkaip reagavę į rezonansinius Lietuvoje $1956 \mathrm{~m}$. Vengrijos ivykius. Bet iš pateiktos ataskaitos matyti, kad chruščiovinio atlydžio baigiamaisiais metais, nepaisant TSRS laimëjimy̨ kosmose, komunizmo statybos šviesia ateitimi mažai kas tikejjo. Marksizmas-leninizmas nei tuomet, nei veliau taip ir netapo nei studentų, nei destytoju pasauležiūros pagrindu. Bet iki šito atviro neigimo dar turëjo praeiti beveik 30 metų.

Kol nebuvo ịsteigtos metodinès komisijos, i specialiąsias katedras buvo priimti destytojai, kurių darbas nebuvo susijęs su tų katedrų profiliu. Pavyzdžiui, Elektronikos katedroje buvo destomos visos elektronikos bei radioelektronikos disciplinos, taip pat ir fizika. Metalų apdirbimo katedroje - visi mašinu gamybos specialieji dalykai, taip pat technine braižyba bei braižomoji geometrija. Statybos katedroje destytos visos statybos disciplinos, taip pat chemija.

KPI Vilniaus filialo destytojų kolektyvą dar gerokai papildè dèstytojai-valandininkai. Kai kurie, atrodo, ištverdavo tik vieną semestrą 
ar vienerius mokslo metus, kol įsitikindavo, kad pedagogo darbas anaiptol nera lengvas. Padèti gelbejjo déstytojai, važinèjantys iš Kauno.

\section{Numatoma mokomuju laboratoriju bazés pletra}

Studijų reikalus dažnai svarste filialo Moksline taryba, kurią dabar sudare jos pirmininkas A. Čyras ir 17 narių: V. Kriščiūnas, A. Kudzys, M. Priluckaja, S. Marazas, A. Aksomitas, I. Nickus, J. Charitas, B. Liaudis, R. Jonušas, M. Paulauskas, D. Kosciukevičius, R. Uždavinys, L. Janulionis, A. Rusteika, D. Maciulevičius, J. Bacevičius ir A. Marcelis.

Tarybos posedžiuose buvo aptarinëjami egzaminų sesijų rezultatai, žemo pažangumo priežastys, déstytojų darbas ir kt. Ypač daug rūpesčio kèle auditorijų ir laboratorijų stoka, visai nebuvo braižyklų diplominiams projektams rengti.

İdomu pažymèti, kad dar 1962 m. gruodžio $18 \mathrm{~d}$. Tarybos posedyje jos mokslinis sekretorius V. Kriščiūnas informavo, kad 1963 m. bus projektuojami KPI Vilniaus filialo naujieji rūmai, kad jau sudaryta planinè projektavimo užduotis. Tai reiškè jau daug stipresnę filialo plètrą. Aiškëjo būsimos suverenios aukštosios technikos mokyklos Vilniuje kontūrai [3.16, p. 1-124].

1963 m. birželio 18 d. filialo Mokslinès tarybos ir partines organizacijos bendrame posedyje buvo konstatuota, kad esamos filialo patalpos "nepritaikytos mokslo istaigos poreikiams, ypač laboratorijoms ir kabinetams ịrengti $\langle\ldots\rangle$. Filiale esančiu specialybiu mokymo procesui užtikrinti reikalinga irengti 24 naujas mokymo laboratorijas $\langle\ldots .$.$\rangle , filia-$ las $<\ldots .>$ bus priverstas dali auditoriju paversti laboratorijomis. Visa tai sudaro rimtas kliūtis normaliam filialo pletimuisi ir stiprejimui.

Filiale visai nera braižykly diplominiam projektavimui ir studentai priversti diplominius projektus atlikti namuose, o tai prieštarauja diplominiu darbu paruosimo metodams.

Nuo ateinančiu mokslo metu pradžios bus isteigtas spec. parengimo katedros filialas, kuriam reikes papildomu izolinoty patalpu...".

„Labai sunkioje padetyje yra studentu aprüpinimas bendrabučiais. Siuo laiku iš viso apgyvendinta tik 25 studentai, tai sudaro tik 27 proc. reikalingu apgyvendinti. Be to, siu studentu dalis gyvena mokymosi patalpose (Gorkio 73), ǔ̌imdami 7-ias auditorijas.

Normaliam filialo pletimui ir jo mokymo bazès sustiprinimui turi büti sudarytas tvirtas pagrindas, t. y. turi büti nedelsiant pradeta projektuoti ir statyti atitinkamu laboratoriju, mokymo patalpu, bendrabučiu ir kitokiu irenginiu kompleksas, sukoncentruotas vienoje vietoje.

Nutarta (cituojame 2 punktus):

6. Prašyti LTSR MT Valstybinio aukštojo ir specialiojo vidurinio mokslo komiteta trumpiausiu laiku apsvarstyti ir išspresti KPI Vilniaus filialo mokymo-laboratorines bazes išpletimo klausima.

7.<...>prašyti< ...> išskirti 1964 metams limita KPI Vilniaus filialo mokymo-laboratoriju bazes projektavimui...".

Skaitant ši dokumentą krinta ị akis du dalykai: 1. KPI Vilniaus filialas sprendžia savo problemas jau visai kaip savarankiška institucija, apeina KPI centrą. 2. Forsuojama veikla sukurti atskirą aukštają mokyklą, nors tam kalbamuoju momentu nèra nei jai būtinos materialinès bazès, nei reikiamy pedagogų. Neaiški ir ketinamos įkurti aukštosios mokyklos specializacija. Bet KPI Vilniaus filialo vadovybė, ypač prorektorius A. Čyras, genialiai pasinaudojo respublikos dalies vadovų nuostata, kad būtina lietuvinti Vilnių, Vilniaus kraštą, ir tai geriausia daryti steigiant čia lietuviškas mokyklas. Todel, jausdamas įtakingu Lietuvos TSR veikejų paramą, Aleksandras Čyras, nepaisydamas KPI centro rodomo skepticizmo, prieštaravimų, mobilizavo visas filialo jègas savarankiškai aukštajai technikos mokyklai Vilniuje sukurti.

1963 m. Prietaisu gamybos fakultete buvo tik 10 diplomantu, 9 iš ju sèkmingai apgyne diplominius projektus ir gavo pramonès įmonių elektrinių ịrengimų inžinieriaus elektriko kvalifikaciją. Negynęs diplominio darbo studentas sirgo ir jo darbo gynimas buvo atidetas.

$1963 \mathrm{~m}$. Mechanines technologijos fakultetą baige 38 studentai. 33 diplomantai igijo mašinu gamybos technologijos, metalo pjovimo stakliu ir įrankiu specialybę, o 5 diplomantai tapo pramoninès ir civilinès statybos specialistais.

1963 m. vasarą pirmą kartą buvo surengta studentų sveikatingumo stovykla Aukštadvaryje.

Dar 1961 m. pavasarị Vilniuje įvyko Profsąjungu Centro tarybos ir komjaunimo CK biuro organizuotas pasitarimas, kur buvo

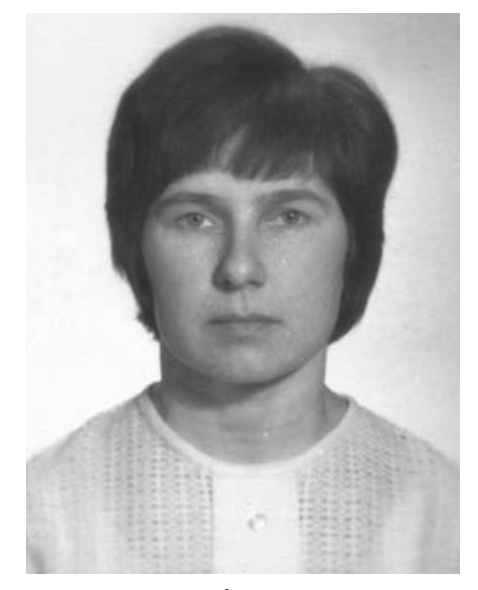

E. Adomeniene

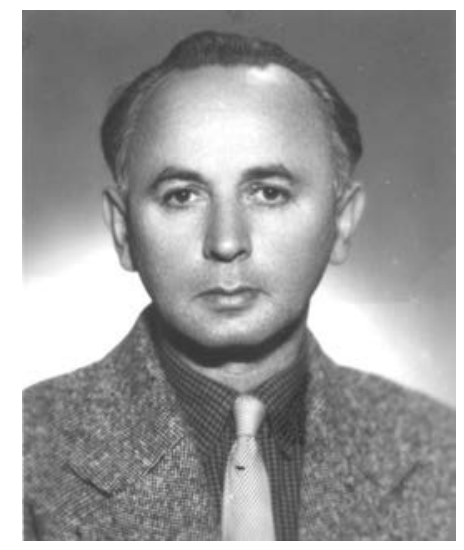

G. Izraelis 
KAUNO

POLITECHNIKOS

INSTITUTO

VILNIAUS FILIALAS nutarta, kad Lietuvoje reikia kurti stacionarias sportines sveikatingumo stovyklas. KPI rektorato $1961 \mathrm{~m}$. kovo $13 \mathrm{~d}$. posédžio protokole rašoma, kad Fizinio lavinimo katedros vedejjas $V$. Vaišys prašo skirti lěšu suomiško tipo namukams Aukštadvaryje statyti. Taigi Aukštadvaryje stovyklai sklypą, matyt, gavo KPI centras. Bet tais pačiais metais rektorius K. Baršauskas išrūpino stovyklai sklypą Kapitoniškèse, greta Kauno marių, netoli Kauno. Aukštadvarị panaudoti stovyklai buvo pasiūlyta KPI Vilniaus filialui. A. Čyras entuziastingai èmési stovyklos kūrimo veiklos [3.17, p. 20v].

Tą patị 1963 m. pavasarį KPI Vilniaus filialas gavo 100 vietų surenkamosios valgyklos medines konstrukcijas. Vasarą buvo pradeti jos montavimo darbai.

Per vasaros atostogas Aukštadvaryje buvo ikurta KPI Vilniaus filialo studentų darbo ir sveikatingumo stovykla dviem pamainoms po 30 studentų. Stovyklą organizavo sudarytas organizacinis komitetas, ị kurị iejejo: V. Kulakauskas - statybos viršininkas, V. Barisas pavaduotojas sporto ir kultūros klausimams, S. Maleckas - pavaduotojas ūkio reikalams, R. Vadlūga - pavaduotojas statybos reikalams, A. Liepinis - komjaunimo komiteto sekretorius, Jukna - studentų profsąjungos pirmininkas ir A. Šeputis - vietos komiteto pirmininko pavaduotojas [3.18, p. 16].

Taigi 1963 m. KPI filiale veike jau ir studentų organizacijos, darbuotojų profsąunga. Partine organizacija turejo 32 narius ir jos ittaka filialo darbui vis didejo. Jos biuro sekretoriumi buvo J. Bacevičius.

\section{Leista aspirantūra}

Filialo katedrose jau dirbo 145 mokslo personalo nariai. Iš jų 86 buvo etatiniai darbuotojai, o 54 - destytojai specialistai, pakviesti iš įvairiu organizacijų ir dirbantys valandininkais. 24 proc. etatiniu darbuotoju turejo mokslinius laipsnius ir vardus.

KPI Vilniaus filialo vadovas A. Čyras žinojo, kad savarankiška aukštoji mokykla gali funkcionuoti tik esant kvalifikuotam pedagogu kolektyvui, todèl jis siekè priimti etatiniais darbuotojais specialistus, turinčius mokslinị laipsnị ar bebaigiančius rengti disertacijas. O norèdamas šį uždavinị išspręsti greičiau, jis sieke, kad filialui būtų leista steigti aspirantūrą. 1962-1963 mokslo metu pavasari toks leidimas buvo gautas. Tai buvo reikšmingas laimëjimas. „Vakarinèse naujienose" filialas skelbe, kad dar $1963 \mathrm{~m}$. bus priimami jaunuoliai ir merginos iki 35 metų amžiaus ị stacionarią ir neakivaizdinę aspirantūrą. KPI Vilniaus filiale turejo būti vykdomas priemimas ị tikslinę aspirantūrą Maskvoje ir Leningrade.

Stacionarioje aspirantūroje buvo trys specialybès: 1) medžiagų atsparumas ir statybinè mechanika; 2) elektros mašinos; 3 ) statybinès konstrukcijos.

Neakivaizdinëje aspirantūroje buvo keturios specialybès: 1) taikomoji geometrija ir inžinerinè grafika; 2) liejininkyste; 3) statybinès konstrukcijos ir 4) statybinès medžiagos.

Tikslinès aspirantūros specialybès buvo šešios: 1) funkcijų analizè ir funkcijų teorija (Maskvos geologinių paieškų institute); 2) kalvystes-presavimo mašinos (Maskvos staklių instrumentų institute); 3) suvirinimo mašinos ir technologija (Leningrado politechnikos institute); 4) skaičiavimo technika (Maskvos fizikos-technikos institute); 5) teoriniai radiotechnikos pagrindai (Leningrado elektrotechnikos institute) ir 6) automobiliu transportas (Maskvos automobilių kelių institute).

Šiais mokslo metais filialo destytojai vykde keletą mokslinių darbų pagal ūkiskaitines sutartis, imta daugiau publikuoti mokslinių straipsnių. 1963 m. buvo išspausdinti arba parengti spaudai M. Paulausko, A. Martinaičio, A. Čyro, I. Nickaus, H. Gutmanienès, A. Kudzio, R. Vadlūgos, V. Kriščiūno ir kt. moksliniai straipsniai [3.19, p. 5]. Daug filialo desstytojų skaite pranešimus mokslinèse konferencijose.

1963-1964 mokslo metus KPI Vilniaus filialas pradëjo turedamas 11 katedrų, 114 etatinių destytojų ir 60 desstytoju valandininkų. Vasarą filialas skelbè priemimą i 7 dieninio skyriaus specialybes ir ị 12 vakarinio skyriaus specialybių.

1963 m. rudeni gerokai padidèjo filialo patalpu plotai. Jam buvo perduoti buvę Karmelitu vienuolyno rūmai (Aušros Vartų g. 12). Šie rūmai pavadinti filialo trečiaisiais rūmais.

Mechaninès technologijos fakulteto dieniniame skyriuje buvo įsteigta statybos ekonomikos ir organizavimo specialybè, o 
vakariniame skyriuje - dvi naujos specialybès: miestų ūkis ir statyba bei sanitarinè technika. Vietoj automobiliu transporto ekonomikos ir organizavimo specialybès priimta $i$ mašinu gamybos pramonès ekonomikos ir organizavimo specialybę. Kiek pakeistas ir buvusios mašinų gamybos technologijos specialybès pavadinimas - mašinu gamybos technologijos, metalo pjovimo stakliu ir įrankiu specialybè.

Prietaisu gamybos fakulteto dieniniame skyriuje buvo paliktos tos pačios buvusios specialybès, bet šiam fakultetui dar priskirta Suvirinimo įrenginių ir technologijos specialybè. Vakariniame skyriuje išliko radijo aparatūros konstravimo ir gamybos technologijos bei matematinių ir skaičiavimų prietaisų bei įrenginių specialybes, o įkurtos dvi naujos: mašinų pramonès gamybos procesu automatizavimo bei elektros pavaru ir gamybos įrenginių automatizavimo specialybès.

Fakultety katedros pasipilde naujais etatiniais dèstytojais, kurių dauguma šioje aukštojoje mokykloje dirbo iki pat savo profesinès veiklos pabaigos.

1963-1964 mokslo metais KPI Vilniaus filiale studijavo 2155 studentai: 817 dieniniame ir 1338 vakariniame skyriuose [3.20, p. 1].

\section{Reikšmingas valdžios dèmesys}

Dieninio skyriaus studentų studijų sąlygos vis dar buvo prastos. Daug nesuremontuotų auditorijų, braižyklų, kai kurių labai reikalingų laboratorijų išvis nebuvo. Sunkios buvo daugelio studentų ir socialinès sąlygos. Stipendiją filialas vieniems mokejo iš biudžeto lěšų, kitiems - iš gamyklų fondo. Stipendija buvo 30-50 rublių dydžio, atsižvelgiant i istudijų kursą. Jas skyre tik pažangiems studentams. Blogiausia buvo bendrabučiu padètis. Studentus apgyvendindavo visai tam nepritaikytose patalpose, netgi šalia auditorijų. Vis delto buvo vilčių, kad padetis artimiausiais metais gerès.

$1964 \mathrm{~m}$. vasario $20 \mathrm{~d}$. KPI Vilniaus filiale buvo suorganizuotas partinès organizacijos ir Mokslines tarybos bendras susirinkimas, kuriame dalyvavo ir itakingi to meto vadovai: LKP CK sekretorius J. Maniušis, LKP Vilniaus miesto komiteto sekretorius K. Mackevičius, LKP CK Ideologinio skyriaus vedëjo pavaduotojas L. Šepetys, Valstybinio aukštojo ir specialiojo vidurinio mokslo komi- teto pirmininkas $\mathrm{H}$. Zabulis, jo pavaduotojas V. Pranaitis, KPI rektorato nariai, KPI filialo vadovai, déstytojai, darbuotojai ir studentų atstovai.

Formalus susirinkimo pretekstas buvo apsvarstyti TSKP CK 1963 m. gruodžio plenumo nutarimą sparčiau vystyti chemijos pramonę, bet susirinkime daugiausia kalbeta ne apie tai, o apie KPI Vilniaus filialo problemas.

Pranešejas A. Čyras, perskaitęs renginiui skirtą „kepurę“, kritikavo respublikos valdžią, kad ji verčianti filialą rengti net 14 specialybių inžinierius, kad klaidinga planuoti vakariniams skyriams specialybes su mažais prièmimo kontingentais. Jis siūlè vakariniuose skyriuose rengti „plataus profilio inžinierius labiausiai masiniu specialybiu“". Jo manymu, tokiomis specialybèmis Vilniaus miesto sąlygomis yra mašinų gamybos technologija, radijo aparatūros konstravimas ir technologija, elektros pavaros ir gamybos įrengimų automatizavimas, pramonine ir civiline statyba bei pramonès ir statybos ekonomika.

A. Čyras sakè, kad jau dveji metai keliamas filialo statybos klausimas. Jis piktinosi, kad KPI Vilniaus filialo materialines bazes pletra susiejama su universiteto miestelio statyba. "Tai juk nesuderinami dalykai “, sake A. Čyras. Gyvenimas įrode, kad suderinami!

Tuo metu filialo vadovas A. Čyras sieke gauti sklypą mokomajam filialo pastatui statyti šalia Vilniaus pedagoginio instituto Studentų gatvejje. Jis motyvavo savo siūlymą tuo, kad filialo darbas susijęs su miesto pramone, nes pagrindinè studentų masé studijuoja vakariniame skyriuje. Po darbo, per vieną valandą studentai turi atvykti i filialą, todèl filialo pastatas turetų būti lengvai pasiekiamas iš visų miesto kampelių. Jei filialui pastatas būtu statomas kartu su senojo universiteto pletra, kurią planavo Antakalnio rajono gale, A. Čyro manymu, vien tam miesteliui projektuoti reikètų ne mažiau kaip 2-3 metų, o statyba prasidettu ne anksčiau kaip $1967 \mathrm{~m}$.

A. Čyras, nesutikdamas su Aukštojo ir specialiojo vidurinio mokslo komiteto vadovų nuostata, siūle filialo mokomųjų ir laboratorinių patalpų korpusą statyti greičiau, tam skiriant sklypą prie Pedagoginio instituto ir naudojant Kaunui arch. V. Dičiaus jau suprojektuotą KPI Radioelektronikos fakulteto projektą. Tame pastate A. Čyras siūle įsteigti Prietaisu gamybos fakultetą, jo mokslines laboratorijas.

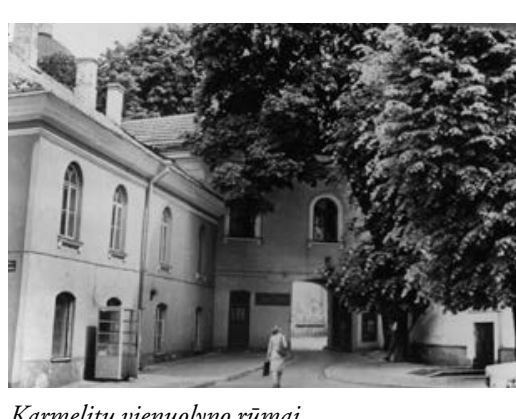

Karmelitu vienuolyno rūmai (iš Aušros Vartu g. pusés)

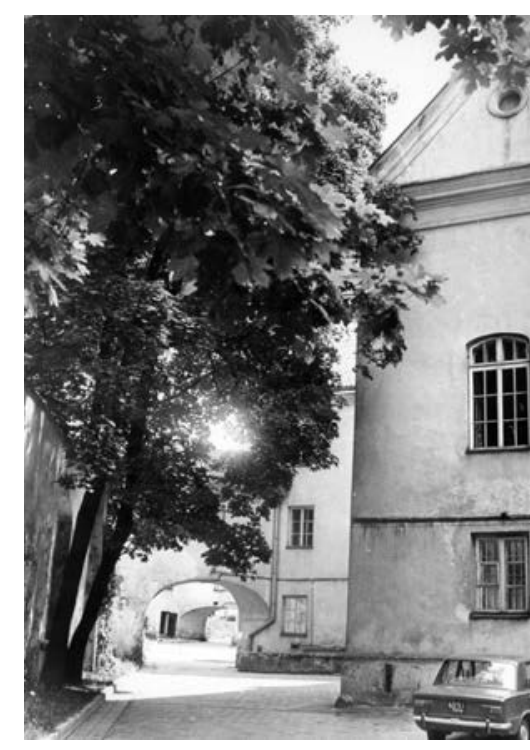

Karmelitu vienuolynas - KPI Vilniaus filialo tretieji rümai 
KAUNO

POLITECHNIKOS

INSTITUTO

VILNIAUS FILIALAS

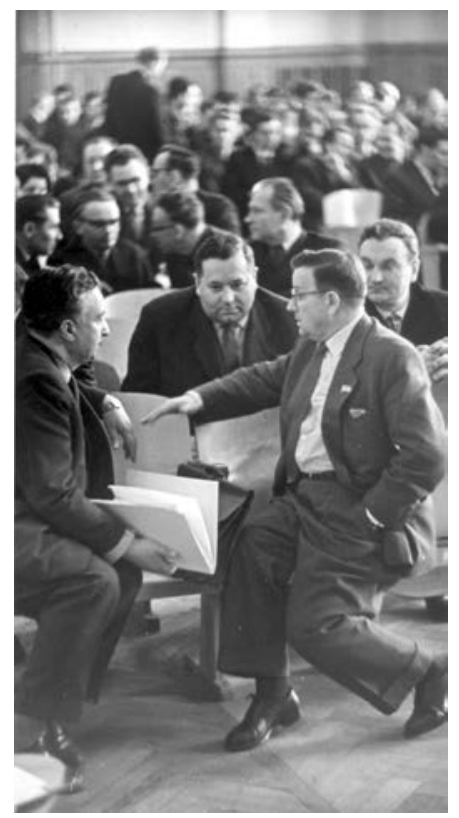

KPI vadovai $1963 \mathrm{~m}$.

Iš kaires: R. Chomskis, M. Martynaitis, $K$. Baršauskas, P. Švenčianas

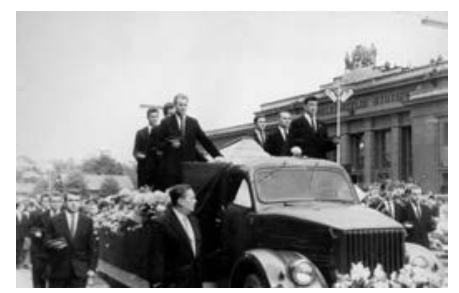

A. Čyras rektoriaus K. Baršausko laidotuvese $1964 \mathrm{~m}$.
Dar vienas filialo vadovo motyvas buvo tas, kad šalia Pedagoginio instituto bendrabučių buvo suprojektuotas ir turejo būti pradetas statyti KPI Vilniaus filialo bendrabutis. Jo manymu, filialas vakarais galetų naudotis dar ir Pedagoginio instituto auditorijomis, kurios tuo metu būna laisvos.

Susirinkime kalbëjęs KPI rektorius K. Baršauskas pažymëjo didelę KPI pagalbą filialui. Jis sake, kad kai kurios filialo laboratorijos gerai įrengtos, net geresnès nei Kauno.

K. Baršauskas ypač akcentavo dèstytoju moksliniu darbų svarbą. „Reikia žinoti, kad be mokslinio darbo aukštoji mokykla - ne mokykla“. Jis tvirtino, kad mokslininkus „visuomet parems, jei būsim naudingi liaudies ūkiuı". Čia galima pažymèti, kad 2004 metais, įteikdamas valstybines mokslo premijas, Lietuvos Vyriausybès Ministras Pirmininkas A. Brazauskas pabrěže tą pačią mintị, bet, atrodo, mūsų šalies mokslo vadybininkai šių minčiu negirdi, nes taikomieji mokslai Lietuvoje menkai vertinami.

Tai buvo paskutinis rektoriaus apsilankymas KPI Vilniaus filiale. Jau po triju mènesių ši tauri, daug Lietuvai davusi asmenybè, išejo Anapilin. Profesorius Kazimieras Baršauskas buvo plataus, gilaus mąstymo vadovas, gerai suvokęs būtinybę pletoti aukštajji technikos mokslą ir kituose miestuose. Laikas įrodè, kad tai buvo išmintingas sprendimas, nemažai padëjęs lietuvinti Vilniaus kraštą.

Kazimieras Baršauskas, kaip ir Aleksandras Čyras, laikytinas vienu aukštosios technikos mokyklos Vilniuje kūrëju.

Tame susirinkime kalbëjęs Skaičiavimo mašinu gamyklos direktorius B. Borisa, garsëjęs kaip talentingas vadovas, teige, kad nepaprastai trūksta inžinierių mechanikų, kurie yra visos gamybos pradžia. Jis siūlè, rengiant inžinierius ekonomistus, daugiausia demesio skirti inžineriniams dalykams, nes inžinieriai lengviau perpranta ir ekonomiką.

J. Maniušis teige, kad ateityje reikès plèsti technines radijo specialybes, nes Lietuvoje sparčiai plètojasi radiotechnikos pramonè. Reikšminga filialui buvo jo frazè: ,Vilniaus filialui reikia pastatyti gera mokomaji korpusa“". $\mathrm{Na}$, žinoma, baigdamas jis neužmiršo deklaruoti, kad „ruošiame ne tik inžinierius specialistus, bet ir naujos komunistines visuomenes statytojus" [3.19, p. 15-18]. Likimo ironija, būtent dauguma šių „statytoju“ 1990 metais èmesi statyti visai ką kita - laisvą ir demokratinę Lietuvą.

\section{Vis solidesni mokslo darbai}

KPI Vilniaus filialo mokslinès jègos pastebimai stiprejo. Filialas turejo 10 aspirantų. Stacionarioje elektros mašinų aspirantūroje buvo R. J. Bulovas (vadovas S. Marazas), statybinès mechanikos $-\mathrm{V}$. Zakarevičius (vadovas A. Čyras), statybinių konstrukciju A. Kvedaras, B. Užpolevičius, M. Rozenbliumas (visų vadovas A. Kudzys). Neakivaizdinëje statybinių medžiagų aspirantūroje buvo A. Žvirènas (vadovas I. Nickus), statybinès mechanikos - H. Gylys (vadovas A. Čyras), liejininkystès - Šernas (vadovas B. Liaudis), taikomosios geometrijos ir inžinerinès grafikos - V. Klimavičius (vadovas J. Charitas) ir statybinių konstrukcijų V. Bagočiūnas (vadovas A. Kudzys).

$1964 \mathrm{~m}$. buvo numatyta priimti dar penketą aspirantų. Disertacijas panoro parengti ir daugelis destytojų be aspirantūros. Jie laike kandidatinio minimumo egzaminus, vykdè eksperimentus. Keli mokslų kandidatai rengè daktaro disertacijas, ejo kūrybinių atostogur.

1964 m. balandžio 16 d. kūrybinių atostogų technikos mokslų daktaro disertacijai užbaigti išejo KPI Vilniaus filialui prorektorius docentas Aleksandras Čyras, o nuo 1964 m. rugsèjo 1 d. - Statybos katedros docentas Antanas Kudzys.

Aleksandras Čyras savo ir savo mokinių darbais ilgainiui suformavo naują mokslinių tyrimų kryptị mūsų krašte. Jis statybinès mechanikos plettotę susiejo su šiuolaikine taikomąja matematika ir kompiuterine technika. A. Čyras pirmasis Rytų Europoje ir TSRS eme taikyti matematinio programavimo metodus konstrukcijoms optimizuoti [3.21, p. 7-9].

Skaičiavimo mašinų naudojimas mokslo tikslams veikia ne tik tiriamųjų darbų metodus, bet ir kuriančių žmonių mąstyseną. Jos apdoroja gausybę informacijos, atlieka milžiniškos apimties skaičiavimo operacijas, taigi leidžia greičiau surasti mokslo tiesas. Bet tik kūrejjas geba kritiškai įvertinti gautus rezultatus ir nagrinejamu klausimu pateikti nauju minčių, naujų idejjų, suformuluoti naują reiškinio sampratą. Tokių kūrejo savybių turejo Aleksandras Čyras. 
Matematinių optimizacijos metody taikymas statybineje mechanikoje A. Čyrui atneše tarptautini pripažinimą. Ilgainiui jis sukūrè mokslinę mokyklą, kuria gali didžiuotis retas mokslininkas. Jai priklauso 27 kandidato disertacijos ir 8 daktaro (habilitacines) disertacijas apgynę mokslininkai - A. Čyro mokiniai.

Gerejo metodinis destytoju darbas. S. Marazas renge vadoveli „Elektro-radio medžiagos", B. Liaudis kartu su V. Babiliumi - „Liejininkyste““, V. Valaitis parenge „Šlifuotojo žinyną“, V. Pranaitis jau beveik užbaige „Inžinerinès geologijos" vadovèlį. Bet apskritai lietuviškos mokymo literatūros katastrofiškai trūko. Jos leidyba buvo labai maža ir tai, matyt, atitiko sovietinès valdžios nuostatas.

\section{Pirmoji studentu moksline konferencija}

1964 m. balandị įvyko pirmoji KPI Vilniaus filialo studenty mokslinès draugijos (SMD) konferencija. SMD pirmininkas G. Vanagas, pradedamas konferenciją, pranešè, kad Studentų mokslinè draugija ịsikūrè dar 1963 metais, kad joje kol kas tik 50 studentu, kad draugijoje yra dvi sekcijos (elektrotechnikos ir mechanikos) ir 6 būreliai.

SMD pirmosios konferencijos plenariniame posedyje braižomosios geometrijos klausimais buvo perskaityti keturi pranešimai ir GT-1 (garso technikos) grupes studento G. Leonavičiaus referatas „Optiniai kvantiniai generatoriai“. Ypač gerai buvo įvertintas studento Aleksandro Zimano pranešimas „Teoriniai paviršiai, gauti eksperimentiškai“, parengtas braižomosios geometrijos būrelyje, kuriam vadovavo doc. J. Charitas.

Elektrotechnikos sekcijoje buvo parengti šeši pranešimai ir vienas jų perskaitytas konferencijoje Kaune. Tai studento R. Jasinavičiaus pranešimas „Elektrinių mikrovariklių akustinio triukšmo ir vibraciju spektrine analize“" [3.22, p. 1].

Pažvelgę atgal matome, kad dažnai studentų žengti pirmieji moksliniai žingsniai studentų mokslineje draugijoje atvede juos i rimtus mokslinius tyrimus. Pavyzdžiui, G. Leonavičius ir R. Jasinavičius tapo mokslų kandidatais, atliko reikšmingų mokslinių darbu.

Gražvydas Stanislovas Leonavičius 19611967 m. studijavo KPI Vilniaus filiale garso

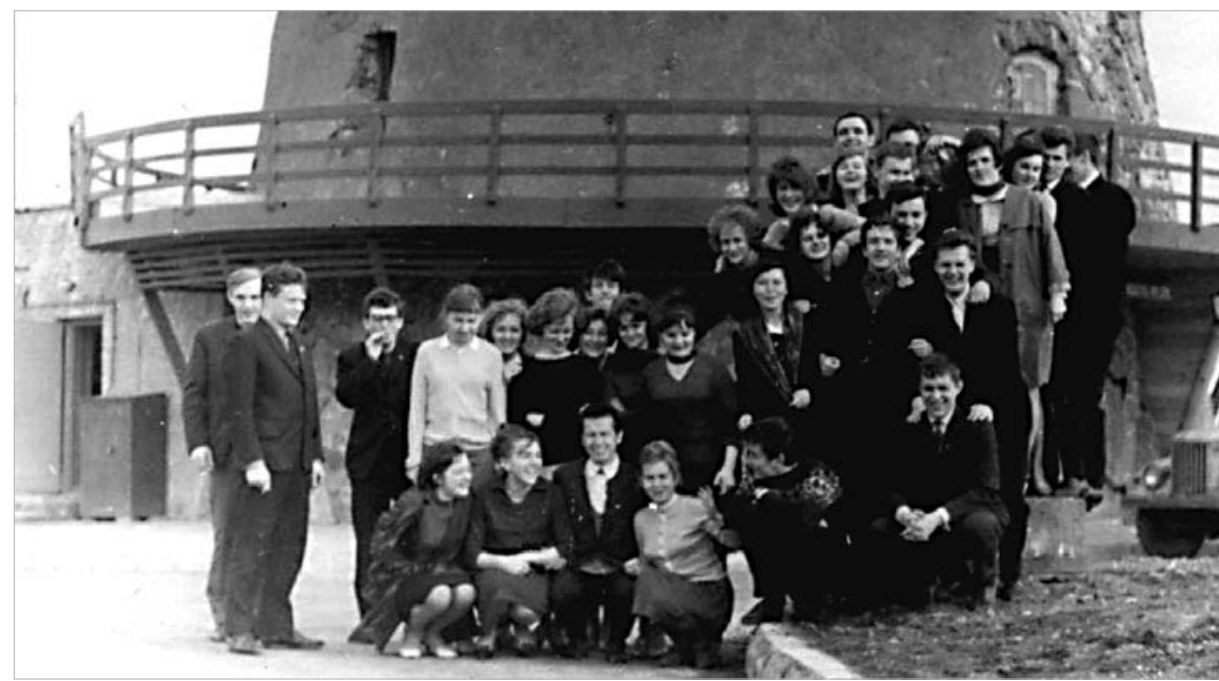

KPI filialo studentai ekskursijoje

techniką. Paskui deste Vilniaus politechnikume. 1969-1973 m. buvo KPI aspirantas, parenge ir apgyne technikos mokslų kandidato disertaciją. 1973-1980 m. buvo KPI ultragarso laboratorijos mokslo darbuotoju, 1980-1994 m. - Vilniaus pedagoginio instituto vyr. déstytoju, docentu. Nuo 1994 m. G. Leonavičius dirbo Pedagoginio universiteto Informatikos katedros vedejju, VPU Matematikos ir informatikos fakulteto dekanu.

Rimvydas Jasinavičius 1961-1967 m. studijavo KPI Vilniaus filiale elektrotechniką ir gavo inžinieriaus elektriko diplomą. 19741976 metais buvo gamybinio susivienijimo „Vilma“ generalinio direktoriaus pavaduotojas mokslui, 1976-1984 m. - Mokslinio ir gamybinio komplekso vadovas, 1990 1991 m. - Lietuvos pramonés ministras. Dr. R. Jasinavičius, debiutavęs kaip jaunas mokslininkas SMD, ilgainiui padare apie 180 technikos išradimų, yra 6 užsienio patentų autorius ir bendraautoris, per 50 mokslinių darbų autorius. 2003 m. R. Jasinavičiui suteiktas profesoriaus mokslinis vardas.

\section{Populiarëja Aukštadvario baze}

KPI Vilniaus filiale nuo 1963 m. pagyvëjo sportinis gyvenimas. Tam didelę įtaką turëjo Fizinio lavinimo katedros įsteigimas. Katedroje tuomet dirbo: V. Kulakauskas, V. Barisas, V. Masaitis, S. Gibieža, A. Mačys, J. Muliuolis, A. Špokas, G. Vileikienè. Valandininkais dirbo V. Sakalys ir P. Pocius.

1963-1964 mokslo metais buvo suorganizuota antroji tarpfakultetine filialo spartakiada, o filialo sportininkai, dalyvaudami Aukštųjų mokyklų spartakiados II grupejje, 
KAUNO

POLITECHNIKOS

INSTITUTO

VILNIAUS FILIALAS

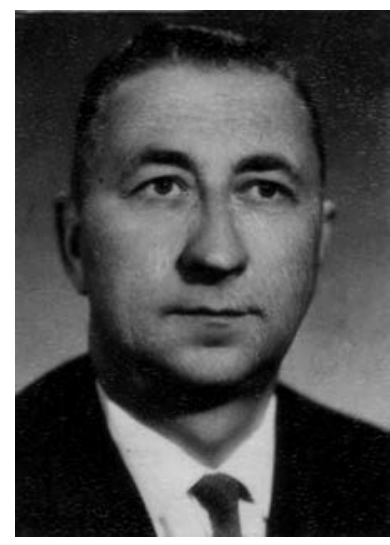

E. Maksimavičius

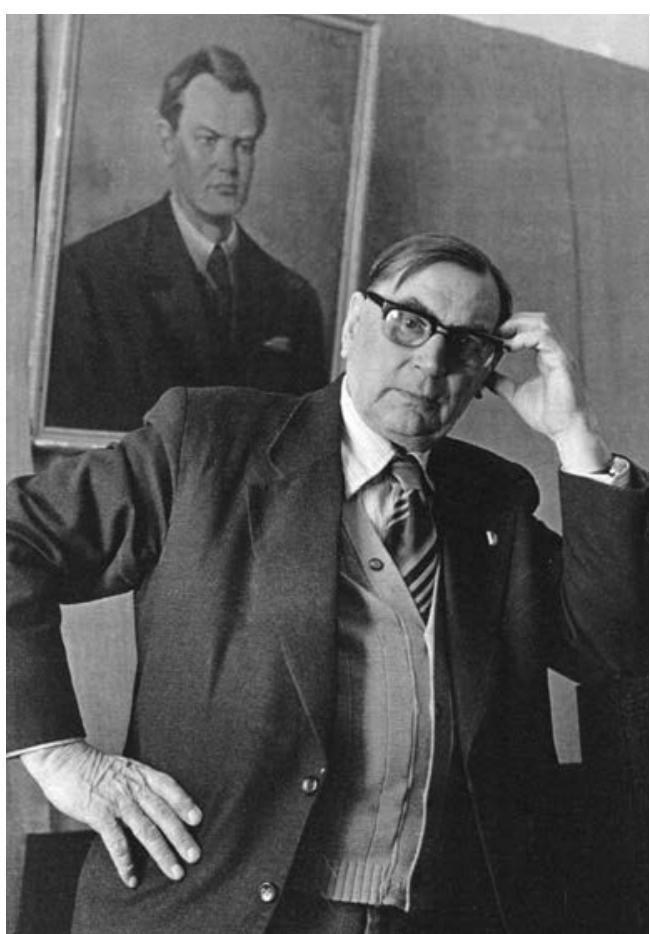

K. Griauzde

užèmé pirmąją vietą. Filialo futbolo komanda sèkmingai kovojo miesto pirmenybių „B“ grupeje [3.23, p. 98, 105].

$1964 \mathrm{~m}$. vasarą, tuoj po egzaminų sesijos, Aukštadvaryje buvo surengta studentiška ge-

\section{Isteigtas Statybos ekonomikos fakultetas}

Daug naujo KPI Vilniaus filiale buvo nuo pat 1964-1965 mokslo metu pradžios.

$1964 \mathrm{~m}$. rugsëjo $1 \mathrm{~d}$. pradëjo veikti Statybos ekonomikos fakultetas. Jo dekanu tapo docentas E. Maksimavičius. Šiame fakultete tuo laiku buvo dvi katedros: Mechanikos (vedejas A. Čyras) ir Statybos (vedëjas V. Kriščiūnas). $\mathrm{O}$ iš viso filiale buvo jau 13 katedrų: naujai įsteigtos Fizinio lavinimo (vedejas V. Kulakauskas) ir Radijo aparatūros technologijos (vedejjas Z. Vainoris).

Šis naujasis fakultetas vykde priemimą $i$ dieninį skyrių, kuriame buvo trys specialybès: pramoninè ir civilinè statyba, miestu statyba, statybos ekonomika ir organizavimas. Keturios specialybès buvo vakariniame skyriuje (trys tos pačios kaip dieninio skyriaus bei mašinu gamybos pramonés ekonomika ir organizavimas).

Eugenijus Maksimavičius gime Rygoje 19201125.1947 m. baige Kauno valstybinį universitetą ir pradejo dirbti ten gužinè, skirta mokslo metų pabaigai. Šventès metu buvo suruošta daug ịdomių varžybų. Ypač visiems patiko figūrinio važiavimo motociklais varžybos. Buvo surengtas saviveiklininkų koncertas ir draugystes laužas. Renginyje buvo svečių iš Konservatorijos ir Dailes instituto.

Vasarą buvo surengtos dar dvi stovyklos. Poilsiavo ir saviveiklininkai. Šią vasarą pirmą kartą ir kolūkiuose veike kelios darbo ir poilsio stovyklos, studentų statybinių būrių pirmtakai [3.24, p. 3].

Dainos entuziastai dar 1963 m. pakviete jiems vadovauti choro dirigentą ir pedagogą Kazimierą Kruopi. Pradeta repetuoti, net surengta choristų išvyka į Minską, bet K. Kruopiui vadovaujant taip ir nebuvo surengta ne vieno koncerto. Viskas atsistojo į reikiamas vèžes, kai organizuoti chorą $1964 \mathrm{~m}$. kovo $8 \mathrm{~d}$. pradejo garsus chorvedys Klemensas Griauzdè.

Jau tą patị mènesị prasidëjo 40 dainininku repeticijos. Maestro K. Griauzdei talkino chormeisteriai Elona Paškūnienè ir Boleslovas Zubrickas. Vasarą Anykščiu rajone buvo surengtas pirmasis choro koncertas. Aukštadvaryje choristai poilsiavo ir repetavo. Tai tapo kasmete tradicija. pat Statybinès mechanikos katedros laborantu, paskui - asistentu, vyr. déstytoju. 1959-1964 m. dirbo Palangos ir Kauno gamybinèse organizacijose vadovaujantịji darbą: valdybos viršininku, direktoriumi. Dèl tarnybinès etikos pažeidimų 1968 m. buvo atleistas iš dekano, o vèliau - vyr. destytojo pareigų.

Prietaisu gamybos fakultetas tą pačią vasarą priemè į dienines studijas studijuoti garso technikos bei radijo aparatūros konstravimo ir gamybos technologijos, o i vakarini skyriu - studijuoti elektros pavarų ir gamybos įrenginiu automatizavimo bei radijo aparatūros konstravimo ir gamybos technologijos specialybių.

Mechaninès technologijos fakultetas priemè ị dieninių studijų mašinų pramonès gamybos procesu automatizavimo bei suvirinimo įrengimų ir technologijos specialybes, o ị vakarini skyriu studijuoti mašinų gamybos technologijos, metalo 
pjovimo staklių ir įrankių, mašinų pramonès gamybos procesų automatizavimo, suvirinimo įrengimų ir technologijos bei automobilių transporto specialybes.

Pavadavęs A. Čyrą, laikinai einantis KPI Vilniaus filialo prorektoriaus pareigas docentas Romualdas Jonušas energingai stengèsi toliau kurti savarankišką Vilniaus aukštąją technikos mokyklą. 1964 m. rugsëjo 12 d. jis siunčia raštą Lietuvos TSR Ministrų Tarybai, kuriame nurodo, kad „<...> Šiuo metu KPI Vilniaus filiale yra kritiška padetis su mokomosiomis patalpomis. Užsiemimai su studentais pravedami penkiose Vilniaus miesto vietose, iš dalies naudojames Vilniaus pedagoginio instituto ir V. Kapsuko v. universiteto patalpomis, $\langle\ldots .>$ skaitome tikslinga 1966 metais pradeti KPI Vilniaus filialo mokomojo-laboratorinio korpuso statyba, pagal turima KPI Radioelektronikos fakulteto mokomojo-laboratorinio korpuso technine dokumentacija...".

R. Jonušo raštas ir pastangos davè rezultatą, nors kiek kitoki, nei norèta.

1964 m. lapkričio $12 \mathrm{~d}$. potvarkiu Nr. 1548-p Lietuvos TSR Ministrų Taryba pa-

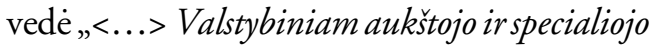
vidurinio mokslo komitetui, suderinus klausima su Valstybine plano komisija ir Liaudies ükio taryba, paruošti 1965 metais technine dokumen-

\section{Mokymo planu ir vadovu pasikeitimai}

1964 m. aukštųjų technikos mokyklų gyvenime svarbus ìvykis buvo mokymo planu pakeitimas. Naujuose mokymo planuose buvo atsisakyta gamybinio darbo pirmajame kurse, sutrumpinta diplomine praktika, įvestos mokomosios gamybines praktikos po trečiojo ir ketvirtojo kursų. Mokslo trukme sutrumpinta pusmečiu. Buvo sumažinta kai kurių fundamentinių mokslų ir bendrųju inžinerijos bei ekonomikos dalyku teoriniu valandu [3.25, p. 125].

Taigi sovietinès partinès nomenklatūros sugalvota reforma apie gamybos ir mokymo spartinimą žlugo jau po kelerių metų. Visos reformos, kai jas sugalvoja nuo mokymo įstaigų atitrūkę biurokratai, kaip rodo patirtis, baigiasi vienodu rezultatu - naujomis reformomis, dažnai sugalvotomis jau naujosios nomenklatūros. Panašių dalykų, deja, nestokojame ir šiandienos Lietuvoje. tacija Kauno politechnikos instituto Vilniaus ir Šiauliu vakariniu skyriu laboratoriniu skyriu statybai.

Liaudies ūkio taryba turi 1966 metais numatyti atitinkamas lèsas minètuju korpusu statybai pramones imoniu Vilniuje ir Šiauliuose kapitalinès statybos lěšu sąskaita.

Vilniaus vakarinio skyriaus laboratorinio korpuso statybos technine dokumentacija turi büti sudaroma, atsižvelgiant i Kauno politechnikos instituto Vilniaus filialo pletimosi perspektyvas ir $i$ tai, kad sis korpusas bütu statomas Vilniaus aukštuju mokyklu objektu statybai numatytoje teritorijoje".

Potvarki pasirašè Lietuvos TSR Ministrų Tarybos pirmininkas M. Šumauskas.

R. Jonušas jau 1964 m. lapkričio 30 d. pateikia tvirtinti Lietuvos TSR Valstybinio aukštojo ir specialiojo vidurinio mokslo komiteto pirmininko pavaduotojui V. Pranaičiui KPI Vilniaus filialo mokomajam-laboratoriniam korpusui pritaikyti skirtą planinę užduotị. Vèl bandyta siūlyti Kaune statomo KPI Radioelektronikos fakulteto korpuso projektą (arch. V. Dičius ir kt.). Bet vèliau šio siūlymo teko atsisakyti ir buvo rengiamas individualus viso komplekso projektas bei statyba numatytame sklype būsimajam studentų miesteliui.

Tais metais filialo mokslininkams atsivere tarptautinio bendradarbiavimo galimybių durys. Prorektorius A. Čyras dalyvavo tarptautinëje mokslinëje konferencijoje Čekoslovakijos sostineje Prahoje, paskui vyko i Vokietijos Demokratinę Respubliką. Čia Veimaro aukštojoje architektūros ir statybos mokykloje užmezgè ryšius, kurie vèliau suintensyvino Veimaro ir Vilniaus aukštosios technikos mokyklų mokslininkų bei studentų bendradarbiavimą.

Reikšmingu pasikeitimų vyko ir KPI centre. Po K. Baršausko mirties KPI rektoriumi buvo paskirtas chemijos mokslu kandidatas docentas Marijonas Martynaitis. Mokymo reikalų prorektoriaus postą užėmé technikos moksly kandidatas docentas Česlovas Jakimavičius. Abu jie buvo žinomi kaip dalykiški, inteligentiški vadovai, bet kartu ir labai reiklūs, pareigingi. Tačiau jausdami A. Čyro siekimą ịkurti suverenią

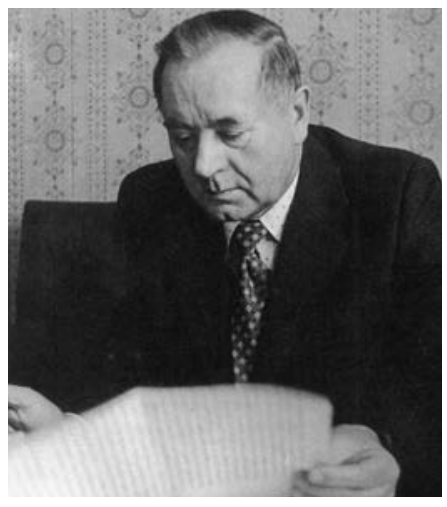

M. Martynaitis 
KAUNO

POLITECHNIKOS

INSTITUTO

VILNIAUS FILIALAS
Vilniaus aukštąją mokyklą, tam priešinosi, kaip ir dauguma KPI profesūros.

1964-1965 mokslo metais KPI Vilniaus filiale studijavo 1028 studentai dieniniame skyriuje ir 1693 studentai vakariniame skyriuje. Iš viso 2721 studentas.

Pasikeite Mokslinès tarybos sudètis. Ją sudare: Metalu apdirbimo katedros doc. t. m. k. Ksaveras Bieliūnas, KPI prorektorius, Mechanikos katedros vedejas doc. t. m. k. Aleksandras Čyras, Kalbų katedros vedeja Ona Glemžiené, Braižybos katedros vedëjas, doc. t. m. k. Judelis Charitas, Prietaisu gamybos fakulteto prodekanas Leonas Janulionis, Mašinu gamybos technologijos metodines komisijos pirmininkas doc. t. m. k. Romualdas Jonušas, Statybos katedros vedejjas, doc. t. m. k. Vytautas Kriščiūnas, Statybos katedros doc. t. m. k. Antanas Kudzys, Fizinio lavinimo katedros vedejas Vytautas Kulakauskas, Karinès katedros viršininkas Konstantinas Kondratovas, Mechanines technologijos fakulteto prodekanas Vaclovas Klimavičius, Mechaninès technologijos fakulteto dekanas doc. t. m. k. Borisas Liaudis, Mašinų teorijos katedros vedëjas, doc. t. m. k. Daumantas Maciulevičius, Prietaisų gamybos fakulteto dekanas, doc. t. m. k. Stanislovas Marazas, Marksizmo-leninizmo katedros vedejas, istorijos m. k. Albertas Marcelis, Fizikos katedros vedëjas Edmundas Mauza, Mašinų teorijos katedros docentas, ekonomikos m. k. Albinas Martinaitis, Statybos ir ekonomikos fakulteto dekanas Eugenijus Maksimavičius, Radiotechnikos katedros e. doc. p. t. m. k. Arkadijus Naidionovas, Marksizmo-leni- nizmo katedros doc. istorijos m. k. Sigita Noreikiené, Chemijos katedros vedejjas, doc. t.m. k. Ipolitas Nickus, Elektrotechnikos katedros doc. t. m. k. Mečislovas Paulauskas, Chemijos katedros doc. chemijos m. k. Marija Priluckaja, Matematikos katedros vedejas, doc. fiz. mat. m. k. Romualdas Uždavinys, Radiotechnologijos katedros vedejas, doc. t. m. k. Zenonas Vainoris, Partinès organizacijos sekretorius, Vietos komiteto pirmininkas, Komjaunimo organizacijos sekretorius [3.26, p. 143-144].

Tuomet partinès organizacijos sekretoriumi buvo J. Bacevičius, Vietos komiteto pirmininku - A. Šeputis, Komjaunimo komiteto sekretoriumi R. Jasinavičius.

1964 m. ruduo didino emocijas politiniame TSRS gyvenime. Spalio mènesị savo posto neteko Nikita Chruščiovas, o valdžią paèmé Leonidas Brežnevas. Prasidëjo „brandaus socializmo" kūrimo laikotarpis, kurị ilgainiui visuomene pavadino stagnacijos periodu. Lietuva tai labai pajuto, kai 1965 m. buvo likviduotos vadinamosios Liaudies ūkio tarybos.

1964 m. pabaigoje iqsiplieskè incidentas tarp JAV ir Šiaures Vietnamo, ilgainiui virtęs pragarišku karu, iš kurio amerikiečiai ištrūko tik 1973 m. Sovietų Sajungai Vietnamo karas taip pat daug kainavo, nes ji teike Šiaurès Vietnamui finansinę ir karinę paramą. Visa tai skaudžiai paveikè TSRS ekonomiką, kartu ir aukštąji mokslą, kurio biudžetas ir šiaip buvo labai skurdus.

1965 m. vasario 15 d. LKP CK ir LTSR MT nutarimu Nr. 81, kurị pasirašè A. Sniečkus ir K. Kairys, Lietuvos TSR Valstybinis statybos reikalu komitetas buvo ippareigotas jau 1965 m. atlikti detalų suplanavimą teritorijos, skirtos aukštųjų Vilniaus mokyklų
KPI rektorato posedyje (iš kairés):

R. Jonušas, J. Deltuva, A. Čyras, R. Chomskis, M. Martynaitis,

C. Jakimavičius, P. Švenčianas, H. Petrusevičius, K. Paulauskas

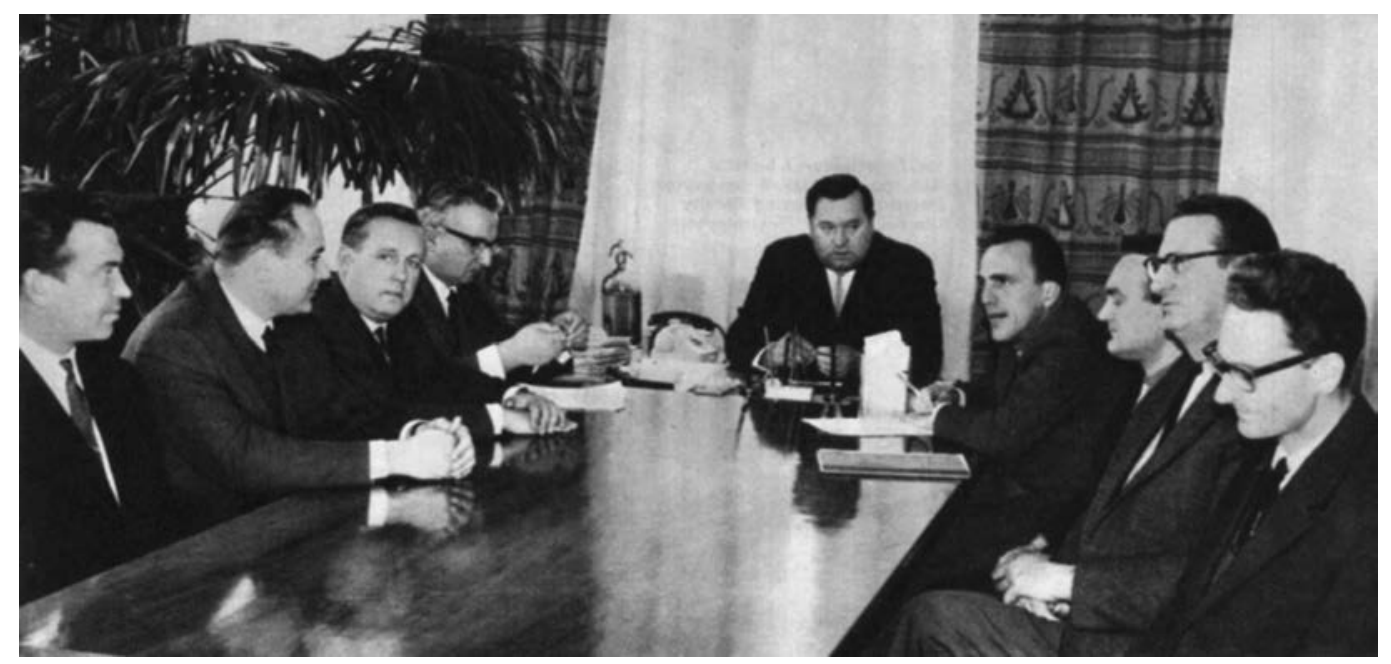


komplekso statybai. KPI Vilniaus filialui ypač buvo svarbi nutarimo dalis, ipareigojanti projektuotojus parengti pirmosios eiles objektų statybos techninius dokumentus. Pirmąją eilę sudare KPI Vilniaus filialo mokymo ir laboratorinis korpusas bei Vilniaus universiteto Ekonomikos fakultetas.

Šis nutarimas, kaip ir dauguma tuometinès aukščiausiosios valdžios nutarimų, paskelbtas rusų kalba. Tokia buvo „suverenios“ respublikos tikrove.

Bet nutarimas buvo labai svarbus dalykine prasme. Juo remdamiesi KPI Vilniaus filialo vadovai pradejo įnirtingą žinybų, nuo kuriu priklausè nutarimo realizavimas, ataką.

Jau 1965 m. gegužę prorektorius A. Čyras raštu LKP CK protestuoja prieš Valstybinès plano komisijos ketinimą skirti leš̌u mokomojo ir laboratorinio korpuso statybai tik 1967 metams, o ne 1966 metams.

1965 m. gegužès 31 d. raštu A. Čyras reikalavo iš Lietuvos TSR Aukštojo ir specialiojo vidurinio mokslo komiteto pirmininko H. Zabulio suteikti prioritetą filialo objektui projektuoti. Rašte, be kita ko, buvo rašoma, kad "<...>Sutinkamai su LTSR MT 1964 XI 12 d. potvarkiu NR. 1548-p filialo laboratorinio korpuso technine dokumentacija turi büti paruošta 1965 metais. Filialas kreipési pas Jus dokumentacijos ruošimo klausimu dar 1964 metu gale. Tuo metu ejusiam prorektoriaus pareigas drg. R. Jonušui buvo užtikrinta, kad kai tik bus provizoriniai suderintas miestelio projektas, bus duotas nurodymas iš komiteto puses vykdyti korpuso projektavimo darbus. Šis klausimas šiuo metu reikalauja skubaus sprendimo, nes priešingu atveju kyla grèsmè, kad nebus juykdyti Vyriausybiniai nutarimai ".

1965 m. KPI Vilniaus filialą baigè pirmoji dieninio skyriaus radijo aparatūros konstravimo ir gamybos technologijos specialybes inžinierių laida, tai: V. Alenin, O. Agejev, V. Bezuglov, E. Braver, L. Cycko, S. Cekys, Z. Drozdova, O. Filipovič, A. Golomyzdo, M. Galanova, A. Komazovskaja, J. Ivanov, G. Levin, L. Lipinska, R. Lokteva, S. Melamed, V. Markin, G. Nikolajev, V. Paski, V. Puteikyte, E. Pileckas, J. Sokol, V. Švecov, V. Šcedrov, E. Vlasov.

Iš viso KPI Vilniaus filialą baigè apie 250 dieninio ir vakarinio skyrių studentų [3.27, p. 75].

KPI Vilniaus filialui tuomet teko spręsti ne tik ūkines bei finansines, bet ir kitas rimtas problemas. Dar 1965 m. žiemą žinomi žurnalistai J. V. Paleckis ir A. Semaška „Kom- jaunimo tiesoje“ paskelbè straipsni „Non multa, sed multum“ („Nedaug, bet giliai“). Šiame straipsnyje autoriai apraše KPI Vilniaus filialą studentų egzaminų metu, gana nuodugniai nagrinejo studentų nusirašinèjimo per egzaminus problemą. Kadangi ši problema gyvybinga Lietuvos aukštosiose mokyklose ir šiandien, kilusią polemiką apžvelgsime kiek detaliau.

Autoriai tvirtino, kad iš pokalbių su egzaminus laikiusiais studentais jie padare išvadą, kad negarbingais egzaminų laikymo būdais naudojosi daug studentų. Studentai skundèsi, kad destytojai reikalauja iš studentu issiminti pagrindines formules, nors patys jas užrašinëja lentoje, žvilgčiodami į užrašus; kad egzaminų daug, o sesija tęsiasi beveik ménesî. Per kelias dienas tarp dviejų egzaminų studentas turi sukimšti į galvą daugybę formulių, apibrežimų, faktų. Studentai tvirtino, kad sesijos rezultatai ne visada teisingai perteikia studento žinias.

Straipsnio autoriai rašè, kad esama studentų tvarka pasenusi, siūlè didinti seminarų, kolokviumų, praktinių užsièmimų skaičių, diegti programuotą mokymą, atsisakyti egzaminų „maratono“, reikalauti minties gilumo, savarankiško interpretavimo, o ne papūgiško ištisu puslapių atkartojimo [3.28, p. 2].

Straipsnis sukèle rezonansą tiek tarp studentų, tiek tarp déstytojų. Buvo pripažinta, kad nusirašinejjimas tapo liga, nes nesimokoma semestro metu, praleidinejjamos paskaitos, kuriose tos konstantos, formules dažnai kartojamos, naudojamos sprendžiant uždavinius, rengiant projektus. Jų negali atsiminti tie, kurie nepareigingi, nesistengia ar nenori.

Buvo diskutuojama, kaip galima reformuoti egzaminų sistemą, ar gali aukštoji mokykla duoti daugiau teorinių ir praktiniu žinių, kaip pasiekti, kad studentas mokytųsi ištisus metus. Neigiamai buvo vertinami kolokviumai, nes prieš kolokviumą apleidžiami kiti dalykai. Kai kurias formules moketi specialistui yra būtina ir t. t. [3.29, p. 3].

Diskusiją baigęs KPI prorektorius Č. Jakimavičius vis dèlto pabrežè, kad laiko stoka dažniausiai skundžiasi kaip tik tie visi tinginiai ir dykinètojai, kuriems sesijos metu dar reikia ir projektą užbaigti, ir laboratorinius darbus apginti, ir įskaitą gauti, ir dar atlikti kitokių darbų, kuriuos jie turejo baigti sesijos išvakarèse.

Optimizmą skleidè studentas, rašęs, kad nusirašymo liga apkresti toli gražu ne visi, kad šiaip ar taip - jų mažuma $[3.30$, p. 1].

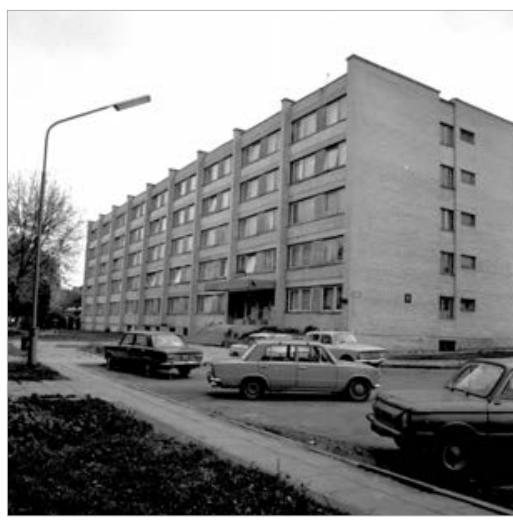

1965 m. VISI gavo bendrabuti Studentu gatvejje 
KAUNO

POLITECHNIKOS

INSTITUTO

VILNIAUS FILIALAS
Viršuje dešinëje:

Stakliu laboratorijoje
Nuo tos diskusijos praejo jau lygiai keturiasdešimt metų. Deja, problema išlieka, o situacija visai ta pati. Tai viena iš studiju kokybes gerinimo problemų.

1965 m. vasarą KPI Vilniaus filialas pirmą kartą organizavo studentų statybinị būrị (SSB), kuris buvo išvykęs i i Kazachstaną. Dar po metų KPI VF studentai dirbo Tiumeneje, o 1967 metais - Altajaus krašte. Tais metais buvo organizuotos darbo bei poilsio stovyklos ir pačioje Lietuvoje, kurios dirbo dviem pamainomis.

Studentų statybiniai būriai jokiu būdu neatstojo gamybinių praktikų, nes dažniausiai studentai dirbo nekvalifikuotą darbą. Bet tai grūdino jaunimą, ugdè organizacinius gebëjimus, teike, ypač būsimiesiems statybu specialistams, nemažai pažintinès patirties.

\section{Daugejja katedru ir déstytoju}

L. Brežnevo laikais šypseną kèle jo išgarsintas šūkis: „Ekonomika turi būti ekonomiška". Bet į tai privalëjo reaguoti ir aukštasis mokslas. Imta teigti, kad ir Lietuvoje trūksta kvalifikuotų inžinierių ekonomistų. KPI Vilniaus filiale 1965-1966 mokslo metais norintys studijuoti inžinerinius-ekonominius dalykus Statybos ekonomikos fakultete buvo priimti i statybos ekonomikos ir organizavimo bei mašinu gamybos pramonès ekonomikos ir organizavimo specialybes.

Gerejjo, nors ir nedaug, filialo materialine bazè. Buvo gautas 490 vietų bendrabutis, padaugèjo auditorijų.

Intensyvesnis buvo filialo studentų kultūrinis ir sportinis gyvenimas. Akademinis mišrus choras (vèliau pavadintas „Gabija“), vadovaujamas meno vadovo, ižymaus chorvedžio Klemenso Griauzdes, 1965 m. dalyvavo Dainų šventëje. Maestro K. Griauzdei talkininkavo choro vadovai E. Paškūnienè ir J. Dubickas. Pirmuosius žingsnius žengiančio choro vadovams labai svarbi buvo choro entuziastu - M. Kubiliūtès, T. Gromyko, V. Daraškevičiūtès, A. Braškio, A. Lingès ir daugelio kitu geranoriška veikla. Gerai choras pasirode Vilniaus miesto chorų apžiūroje [3.31, p. 3]

1965-1966 mokslo metus KPI Vilniaus filialas pradejo turèdamas daug optimizmo.

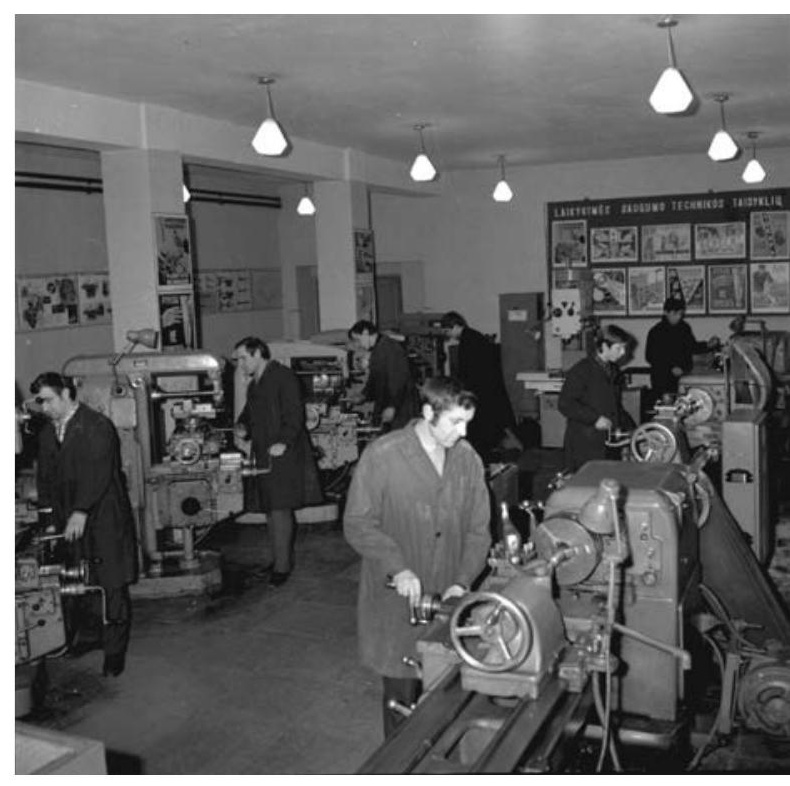

Vasarą i dienines studijas buvo priimta 280 studentu, o stojančiųjų buvo net 830 . Pagal šị rodiklį Vilniaus filialas buvo antrasis Lietuvoje. Bet stojančiųju kontingentas nebuvo stiprus: iš 830 egzaminus išlaikè tik 398 stojantieji. I vakarinị skyrių stojančiųjų buvo 1130 , o egzaminus išlaike 529 . I vakarines studijas buvo priimta 425 jaunuoliai. Iš 280 dieninio skyriaus studentų 224 - vyrai. Daugiau kaip puse dieninio skyriaus studentų buvo lietuviai - 152, rusų buvo 63 , likę - kitu tautybių.

$1965 \mathrm{~m}$. rugsèjo $1 \mathrm{~d}$. KPI Vilniaus filiale pradejo veikti keturios naujos katedros. Vietoje Statybos katedros buvo įsteigtos dvi: Miestu statybos (vedejas V. Kriščiūnas) ir Statybinių konstrukcijų (vedëjas A. Kudzys). Naujai įsteigtos dar dvi: Gamybos ekonomikos (vedëjas A. Martinaitis) ir Mašinų gamybos automatizavimo (vedejjas R. Jonušas).

Trijuose filialo fakultetuose mokesi 1182 dieninio ir 2024 vakarinio skyrių studentai.

Vilniaus filiale 1965 m. rudenị dirbo 179 etatiniai destytojai, tarp jų buvo 35 su moksliniais laipsniai. Veike trys fakultetai, kurių dekanais dirbo S. Marazas (Prietaisu gamybos), B. Liaudis (Mechanines technologijos) ir E. Maksimavičius (Statybos-ekonomikos). Partinès organizacijos sekretoriumi buvo R. Jonušas, Vietos komiteto pirmininku A. Ražinskas.

Spalio menesį „Tiesoje“ buvo paskelbtas konkursas šešiu katedrų docentų etatinèms vietoms užimti. Tas konkursas niekuo nesiskyre iš iki tol buvusiųjų, bet pažymetina, kad i Marksizmo-leninizmo katedros 0,5 docento etatą pretendavo ilgainiui liūdnai pagarsëjęs Mykolas Burokevičius. Faktiškai 
tie konkursai būdavo be konkurencijos. Dažniausiai ì vieną vietą tebūdavo vienas kandidatas. Taigi Mykolas Burokevičius èmè dirbti 0,5 etato, o kiek vèliau ir visu etatu. Šio žmogaus veikla Vilniaus aukštojoje technikos mokykloje pasižymejo radikaliu partiškumu ir intrigomis.

\section{„Paskaitos nedaro idëjinio poveikio“}

M. Burokevičius, matyt, buvo deleguotas į KPI Vilniaus filialą, kad pagerintų studentų komunistinį auklejimą. Kaip tuomet atvirame partiniame susirinkime, vykusiame kartu su Moksline taryba, buvo pažymèta, „komunistiniame auklejamajame darbe yra ir rimtu trūkumu. Dekanai ir kai kurios katedros ne visada reikiamai panaudojo visa mokymo procesq studenty komunistiniam samoningumui ugdyti ir mokslinei pasauležiūrai formuoti $\langle\ldots\rangle$, pasitaiko paskaitu ir praktiniu užsiemimu, kuris nedaro reikiamo idejinio poveikio studentams $<\ldots . .>$ " [3.32, p. 130].

Studentų nuotaikos, matyt, netenkino tuometines valdžios. 1965 m. lapkritị KPI apsilankęs LKP CK pirmasis sekretorius A. Sniečkus, susitikime su destytojais ir darbuotojais, kuriame dalyvavo ir gausus KPI Vilniaus filialo atstovų būrys, įtikinëjo susirinkusiuosius, kad, be savo specialybès žinių, būsimasis specialistas turi giliai įsisąmoninti marksistinę-lenininę teoriją, sugebeti ją taikyti praktinejje veikloje. A. Sniečkus pabrěžè, kad negalima atplešti komunistinio jaunimo auklejimo nuo mokomojo proceso turinio [3.25, p. 113].

Tačiau realiame gyvenime tokias partijos direktyvas tyliai ignoravo ne tik nepartiniai, bet dažniausiai ir partijos nariai. Laisvą mintị reikšti buvo draudžiama visiems, todèl paprastai dèstytojai tik imituodavo „auklejimo " momentus, o daugiausia dèmesio skirdavo destomajam dalykui.

Minètame susirinkime A. Sniečkus įteikè vyriausybinius apdovanojimus daugeliui KPI destytojų ir darbuotojų. Tarp jų buvo ir KPI Vilniaus filialo narių.

\section{Mokslinis A. Čyro laimëjimas}

Reikšmingiausias 1965-1966 mokslo metu ịvykis KPI Vilniaus filiale buvo jo vadovo Aleksandro Čyro daktaro disertacijos (dabar - habilituoto daktaro) gynimas
1966 m. sausio 14 d. KPI mokslineje taryboje. A. Čyro disertacinį darbą „Matematinio programavimo metodai skaičiuojant tamprias-plastines vienmates sistemas" puikiai ịvertino visi disertacijos oponentai, kiti mokslininkai.

Maskvietis profesorius I. Goldenblatas sake, kad A. Čyro darbas yra didelis indèlis i statybinę mechaniką, kad disertantas sèkmingai pritaike matematinio programavimo metodus tampriųju plastinių vienmačių sistemy analizei ir sintezei.

Maskvos transporto inžinerinio instituto profesorius A. Petropavlovskis pabrèže, kad A. Čyras surado konstrukcijų ir statinių rezervus, išsprende minimalaus svorio bei optimalių įvairiais kriterijais didelio patikimumo konstrukcijų kokybes klausimus.

TSRS Mokslų akademijos narys korespondentas, profesorius J. Panovko teige, kad disertacija parašyta šiuolaikinio mokslo lygiu, itin vaizdžiai parodo aukštą matematinę autoriaus kultūrą.

Aleksandro Čyro disertacijos aktualumą gerai įvertino Maskvos centrinis statybinių konstrukcijų tyrimo institutas. A. Čyro disertacijos recenzijoje pažymetta teorinè ir praktine darbo verte, kaip ypatingas privalumas nurodyta tai, jog autorius išvede algoritmu sprendimus, naudodamasis matricų teorija.

Gerai disertaciją vertino ir kiti mokslininkai, ypač pabrežę jos novatoriškumą, puikiai išnaudotas matematinio programavimo galimybes. Jau veliau profesoriai J. Atkočiūnas ir A. Čižas yra rašę, kad A. Čyro disertacijos ketvirtasis skyrius , ¿žvalgiai buvo skirtas besiformuojančiaiperspektyviai mechanikos krypčiaistochastiniamstampriuju-plastiniusistemu skaiciavimo ir optimizavimo metodams ".

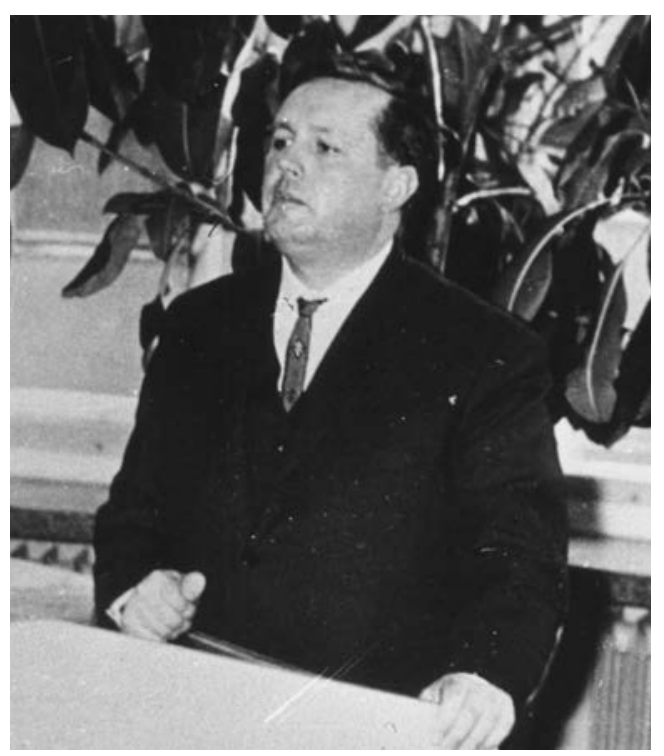

A. Cyras gina daktaro (dabarhabilituoto) disertacija 
KAUNO

POLITECHNIKOS

INSTITUTO

VILNIAUS FILIALAS
KPI mokslinès tarybos nariai vienbalsiai balsavo už technikos mokslų daktaro mokslinio laipsnio suteikimą Aleksandrui Čyrui $[3.33$, p. 1].

\section{Filiala pertvarkys į instituta}

Grižęs į KPI Vilniaus filialą eiti prorektoriaus pareigas, A. Čyras dabar su nauja energija kibo ị kasdienius filialo darbus. Jo veiklos centru šiuo metu buvo mokomojolaboratorinio pastato statyba būsimajame studentų miestelyje.

KPI Vilniaus filialo vadovų nuolat spaudžiama Valstybine plano komisija ir Aukštojo ir specialiojo vidurinio mokslo komitetas išskyre 1965 metams lěšų ir limitą projektinei užduočiai sudaryti, bet darbo brěžiniams sudaryti nei lěšų, nei projektavimo darbų limito nebuvo numatyta. A. Čyras skundžiasi LKP $\mathrm{CK}:$, $<\ldots>$ tai reiškia, kad technine dokumentacija nebus paruošta ir 1966 metais"(1966 m. vasario 15 d. raštas $\mathrm{Nr}$. 265).

Nors dar prieš porą metų KPI Vilniaus filialo vadovas A. Čyras siekè gauti filialo statyboms sklypą Žveryne, vis dèlto teko nusileisti ir sutikti su sklypo skyrimu Antakalnio gale. Čia buvo numatyta pastatyti pastatų Vilniaus universitetui, o šalia - KPI Vilniaus filialui, kuris jau rengèsi tapti savarankišku inžineriniu institutu.

1966 m. vasario 14 d. KPI Vilniaus filialo rektorato posedyje buvo pranešta, kad Miestų statybos projektavimo institutas jau parenge būsimojo studentų miestelio suplanavimo projektą, kad pagal projektinę užduoti projektuojamas filialui skirtas mokomasis laboratorinis korpusas.

Iš Lietuvos TSR Valstybinio statybos reikalu komiteto pirmininko A. Aksomito 1966 m. vasario 23 d. rašto MT pirmininko pavaduotojui K. Kairiui (nuorašas A. Čyrui) matyti, kad skundas LKP CK „suveike“". Miestų statybos projektavimo institutui buvo pavesta iki $1966 \mathrm{~m}$. kovo $16 \mathrm{~d}$. parengti mokomojo-laboratorinio korpuso darbo brě̌inių paruošimo grafiką, suderinti su KPI Vilniaus filialu.

1966 m. kovą vyko LKP XV suvažiavimas, kuriame KPI rektorius M. Martynaitis pagarsino vyriausybès priimtą nutarimą apie tai, kad nutarta Vilniaus filialo pagrindu issteigti Vilniaus inžinerijos-ekonomijos institutą. Prof. M. Martynaitis teigè, kad būsimąji institutą reikia taip specializuoti, kad nebūtų jokio dubliavimosi su Kauno politechnikos instituto dieniniu skyriumi [3.34, p. 1].

M. Martynaitis čia minëjo LKP biuro nutarimą, kuriame, be kitų klausimų, sakoma:

„Laikyti tikslingu kelti prieš sajungine vyriausybę klausima apie Kauno politechnikos instituto Vilniaus filialo pertvarkyma nuo 1966-1967 mokslo metu i Vilniaus inžineriniekonomini instituta, išplečiant jame inžinieriu-ekonomistu rengima ir paliekant inžinieriu rengima pagal esama profili".

Visa tai rode, kad suverenios Vilniaus aukštosios technikos mokyklos įsteigimas tapo realybe. Bet dar buvo daug klausimy dèl būsimo instituto specializacijos, jo finansinių, ekonominių reikalų. Be Maskvos leidimo aukštoji mokykla Lietuvoje negalëjo būti įkurta. Visiems klausimams išspręsti dar prireike beveik ketverių metu.

\section{Gimsta naujų rūmu projektas}

Tuo metu, nuolat spaudžiant filialo administracijai, specialistai intensyviai projektavo būsimąją akademinių pastatų teritoriją, pačius pastatus, inžinerinius tinklus, gatves ir kt.

Studentų miestelio planą renge architektai Zigmas Daunora, Rimantas Dičius ir Juozas Vaškevičius, o mokomąjilaboratorinį korpusą projektavo architektas Julius Jurgelionis. Kad pastato projektine užduotis būtų kvalifikuotai parengta pagal specifinius įvairių katedrų reikalavimus, projekto autoriui konsultuoti buvo sudaryta patyrusių specialistų komisija: architektūros klausimais - M. Urbelis, statybiniu konstrukcijų klausimais - A. Kudzys, Prietaisų gamybos fakulteto laboratoriju įrengimo klausimais - S. Marazas, radijo specialybių laboratorijų klausimais -Z. Vainoris, Fizikos katedros laboratorijų klausimais - E. Mauza, Mechanines technologijos fakulteto laboratoriju klausimais - B. Liaudis, Statybos-ekonomikos fakulteto laboratoriju klausimais - E. Maksimavičius [3.35, p. 3].

Taigi iš komisijai pavestų užduočių matyti, kad 1966 m. manyta į naujai pastatytą korpusą ịkelti daugeli visų trijų fakultetu laboratorijų. Bet vèliau pasikeite ne tik šis sumanymas, bet ir pačios būsimos savarankiškos aukštosios mokyklos profilis, 
kai buvo nuspręsta kurti inžinerinị statybos institutą.

1966 m. pavasari, vykdydamas TSRS Aukštojo ir specialiojo vidurinio mokslo ministerijos $1965 \mathrm{~m}$. lapkričio $25 \mathrm{~d}$. įsakymą Nr. 350, KPI Vilniaus filialas reorganizavo tinklinio ir akademinio irklavimo sportinio meistriškumo grupes ị jungtines tarpmokyklines akademinio irklavimo ir tinklinio sportinio meistriškumo grupes.

Tinklinio grupés déstytoju treneriu buvo paskirtas etatinis filialo Fizinio lavinimo katedros vyr. destytojas V. Masaitis, o irklavimo - déstytojas valandininkas P. Zinkevičius.

Abi grupès buvo sudarytos daugiausia iš KPI Vilniaus filialo studentų.

Tinklinio grupè laimèjo $1966 \mathrm{~m}$. Vilniaus miesto pirmenybes ir Lietuvos aukštųjų mokyklų spartakiadą. Penki studentai buvo įtraukti į miesto ir respublikos rinktiniu sudetį.

Akademinio irklavimo grupę (akademinę aštuoniukę) sudare daugiausia KPI Vilniaus filialo studentai. Akademinè aštuoniuke laimëjo I vietą aukštujjų mokyklų spartakiadoje, „Didžiąją Maskvos regatą“, o Kijeve iškovojo TSRS čempiony vardus.

1966 m. birželio 27 d. Statybininkų kultūros rūmuose buvo iškilmingai įteikti inžinieriaus diplomai 162 vakarinio skyriaus diplomantams.

Vasarą sèkmingai buvo surinktas studijuojančių KPI Vilniaus filiale kontingentas. Visos specialybès liko tos pačios. Visuose trijuose fakultetuose veike dieniniai ir vakariniai skyriai.

Nuo 1966 m. rugsejo 1 d. doc. t. m. k. Romualdas Jonušas buvo paskirtas KPI Vilniaus filialo mokymo reikalų prorektoriumi. 1954 m. baigęs Kauno politechnikos institutą, $\mathrm{R}$. Jonušas gerai užsirekomendavo gamyboje. 1958-1959 m. jis dirbo Vilniaus „Žalgirio“ staklių gamyklos vyriausiuoju inžinieriumi, o 1959-1961 m. buvo jos direktoriumi. 19611962 m. jis - LTSR Liaudies ūkio tarybos Mašinų gamybos valdybos viršininkas.

Dirbdamas ir aukštojoje mokykloje docentas Romualdas Jonušas pasižymejo kaip puikus organizatorius, jam būdinga labai gera orientacija, dalykiné nuojauta. Buvo gerai tvarkomas studijų procesas, diegiamos naujoves, daug nuveikta moderninant auditorijas, įrengiant laboratorijas. R. Jonušas - ryški asmenybe KPI Vilniaus filialo ir kartu VISI istorijoje.

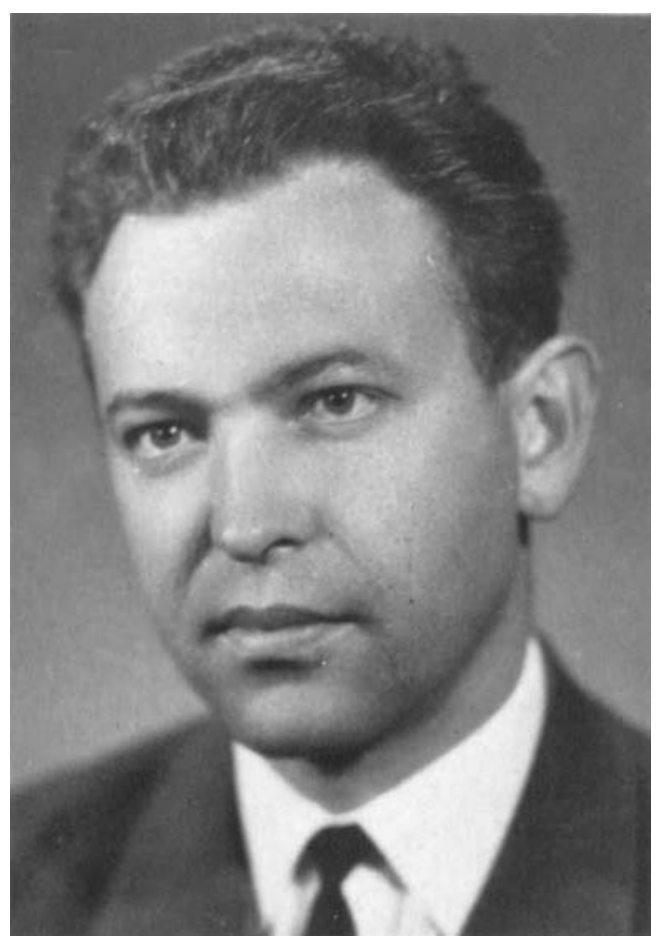

Romualdas Jonušas

1966 m. KPI Vilniaus filiale naujus metus pradëjo 1456 dieninio ir 2277 vakarinio skyrių studentai. Prietaisu gamybos fakulteto dekanu buvo paskirtas t. m. k. Č. Teišerskas. Filiale jau dirbo vienas technikos mokslų daktaras - Aleksandras Čyras, o Antanas Kudzys disertaciją buvo jau bebaigiąs. Filialo 43 destytojai buvo mokslų kandidatai, 22 - docentai. Pedagoginį darbą dirbo iš viso 224 destytojai.

Nuo 1966 m. rugsëjo KPI Vilniaus filiale veike jau 20 katedrų: Skaičiavimo technikos ir matematikos, Fizikos, Chemijos, Braižybos, Kalbų, Elektrotechnikos, Statybos, Mechanikos, Metalų apdirbimo, Mašinų teorijos, Radijo elektronikos, Gamybos ekonomikos, Mašinų gamybos automatizavimo, Miestų statybos, Statybinių konstrukcijų, Fizinio lavinimo, Marksizmo-leninizmo, Politinès ekonomikos ir mokslinio komunizmo, TSKP istorijos ir filosofijos bei Karine.

1966 m. spalio 11 d. issakymu KPI Vilniaus filialo prorektorius, jau technikos mokslų daktaras, einantis profesoriaus pareigas A. Čyras KPI Vilniaus filialo mokomojo korpuso naujame studentų miestelyje projektinès užduoties ekspertizei atlikti paskyre tokios sudèties komisiją: doc. t. m. k. B. Liaudis, e. doc. p. arch. m. k. M. Urbelis, e. doc. p. fiz. mat. m. k. E. Mauza, doc. ch. m. k. I. Nickus, e. doc. p. t. m. k. Z. Vainoris, e. doc. p. J. Stanaitis.

Deja, tenka konstatuoti, kad rūmų projekto architektui J. Jurgelioniui nepavyko 
KAUNO

POLITECHNIKOS

INSTITUTO

VILNIAUS FILIALAS

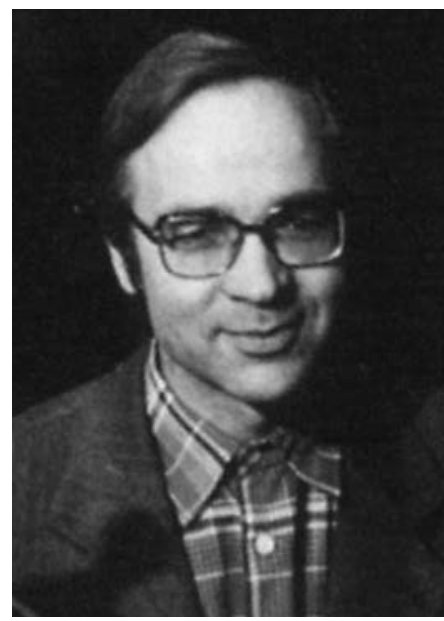

J. Jurgelionis rasti tobulos architektūrinès-konstrukcinès pastato sandaros. Ilgainiui eksploatuojant išryškejjo daug rūmų suplanavimo trūkumų. Jų, matyt, nepastebëjo ir ekspertizę vykdžiusi komisija. Galimas dalykas, kad, neatsisakius pritaikyti KPI Radioelektronikos korpuso projekto Vilniuje, būtų gautas geresnis rezultatas.

\section{Filialas intensyvina pletros ir statybos pastangas}

1966 m. spalio 22 d. rašte Nr. 1805 KPI Vilniaus filialo vadovai jau tiesiai šviesiai kelia klausimą respublikos valdžiai dèl savarankišskos aukštosios mokyklos įkūrimo. Rašte dèl butų personalui ir laboratorinio korpuso projektavimo Lietuvos TSR MT pirmininkui M. Šumauskui A. Čyras informuoja, kad „<...> nei vienas is šiu Vyriausybiniu pavedimu laiku nebuvo įvykdyti. Reikia pažymeti, kad šie klausimai buvo sprendžiami esant dideliam demesiui is Vyriausybes pusès bei iniciatyvai iš filialo pusés, tačian jie nutrükdavo tarpineje grandineje. Vyriausybiniai nutarimai buvo revizuojami, o Aukštojo ir spec. vidurinio mokslo ministerija nesieme reikalingu priemoniu, kad jie būtu laiku ivykdyti <...>. Tačiau nesant principiniu nurodymu, ka ir kada reikia statyti, kyla gresme, kad ir 1967 metais miestelio statyba nebus pradeta <...>.

KPI Vilniaus filialas pagal studenty skaiciu stacionare ir vakariniame skyriuje yra respublikoje trečioje vietoje. Šiuo metu jame mokosi viso 3838 studentai. Be abejo, sutinkamai su aukštosios mokyklos valdymo ir darbo organizavimo specifika yra tikslinga ji organizuoti i savarankiškq aukštaja mokykla. Tai atžymeta ir LKP CK ir LTSR MT 1965 m. gruodžio men. 29d. nutarime Nr. 653. Šiuo klausimu mes pateikème Aukštojo ir spec. vidurinio mokslo ministerijai visa eile pasiūlymu, tačiau ne vienas iš ju nebuvo giliai nagrinetas ir iki siol principiniai neišspręstas. Mūsu nuomone, filialo specializavimo klausima reikia spresti neatideliotinai ir nustatyti jojo reorganizavimo $i$ savarankiškq aukstaja mokykla terminus..." [3.36, p. 214].

KPI centras i tai reagavo ramiai, Vilniaus filialo separatizmas jiems buvo seniai ịprastas dalykas, niekas neabejojo, kad Vilniuje ilgainiui bus ịkurta aukštoji technikos mokykla. Bet kaltinimai neveiklumu jau užgavo ministrą H. Zabuli. 1966 m. gruodžio 17 d. raštu Nr. 1-6594 Lietuvos TSR MT pirmininko pavaduotojai L. Diržinskaitei $\mathrm{H}$. Zabulis praneša, kad KPI Vilniaus filialo vadovu , «...> visi rašte iškelti klausimai yra sprendžiami, tik ju sprendimo eiga yra ne tokia, kaip pateikia rašto autoriai ".

Kadangi ministro H. Zabulio minètame rašte daug ịdomios istoriniu požiūriu medžiagos, pateikiame didesnę jo dalị:

„2. KPI Vilniaus filialas visiškai neteisingai pateikia faktus, liečiančius jo materialine bazę ir jos pletimo perspektyvas. Rašte neteisingai teigiama, kad 1962 m. rugsejo 1 d. buvo duoti nurodymai ruošti medžiaga KPI Vilniaus filialo korpuso projektavimui. Pasiūlymus, lieciančius jo perspektyvas ir statyba, savo iniciatyva parenge pats filialo kolektyvas. Ministerija (tuomet Komitetas) visuomet laikesi nuomones, kad Vilniuje aukstuju mokyklu bazès stiprinimas turi būti pradetas nuo universiteto, bet vis delto nagrinejo Filialo pateiktus projektus. Efektyvioseigos KPI Vilniaus filialo pasiūlymai statybos klausimu negavo del to, kad, prasidejus KPI miestelio statybai Kaune, jokiu finansiniu rezervu nebuvo. Be to, 1961 m. liepos $4 d$. LTSR Ministry Taryba prieme specialy nutarima Nr. 397, kuriame buvo sprendžiami KPI, tame tarpe ir jo Vilniaus filialo, materialines bazes klausimai.

1964 m., pasiremus Baltarusijos patyrimu, müsu buvo iškelta respublikos direktyvinems instancijoms ideja dèl platesnio gamybiniu lësu panaudojimo aukštuju mokyklu ir technikumu materialinei bazei stiprinti. Šiuo klausimu, be to, kreipesi Šiauliu miesto vadovai, prašydami leisti panaudoti gamybos lèsas KPI Šiauliu vakarinio fakulteto statybai. $1964 \mathrm{~m}$. rugsejo $19 \mathrm{~d}$. Ministru Taryba išleido potvarki Nr. 1948-p, kuriame buvo keliamas klausimas dè KPI Vilniaus ir Šiauliu vakariniu skyriu laboratoriniu korpusu statybos technikines dokumentacijos parengimo 1965 m., o statyba buvo numatoma iš Vilniaus ir Šiauliu pramones imoniu asignavimu. Projektavimo darbu Vilniuje nebuvo galima greitai vykdyti, nes nuo 1962 m. su Vilniaus miesto architektais tebevyko derybos del akademinio miestelio vietos, kol pagaliau buvo nusistatyta patvirtinti sklypa Antakalnyje prie Nemenčines ir Dvarčioniu plento. Aukstojo ir specialiojo vidurinio mokslo komitetas, nenoredamas padaryti architektūiniu ir funkcionaliniu klaidu, kartu su 


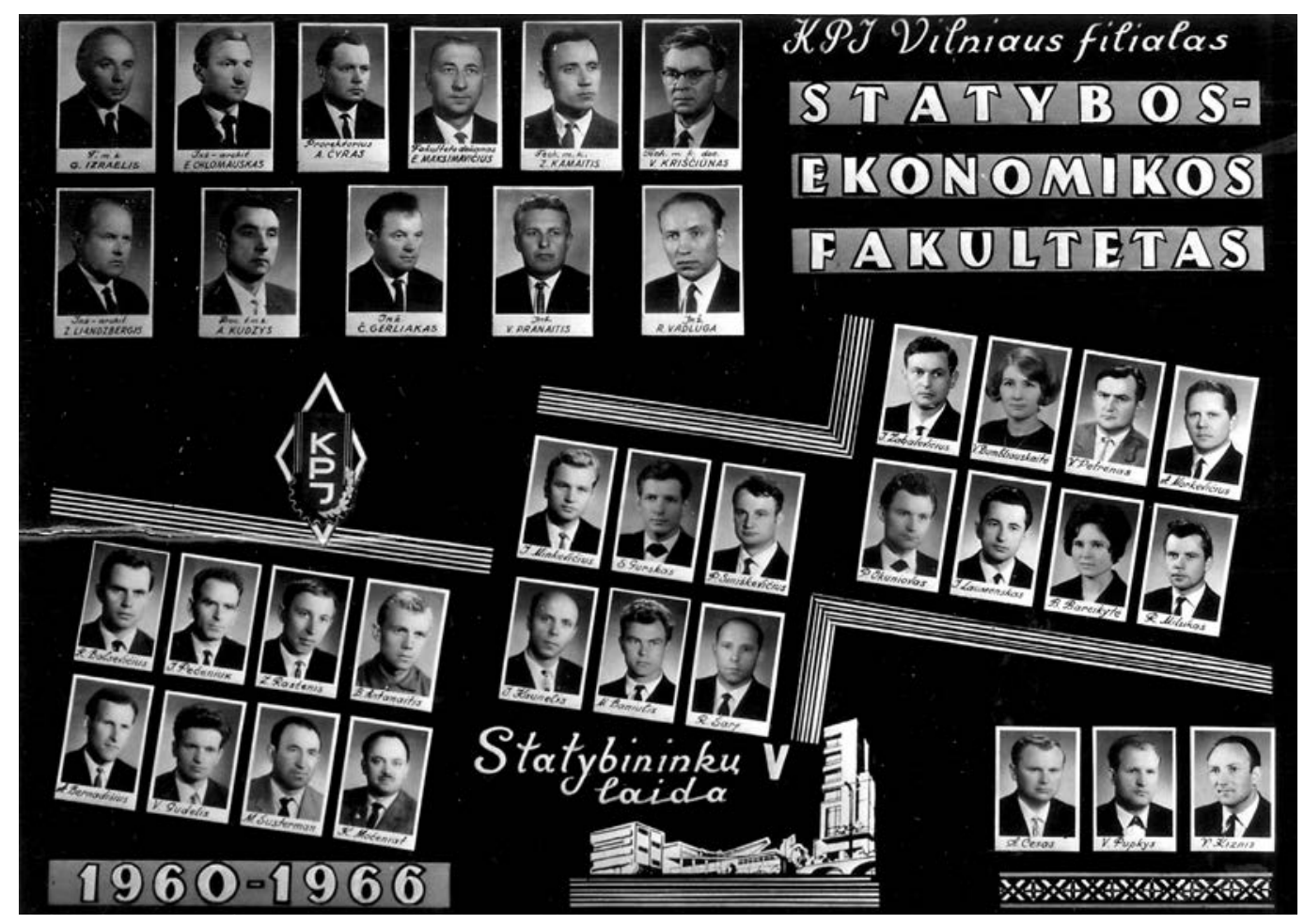

Architektu sajunga (drg. V. Mikučianis) ruoše salygas Vilniaus miesto akademinio miestelio genplano konkursui. Šis konkursas, LTSR Ministru Tarybai leidus, 1964 m. buvopaskelbtas ir pravestas, o 1965 m. buvo paruoštas šio miestelio genplanas. KPI Vilniaus filialas tuo metu, noredamas atsiriboti nuo Vilniaus universiteto statybu, ieškojo sklypo miesto centre. Jo pasiūlymu ministerija palaikyti negalejo, nes buvo siekiama statytis prie Vilniaus pedagoginio instituto, kurisirpats atsidūre visiškai neperspektyvioje ir suvaržytoje vietoje.

1965 m. vasario 15 d. svarstant LKP CK ir LTSR Ministru Taryboje Vilniaus Valstybinio $V$. Kapsuko vardo universiteto materialines bazés klausima, mūsu pasiūlymu papildomai buvo irašytas ir KPI Vilniaus filialo klausimas, nes projektuojamas miestelis buvo visa laika traktuojamas, kaip dvieju mokyklu objektas. Reikia pasakyti, kad Statybos reikalu komitetas, gavęs vyriausybes nutarima, užprotestavo prieš jame nurodytus terminus ir, vadovaudamasis valstybinemis projektavimo normomis, irode Plano komisijai, kad atskiru korpusu darbo brëžinius jie gali parengti tik 1966 m. Ryšium su tuo nebuvo sprendžiamas ir statybos finansavimo klausimas. Savo ruožtu, $L \bar{U} T$ lësu panaudojimas iš viso atpuole, nes ji buvo panaikinta.

Pagaliau, būtina pabrežti, kad KPI Vilniaus filialo vadovai, iš esmès energingai siekdami sustiprinti savo mokyklos baze, perdetai menkina turimus plotus. KPI Vilniaus filialo baze nera blogesné, negu kitu aukštuju mokyklu. Vienam dieninio skyriaus studentui cia tenka $11,1 \mathrm{~m}^{2}$ (pagal vakarini kontingenta $7,5 \mathrm{~m}^{2}$ ), KPI centre 7,8 $\mathrm{m}^{2}$, Vilniaus universitete $8,5 \mathrm{~m}^{2}$ Vilniaus pedagoginiame institute 5,7 $\mathrm{m}^{2}$, Kauno medicinos institute 4, $8 \mathrm{~m}^{2}$.

Antra vertus, Filialo vadovai dažnai neatsakingai siülosi atlikti savo jegomis sudetingus projektavimo darbus (aukštuminis bendrabutis ir pan.), nors visiems yra visiškai aišku, kad tai yra nerealu, o be to, uždrausta.

3. KPI Vilniaus filialo profiliavimo klausimu Aukstojo ir specialiojo vidurinio mokslo ministerija jau yra itteikusi savo pasiūlymus LKP Centro Komitetui. Ministerijos nuomone, KPI Vilniaus filialo teikiamas radioelektronikos profilis iš visu galimu profiliu yra silpniausiai argumentuotas ir mažiausiai priimtinas.

Pranešdamas tai, noriu pasakyti, kad Ministerija ir toliau des pastangas gerinti aukštuju mokyklu, tame tarpe ir KPI Vilniaus filialo materialine baze ir mokymo salygas. Visiškai neseniai Ministerija perdave jam viena Vilniaus pedagoginio instituto bendrabuti (Gorkio g. 88), kuriame isiküre Statybos-ekonomikos fakultetas" [3.36, p. 214-217].

Reikia pažymèti, kad daugelị metų, galbūt nuo minetu raštu gimimo, ministro H. Zabulio ir rektoriaus A. Čyro santykiai buvo, švelniai kalbant, šaltoki. A. Čyras nepataikavo jokių žinybų vadovams, kovojo dèl savo mokyklos interesų, nepaisydamas hierarchinès struktūros, žinybų autoritetų. Tai sukeldavo įtampą ir su finansinių, 
KAUNO

POLITECHNIKOS

INSTITUTO

VILNIAUS FILIALAS

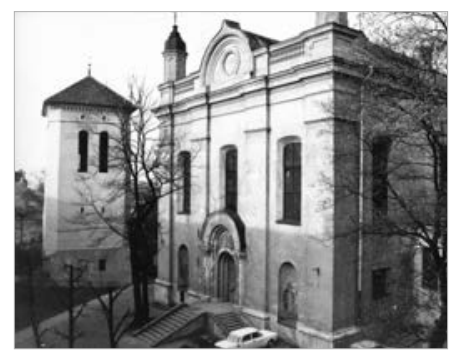

Viršuje dešinëje -

A. Kudzys ir R. Vadlūga bandymu metu projektavimo bei statybos organizaciju darbuotojais, nors galiausiai norimas rezultatas buvo pasiekiamas. Tiesa, administracines karjeros pabaigoje abieju profesoriu - H. Zabulio ir A. Ćyro santykiai tapo bičiuliški.

KPI Vilniaus filialo mokomojo korpuso statybai pirmieji tūkstančiai (375 000) rublių buvo skirti tik 1968-iems metams. Statybą vykdyti Vilniaus statybos trestas Nr. 1 (valdytoju buvo A. Ralys) pradejo $1968 \mathrm{~m}$. vasario $16 \mathrm{~d}$. Septynių aukštų $34000 \mathrm{~m}^{3}$ korpusas turëjo būti pastatytas 1970 m. pirmajji pusmeti.

\section{„Šeimininkas“ lankosi cerkveje}

KPI Vilniaus filialo Statybinių konstrukcijų laboratorija, atrodo, nuo $1963 \mathrm{~m}$. buvo įrengiama buvusioje Šv. Trejybès cerkveje, pastatytoje $1514 \mathrm{~m} .1608-1827 \mathrm{~m}$. cerkve ir vienuolynas, kuriame dabar buvo filialo centriniai rūmai, priklausè unitų vienuoliams bazilijonams. Ankstyvoji cerkves architektūra buvo būdinga gotikai, bet po XVII ir XVIII amžiuose kilusių gaisrų $1761 \mathrm{~m}$. architektas J. K. Glaubicas padare barokinę jos rekonstrukciją. XIX a. antrojoje pusëje pagal architekto N. Čagino projektą buvo sumūrytas naujas rytinis frontonas, o vakariniame fasade, manoma, pagal J. K. Glaubico projektą pastatyti du liekni bokšteliai.

Šv. Trejybès cerkve pirmą kartą buvo išniekinta, kai buvo paversta sandèliu. Kai ji kartu su buvusiu vienuolynu atiteko KPI Vilniaus filialui, pradžioje čia taip pat buvo sandèlis, bet labai trūko patalpų Statybinių konstrukcijų laboratorijai. Tiesa, patalpos buvo labai apleistos, užterštos šiukšlemis, čia gyveno gausybès balandžių. Laboratorijai ịrengti pirmiausia reikejjo atlikti daug remonto darbų. Šiuos darbus vykdydami, darbininkai, bandymų mašinomis-presais irrengdami pamatus, kai kuriose vietose arde grindis, kasè duobes. Mètesi žmonių kaulai, karstų liekanos. Toks buvo tuometinis gyvenimas. Nieko nebuvo švento...

Cerkvè primena halę, joje yra beveik po 5 metrus pločio navos. Planuota įrengti perdangas, kad būtų ir antras aukštas. Patalpu, žinoma, labai trūko. Bet atsiradus naujų fi-

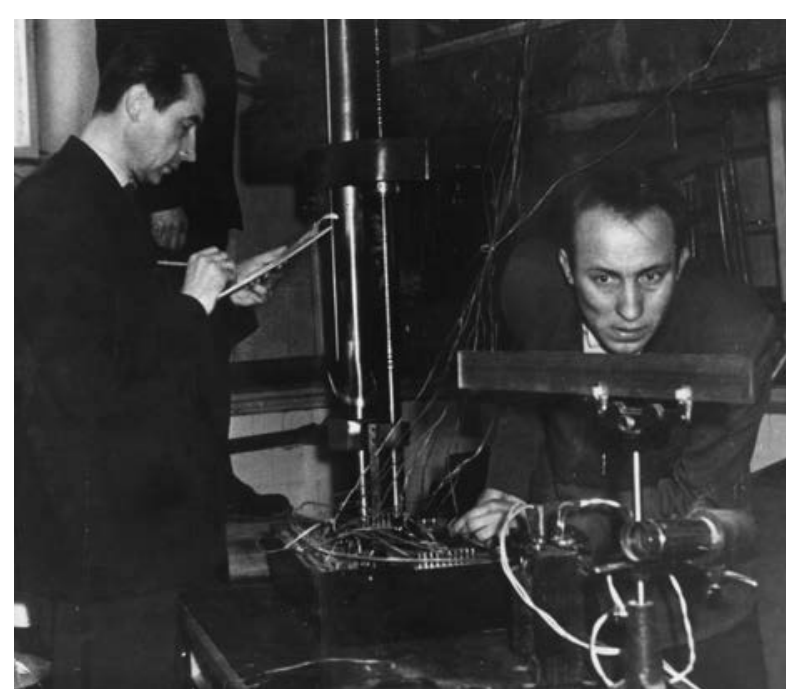

lialo statybų perspektyvai, antrą aukštą cerkvëje įrengti buvo atsisakyta.

Pietinèje cerkvès pusèje, buvusioje koplyčioje ir zakristijoje, buvo įrengta vadinamoji klimatine kamera, kurioje buvo tiriami betono arba gelžbetonio bandiniai, ir aspirantų kambarys, o šiaurinëje pusëje - geologijos kabinetas.

Statybinių konstrukcijų laboratorijai gauti įrengimus daug padëjo Romualdas Jonušas, prieš keletą metų dirbęs Liaudies ūkio tarybos Mašinu gamybos valdybos viršininku. Kai 1965 m. tokios tarybos buvo likviduojamos, daug ką buvo galima gauti iš valdybos įmonių, jei tureta geru ryšių.

1966 m. kilo vis daugiau aistrų dèl būsimojo inžinerinio profilio instituto Vilniuje. Jos, žinoma, pasieke ir Lietuvos komunistų partijos Centro komitetą, jos pirmąji sekretorių A. Sniečkų. Noredamas geriau suprasti problemą, jis nutare apsilankyti KPI Vilniaus filiale.

Respublikos „pirmajam“ buvo parodytos buvusiame vienuolyne įrengtos auditorijos, Elektronikos ir kitos laboratorijos. Pakeliui kalbèta apie tai, ko filialas trokšta, ko labai reikètų normaliam akademiniam procesui.

Kai A. Sniečkus, lydimas A. Čyro ir palydos, atejo ị Statybinių konstrukcijų laboratoriją A. Kudzys ten dirbęs kartu su savo aspirantu A. Kvedaru. „Šeimininkas“ (taip dažnai vadindavo Lietuvos komunistų partijos vadovą), apžiūreję̧s laboratorijos irrenginius, paklause A. Kudzi, kokio profilio institutą reiketu kurti Vilniuje. A. Kudzys gerokai nustebino A. Sniečku energingai įrodinedamas, kad KPI Vilniaus filialas nereikalingas pertvarkymu, bet vis dèlto tolesneje ateityje tikslinga steigti Statybos institutą. Ši pokalbị tarp A. Sniečkaus ir 
A. Kudzio gerai prisimena buvęs Aukštojo ir specialiojo vidurinio mokslo komiteto primininko pavaduotojas Vaclovas Pranaitis. Jo manymu, A. Kudzio argumentus A. Sniečkus labai atidžiai išklause ir atrodo, kad tai turëjo didelę ịtaką valdžios sprendimui dèl būsimo instituto profilio.

V. Pranaitis J. Stražnickui, knygos apie A. Čyrą autoriui, pasakojo, kad veliau „svarstant naujo instituto profili, pasirode, kad inžinerinis statybos institutas visais atžvilgiais yra labiausiai priimtinas. Pirmiausia del to, kadstatybinès specialybès, büdamos mažiausiai sujungtos su bendru politechnikos kompleksu, politechnikos institutams augant, pirmiausia išskiriamos $i$ savarankiškus institutus. Antra, prijungus prie statybiniu specialybiu statybiniu ir keliu mašinu bei automobiliu transporto specialybes, susiformuoja labai apibrěztas, visiškai nesikertantis su KPI profiliu, institutas, susijes su keturiomis respublikos žinybomis: Statybos, Kaimo statybos, Komunalinio ūkio bei Automobiliu transporto ir plenty ministerijomis. KPI palaiko ryšius su ivairiu pramones šaku ministerijomis. Trečia, stiprus šio profilio instituto studenty ir kadru potencialas apsaugo nuo nepageidautinu deformaciju jo vystymosi raidoje. Jis, iš pat pradžiu perkelus danguma statybinio profilio profesoriu ir destytoju is KPI, tures savo varda ne tik Lietuvoje, bet ir plačiau, tures teise priimineti kandidato ir daktaro disertacijas, gales formuoti mokslines kryptis " [3.37, p. 208].

J. Stražnickas knygoje apie A. Čyrą pateikia dar vieną žiupsnelị A. Kudzio prisiminimų:

"1967 metais pokalbio mane pakviete naujasis LTSR Ministru Tarybos pirmininkas J. Maniusis. Ašjau seniai žinojau, kad jis keliu statybos inžinierius ir statybos ekonomikos mokslu kandidatas. Iš pokalbio supratau, kad jis noritu kuo greičiau matyti Vilniuje ikurta statybos ir transporto profilio inžinerini instituta. Jo noras, kad tokio profilio institutas būtu vienintelis Baltijos šalyse, mane nuliüdino ir netgi išgasdino. Matyt, kai kam Lietuvoje labai rūpejo, kad pagrindine destomoji kalba institute bütu rusu, o tik atskirose studentu grupese būtu dèstoma lietuviu kalba. Sako, kad veliau jis rekomendavo ikurti Vilniuje prietaisu gamybos profilio instituta (jo dukte studijavo mūsu filiale radioelektronika).

Sužinojęs, kad J. Maniusis rengia statybos ekonomikos moksly daktaro disertacija, suvokiau jo ketinimus ateityje dirbti büsimajame institute kokiu nors vadovu, o gal ir rektoriumi.
Tačiau veliau jis buvo paskirtas Mokslu akademijos Ekonomikos instituto direktoriumi...

Sužinoje, kad Vilniuje rengiamasi reorganizuoti KPI filiala, Vilniaus mokslininkai Vyriausybei siūle savuosius variantus. Prisimenu, kaip akademikas A. Jucys kelis kartus mane itikinejo, kad reikètu Vilniuje isteigti savarankiškq fizikines technikos profilio mokslo istaiga..."

J. Stražnickas pateikia ir tuometinio LTSR Aukštojo ir specialiojo vidurinio mokslo komiteto pirmininko (veliau ministro) prisiminimus ir samprotavimus KPI Vilniaus filialo pertvarkymo į institutą klausimu. Profesorius Henrikas Zabulis pasakojo:

„Pastarasis klausimas, net ir pasiekęs aukštasias Respublikos instancijas, nebuvo toks paprastas, kaip dabar meginama paaiškinti. Buvo labai daug objektyviu ir subjektyviu niuansu, kuriuos reikejjo ivvertinti nieko neužgaunant ir nieko neužmirštant. Pirmiausia reikejo atrasti perspektyvu naujos mokslo istaigos profili, kad bütu galima ji visuose lygiuose itikinamai apginti. Maniusis, nors pats buvo statybos inžinierius, protegavo radioelektronika, laikydamas ja perspektyviausia technikos mokslu sritimi. Tačiau Vilniuje veike net keli karinio pobudžio radioelektronikos centrai, kimšte prikimšt $i$ lietuviškai nemokančiu darbuotoju. Iščia grèse pavojus, kad radioelektronikos institutas pavirs ju susitelkimo vieta: vieni ateis studijuoti, kiti - destyti, o prievarta atkeltos is Kauno radioelektronikos katedros tures problemu. Tiesiai to negaledami akcentuoti mes su Pranaičiu radom kita svarbu priešnuodi: Minske, vos už poros simtu kilometru, yra giminingo profilio Radioelekronikos institutas, kurisstabdys mūsu instituto atidaryma ir tolesne pletotę. Martynaitis, kuris senokai susitaike su mintimi, kad Vilnius jau išeina iš KPI sudeties, siūle mažiausiai skausmo sukeliančiq operacija: visoms Vilniuje esančioms vakarinems specialybems duoti dienini skyriu, išpletoti jau esamas dienines grupes ir atidaryti Vilniaus politechnikos instituta. Toks variantas išties bütu sklandžiai realizuojamas nuoseklaus pletojimo būdu, bet jis kele panašu pavoju kaip ir radioelektronika. KPI vakarinis skyrius Vilniuje buvo gana rusiškas, nes toks buvo stojančiuju kontingentas. Pletojant tomis pačiomis specialybemis ir dienini skyriu sunku būtu išvengti rusišku grupiu dominavimo. Susiklostytu rizikinga takoskyra: Kaune egzistuotu lietuviškas politechnikos institutas, Vilniuje - rusiškas. Ař išdèsčiau tokią prognoze Martynaičiui, ir jis sutiko, kad sis kelias, nors ir neskausmingas pradineje stadijoje, gali sukelti labai dideliu problemu veliau.

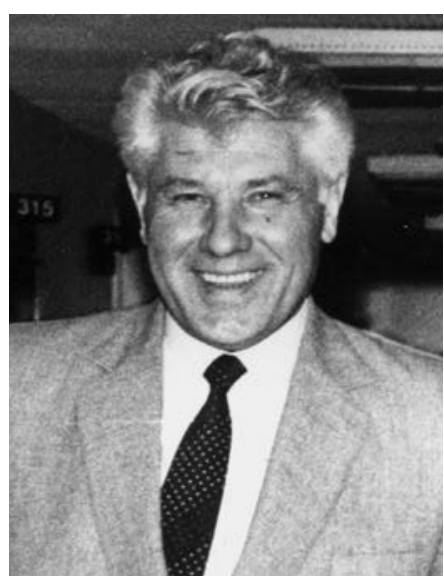

H. Zabulis

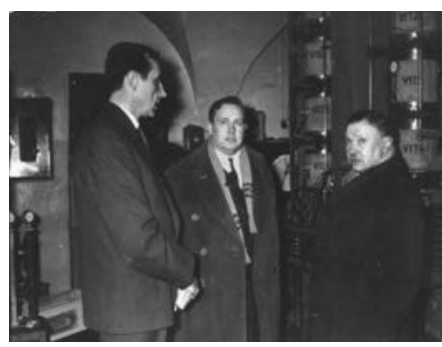

Is kairès: A. Kudzys, A. Cyras ir A. Sniečkus laboratorijoje

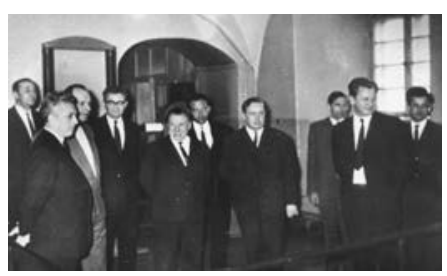

A. Sniečkaus apsilankymo laboratorijoje metu (iš kaires): E. Maksimavičius, V. Pranaitis, J. Bacevičius, V. Kriščiūnas, A. Sniečkus, R. Jonušas, A. Cyras,

A. Marcelis, V. Jemeljanovas, S. Marazas 
KAUNO

POLITECHNIKOS

INSTITUTO

VILNIAUS FILIALAS

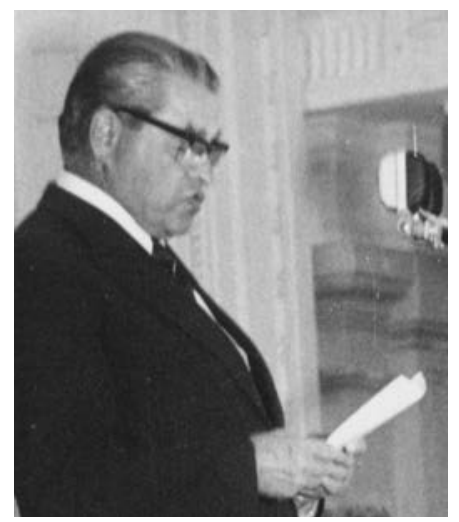

J. Maniušis
Oficialiai mes šc variantq atmetem irgi formaliu pretekstu: Maskva draudžia tureti dvi vienodo profilio aukstasias technikos mokyklas, nes ji vienu metu reikalavo, kad net tarp Kauno, Rygos ir Talino politechnikos instituty bütu isgryninta ir atribota specializacija. Todel atsirado trečias variantas, kurio autoriai, berods, buvo Kudzys su Pranaiciu, abu statybininkai, abu vieno kurso kolegos: tolydžio vis garsiau ir plačian imta kalbeiti apie statybos instituto steigima Vilniuje. Man ši ideja patiko dvejopai: kaip biurokratui, kurio lauke ilgas vaikščiojimas po Maskvos instancijas, ji man buvo paranki motyvacijos argumentais, nes statybininku trükumas Lietuvoje buvo aiškiai juntamas, o kaip politikui, kuriam rüpejo pačios aukštosios mokyklos esme ir perspektyva, man buvo svarbu tai, kad statybos institutas ruoštu specialistus ne vien Vilniaus įmonems ar tuo labiau uždarai ju grupei, o visai Lietuvai. Vadinasi, tokiu atveju jaunimas $i j i$ stos is visos Lietuvos, neš $j$ Vilniu lietuvybę, o grižęs namo tarnaus savo gimtines labui. Pastaraji argumenta mes aptarem su Pranaiciu, jz remé Cyras, bet jis, žinoma, oficialiai buvo nutylimas. Oficialia motyvacija skaičiais parenge profesorius Antanas Kudzys. Mums palengvejo, kai statybos varianta pareme Maskvos ekspertas, Aukštojo ir specialiojo vidurinio mokslo ministerijos Aukstuju mokyklu valdybos viršininko pavaduotojas A. Judinas, labai kuklus žmogus, beje, nepartinis ir pats statybininkas. Sniečkus taip norejo, kad koks nors Maskvos atstovas pasakytu savo nuomone, nes žinojo, kad po to vis vien reikes ten gauti nutarima. Judinas su manimi aplanke pirmaji sekretoriu ir dalyvaujant Maniušiui pasisake už statybos instituta" [3.37, p. 207-208].

Taigi Antanas Kudzys buvo pagrindinis KPI Vilniaus filialo pertvarkymo būtent î Statybos institutą iniciatorius ir pagrindejas. Tam ypač kategoriškai prieštaravo KPI Statybos fakulteto profesūra. Bet nenorintys persikelti i Vilnių jau nieko negalejo pakeisti. Su tuo, kad Vilniuje bus Inžinerinis statybos institutas, galiausiai susitaike KPI administracija.

J. Maniušiui, kai jau buvo įkurtas Inžinerinis statybos institutas, rektorius A. Čyras pasiūle būti VISI mokslinès tarybos nariu. Jis sutiko, dažnai dalyvaudavo tarybos posèdžiuose. Tai daug kam kèle nuostabą. Vis dèlto - premjeras, šitiek reikalų! Posedžiuose sèdejo nekalbus, beveik nieko neklausdavo. Tas jo dažnas dalyvavimas filialo tarybos posèdžiuose, matyt, tikrai buvo susijęs su tam tikais ketinimais.

Lionginas Šepetys, buvęs LKP ideologas, o 1990 m. tapęs Atkuriamojo seimo signataru, savo prisiminimuose rašo, kad, mirus A. Sniečkui, J. Maniušis buvo Maskvos kandidatas ị „pirmojo “ postą. Esąs tikras internacionalistas, ištikimas partijos reikalui, bet, anot L. Šepečio, „Kaip tik dèl maskviečiu giriamu internacionalisto J. Maniušio bruožu jo kandidatūra buvo nepriimtina respublikos aktyvo daugumai. Tiesa, kiti ejo prieš ji tik todel, kad siame poste mate save. Dar kitiems nepatiko jo uždaras, šeimyninis būdas - „ne kompanijos žmogus" [3.38, p. 220].

J. Maniušis buvo gimęs ir augęs Rusijoje, žmona ruse, pramokusi lietuviškai, nors kalbejo su rusišku akcentu, be to, išsimokslinęs, dirbęs partinị ir administracinị darbą - labai tinkamas valdyti šią per daug lietuvišką Lietuvą!

L. Šepetys atskleidžia, kodèl J. Maniušis netapo „pirmuoju“. „Pasirodo, kol tuščiai ausinome burnas, svarstydami juairias kandidatūras, labiau patyre nomenklatūriniu intrigu meistrai M. Šumauskas, F. Bieliauskas, A. Drobnys suloše maskviečiu kortomis. Sukurste prieš J. Maniuši dar didesnį internacionalista ir, svarbiausia, L. Brežnevo jaunystès bendražygi K. Liaudį. Šis paskambino gensekui, ir ligtoliniu rinkiminiu svarstymu lyg nebūta. Tokios tokeles...

Poporos menesiu kažkaip nejučiomis, tyliai ir ramiai i LKP viršünę užkope išpažiūros toks patramus P. Griškevičius. Pensininkas K. Liaudis gavo socialistinio darbo didvyrio žvaigždutę. İsibegejo sastingis..." [3.38, p. 221].

Kazimieras Liaudis 1954-1959 metais buvo LTSR saugumo šefu. KGB vien pavadinimas kèlè siaubą daugumai žmonių. Tačiau K. Liaudžio sūnus Borisas Liaudis - KPI Vilniaus filialo dekanas, katedros vedejas ir fakulteto, ir katedros bendradarbiu charakterizuojamas kaip padorus žmogus, daug prisidejęs prie Mechaninès technologijos fakulteto kūrimo ir stiprinimo.

Prof. A. Kudzys 2006 m. mokslo istoriky itteiktame pranešime taip prisimena aprašomąji laikotarpi:

„1961 metais Vilniaus technikos universiteto küdikis pabande atsistoti: buvo ikurtas KPI Vilniaus filialas pradžioje su dviem, o veliau su trim fakultetais. Šio filialo vadovu, kaip KPI 
Vilniaus filialo prorektoriumi, buvo paskirtas doc. A. Čyras. Tuo metu, kai trūko destytoju, laboratoriju ir mokslinès literatūros, išryškejo prorektoriaus A. Cyro ryžtingas charakteris ir organizaciniai sugebejimai. Jis sugebejo Vilniuje komplektuoti darbštu ir išprususi kolektyva, o filialas netrukus tapo žinoma mokslo istaiga ne tik tuometineje Tarybu Sajungoje, bet ir užsienyje. Cia ir prasidejo kai kurios netiketos bedos.

I Lietuvos komunistu partijos vadovus kreipesi jvairiu tautybiu mokslininkai ir inžinieriai, prašydami priimti juos dirbti $i$ KPI Vilniaus filiala, o veliau ir $i$ VISI. Vienas iš respublikos vadovu, LKP CK sekretorius Juozas Maniušis rengesi ginti statybos ekonomikos kandidato ir daktaro disertacijas, bendravo su Maskvos aukštosiomis mokyklomis ir todel tarpininkavo patenkinti prašytoju pareiškimus. Visa laime, kad nauju katedru planavimas ir steigimas buvo tvirtinamas ne Vilniaus filiale, o KPI centre Kaune. Ta proga negaliu nepamineti to svarbaus teigiamo vaidmens, kuri tuo metu atliko KPI prorektorius, o nuo 1964 mety rektorius prof. $M$. Martynaitis. Jis daug padejo prorektoriui A. Cyrui tvarkytis nebūtinai taip, kaip to norëjo respublikos valdžia, todel Vilniuje buvo galima isteigtiaukštaja technikos mokykla, nekviečiant ija rusakalbès profesūros. Tampadejo ir tuometinis Vilniaus universiteto rektorius Jonas Kubilius, kuris viešai pareiškè, kad atsisakius universiteto parengtumatematiku, fiziku ir kitu specialistu bütu neleistinai sumenkintas universiteto mokslinis lygis ir vaidmuo.

Prorektorius A. Cyras galejo laisvai interpretuoti Vilniaus partiniu vadovu nurodymus dar ir todel, kad miesto partijos komiteto pirmojo sekretoriaus K. Mackevičiaus ir kitu veikejuz žmonos dirbo filiale, o LKP CK pirmojo sekretoriaus A. Sniečkaus sünus ir J. Maniušio dukte buvo šio filialo studentai. Filiale labai aktyvus buvo šio filialo Technologijos fakulteto dekanas doc. Borisas Liaudis, kurio tevas 1954-1959 m. buvo Valstybinio saugumo komiteto pirmininku, o veliau ilgamečiu LKP CK revizijos komisijos pirmininku. Tačiau prorektorius $A$. Cyras sugebedavo su juo susitarti, kai reikedavo priimti filialui naudingus sprendimus. Cia jam padedavo filialo partinès organizacijos sekretorius doc. Juozas Bacevičius.

Skubiai irengti filiale naujas tinkamas mokymui ir moksliniams tyrimams laboratorijas mums padejo tuo metu gyvavusi vadinamoji Liaudies ükio taryba. Jis pastangomis Vilniaus miesto pramones, transporto ir kitos imones padovanojo mums daug mašinu, irangos ir prie- taisu. Gaila, kad šias laboratorijas teko jrengti visiškai šiam tikslui nepritaikytose patalpose ir netgi apleistuose rūsiuose. Likvidavus šiq taryba, 1965 metais vienas iš jos vadovy doc. Romualdas Jonušas buvo paskirtas KPI Vilniaus filialo prorektoriumi.

Kai 1967 m. Vilniaus technikos universiteto küdikis pradejo vaikščioti, ji aplanke A. Sniečkus. Apžiūredamas mūsu katedroje ilgalaikiu procesu laboratorija, jis netiketai manes paklause, kokio profilio savarankiška instituta reiketu kurti Vilniuje, nes respublikos sostines reputacijai tartum bütina turèti aukštaja technikos mokyklą. Jo nuostabai aš kategoriškai pasisakiau prieš bet koki KPI Vilniaus filialo pertvarkyma, tačiau pareiškiau, kad ateityje galètu büti jkurtas statybos profilio institutas. Šiq mintį buvau aptaręs su Aukštojo ir specialiojo mokslo ministro pavaduotoju doc. Vaclovu Pranaičiu, kuris dirbo ir filialo Statybiniu konstrukciju katedroje.

Tam, kad nereiketu skubiai atsiskirti nuo KPI, aš turëjau daug argumentu ir netgi egoistiniu priežasčiu. Filiale dèstytojai galejo aktyviai dirbti mokslinius darbus, nes jame buvo daug vakarinio ir neakivaizdinio mokymo studentu, todel diena destytojai buvo laisvi nuo užsiemimu. Be to, filiale destytojai nebuvo varginami, vadinamuoju visuomeniniu darbu politiniu švietimu, jvairiais posédžiais ir susirinkimais, kuriu nemego nei $B$. Liaudis, nei J. Bacevičius, o tuo labiau prorektorius $A$. $\check{C}$ ras. Ivairūs raštai ir nurodymai bei isakymai iš Vilniaus buvo siunčiami i Kauna, o iš ten jie mus pasiekdavo dažniausiai pavelavę.

Pasinaudojes palankia darbo situacija, aš filiale per trejus metus parengiau habilituoto daktaro disertacija, apibendrindamas centrifuguotojo betono ir gelžbetonio tyrimo rezultatus. 1963 metais filiale lankesi KPI mokslo prorektorius Romanas Chomskis. Jis susipažino su atliekamais moksliniais tyrimais ir tarpininkavo KPI tarybai suteikti docentams A. Cyrui ir A. Ruseckui kūrybines vieny mety atostogas daktaro disertacijoms iforminti. Negavęs siu atostogu labai pasipiktinau ir sunkiai dirbdamas $1964 \mathrm{~m}$. vasarq savaji darba išspausdinau. Ji iteikiau Maskvos betono ir gelžbetonio instituto mokslo tarybai, žinodamas, kad KPI taryboje jos ginti negalesiu. Perëus visus formalumus, disertacija buvo ginama tik $1967 \mathrm{~m}$. sausio menesi, bet jau tais pačiais metais tapau pirmuoju VISI, o kartu ir VGTU profesoriumi.

1967 m. mane pakviete pokalbio J. Maniušis. Iš pokalbio supratau, kad jis norètu 
KAUNO

POLITECHNIKOS

INSTITUTO

VILNIAUS FILIALAS
Susitikimai ir pokalbiai Kaune buvo labai nemalonūs. Manau, kad normaliai bendrauti galejau tik todel, kad büdamas profesoriumi nepretendavau $i$ bet kokias administracines pareigas. Kauniečiu ivairios abejones ir nepasitikejimai man buvo gerai suprantami. Kaune buvo likę tam tikros geros Vytauto Didžiojo universiteto akademines tradicijos, nauji rūmai, modernios laboratorijos, tai yra tai ko nebuvo ir tuo metu negalejo büti Vilniuje. Kolegoms irodinejau, kad katedros ir specialybes bus perkeltos $i$ Vilniu tolydžio, remiantis tarpusavio susitarimu, destytojai bus apgyvendinti naujuose namuose, institute bus ikurtas architektūros fakultetas, bus pastatyti nauji rūmai ir bendrabučiai. Tačiau, išskyrus architektus, kelininkus ir geodezininkus, kauniečiai naujuoju Vilniaus institutu nesidžiangè.

1965 m. KPI Vilniaus filiale buvo isteigta Statybiniu konstrukciju katedra, o aš išrinktas jos vedeju. Nors ši katedra buvo reikalinga, ja atidaryti buvo labai sunku, nes dauguma destytoju buvo nepartiniai. Be to, $R$. Vadlüga ir A. Śniukšta buvo Sibiro tremtiniu vaikai. Jie, taip pat B. Užpolevičius, M. Rozenbliumas, V. Vaitkevičius ir V. Bagočiūnas buvo laikomi nelojaliais tarnybinei santvarkai asmenimis".

\section{Vis daugiau svariu mokslo darbu}

KPI Vilniaus filialo mokslininkų gretos kasmet stiprëjo, pasipildydavo naujais mokslų kandidatais: kai kurie filialo destytojai apgindavo disertacijas, o dažnas ateidavo iz filialą destyti iš kitų institucijų. Daugëjo ir užsakomųju mokslinių darbų.

1966 m. KPI Vilniaus filialo mokslininkai atliko 17 ūkiskaitinių darbų.

Vadovaujami KPI Vilniaus filialo prorektoriaus e. prof. p. A Čyro, filialo mokslininkai parengé tampriųjų-plastinių remų skaičiavimo su įvairiais optimalumo kriterijais algoritmą ir sudare programą skaičiavimo mašinai. Tris darbus baige vadovaujami doc. A. Kudzio: 1. Kai kuriu priemonių, padedančių išvengti avariju elektros tiekimo linijose, tyrimas; 2. Vibruotojo gelžbetonio atramy gamybos technologijos pagerinimo tyrimas. 3. Rodūnès viaduko Vilniuje tyrimas, veikiant statinei ir dinaminei apkrovai. Doc. D. Maciulevičius atliko magnetiniu diskų ir plūdriųjų elementų darbo dinaminio tikslumo tyrimą. Doc. I. Nickus nustate poliesterinių dervų su užpildais naudojimo 
galimybes $10 \mathrm{kV}$ ịtampos elektros laidams tvirtinti. Du darbus atliko doc. R. Jonušo vadovaujami Mechaninès technologijos fakulteto mokslininkai - sukūre ịrengini šlifuojamos detales paviršiaus glotnumui tirti ir atliko horizontalių frezavimo staklių 6 H80T pagrindinių dinaminių charakteristikų tyrimą.

Čia nepaminetų ūkiskaitinių darbų vadovais buvo Z. Vainoris, S. Marazas, M. Paulauskas, J. Šalna, A. Valančius, A. Naidionovas, A. Kazragis, A. Čiužas, A. Jovaiša.

1967 m. sausio 19 d. Maskvoje TSRS valstybinio statybos komiteto Betono ir gelžbetonio mokslinio tyrimo institute KPI Vilniaus filialo docentas Antanas Kudzys sèkmingai apgyné technikos mokslų daktaro disertaciją „Gelžbetoninių žiedinio skerspjūvio elementų darbo tyrimas, veikiant trumpalaikems apkrovoms“. Darbą gerai ịvertino oficialūs oponentai profesoriai I. Achverdovas (Minskas), O. J. Bergas (Maskva) ir A. P. Vasiljevas (Maskva). Visi trys buvo labai garsūs betono ir gelžbetonio konstrukcijų specialistai.

A. Kudzys savo disertaciniame darbe pasiūlè naujus teorinius metodusžiedinio skerspjūvio elementams skaičiuoti ir projektuoti.

Ilgainiui A. Kudzys išugde didelị būrị jaunų mokslininkų. Prof. G. Marčiukaitis 1967 m. raše: „Jo skaitomoms paskaitoms büdingas didelis kvalifikuotumas, jis megstamas studenty ir inžinieriu. Doc. A. Kudzys dideli mokslini patyrima perduoda jaunesniesiems draugams - vadovauja grupei aspirantu. Tai tikras mokslininkas, nes tikras mokslininkas negali isivaizduoti savęs be savo specialybès tęseju, negali istverti be perstojo nedirbdamas" $[3.39$, p. 1].

A. Kudzys yra daug pasiekęs ne tik mokslo dirvonuose. Jis daug nuveike ir kuriant suverenią Vilniaus aukštąją technikos mokyklą. Anot V. Pranaičio, kad ši mokykla per 20 metų buvo statybinio profilio - tai A. Kudzio nuopelnas.

$1967 \mathrm{~m}$. buvo atlikti 26 ūkiskaitiniai moksliniai darbai - daug daugiau nei anksčiau.

A. Kudzys tyre elektros tiekimo linijų centrifuguotas gelžbetonines atramas, polimerais pagerinto betono ir gelžbetonio savybes.

A. Čyras rengè naują tampriųju-plastinių rèmų skaičiavimo metodiką, vadovavo jam kiek nebūdingam darbui - „Ignalinos drenažo vamzdžių įmonés optimalios statybos vietos techninis ekonominis pagrindimas".

D. Maciulevičius nustate apskritojo atraminio elemento, dirbančio su besisu- kančiu disku, oro plèvelès tampriąsias charakteristikas.

Du darbus atliko R. Jonušas. Jis tyrè gamybos automatizavimo perspektyvas ir šlifavimo staklių 36153 paviršiaus glotnumo priklausomybę nuo šlifavimo režimų.

Filiale buvo vykdomi geodezininku, hidrotechnikų užsakomieji darbai.

V. Tulevičius geodeziniais metodais nustatinëjo žemés plutos judesius, V. Marčènas maksimalų nuotakị tiltų ir pralaidų angoms skaičiuoti, K. Baškys - drenažo nuotakio formavimąsi mineraliniuose dirvožemiuose.

Daugiausia užsakomųju darbu - septynis - atliko Prietaisu gamybos fakulteto mokslininkai.

Z. Vainoris nustatinëjo bejgančiosios bangos atlenkimo sistemu plačiajuostiškumo padidinimo būdus, A. Naidionovas tyre plačiajuosčių oscilografų su spektrine transformacija sukūrimo galimybes naujais metodais, C. Paulauskas kūrè pramoninę plieno tikrinimo metodiką juostinių magnetolaidžių gamybai, M. Paulauskas ištyre paaukštinto dažnio generatoriaus srovès grandinę.

Našiai dirbo mokslinį darbą $S$. Marazas. Jis vadovavo dviem užsakomiesiems darbams. Buvo atlikti kondensatorinių asinchroninių mažo galingumo variklių triukšmo ir vibraciju bei vienfazių kolektorinių buitinių variklių tyrimai.

Užsakomuosius darbus 1967 m. atliko ir P. Vosilius, E. Maksimavičius, I. Nickus, A. Butkus, J. Steikūnas, A. Čiužas, K. Bieliūnas, G. Eidukevičius, J. Šalna.

Užsakomųjų darbų didëjimas gerokai papildydavo ir filialo, ir asmeninį mokslininkų biudžetą, o svarbiausia - moksliniai tyrimai tiesiogiai padejo gamybai, leido mokslininkams geriau jausti esamas problemas ir, jas sprendžiant, kelti savo kvalifikaciją.

1967 m. pradžioje administracija parengè KPI Vilniaus filialo valdymo funkcinę schemą, kuri, matyt, buvo sudaryta turint galvoje būsimą savarankišką institutą. Schemoje, jau be filialo vadovo - Vilniaus filialo prorektoriaus, numatyti dar trys prorektoriai, septyni skyriai, trys fakultetai ir Karine katedra. Ši schema vis dèlto gerokai skyrèsi nuo tos, kuri ėmé funkcionuoti po trejų metų, kai buvo ịsteigtas Vilniaus inžinerinès statybos institutas.

$\mathrm{Na}$, bet daugiausia demesio administracija telkè statyboms. 1967 m. vasarị buvo sudaryta studentu miestelio pirmosios eiles statybos generalinio plano ir KPI Vilniaus

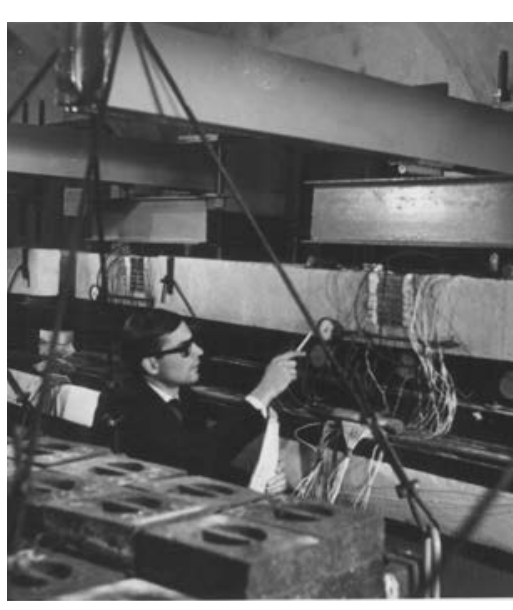

A. Šniukšta bando gelžbetonines sijas 
KAUNO

POLITECHNIKOS

INSTITUTO

VILNIAUS FILIALAS filialo mokomojo korpuso ekspertizès komisija: pirmininkas V. Kriščiūnas, nariai: A. Kudzys, M. Urbelis, M. Raibys, J. Šalna, G. Izraelis, K. Baškys, Z. Vainoris, J. Imbrasas, H. Papajanov ir D. Bodunov. Pirmieji aštuoni - pedagogai, kiti trys - Ūkio skyriaus inžinieriai.

Vasarą buvo numatyta vykdyti Aukštadvario sveikatingumo bazes pirmosios eilès statybos darbus, pagal e. doc. p. A. S. Pilypaičio parengtą parengtą dviejų aukštų mūrinio pastato projektą.

Antanas Simonas Pilypaitis (1932-2000) daug metų dèste KPI Vilniaus filiale, Vilniaus inžineriniame statybos institute. $1955 \mathrm{~m}$. KPI Statybos fakultete igijo architektūros specialybę. Daugiausia dirbo Paminklų restauravimo institute, buvo projektu vyr. architektu, o 1970-2000 m. - instituto vyr. architektu.

\section{Išvažiuojamasis KPI tarybos posedis Vilniaus filiale}

1967 m. kovo 24 d. KPI Vilniaus filiale vyko išvažiuojamasis KPI mokslinès tarybos posedis. Jame buvo svarstomas Vilniaus filialo Mechaninès technologijos fakulteto darbas ir siūlymai respublikinei premijai skirti.
Pirmuoju klausimu išsamų pranešimą skaite dekanas B. Liaudis. Jis buvo klausiamas, kodel dieniniame skyriuje, po sesijos praejus 6 savaitems, yra daug skolininkų, kaip dekanatas orientuoja studentus dirbti mokslinį darbą, kodèl aspirantai laiku neatlieka eksperimentinių darbų ir kt.

Diskusijose KPI prorektorius Č. Jakimavičius pažymëjo, kad buvo aplankyti 23 destytojų užsiemimai, buvo analizuojami egzaminų sesijos rezultatai. Esminių trūkumų nenustatyta. Ypač pagyrė Braižybos katedros (vedejjas J. Charitas) destytojų darbą. Baigdamas prelegentas sakè, kad Mechaninès technologijos fakulteto kolektyvas geras, stiprus.

KPI prorektorius R. Chomskis sake, kad visos filialo katedros mokslinį darbą dirba pagal savo profili. Pagyrè Mašinų teorijos (vedèjas D. Maciulevičius) katedrą, bet kritikavo, kad filiale yra destytojų, kurie nevykdo jokio mokslinio darbo.

Naudingu jauniems desstytojams patarimų išsake KPI Mašinų gamybos fakulteto dekanas prof. L. Kumpikas.

Rektorius prof. M. Martynaitis apibendrino nuomones, pozityviai įvertino KPI Vilniaus filialo darbą.

Filialo bendruomene, su nerimu laukusi šio KPI tarybos posèdžio, dabar galëjo ramiai atsikvèpti. Dar daugiau, visų laukè malonus siurprizas - respublikinei premijai gauti KPI taryba pristate e. prof. p. t. m. dr. Aleksandrą Čyrą. Be jo, premijai gauti buvo pristatyti

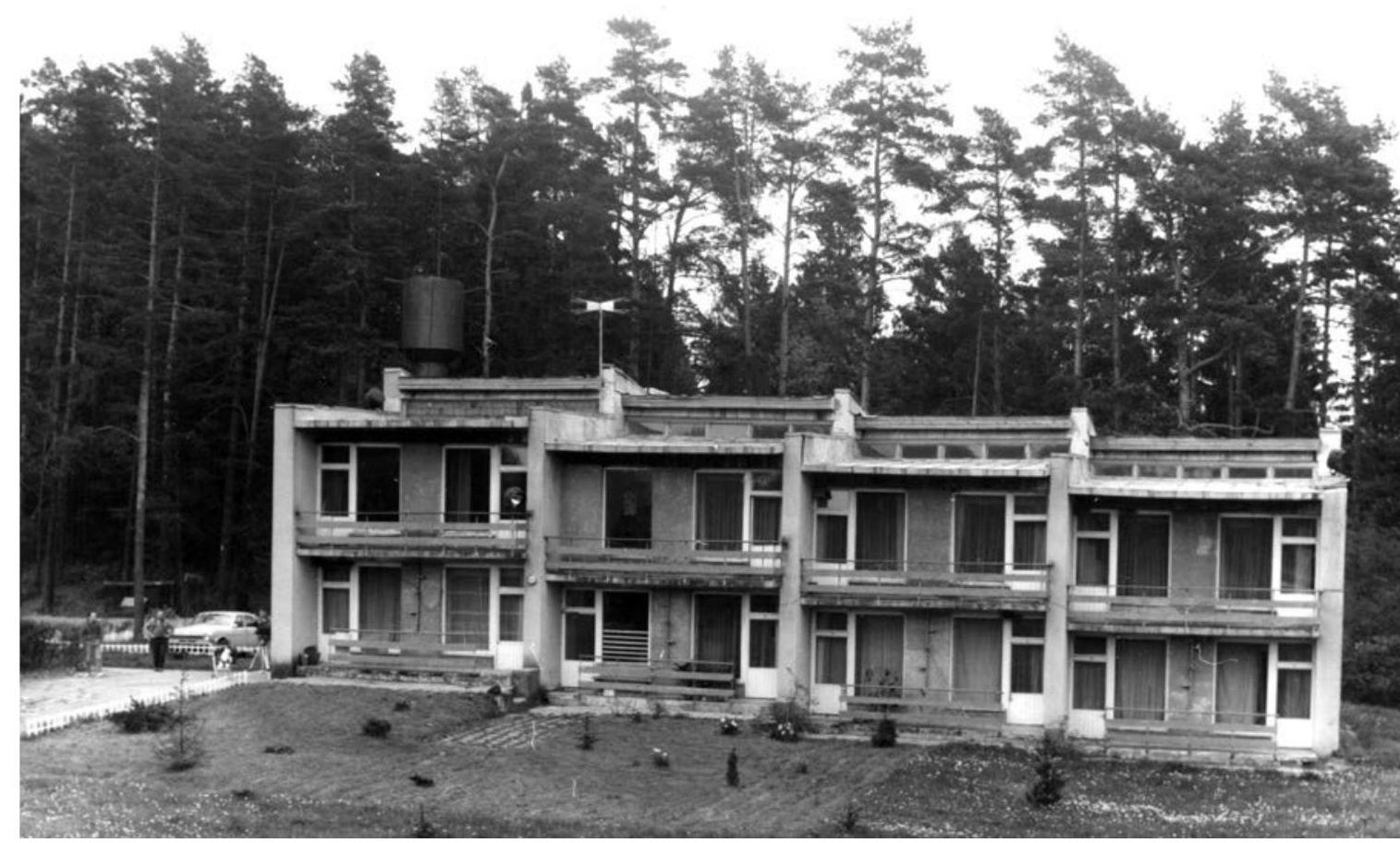


K. Ragulskis, L. Kaulakis, J. Vidmantas ir

A. Briedelis [3.40, p.1-8].

1967 m. birželio 13-15 d. Kaune įvyko trečioji TSRS konferencija, skirta pastovumo problemoms statybineje mechanikoje tirti. Konferencijos pirmininku buvo garsus tos srities specialistas profesorius A. Smirnovas, o pavaduotojais - prof. V. Bolotinas ir e. prof. p. A. Čyras.

Konferencijoje dalyvavo net 420 dalyvių. Tarp jų buvo 45 mokslų daktarai, 150 mokslų kandidatų ir docentų. Daug dalyvių atstovavo ministerijoms ir žinyboms. Buvo užsieniečių iš Lenkijos, Čekoslovakijos, VDR, Bulgarijos ir Vengrijos.

Suprantama, pagrindinis konferencijos organizatorius buvo Aleksandras Čyras. Jis imponavo konferencijos dalyviams ne tik organizaciniais sugebejjimais, o ir novatorišku požiūriu ị statybinę mechaniką, puikiu problemų suvokimu. Konferencijos dalyviai rode daug demesio lietuvių mechaniky darbams.

Visasajunginès konferencijos sèkmè padare Aleksandrą Čyrą gerai žinomą tarp statybinès mechanikos specialistu. Tai sudare geras galimybes plačiai skleisti šios srities lietuvių specialistų laimëjimus tiek TSRS, tiek užsienio spaudoje. Nuo šiol mezgèsi tarptautiniai ryšiai, daugèjo išvykų ị užsienį, kvietimų $i$ tarptautines mokslines konferencijas. Bet „savame kieme“ problemų, pavydo, net keršto buvo į valias.

\section{„Smūgis žemiau juosmens“}

Lygiai po dviejų ménesių ta pati KPI moksline taryba „smoge A. Čyrui žemiau juosmens“...

Tarybos posedyje buvo pristatytos dvi kandidatūros profesoriaus ir trys kandidatūros docento moksliniam vardui gauti.

Kai prorektorius R. Chomskis pristate minètas kandidatūras, niekas nepareiške kokių nors pastabų. Bet po slapto balsavimo paaiškejo, kad Maskvai bus pristatyti tik keturi kandidatai.

Už Aleksandro Čyro kandidatūros pristatymą profesoriaus moksliniam vardui gauti balsavo tik 15 tarybos narių, prieš 19 , susilaike 3.

A. Čyras, dar dirbamas Kaune, garsëjo kaip puikus statybinès mechanikos dèstytojas, Vilniuje išryškejjo jo organizacinis talentas, jo mokslinę kompetenciją puikiai vertino žymiausi TSRS statybinès mechanikos specialistai.

Šis KPI tarybos balsavimas, pristatant A. Čyro kandidatūrą profesoriaus moksliniam vardui gauti, - negražus puslapis KPI tarybos istorijoje. Visiems buvo aišku, kad tai kerštas už A. Čyro separatizmą, jo norą ir pastangas įkurti suverenią aukštają technikos mokyklą Lietuvos sostinëje.

Matyt, dèl panašių priežasčiu A. Čyrui nebuvo paskirta $1967 \mathrm{~m}$. respublikine premija. Neaiškinant priežasčiu, jo kandidatūra buvo perkelta ị $1968 \mathrm{~m}$. pretendentų sąrašą.

Bet vis dèlto jau birželio $16 \mathrm{~d}$. KPI tarybos posedyje buvo pritarta naujai KPI struktūrai, kuri turëjo įsigalioti ịsteigus Vilniaus inžinerinį statybos institutą. Kaip sakoma, suum quique (lot. - kiekvienam savo).

Kai tų pačiu 1967 m. rugsèji profesoriaus vardui gauti buvo pristatytas Antanas Kudzys, balsavimo rezultatu taip pat laukta su nerimu. Taryba balsų dauguma pritare A. Kudzio kandidatūrai.

1967 m. KPI Vilniaus filialą baige 150 diplomantų. Diplomus įteike Aukštojo ir specialiojo vidurinio mokslo ministras H. Zabulis, KPI rektorius M. Martynaitis, prorektorius A. Čyras, dekanai.

Buvo pasidžiaugta filialo studento G. Kazako laimëjimu. Jo sukurtas maketas TSRS liaudies ūkio pasiekimų parodoje pelnè bronzos medali.

Buvęs KPI Vilniaus filialo korespondentu KPI laikraštyje Už tarybinį mokslą Arvydas Matulionis, ilgainiui tapęs profesoriumi, dirbęs Lietuvos Prezidento Algirdo Brazausko patarëju kultūros ir mokslo klausimais, rašè apie tai, kad dalis 1967 metų baigusiu absolventu buvo palikti destyti filiale: „Dabar $R$. Jasinavičius, buvęs komjaunimo sekretorius ir klubo pirmininkas, A. Vyskupaitis (klubo pirmininkas), G. Vanagas (SMD pirmininkas), H. Siškus (sporto tarybos narys), A. Braškys (choro seniūnas) vel pirma karta atvere auditoriju duris. Tik ši karta jau ne kaip studentai, o kaip destytojai. Visi jie buvo aktyvüs visuomenininkai, saviveiklininkai, o sukauptas darbo su žmonemis patyrimas pades pasidalinti žiniomis su jaunesniaisiais draugais" $[3.41$, p. 2].

Tame pačiame straipsnyje rašoma apie studentų stovyklas Aukštadvaryje, kur kas vasarą rinkdavosi šokejai, choristai, visuomenininkai. Prisimenamos vakaronès „Karčiamoje“ (tuometineje valgykloje), ịvairūs konkursai, varžybos. A. V. Valiulis ir A. Paulauskas buvo 
KAUNO

POLITECHNIKOS

INSTITUTO

VILNIAUS FILIALAS

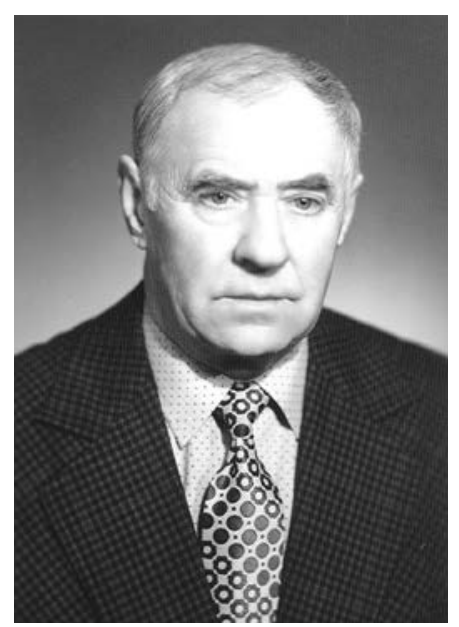

V. Kulakauskas

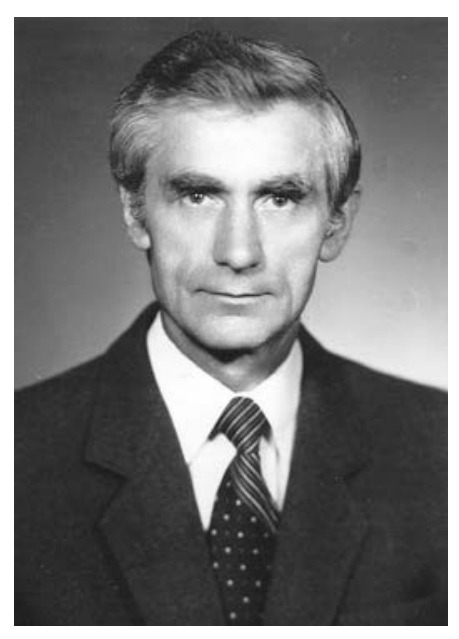

S. Rokas

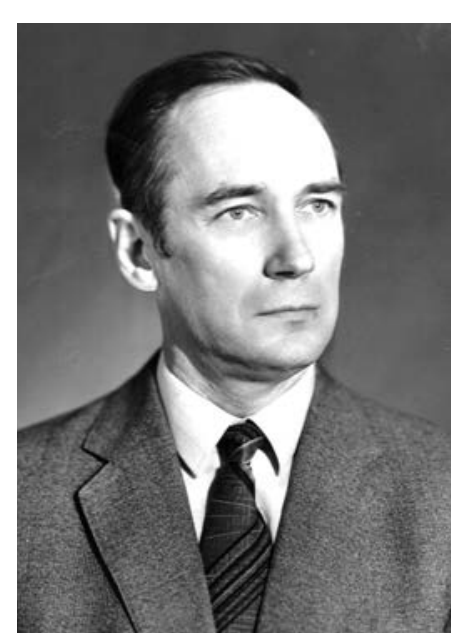

A. Smilgevičius šokejjų sielos. „Veteranai“ nuoširdžiai atsisveikino su draugais. Bet Algirdas Vaclovas Valiulis, kaip rašo A. Matulionis, paskirtas filiale kaip ir anksčiau „prakaituos“ per repeticijas, šoks vis dar taip pat su studentiška ugnele per koncertus.

\section{Tolesné filialo plètra}

1967 metų vasarą į KPI Vilniaus filialą buvo numatyta priimti 825 studentus, iš ju i dienines studijas - 375 .

Statybos-ekonomikos fakultetas priemè studentų i tokias specialybes: 1 . Miestų statyba (dieninis ir vakarinis skyriai). 2. Statybos ekonomika ir organizavimas (dieninis ir vakarinis skyriai). 3. Mašinu gamybos pramonès ekonomika ir organizavimas (dieninis ir vakarinis skyriai). 4. Autotransporto ekonomika ir organizavimas (dieninis ir vakarinis skyriai). 5. Pramonine ir civiline statyba (dieninis ir vakarinis skyriai).

Mechanines technologijos fakultetas prièmè į tokias specialybes: 1 . Mašinų gamybos pramonés procesu automatizavimas (dieninis ir vakarinis skyriai). 2. Suvirinimo įrengimai ir technologija (dieninis ir vakarinis skyriai). 3. Mašinų gamybos technologija, metalo pjovimo stakles ir įrankiai (vakarinis skyrius). 4. Automobilių transportas (vakarinis skyrius).

Prietaisu gamybos fakultetas priemè į tokias specialybes: 1 . Radijo aparatūros konstravimas ir gamybos technologija (dieninis ir vakarinis skyriai). 2. Elektros pavaros ir gamybos įrengimu automatizavimas (vakarinis skyrius).

Sumažèjo specialybių skaičius, kuriose buvo destoma rusu kalba. $1964 \mathrm{~m}$. rusu kalba destomu specialybių buvo keturios, o 1967 m. ju liko tik dvi ir tik vakariniame skyriuje.

Nuo 1967 m. rugsëjo 1 d. KPI Vilniaus filiale studijavo 1456 studentai dieniniame ir 2277 - vakariniame skyriuose, iš viso 3733 studentai.

Nuo 1967 m. rugsejo pradeda funkcionuoti (nors oficialiai dar neįsteigta) iš KPI centro perkelta Kelių katedra (vedejjas S. Rokas). Ji ima dirbti Statybos ekonomikos fakultete, kurio dekanu paskiriamas doc. t. m. k.
Viktoras Krušinskas. Prietaisų gamybos fakultete įkuriamos Elektros įrengimu (5 etatiniai destytojai, 2 - su moksliniu laipsniu) bei Elektronikos ir skaičiavimo technikos katedra (10 etatinių destytojų, 3 - su moksliniu laipsniu). Buvo panaikintos Skaičiavimo technikos ir matematikos bei Radioelektronikos katedros.

Taigi 1967-1968 mokslo metais KPI Vilniaus filialo trijuose fakultetuose buvo 21 katedra.

Prietaisu gamybos fakultetui priklausè: 1. Elektronikos ir skaičiavimo technikos katedra (vedëjas J. Stanaitis). 2. Elektros įrengimų katedra (vedejas V. Česonis), 3. Radijo aparatūros ir technologijos katedra (vedejjas Z. Vainoris). 4. Elektrotechnikos katedra (vedèjas M. Paulauskas). 5. Bendrosios fizikos katedra (vedejjas E. Mauza). 6. Matematikos katedra (vedejas V. Kubilius).

Mechaninès technologijos fakultetui priklausè: 1. Braižybos katedra (vedejas J. Charitas). 2. Metaly apdirbimo katedra (vedëjas B. Liaudis). 3. Mašinų teorijos katedra (vedejjas D. Maciulevičius). 4. Mašinų gamybos automatizavimo katedra (vedëjas R. Jonušas). 5. Gamybos ekonomikos katedra (vedëjas A. Martinaitis).

Statybos-ekonomikos fakultetui priklausè: 1 . Statybos ekonomikos katedra (vedejjas V. Krušinskas), 2. Mechanikos katedra (vedejas A. Čyras), 3. Statybinių konstrukcijų katedra (vedejas A. Kudzys), 4. Miestu statybos katedra (vedejjas V. Kriščiūnas), 5. Chemijos katedra (vedëjas I. Nickus).

Vadinamosios bendrosios katedros buvo: 1 . TSKP istorijos ir filosofijos (vedejas A. Marcelis). 2. Politines ekonomijos ir mokslinio komunizmo (vedëjas J. Grèska), 3. Kalbų (vedëja A. Glemžienè), 4. Fizinio lavinimo (vedejjas V. Kulakauskas). 5. Karinè (vedejjas V. Sartakovas).

Elektros įrengimu katedros vedëju tapo A. Smilgevičius, o Elektronikos ir skaičiavimo technikos - J. Stanaitis.

Viktoras Krušinskas Statybos-ekonomikos fakulteto dekanu buvo paskirtas vietoj Eugenijaus Maksimavičiaus, kuris vis dažniau ème draugauti su stikliuku ir, suprantama, tapo nepareigingas, neiniciatyvus, blogai atliko savo pareigas. Ilgainiui jis turejo palikti aukštąją mokyklą.

Viktoras Krušinskas 1955 m. baigè Kauno politechnikos instituto Statybos fakultetą. Studijų metu užsirekomendavo kaip geras sportininkas ir pavyzdingas studentas. 
Žaide futbolą respublikos pirmenybèse už KPI komandą. Baigęs studijas, buvo paskirtas asistentu į Statybos darbų organizavimo ir technologijos katedrą. 1959-1962 m. mokèsi aspirantūroje. Apgynè technikos mokslų kandidato disertaciją iš statybinių medžiagų. $1967 \mathrm{~m}$. buvo perkeltas ị Vilnių, $1968 \mathrm{~m}$. gavo docento mokslinį vardą. 1969-1977 m. dirbo VISI Statybos darbu technologijos katedros vedeju, o 1970 1980 m. - dar ir VISI Statybos fakulteto dekanu, 1980-1986 m. V. Krušinskas buvo VISI Kvalifikacijos tobulinimo fakulteto dekanu.

Algirdas Smilgevičius 1959 m. baige Kauno politechnikos instituto Elektrotechnikos fakultetą ir igijo elektros mašinų ir aparatūros specialybès inžinieriaus diplomą. 1959-1960 m. dirbo Vilniuje elektrotechnikos gamykloje „Elfa“ inžinieriumi konstruktoriumi, o 1960-1967 m. - prie „Elfos“ veikusiame specialiame konstruktorių biure. 1967 m. apgyne technikos mokslų kandidato disertaciją ir pradejjo dirbti KPI Vilniaus filiale.

Jonas Stanaitis (1910-1983) nuo $1927 \mathrm{~m}$. studijavo Lietuvos universiteto Technikos fakulteto Elektrotechnikos skyriuje. Studijas baige $1935 \mathrm{~m}$. ir gavo elektrotechnikos specialybès technologijos inžinieriaus diplomą. Jau nuo $1932 \mathrm{~m}$. dirbo tame pačiame universitete jaunesniuoju laborantu, vyresniuoju laborantu, jaunesniuoju asistentu. 1939 m. universitetas pasiunte J. Stanaiti i Vokietiją, kur jis tobulinosi elektrotechnikos, elektroakustikos ir aukštojo dažnio technikos klausimais Berlyno aukštojoje technikos mokykloje.

Nuo 1940 m. Kauno universitete buvo vyresniuoju asistentu, vyresniuoju dèstytoju. Nuo 1951 m. - KPI vyr. déstytojas, o nuo $1963 \mathrm{~m}$. ejo docento pareigas.

\section{Kokia turètu būti būsimo instituto struktūra?}

1967 m. spalio 20 d. KPI taryba vèl nuodugniai svarstè būsimojo Vilniaus inžinerinio statybos instituto struktūrą [3.40, p. 1-12].

Prorektorius A. Čyras supažindino Tarybos narius su struktūros projektu, siūlomų fakultetų sudetimi, jų ir katedru steigimo ar perkèlimo iš Kauno į Vilniu arba iš Vilniaus i Kauną tvarka. A. Čyras pranešè, kad gautas leidimas suprojektuoti 50 butu gyvenamajji namą dèstytojams. Jame numatoma apgyvendinti 20 perkeliamu destytoju šeimų. Antrą namą planuojama pastatyti apie 1970 metus.

A. Čyras pažymëjo, kad sunku suderinti perkeliamų dèstytoju akademini krūvị ir aprūpinimą butais laiku.

Gyvoje diskusijoje vèl ginčytasi dèl instituto profilio. Prof. M. Kaveckis pabrèže, $\mathrm{kad}$ jis buvęs vienintelis, visą laiką remęs ideją, „kad toks institutas bütu ikurtas“. Doc. N. Milenskis siūlè išlaikyti steigiamame institute tik statybinị profili bei siūle panaikinti Mechaninès technologijos fakultetą ir kurti Statybinių medžiagu pramonès fakultetą. Prof. J. Janickis instituto struktūros projektą pavadino nevykusiu: „Neitikina prorektoriaus A. Čyro aiškinimas, kodè siūlomas įkurti Mechanines technologijos fakultetas. Kombinacija nevykusi. Neracionalu, kad visos bendramok-

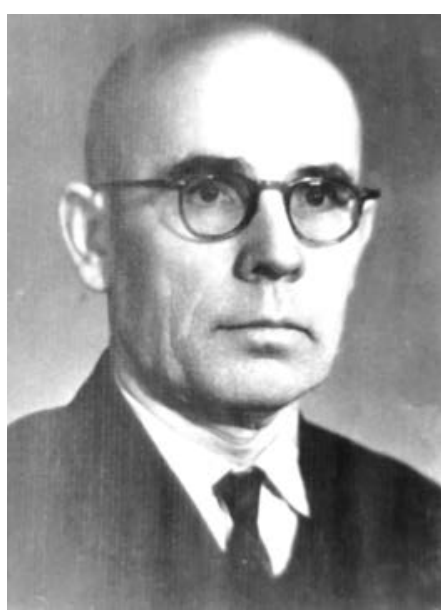

J. Stanaitis slines disciplinos išbarstytos po fakultetus. Jos turètu büti kartu viename fakultete".

Vilniaus ir Kauno nesutarimus èmèsi gludinti ministro pavaduotojas Vaclovas Pranaitis. Jis pažymejo, kad tai pirmasis bandymas sudaryti steigiamojo inžinerinio statybos instituto struktūrą. Vèliau pats gyvenimas įnešiąs tam tikrų korektyvų. Pradinè schema būsianti pagrindu direktyvinèms instancijoms, išleisiančioms nutarimą. Jis siūlè patikslinti dèstytoju perkèlimo planus.

Rektorius M. Martynaitis pabrežè, kad diskusijos dèl struktūros buvo blankios, kad, jo manymu, susitaikyta su instituto įsteigimo fatališkumu ir pasiduota likimo valiai. Jis pabrěžè, kad nesutinka su A. Čyro nuostata dèl perkeliamų destytojų. M. Martynaitis sake: „Persikeliančiuju pavardès buvo duotos ministerijai, isskirti butai, o dabar jau nuo vieno atsisakoma. Is principo negerai gavosi, ir tas jau duoda pagrinda kalbom. Priimti reikia ir laipsniuotus ir nelaipsniuotus. Jau jeigu bus vienas precedentas, bus ir kiti " [3.40, p. 8].

KPI taryba sutiko tik vieną fakultetą pavadinti Technologijos. Vietoj Technologijos fakulteto buvo siūlomi tokie pavadinimai: 1) Mechanines technologijos fakultetas. 2) Statybinių mašinų fakultetas. 
KAUNO

POLITECHNIKOS

INSTITUTO

VILNIAUS FILIALAS

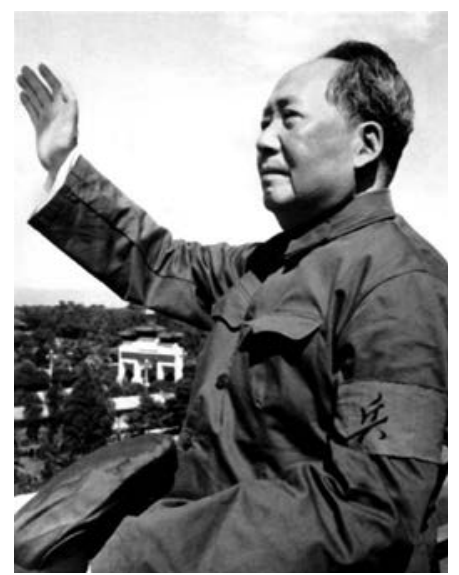

Mao - „didysis kultūrininkas“

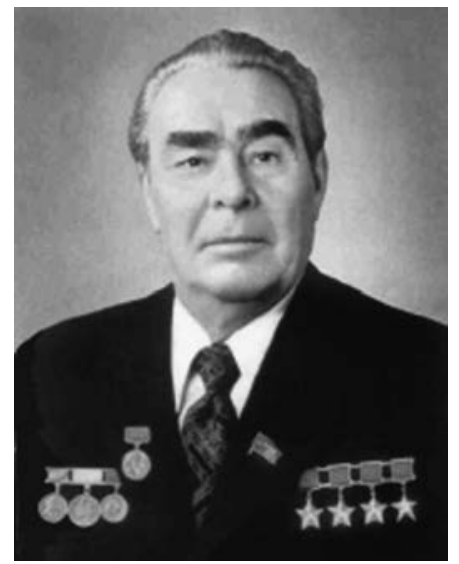

L. Brežnevas - „didysis ekonomistas“
3) Bendramokslinis fakultetas. 4) Vakarinis fakultetas ir kt.

KPI taryba, nors ir be entuziazmo, vis dèlto nutare patvirtinti instituto struktūros projektą. Tarybos nutarime „Dèl Vilniaus inžinerinio statybos instituto struktūros" rašoma, kad bus 5 savarankiškos katedros ir 4 fakultetai.

Savarankiškos katedros numatytos tokios: TSKP istorijos ir filosofijos, Politines ekonomijos ir mokslinio komunizmo, Kalbų, Fizinio lavinimo ir Karinio rengimo.

Fakultetai buvo planuojami tokie: Architektūros ir miestų statybos, Statybos, Technologijos ir Santechnikos.

Architektūros ir miestų statybos fakultetas turëjo rengti keturių specialybių inžinierius: architektūros, miestų statybos, inžinerinès geodezijos ir automobilių kelių. Šiame fakultete turëjo veikti 8 katedros: Braižybos, Geodezijos, Pagrindų ir pamatų, Architektūros, Gyvenviečiu planavimo ir tvarkymo, Kelių, Dailes ir Matematikos.

Statybos fakultete buvo numatytos 3 specialybès: pramoninè ir civilinè statyba, žemès ūkio statyba, statybos ekonomika ir organizavimas. Fakultete turejo veikti 9 katedros: Teorines mechanikos, Medžiagų atsparumo, Statybines mechanikos, Statybinių medžiagu, Pastatų konstrukcijų, Gelžbetoninių konstrukcijų, Metalinių ir plastmasinių konstrukcijų, Statybos darbų technologijos bei Statybos ekonomikos ir organizavimo.

Technologijos fakultete planuotos 7 specialybès: mašinu gamybos technologijos, suvirinimo įrengimų ir technologijos, statybos ir kelių mašinų bei įrengimų, elektros pavaru ir gamybinių įrenginių automatizavimo, radijo aparatūros konstravimo ir gamybos, automobilių transporto bei automobilių transporto ekonomikos ir organizavimo. Fakultete turëjo veikti 10 katedrų: Mašinų teorijos, Metalų technologijos, Elektrotechnikos, Suvirinimo technologijos, Automobiliu transporto, Mašinu gamybos technologijos, Radijo aparatūros technologijos, Elektrotechnikos ir skaičiavimo technikos, Elektros irrengimų ir Pramonés ekonomikos.

Santechnikos fakultete buvo planuojamos dvi specialybes: dujų tiekimas, šildymas ir ventiliacija bei vandentiekis ir kanalizacija. Numatyta, kad veiks 5 katedros: Fizikos,
Chemijos, Hidrotechnikos, Vandentiekio ir kanalizacijos bei Šildymo ir vedinimo.

KPI taryba mane, jog tikslinga 1968-1969 mokslo metais ị Vilnių perkelti visus dieninio skyriaus geodezijos ir keliu specialybiu studentus bei ịsteigti Architektūros ir miestų statybos fakultetą. Nuo 1969-1970 mokslo metų ketinta perkelti į Vilnių visus dieninio skyriaus automobiliu transporto, statybos bei kelių mašinų ir įrengimų specialybių studentus. Buvo numatyta nuo 1970-1971 mokslo metu panaikinti Prietaisu gamybos fakultetą.

Buvo sudarytas Vilniaus filialo katedru steigimo, reorganizavimo arba perkelimo iš Kauno kalendorinis grafikas. Naujai steigti planavo Teorinès mechanikos, Statybiniu medžiagu ir Hidrotechnikos katedras.

Planuota būsimojo instituto struktūra nebuvo igyvendinta. Gyvenimo realijos įnešè ir instituto sudeties, ir igyvendinimo terminu laikotarpio pataisų.

Moksliniu filialo ir ypač A. Čyro laimejimu laikytinas „Lietuvos mechanikos rinkinio" pirmojo numerio išleidimas. 1967 m. spalio 20 d. KPI tarybos posedyje Vilniaus filialo prorektorius A. Čyras ne be patoso pabrežè, kad filialo „žinybinëje Statybines mechanikos laboratorijoje atliekami darbai gavo platu ir teigiama ivertinima visoj Sajungoj. Pasiūlyta skaičiavimo metodika rekomenduojama juesti $j$ statybos normas" [3.40, p. 10].

Nors Vilniaus filialas aprašomais pastaraisiais metais džiaugèsi žengiąs ị suverenią aukštąją mokyklą, vis dèlto išgyveno daugybę sunkumų, kurių vis daugejo įsigalint brežnevinei stagnacijai. Sovietų Sąjunga vis daugiau ginklavosi, todèl trūko lěšų švietimui, mokslui, visoms socialinems reikmèms. Sudetingas buvo ir to meto visas pasaulis. Kinijoje nuo 1966 m. vyko Mao Dzeduno sugalvota „kultūrinè revoliucija“, 1967 m. vasarą Izraelis pradëjo karą prieš Egiptą, sovietai plètojo „„šsivaduojamuosius“ karus Afrikoje, Lotynų Amerikoje.

Praejus penkiasdešimčiai metų nuo bolševikinès revoliucijos, buvo matyti, kad TSRS, nors ir blykstelejo kosminiais laimëjimais, pradeda sekti. Didejo žmonių nepasitenkinimas tuščiomis parduotuvių lentynomis, mažais atlyginimais, stiprejo disidentinis judejjimas. Imta vèl blokuoti užsienio radijo transliacijas, aktyvejjo KGB veikla. Bliuško viltys, kad gyvenimas gerès, kad bus daugiau demokratijos. 
Lietuvai skausmingas buvo Liaudies ūkio tarybų panaikinimas. Kai Lietuvai buvo perduota didesnè atsakomybe už pramonès ir statybų reikalus, gerokai protingiau vykdyta krašto industrializacija, lietuvejo įmonès, sumaniau vyko urbanizacijos procesas, stiprejo pramonés ir aukštųjų mokyklų ryšiai. Vis daugiau lietuvių, baigusių aukštąsias mokyklas, užimdavo pramonèje vadovaujančiąsias vietas. Tai nepatiko ir gąsdino Maskvą.

L. Brežnevas 1965 m. rugsèjo TSKP CK plenume paskelbe, kad ekonomika turi būti vieninga, kad negalima atimti iš centro teisès valdyti įmones, nes tai, anot V. Lenino, "bütu savotiškas anarchosindikalizams, o ne komunizmas" [3.42, p. 316].

Visos šios aplinkybès mažai teikè optimizmo. Bet ir tokiomis aplinkybemis Aleksandro Čyro vadovaujamas KPI Vilniaus filialas nenuleido rankų.

1967 m. rudenį KPI Vilniaus filialo valdžia toliau spaudžia savąją žinybą. Rašte Vilniaus miesto partinei valdžiai, kurị pasiraše prorektoriai A. Čyras ir R. Jonušas, partijos sekretorius J. Bacevičius ir vietos komiteto pirmininkas A. Pilypaitis, sakoma:

„KPI Vilniaus filialas yra numatomas reorganizuoti i savarankiškaja aukštaja mokykla. Nors tam yra TSRS Aukštojo ir specialiojo vidurinio mokslo ministerijos kolegijos teigiamas pritarimas, priimtas beveik prieš metus, ir ryšium su tuo išleistas TSRS Gynybos ministro isakymas, tačiau, mūsu nuomone, filialo reorganizacijos klausimai užsitęse pernelyg ilgai. To nebütu, jeigu respublikos Aukštojo ir specialiojo vidurinio mokslo ministerija operatyviau pateiktu tuo reikalu medžiaga respublikos Vyriausybei.

Prašome <...> padèti KPI Vilniaus filialo kolektyvui savarankiško instituto organizavimo klausimuose. Kolektyvo siülymu naujo instituto steigimo data galetu būti 1968/69 mokslo metu pradžia arba nauji biudžetiniai metai" [3.36, p. 217].

\section{Premija A. Čyrui suteikè nauju jęgu}

$1968 \mathrm{~m}$. vasario $16 \mathrm{~d}$. (iddomus sutapimas lygiai 50 metu nuo Vasario 16-osios akto!) buvo šventiška KPI Vilniaus filialo žmonèms. Prasidejo mokomojo-laboratorinio korpuso statyba. Tai buvo statybų pradžia būsimajame studentų miestelyje. Po poros metu - 2008 metais - švęsime 90-ąsias Lietuvos Valstybes atkūrimo metines. Bus nesunku prisiminti, kad tą pačią dieną, tik po 50 metų, buvo pradèta Vilniaus studentu miestelio ir konkrečiai Vilniaus Gedimino technikos universiteto pirmtako - KPI Vilniaus filialo pirmojo naujo pastato statyba. Prie šio korpuso dabar kasdieną plevésuoja Lietuvos valstybine veliava, skelbianti, kad Lietuva laisva ir nepriklausoma. O greta esanti Europos Sąjungos vèliava primena mums, kad mūsų valstybe dabar saugi ir turi gražią ateitị.

Pirmajame būsimųjų KPI Vilniaus filialo rūmų korpuse buvo numatyta, kad dirbs du fakultetai - būsimųjų statybininkų ir architektų. Statybos procesui paspartinti A. Čyro iniciatyva buvo planuojama organizuoti statybos darbų talkas, pasitelkiant ir studentus, ir pedagogini personalą. Statybos darbus vykde Vilniaus statybos tresto statybos valdyba Nr. 2 (valdybos viršininkas Stulpinas). Valdyba labai stokojo darbininku ir darbams paspartinti praše talkininkauti. Ateityje talkų buvo vis daugiau. Vardan siekiamo tikslo - tureti naujus, modernius rūmus, filialo vadovas buvo pasiryžęs kiek trikdyti studijų procesą. Kaip sakoma malum nullum est sine aliquo bono (lot. - nèra to blogo, kas neišeitu i gera)!

1968 m. pradžia buvo labai sèkminga ir asmeniškai KPI Vilniaus filialo vadovui. Jis buvo apdovanotas sąjungine akademiko A. Galiorkino (1871-1945) premija.

Aleksandrui Čyrui ši premija buvo paskirta už darbų ciklą „Tampriųjų plastinių sistemų skaičiavimas, taikant matematinio programavimo metodus", kurie buvo paskelbti TSRS ir užsienyje 1965-1967 metais.

Vienas žymiausiu statybinès mechanikos specialistų prof. A. Ržanycinas teigé, kad A. Čyrui priklauso neginčijamas prioritetas, pletojant labai svarbią statybinès mechanikos krypti - tiesinio programavimo metodu taikymas konstrukciju laikomajai galiai skaičiuoti.

Akademikas L. Kantorovičius pabrèžè, kad A. Čyro darbas labai pralenkia šios srities užsienio specialistų pasiektą lygị.

A. Galiorkinas buvo pasaulinio garso mokslininkas, sulaukęs plataus pripažinimo už efektyvių matematinių metodų sukūrimą $[3.43$, p. 3].

A. Galiorkino premijos skyrimas A. Čyrui suteike daug naujos energijos, didelio pasitikejjimo savo jëgomis. Nè kiek nemažindamas demesio moksliniams tyrimams, A. Čyras ryžtingai siekia spartinti instituto steigimo 
KAUNO

POLITECHNIKOS

INSTITUTO

VILNIAUS FILIALAS naudingas. Visu pirma, būsimojo Vilniaus inžinerinio statybos instituto pagrindine profiliuojanti sudetis iki šiol yra sutelkta Kaune. Kadangi del mokomuju patalpu ir bendrabučic stokos negalima is karto perkelti pagrindiniu specialybiu, destytoju personalo ir studentu kontingento $i$ Vilniu, per anksti isteigus instituta, jo pavadinimas iš esmes neatspindetu jo turinio. Tai sukomplikuotu moksliniu tarybu sudaryma, supainiotu aspirantūros, disertaciju gynimo klausimus, nes visa tai reikètu iš naujo užtvirtinti TSRS Aukštojo ir specialiojo vidurinio mokslo ministerijoje, kuri šiuo metu yra nusistačiusi labai griežtas moksliniu tarybu sudarymo ir aspirantūros ivedimo sąlygas.

Kita vertus, kol naujasis institutas formuojasi, nuolat iškyla ivairiu problemu, ypač kadru komplektavimo, studentu kontingento išdestymo srity. Tai žymiai lengviau yra spresti vieno instituto ribose. Deja, KPI Vilniaus filialas, per anksti pasiskelbęs savarankiška aukštaja mokykla, daugeliu atveju elgiasi ne tik nesuprantamai, bet ir nepateisinamai, tuo pats sukomplikuodamas naujo instituto steigimo pradine stadija " [3.36, p. 218-219].

Bet Aleksandras Čyras vèl atakuoja. 1968 m. kovo 13 d. rašte Nr. 536 Lietuvos TSR Ministrų Tarybai rašoma:

„KPI Vilniaus filiala specializuojant pagal inžinerini-statybini profili, padarytas nemažas darbas: sudarytas studentu priemimo ir perkelimo grafikas; apskaičiuotas akademinis krūvis büsimo instituto katedroms iki 1975 metu; sudaryta instituto struktūra, kuri patvirtinta KPI Mokslineje Taryboje ir veliau respublikos Aukštojo ir specialiojo vidurinio mokslo ministerijos kolegijoje; sudarytas destytoju perkelimo iš Kauno $i$ Vilniu personalinis grafikas. Visu priemoniu tolimesnis vykdymas pagrindinai priklauso nuo filialo materialines mokymo bazés kūrimo, atvykstančiu déstytoju iš Kauno apgyvendinimo salygu bei augančio studenty kontingento aprüpinimo bendrabučiais..." [3.36, p. 219].

Toliau rašte KPI Vilniaus filialas pateike pasiūlymų ir pageidavimų: 1) jau 1969 m. pradeti statyti srautinių auditorijų korpusą; 2) leisti pačiam filialui parengti gyvenamujų namų, skirtų persikeliantiems iš Kauno dèstytojams apgyvendinti, projektus; 3) 1968 m. pabaigoje pradèti statyti 9 aukštų 108 vieno kambario butų tipinị namą jauniems filialo specialistams.

Vèl apgailestaujama dèl Lietuvos TSR Aukštojo ir specialiojo vidurinio mokslo ministerijos neveiklumo sprendžiant filialo 
reorganizavimą ì savarankišką aukštąją mokyklą.

Panašiai buvo spaudžiamos ir statybos organizacijos. 1968 m. spalio 16 d. raštu LTSR statybos ministro pavaduotojui M. Dulmanui filialo prorektorius A. Cyras rašè: „Mes jau ne karta kreipemes i Jus, nurodydami darby vilkinimo tendencijas ir, apskritai, nenormalia padeti KPI Vilniaus filialo mokomojo-laboratorinio korpuso statyboje..." [3.36, p. 220]. Išdèsčius darbo trūkumus, buvo pasiūlyta studentų miestelio objektų statybai organizuoti atskirą statybos aikštelę su kvalifikuotais vadovais.

Reikia pripažinti, kad ir vèliau, jau būdamas VISI rektoriumi, profesorius A. Čyras skyrè išskirtinị demesị kapitalinei statybai. Dèl to šiandien turime rūmus, kuriais pelnytai didžiuojasi ne vienas mūsų absolventas.

A. Čyras išnaudodavo bet kurią padorią galimybę statyboms paspartinti. 1970 m. vasarą turëjo vykti Dainų švente. Norint greičiau pastatyti 108 vieno kambario butų ir 30 butų gyvenamuosius namus déstytojams ir jauniesiems specialistams apgyvendinti, 1969 m. pavasarị A. Čyras rašo raštą šventes org. komiteto pirmininkei L. Diržinskaitei, kad padetų paspartinti tų pastatų statybą, nes esą juose galima būtų apgyvendinti šventès dalyvius, ir gauna jos paramą. Statyba nepagreitejo, bet situacija pasinaudoti bandyta išradingai.

1967-1968 mokslo metai buvo derlingi KPI Vilniaus filialo mokslininkams. Jau minëjome apie Aleksandrui Čyrui paskirtą Galiorkino premiją. 1968 m. pradžioje profesoriaus mokslinis vardas buvo suteiktas Antanui Kudziui, o po poros ménesių - jau ir A. Cyrui.

Taip pat tų metų pradžioje Statybinių konstrukcijų katedros vyr. destytojas Audronis Kvedaras apgyne disertaciją „Ilgalaikio apspaudimo, polimerinių priedų ir spiralinio armavimo įtakos centriškai gniuždomo centrifuguoto betono mechaninems savybèms tyrimas" ir gavo technikos mokslų kandidato laipsni.

Tos pačios katedros asistentas Benediktas Užpolevičius parenge ir apgyne disertacini darbą „Netiesioginio betono stiprumo nustatymo gelžbetonio konstrukcijose tyrimai“. Šioje katedroje jis dirba nuo 1966 m. 1973 m. jam suteiktas docento mokslinis vardas.

Statybos-ekonomikos katedros asistentas Kazimieras Antanavičius apgynè disertaciją „Racionalių metinių programų pramoninems statybos-montavimo valdyboms formavimo klausimu (Lietuvos TSR sąlygomis) “ ir gavo ekonomikos mokslų kandidato laipsnị.

Kiek vèliau technikos mokslų kandidatais tapo dar 3 KPI Vilniaus filialo mokslininkai.

Henrikas Gylys, Mechanikos katedros vyr. dèstytojas, apgyne disertaciją „Eksperimentinio réminių konstrukcijų tyrimo tampriojoje-plastineje stadijoje klausimu“. Kurị laiką jis dirbo Statybos fakulteto prodekanu.

Romualdas Baronas, Mechanikos katedros aspirantas, apgynè disertaciją „Tiesinio programavimo metodai, nustatant pasislinkimus tampriosiose plastinèse strypinèse konstrukcijose“. Po kelerių metų gabus mokslininkas, deja, pažeidinëjo destytojo etiką ir aukštąją mokyklą teko apleisti.

Jaunutis Barauskas, taip pat Mechanikos katedros vyr. dèstytojas, apgynè disertaciją „Gulinčių ant gruntinio pagrindo juostų ir apvalių plokščių įtempimų-deformacijų būvio tyrimas".

Kai 1968 m. pradžioje buvo apsvarstyti filialo Mokslinejje taryboje praejusių metų mokslinių darbų rezultatai. Buvo konstatuota, kad filialo destytojai per metus paskelbe 169 straipsnius ir 78 įteike spaudai. Tai buvo ryški pažanga, palyginti su ankstesniais dešimtmečio metais. Pagal visus mokslinių darbų vertinimo rodiklius geriausiai atrodè A. Kudzio vadovaujama Statybinių konstrukcijų katedra. Apskritai Statybos-ekonomikos fakultetas buvo aiškus mokslo lyderis. Šio fakulteto vienam dèstytojui teko maždaug 1,5 straipsnio, o Prietaisu gamybos $-0,5$, Mechanines technologijos - vos 0,18 straipsnio. Neblogai atrode ir Miestų statybos bei Mechanikos katedrų mokslininkai.

Statybos katedrų pirmavimas mokslineje veikloje lyg ir patvirtino nuostatą, kad būsimasis institutas turi būti statybinio profilio.

Statybų mokslininkams gera žinia buvo ir ta, kad filialo prorektoriaus A. Čyro darbų ciklas „Tampriųjų-plastinių sistemų matematiniai modeliai ir jų sprendimo algoritmai“, kurị respublikinių premijų komitetas buvo atidèjęs toliau svarstyti, dabar pristatomas $1968 \mathrm{~m}$. premijai gauti. Deja, ir antras kartas melavo. Ne visada premijos skiriamos tiems, kas jų labiausiai nusipelne.

1967-1968 mokslo metų pabaigoje KPI taryba nutaré nuo $1968 \mathrm{~m}$. rugsëjo $1 \mathrm{~d}$. ịvesti visuose fakultetuose, tarp jų ir Vilniaus filiale, signalinę 0-1-2 sistemą studentų darbui kontroliuoti.
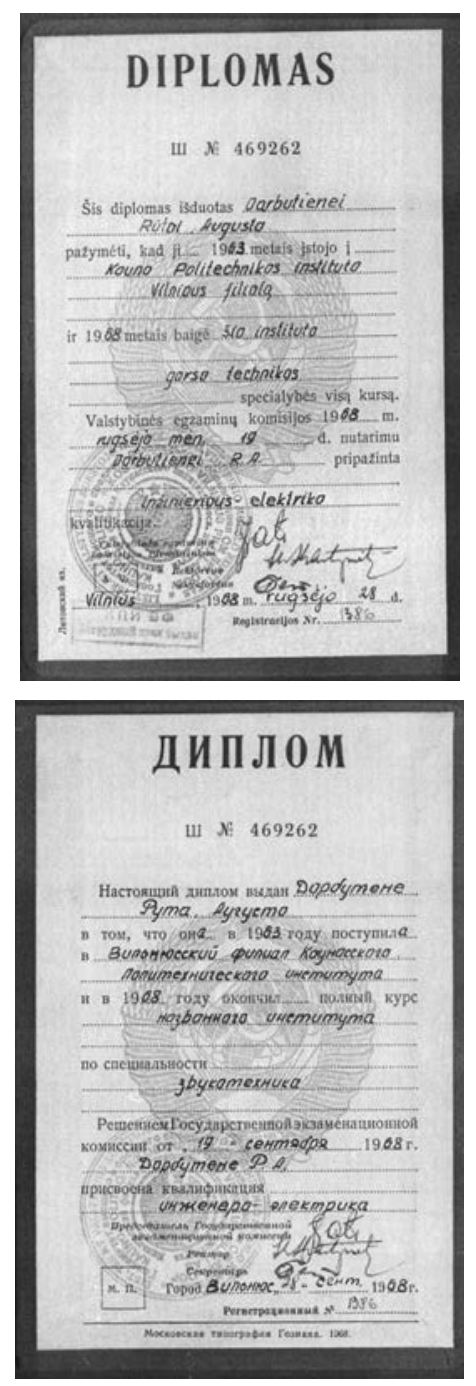

Tokie buvo diplomai 
KAUNO

POLITECHNIKOS

INSTITUTO

VILNIAUS FILIALAS
Visos studentu atliktos ir dèstytojų pripažintos tinkamomis atliktos privalomos užduotys (namų darbai, kursiniai darbai ir projektai, kontroliniai darbai, kolokviumai, grafiniai darbai, seminarai ir t. t.) iki tol buvo vertinamos ịprastiniais pažymiais: 3,4 ir 5, arba tiesiog , ,iskaityta“, „atlikta“ ir pan. Blogai įvertintą užduotį studentas privalejo taisyti arba atlikti iš naujo. Savarankiško darbo vykdymo kontrole 0-1-2 turëjo tikslą papildyti įprastinę pažymių sistemą atlikimo savalaikiškumo rodikliu.
Kiekvieno menesio 17-19 dienomis dèstytojas turëjo duoti vertinimą, kaip studentas lankè užsièmimus, dalyvavo seminaruose, rengè projektus, atliko laboratorinius darbus ir kt.

Studentas, gavęs porą „,“, tą mènesị prarasdavo stipendiją, o jei nuliai buvo rašomi ne vieną mèneși iš eilès - galëjo būti pašalintas nelaukiant sesijos.

Ši kontrolès sistema turëjo paskatinti studentus dirbti sistemingai, turejo padidinti jų pareigingumą ir pagerinti pažangumą. Bet ilgainiui paaiškèjo, kad iš esmès kontrolès sistema tik padidino biurokratizmą, o studiju rodikliai liko tie patys.

„Sèk, sesule, žalią rūta, kad Lietuva laisva būtų... “

$1968 \mathrm{~m}$. pavasarị prasidëjęs vadinamasis „Prahos pavasaris“" teike vilčių, kad ir sovietijoje bus pozityvių permainų. Čekoslovakijoje valdžią paemęs komunistas Aleksandras Dubčekas liberalizavo daug gyvenimo sričiu, praktiškai panaikino tradicinę komunistinę cenzūrą. Kai tik atsirado daugiau laisvès, ėme aišketti, kad artëja prosovietinès komunistinès valdžios griūtis.

Ir Lietuvą pasieke gaivūs Prahos pavasario vẻjai. Buvo graibstomi čekiški žurnalai, daugelis klausèsi „Laisves“ radijo pranešimų, apie tai daug buvo kalbama darbovietese, informacija iš Čekoslovakijos praslysdavo ir sovietineje spaudoje. Informacija pasieke ir kitas sovietines respublikas. Kremlius buvo išgąsdintas ir nutarè užgniaužti gležnus demokratijos daigus.

1968 m. rugpjūčio 20 d. sovietinè kariuomene, pasitelkusi Rytų vokiečių, lenkų, bulgarų ir vengru pulkus, įsiveržè i Čekoslovakiją. Dubčeką areštavo, o i jo vietą pasodino Husaką, ,ištikimą leninietį“. „Prahos pavasaris" baigèsi.

Kaip ir 1956 m. Vengrijos įvykių metų, Vakarai niekaip nereagavo. Buvo tik padejuota,

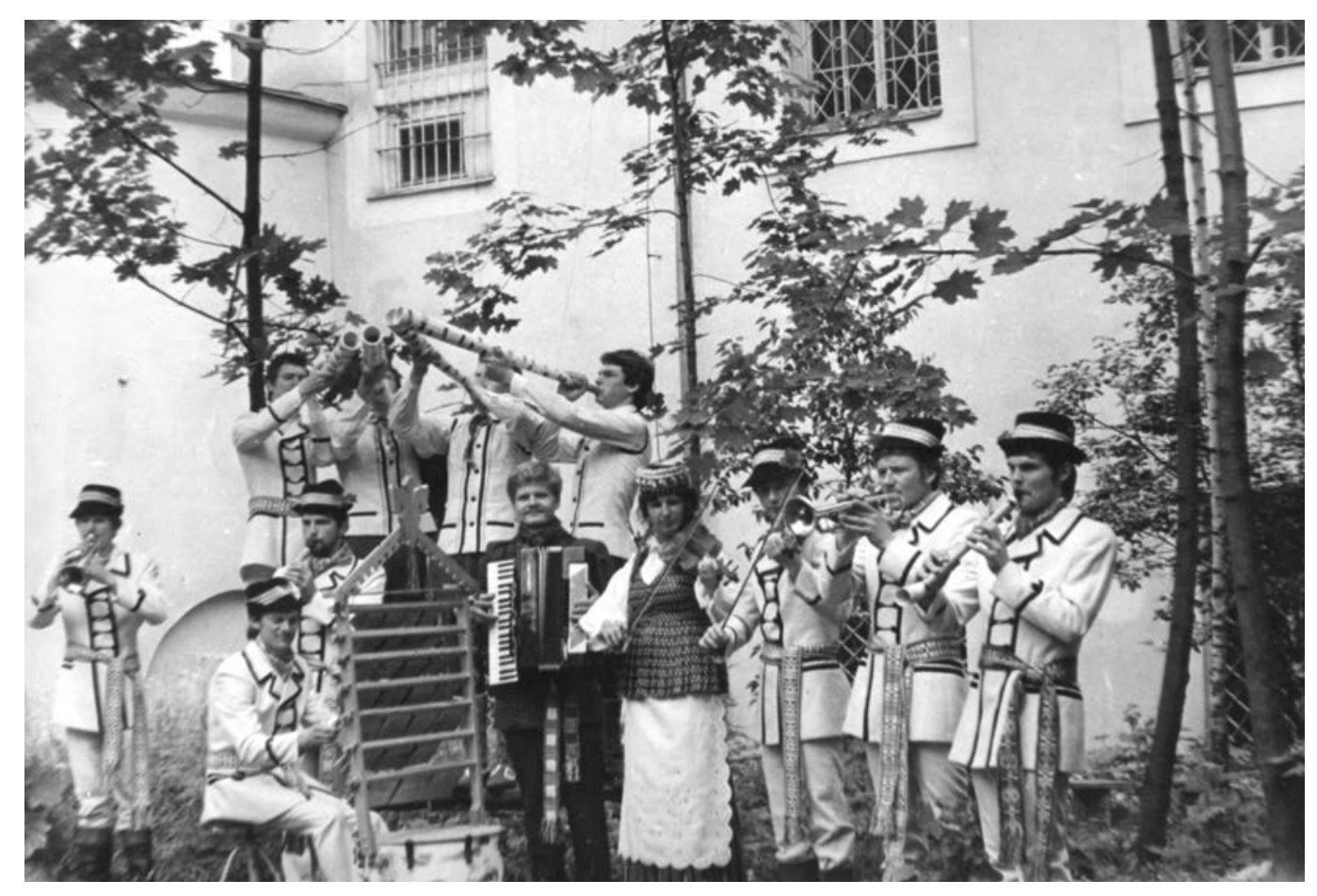


užjausta. Pasirodo, skęstančiųju gelbëjimas pačių skęstančiųjų reikalas. Verta įsidemèti tokias istorijos pamokas, ypač prisimenant, kaip ilgai užtruko Lietuvos nepriklausomybès pripažinimas prieš keliolika metų.

Taigi 1968-1969 mokslo metus KPI Vilniaus filialas pradèjo gyvuoti mažai gero žadančio politinio gyvenimo sąlygomis. Nebuvo jokiu abejoniu, kad sovietijoje neatsiras daugiau laisvių, kad bus mažiau skriaudų, mažiau negerovių ir trūkumų. Juokingai atrode partijos kvietimas susitelkti apie sovietinę komunistų partiją, neprarasti revoliucinio budrumo, vykdyti didžiulius socialistinius visuomenés pertvarkymus, spręsti sudetingus kuriamojo darbo uždavinius.

Žmonès netikèjo sovietine propaganda. Vieną galvojo, kitą sake ir trečią darè. Toks žmogaus modelis sovietinio režimo sąlygomis buvo dažniausias. Mažai kas betikejo, kad lietuvių tautą išlaisvinti ir Lietuvos valstybę atkurti yra įmanoma. Dauguma turejo savo pogrindinę viltị, kad gal įvyks stebuklas, gal viskas pasikeis i gerą. O belaukiant stebuklo, reikia dirbti savo ir savojo gimtojo krašto labui. Išsimokslinęs, kultūringas, ekonomiškai nenuskurdęs kraštas turëjo daugiau šansų būti neperlaužtas, neprarasti tautinès savasties, tiketis palankios progos savo viltims igyvendinti.

Bet sovietine valdžia neturejo visiškos ramybès. Ją drumste disidentai, jų leidžiami nelegalūs leidiniai, užsienio radijo laidos. Ir KPI Vilniaus filiale pasireikšdavo „nacionalistiniai išsišokimai ir nuotaikos".

1968 m. KPI Vilniaus filiale buvo apsvarstytas filialo politinis ir auklejamasis darbas. Išlikusiuose posedžio dokumentuose rašoma:

"Kai kurie studentai nihilistiškai žiūri j marksistine-leninine teorija, mano, kad ji busimam inžinieriui nereikalinga. Dar daugiau, pas atskirus studentus pasitaiko nesveiku nuotaiku netikëjimo socialistinès santvarkos pranašumais prieš kapitalizma atvejų. Nežinodami ir nesuprasdami visuomenes vystymosi desningumu atskiri studentai, pastebédami mūsu gyvenime pasitaikančius trükumus ir klaidas, patenka i buržuazines ideologijos pinkles. Apie tai kalba ne tik kartais pasitaikantieji antitarybiniai nacionalistiniai užrašai ant sienu, bet ir nacionalistiniai ǐssišokimai.

Praejusiu mokslo metu pavasari choro išsykos $i$ Rokiški metu dalis choristu dainavo daina, kuri baigiasi žodžiais: „sekk sesute ir gvazdiku, kad nebūtu bolševiku“. Buvo taip pat dainuo-

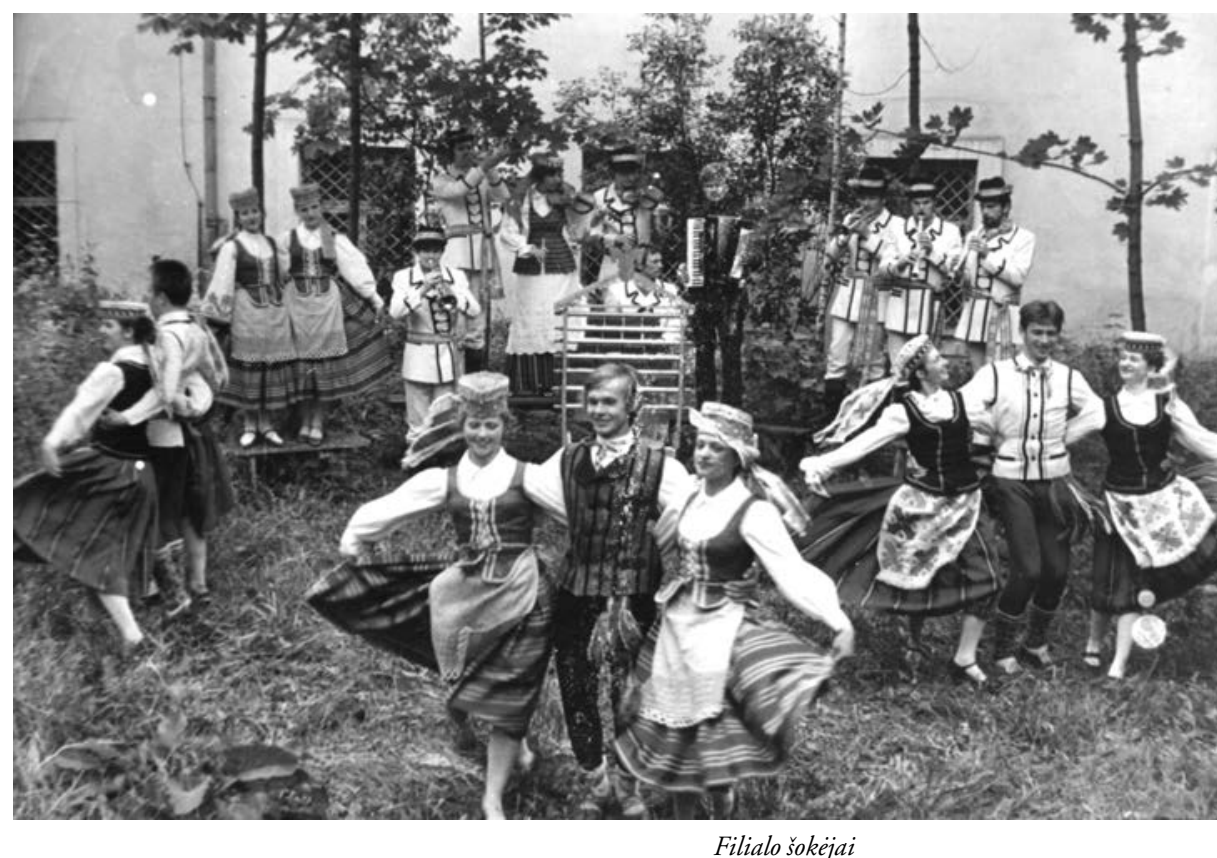

jama daina, kurioje žodžiai "lietuvi, prikask liežuvi, nes rusai valdo mus".

Šios dainos buvo dainuojamos grupes choristu ir per Gegužés Pirmosios demonstracija. Pirmaja daina dainavo atskiri liaudies ansamblio dalyviai vasaros stovyklos Merkineje metu. Šiu dainu iniciatoriai išaiškinti ir nubausti: Jonikui ir Guobiui - prietaisu gam. fak. $V$ kurso diplomantams atidetas gynimas vieneriems metams, to pat fakulteto Girčiui ir Pikeliui, kurie jau buvo apsigyne diplominius projektus, komjaunimo komitetas pareiške griežtus papeikimus, jiems pakeistos darbo vietos, pasiunčiant dirbti i gamybą. Prietaisu gamybos fakulteto III kurso studentas Bukauskas pasiustas metams i gamyba. Ramanauskaitei-Lenino v. stipendiatei atimta teise gauti stipendija. Ji nubausta griežta komjaunuoliska bausme. Straupys III k., Jakubenas IV k., Darbutas III k., Braškys IV k, Meslinas II $k$. nubausti komjaunuoliškomis ir administracijos bausmemis.

Šiu poelgiu šaknys glūdi tame, kad marksistine pasauležiūra šiems studentams netapo giliu isitikinimu. Rimta susirūpinima kelia tai, kad net geri studentai komjaunuoliai grupiu aktyvistai nesugebejo duoti panašioms nuotaikoms rimto atkirčio, nutylëjo, taikési su jomis..." [3.37, p. 371-372].

Taigi daugelis gyveno dvigubą gyvenimą, taip pat ir komjaunuoliai, ir partiniai, ir nepartiniai. Žinoma, buvo ir kitokių, ypač vadinamosiose visuomenès mokslų katedrose, bet ar visi jie buvo nuoširdūs?.. Svetimųju primesta tvarka, idejos neužgože tautos noro gyventi laisvai ir nepriklausomai. 
KAUNO

POLITECHNIKOS

INSTITUTO

VILNIAUS FILIALAS

\section{KPI Vilniaus filialas lietuveja}

1968-1969 mokslo metus KPI Vilniaus filialas pradejo turèdamas 4220 studentų: 1683 dieniniame ir 2537 vakariniame skyriuose. Filiale veike 4 fakultetai ir 22 katedros, dirbo 263 pedagogai.

Savarankiškos aukštosios mokyklos įkūrimo išvakarese KPI Vilniaus filiale veikè šios katedros: Prietaisu gamybos fakultete Elektrotechnikos, Elektros įrenginių, Radijo aparatūros technologijos, Elektronikos skaičiavimo technikos, Bendrosios fizikos; Mechanines technologijos fakultete-Braižybos, Metalų apdirbimo, Mašinų teorijos, Mašinų gamybos automatizavimo, Gamybos ekonomikos; Statybos ekonomikos fakultete - Mechanikos, Statybiniu konstrukciju, Chemijos, Statybos ekonomikos; Miestų statybos fakultete - Matematikos, Miestu statybos, Kelių. Be to, filiale buvo TSKP istorijos ir filosofijos, Politines ekonomijos ir mokslinio komunizmo, Karinio parengimo, Kalbų ir Fizinio lavinimo katedros.

Dar 1968 m. sausio 26 d. KPI tarybos nutarimu „Dèl Miestų statybos fakulteto steigimo KPI Vilniaus filiale" Miestų statybos fakultetui buvo priskirtos trys specialybès: 1 . Miestų statybos specialybè, perkelta iš Statybos-ekonomikos fakulteto filialo; 2. Automobilių kelių specialybe, perkelta iš KPI Santechnikos fakulteto; 3. Inžinerines geodezijos specialybè, taip pat perkelta iš Santechnikos fakulteto.

Miestų statybos fakultetui buvo priskirtos 4 katedros: 1. Miestuc statybos katedra, perkelta iš filialo Statybos-ekonomikos fakulteto; 2. Keliu katedra, perkelta iš Santechnikos fakulteto; 3. Geodezijos katedra, perkelta iš Santechnikos fakulteto. 4. Matematikos katedra, perkelta iš filialo Prietaisu gamybos fakulteto. Tokia struktūra veike nuo rugsèjo $1 \mathrm{~d}$., išskyrus Geodezijos katedrą, kuri buvo įsteigta praëjus vieneriems metams.

Miestų statybos fakulteto dekanu $1968 \mathrm{~m}$. liepos $1 \mathrm{~d}$. buvo paskirtas iš Kauno perkeltas docentas, geologijos-minerologijos mokslų kandidatas Bronius Sidauga. Ėjo jis šias pareigas energingai, sumaniai ir ilgainiui tapo prorektoriumi.
Buvo numatę persikelti, bet galop atsisake geodezininkas Z. Tamutis, kelininkai S. Lukošiūnas ir A. Tamoševičius.

Pusè persikèlusių iš Kauno ị Vilnių buvo mokslų kandidatai, docentai, kiti - bebaigią kandidatines disertacijas.

KPI filiale $1968 \mathrm{~m}$. rugsëjo $1 \mathrm{~d}$. Miestų statybos fakultete buvo 17 akademiniu grupių. Visos jos studijavo lietuvių kalba.

Miestu statybos specialybès dieninèse studijose I kurse buvo dvi grupes, o II-V kursuose - po vieną grupę. Inžinerinès geodezijos specialybès studijas pradejo dar tik viena pirmakursiu grupé, o automobiliu kelių specialybès - I kurse studijavo dviejų akademinių grupių, antrame - vienos grupès studentai.

Vakarines studijos buvo tik Miestų statybos specialybè - I ir II kursuose buvo po dvi grupes, o III, IV ir VI kursuose - po 1 grupę. Taigi vakarais studijavo 7 akademines grupès.

Statybos fakultete minimus mokslo metus pradejo 44 dieninių ir vakarinių studiju akademinès grupés.

Pramoninès ir civilinès statybos specialybès dieninèse studijose I kurse buvo 6 akademinès grupess: 4 lietuviškos ir 2 rusiškos; II kurse -4 grupès: 2 lietuviškos ir 2 rusiškos; III kurse -2 rusiškos ir IV bei V kursuose - po 1 rusišką. Taigi šios specialybès 14 akademinių grupių sudare 6 lietuviškos ir net 8 rusiškos grupès. Žemès ūkio statybos specialybès buvo 3 lietuviškos grupes: 2 - I ir 1 - II kursuose. Statybos ekonomikos ir organizavimo specialybes studijose buvo tik lietuviškos grupes: I kurse - 3, II kurse - 2 ir likusiuose trijuose kursuose - po 1 grupę.

Statybos fakulteto vakarinese studijose buvo 18 akademinių grupių.

Pramoninès ir civilinès statybos specialybès I kurse buvo 1 grupe rusu kalba, II kurse -2 grupes rusu kalba, III kurse -1 lietuvių kalba ir 2 rusų kalba, IV ir $\mathrm{V}-$ po 1 grupę lietuvių ir rusų kalbomis bei VI kurse 1 grupé rusų kalba. Taigi vakarinese PCS studijose iš 11 akademinių grupių aštuoniose studijos vyko rusų kalba.

Vakarines studijos buvo ir statybos ekonomikos bei organizavimo specialybès studentų. Iš viso buvo 7 akademinès grupès ir visos jos studijavo lietuviu kalba. Tik antrajame kurse buvo 2 akademines grupés, o visuose kituose kursuose - po 1 .

Mechaninès technologijos fakultete 19681969 mokslo metais buvo 62 akademinès grupes. 
Suvirinimo įrengimų ir technologijos specialybès dieninių studijų visuose kursuose buvo po vieną akademinę grupę ir visose buvo studijuojama lietuviu kalba. Automobiliu transporto specialybès dieninèse studijose I kurse buvo 2 grupes lietuvių kalba ir 1 grupe rusų kalba, o II kurse - 2 lietuviškos grupès. Mašinų gamybos technologijos specialybès studentai studijavo tik vakarais. Mašinų gamybos procesų automatizavimo specialybès III kurse buvo 2 grupes, o IV ir V kursuose - po 1. Jose studijos vyko lietuvių kalba. Visos trys akademines grupés buvo lietuviškos ir statybos kelių mašinų bei įrengimų specialybès: 2 - I ir 1 - II kursuose. O Autotransporto ekonomikos ir organizavimo specialybes I, II ir III kursuose buvusios akademinès grupès buvo tik rusiškos.

Mechaninès technologijos fakultete vakarais studijavo net 36 akademines grupés.

Suvirinimo irrengimu ir technologijos specialybeje I-V kursuose buvo po 1 akademinę grupę. Visos jos studijavo rusu kalba. Automobilių transporto specialybès I-V kursuose buvo po 1 akademinę grupę, o VI - 2 grupés. Visos šios septynios grupès studijavo rusų kalba. Mašinų gamybos technologijos specialybès vakarinioku I kurse buvo 3, II kurse - 4, III - V kursuose po 5 ir VI - 2 grupes. 15-oje grupiu buvo destoma lietuviškai, o 9-iose - rusiškai. Mašinų gamybos pramonés ekonomikos ir organizavimo specialybès buvo 4 grupés - po 1 III-VI kursuose.

Prietaisu gamybos fakultete 1968-1969 mokslo metais buvo 49 akademinès grupès. Garso technikos specialybès dieninèse studijose tebuvo 3 grupès - po vieną III-V kursuose. Radijo aparatūros konstravimo ir gamybos specialybès studentai dieną studijavo 15 grupiu ir tik III-V kursuose. Visose grupèse studijos vyko lietuvių kalba.

Prietaisu gamybos fakultete vakarais studijavo 31 akademiné grupé.

Radijo aparatūros konstravimo ir gamybos specialybes I, II, IV, V ir VI kursuose vakarinèse studijose buvo po 3 grupes, III kurse -4 grupess. 12 grupių studijavo rusu kalba, 7 - lietuvių kalba. Tik vakarinèse studijose studijavo Elektros pavaru ir gamybos įrenginiu automatizavimo specialybès studentai. Pirmuose penkiuose kursuose buvo po 2 akademines grupes, IV kurse -1 . Visose grupèse dèstyta lietuviškai. Tik viena akademine grupe tebuvo Matematiniu skaičiavimo prietaisų bei įrenginiu specia-
KPI Vilniaus filialo akademines grupes 1968-1969 mokslo metais

\begin{tabular}{|c|c|c|c|c|c|c|c|c|}
\hline \multirow{2}{*}{\multicolumn{2}{|c|}{ Rodiklis }} & \multicolumn{6}{|c|}{ Kursas } & \multirow{2}{*}{$\begin{array}{c}I_{S}^{\vee} \\
\text { viso }\end{array}$} \\
\hline & & $I$ & $I I$ & $I I I$ & $I V$ & $V$ & $V I$ & \\
\hline \multicolumn{2}{|c|}{$\begin{array}{l}\text { Bendras grupiu } \\
\text { skaičius }\end{array}$} & 37 & 31 & 33 & 28 & 28 & 15 & 172 \\
\hline \multirow{3}{*}{$\begin{array}{l}\text { Dieni- } \\
\text { niu } \\
\text { studiju } \\
\text { grupiu } \\
\text { skaicius }\end{array}$} & Bendras & 23 & 14 & 14 & 11 & 11 & - & 73 \\
\hline & $\begin{array}{l}\text { Lietuviu } \\
\text { kalba }\end{array}$ & 19 & 11 & 8 & 7 & 7 & - & 52 \\
\hline & $\begin{array}{l}\text { Rusy } \\
\text { kalba }\end{array}$ & 4 & 3 & 6 & 4 & 4 & - & 21 \\
\hline \multirow{3}{*}{$\begin{array}{l}\text { Vaka- } \\
\text { riniu } \\
\text { studiju } \\
\text { grupiu } \\
\text { skaicius }\end{array}$} & Bendras & 14 & 17 & 19 & 17 & 17 & 15 & 99 \\
\hline & $\begin{array}{l}\text { Lietuviy } \\
\text { kalba }\end{array}$ & 8 & 9 & 11 & 10 & 9 & 10 & 57 \\
\hline & $\begin{array}{l}\text { Rusy } \\
\text { kalba }\end{array}$ & 6 & 8 & 8 & 7 & 8 & 5 & 42 \\
\hline
\end{tabular}

lybès - tai lietuviška grupe VI vakarinių studijų kurse.

Taigi paskutiniais KPI Vilniaus filialo mokslo metais jame buvo 172 akademinès grupes: 109 akademinèse grupèse buvo dèstoma lietuvių kalba, o 63 - rusų kalba. Lietuviškų grupių buvo $63 \%$. Dieninèse studijose buvo 73 akademinès grupes: 52 grupése buvo destoma lietuvių kalba, o 21 - rusų kalba. Taigi lietuviškos grupes čia sudare jau $71 \%$ kontingento. Vakarinese studijose buvo 99 akademinés grupes: 57 grupese dèstoma lietuvių kalba, o 42 - rusų kalba. Taigi vakarinès lietuviškos grupes dar sudare tik $58 \%$ kontingento.

Iš fakultetų 1968-1969 mokslo metais lietuviškiausias buvo Miestų statybos fakultetas, kuriame rusų kalba destomų grupių nebuvo. Statybos fakultete tokios grupès sudare $36 \%$, o rusiškiausi buvo Mechanines technologijos ir Prietaisų gamybos fakultetai.

Imant paskutinius trejus metus matyti, kad apskritai didëjo lietuvišku grupių skaičiai: 1966-1967 mokslo metais jų buvo 57,6 \%, 1967-1968 m. m. jau 73 \%. Taigi Vilniaus aukštoji technikos mokykla - KPI Vilniaus filialas turèjo ryškią tendenciją didinti lietuviškų grupių skaičių ir nedidinti grupių rusų kalba. Kas labiausiai paveike ši procesą, sunku pasakyti, bet pats procesas teike vilčių, kad pradèsianti funkcionuoti suvereni aukštoji mokykla taps lietuvių tautybès aukštos kvalifikacijos specialistų, taip reikalingų Lietuvos sostinei ir Vilniaus kraštui, rengimo kalve.

Filialo vadovo A. Čyro iniciatyva $1968 \mathrm{~m}$. filiale įkurta Elektronikos ir skaičiavimo technikos katedra, kuri turejo visiems studentams skaityti skaičiavimo kursą. Filialas 
KAUNO

POLITECHNIKOS

INSTITUTO

VILNIAUS FILIALAS
1968-1969 mokslo metų pradžioje turëjo 7 analogines skaičiavimo mašinas. Jos naudotos katedrų moksliniams darbams, studentų kursiniams bei diplominiams projektams atlikti. Bet savos diskretinès elektronines skaičiavimo mašinos filialas neturejo, todèl mokslinio tyrimo darbams teko naudotis kitų Vilniaus organizacijų skaičiavimo mašinų paslaugomis. Padètis pasikeitè į gerąją pusę, kai filialas metu pabaigoje issigijo elektroninę skaičiavimo mašiną „Minsk 22“. Tuomet ir buvo įkurtas filialo skaičiavimo centras. Pirmuoju jo vadovu buvo paskirtas A. Vyskupaitis.

Filialo autoritetą sustiprino $1968 \mathrm{~m}$. birželį 4 dienas Vilniuje vykusi tarptautine mokslinè konferencija dèl matematinio programavimo metodų taikymo skaičiuojant optimalias konstrukcijas. Joje dalyvavo tokios ižymybès, kaip A. Gvozdevas, A. Ržanycinas, A. Vinogradovas. Šie mokslininkai gerai žinomi visame pasaulyje.

1968 metai buvo vaisingi ir vis intensyviau veikusiai SMD (studentų mokslinei draugijai). Tais metais ịvykusiame respublikiniame SMD darbų konkurse dalyvavo 35 studentai. 8 iš ju buvo apdovanoti III laipsnio diplomais. Pažymètina, kad vienas iš apdovanotųjų buvo būsimasis Vilniaus Gedimino technikos universiteto rektorius Romualdas Ginevičius. Tuomet IV kurso Statybos-ekonomikos fakulteto studentas R. Ginevičius buvo pažymetas už mokslini darbą „Kai kurių faktorių, turinčių įtakos SMV (statybos montavimo valdybų) darbo našumui Lietuvos TSR, analizé". Pletojant SMD veiklą, pasižymejjo jos pirmininkas A. Lekaravičius.

1968 m. aktyvios buvo studentų ir kitos organizacijos. Komjaunimo komiteto sekretoriumi buvo J. Mureika, Studentų profkomiteto pirmininku A. Tarvydas, Kultūros klubo pirmininku A. Grodzenskis.

Komjaunimas tvarkè visuomeninių dalyku ir apskritai visų dalykų pažangumo pagerinimo klausimus, rūpinosi „Komjaunimo prožektoriaus" (kuri buvo nepertraukiamai blanki) veikla (jis „,kovojo“ su nepažangumu), leninine iskaita, darbo ir poilsio stovyklomis ir kt.

Studentų profsąjunga buvo konkretesnè. Jai priklause bendrabučių kuravimas, vasaros poilsio organizavimas, kiti socialiniai klausimai ir t. t.
Kultūros klubas rūpinosi meno saviveikla, poilsio vakarų organizavimu.

1968 m. KPI Vilniaus filiale bandyta suorganizuoti mejgejišką kino studiją. Tokią studiją turëjo KPI centras, ir ji tiems laikams buvo gana produktyvi. Bet KPI mejgejiška kino studija buvo įkurta remiantis studentu iniciatyva, o Vilniuje, deja, prorektoriaus isakymu.

Studijos vadovu buvo paskirtas prorektoriaus pavaduotojas statybų reikalams A. Mikšys (KPI Vilniaus filialo I laidos absolventas), nariais: A. Lubys - Gamybos ekonomikos katedros aspirantas, Slavinskas - Staklių laboratorijos meistras, e. doc. p. Budrys - Mašinų teorijos katedros destytojas, A. Tarvydas studentu profkomiteto pirmininkas.

Tiekimo skyriaus viršininkas B. Marašinskas buvo ịpareigotas stiprinti kino studiją inventoriumi ir medžiagomis, o studentų klubas privalëjo perduoti studijai filmavimo kameras.

Iš šios informacijos galima susidaryti įspūdị, kad studentų kultūros klubas jau buvo filmavęs kai kuriuos įvykius. Tačiau mums nepavyko rasti jokių tokios kultūros klubo veiklos bei įkurtosios kino studijos atliktų darbų pedsakų.

$\mathrm{Na}$, o studentu KPI filiale vis daugejo. 1968-1969 mokslo metais KPI Vilniaus filialo dieniniame skyriuje studijavo 1683 jaunuoliai ir merginos, vakariniame skyriuje -2 537, iš viso 4220 studentu. Tokiu skaičiumi galëjo didžiuotis bet kuri savarankiška aukštoji mokykla.

1969 m. gegužes 23 d. KPI tarybos posèdyje Vilniaus filialo prorektorius R. Jonušas pateike pasiūlymą dviejų katedrų pagrindu ikurti penkias katedras. Būtinybe tai daryti kilo del KPI Statybos ir Santechnikos fakultetų kai kurių katedrų perkèlimo į Vilnių. Buvo pasiūlyta TSKP istorijos ir Politines ekonomijos katedrų pagrindu įsteigti 3 katedras: 1. TSKP istorijos katedrą, 2. Politinès ekonomijos katedrą. 3. Filosofijos ir mokslinio komunizmo katedrą; Statybinių konstrukciju katedros pagrindu: 1. Statybinių konstrukcijų katedrą ir 2. Specialiųjų konstrukcijų katedrą. KPI taryba pasiūlymui neprieštaravo, ir kiek veliau, Aukštojo ir specialiojo vidurinio mokslo ministerijos sprendimu minetos katedros buvo įsteigtos ir émé veikti jau ịkurtame Vilniaus inžineriniame statybos institute.

Jau po ménesio tos pačios Tarybos posedyje buvo pažymèta, kad toliau profiliuojant KPI Vilniaus filialą, 1969 m. numatyta 


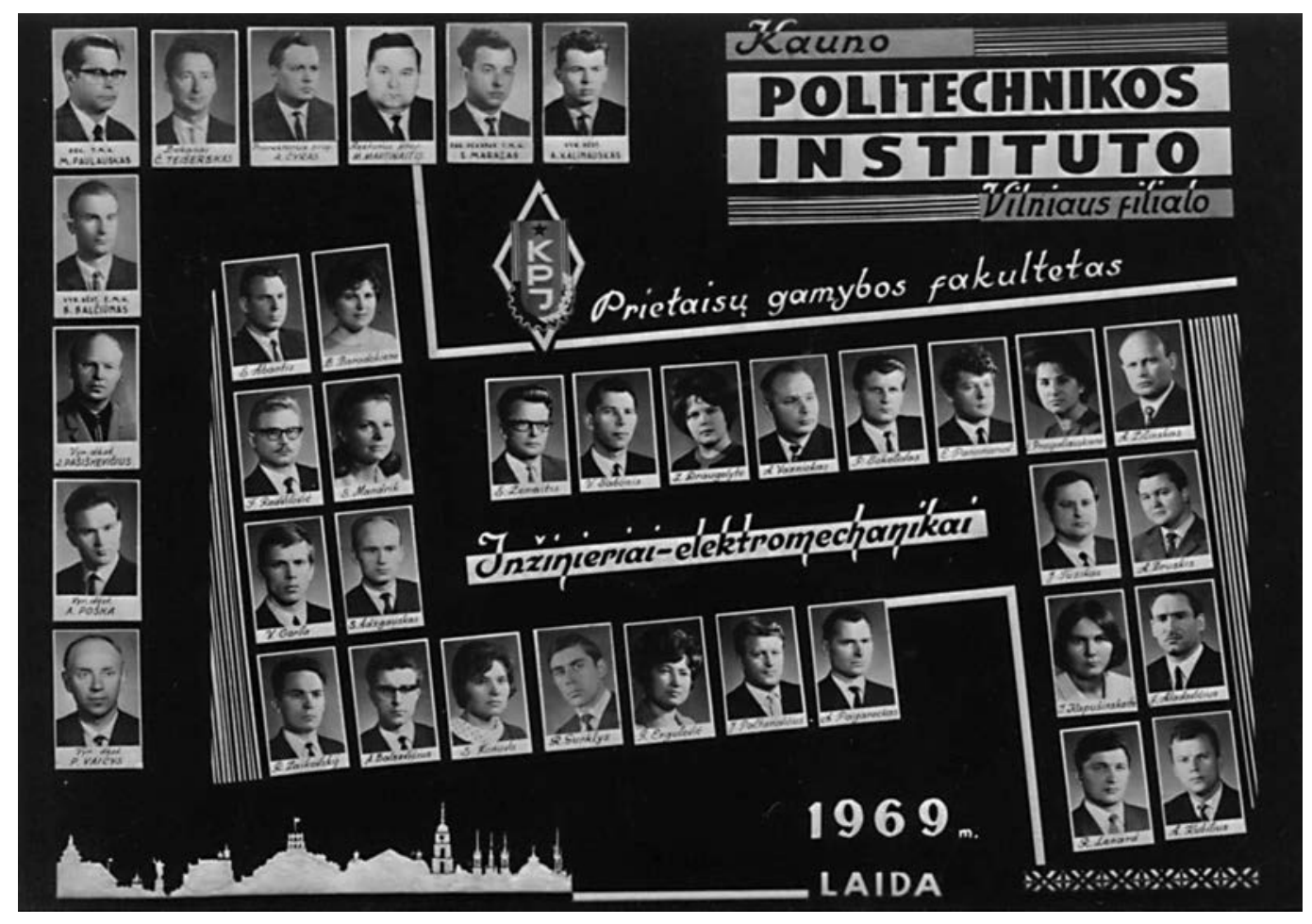

nebepriimti studijuoti į Pramonès ir civilinès statybos specialybę. Nuo rugsëjo $1 \mathrm{~d}$. iš Kauno ị Vilnių turëjo persikelti kelių statybos ir geodezijos specialybių aukštesniuju kursų studentai bei abi profilinès katedros. $\mathrm{O}$ iš Vilniaus ị Kauną buvo perkeliami Radijo aparatūros konstravimo ir technologijos specialybès IV kurso studentai.

1969 m. paskutiniais KPI Vilniaus filialo metais, išleistas gausus diplomantų būrys. Filialą baige 523 diplomantai. Tai buvo aštuntoji KPI Vilniaus filialo diplomanty laida. Šie diplomantai gavo diplomus, pasirašytus Kauno politechnikos instituto rektoriaus Marijono Martynaičio. O nuo kitu metu Vilniaus aukštoji technikos mokykla turëjo jau kitą pavadinimą ir kitą rektorių.

\section{Dèstytoju perkèlimas iš Kauno}

Steigiant Vilniaus inžinerinį statybos institutą labai svarbus ir sunkus organizacinio darbo baras buvo dèstytojų iš Kauno perkèlimas i Vilnių, ir atvirkščiai.

$1968 \mathrm{~m}$. kovo $28 \mathrm{~d}$. Aukštojo ir specialiojo vidurinio mokslo ministerijos kolegija prièmè nutarimą „Dèl Kauno politechnikos instituto Santechnikos ir Statybos fakultetu specialybių ir destytoju perkèlimo ị Vilnių tvarkos", kuriame buvo numatyta, kokios specialybes, kokios katedros ir kada turi būti perkeltos, destytoju perkèlimo tvarka.
Bet šiuo nutarimu neišspręsti visi klausimai, kuriuos iškèlè gyvenimas. Todèl kolegijai teko patikslinti minètąji nutarimą.

$1969 \mathrm{~m}$. balandžio $29 \mathrm{~d}$. nutarime rašoma:

1. Pritarti 1969 m. vasario 25 d. ministro isakymu Nr. 49 sudarytos komisijos pasiūlymams siais klausimais:

a) perkelti 1969 m. iš Kauno i Vilniu geodezijos ir keliu katedras, o 1970 m. - automobiliu transporto, architektūros, gyvenviečiu planavimo ir tvarkymo katedras;

b) 1969 m. studentus i pramones ir civilines statybos specialybe priimti tik Vilniuje;

c) del patalpu stokos $1969 \mathrm{~m}$. perkelti iš Vilniaus $\dot{i}$ Kauna radijo aparatūros gamybos technologijos ir konstravimo specialybes $I V$ kurso studentus;

d) garso technikos specialybès IV kurso studentus, sumažejus specialistu pareikalavimui, pervesti i radijo aparatūros gamybos technologijos ir konstravimo specialybe, perkeliant juos 1969 m. iš Vilniaus $i$ Kauna;

e) 1969 m. is Kauno i Vilniu perkelti geodezijos ir automobiliu specialybès aukštesniuju kursu studentus;

f) 1970 m. perkelti iš Kauno į Vilniu visus architektūros, automobiliu transporto, statybos ir keliu mašinu specialybiu studentus.

Sutikti su komisijos nuomone, kad bendrabučiais aprüpinami pirmiausia tie studentai, kurie prieš perkèlima gyveno bendrabučiuose arbapastevus. 
KAUNO

POLITECHNIKOS

INSTITUTO

VILNIAUS FILIALAS

Suvirinimo specialybès diplomantai su destytojais

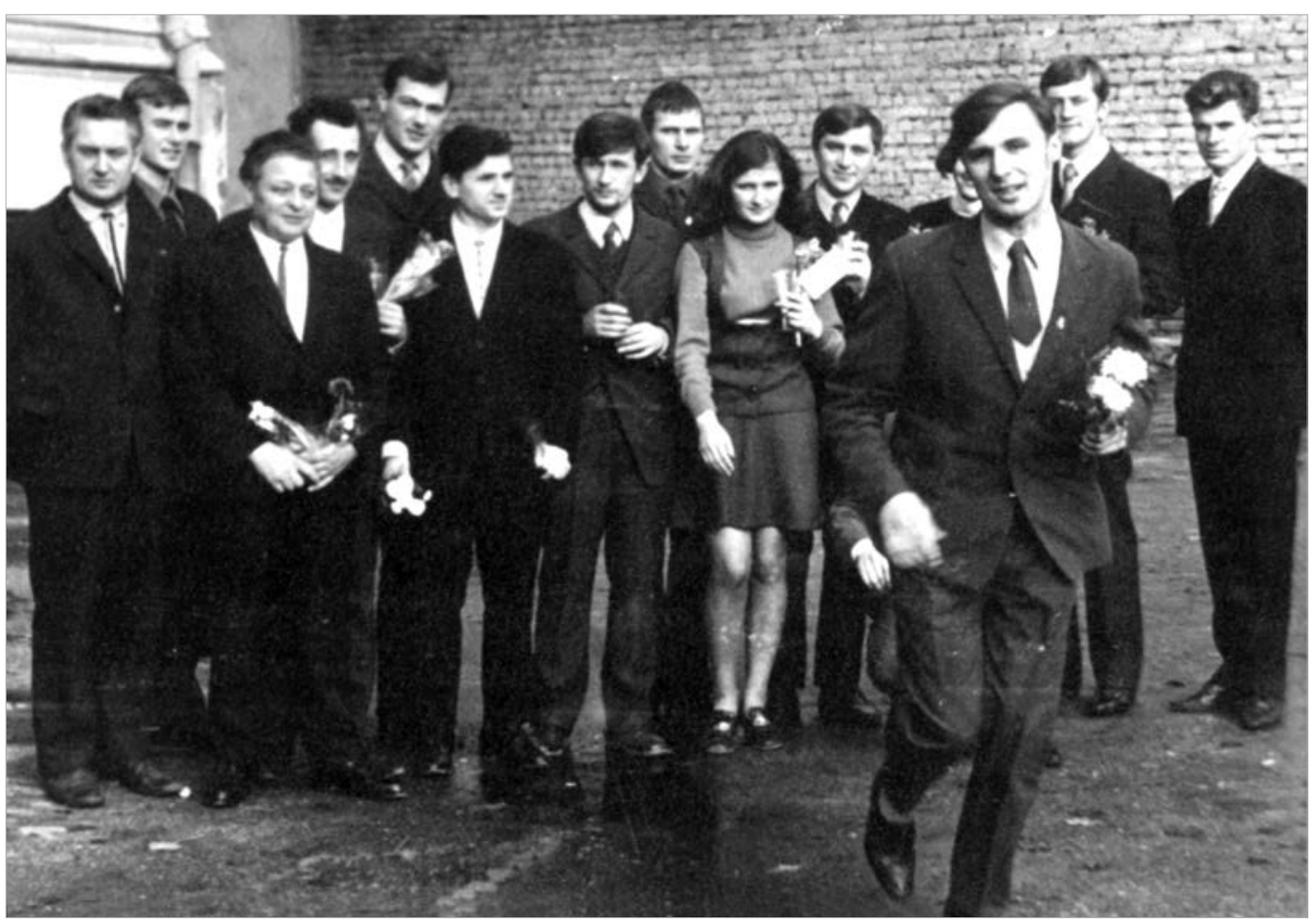

2. Pasikeitus kai kuriu specialybiu studentu ir katedruperkelimo terminams, patvirtinti komisijos patvirtinta destytojuperkèlimo iš Kauno i Vilniu grafika 1969 m. ir 1970 m. (priedelis Nr. 1) ir destytoju, kurie 1969 m. perkeliami is Vilniaus i Kauna sarašą (priedelis Nr. 2).

Ipareigoti komisija, atsižvelgiant $i$ 19711975 m. penkmečio statybu plano projekta, iki š. m. birželio $15 d$. nustatyti santechnikos fakulteto specialybiu studenty ir katedru perkelimo grafika.

3. Pripažinti, kad destytojai, perkeliami is Kauno $i$ Vilniu arba iš Vilniaus $i$ Kauna, privalo būti aprūpinami gyvenamuoju plotu ne eiles tvarka.

4. Ipareigoti KPI Vilniaus filiala (prof. A. CYRA) išskirti perkeliamiems iš Kauno destytojams butus gyvenamame name, kuris ivedamas $1969 \mathrm{~m}$. Krantines gatveje, pagal pridedama saraša (priedelis Nr. 3), o likusi gyvenamaji plota leisti paskirstyti bendros eiles tvarka, priimant demesin, kad pirmiausia būtina iškelti déstytojus iš bendrabučiu.

5. Apgyvendinti $1970 \mathrm{~m}$. perkeliamus is Kauno destytojus 30 butu gyvenamame name, kuris tais metais bus ivestas Krantines gatveje.

6. Priimti demesin Kauno Politechnikos instituto rektoriaus prof. M. Martynaičio pareiškima, kad visi destytojai, perkeliami iš Vilniaus i Kauna 1969 m. bus apgyvendinami 108 butu viešbutinio tipo name, o $1970 \mathrm{~m}$. jiems bus išskirtas gyvenamasis plotas persikeliančiu $\dot{i}$ Vilniu destytoju saskaita.
7. Atsižvelgiant i nepatenkinama KPI Vilniaus filialo déstytoju aprūpinima butais, $o$ be to i tai, kad $1970 \mathrm{~m}$. vien juedamu gyvenamuoju plotu negalima aprüpinti visu perkeliamu iš Kauno destytoju, prašyti LTSR Ministru Taryba:

a) atleisti $1969 \mathrm{~m}$. pradedama statyti Krantines gatveje 30 butu nama nuo privalomo fondo išskyrimo Vilniaus miesto DŽDT vykdomajam komitetui ir LTSR statybos ministerijai;

b) ipareigoti Vilniaus miesto DŽDT Vykdomaji komiteta atlikti gyventoju nukeldinima (7 butai) savo gyvenamojo fondo saskaita;

c) ipareigoti Vilniaus miesto DŽDT vykdomaji komiteta kasmet išskirti KPI Vilniaus filialui ne mažiau kaip 10 butu, kol bus galutinai užbaigtas reorganizavimas $i$ savarankiška instituta.

Perkelti iš Kauno į Vilnių ir gauti butus 1969 m. turëjo šie dèstytojai: Kunigelis Juozas (Hidrotechnikos katedra), Sidauga Bronius ir Alikonis Antanas (Inžinerinès geologijos katedra), Rokas Steponas, Vidugiris Linas, Palšaitis Evaldas, Sausenavičius Henrikas, Sakalauskas Kazimieras, Jasulaitis Vytautas (Kelių katedra), Tamutis Zigmas, Kosčiauskas Mykolas, Vainauskas Vincas, Gužauskas Jonas, Zakarevičius Algimantas, Žalnieriukas Albinas (Geodezijos katedra), Remišauskas Mikalajus, Baublys Petras, Žekevičius Jonas (Statybines mechanikos katedra), Pilénas Stasys (Statybos darbų organizavimas), 
Kivilša Jokūbas, Rozenbliumas Anatolijus (Gelžbetoninių konstrukcijų katedra), Lazarevičius Henrikas, Steponavičius Algirdas (Metalinių konstrukcijų katedra), Geršas Nisonas, Strigūnas Vytautas (Pastatų konstrukcijų katedra), Blažys Kazimieras (Vandentiekio ir kanalizacijos katedra), Gailius Albinas, Naujokaitis Algimantas (Statybinių medžiagų katedra), Zdanavičius Anatolijus, Gruzdys Brunonas (Grafinių darbų katedra), Tupinis Arnoldas (Gyvenviečių planavimo ir tvarkymo katedra) ir Indriūnas Algimantas (Šildymo ir vèdinimo katedra).

1970 m. buvo numatyta perkelti iš Kauno ì Vilnių net 34 dèstytojus. Turëjo persikelti: Puodžiukynas Leonas (Statybos darbų organizavimo katedra), Rachlevičiene Danute (Šildymo ir vedinimo katedra), Brazys Romualdas, Gastila Leonas, Jurgaitis Jonas, Lukoševičius Kęstutis, Poviliūnas Jonas,
Žeromskas Renius (Automobilių transporto katedra), Skeivalas Jonas (Geodezijos katedra), Viršilas Vytautas ir Senuta Algirdas (Statybinès mechanikos katedra), Lukošaitis Adolfas, Peras Jokūbas, Abramauskas Stasys, Vaivada Anicetas, Saunoris Vytautas, Kasputis Vytautas, Ziberkas Leonidas, Keturka Alfonsas (Architektūros katedra), Šešelgis Kazimieras, Kleinas Mečislovas, Jurkštas Vytautas, Vanagas Jurgis, Dičiuviene Neringa(Gyvenviečių planavimo ir tvarkymo katedra), Marčiukaitis Gediminas (Gelžbetoniniu konstrukcijų katedra), Paulauskas Jonas (Metalinių konstrukcijų katedra), Ušinskas Stasys, Janulis Alfonsas, Degutis Albinas (Grafinių darbų katedra), Žintelis Bernardas, Nakas Algimantas, Verbickis Valerijonas (Pastatų konstrukcijų katedra), Šimkus Jonas ir Furmanavičius Liudvikas (Inžinerinès geologijos katedra).

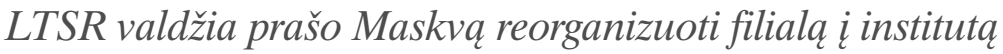

1968 m. gruodžio 3 d. Lietuvos kompartijos lyderis A. Sniečkus ir premjeras J. Maniušis pasiunte raštą TSRS Ministru Tarybai, kuriame išdeste motyvus, kodèl reikia reorganizuoti KPI Vilniaus filialą ¿̇ Vilniaus inžinerinị statybos institutą. Svarbiausia - išaugo ir toliau dideja statybu apimtys ir reikia labai daug specialistų.

Rašte teigiama, kad tokiai reorganizacijai pritare TSRS Aukštojo ir specialiojo vidurinio mokslo ministerija.

Išvardytas studentų ir pedagogų skaičius, numatomos jo augimo apimtys. Pabrèžiama, kad 1969-1970 mokslo metais institute dirbs 320 destytojų, iš kurių 96 su mokslo laipsniais ir vardais. Pažymèti filialo profesūros moksliniai laimejjimai, turima filialo materialinè bazè.

LTSR valdžia praše Maskvą KPI Vilniaus filialą reorganizuoti i Vilniaus inžinerinị statybos institutą nuo 1969-1970 mokslo metų pradžios.

Atrodytu, filialas paverstas institutu - ir jau viskas padaryta. Tačiau laikas ejo, o sprendimo vis dar nebuvo. Prisimindamas tą situaciją, švenčiant VISI 20-metị, Aleksandras Čyras raše:

„Šitai pavyko ne iš karto. Pirmame posedyje $1969 \mathrm{~m}$. klausimas buvo atidetas, matyt, dèl tuo laiku posedžiui pirmininkavusio TSRS
Ministru Tarybos pirmininko pavaduotojo K. Mazurovo neryžtingumo. Tada teko kreiptis pagalbos $i$ LTSR Ministry Tarybos pirmininka J. Maniušz, ir tik po jo pokalbio su tuometiniu TSRS Ministry Tarybos pirmininku A. Kosyginu 1969 m. liepos $18 d$. posedyje buvo priimtas nutarimas Nr. 559, kuriuo KPI Vilniaus filialas buvo pertvarkytas i Vilniaus inžinerini statybos instituta. Šis klausimas TSRS Ministru Tarybos posedyje buvo išsprestas labai operatyviai ir nereikejo netgi TSRS aukštojo ir specialiojo vidurinio mokslo ministro V. Jeliutino pasisakymo " $[3.44$, p. 3].

1969 m. liepos 25 d. Lietuvos TSR Ministru Taryba priemè nutarimą Nr. 313 „Dèl Vilniaus inžinerinio statybos instituto organizavimo“, o liepos $31 \mathrm{~d}$. Lietuvos TSR Aukštojo ir specialiojo vidurinio mokslo ministro pareigas einantis Vaclovas Pranaitis išleido įsakymą Nr. 231 „Dèl Kauno politechnikos instituto Vilniaus filialo pertvarkymo ic Vilniaus inžinerinị statybos institutą". Jame skelbiama:

"1. Vilniaus inžinerinio statybos instituto rektoriaus pareigas nuo $1969 \mathrm{~m}$. rugpjūčio 1 d. pavesti laikinai eiti profesoriui, technikos moksly daktarui Aleksandrui Čyrui, atleidžiant ji iš Kauno Politechnikos instituto prorektoriaus Vilniaus filialui pareigu. 
KAUNO

POLITECHNIKOS

INSTITUTO

VILNIAUS FILIALAS
БЮЛЛЕТЕНЬ

Министерства высшего и среднего специального образования СССР

2. Skirti laikinai eiti Vilniaus inžinerinio statybos instituto prorektoriaus mokymo reikalams pareigas docenta, technikos moksly kandidatq Romualda Jonuša nuo 1969 m. rugpjūčio $1 d$., atleidžiant ji iš Kauno politechnikos instituto prorektoriaus Vilniaus filialui mokymo reikalams pareigu..." [3.37, p. 229-230].

Kiek vèliau buvo paskirti mokslo reikalų bei administracijos ir ūkio reikalų prorektoriai.

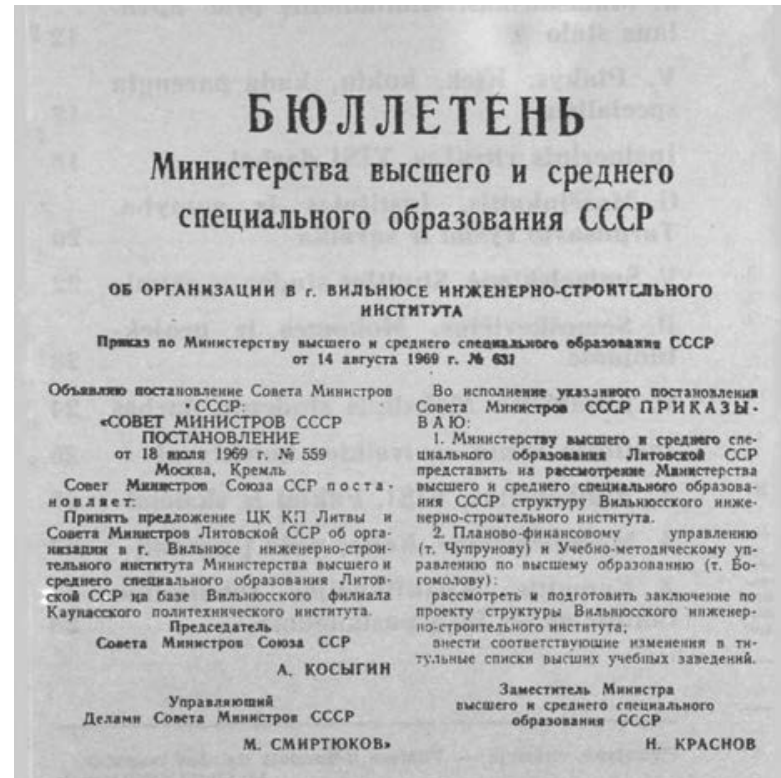

\section{KPI Vilniaus filialo įsteigimo ir veiklos reikšme}

Be abejo, rengti respublikos reikmèms reikalingus specialistus $1956-1969 \mathrm{~m}$. galejo Kaune veikiantis politechnikos institutas. Nuolat didinant studentų kontingentą, suprantama, būtų tekę didinti pedagogu skaičių, atitinkamai plètoti materialinę instituto bazę. Tačiau tokia aukštujjų technikos mokslų koncentracija galëjo turèti ir minusų, ir pliusų.

Pirmiausia - sostinès lietuvinimas būtų vykęs daug lečíau, ypač įvertinant tai, kad Kaune baigę aukštuosius technikos mokslus nesiverže gyventi ir dirbti ị aprusejjusį Vilnių. Taigi tokiomis aplinkybemis pramonés, eksploatacinių tarnybų inžinerinis personalas daugiausia tebūtų ne lietuvių tautybès, nes pakeisti ateivius lietuviais lengviausia buvo, jei jie, kaip specialistai, išaugdavo tose pačiose gamyklose, įmonèse, îstaigose. Todèl vakarines studijos KPI Vilniaus skyriuje, fakultete ir galop filiale tuo klausimu buvo labai svarbios.

Antrosios technikos mokyklos atsiradimas jau sudare tarp KPI centro ir KPI Vilniaus filialo tam tikrą konkurenciją, kuri nuolat augo ir, žinoma, abipusiškai gerino tiek pedagogini, tiek mokslinį darbą.

Suverenios aukštosios mokyklos kūrimas Vilniuje reikalavo reikšmingu papildomu lěšų, studijoms ir mokslui skirtu patalpų, bendrabučiu ir kt. Tai sumažino Kauno instituto materialines galimybes, bet Vilnius kasmet pasipildydavo gausiu būriu tautinio jaunimo, kuris, baigęs studijas, dažniausia dirbdavo pagal specialybę Vilniuje ar Vilniaus krašte.
Taigi 1969 m. rugsëjo1 d. prasidëjo jau naujas visiškai savarankiškos aukštosios mokyklos gyvenimo etapas, trukęs per du dešimtmečius.

Kartais iš toli matyti geriau. Negalime nepacituoti Bronio Railos, kuris tais 1969 metais, gyvendamas Jungtinèse Amerikos valstijose raše: „Nepaisant visiško padeties beviltiškumo, kruvinai sumaitoto tautos kūno, suardytos ekonomines ir socialines sarangos, vulgariausio Nepriklausomybes squvokos išjuokimo, nepaisant iki minimumo sumažejusiu gyvuju lietuvišku pajegu, rusu kolonistu ir tūkstančiu sargybiniu is "plačiosios tevynes" infiltravimo, Dievo garbinimo ir visu kitu žmogaus laisviu ikalinimo, visu gyvenimo sričiu pajungimo ir persunkimo okupacines funkcijos ir sovietizacijos pareigai atlikti, - lietuviu tautos nugarkaulis nebuvo sulaužytas <...>".

Lietuvių tauta „<...> susirinko ir susitvarke, kiek tik buvo imanoma ir neimanoma, smurtu jvestuose sovchozuose ir kolchozuose, dirbtuvese ir fabrikuose, mokyklose ir akademinese katedrose, kaimuose, miesteliuose ir miestuose, o senaja Lietuvos sostine Vilniu skubina paversti lietuviškesniu, negu bet kada per $d u$ pastaruoju šimtmečiu. Ji aktyviai sugeba dalyvauti Lietuvos supramoninimo procese, kai kuriais atvejais tegu ir dirbtiniame, okupanto sukurtam Lietuvos ūkiniam išnaudojimui ir kolonizacijai spartinti, bei šaip jau teigiama ir svarbia linkme, kuri Lietuva pavers modernia industrine valstybe ir sudarys pusiausvyra tarp jos sodietiškumo ir miestiškumo. Krašto supramoninimas ir stambiu lietuviu miestu išvystymas yra modernines civilizacijos būtinybe, 
kuria lietuviu tauta turi skubiai pasiekti, jei nori išlikti šiu laiku bendruomenes respektuojamu dalyviu " [3.45, p. 154-155].

Mūsų manymu, šios citatos autorius labai taikliai apibūdino tuometinę situaciją. Tai ką B. Raila raše 1969 metais - tuomet, kai buvo ịkurtas Vilniaus inžinerinis statybos institutas. Ar čia yra ką komentuoti? Anot E. Nekrošiaus, jeigu mes verpstes drožtume, kam mes būtume įdomūs?

KPI Vilniaus filialas nuo 1956 iki $1969 \mathrm{~m}$. parengè respublikai 1945 puikios kvalifikacijos technikos specialistus inžinierius, kurių absoliuti dauguma užsirekomendavo kaip dori žmonès, gerai išmanantys profesinius dalykus. Daug KPI Vilniaus filialo absolventų tapo gamyklų, įvairiu įmonių, statybų vadovais, kai kurie - mokslininkais, pedagogais, administracijos darbuotojais.

KPI Vilniaus skyriaus, fakulteto ir filialo kūrimo procesas buvo sudetingas. Dideli nuopelnai priklauso idejos iškelejjui ir igyvendinimo generatoriui KPI rektoriui profesoriui Kazimierui Baršauskui. Tačiau vargu ar per 13 metų būtų susiformavusi suvereni Vilniaus aukštoji technikos mokykla, jei filialo priešakyje nebūtų stovëjęs profesorius Aleksandras Čyras. Tai dèl jo didelès energijos, sumanumo ir, be abejo, asmeniniu ambicijų, nepaisant įvairiausių sunkumų ir kliūčių, 1969 m. rugsëjo $1 \mathrm{~d}$. pradejo funkcionuoti suvereni aukštoji technikos mokykla Lietuvos sostineje - Vilniaus inžinerinis statybos institutas.

Vis dellto reikia teigti, kad Vilniaus aukštosios technikos mokyklos įkūrejais laikytinos dvi Lietuvos istorijoje ryškios asmenybès. Tai - profesorius Kazimieras Baršauskas ir profesorius Aleksandras Čyras.

Negalima pamiršti ir pozityvios kai kuriu respublikos vadovų paramos.

Mes nesiimame vertinti plačiąja prasme A. Sniečkaus, M. Šumausko, J. Maniušio veiklos Lietuvoje. Bet Vilniaus inžinerinis statybos institutas nebūtų ịsteigtas be palankios minèty asmenu nuomones.

Teigiamai reikia vertinti, nepaisant kai kurių suprantamų prieštaravimų kai kuriais instituto kūrimo klausimais, tuometinių Lietuvos aukštojo ir specialiojo vidurinio mokslo ministro profesoriaus Henriko Zabulio ir jo pavaduotojo docento Vaclovo Pranaičio veiklą. Jų indèlis ir parama steigiant institutą - labai reikšmingi.

Daug padejo plètoti KPI Vilniaus filialą Vilniaus pramonès įmonès. Pradiniu kūrimosi Vilniuje etapu neužmirštamas mūsų senojo - Vilniaus universiteto - geranoriškumas.

Labai nelengvą darbą atliko ir didžiules pastangas skyre patys KPI Vilniaus filialo darbuotojai. Būtina paminèti Jeronimą Kudabą, Romualdą Jonušą, Antaną Kudzị, Vytautą Kriščiūną, Daumantą Maciulevičių, Borisą Liaudį, Stanislovą Marazą, Ipolitą Nickų, Romualdą Uždavinị, Zenoną Vainorị, Antaną Simoną Pilypaitị, Algirdą Baliuli, Joną Žemkų, Judelį Charitą, Albiną Martinaitị, Edmundą Mauzą ir daugelį kitų, kurių pečius užgule kūrimosi sunkumai, o jiems atlaikyti atiduota daug energijos ir sveikatos.

KPI Vilniaus filialas nebūtu palyginti taip sparčiai augęs, tvirtęjęs be kauniečiu paramos. Daug Kauno politechnikos instituto katedru desstytojų važinëjo ị Vilnių skaityti paskaitu, vesti praktinių užsiemimų, laboratorinių darbų. Kai kuriuos laboratorinius darbus Vilniaus studentai atlikdavo atvykę i Kauną. Visa tai buvo įmanoma esant geranoriškam tų katedrų darbuotojų požiūriui į filialą, o požiūris formuotas ne be rektoriaus K. Baršausko neslepiamo palankumo.

Visos Lietuvos aukštųjų mokyklų, universitetų šaknys įleistos ị senąji Vilniaus universitetą. Iš jo išaugo visi institutai, visi universitetai. Iš senojo Universiteto buvo ir yra semiamasi dvasingumo, istorines patirties ir išminties. Vilniaus universitetas buvo ir visada bus Lietuvos aukštojo mokslo avangardas. Malonu pažymèti, kad per 50 savo veiklos metų Vilniaus aukštoji technikos mokykla tvirtai atsistojo ant trečiojo aukštųjų mokyklų eilutes laiptelio.

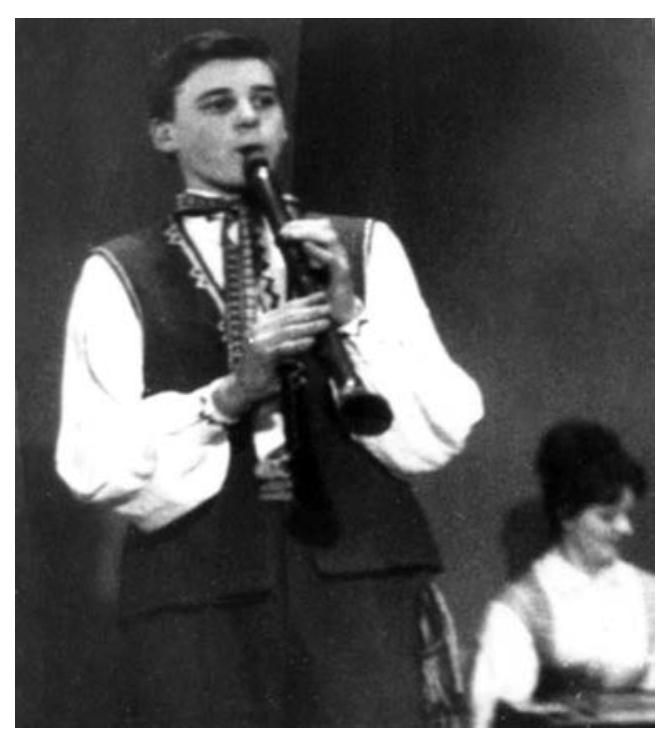






\section{VILNIAUS}

INŽINERINIS STATYBOS

INSTITUTAS

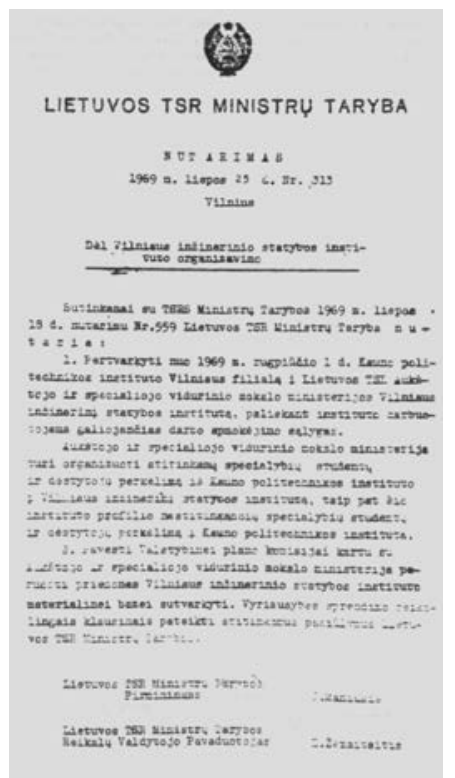

Institutas veiklos pradžioje

1969-1970 mokslo metų pradžia buvo ypatinga. Vilniaus aukštoji technikos mokykla - jau savarankiška. Solidūs buvo ir studijuojančiujų skaičiai: dieniniame skyriuje studijavo 1939 studentai, vakariniame - 2 426, $\mathrm{o}$ iš viso 4365 studentai.

İkurtąji institutą sudare 4 fakultetai: Statybos ekonomikos, Miestų statybos, Prietaisu gamybos ir Mechanines technologijos.

Statybos ekonomikos fakultetas renge dviejų specialybių inžinierius: 1721 - statybos ekonomikos ir organizavimo ir $1202-$ pramoninès ir civilinès statybos. Šiame fakultete veike 5 katedros: Statybos ekonomikos, Mechanikos, Statybinių konstrukcijų, Specialiųjų konstrukcijų ir Chemijos.

Miestų statybos fakultetas renge trijų specialybių inžinierius: 1206 - Miestų statybos, 1211 - Automobilių kelių ir 1301 - Inžinerinès geodezijos. Šiame fakultete veikè $5 \mathrm{ka}$ tedros ir 1 metodine komisija, besirengianti tapti katedra: Kelių, Hidraulikos, Miestų statybos, Geodezijos, Matematikos katedros bei Pagrindų ir pamatų metodinè komisija.

Mechaninès technologijos fakultetas renge septynių specialybių inžinierius: 1609 -automobiliu transporto, 1725 - automobiliu transporto ekonomikos ir organizavimo, 0511 - statybos ir kelių mašinų bei įrengimų, 0504 - suvirinimo įrenginių ir technologijos, 0636 - mašinu gamybos procesu automatizavimo, 0501 - mašinų gamybos technologijos ir 1709 - mašinu gamybos pramonès ekonomikos ir organizavimo. Šiame fakultete veikè 5 katedros: Mašinų teorijos, Mašinu gamybos automatizavimo, Braižybos, Metalų apdirbimo ir Gamybos ekonomikos.

Prietaisu gamybos fakultetas renge triju specialybių inžinierius: 0705 - radijo aparatūros konstravimo ir gamybos, 0615 - garso technikos, 0628 - elektros pavarų ir gamybos įrengimu automatizavimo. Šiame fakultete veike 5 katedros: Elektrotechnikos, Elektros įrengimų, Radijo aparatūros technologijos,
Fizikos bei Elektros ir skaičiavimo technikos (pastaroji vèliau pavadinta Radioelektronikos katedra).

Be minetujjų, institute veikè 6 vadinamosios bendrosios katedros: TSKP istorijos, Politinès ekonomijos, Filosofijos ir mokslinio komunizmo, Karinio parengimo, Kalbų ir Fizinio lavinimo.

Taigi tuo metu VISI veike 26 katedros ir 1 metodine komisija.

Atskirų specialybių studentų skaičius buvo labai nevienodas. Daugiausia buvo rengiama pramonines ir civilinès statybos bei mašinų gamybos technologijos specialistu. Štai koks buvo studentų pasiskirstymas pagal specialybes 1969-1970 mokslo metais:

Statybos ekonomikos fakultete studijavo 872 dieninio ir 419 vakarinio skyrių studentų. Pagal specialybes tai sudare: statybos ekonomikos ir organizavimo specialybès dieniniame skyriuje - 262, vakariniame skyriuje - 176 studentai; pramonines ir civilines statybos specialybes dieniame skyriuje - 610 , o vakariniame skyriuje - 243 studentai.

Miestų statybos fakultete studijavo 376 dieninio ir 155 vakarinio skyrių studentai. Pagal specialybes tai sudare: miestu statybos specialybès dieniame skyriuje - 161, vakariniame skyriuje - 155 studentai, automobilių keliu specialybès dieniame skyriuje - 128 , inžinerinès geodezijos specialybès dieniame skyriuje - 87 studentai.

Mechanines technologijos fakultete studijavo 568 dieninio ir 1029 vakarinio skyrių studentai. Pagal specialybes tai sudarè: automobilių transporto specialybes dieniame skyriuje - 194, vakariniame skyriuje - 152 studentai; automobiliu transporto ekonomikos ir organizavimo specialybès dieniame skyriuje - 114; statybos ir kelių mašinų bei įrengimų dieniniame skyriuje - 106 studentai; suvirinimo įrengimy ir technologijos dieniniame skyriuje - 100, vakariniame 
skyriuje - 130 studentų; mašinų gamybos procesu automatizavimo dieniniame skyriuje - 54, vakariniame skyriuje - 23 studentai; mašinu gamybos technologijos vakariniame skyriuje - 644; mašinu gamybos pramonés ekonomikos ir organizavimo vakariniame skyriuje - 80 studentu.

Prietaisu gamybos fakultete studijavo 123 dieninio ir 823 vakarinio skyriu studentai. Pagal specialybes tai sudare: elektros pavaru ir gamybos îrengimų automatizavimo vakariniame skyriuje - 307; radijo aparatūros konstravimo ir gamybos dieniame skyriuje -108 , vakariniame skyriuje - 516; garso technikos dieniame skyriuje - 15 studentu.

Nors institutas buvo statybos profilio, statybos specialybiu tebuvo penkios. Net šešios specialybè buvo mechaninio profilio [4.1, p. 32].

Vilniaus inžinerinis statybos institutas nuo pat savo veiklos pradžios buvo vyriška aukštoji mokykla: 1969-1970 mokslo metais čia studijavo 3118 jaunuoliu ir 1231 mergina, arba $72 \%$ vyrų ir $28 \%$ moteru.

Mums įdomus studentų kontingentas pagal tautybę: lietuvių buvo 2525 , rusų 1294 , lenku - 99, kitu tautybiu - 431 studentas. Taigi lietuviai sudare $58 \%$ visu studentu.

Socialinès studentų sąlygos buvo nelengvos. Iš 1939 dieninio skyriaus studentų stipendijas gavo 1214 , arba $63 \%$. Bet ypač sunki buvo bendrabučiu padetis. Juose gyveno tik 674 studentai, arba $35 \%$ visų dieninio skyriaus studentų, kurių dauguma buvo atvykę iš provincijos.

Stipendijos buvo dvejopos: iš valstybès biudžeto ir įmonių lešú. Tačiau pastarųjų buvo nedaug - tik 84 . Tai sudare $7 \%$ visu stipendijų. 48 studentai gavo pirmūno stipendijas, 1 - vardinę (Lenino).

1969-1970 mokslo metais pedagogini personalą sudare 380 déstytojų: 271 déstytojas buvo etatinis, po 0,5 etato turejo 12 asmenu, o 87 buvo valandininkai.

Institute dirbo 3 mokslų daktarai profesoriai, 91 mokslų kandidatas, 66 docentai. Mokslinius vardus ir laipsnius turejo iš viso 94 pedagogai.

Tautiniu požiūriu VISI pedagogų komanda buvo labai lietuviška. Lietuvių buvo 238 , rusu -24 , lenku -5 , kitų tautybiu -14 . Taigi pedagoginį-mokslinị personalą sudaré $85 \%$ lietuvių ir tik $15 \%$ - kitų tautybių.

Daugumos VISI destytoju pedagoginis stažas nebuvo didelis, bet tai kompensavo jaunų žmonių entuziazmas, energija ir pažinimo troškimas. Iki 5 metų pedagoginį stažą turëjo net 112 déstytojų, 5-10 metu - 79, 10-15 metu - 46, likę - per 15 metų.

Studijos institute vykdytos pagal dar KPI parengtus mokymo planus. Buvo sudarytos disciplinų darbo programos, kurios turejo užtikrinti tiek fundamentaliųjų, tiek specialiųju žinių pakankamai gerą išmokimo lygị.

Destytojai, remdamiesi disciplinos darbo programomis, nustatydavo (kaip ir dabar) reikalingą vienu ar kitu klausimu informacijos rūšį ir kiekị paskaitoje. Tai daugiausia priklause nuo destytojo pedagoginio meistriškumo, inžinerines praktikos ir mokslinio potencialo. Siekiant parengti aukštos kokybès visapusiškus specialistus, pirmuose kursuose daugiausia laiko skirta fundamentaliesiems mokslams, ypač matematikai. Vèliau, aukštesniuose kursuose, vyravo specialiosios disciplinos, nuo kurių destymo ir išmokimo lygio priklauso, kaip absolventas adaptuosis konkrečioje darbo vietoje.

VISI studiju sistema numate paskaitas, praktinius užsièmimus (pratybas, laboratorinius darbus, seminarus), egzaminus, iskaitas, kursinius darbus ir kursinius projektus, mokomąsias pažintines ir gamybines praktikas.

Buvo teigiama, kad mokymo turinį lemia ne tik dèstytojo mokslinis ir praktinis (gamybinis) pasirengimas, bet ir jo gebejimas didaktiškai pagrissti parinktą paskaitų medžiagą.

Studiju kokybei ypač daug reikšmès turi mokomoji literatūra, laboratoriju galimybès, mokomosios ir gamybines praktikos. Todèl instituto vadovybe nuo pat pirmujuc savo veiklos dienų daug demesio skyre bibliotekos plètrai, laboratorijų įrangai issigyti, praktiku galimybems gerinti. Daugeliu atvejų visa tai

VISI mokymo bazes plètimo schemos maketas

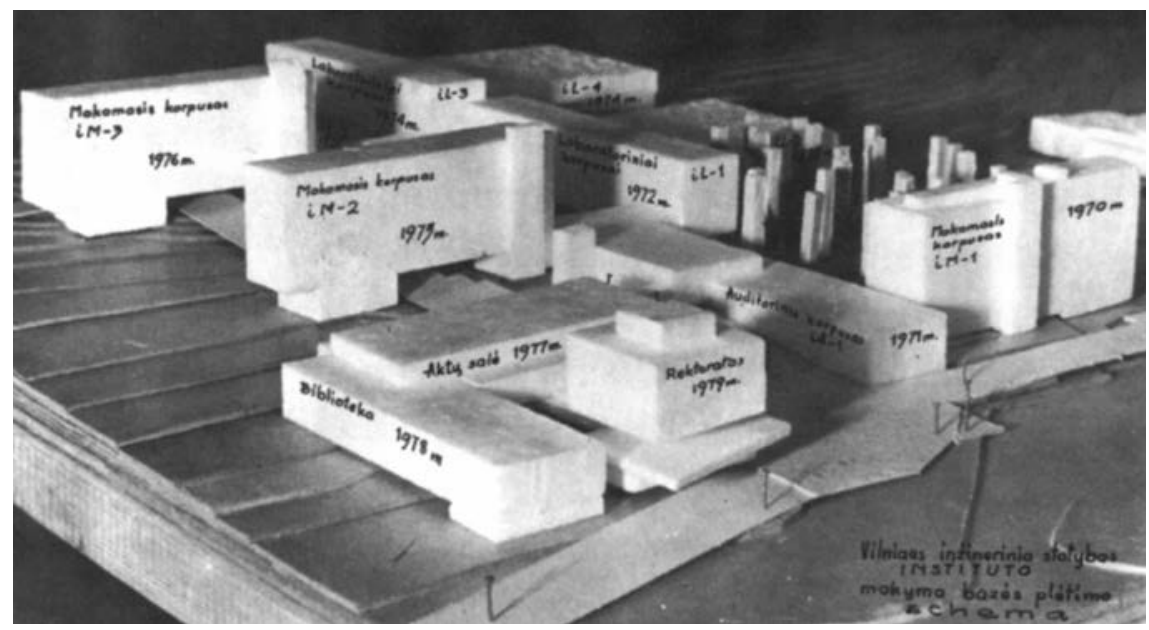


VILNIAUS

INŽINERINIS STATYBOS

INSTITUTAS
Prorektoriu mokymo reikalams skiria LTSR Aukštojo ir specialiojo vidurinio mokslo ministerija, parinkdama ji is labiausiai kvalifikuotu mokslo pedagoginiu darbuotoju, turinčiu mokslo varda arba mokslo laipsni.

Prorektorius mokslo reikalams vadovauja instituto moksliniam darbui. Jis atsakingas rektoriui už instituto mokslo tiriamaja veikla.

Prorektorius mokslo reikalams organizuoja

\section{Pirmieji vadovai}

Vilniaus inžinerinio statybos instituto Statutas buvo patvirtintas LTSR Aukštojo ir specialiojo vidurinio mokslo ministerijos kolegijos nutarimu Nr. 521970 m. gegužès 27 d. Šio Statuto aštuntajame skirsnyje apie instituto vadovybę pasakyta, kokios rektoriaus, prorektorių, dekanų, instituto tarybos ir visuomeninių organizacijų teisès bei pareigos. Statute rašoma (pateikiame sutrumpintai): Vilniaus inžineriniam statybos institutui vadovauja rektorius. Jis skiriamas LTSR Aukštojo ir specialiojo vidurinio mokslo ministerijos is labiausiai kvalifikuotu moksliniu-pedagoginiu darbuotoju, turinčiu mokslini laipsni ir praktinio darbo patyrima.

VISI rektorius vadovauja visai instituto veiklai ir atsakingas už ją. Jis atstovauja institutui visose istaigose ir organizacijose. Laikydamasis istatymu rektorius disponuoja instituto lëšmis bei turtu, sudaro sutartis, išduoda igaliojimus, atidaro bankuose biudžetines ir kitas instituto saskaitas. Jis leidžia VISI įsakymus; remdamasis darbo istatymais, skiria ir atleidžia darbuotojus. Bet prorektorius ir vyriausiajz buhalteri skiria ir atleidžia aukšciau stovinti organizacija - ministerija.

VISI rektorius vykdo savo teises ir pareigas, numatytas TSRS aukstuju mokyklu nuostatuose ir VISI statute.

Vilniaus inžinerinio statybos instituto mokomajam mokslo-metodiniam darbui vadovauja prorektorius mokymo reikalams. Jis atsakingas rektoriui už instituto mokomaja, metodine ir idejine auklejamaja veikla.

Prorektorius mokymo reikalams organizuoja fakultetu ir katedru mokomaji, mokslo metodini ir idejini auklejamaji darba; vadovauja vadoveliu, mokymo priemoniu ir metodines literatūros paruošimui bei leidimui, mokomuju dirbtuviu ir kitu mokymo pagalbiniu istaigu veiklai; kontroliuoja studentu mokomuju ir gamybiniu praktiku pravedima; organizuoja mokomasias metodines konferencijas; vadovauja studentu fiziniam lavinimui; pavaduoja rektoriu, jam išyykus. fakultety ir katedru mokslo tiriamaji darba; vadovauja instituto moksliniu darbu leidimui, bibliotekai, mokslinio tyrimo sektoriui, studentu projektavimo konstravimo biurui, probleminems ir žinybinems laboratorijoms; organizuoja mokslines konferencijas; kontroliuoja aspirantu paruošima ir mokslo pedagoginiu kadru kvalifikacijos kelima; vadovauja ir padeda studentu mokslinei draugijai; organizuoja priemones moksliniams darbams $\dot{i}$ liaudies $\bar{u} k \dot{k}$ idiegti; pavaduoja rektoriu, jam išvykus.

Prorektoriu mokslo reikalams skiria LTSR Aukštojo ir specialiojo vidurinio mokslo ministerija, parinkdama jz iš daugiausia kvalifikuoty mokslo pedagoginiu darbuotoju, turinčiu mokslo varda arba mokslo laipsni.

Prorektorius administracijos - ükio reikalams vadovauja visai instituto administracinei ir ükio veiklai. Ji skiria ir atleidžia ministerija. Jis privalo vadovauti instituto ükinems ir kultūrinems - buitinems jistaigoms, užtikrinti auditoriju, laboratoriju, kabinetu, mokymosportiniu baziu, bendrabučiu, valgyklu ir kt. tvarka ir sanitarini higienini stovi; vadovauti statybai, kapitaliniam ir begamajam remontui; aprüpinti mokymo patalpas, laboratorijas, kabinetus, ükines ir kultūrines - buitines istaigas irengimais, inventoriumi ir medžiagomis; igyvendinti priemones, gerinant studenty ir destytoju bei profesoriu materialines buitines salygas; rektoriui pavedus, jis sudaro sutartis, dalyvauja sprendžiant finansinius ir ükinius reikalus.

Prorektorius administracijos - $\bar{u}$ kio reikalams už savo veikla atsakingas rektoriui ir Aukštojo ir specialiojo vidurinio mokslo ministerijai.

Kaip minèta, Vilniaus inžinerinio statybos instituto rektoriumi buvo paskirtas technikos mokslų daktaras, profesorius Aleksandras Čyras, prorektoriumi mokymo reikalams - technikos mokslų kandidatas, docentas Romualdas Jonušas, prorektoriumi administracijos ir ūkio reikalams - inžinierius Jonas Žemkus.

1969 m. gruodžio 30 d. Aukštojo ir specialiojo vidurinio mokslo ministro įsakymu 


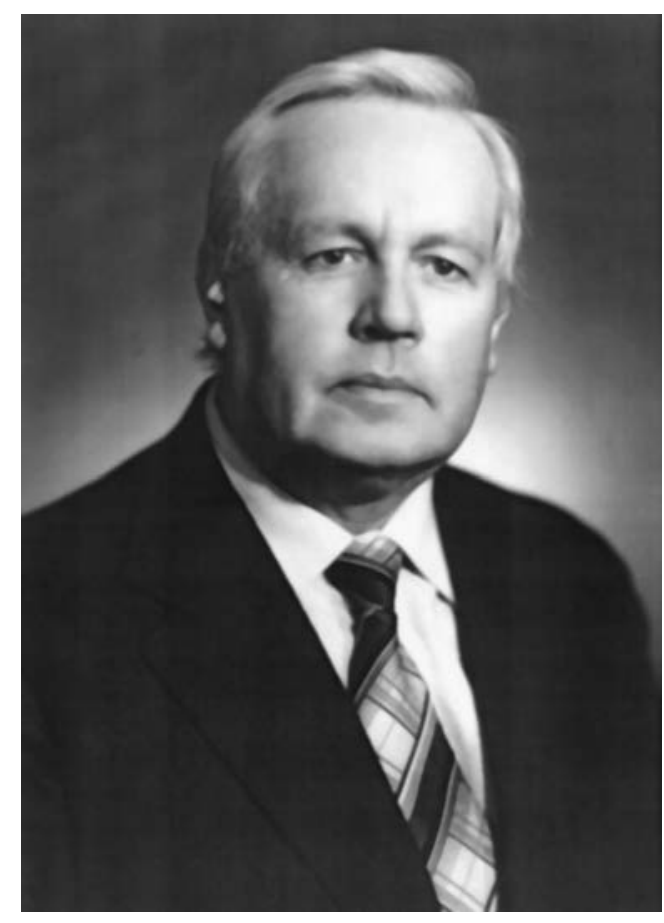

buvo paskirtas ir ketvirtasis prorektorius. VISI prorektoriumi mokslo reikalams tapo technikos mokslų kandidatas, docentas Gediminas Marčiukaitis.

Visi Vilniaus inžinerinio statybos instituto vadovai buvo palyginti labai jauni, energingi, sumanūs.

Aleksandras Cyras gime 1927 m. kovo 15 d. Merkineje, provizoriaus šeimoje. $1945 \mathrm{~m}$. jis baigè Merkinès gimnaziją aukso medaliu ir ịstojo ị Vytauto Didžiojo universiteto Statybos fakultetą. $1950 \mathrm{~m}$. gavo statybos inžinieriaus diplomą su pagyrimu ir liko Statybos fakultete dirbti. Toliau - aspirantūra, kandidato disertacija, persikèlimas ị Vilnių, fakulteto dekano, filialo prorektoriaus pareigos. Apgynè technikos mokslų daktaro disertaciją, gavo profesoriaus mokslinį vardą. A. Čyrą išgarsina mokslo darbai iš statybinés mechanikos, jis gauna aukštai vertinamą Galiorkino premiją, jo darbai tampa žinomi tarptautiniu mastu. Dèl A. Čyro pastangu ir sumanumo KPI Vilniaus filialas išauga i Vilniaus inžinerinị statybos institutą, o jis pelnytai skiriamas instituto rektoriumi.

Romualdas Jonušas gime $1931 \mathrm{~m}$. balandžio 10 d. Kaune. Mokèsi „Aušros“ gimnazijoje, Kauno politechnikume, Kauno politechnikos institute, kuri baige su pagyrimu ir gavo mašinu gamybos inžinieriaus technologo diplomą. Dirbo moksliniu bendradarbiu, dèste politechnikume. Paskui - jau Vilniuje. Buvo „Žalgirio“ stakliu gamyklos vyriausiuoju inžinieriumi, direktoriumi. 1960 m. R. Jonušas apgynè disertaciją „Kumštinių mechanizmų projektavimas ịvertinant nusidèvejimą". 1961 m. buvo paskirtas Liaudies ūkio tarybos Mašinu gamybos valdybos viršininku. Nuo 1962 m. èmé dèstyti KPI Vilniaus filiale. 1964 m. tapo docentu, 1965 m. - Mašinų gamybos automatizavimo katedros vedeju. Nuo 1966 m. - KPI Vilniaus filialo prorektorius mokymo reikalams. Šias pareigas ejo ir ịsteigtame VISI.

Gediminas Marčiukaitis gimè 1932 m. rugpjūčio 29 d. Kalnynų kaime, Marijampoless rajone. 1948-1952 m. mokesi Marijampolès Rygiškių Jono gimnazijoje. 1952-1957 m. studijavo KPI Statybos fakultete pramoninę ir civilinę statybą, gavo statybos inžinieriaus diplomą. 1957-1959 m. dirbo Kauno politechnikos instituto Statybinių konstrukciju katedros asistentu. 1959-1962 m. buvo KPI Gelžbetoninių konstrukciju katedros aspirantu, $1963 \mathrm{~m}$. apgyne technikos mokslų kandidato disertaciją iš statybinių konstrukciju srities. 1964-1969 m. - KPI Statybos fakulteto prodekanas, nuo $1966 \mathrm{~m}$. - docentas. 1969 m. stažavosi JAV. Iš ten grižęs, buvo paskirtas VISI prorektoriumi mokslo reikalams.

Jonas Žemkus gime 1935 m. lapkričio 2 d. Pailiu kaime, Joniškio rajone. 1957 m. baigè Kruopių vidurinę mokyklą. 1957-1958 m. dirbo Pailiu apylinkes pirmininku. 1958-1961 m. tarnavo armijoje. 1961-1965 m. - KPI Vilniaus filialo Kadrų skyriaus viršininkas. 1962-1968 m. studijavo KPI Vilniaus filialo Mechanikos fakultete ir gavo mašinų gamybos ekonomikos ir organizavimo inžinieriaus diplomą. 1967-1969 m. dirbo KPI Vilniaus filialo prorektoriaus pavaduotoju administracijos ir ūkio reikalams. Nuo 1969 m. rugpjūčio 1 d., ryšium su KPI Vilniaus filialo reorganizacija $\mathfrak{i}$ Vilniaus inžinerinį statybos institutą, ministro ịsakymu paskirtas VISI prorektoriumi administracijos ir ūkio reikalams.

VISI Statutas skelbe, kad pagrindiniams VISI veiklos klausimams svarstyti (tik svarstyti, ne spręsti!) prie rektoriaus organizuojama taryba, veikianti TSRS Aukštojo ir specialiojo vidurinio mokslo ministerijos patvirtintų nuostatų pagrindu.

Disertacijoms svarstyti VISI sudaroma taryba, kurios sudetį tvirtina Aukščiausioji atestavimo komisija prie TSRS Aukštojo ir specialiojo vidurinio mokslo ministerijos. Ši komisija nustato ir disertaciju priemimo ginti, mokslo laipsnių suteikimo, taip pat
Aleksandras Čyras

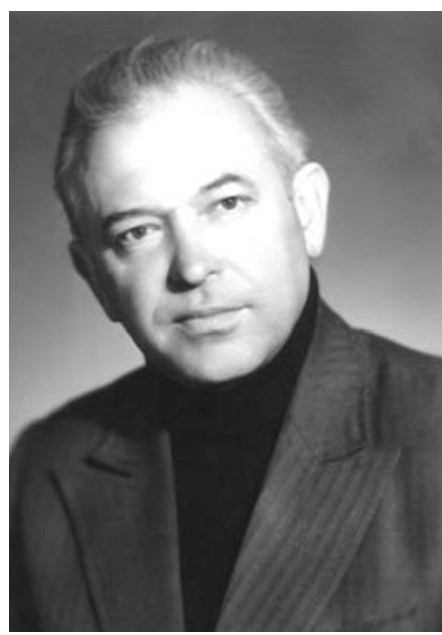

Romualdas Jonušas

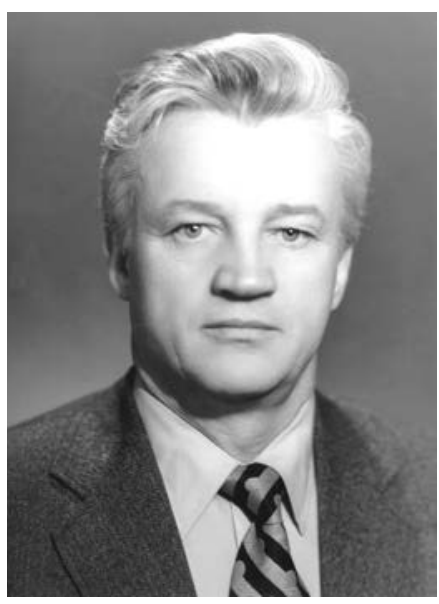

Gediminas Marčiukaitis

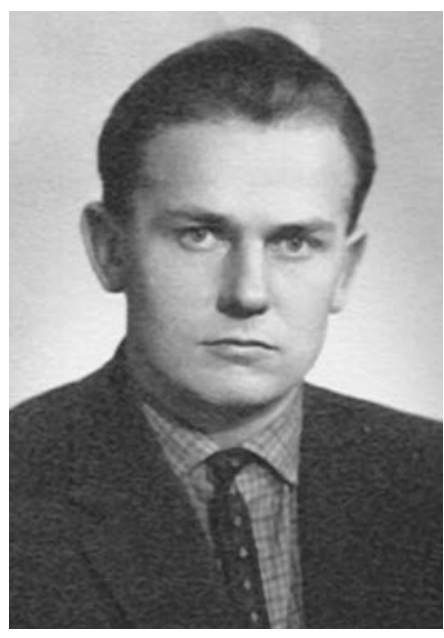

Jonas Žemkus 
VILNIAUS

INŽINERINIS STATYBOS

INSTITUTAS

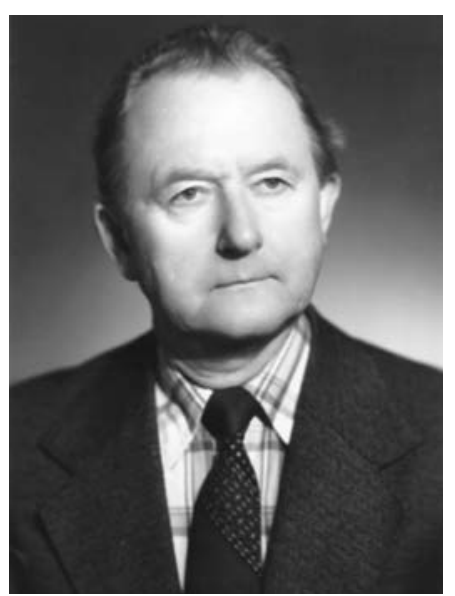

B. Sidauga

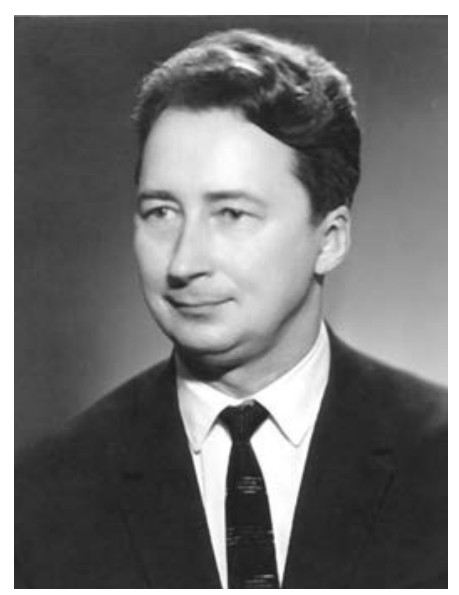

C. Teišerskas pasiūlymų mokslo vardams patvirtinti tvarką.

1969 m. spalio 31 d. LTSR aukštojo ir specialiojo vidurinio mokslo ministro issakymu Nr. 337 buvo patvirtintas VISI mokslines tarybos narių sąrašas. Tarybos nariais buvo šie mokslininkai: Aleksandras Čyras, Romualdas Jonušas, Gediminas Marčiukaitis, Mykolas Burokevičius, Kęstutis Baškys, Vytautas Česonis, Ona Glemžiené, Jeronimas Greska, Judelis Charitas, Viktoras Krušinskas, Antanas Kudzys, Vytautas Kulikauskas, Vytautas Kriščiūnas, Borisas Liaudis, Daumantas Maciulevičius, Albertas Marcelis, Albinas Martinaitis, Edmundas Mauza, Ipolitas Nickus, Anatolijus Rozenbliumas, Steponas Rokas, Antanas Ražinskas, Vasilij Vlasenko, Bronius Sidauga, Algimantas Smilgevičius, Jonas Stanaitis, Česlovas Teišerskas, Zenonas Vainoris. Be to, tarybos nariais buvo partines, komjaunimo ir profsajunginès organizacijų atstovai.

Instituto partinès organizacijos sekretoriumi buvo Algimantas Naujokaitis, profsąjungos vietos komiteto pirmininke - Beatriče Girčienè, komjaunimo komiteto sekretoriumi - Juozas Mureika, Studentų profkomiteto pirmininku - Bronius Dasevičius.

VISI Statutas nustate, kad fakulteto dekanas vadovauja visai fakulteto veiklai. Jis yra renkamas slaptu instituto tarybos balsavimu iš profesorių arba prityrusių docentų TSRS Aukštojo ir specialiojo vidurinio mokslo ministerijos nustatyta tvarka.

Fakulteto dekanas, pažymèta Statute, vadovauja fakultetui pagal teises, nustatytas TSRS aukštujjų mokyklų nuostatais ir fakulteto nuostatais.

Statute nieko nepasakyta apie fakultetu prodekanu teises ir pareigas. Nieko nera ir apie katedrų vedejų funkcijas bei teises.

Statybos ekonomikos fakulteto dekanu tapo docentas, technikos mokslų kandidatas Viktoras Krušinskas, šio fakulteto prodekanais - docentas, technikos moksly̨ kandidatas Audronis Kvedaras ir docentas, technikos mokslų kandidatas Henrikas Gylys.

Miestu statybos fakulteto dekanu tapo docentas, geologijos ir mineralogijos mokslu kandidatas Bronius Sidauga.

Mechanines technologijos fakulteto dekanu tapo docentas, technikos mokslų kan- didatas Borisas Liaudis, šio fakulteto prodekanais - docentas, technikos mokslų kandidatas Kazimieras Markauskas ir vyr. destytojas Vaclovas Klimavičius.

Prietaisu gamybos fakulteto dekanu tapo Česlovas Teišerskas, o prodekanu - vyr. dèstytojas Leonas Janulionis.

Česlovas Teišerskas gime $1932 \mathrm{~m}$. liepos $17 \mathrm{~d}$. Raseiniu rajono Leonavos kaime. Mokesi Raseinių ir Kauno 1-ojoje vidurinèse mokyklose, o nuo 1947 m. - Kauno politechnikume, kurị baige $1951 \mathrm{~m}$. ir gavo techniko elektriko diplomą. 1951-1957 m. mokesi Leningrado elektrotechnikos institute, kurị baigęs gavo inžinieriaus elektriko diplomą. 1957-1959 m. dirbo Vilniuje Energetikos ūkio valdybos relinès apsaugos ir automatikos tarnybos inžinieriumi, vèliau vyr. inžinieriumi. 1959-1963 m. buvo Vyriausiosios energetikos ir elektrifikavimo valdybos prie Lietuvos TSR MT Gamybinio techninio skyriaus viršininko pavaduotoju. Nuo 1959 m. iki 1960 m. dar desste Vilniaus elektromechanikos technikume, o nuo 1960 m. iki 1963 m. - KPI Vilniaus filiale. 1963-1965 m. dirbo LTSR Ministrų Tarybos Valstybinio mokslinio tyrimo darbų koordinavimo komiteto vyriausiuoju specialistu, ejo ne pagrindines pareigas KPI mokslinio tyrimo sektoriuje. 1965-1966 m. ejo docento pareigas KPI Vilniaus filialo Elektrotechnikos katedroje. Nuo 1967 m. buvo fakulteto prodekanu. Buvo bebaigiąs disertacinį darbą mokslų kandidato laipsniui gauti.

\section{Atidarymo iškilmès}

1969 m. rugsëjo 5 d. Profsąjungų kultūros rūmuose įvyko naujujų mokslo metų pradžios iškilmès, kurios faktiškai buvo skirtos Vilniaus inžinerinio statybos instituto veiklos pradžiai pažymèti.

Iškilmingame mokslo metų atidaryme dalyvavo didelis būrys valdžios atstovų: LTSR Aukščiausiosios Tarybos Prezidiumo pirmininkas M. Šumauskas, Ministrų Tarybos pirmininkas J. Maniušis, jo pavaduotoja L. Diržinskaite, Lietuvos KP CK skyriaus vedejai A. Rimkus ir F. Jekateriničevas, Valstybinès plano komisijos pirmininko pavaduotojas A. Brazauskas, Aukštojo ir specialiojo vidurinio mokslo ministras $\mathrm{H}$. Zabulis, jo pavaduotojas V. Pranaitis, kitų ministeriju ir žinybų, aukštųjų mokyklų vadovai. 
Dalyvavo iškilmèse ir svečias iš Maskvos - TSRS Aukštojo ir specialiojo vidurinio mokslo ministerijos kolegijos narys D. Čiuprunovas.

VISI rektorius profesorius A. Čyras gausiai susirinkusiems studentams, dèstytojams, svečiams papasakojo apie dar iki instituto ¡̨ūrimo atliktus darbus, apie svarbiausius uždavinius, kurie keliami naujajam institutui. Vienas jų - rengti kokybiškai naujo tipo inžinierius, gebančius savarankiškai spręsti techninès revoliucijos laikais iškylančius uždavinius, matyti respublikos ir visos šalies ekonomikos, technikos raidos perspektyvas, kokybiškai taikyti teoriją gamyboje.

Ministrų Tarybos pirmininkas J. Maniušis pabrěžè, kad naujieji mokslo metai reikšmingi ir tuo, kad Lietuvoje įsteigta dvyliktoji aukštoji mokykla. „Kauno politechnikos instituto Vilniaus filialas pertvarkytas $i$ savarankiška aukštaja mokykla - Vilniaus inžinerini statybos instituta. Ikurta svarbi ir labai reikalinga aukštoji mokykla, mūsu statybiniu kadru kalve " $[4.2, \mathrm{p}$ 1]. Jis sake, kad respublikos aukštosiose mokyklose 1969-1970 mokslo metais studijuos 57 tūkstančiai studentų, kad proporcingai gyventojų skaičiui Lietuva turi kelis kartus daugiau studentų nei daugelis išsivysčiusių kapitalistinių šalių. Na ir, suprantama, negalejo nepasakyti, kad „Šiu dieny inžinierius ne tik privalo büti geras specialistas, bet ir tureti platu akirati, marksistine-leninine pasauležiūra, büti visapusiškai moksliškai ir politiškai išsilavinusiu žmogumi. Jūsu pasirinkta inžinieriaus profesija yra didelio kürybiškumo ir išradingumo profesija. Todel kiekvieno studento pareiga - atkakliai siekti mokslo žiniu, gerai isisavinti marksistine-leninine teorija, aktyviai dalyvauti visuomeniniame gyvenime, ištvermingai siekti užsibrëžto tikslo - ruoštis savarankiškam darbui" [4.3, p. 1].

Marksistinę-lenininę teoriją studentai „savinosi“ nenoriai, nes beprasmiškai buvo prarandamas studijų laikas. Bet, kaip parode $\mathrm{XX}$ a. priešpaskutinès dekados metai, tą teoriją perkando pakankamai, kad suvoktų jos negyvybingumą, neperspektyvumą ir net absurdiškumą.

Daug kūrybiškumo, energijos destytojams ir studentams palinkejo Aukštojo ir specialiojo vidurinio mokslo ministras $\mathrm{H}$. Zabulis. Jis iškilmių dalyviams teige, kad nors institutas gime didelèse kančiose, sunkiai, bet dabar esąs sveikas ir stiprus, turi gražią ateiti.

Neatvykus į iškilmes KPI rektoriui M. Martynaičiui, Politechnikos instituto vardu sveikino prorektorius mokymo reikalams Č. Jakimavičius. Jis šmaikštavo, kad pabegèlius sveikina pasiekus savarankiškumą, bet linki per daug nesipūsti.

Jau rytojaus dieną spauda rašè:

„TSRS Ministry Tarybos nutarimu KPI Vilniaus filialo bazeje ikurtas savistovus institutas.

Vakar Vilniuje, Profsajungu kultūros rūmuose, ivyko iškilmingas Inžinerinio statybos instituto atidarymas.

Ši, kaip ir bet kuri kita mūsu sostinès sale per maža, kad sutalpintu visus šios šventes dalyvius. Juk vien $i$ dieninio skyriaus pirmaji kursa šimet priimta 675 studentai. Naujasis institutas savo gyvenima pradeda, turedamas 4396 studentus ir <...> kylančius centrinius rümus Nemenčines plento pradžioje. Vèliau čia isikurs visas kompleksas: fakultetu rūmai, inžineriniai-laboratoriniai korpusai, bendrabučiai.

Apie gražias naujojo instituto studentu tradicijas kalba raportai. Darbo ir poilsio stovyklose šiq vasara pabuvojo 575 studentai. Atliktu darbu sąmatinè verté - 464 tūkstančiai rublių. Ir planai $<\ldots .>$ talkininkauti savu rümy statybai, kad kita rugsẹj galima būtų švęsti naujose auditorijose. Na, o svarbiausia - gerai mokytis, tapti visapusiškai išsilavinusiems inžinieriams, kuriu laukia vis gausëjantys pastoliu miškai “ [4.4, p. 1].

Šventès trunka neilgai. Toliau tenka daug ir atkakliai dirbti. Vilniaus inžinerinio statybos instituto jaunas kolektyvas energingai èmèsi darbo. Ypač svarbus darbų baras buvo naujosios statybos. Per 20 metų instituto kapitalines statybos reikalus rektorius A. Cyras laike vienu svarbiausių savojo darbo barų.

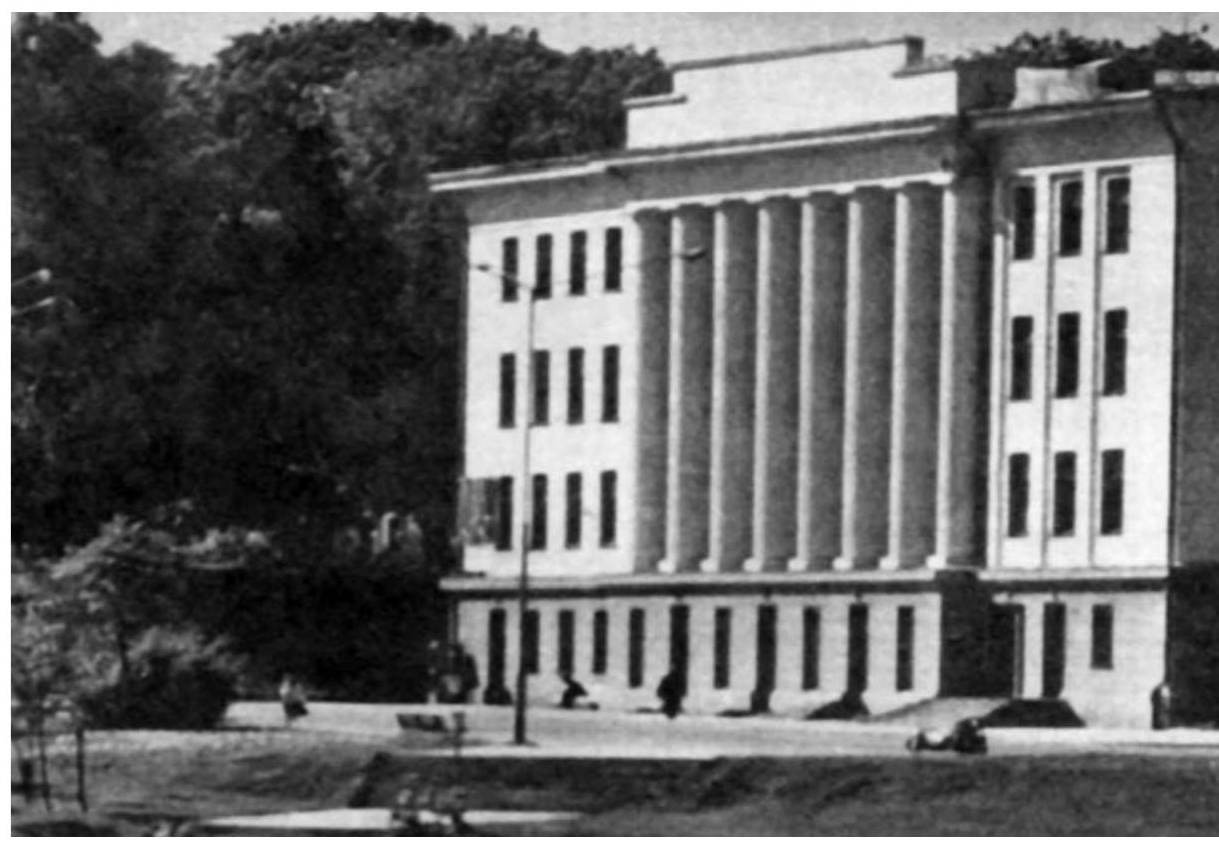

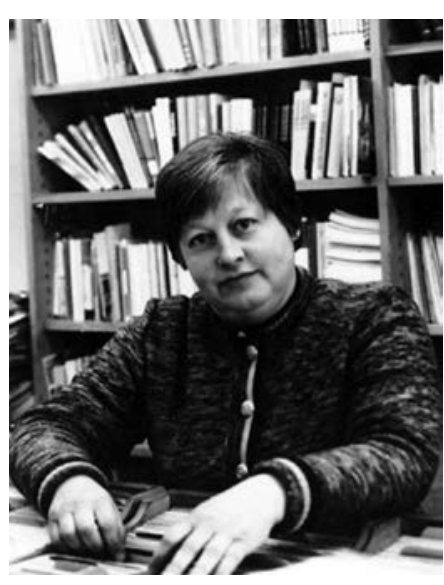

V. Antanaityte - VISI bibliotekos direktore 1969-1972 m.
VISI veiklos pradžia pažymèta Profsajungu rūmuose 
VILNIAUS

INŽINERINIS STATYBOS

INSTITUTAS

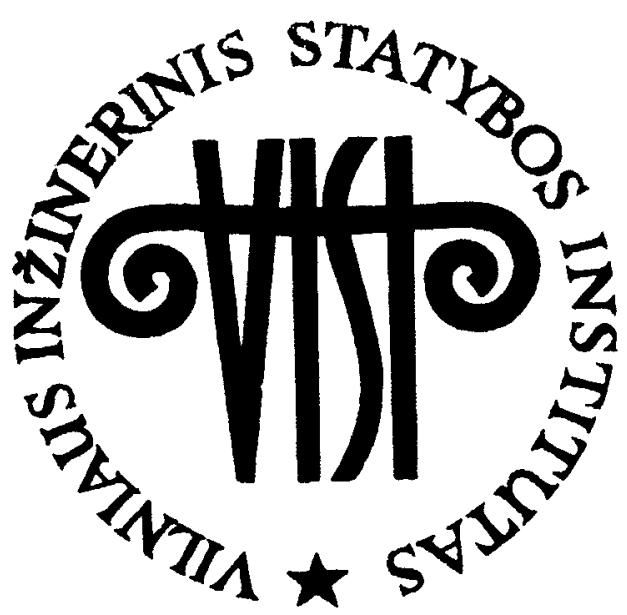

VISI ženklelio projektams žiuri pirmosios premijos neskyré. Antrąja premija buvo apdovanotas PCS 8/4 grupés studentas Vladas Puzakovas, o paskatinamosiomis premijomis - MDV 8/1 grupés studentas Vaclovas Birutis bei VISI aspirantas Antanas Lubys.

Vaclovas Birutis gavo pirmąją premiją už studentiškos kepuraitès projektą [4.5, p. 32, 38].

\section{Nauji organizaciniai dariniai}

1969-1970 mokslo metų pradžiai būdinga intensyvi organizacine naujojo instituto veikla. Formuojamos tarybos, komisijos, žiuri ir pan. Visuose keturiuose fakultetuose VISI rektoriaus įsakymu buvo sudarytos fakultetines tarybos.

Statybos-ekonomikos fakulteto tarybą sudare: pirmininkas dekanas doc. V. Krušinskas, sekretorius doc. A. Čižas, nariai: prof. A. Rozenbliumas, prof. A. Kudzys, doc. I. Nickus, prodekanai e. doc. p. H. Gilys ir e. doc. p. A. Kvedaras. Be to, prie tarybos darbo prisidejo fakulteto partinio biuro sekretorius, darbuotojų ir studentų profsąjungų pirmininkai bei komjaunimo biuro sekretorius.

Prietaisu gamybos fakulteto tarybą sudare: pirmininkas e. dekano pareigas vyr. dest. Č. Teišerskas, sekretorius doc. J. Stanaitis, nariai: doc. V. Česonis, prodekanas vyr. dest. L. Janulionis, doc. E. Mauza, doc. A. Smilgevičius, doc. Z. Vainoris. Be to, tarybos darbe dalyvavo fakulteto partinio biuro sekretorius ir darbuotoju profsąjungos pirmininkas.

Miestų statybos fakulteto tarybą sudare: dekanas doc. B. Sidauga, sekretorius doc.
A. Ražinskas, nariai: doc. S. Rokas, doc. K. Baškys, e. doc. p. R. Jasilionis, doc. V. Kriščiūnas, doc. V. Šeštokas. Be to, tarybos darbe dalyvavo fakulteto partinio biuro sekretorius, darbuotojų ir studentų profsąjungų pirmininkai bei komjaunimo biuro sekretorius.

Mechanines technologijos fakulteto tarybą sudare: pirmininkas dekanas doc. B. Liaudis, sekretorius doc. R. Popilskis, nariai: prodekanai doc. K. Markauskas ir vyr. dest. V. Klimavičius, doc. J. Charitas, doc. D. Maciulevičius, doc. R. Jonušas, doc. A. Martinaitis. Be to, tarybos darbe dalyvavo partinio biuro sekretorius, komjaunimo biuro sekretorius, darbuotojų ir studentų profsąugų pirmininkai.

Kokios funkcijos buvo skirtos fakultetu taryboms rektoriaus įsakyme, nepasakyta. Nieko apie tai nera ir VISI statute. Apie fakultetus nurodyta tai, kad fakulteto dekanas vadovauja visai fakulteto veiklai pagal teises, numatytas TSRS aukštųjų mokyklų nuostatų ir fakulteto nuostatų.

Tačiau žinome, kad tuometinès fakultetų tarybos faktiškai teturëjo patariamąją funkciją. Iš esmès tai buvo dekanų, prodekanų, 
katedrų vedëjų ir visuomeninių organizacijų vadovų pasitarimai. Sprendimus priimdavo dekanas, išklausęs tarybos narių nuomones svarstomais fakulteto klausimais ar problemomis.

Siekiant daryti efektyvesni studiju procesą, mokslinius tyrimus, institutas ieškojo būdų pagerinti bibliotekos darbą.

1969 m. vasarą bibliotekos vedeją Algirdą Baliuli pakeite Vida Antanaityté. Buvo sudaryta VISI bibliotekos taryba: pirmininke vedëja V. Antanaitytè, nariai: doc. K. Bieliūnas, doc. H. Lazarevičius, doc. D. Maciulevičius, doc. A. Marcelis, doc. E. Mauza ir doc. B. Sidauga.

Tais metais dalis bibliotekos fondų iš Giedrio gatvès buvo perkelta ì tuometinius VISI centrinius rūmus (vèliau - IV rūmai).

1969 m. VISI bibliotekos fonduose buvo beveik 120000 knygų, apie 4,5 tūkstančio skaitytojų, 10 etatinių darbuotojų. Bet bibliotekos skaitykloje buvo tik 24 vietos. Taigi bibliotekos pletra buvo nepaprastai svarbus instituto rūpestis. Vis dar labai trūko techninès literatūros, o turimos patalpos mažos, netinkamos, labai prasti baldai, kitas inventorius. Pagirti buvo galima tik nuoširdų bibliotekos personalo darbą.

1969-1970 mokslo metais veiklą pradejo VISI parengiamasis skyrius. Jam vadovauti buvo paskirtas vyr. déstytojas Petras Lukošius, dirbęs ši nelengvą darbą net 20 metur.

Kasmet i parengiamąji skyrių institutas priimdavo po 100 klausytojų: 50 - i dienines grupes ir $50-\mathrm{i}$ vakarines. Klausytojai buvo pramonès įmonių, statybos organizacijų darbininkai, kolūkiečiai, demobilizuoti kariai. Jie turèjo būti baige vidurines mokyklas ir turèti ne mažiau kaip vienerių metų nepertraukiamą darbo stažą. Klausytojai turejo išlaikyti baigiamuosius egzaminus ir paskui galejo studijuoti dieniniame skyriuje.

VISI parengiamasis skyrius veike iki $1989 \mathrm{~m}$.

1969 m. gruodžio 8 d. Lietuvos TSR aukštojo ir specialiojo vidurinio mokslo ministro įsakymu Nr. 988/385 buvo įkurta Žinybine statybos valdymo sistemų mokslo tiriamoji laboratorija. Jos vedeju buvo paskirtas Statybos ekonomikos katedros e. doc. p. t. m. k. Kazimieras Antanavičius [4.5, p. 62].

Po Naujujų metų „organizavus nauja Taikomosios matematikos ir mechanikos katedra, Mechanikos katedra pavadinti nuo s. m. balandžio $1 \mathrm{~d}$. Statybinés mechanikos katedra" - taip rašoma 19700401 rektoriaus įsakyme Nr. 26 [4.5, p. 44].

Institutas, ir ypač A. Čyras, nepamiršta siekimo kuo plačiau naudoti elektronines skaičiavimo mašinas studijų procese. Balandžio $17 \mathrm{~d}$. rektoriaus įsakymu buvo suorganizuoti programavimo su algoritmine „MALGOL" kalba kursai, patvirtintas klausytojų sąrašas. Déstyti pakviestas KPI vyr. déstytojas Stasys Buožis.

\section{Stiprëja mokslininku gretos}

Vilniaus inžinerinio statybos instituto ¡̨kūrimo data sutapo su ižymaus statybos mokslo atstovo persikèlimu iš Kauno ị Vilnių. Rektorius Aleksandras Čyras skyrè labai daug demesio tam, kad VISI suburtu kuo stipresnes mokslines pajegas. Jis ịtikino technikos mokslų daktarą, profesorių, garsu statybinių konstrukcijų specialistą Anatolijų Rozenbliumą gražia instituto perspektyva ir šis, Vilniui turedamas savų sentimentų, sutiko dirbti VISI Specialiųjų konstrukciju katedros vedëju.

A. Rozenbliumo atvykimas dirbti į Vilniaus inžinerinį statybos institutą buvo dar vienas reikšmingas A. Čyro laimëjimas.

Anatolijus Rozenbliumas (1902-1973) 1922-1927 m. studijavo Austrijoje ir Vokietijoje. Metus dirbo projektuotoju Berlyne, o nuo 1929 m. - Kaune, kur greitai buvo pripažintas kaip vienas geresnių statybinių konstrukcijų specialistų. Statybinems konstrukcijoms suprojektuoti ji kviesdavo žymiausi Lietuvos architektai: Vytautas Landsbergis-Žemkalnis, Stasys Kudokas, Feliksas Vizbaras ir kt.

A. Rozenbliumą ypač išgarsino jo per trumpą laiką suprojektuota Kauno sporto hale, kurioje Lietuvos krepšininkai laimejjo Europos čempionatą. Jo suprojektuotas Alytaus gelžbetoninis tiltas per Nemuną buvo didžiausias tokios konstrukcijos tiltas Pabaltijo valstybèse.

Per Antrąji pasaulinị karą stebuklingai išvengęs mirties, po karo, 1948 m., apgynè disertaciją „Betono ir skiedinių optimalių sudečiu nustatymo klausimu", gavo technikos mokslų kandidato laipsnị.

A. Rozenbliumas - vienas iš gelžbetonio mokslinių tyrimų Lietuvoje pradininkų. Jo sukurta gelžbetoninių konstrukciju skaičiavimo teorija buvo pripažinta pasaulinio garso specialistų, jis išugde daug gelžbetoninių

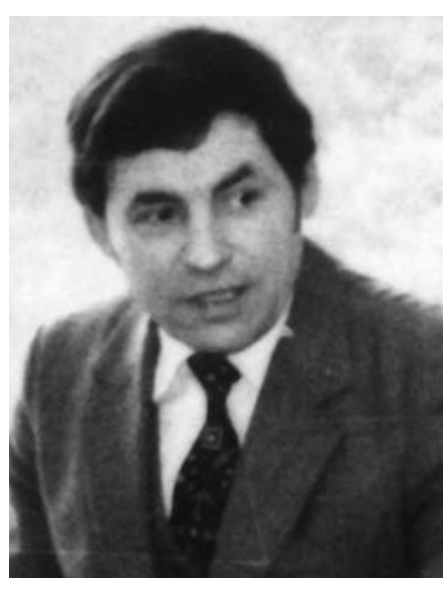

K. Antanavičius

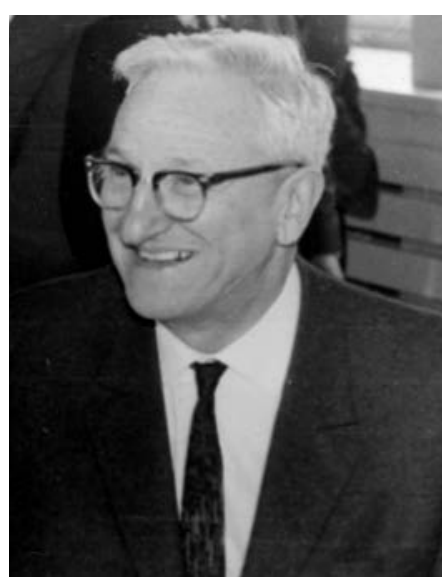

A. Rozenbliumas

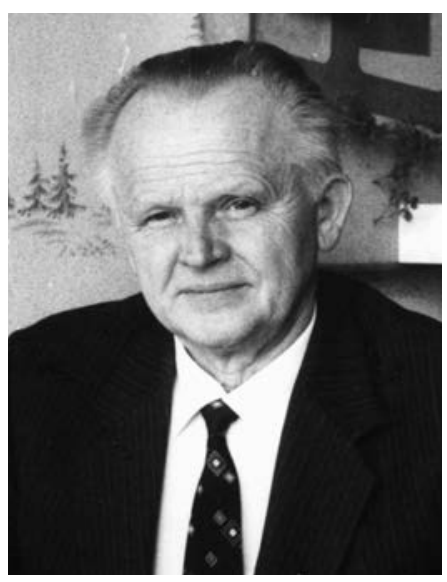

P. Lukošius 
VILNIAUS

INŽINERINIS STATYBOS

INSTITUTAS
Profesorius A. Čyras sake, kad, vadovaujant profesoriui N. Prigorovskiui, D. Maciulevičius gavo naudingų, įdomių rezultatų tiriant smūgius tampriosiose sistemose su paskirstytaisiais parametrais ir sèkmingai apgyne kandidato disertaciją, kuri ir lemè jo mokslinę kryptị - statybinę mechaniką. Toliau dirbdamas D. Maciulevičius nagrinejo matematinio programavimo metodus, parengè būrį aspirantų.

Teigiamai D. Maciulevičiaus disertaciją ìvertino profesorius A. Kudzys.

Pažymètina, kad už technikos mokslų daktaro laipsnio suteikimą D. Maciulevičiui balsavo visi $32 \mathrm{KPI}$ mokslo tarybos nariai.

Tuo metu buvo bebaigią daktaro disertacijas dar du instituto mokslininkai: V. Kriščiūnas ir V. Šeštokas.

Kai instituto Mokslo taryba apsvarste 1969 m. mokslo rezultatus, buvo pažymèta, kad disertacijas VISI apgyne 12 asmenų, iš ju 8 VISI destytojai: A. Rosinas, A. Borkauskas, M. Prikšaitis, A. Žalnieriukas, J. Skeivalas ir kt. Metų pabaigoje institute dirbo trys mokslų daktarai ir 89 mokslų kandidatai. Pasidžiaugta, kad du instituto profesoriai dalyvavo mokslinèse konferencijose užsienyje, kad architektas docentas M. Urbelis stažavo Danijoje, o ypač pasidžiaugta, kad institutas pagaliau pradejo leisti du mokslinių darbų rinkinius.

$1969 \mathrm{~m}$. instituto katedros nagrinëjo 200 mokslinių temų, iš jų 39 - ūkiskaitinių sutarčiu pagrindu.

Daugiausia užsakomųjų darbų atliko prof. A. Kudzio vadovaujami mokslininkai. Jie tyre tiltą per Neries upę Vilniuje ties „ŠEC-2“, bande statine ir dinamine apkrova tiltą per Vokès upę kelyje Paneriai-Trakai, tyre iš anksto įtemptų tiltų sudètinių gelžbetoninių konstrukciju suklijavimo galimybes, renge sijų-sienučiu skaičiavimo nurodymus.

Prof. A. Čyro vadovaujami mokslininkai nustate strypinių sistemų laikančiąją galią matematinio prognozavimo metodais, parengé tamprių-plastinių plokščių skaičiavimo metodiką matematinio programavimo būdais.

Doc. A. Valentinavičius atliko pokraninių sijų defektų tyrimą ir parenge jų sustiprinimo projektą, doc. Z. Kamaitis atliko architektūrinio paminklo - Šv. Onos bažnyčios Vilniuje konstrukcijų tyrimus.

Vadovaujant doc. D. Maciulevičiui, buvo tiriami aerodinaminio elemento stabilūs darbo režimai esant mažiems tarpams, aerotamprūs reiškiniai diskų pakete. 
VILNIAUS

INŽINERINIS STATYBOS

INSTITUTAS

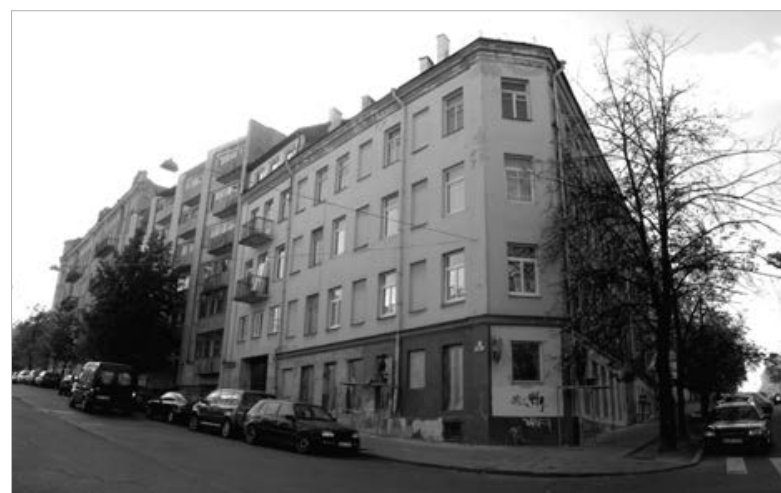

o H. Zabulis teige, kad „Studentu apgyvendinimas rüpi mums visiems. Ministerija stengsis ieškoti išeities “.

A. Ferensą, kaip aukščiausiosios valdžios atstovą, žeide kategoriškas rektoriaus reikalavimu tonas. Jis sake, kad „visi susirüpine instituto mokymo ir laboratorines bazés bükle. Suprantamas visu noras tureti puikias auditorijas, laboratorijas, kabinetus. Tačiau reikia atsižvelgti ir $i$ tai, kaip galima patenkinti visus norus. Respublikos vyriausybe ir LKP Centro komitetas stengési ikurti nauja mokykla. Dabar rüpinamasi tuo, kad mokykla turètu kur ir kaip augti, pletotis. Respublikos statybininkai laukia inžinieriu. Inžinerinis statybos institutas yra inžinieriu ruošimo bazé. Todèl statybinès organizacijos turi susirūpinti, kad sparčiau bütu pabaigtas instituto korpusas. Ars, kaip instituto šefas, stengsiuosi tuos dalykus sutvarkyti taip, kad bütu visi patenkinti-statybininkai, ir institutas. Ašmanau, kad rasim bendra kalba. Juk negalima nepletoti ir neremti naujos aukštosios mokyklos, jeigu ji jau atidaryta, jeigu joje mokosi keli tükstančiai studentu" " [4.1, p. 23].

Rektorius A. Čyras kaip gladiatorius per visą savo rektoriavimo laiką atkakliai kovojo statybų, o ypač studentų miestelio klausimais. Susilaukdavo vadų kritikos, statybininkų antipatijos, apkalbų. Bet tikslą pasieké. Dabartiniai VGTU Sauletekio rūmai - vienas gražiausių profesoriaus A. Čyro sumanios veiklos rezultatu.
Kalbeta ir apie VISI bibliotekos problemas, patalpu remontus ir kt.

I. Dulmanas pažadëjo „detti visas pastangas, kad statomas mokomasis korpusas būtu atiduotas iki naujuju mokslo metu pradžios ",

\section{Baigiant pirmuosius instituto mokslo metus}

1969-1970 mokslo metais Vilniaus inžinerinis statybos institutas išleido 586 aukštos kvalifikacijos specialistus inžinierius. Diplomus gavo: Statybos ekonomikos fakulteto 45 dieninio ir 59 vakarinio skyriu absolventai; Mechaninès technologijos fakulteto 39 dieninio ir 178 vakarinio skyrių absolventai; Prietaisu gamybos fakulteto 118 dieninio ir 103 vakarinio skyrių absolventai; Miestų statybos fakulteto 44 dieninio skyriaus absolventai.

Pramonines ir civilines statybos inžinieriaus diplomus gavo 60 žmonių, Statybos ekonomikos ir organizavimo -44 .

Mašinų gamybos technologijos, metalų pjovimo staklių ir įrengimų inžinieriais tapo 105 žmones, suvirinimo įrenginių ir 
technologijos - 30, automobilių ir automobilių ūkio - 19, mašinų gamybos automatizavimo - 44, mašinų gamybos pramonès ekonomikos ir organizavimo - 12 .

Elektros pavarų ir pramonès įrengimų automatizavimo inžinieriais tapo -44 , radijo aparatūros konstravimo ir gamybos technologijos - 164, garso technikos - 13 žmonių.

Miestų statybos inžinieriais tapo 17 žmonių, automobilių kelių - 14, taikomosios geodezijos - 13 .

Kauno politechnikos institutas $1970 \mathrm{~m}$. išleido 1652 absolventus, t. y. 2,81 karto daugiau nei VISI. Bet jau 1975 m. šis rodiklis buvo jau tik 2,25, 1979 m. - 2,13, o 1984 m. - tik 1,42.

VISI parengtų specialistų kokybès kontrolę praktiškai vertino pats gyvenimas. Bet daug ką iliustravo ir diplomantų atlikti darbai, kuriuos jie gynè Valstybinèse egzaminu komisijose (VEK).

Rektorius A. Čyras visuomet reikalavo, kad VEK pirmininkai būtų geri, pasižymëję profesinëje veikloje specialistai, dažniausiai užimantys vadovaujančiąsias inžinerines pareigas, taigi plačiau suvokiantys problemas, nei tik turintys siaurą specializaciją.

1970 m. Valstybinių egzaminų komisijų pirmininkai buvo: Mechaninès technologijos fakultete - t. m. k. A. Ramonis, ENIIMS Vilniaus filialo vyr. inžinierius; D. Kostiukevičius, LTSR MT Mokslo ir technikos skyriaus viršininkas; A. Paštukas, Visasąunginio suvirinimo mokslo tyrimo instituto Vilniaus filialo direktorius; V. Davulis, Vilniaus autoremonto gamybos direktorius; A. Juršènas, Radijo komponentų gamyklos direktoriaus pavaduotojas; M. Dambrauskas, Šlifavimo staklių gamyklos direktorius.

Prietaisu gamybos fakultete VEK pirmininkais buvo: J. Šatkus, Magnetinių įrašų biuro vyr. inžinierius, ir Saržickas Henrikas, Vilniaus miesto liaudies kontrolès komiteto pirmininkas.

Statybos ekonomikos fakultete VEK pirmininkavo: A. Aksomitas, LTSR MT valstybinio statybos reikalų komiteto pirmininkas, ir J. Rakauskas, Statybos organizavimo ir technikos tobulinimo tresto valdytojas.

Miestų statybos fakulteto VEK pirmininkai buvo: A. Cibas, Visasąjunginio mokslinio tiriamojo technines estetikos instituto Vilniaus filialo direktorius, ir H. Jackevičius, LTSR automobilių transporto ir plentų ministro pavaduotojas.

Visą Vilniaus inžinerinio statybos instituto $1970 \mathrm{~m}$. intelektinę produkciją rengè 28 instituto katedrų déstytojai.

Statybos-ekonomikos fakulteto katedroms vadovavo: Statybos ekonomikos katedrai - t. m. k. V. Krušinskas, Chemijos katedrai - t. m. k. doc. I. Nickus, Mechanikos katedrai - t. m. dr. prof. A. Čyras, Statybinių konstrukcijų katedrai - t. m. dr. prof. A. Kudzys, Specialiųjų konstrukcijų katedrai - t. m. dr. prof. A. Rozenbliumas.

Mechaninés technologijos katedroms vadovavo: Mašinų teorijos katedrai - t. m. k.

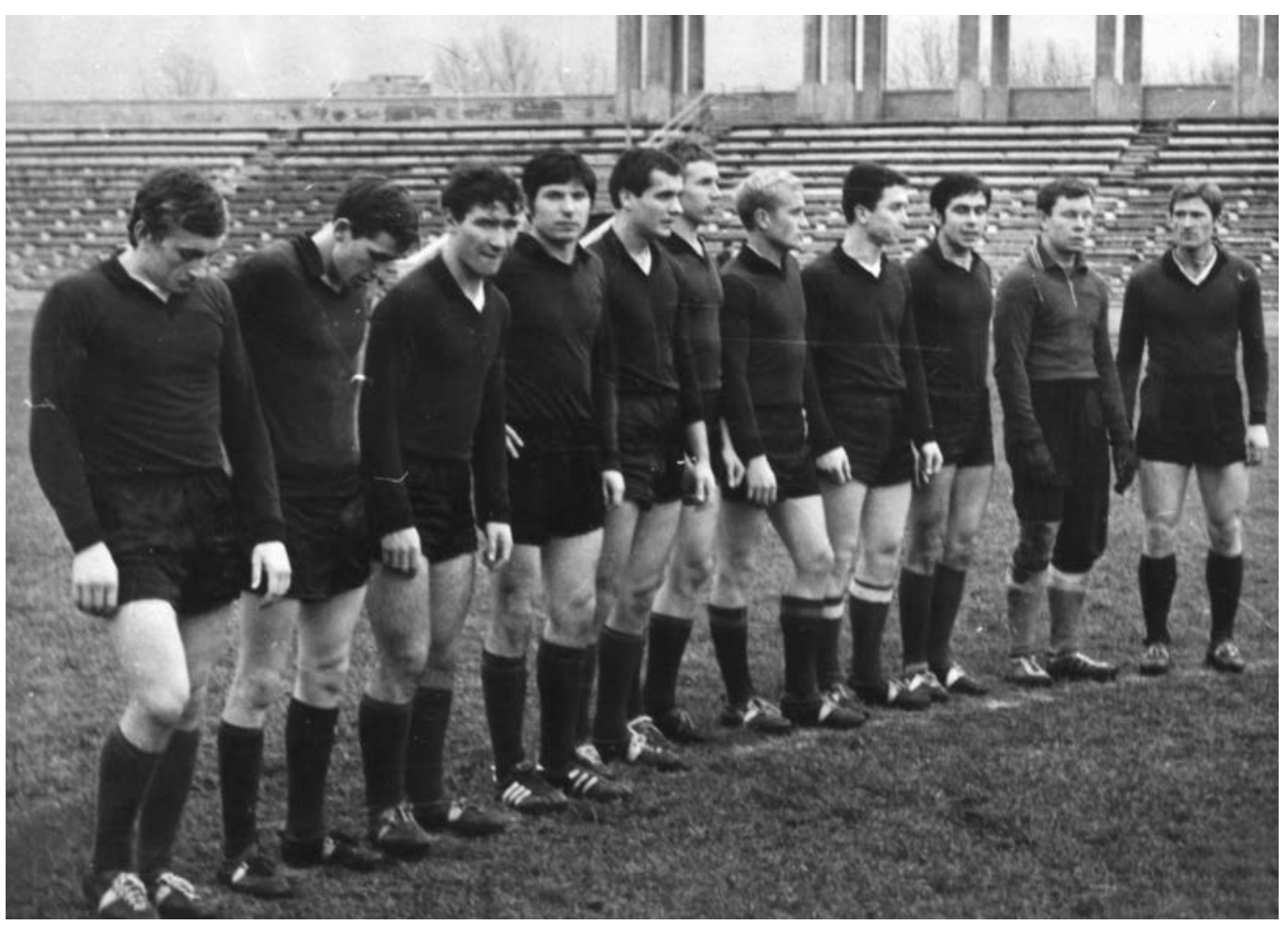


VILNIAUS

INŽINERINIS STATYBOS

INSTITUTAS

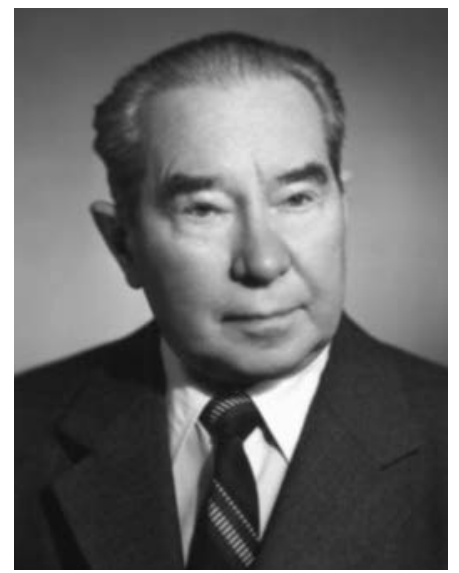

E. Borkauskas

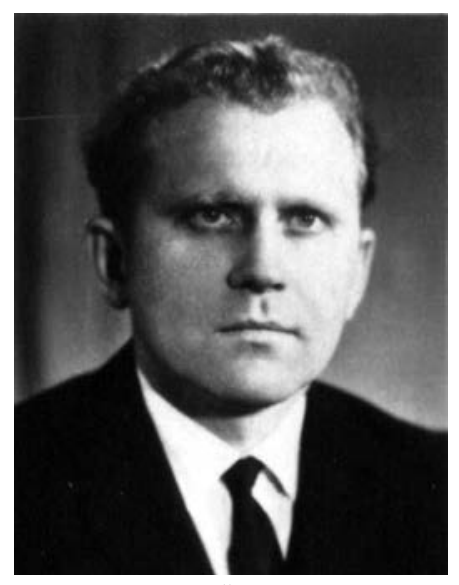

V. Česonis doc. J. Charitas, Metalų apdirbimo katedrai - t. m. k. doc. B. Liaudis, Gamybos ekonomikos katedrai-ekon. m. k. doc.

\section{A. Martinaitis.}

Prietaisu gamybos fakulteto katedroms vadovavo: Elektrotechnikos katedrai - t. m. k. doc. V. Česonis, Elektros įrenginių katedrai - t. m. k. doc. A. Smilgevičius, Radijo aparatūros technologijos katedrai - t. m. k. doc. Z. Vainoris, Fizikos katedrai - fiz. mat. m. k. doc. E. Mauza, Elektronikos ir skaičiavimo technikos katedrai - doc. J. Stanaitis.

Miestų statybos fakulteto katedroms vadovavo: Kelių katedrai - t. m. k. doc. S. Rokas, Hidraulikos katedrai - t. m. k. doc. K. Baškys, Miestų statybos katedrai - t. m. k. doc. V. Kriščiūnas, Geodezijos katedrai - geol. miner. m. k. doc. A. Ražinskas, Matematikos katedrai - fiz. mat. m. k. R. Jasiulionis, Pagrindų ir pamatų metodinei komisijai - geol. miner. m. k. doc. B. Sidauga.

Prieš pat naujuosius 1970-1971 mokslo metus įvykusiame VISI mokslo tarybos posèdyje buvo paskelbta, kad keičiami kai kuriu katedrų ir fakultetu pavadinimai.

Statybos-ekonomikos fakultetas pavadintas Statybos fakultetu (faktiškai tai padaryta nuo $1971 \mathrm{~m}$. rugsëjo $1 \mathrm{~d}$.), Prietaisu gamybos fakultetas - Vakariniu fakultetu, Mašinu gamybos automatizavimo katedra - Mašinu gamybos technologijos katedra, Statybos ekonomikos katedra suskaidoma i dvi: Statybos ekonomikos ir organizavimo (ved. E. Borkauskas) bei Statybos darbu technologijos (ved. V. Krušinskas). Iš Kauno perkeliama Pamatų, pagrindų ir požeminių įrengimų katedra (ved. J. Šimkus). Ji toliau buvo vadinama Pagrindų ir pamatu katedra.

Instituto mokslo taryba nustate tokius VISI rūmų pavadinimus: Centriniai rūmai - naujas korpusas Studentų miestelyje, Pirmieji rūmai - Basanavičiaus g. 28, Antrieji rūmai - Mindaugo g., Tretieji rūmai - Gorkio g., Ketvirtieji rūmai - Gorkio g. 73.

Vasarą VISI studentai sudare penkis studentų statybos būrius (SSB) ir atliko darbu už 275000 rublių. Būriuose dirbo 370 studentų. SSB štabo vadu dirbo A. Pikūnas.

Lietuvoje vis labiau garsejo instituto meno saviveiklos kolektyvai. 1970 m. Dainų šventèje ypač gražiai pasirodè VISI pučiamųju orkestras (vadovas Algirdas Radzevičius). Lietuvos respublikinès profesinių sąjungu tarybos prezidiumo ir Lietuvos kultūros ministerijos kolegijos $1970 \mathrm{~m}$. lapkričio $27 \mathrm{~d}$. Nr. 43 „Už plačia koncertine veikla ir pasiektus kürybinius laimejimus Vilniaus inžinerinio statybos instituto pučiamuju orkestrui suteikti LTSR pavyzdinio meno saviveiklos kolektyvo varda "INŽINERIJA “.

Minetame nutarime sakoma, kad „Vilniaus inžinerinio statybos instituto pučiamuju orkestras per septynerius savo gyvavimo metus išango ì gera, gero meninio lygio kolektyva $\langle\ldots\rangle$, visuomet büdavo gerai žiürovu sutiktas ir teigiamai ivvertintas. Reguliariai, kürybingai dirbdamas pučiamuju orkestras $1970 \mathrm{~m}$. ǐ̌kovojo absoliučiai geriausio Tarybu Lietuvos pučiamuju orkestro varda " $[4.7$, p. 1].

Dainų šventeje gražiai pasirodè ir akademinis mišrus choras "Gabija“ (vad. Klemensas Griauzdè). Šventeje choras dainavo pasipuošęs nauja apranga. Sceninius choristu rūbus sukūrè J. Norvaišienè.

\section{Ikurtuvès studentų miestelyje}

Nors Studentu miestelyje dar nebuvo baigtas statyti ne vienas pastatas, LTSR Ministru Taryba $1970 \mathrm{~m}$. liepos $9 \mathrm{~d}$. priemé nutarimą Nr. 219. Jame buvo numatyta per 1971-1975 metus pastatyti visus suprojektuotus VISI mokomuosius-laboratorinius korpusus. Tai buvo labai sunkus uždavinys, kuris buvo igyvendintas tik iš dalies. Vis labiau ịsigalejo brežnevinè stragnacija. Tai matyti ir iš instituto studentu skaičiaus didējimo rodiklių. Jie nuo 1970 m. didëjo menkai, o vèliau ėmè mažèti. Tai ryškiai iliustruoja priémimo ị studijas skaičiais per pirmajji instituto veiklos dešimtmetị.

Tiek studijos, tiek mokslas, tiek statybos buvo vis prasčiau finansuojamos. Buvo smarkiai atsilikta nuo planuose numatytu rodiklių.

Bet 1970 m. vasara buvo karšta statybininkams, stačiusiems pirmąji Studentų miestelio objektą - VISI mokomąji-auditorinị korpusą. Jau nuo pavasario VISI rektoriaus ịsakymu buvo sudarytos talkininkų brigados.

Ypač pasižymëjo talkose Statybinių konstrukcijų laboratorijos vedëjo Romano Podagèlio vadovaujama brigada. Dauguma talkininkų dirbo entuziastingai, nors už darbą atlyginti niekas net negalvojo. 
Mokomąji-auditorini korpusą Nr. 1, kurio naudingasis plotas $-8200 \mathrm{~m}^{2}$, buvo planuojama atiduoti eksploatuoti $1970 \mathrm{~m}$. birželị. Pagrindiniai statybos darbai buvo baigti, bet kai kur bebuvo baigta apdaila, reikejjo atlikti daug valymo darbų, trūko baldų ir kt. Vis delto rugsëjo 1-ąją pirmajame korpuse ịsikūre Statybos fakultetas ir administracija. Manyta, kad veliau administracija persikels i jai specialiai numatytą pastatyti administracinį korpusą. Dabar žinome, kad tam tures praeiti beveik 40 metų (suprantama, jei bus realizuoti dabarties projektai).

1970-1971 mokslo metus Vilniaus inžinerinis statybos institutas pradejo pakiliai. Tam pagrindą teike ne tik ịkurtuves naujajame pastate, bet ir tolesnis instituto augimas. Dieniniame skyriuje studijavo 2540 , o vakariniame - 2335 studentai, taigi iš viso beveik penki tūkstančiai -4875 . Tai jau buvo solidūs aukštosios mokyklos studentų skaičiai. Kai 1956 m. buvo kuriamas KPI Vilniaus skyrius, Kauno politechnikos institute studijavo tik 3978 studentai.

VISI 1970-1971 mokslo metais, kaip ir dera statybos profilio aukštajai mokyklai, daugiausia studijavo pramonines ir civilinés statybos specialybès jaunimo - 1115 žmonių, statybos ekonomikos ir organizavimo - 480, miestų statybos - 365, automobilių keliu -160 , inžinerinés geodezijos -90 . Nuo 1971 m. - dar prisidejjo 230 būsimųju architektu. Taigi statybos profilio studentų buvo jau 50 proc.
Institute nebebuvo garso technikos specialybès.

Nuo 1970 m. rugsèjo 1 d. VISI veikè jau 30 katedrų. Bendrosios katedros buvo šešios: TSKP istorijos, Filosofijos ir mokslinio komunizmo, Politinès ekonomijos, Karinio parengimo, Fizinio lavinimo ir Kalbų.

Statybos fakultetas turëjo septynias katedras: Statybiness mechanikos, Statybiniu konstrukcijų, Specialiujų konstrukcijų, Statybos ekonomikos ir organizavimo, Statybos darbų technologijos, Pagrindų ir pamatų bei Dailes katedrą. Pastaroji Statybos fakultetui buvo priskirta tik iki Naujujų metų, kai buvo ¡ikurtas Architektūros fakultetas.

Miestu statybos fakultete buvo: Miestų statybos katedra, Kelių, Geodezijos, Hidraulikos, Chemijos, Fizikos ir Matematikos katedros.

Mechaninès technologijos fakultete nuo 19700901 veikè naujai įkurta Automobilių transporto katedra (vad. K. Lukoševičius) ir dar šešios katedros: Metalų technologijos, Mašinų teorijos, Mašinų gamybos technologijos, Pramones ekonomikos, Braižybos ir Taikomosios matematikos ir mechanikos.

Vakariniame fakultete buvo tik trys katedros: Radijo aparatūros technologijos, Elektrotechnikos ir Elektros pavaru.

Daug déstytoju persikèle iš Kauno, bet jiems skirtas gyvenamasis namas dar nebuvo pastatytas. Vis delto metų pabaigoje VISI sudaryta namo priemimo komisija, kurią sudare prorektoriaus pavaduotojas statybos reikalams

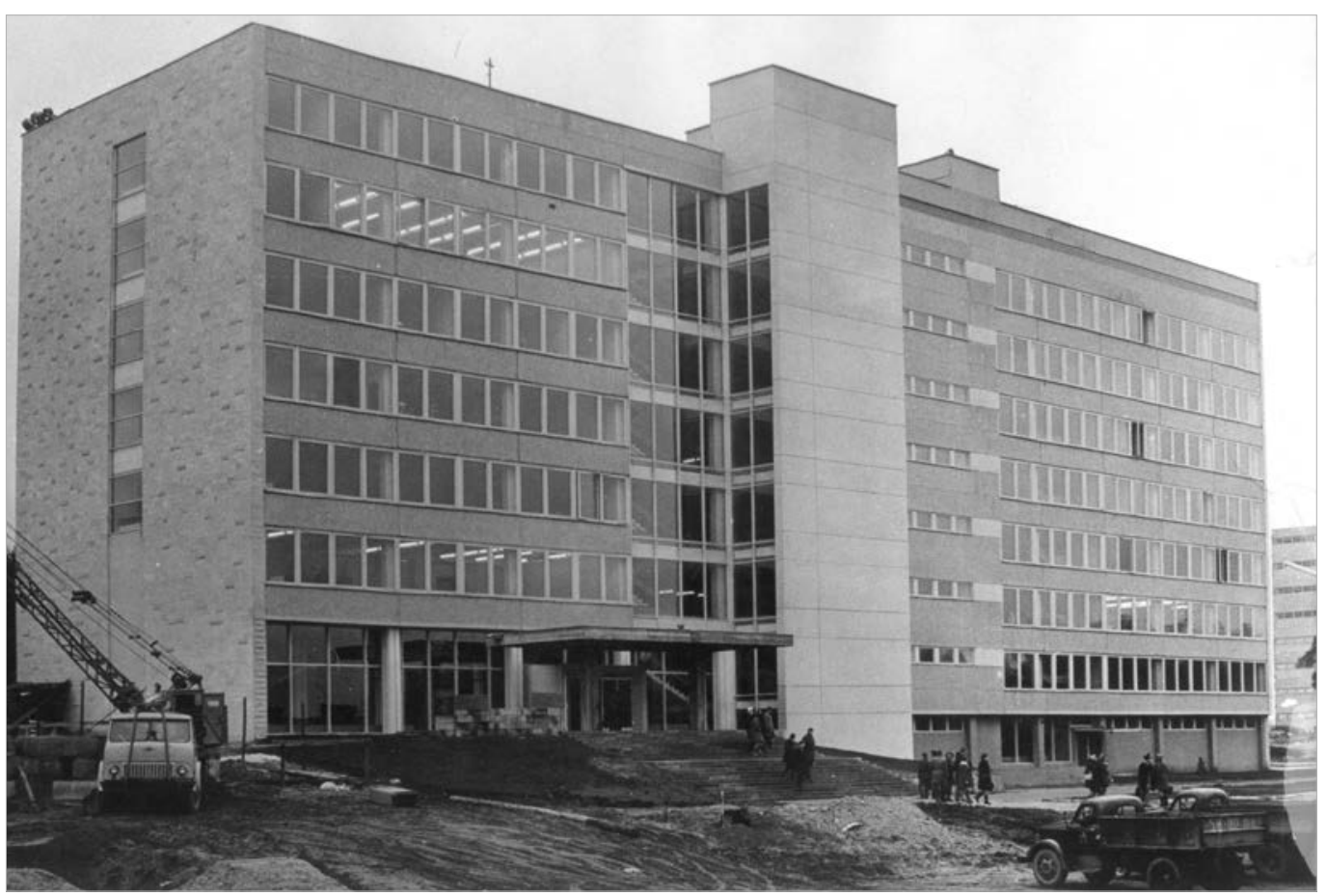

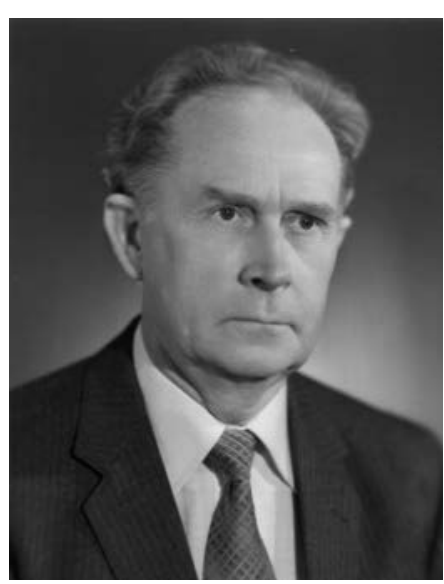

J. Šimkus 
VILNIAUS

INŽINERINIS STATYBOS

INSTITUTAS

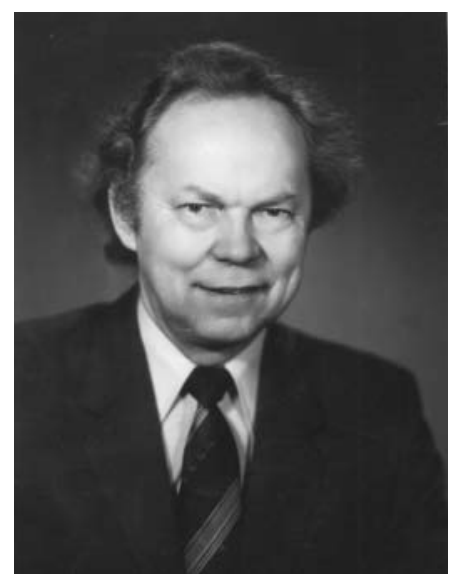

V. Šeštokas

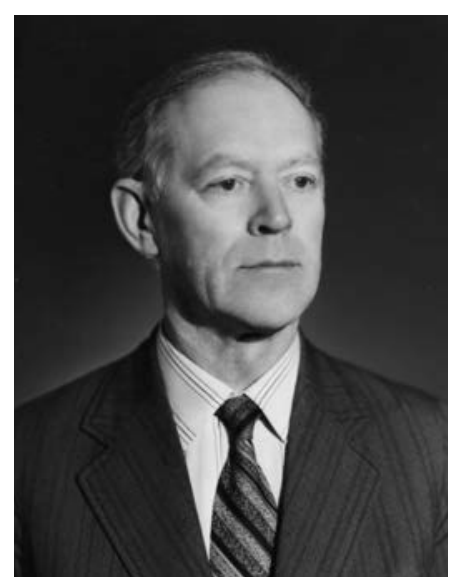

K. Lukoševičius
A. Mikšys, generalinio rangovo atstovas SV-2 vyriausiasis inžinierius S. Šilževičius, projekto autorius V. Strigūnas, techninès priežiūros inžinierius T. Rakuckij ir VISI profsąjungos vietos komiteto atstovas $\mathrm{V}$. Pauža, priemè iš statybininkų baigtą statyti pastatą. Vilniečiais tapusiems kauniečiams gyvenimas gerokai palengvejo, nes kai kurie vos ne kasdien turëjo važinèti ị paskaitas ir kitus darbus iš Kauno ị Vilnių ir atgal, o tai labai vargino.

\section{Dideja demesys inžineriniam rengimui}

Aukštajai mokyklai keliamas uždavinys ne tik parengti gerą specialistą, bet ir ugdyti gerą žmogu, asmenybę. Anot profesoriaus V. Šerno, „Asmenybè yra žmogus, pasiekęs tam tikro tobulumo lygio, gebantis dirbti, bendrauti ir pažinti, keisti aplinka, save, kitus, skleisti idealines vertybes, nusistatymus, iprasminti savo gyvenima " [4.7, p. 64]. Vis delto tenka pripažinti, kad aukštajai technikos mokyklai svarbiausia yra parengti specialistą, turintį ne tik pakankamai žinių praktinei veiklai, bet ir išugdyti labai svarbias inžinieriaus savybes: atsakingumą, sąžiningumą, pareigingumą ir, svarbiausia, saviugdos gebejimą. Studentas gauna daug žinių studijų proceso metu, daug ko išmoksta gana giliai, bet praktinëje veikloje inžinierius turi nuolat savarankiškai tęsti mokymąsi. Todel institutas formulavo uždavini parengti absolventą taip, kad jis darbineje veikloje nepamirštu techninès literatūros, sugebetų kūrybiškai ja pasinaudoti sprendžiant ịvairiausius inžinerinius uždavinius, kurių studijų metu ir neteko sutikti.

Lietuviškos techninès literatūros buvo nedaug. VISI vadovybè ieškojo galimybių leisti kuo daugiau tokių leidinių, bet galimybès buvo menkos.

$1970 \mathrm{~m}$. buvo pradètas leisti VISI destytojų mokslo darbų tęstinis leidinys „Statybos ekonomika ir organizavimas". Buvo išleisti 3 desstytojų (V. Šeštoko, V. Kriukelio, A. Ražinsko) parengti paskaitų konspektai. „Minties" leidykla išleido instituto docentų A. Valentinavičiaus ir H. Lazarevičiaus vadovèli, skirtą aukštosioms mokykloms - „Plastmasinés konstrukcijos". Vadovelių leidyba sovietmečiu buvo bene sąmoningai skurdžiai
Dešimčiai VISI dèstytojų butai buvo paskirti komfortiškame gyvenamajame name Žverryne, kuris buvo „rekvizuotas“ iš tuometinès nomenklatūros. Bet „kova su korupcija“ nebuvo rimta. Ta pati nomenklatūra netrukus sau pasistate greta dar komfortiškesni gyvenamąji namą. Taip buvo ir yra, taip turbūt bus visada. Žmonija neišrado kitaip lankstomų rankų pirštų...

Toliau keliant dèstytojus iš Kauno ị Vilnių, jiems butai buvo skiriami daugiausia tolimesniuose Vilniaus rajonuose - Karoliniškèse, Viršuliškèse.

finansuojama. Honorarai buvo apgailetini. $\mathrm{O}$ lietuviškų vadovelių labai trūko.

Tiesa, dar 1969 m. rotaprintu VISI buvo išleistas prof. A. Rozenbliumo ir doc. V. Jokūbaičio parengtas vadovelis „Gelžbetoninių ir mūrinių konstrukcijų pagrindai“, o „Minties" leidykla išleido aukštosioms mokykloms skirtą vadoveli „Inžinerinè geodezija“, kurio autoriai buvo du VISI docentai - M. Kosčiauskas ir V. Vainauskas bei KPI destytojas M. Ratautas.

Tais $1969 \mathrm{~m}$. Leningrade buvo išleista rektoriaus A. Čyro parengta monografija rusų kalba „Tiesinio programavimo metodai skaičiuojant tampriąsias-plastines sistemas". 1970 m. ir veliau VISI leidykla išleisdavo daug, bet daugiausia nedidelés apimties leidinių. Tai paskaitų konspektai, mokomosios priemones, metodiniai nurodymai, laboratorinių darbų aprašymai, mokymo programos, seminarų medžiaga, uždavinių, formulių, normatyvų, iliustracijų rinkiniai. Nemažai leista įvairių žodynelių.

1970 metams baigiantis, iš stažuotès Prancūzijoje grižo doc. Z I. Kamaitis. Jo paskleista VISI destytojams informacija apie Prancūzijos aukštụjų mokyklų darbą, jų aprūpinimą įranga studijų procesui, moksliniam darbui kele visiems nuostabą. Kad pas mus Lietuvoj taip kada nors bus, niekas netikejjo. Beliko galimybe pasvajoti. Tebesvajojame ir šiandien...

1971 m. sausio 22 d. technikos mokslų daktaro mokslinis laipsnis buvo patvirtintas Vaclovui Vytautui Šeštokui, 1970 m. apgynusiam technikos mokslų daktaro disertaciją „Lietuvos TSR didelių miestų 
transporto įtakos transporto tinklų formavimui tyrimas“, o kovo 19 d. - Daumantui Maciulevičiui. Netrukus jie pradejo eiti profesorių pareigas.

\section{Ikuriamas Architektūros fakultetas}

Nors studijuoti architektūros buvo priimama $1970 \mathrm{~m}$. vasarą, šiuos 50 pirmoku nuo rugsëjo $1 \mathrm{~d}$. globojo Statybos-ekonomikos fakultetas, kuriam laikinai buvo priskirta Dailes katedra.

Vilniaus inžinerinio statybos instituto Architektūros fakultetas savo veiklą pradejjo $1971 \mathrm{~m}$. vasario 1 d., kai fakulteto dekano pareigas rektorius pavede vykdyti arch. kandidatui, docentui Jurgiui Vanagui.

Architektūros fakultetas veiklos pradžioje turejo tris katedras: Architektūros (ved. A. Lukošaitis), Gyvenviečių planavimo ir tvarkymo (ved. K. Šešelgis) ir Dailès (ved. A. Janulis).

Architektūros katedroje nuo pat pradžios dirbo Adolfas Lukošaitis, Stasys Abramauskas, Vytautas Kasputis, Leonidas Ziberkas, Alfonsas Keturka, Vytautas Dičius ir Anatolijus Uljanovas. Visi jie persikèle iš Kauno. Netrukus katedros destytoju gretas papilde du vilniečiai - Antanas Spelskis ir Vytautas Vaitkus.

Gyvenviečiu planavimo ir tvarkymo katedroje dirbo Kazimieras Šešelgis, Jurgis Vanagas, Mečislovas Kleinas, Vytautas Jurkštas, Neringa Dičiuviene. Visi jie persikèle iš Kauno. Prie jų prisijunge vilnietis Antanas Pilypaitis, o po metu - Zigmas Daunoravičius (dabar Daunora).

Dailes katedroje dirbo Alfonsas Janulis ir Stasys Ušinskas, kurie atvyko iš Kauno. Bet prof. S. Ušinskui negavus leidimo įsirengti stiklu deginimo krosni jam skiriamame bute Krantines gatveje, jis persikelti i Vilniu atsisake (dirbo 197009 01-1971 12 31). Katedrą papildè vilniečiai Vytautas Bačènas ir Jonas Čeponis.

Architektūros fakultetas įsikūrè nauju rūmu 6 ir 7 aukštuose, t. y. virš rektorato. 3 ir 4 aukštuose dirbo Statybos-ekonomikos fakultetas.

Pradiniu naujųjų rūmų eksploatavimo etapu vandentiekio sistema dažnai į viršutinius aukštus nepajègdavo tiekti vandens dèl mažo spaudimo. Praustuvai, kaip ir dera, buvo įrengti visose auditorijose ir braižyklose. Studentai dažnai atsukdavo čiaupus laukdavo vandens. Bet kartą ir čiaupą buvo užmiršta užsukti, o praustuvas buvo pilnas popierių. Tai turejo tokiu padarinių, kurių rezultatai jaučiami dar ir po 35-erių metų, nes praustuvai daugumoje akademinių patalpų iki šiol demontuoti.

1971 m. balandžio 21 d., kai studentai palikto neužsuktą vandens čiaupą 0611 braižykloje, vandeniui pradejjus tekèti, praustuvas užsipildè ir per vakarą bei naktį užpyle penkių aukštų patalpas, taip pat ir rektoratą. Rektorius ị tai reagavo tą pačią dieną. Papeikimą gavo budetoja, o administracijos ir ūkio prorektoriui bei Architektūros fakulteto dekanui rektoriaus įsakymu buvo pareikšta pastaba. Rektoriaus manymu, nelaimes buvo galima išvengti, jei katedra būtų emusi atitinkamų atsargumo priemonių, o ūkio dalis instruktavusi ir organizavusi kokybišką patalpų apžiūrą ne užsièmimų metu. 0611 braižykloje studentai ištisai renge kursinius projektus, šiam darbui vadovavo Gyvenviečių planavimo ir tvarkymo katedra, o užsiemimus vede docentai J. Vanagas ir V. Jurkštas [4.8, p. 66]. Doc. J. Vanagas rektoriaus pastabą laike nepelnyta. Jis tuoj įteike atsistatydinimo iš dekano pareigu prašymą, kurị rektorius patenkino.

Šiandien, žiūrint ì praeitị, galima tik apgailestauti dèl tokios susiklosčiusios situacijos.

Jurgis Vanagas - didelés mokslinès potencijos, inteligentiškas, geras destytojas, aktyvus darbuotojas, neabejotinai būtų daug prisidëjęs prie fakulteto pletros. Jị pakeitęs žmogus, turejęs ir gerų savybių, buvo tipiškas brežnevinio sąstingio atstovas, be iniciatyvos, be nuomones, formaliai atliekantis savo pareigas, bet įtinkantis vadovams pabrežtinu paklusnumu. Architektūros fakultetas daug prarado, netekęs perspektyvaus, kūrybingo vadovo.

Jurgis Vanagas dar èjo pareigas iki rugsèjo 1 d., kai ji pakeite iš Vilniaus dailès instituto ị VISI Architektūros katedrą atëjęs dirbti architektūros daktaras, profesorius Antanas Spelskis, dekano pareigas ëjęs net 17 metų.

Nuo 1971 m. gegužès $14 \mathrm{~d}$. buvo sudaryta Architektūros fakulteto taryba: pirmininkas - e. doc. p. J. Vanagas (einantis fakulteto dekano pareigas), nariai: prof. K. Šešelgis, e. prof. p. A. Lukošaitis, prof. A. Spelskis, e. prof. p. A. Janulis, e. doc. p. V. Vaitkus (fakulteto part. org. sekretorius), e. doc. p. $V$. Bačènas (fakulteto profbiuro pirmininkas) [4.8, p. 89].
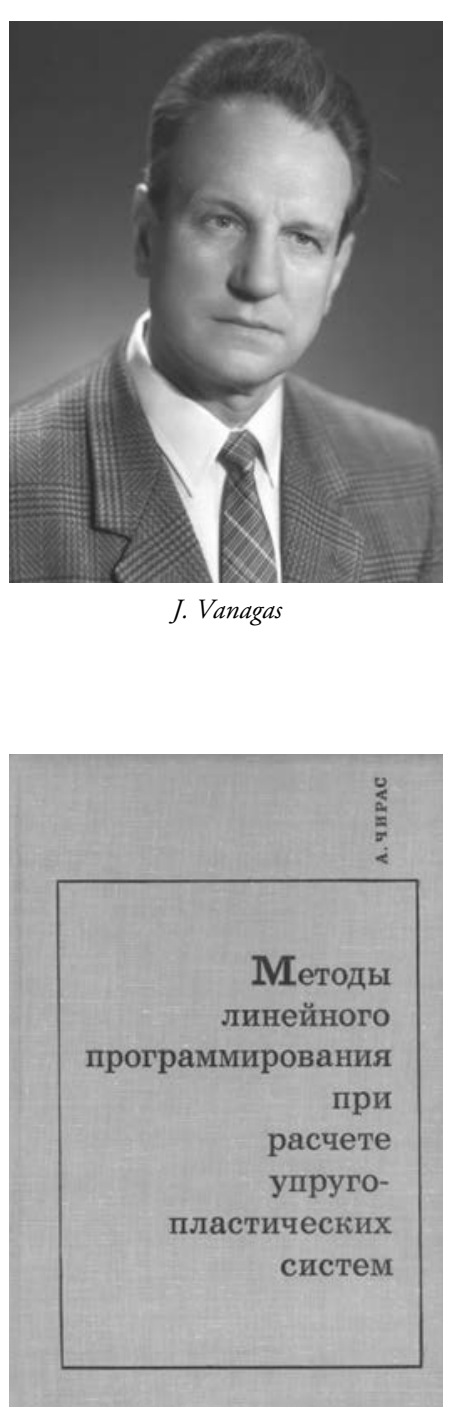

A. Čyro monografijos viršelis

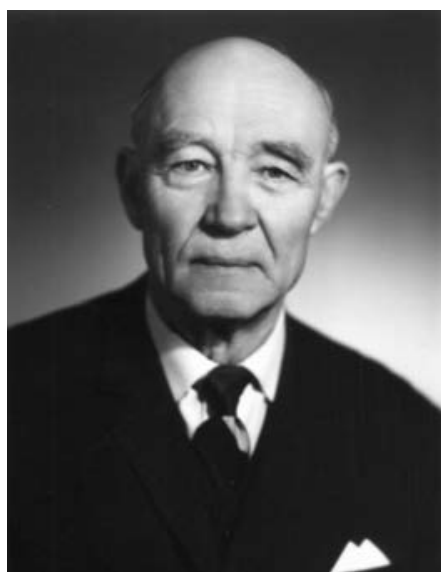

A. Lukošaitis 
VILNIAUS

INŽINERINIS STATYBOS

INSTITUTAS

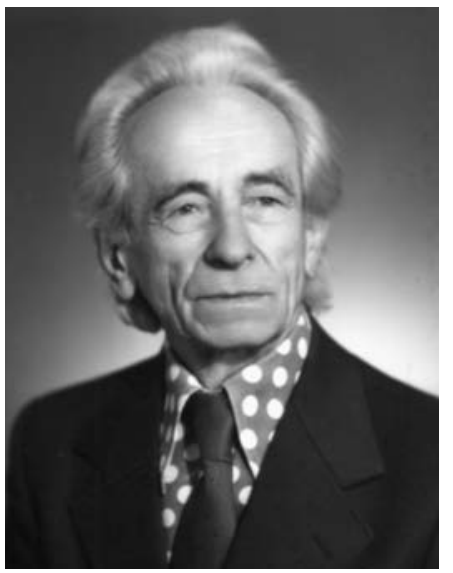

K. Šěselgis

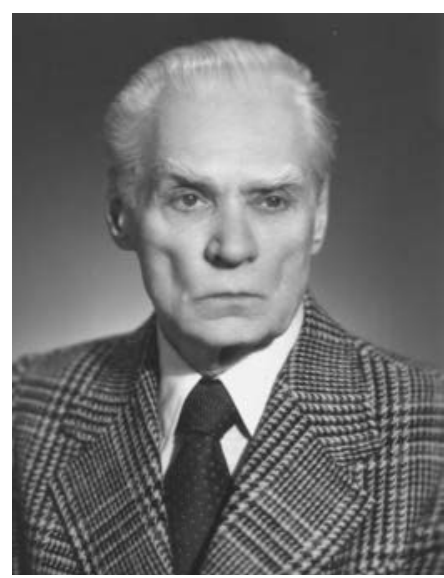

A. Janulis

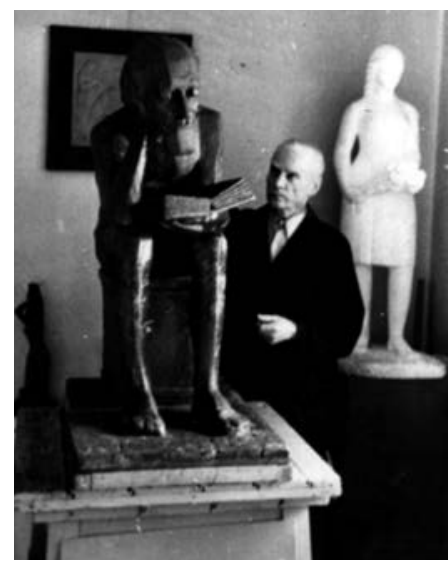

Skulptorius A. Janulis dirbtuveje
Vèl buvo surengtas konkursas VISI emblemai sukurti. Dabar - Architektūros fakulteto studentų. Būsimieji architektai gausiai dalyvavo konkurse gal ir todèl, kad ji organizavo ižzymus grafikas, e. doc. p. Dailes katedroje Vytautas Bačènas.

Konkurso nugalètoju tapo A 7/1 grupès studentas Kęstutis Pempé. İdomu pažymèti, kad K. Pempe yra dabartinis Lietuvos architektų sajungos pirmininkas. Rektoriaus įsakymu buvo pagirti dar 6 studentai: A. Remutyte, A. Černiauskas, V. Markelytė, J. Smilgytè, N. Valenskaite ir R. Guzaitis.

Tenka pažymèti, kad tuo metu Architektūros fakultete studijavo nemažai studentų, kurie ilgainiui tapo gerai žinomi šalies visuomenei.

A0/1 grupëje mokèsi Eugenijus Miliūnas, daugelio žymių architektūros kūrinių, taip pat dailininko M. Žilinsko galerijos pastato, autorius. Toje grupeje studijavo Henrikas Žukauskas, gabus architektas, šaržo meistras, Lietuvos Respublikos Seimo narys. Eugenijus Palavinskas daug metų buvo vyriausiuoju Druskininku architektu. Ryškūs tos pačios grupes absolventų Kęstučio Kisieliaus ir Reginos Masilionytes architektūros darbai.

A1/2 grupeje reikia paminèti Algirdą Kaušpedą, Atgimimo metais labai pagarsejjusį koncertais su grupe „Antis“, Sigitas Čereškevičius ne tik projektuoja, bet ir dessto fakultete. A9/1 grupeje studijavęs Eugenijus Staniūnas tapo mokslininku, dirbo fakulteto dekanu. A8/2 grupeje studijavęs Juozas Mureika - Klaipedos vyriausiasis architektas.

Absoliuti dauguma Lietuvos architektų išugdyti Vilniaus aukštosios technikos mokyklos - VISI arba VGTU. 2006 m. Architektūros fakultetas gali pažymèti jau 35-ąsias gyvavimo Vilniuje metines.

Nuo $1971 \mathrm{~m}$. sausio pradejo veikti Tiesinių elektros mašinų mokslinio tyrimo žinybine laboratorija. Jos moksliniu vadovu buvo paskirtas t. m. k. doc. Vytautas Česonis, kuris jau anksčiau vadovavo daugeliui išskirtinių darbų, kuriuose buvo tiriamos įvairios elektros varikliu charakteristikos. Tai buvo jau ketvirtoji VISI žinybinè laboratorija, nes trečioji buvo perkelta iš Kauno - tai Pagrindu ir pamatų žinybinè laboratorija.
Metų pradžioje buvo apsvarstyti praejusiais metais atlikti instituto moksliniai darbai. Pažymètina gausëjanti aspirantūra. VISI studijavo 36 asmenys stacionarioje ir 16 - neakivaizdinëje aspirantūroje. Per karo metus buvo apginta 11 kandidatinių ir viena daktaro disertacijos. Mokslų kandidatais tapo A. Lubys, B. Martinenas, Č. Teišerskas, J. Bendikas, A. Tupinis, A. Šeputis ir kt. Pagerëjo vadinamųjų biudžetinių mokslo darbų atsiskaitymo tvarka. Atlikta nemažai vertingų gamybinems organizacijoms užsakomųjų, t. y. ūkiskaitinių, mokslo darbų - už 316,7 tūkstančio rublių.

Daugiausia ūkiskaitinių darbų atliko Statybos-ekonomikos fakulteto mokslininkai - 12, iš kurių keturiems darbams vadovavo prof. A. Kudzys, dviem darbams - prof. A. Čyras. Kitų darbų vadovais buvo docentai G. Marčiukaitis, G. Izraelis, V. Bagdonas, A. Alikonis, e. doc. p. K. Antanavičius, A. Naujokaitis.

Miestų statybos fakulteto mokslininkai atliko 11 ūkiskaitinių darbų. Trims darbams vadovavo doc. S. Rokas, dviem darbams - doc. E. Palšaitis, kitiems - docentai V. Kriščiūnas, V. Jasulaitis, A. Kazragis, E. Mauza, vyr. destytojai K. Sakalauskas, M. Prikšaitis.

Mechanines technologijos fakultetas atliko septynis ūkiskaitinius darbus: dviem vadovavo doc. R. Jonušas, po vieną - D. Maciulevičius, V. Lemke, A. Butkus, A. Martinaitis, A. Čižas.

Vakarinio fakulteto mokslininkų lyderiai - V. Česonis ir A. Naidionovas, turëję po du darbus. Po vieną darbą turëjo Z. Vainoris, $Z$. Jankauskas, A. Seilius. Taigi iš viso fakultetas atliko septynis ūkiskaitinius darbus [4.8, p. 17-22].

Ryškiai daugèjo išradëjų. $1970 \mathrm{~m}$. buvo pateikta 30 paraišku išradimams į TSRS išradimų ir atradimų komitetą.

1970 m. VISI mokslininkai paskelbè 288 mokslinius straipsnius, išleido 12 leidinių: vieną monografiją, dešimt darbų rinkinių, vieną vadoveli.

Instituto mokslininkai vykdè dešimties temų tyrimus:

1. Statybinès mechanikos optimizacijos teorijos ir metodų sukūrimas, naudojant matematini programavimą.

2. Betono ir gelžbetonio konstrukcijų skaičiavimas, ịvertinant polimerinių medžiagų ir technologinių faktorių įtaką.

3. Statybos valdymo ir organizavimo tobulinimas. 


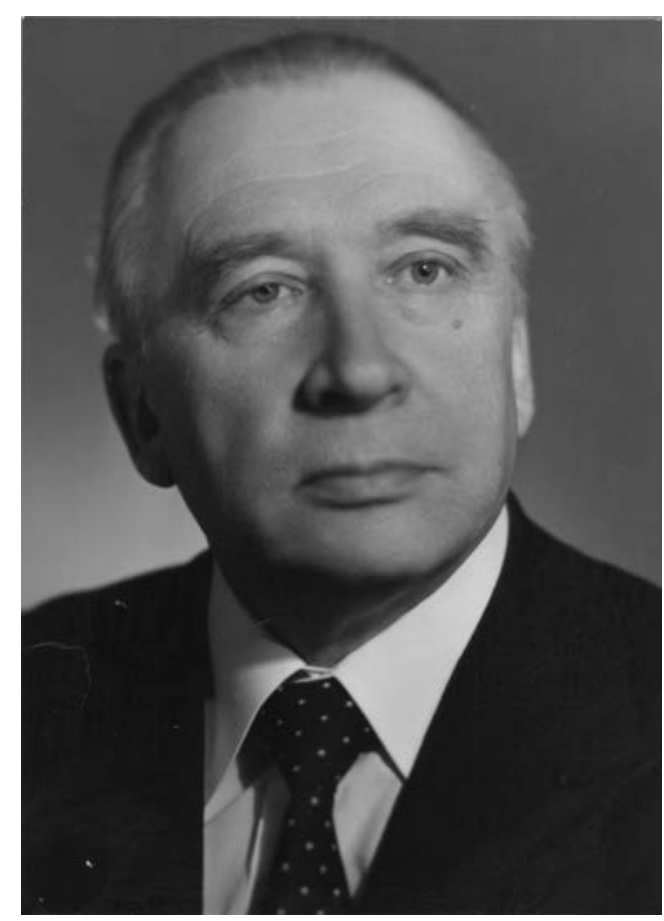

A. Spelskis

4. Ekonomiškų ir stabilių automobilių kelių mobilių dangu tyrimas ir tobulinimas naudojant vietines žaliavas.

5. Gyvenviečių architektūros ir jų išdèstymo Lietuvos teritorijoje formu ir sistemų tyrimas.

6. Pagrindų iš regioninių smèlingųjų ir molinguju gruntų skaičiavimo metodu parengimas.

7. Lietuvos miestu gatvių ir kelių tinklo plètros klausimų tyrimas.

8. Elektros signalų perdavimo bangomis elektrinemis sistemomis su išskirstytaisiais parametrais ir kietuosiuose kūnuose sąlygų tyrimas.

9. Tiesialinijinių elektros mašinų ir jų prietaisų tyrimas ir sukūrimas.

$\mathrm{Na}$, o 10-oji problema šiandien kelia šypseną: socialistines revoliucijos ir socializmo statybos Lietuvoje désningumai.

Jei buvę marksistinių-lenininių mokslų dèstytojai šiandien būtų nuoširdūs ir dori, jie nevengtų deklaruoti, kad Lietuvoje jokios socialistinès revoliucijos nebuvo, o buvo tik svetimos valstybès įvykdyta žiauri okupacija, atnešusi daug aukų, skriaudų, pažeminimo ir vargo. Kuo baigesi socializmo statyba gerai visiems žinoma. Tuo, suprantama, neneigiami kai kurie objektyvūs, daugiausia vèlesni laimëjimai, kurių nuopelnai tenka visiems Lietuvos žmonems, ne tik partinei nomenklatūrai, kaip tai bandoma vaizduoti šiandienos memuaruose.

\section{Nauji instituto laimejimai}

Rektoratas daugiau dèmesio skyre studijoms. Joms gerinti imta skatinti daugiau rengti paskaitu konspektų, metodinių priemonių. 1971 m. V. Šeštokas išleido mokomąją knygelę „Eismo reguliavimas ir saugumas“, M. Remišauskas su P. Baubliu „Plokščios strypines sistemos skaičiavimai“, A. Rozenbliumas - „Mūrinių konstrukcijų projektavimas" ir t. t. Bibliotekos fondai jau turejo 153 tūkst. ịvairių leidinių.

Maloni žinia buvo institutui, kad Architektūros fakulteto e. doc. p. Vytautas Dičius ir vyr. desst. Michailas Prikšaitis už visuomeninius pastatus, suprojektuotus ir pastatytus 1962-1970 m., buvo apdovanoti TSRS Ministrų Tarybos premijomis. Abu šie talentingi, daug praktinių darbų atlikę specialistai daug metų sumaniai perteikinejo savo didžiulį patyrimą jaunajai kartai - būsimiems architektams ir statybininkams.

1971 m. Vilniaus inžinerinị statybos institutą baigè ir inžinieriaus diplomus gavo 527 žmonès. Statybos ekonomikos fakultetą baige 67 dieninio, 39 vakarinio ir 8 neakivaizdinio skyrių studentai. Miestu statybos fakultetą baige 47 dieninio ir 10 vakarinio skyrių studentai. Mechaninès technologijos fakultetą baige 104 dieninio, 134 vakarinio ir 2 neakivaizdinio skyrių studentai. Vakarinį fakultetą baige 116 vakarinio mokymo studentai.

$1971 \mathrm{~m}$. vasarą studijuoti į VISI buvo priimta 1170 jaunuolių ir merginų. Architektūros fakultetas prièmé 52 asmenis ị dienines studijas; Vakarinis fakultetas - $125 \mathrm{i}$ vakarines studijas; Mechanines technologijos fakultetas - 303: 177 i dienines, 126 - vakarines ir 25 - neakivaizdines studijas; Statybos-ekonomikos fakultetas - 515: 388 i dienines, 52 - vakarines ir 75 - neakivaizdines studijas.

Daugiausia priimta studijuoti i pramonines ir civilinès statybos specialybę - 387, statybos ekonomikos ir organizavimo specialybę - 164, automobilių ir automobilių ūkio specialybę - 112 jaunuolių ir merginų.

Tą pačią vasarą 316 studenty dirbo šešiuose statybiniuose būriuose ir atliko statybos darbų už 316 tūkstančių rublių. SSB štabo vadovu buvo $\mathrm{D}$. Kvartūnas.

Akademinis mišrus choras "Gabija“ (tuomet vadintas liaudies choru „Gabija“) dalyvavo studentų choru festivalyje Čekoslovakijos mieste Pardubiceje ir laimëjo

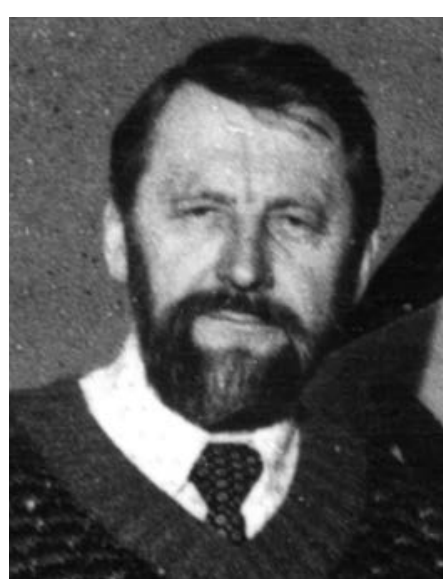

V. Dičius

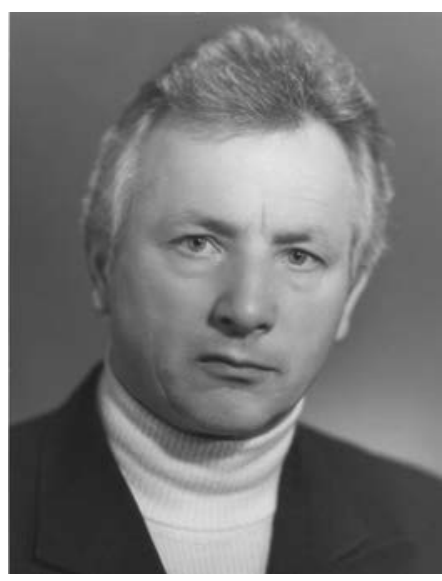

M. Prikšaitis 
VILNIAUS

INŽINERINIS STATYBOS

INSTITUTAS

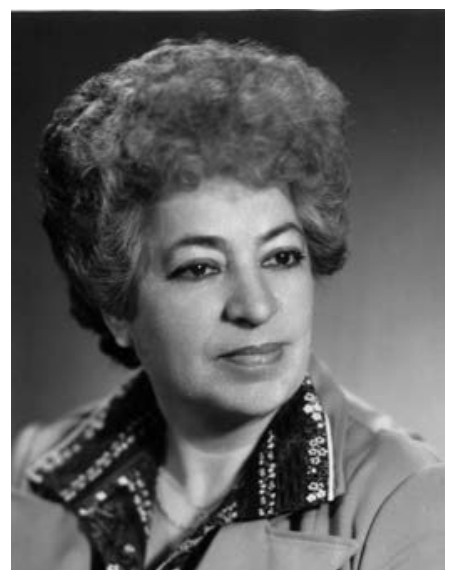

I. Aleksaité

sektoriaus Projektavimo-konstravimo biuras (formaliai-MTS projektavimo-konstravimo skyrius).

Eiti VISI PKB viršininko ne pagrindines

festivalio laureato diplomą. Tai buvo pirmas tarptautinis „Gabijos“ laimëjimas.

1971-1972 mokslo metus VISI pradëjo, turedamas 33 katedras, 5315 studentų. Veike 5 fakultetai, déste 378 desstytojai: 7 profesoriai, 131 docentas, 148 vyr. destytojai, 91 asistentas. $40 \%$ pedagoginio personalo jau turëjo mokslinius laipsnius.

VISI pedagogai buvo gana jauni, pakankamai patyrę. Beveik $60 \%$ destytojų turejo nuo 5 iki 20 metu pedagoginio darbo stažą.

Nuo 1971 m. rugsejo $1 \mathrm{~d}$. Statybosekonomikos fakultetas pavadintas Statybos fakultetu.

Architektūros fakultete pradejjo veikti nauja Pastatų konstrukcijų katedra. Ją sudare destytojai, atkelti iš Miestų statybos katedros: doc. V. Kriščiūnas (paskirtas katedros vedeju), docentai M. Urbelis, M. Prikšaitis, B. Žintelis, e. doc. p. N. Geršas, vyr. dèst. A. Nakas, asist. V. Strigūnas. Netrukus ją papilde mokslų kandidatai A. Radzivonas ir Č. Ignatavičius - eiti vyr. destytojo pareigas bei L. Guokas - asistento pareigas.

Instituto dèstytojai èmé dažniau vykti i užsienio stažuotes. Rugsëjo mènesi i i šešiu mènesių mokslinę stažuotę ị Olandiją išvyko Hidraulikos katedros vedejas doc. Kęstutis Baškys, spalio menesi i pavarų katedros vedejas Algirdas Smilgevičius.

Stacionarioje aspirantūroje $1971 \mathrm{~m}$. studijavo 9 žmonés, o neakivaizdineje -8 .

$1971 \mathrm{~m}$. buvo gausus mokslo kandidatu derlius. Jais tapo A. Jurkša, A. Keturka, A. Baradokas, N. Dičiuvienè, V. Adomavičius, A. Rukšènas, P. Baublys, A. Krutinis, J. Nagevičius, E. Šeibokienè ir kt., iš viso 14 žmonių. Taigi mokslininkų, turinčiu laipsnių, VISI vis daugejjo. Daugèjo ir mokslinių darbų.

1971 m. pavasarị Vilniaus inžineriniame statybos institute buvo ikkurtas Mokslo tiriamasis sektorius. Jam priklause 110 etatiniu darbuotojų, 4 šakinès laboratorijos. Jose buvo 97 darbuotojai.

Daugumai VISI desstytojų labai trūko praktinių igūdžių, ypač vedančiu kursinio projektavimo užsiemimus. Kad labiausiai to reikalingi desstytojai turètu galimybę tobulèti ir projektavimo klausimais, $1971 \mathrm{~m}$. spalio $1 \mathrm{~d}$. buvo įkurtas VISI Mokslinio tyrimo pareigas buvo paskirtas Pastatų konstrukcijų katedros vyr. destytojas, kurị laiką dirbęs projektavimo darbus Kauno „Pramprojekte“ ir KPI PKB, Algimantas Nakas.

VISI PKB projektu vyriausiuoju architektu buvo paskirtas Architektūros katedros e. doc. p. Vytautas Dičius, turëjęs jau didelę projektavimo patirti. Projektų vyriausiojo inžinieriaus funkcijoms vykdyti rektorius paskyrè Pastatų konstrukcijų katedros docentą Bernardą Žintelį, turëjusị didelę gamybinę patirti.

Atskirų projektų dalių vyriausiųjų specialistų funkcijas vykdè: tyrinejjimų - Geodezijos katedros vyr. destytojas S. Kazakevičius, architektūrinio projektavimo - Architektūros katedros vyr. destytojas A. Keturka, konstrukcinio projektavimo - Pastatų konstrukcijų katedros vyr. destytojas M. Prikšaitis, pagrindu ir pamatu - Pamatu ir pagrindy katedros asistentas J. Sčesnulevičius, vandentiekio ir kanalizacijos - Hidraulikos katedros docentas M. Gedgaudas, elektrotechnikos ir ryšiu - Elektrotechnikos katedros asistentas A. Žalnieriūnas, generalinio plano - Gyvenviečių planavimo katedros asistente N. Dičiuvienè ir sąmatu - Statybos ekonomikos ir organizavimo katedros docentas G. Izraelis.

\section{Darbui gerinti}

1971 m. rektorius A. Čyras èmé plačiai taikyti personalo drausminimo priemones. Kiekvieną mènesį net už nedidelius prasižengimus ar trūkumus buvo išleidžiami ịsakymai, kuriais reiškiami papeikimai, įspëjimai, pastabos. Juos gavo ir profesoriai, ir docentai, ir visi kiti destytojai bei darbuotojai. Tie ìsakymai buvo argumentuojami „už nepakankamą kontrolę“, „už aplaidumą darbe“, „už nepakankamą patalpų paruošimą "ir pan. Kartais buvo akivaizdu - baudžiant vadovautasi nuostata, kad kažkas vis tiek turi būti kaltas, nors buvo nemažai atvejų, kai kalta buvo pati nevykusi mokymo proceso ar mokslo tyrimų sistema, kai trūko medžiagų, etatų, kai daug laiko buvo prarandama būtinai dalyvaujant be galo dažnuose susirinkimuose, posèdžiuose, pasitarimuose, komisijose ir pan., faktiškai visai nesusijusiuose su pagrindiniu tiesioginiu darbu. Deja, rektoriaus dažnas 
„mojavimas vèzdu“ dave pagrindą kalboms apie jo autokratinį valdymą. Apie tai viešai prabilta tik Sąjūdžio metais.

Prieš pat Naujuosius metus buvo ịkurta VISI metodine taryba, kuri turejo tobulinti mokymo procesą, apibendrinti darbo patirti ir svarstyti dar daugelį klausimų, susijusių su studijomis. Pirmininku buvo doc. R. Jonušas, pavaduotojais - prof. K. Šešelgis ir doc. R. Popilskis, nariais - docentai A. Butkus, P. Dilys, H. Gylys, R. Jasilionis, V. Kriukelis, E. Mauza, A. Rosinas, J. Šimkus, B. Zabotka, B. Žintelis, J. Grèska, B. Girčiené, J. Vanagas, J. Kivilša, e. doc. p. Z. Kulaitis, V. Vaitkus, A. Žalnieriukas, V. Zakarevičius, vyr. destytojai P. Vaičys, R. Čepas, A. Gaižutis, V. Tutkus, K. Sakalauskas, A. Kuzmickas, asistentas L. Ziberkas ir Skaičiavimo centro darbuotojas V. Podviezko.

Metodinę tarybą sudare šešios sekcijos: 1. Mokomojo-auklejamojo darbo (pirm. J. Grèska); 2. Auklejamajam darbui bendrabučiuose (pirm. V. Tutkus); 3. Mokomojo-metodinio darbo (pirm. doc. R. Popilskis); 4. Mokomojo organizacinio darbo (pirm. K. Šešelgis); 5. Techninių priemonių naudojimo mokymo procese (pirm. doc. E. Mauza).

1972 m. sausio 3 d. buvo sudaryta VISI meno taryba, kuri turejo gerinti instituto studentų meno saviveiklos darbą, kontroliuoti jos meninị ir idejinị lygị. Tarybos pirmininke buvo paskirta Filosofijos ir mokslinio komunizmo katedros destytoja e. doc. p. Irena Aleksaite, ižzymi teatrologe. Pavaduotoju paskyre A. Cižž, nariais - V. Marčèną, L. Janulioni, A. Naką, J. Žakevičių, A. Gaižuti. Tarybai priklause meno kolektyvų vadovai, Studentų kultūros klubo vedëjas, instituto komjaunimo komiteto atstovas.

Kovo menesị VISI gavo leidimą projektuoti bendrabučio tipo gyvenamąji namą Žirmūnuose. 100 butų stambiaplokščio gyvenamojo namo pritaikymo projekto vyriausiuoju inžinieriumi rektorius paskyre doc. B. Žinteli, projekto architektu -A. Uljanovą, projekto konstruktoriumi - A. Senutą, generalinio plano architektu - N. Dičiuvienę, inžineriniams tyrinëjimams vykdyti - J. Sčesnulevičių, geodeziniams darbams - S. Kazakevičių, elektrotechninei daliai - A. Žalnieriūną, šildymo, védinimo ir dujotiekio daliai - M. Gedgaudą, vandentiekiui ir kanalizacijai - K. Blažį, ryšiams ir silpnosioms srovems projektuoti - A. Gražulevičių, sąmatoms rengti - G. Izraelį [4.9, p. 24].
Kaip matome, rektorius visas problemas sprende paprastai - issakymu. Bet norint ką nors padaryti greičiau, tai buvo vienintelis kelias. Limitu projektavimui gauti buvo sunku, tai buvo ir ilgas kelias. Tiesa, šikart, nors ir menkai, projektuotojams buvo atlyginta. Bet atsisakyti šių darbų, motyvuojant, kad tai neįeina į destytojo pareigas, nebuvo įmanoma. Tai būtų reiškę, kad dirbti institute būtų tekę iki pirmos, kad ir nedideles, klaidos arba iki artimiausio konkurso.

1972 m. pradžioje instituto taryba apsvarste elektroninių skaičiavimo mašinų naudojimo mokymo procese padetį. Šiuo klausimu pranešimą skaitè prof. D. Maciulevičius, apžvelgęs visų fakultetų darbą. Prof. A. Kudzys pažymëjo, kad skaičiavimo technikos disciplina įvesta tik dieninio skyriaus studentams, bet gi tokị pat inžinieriaus diplomą gauna ir vakarinio skyriaus absolventai. Doc. A. Ražinskas papasakojo apie ESM naudojimą Suomijoje. Ten skaičiavimo centrai turị teletaipini ryšį ir susisiekę skaičiuoja. Katedros turi savo programuotoją. Doc. K. Antanavičius pabrežè, kad „mūsu uždavinys išmokyti studentus formuluoti uždavinius, suprasti fizine ir ekonomine gaunamy tarpiniu duomenu ir rezultatu reikšmę, todèl kartais formalus ESM pritaikymas nepadeda gilinti specialybès žinias. ESM reikia taikyti nauju uždaviniu sprendimui. Prof. D. Maciulevičiaus nuomone, programuoti turetu patys destytojai, o norint gerai programuoti, reikia tuo užsiimineti pastoviai. Mano nuomone, be skaičiavimo centro programuotoju apseiti negalima " [4.10, p. 9-10]. Dalykiška buvo ir prof. A. Rozenbliumo kalba: „Buvo ivesta patogi sistema, kai studentai palikdavo Skaičiavimo centre duomenis ir po to ateidavo patys paimti rezultatu. Tačiau kažkodel pradejo dingti rezultatai. Skaičiavimo centras dirba labai jtemptai ir destytojai, dirbantys mokslini darba, gauna vis mažiau laiko" [4.10, p. 10].

Tuo metu VISI turëjo vienintelę skaičiavimo mašiną - „Minsk 22“. Kalbëjęs rektorius A. Čyras sake, kad 1974 m. numatoma gauti skaičiavimo mašiną „Minsk 32“.

Kitame instituto tarybos posedyje buvo apsvarstyta VISI mokslinių darbų ataskaita, kurią pateike prorektorius doc. G. Marčiukaitis.

Jis pranešè, kad 325 VISI déstytojai 1971 m. vykdè 157 biudžetinius ir 106 ūkiskaitinius mokslo darbus. Atlikta ūkiskaitinių darbų už 751,8 tūkstančio rublių. 
VILNIAUS

INŽINERINIS STATYBOS

INSTITUTAS

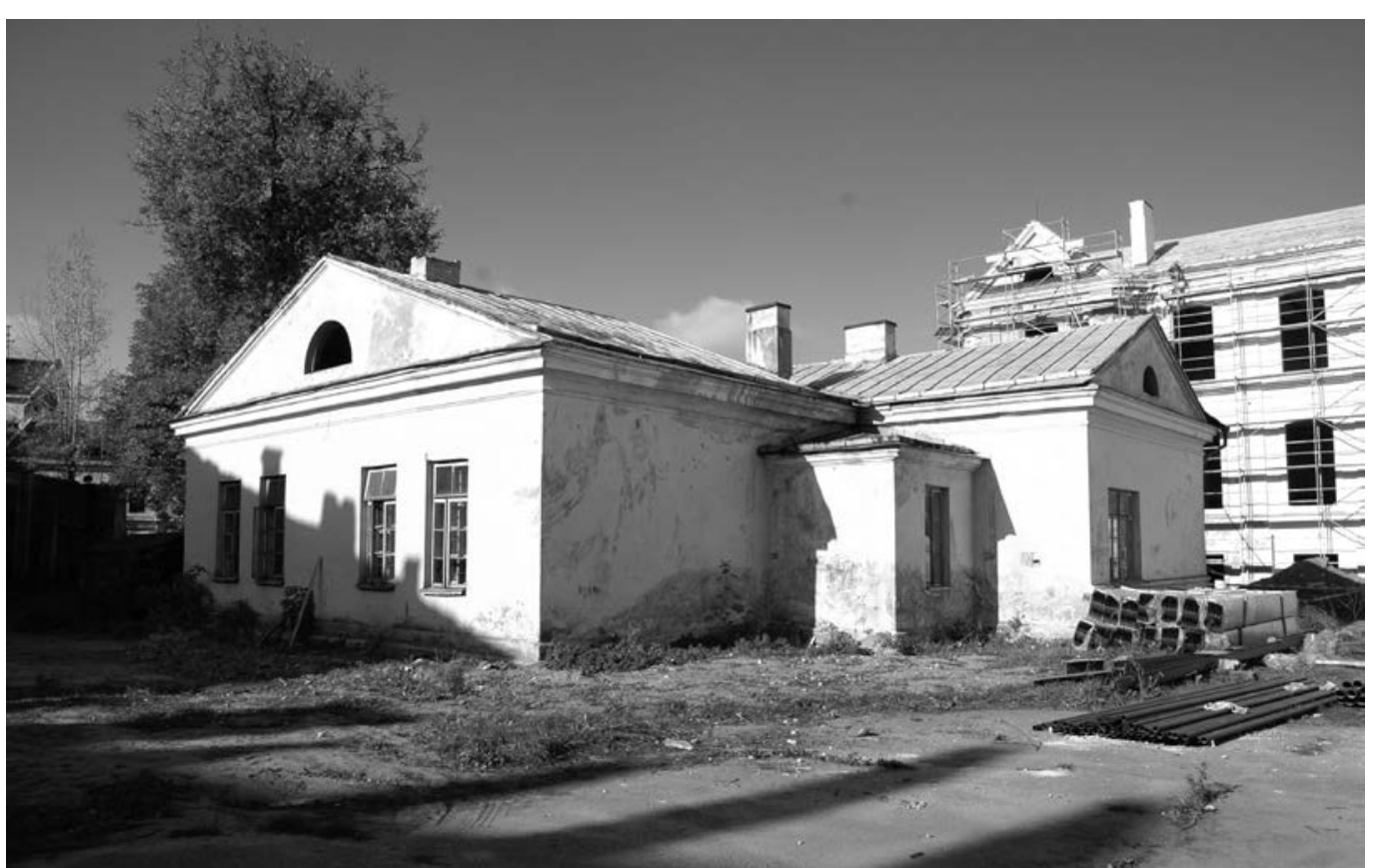

Išleista 17 leidinių, paskelbti 434 moksliniai straipsniai, pateiktas 31 autorinis pareiškimas išradimų komitetui, instituto Mokslo taryboje apgintos 6 disertacijos, net 468 studentai skaite pranešimus dviejose mokslinese studentų konferencijose.

İdomi buvo VISI statistine ataskaita, sudaryta 1971 m. birželio 15 d. Joje nurodyta, kad VISI dirba 742 darbuotojai - 469 vyrai ir 273 moterys; destytoju - 377: 7 mokslu daktarai, 147 - mokslų kandidatai.

Visi pedagogai - daugiausia lietuviai. Jų buvo 322 (85,4 \%): 6 mokslų daktarai, 132 - mokslų kandidatai.

\section{Stanislovo Jako areštas}

1972 m. Lietuvoje iš „Laisvès“ radijo sužinojome apie spausdinamą ir platinamą „Lietuvos katalikų bažnyčios kroniką“, kurią leido, kaip vèliau sužinojome, Kybartų kunigas Sigitas Tamkevičius. KGB labai ieškojo leidëjų, bet nieko nepešè. Nors kunigas vèliau buvo suimtas ir įkalintas, LKBK kronika ejjo ir toliau. Buvo ir kitu leidinių. Lietuvoje prasidëjo vadinamasis disidentinis judëjimas. Jo atgarsiai pasieke ir VISI.

Kai 1972 m. gegužes 14 d. prie Kauno muzikinio teatro susidegino Romas Kalanta, KGB pasistenge slepti laidotuvių laiką ir vietą. Kauno jaunimas tuomet surenge protesto demonstraciją su šūkiais „Laisvę Lietuvai“, „Šalin okupantus“ ir t. t. Daug dalyvių buvo suimti ir nuteisti.
Romas Kalanta tapo kovos prieš okupantus simboliu. Anot S. Santvaro, „Nepamirštami, laiko dulkèm neapnešami, našliu ir našlaičiu ǎsarom nuskaidrinami, kurie išdrista didvyriškai mirti, kad amžiais bütu gyva Lietuva “ (iš JAV lietuvių leidinio „Lietuva“).

Romo Kalantos demonstratyvus susideginimas, anot L. Dambrausko, „1972 metais visam pasauliui parode, kad lietuviu tautos laisves troškimo dvasia ne tik gyva, bet ir gali susidarius sąlygoms pasipriešinti režimui " [4.11, p. 197].

Vilniaus inžineriniame statybos institute apie disidentus prabilta, kai KGB susidomëjo Mechaninès technologijos fakulteto Mašinų gamybos technologijos katedros meistro Stanislovo Jako antitarybine veikla. Vieną 1972 m. birželio dieną i fakulteto Staklių laboratoriją įsiverže čekistai. Jie areštavo $S$. Jaką ir išveže ji, kaip vèliau sužinota, i KGB. Stanislovas Jakas VISI Mechanines technologijos fakulteto Staklių laboratorijoje dirbo nuo $1970 \mathrm{~m}$. rugsejo $28 \mathrm{~d}$. VGTU archyve išlikusiuose dokumentuose nurodyta, kad S. Jakas gime 19410801 Kedainiu rajono Zubieliškiu kaime. Savo autobiografijoje S. Jakas raše:

"Tèvas, Jakas Stasys, s. Kazio, gimęs 1904 m., visa laika (42 metus) dirbo Kédainiu ryšiu kontoroje. Susirgo ir mire 1964.

Motina, Jakiene Elena, d. Kazio, gimusi 1912 m. buvo namu šeimininkè. Miré $1954 \mathrm{~m}$.

Be manęs, šeimoje buvo brolis Romas (g. 1938 m.) ir sesuo Danute (g. 1935 m.). 
Šiuo metu brolis gyvena Akmenëje, o sesuo Kédaininose".

Toliau S. Jakas išdèsto, kur yra mokęsis ar dirbęs, būtent: 1955-1958 m. buvo Kauno politechnikumo moksleivis; 1958-1959 m. dirbo pirmiausia darbininku kroveju Kèdainių miškų ūkyje, vèliau - Kèdainių prekybos tiekimo kontoroje; 1959-1960 m. mokèsi Vilniaus auto-, motoklubo kursuose; 1960-1961 m. tarnavo sovietineje armijoje; 1962-1963 m. mokèsi Vilniaus technikos mokykloje; 1962-1966 m. dirbo Vilniaus valgyklų treste pagalbiniu darbininku, Skaičiavimo mašinų gamykloje šaltkalviu. 1966 $1967 \mathrm{~m}$. buvo gamybinio mokymo meistru Vilniaus proftechninëje mokykloje, šaltkalviu Elektros skaitiklių gamykloje [4.12, p. 2-4]. Buvo vedęs: žmona Marija, dukte Dalia. Nuo 1965 m. rugsëjo buvo TSKP narys. VISI rektorius A. Čyras 1972 m. birželio 29 d. išleido įsakymą Nr. 309-K, kuriame rašoma:

„S. Jaka, Mašinu gamybos technologijos $k$-ros meistra, atleisti pagal TSR sajungos ir sajunginiu respubliku darbo istatymu pagrindu 106 str. p. 4 nuо š. m. liepos mèn. 3 d., buhalterijai su juo pilnai atsiskaitant" [4.12, p. 33].

Norint atleisti iš darbo žmogu, reikia jam nurodyti už ką, gauti pasiaiškinimą ir t. t. $\mathrm{O}$ kaip tai padaryti, jei žmogus sedi areštineje?

Matyt, KGB prašymu VISI rektorius ir partines organizacijos sekretorius A. Naujokaitis parenge tokią S. Jako charakteristiką:

"Jakas Stanislovas stakliu laboratorijos mokymo meistru dirba nuo 1970 m. rugsejo men. 28 d. Dirbdamas institute, $1971 \mathrm{~m}$. baige parengiamaji skyriu ir be stojamuju egzaminu buvo priimtas $j$ dieninio skyriaus automobilit transporto specialybes I kursa. $1971 \mathrm{~m}$. gruodžio men. buvo pervestas i Mechanines technologijos vakarini skyriu. Mokosi silpnai.

Jakas Stanislovas yra penktos kategorijos saltkalvis, gerai žinantis savo specialybę, laiku atliekantis gamybines užduotis. Jakas Stanislovas megsta diskutuoti jvairiais klausimais. Aukšta erudicija, apsiskaitymu neišsiskiria, tačiau pasižymi atkaklumu, gindamas savo subjektyviq nuomonę. Politiškai yra nesubrendes, visuomeninius juykius vertina ne iš klasiniu poziciju, nihilistiškai žiüri $j$ atskirus socializmo reiškinius. Jakas Stanislovas bande dauginti ir platinti antitarybinio pobüdžio literatūra. Ǔ̌ tai VISI partinis komitetas pašalino iš TSKP nariu.

Jakas Stanislovas, vartojant alkoholinius gerimus nepastebetas. Instituto visuomeniniame gyvenime nedalyvauja, partiniu ipareigojimu neturëjo " [4.12, p. 22].

Skaitant šią charakteristiką galima nujausti, kad ji rašyta, greičiausiai, Mykolo Burokevičiaus, megusio susirinkimuose ir kitur dažnai deklaruoti klasines pozicijas, komunistinį auklejimą, minèti atskirus socializmo reiškinius ir pan. Jis buvo VISI partinio komiteto sekretoriaus pavaduotojas ideologijai, tai kaip gi čia buvo galima apseiti be jo.

Bet formaliai atleistas $S$. Jakas buvo tik 1972 m. spalio 20 d., matyt, kai ištrūko iš KGB rūsio. Jam atleisti iš pareigų buvo reikalingas profsajungos komiteto sutikimas. Jame rašoma:

"Profsajungos Vietos komitetas duoda sutikima administracijai atleisti S. Jakq iš užimamu pareigu kaip moraliai ir politiniai susikompromitavusi darbuotoja ir netinkanti dirbti su studentais (, TSRS sajungos ir sajunginiu respubliku darbo istatymu pagrindai ", XV skirsnis, 106 straipsnis, 4 punktas) [4.12, p. 7].

Kaip vèliau sužinota, S. Jakas platino „Katalikų bažnyčios kroniką", kurios leidybos sovietinè valdžia išsigando kaip velnias kryžiaus. S. Jakas tapo plačiai žinoma asmenybe Atgimimo metais. Jis buvo vienas tų, kurie atveže iš Maskvos į Vilnių Molotovo-Ribentropo siaubingojo pakto kopiją. S. Jakas mire 1998 m. Palaidotas Antakalnio kapinèse.

\section{Pastatytas auditorinis korpusas}

1972 m. VISI baige 620 absolventų: dieninị skyriu - 261, vakarinį skyrių - 332 ir neakivaizdini skyriu - 27.

Architektūros fakultetą baige 33, Vakarinį fakultetą - 98, Mechaninès technologijos fakultetą 252 (dieninį skyrių - 84, vakarinị skyriu -160 ir neakivaizdini skyriu -8 ), Miestu statybos fakultetą - 59 (dieninį skyriu -41 , vakarini skyriu -11 ir neakivaizdini skyriu - 7), Statybos fakultetą - 178 (dieninį skyriu - 103, vakarinį skyriu - 63 ir neakivaizdinį skyriu - 12).

$1972 \mathrm{~m}$. vasarą i VISI buvo prïmta studijuoti 1230 jaunuolių ir merginų. Daugiausiai priemé Statybos fakultetas - 514, mažiausiai - Architektūros fakultetas - 51 .

1972 m. spalio 1 d. buvo atiduotas eksploatuoti Studentu miestelyje pastatytas dar vienas korpusas. Tai priblokuotas prie pirmojo korpuso auditorinis korpusas. Jị sudare 3 srautines $(04,05,06)$ auditorijos, maždaug 
VILNIAUS

INŽINERINIS STATYBOS

INSTITUTAS darbų efektyvumas, švelniai tariant, neatitiko tikroves. O ūkiskaitinių darbų naudą taikliai apibūdino K. Antanavičius: „Kalbant apie moksliniu tiriamuju darbu efektyvuma, neatsižvelgiame, kokị efekta duoda šie darbai mums. Juk kyla müsu kvalifikacija, gerëja studentams destomo dalyko kokybé. Reiketu žiüreti, kokia nauda gauna destytojas, o žiurime tik $\dot{z}$ tas gaunamas papildomas lësas. O pagaliau ir už tas lësas perkame mokymo procesui reikalingas priemones ir t. t. [4.13, p. 6-7].

$\mathrm{K}$. Antanavičius prieštaravo rektoriui A. Čyrui, teigusiam, kad institute yra antagonizmas tarp ūkiskaitinio ir biudžetinio mokslinio darbo: „Müsu institute kaip tik nera jokio antagonizmo tarp mokslinio darbo formu. Mes juk gyvename socialistineje valstybeje ir mums nesvarbu, iš kokios kišenes finansuojami darbai ", - kalbejjo K. Antanavičius. Jis dažnokai kritiškai vertindavo rektoriaus teiginius ir tai, galima manyti, apsunkino jo daktaro (habilitaciness) disertacijos realizaciją.

Instituto mokslininkai 1972 m. spaudoje paskelbẻ 301 straipsnị (penkis užsienio spaudoje), paraše dvi monografijas ir du vadovèlius, pateike 44 paraiškas išradimams, apgyne 17 kandidatinių disertaciju [4.13, p. 1].

$1973 \mathrm{~m}$. sausio $17 \mathrm{~d}$. Tarybos posedyje buvo svarstomas vyr. destytojo Stasio Pileno pedagoginis darbas. Studentai blogai lanke jo paskaitas, katedra abejojo, ar jis tinkamas pedagoginiam darbui. Buvo pažymeta, kad S. Pileno užmegzti ryšiai su užsieniu neturi nieko bendra su tiesioginiu darbu, tad, suprask, kad tai nepageidautina. Paskaitose jis rekomenduojąs studentams netinkamą literatūrą ir kt. Bet bene svarbiausius S. Pileno netinkamumo pedagoginiam darbui kriterijus išdesste M. Burokevičius: „Svarstomas klausimas aktualus. Vyr. destytojas S. Pilenas neatlieka savo tiesiogines paskirties, taip pat nusižengia studentu komunistinio auklejimo principams, nukreipia studentus neteisinga kryptimi.

Kas dèl anketu, kurias S. Pilenas pateike studentams užpildyti, tai visu pirma savivaliavimas. Müsu katedra turi ryšş su studentais, kuriems deste drg. S. Pilenas, ir klaidas tenka taisyti mums.

Drg. S. Pilenas kompromituoja marksistine filosofijg" [4.14, p. 4].

Taryba nutare, kad S. Pilenas netinkamas dirbti pedagoginį darbą ir buvo atleistas.

Vèliau jis susirgo, gydesi psichiatrinëje ligoninëje. Kas žino, ar S. Pilènas nebuvo vienas tų, kuriuos už politinius motyvus 
guldydavo ì "psichuškes“? Neužilgo S. Pilènas mirè.

Pavasario semestrui buvo paskirtos vardinès stipendijos. Aukščiausia buvo laikoma Lenino stipendija. Buvo dar čekisto Dzeržinskio ir revoliucionieriaus Angariečio stipendijos. Ką bendro jos turejo su inžinerijos mokslais? Tik L. Gucevičiaus stipendija architektui turejo profesinę prasmę. Bet tenka pripažinti, kad visos minetos stipendijos atitekdavo labai gerai studijavusiems studentams. Daugelis šių stipendininkų vèliau tapo destytojais. Tarp 1972-1973 mokslo metu vardinių stipendininkų laureatų tokių buvo net keturi: R. Kačianauskas, M. Šukšta, B. Krištaponis, E. Staniūnas.

1973 m. TSRS Aukštojo ir specialiojo vidurinio mokslo ministerijos Aukštųju mokyklų inspekcija tikrino, kaip vedamos mokomosios ir gamybines praktikos Vilniaus inžineriniame statybos institute. Paskui tikrinimo medžiaga apsvarstyta ministerijos kolegijos posedyje.

Inspekcija teigiamai įvertino mokomųju praktikų organizavimą, bet rado gamybinių praktikų trūkumų: kai kurie studentai neturëjo gamybinés praktikos programu, retai juos aplankydavo praktiku vadovai, kai kur praktikantai dirbo darbininkais ir t. t. Nors praktikų reikšmè būsimajam specialistui yra be galo svarbi, deja, tokie jos organizavimo trūkumai buvo būdingi visam „brandaus socializmo" laikotarpiui. Praktiku stoka yra viena didžiausių priežasčių ir šiais lakais, dèl ko prailgsta jaunojo specialisto adaptacija darbo vietoje.

Siekiant pagerinti mokomąsias ir gamybines studijų praktikas, VISI taryba nutare parengti praktikų nuostatus, kurių sudarymui vadovavo doc. J. Kivilša [4.14, p. 42].

Metams baigiantis instituto Taryba svarste naują pramoninès ir civilines statybos specialybés mokymo planą. Tai buvo ypatingas plano keitimo atvejis, kadangi TSRS Aukštojo ir specialiojo vidurinio mokslo ministerija leido Vilniaus inžineriniam statybos institutui parengti studijų proceso individualu planą minètos specialybès studentams. Šiaip jau Maskva nieko neišleisdavo iš savo rankų, bet VISI ryškiai išsiskyre iš TSRS aukštųjų mokyklų intensyviu elektroninès skaičiavimo technikos naudojimu mokymo procese ir todel buvo leista parengti tą planą. Bet jis turejjo būti parengtas tipinio visasąjunginio plano pagrindu. Taigi tai buvo aukštas instituto darbo įvertinimas. Didžiausi nuopelnai, ži- noma, teko rektoriui A. Čyrui, kuris atkakliai ir sistemingai skatino kuo daugiau naudoti elektroninę skaičiavimo techniką ne tik PCS, bet ir visu instituto specialybių studijose.

Naujame PCS specialybés studiju plane buvo numatyta sumažinti 150 mokymo valandų, tolygiau paskirstyti kursinius darbus ir projektus semestruose, sumažinti kursinių projektų skaičių nuo 12 iki 11, įskaitu - nuo 48 iki 46. Visuose semestruose neturejo būti daugiau kaip 5 egzaminai, o įskaitu - ne daugiau kaip 6. Savaitinių valandų plane buvo numatyta ne daugiau kaip 34 .

Rektorius A. Čyras Tarybos posedyje pabrěže fundamentinių moksly̨ svarbą rengiant specialistą. Matyt, atsižvelgiant į rektoriaus nuomonę buvo skiriama daugiau paskaitu valandu fizikai, matematikai, hidraulikai ir kiek sumažinta laiko tokiems specialiesiems dalykams, kaip statybinès mašinos, šiluminè technika, statybos darbų technologija ir kt. [4.14, p. 72-75].

Toks požiūris į mokymo planus negalëjo būti vertinamas vienareikšmiškai. Be abejo, fundamentinių dalykų išmanymas yra inžinerinio pasirengimo pagrindas. Bet sumažinus specialiuosius dalykus, absolvento, atëjusio i darbovietę, prisitaikymo laikas konkrečioje darbo vietoje pailges, o tai visada kelia gamybinių organizacijų nepasitenkinimą. Ši problema aktuali ir šiandien. Gamybininkai turetų žinoti, kad jaunas specialistas, turintis gerų fundamentinių žinių, ilgainiui gerokai lenks tuos, kurie tų žinių gauna mažiau, bet pradžioje yra tinkamesni konkrečiai darbo vietai. Pastaruosius tuomet rengè technikumai, dabar - kolegijos.

$1973 \mathrm{~m}$. vasario $8 \mathrm{~d}$. VISI rektorius A. Čyras ir partinio komiteto sekretorius A. Naujokaitis nusiunte raštą Lietuvos TSR aukštojo ir specialiojo vidurinio mokslo ministrui $\mathrm{H}$. Zabuliui, kuriame rašè, kad per trejus metus Vilniaus inžinerinis statybos institutas tapo stambia aukštąja mokykla. Jame studijuoja 5529 studentai, iš jų - 3096 dieniniame, 2025 - vakariniame ir 408 - neakivaizdiniame skyriuose.

Dauguma studentų dabar jau studijavo statybos specialybes. Bet būtent šių specialybių studijoms labai trūko laboratorijų. Esamos buvo labai mažos, o kai kurių dalykų laboratoriju išvis nebuvo. VISI vadovai prašè, kad, atsižvelgiant ị būsimą instituto studentų skaičiaus didejjimą, būtų sudarytas VISI materialinès bazès pletros priemoniu planas.

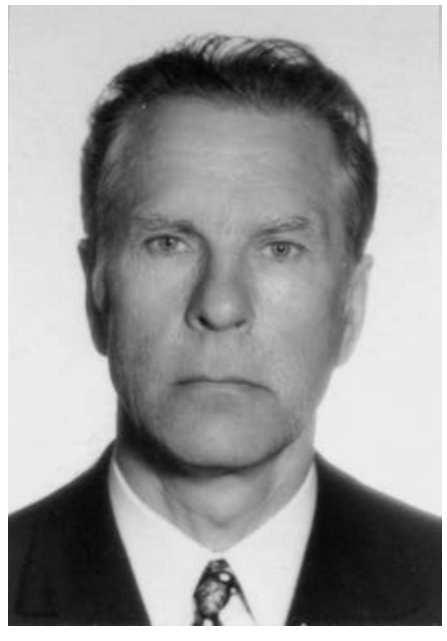

J. Kivilša 
VILNIAUS

INŽINERINIS STATYBOS

INSTITUTAS

Charakteristiką, prieš pasirašant, turèdavo apsvarstyti katedroje, svarstymo protokolą privalejo vizuoti katedros vedëjas.

Pirmines charakteristikos pagrindu

Tokie raštai - iprastas augančio instituto reiškinys. Bet stebina, kad dažnai jie buvo rašomi „broliškaja“ - rusų kalba. Ne išimtis buvo ir minetasis A. Čyro ir A. Naujokaičio raštas $\mathrm{H}$. Zabuliui.

Ir vèliau pasitaikydavo keistoku sprendimų. Pavyzdžiui, 1973 m. balandžio 5 d. VISI rektoriaus pareigas ejęs prorektorius $\mathrm{R}$. Jonušas paskelbè įsakymą, kad kiekvienas studentas, atvykdamas į instituto patalpas, privalejo su savimi turèti galiojantị studento bilietą ir budinčio destytojo (!) prašymu turejo ji parodyti. Desstytojai, su raudonais raiščiais ant rankos vaikščiodami koridoriais, sudare isspūdị, kad esama ne aukšstojoje mokykloje, o kokiame nors lageryje.

\section{KGB kontrole ir A. Sniečkaus vizitas}

Su lagerio tvarka asocijavosi vadinamojo 1-ojo skyriaus veikla. Šis skyrius faktiškai buvo penktoji KGB kolona institute. Skyriaus reikalams skirti rektoriaus įsakymai pažymèti specialia žyme - „tarnybiniam naudojimui. Egz. Nr.__". Skyrius destytojų ir studentu veiklą, ar ji nèra priešiška valdžiai, kontroliavo, ar tiksliai vykdomos desstytojų ir studentų išvykų i užsieni TSRS Aukštojo ir specialiojo vidurinio mokslo ministerijos (o, matyt, faktiškai sudarytos KGB) instrukcijos.

1-asis skyrius kaupe visus komandiruojamojo asmens dokumentus. Pirminę charakteristiką turëjo parengti fakulteto dekanas arba savarankiškos katedros vedejas. Be to, pasirašydavo partbiuro sekretorius, profbiuro pirmininkas ir komjaunimo sekretorius.
Kadru skyrius rengdavo charakteristikos projektą ir ji suderindavo su atitinkamu prorektoriumi. Paskui charakteristiką Kadrų skyrius galutinai ifformindavo ir teikdavo pasirašyti rektoriui, partinio komiteto sekretoriui ir Vietos komiteto pirmininkui (déstytojų, darbuotojų) arba Komjaunimo komiteto sekretoriui (studentų).

Bet tai dar ne viskas. Toliau vadinamąją objektyvinę pažymą renge Kadrų skyriaus viršininkas. Ją jis pasirašydavo, uždèdavo instituto herbinį antspaudą ir..., manote, viskas - gali keliauti? Ne, tą pažymą perduodavo 1-ojo skyriaus viršininkui, kuris „suderina atatinkamose instancijose [paryškinta autoriaus - A. N.] komandiruojamojo tinkamuma išvykimui $\dot{j}$ užsienį. Ant egzemplioriaus, liekančio institute, turi būti I-ojo skyriaus viršininko atžyma apie atitinkamus pokalbius su išrykstančiu ir kitais atsakingais asmenimis ". Bet ir tai dar ne viskas!

1-ojo skyriaus viršininkas toliau renge "galutinę" bylą bei rektoriaus pristatomąji lydraštị ministerijai. Tą bylą turejo peržiūrèti prorektorius ir vizuoti, kad visi dokumentai parengti pagal TSRS ministerijos instrukciją. Toliau dar vienas tragikomiško spektaklio veiksmas - komandiruojamasis kartu su prorektoriumi ir 1-ojo skyriaus viršininku turejo atvykti pas rektoriu, „kurju akivaizdoje rektorius pasirašo pristatyma“. Visus dokumentus 1-ojo skyriaus viršininkas "personaliai pateikia LTSR Aukštojo ir specialiojo vidurinio mokslo ministerijos Užsienio ryšiu skyriaus viršininkui " [4.14, p. 41-42].

Nors iškabos bylojo ką kita, visi nujaute, kad tas Užsienio ryšių skyrius faktiškai buvo KGB padalinys.

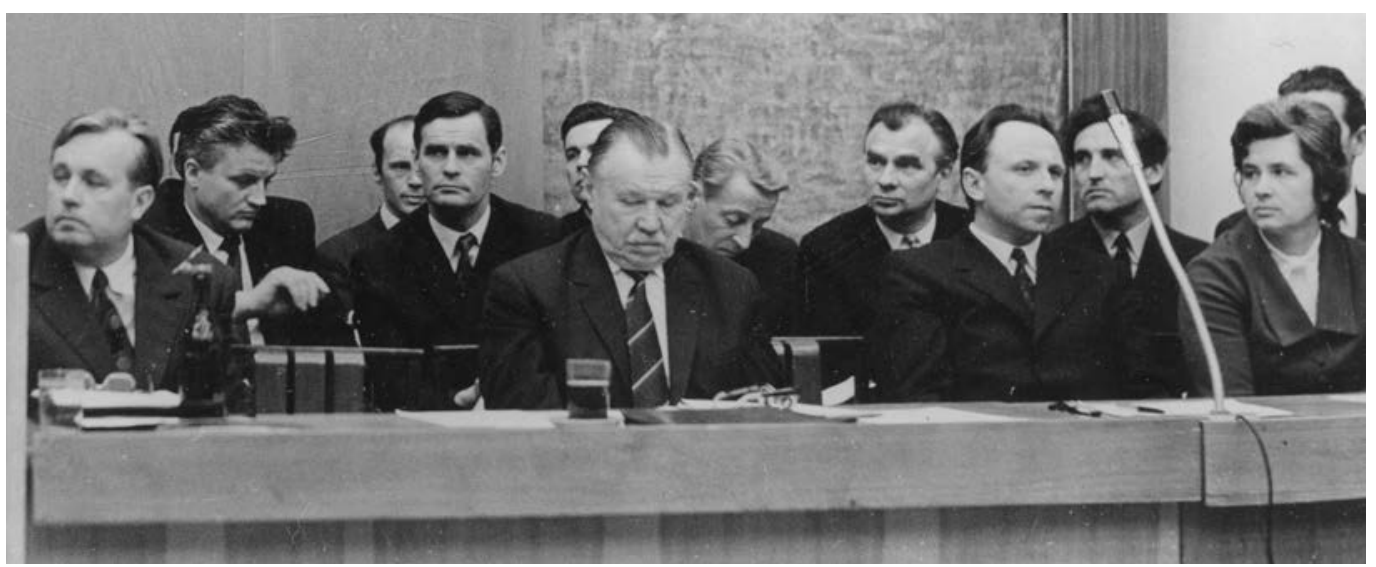


Tokia tad buvo to brandaus socializmo „demokratija“, tokios buvo jos „laisvès“, kurias kasdien deklaravo „socialistine“ propaganda: „Kito tokio krašto nesurasi, kur taip žmogui gera ir jauku“...

1973 m. kovo 28 d. Vilniaus inžineriniame statybos institute nuo pat ryto buvo didelis sujudimas. Buvo laukiama valdžios apsilankymo, taip sprende ne vienas, matydamas valytojų blizginamus langus ir grindis, rengiamą susirinkimui Didžiąją auditoriją.

Taigi toje auditorijoje ivvyko atviras VISI partinès organizacijos susirinkimas, kuriame dalyvavo „šeimininkas“ - Lietuvos KP CK pirmasis sekretorius A. Sniečkus, jo didele palyda, ministras $\mathrm{H}$. Zabulis ir kt.

A. Sniečkui buvo parodyti naujieji korpusai, papasakota apie instituto struktūrą, studijų ir mokslo padeti, kalbèta apie nauju statybu, socialines problemas. Apie tai buvo kalbama ir susirinkime, o A. Sniečkus nieko neprižadejo, sakè, ką reikia gerinti ir tobulinti, palinkèjo institutui dar sèkmingiau spręsti partijos ir vyriausybès keliamus uždavinius.

Kaip netrukus paaiškejo, A. Sniečkus aplankè VISI ne atsitiktinai. Jau kuris laikas dideli nesutarimai ryškejo tarp instituto vadovų, ypač tarp rektoriaus A. Čyro ir prorektoriaus R. Jonušo. J. Stražnickas apie tai rašo savo knygoje apie A. Čyrą:

„Iš pradžiu pašlijo artimu draugu - Aleksandro Cyro ir prorektoriaus Romualdo Jonušo santykiai. Kada tarp ju pirma karta perbego juoda katè? Ar tada, kai grižes po pusmečio kūrybiniu atostogu, A. Cyras pakeite kai kuriuos savo patiketinio nurodymus ir neatsižvelge $i j o$ nuomone, ar veliau, kai rektorius savo rankose sutelke visas galias ir svarbius klausimus spręsdavo vienas, nepasitaress su kitais, pirmiausia prorektoriais, fakultety dekanais? Atleisdavo darbuotojus, juos perkeldavo i kitas pareigas, skelbdavo konkursus, bausdavo. Nuskriaustieji dažniausiai begdavo skustis ir ieškoti paguodos pas R. Jonušą. Šis buvo ne mažiau ambicingas ir išdidus nei rektorius. Nesusipratimai pamažu virto konfliktais " [4.15, p. 267-268].

Institute susiformavo du blokai: vieni rèmé A. Čyrą, kiti - R. Jonušą. Prieš rektorių pasipyle skundai i CK, ministeriją, „gorkomą“, „rajkomą“. Kolektyve įsivyravo įtampa, žmonés vengè viešai bendrauti, kad vieno bloko atstovai nepastebetų kitam blokui neva jaučiamų simpatiju. Toje situacijoje, atrodo, ypač gerai jautèsi partijos sekretoriaus pavaduotojas M. Burokevičius, dažnai vars- tęs rektoriaus kabineto duris ir, daugelio manymu, kaitinęs nesantaikos atmosferą.

Vadovų nesutarimai tapo susirinkimų, komitetų posèdžių dažnu darbotvarkès klausimu, tęsèsi skundai, komisijos, tikrinimai. Bet, kaip sakoma, gyvenimas nestovejo vietoje. Institutas dirbo, buvo ir gražių rezultatų, tikètasi, kad vadovų darbą temdantys debesys išsisklaidys.

\section{Plečiami ryšiai ir bazé}

1973 m. gegužę institutą aplankè Maskvos inžinerinio statybos instituto (Kuibyševo vardo) vadovai: rektorius techn. m. dr. prof. N. Strelčiukas, MISI partinio komiteto sekretorius L. Šubinas ir profsąjungos vietos komiteto pirmininkas A. Mastiuginas. Buvo pasirašyta bendradarbiavimo tarp MISI ir VISI sutartis, kuri išties daugelị metų buvo labai efektyvi. Dalykiškai bendradarbiavo katedrų desstytojai, vadovai, studentai.

MISI sovietmečiu buvo aukštųjų statybos mokyklų „flagmanas“. Jis koordinavo daugumą statybos mokslo, studijų klausimų, jame dirbo įžymūs ịvairių statybos sričių mokslininkai, daugumos rusiškų vadovèlių, mokomųjų priemonių autoriai. MISI vien 1973 m. buvo apgintos 6 daktaro ir 37 kandidato disertacijos, parašyta 17 monografijų, 39 vadovèliai ir kt. VISI žmonèms maskviečiai padedavo spręsti tuos klausimus, kurių be Maskvos leidimo nebuvo galima sutvarkyti, o vilniečiai padedavo jiems spręsti jų poilsio problemas. VISI poilsinèse dažnai matydavome ne vieną MISI įžymybę su šeimomis, vaikais ar anūkais.

MISI buvo tarpininku užmezgant dalykinị bendradarbiavimą su Veimaro aukštąja statybos ir architektūros mokykla. Naudingas Veimaro ir Vilniaus mokslininkų

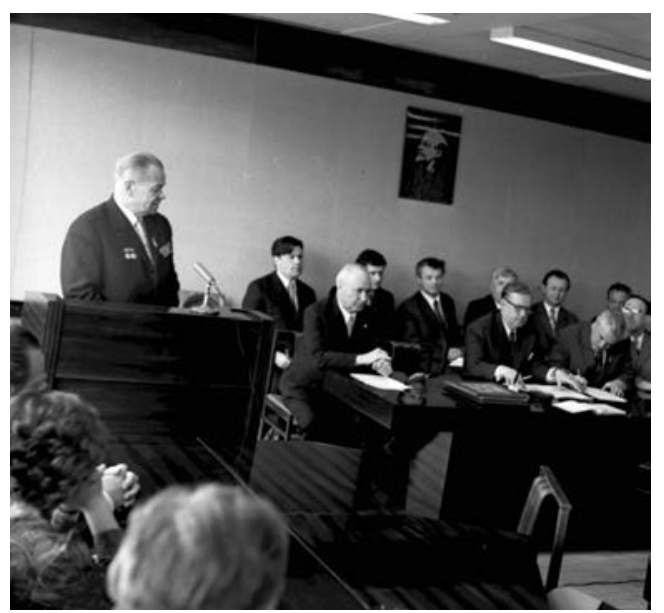


VILNIAUS

INŽINERINIS STATYBOS

INSTITUTAS

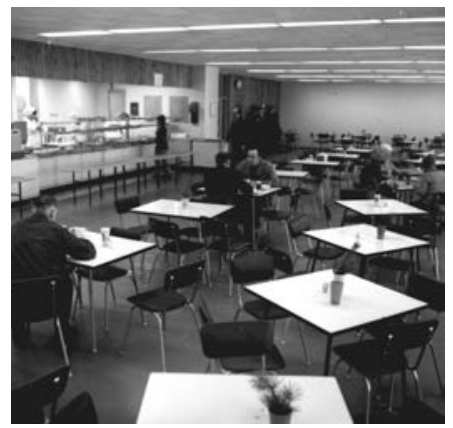

150 vietu VISI valgykla bei studentų bendradarbiavimas gyvas ir šiandien.

$1973 \mathrm{~m}$. institutas parenge 718 diplomuotų inžinierių. Prie būsimųjų aukštybinių bendrabučiu (ilgainiui tą vietovę studentai pakrikštijo „Niujorku“) buvo pastatytas pastatas, kuriame įrengta 150 vietų valgykla, maisto produktu parduotuve, poilsio patalpos. Jauniesiems specialistams Žirmūnuose pastatytas 5 aukštų stambiaplokštis gyvenamasis namas. Šalia tuometinių VISI centrinių rūmų buvo pastatyta pneumatiné sporto salè. Bet ja naudotis žiemą buvo neįmanoma, nes esami šilumą generuojantys agregatai gebejo pakelti temperatūrą tik $+7^{\circ} \mathrm{C}$. Taigi kai lauke oro temperatūra buvo $-17^{\circ} \mathrm{C}$, saleje $-10^{\circ} \mathrm{C}$. Pneumatine sporto sale buvo pastatyta VISI studentu jegomis, darbų kokybe buvo apgailetina. Tai, taip pat ir eksploatavimo klaidos dave prastą rezultatą: stipraus vëjo salès apvalkalas buvo sudraskytas ir jos eksploatavimas nutrauktas.

1973 m. labai išaugo studentų statybiniu būrių skaičius - buvo net 19 būrių. Bet studentų darbas statybiniuose būriuose, deja, neprilygo gerai organizuotoms mokomosioms ir gamybinems praktikoms. Dauguma dirbo mažai kvalifikuotą ir mažai mokamą darbą, todel visa tai, nors ir turejo kai kuriu privalumų, neprisidejo prie geresnio specialistų rengimo.

1973 m. VISI studentai pasiekè gražių sporto laimëjimų. Net 31 pelnè Lietuvos čempionatų keturiolikos sporto šaku aukso, sidabro ar bronzos medalius. 1973 m. LTSR čempionais tapo 15 VISI studentų: irkluotojai Arūnas Šatas, Gintaras Pečiukaitis ir Kęstutis Lapè, badmintonininkè Nijole Sabaite, fechtuotojai Edvardas Jančiauskas ir Ričardas Venckūnas (kardas, komandos), šauliai - Vladas Turla ir Juozas Petkevičius, lengvaatlečiai - Aleksandras Petrušinas (estafete $4 \times 100 \mathrm{~m}$ ) ir Anatolijus Jeršovas $(200 \times 400 \mathrm{~m})$, regbininkai - Henrikas Stankevičius ir Juozas Kukys („Plieno“ komanda), penkiakovininkai - Vytautas Bručas ir Arūnas Aidukas. Čempione tapo ir destytoja sklandytoja Algimante Kryžanauskaitè.

Rudenį sustiprejo VISI mokslininkų galimybès. Lapkričio mènesi pradejjo veikti antroji elektroninè skaičiavimo mašina - „Minsk 32 ". Buvo gauta daug naujų irrenginių, apa- ratų ir prietaisų moksliniams tyrimams atlikti. Net 26 mokslininkai institute apgyne kandidatines disertacijas. Pažymetina, kad tuomet ypač pasižymëjo gelžbetonį tyrinëję jaunieji mokslininkai. Pastatų konstrukcijų katedros vyr. destytojas Č. Ignatavičius gyne darbą „Gelžbetoninių sijų stiprumo tyrimai nuožulniame pjūvyje“, Statybinès mechanikos katedros vyr. destytojas V. Viršilas - „Iš anksto įtemptų kintamo aukščio gelžbetoninių elementų supleišejimo ir stiprumo įstrižuose pjūviuose tyrimas", Statybos darbų technologijos katedros asistentas E. K. Zavadskas - „Klijuotų betono ir įtempto gelžbetonio elementų, naudojant polimerinius klijus su derva LKS-1, tyrimas“. Jis vèliau pakeite mokslinių tyrimų krypti, tapo technikos mokslų daktaru (habilituotu), buvo išrinktas eiti rektoriaus pareigas, kurias sèkmingai vykdè net 12 metų. Reikšmingiausias E. K. Zavadsko laimëjimas - Technikos universiteto sukūrimas.

Gyne kandidato disertacijas ne tik inžinieriai. VISI Kalbų katedros vedëja A. Glemžiené Kijevo universitete apgyne disertaciją „Leksiné anglų kalbos interferencija JAV lietuviu kalboje" ir gavo filologijos mokslų kandidato laipsni.

1973 m. spalio 17 d. poligrafiniu būdu išleistas pirmasis savaitraščio „Inžinerija“ numeris. Jo tiražas buvo 1000 egzempliorių. Vyriausiuoju redaktoriumi buvo paskirtas Kalbų katedros docentas Vytautas Būda, dirbęs šį darbą visuomeniniais pagrindais. Netrukus buvo priimtas redaktorius A. Alionis, dirbęs tą darbą vienerius metus. Paskui ji pakeite $\mathrm{D}$. Anuškevičienè.

Laikrašti „Inžinerija“ buvo bandyta leisti ir ankščiau. Apie tai yra rašęs doc. G. Likas:

"1970 metu rugsejo menesi buvo išleistas pirmasis "Inžinerijos" numeris. Jo atsakingoji redaktore buvo doc. I. Gaidamavičiene. Šis laikraštis išeidavo karta per meneși. Iki 1973 m. birželio buvo išleista 30 numeriu. Juose buvo pateikiama informacija apie svarbiausius ir idomiausius VISI veiklos ir studentu gyvenimo momentus. Šis laikraštis buvo labai originalus, panašus j̧ sienlaikraštzi. Tekstai buvo spausdinami mašinele, pavadinimai įvairiais šriftais užră̌yti ranka naudojant tušą, nupieštos karikatūros. Po to paruostas laikraštis buvo dauginamas elektrografiniu aparatu „Era“, $o$ padauginus - priklijuojamos iliustracijos, t. $y$. nuotrankos. Nuotrauku buvo padaroma tiek, kiek ruošiama laikraščio egzemplioriu " [4.16, p. 169]. 


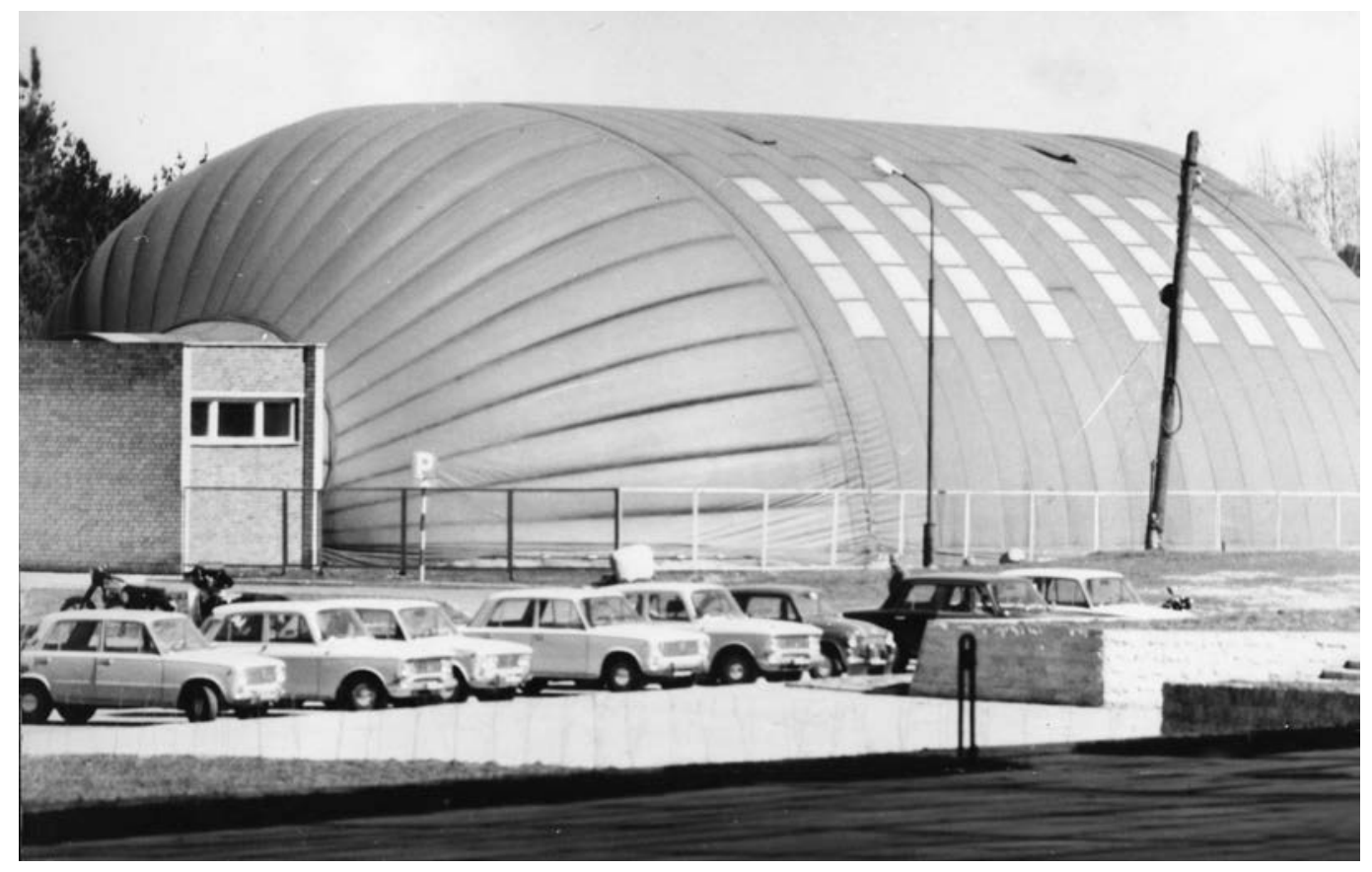

„Inžinerijos“ 1973 m. spalio 17 d. numeryje redakciniame straipsnyje, be kita ko, buvo rašoma:

„Tad kviečiame visus visus $\dot{z}$ darbq - rašyti korespondencijas, apybraižas, vaizdelius, méginti savo plunksną literatūros žanre, piešti karikatūras ir draugiškus šaržus, informuoti apie menkiausia instiuto viěsosios kalbos aplaiduma. Tegul ne vienas instituto ivykis neprasprūsta pro akyla visuomeninio „Inžinerijos" korespondento žvilgsnį. Juk ir žmoniu nuo seno sakoma: „Kur du stos, visados daugiau padarys".

Tas redakcijos kvietimas bendradarbiauti aktualus ir dabar. Noretųsi, kad „Inžinerijos" laikraščio bendradarbiavimas su dèstytojais, studentais ir darbuotojais būtų intensyvesnis.

Gražių laimëjimų pasiekè VISI SMD, sąjunginiame konkurse laimëjusi II premiją. Buvo baigiamas statyti 16 aukštų bendrabutis.

Dèta nemažai pastangu įkurti VISI poilsio bazę Baltijos pajūryje. Palangoje institutas galëjo iggyti vieną iš triju siūlomų objektų Kęstučio arba Aksionaičio gatvèse, bet už tai VISI turëjo iš jai skiriamy buty atsisakyti apie $200 \mathrm{~m}^{2}$ ploto ir perduoti kurortui. Plano komitetas tam neprieštaravo. Tačiau nesutarimai VISI vadovybeje neleido to realizuoti. Kitos aukštosios mokyklos - Vilniaus universitetas, Kauno politechnikos institutas, Vilniaus pedagoginis institutas, Žemès ūkio akademija Palangoje turejo puikius pastatus ir dar gi juos pletee. VISI tuomet neišnaudojo puikios progos, nors turejo galimybių.
1973-1974 mokslo metais instituto Tarybą sudare 43 asmenys: prof. A. Čyras (pirmininkas), doc. V. Kriščiūnas (mokslinis sekretorius), nariai: doc. R. Jonušas, doc. G. Marčiukaitis, doc. M. Burokevičius, doc. Baškys, doc. E. Barkauskas, doc. V. Česonis, e. doc. p. A. Glemžiene, doc. J. Grèska, doc. H. Gylys, prof. A. Janulis, doc. R. J. Jasilionis, doc. V. Krušinskas, prof. A. Kudzys, doc. V. Kulakauskas, doc. A. P. Kavolelis, doc. K. Lukoševičius, prof. A. Lukošaitis, doc. B. Liaudis, prof. D. Maciulevičius, doc. J. Bacevičius, doc. K. Sasnauskas, e. doc. p. A. Samulevičius, doc. E. Mauza, doc. I. Nickus, doc. A. Valentinavičius, doc. S. Rokas, doc. A. Ražinskas, pulk. V. Vlasenko, doc. B. Sidauga, doc. A. Smilgevičius, prof. A. Spelskis, MTS viršininkas E. Stankus, doc. J. Šimkus, prof. K. Šešelgis, prof. V. Šeštokas, doc. Č. Teišerskas, doc. Z. Vainoris, inž. J. Žemkus, partinio komiteto sekretorius doc. A. Naujokaitis, komjaunimo komiteto sekretorius A. Gaižutis, profsąjungos Vietos komiteto pirmininkas A. Gailius.

Tais metais Kadrų skyriaus viršininku dirbo A. Šlekienè, Mokymo dalies vedèja - G. Kazlauskiené, vyr. buhalteriu - K. Stonis.

$1974 \mathrm{~m}$. vasario $26 \mathrm{~d}$. buvo įsteigta VISI MTS žinybinè Kelių ūkio mokslinio tyrimo laboratorija. Jos steigejas buvo Komunalinio ūkio ir Aukštojo ir specialiojo vidurinio mokslo ministerijos.

Šios laboratorijos Miestų kelių tinklo sektoriaus moksliniu vadovu buvo paskirtas

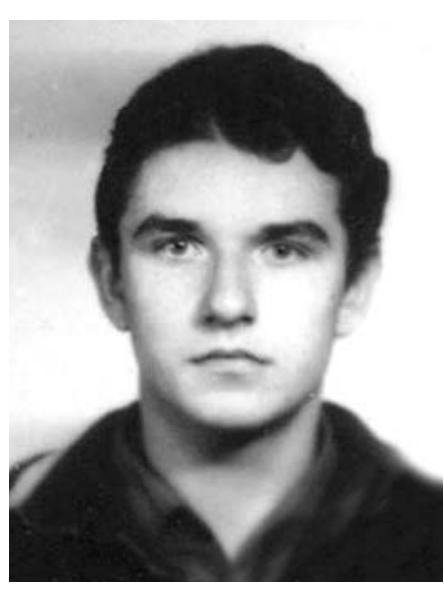

S. Turla

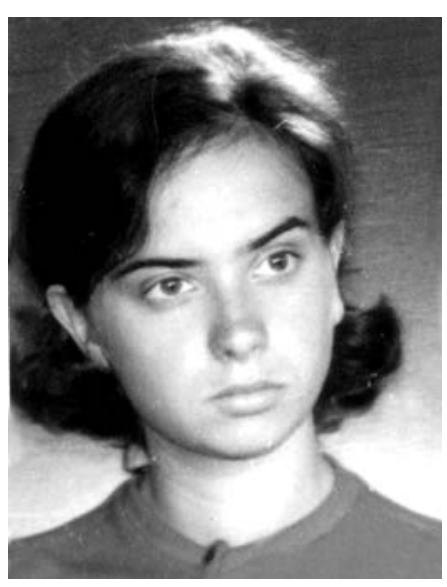

S. Sabaite 
VILNIAUS

INŽINERINIS STATYBOS

INSTITUTAS

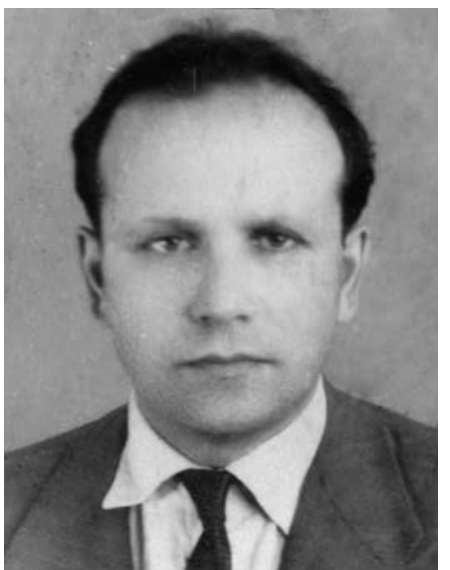

A. Naidionovas

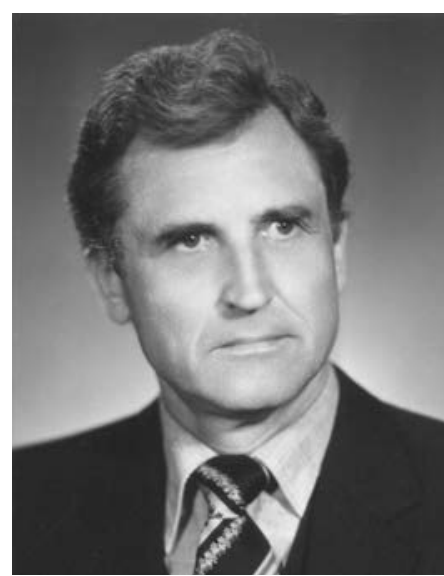

A. Čižas
Miestų statybos katedros vedëjas prof. V. Šeštokas, o Kelių konstrukcijų sektoriaus moksliniu vadovu - Kelių katedros vedejas doc. S. Rokas.

1974 m. sausį Kijeve technikos mokslų daktaro disertaciją „Elektrinių signalų tiesine laiko mastelio transformacija" sèkmingai apgyne Arkadijus Naidionovas.

1973 m. VISI mokslininkai baige 27 biudžetinius ir 52 ūkiskaitinius darbus. Pažymėtinas Pagrindų ir pamatų katedros bendradarbiu atliktas darbas - „Pastatu pagrindu ant moreniniu gruntu Lietuvos TSRS sąlygomis projektavimo laikinieji nurodymai“, kuris buvo pagristas gausybe atliktų eksperimentų, teorinių tyrimų. „Nurodymais" privalejo vadovautis visos Lietuvos projektavimo organizacijos.

$1973 \mathrm{~m}$. buvo paskelbta 314 moksliniu straipsnių respublikoje, 102 - sajungineje ir 10 - užsienio spaudoje. Buvo išleisti 8 mokslo darbų tomai.

1974 m. sausio 22 d. mire LKP CK pirmasis sekretorius Antanas Sniečkus. Jo laidotuvese dalyvavęs TSKP CK sekretorius I. Kapitonovas sausio 26 d. apsilankè Vilniaus inžineriniame statybos institute. Kartu atvyko visi trys svarbiausi respublikos vadai: V. Charazovas (II LKP sekretorius, visada tokie buvo atsiunčiami iš Maskvos ir „demokratiškai“ išrenkami, o žmonių tyliai vadinami „generalgubernatoriais“), P. Griškevičius (Vilniaus m. LKP sekretorius, netrukus tapęs pirmuoju, bet niekada nevadintas „šeimininku“) ir J. Maniušis (Ministru Tarybos pirmininkas, taikęs i i ,šeimininko“ kèdę).

Vizitas buvo labai formalus, neliko ką prisiminti. Anot „Inžinerijos“, „Instituto rektorius prof. Aleksandras Cyras, doc. Algimantas Naujokaitis, doc. Gediminas Marčiukaitis ir filos. m. kand. Algirdas Gaižutis supažindino svečius su instituto mokomosiomis auditorijomis. Sveciai domëjosi studentu mokymosi, buitinemis ir gyvenimo salygomis " [4.17, p. 1].

$1974 \mathrm{~m}$. vasario $8 \mathrm{~d}$. paminetas VISI mišraus akademinio choro gimtadienis. 1964 m. ìvyko studentų dainos myletoju susitikimas su įžymiu dirigentu ir kompozitoriumi Klemensu Griauzde. Buvo nutarta kurti rimtam darbui studentų chorą. Studentų dainininkų lyderiu tapo A. Braš- kys. Jau po dviejų savaičiu įvyko pirmoji repeticija. İ ją susirinko apie 40 būsimųju choro dalyviu [4.18, p. 3].

Vasario 18 d. LKP CK plenumas pirmuoju sekretoriumi išrinko Petrą Griškevičių, brežnevinès stagnacijos dvasią bene geriausiai atitikusi partinị veikejją.

$1974 \mathrm{~m}$. kovo $1 \mathrm{~d}$. buvo įsteigta ir pradëjo veikti Medžiagu atsparumo katedra, o nuo $1974 \mathrm{~m}$. balandžio $1 \mathrm{~d}$. - Taikomosios matematikos ir mechanikos katedra.

Medžiagu atsparumo katedros vedeju buvo paskirtas doc. Algirdas Čižas. Jis tais pačiais metais KPI apgyne technikos mokslų daktaro disertaciją „Optimalių tamprių plastinių tiesiškai stiprejančiu sistemų skaičiavimo teorija ir metodai“.

Taikomosios matematikos katedros vedëju tapo prof. D. Maciulevičius.

Balandžio pirmoji - melagių diena. Sovietmečiu melagystei vienos dienos neužteko. 1974 m. balandžio 18 d. VISI centrinių rūmų perpildytoje Didžiojoje auditorijoje susirinko (pabandyk neateiti!) destytojai, studentai, administracijos darbuotojai „ir visi vienu balsu pritare profesoriaus, technikos moksly daktaro Aleksandro Čyro minčiai: TSKP CK Generalini sekretoriu dranga Leonida Brežneva iškelti kandidatu i TSRS Aukščiausiosios Tarybos Sajungos Tarybos deputatus Vilniaus 706 rinkimineje apygardoje.

Iškilminga susirinkima vedè VISI partijos komiteto sekretoriaus pavaduotojas, docentas Mykolas Burokevičius..." [4.19, p. 1].

Keistai ir komiškai visa tai atrodo dabar, žvelgiant į praeitį. „Šou“ artistais buvome visi, taip pat iškilūs mokslininkai ir menininkai. Gal tik M. Burokevičius manè esąs nuoširdus, bet tuomet suabejoji žmogaus sveiku protu.

Brežnevui susirinkimas pasiuntè telegramą. Tai buvo privaloma tokio siužeto dalis - pabrežta, kaip daug jis padare, koks neịkainojamas jo ǐnašas, kokia nenuilstama jo veikla ir pan. Žinoma, Brežnevas kandidatu buvo iškeltas „vieningai“, pasižadant, kad „mes stengsimè“", „visas jegas skirsime“, „tapsime geri“, „dirbsime geriau negu dirbome" ir t. t. Bet juoktis buvo pavojinga.

1974 m. balandžio 17 d. VISI taryba nutare prašyti Aukštojo ir specialiojo vidurinio mokslo ministeriją issteigti naują fakultetą - Statybos ekonomikos. Šio fakulteto dieniniame skyriuje buvo numatoma rengti statybos ekonomikos inžinierius, vakariniame skyriuje - statybos ekonomikos bei 
pramoninès ir civilinès statybos inžinierius ir neakivaizdiniame skyriuje - statybos ekonomikos inžinierius.

Statybos ekonomikos fakultetui turejo priklausyti trys katedros: Statybos ekonomikos ir organizavimo, Fizikos ir Chemijos. Statybos fakultetui buvo siūloma palikti tik dienini skyrių, kuriame rengti pramonines ir civilinès statybos inžinierius.

Permainų buvo VISI bibliotekos darbe. Naujaja jos vadove - direktore buvo paskirta Vanda Likienè. 1974 m. Aukštojo ir specialiojo vidurinio mokslo ministerija kartu su bibliotekų taryba paskelbè VISI biblioteką eksperimentine, turëjusią spręsti aukštujjų mokyklų mokslo ir mokymo procesų informacinio aprūpinimo klausimus. $1974 \mathrm{~m}$. VISI biblioteka turejo 288744 leidinius. Joje dirbo 23 darbuotojai, buvo per 6 tūkstančius skaitytojų.

VISI vadovų nesutarimai tapo ir instituto Tarybos darbo klausimu. Rektoriaus A. Čyro iniciatyva (jis buvo Tarybos pirmininkas) jau minèto 1974 m. balandžio 17 d. Tarybos posèdžio pagrindinis klausimas buvo pavadintas taip: „Dèl rektorato darbo stiliaus gerinimo“. Posedžiui pirmininkavo pats rektorius, pats skaitè ir pranešimą.

Rektorius A. Čyras sake, kad viso kolektyvo pastangomis institute pasiekta daug laimëjimų, bet bus gerai, jei kritiškai bus įvertinti viso darbo vaisiai. Jis pranešé, kad rektorato darbo stiliaus klausimai buvo aptarti LKP CK, dalyvaujant LKP CK sekretoriui A. Barkauskui, ministrui H. Zabuliui, VISI atstovams: A. Naujokaičiui, M. Burokevičiui, R. Stanislovaičiui, R. Jonušui, G. Marčiukaičiui ir, žinoma, jam pačiam. Paskui tą pati klausimą svarste VISI partijos komitetas. A. Čyras sakè: „Šiu posédžiu metu buvo pareikšta visa eile kritiniu pastabu del rektorato darbo stiliaus. Dauguma šiu pastabu teko man. Ǎ̌ pilnai suprantu, kadaš, kaip rektorius, atsakingas ne tik už rektorato, bet ir už viso kolektyvo veikla ir mano pirmaeile pareiga daryti viska, kad mūsu darbas būtu našus, kūrybiškas, apgaubtas nuoširdumo, vieni kitiems pasitikejimo irprincipingumo reiklumo dvasia. Deja, čia ne viskas buvo padaryta, del ko sulaukiau principines partines kritikos. Šia kritika aš pripažistu teisinga ir keliu sau pirmaeili uždavini ištaisyti savo darbo klaidas. Šiu svarstymu metu kritiniu pastabu gavo ir prorektoriai drg. R. Jonušas ir G. Marčiukaitis..." [4.20, p. 45].

Toliau rektorius kalbejo apie darbo barų pasidalijimą, administracijos darbo supapra- stinimą, formalizmo išgyvendinimą, kolektyvumo darnumą, reiklumą, kovą su paskalomis. Jis pažymëjo, kad negerai, kai sklinda paskalos del vadovybès veiksmų.

Svarstomu klausimu kalbejo tik du Tarybos nariai: Geodezijos katedros vedejas doc. A. Ražinskas ir Politinès ekonomijos katedros vedejjas doc. J. Grèska.

A. Ražinskas pabrěžè tai „kad iš nedidelès užuomazgos išaugo didžiulis institutas, priklause ir nuo to, kad kolektyvo priešakyje stovejo dabartinis instituto rektorius prof. A. Cyras<...>. Pradžioje A. Čyrui užteko laiko pabuvoti ir katedrose <...>. Veliau, atsiradus prorektoriams, rektorato ryšiai su katedromis daresi vis formalesni $<\ldots$. , isigalëjes biurokratizmas sustabdè, suvarže katedru iniciatyva $<\ldots>$, prorektoriu darbe per daug formalizmo $<\ldots>$, grupes darbuotoju, katedru vedejai visada stovineja eilutese prie prorektoriu dury $<\ldots>$, kabinetinis vadovavimas yra bet kokios pažangos stabdis <...>, jsigyvenęs popierizmas “ ir t. t., ir pan.

Baigdamas savo kalbą, kuria buvo aiškiai paremta rektoriaus pozicija, A. Ražinskas sakè: „Labai svarbu, kad kolektyve bütu vienybe <...>. Bet koks asmeniškumas, bet koks pavydas turi büti svetimas mūsu kolektyvui. Müsu pergaliu laidas - tai vienybe, aukšta kultūra ir erudicija".

J. Grèska pažymejo, kad santykiuose dažnai trūksta taktiško elgesio, kad institute daug formaliai sprendžiamų klausimų, kad formalizmo neturi būti.

1974 m. gegužès 6-10 d. VISI buvo surengtos Maskvos inžinerinio statybos instituto dienos. Jų metu mūsų institute paskaitas skaitè žymūs Maskvos mokslininkai A. K. Šreiberis, J. I. Belenia, V. N. Bogoslovskis ir kt. Vyko jungtiniai kai kurių katedrų posèdžiai, turininga buvo kultūros

$$
\text { A. Ražinskas }
$$

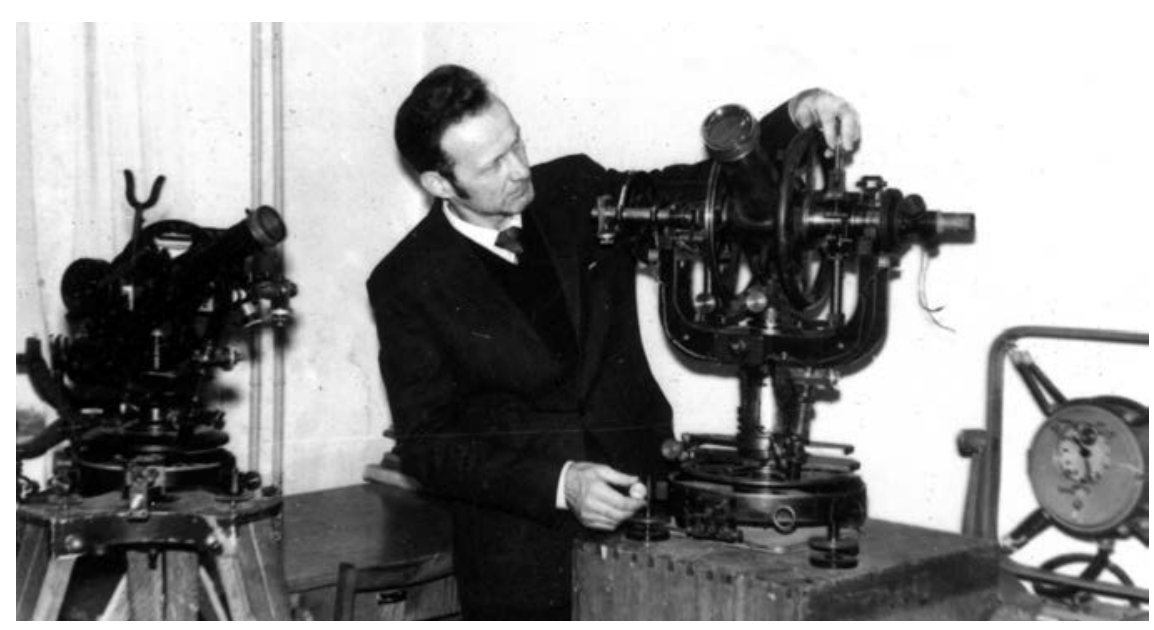


VILNIAUS

INŽINERINIS STATYBOS

INSTITUTAS

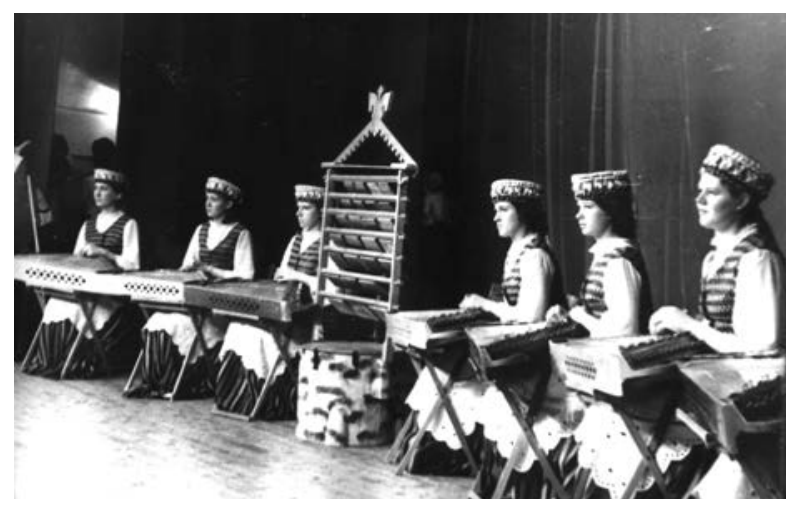

aktoriai Zinaida Slavina, Valerijus Zolotuchinas, Venjaminas Smechovas, Leonidas Filatovas ir Ivanas Dichovičnyj.

Tai, kad VISI aplanke jau tuomet maištaujantis prieš sovietinę valdžią, vèliau net emigravęs į Vakarus ižyymus teatro režisierius J. Liubimovas ir rusų aktorių žvaigždynas, buvo docentes Irenos Aleksaites nuopelnas. Jai dirbant VISI vyko prasmingi kultūros renginiai, kurie, palyginti su praeitimi ar ateitimi, buvo dažni.

1974 m. Vilniaus inžinerinị statybos institutą baige 819 absolventų: dieninị skyrių 459, vakarini - 330 ir neakivaizdinį - 30 .

Architektūros fakultete dienines studijas baige 60 žmonių, Vakarinị fakultetą - 111, Mechaninès technologijos fakultetą 255 (dieninị skyriu - 123, vakarinị skyriu - 117 ir neakivaizdinį skyriu - 15), Miestų statybos fakultetą (dieninį skyrių - 78, vakarinį skyriu -45 ir neakivaizdinį skyriu -2 ), Statybos fakultetą (dieninį skyrių - 198, vakarinį skyrių - 57 ir neakivaizdinį. skyriu -13).

1974 m. vasarą buvo pradetas statyti VISI Statybos fakulteto jau minetas laboratorijų korpusas, kurio sąmatinè verte $-2,12 \mathrm{mi}$ lijono rublių. Jame buvo numatyta įrengti bendrujjų technikos disciplinų bei kai kurias specialiąsias laboratorijas.

Birželiui baigiantis, Estijoje, Tartu, vyko tradicinè studentu dainų šventè „Gaudeamus VI“. Joje dalyvavo VISI pučiamųjų instrumentų orkestras „Inžinerija“, VISI akademinis choras „Gabija“ ir VISI šokių kolektyvas.

Su studentų kolektyvais į Tartu išvyko prorektorius doc. R. Jonušas, doc. A. Čižas, kultūros klubo vedejjas J. Čepulis ir kolektyvų vadovai: K. Griauzdè, F. Viskantas, J. Jonušas, B. Navickaite. Nuo birželio 17 iki $28 \mathrm{~d}$. buvo suorganizuota visu triju kolektyvų repeticijų stovykla. Chorą sudare 80 žmonių, pučiamųjų orkestrą -45 ir šokių kolektyvą -20 . 
„Kodèl dainuojii?“ - „Gabijos“ veteraną Egidijų Darbetą paklause mokslo metų pradžioje žurnalistas. İ tai daug metų dainavęs chore Egidijus atsakè: „Dainuoju, kad be dainos, kaip be duonos ar vandens, kažkaip neimanoma gyventi... Matyt, tas pats alkis, tik ne kūno, o sielos, verčia žmogu ieškoti grožio, dermes...". Gal tuo viskas ir pasakyta, kodel daug studentų labai noriai dalyvauja meno kolektyvų veikloje.

1974 m. vasarą net du VISI studentų statybiniai būriai dirbo Jakutijoje.

Trys VISI SSB studentų būriai vyko jau i tris užsienio valstybes: Lenkiją, Vokietiją (VDR) ir Vengriją. VISI studentai dirbo Glivicuose, Veimare ir Debrecene. Bet teko padeti ir savajam institutui. 50 studentų liko statyti VISI laboratorijų korpusą.

$1974 \mathrm{~m}$. VISI organizavo iš viso 22 statybinius studentų būrius, kuriuose dirbo 700 studentų.

\section{Pradedant 1972-1975 mokslo metus}

1974 m. vasarą studijuoti į VISI buvo priimti 1263 žmonès. İ Architektūros fakultetą - 76, Vakarinị fakultetą - 125, Mechaninès technologijos fakultetą - 351, Miestu statybos fakultetą - 151 ir Statybos fakultetą - 560. Taigi padaugejo architektų ir statybininku, bet studijuoti miestų statybos priimta mažiau nei visais ankstesniais metais.

Naujuju 1974-1975 mokslo metu pradžią Vilniaus inžinerinio statybos instituto kolektyvas pažymejo rugsejo $2 \mathrm{~d}$. Valstybinès filharmonijos rūmuose. Dalyvavo Ministru Tarybos pirmininkas J. Maniušis, aukštojo ir specialiojo vidurinio mokslo ministras $\mathrm{H}$. Zabulis, statybos ministras R. Sakalauskas, miesto Vykdomojo komiteto pirmininkas A. Vileikis ir kt.

Rektorius A. Čyras pranešè, kad 19741975 mokslo metus pradeda 420 profesorių, docentų ir destytojų, $43 \%$ jų turi mokslinius laipsnius. Per penkerius VISI veiklos metus instituto mokslininkai gavo 65 autorinius išradimų liudijimus, išleista 15 monografiju, paskelbta apie 1800 moksliniu straipsnių.

Naujam institutui pastatyti du mokomieji korpusai, buvo statomas trečias - Statybos fakulteto katedru ir laboratorijų korpusas. Institutas jau turi dvi elektronines skaičiavimo mašinas, studentai jau pirmame kurse išmoksta algoritminių kalbų, per visas stu-

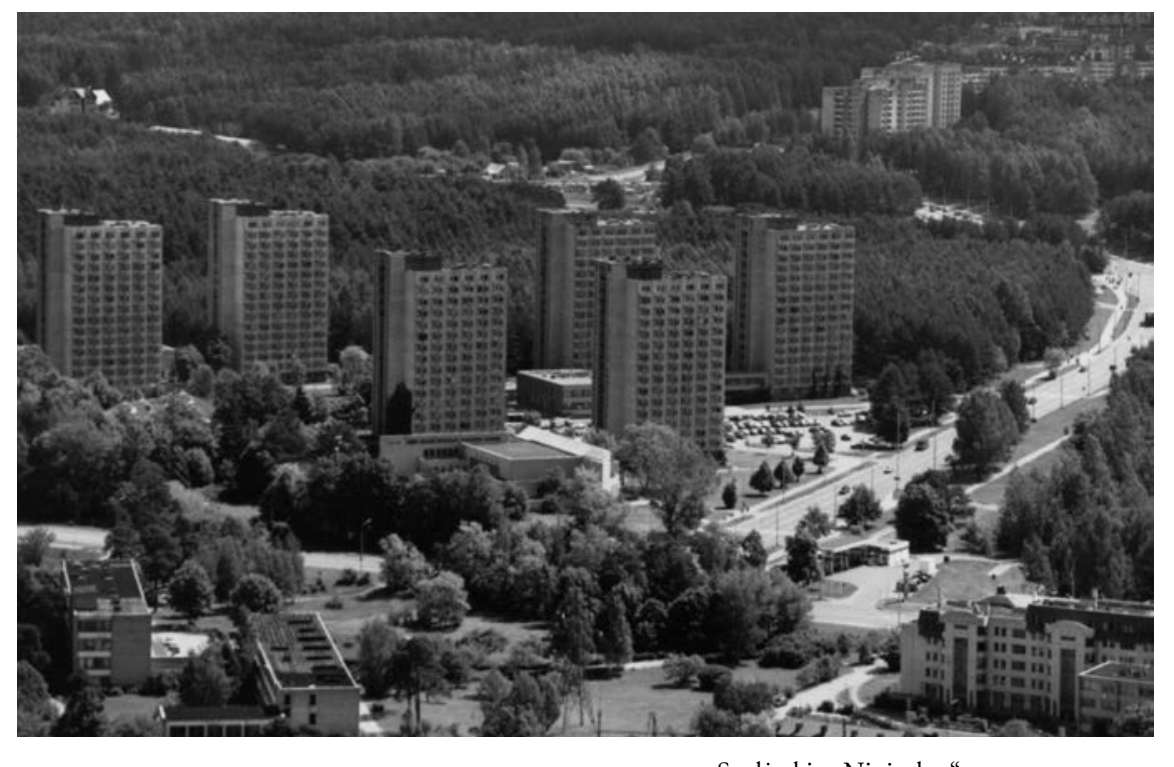

Sauletekio „Niujorkas“

dijas ESM rengia namų darbus, kursinius ir diplominius darbus.

Kreipdamasis i pirmojo kurso studentus rektorius sake: "Jus i aukstaja mokykla palydejo tevai, broliai, seserys, globejai. Kiekvienas iš ju, išleisdamas jus mokytis, galbūt aukoja ir savo geresni kasni, tikedamasis veliau paramos šeimai. Todel supraskite ir ivertinkite ta atsakomybę ir pareiga, kuri jums tenka kaip tarybines aukštosios mokyklos studentams" [4.21, p. 1].

$1974 \mathrm{~m}$. spalio 14 d. aukštojo ir specialiojo vidurinio mokslo ministro įsakymu $\mathrm{Va}$ karinis fakultetas pavadintas Automatizacijos fakultetu [4.22, p. 1].

Po savaitès - vèl reikšmingas įvykis: baigta 16 aukštu VISI bendrabučio statyba. Tuo metu tai buvo aukščiausias pastatas Vilniuje. Buvo pastatyti šeši tokie pastatai VU ir VISI. Studentai šių pastatų grupę ilgainiui pramine „Niujorku“. Taip ir tebevadina.

\section{Malonūs svečiai ir kasdienos darbai}

Reikšminga mūsų istorijai 1974 m. spalio $28 \mathrm{~d}$. Tuomet VISI apsilanke JAV lietuvis Valdas Adamkus. Praeis per 20 metu ir jis taps Lietuvos Prezidentu. Ar galëjo kas nors apie tai pagalvoti?

Svečias daug pasakojo apie gamtos apsaugos problemas Šiaurès Amerikoje, apie tai, kokiomis priemonemis kovojama su oro užterštumu: vietoj šiluminių elektrinių statomos atominès, miesto centras privačiais automobiliais pervažiuojamas nesustojant, automobiliai laikomi miesto pakraštyje, o i centrą važiuojama visuomeniniu transportu, branginamas benzinas, kad būtų mažiau

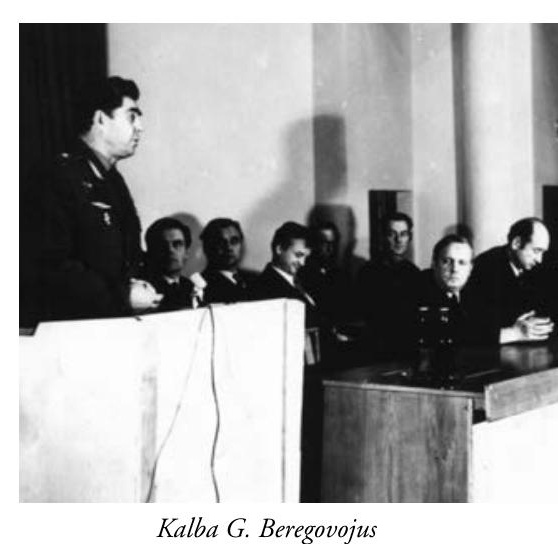

Kalba G. Beregovojus 
VILNIAUS

INŽINERINIS STATYBOS

INSTITUTAS

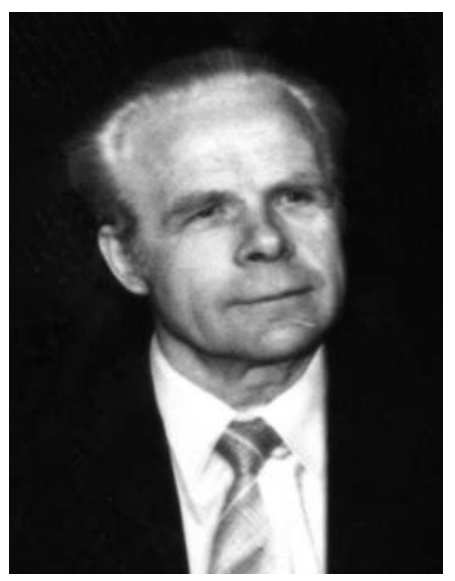

K. Baškys naudojamasi savais automobiliais, teršiančios aplinką įmonès baudžiamos didelemis baudomis. V. Adamkus domejosi, kaip VISI studentai rengiami gamtos apsaugos klausimais. Jam patiko VISI rūmai.

Bet pokalbiai vyko tik su labai ribotu VISI pedagogu skaičiumi. Dalyvavo prorektorius R. Jonušas, profesoriai K. Šešelgis, V. Šeštokas, A. Spelskis, po keletą dèstytojų iš Miestų statybos, Architektūros, Gyvenviečiu planavimo ir tvarkymo, Automobilių keliu ir Hidraulikos katedrų. Trys šimtai žmonių susirinko susitikti su V. Adamkumi į Didžiąją auditoriją tik po 20 metų.

$\mathrm{Na}$, kaip gi galejo studentai susitikti su JAV lietuviu, jei jie, anot M. Burokevičiaus, "nemoka pasiremti marksizmo-leninizmo klasiku teorinemis mintimis, nagrineti dabarties socialines politines problemas. Uždavinys - ǐsmokyti studentus isisamoninti marksizmo-leninizmo teorini palikima, kaip metodologini mokslinio komunizmo problemu tyrinejimo pagrinda, kaip klasini partini požiūri tiek praeities, tiek i šiuolaikinius visuomenes procesus" [4.23, p. 1].

Bet vis dèlto kontaktai su užsieniu kasmet kiek gerëjo. 1974 m. vasarą užsienyje pabuvojo 70 VISI studentų ir 12 destytojų.

Kosmosas dar ir šiandien paslaptingas, kažkoks nepaprastas. Suprantamas buvo studentų didelis susidomejjimas žinia, kad 1974 m. gruodžio 23 d. VISI Didžiojoje auditorijoje galima pamatyti ir išgirsti kosmonautą Georgiju Beregovojų. Auditorija buvo pilnutele. İdomus buvo generolo kosmonauto pasakojimas apie kosminių kelionių rengimą, jų parinkimą, neišdildomus skrydžio įspūdžius. Nebuvo politizuojama, tai buvo malonu Šv. Kaledų išvakarese. $\mathrm{Ne}$ paslaptis, kad švente jas dauguma, bet tai, deja, dare paslapčiomis.

1974 m. gruodžio $31 \mathrm{~d}$. gautas aukštojo ir specialiojo vidurinio mokslo ministro įsakymas Nr. 532, kuriame pasakyta, kad nuo 1975 m. liepos $1 \mathrm{~d}$. Statybos fakultetas reorganizuojamas ị du - Statybos ir Statybos ekonomikos fakultetus.

1974 m. rugpjūtị buvo baigta bendrabučio Nr. 1 statyba, o gruodžio ménesi - bendrabučio Nr. 2. Šie du bokštai Studentu miestelyje turi po 510 vietų. Taigi VISI bendrabučių fondas padidejo 1020 vietų.
Tai buvo rimta socialinè parama studentams. Už nuoširdų darbą atiduodant bendrabučius eksploatuoti rektorius A. Čyras premijavo prorektorių J. Žemkų, vyr. buhalterị K. Stonį, prorektoriaus pavaduotoją statybos reikalams A. Karulaiti, Technikos skyriaus vedejją B. Rasimavičiu, Ūkio skyriaus vairuotoją $\mathrm{H}$. Motiejūną ir kt.

1975 m. pradžioje, kaip visada, VISI taryba apsvarste praejusių metų mokslo rezultatus. Prorektorius G. Marčiukaitis pranešè, kad metų pabaigoje institute dirbo 935 žmonès, iš jų septyni profesoriai ir mokslų daktarai, 213 docentų ir mokslo kandidatų. Institutas turejo penkias šakines mokslo tyrimo laboratorijas. Mokslinių tyrimų kryptys $1974 \mathrm{~m}$. buvo devynios: 1 . Industrializavimo lygio kèlimas ir konstrukcijų statyboje tobulinimas. 2. Vieningos teritorinès šakinès skaičiavimo centrų ir automatizuotų valdymo sistemų bendros sistemos sukūrimas. 3. Darbo organizacijos ir valdymo tobulinimas. 4. Perspektyvinio LTSR signalines transporto keliu sistemos pletros generalinès schemos sudarymas. 5. Naujų elektrinių mašinų ir prietaisų kūrimas ir tyrimai. 6. Mašinų patikimumas ir ilgaamžiškumas. 7. Natūralių ir dirbtinių vandens telkinių apsauga nuo užterštumo. 8. Vandens režimo reguliavimo metodų tyrimas ir nusausinamų žemių įsisavinimas LTSR. 9. Mokymo proceso tobulinimas.

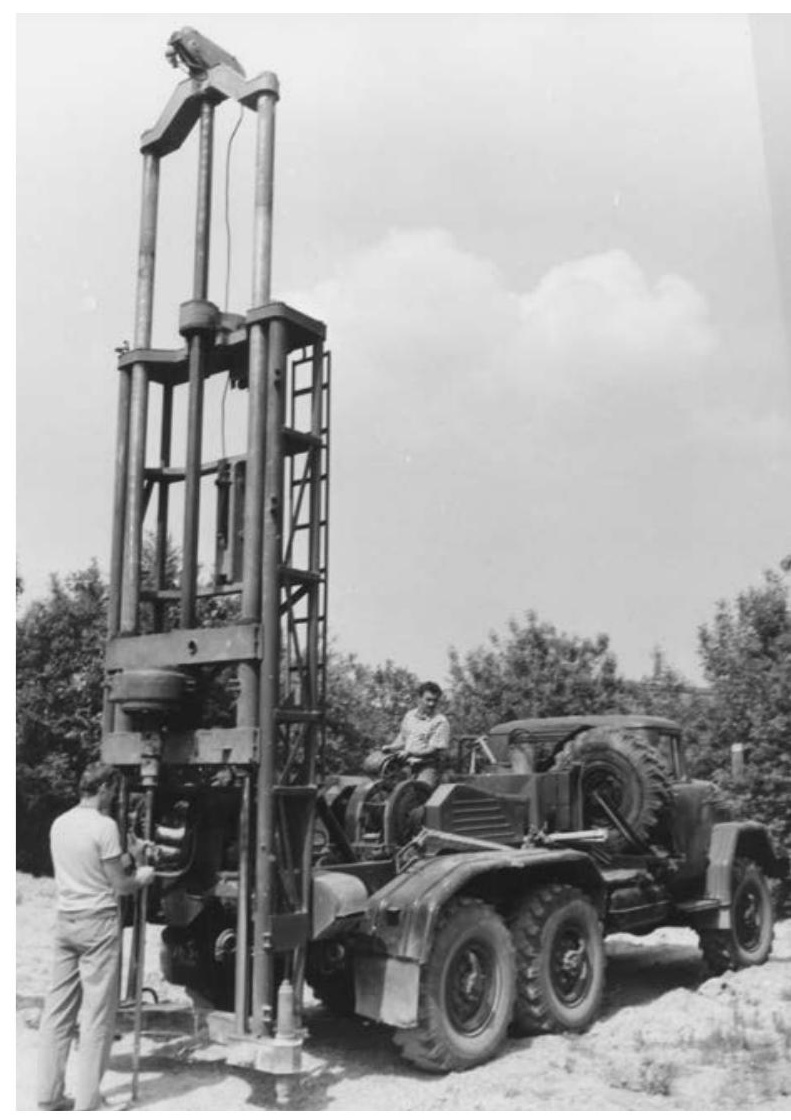


VILNIAUS

INŽINERINIS STATYBOS

INSTITUTAS

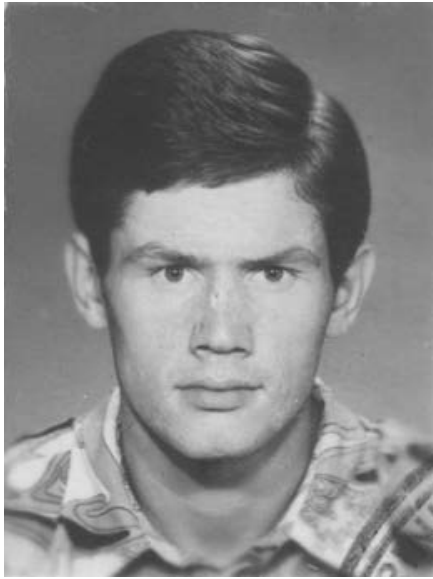

Studentas V. Muntianas büsimasis LRS pirmininkas ros dèstytojas Jonas Žekevičius tema „Kintamo aukščio dvitëjo skerspjūvio elementu skersinis lenkimas" ir Statybos ekonomikos ir organizavimo katedros asistentas Romualdas Ginevičius tema „Namų statybos kombinatu pramonés sferos srautinių technologiju linijų funkcionavimo patikimumo klausimai (Lietuvos TSR NSK pavyzdžiu) “. Praeis kiek per 30 metu ir R. Ginevičius taps tos pačios mokyklos rektoriumi - ,fortuna favet fortibus " (lot. likimas palankus stipriesiems).

1975 m. birželio 3-5 d. Vilniaus inžineriniame statybos institute vyko ketvirtoji sąjunginé Statybinès mechanikos patikimumo problemu konferencija. Konferencijos pirmininku buvo įžymus specialistas, TSRS mokslu akademijos narys korespondentas prof. Vasilijus Bolotinas, pavaduotoju - prof. Aleksandras Čyras.

I konferenciją atvyko 180 dalyvių: 34 profesoriai, moksly daktarai, 97 docentai, mokslų kandidatai iš Maskvos, Kijevo, Rygos, Novosibirsko, Leningrado, Sverdlovsko ir kt. miestu.

Tą 1975 m. vasarą du VISI docentai gyné daktaro disertacijas: technikos mokslų - Zenonas Vainoris, istorijos mokslų - Mykolas Burokevičius. 1975 m. Zagrebo (Jugoslavija) mugeje buvo eksponuojamas doc. Benedikto Užpolevičiaus prietaisas neardančiajam betono stiprumui nustatyti.

1975 m. VISI parenge 880 aukštai kvalifikuotų specialistu. Dieninį skyrių baige 562 , vakarinị - 277 ir neakivaizdini - 41 jaunuolis ir mergina. Architektūros fakultetą baige 48, Automatizacijos - 80, Mechaninès technologijos - 239, Miestų statybos - 141, Statybos - 226 ir Statybos ekonomikos - 146 žmonès.

I institutą studijuoti buvo priimta 1316 žmonių: ị Architektūros fakultetą - 80, Automatizacijos - 125, Mechaninès technologijos - 375, Miestų statybos - 154, Statybos - 356 ir Statybos ekonomikos - 226. Kaip matyti, daugumą sudare statybos studijos.

1975-1976 mokslo metu pradžia buvo pažymeta tradiciniu renginiu, pagal tą pati scenariju, su tomis pačiomis arba panašiomis kalbomis. Pasidžiaugta prie bendrabučio pastatytu aptarnavimo bloku. SSB raportavo, kad statybose buvo 23 SSB būriai, kuriuose dirbo 730 studentų, kad atliktų darbų vertè - beveik 2 milijonai rublių.

1975 m. rudenį „Inžinerijos“ pučiamujjų orkestras, vadovaujamas J. Jonušo, lankesi Bulgarijoje, daug koncertavo, turëjo dideli pasisekimą.

1976 m. pradžioje „Gabija“ keliavo po Užkaukazę, lankèsi Tbilisyje, Baku, Jerevane, Soči kurorte, Maskvoje, o grįžę iš puikios, turiningos keliones „Gabijos“ daininkai Vilniaus miesto saviveiklinių kolektyvų apžiūroje iškovojo geriausio Lietuvos sostinès mišraus choro vardą (meno vadovas - F. Viskantas, chormeisteriai - Br. Jankauskas, R. Vitkauskaite, J. Rimša).

$1976 \mathrm{~m}$. kovo $17 \mathrm{~d}$. VISI tarybos posèdyje ir visų pedagogų susirinkime buvo svarstomi mokymo proceso tobulinimo klausimai. İdomių minčių pareiškè dalyvavę diskusijoje. Doc. V. Liutikas teige, kad destytojo lygis priklauso nuo kelių veiksnių: mokslinio pasirengimo, pedagoginio meistriškumo ir darbštumo. "Mokslinems kvalifikacijoms demesio skiriama pakankamai, o pedagoginiam meistriškumui-ne. Geras destytojas kotiruojamas prasčiau nei blogas, turintis mokslini laipsni ir varda. Katedros nesvarsto ir nevertina destytojo pagal pedagogini meistriškuma. Reikalinga šiuo požiūriu atstatyti lygsvarą" [4.24, p. 17]. Prof. V. Šeštokas kalbëjo apie sunkumus naudojant technines mokymo priemones, doc. B. Sidauga pabrezžè, kad daugelis katedrų per daug susižavejo ūkiskaitiniu moksliniu tyrimo darbu ir dažnai neskiria reikiamo demesio mokymo reikalams. Vyr. destytojas M. Remišauskas sake, kad stojamųjų egzaminų rezultatai neiliustruoja stojančiųju tinkamumo. Vilniečius rengia repetitoriai, todèl jie egzaminus išlaiko geriau už rajonų moksleivius, tačiau vèliau studijuodami vilniečiai atsilieka.

Tenka pripažinti, kad ir po 30 metų daugelis studiju proceso problemų liko tos pačios.

Aptariamame posedyje buvo paskirtos vardinès stipendijos: V. Muntianui, R. Kupliauskui, L. Rimkui, S. Vaitkevičiui, G. Šturo, V. Turlai ir K. Norkui - Lenino, R. Jurgučiui - Angariečio, R. Kurcevič - Dzeržinskio ir V. Kličiui - Gucevičiaus.

1976 m. kovą Telšiuose instituto menine agitbrigada "Studentiškas šiupinys“ (meno vad. R. Karvelis, kuratore V. Kazlauskienè) miestų kategorijoje laimëjo 3 vietą. 


\section{Dažnëja išvyku i užsieni}

VISI taryba balandžio $21 \mathrm{~d}$. svarste stažuočių ir komandiruočiu užsienyje efektyvumą. Buvo pažymèta, kad užsienyje igytas patyrimas ir gauti rezultatai naudojami mokymo procesui gerinti, toliau vykdant mokslinius tyrimus. Kai kurie rezultatai taikomi gamybinèse ūkio šakose. Katedros išsamiai svarsto komandiruotujju ataskaitas, priima priemoniu planus gautiems rezultatams panaudoti.

1973-1975 m. ì 10 ménesių stažuotes buvo išvykę trys instituto mokslininkai: A. Kvedaras (ČSSR), N. Pošiūnaite (LLR), A. Lukoševičius (JAV), kurie įvykde darbo planus, numate priemones gautiems rezultatams įdiegti.

I 1-2 menesių stažuotes buvo išvykę: A. Lubys (Prancūzija), A. Kryžanauskaite (Prancūzija), A. Stanislovaitis (ČSSR), V. Karkauskas (LLR), J. Šimkus (VLR), A. Naruškevičius (LLR), S. Abramauskas (VDR). I trumpesnes mokslines komandiruotes vyko: V. Šeštokas (VDR), V. Vaitkus (Suomija), Z. Kamaitis (Prancūzija), A. Kudzys (JAV). Tame pačiame posedyje buvo apsvarstytas M. Burokevičiaus pareiškimas, kuriame jis protestuoja dèl padarytų pažeidimu perrenkant Mokslinio komunizmo katedros vedejją. M. Burokevičius norejo būti išrinktas katedros vedeju antrai kadencijai, bet VISI taryba jo neišrinko. Iki Tarybos posèdžio M. Burokevičiaus darbas katedros posedyje nebuvo svarstytas, Taryboje nebuvo išklausyta jo ataskaita. Tie faktai reiške nustatytos procedūros pažeidimus. Taryba nutare Mokslinio komunizmo katedros vedejo rinkimus laikyti neįvykusius [4.24, p. 53]. Tai M. Burokevičiaus neišgelbëjo. Vèliau įvykusiame Mokslinio komunizmo katedros posedyje jis rinkimus pralaimejo ir buvo perkeltas dirbti ì Vilniaus pedagoginị institutą.

$\mathrm{Na}$, o kuo gi pasibaige nesutarimai ir galop arši kova tarp instituto vadovų?

Tų nesutarimų tikrąsias priežastis ilgainiui taikliai apibūdino tuometinis aukštojo ir specialiojo vidurinio mokslo ministras prof. H. Zabulis:

„Kai labai daug tobulybiu susikaupia viename asmenyje, iš ju - nors tai gal atrodo paradoksalu - gali susiklostyti ir tam tikros ydos. Būdamas ǰžvalgesnis užsavo kolegas, Čyras tiksliau ir greičiau suvokdavo, ka reikia daryti, greit pastebedavo ir tai, kas padaryta prastai. Užkliūvančias negeroves - realias ar kartais ir

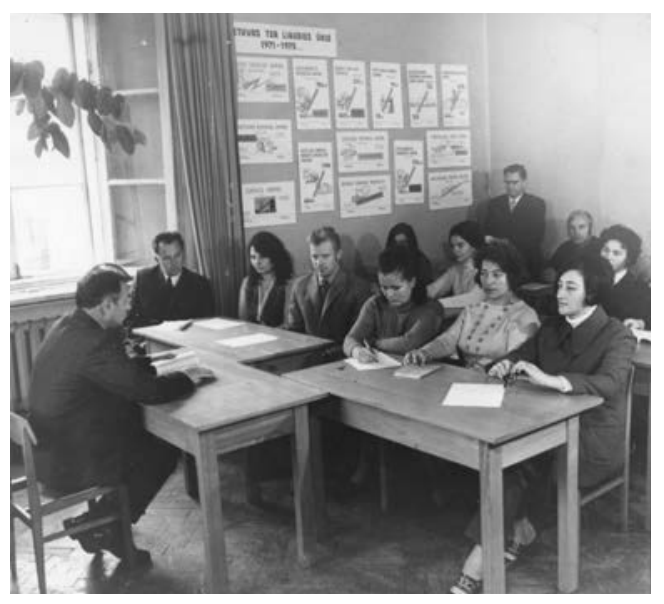

Katedra M. Burokevičiaus vedeju nebeišrinko

reliatyvias - rektorius kritikavo griežtai, reikalavo jas taisyti arba pats jas taisydavo. Tai toli gražu ne visada buvo priimama palankiai, nes tokiu dalyku pasitaiko kiekviename kolektyve, bet Vilniaus inžinerinio statybos instituto raida vidaus vaidai lydejo lyg kokia rykštee. Dèl permanentinio ju pobūdžio sunkoka büdavo net nustatyti, kuri puse yra kaltesne, nes veiksmas visada žadino atoveiksmi, o po to šitos paskatos susikeisdavo vietomis" [4.15, p. 267].

1976 m. dèl nesibaigiančios konfliktinès situacijos Vilniaus inžineriniame statybos instituto rektorate respublikos valdžia prarado kantrybę. Doc. Romualdas Jonušas birželio menesi ministro $\mathrm{H}$. Zabulio ịsakymu buvo atleistas iš prorektoriaus mokymo reikalams pareigu. Jis liko dirbti Mechanines technologijos fakulteto Mašinų gamybos technologijos katedroje.

1976 m. pavasarị VISI 03 aud. vyko sąjungines olimpiados „Studentas ir mokslo bei technikos pažanga " medžiagų atsparumo konkurso respublikinis turas. Dalyvavo KPI, LŽŪA ir VISI. VISI studentai užemé pirmąsias 7 vietas ir komanda - pirmą. Gerai paruoše komandą vyr. dest. J. Žekevičius. $[4.25$, p. 1$]$

1976 m. respublikines premijas gavo A. Čyras ir K. Šešelgis.

1976 m. VISI baige 890 žmonių: dieninị skyrių - 551, vakarini - 307 ir neakivaizdinį - 32, Architektūros fakultetą - 45, Automatizacijos - 93, Mechaninès technologijos - 254, Miestų statybos - 195 ir Statybos ekonomikos - 145 .

$1976 \mathrm{~m}$. liepos $5 \mathrm{~d}$. rektoriaus įsakymu pasakyta, kad stacionarią aspirantūrą baige Vladas Sniečkus. Jis toliau dirbo Radijo aparatūros katedroje. Dabar jis dirba VISI Antano Gustaičio aviacijos institute ir jam - Antano Sniečkaus sūnui - niekas nereiškia jokių pretenzijų. O kaip identiškoje situacijoje buvo 
VILNIAUS

INŽINERINIS STATYBOS

INSTITUTAS trukcijų (vedëjas A. Valentinavičius), Statybos darbų technologijos (vedëjas V. Krušinskas), Matematikos (vedejas V. Liutikas), Pagrindų ir pamatų (vedejjas J. Šimkus) ir Medžiagų atsparumo (vedejjas A. Čižas).

Statybos ekonomikos fakultete (dekanas daugeliui, kai dèl tèvų biografijos kentejo ir vaikai. Ačiū Dievui, laikai kiti.

Vasarą VISI buvo priimama iz dienines, vakarines ir neakivaizdines studijas. I dieninio skyriaus studijas buvo priimami 875 žmonès: ì architektūros specialybę -75 , suvirinimo įrenginių ir technologijos -50 , automobilių ir autoūkio - 100, automobilių transporto ekonomikos ir organizavimo - 25, statybos ir kelių tiesimo mašinos bei įrengimai - 50, miestų statybos - 50, taikomosios geodezijos - 50, automobilių kelių - 50, pramonines ir civilinés statybos - 350, statybos ekonomikos ir organizavimo - 75, automobilių ir autoūkio - 25, mašinų gamybos technologijos, metalo pjovimo staklių ir įrenginių - 100, radijo aparatūros konstravimo ir gamybos - 75, elektros pavarų ir gamybinių irrengimų automatizavimo - 50 .

I vakarinio skyriaus studijas buvo priimami 325 žmonés: ị automobilių ir autoūkio specialybę - 25, mašinų gamybos technologijos, metalo pjovimo staklių ir įrengimų - 100, radijo aparatūros konstravimo ir gamybos - 75, elektros pavarų ir gamybinių įrengimų automatizavimo - 50, pramoninès ir civilinès statybos - 50 ir statybos ekonomikos ir organizavimo -25 .

I neakivaizdinio skyriaus studijas buvo priimama 100 žmonių: automobilių ir autoūkio specialybès - 25, pramoninès ir civilines statybos - 50 ir statybos ekonomikos ir organizavimo -25 .

1976-1977 mokslo metus Vilniaus inžinerinis statybos institutas pradejo turedamas 37 katedras, 450 profesorių ir destytojų. Iš jų 12 profesorių mokslo daktarų ir 230 docentų mokslo kandidatų. Apie tai praneše rektorius A. Čyras iškilmèse Profsąjungų rūmuose, skirtose mokslo metų pradžiai. Jose dalyvavo ministras pirmininkas J. Maniušis, statybų ministrai ir kt.

Architektūros fakultete (dekanas A. Spelskis) buvo 4 katedros: Architektūros (vedejas A. Lukošaitis), Gyvenviečių planavimo ir tvarkymo (vedejas K. Šešelgis), Pastatų konstrukcijų (vedejjas A. Nakas) ir Dailès (vedejas A. Janulis).

Statybos fakultete (dekanas V. Krušinskas) buvo septynios katedros: Statybinès mechanikos (vedejas A. Čyras), Gelžbetoninių konstrukcijų (vedëjas A. Kudzys), Metalinių kons-
A. Naujokaitis) buvo trys katedros: Statybos ekonomikos ir organizavimo (vedejjas E. Borkauskas), Statybinių medžiagų (vedëjas A. Gailius), Chemijos (vedejjas P. Norkus).

Miestų statybos fakultete (dekanas B. Sidauga) buvo penkios katedros: Miestų statybos (vedejas V. Šeštokas), Kelių (vedejas S. Rokas), Geodezijos (vedejjas A. Ražinskas), Hidraulikos (vedëjas K. Baškys) ir Fizikos (vedejas A. Urbelis).

Mechanines technologijos fakultete (dekanas B. Liaudis) buvo septynios katedros: Metalų technologijos (vedejas A. Šriupša), Automobilių transporto (K. Lukoševičius), Mašinų gamybos technologijos (vedejjas A. Samulevičius), Mašinų teorijos (vedejjas A. Kavolèlis), Pramonès ekonomikos (vedëjas A. Martinaitis), Braižybos (vedëjas H. Gylys) ir Taikomosios matematikos ir mechanikos (vedejas D. Maciulevičius).

Automatizacijos fakultete (dekanas Č. Teišerskas) buvo trys katedros: Radijo aparatūros technologijos (vedejas Z. Vainoris), Elektrotechnikos (vedëjas J. Valiukenas) ir Elektros pavarų (vedèjas A. Smilgevičius).

Dar buvo aštuonios bendrosios katedros: TSKP istorijos (vedejas A. Marcelis), Mokslinio komunizmo (vedeja S. Juonienè), Filosofijos (vedejjas J. Mureika), Politinès ekonomijos (vedejas J. Grèska), Kalbų (vedëja A. Glemžienè), Fizinio lavinimo (vedëjas V. Kulakauskas), Estetinio lavinimo (vedèjas R. Tamutis) ir Karinio rengimo (vedejas V. Vlasenko).

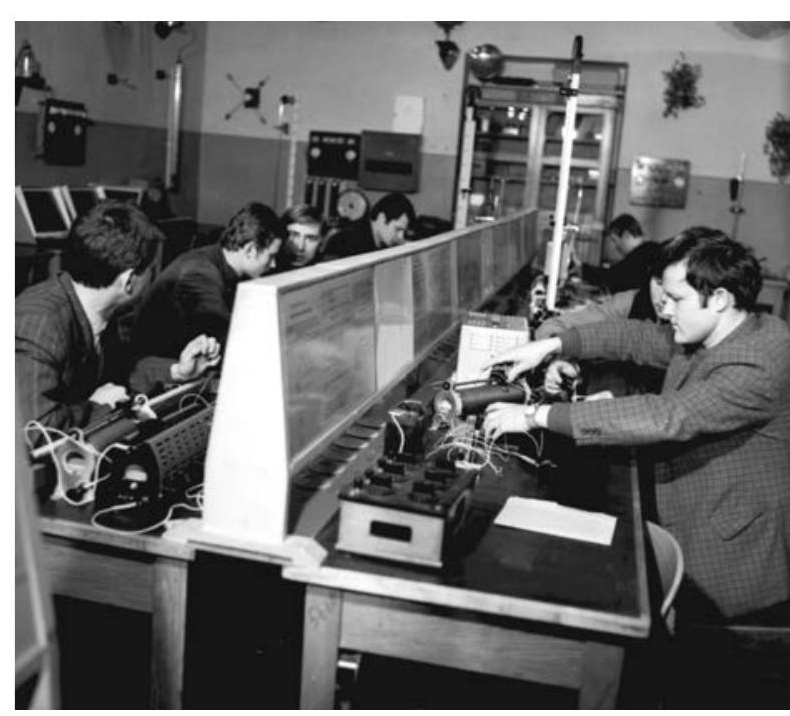




\section{Permainos}

Pasikeite vadovų gretos. Aukštojo ir specialiojo vidurinio mokslo ministras atleido doc. Romualdą Jonušą iš prorektoriaus pareigų. Ne be prorektorių-maištininkų iniciatyvos nebuvo perrinktas Mokslinio komunizmo katedros vedeju $M$. Burokevičius.

1976-1977 mokslo metų pradžioje buvo paskelbta rektorato narių sudetis: rektorius prof. A. Čyras, prorektoriai - prof. D. Maciulevičius, doc. G. Marčiukaitis, doc. B. Sidauga, B. Gajosinskis, partijos komiteto sekretorius doc. A. Lubys, Vietos komiteto pirmininkas doc. A. Gailius, komjaunimo komiteto sekretorius V. Papinigis, studentu profkomiteto pirmininkas R. Kupliauskas, dekanai - prof. A. Spelskis, doc. V. Krušinskas, doc. B. Liaudis, e. doc. p. K. Sakalauskas, doc. Č. Teišerskas, doc. A. Naujokaitis, katedrų vedëjai - doc. A. Marcelis, doc. S. Juonienè, doc. J. Greska, doc. J. Mureika, e. doc. p. R. Tamutis, doc. V. Kulakauskas, e. doc. p. O. Glemžienè ir papulkininkis V. Andriu- šinas, Kadrų skyriaus viršininke A. Šlekiene, MTS viršininkas E. Stankus, bibliotekos direktore V. Likiene, mokymo skyriaus viršininkas S. Žegunis, vyr. buhalteris J. Kliauza ir „Inžinerijos“ vyr. redaktorius G. Butkus.

Buvo sudaryta ir naujos sudeties instituto Taryba, ị kurią buvo įtraukti visų esamų katedrų vedejai, taip pat atviru balsavimu (jau šiek tiek demokratijos!) fakultetų tarybų išrinkti atstovai.

Blèstant vadovų „džihadui“, instituto rektorate, taryboje, susirinkimuose viskas aprimo. Buvo svarstomi eiliniai darbo klausimai, mažiau besiginčyta, ramiai tekëjo kasdienybè, taip būdinga „brandžiam“ socializmui. Daug kas buvo daroma, kaip sakoma, del paukščiuko. Bet studijų procesas buvo normalus, dūzgè laboratorijos, buvo daromi ūkiskaitiniai, disertaciniai, biudžetiniai mokslo darbai, augo mokslininkų gretos, buvo politiškai sergejjamas, bet vis dellto pakankamai turiningas studenty gyvenimas.

\section{„Visytès“ pradžia, „Šiupinio“ ir „Hiperbolès“ laimëjimai}

1976 m. spalio 13 d. iškilmingai buvo atidaryta studentiška kavine „Visyte“", ilgainiui garsëjusi savo renginiais. Bendrabučiu („Niujorko“) aptarnavimo bloke dieną veikusi studentų valgykla (Nr. 1) vakarais virsdavo kavine. Patys studentai įrenge interjerą, barą. „Visytę" prisimena daugelis absolventų. Dabar čia VGTU biblioteka.

Studentų maitinimas buvo svarbus rektorato darbo baras. Tuo klausimu rūpinosi ir studentų profsąunga. 6500 instituto studentų valge jau minètoje valgykloje prie bendrabučiu, atidaryta valgykla VISI CR (Nr. 2). Trijuose fakultetuose tuomet veike bufetai (Architektūros - centriniuose rūmuose, Miestų statybos - trečiuosiuose rūmuose ir Mechaninès technologijos - pirmuosiuose rūmuose).

1976 m. buvo užbaigtas statyti laboratorinis korpusas. I jị įsikèle Statybos, Statybos ekonomikos fakultetu katedros, Architektūros fakulteto Pastatu konstrukciju katedra, daug mokomųjų laboratorijų, skaičiavimo centras. Reikšmingai pagerejo ir destytojų, ir studentų darbo sąlygos.

$1976 \mathrm{~m}$. buvo pereita prie universalios algoritmines kalbos FORTAN kaip pagrindinès ESM programų rašymo kalbos institute, išleisti metodiniai nurodymai destytojams „Disciplinos matematinio aprūpinimo sudarymas".

1976 m. VISI regbio komanda „Inžinerija“ laimejo respublikos pirmenybių bronzos medalius.

1976 m. pirmą kartą Vilniaus inžinerinio statybos instituto studentų statybiniai būriai

VISI regbio komanda

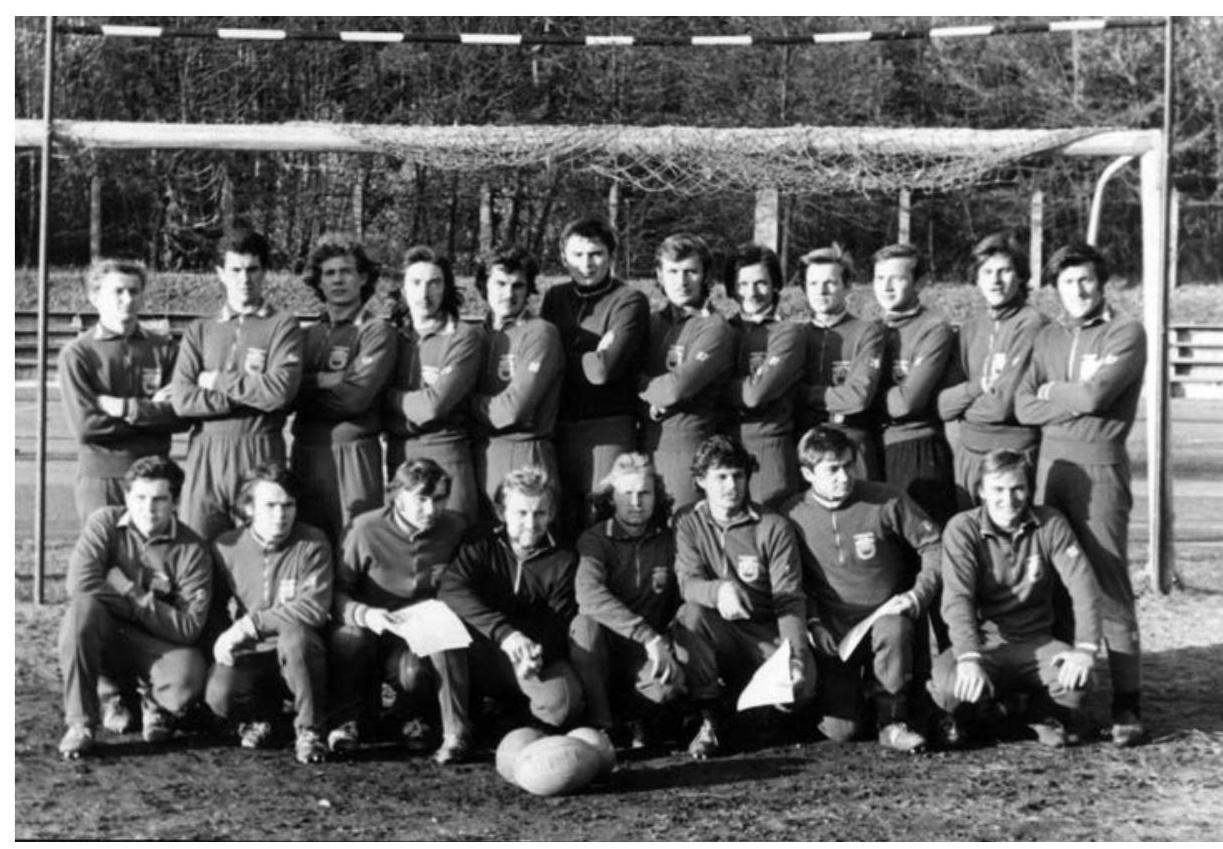




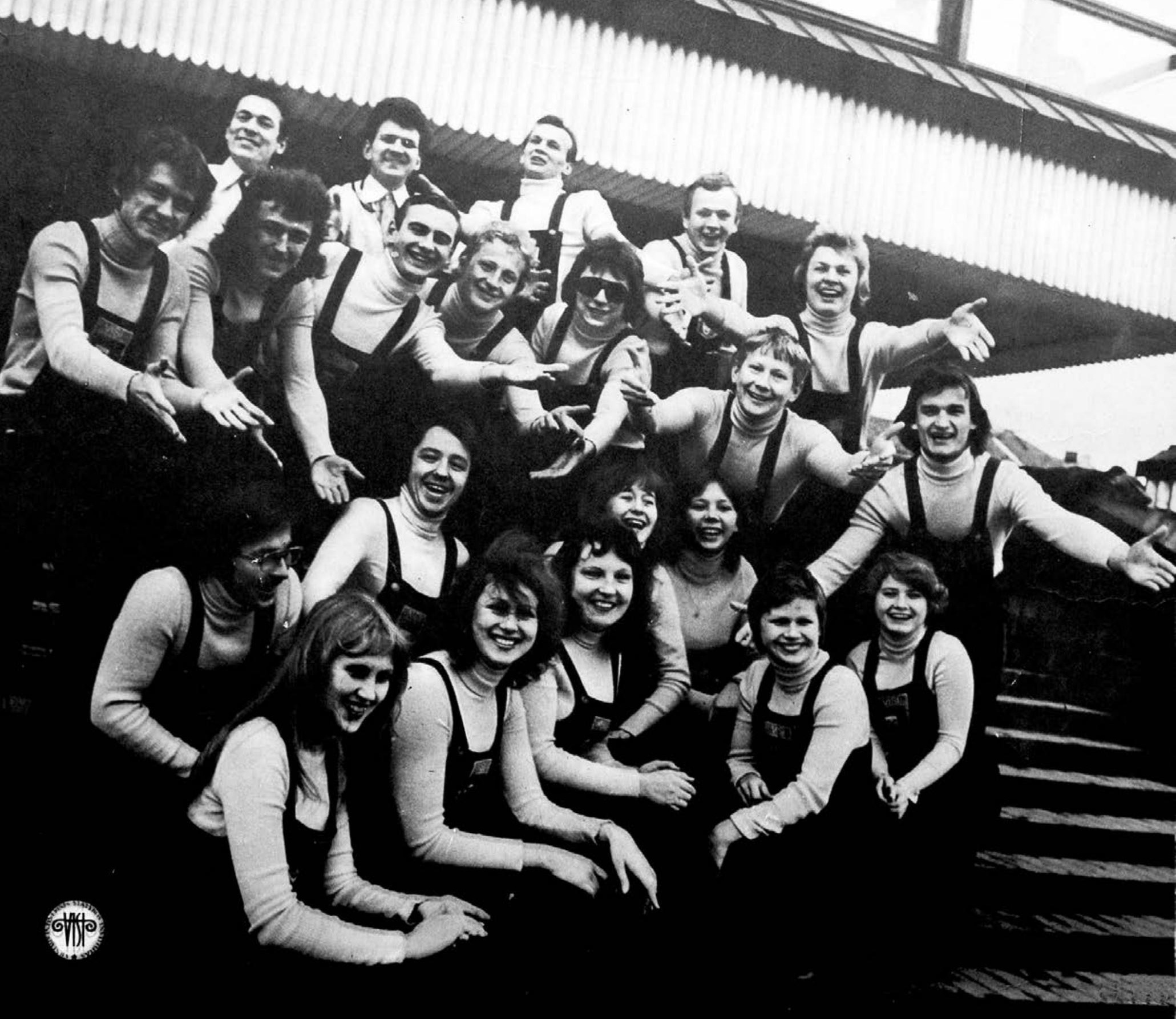

„Šiupinys“

Meno vadovas R. Karvelis

buvo pripažinti geriausiais tarp Lietuvos visu aukštujju mokyklu. Garsëjo ir meno saviveiklos bei sporto kolektyvai.

1977 m. vasario 6 d. įvykusioje Vilniaus miesto agitacinių meninių brigadų apžiūroje, kurioje dalyvavo 13 kolektyvu, pirmą vietą iškovojo „Šiupinys“ (taip jis buvo vadinamas), parodęs programą „Adom ir badom". Tuo pat metu vykusiose Lietuvos jaunimo lengvosios atletikos pirmenybèse tik ką pastatytame Vilniaus lengvosios atletikos manieže Statybos fakulteto PCS 5/9 grupès studentas Edvardas Peleckas užèmé antrąją vietą.

Puikiu laimejjimu pasiekè VISI vokalinis instrumentinis ansamblis „Hiperbole“. Sporto rūmuose surengtoje Vilniaus miesto ansamblių, grojančiu poilsio vakaruose, apžiūroje „Hiperbole“ tapo laureatu. „Inžinerijos" laikraštis rašè: „Po poros savaičiu itemptu 
repeticiju vel konkursas. Ši karta Klaipedoje. "Hiperbolei“ dèl geriausiuju vardo teko varžytis su ansambliais iš Rygos, Kauno, Kijevo. Jai ir čia atiteko pirmoji vieta. Ansamblio atlikta B. Gorbulskio ir A. Dabulskio daina "Kad žaliuotu rūta" nuskambejo geriausiai.

Nelengva studentams ansambliečiams gerai mokytis ir kasdien po kelias valandas skirti repeticijoms. Tačiau didelis noras, talentas, entuziazmas nugali viską. Ansamblio siela - jo vadovas ir solistas Michailas Garberis. Subtilus jo skonis ir sugebejimas pajusti publikos nuotaikas padeda parinkti vykusiz repertuara.

Drange su kitais tarybiniu kompozitoriu küriniais ansamblis atlieka ir šiuolaikines lietuviu autoriu dainas. Jo repertuare yra ir užsienio kompozitoriu melodiju.

Nemaža kūriniu ansambliečiai parašé patys. Bene didžiausio pasisekimo susilauke A. Gruzdžio pjese „Bamas“[4.26, p. 1].
„Hiperbole““

Iš kaires tupi

M. Garberis,

A. Sriubas

Stovi:

V. Prapras, R. Bartusevičius,

A. Gruzdys, A. Šnaras

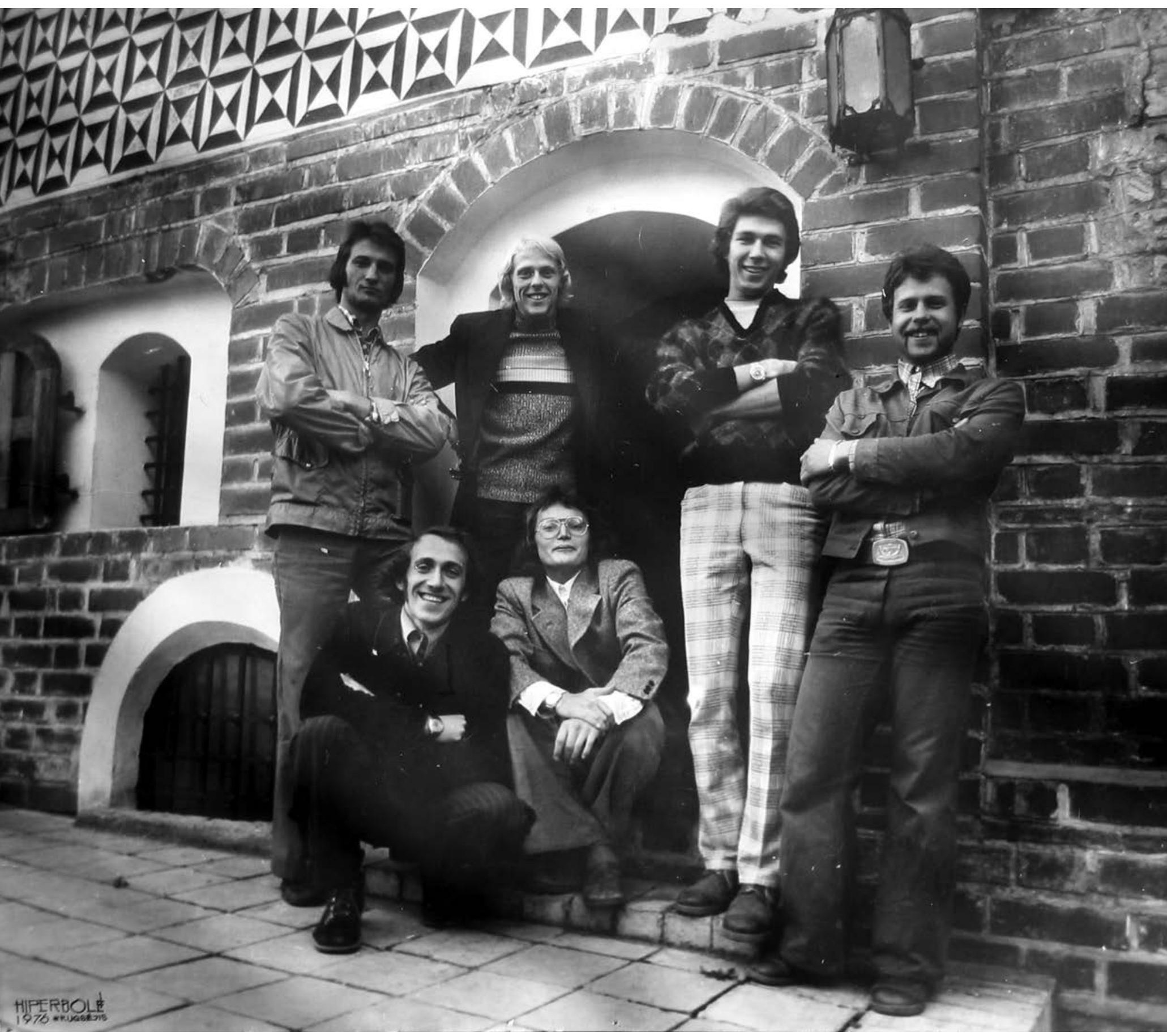


VILNIAUS

INŽINERINIS STATYBOS

INSTITUTAS

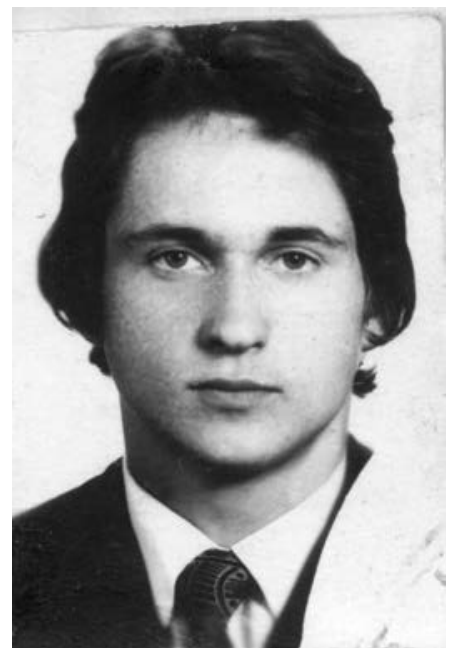

R. Augustinavičius

\section{Ne viskas gerai}

Bet buvo ir nesèkmių, liūdnų dalykų. 1977 m. sausio $20 \mathrm{~d}$. prie VISI bendrabučių miškelyje buvo rastas pasikoręs $\mathrm{Me}$ chanines technologijos fakulteto studentas Stasys Vilkas. Kaip paaiškejjo, trys fakulteto studentai, išeję iš alinès, priekabiavo prie merginų, o šios pasiskundè milicijai. Apie ịvykị buvo pranešta institutui. Studentu elgesi svarste dekanatas, komjaunimas. Gerai visko neišsiaiškinus, jaunuoliams pareikšti papeikimai ir nutarta pranešti tèvams. S. Vilkas neprieštaravo bausmei, bet labai praše tèvams nepranešti. Deja, jo norų nepaisyta. II kurso SKM 5/1 studentas S. Vilkas išejo iš komjaunimo biuro ir jo daugiau niekas nemate. Rado S. Vilką miškelyje, visai arti kelelio į institutą, praejus beveik dviem menesiams. Tragiškas įvykis atskleide studento savižudybès tyrejjams aplinkybes: nemokejjimą įsiklausyti į jo paaiškinimus, pasiteisinimus; gąsdinimą pernelyg didele nuobauda; abejingumą jo prašymui. Tai buvo rimta, skaudi pamoka ir fakultetui, ir institutui. Deklaruodami būtinybę komunistiškai aukletti jaunimą, komjaunimo veikejjai paprasčiausiai pamiršo žmogiškumą. Neužteko geranoriškumo, nuovokos suprasti jaunuolị.

Kitas sausio įvykis - jau grynai politinis, turëjęs rezonansą valdžios kabinetuose.

1977 m. sausio 23 d. grupé senojo universiteto ir VISI studentu Vilniaus centriniame pašte nukabino nuo sienos Lenino bareljefą ir, nueję ant Žaliojo tilto, įmete jị i Nerị. Visi jie buvo areštuoti ir tardomi.

Vilniaus universiteto leidinyje rašoma: „Poelgis idejinès dorovés saugotoju buvo išpūstas iki didžiules bylos, turejusios sunkiu padariniu. Visi keturi universiteto studentai - Romas Grigas, Saulius Marcinkevičius, Vytas Šimkūnas ir Gintaras Stankevičius pašalinti iš komjaunimo ir universiteto, fakultetai ir katedros priekabiai tikrintos ivairiu komisiju. Pagrindinis kaltininkas - Romas Grigas - laikytas Lukiskkiu kalejime, Naujosios Vilnios psichoneurologineje ligonineje, nuteistas 10 men. laisves atemimo. Saulius Marcinkevičius, auges nepatikimoje šeimoje (tevas $10 \mathrm{~m}$. kalejo Intos lageriuose, del tos priežasties motina pašalinta išuniversiteto Gamtos fakulteto), paimtas ikariuomene, ten tardytas saugumo, o baigiantis tarnybos laikui neaiškiomis aplinkybèmis žuvo " $[4.27$, p. 316].

Pasistenge ir VISI valdžia. „Už grubų viešosios tvarkos pažeidimą" Mechaninès technologijos fakulteto II kurso studentui P. Skardžiui, Statybos fakulteto III kurso studentui R. Augustinavičiui, Architektūros fakulteto II kurso studentui D. Nainiui, Mechaninès technologijos fakulteto studentams A. Veršeliui ir R. Kuprioniui pareikšti griežti papeikimai.

Apmaudu, visuomeniniu mokslų katedrų destytojai savo darbe taip nuoširdžiai komunistiškai auklëja, tinkamai naudoja L. Brežnevo knygose „Mažoji žeme““ ir „Atgimimas" pateiktus narsumo ir idejjinio įsitikinimo pavyzdžius jaunimo patriotiniam auklejjimui (tai pagal VISI tarybos posedžio protokolą), o tų laidokų studentų vis dar pasitaiko, nes ne visi išsamiai studijuoja marksizmo-leninizmo klasiku veikalus!..

Nubausti ir atitinkamy akademiniu grupių kuratoriai: doc. A. Keturka, doc. R. Limba ir asist. G. Bivainis - papeikimais už aplaidumą auklejjamajame darbe.

$\mathrm{Na}$, bet kas gera - prisiminkime, kas bloga - teišblès.

$1977 \mathrm{~m}$. vasario 21-26 d. Jerevane vyko tarptautinis politines dainos festivalis „Politine daina-77“, kuriame VISI vokalinis instrumentinis ansamblis „Hiperbole“ iškovojo pirmąją vietą. Dalyvavo 30 ansamblių, tarp ju iš Vokietijos, Lenkijos, Bulgarijos, Čekoslovakijos, Rumunijos. Buvo dainininkas iš JAV. „Hiperboles“" vadovas Michailas Garberis tikejjo gražia ansamblio ateitimi, bet didžiule problema - kaip įsigyti naują aparatūrą.

O politiką konkurse lietuvaičiu atliktose dainose sunku ižiūrèti. „Hiperbole“ atliko V. Lopo ir A. Mikutos dainą "Dilgèle“, B. Gorbulskio ir A. Dabulskio „Kad žaliuotu rūta" ir Arūno Gruzdžio, Architektūros fakulteto studento, instrumentinę pjesę „Bamas“. Grižusi į Vilnių, „Hiperbolë“ pasidare dar populiaresné.

\section{Studentų laimèjimai}

1975-1976 m. m. ìvykusiame Lietuvos aukštųjų mokyklų studentų mokslo darbų konkurse statybos architektūros sekcijoje mūsų studentai gavo 4 medalius ir 12 diplomų. Pažymètinas Raimundo Palubeckio 
A3/2 grupès studento darbas „Architektūrinio kūrinio proporcijų harmonizavimas ir jo pritaikymo galimybès šiuolaikinejje architektūroje“, Algirdo Kudzio PCS 4/1 grupès studento darbas „Klijuotu gelžbetoniniu konstrukciju darbo teorinis eksperimentinis tyrimas", Virgaudo Juocevičiaus ir Ondijaus Zono (abu PCS 2/6 studentai), darbas, kuriame jie parenge programą ESM medžiagu atsparumo namy darbui atlikti $[4.28$, p. 1$]$.

Architektūros fakulteto studentai kasmet geriausius diplominius darbus pateikdavo sąjunginei apžiūrai. Jos rezultatai leisdavo palyginti architektų rengimo lygị su kitomis TSRS aukštosiomis mokyklomis, kurios turëjo architektūros specialybę.

1977 m. balandị Maskvoje buvo įvertinti 41 architektūros mokyklos 237 diplominiai 1976 metų darbai.

Aukščiausią įvertinimą - pirmąją premiją gavo Roma Stundžaite. Jos diplominio darbo "N" miesto teritorinis išvystymas" vadovu buvo doc. Vytautas Jurkštas.

Trys VISI Architektūros fakulteto diplomantų darbai gavo antrąsias premijas: Sigito Čereškevičiaus „N“ miesto rytinis gyvenamas rajonas" (vadove doc. Neringa Dičiuvienè), Vytauto Kundroto „Poilsio namai Vanagupeje“" (vadovas prof. A. Lukošaitis) ir Arvydo Kaušpedo „Vilniaus aerouosto keleivinis pastatas" (vadovas doc. Vytautas Dičius).

Kai šiandien žvelgiame atgal, matome, kad studentai, gerai užsirekomendavę studentų moksliniame darbe ar puikiai parengę diplominį projektą, ilgainiui pasiekia gražiu profesinio darbo rezultatų.

Architektas Raimundas Palubeckis - garsios projektavimo firmos $\mathrm{UAB}$,Jungtines architektų dirbtuvès" grupés vadovas. Be kitu objektu, jis suprojektavo „Iki“ prekybos bazę ir tris „Iki“ prekybos centrus Vilniuje.

Statybos inžinierius Algirdas Kudzys tapo habilituotu daktaru, profesoriumi. Kurị laiką buvo Vilniaus vicemeru, Vilniaus apskrities viršininku. Nuo 2001 m. - Lietuvos Respublikos nepaprastasis ir igaliotasis ambasadorius Japonijoje.

Statybos inžinierius Virgaudas Juocevičius - mokslų daktaras, 2000-2003 m. buvo UAB „Skanska statyba“ prezidentu, nuo 2003 m. - UAB „Constructus“ generalinis direktorius. Ši firma pastate Vilniaus m. savivaldybes pagrindinį pastata, rekonstruoja senus pastatus, stato gyvenamuosius namus.

Gerai užsirekomendavo profesineje veikloje ir visi minetieji architektai diplomantai.

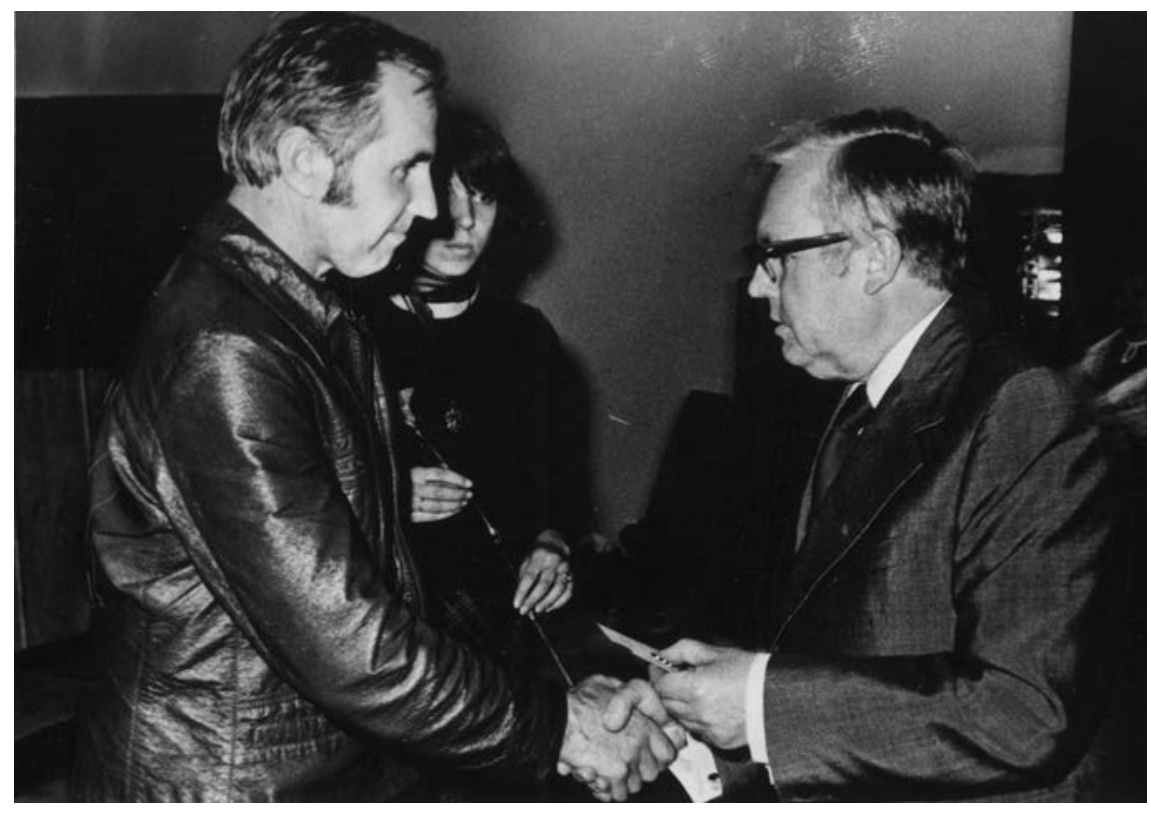

Rektorius apdovanoja doc. V. Jurkštą

Pažymètina, kad pažangūs, geri studentai rasdavo laiko ir plačiai kultūrinei veiklai. Tarkim, ilgainiui garsèjo A. Kaušpèdo koncertine grupe „Antis“. Jaunimo diskotekų organizatoriumi buvo A. Kudzys. 1977 m. buvęs VISI kultūros klubo pirmininku Liudas Rimkus, dabar mokslų daktaras, docentas, buvo ịvairių renginių siela „Visyteje“.

„Visyte“ greit tapo vienu populiariausių studentiškų kultūros klubų Vilniuje. Tik 120 vietų turinčioje saleje nuolat nebuvo tuščiu vietų. Klube vyko šokių vakarai-diskotekos, susitikimai su mokslininkais, menininkais, kitų aukštųjų mokyklų studentais.

\section{Taisome Brežnevo konstitucija}

1977 m. birželi buvo paskelbtas TSRS konstitucijos projektas. Ją iškart imta vadinti brežnevine. Visiems darbo kolektyvams buvo liepta rengti mitingus konstitucijai pritarti. Žinoma, nuošaly negalejo likti ir VISI. Kaip raše spauda, tuose mitinguose „visos šalies darbo žmonés su pasididžiavimu ir džiaugsmu vieningai pritaria paskelbtam TSRS konstitucijos projektui, istoriniam dokumentui, kuris išreiškia politine, ekonomine ir kultūrine müsu nuostabios šalies padetị. Visa tai ikvepia.." t. t., ir t. t. [4.29, p. 1]. Pritare, nors visiems žinoma, kad absoliuti žmonių dauguma tos konstitucijos projekto net nebuvo skaitę.

Rugsëjo ménesị konstitucijos projektui mitinge pritare fakultetai. Toks mitingas vyko Centrinių rūmų Didžiojoje auditorijoje. 
VILNIAUS

INŽINERINIS STATYBOS

INSTITUTAS

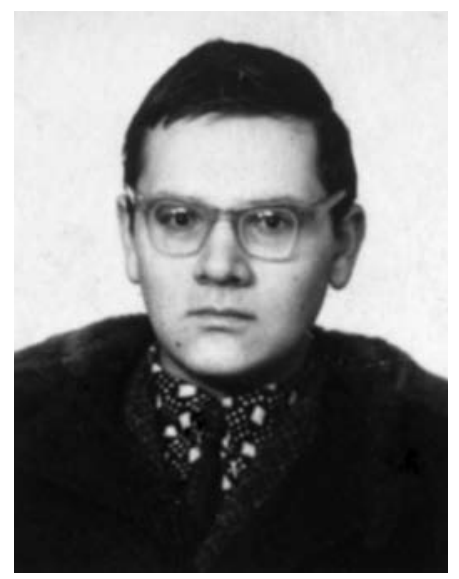

J. Radovičius
Pasirašius bendradarbiavimo sutartị tarp MISI ir VISI 1973 m., per praejusius metus gana intensyviai ir dalykiškai bendradarbiavo abiejų institutu atitinkamos katedros. Ypač aktyvios, plečiant dalykinius ryšius, buvo Gelžbetoninių, Metalinių, Pastatų konstrukcijų ir Miestų statybos katedros. Buvo keičiamasi vizitais, susipažistama su mokymo tvarka, laboratorijomis. Dalis VISI studentu Maskvos institute atliko ikidiplominę praktiką. Institutai keitesi metodine literatūra, kursiniais projektais. Nemažai vilniečių desstytojų vykdavo ị MISI kelti kvalifikacijos, ì mokslines konferencijas, skelbe straipsnius MISI mokslo leidiniuose.

VISI delegacija, kurią sudare 250 studentų ir destytojų, buvo sutikta Maskvoje išties labai šiltai. Buvo surengtos įdomios ekskursijos, vadovų susitikimai, VISI meno kolektyvų koncertai. Koncertavo „Gabija“, liaudies šokių kolektyvas, „Inžinerija“, „Šiupinys“, „Hiperbole“", skaitovai. Kad ir kur mūsų saviveiklininkai renge pasirodymus, visur pelnydavo dideli pasisekimą.

VISI profesoriai tomis dienomis skaite MISI destytojams ir studentams paskaitas: rektorius A. Čyras - apie naują statybinès mechanikos dèstymo metodiką mūsų institute, prorektorius D. Maciulevičius - apie elektroninių mašinų taikymą studijų procese, Miestų statybos katedros vedejjas V. Šeštokas - apie Lietuvos miestų užstatymo ir transporto pletros problemas.

Suprantama, neapsieita be tuomet privalomų politinių komponentų. İvykusiame iškilmingame abiejų institutų atstovų susirinkime buvo su patosu pasiūlyta pasiųsti laišką draugui Leonidui Iljičiui Brežnevui. Jame užtikrinome Leonidą Iljičių, kad skirsime visas jegas, patyrimą ir žinias, naujais darbo laimejjimais pasitiksime ir t. t., ir pan.

Laiškas baigtas tokiais žodžiais: „Tegyvuoja TSKP lenininis Centro komitetas, vadovaujamas ižzymaus mūsų epochos partinio ir valstybinio veikëjo draugo Leonido Iljičiaus Brežnevo!“ Tam „epochos veikejjui“ buvo belikę valdyti penketą metų, vaikščiojo prilaikomas kolegų. Bet tokiu kaip šio susirinkimo siųstų laiškų, žinoma, jis gi niekada neskaitè... Veidmainyste buvo iprastas reikalas.

Dar vienas panašus spektaklis netrukus vyko jau Vilniaus inžineriniame statybos institute. Lapkričio $4 \mathrm{~d}$. ị VISI atvyko Lenkijos partinè-vyriausybine delegacija, vadovaujama pirmojo tuomet Lenkijos 
žmogaus - Lenkijos jungtines darbo partijos CK pirmojo sekretoriaus Edvardo Gereko. Lydëjo ị VISI svečius iš Lenkijos (o kartu ir pulkelị Maskvos kagèbistų) Lietuvos komunistu pirmasis - P. Griškevičius su savąja gausia aplinka. Atrodytu, kad jei atvyko tiek svarbiu personu, teks jiems parodyti institutą, papasakoti apie rengiamus specialistus, mokslinius darbus, VISI ryšius su Lenkija ir t. t. Nieko panašaus! Vos įžengę i vestibiuli svečiai pasisveikino su keletu pasitikusiųju. E. Gerekas pasikeite su lenkiškai kalbëjusiu A. Čyru keliais sakiniais, o lydëję nomenklatūrininkai tuoj pat pasiūle E. Gerekui vestibiulyje pasirašyti VISI Garbès svečiu knygoje. Per minutę parašęs porą sakinių, E. Gerekas ir P. Griškevičius atsisveikino ir iškeliavo atgal. Visas priemimas truko 7 minutes.

Taigi Lenkijos vadovui atvykimas i VISI buvo reikalingas, kaip sakoma, tik protokolui. Kad apie tai rytdieną laikraščiai galetų parašyti, jog maloniai buvo priimtas studentų, destytojų ir darbuotojų. Tik iš spaudos kitą dieną sužinota, kad kartu su E. Gereku VISI apsilanke ir Lenkijos liaudies respublikos Valstybès tarybos pirmininkas H. Jablonskis - laikytas lyg prezidentu. Bet i ji niekas neatkreipe jokio demesio. Tokie vizitai, toks prezidentas - taip pat veidmainyste.

Buvo ir rimtų vizitu. Gruodį į Vilnių atvyko ir neaplenke ir VISI, JAV universitetų vadovaujančiųjų darbuotojų delegacija, vadovaujama švietimo tarybos prie JAV valstybès departamento švietimo skyriaus prezidento D. Peltasono. Su delegacija atvyko Tafto universiteto Džeksono koledžo dekanè, mokslininku tarptautinio pasikeitimo tarybos prie JAV valstybès departamento nare profesore N. S. Milbern, Vašingtono universiteto administracinio biznio mokyklos dekanas profesorius K. O. Hensonas, Hovardo universiteto Psichologijos katedros vedejas profesorius D. H. Hiksas, Indianos universiteto Rusijos Rytu europos instituto direktorius profesorius A. Rabinovičius, mokslininkų tarptautinio pakeitimo tarybos prie JAV valstybès departamento darbuotojas D. Reilis.

JAV delegacija vede derybas su respublikos aukštujjų mokyklų atstovais, vadovaujamais aukštojo ir specialiojo vidurinio mokslo ministro profesoriaus $\mathrm{H}$. Zabulio. Buvo aptartos galimybes plesti JAV ir Lietuvos TSR aukštųjų mokyklų mokslinị bendradar-

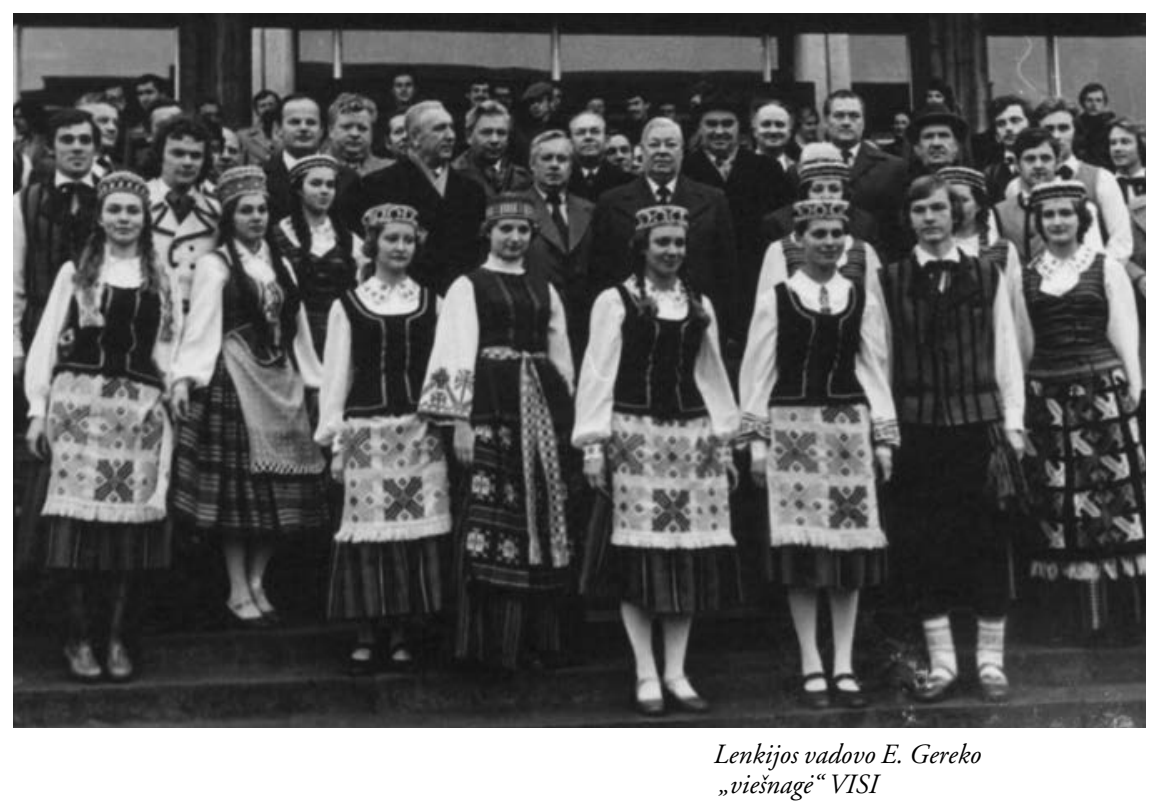

biavimą. Derybose dalyvavo Lietuvos TSR užsienio reikalų ministras $\mathrm{V}$. Zenkevičius. Be to, šiuo klausimu JAV delegacija tarèsi su Vilniaus valstybinio Kapsuko universiteto ir Inžinerinio statybos instituto vadovais. Delegaciją lydëjo JAV konsulas Leningrade R. K. Gaisas [4.30, p. 1].

Metų pabaigoje „Inžinerijoje“ VISI sporto klubas paskelbè instituto geriausių sportininkų dešimtuką: 1 . Viktoras Šurpikas, AT 5/4 - sporto meistras, LTSR absoliutus gimnastikos čempionas. 2. Jūratė Jovaišaite, MS $5 / 1$ - sporto meistre, TSRS akademinio irklavimo rinktinès kandidate, LTSR rinktinès narè. 3. Arvydas Sabonis, A 3/7 - kandidatas i sporto meistrus, LTSR lengvosios atletikos rinktinés narys, LTSR pirmenybių prizininkas. 4. Sergejus Artiomenka, AT 3/3 - kandidatas į sporto meistrus, LTSR laisvųjų imtynių čempionas. 5. Juozas Lapeika, SKM $5 / 2$ - kandidatas ị sporto meistrus, LTSR tinklinio rinktinès narys. 6. Stanislavas Kliukojtis, AT 5/4 - kandidatas i sporto meistrus, LTSB sunkiosios atletikos rinktines narys. 7. Saulius Deimantavičius, MS 5/2 - kandidatas į sporto meistrus, „Statybos" meistru komandos žaidejas. 8. Vytautas Stanevičius, SEO 6/1 - kandidatas i sporto meistrus, akademinis irklavimas, I atskyris lengvojoje atletikoje, LTSR lengvosios atletikos jaunimo žaidynių čempionas. 9. Kęstutis Blonskis, SKM 5/1 - sporto meistras, LTSR stendinio šaudymo rinktinès narys. 10. Dainius Pavilionis, SKM 6/1 - kandidatas i sporto meistrus, LTSR akademinio irklavimo rinktinès narys.

1978 m. sausio 31 d. Aukštojo ir specialiojo vidurinio mokslo ministerijos kolegija 
VILNIAUS

INŽINERINIS STATYBOS

INSTITUTAS

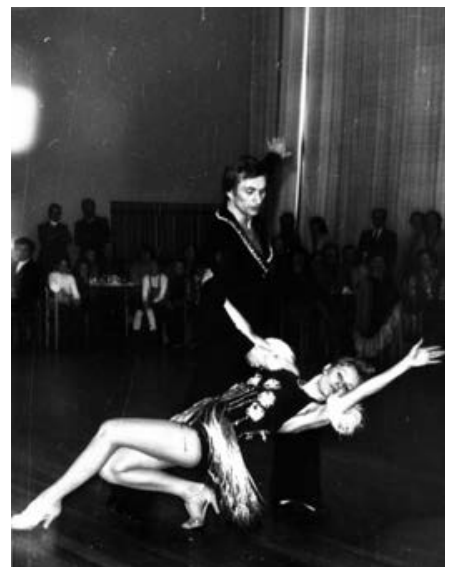

Pramoginiu šokiu meistrai Vidas ir Dalia Kamaičiai daug mety dirbo VISI svarstė studentų nubyrëjimo aukštosiose mokyklose problemą. Studentų sumažeja, nes jie nelikviduoja skolų. Kolegija kritikavo už didelį skolininkų skaičių Kauno medicinos institutą (skolininkų buvo 13,3 \%) ir Kauno politechnikos institutą (12,7 \%). VISI kritikavo ir už specialistų laidos plano neįvykdymą. Ką gi, pliekè už nubyrejimus, taigi už destytojų reiklumą, bet specialistų rengimo kokybe niekas nesiskunde.

Vasari VISI taryba apsvarste 1977 m. mokslinio darbo rezultatus. Buvo vykdomas 81 mokslinis darbas. Ükiskaitinių darbų atlikta už 1,558 milijono rublių, o tai 26,9 tūkstančio rublių mažiau nei 1976 m. Ir šiuo klausimu jautesi stagnacija, mokslo darbų finansavimo prastejimas.

Buvo paduota 31 paraiška išradimams, gauta tik 11 teigiamų sprendimų. Per $1977 \mathrm{~m}$. buvo apginta 1 daktaro ir 13 kandidato disertacijų, išleista 12 monografijų, paskelbti 506 moksliniai straipsniai. Net 861 studentas dalyvavo SMD veikloje, žengè pirmuosius žingsnius moksliniuose tyrimuose.

Taryba konstatavo, kad gerai dirbo VISI visos penkios žinybinès mokslinio tyrimo laboratorijos.

Statybos valdymo sistemy laboratorija vykdè darbus pagal „Orgtechstatybos“ tresto ir Statybos ekonomikos mokslinio tyrimo instituto užsakymus.

Statybinès mechanikos laboratorijos darbų užsakovai buvo keturi: Maskvos statybinių konstrukcijų tyrimo institutas, Kijevo statybinis projektavimo ir mokslinio tyrimo institutas, LTSR statybos reikalų komitetas ir pašto dèžute A-7291 (taip vadindavo įslaptintas imones).

Statybos technologijos ir mechanizavimo laboratorija atliko septynis darbus, kuriu užsakovais buvo Statybos ministerijos įvairios organizacijos.

Pamatų ir pagrindų laboratorija atliko šešis darbus. Jos darbų užsakovai buvo Statybos ir Paruošų ministerijų organizacijos, Vyriausioji gamybinè energetikos valdyba, Valstybes statybos reikalu komitetas.

Miestų kelių ūkio laboratorijos užsakovai buvo šeši: Komunalinio ūkio ministerija, Vilniaus vykdomasis komitetas, Vilniaus taksi parkas, Vilniaus asfaltbetonio gamykla, Kauno komunalinio ūkio valdyba,
Vilniaus miesto keliu statybos ir remonto valdyba.

Žinybinių laboratorijų atliekami darbai priskirtini taikomiesiems mokslams. Jie buvo naudingi užsakovams ir kartu labai padèjo destytojams gilinti praktines žinias. Vykdydami taikomuosius tyrimo darbus mokslininkai dažnai apčiuopdavo ir rimtu problemų, kurios tapdavo ir teorinių bei eksperimentinių tyrimų temomis.

Mokslinei kvalifikacijai kelti padejo ne tik užsakomieji darbai. Labai naudingos nedaugeliui laimingụjų, turëjusių galimybių išvykti ¡ Vakarus, buvo mokslines stažuotes užsienyje. Grįžęs iš tokios stažuotes Anglijoje doc. Audronis Kvedaras savo ataskaitoje VISI tarybai raše: , 10 menesiu praleidau mokslineje stažuotëje Londono universiteto Imperiniame mokslo ir technologijos koledže. Prieš išvykstant buvo planuota vykdyti mokslini darba pagal tema ",Kompleksiniu kolonu iš plieno vamzdžiu, užpildytu betonu, darbo tyrinejimas". Man pavyko, nes Imperinio koledžo Statybos fakulteto Metaliniu konstrukciju katedroje tokiu konstrukciju tyrimai vyksta jau daugiau kaip 10 metu ir todel aš iš karto galejau įsijungti i mokslini darbą. Buvo galimybe išnagrineti anksčiau atliktu tyrimu rezultatus, taip patsusipažinti su tuo metu vykdomu tyrinejimu medžiaga, kompleksiniu ir metaliniu konstrukciju Didžiosios Britanijos standartu instituto projektavimo normomis, $k u-$ rios tuo metu buvo ruošiamos.

Stažuotés metu taip pat aplankiau kitas Didžiosios Britanijos aukštasias mokyklas (Edinburgo, Mančesterio, Kardifo, Kembridžo, Sauthemptono ir kt. universitetus), Britanijos suvirinimo instituta, Šiaures jūros naftos grężimo bokštu supermetaliniu vamzdžiu konstrukciju gamykla ir montavimo aikštelę Šiaurès Škotijoje. Dalyvavau FIP'78 kongreso ir eilestarptautiniu bei vietiniu konferenciju ir seminarustatybiniu konstrukciju klausimais darbe.

Stažuotés metu buvo dirbamas pagrindinai teorinis mokslinis darbas, taip pat atlikta dideles apimties eksperimentiniu teoriniu ir norminiu duomenu analize, naudojant elektronines skaičiavimo mašinas. Buvo sukurta universali tyrinetu konstrukciju skaiciavimo metodika, sudariusi pagrindine kartu su moksliniu vadovu paruošto Anglijos projektuotojams vadovelio žinyno dali. Taip pat buvo paruošti spaudai 2 moksliniai straipsniai “ [4.31, p. 1-2].

Mokslinëje stažuoteje sukaupti moksliniai duomenys ir patirtis buvo labai naudingi Metalinių konstrukcijų katedrai. A. Kvedaras pabrěžè, kad labai svarbus veiksnys stažuotès 
eigai yra tai, kad stažuotojo mokslinio tyrimo tematika būtų adekvati katedros darbams, kurioje vyks stažuote. Dar vienas sèkmès veiksnys - mokèti kalbų.

Instituto taryba 1978 m., palyginti su 1977 m., kiek pasikeite. Ją sudare 56 asmenys: A. Čyras, D. Maciulevičius, G. Marčiukaitis, B. Sidauga, V. Kriščiūnas, A. Alikonis, V. Andriušinas, P. Baradokas, K. Baškys, E. Borkauskas, A. Čižas, J. Dilba, P. Dilys, B. Gajauskas, M. Gedgaudas, O. Glemžienè, Z. Jankauskas, A. Janulis, S. Juoniene, A. Kavolèlis, V. Krušinskas, A. Krutinis, A. Ku- dzys, V. Kulikauskas, B. Liaudis, G. Likas, V. Likiene, V. Liutikas, A. Marcelis, J. Mureika, A. Naidionovas, A. Nakas, H. Nakas, A. Naujokaitis, P. Norkus, J. Raslanas, A. Ražinskas, K. Sakalauskas, A. Smilgevičius, K. Sasnauskas, A. Samulevičius, A. Spelskis, E. Stankus, K. Šešelgis, V. Šeštokas, J. Šimkus, A. Šriupša, R. Tamutis, Č. Teišerskas, V. Tilindis, A. Urbelis, Z. Vainoris, A. Valentinavičius, partinès organizacijos sekretorius G. Butkus, Komjaunimo organizacijos sekretorius R. Kačianauskas ir profsąjungos Vietos komiteto pirmininkas A. Gailius.

\section{Turiningas laisvalaikis ir puikūs architektų darbai}

Nors apskritai žmonių gyvenimas sąstingio metais kasmet pastebimai prastejo, kas buvo daugiau jaučiama ir institute, tu metų studentija gyveno visaverti gyvenimą: mokesi, draugavo, buvo rengiami turiningi poilsio vakarai - diskotekos, daugelis buvo meno ir sporto kolektyvų dalyviai.

Kas savaitę ir dažniau įdomūs vakarai vyko kavinëje „Visyte“. Ypač aktyvūs buvo Statybos fakulteto studentai, šio fakulteto pedagoginio ir mokslinio personalo jaunimas.

İdomiai gyveno meno kolektyvu studentai. Balandi vyko VISI mokslo dienos Panevežio rajone. I jas nuvyko didele VISI delegacija: rektorius A. Čyras, dekanas V. Krušinskas, doc. J. Vanagas, doc. J. Mureika, doc. A. Gaižutis ir du meno saviveiklos kolektyvai - „Hiperbole“ ir „Šiupinys“. Profesūra pasakojo moksleiviams ir mokytojams apie VISI, o koncertavę studentai susilaukè aibės plojimų.

İdomios ir linksmos balandị buvo architektų dienos, tapusios tradicinemis.

Aktyvūs buvo ir sportininkai. Vis labiau pasižymedavo dziudo imtynèse VISI sporto klubo „Inžinerija“ atstovai. Balandžio 15$16 \mathrm{~d}$. vykusiose Vilniaus miesto „Žalgirio“ draugijos pirmenybese VISI pagal komandinius rezultatus užèmé pirmąją vietą.

Vilniaus miesto 8-osios spartakiados čempionais tapo VISI rankininkai.

Dar didesnį laimëjimą pasiekè VISI regbio komanda. Vaikinai iškovojo $1978 \mathrm{~m}$. Lietuvos čempionų vardus.

1978 m. gegužę vèl vyko politinès dainos konkursas Jerevane. „Hiperbolë“šs kartą laimejo antrojo laipsnio diplomą.
Trečius metus iš eilès pirmą vietą Vilniaus miesto meninių agitbrigadų apžiūroje laimëjo instituto saviveiklininkai, pasivadinę šį kartą „Na palauk!“, vadovaujami Rimgaudo Karvelio. VISI meninè agitbrigada buvo pripažinta absoliučiai geriausia mieste.

Šioje apžiūroje „sublizgejo“ šiupiniečio Albino Arkausko talentas. Neatsitiktinai juo greitai susidomëjo Valstybinè konservatorija. Jis paliko VISI ir nuejo tarnauti Melpomenei. „Inžinerijoje“ TG 7/1 studente po metų raše: "Meno saviveikla reikalauja daug meniniu sugebejimu, fiziniu jegu, atima daug laiko, bet ir labai praturtina žmogaus dvasini pasauli. Juk nemažai menininku savo kürybini keliq pradejo meno saviveiklos kolektyvuose" [4.32, p. 2]. Kaip matysime, tokių precedentų bus ir ateityje.

Bet ypač buvo malonūs VISI studentų laimëjimai būsimos profesijos baruose.

Vasaros pradžioje paaiškejjo architektu 1977 m. diplominių darbų sąjungineje apžiūroje rezultatai. Geriausiems diplominiams darbams buvo skiriamos vadinamosios žvaigždutes - jos reiškè pirmojo laipsnio diplomą. Tokių žvaigždučių šiame konkurse paskirta penkios.

VISI Architektūros fakultetas apžiūrai buvo pateikęs 4 diplominius projektus. Vienas jų buvo pažymetas pirmojo laipsnio diplomu ir trys - antrojo laipsnio diplomais.

Žvaigždute buvo pažymètas diplominis projektas „Liejyklos gatvès Vilniuje rekonstrukcija“, autorè J. Melko-Staniūnienè (vadovas doc. arch. k. V. Jurkštas). Antrojo laipsnio diplomais įvertinti: „,500 vietų viešbutis „Turistas"Vilniuje“, autorius E. Palavinskas 
VILNIAUS

INŽINERINIS STATYBOS

INSTITUTAS
Jurgis Kairys gimè 1952 m. Krasnojarsko srityje, iš Šilalès rajono kilusių tremtiniu Vlado ir Zofijos Kairių šeimoje. 1973 m. baige Vyborgo aviatechnikos mokyklą ir ịsidarbino Lietuvos civilines aviacijos valdyboje. Nuo 1977 m. dirbo Vilniaus aeroklube lakūnu-instruktoriumi.

1978 m. įstojo ị VISI Automatizacijos fakulteto vakarini skyrių studijuoti elektros pavarų. Studijuodamas priklausè TSRS lekktuvu sporto aukštojo pilotažo rinktinei. Sẻkmingai ìveike pirmajji studijų kursą, bet nuo $1980 \mathrm{~m}$. kovo studijas VISI nutrauke ir įstojo į Leningrado civilines aviacijos akademiją.

Vilniaus Gedimino technikos universitetas didžiuojasi tuo, kad Lietuvos, Europos, pasaulio čempionas kurị laiką buvo mūsų mokyklos studentu.

Vis daugejo studentų statybinių būrių. 1978 m. VISI organizavo 28 SSB. 850 studentų atliko darbų beveik už 3 milijonus rublių. Pagal SSB darbo rodiklius VISI užèmè antrąją vietą respublikoje.

\section{Politrukams - lengvatos}

1978-1979 mokslo metų pradžią VISI pažymëjo renginiu Profsąjungu rūmuose. Aukščiausiosios valdžios pareigūnų nebuvo. Atvyko tik pavaduotojai, antri sekretoriai, skyrių vedejai, tiesa, vienas ministras - automobilių transporto ir plentų. Rektorius A. Čyras teviškai dalijo pamokymus pirmakursiams, akcentavo jų teisę ir pareigą rimtai mokytis. Komjaunimo sekretorius R. Kačianauskas pasakojo apie studentu visuomeninio gyvenimo ypatumus. Pirmakursiai davè „Pažada mokytis ir dirbti komunistiškai, būti vertais tarybinio studento vardo..." [4.34, p. 1]. Koncertavo „Gabija“ ir liaudies dainy ir šokiu ansamblis.

1978 m. rugsëjo $1 \mathrm{~d}$. VISI buvo šeši fakultetai: Architektūros, Statybos ekonomikos, Statybos, Miestu statybos, Mechaninès technologijos ir Automatizacijos.

Architektūros fakultete buvo keturios katedros, jos turejo 40,25 etato; Statybos ekonomikos - trys katedros ir 34,5 etato; Statybos - septynios katedros ir 91,25 etato; Miestų statybos - penkios katedros ir 63 etato; Mechanines technologijos - septynios katedros ir 95,5 etato ir Automatizacijos - trys katedros ir 24,25 etato. Visu čia minetų katedrų déstytojų vadinamasis akademinis krūvis per metus sudare 342825 
valandas. Vienam dèstytojui vidutiniškai teko 983 valandos.

Bendrosios katedros buvo devynios. Ju akademinis krūvis per metus sudare 109361 valandą. Vienam dèstytojui teko tik 767,5 valandos. Atrodytų, kad inžinerijos dalykai daug lengvesni destyti, nes, kaip matome, inžinerijos disciplinas destantis destytojas turejo dirbti auditorijoje daugiau kaip 200 valandų, nei bendrųjų katedrų destytojas!

Bet tai dar ne viskas. Visi žino, kokios būsimo statybos inžinieriaus nelengvos studijos. Jam parengti sunkus bei atsakingas ir statybos mokslus déstančio pedagogo darbas. Vidutinis Statybos fakulteto destytojo krūvis 1978 m. sudare 1016 valandų, o Mokslinio komunizmo katedros destytojo metinis krūvis sudare tik 505 valandas! Taigi profesinio rengimo pedagogas už tą patį atlyginimą turejo dirbti du kartus daugiau. Še tau ir socialinis teisingumas, apie kuri labai mégo šnekèti komunizmo apologetai!

Privilegijuotos taip pat buvo TSKP istorijos (537 val. / 1 dest.), Politinés ekonomijos (568 val. / 1 dèst.), Filosofijos (554 val. / 1 dèst.) katedros.

Mažesnis vadinamųju visuomeniniu mokslų katedrų déstytojų akademinis krūvis buvo aiškinamas tuo, kad esą tie destytojai turi daug dirbti studijuodami naujausius partijos dokumentus. Bet ir lengvatos, kaip jau po dešimtmečio paaiškejjo, nepadejo. Nors buvo girtasi gerais šių mokslų rezultatais, faktiškai studentai sieke kaip nors apeiti tą kretinizmą. Tik apie tai kalbèta pašnibždomis, dairantis. Tokia buvo tikrovè.

\section{Valstybine premija elektrikams}

1978 m. trys instituto žmonès tapo respublikinių premijų laureatais. Už plačiajuosčių velinimo ir atlenkimo sistemų teorijos ir konstrukcijų sukūrimą bei įdiegimą ūkyje laureatais tapo Zenonas Vainoris, Stanislovas Štaras ir Raimundas Kirvaitis. Zenonui Vainoriui 1978 m. išties buvo labai sèkmingi. Metams baigiantis iš Maskvos atëjo žinia apie jam suteiktą mokslini profesoriaus vardą.

Instituto laikraščio „Inžinerija“ dvigubas numeris metų pradžioje buvo skiriamas abiturientams. Jame buvo išspausdinti VISI profesūros straipsniai apie VISI specialybes, studentų gyvenimą, priemimo tvarką ir kt. Tuomet interneto net sąvokos nebuvo. Todèl tokie laikraščio numeriai, patekę į vidurines mokyklas, buvo labai svarbus moksleiviu informavimo ir agitavimo stoti $\underset{i}{i}$ VISI komponentas. Nuoširdžiai parašytas straipsnis ne vienam jaunuoliui ar merginai turëjo lemiamą reikšmę renkantis būsimą profesiją. Kelių katedros doc. Evaldas Palšaitis savo publikacijoje apžvelgè pagrindinius istorinius automobilių kelių statybos momentus, atskleide kelių inžinieriaus darbo romantiką, apraše įdomias ir naudingas studentų kelininkų praktikas.

Doc. R. Ginevičius straipsnyje „Ekonomistas ar statybininkas“ teige, kad „sinolaikiniam statybos vadovui nepakanka žinoti technines statybos paslaptis, jis turi žinoti statybos ekonomika, valdymo principus, būti susipažinęs su teises, psichologijos, sociologijos ir net darbo fiziologijos pagrindais. Dabar statybos vadovas, spresdamas gamybinius ir kitus klausimus, neturi paskesti milžiniškuose informacijos srautuose, o to isvengiame pasitelkdami i pagalba matematinius planavimo ir valdymo metodus bei elektronine skaičiavimo technika. Taigi jis privalo tureti žiniu apie skaičiavimo mašinas ir programavima, turi büti intelektualus, kūrybingas, mokèti savarankiskai mastyti ir veikti. Statybos ekonomikos fakulteto studentai šias savybes ir žinias igyja studijuodami" [4.35, p. 2].

1979 m. trečioji vasario savaitè Vilniaus inžineriniame statybos institute buvo ypatinga. Ji buvo skirta mūsų senojo Vilniaus universiteto 400 metu jubiliejui. Institute atvyko surengtos $\mathrm{VU}$ mokslo dienos.

Vilniaus universiteto mokslo dienos VISI prasidejo iškilmingu plenariniu posèdžiu, $\mathfrak{i}$ kuri atvyko VU rektorius prof. J. Kubilius, prof. A. Marcinkevičius, doc. L. Butkevičius, doc. V. Jakelevičius ir kt. Didžioji auditorija (03) buvo pilnutèle studentų ir desstytojų, atvyko visi instituto vadovai.

Prof. J. Kubilius pasakojo apie garbingą Alma Mater Vilnensis praeiti, jai šlovę suteikusius mokslo ir meno vyrus. VU rektorius kalbëjo apie esamą universiteto struktūrą, mokslo darbus, studijų procesą. Jis pabrèže, kad tarp VU ir VISI yra gana tvirta draugysté, priminé, kad kai kūrèsi KPI filialas, senasis universitetas priglaude po savo stogu, „paskolino“" desstytojų.

Prof. A. Marcinkevičius - iž̌ymus širdies kraujagyslių ligu specialistas - kalbejo apie medicinos ryšius su inžinerija: be inžinierių statybininkų nebūtų ligoninių, be sudètingos technikos (elektronines aparatūros) neįmanomos tikslios diagnozes ir t. t.
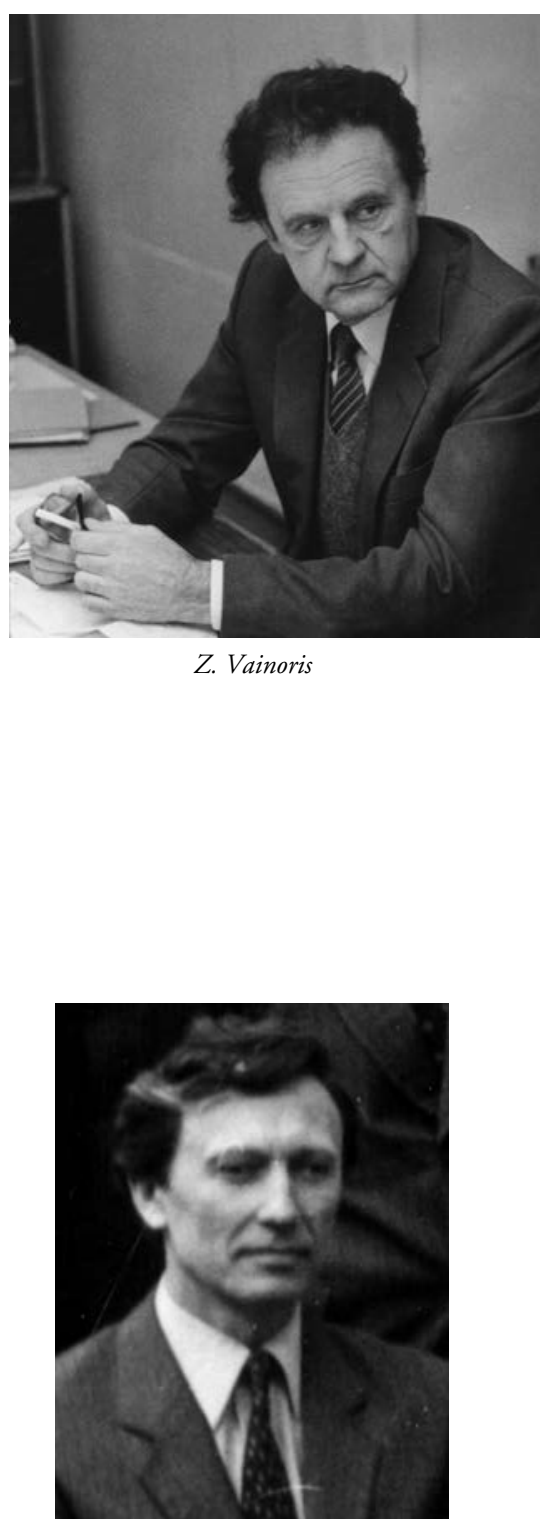

S. Štaras

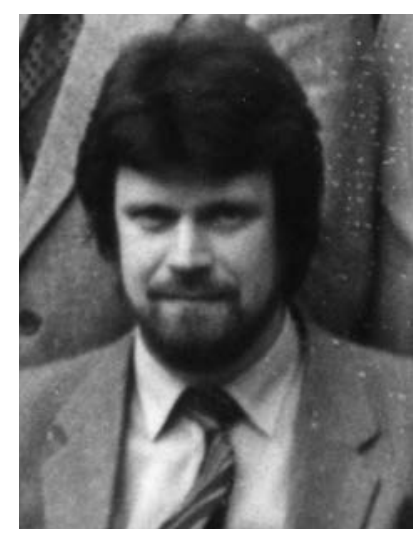

R. Kirvaitis 
VILNIAUS

INŽINERINIS STATYBOS

INSTITUTAS

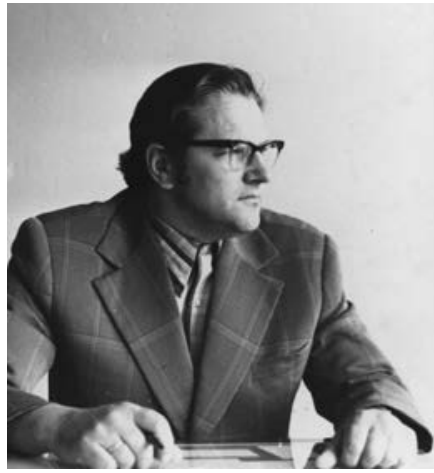

L. Syrus - prorektorius vakarinio ir neakivaizdinio mokymo reikalams 1979-1981
VU dienų renginiai vyko ir fakultetuose, studentai bendravo „Visyteje“ bei kt. [4.36, p. 1].

Šiandien aukštųjų mokyklų bendravimas igijo kitokį pobūdį. Daugelyje sričiu tapome konkurentais. Gerai, jei tai skatins aukštojo mokslo progresą. Kartu dera nepamiršti, kad gyvename po ta pačia téviškès padange ir todèl turime siekti tarp visų mokyklų harmoningo ir tauraus bendradarbiavimo Lietuvos gražios ateities vardan.

\section{Iprotis nuolat dirbti - sèkmès laidas}

1979 m. balandžio 17 d. VISI taryba svarste Estetikos ir Fizinio lavinimo katedrų darbą. Pasidžiaugta meno ir sporto kolektyvų laimejjimais, kalbèta apie tai, kas taisytina. Pažymeta, kad studentas, aktyviai dainuojantis, grojantis, šokantis ar sportuojantis, daug laiko praleidžia repeticijose, koncertuose, treniruotese ar varžybose. Tarkim, meno saviveiklininkai vien repeticijose praleidžia per metus apie 350 valandų, o „Inžinerijos“ dūdoriai - dar daugiau - apie 500 valandu, nes jie ne tik repetuoja ir koncertuoja, bet ir dalyvauja iškilminguose minejjimuose pasitinkant svečius, pagerbimo ceremonijose ir kt.

Vis dèlto meno kolektyvų narių pažangumas net didesnis už bendrąji: meno kolektyvu - 94 proc., bendrasis instituto 87,9 proc. Kai „Šiupinio“ konferansje PCS 4/3 grupès studentą Nerijų Žuką, išlaikiusi sesiją, kaip ir daugeli kitų sesijų, labai gerais pažymiais, paklausè, kas lemia sèkmę, jis atsake: „-Iprotis nuolat dirbti. Nesuprantu tu, kuriu studentiškas gyvenimas prasideda ir baigiasi atejimui paskaitas. Nuo pirmo kurso reikia pradeti dometis arba sportu, arba mokslu, arba saviveikla.

- Bet juk tai papildomas krūvis, argi jis netrukdys mokymuisi?

- Ne, - sako Nerijus, - darbas išmoko planuoti laika. Paprastai tie, kuriuos matome scenoje, tie, kurie gilinasi z mokslo paslaptis SMD ir mokymuisi laiko suranda, jie iprate branginti kiekviena minute.

Nerijus - instituto SMD pirmininkas, dirba medžiagu atsparumo ir statybines mechanikos sekcijose, jo darbas buvo gerai ivertintas visasajunginiame studenty moksliniu darbu konkurse" [4.37, p. 1].

$\mathrm{O}$ „Šiupinys“, kuriame elegantiškas, mokantis sukurti gerą nuotaiką Nerijus Žukas vede programą, balandžio ménesị Alytuje vykusiame respublikiniame meniniu agitbrigadų konkurse laimejo pirmąją vietą. Ypač pasižymejo V. Kontrauskas, kurio pasirodymas scenoje iškart sukeldavo šurmulį žiūrovų salëje.

„Šiupinys“ pergalingai žygiavo ir už Lietuvos ribų. Dalyvaudamas 2-ajame Taškento studentų teatrų festivalyje, kuriame pasirode 38 kolektyvai, tarp jų - iš Lenkijos, Čekoslovakijos, Vengrijos ir VDR, iškovojo laureatų diplomą, gavo prizą kaip linksmiausias teatras.

Po Taškento seke festivalis Jerevane „Studentų pavasaris-79“, kur „Šiupinys“ buvo pripažintas geriausiu ir laimejjo pagrindinį festivalio prizą.

Pirmąją vietą ir absoliučiai geriausio mišriojo choro vardą Vilniaus miesto apžiūroje vèl laimëjo „Gabija“.

Buvo tą pavasarị laimèjimų ir moksle. Maskvos energetikos instituto specializuotoje taryboje technikos mokslų daktaro disertaciją „Tiesinių elektrinių signalų laiko mastelio pakeitimas matavimo technikoje" sèkmingai apgynè VISI Radijo aparatūros technologijos katedros docentas Arkadijus Naidionovas. L. Radzevičius tuomet „Inžinerijoje“ raše:

„Šios daktaro disertacijos rezultatai daro nauja mokslinę krypti radiotechnikoje ir plačiai taikomi nanosekundineje matavimo technikoje bei moksliniu prietaisu gamyboje. Pagal gautus rezultatus galima kurti nauja aparatūrą nanosekundžiu ir pikosekundžiu trukmes impulsu formos ir parametru oscilografavimui. Atlikto darbo praktine verte labai didele.

Dvi daktaro disertacijos Radijo aparatūros technologijos katedroje, respublikines premijos paskyrimas šios katedros darbuotojams (dr. prof. Z. Vainoris, t. k. doc. S. Štaras, t. k. doc. V. Kirvaitis) - tai nuolat augančio mokslinio potencialo išradiotechnikos srities mūsu institute rezultatas irjo ivertinimas " [4.38, p. 1].

Bene svarbiausias mokslo įvykis $1979 \mathrm{~m}$. Vilniaus inžineriniame institute buvo jau tradicine tapusi sąjungine moksline konferencija „Optimizavimo ir patikimumo problemos statybineje mechanikoje“.

Konferencijos plenarinis posedis vyko Meno darbuotojų rūmuose (dabar - Prezidentūra). İ konferenciją atvyko TSRS ir respublikos valdžios atstovai, daug mokslininkų 
iš Maskvos, Kijevo, Leningrado, Sverdlovsko ir kitų miestų.

TSRS aukštojo ir specialiojo vidurinio mokslo ministro pavaduotojas, TSRS mokslų akademijos tikrasis narys I. Obrazcovas skaite pranešimą apie sudètingu inžinerinių konstrukcijų optimizacijos problemas statybinëje mechanikoje, TSRS MA narys korespondentas V. Bolotinas - apie unikalių sistemų ilgaamžiškumo prognozavimą pagal stebejimų rezultatus, prof. A. Čyras - apie statybinès mechanikos raidą Lietuvoje. Vèliau konferencija vyko šešiose sekcijose. Buvo perskaityta ir aptarta 150 mokslinių pranešimų.

Ši konferencija - jau ketvirtoji sąunginè konferencija, vykusi VISI. Tai buvo didelis lietuvių mechanikos mokslininkų pripažinimas. Svečiai konferencijos organizatorių prof. A. Čyrą vadino „krupnym učionym“ - dideliu mokslininku.

\section{Minëjo VISI dešimtmeti}

1979 m. Vilniaus inžinerinị statybos institutą baigè 1044 žmonès: dieninị skyrių 712 , vakarinị skyrių - 273 ir neakivaizdinị skyrių - 59 .

Per pirmąji VISI veiklos dešimtmetị buvo parengti 7989 inžinieriai, o per visą savo veiklos laikotarpi, t. y. nuo 1956 iki 1979 m. - 9786.

Vasarą pagal planą priemimas buvo numatytas praktiškai toks pat, kaip ir praejusiais metais - 1275 žmonès.

1979 m. rudenị Architektūros fakultete studijavo 368 studentai, Automatizacijos fakultete - 679, Mechaninès technologijos fakultete - 1 910, Miestų statybos fakultete - 732, Statybos fakultete - 1546 ir Statybos ekonomikos fakultete - 1333 . Iš viso Vilniaus inžineriniame statybos institute studijavo 6568 studentai (visuose skyriuose - dieniniame, neakivaizdiniame ir vakariniame).

1979-1980 mokslo metus Vilniaus inžinerinis statybos institutas pradejo minèdamas savo savarankiškos veiklos dešimtmeti. Rugsëjo 3 d. iškilmingas VISI 10-mečio minejimas buvo surengtas Valstybiniame akademiniame operos ir baleto teatre. Apie kelią, kurį nuejo institutas per tuos metus, kalbejo rektorius A. Čyras. Sveikino ir šiltus žodžius VISI tarè LTSR rektorių tarybos pirmininkas KPI rektorius prof. M. Martynaitis. Jis pa- brèžè inžinieriaus atsakomybę, linkëjo jaunimui ryžto ir sèkmés siekiant žinių, nauju mokslo aukštumų. Nuoskaudos dèl praeities nesutarimų jau neliko.

Kalbą perskaite ir LKP pirmasis sekretorius P. Griškevičius, kurioje gyre institutą, rektorių A. Čyrą ir, žinoma, draugą Leonidą Brežnevą. Nè vieno žodžio be teksto! Turejome tikrą lietuviškąjị Brežnevą, tik gerai, kad jo dar nereikëjo ramstyti...

Rugsëjo mènesị i VISI atvyko TSRS aukštojo ir specialiojo vidurinio mokslo ministras V. Jeliutinas, dalyvavęs Vilniaus universiteto 400 metų jubiliejaus iškilmèse. Jam buvo parodytas institutas, papasakota apie mokymo procesą, elektroninių skaičiavimo mašinų taikymą ir kt.

Garbès svečiu knygoje V. Jeliutinas, be kita ko, parašè: „Malonu buvo pamatyti, kokiu puikiu rezultatu pasieke instituto kolektyvas. Kuriant instituta, buvo tikima kolektyvo jegomis, tačiau rezultatai viršijo mūsu viltis, buvo padaryta daugiau, greičiau ir geriau, nei mes laukeme" $[4.39$, p. 2].

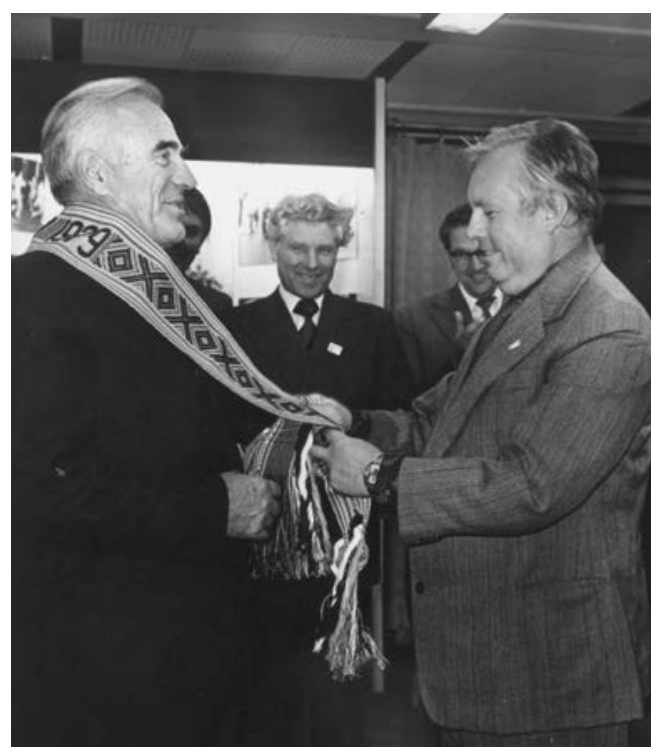

V. Jeliutinas VISI muziejuje

1979 m. buvo baigta antrojo laboratorinio korpuso statyba. Jame ịsikūre Statybos fakulteto profilinès katedros ir jų laboratorijos bei Architektūros fakulteto Pastatų konstrukcijų katedros Šiluminès technikos laboratorija.

Kai 1975 m. pasibaige karas Vietname, pasaulyje ramybès nepadaugëjo. Vyko karai Lotynų Amerikoje, Afrikoje, arabų žemėse, Azijos žemyne, bet tai atrodè toli nuo mūsų ir faktiškai mus tai mažai jaudino. Prie tokių ìvykių buvome pripratę. Bet 1979 m. žiemą prasidejo įvykiai, kurie sujaudino ir Lietuvos žmones. 
VILNIAUS

INŽINERINIS STATYBOS

INSTITUTAS disciplinu, kuriu pagrinda statybinio profilio specialybems sudaro matematika ir mechanika, taip pat specialiu konstruktoriniu, kaip gelžbetonines, metalines ir kitos konstrukcijos, naujoviška pateikima. Šis naujoviškumas remesi plačiu elektroninès skaičiavimo technikos panaudojimu. Drasiai galima teigti, kad mūsu išleidžiamu statybos inžinieriu konstruktorinis paruošimas neatsilieka ne tik nuo geriausiu müsu šalies aukštuju mokyklu, bet jis prilygsta pažangiausiems pasauliniams inžinieriaus paruošimo standartams" [4.40, p. 2].

Bet vis dèlto rektorius teige, kad netenkina inžinierių statybininkų parengimas gamybiniam darbui, kad juos rengiant reikia sustiprinti technologijų, darbo organizavimo ir ekonomikos žinias.

Rektorius gyre VISI katedras, kuriose išryškejjo mokslo ir mokymo vienove. Jis šiuo klausimu pažymëjo Gelžbetoninių konstrukcijų, Kelių, Miestų statybos, Medžiagų atsparumo, Statybines mechanikos ir Radijo aparatūros katedras. Noredamas „pralinksminti“" auditoriją, A. Čyras pacitavo ištrauką iš P. Griškevičiaus Kaune perskaityto pranešimo:

"Kiekvieno visuomenés mokslu destytojo pareiga - argumentuotai, jitikinamai atskleisti nepaprasta marksistines-leninines teorijos turininguma ir didžia kuriamaja jega, didžiuli Tarybu Sajungos Komunistu partijos Centro komiteto, draugo Leonido Brežnevo indèli toliau vystant šiq teorija šiuolaikinemis sąlygomis, aktyviai siekti, kad kiekvienas studentas igytu kuo daugiau igūdžiu pritaikyti savo socialines-politines žinias praktikoje. Deja, nors ir nedažnai, tačiau vis dar pasitaiko studentu neigiamo elgesio faktu, kurie rodo, jog igytos žinios dar netapo teigiamais igüüžiais “.

$\mathrm{Na}$, ir savo pranešimo pabaigoje rektorius išreiške įsitikinimą, kad kolektyvas padarys viską, kad aukščiau pakiltų mūsų veikla, kad aktyviau įsijungsime, ..., atiduosime visas jegas ir t. t.

Suprantama, galejo būti linksma, jei nebūtų liūdna. Realus gyvenimas teigè ką kita, nei su patosu skaitomi pranešimai.

1980 m. prasčiau atrode ir meno kolektyvai. „Inžinerijos“ orkestras Dainų šventëje tebuvo trečias, tautinių šokių ansamblis, dabar jau vadinamas „Vingiu“ (buvo siūlomas ir "Žaros"vardas), užemè 5-ąją vietą, o „Gabijos" choras - tik šeštąją. Labai kritikuotas Estetikos katedros darbas.

Paguoda galëjo būti puikus šiupiniečių pasirodymas Novovoronieže estradinių 
miniatiūrų teatrų festivalyje bei Statybos ekonomikos fakulteto studento G. Rakausko vadovaujamo VISI instrumentinio ansamblio iškovotas laureato diplomas Kaune ìvykusiame estradiniu kolektyvų konkurse "Gintarinè triūba“.

$1980 \mathrm{~m}$. VISI baige studijas ir gavo inžinieriaus diplomus 1006 jaunuoliai ir merginos, o ị institutą studijų buvo priimti 1275 žmonès: ị dienines studijas - 850 , ị vakarines -235 ir neakivaizdines -69 .

1980 metai Vilniaus inžineriniam statybos institutui pažymėtini ir tuo, kad buvo išleistas 10000 -asis absolventas. Specialistu rengimo dinamika 1970-1980 metus pateikta lentelëje.

Vasarą 850 VISI studentų dalyvavo studentų statybinių būrių darbuose ir atliko darbų už 2,3 milijono rublių.

Gražų laimejjimą pasiekè VISI moteru tinklinio komanda, laimejjusi 1980 metu Lietuvos studentu spartakiadoje.

1980-1981 mokslo metų pradžioje VISI buvo 488 etatiniai destytojai, kurie dirbo 39 katedrose. Dirbo 11 profesoriu daktaru, 3 profesoriai ir 234 docentai.

Architektūros fakultete buvo Architektūros, Dailes, Gyvenviečiu planavimo ir tvarkymo bei Pastatu konstrukcijų katedros.

Statybos fakultete buvo Matematikos, Medžiagu atsparumo, Statybines mechanikos, Gelžbetoninių konstrukcijų, Statybos darbų technologijos, Pagrindų ir pamatų bei Metalinių konstrukcijų katedros.

Statybos ekonomikos fakultete buvo Statybos ekonomikos, Statybos organizavimo ir valdymo, Statybinių medžiagų ir Chemijos katedros.

Miestų statybos fakultete buvo Miestų statybos, Kelių, Geodezijos, Hidraulikos ir Fizikos katedros.

Mechaninès technologijos fakultete buvo Metaly technologijos, Automobiliu transporto, Mašinu gamybos technologijos, Mašinu teorijos, Pramonés ekonomikos, Braižybos bei Taikomosios matematikos ir mechanikos katedros.

Automatizacijos fakultete buvo Radijo aparatūros technologijos, Elektrotechnikos ir Elektros pavaru katedros.

Institutą vis dažniau aplankydavo svečiai iš Vokietijos (VDR). Rugpjūtį buvo atvykęs Veimaro aukštosios architektūros ir statybos mokyklos rektorius dr. Fuchsas, o spalio ménesi - VDR valstybes tarybos pirmininko pavaduotojas M. Gerlachas.
Dažnai svečiai, kviesti ir nekviesti, vyko ir iš Maskvos. Tenka pripažinti, kad bendradarbiavimas su Maskvos inžinerinio statybos instituto žmonèmis buvo nuoširdus ir naudingas. Kai lapkritị Vilniaus inžineriniame statybos institute vyko MISI dienos, vyko daug gražiu renginių. Vilniečius ypač sužavejo MISI dramos studijos spektaklis, parodytas bendrabučių aptarnavimo bloko salytejje. Maskviečiai parode rusų klasiko A. Čechovo dramą „Dèdè Vania“ ir sulauke didelio pasisekimo.

Maskviečiu delegacijos vadovas MISI prorektorius E. V. Šilovas daug metų buvo MISI ir VISI bendradarbiavimo „stuburas“. Daugiausia jam padedant nuolat augo atskiru katedrų mokslininkų asmeninių ryšių plètra, ir tie ryšiai intensyvejo.

Toliau stiprëjo Skaičiavimo centro darbas. Turedamas keturias skaičiavimo mašinas (,Minsk-22“, „Minsk-32“ ir dvi mašinas EC-1022) centras dirbo ne tik mokymo procesui, bet ir kūrè informacinę sistemą (AIS) mokymo procesui valdyti. $1981 \mathrm{~m}$. pradžioje jau veike keli AIS posistemiai. Posistemiu „Abiturientas“ buvo apdorojami stojančiųjų i institutą duomenys ir stojamųjų egzaminu rezultatai. Posistemiu „Sesija“ buvo apdorojami egzaminu sesijos rezultatai. Buvo parengti dar du posistemiai: „Lankomumas“ ir "Studentu kadrai ir kontingentas“. Buvo ir destytojų akademinio krūvio skaičiavimo naujienų. Buvo parengta programa tokiems apskaičiavimams su ESM atlikti.

1980 m. lapkričio 20 d. Vilniaus inžineriniame statybos institute buvo įsteigtas Kvalifikacijos tobulinimo fakultetas. Buvo numatyta, kad jame kels kvalifikaciją vadovaujantieji inžinerijos ir technikos darbuotojai iš statybos, transporto ir projektavimo organizacijų. Dekanu buvo paskirtas V. Krušinskas.

Lapkričio $24 \mathrm{~d}$. VISI rektorate, svarstant užsienio mokslinių stažuočių ir komandiruočių efektyvumą, buvo pažymèta, kad 19761980 m. mokslinèse stažuotese bei komandiruotèse užsienyje pabuvojo 10 destytojų: R. Podagèlis - Italijoje, A. Jurkša - Anglijoje, J. Nagevičius - Prancūzijoje, A. Kaminskas Anglijoje, J. Atkočiūnas - Lenkijoje, V. Stragys - Norvegijoje, A. Kvedaras - Anglijoje, A. Valentinavičius ir A. Čyras - Vokietijos Federacinëje Respublikoje.

1980 m. VISI mokslininkai atliko užsakomųjų mokslo-tiriamųjų darbų už 1,734 milijono rublių, gavo 40 autorinių išradimų pažymëjimų. Mokslinius biudžetinius ir 
VILNIAUS

INŽINERINIS STATYBOS

INSTITUTAS
1980 metų geriausiais VISI išradejjais buvo pripažinti Antanas Kavolèlis ir Bronius Spruogis - abu Mašinų teorijos katedros docentai.

VISI mokslininkų 1980 metų laimëjimus ūkiskaitinius darbus vykde 328 VISI mokslininkai.

1980 m. VISI išleido 557 leidinius, iš jų 6 monografijas, 9 mokslo darbų rinkinius. 399 instituto mokslininkų straipsniai buvo publikuoti moksliniuose žurnaluose bei rinkiniuose. 59,2\% mokslinio pedagoginio personalo turëjo mokslinius laipsnius ir vardus.

\section{Gražūs studentų ir dèstytojų laimëjimai}

1981 m. sausio 4 d. rektorius A. Čyras paskelbe įsakymą „Dèl stažuotès vadovu paskyrimo". Stažuotes vadovai buvo paskirti jauniesiems specialistams, $1980 \mathrm{~m}$. baigusiems aukštąsias mokyklas ir paskirtiems dirbti i VISI. Pažymètina, kad tarp jų buvo Gediminas Vagnorius, ilgainiui tapęs Lietuvos Ministru Pirmininku, Birute Tamulaitiene - dabartine VGTU Tarptautinių studiju centro direktore, Alfredas Laurinavičius - dabar VGTU Kelių katedros vedejjas, Juozas Valivonis - dabar VGTU Gelžbetoninių konstrukcijų katedros docentas ir t. t.

1981 m. kovą vykusiame studentų mokslinių darbų respublikiniame konkurse daugelis VISI studentų pelnę įvairius diplomus ir apdovanojimus. Tai Statybos fakulteto studentai G. Kaklauskas, M. Šneiderova, R. Baušys, A. Šapalas, V. Palčiauskas, J. Rimkevičius, R. Kliukas, V. Beručka, V. Galvanauskas, S. Šutovas, V. Klimašauskas; Architektūros fakulteto studentai D. Šarakauskas, A. Navidauskas, A. Satkūnaite, P. Petrauskaite; Mechaninès technologijos fakulteto studentas J. Panamariovas ir kt.

Kovo ménesi Baku vyko 1980 metų laidos architektūros specialybè diplomantų sąunginis darbų konkursas. Ir vèl gražiai pasirode VISI absolventai. I laipsnio diplomus gavo S. Plungè už darbą „Klaipèdos senamiesčio turgaus rekonstrukcija“ (vadovas G. Baravykas), A. Laurinavičius - „Krematoriumas Vilniuje“ (vadovas R. Dineika), J. Bombliauskas - „Visuomeninis-gyvenamasis kompleksas N mieste“ (vadovas A. Nasvytis).

1981 metai buvo VISI meno kolektyvu ypatingo suklestejjimo metai.
Pirmąjį koncertą surenge tik ką susikūręs instituto folklorinis ansamblis, kurio meno vadovu buvo Evaldas Vyčinas.

Labai populiarus tapo miniatiūrų teatras „Šiupinys“, vokalinè instrumentinè grupe „Hiperbolë“, ansamblis „Saulès laikrodis“.

Apie 1981 metų VISI miniatiūrų teatro programą kovą „Inžinerija “ išspausdino J. Erlicko, ilgainiui tapusio vienu žymiausių lietuvių humoristu, straipsni „Koks šiupinio skonis?“. Jis rašě: „<...> Iš kitu panašaus pobūdžzio kolektyvu VISI studentai isssiskiria jaunystès entuziazmu, nauju išraiškos formu ieškojimais, idomiais bandymais $\dot{i}$ vientisa menini audini pinti teksta, siuolaikiniu ritmu muzika, daina ir šoki, svviesos bei garso efektus <...>. Didesni demesi vertetu skirti moralinems problemoms, žmoniu tarpusavio santykiams, kadangi daugumos trūkumu šaknys slypi būtent čia <...>. Teatro kolektyvas turi tikrai idomin aktoriu, mokančiu scenoje gyventi, sugebančiu net iš nelabai idomios medžiagos sukurti įimenančius personažus" [4.41, p. 1].

VISI studentų iniciatyva buvo organizuojami tarptautiniai jaunimo muzikos festivaliai „Opus“. 1981 m. festivalio „Opus 81“ laureatu tapo „Hiperbole“", apie kurią kompozitorius L. Vilkončius rašè, kad ji , <...> buvo vienintelis kolektyvas, papirkęs visapusiškumu. Jokiu priekaistu negalëjome padaryti ansamblio vokalistams, labai gerai reikia vertinti ansamblio garso režisieriaus darba, jie moka dirbti su šviesom " $[4.42$, p. 2].

Festivalyje „Opus 81 “ nedalyvavo kitas instituto ansamblis - „Saules laikrodis“, bet jam L. Vilkončius taip pat negailejo gražiu žodžių: ,_...> kito tokio kolektyvo, atrodo, respublikoje neturime. Ansamblis eina savo keliu, 
jo muzika verčia žmones mastyti. Ansamblio kūriniuose daug jauno, gaivaus. Ju kūryboje džiazroko muzikai panaudojamos simfonines muzikos išraiškos priemones " [4.42, p. 2].

Džiaugesi laimejjimais ir sportininkai. VISI krepšinio rinktine „Inžinerija “ iškovojo teisę kovoti Lietuvos pirmenybių I lygoje. Ta pati komanda svečiavosi Maskvoje ir laimejo 81:78 prieš MISI rinktinę.

Balandžio pradžioje îvyko jau penktosios tradicinès Architektų dienos. Nuo bendrabučių iki centrinių rūmų žygiavo studentų kolona, pasipuošusi įvairiaspalvèmis vèliavomis ir plakatais. Prie rūmų studentus pasitiko Architektūros fakulteto dekanas prof. A. Spelskis. Tų dienų metu buvo įvairių atrakcionų, koncertų, vyko paroda, plakato konkursas, humoro vakaras, mugè. Dalyviai vaišinosi sūriu, kepta duona. Renginio metu tarp studentų buvo daug fakulteto destytoju. Studentai išrinko populiariausią fakulteto destytoją. Juo tapo žinomas architektūros istorikas docentas Stasys Abramauskas.

Kad būsimieji absolventai rengiami Vilniaus inžineriniame statybos institute daugiausia kokybiškai, parodè VII sąjunginès olimpiados „Studentas ir mokslo bei technikos pažanga" respublikinio turo rezultatai. VISI tapo fizikos (ne specialistu), užsienio kalbų (ne specialistų) ir medžiagų atsparumo konkursų komandines įskaitos nugaletojais. Šiame konkurse I vietą laimëjo VISI Mechaninès technologijos fakulteto II kurso studentas Algimantas Kondrusevičius, o Elektrotechnikos konkurse pirmas buvo taip pat šio fakulteto, bet III kurso studentas Egidijus Staškus.

$\mathrm{Ne}$ vienas tokių olimpiadų laimètojas, baigęs studijas, tapdavo žinomu Lietuvos inžinieriumi. Minètasis A. Kondrusevičius, keliolika metų dirbęs gamybinèse ar verslo imonèse, nuo $2001 \mathrm{~m}$. yra Lietuvos nacionalinès vežeju automobiliais asociacijos „Linava" prezidentas.

Kasmet vis dažniau į VISI užsukdavo svečiai iš Vakarų. Iš Kanados atvyko Gediminas Kurpis, iš JAV - Povilas Ričardas Abelkis. Jie skaite paskaitas savo srities mokslo klausimais.

Net tris mènesius institute viešèjo Čikagos firmos "Sargent and Lundy Engineers“ atstovas - skaičiavimo technikos specialistas Antanas Dundzila.

Buvo svečių ir iš Veimaro. Tai Aukštosios architektūros ir statybos mokyklos dèstytojai Uta Hahn ir Klaus Ahner, bibliotekos direktorius J. Schild.

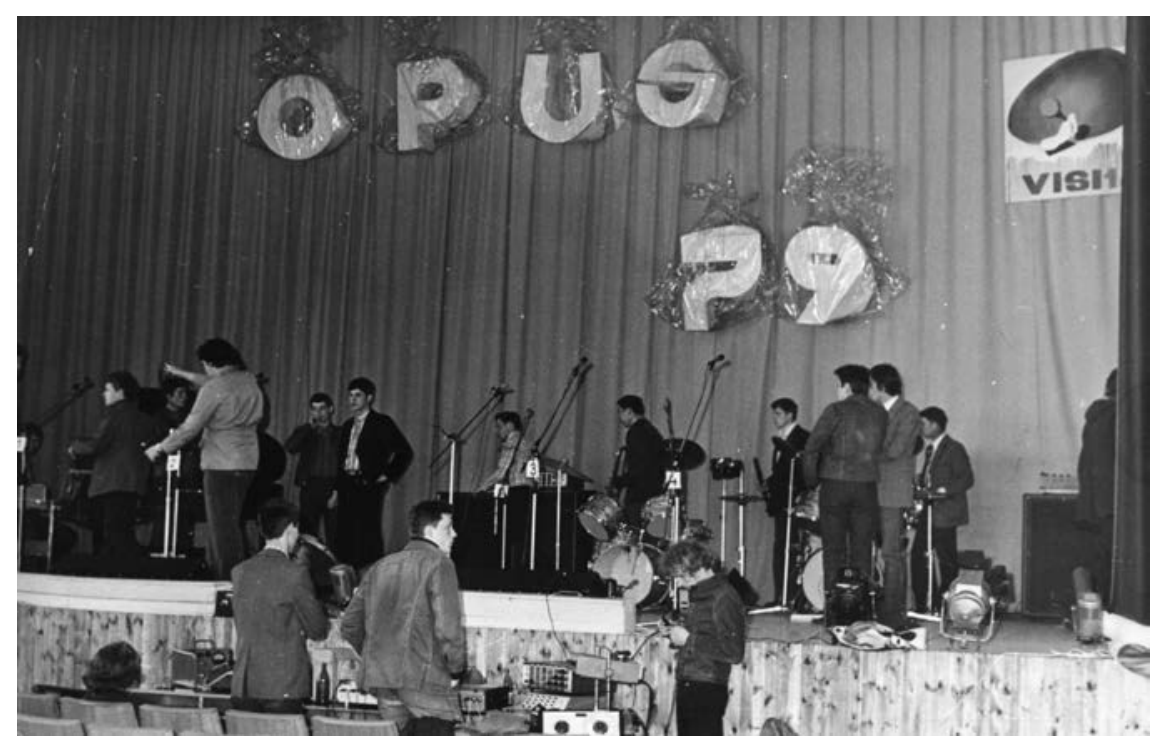

VISI studentai 1979 m. festivalyje OPUS

Lietuviai mokslininkai iš Amerikos lankèsi „Tèviškes“ draugijos kvietimu. Tai jau buvo šioks toks langas ị Vakarus, nes teko išgirsti nemažai naudingos profesinès informacijos. Bet, gink Dieve, jokios politikos!

Norint bendradarbiauti su vadinamosiomis liaudies demokratijos šalimis, reikèjo Maskvos leidimo. $1981 \mathrm{~m}$. balandžio 9 d. TSRS aukštojo ir specialiojo vidurinio mokslo ministerijos įsakymu Nr. 381 Vilniaus inžinerinis statybos institutas gavo leidimą pasikeisti studentu grupemis, atlikti pažintinę praktiką su Bratislavos slovakų aukštąja technikos mokykla (10 studentų), su Veimaro aukštaja architektūros ir statybos mokykla (20 studentų) ir su Pečo inžineriniu statybos institutu (10 studentu).

Gegužę VISI centrinių rūmų rektorato aukšte Architektūros fakulteto doc. Alfonsas Keturka surenge savo akvarelių parodą. İspūdingų akvarelių pasižiūrèti i i 5-ąji rūmų aukštą plūdo gausūs studentų, dèstytojų, darbuotoju būriai. Apie A. Keturkos akvareles tuometinis VISI Estetikos katedros vedejas docentas, dabar Pedagoginio universiteto rektorius, akademikas, profesorius Algirdas Gaižutis rašè, kad A. Keturka „<...> turettu aktyviau dalyvauti respublikinese akvarelistu

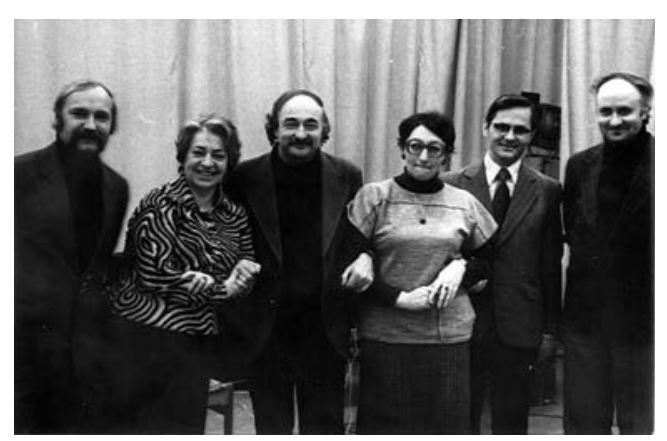

Su „Šiupinio“vadovu R. Karveliu Meno tarybos nariai (iš kaires):

A. Gaižutis, I. Aleksaite, R. Karvelis, H. Kobeckaite, J. Žekevičius, A. Nakas 
VILNIAUS

INŽINERINIS STATYBOS

INSTITUTAS

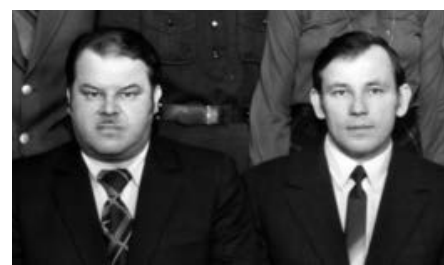

A. Kavolelis ir B. Spruogis
Dešineje -

VISI studentu grupé su kuratoriumi doc. R. Limba kolükyje parodose, tuo labiau, kad jo küriniai nereikalauja jokiu išlygu ar nuolaidu. Jie profesionalūs, saviti ir subtilūs " [4.43, p. 2].

Daug įdomių pranešimų parengè studentai - XII VISI SMD konferencijos dalyviai. 905 pranešimų autoriais buvo 1415 studentų. Geriausiais darbais įvardinti: geodezijos sekcijoje S. Žvirblio „Fotokamerų kalibravimo metodikos tyrimas“ (vad. A. Žalnieriukas), architektūros sekcijoje - A. Trimonio „Kai kurios naujausios architektūros kryptys “ (vad. V. Dičius), pramonès ekonomikos sekcijoje - I. Tarasevičiaus ir S. Eičaitès „Visuomeninio transporto raidos analize Vilniuje“ (vad. I. Butkevičius) ir t. t.

Tą pačią gegužę buvo pasirašyta bendradarbiavimo sutartis su Bresto inžineriniu statybos institutu. Sutartyje buvo numatyta reguliariai keistis destytojais ir mokslininkais, bendradarbiauti mokslo tiriamųjų darbų srityje, keistis mokymo planais, programomis, moksliniais straipsniais, vadoveliais ir mokomosiomis priemonemis, bendradarbiauti, ugdant jaunuosius mokslininkus. Kas 2-3 metai VISI ir BISI planavo rengti aukštųjų mokyklų savaites, kurių metu organizuoti mokslines konferencijas, pasitarimus, simpoziumus, skaityti pranešimus aukštosioms mokykloms aktualiais moksliniais ir pedagoginiais klausimais ir t. $t$.

Bet praktiškai ta sutartis buvo realizuojama labai silpnai, merdëjo. Ilgainiui ryšių ir nebeliko.

1981 m. VISI parenge 1030 aukštos kvalifikacijos specialistų: architektūros specialybès - 73, pramoninès ir civilinès statybos -344 , miestų statybos - 41, automobilių kelių - 42, taikomosios geodezijos -43 , statybos ekonomikos - 120, automobiliu transporto eksploatavimo - 22, automobiliu transporto - 128, statybos kelių mašinų - 44, suvirinimo įrengimu -37 , mašinu gamybos technologijos - 56, elektros pavaru - 33 ir radijo aparatūros -47 .

Vasarą VISI išsiunte dirbti į statybinius studentu būrius 860 studentu. Buvo suformuoti 32 būriai: 20 - Lietuvoje, 3 - Smolensko srityje, 2 - Jakutijoje, 1 - Tiumenès srityje, 1 - Stavropolio krašte ir 5 išvyko i užsienị.

Studijuoti i VISI buvo priimti 763 jaunuoliai ir merginos. Stipriausi mok- sleiviai pagal brandos atestatų rodiklius stojo į Architektūros fakultetą. Jų atestatų vidurkis buvo 4,80. I Automobilių ir autoūkio bei Statybos ir kelių tiesimo mašinų specialybes stojamujuc atestatų vidurkis buvo 4,72. Nedaug atsiliko miestų statybos specialybe - 4,71. Pirmosios dvi specialybès ilgą laiką abiturientų buvo laikomos prestižinemis.

Naujųjų - 1981-1982 - mokslo metų atidarymas įvyko Filharmonijos saleje. Viskas vyko jau pagal tradiciniu tapusį scenarijų. $̌$ Zymiausias tarp svečių - Vilniaus KP pirmasis sekretorius Vytautas Sakalauskas. Jo ir kitų kalbos buvo trafaretinès, nepaliko kokių nors gražių prisiminimų.

Pirmakursiai, vos įžengę i savosios Alma Mater rūmus, tuoj turëjo juos palikti. Jau nuo rugsëjo $3 \mathrm{~d}$. 914 VISI pirmakursių buvo pasiųsti dirbti ì kolūkius ir tarybinius ùkius. Tas nelengvas jaunimo darbas buvo vadinamas talkomis. Kolchozinis ir sovietinis ūkis niekaip be studentų negalejo apsieiti, nors buvo deklaruojama apie „priešakinị tarybinị žemès ūkị“. Tai buvo didele skriauda studijų procesui ir, be abejo, paveikè rengiamų specialistų kokybę.

Kasmet buvo tobulinamas instituto bibliotekos darbas. $1981 \mathrm{~m}$. rudeni biblioteka turejo 8743 nuolatinius skaitytojus, bibliotekos knygu fondas sudare apie 670000 egzempliorių. Bibliotekos darbuotojai kūrè tvirtą informacinę bazę - katalogus ir bibliografines kartotekas. Ypač studentai mégo automatizuotą mokomosios literatūros kartoteką, kuriai sudaryti buvo panaudotas automatinis informacinis įrenginys ACU-50.

Lapkriti VISI surenge mokslo dienas Alytuje. Šiame mieste daugëjo pramonès ir statybos imonių, todèl buvo siekiama suintensyvinti agitaciją, kad jaunimas stotų studijuoti i VISI. Tokio darbo patyrimas moke, kad agituoti reikia ne tik moksleivius,

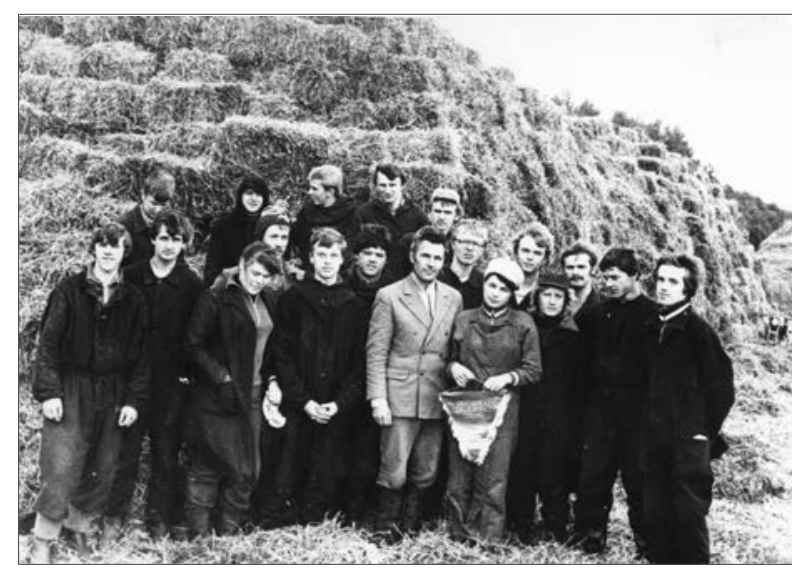


bet ir jų tèvus. Todèl susitikimai vyko ir mokyklose, ir gamybos įmonèse. Prof. A. Čyras, A. Kudzys, doc. A. Kunčinas, L. Gastila, L. Klimka, V. Liutikas skaite paskaitas, vyko pokalbiai, koncertavo „Šiupinys“. Renginys buvo gerai organizuotas, buvo aplankytas Eksperimentinis namy statybos kombinatas, Šampano ir vyno gamykla, Šaldytuvų gamykla ir kt.

Maloni žinia pasieke institutą gruodžio pabaigoje. Medžiagu atsparumo olimpiados sąjunginiame ture, ịvykusiame $1981 \mathrm{~m}$. gruodžio 16-19 d. Baku, trečiają vietą užème Lietuvos komanda, ị kurią ięjo trys mūsų instituto studentai: Algimantas Kondrusevičius (AT 9/2 gr.), Arvydas Ežerskis (AT 9/2 gr.), Gintautas Janulevičius (AK 9/1 gr.).

1981 metams baigiantis pasikeite kai kurių visuomeninių organizacijų vadovai. Partijos komiteto sekretoriumi tapo A. Kunčinas, profsajungos Vietos komiteto pirmininku buvo A. Gailius, komjaunimo komiteto sekretoriumi - R. Gudavičius, studentų profkomiteto pirmininku A. Žilionis ir studentų kultūros klubo pirmininku - G. Rakauskas.

Kitų metų pradžioje buvo suvesti $1981 \mathrm{~m}$. mokslo tiriamųjų darbų rezultatai. Mokslo reikalų prorektoriaus G. Marčiukaičio parengtoje ataskaitoje pažymèta, kad mokslo tiriamajji darbą dirbo 396 destytojai, 4073 studentai, 13 aspirantu, 67 mokslo tiriamojo sektoriaus inžinerijos ir technikos darbuotojai. Mokslininkai įvykde 194 temas, gavo 22 išradimų autorinius liudijimus. Geriausiu 1981 metų išradimu buvo pripažintas $\mathrm{Pa}$ grindų ir pamatų katedros doc. A. Alikonio „Grunto atsparumo kirpimui bandymo aparatas“. Mašinu teorijos katedros kolektyvas pirmavo tarp visų instituto katedrų. Šios katedros docentai A. Kavolèlis ir B. Spruogis buvo ryškūs VISI išradejju lyderiai, katedros aspirantas V. Turla buvo pripažintas 1981 metu geriausiu jaunuoju instituto išradeju.

Mechaninès technologijos fakulteto mokslininkai pasižymëjo ir TSRS liaudies ūkio pasiekimų parodoje. Už darbą „Dispečerinès kontroles ir keleivių informacijos automatizuota sistema Vilniaus autobusu stotyje" Automobiliu transporto katedros doc. V. Tilindis buvo apdovanotas TSRS liaudies ūkio pasiekimų parodos aukso medaliu.

Per $1981 \mathrm{~m}$. VISI mokslininkai parengè ir išleido 5 mokslines monografijas, 23 vadovelius, paskelbe 410 mokslinių straipsnių ir kt.
Instituto mokslininkai įvykdè ūkiskaitinių mokslinio tyrimo darbų už 1,83 milijono rublių. Tai buvo daug mažiau, nei įvykde KPI (10,1 mln. rub.) ir VU (4,3 mln. rub.). Bet vis delto pagal užsakomuosius mokslo tyrimo darbus VISI jau buvo trečiasis respublikoje.

Mokslinio darbo efektyvumui įvertinti buvo taikoma gana sudetinga vertinimo sistema, bet tik pinigine išraiška. Buvo reiškiamos nuomonès, kad toks formalus mokslinio darbo vertinimas jokiu būdu neperteikia tikrosios kai kurių darbų vertes. Abejonių kèlè ir parodyti tūkstančiai mokslinį darbą dirbančiu studentų. Žinoma, tarp jų buvo ir rimtų darbų, bet tokie skaičiai buvo „pritemti“, o tai buvo neretas dalykas „brandžiame socializme“.

$1982 \mathrm{~m}$. sausio $20 \mathrm{~d}$. įvykusiame VISI tarybos posedyje buvo svarstoma statybos inžinierių rengimo praktiniam darbui problema. Buvo pažymeta, kad jauni inžinieriai stokoja žinių ir ịgūdžių, reikalingu praktiniam darbui ir ypač darbui su žmonemis. Taryba numate daugelị priemonių, padessiančių pagerinti specialistų rengimą šiuo klausimu.

İdomu pažymèti, kad tame posedyje buvo keliamas klausimas dèl Statybos technologijos fakulteto įsteigimo, kuriame manyta rengti PCS specialybès inžinierius pagal sustiprintą technologinio-organizacinio rengimo programą. Bet šis sumanymas nei tuomet, nei vèliau nebuvo realizuotas.

1982 m. VISI taryba kiek padidejo. Ją sudare 59 žmones: Aleksandras Čyras, Bronius Sidauga, Gediminas Marčiukaitis, Zenonas Kamaitis, Antanas Alikonis, Viktoras Andriušinas, Kazimieras Antanavičius, Vilhelmas Bagdonas, Juozas Baršauskas, Aldona Blažienè, Vytautas Būda, Algirdas Čižas, Jurgis Dilba, Povilas Dilys, Algirdas Gaižutis, Marijonas Gedgaudas, Zigmantas Jankauskas, Alfonsas Janulis, Pranciškus Juškevičius, Antanas Juzenas, Antanas Kavolèlis, Stasys Kelminskas, Viktoras Krušinskas, Antanas Krutinis, Borisas Liaudis, Vanda Likiene, Vytautas Liutikas, Daumantas Maciulevičius, Albertas Marcelis, Juozas Mureika, Arkadijus Naidionovas, Algimantas Nakas, Henrikas Nakas, Algimantas Naujokaitis, Povilas Norkus, Juozapas Nemira, Juozas Raslanas, Kazimieras Rukšènas, Kazimieras Sakalauskas, Vytautas Sakalys, Algimantas Samulevičius, Konstantinas Sasnauskas, Algirdas Seilius, Antanas Spelskis, Bronius Spruogis, Edvardas Stankus, Kazimieras Šapalas, Vaclovas Šeštokas, Jonas Šimkus, Algimantas Šriupša,

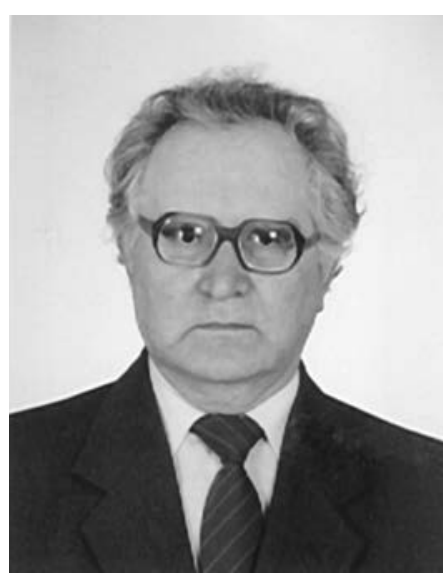

A. Alikonis

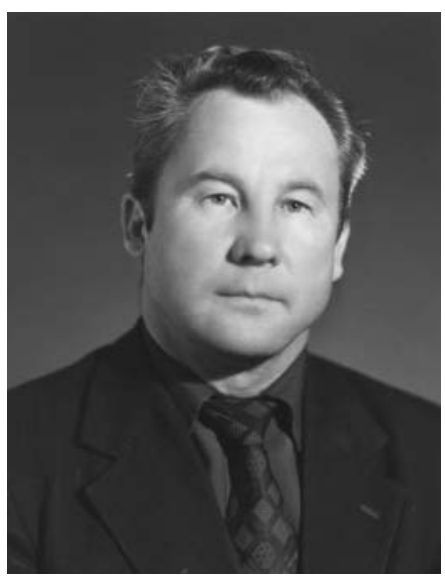

V. Tilindis 
VILNIAUS

INŽINERINIS STATYBOS

INSTITUTAS

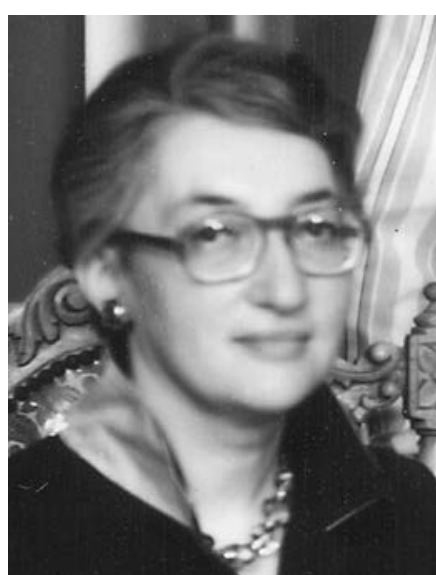

H. Kobeckaite
Česlovas Teišerskas, Vytautas Tulevičius, Antanas Urbelis, Zenonas Vainoris, Jurgis Vanagas. Be to, Tarybos nariais buvo partinio komiteto sekretorius Algirdas Kunčinas, profsąjungos Vietos komiteto pirmininkas Albinas Gailius ir komjaunimo komiteto sekretorius Rimantas Gudavičius.

Šios sudeties instituto taryba dirbo gana intensyviai. Posedžiuose vykdavo karštos diskusijos svarstomais klausimais, nevengta atskirų instituto darbų barų veiklos kritikos, radikalių pasiūlymų darbui gerinti. Tačiau priimti nutarimai gana dažnai likdavo tik popieriuje, kaip ir visos tos griozdiškos šalies mastu.

Institute imta vis daugiau kalbeti apie pedagoginį meistriškumą, buvo organizuojami įvairūs renginiai, imta skelbti daug publikacijų apie moksleivių adaptaciją aukštojoje mokykloje, didaktikos principu diegimą paskaitose, déstytojo asmenybès įtaką besiformuojančiai studento asmenybei ir kt.

Vasarị instituto laikraštyje buvo rašoma: „Beveik kiekvienoje katedroje yra kelios destytoju kategorijos. Yra déstytojai-švyturiai. Jie

\section{Ir inžinieriai gali būti humanitarais}

Pedagoginio meistriškumo klausimams šiandien, deja, skiriama labai mažai dèmesio. Tai neabejotinai neigiamai veikia rengiamu specialistų kokybę. Geras destytojas sugeba išdestyti dalyką moksliškai ir suprantamai, geba sužadinti studento savarankišką mąstymą, realiais pavyzdžiais parodo destomo dalyko ryšį su praktika, supažindina su naujovemis, paskaitose ir pratybose bei seminaruose moka rasti kontakta su studentais, įtraukia juos į polemiką vienu ar kitu klausimu. Studentai tokiam destytojui paprastai nereiškia pretenziju dęl jo didelio reiklumo per egzaminus ar įskaitas, nes gerai išdestytas kursas paprastai sukelia studentui reikmę gerai pasirengti ir atsiskaityti už ji.

Aukštojo mokslo istorija atskleidžia mums daug puikių desstytojų, kurių pedagoginè veikla paliko ryškių pavyzdžių. Galima pamineti kai kuriuos iš jų, rengusių inžinierius: Vytauto Didžiojo universitete - profesoriai Steponas Kairys, Kazimieras Vasiliaus- turiningai ir idomiai desto, nes yra ne tik geri savo destomo dalyko žinovai, bet ir gerai išmano pedagogikos, didaktikos ir dalyko destymo metodikos pagrindus, nuolat domisi ju naujovemis, taiko jas. Be to, jie aktyviai dirba mokslini darba ir pagal galimybes savo moksliniu tyrimu rezultatais papildo (bent informacija apie tuos rezultatus) paskaitas. Yra destytoju, geru savo dalyko žinovu, labai daug demesio skiriančiu pedagogines veiklos meistriškumui, nors moksliniame darbe jie ir pasyvūs. Tokia kategorija iš dalies vis delto priimtina: aukstoji mokykla siaip ar taip pirmiausia mokymo istaiga, o ne mokslo tiriamasis institutas. Trečiai kategirijai priskirtini destytojai, kurie yra geri savo dalyko žinovai, labai aktyvūs mokslo tiriamajame darbe, bet mažai rūpinasi savo pedagoginiais sugebejimais. Toks destytojas visada turetu prisiminti paprasčiausia tiesa: kiekvienos informacijos efektyvumas priklauso ne tik nuo informacijos turinio, bet ir nuo jos perteikimo formos. Pastarosios kategorijos destytoju pedagoginio meistriskumo pakelimas, sudarant galimybes plačian ir giliau susipažinti su didaktikos ir dalyko destymo metodikos pagrindais, idiegiant ipratima nuolat dometis metodikos naujovemis, yra didžiulis rezervas mokymo lygini aukštosiose mokyklose kelti, mokymo įtaigumui suefektyvinti" [4.44, p. 2].

kas; Kauno politechnikos institute - Jonas Matulionis, Vytautas Klimavičius, Izidorius Liesis, Kostas Dirgela; KPI Vilniaus filiale ir VISI - Aleksandras Čyras, Judelis Charitas, Antanas Kudzys, Kazimieras Antanavičius, Vaclovas Šeštokas, Vytautas Liutikas ir kt.

Aukštosiose technikos mokyklose visuomet jaučiamas humanitarinių dalykų alkis. Gal todèl ir Vilniaus inžineriniame statybos institute studentai ir destytojai mielai dalyvaudavo įvairiuose ugdančius tauresnę asmenybę renginiuose, grodavo, dainuodavo ar šokdavo meno saviveiklos kolektyvuose. Buvo institute ir tarnaujančių literatūros mūzai. Apie tai rašè "Inžinerijoje“ doc. Vytautas Būda.

Rusų ir lietuvių kalbų katedros destytojas Vytautas Blinkevičius jau nuo $1947 \mathrm{~m}$. rašè eileraščius. Jo žodžiais dainų parašè kompozitoriai K. Belozaras, K. Kaveckas, J. Karosas, A. Raudonikis, V. Barkauskas ir kt. V. Blinkevičiaus eiles buvo spausdintos 
„Literatūroje ir mene“, „Genyje“. Jis yra išvertęs Puškino, Ševčenkos, Rilkès eilių, Antokolskio pjesę „Apie tuos, kurie myli“.

V. Blinkevičiaus profesija - rusų kalbos desstytojas, o VISI Braižybos katedros vyr. destytojas Linas Broga - 1951 metu KPI absolventas, kelių inžinierius. L. Broga jau mokykloje raše eileraščius, o studijų metais ème versti ị lietuvių kalbą Jurgị Baltrušaitị. L. Broga, nepaisant didelio pedagoginio krūvio, išverte ir 1973 m. išleido du J. Baltrušaičio eilèraščių rinkinius - „Žemès laiptai“ ir „Kalnų takas“. Ypač L. Brogą išgarsino Rytu poezijos vertimai: jis išverte Omaro Chajamo „Rubajatus“, Hafizo „Gazeles" ir kt.

Vertimais iš prancūzų kalbos garsëjo Užsienio kalbų katedros vyr. déstytojas Algimantas Gudaitis. Jis išverte septynis prancūzų literatūros kūrinius - E. Triolès romaną „Lunaparkas“, Ch. Semprūno „Didžiosios keliones" ir kt. A. Gudaitis išvertè iš italų kalbos Džovanjolio romaną apie Romos vergu sukilimo vadą Spartaką ir kt.

Filosofijos katedros docente Halina Kobeckaite garsëjo Rytų tautų literatūros vertimais. Ji išverte azerbaidžianiečių rašytojo M. Huseino romaną „Nesantaika“, kazachų rašytojo A. Nurpeisovo trilogiją „Kraujas ir prakaitas“, uzbekų rašytojų A. Muchtaro romaną „Laikas ir likimai“, G. Guliamo „Padaužos“, O. Jokubovo romaną „Sąžine““ ir kt.

Užsienio kalbų katedros anglų kalbos destytoja Leticija Rakauskienè raše satyrines miniatiūras. Jas skelbe „Jaunimo gretos“, „Inžinerija“. Dideli nuopelnai jai priklauso ir dèl VISI miniatiūrų teatro „Šiupinys“ sèkmès. Tai ji paraše „Šiupinys 80 “ ir „Šiupinys 81 “ programas, kuriu „Aktualus turinys ir šmaikš tus žodis šiam kolektyvui pelné visos respublikos pripažinima. O tai didelis ir Leticijos Rakauskienes nuopelnas, nes ji - šiu koncertu koautore" " $[4.45$, p. 2].

Užsienio kalbų katedros dèstytoja (dabar katedros vedejja) Laima Kitkauskienè skelbè straipsnius lietuvių kalbos mokslo, ypač vaikų pedagogikos klausimais, yra laimëjusi moterų žurnalo literatūrinę premiją.

V. Būda pažymèjo, kad institute yra ir daugiau technikos mokslų specialistų, turinčiu polinkị i literatūrą, bet kurie drovisi pateikti savo kūrybą plačiajai visuomenei. Vienas tokių - Miestų statybos fakulteto docentas Antanas Ražinskas, rašantis eiles, bet pasitenkinantis tik instituto auditorija.
Na, o minètasis „Šiupinys“ 1982 m. kovą džiaugèsi ju nuoširdaus darbo įvertinimu. Jam buvo suteiktas liaudies teatro vardas. Tai buvo visu šiupiniečių, ir ypač meno vadovo Rimgaudo Karvelio bei kolektyvo entuziastingosios kuratorès - Vidos Kazlauskienès (Montvilienès) didelis laimejimas.

Balandi Vilniuje vyko tradicinis festivalis „Opusas“. Šiame tarptautiniame festivalyje vèl dalyvavo „Hiperbole““. Ši kartą ji pasirode silpniau. Muzikologas L. Šaltenis rašè: "Hiperbolei" "Opuse "siais metais nepasiseke ta prasme, kad ansamblis visai neseniai koncertavo Sporto rümuose, ir daugeliui jo programa jau buvo girdeta. O juk visada traukia tai, kas nauja, negirdeta. Ansamblis issiskiria rimtu darbu, apgalvotomis kompozicijomis, geru instrumentu valdymu. Silpnoji "Hiperboles" vieta - vokalas. Daugiau demesio reiketu skirti ir konferansje tekstui " [4.46, p. 1].

1982 m. TSRS gynybos ministras išleido ìsakymą dèl karinès prievolès. Nuo 1983 metų pirmą kursą baigę studentai, buvę tinkami karinei tarnybai, turejo būti pašaukti ị sovietinę armiją dviem arba trims metams. Atlikę tarnybą galëjo grižti studijuoti toliau. Tai gerokai sujaudino jaunimą, būsima studiju proceso sumaištis kèlè naujų būsimų rūpesčiu profesūrai.

Visi suprato, kad studijų pertraukimas tokiam ilgam laikotarpiui padarys įtaką specialistų rengimo kokybei, nes nemažai bus primiršta, ne visi, pradeję studijas ir atitarnavę armijoje, sugrị̌s ị institutą. $\mathrm{O}$ ir sugrị̌s studijuoti ne vienu metu - vieni anksčiau, kiti - vèliau. Teks rengti papildomus užsiemimus, kai ką teks pakartoti. Gali likti neatsiskaičiusiųjų už pirmąjį kursą. Ką gi teks su jais daryti? Žodžiu, lauke rimtas studiju proceso išbandymas, nieko gero nežadantis nei studentams, nei dèstytojams. Bet Afganistano karas buvo lyg nepasotinamas drakonas, reikalaujantis vis daugiau ir daugiau auku. Sovietinei armijai ème trūkti ir kareivių, ir karininkų.

1982 m. vasarą VISI baige ir inžinieriaus diplomus gavo 1024 jaunuoliai ir merginos. Ir tolesnius kelerius metus išleidžiamųjų skaičiai praktiškai nekito. Sąstingis pasieke savo piką.

Architektūros specialybę baigè 75, PCS 332, miestu statybos - 37, autokeliu - 39, taikomosios geodezijos - 39, statybos ekonomikos - 119, autotransporto eksploatavimo - 24, automobilių transporto - 141 , statybos kelių mašinų - 24, suvirinimo įrengimų -40 , mašinų gamybos technologijos -

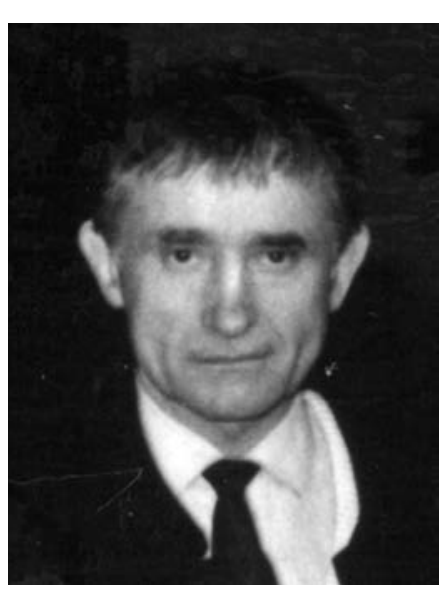

V. Blinkevičius

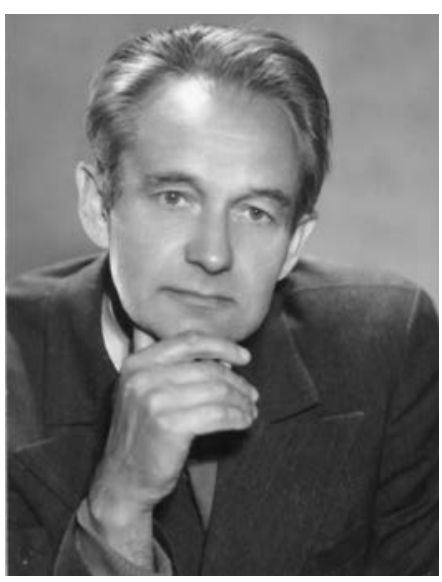

L. Broga 
VILNIAUS

INŽINERINIS STATYBOS

INSTITUTAS

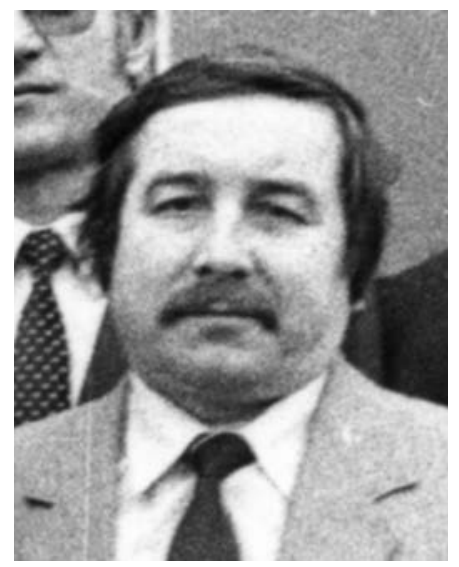

J. Rudalevičius
66 , elektros pavarų - 28, radijo aparatūros technologijos - 60 žmonių.

Nuo 1982-1983 mokslo metų priimti studijuoti buvo planuota: į dienini skyrių 850 , į vakarinị -325 ir ị neakivaizdinị -175 , iš viso 1350 studentų. Tiek ir priimta.

Tą vasarą, kaip ir ankstesniais metais, gerai pasirodè VISI statybiniai būriai. Kartu su Kauno medicinos institutu respublikoje jie buvo antri. Kaip minejome, statybiniai būriai iškeldavo gabius darbų organizatorius, kurie ilgainiui padarydavo puikią profesinę karjerą. $1982 \mathrm{~m}$. vasarą labai gerai dirbo Lietuvos studentų statybinis būrys Jakutijoje, kuriam vadovavo VISI Statybos valdymo ir organizavimo katedros asistentas Jonas Rudalevičius. Vèliau jis tapo mokslų kandidatu, docentu, o dabar - Jo Ekscelencija Jonas Rudalevičius - Lietuvos Respublikos nepaprastasis ir igaliotasis ambasadorius Austrijos Respublikoje, Slovenijos Respublikoje, Slovakijos Respublikoje ir Kroatijos Respublikoje.

\section{Gelžbetonininku laimëjimai}

1982-1983 mokslo metus Vilniaus inžinerinis statybos institutas pradejo turedamas 6 fakultetus, kuriuose buvo 39 katedros.

Architektūros fakultete buvo Architektūros, Dailès, Gyvenviečių planavimo ir tvarkymo bei Pastatų konstrukcijų katedros. Automatizacijos fakultetas turëjo 3 katedras: Elektrotechnikos, Elektros pavarų ir Radijo aparatūros technologijos.

Mechanines technologijos fakultete buvo Automobilių transporto, Braižybos, Mašinu gamybos technologijos, Mašinu teorijos, Metalų technologijos, Pramones ekonomikos bei Taikomosios matematikos ir mechanikos katedros.

Miestu statybos fakultete buvo Fizikos, Geodezijos, Hidraulikos, Kelių ir Miestų statybos katedros.

Statybos ekonomikos fakultete buvo Chemijos, Statybinių medžiagų, Statybos ekonomikos bei Statybos valdymo ir organizavimo katedros.

Statybos fakultete veike Gelžbetoniniu konstrukcijų, Matematikos, Medžiagu atsparumo, Metalinių konstrukcijų, Pagrindu ir pamatu, Statybos darbų technologijos ir Statybinès mechanikos katedros.

Bendrosios katedros buvo 9: Estetikos, Filosofijos, Fizinio lavinimo, Karinio parengimo, Mokslinio komunizmo, Politines ekonomijos, Rusų ir lietuviu kalbų, TSKP istorijos bei Užsienio kalbų.

Spalị visose Lietuvos aukštosiose ir specialiosiose vidurinèse mokyklose baigiamųju kursų studentams ir moksleiviams buvo įvestas naujas kursas - „Socialistines visuomenès internacionalizacijos procesai“. Per metus tam buvo skirta po 24 valandas užsiemimų, paskui reikejjo laikyti diferencijuotą ịskaitą. Sis kursas turejo tikslą intensyviau rusinti jaunimą, nes Kremlius jaute, kad respublikose vis daugiau stiprëja tautiškumo dvasia. İsakymą Nr. 476 dèl šio kurso įvedimo LTSR aukštojo ir specialiojo vidurinio mokslo ministerija išleido $1982 \mathrm{~m}$. spalio $10 \mathrm{~d}$., o lygiai po mènesio baigèsi brežnevinè era. Leonidas Brežnevas mire $1982 \mathrm{~m}$. lapkričio $10 \mathrm{~d}$. Valdžios pranešimas skelbè „Leonido Brežnevo didžiojo Lenino žygio tęsejo, karšto kovotojo už taika ir komunizma - vardas visada bus gyvas tarybiniu žmoniu ir visos pažangiosios žmonijos širdyse " $[4.47$, p. 1]. Visa tai skambëjo, švelniai sakant, tragikomiškai.

Metų pabaigoje institute buvo įkurta Pedagogų draugija. Jos tarybos pirmininku išrinktas pedagogikos mokslų daktaras Vytautas Šernas. Draugija, vadovaujama V. Šerno, nuveikè daug gražių darbų.

1982 m. pabaiga vèl buvo reikšminga VISI mokslininkams. Vadovelio „Gelžbetonines konstrukcijos" autoriai - profesorius Antanas Kudzys, docentai Vidmantas Jokūbaitis, Jokūbas Kivilša ir Romualdas Vadlūga tapo valstybinès premijos laureatais. A. Kudzys pasakojo „Inžinerijos“ korespondentui, kad vadoveli rengè apie dešimt metų. Vadovelyje aptariami klausimai apie gelžbetonio teorijos ir praktikos raidą, pateikta medžiaga apie naujausius mokslo ir technikos laimejimus projektuojant ir taikant gelžbetonines konstrukcijas $[4.48,1.1]$.

Maloni žinia visam VISI kolektyvui buvo tai, kad VISI absolventą Vladą Turlą išrinko geriausiu 1982 metu Lietuvos sportininku.

Po Brežnevo mirties TSKP CK generaliniu sekretoriumi tapo buvęs KGB šefas, 1956 metų vengrų sukilimo numalšinimo vienas pagrindinių veikeju Jurijus Andropovas. Buvo labai sugriežtintas Darbo ìstatymas. Iš pareigu žmogus galëjo būti 
atleidžiamas, jei nebuvo darbe daugiau kaip tris valandas, darbe pasirodè neblaivus, padidintos baudos už padarytą žalą ir t. t. Buvo rengiama organizaciniu, ekonominiu ir moralinių priemonių sistema, kuri turëjo padidinti vadovų, mokslininkų, darbininkų suinteresuotumą technikos atnaujinimu ir kt. Siekiant sustiprinti darbo drausmę, imta ieškoti darbuotoju kino teatruose, kavinese. Visa tai nieko negalejo pakeisti. Pati santvarka buvo tokia, kuri neskatino, nesuinteresavo gerai dirbti, todèl kosmetines reformos nieko nedave ir negalejo duoti. Gal tik tai, kad stiprinant kontrolę buvo jaučiamas NKVD ar KGB ,šinelių“ ar rūsių tvaikas, kurio ne vienas vyresnès kartos žmogus nespejjo pamiršti.

Taupymo, gerinimo, tvarkos ir drausmès stiprinimo kontekste emé dirbti ir Vilniaus inžinerinis statybos institutas.

Kovo ménesị rektoriaus įsakymu buvo sudaryta instituto skaičiavimo technikos išteklių naudojimo ir plètotés komisija, pirmininkaujama prof. D. Maciulevičiaus ir narių: skaičiavimo centro viršininko $\mathrm{V}$. Ol- šausko, skaičiavimo centro sektoriaus vadovo A. Boguševičiaus, Taikomosios matematikos ir mechanikos katedros docento A. Gulbino, Taikomosios matematikos ir mechanikos katedros vyr. dèstytojo G. Kulviečio, AIS komisijos pirmininko doc. J. Skrebes ir ESM naudojimo mokymo procese sekcijos pirmininko prof. A. Baublio.

Komisija svarste sisteminius ir probleminius programines įrangos kūrimo ir įdiegimo planus, numate $\mathrm{SC}$ organizacines priemones, padesiančias racionaliai naudoti skaičiavimo techniką. Komisijos darbu nuolat domëjosi rektorius A. Čyras, skyręs nuolatinị demesị skaičiavimo technikos modernizavimui.

Stiprinti studentų drausmę ir atsakomybę èmèsi komjaunimas. Čia pasižymëjo instituto „Komjaunimo prožektorius“, kurio štabo vadas buvo Juozas Grabys, ilgainiui tapęs VISI prorektoriumi. Buvo rengiami reidai ị bendrabučius, lankomos paskaitos, norint išsiaiškinti, kaip laikomasi studijų drausmès.

Suprantama, studentus daugiau domino tradicinès akademinès veiklos formos.

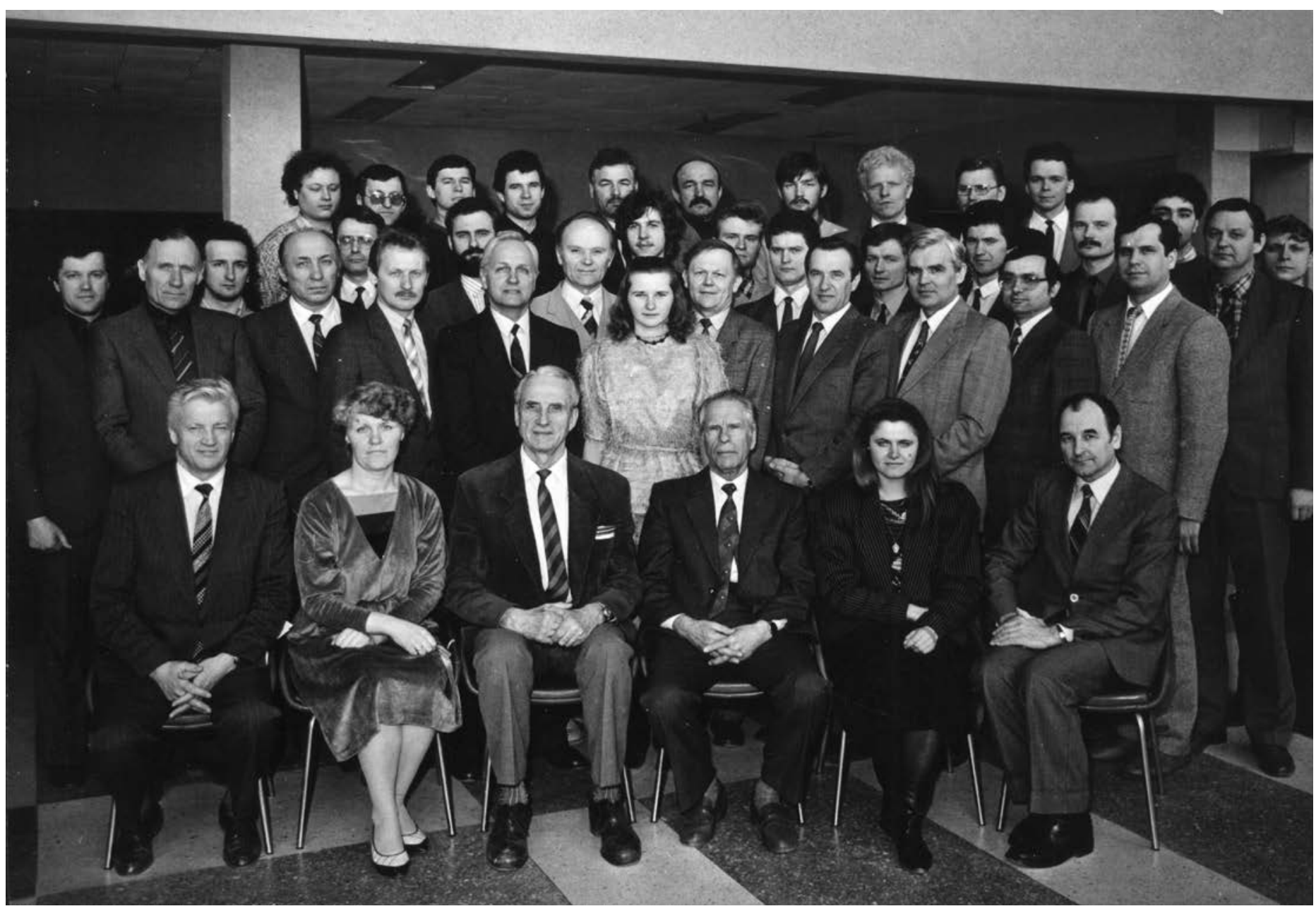

Gelžbetoniniu konstrukciju katedros darbuotojai su1982 metu valstybines premijos laureatais

Iš kairés pirmoje eileje: A. Kudzys (3), J. Kivilšsa (4); antroje eileje: R. Vadlüga (4), V. Jokübaitis (6) 
VILNIAUS

INŽINERINIS STATYBOS

INSTITUTAS statybos - 49, autokeliu - 41, taikomosios geodezijos -45 , statybos ekonomikos - 119, automobilių transporto eksploatavimo - 32, automobiliu transporto - 137, statybos kelių mašinu -13 , suvirinimo įrengimu -54 , mašinu gamybos technologijos - 64, elektros pavaru -42 ir radijo aparatūros technologijos -43 .

Lietuvos ir kartu VISI meno kolektyvai, ypač estradinio žanro, vis dažniau atlikdavo Vakarų kūrejų muziką, mègdžiojo vakarietišką stilių. Tai nedavè ramybès valdantiems „organams“. I t tai atkreipe demesị LTSR aukštojo ir specialiojo vidurinio mokslo ministerija. Buvo parengti aukštųjų mokyklų meno tarybu nuostatai, kuriuose buvo pasakyta, kad Meno tarybu tikslas - padèti spręsti studentų komunistinio auklëjimo uždavinius meno priemonemis, turtinti ju estetinius poreikius. Bet, apibrěžiant Meno tarybų funkcijas, tampa aišku, kad jos turi tapti griežtos ideologinès kontrolès instancijomis. Jos privalëjo: 1. Kasmet peržiūreti ir tvirtinti meno kolektyvų repertuarą. 2. Organizuoti koncertų programų, spektaklių, parodų peržiūras-perklausas ir išduoti leidimus (!) koncertuoti. 3. Aprobuoti kultmasiniu renginių scenarijų, poilsio renginių muzikos repertuarą. 4. Kontroliuoti diskoteku veiklą ir tikrinti jų programas ir t. t., ir t. t.

Nežinome, kas turëjo stoveti už ministro $\mathrm{H}$. Zabulio nugaros, kai jis buvo verčiamas pasirašyti tą įsakymą, bet neįmanoma patiketti, kad tai buvo Lietuvos ministerijos kūrinys. Greičiausiai tai buvo sąjunginès valdžios dokumento kopija.

Vadovaudamasis aukštesnès valdžios nurodymu, rektorius A. Čyras sudare naujos sudeties Meno tarybą: pirmininkas doc. A. Ražinskas, pavaduotojas - doc. A. Gaižutis, nariai: prof. A. Čižas, doc. I. Aleksaite, doc. H. Kobeckaite, doc. V. Adomavičius, doc. J. Žekevičius, doc. B. Gruzdys, doc. H. Bogdanas, vyr. dest. J. Jonušas, vyr. dest. F. Viskantas, vyr. dest. R. Tamutis, dèst. G. Žalenas, komjaunimo komiteto atstovas ir Kultūros klubo pirmininkè.

Visi šios tarybos nariai po keliu metu džiaugsmingai pasitiko permainas mūsų šalyje, įsitrauke i laisvos ir nepriklausomos Lietuvos kūrimą. Žinoma, burokevičininkų manymu, jie, prasti ideologiniai sargai, nieko tais klausimais ir nenuveikè.

Vis dellto, institutas nusprende parodyti, kad vykdo „partijos liniją“. Birželio 28 d. rektorius A. Čyras išleido įsakymą Nr. 196 
VILNIAUS

INŽINERINIS STATYBOS

INSTITUTAS

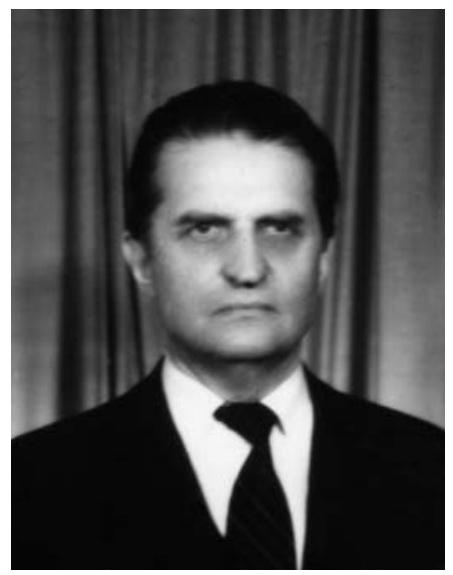

V. Šernas
Organizatoriu „spiritus movens" buvo studentas Narkevičius. Jis su savo draugais tikrai parode, ka gali. Po gegužines ir diplominiu darbu gynimo ir Narkevičius, ir kelios dešimtys kitu diplomantu išvyko (pagal privaloma paskyrima) tarnauti karininkais i Soviety Armija. Po keleriu metu, atitarnavęs ten, jis buvo užsukęs i tapusia tradicine Statybos fakulteto diplomantu gegužinę. Jis, berods, buvo tapęs Plungès statybos technikumo destytoju.

Diplomantu gegužines dar keleta metu vyko, bet ju mastas silpnejo, nes, pasikeitus emimo i armija taisyklems, fakultete beveik nebeliko vyru diplomantu. Gaila, kad ši tradicija nebuvo atgaivinta, kai studentiskas gyvenimas vel tapo pilnakraujis" [4.50, p. 1-3].

Turiningas buvo $1983 \mathrm{~m}$. pavasaris didiesiems VISI meno kolektyvams. „Gabija“ tapo diplomantu ir prizininku tarprespublikiniame konkurse „Juventus - 83“, vasarą koncertavo Bulgarijoje. Dūdų orkestras „Inžinerija" net 26 kartus koncertavo Lietuvos miestuose. „Šiupinys“ daug koncertavo Lietuvoje, dalyvavo studentišku teatrų festivalije Tartu mieste. Liaudies šokiu ansamblis švente veiklos 20-metį, respublikos apžiūroje buvo antras, gastroliavo Vengrijoje.

Vasarą studijuoti ị Vilniaus inžinerinio statybos instituto dieninį skyrių buvo priimta 850 , vakarinị -325 , neakivaizdini -175 , iš viso 1350 jaunuolių ir merginų.

$1983 \mathrm{~m}$. vasarą SSB buvo 860 VISI studentų - iš viso 29 būriai. Atliko darbų už $2,5 \mathrm{mln}$. rublių.

İ iškilmingą 1983-1984 mokslo metu atidarymą atvyko ne aukščiausieji valdžios atstovai. Be linkëjimu pirmakursiams sèkmès studijose, pabrežta, kad rezultatus lems atkaklus, nuoseklus darbas.

Kadangi naujasis TSKP gensekas birželi pasake kalbą, buvo nurodyta, kad ji turi būti ittraukta į TSKP istorijos, filosofijos, politinès ekonomijos, mokslinio komunizmo ir kitų disciplinu privalomos literatūros sąrašus. Deja, visi buvo priversti būti pakantūs kvailybei. Niekas tam nurodymui neprieštaravo.

Rugsëjo $30 \mathrm{~d}$. įvyko pedagogu draugijos ataskaitinis rinkiminis susirinkimas, kuriame pirmininku vel išrinko e. prof. p. V. Šerną. Visi kalbetojai - prof. V. Šeštokas, doc. R. Ginevičius, doc. A. Jonaitis ir kiti - gerai ivvertino pedagogu draugijos tarybos veiklą.
Gruodžio menesį gerą žinią iš Maskvos gavo VISI mokymo ir auklejimo reikaly prorektorius B. Sidauga. Jam buvo suteiktas profesoriaus mokslinis vardas.

1983 metai sèkmingi buvo Užsienio kalbų katedros docentui Juozui Stoniui, sèkmingai apgynusiam filosofijos daktaro disertaciją „Psichologizmo raida lietuvių prozoje (XIX a. pabaiga - XX a. pradžia)“. Oficialūs oponentai - V. Zaborskaite ir V. Kubilius bei rygietis $\mathrm{B}$. Tabuns - pažymëjo disertacijos novatoriškumą, disertanto analitinius gebëjimus.

Moksliniame darbe gražiai pasirodè ir studentai.

Sąjunginëje aukštujjų technikos mokyklų studentų olimpiadoje Lietuvos rinktinę sudare KPI ir VISI studentai. Jie ir laimèjo pirmąją vietą.

Sajunginiame gamtos, technikos ir humanitarinių mokslų konkurse VISI Architektūros fakulteto studentai E. Sermontis, K. Gaule, J. Tamulyte, R. Lapinskaite ir I. Naginevičiūte už mokslinị darbą „XIX a. pabaigos ir XX a. pirmosios pusès liaudies architektūros progresyvinių tradiciju vystymas Vilniaus Antakalnio, Žveryno rajonų ir Kauno Naujamiesčio mažaaukšteje gyvenamųjų namų ir kai kurių visuomeninių bei buitinių pastatų architektūroje" (mokslinis vadovas prof. J. Baršauskas) buvo apdovanoti medaliu.

\section{Sportininku šventè}

Prieš Naujuosius metus buvo didele švente VISI sportininkams. Pastatyta ir atiduota eksploatuoti $60 \times 20 \mathrm{~m}$ ploto sporto sale, o prie jos - dviejų aukštu priestatas, kuriame įsikūre Fizinio lavinimo katedra, sporto klubas, buitines patalpos ir kt. Sporto klubo valdyba paskelbè 1983 metų geriausių VISI sportininkų dešimtuką:

1. Rima Liutkaityte, MS 2/1 - sporto meistré, VIII TSRS vasaros tautų spartakiados akademinio irklavimo bronzos medalininke. 2. Loreta Virbickaite, MS 0/1 - sporto meistre, Vilniaus „Kibirkšties“žaidëja. 3. Henrikas Gulbinovičius, AT 1/4 - kandidatas i sporto meistrus, lengvoji atletika, respublikos ir aukštụjų mokyklų čempionas. 4. Valdas Berūkštis, AT 0/1 - sporto meistras, sunkioji atletika, respublikos ir aukštujų mokyklų čempionas. 5. Juozas Sabaliauskas, PCS 2/11 - kandidatas ị sporto meistrus, akademinis irklavimas, 


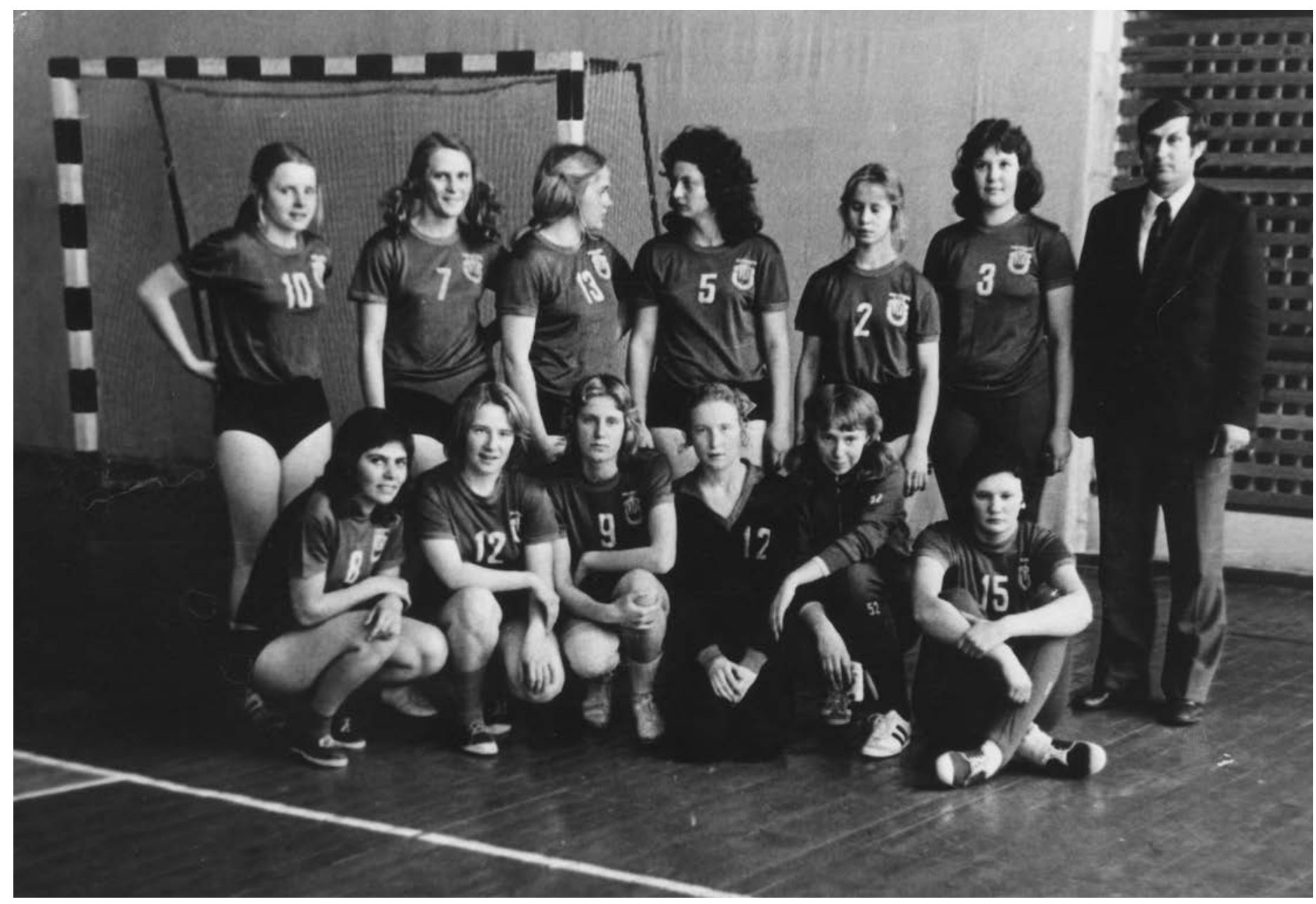

VISI merginu rankinio rinktine

aukštųjų mokyklų čempionas. 6. Rimvydas Mugevičius, SE 2/2 - kandidatas ị sporto meistrus, lauko tenisas, LTSR rinktines narys, aukštųjų mokyklų absoliutus čempionas. 7. Vladimiras Surpinas, AT 2/4 - kandidatas i sporto meistrus, gimnastika, LTSR čempionas. 8. Jolanta Šostakaite, SE 0/3-kandidate i sporto meistrus, rankinis, TSRS jaunimo čempionè, „Eglès“ žaidejja. 9. Violetas Makarevič, PCS 1/14 - kandidate į sporto meistrus, kulkinis šaudymas (pistoletas), aukštujju mokyklų čempionè. 10. Galina Kondratenko, PCS 9/12 - sporto miestré, LTSR baidariu ir kanoju rinktinès narè.

VISI futbolo komanda $1983 \mathrm{~m}$. vèl iškovojo antrąją vietą Vilniaus miesto pirmenybese.

1984 metus visuomenè sutiko su didèjančiu nerimu. Jau penkti metai vyko karas Afganistane ir buvo aišku, kad sovietine armija to karo niekada nelaimes. Kai 1979 m. Didžiojoje Britanijoje rinkimus laimejo konservatoriai su Margaret Tečer, o $1981 \mathrm{~m}$. JAV prezidentu tapo Rolandas Reiganas, Vakarų pasaulis aiškiai dave suprasti, kad sovietinei ekspansijai jie nenuolaidžiaus.
Tvirta Vakarų pozicija stiprino išsilaisvinimo idejas Rytų Europos valstybese, žadino tokias pat viltis ir nerusiškųjų respublikų gyventojams.

Pradžią davè lenkai, kai dèl kilusių 1981 m. masinių neramumų buvo nuversta E. Gereko valdžia, bet generolas V. Jaruzelskis įvede karinę padètí. Ėmè braškèti visi komunistiniai režimai. Vis daugiau garsejo disidentine veikla.

R. Reiganas labai padidino išlaidas ginklavimuisi, teigdamas, kad padarys Ameriką stiprią. Šitai vertè sovietų valdžią atsakyti tuo pačiu. Suprantama, tai galutinai pakirto sovietinę ekonomiką. Jau ir iki to meto nepasižymejjusios maisto ir pramonés prekiu gausa parduotuvès visiškai nuskurdo. Prie ju didèjo eilès, augo žmonių nepasitenkinimas. Tik kremliaus vadeivos apsimete, kad nieko nemato, vis demagogiškai tvirtino apie laikinus sunkumus, kapitalistinio pasaulio klastą, šviesią komunizmo ateitị. O prastai valdomas vežimas jau vis greičiau riedejo nuo kalno...

Afganistano karo siaubą tiesiogiai pajautè ir VISI studijuojantis jaunimas. Praejusią vasarą instituto pirmakursiai buvo pašaukti ị 
VILNIAUS

INŽINERINIS STATYBOS

INSTITUTAS narius surinkti ne taip paprasta " [4.52, p. 1]. Komjaunimo, kaip ir komunistų partijos, marazmas buvo akivaizdus.

Buvo išrinktas naujas VISI komjaunimo

sovietinę armiją. Buvo surengtos iškilmingos palydos, kuriose linkèta daug laimès, reikšta, kad pirmokèliai garbingai atstovaus „savo kraštui, mūsu institutui “ $[4.51$, p. 1].

Sovietinëje armijoje lietuvaičiai niekam neatstovavo - nei savam kraštui, nei savajam institutui. Prievarta priversti tarnauti jaunuoliai į tą armiją žiūrèjo kaip ì rekrūtus. Jaunimas jau nevenge viešai rodyti apatijos režimui, pasitaikydavo ir atvirai priešiškų valdžiai veiksmų. Visa tai atsispindejo VISI komjaunimo organizacijos ataskaitineje konferencijoje, vykusioje prieš pat Naujuosius - 1984 metus.

Komjaunimo aktyvistai skundesi, kad Vilniaus inžineriniame statybos institute yra tokių akademinių grupių organizacijų, kuriose nè vienas komjaunuolis (ir sekretorius!) neužsiprenumeravo jokio laikraščio, nors TSKP CK birželio ménesio plenume J. Andropovas akcentavo svarbą teisingai naudoti gausų švietimo ir auklejimo priemonių arsenalą komunizmo reikalui.

Konferencijoje konstatuota, kad per „25\% akademiniu grupiu komjaunimo organizaciju sekretoriu neatitinka užimamu pareigu, taiyra neturi tvirtu moraliniu isitikinimu, autoriteto, nera darusmingi ir pan.

Metai iš mety vis sudetingiau organizuoti aktyvo mokyma, jaunojo lektoriaus mokyklos užsiemimus, masinius instituto renginius. Priežastis paprasta - studentai juos blogai lanko. Net pirminiu komjaunimo organizaciju sekretorius, fakultety komjaunimo komitety ir biury

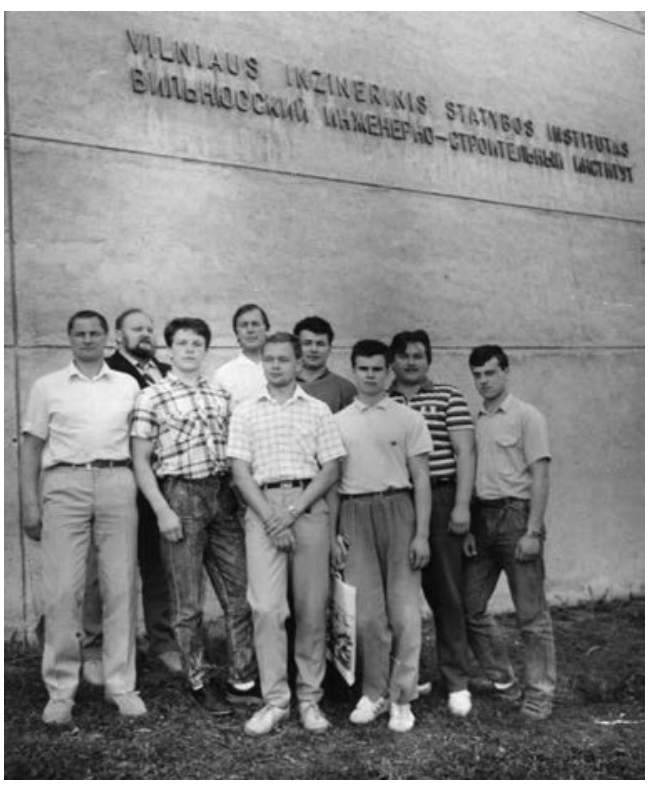

komitetas. Tenka pažymèti, kad tuometiniams VISI komjaunimo lyderiams R. Gudavičiui, R. Busilai ir dar ankstesniems, nebuvo būdingas komjaunuoliškas aršumas, kuo, tarkim, pasižymejo kai kurie KPI ar VU komjaunimo vadukai Stalino ir net Chruščiovo laikais. VISI komjaunimo sekretoriai buvo inteligentiški, mąstantys, jų veiklai buvo būdinga daugiau kultūrinè nei politinè veikla.

\section{Vèl permainos}

1984 m. vasario 9 d. mire gensekas J. Andropovas, neišbuvęs soste nè dvejų metų. Po kelių dienų įvykusio TSKP CK plenumo informaciniame pranešime buvo rašoma, kad J. Andropovas dideliu indèliu prisidejo prie visapusiško socialistinès sandraugos šalių bendradarbiavimo pletojimo, tarptautinio komunistinio darbininkų judëjimo vienybès ir susitelkimo stiprinimo, teisingos kovos už laisvę ir nepriklausomybę rèmimo.

Šis laisvès ir nepriklausomybès ,teisingas kovotojas“ nuo 1940 m. iki 1951 m. vadovavo Karelijos gyventojų genocidui, rusinimui. 1956 m., būdamas TSRS pasiuntiniu Vengrijoje, tiesiogiai vadovavo Vengrijos sukilimo prieš komunistinį režimą numalšinimui ir susidorojimui su vengrų kovotojais. Nuo 1967 m. J. Andropovas buvo KGB šefas ir $1968 \mathrm{~m}$. buvo viena svarbiausių sovietinès valdžios figūrų likviduojant Čekoslovakijoje kilusi „Prahos pavasarį“.

Vietoj J. Andropovo genseku išrinktas Konstantinas Černenka, prieš porą metų prilaikydavęs einantị Brežnevą, bet kai jis tapo TSRS vadovu, netrukus buvo prilaikomas jau jis. Per visą TSRS istoriją turbūt nebuvo kito vargingesnio intelektiniu, o galop ir fiziniu požiūriu komunistų partijos vadovo. Žmonès viešai šaipesi iš valdžios, o partokratai, nors ir suvokè, kad politinis režimas jau patiria agoniją, vis dar sieke pagerinti padèti stiprindami propagandą. Tai tik kèle dar didesnę pašaipą, buvo kuriami nauji anekdotai.

Vilniaus inžineriniame statybos institute „siekiant pagerinti studenty komunistini auklejimq“, iškart po J. Andropovo mirties, buvo sudaryta studentų komunistinio auklejjimo taryba. Jai buvo keliamas uždavinys „užtikrinti metodini vadovavima studentu 
komunistiniam auklejimui grupese, teikti parama fakultetu partinems organizacijoms, kuratoriams, palaikyti glaudesnius ryšius su komjaunimo organizacija ir kitomis studentu visuomeninemis organizacijomis " [4.53, p. 1].

O studentai nebuvo kažkokie parapitekai. Visas tas komunistinis auklejimas tebuvo apsimetinëjimas. Šalyje jau aiškëjo ekonominès ir moralines katastrofos šmèkla ir kalbos apie „šviesią“" ateitį nieko negalejo pakeisti.

Nors draugas Konstantinas Černenka užtikrino, kad visas savo jègas, žinias ir gyvenimo patyrimą skirs tam, kad būtų sèkmingai įvykdyti komunizmo kūrimo šalyje uždaviniai, žmonès mate, kad ir Černenka, ir TSRS visiškai išsekę ir visos kalbos apie tai, kad bus toliau stiprinama ekonomine ir gynybine TSRS galia, keliama tarybinès liaudies gerove - tèra blefas. Komunizmas neišlaike politinių, ekonominių ir technologiniu lenktynių su Vakarais. Brendo neišvengiamos permainos.

Blefo nevengdavo ir VISI padaliniai, nes tokia jau buvo primesta tvarka. Pirmiausia tai pažymètina kalbant apie socialistinị lenktyniavimą, mokslo darbų įdiegimą. Kad šių veiklų rezultatai neperteike tiesos, faktiškai žinojo visi, bet rezultatus instituto, ministeriju vadovai tvirtindavo, nes toks jau buvo visuotinis žaidimas. Kartais maskvietiškos komisijos suabejodavo, bet del netikrų duomenų nelabai bausdavo. Tarkim, kai TSRS Liaudies kontroles komiteto komisija patikrino VISI vykdomy ūkiskaitinių mokslinio tyrimo darbų efektyvumą ir šių darbų vykdytoju materialinị skatinimą, nustate, kad ekonominis efektas - ne 4,1 mln. rublių, o tik 735 tūkst. rublių. Šis skaičius ir buvo įskaitytas, o kad parodytas buvo per 4 kartus didesnis - tai komisijos nesujaudino. Dèl neteisingų pateiktų rodiklių nebaudè. Tai buvo ipprastas dalykas daugelyje TSRS veiklos sričių.

Studentų atostogų dienomis VISI vyko respublikinè mokslinè konferencija „Kaimo architektūros ir statybos industrializavimo problemos".

Pagrindinis konferencijos pranešejas LTSR Valstybinio statybos reikalų komiteto pirmininkas R. Sakalauskas ypač daug dèmesio skyrè architektų rengimui. Jis pabrèžè, kad inžinierius architektas privalo gauti daugiau žinių apie kaimo statybų specifiką, kad paskirtas ị kaimą jaunas specialistas galetų savarankiškai ir kvalifikuotai spręsti įvairius klausimus: „Juk jam dažnai nera su kuo pasitarti, o savarankiškam sprendimui jis nepasiruošşs" [4.54, p. 2.]. Pranešejas kviete mokyti architektus projektuoti racionalius, kuklius ir ekonomiškus gyvenamuosius namus ir socialinius buitinius objektus, stiprinti dendrologijos, ekologijos, inžinerinių komunikaciju projektavimo bei statybos žinias.

Iš viso konferencijoje buvo perskaityti 302 pranešimai. Kai kurie pranešimai buvo parengti bendromis mokslininku ir gamybininku jegomis. Tarkim, Statybos darbu technologijos katedros doc. E. K. Zavadskas pranešimą „Žemès ūkio gamybinių pastatų racionalaus montavimo metodo parinkimas su ESM" parenge drauge su Respublikinio TSO technikos valdybos viršininku S. Zavecku, tos pačios katedros doc. V. Kriukelis pranešimą „Apie atskirinio betonavimo metodo taikymą kaimo statybose" - su Statybos ministerijos technikos valdybos vyr. inžinieriumi J. Jauniškiu ir t. t.

Analizuojant žiemos egzaminu sesijos rezultatus, konstatuota, kad ypač daug skolininkų Statybos fakultete. Buvo aiškinamos studentų atsilikimo priežastys.

Kovą VISI folklorinis ansamblis pasirode gerai ir užèmé antrąją vietą. Šio kolektyvo populiarumas vis augo, jis, sumaniai ir profesinaliai vadovaujamas Evaldo Vyčino, deramai atstovavo Vilniaus inžineriniam statybos institutui įvairiuose šalies renginiuose.

Balandžio 14-15 dienomis Klaipedoje vyko Stasio Šimkaus chorų konkursas. Jame dalyvavo daug chorų iš visos Lietuvos. Mišrių nusipelnusių ir liaudies choru grupeje "Gabijos" choras, vadovaujamas meno vadovo Felikso Viskanto, pasirode geriausiai ir laimejo pirmojo laipsnio diplomą. Tuoj po konkurso A. Gaižutis raše: „Kiekvienas talentingas menininkas - vis kitoks. F. Viskantas dar karta patvirtina šia tiesa. Jis - muzikos juvelyras. F. Viskantas gali taip nušlifuoti atskira muzikos kürini, kad galima jì pavadinti "perliuku“. Tai subtilios kürinio instrumentuotes meistras. F. Viskantui reikalingi ne balsai, bet dainuojanti dvasia. Ir tik su tokiais žmonemis jis atranda bendra kalba repeticijose ir koncertuose.

Kaip rodo ịvairūs meno kolektyvu (tarp ju ir choro) sociologiniai tyrimai, ju sèkme lemia vadovo asmenybe. F. Viskantas turi daug patraukliu bruožu kaip žmogus ir kaip pedagogas “ $[4.55$, p. 2].

1984 m. gegužès 22-24 d. Vilniaus inžinerinis statybos institutas suorganizavo visų 
VILNIAUS

INŽINERINIS STATYBOS

INSTITUTAS neakivaizdžiai, o likusius (15-20\%) kviesdavo ị rektoratą, kur galutinai spręsdavo jų prièmimo ị institutą klausimą. Jei stojantysis nesutikdavo su egzamino įvertinimu, turejo teisę kreiptis į apeliacinę komisiją, kuriai vadovavo instituto prorektorius.

İkūrus VISI, buvo įsteigtas Parengiamasis skyrius. I $\mathrm{j}$ ji buvo priimami darbininkai ir kolūkiečiai, turintys ne mažesnį kaip vienerių metų nepertraukiamojo gamybinio darbo stažą, su įmonių arba ūkių siuntimais. Be to, su karinio dalinio siuntimais ir tarnybinemis charakteristikomis priimdavo demobilizuotus karius.

Asmenys, sèkmingai baigę Parengiamajji skyrių, kuriame buvo destoma matematika, fizika, lietuvių kalba ir literatūra, rusų kalba ir literatūra, braižyba bei piešimas, be stojamųju egzaminų buvo priimami ị instituto pirmąji kursą.

Per visą VISI Parengiamojo skyriaus veiklos laikotarpi jo vedejju buvo Fizikos katedros destytojas docentas Petras Lukošius. Jo darbas visus tuos metus buvo nepriekaištingas ir dažniausiai susilaukdavo tik pagyrimų.

1984 m. Vilniaus inžinerinị statybos institutą baige 1059 studentai: architektūros specialybę - 88 , PCS - 342, miestų statybos -42 , autokeliu -45 , taikomosios geodezijos - 41, statybos ekonomikos - 115 , autotransporto eksploatavimo - 31, automobiliu transporto - 136, statybos kelių mašinu - 26, suvirinimo įrengimų - 39, mašinų gamybos technologijos - 69, elektros pavaru - 34 ir radijo aparatūros technologijos -51 . Tais metais buvo įteiktas 15000 -asis diplomas.

Vasarą studijuoti i VISI buvo priimta 1350 studentų: į dieninị skyrių - 825, ị vakarini -350 ir neakivaizdini -175 . Vis delto konkursas ịstoti i VISI nebuvo didelis. İ vieną vietą buvo kiek per 1,1 pareiškimo. Trūko pareiškimu i 2 specialybes.

Vilniečiai sudare $32 \%$ visų įstojusiųjų, vyrai-71\%. VISI buvo vyriškesnis nei KPI, kur vyrai sudare $57 \%$. Tai reiške, kad po pirmojo kurso daugiau nei KPI teks išsiųsti tarnauti ị sovietinę armiją.

Rugsëjo 1-ąją îvyko trafaretiniu tapęs iškilmingas naujujju 1984-1985 mokslo metų atidarymas, nepalikęs didesnio įspūdžio nei svečiais, nei jų bei šeimininkų kalbomis. Koncertavo VISI kolektyvai ir tik jie praskaidrino susirinkusiųjų nuotaiką. Tiesa, malonu buvo išgirsti, kad respublikiniame folklorinių ansamblių konkurse „Ant marių krantelio“, kuris įvyko Rumšiškèse, laureatu 


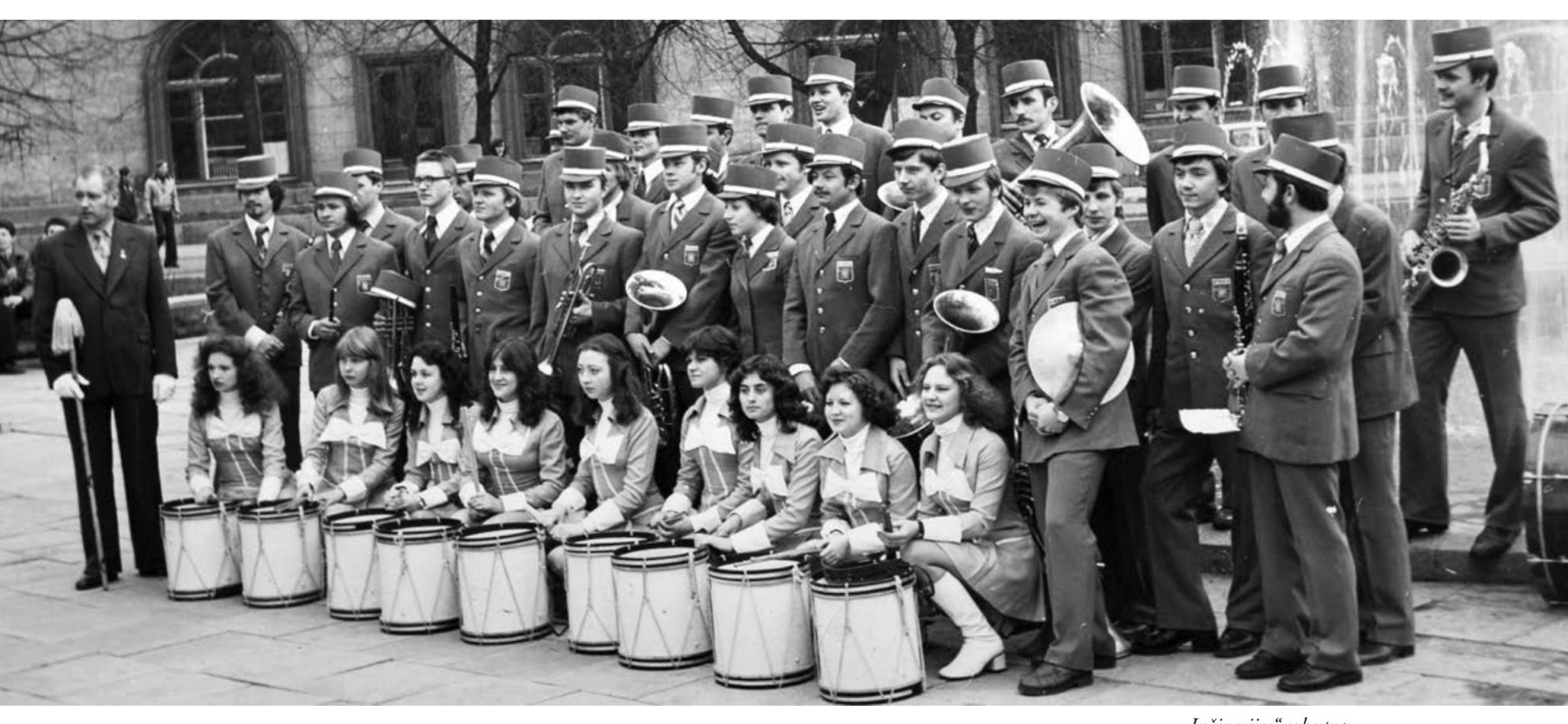

tapo VISI folklorinis ansamblis, vadovaujamas Evaldo Vyčino. Jis pats, ansambliečiu padedamas, atkūrè senąsias lietuviškas kankles, lumzdelius, birbynes, ožragi, švilpą ir kitus liaudies muzikos instrumentus. E. Vyčino vadovaujami ansambliečiai per atostogas kasmet vykdavo i ekspedicijas i iqvairius Lietuvos rajonus, kur ieškojo ir užrašinëjo senų žmonių dainuojamas dainas, šokius.

Per penkerius veiklos metus VISI folklorinis ansamblis daug koncertavo Lietuvoje, kitose TSRS respublikose, užsienyje ir visur būdavo labai šiltai priimamas.

Mokslo metu pradžioje buvo tas pats, kaip ir praejusiais mokslo metais, katedru skaičius - 39, bet déstytojų etatų padaugejo nuo 461 iki 487.

Didžiausios etatų skaičiumi buvo tokios katedros: Karinio parengimo - 30,5, Matematikos - 30,5, Fizikos - 21, Geodezijos, Užsienio kalbu ir Automobilių transporto po 19 , Fizinio lavinimo - 18,5, Braižybos bei Taikomosios matematikos ir mechanikos - po 18.

Mažiausiai etatu turëjo šios katedros: Statybinių medžiagų - 5,25, Elektrotechnikos ir Dailès - po 6 ir Elektros pavaru - 7 .

Rugsèjo antrojoje puseje institute apsilanke Veimaro aukštosios architektūros ir statybos mokyklos rektorius prof. Hansas Glismejeris, Užsienio ryšiu skyriaus viršininkas Holgeris Bènke. Buvo pažymeta, kad VISI ir Veimaro mokyklos bendradarbiavimas teikia abipusę naudą ir bus toliau plètojamas.
Veimaro aukštosios architektūros ir statybos mokyklos pirmtaku buvo $1860 \mathrm{~m}$. ìsteigta Dailes mokykla. Nuo 1902 m. joje dirbo įžymusis H. Van de Veldè. Ši mokykla turejo didelę įtaką meninès „moderno“ pakraipos sklidimui Vokietijoje. Pasaulinio karo metais Van de Veldei išvykus iš Vokietijos, ji mokykloje pakeite architektas V. Gropiusas. Nuo 1919 m. mokykla buvo reformuota ir vadinama Bauhauzu. Čia buvo siekiama panaikinti atotrūkį tarp grynosios ir taikomosios dailès. Mokykla veikè iki 1925 m. Ji vèl pradëjo veikti Veimare po karo.

VISI dirbusio architektūros istoriko doc. S. Abramausko žiniomis, Veimaro aukštąją architektūros ir statybos mokyklą sudarè 6 sekcijos: architektūros, rajoninio planavimo ir urbanistikos, statybos, statybinių medžiagų technologijos, skaičiavimo technikos bei duomenu apdorojimo ir marksizmo-leninizmo. Joje mokesi 2500 studentu. Mokykla nuo 1964 m. turëjo teisę pripažinti technikos mokslų daktaro, daktaro inžinieriaus ir gamtos moksly daktaro laipsnius. Joje tuomet dirbo 6 profesoriai ir per 200 aukštos kvalifikacijos dèstytojų.

Dalykiški ryšiai su šia mokykla buvo užmegzti nuo 1970 metų. Kasmet buvo keičiamasi studentais praktikantais, publikacijomis, destytojų stažuotemis, dalyvaujama mokslinèse konferencijose ir kt. [4.56, p. 2].

1984 m. buvo ir liūdnų dalykų. Didelè netektis institutui - netiketa profesoriaus Vaclovo Vytauto Šeštoko mirtis. Jis buvo labai produktyvus mokslininkas, kurio darbus
„Inžinerijos" orkestras, vadovaujamas J. Jonušo

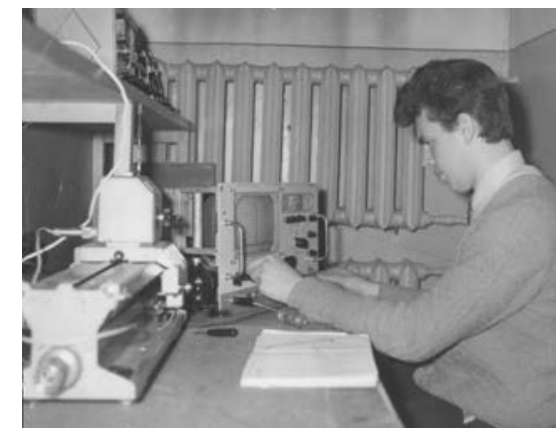

Elektronikos laboratorijoje tyrimus vykdo J. Stankūnas

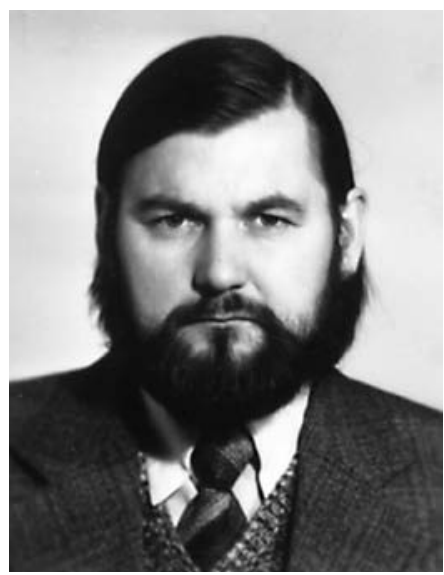

V. Matonis 
VILNIAUS

INŽINERINIS STATYBOS

INSTITUTAS

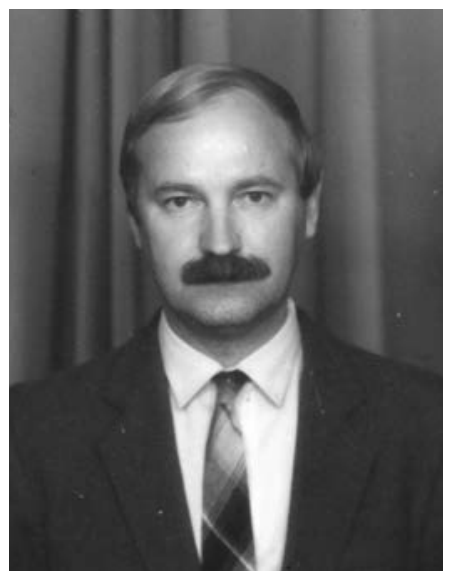

A. Gaižutis

Viršuje dešineje -

$1984 \mathrm{~m}$. VISI rektorius A. Cyyras ir Statybos technikumo

direktorius R. Durasevičius pasiraše mokykly bendradarbiavimo sutarti gerai vertino ir TSRS, ir užsienio mokslininkai. Kaip gerą destytoją ji mégo studentai. Jo energija ir sumaniu organizaciniu darbu i SMD veiklą buvo įtraukta labai daug studentu.

Vilniaus inžineriniame statybos institute išties puikia kultūrine veikla pasižymejo Estetikos katedra. Jos kvietimu metu pabaigoje centrinių rūmų didžiojoje auditorijoje lankẻsi kompozitorius Julius Juzeliūnas, muzikologas Donatas Katkus ir garsusis Vilniaus kvartetas. Estetikos katedros destytojas V. Matonis po to raše: „...ne vien iš pagarbos muzikos meno meistrams entuziastingai plojo mūsu destytojai ir studentai, nutilus paskutiniesiems kvarteto garsams. Kürinio raiškos priemones, visumos konceptualumas, pagaliau atlikëju virtuoziškumas, ansambline darna sužavejo klausytojus, žadino gilia mintį.

Po to prof. J. Juzeliūnas gyvai, suprantamai papasakojo apie šinolaikines muzikos ypatumus, jos raidos perspektyvas, muzikinio kūrinio prigimti. Atsakinedamas i klausimus, profesorius kalbejo ir apie mažai respublikos spaudoje gvildenama muzikos ateiti. Kaip galvoja kompozitorius, ateities konservatorija tures galinga technine baze, kurioje dirbs matematikos ir technikos specialistai. Elektronikos laimejjimu, sintezatoriu naudojimas, kuriant ir atliekant muzika, J. Juzeliūno nuomone, turetu büti nuosaikus, neignoruojantis muzikines kultūros tradiciju. Jis mano, jog kada nors orkestru dirigentai stoves prie elektroniniu valdymo pultu, $o$ atlikejai-prie sintezatoriu.

Svečias idomiai papasakojo apie savo pedagogini darba su konservatorijos studentais - busimaisiais kompozitoriais" [4.57, p. 1].

Buvo tęsiama graži tradicija VISI centrinių rūmų 5 aukšte rengti dailès kūrinių parodas. Jas jau buvo eksponavę Architektūros fakulteto docentai Alfonsas Keturka ir Henrikas Bogdanas, o 1984 m. akvareliu parodą surenge Miestų statybos katedros docentas Arnoldas Tupinis ir nustebino daugeli turimais savo gebejimais - puikiais kaimo ir miesto peizažais, gèlemis ir kt.

VISI sporto klubo valdyba „Inžinerijoje“ paskelbe, kas buvo geriausi $1984 \mathrm{~m}$. VISI sportininkai:

1. Valdas Berūkštis, AT 0/1 - sporto meistras, sunkioji atletika. Daugkartinis LTSR čempionas. 2. Loreta Virbic-

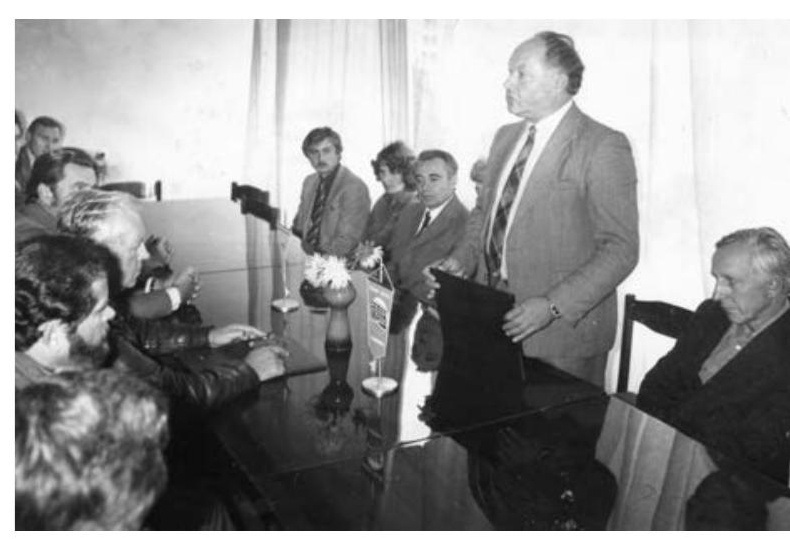

kaite, MS 1/1 - sporto meistré, krepšinis. TSRS pirmenybių prizininke, „Kibirkšties“ komandos žaideja. 3. Rima Liutkaité, MS 2/2 - sporto meistre, akademinis irklavimas, TSRS studentų žaidynių čempionè. 4. Juozas Sabaliauskas, PCS 3/11, Gintautas Rimkus, SI 3/1 - TSRS sporto meistrai, akademinis irklavimas. TSRS studentu žaidynių čempionai (aštuonvietè). 5. Henrikas Gulbinavičius, AT 2/4 - kandidatas i sporto meistrus, lengvoji atletika. LTSR čempionas.

Gruodžio 21 d. Maskvos M. Lomonosovo universiteto specializuotoje estetikos taryboje humanitarinių mokslų daktaro disertaciją apgynè VISI estetikos katedros vedejjas Algirdas Gaižutis. Jo disertacija - „Dvasinis kūrybinis menininko pasaulis“.

1984-1985 mokslo metais Vilniaus inžineriniame statybos institute labai didelio demesio sulauke VISI pedagogu draugijos veikla. Respublikoje jau daugelį metu buvo jaučiamas inžinierių pedagogų poreikis profesinese technikos mokyklose rengti darbininkus. Ju rengimo specifika reikalavo, kad tų mokyklų destytojai ne tik galètų desstyti inžinerijos ir technikos dalykus, bet ir galètu vadovauti darbams dirbtuvese, taip pat sugebèti aukleti PMT moksleivius. Taigi tų mokyklų destytojai privalëjo gerai suvokti pedagoginę psichologiją, išmanyti auklejjamojo darbo organizavimą ir metodiką.

1985 m. pavasarị turëjo baigti pirmoji VISI Statybos fakulteto parengtu inžinierių pedagogų laida. Rengiant šią pirmąją laidą, buvo sukauptas tam tikras patyrimas, kuri „Inžinerijos" laikraštyje apibendrino VISI pedagogu tarybos pirmininkas prof. V. Šernas. Jis rašè, kad stojantieji ị šią specialybę turi tureti potrauki pedagoginiam visuomeniniam mokslui, gerą balsą, išugdytą reiklumą sau ir kitiems. V. Šernas siūle tobulinti technologinę ir pedagoginę 
praktikas, pastarąsias - prailginti. Profesoriaus manymu, reikejo sudaryti sąlygas PMT gamybinio mokymo meistrams studijuoti inžinieriaus pedagogo specialybę neakivaizdiniu būdu ir t. t.

Tame pačiame laikraštyje VISI rektorius A. Čyras teige, kad padidinus PMT destytoju atlyginimus, $i \mathfrak{z}$ tas mokyklas gausiai ir noriai pereina inžinieriai gamybininkai, bet jie, neturedami pedagoginio išsilavinimo, susiduria su sunkiai ịveikiamomis mokymo ir auklejimo problemomis $[4.58$, p. 1$]$.

Sausio menesî, sugrižęs iš Jungtinių Amerikos valstijų profesorius Kazimieras Šešelgis interviu „Inžinerijos“ laikraščiui papasakojo įdomių minčių. Pateikiame kai kurias iš jų:

„Savo akimis pamačiau Čikagq, Bostona, Niujorka, Vašingtona. Susipažinau su minèty miestu architektūra $\langle\ldots\rangle$. Daugiausia JAV statoma utilitariu, paprastu formu, praktiškos paskirties pastaty <...>. Statybai naudojamos ivairios ir brangios medžiagos, pastatai pasižymi aukšta darbu kokybe, geru inžineriniu aprüpinimu - vedinimas, apšildymas ir $t$. $t$. $\langle\ldots\rangle$, nemažai dèmesio skiriama ekologinei problemai.

JAV nepakanka aukštosios mokyklos baigimo, architektai dar trejus metus dirba pasirinktoje srityje ir tik tuomet laiko valstybinius egzaminus iš visu specialybes dalyku. Kiekvienas jaunas architektas privalo gerai moketi statybos istatymus ir normas <...>, kada architektas išlaiko valstybinius egzaminus, jis gauna teise pasirašyti po projektu ir gali pradeti savarankiškai dirbti, t. y. priimti ǔ̌sakymus <...>. Stambioje projektavimo firmoje dirbančiu architektu pavardžiu po projektais nera. Pasirǎso firmos savininkas, kitais atvejais rašomas firmos pavadinimas.

Būdamas Bostone, apsilankiau Harvardo universitete $<\ldots . .>$. Charakteringas JAV studentu bruožas - jie labai daug dirba, kruopščiai mokosi, labai domisi savo specialybe. Už moksla Jungtinese Amerikos valstijose reikia mokèti (vidutiniškai keliolika tūkstančiu doleriu per metus). Stipendijas gauna tik patys gabiausieji. Jas moka juvairios projektavimo firmos" $[4.59,1.1]$.

Sovietmečiu domejjimasis Vakaru gyvenimu buvo labai didelis, o informacijos buvo nedaug arba ji buvo iškreipta. Todèl autentiški liudininku rašiniai, pasakojimai buvo skaitomi ar klausomi su dideliu susidomëjimu.

Vasario mènesị Vilniaus inžinerinis statybos institutas paskelbè apie priemimą įstudijas nuo 1985-1986 mokslo metų pradžios. Buvo numatyta, kad nuo rugsèjo $1 \mathrm{~d}$. pradès veikti dar vienas - Santechnikos fakultetas su dviem specialybèmis: šilumos, dujų tiekimo ir vedinimo bei vandentiekio ir kanalizacijos.

I šsilumos, dujų tiekimo ir vedinimo specialybès dienines studijas buvo numatyta priimti 75, o į vandentiekio ir kanalizacijos specialybès dienines studijas - 50 ir ị neakivaizdines studijas - 25 žmones.

Kovo menesį sužinota, kad Liaudies ūkio pasiekimų parodoje Maskvoje koncertavęs VISI etnografinis ansamblis (vad. E. Vyčinas) buvo apdovanotas parodos bronzos medaliu. Tą patį menesį ansamblis Vilniaus plokštelių studijoje įraše pirmąją plokštelę.

Bet reikšmingiausias kovo mènesio ịvykis - valdžios Kremliuje permaina.

1985 m. kovo 10 d. mire K. Černenka, kurio vardas, anot TSKP CK pranešimo, , ,visiems laikams išliks tarybiniu žmoniu, visos pažangiosios žmonijos širdyse ". Menkai jį žinojo tie tarybiniai žmonès, o ką jau bekalbèti apie žmoniją...

Jau rytojaus dieną generaliniu sekretoriumi tapo Michailas Gorbačiovas. Jis iškart žadèjo tarnauti didiesiems Lenino idealams. Žmonès nieko gero nesitikejo. Tik tuoj pat pasklido humoras apie puošnių laidotuvių penkmetị. Netrukus žmonés sukluso - prabilta apie kažkokią pertvarką. İsižiebè nedidelè viltis - o gal gi kas nors keisis?

Institute, deja, permainų dar ilgai nebuvo. Periodiškai vyko rutina tapę atviri partiniai susirinkimai, instituto tarybos posèdžiai. Kasmet buvo kuriami įvairūs perspektyviniai planai ir kasmet jie buvo koreguojami, nes aiškejjo, kad juos igyvendinti nèra galimybių. Bet žmonès dirbo, kūrè: skaite paskaitas, vede pratybas, vykdè tyrimus mokslo laboratorijose, kuriu įranga seno, devejosi, o atnaujinimo beveik nebuvo. Bet buvo siekiama daugiau padaryti ir tokiomis sąlygomis.

Balandžio 22 d. vykusiame rektorato posedyje buvo pagirtas VISI skaičiavimo centro darbas už jo išaugusias paslaugas tobulinti studentų mokymo procesą. Skaičiavimo centras turëjo įdiegęs 154 programas, skirtas studijoms. Studentai naudojosi skaičiavimo kompleksu - CM-1600, EC-1022 ir „Minsk-32“ skaičiavimo mašinomis. Studentai sunaudojo $63 \%$, o destytojai - $37 \%$ mašinų laiko. Daugiausia mašinų laiko sunaudojo Statybos fakulteto studentai ir destytojai.

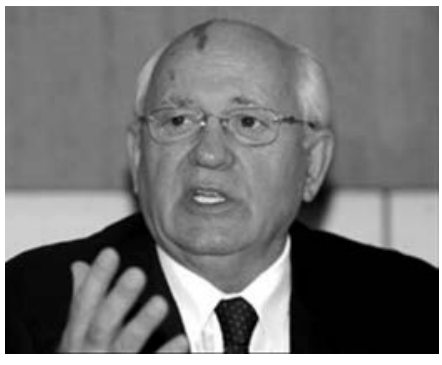

M. Gorbačiovas 
VILNIAUS

INŽINERINIS STATYBOS

INSTITUTAS džioje surengtame forume skundèsi, kad ju bendrabučiuose (16 aukštų!) šeštadieniais ir sekmadieniais neveikia liftai, centriniuose rūmuose šeštadieniais nedirba valgykla, skaičiavimo centro perforatorine atidaroma tik nuo 14 valandos. Studentai pageidavo daugiau valandų inžinieriaus psichologijos kursui, norëjo savivaldos bendrabučiuose, geresnių sąlygu turiningam laisvalaikiui organizuoti. Forume dalyvavę instituto vadovai žadejo daugelį klausimų neatidèliotinai išspręsti. Kartu rektorius A. Čyras ragino studentus būti aktyvesnius, rodyti daugiau iniciatyvos, didinti reiklumą sau.

Kai „Hiperboles“ ansamblio dalyviai baigè studijas ir galop nebeliko joje VISI studentu, ansamblis tapo savarankišku kolektyvu ir praktiškai nutrauke ryšius su VISI administracija. Tuomet rektorius iškèle uždavinị sukurti naują estradinio žanro kolektyvą.

Tam reikalui buvo pakviestas Juozas Gabartas, kuris ir subūrè gabų jaunimą i VISI vokalinị instrumentinị ansamblị. Ir štai, vos pirmus metus egzistuojantis ansamblis, 1985 m. gegužę nuvykęs $i \mathfrak{\text { tradicinị }}$ Jerevano festivalì, tapo laureatu. „Inžinerija“ rašè, kad „Ansamblio siela - dainu autorius ir atlikejas Alius Lisauskas <...>. Savarankiškai bando kurti ir ansamblio gitaristai Vytautas Kinderis bei Dmitrijus Vorobjovas. Nepakeičiamas Eugenijus Pugačiukas, grojantis mušamaisiais. Liutauras Sinikas groja klavišiniais instrumentais " $[4.60$, p. 1$]$.

Grịžę i Vilnių, J. Gabarto vadovaujami ansambliečiai dalyvavo aukštųjų ir specialiųjų vidurinių mokyklų vokalinių ir instrumentinių ansamblių apžiūroje-konkurse ir laimèjo II vietą. Bet pirmosios vietos kompozitoriaus T. Makačino komisija neskyre niekam.

\section{Maskvos inspekcijos komisija}

Ne vien linksmybès lydëjo VISI 1985 m. pavasarį. Nuo gegužès $20 \mathrm{~d}$. iki birželio $3 \mathrm{~d}$. TSRS aukštųjų mokyklų valstybinès inspekcijos komisija tikrino VISI darbą. Tai, žinoma, sukèlè nemažą įtampą instituto destytojams, o ypač instituto administracijai. Komisija konstatavo, kad VISI veikia 7 fakultetai: Statybos, Statybos ekonomikos, Miestų statybos, Architektūros, Mechaninès technologijos, Automatizacijos ir Kvalifikacijos kèlimo. 13-oje specialybių studijavo 6500 studentu, iš jų 4000 - dieninese studijose. 
1984-1985 mokslo metais institute dirbo 1267 žmonès, tarp jų 477 profesoriai ir destytojai. Yra 28 mokslo daktarai, profesoriai (tai sudaro $6 \%$ déstytojų) ir 303 mokslų kandidatai (tai $63 \%$ déstytojų). VISI turi 39 katedras. Pažymèta, kad institutas turi 3 bendrabučius, bet tai leidžia aprūpinti bendrabučiais tik $61 \%$ atvykusių iš kitų miestų. Instituto pastatuose veike 3 valgyklos ir 4 bufetai. Valgyklose - 310 vietu, bufetuose - 140 vietu. VISI biblioteka turëjo 860000 egzempliorių knygur. Joje - 8 skaityklos su 300 vietų. Institute veike 5 žinybinès laboratorijos. $1981 \mathrm{~m}$. Plytinès gatveje buvo pastatytas eksperimentinis namaslaboratorija, $1983 \mathrm{~m}$. - Mechaninès technologijos fakulteto priestatas, $1984 \mathrm{~m}$. - antras mokymo laboratorinis korpusas. Pažymèta, kad nuo 1970 m. elektroninès skaičiavimo mašinos „Minsk-22“ pagrindu pradëjo funkcionuoti automatizuota informacine sistema, kuri kasmet buvo tobulinama. Nuo $1984 \mathrm{~m}$. ta sistema èmè veikti dviejų ESM - „EC1022 “ ir „Minsk-32“ - pagrindu. Ypatinga dèmesi Maskvos komisija parode mokslinio komunizmo egzaminams. Komisijos sudarytame akte, be kita ko, parašyta: „Studenty atsakymai per egzamina parodè, kad daugelis büsimuju specialistu neisisavino žiniu, bütiny vykdyti aktyvia puolamaja kovq su buržuazine ideologija, reformizmu ir revizionizmu, argumentuotos antimarksistiniu ideju kritikos “. Ką gi, tai reiške, kad blogai dirbo
M. Burokevičiaus, o vèliau S. Juonienès vadovaujamos Mokslinio komunizmo katedros destytojai. Bet ar čia jie buvo kalti? Pati komunizmo, mokslinio ar kitokio, idejja buvo realaus gyvenimo jau visiškai sudevèta ir puikiausi destytojai negalejo įkvèpti studentu ja tikèti, nuoširdžiai mokytis jos postulatų. Valstybès inspekcija pagyre institutą dèl skaičiavimo technikos plataus taikymo studiju procese, bet priekaištavo, kad informacija paruošiama perfojuostose. Institutas naudojo tokią technologiją ne dèl nežinojimo apie naujos technikos galimybes. Paprasčiausiai trūko lěšų jai igyti. Inspekcija gerai iqvertino Matematikos katedros darbą, destytojų kvalifikaciją, naudojamą studijoms lietuvių autoriu parengtą literatūrą, tačiau priekaištavo, kad matematikos destytojai nedalyvauja diplominių darbų gynimo komisijose. Inspekcijos nuomone, Matematikos katedra neturi galimybès stebèti, koks studentų matematikos mokejjimo lygis paskutiniu studiju etapu. Inspekcija priekaištavo, kad Statybos fakultetas neturi recenzuotų paskaitų konspektų, kad kai kurie kursinio projektavimo metodiniai nurodymai pasenę, kad neatliekami visi mokymo plano numatyti laboratoriniai darbai, kad kai kurių laboratoriju ịranga moraliai pasenusi. Maskvos tikrintojai kritikavo institutą, kad VISI studentų nubyrejimas sudaro apie $19 \%$, kai sajungoje 6-7\%. Bet nebuvo analizuojamos tokio nubyrejimo priežastys.

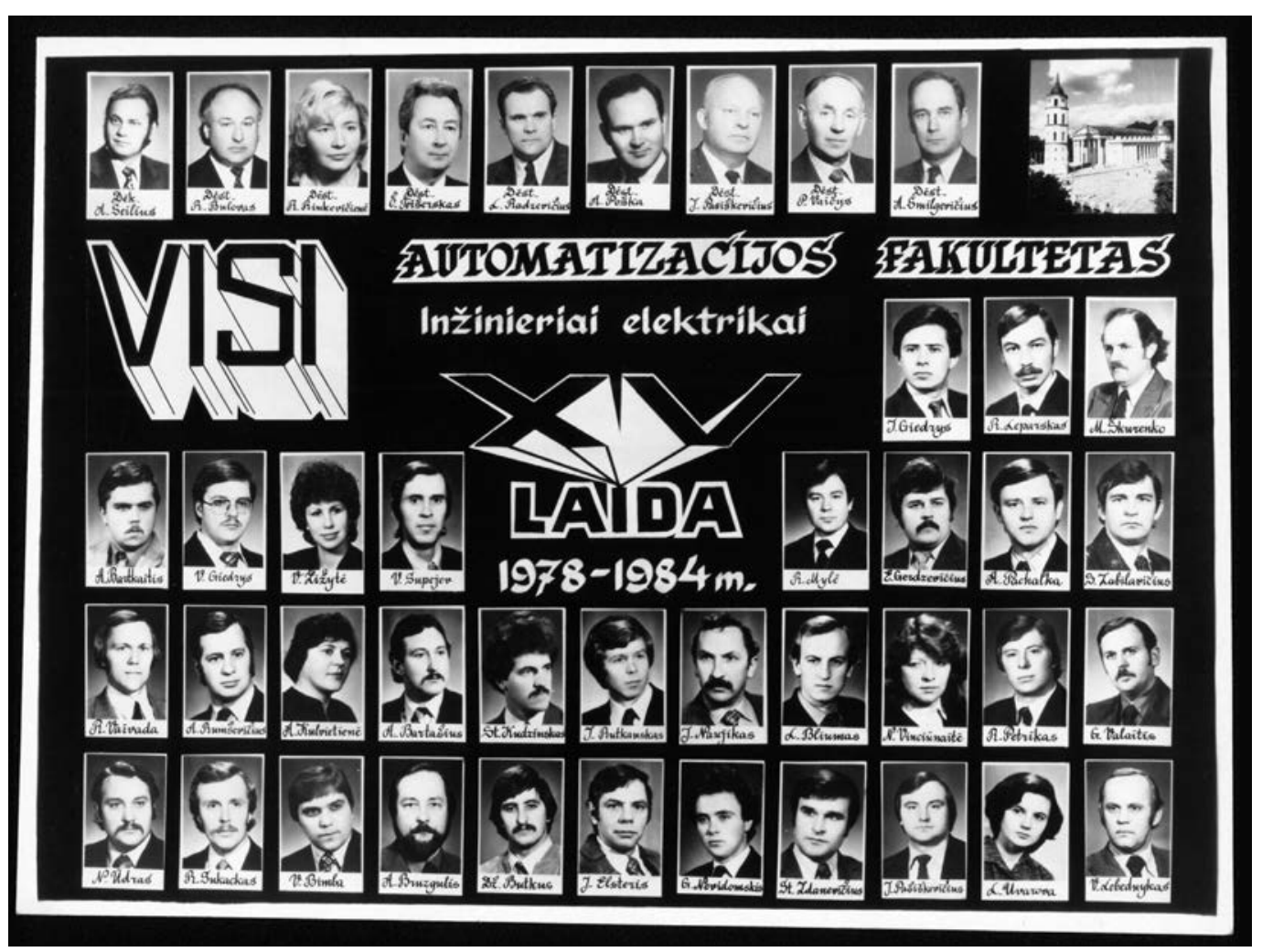


VILNIAUS

INŽINERINIS STATYBOS

INSTITUTAS

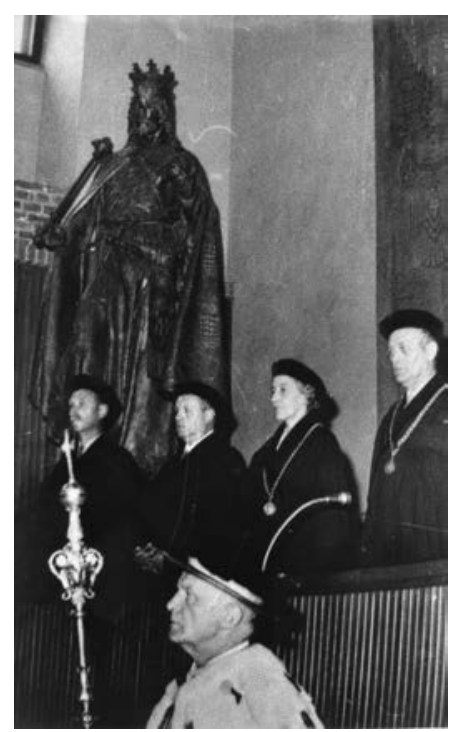

A. Čro inauguracija Garbes daktaru Prahos Karlo universitete

Viršuje dešinëje -

Kandidatu disertacija gina S. Kalanta
Komisija kritikavo institutą už tai, kad dalis VISI vykdomų darbų pagal ūkiskaitines sutartis neatitinka nustatytų 9 mokslo krypčių, kad kai kurios sutartys nedideles apimties ir t. t. Tai paaiškinti nebuvo sunku. Pramonès imonès, statybos organizacijos buvo finansiškai silpnos ir net labai joms reikalingiems mokslinio tyrimo darbams atlikti tegalejo pasiūlyti labai skurdžias sąlygas. Kita vertus, maži dèstytojų atlyginimai verte juos priimti net ir mažai mokamų darbų pasiūlymus.

Vis delto inspekcijos komisija teigiamai ìvertino instituto mokslinių tyrimų tematiką. Pagyre, kad mokslinių tyrimų rezultatai naudojami studiju procese.

Būdingas tiems laikams galutinis VISI mokslinio darbo vertinimas: ,Nustatyti mokslinio tiriamojo darbo trūkumai neturi sisteminio charakterio ir gali būti lengvai pašalinti tolimesniame darbe" [4.61, p. 1-26].

Inspekcijos nurodyti trūkumai nebuvo naujiena nei destytojams, nei instituto vadovams. Ju šaknys slypëjo pačioje sovietinëje santvarkoje, joje egzistuojančioje aukštojo mokslo sistemoje. Toji sistema nuolat plyšinëjo ir periodiškai buvo užlopoma. Radikaliai pakeisti studijų ir mokslo padètį aukštajame moksle nebuvo įmanoma be ryškaus finansinio padidinimo. O TSRS gamino tūkstančius raketų, tankų ir kitos ginkluotes, o mokslui, nesusijusiam su karyba, likdavo tik trupiniai.

1984-1985 mokslo metais VISI viena po kitos ištikos skaudžios netektys. Mire technikos mokslų daktarai, profesoriai Arkadijus Naidionovas ir Steponas Rokas bei visai bebaigiąs parengti technikos mokslu daktaro disertaciją docentas Rimas Jonas Bulovas. Visi trys turejo dar daug mokslinès potencijos, juos supo jauni perspektyvūs mokslininkai. Tai buvo didelis nuostolis instituto mokslui.

1985 m. VISI parengtų specialistų derlius buvo kiek didesnis nei 1984 m.: 1984 m. 1059, o 1985 m. - 1086.

Institutą baigè: architektūrą -76 , PCS 366, miestų statybą - 47, automobilių kelius - 39, taikomąją geodeziją - 45, statybos ekonomiką - 138, autotransporto eksploatavimą - 30, automobilių transportą - 131, statybos kelių mašinas - 20 , suvirinimo įrengimus - 37 , mašinų gamybos technolo-

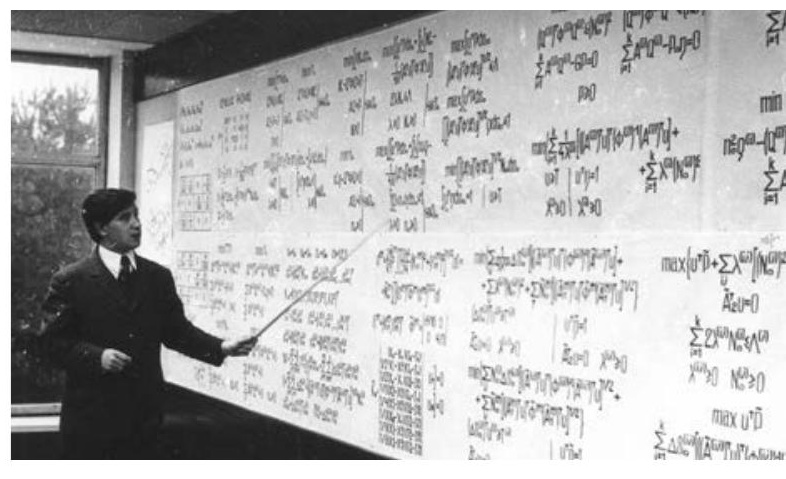

giją - 72, elektros pavaras - 34, radijo aparatūrą - 51 studentas.

Spalio menesį, švenčiant Veimaro architektūros ir statybos mokyklos jubiliejų, šios aukštosios mokyklos garbès daktaru buvo inauguruotas VISI rektorius profesorius Aleksandras Čyras. Tuo metu TSRS ir užsienyje garsëjo A. Čyro moksliniai darbai. Jis jau buvo parengęs 2 technikos mokslų daktarus, 23 technikos mokslų kandidatus, rengè naują originalų statybinès mechanikos vadovèli. Be to, vokiečiai labai vertino A. Čyro indèli stiprinant Vilniaus ir Veimaro inžinerinių mokyklų bendradarbiavimą.

A. Čyras buvo pirmas VISI mokslininkas, gavęs garbès daktaro vardą. Ilgainiui taip pat ji pagerbe Prahos Karlo universitetas, o Lenkijos mokslų akademija išrinko A. Čyrą jos užsienio nariu.

1985 m. gruodic VISI taryba rekomendavo pristatyti visasąjunginiam konkursui geriausiam aukštųjų mokyklų moksliniam darbui nustatyti 3 darbus:

1. A. P. Kavolèlio monografiją «Mexaнизмы и устройства для передачи вращения, виброзащиты и стабилизации на основе центробежых сил” („Sukimosi, vibroizoliacijos ir stabilizacijos mechanizmai bei įtaisai išcentrinių jegų pagrindu").

2. V. Šeštoko, V. Adomavičiaus, P. Juškevičiaus mokomąją priemonę «Гаражи и стоянки» („Garažai ir stovëjimo aikštelès“).

3. E. K. Zavadsko ir kt. mokslinį darbą «Исследовать и разработать предложения и техническую документацию по применению рациональной технологии возведения производственных одноэтажных зданий в условиях Литовской ССР» („Ištirti ir parengti pasiūlymus bei techninius dokumentus vienaaukščiu pramonés pastatų statyboje racionaliai technologijai taikyti Lietuvos TSR sąlygomis").

1986 m. pradžioje Vilniaus inžinerinis statybos institutas turejo 6 ir projektavo septintąji bendrabučius. Rektoriaus įsakymu 
buvo pakeista jų numeracija: 1. Jaunųjų specialistų bendrabutis, esntis Žirmūnų g. 127, pavadintas bendrabučiu Nr. 1. 2. Studentu bendrabutis, esantis Bistryčios g. 9, pavadintas bendrabučiu Nr. 2. 3. Studentu bendrabučiai, esantys Sauletekio al. 16, 18 ir 19 pavadinti Nr. 3, 4 ir 5. 4. Projektuojamą studentų bendrabutį Sauletekio al. 19 pavadino bendrabučiu Nr. 6 .

Bendrabučiuose gyveno beveik puse institute besimokančių studentų. Nors buities sąlygos studentų būstuose buvo nekokios labai prasti sanitariniai mazgai, virtuves, bet daugiausia dèl netvarkos buvo kalti patys gyventojai. Bendras turtas nebranginamas, dažnai sugadinamas, netausojami energija, vanduo - problemos tos pačios, kaip ir „komunalkų“. Pasitaikydavo vagysčių, muštynių, neretai paaiškedavo piktnaudžiavimo alkoholiu faktų, buvo ir nelaimingų atsitikimų. Padečiai taisyti buvo pasiekta, kad aukštybinių bendrabučių rajone vakarais budetų milicijos patruliai.

Tenka konstatuoti, kad ir po 20 metu problemos lieka panašios. Bendrabučiai - ir šiandien reikšminga socialine parama daugeliui studentų, bet, deja, jaunimo elgesio kultūra nè kiek nepagerejo. Gal atvirkščiai daugiau agresijos, cinizmo. Tenka viltis, kad kai bendrabučius ims eksploatuoti privačios struktūros, tvarkos bus pasiekta daugiau.

1986 m. sausi VISI dirbo 511 pedagoginių mokslo darbuortojų. Buvo 26 mokslo daktarai ir profesoriai, 318 mokslo kandidatu ir docentų.

Sausio 29 d. VISI taryba apsvarste pirmųjų penkerių metų Kvalifikacijos tobulinimo fakulteto darbą. Buvo pažymèta, kad per penkerius metus fakultetą baige 2342 gamybininkai bei projektuotojai. Fakultete deste dideli patyrimą turintys instituto destytojai bei gamybiniu ar projektavimo organizaciju specialistai. Deja, dar $38 \%$ fakulteto klausytoju neturejo aukštojo mokslo išsilavinimo. Taigi respublikoje labai trūko aukštos kvalifikacijos specialistų, kad jie galètu pakeisti vis dar užimančius, ypač gamyboje, inžinierių vietas technikus ar net praktikus.

Vasario ménesi buvo atlikta KPI Santechnikos fakulteto perkèlimo ị VISI galimybiu analizé. Buvo nustatyta, kad toks perkèlimas bus įmanomas tik nuo $1987 \mathrm{~m}$. rugsejo 1 d., kai VISI susidarys pakankama akademine apkrova: Šildymo ir vedinimo katedroje - 7 destytojams bei Vandentiekio ir kanalizacijos katedroje - 6 destytojams. Pažymetta, kad visi, kurie yra įstoję i KPI Santechnikos fakultetą iki 1985 metų, turetų ir baigti KPI.

Buvo patikslintas KPI Statybos ir santechnikos fakulteto darbuotojų, norinčiu keltis ị Vilnių, sąrašas. Tai 9 šildymo ir vedinimo bei 3 vandentiekio ir kanalizacijos specialistai. Šildymo ir vedinimo katedros: V. Martinaitis, B. Narbutis, S. Paulauskaite, E. Tuomas, A. Budriūnas, A. Norkus, R. Petruškevičius, J. Diedonis, V. Mikaila. Vandentiekio ir kanalizacijos: V. Šulga, A. Kliučius, A. Butkus.

Realus gyvenimas gerokai pakoregavo ši sąrašą. Persikèlè ne visi, kuriuos planavo ir tas procesas vyko net iki 1989 metu.

Vasario $7 \mathrm{~d}$. VISI apsilankęs TSRS aukštojo ir specialiojo vidurinio mokslo ministro pavaduotojas I. Makarovas įteike institutui Garbès raštą už gerus darbo rezultatus. Nors tai buvo palyginti nedidelis dalykas, jaunam institutui tai reiške tam tikrą pripažinimą, kas buvo malonu.

Vasario viduryje buvo paskelbti priemimo i VISI skaičiai: į dienines studijas - 950, vakarines -350 ir neakivaizdines -200 , iš viso 1500 žmonių.

1986 m. pavasarị èmème jausti tarptautinio klimato pagerejimą. Jis teike vilčių, kad tai teigiamai paveiks ir TSRS vidaus gyvenimo sritis. Gilejanti sovietinès ekonomikos krize ir augantis nestabilumas Rytų Europoje leido M. Gorbačiovui suprasti, kad TSRS toliau nepakels ginklavimosi varžybų tempo. Jis èmè kelti idejas dèl branduolinio ginklavimosi varžybų apribojimo, draudimo jas perkelti i kosmosą. Ilgainiui, po serijos susitikimu su JAV prezidentu R. Reiganu, M. Gorbačiovas pasieke reikšmingų susitarimų dèl ginklavimosi sumažinimo, bet jam teko ir kiek demokratizuoti savosios šalies gyvenimą. TSRS gyvenimas tapo atviresnis, viešesnis, laisvesnis. Bet iki tikro laisvejjimo dar buvo toli.

Permainos Vilniaus inžineriniame statybos institute dar nebuvo jaučiamos. Blogejjant ekonominei TSRS paděčiai, tai ypač paveike mokslą. Imta raginti mokslininkus glaudžiau bendradarbiauti su gamybinemis organizacijomis, atmesti „rutininę popierinę gerovę".

VISI mokslininkai turëjo nemažai ūkiskaitinių sutarčių, kurios tikrai dave naudos gamybai, bet ju pinigine išraiška nebuvo didelè. Taip kelininkai vykdè „LTSR automobilių 
VILNIAUS

INŽINERINIS STATYBOS

INSTITUTAS
Praktiškai galejo būti pritaikyti VISI fizikų fundamentalūs tyrimai. Doc. J. Jakimavičiui vadovaujant atlikti kristalų elektroninių savybių tyrimai buvo diegiami puslaidininkinių daviklių gamyboje. E. doc. p. D. Styra atliko aplinkosaugini darbą "Žmogus ir biosfera“.

Kaip jau ịprasta, gana daug ūkiskaitinių sutarčių turejo statybinių konstrukcijų katedros, Hidraulikos, Miestu statybos ir kt. katedros.

\section{Gorbačiovo „perestroikos“ startas}

„Perestroikai“ igyvendinti buvo skirtas TSRS XXVII suvažiavimas. Jame M. Gorbačiovas kaip vieną pagrindinių uždavinių nurode būtinybę spartinti mokslinį technini progresą, kuris turejo būti socialinès ekonomines plètros pagrindu. Tai galima pasiekti tik aukštos kvalifikacijos specialistų darbu, o norint juos parengti aukščiausiu reikalavimu lygiu - reikia pertvarkyti aukštąji mokslą.

M. Gorbačiovas manè, kad įmanoma pertvarkyti visas ūkio šakas tobulinant ūkio valdymą, jis nesuvoke, kad reikejjo „ne valdyma keisti, o suteikti žmogui galimybę pačiam iniciatyviai veikti “ [4.62, p. 55]. Valstybé valde ne tik visas - dideles ir mažas gamyklas, bet ir kirpyklas, taisyklas, valgyklas, valyklas ir t. t.

Tokios tvarkos rezultatai buvo apgailètini. Nors TSRS turëjo didžiausią teritoriją pasaulyje, kurioje buvo neišmatuojamai daug derlingų žemių, jai nuolat pritrūkdavo maisto produktų. Dél blogo valdymo statyboms trūko cemento, metalo, medienos, naujausių medžiagų. Dèl dideles centralizacijos atskiru ū ukio šakų suderinamumas buvo prastas ir planai sistemingai nebuvo ịvykdomi. O partijos suvažiavime buvo vis kartojami jau ikyrëję kvietimai: pasiekti, kelti, pagerinti, sustiprinti ir t. t., ir pan.

Pagal rutina tapusią sovietinio gyvenimo tvarką įvykusio partijos suvažiavimo medžiagą privalejo svarstyti visi darbo kolektyvai ir numatyti priemones, kaip tuos partijos nutarimus kuo greičiau igyvendinti.

1986 m. balandžio $18 \mathrm{~d}$. VISI įvyko atviras partinès organizacijos susirinkimas, kuriame ir buvo svarstyta TSKP XXVII ir paskui i̇vykusio LKP XIX suvažiavimų medžiaga.

Pranešejas rektorius A. Čyras pranešimą sukurpe pagal nustatytus kanonus: pirmiausia pabrèžè tų suvažiavimų vos ne pasaulinę reikšmę, pažymëjo, kad jie vyko „bolševikinès tiesos atmosferoje“. A. Čyras praneše, kad VISI 1981-1985 m. parenge 5184 specialistus, kad aspirantūrą baige 55 asmenys, o kandidato disertacijas apgyne 47 , daktaro - 11 instituto mokslininkų. $1986 \mathrm{~m}$. pradžioje $71 \%$ VISI déstytojų turëjo mokslinius laipsnius ir vardus. Tai buvo geriausias rodiklis tarp Lietuvos aukštųjų mokyklų ir sąjungos statybos institutų.

Per tuos metus institutas išleido 103 mokomosios literatūros leidinius, 37 mokslo darbų rinkinius, 17 vadovelių ir mokomųjų priemonių, 30 monografijų. Laimèjimai buvo išties reikšmingi. Buvo kalbeta ir apie trūkumus, nesèkmes: neįvykdytas statybos inžinierių rengimo planas, nepakankamas profesinio orientavimo darbas, silpnas studentų pažangumas, laiku negina disertacijų dauguma aspirantų, senëja profesūra ir t. t.

Buvo priimtas nutarimas, kuriame nutarta sudaryti, parengti, ipareigoti, pavesti... Taigi pažadèta viską gerinti. Taip jau buvo priimta: pažadèjai - patiešijai, netesèjai - negriešijai...

"Inžinerijoje“ paskelbtas priemimas studijuoti nuo 1986-1987 mokslo metų pradžios: 950 - $i$ dienines studijas, 350 - $i$ vakarines ir 200 - i neakivaizdines, iš viso 1500 žmonių.

İdomių minčių instituto laikraštyje išdèstè Architektūros katedros vedejas doc. Arnas Dineika. Jis raše apie architektų galimybes rengti architektūros projektus: „Dar viena būsimojo specialisto pasiruošimo problema liečia kursinius projektus, kuriu yra daug ir ivairiu. Diplomuotas architektas niekada neskaičiuos nei formos, nei varžtu diametro bei 
skaičiaus, nei šilumos nuostoliu ar apšildymo sistemu, nei kitu inžinerinés irangos elementu. Tad ar reikalingos studijuojančiam būsimam architektui šios inžinerines disciplinos irju kursiniai projektai? Reikalingi, jei padeda suvokti architektüriniu ir inžineriniu problemu saryšz, kompleksiško sprendimo reikšmę. Be abejo, disciplinu saryšis būtu akivaizdžiau suvoktas, jei inžineriniu disciplinu kursiniai projektai bütu atliekami eilinio architektürinio projekto pagrindu. Architektas, kuris nesugeba atlikti Dirigento vaidmens kompleksiškai sprendžiant architektūrines inžinerines problemas, nepilnai atlieka savo profesijos funkcija. Architektūra, kuri pasižymi dvasinemis, kultūinemis vertybemis, tuo pačiu yra ir materiali struktūra ir inžinerines problemos, sistemos privalo būti sprendžiamos kompleksiškai, organiškai. Kompleksiško sprendimo lygis priklauso ir nuo architekto bei jo kolegu, inžinieriu kvalifikacijos, sugebejimo kūrybiškai bendradarbiauti.

Šaliai reikalingi ne specialistai - "mokiniai", sugebantys išmokti "užduotq" pamokq, studiju metu vien „ǐ̌eje "visq kursa, o mątantys, iniciatyvūs, atkaklūs ir kompetentingi specialistai" [4.63, p. 2].

Atèjo Gegužès 1-oji. Instituto žmonès buvo „paprašyti“ dalyvauti „darbo žmoniu demonstracijoje“. Pavasarišką, saulètą dieną kaito nuo saules spindulių veidai, atrodytų, saule lyg buvo karštesnè, intensyvesne. Tik kitą dieną tapo žinoma - branduolinè katastrofa Ukrainoje.

1986 m. balandžio 26 d. sprogimas šalia Kijevo esančioje Černobylio atominëje elektrinëje ją sugriovè. I atmosferą jau kelinta diena išmetami dideli radiacijos kiekiai. Ir visa tai nuslepta nuo visuomenes, nuo „taip mylimos ir gerbiamos tarybines liaudies".

Radiacija pasieke Skandinavijos šalis ir tik tuomet pasaulis sužinojo apie katastrofą. Neaplenke radiacija ir Lietuvos. Štai kodèl raudo veidai ir ypač skruostai privalomosios demonstracijos dalyviams. Tai, kad buvo nuslepta informacija apie katastrofą nuo žmonių - vienas iš didelių komunistinio režimo nusikaltimu.

Dabar jau žinome, kad del Černobylio katastrofos mire per 15000 ir serga apie 50000 žmoniụ!

Labai ilgai trukęs Černobylio katastrofos nutylëjimas gerokai sumenkino "perestroiką“ ir M. Gorbačiovo šiaip nelabai kokị tuometini prestižą. Gal todèl imta vis daugiau deklaruoti viešumo būtinumą - vis dažniau girdima "glasnost“.
Gegužei baigiantis buvo paskelbtas TSKP CK projektas - kaip pertvarkyti aukštąji ir specialųji vidurinį mokslą. Paskelbtose pagrindinèse pertvarkos kryptyse buvo teigiama, kad reikia iš pagrindu pagerinti specialistų profesini ir marksistini lenininį rengimą. Projekte buvo pažymèti mokyklų darbo trūkumai ir nurodyti keliai padèčiai pagerinti.

Manifesto tipo dokumentas nieko gero nežadejo. Tos pačios, jau girdetos frazès, neparemtos žmonių iniciatyva, buvo svarstomos su tam tikra nuobodžia monotonija, niekas jomis netikejjo. Propagandinis partijos išteklius buvo išsemtas. Ką nors pakeisti buvo galima tik radikaliomis priemonemis, išlaisvinant visuomenes iniciatyvas nuo partinio ir valstybinio diktato. Bet vis dèlto M. Gorbačiovas, pabandęs ribotai demokratizuoti didžiulę šalì, išleido džiną iš butelio: žmonès pradejo kalbeti drąsiau, ir pagaliau, kaip sake pats M. Gorbačiovas, „proces pašol“ (procesas pajudejo).

$1986 \mathrm{~m}$. vasarą buvo sukomplektuota 20 studentų statybinių būrių, kuriuose dirbo 526 studentai. Buvo atlikta darbų už 1,22 milijono rublių.

1986-1987 mokslo metus Vilniaus inžinerinis statybos institutas pradejjo iškilmèmis Vidaus reikalų ministerijos kultūros rūmuose. Buvo ịprastine oficialioji dalis, koncertas. Jis tapo skandalu rytdienos rektorato posedyje.

Vieną koncerto programos numerių atliko tuomet dar nežinomas dainininkas. Jam akomponavusi vokalinè instrumentinè grupe naudojosi fonograma, kai kurių rektorato narių manymu, atliekama buvo per garsiai, vokalistą užgoždavo instrumentai, dainininko tartis neaiški. Ne visiems patiko muzikos stilius. Bet labiausiai papiktino valdžią tai, kad vokalistas iki puses buvo išsirengęs, o dainavo užsilipęs ant stalo! Sprendimas aiškus - netoleruoti, ansambli paleisti.

Likimo ironija - sako, kad tai buvo Andrius Mamontovas. Po kelių metų, jau po tarnybos sovietineje armijoje, jis tapo vienu iš populiariausių Lietuvoje popmuzikos atlikejų! Tebera populiarus ir dabar.

Rektorius A. Čyras, apibendrinęs rektorato narių pasisakymus, pareiške, kad „vadovas nieko nepadare šio ansamblio meniniam, auklejamajam ir estetiniam lygiui pakelti. Su juo bus nutraukta darbo sutartis ". Taip ir padarè. Suprantama, instituto vadovas padare tai teisetai. Bet gi ne viskas, kas teiseta, yra 
VILNIAUS

INŽINERINIS STATYBOS

INSTITUTAS

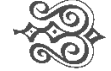

teisinga... (liaudies išmintis). VISI vèl liko be vokalinio instrumentinio ansamblio.

Rugsëjo pradžioje buvo ir dar liūdnesnių dalykų. Rugsejjo $9 \mathrm{~d}$. Minske automobilio avarijoje žuvo du talentingi jaunimo vadovai - vyras ir žmona Vaidilute Gudavičiené ir Romas Gudavičius. Vaidilute - Šiaulių pedagoginio instituto Klaipedos filialo absolvente, Rimas - VISI Statybos fakulteto absolventas. Abu jie daug nuveike, kad atsirastų ir gyvuotų studentiškoji kavine „Visyte“ (vèliau vadinta „Studija“), jaunimo estradinès muzikos festivaliai „Opus“, saviveikliniai kolektyvai „Hiperbole“" ir "Saules laikrodis“, studentų pamegtosios diskotekos ir kt.

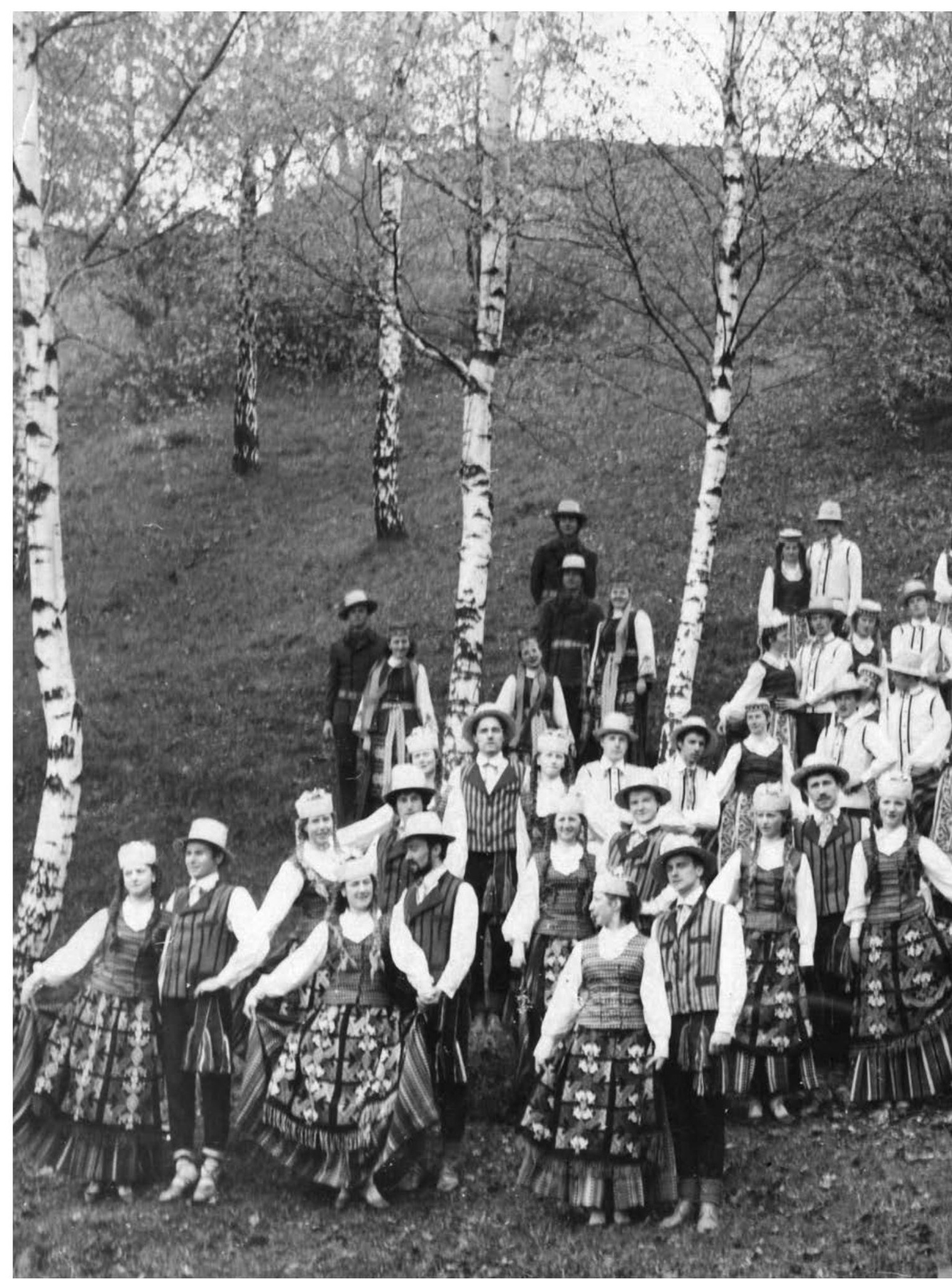


1986-1987 mokslo metu studentu pirmojo kurso komplektavimo klausimas rugsèjo pabaigoje buvo apsvarstytas Aukštojo ir specialiojo vidurinio mokslo kolegijoje. Iš viso Lietuvoje ị dieninius skyrius buvo priimti 8975 studentai, o prašymu priimti gauta 14300 , taigi 1,64 prašymo į vietą. Di- džiausi konkursai tuomet buvo Kauno medicinos institute $-3,3$, Valstybiniame dailes institute $-2,9$, Vilniaus universitete $-2,3$ prašymo į vietą. Mažiausi konkursai - po 1,1 prašymo ị vietą buvo Kauno politechnikos, Vilniaus inžineriniame statybos institutuose bei Lietuvos veterinarijos akademijoje.

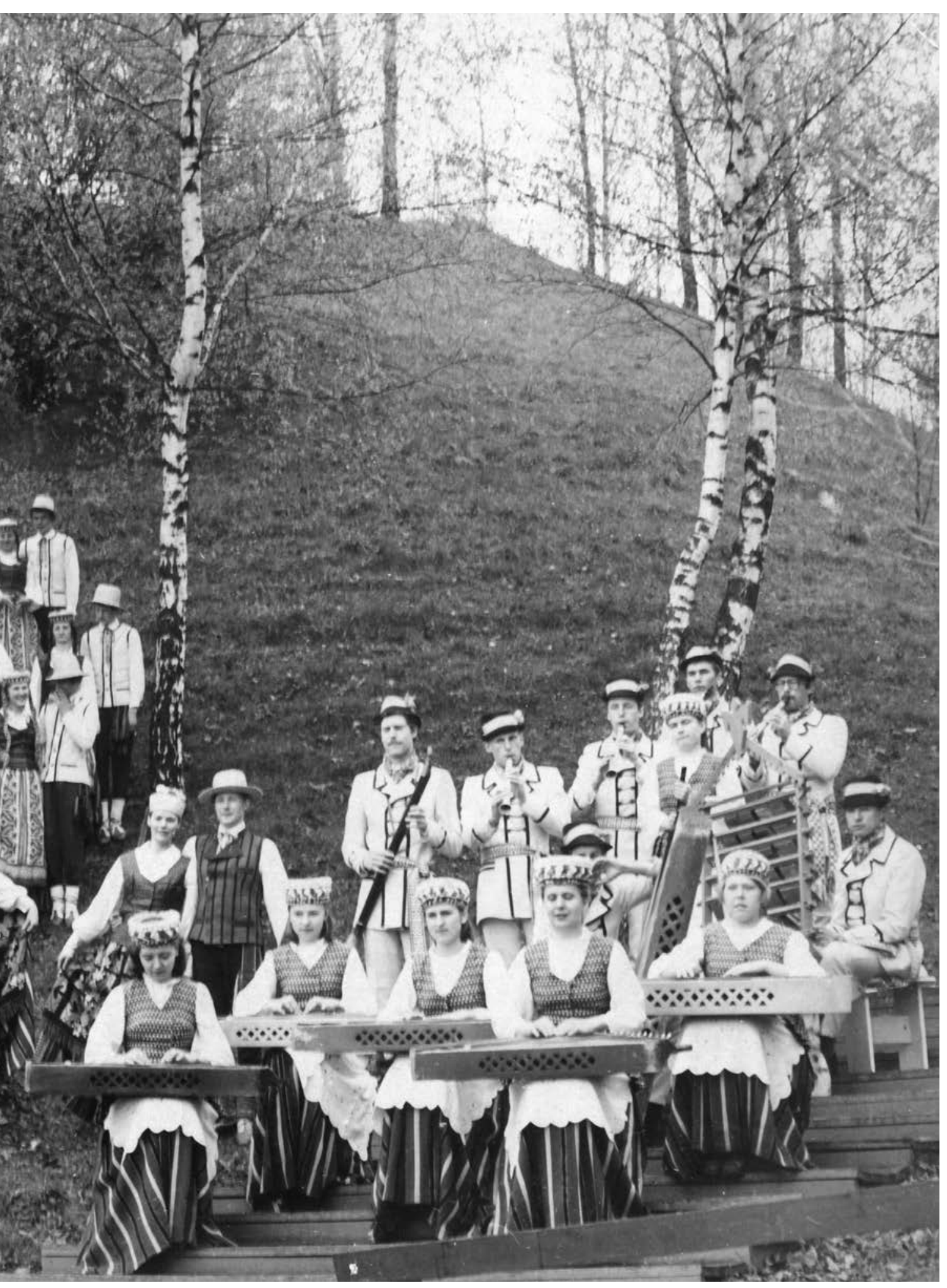


VILNIAUS

INŽINERINIS STATYBOS

INSTITUTAS

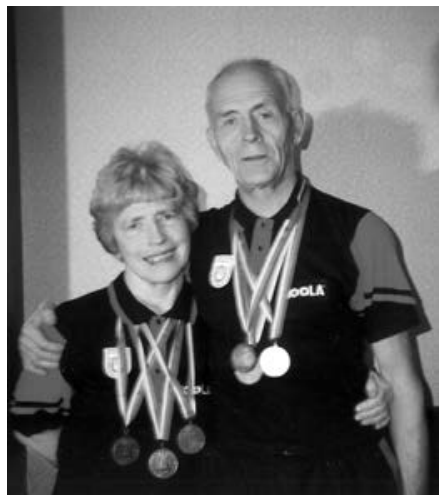

H. Sausenavičius su žmonaVISI destytojai
Tokie nedideli konkursai $\mathfrak{i}$ inžinerijos specialybes kèle didelį susirūpinimą instituto vadovams. Dèl mažos konkurencijos i institutą ístodavo dauguma silpnai baigusieji vidurines mokyklas ir tai veliau skaudžiai paveikdavo studentų pažangumą. Iš įstojusiųjų kas ketvirtas dèl nepažangumo palikdavo institutą. Todel rektoratas ieškojo būdų gerinti moksleiviu profesinį orientavimą, propagandinį darbą mokyklose, kaip sudaryti geresnes galimybes stojantiesiems lankyti parengiamuosius kursus.

Prof. Vytautas Liutikas bandè nustatyti trūkumus, kuriuos pirmakursiai atsineša i aukštąją technikos mokyklą. Instituto dèstytojams tenka užkamšyti tas moksleivių rengimo spragas, kurios liko iš vidurinès mokyklos. Štai kokias silpnų žinių priežastis įvardijo V. Liutikas: 1) bloga pirmakursiu adaptacija $(24,1 \%)$, nenoras mokytis $(12,8 \%)$, valios stoka rimtai studijuoti $(41,2 \%)$, nesugebéjimas derinti studijų su visuomenine veikla $(4,9 \%)$.

Prof. Vytautas Šernas teige, kad studiju procese ypač svarbus dèstytojo vaidmuo. Dèstytojas ,turi sudominti, patraukti studenta, ugdyti jo mastyma, gebejima bendrauti, nugaleti savo silpnybes, racionaliai, operatyviai dirbti, nuodugniai nagrineti iškilusias problemas, išmokti nuosekliai destyti savo mintis. Destytojo asmenybe, sakoma, formuoja būsimo inžinieriaus asmenybę, charakteris - charakteri, valia - valia, dalyko pomegis - darbo, savo specialybes pomegi. Aukstosios mokyklos destytoju ir studentu kolektyvu geda, jei instituta baigia tokie, kurie nemegsta savo büsimos specialybès. Vadinasi, nesveikas studentu grupes psichologinis klimatas, destytojai neugdo savo dalyko pomegio, susidomejimo juo " [4.64, p. 1].

Maloniai nustebino gražia pergale aukštụjų mokyklų spartakiadoje VISI stalo tenisininkai, laimëję komandinę pergalę. Aukso medaliai buvo itteikti šiems visuomeniniais pagrindais dirbančio trenerio docento Henriko Sausenavičiaus aukletiniams: I. Godbergui (SI 5/2 gr), E. Brazauskui (AT 1/2 gr.), S. Skrinskui (AK 4/1 gr.), D. Sadauskaitei (A 5/1 gr.), E. Bučiūtei (SE 2/4 gr.).

Puikiai pasirodè asmeninèse varžybose Igoris Goldbergas, tapęs Lietuvos aukštuju mokyklų stalo teniso čempionu. Bronzą laimejo Egidijus Brazauskas.
Sporto klubo „Inžinerija“ pirmininkas P. Jasaitis rašè „Inžinerijoje“: „Žaidëju ryžtas ir trenerio, braižybos katedros docento H. Sausenavičiaus, dirbančio visuomeniniais pagrindais, pasiaukojamas aštuoneriu metu darbas dave gerus vaisius. Dar 1978 metais jis tapo stalo tenisininku sekcijos globeju. <...> is paprastos studentu sekcijos susiformavo žinoma respublikoje komanda, sudaryta iš meistrišku sportininku (7-pirmaatskyrininkai, 7-kandidatai i sporto meistrus), o I. Goldbergas pakviestas $i$ respublikos studentu rinktine dalyvauti Pabaltijo aukstuju mokyklu pirmenybese. Grižtant prie paskutiniu pirmenybiu, tenka apgailestauti, kad treneris negalejo pasidžiaugti šauniojo penketuko pergale, nes darbavosi rudens talkose. Keista, ar ne? O taip norejosi paspausti jam "dešinę "ir nuoširdžiai padekkoti už pasiaukojima sportui, studentams, $u \check{z}, j$ juoda darba". Niekas nesuskaičiavo trenerio telefono skambučiu, pasirašytu raštu, vestu derybu, kai reikejo... atstovauti instituto garbei.

Gerbiamas docente, sporto entuziaste, dekojame Tamstai. Sporto klubas linki Tamstai stiprios sveikatos, darbo sekmés ir nauju sporto pergaliu" [4.65, p. 2].

Bet kurioje veiklos srityje žmogus daugiausia pasiekia, jei yra entuziastas. Gerai, kai tokie žmonés pastebimi, skatinami. Deja, taip būna ne visuomet.

1986 m. rugsëji, kaip ir kiekvienais metais, per 1000 studentų, daugiausia pirmakursių, buvo išsiųsta dirbti žemès ūkio darbų. Išsiuntè ir visuomeninį trenerį $H$. Sausenavičių, nors vyko spartakiada. Kitas gal būtų ir metęs ši taurų darbą, bet $\mathrm{H}$. Sausenavičius - valingas, ištvermingas žmogus, tuomet ne tik ištverè nuoskaudą, bet ir toliau sèkmingai ugdo mūsų stalo tenisininkus, praëjus net 30 metų. Ir jo darbą vainikuoja šaunios augintinių pergalès. Tai žmogus, nusipelnęs dideles pagarbos ir įvertinimo.

Spaliui besibaigiant ministerijos kolegija svarste 1986 m. specialistų laidos planų ìvykdymą.

VISI planą îvykdè $(101,1 \%)$, bet buvo kritikos, kad $3 \%$ diplomantų neapgyne diplominiu projektu, kad kas ketvirtas diplomantas tik patenkinamomis žiniomis baigè institutą.

Kritikavo VISI už tai, kad 1985-1986 mokslo metais buvo nemažas studentų nubyrejimas $-7,4 \%$. Bet norint pagerinti rengiamų specialistų kokybę, tenka didinti reikalavimus studentams. Žinoma, silpniau pasirengę arba ne tokie gabūs neišlaiko 


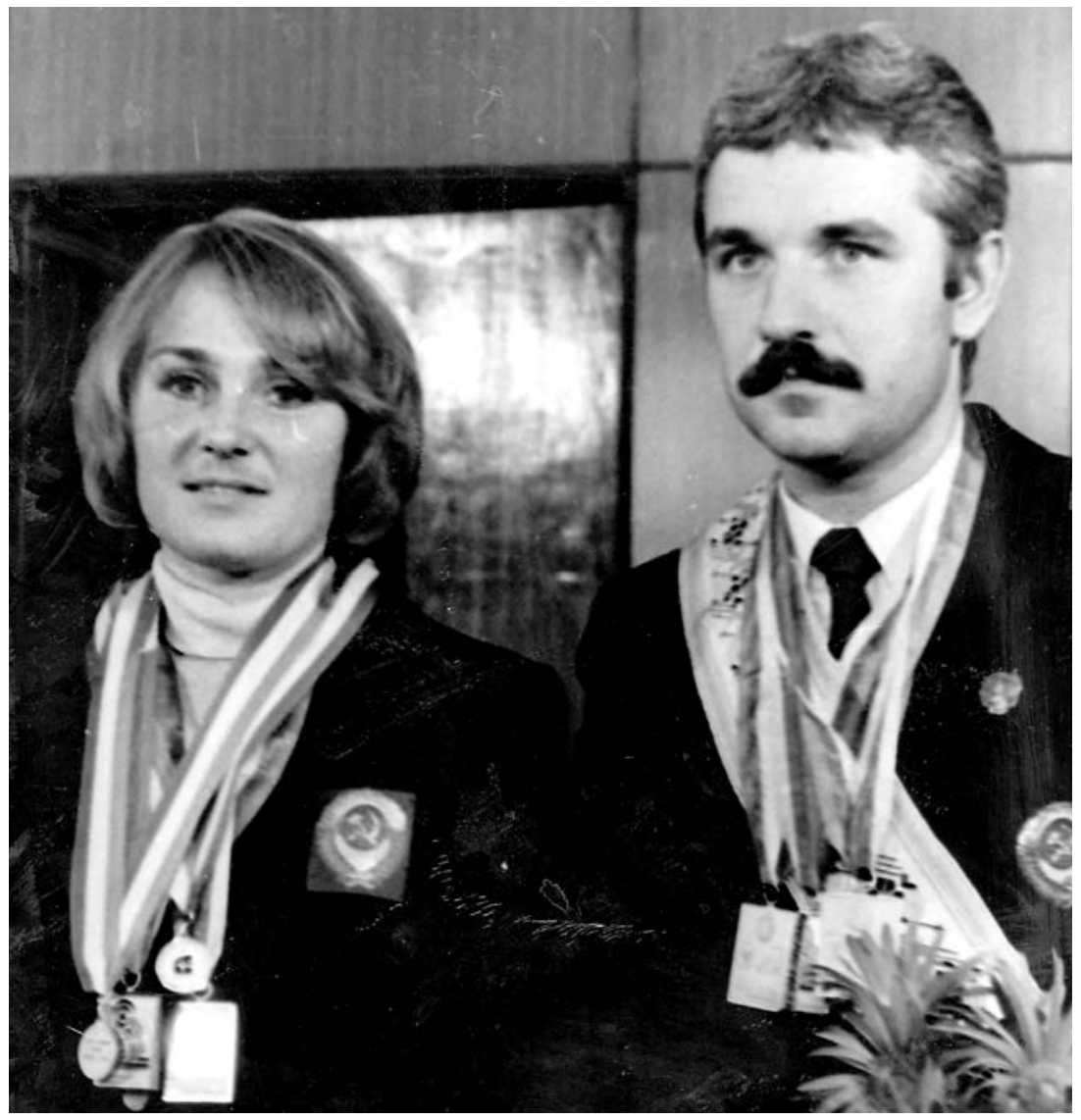

studiju ịtampos ir „nubyra“. To išvengti niekada nebuvo ir nebus įmanoma.

Vis delto dauguma studentu puikiai studijavo, rasdavo laiko sportui, menui, moksliniam darbui. Doc. R. Pocius „Inžinerijoje" rašè, kad Automatizacijos fakultetas džiaugiasi studentų mokslinès techninès draugijos narių darbo rezultatais: „Nemažai radiotechnikos bürelyje subrendusiu specialistu inžinieriu pasuko mokslo keliu. Pavyzdžiui, buvęs sajunginio studentu mokslo darbu konkurso nugaletojas J. Stankūnas ǐ̌pletojo savo studiju mokslo tiriamojo darbo tema ir apgyne kandidato disertacija. Dabar jis sèkmingai vadovauja katedros mokslinei laboratorijai, Sajunginio konkurso laureatas J. Skardžius jau baigia rašyti disertacija, mokslo tiriamaji darba katedroje tesia jaunesnysis mokslinis bendradarbis S. Mackevičius, inžinierius V. Urbanavičius" [4.66, p. 3].

Gražiai pasirodè Architektūros fakulteto studentai Armènijoje. Jerevano politechnikos instituto Architektūros fakulteto surengtame konkurse „Vaikų žaidimo aikštelès" tris premijas gavo VISI atstovai: I premiją - G. Tamulevičiūtè, A 3/1 gr., II premiją - S. Slavinskas, A 3/1 gr., III premiją-M. Sudžiūté, A $2 / 1 \mathrm{gr}$.

Instituto vadovybè daug dèmesio skyre studentu gamybinèms praktikoms. Tam buvo skirtas ir VISI rektorato $1986 \mathrm{~m}$. gruodžio $12 \mathrm{~d}$. posèdis.

Buvo pranešta, kad VISI studentai 1986 m. gamybines praktikas atliko 133 praktikų bazese Lietuvoje ir 12 - už respublikos ribų. Dauguma trečio kurso studentų gamybinès praktikos metu buvo įdarbinta, o $73 \%$ praktikantų gavo darbininkių kvalifikacijos kategorijas.

Rektoratas nutare, kad dera rimčiau kontroliuoti praktikų eigą, sustiprinti reikalavimus praktikų ataskaitų parengimo kokybei, organizuoti praktiku konferencijas.

Naujujų metų išvakarese rektoratas susirūpino dauginimo aparatų ir mašinų naudojimu. Garbačioviškoji pertvarka kiek atleido cenzūros varžtus ir, matyt, tai sukèle KGB didelių rūpesčiu. Daugëjo nelegalios literatūros, neretai galejai matyti žmones turint disidentu rašiniu kopiju. Taigi VISI rektoratas, turbūt KGB paliepus, gruodžio $22 \mathrm{~d}$. svarste tos aparatūros naudojimo tvarką. Posedyje pažymeta, kad „dauginimo darbas teisingai organizuotas tik operatyvines poligrafijos laboratorijoje ir bibliotekoje. Sie padaliniai turi dauginimo masinu ir aparaty naudojimui ir darbui su jais specialius leidinius, juose tvarkingai vedama juykdyto darbo apskaita " [4.67, p. 43]. Buvo uždrausta naudoti dauginimo mašinas ir aparatus be specialių leidimų. 
VILNIAUS

INŽINERINIS STATYBOS

INSTITUTAS

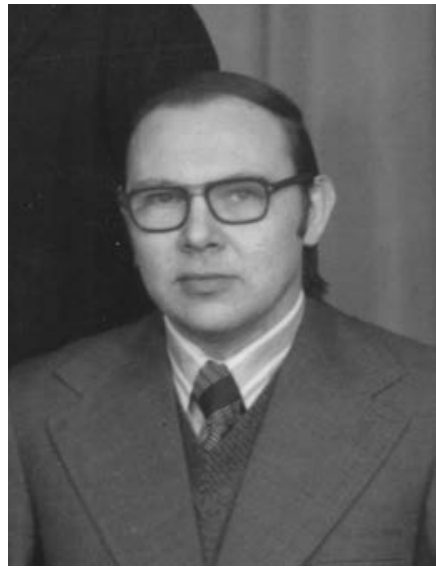

1987 m. E. K. Zavadskas apgyne habilituoto daktaro disertacija
Kai palyginame šią situaciją su dabartimi, net sunku suvokti tų laikų marazmą. Dabar ịvairiausių dauginimo aparatų rasi vos ne kiekviename kabinete, daugelis turi jų ir namuose. O prisiminti netolimą praeitị labai verta - tuomet turima laisve išties saldesne, brangesnè.

1987 m. pradžioje VISI paskelbe apie prièmimą studijuoti nuo 1987-1988 mokslo metu pradžios. Buvo numatyta priimti studijuoti i pirmą kursą 1450 žmonių: 925 - i dienines studijas, $325-i \mathfrak{i}$ vakarines studijas ir 200 - i neakivaizdines studijas. Architektūros fakultete buvo tik viena - dieninių studiju architektūros specialybe ir ì ją planuota priimti 50 žmonių. Statybos fakultetas skelbè priemimą i dvi specialybes, abi dieninių studijų: $300-i \mathfrak{i}$ PCS ir 25- $\mathfrak{i}$ statybos (inžinierių pedagogu). Miestu statybos fakultetas turejo tris specialybes. I miestų statybos ir taikomosios geodezijos specialybes numatyta priimti po 50 žmonių i dienines studijas bei $25-i$ neakivaizdines studijas.

Mechaninès technologijos fakultetas planavo priimti i penkias specialybes. I automobilių ir automobiliu ūkio specialybę iš viso 150 žmonių: dieninių studijų - 100, vakarinių studijų - 25 ir neakivaizdinių studijų - 25 žmones. I metalo gamybos technologijos, metalo pjovimo staklių ir įrankiu specialybès tik vakarines studijas - 75 žmones. İ suvirinimo įrenginiu ir technologijos specialybès tik dienines studijas - 50 žmonių. İ statybos ir kelių tiesimo mašinų bei įrenginių specialybę - 50 žmonių dieninių studiju ir 25 - neakivaizdinių. İ automobilių transporto ekonomikos ir organizavimo specialybe iš viso 75 žmones: po 25 į dienines, vakarines ir neakivaizdines studijas.

Statybos ekonomikos fakultetas pasiūlè stojantiesiems dvi specialybes. İ statybos ekonomikos ir organizavimo specialybes dienines studijas - 50 žmoniu ir po 25 i vakarines ir neakivaizdines studijas. I pramonines ir civilinès statybos specialybès vakarines ir neakivaizdines studijas - po 50 žmonių.

Automatizacijos fakultetas planavo priimti studijuoti ị radijo aparatūros konstravimo ir gamybos specialybes vakarines studijas 75 žmones ir pramonès įrenginių elektros pavarų ir automatizavimo specialybes vakarines studijas - 50 žmonių.
I planuojamą Santechnikos fakultetą paskelbtas priemimas i dvi specialybes. I šilumos, dujų tiekimo ir vedinimo specialybes studijas planuota priimti 75 žmones, i vandentiekio ir kanalizacijos specialybes dienines studijas - 50 ir neakivaizdines studijas - 25 žmones.

İdomių minčių apie abiturientų kelią instituto laikraštyje išdèste VISI Matematikos katedros vedejjas doc. V. Liutikas. Štai kai kurios jų: „Kad studentui kelias $\underset{i}{ }$ aukstaji moksla nesibaigtu skausmingu nusivylimu, būtina pirmiausia pačiam abiturientui labai rimtai ir atsakingai pasverti visus tuos objektyvius rodiklius, kurie rodo, kiek iš tikruju esi pajegus pasiekti pasirinkta specialybe <...> Ir, tarkime, jeigu atestatas pilnas trejetu, tarp kuriu pasitaiko tik vienas kitas ketvertas ir penketas, tai kokia kalba čia gali büti apie aukštojo mokslo studijas. Net ir geras atestato vidurkis ne viska pasako. Tarkime, abiturientas ryžosi meginti studijuoti VISI, nes atestato vidurkis gerokai pranoksta ketverta. Tačiau šiuo atveju nepakanka džiaugtis tik atestato vidurkiu. Inžineriniai mokslai pirmiausia remiasi matematika, braižyba, fizika. Ir, tarkime, jeigu abiturientui, nors ir turinčiam pakankamai gera atestato vidurki, tame pačiame atestate is minetu mokomuju dalyku irašyti tik trejetai, tai jis menkas kandidatas inžineriniams mokslams studijuoti, <...> neretai nepakankamai apgalvotai pasirenkama aukštoji mokykla arba kokia nors jos specialybe. Pasirenkama, nesiskaitant nei su mokyklos, nei su profesinio orientavimo specialisty nuomone" $[4.68,1.1]$.

Tenka pripažinti, kad per daugelị metų aptariama situacija ne tik nepagerejo, o gal dar ir pablogejo. Tai skaudžiai paveikia rengiamų specialistų kokybę, nes jei specialybė pasirenkama neatsižvelgiant į savo prigimti pagal valios ir charakterio bruožus, pagal svao gabumus ir polinkius - gero specialisto nèra ko laukti.

1987 m. balandį rektoratas svarste visuomeninio maitinimo institute klausimą. Pažymeta, kad pagal normas reikia 680 vietu studentiškose valgyklose, 50 vietų - déstytoju valgykloje, 110 vietu - dietinëje valgykloje, 160 vietų studentų bufetuose, 60 vietu dètytojų ir darbuotojų bufetuose. Bet faktiškai VISI turejo tik 336 vietas, vietoj 1060 reikalingu.

Prastas buvo valgyklų ir bufetų valgiu asortimentas, kokybe, nekokia aptarnavimo kultūra. 
Visa tai ir ypač pustuštés miesto parduotuvès kèle dideli profsąjungos komiteto susirūpinimą. Šio komiteto narys painformavo, kad padèčiai centriniuose rūmuose pagerinti rengiamasi atidaryti maisto produktu parduotuvę, destytojų ir darbuotojų kavinę.

Neliko be demesio pavasario semestro mokslinių tiriamųjų darbų reikalai.

Gelžbetoninių konstrukcijų katedra daug nuveike kurdama ar tobulindama statybines konstrukcijas. Prof. A. Kudzys pažymëjo, kad per penkerius metus katedra padave 15 paraiškų išradimams ir gavo 4 autorinius liudijimus. Sukurtos arba patobulintos 9 gelžbetoninès konstrukcijos.

Metalinių konstrukcijų katedra pateike 6 naujus konstrukcinius sprendimus. Per penkerius metus Baltarusijoje Bobruisko miesto „ŠEC-2“ termofikacinès katilinès karkasui buvo sukurtos centrifuguoto skerspjūvio kolonos, daug dirbta diegiant klijuotojo medžio konstrukcijas Lietuvos statybose.

Buvo pasidžiaugta nauju mokslo darbų leidiniu - išleistas pirmasis rinkinio „Automobilių transportas" numeris.

Didelę netekti patyre institutas $1987 \mathrm{~m}$. vasarą. Staiga mire Mašinų teorijos katedros vedejas, technikos moksly daktaras profesorius Antanas Kavolelis. Jis suformulavo naują perspektyvią mokslo kryptį: specialių mechanizmų ir įrenginių konstrukcijų, veikiančių išscentrinių jègų principu, kūrimas ir teorinis pagrindimas. Jo vadovaujami moksly̨ kandidatais tapo H. Norvilas, B. Spruo- gis, J. Jurevičius, V. Turla, E. Jurkonis. Jis paskelbe per 280 mokslinių straipsnių TSRS ir užsienyje, parašè 2 monografijas, padare per 90 išradimų, gavo 3 užsienio patentus. Jis buvo pirmojo gauto VISI mokslininko užsienio patento autoriumi. Buvo talentingas mokslininkas, santūrus, kuklus, geras žmogus, puikus vadovas.

1987-1988 mokslo metų iškilmingas atidarymas įvyko Vidaus reikalų ministerijos kultūros rūmuose, dalyvaujant pirmojo kurso studentams, desstytojams, nemažam būriui svečių, daugiausia iš statybos profilio ministeriju.

Rektorius A. Čyras pranešè, kad naujuosius mokslo metus VISI pradeda turedamas 5824 studentus: 3375 - dieniniame skyriuje, 1043 - vakariniame skyriuje ir 1281 - neakivaizdiniame skyriuje. Rektorius džiaugesi, kad šiais mokslo metais VISI iš viso bus baigę, skaičiuojant nuo $1970 \mathrm{~m}$., jau beveik 18000 žmonių.

I institutą vasarą buvo priimtas planinis dieninių ir neakivaizdinių studiju žmonių skaičius - 925 ir 200, o ị vakarines studijas 125 mažiau - tik 200 žmonių.

Vilniaus inžinerinis statybos institutas ir toliau liko vyriškas. Vyrai sudare $74,5 \%$ visų priimtuju studijuoti.

Rektorius kviete rimtai mokytis. Sake, kad pirmūnams numatytos gerokai didesnès nei anksčiau stipendijos. Jos bus didesnès $50 \%$. Kas mokysis be trejetu, gaus $25 \%$ didesnę stipendiją.

\section{Ikuriamas Komunalinio ūkio fakultetas}

Nuo 1987 m. rugsejo $1 \mathrm{~d}$. Vilniaus inžineriniame statybos institute buvo ikurtas Komunalinio ūkio fakultetas. Institute buvo 7 fakultetai: Architektūros, Statybos, Inžinerines ekonomikos, Miestu statybos, Komunalinio ūkio, Mechaninès technologijos ir Kvalifikacijos tobulinimo.

Bene pirmą kartą rektorius prabilo apie rektoriaus rinkimus. Jis sake, kad studentai sudarys ketvirtadalį instituto tarybos, o rektoriaus rinkimuose - net trečdalị.

Visa tai buvo gorbačioviškos „perestroikos" atspindžiai. Realus gyvenimas buvo kiek kitoks.

Rugsëjo 11 d. mire iki 1987 m. buvęs Architektūros fakulteto dekanu, Architek- tūros katedros vedëju architektūros daktaras profesorius Antanas Spelskis. Jis buvo dirbęs Valstybinio statybos ir architektūros reikalų

Komunalinio ükio fakulteto atidarymas

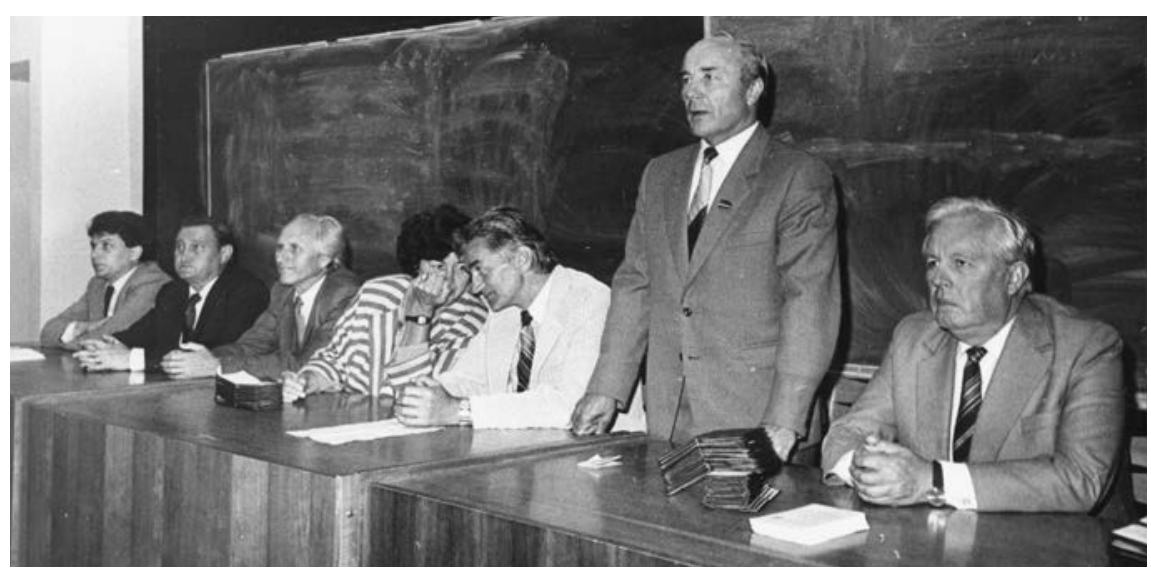


VILNIAUS

INŽINERINIS STATYBOS

INSTITUTAS

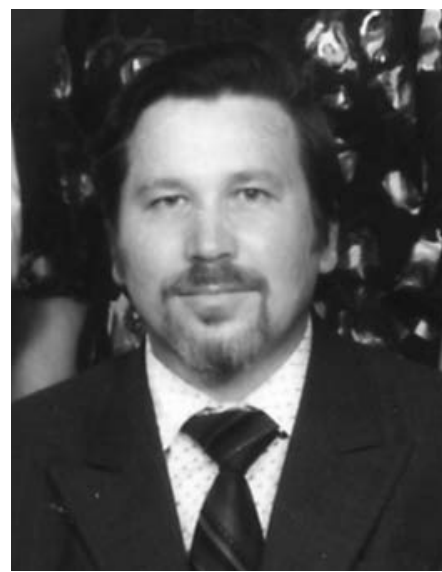

J. Mureika

Viršuje dešineje -

Aukštadvario bazeje $1987 \mathrm{~m}$.

Dešinëje - L. ̌̌epetys komiteto pirmininko pavaduotoju, Miestu statybos projektavimo instituto vyriausiuoju architektu, kurị laiką dèste Vilniaus dailes institute. Paskelbe per 70 darbų, straipsnių urbanistikos ir architektūros klausimais.

1987 m. rudenịivykusiame VISI bendruomenés susirinkime buvo daug ir atvirai kalbeta apie įvairias instituto problemas. Apie tai plačiai parašè instituto laikraščiui doc. V. Dičius. Pateikiame kai kurias šio straipsnio ištraukas:

„Institutas yra Vilniaus pakraštyje, kurnera parduotuviu, viešojo maitinimo istaigu, todel profkomitetas daug demesio skiria valgyklu, bufetu darbui gerinti, prekybai plesti. Veiksmingai padedant administracijai, centriniuose rümuose bus atidaryta maisto produktu parduotuve (parduotuve buvo atidaryta birželio 16 d. - red. pastaba), pradeta bufeto rekonstrukcija, tačiau valgyklu ir bufetu vietu skaicius sudaro tik $32 \%$ normatyvinio, neišspręstas maitinimo klausimas šeštadieniais, vakarais. Noretusi, kad prekyba kulinarijos gaminiais vyktu ne epizodiskai, o nuolat. Bütina ir efektyvesne instituto pagalba įtaigoms.

Darbuotoju sveikatingumo analize rodo, kad $1986 \mathrm{~m}$. buvo 946 susirgimo atvejai. Nedarbingumo lapeliais pateisinta net 9819 darbo dienu. Tiek susirgimu dar nera buve. 1300 darbo dienu praleista del kvepavimo organu ligu. Priežastys - ir šaltos patalpos, skersvejai, ir tai, kad per didžiausius šalčius 5 ir 14 maršrutu autobusai kursuoja neapšildomi. Kita vertus, gal per mažai stengiames, kad būtu pratęsta troleibusu linija. Reikia gerinti ir medicinini aptarnavima. Institutas pajegus irengti stomatologini kabineta, būtina aprūpinti skyrius, katedras vaistinelemis, pirmosios pagalbos priemonemis. Blogai, kad institute neveikia moters higienos patalpos.

Ypač opi butu problema. Šiuo metu komunaliniu butu reikia 48 darbuotojams, kooperatiniu - 56. Reikia ieškoti nauju keliu ir šiai problemai spręsti. Gal yra galimybe gyvenamuosius namus statyti $\bar{u} k i o ~ b u \overline{d u}$, kooperuoti valstybines ir darbuotoju lěsas, panaudoti dali ukiskaitiniu darbu pelno ir pan. Verta pasvarstyti ir mus šefuojančiu statybiniu organizaciju duris, paieškoti galimybiu gauti iš ju jei ne gatavus butus, tai gal lésas, fondus ar limitus. Juk specialistus ruošiame jiems.

Daug problemu iškyla, organizuojant vasaros poilsi. Dauguma darbuotoju nori ilsetis

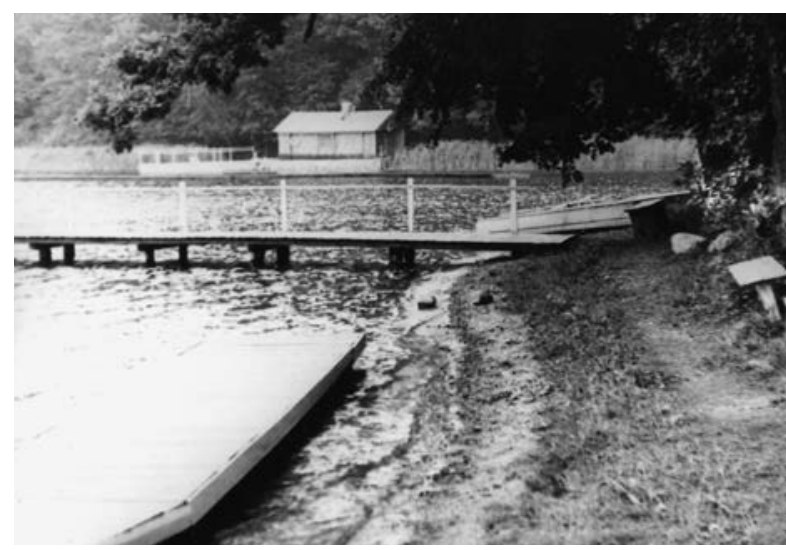

pajūryje, ir tik liepos ar rugpjūčcio menesiais, o mūsu galimybes menkos - 28 vietos "Lino" ir 7 vietos "Neringos" poilsio namuose Palangoje, dar 38 vietos samdomos privačiuose namuose ir tos profsajungai labai nuostolingos.

Turime nedideles poilsiavietes prie Pakaso, Lavyso ežeru, Aukštadvaryje. Tačiau šios bazes, ypač prie Lavyso ežero, laukia skubaus remonto, o ir ju panaudojimo poilsiui efektyvumas menkas. Reikia išnagrineti galimybe organizuoti pionieriu stovykla Aukstadvaryje, poilsio organizavima svaitgaliais.

Mūsu institutas - vienintele respublikos aukštoji mokykla, neturinti nuosavos poilsio bazes pajūryje. Šiuo metu ieškoma galimybiu rekonstruoti laikinai nuomojama Neringos mišku ükio nama Nidoje, išplečiant ji iki 3040 vietu, 11 vietu išsaugant mišku ükiui. Jei institutas atliks savo isipareigojimus, už poros metu, rekonstravus Palangos "Agilos" poilsio namus, kasmet gautume 32 vietas juose. Deja, neatsiranda vadovo studentu statybos büriui vasara Palangoje, nera žmoniu, norinčiu projektuoti" $[4.69,1.2]$.

Bendruomenes susirinkime, kuri organizavo darbuotojų profsąjungos Vietos komitetas, aštrios diskusijos vyko daugiausia buities klausimais, o spalio $2 \mathrm{~d}$. naujųjų mokslo metų metodologinių instituto darbuotoju

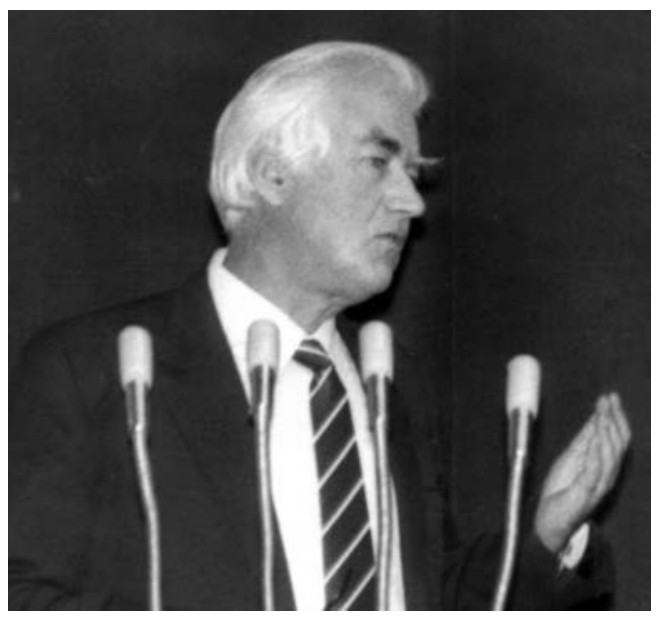




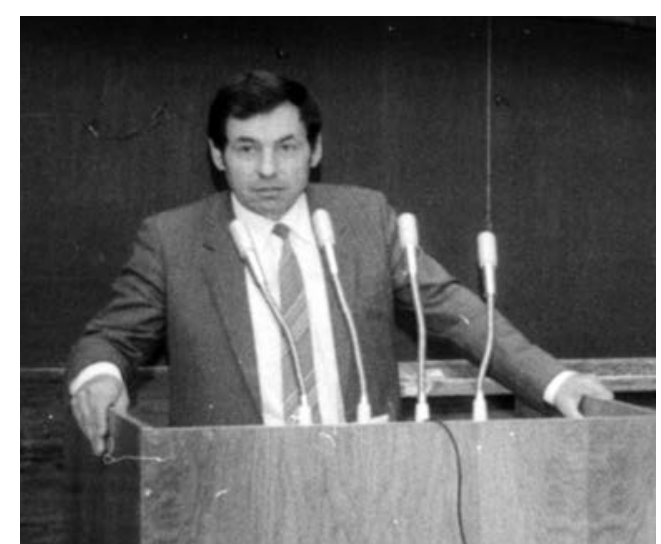

seminaru pradžios proga jau skambejo politinio ir ekonominio gyvenimo kritika.

Renginyje kalbëję VISI profesoriai Juozas Mureika ir Kazimieras Antanavičius pabrèžè, kad visu pertvarkymų sékmès veiksnys yra naujai mąstantis ir dialektiškai mąstantis žmogus.

J. Mureika sakè, kad vidiniai prieštaravimai yra esminis žmogaus ir darbo kolektyvų vystymosi ir pažangos šaltinis. „Taigi bütina juos jžzvelgti, nes koreguodami, spręsdami juos galime efektyviau vystyti socialinius, ekonominius, kultūinius ir politinius procesus" $[4.70,1.1]$.

LKP CK ideologui Lionginui Šepečiui, dalyvavusiam renginyje, daugiausia rūpesčio sukèle prof. K. Antanavičiaus emocinga kalba, kurioje jis tvirtino, kad ten, kur nesilaikoma dialektinio mąstymo logikos, ten apie jokius ekonominius problemų sprendimus netenka ir kalbeti. Tai jau buvo taikli komunistų partijos politikos kritika, kas buvo dar labai neįprasta viešajame gyvenime.

L. Šepetys nepuolè į ginčą su K. Antanavičiumi, o sakydamas, kad žmogaus tobulejjimo procese ypač svarbi dialogo pozicija tarp visu socialinès visuomenes narių, lyg ir sutiko su K. Antanavičiumi.

Aukštojo mokslo pertvarkos vienas uždaviniu - skatinti studentus studijuoti savarankiškai. Sąjungine ministerija leido aukštujju mokyklų rektoriams ir taryboms pertvarkyti mokymo planus taip, kad juose dominuoty savarankiškos studijos, o privalomųju paskaitu sumažetu iki 28 valandu žemesniuose kursuose ir iki 24 valandu aukštesniuose kursuose. Buvo leista keisti mokymo planus, egzaminų ir ịskaitų tvarką.

Pirmieji ème daryti permainas Statybos fakultete. Bet studentai liko abejingi tokiai reformai: nesą geros literatūros, per mažai naujoviu gaunama individualaus projektavimo metu, nèra destytojo pasirinkimo laisvès, neleidžiama atsiskaityti anksčiau egzaminų sesijos, neatsižvelgiama ị studentų nuomonę ir t. t.

Rektorius A. Čyras Tarybos posedyje kritikavo Metalinių, Gelžbetoninių bei Pagrindų ir pamatų katedras už per didelę projektų apimti, nes visų trijų projektų suma - beveik diplominis darbas: 117 psl. skaičiavimų ir 5 lapai brežinių.

Studentai skundèsi per didelèmis ir užsienio kalbos užduotimis. Joms atlikti reikią 4 valandu.

Kai kurie Metalinių konstrukcijų katedros destytojai kursinio projekto dalykus aiškina iki pat įskaitų savaites, todèl projekto laiku niekas ir nepadaro.

TSKP istorijos seminarams užduodama labai daug konspektuoti, tam reikia daug laiko. Politinei ekonomijai studijuoti visi rekomenduojami vadoveliai nebetinkami, nes pasenę.

A. Čyras sakè, kad leningradiečiai nustate, jog ị užsièmimus neatvyksta iki $50 \%$ studentų, nes nepatenkinti paskaitų kokybe. Tyrimai rodo, kad nèra neįdomių ir sunkių disciplinų - yra tik nuobodūs ir blogai dèstantys déstytojai.

Studentai pabrèžè, kad labai svarbus yra destytojų objektyvumas. Tokiais Miestų statybos fakulteto studentai nurode doc. O. Vasilecą, doc. A. Raudeliūnienę, vyr. dèst. T. Bilkį.

Taigi gerinant išleidžiamų specialistų pasirengimo inžineriniam darbui kokybę problemų kildavo visokių. Jų turejo ir studentai, ir destytojai.

Taryba priemè nutarimą, kaip gerinti padetį. Ilgainiui paaiškejo, kad mažai kas pasikeite. Norint išmokti, pirmiausia reikia noreti.

Lapkritį VISI pradejo veiklą darbuotojų kultūros klubas. Centrinių rūmų auditorijų korpuse buvo įrengtos patalpos, papuoštos H. Bogdano, A. Keturkos ir A. Dineikos paveikslais.

Klube pirmasis renginys įvyko dalyvaujant Vidaus reikalu ministerijos Kriminalinés paieškos valdybos skyriaus viršininkui A. Sadeckui.

1987 m. rudeni studentai iš kolūkių buvo atšaukti anksčiau, nei buvo numatyta pradžioje. Sąungineje spaudoje, „perestroikos" paskatinti, daugelis autoriu kritikavo studentų darbus vadinamosiose žemès ūkio talkose. Pabrežta, kad studentas per 4 metus praranda vieną semestrą. Buvo siūloma
Kairëje - K. Antanavičius

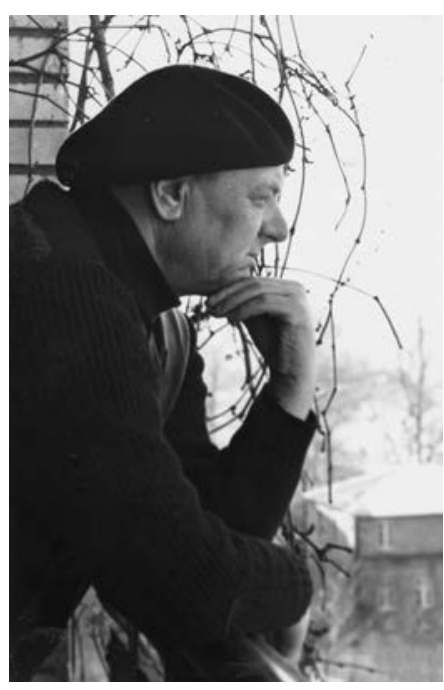

A. Keturka

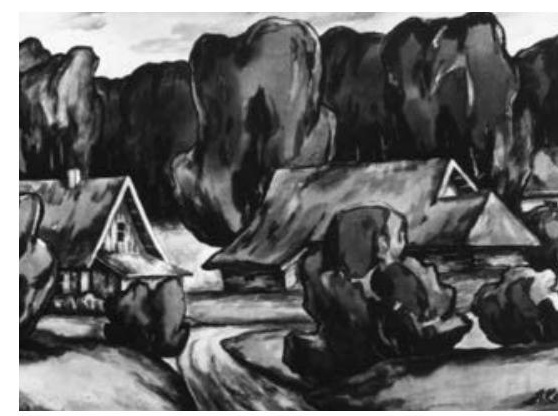

A. Keturkos akvarele

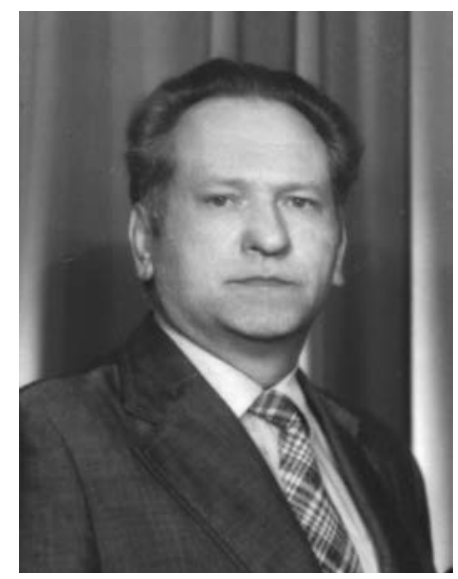

H. Bogdanas 
VILNIAUS

INŽINERINIS STATYBOS

INSTITUTAS

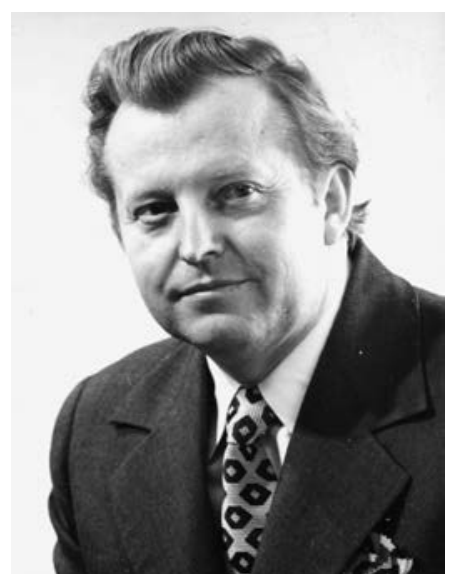

K. Jakovlevas-Mateckis

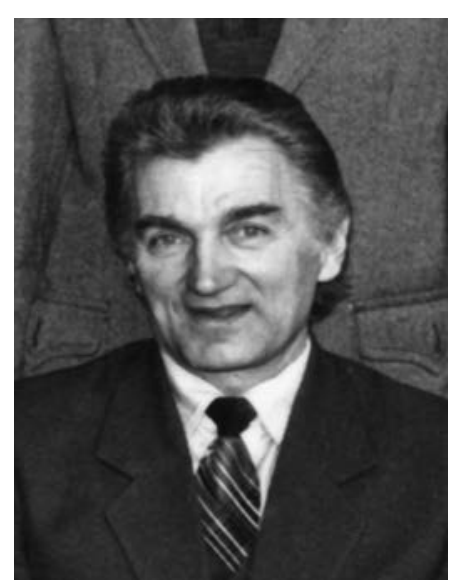

J. Duoba

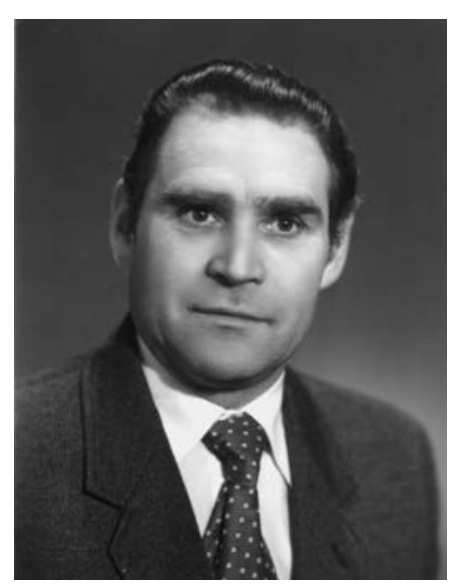

K. Sakalauskas padeti žemdirbiams tik ekstremaliomis sąlygomis.

Buvo daug kalbama apie naujos VISI bibliotekos statybą, bet realių žingsnių ta kryptimi nebuvo, o problema buvo be galo aktuali. Bibliotekos skaitytojai tuomet buvo aptarnaujami trijuose abonentuose ir septyniose skaityklose. Jose buvo tik 270 darbo vietu. Rektorato posedyje prorektorius G. Marčiukaitis sakè: „Ar galima kalbeti apie studentu savarankiska darba, jei jiems neduodame irankasknygos".

1987 m. gruodžio 3 d. staiga mire Dailes katedros docentas Henrikas Bogdanas. Jis dažnai rengè savo puikių akvarelių parodas, jo paveikslai ir šiandien puošia kai kurias VGTU patalpas.

1987 m. gruodžio 7 d. posedyje rektoratas analizavo valstybinių egzaminų komisiju darbą. Buvo pažymèta, kad institutą $1987 \mathrm{~m}$. baige 663 inžinieriai. 184 diplomantų projektus iqvertino „labai gerai“, o tai sudare $28 \%$. Gerą ịvertinimą gavo 322 studentai, arba $49 \%$, patenkinamą - 157, arba $24 \%$.

$60 \%$ diplominių projektų parengta naudojant elektronines skaičiavimo mašinas, $44 \%$ diplominių projektų turejo mokslinio darbo elementu.

Taigi specialistų rengimas vyko visai gerai, nes abejoti komisijų, vertinančių diplominius darbus, kompetencija nebuvo jokio pagrindo.

1987-1988 mokslo metais buvo patvirtintos naujos visų fakultetų Tarybų sudetys.

Architektūros fakulteto tarybą sudarè: pirmininkas K. Jakovlevas-Mateckis - fakulteto dekanas; nariai: J. Vanagas - Urbanistikos katedros vedejas; A. Janulis - Dailes katedros vedëjas; A. Dineika - Architektūros katedros vedëjas; Č. Ignatavičius - Pastatu konstrukcijų katedros vedejjas; R. Pikutis Pastatų konstrukcijų katedros vyr. déstytojas; J. Gajauskas - partinio biuro sekretorius; A. Radzivonas - profbiuro pirmininkas; studentai G. Šernius, D. Jakubauskas ir R. Jaksebogaitè.

Komunalinio ūkio fakulteto tarybą sudare: pirmininkas J. Duoba - fakulteto dekanas; sekretorius Z. Jankauskas - Elektrotechnikos katedros docentas; nariai: A. Liaukonis - Šildymo ir vedinimo kated- ros profesorius; R. Alekna - Hidraulikos katedros docentas; M. Gedgaudas - Šildymo ir vedinimo katedros vedejjas; G. Valiukènas Elektronikos katedros vedejjas. I fakulteto Tarybos posedžius buvo kviečiami partinio biuro sekretorius, profbiuro pirmininkas ir keturi studentų organizacijų vadovai.

Miestų statybos fakulteto tarybą sudare: pirmininkas K. Sakalauskas - fakulteto dekanas; pirmininko pavaduotojas Z. Kumetaitis - Geodezijos katedros docentas; sekretorius J. Skeivalas - Geodezijos katedros vedëjas; V. Jasulaitis - Kelių katedros vedèjas; D. Styra - Fizikos katedros profesorius; V. Tulevičius - Geodezijos katedros vedejas; studente Kleišaitè.

Mechaninès technologijos fakulteto tarybą sudarè: pirmininkas M. Mariūnas fakulteto dekanas; sekretorius A. Samulevičius - Mašinu gamybos technologijos katedros vedejas; nariai: K. Olšauskas - fakulteto prodekanas; V. Mickūnaitis - fakulteto prodekanas; D. Maciulevičius - Taikomosios matematikos ir mechanikos vedejas; V. Turla - Mašinų teorijos katedros vedejas; A. Pikūnas - Autotransporto katedros vedèjas; B. Spruogis - Statybos ir kelių mašinų katedros vedejas; B. Zabotka - Braižybos katedros vedejas; M. Nemira - fakulteto metodines komisijos pirmininkas; $\mathrm{V}$. Tilindis - partinio biuro sekretorius; E. Strumskienè - profbiuro pirmininke; V. Sivilevičius - SMD mokslinis vadovas; studentai A. Katkauskas, G. Piliauskas, E. Daubaras, M. Ždanovičius ir R. Kirilevičius - studentų organizaciju atstovai.

Statybos ekonomikos tarybą sudare: pirmininkas A. Naujokaitis - fakulteto dekanas; sekretorius A. Šimènas - Statybos ekonomikos katedros docentas; nariai: K. Antanavičius - Statybos valdymo ir organizavimo katedros vedejjas; V. Bagdonas - Statybos ekonomikos katedros vedejas; A. Baublys - Autotransporto ekonomikos katedros vedëjas; A. Lukoševičius - Statybos valdymo ir organizavimo katedros docentas; P. Norkus - Chemijos katedros vedejas; fakulteto partbiuro sekretorius ir profbiuro pirmininkas; studentai: M. Smuika, A. Survilaité, A. Mockevičius - studentų organizaciju vadovai.

Statybos fakulteto tarybą sudare: pirmininkas P. Vainiūnas - fakulteto dekanas; nariai:A. Alikonis-Pagrindų ir pamatų katedros vedejas; P. Baublys - Statybinés mechanikos katedros docentas; R. Čechavičius -Statybos 
fakulteto prodekanas; S. Čirba - Matematikos katedros docentas; A. Čižas - Medžiagu atsparumo katedros vedejas; P. Čyras-Darbo ir aplinkos apsaugos katedros vedejas; $\mathrm{V}$. Kagan - Medžiagu atsparumo katedros docentas; S. Kalanta - Statybines mechanikos katedros docentas; J. Kivilša - Gelžbetoninių konstrukcijų katedros e. prof. pareigas; V. Liutikas - Matematikos katedros vedejjas; A. Kudzys - Gelžbetoninių konstrukcijų katedros vedejas; L. Rimkus - Statybos fakulteto prodekanas; J. Šimkus - Pagrindu ir pamatu katedros profesorius; V. Vaitkevičius - Metalinių konstrukcijų katedros vedejas; E. Zavadskas - Statybos darbų technologijos katedros vedejas; partinio biuro sekretorius ir profbiuro pirmininkas; studenty komjaunimo komiteto sekretorius ir studentu profbiuro pirmininkas; studentai: G. Dragūnas, O. Gloyova, R. Lisys, I. Mumgaudyte, A. Vilkauskaite.

1988 m. pradžioje, sausio mènesį, instituto valdžios požiūriu keistų pretenziju pareiške studentai. Jie ėmè reikalauti leisti lankyti paskaitas Karineje katedroje apsirengus bet kokiais rūbais ir bet kaip susišukavus. Ne paslaptis, kad tuomet pagal Vakaru pasaulyje paplitusią madą jaunimas dažnai augino ilgus, net žemiau sprando, plaukus, dažnas nešiojo džinsus. Bet gi tai - pataikavimas Vakarams, su kuo jau kelintą dešimtmeti kovojo sovietija!

Karinès katedros vedëjas V. Andriušinas tuo klausimu paraše „Inžinerijai“, kad TSKP CK ir TSRS Ministry Tarybos 1983 m. nutarimu Nr. 45-19, be kita ko, reikalaujama, kad studentas į užsièmimus privalo atvykti tvarkingai apsirengęs bei kruopščiai susišukavęs. Leidžiama turèti trumpų plaukų šukuoseną.

Taigi studentai lyg ir nieko nelaimejo. Bet stebino jau tai, kad jie drịso reikšti pretenzijų. Jų, daug rimtesnių, neteko ilgai laukti.

Sausi rektoratas svarste architektų rengimo kokybę. Buvo pažymèta, kad fakultete mokosi 287 studentai, kad studentas per visą studijų laikotarpi išklauso 50 dalykų.

Dekanas K. Jakovlevas-Mateckis pareiške turịs informacijos apie tai, kad architektai netolimoje ateityje bus rengiami 6 mokslo metus, o tai padidintų specialistų kokybę.

İdomių mintčių dèsté posédyje dalyvavęs Statybos reikalų komiteto pirmininko pirmasis pavaduotojas V. Parčiauskas:

"Mūsu architektu laimejjimai žinomi, tad trumpai apie negatyvia puse. Visq laikg reikalavimai dideja ir visuomene iš architektu laukia labai daug. Nori labai geros architektūros. Beida ta, kad medžiagos lieka tos pačios ir taip pat jas reikia taupyti. Mes laukiam architektu, kurie sprestu visai naujas konstrukcijas. Reikia architektu, mokančiu labai gerai dirbti su konstruktoriais. Svarbu išsaugoti mastanti specialista. Visuomenes moksly destytojai turetu išmokyti būsimaji architekta. suprasti, kad jis, vos baigęs, nera visažinis ir jau viska mokantis. Tad neturety vos atejusi dirbti reikalauti savarankiškai daryti projekta. Reikia studenta mokyti myleti gamta, aiškinti apie gamtos kultūra, apie senaja architektūra. Noriu jūsu studentams palinkèti didelio kurybingumo" [4.71, p. 47].

Gaila, kad beveik prieš 20 metų išsakytų minčiu neišgirdo šių dienų gamybininkai, verslininkai, reikalaujantys, kad absolventas, pradējęs dirbti konkrečioje vietoje, jau iš karto būtų visažinis. Taip nebūna. Tarkim, JAV absolventas, pradejęę dirbti, 2-3 metus tik talkininkauja patyrusiam specialistui. Tai vadinama adaptacija darbo vietoje. Tie, kuriuos šiandien netenkina universitetu, institutų parengtų specialistų kokybè, kažkodèl pamiršta, kad patys baige tas pačias mokyklas ir savo pasirengimu darbui kažkodèl neabejojo. Jaunam specialistui būtina tolerancija, geranoriškumas, pagalba. Geros klasès specialistą konkrečiai darbo vietai įmanoma išugdyti tik bendromis mokyklu ir verslo pastangomis. Abieju pusių tikslas yra vienas, bet uždaviniai skirtingi.

Sovietine valdžia su nerimu lauke 1988 m. vasario 16 d. Prieš 70 metų, tą dieną, buvo paskelbtas Lietuvos Nepriklausomybès aktas. Buvo nujaučiama, kad ši diena Lietuvos žmoniu bus pažymèta. Itampą padidino JAV Prezidentas R. Reiganas, pasirašęs pareiškimą, skirtą Lietuvos valstybès nepriklausomybei.

Valdžia vasario 15 d. Katedros aikštëje surengè mitingą, smerkiantị JAV Prezidento pareiškimą, nors Lietuvoje jo niekas neskaite, nes nebuvo paskelbtas. Jau vèliau sužinojome to pareiškimo turinị. Jame, be kita ko, pasakyta:

„1940 m. birželi, nepraejjus ir metams po Molotovo-Ribentropo pakto, TSRS jsiverže i Lietuva ir kitas Pabaltijo valstybes ir okupavo jas. JAV nedviprasmiškai pasmerke š š lietuviu tautos nacionalinio suvereniteto ir teritorinio vientisumo pažeidima ir to mes laikemes visa laika. Mes niekuomet nepripažinome ir nepripažinsime teisetu Lietuvos ijungima i SSSR sudetį" [4.72, p. 219].

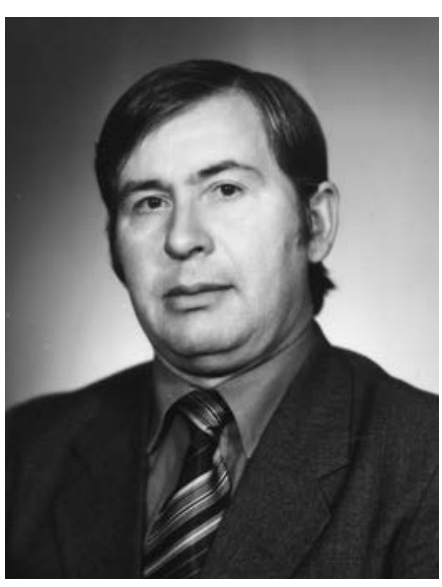

M. Mariūnas

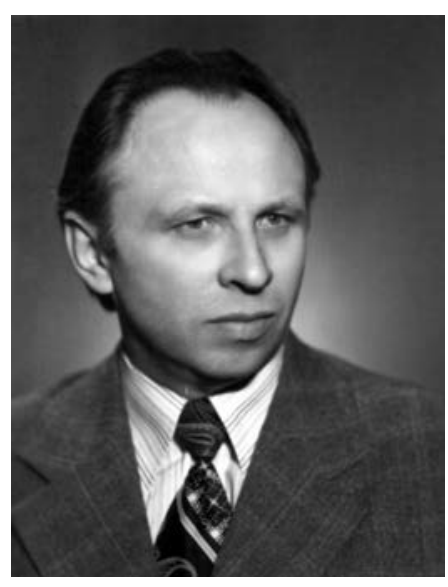

A. Naujokaitis

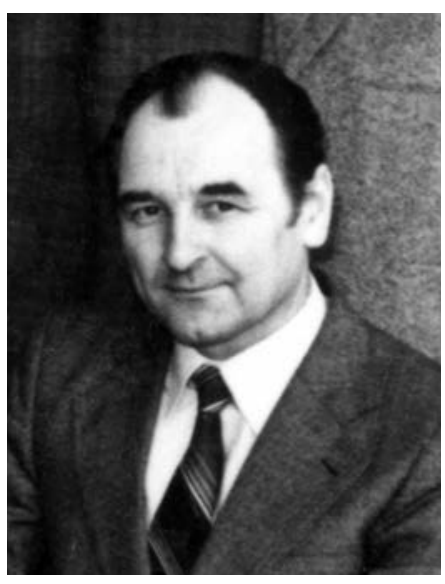

P. Vainiūnas 
VILNIAUS

INŽINERINIS STATYBOS

INSTITUTAS

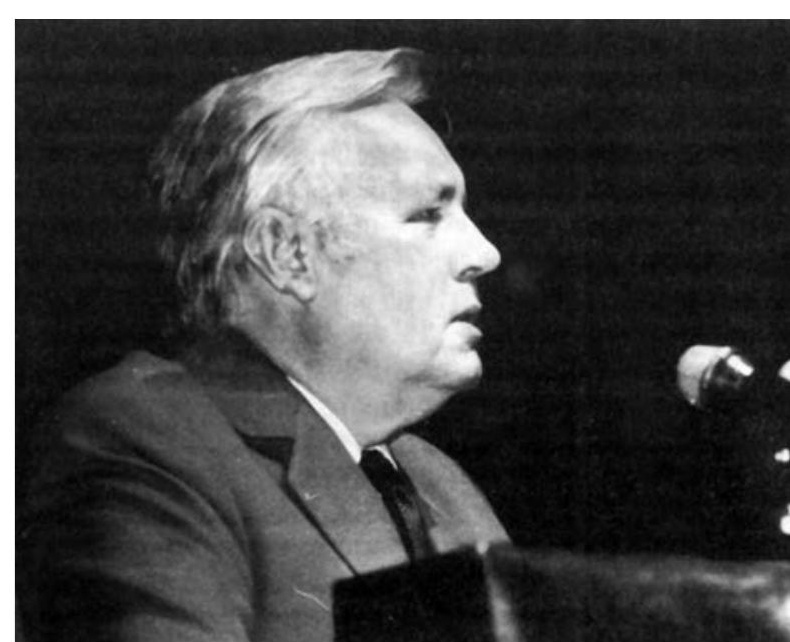

prantama, rektorius savo pranešime minëjo partijos nutarimus, citavo TSKP veikejus. Bet buvo pasakyta ir jiems nerimą keliančių minčių: "Tačiau bütu klaidinga manyti, jog mes neturime problemu, susijusiu tiek su internacionalumu, tiek ir su patriotiniu auklejimu $<. .>$ Matyt, dalies jaunimo neatsakingumo šaknys - mūsu visuomenés gyvenimo klaidos". Rektorius apgailestavo, kad per pastaruosius metus instituto mokslininkai negavo valstybinių premijų, kad ne visi aspirantai užbaigia darbus. Didelis pranešimas apèmè ịvairiausias instituto veiklos sritis. Rektorius baigdamas pabrèže, kad „Ataskaitoje išdestytos mintys ir problemos jokiu büdu negali pretenduoti $j$ absoliučias tiesas ir kanonus". Tai išgirsti iš rektoriaus A. Čyro, švelniai tariant, buvo neiprasta. Ką gi, laikai keitesi.

Nors ir subtiliai, rektoriaus adresu pasigirdo ir kritikos. Rektoratą kritikavo prof. V. Liutikas, kad reikia keisti darbo stiliu prof. J. Mureika. Vis delto Taryba rektoriaus ataskaitą patvirtino, todel rektorius A. Čyras ir toliau liko savo poste.

Mokslo metu pabaigoje vieni déstytojai palikdavo VISI, kiti buvo priimami naujiems mokslo metams. Kai kurios pavardes ilgainiui tapo gerai žinomos mokslo visuomenei.

Eiti ne pagrindines pareigas VISI Matematikos katedroje buvo įdarbinti fizikos-matematikos mokslų daktaras Mokslų akademijos Matematikos ir kibernetikos instituto vadovaujantysis mokslinis bendradarbis Leonas Saulis, fizikos-matematikos mokslų kandidatas, to paties instituto mokslinis bendradarbis Albertas Žalys. Statybos ir kelių mašinų katedroje buvo įdarbintas technikos mokslų kandidatas, Kelių statybinių medžiagų įmonių susivienijimo „Granitas“ vyriausiasis inžinierius Jonas Biržiškis. 
Iš VISI pasitrauke Estetikos katedros vedejas V. Matonis, kuris 19880827 buvo atleistas ir perkeltas i Vilniaus aukštąją partinę mokyklą.

Tuo metu labai pablogèjo gyventojų aprūpinimas maisto ir kitomis prekemis, akivaizdžiai prastejo socialinès sąlygos. $\mathrm{Pa}$ dèti savajam kolektyvui iniciatyvos èmési darbuotojų profsąungos Vietos komitetas. VISI centriniuose rūmuose buvo atidarytos maisto ir pramonés prekių parduotuvès, sto- matologijos kabinetas, įrengtos darbuotojų kultūros klubo patalpos. Architektas L. Ziberkas suprojektavo kavinę „Arka“, kuri netrukus buvo įrengta.

Daug nuveikta siekiant pagerinti darbuotojų vasaros poilsio sąlygas. Buvo išrūpintas leidimas statyti poilsio namus Nidoje. Architektas V. Dičius suprojektavo dviejų aukštų korpusą, kuris turejo būti pastatytas Purvynès gatveje visai prie Kuršių marių. Deja, tai dèl įvairių aplinkybių nebuvo realizuota.

\section{İkuriamas Lietuvos persitvarkymo sajūdis}

Svarbiausias 1988 m. įvykis buvo Lietuvos persitvarkymo sąūdžio iniciatyvinès grupes sukūrimas.

1988 m. birželio 3 d. perpildytoje Lietuvos mokslų akademijos saleje vieningai buvo išrinkti Iniciatyvinès grupès nariai: R. Adomaitis, J. Bulavas, V. Bubnys, A. Čekuolis, V. Čepaitis, V. Daunoras, S. Geda, B. Genzelis, A. Juozaitis, J. Juzeliūnas, A. Kaušpedas, Č. Kudaba, B. Kuzmickas, V. Landsbergis, B. Leonavičius, M. Lukšiene, A. Maldonis, J. Marcinkevičius, A. Medalinskas, J. Minkevičius, A. Nasvytis, R. Ozolas, R. Pakalnis, S. Pečiulis, V. Petkevičius, K. Prunskienè, V. Radžvilas, R. Rajackas, A. Skučas, G. Songaila, A. Šaltenis, V. Tomkus, Z. Vaišvila, A. Žebriūnas.

Nuo pat Sąjūdžio veiklos pradžios jo pagrindinis tikslas - atkurti Lietuvos valstybingumą. Sąjūdžio rèmimo grupés ėmé steigtis darbo kolektyvuose. Po trijų ménesių tokia grupe susikūre ir Vilniaus inžineriniame statybos institute.

Jau Lietuvos Sąjūdžio iniciatyvinëje grupëje buvo du VISI absolventai (architektai A. Kaušpedas ir A. Skučas) ir du destytojai, eję VISI ne pagrindines pareigas (B. Kuzmickas ir A. Nasvytis). Spalio 21-22 d. įvykusiame pirmajame Sajūdžio suvažiavime buvo išrinktas Sąjūdžio Seimas, o jis išrinko 35 narių tarybą. Joje buvo keturi vienaip ar kitaip su VISI susiję žmonès. Tai K. Antanavičius, B. Kuzmickas, A. Nasvytis ir A. Kaušpedas. Sąjūdžio Seimo nariu, be minètųjų, buvo išrinktas A. Čižas.

Sąjūdis tapo pagrindine politine jèga. Dèl jo veiklos įtakos Lietuvos Komunistų partija jau po metu atsiskyre nuo TSKP. Pagyvejo politinis gyvenimas ir Vilniaus inžineriniame statybos institute, bet nebuvo pamiršti ir kasdienos darbai.
1988 m. VISI baigè tik 611 žmonių: 360 dieninį skyrių, 137 - vakarinị skyrių ir 114 neakivaizdini skyrių. 1956-1988 m. Vilniaus inžinerinis statybos institutas parenge iš viso 18383 inžinierius.

Vasarą stojančiųjų i VISI buvo pakankamai. Buvo surinktas reikalingas kontingentas, sukomplektuotos visos akademinès grupès. Per 100 stojančiųjų, kurie buvo išlaikę egzaminus, nebuvo priimti. Daugiausia pareiškimų paduota $\mathfrak{i}$ automobilių transporto specialybę (rusų grupę) - 2,79 $\mathfrak{i}$ vieną vietą, $\mathfrak{i}$ architektūrą $-2,27$, i automobilių transportą (lietuvių grupę) - 2,08, i statybos ekonomiką - 2,04, į transporto ekonomiką - 1,91.

Mažiausia pareiškimų gauta ị taikomosios geodezijos specialybę - 0,6 ị vieną vietą.

I dienines studijas stojo 52 medalininkai ir 25, baigę specialiąsias vidurines mokyklas su pagyrimu. Bet pastebèta, kad kasmet mažeja stojančiųjų atestatų vidurkis. Šio reiškinio priežastys galejo būti dvejopos: pakelti reikalavimai vidurinèse mokyklose arba tai, kad į VISI stoja silpniau pasiruošę jaunuoliai ir merginos. Tai, suprantama, VISI vadovams kèle susirūpinimą. Reikëjo numatyti priemones, kaip pasiekti geresnę priimamo kontingento kokybę.

Naujuosius 1988-1989 metus VISI pradejjo turedamas 2687 studentus dieniniame skyriuje, 805 - vakariniame ir 1124 - neakivaizdiniame skyriuose.

Rugsëjo 1-ąją įvykusiame mokslo metų atidaryme dalyvavo LKP CK sekretorius A. Brazauskas, Valstybinio plano komiteto pirmininko pirmasis pavaduotojas $\mathrm{H}$. Jackevičius, LKP CK Statybos ir miestu ūkio skyriaus vedejjas A. Daukša, Valstybinio kooperatinio respublikinio statybos susivienijimo pirmininkas K. Baltušis, Vilniaus m.

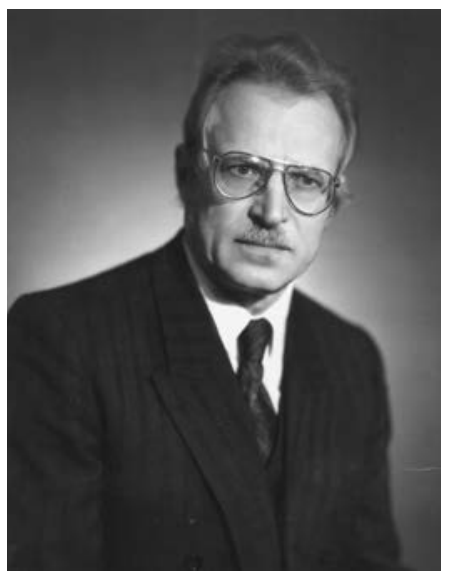

B. Kuzmickas

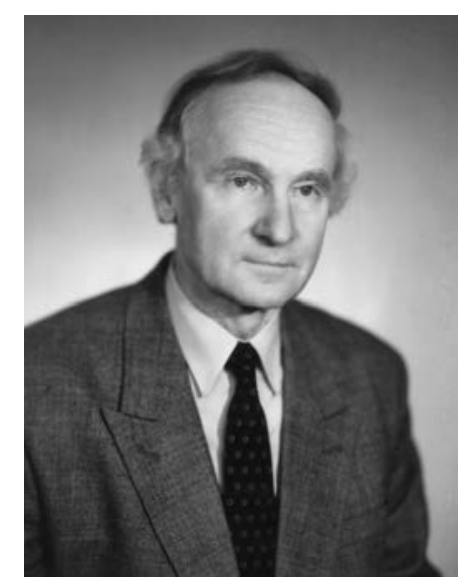

A. Nasvytis 
VILNIAUS

INŽINERINIS STATYBOS

INSTITUTAS
Prof. D. Maciulevičius: „Respublikos sqjüdis per trumpq laikq išjudino visuomene, padrasino sakyti tiesa. Svarbu žinoti, dèl ko ja. sakom. Mokytis reikia demokratiškai ta tiesq pasakyti. Paskutinis mitingas Vingio parke parode, kad mes pribrende prie demokratijos, reikia tai saugoti. Turime remti LPS idejas, kai kurios jau ir igyvendinamos. Valdžia gali dekoti Sajüdžiui, kad nuveike per trumpa laika tai, ko ji dèl negalejimo, o gal dèl nesugebejimo nepadare".

TSKP katedros destytojas V. Brandišauskas: „<...> užregistravęinstituto sajüdžio grupe, galesime tureti ir laikrašti "Atgimimas “. Tik reikia stendo, tada bus garantija, kad niekas jo nenuplěs “. Kalbetojas siūle pasirašyti kreipimąsi, kad būtų peržiūretas įsakas dèl mitingu ir demonstracijų rengimo tvarkos.

Sąjūdžio grupe VISI, anot V. Brandišausko, turetų užsiimti instituto problemomis, neatsiribodama nuo bendros platformos. Minčiai, kad instituto Sąjūdžio grupès uždavinys - spręsti mūsų problemas, vèliau pritare visi kalbètojai.

Prof. A. Kudzys pasakè, kad Sąjūdžio atžvilgiu nusiteikęs skeptiškai, nes šis apvertęs Maironio šūkį „Paimkim arklą, knygą, lyrą“" ir pradejjęs nuo lyros. Reikia arklo. Siandieninę situaciją šalyje prof. A. Kudzys palygino su situacija gamykloj, kai, užuot naudojus naują techniką, racionalizuojama sena. XIX partine konferencija pasiūliusi naują techniką, bet valdžia neleidžia jos diegti, siūlo racionalizaciją. Kalbetojo nuomone, mūsų instituto Sąjūdžio grupe turètų rūpintis tik instituto reikalais.

Prof. A. Čižas laiko save Sąjūdžio dalyviu, pritaria jo idejoms:

„Reikia atkreipti demesi, kad lietuviškaisakome "perSItvarkymas". Aš užperSItvarkyma visos visuomenes, partijos, aparato iki jo beveik visiško nunykimo. Mūsu uždavinys - padeti perSItvarkymui. Sajüdžio grupe institute turi būti ir bus. Ka ji galetu daryti? Pirmiausia, ji turi pasisakyti prieš pernelyg griežta visa ko reglamentavima, kuritaiko aparatas. Ji turetu siekti katedru savarankiškumo, padeti perSItvarkyti destytojo sążinei. Dar reiktu rüpintis lietuviu kalba, jos destymu. Reikia sužadinti nora jos mokytis irne tik kitataučiams, bet ir lietuviams. Bütina padèti ir tiems, kas dèsto rusu kalba, nes rašyt, kalbèti turime mokèti visi. Dar viena pastaba - del veliavos. Kiekviena veliava-trispalve taip pat-reikalauja pagarbos, negalima ja mosuoti kur pakliūva ir paskui per grūstynes sumindyti. Ji netenka tada savo prasmes “. 
Kartų konsolidacijos ir politinès pozicijos konsolidacijos problema - tokia buvo pagrindine prof. V. Liutiko kalbos tema. Pateikdamas iš asmenines patirties žinomy to meto Lietuvos vadų J. Paleckio, M. Šumausko, N. Gedvilo elgesio sudètingomis sąlygomis faktus, prof. V. Liutikas pabrežè, kad tos problemos, kurias šiandien kelia Sąjūdis, buvo atejusios komunistams į galvą ir anksčiau. Sąjūdžio ir komunisto vardas nèra nesutaikomi dalykai, nors kai kam tokiu aspiraciju gali kilti.

Pasibaigus diskusijoms, buvo surengti LPS VISI tarybos rinkimai. Iš 30 pasiūlytu kandidatų buvo renkami devyni asmenys. Urnoje buvo rasti 166 biuleteniai, taigi tuomet tiek institute buvo LPS remëjų. İ tarybą buvo išrinkti: S. Abramauskas, K. Antanavičius, V. Brandišauskas, P. Didžiapetriené, A. Čižas, A. Jonaitis, H. Kobeckaite, V. Liutikas, A. Rosinas.

Taigi išties Sąjūdis perženge VISI slenkstị. Prasidejo intensyvi jo veikla institute.

Jau po kelių dienų LPS rèmimo grupès instituto taryba susitiko su VISI rektorato, partinio ir profsąjungos Vietos komiteto atstovais. Su tarybos uždaviniais supažindino A. Čižas. Vienas svarbiausių tikslų - aukštosios mokyklos persitvarkymas, o tam būtinas viešumas. A. Čižas pabrežè, kad reikia decentralizuoti instituto valdymą, didinti katedru savarankiškumą.

K. Antanavičius siūlè paskelbti atviras paskaitas, didinti katedrų savarankiškumą moksliniame darbe. A. Rosinas siūlè rūpintis desstytojų ir studentų kalbos kultūra. Jo manymu, reikia, kad naujai priimamas destytojas skaitytų viešą paskaitą, kad reikia vèl laikyti stojamąji lietuvių kalbos egzaminą. H. Kobeckaite kviete institute sudaryti tokią atmosferą, kad būtų kalbama atvirai ir be baimès, kad dèl teisingos kritikos, dèl teisingo žodžio nebūtų keliama panika.

Kalbëjęs rektorius A. Čyras atrodo neišgirdęs, ką siūlè LPS remimo grupes Tarybos nariai. Jis nekomentavo ju minčių, o tik pabrežè, kad pagrindinis aukštosios mokyklos persitvarkymo uždavinys - rengti geresnès kvalifikacijos inžinierius; tam reikia padidinti dèstytojų darbo kokybès kontrolę, kelti mokslinę kvalifikaciją, aktyviau įtraukti ị darbą studentus.

Deja, studentų aktyvumas Vilniaus inžineriniame statybos institute buvo menkas. Kai jau visose Lietuvos aukštosiose mokyklose veike Sąjūdžio rèmimo grupès, tik spalio
$5 \mathrm{~d}$. VISI studentai buvo pakviesti į steigiamąji studentų Sąjūdžio rèmimo grupès susirinkimą. Instituto dieninese studijose tuomet buvo 3580 studentų, o ị susirinkimą atëjo tik 100.

Tą dieną instituto studentų LPS rèmimo grupe nebuvo sukurta, bet buvo nuspręsta jas kurti fakultetuose. Tuo pat metu išaiškeejo, kad kiek anksčiau Sąjūdžio remimo grupe jau susikūrè Architektūros fakultete.

\section{Iškelta trispalvė Gedimino bokšte}

Istorine Lietuvai diena buvo $1988 \mathrm{~m}$. spalio $7 \mathrm{~d}$. Virš Gedimino pilies bokšto iškelta tautine lietuvių veliava - trispalvé: geltona, žalia ir raudona. Tai buvo nepaprastai jaudinantis momentas, kurio lietuviai troško ilgus dešimtmečius.

Spalio 22 d. - taip pat istorinè. Tą dieną Vilniaus sporto rūmuose prasidejo Lietuvos Persitvarkymo Sąjūdžio steigiamasis suvažiavimas. Jị transliavo televizija. Bene visi Lietuvos gyventojai su jauduliu ir įtampa

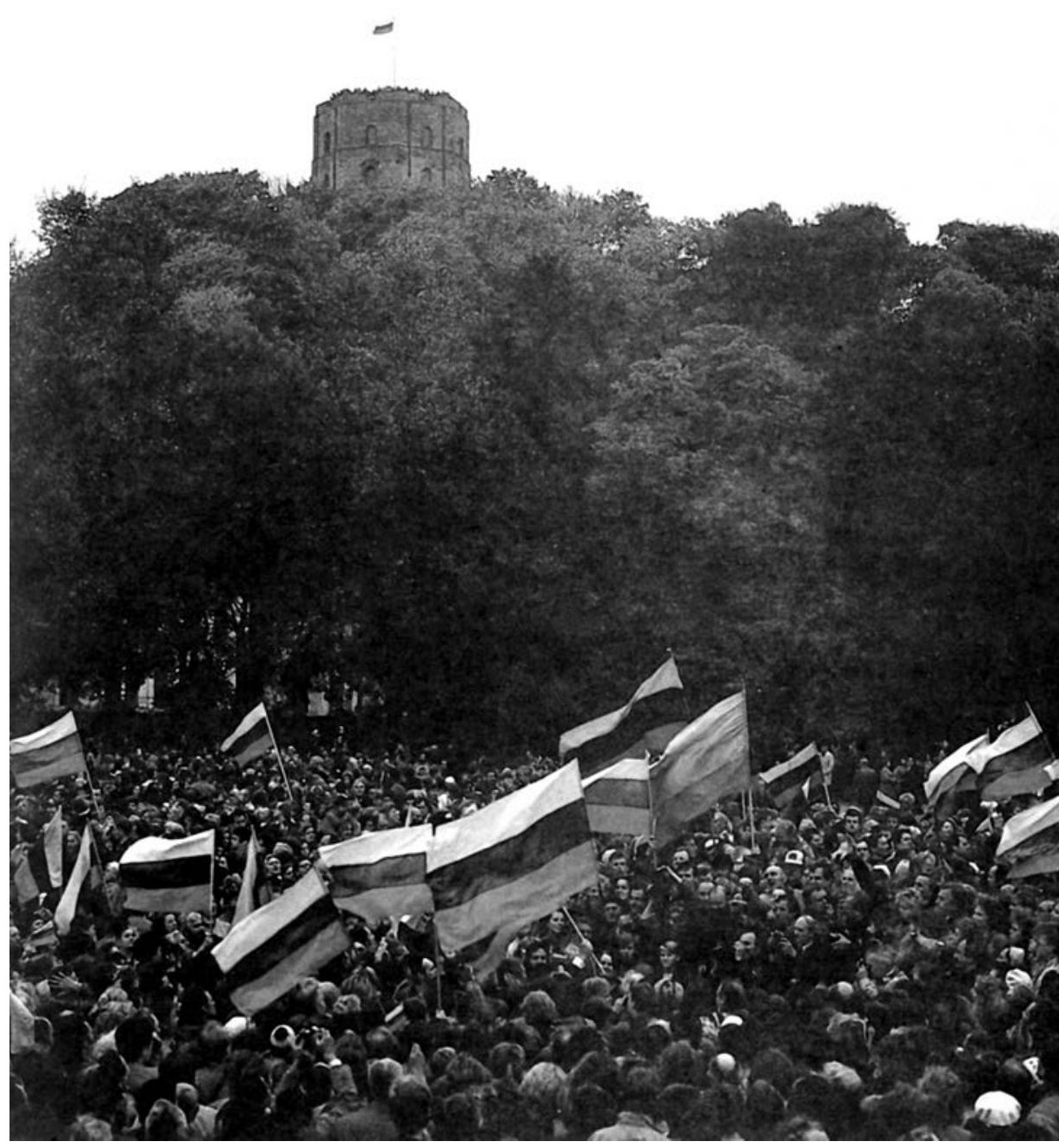


VILNIAUS

INŽINERINIS STATYBOS

INSTITUTAS

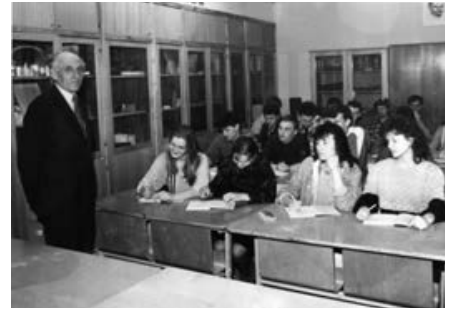

Doc. J. Dyčmono paskaita stebëjo suvažiavimo darbą. Visame krašte vyravo dvasinis pakilimas, bet nesvetimas kiekvienam buvo ir nerimas. Lietuva dar buvo okupanto gniaužtuose, gatvese patruliavo sovietine kariauna, daugiau nei iprasta buvo galima matyti milicijos. Nors daugelis vylesi, kad Lietuva kiek išlaisves, istorinès Vengrijos, Čekoslovakijos, Lenkijos pamokos nebuvo pamirštos. Bet tikëjimas šviesia, klestinčia Tèvynès ateitimi vis stiprëjo. Visuomenè vis daugiau konsolidavosi, tai rode visoje Lietuvoje vis dažnesni ir gausesni mitingai.

O VISI rektoratas tebegyveno sena tvarka spalio $24 \mathrm{~d}$. pirmuoju klausimu rektorato posedyje buvo „Pasiruošimas Spalio 71-osioms metinems ir Tarybų valdžios paskelbimo Lietuvoje 70-mečiui“...

İdomi buvo partinio komiteto sekretoriaus J. Nagevičiaus informacija. Jis pabrěže, kad "darbo žmoniu demonstracija nevyks". Būsiąs tik karinis paradas, mitingas Lenino aikštëje, koncertas Gedimino aikšteje, kuriame gros ir VISI dūdų orkestras „Inžinerija“.

Visa tai rodè, kad valdžia jau bijojo didelio žmonių susibūrimo, kuris būdavo privalomas visiems žmonems organizuojant šventines demonstracijas. Lietuvoje stiprejo politine įtampa, bijota susidūrimų tarp lietuvių ir rusakalbių, disidentų galimų viešu pareiškimų ir kt. Lietuvoje vell plazdejo tautine veliava. Neįmanoma įsivaizduoti, kad su ja būtų žygiuojama šlovinančioje „Didžiojo Spalio socialistines revoliucijos idealus" demonstracijoje.

Ėme brašketi ir pati VISI partine organizacija. Tai ryškiai parode 1988 m. spalio $26 \mathrm{~d}$. îvykęs instituto partijos komiteto ataskaitinis rinkiminis susirinkimas.

Tuomet VISI partineje įskaitoje buvo 309 nariai ir 16 kandidaty i narius. Sekretorius J. Nagevičius pranešime, be kita ko, sakè: „Šiandien instituto kolektyve yra sudaryta Lietuvos persitvarkymo sajūdžio iniciatyvine grupe, kurios programiniams principams instituto partinis komitetas pritaria. Numatoma deti pastangas instituto autonomijai pletoti, šalinti tas kliūtis, kurios trukdo rengti specialistus, vystyti institute demokratija ir decentralizacija, stiprinti katedru ir kitu padaliniu savarankiškuma. Sajūdžio grupes nuomone, bütina parengti nauja kolektyvo socialines pletotes ir autonomijos programos projekta ir jì viešai apsvarstyti. Taryba pasiryžusi pradeti plètoti viešuma ir, kas ypač svarbu, tirti VISI kolektyvo viešaja nuomonę. Pirmasis bandymas jau padarytas, aptariant katedru savarankiškumo problemas.

Didele mūsu komjaunimo organizacija3509 komjaunuoliai. Tai didele potenciali jega. Deja, akademinese grupese ir institute komjaunimas neatlieka studijuojančio jaunimo avangardinio vaidmens. Cia yra ir partinio komiteto kalte. Komjaunimo komitetas teisingai pastebi, kad rektorato, dekanato, partinio komiteto vadovai retai susitinka su studentais, kurie dabar turi daug klausimu. Komjaunimo komitetas galvoja organizuoti nuolat veikianti studentu visuomeniniu organizaciju atstovu seminara susitikimams su instituto vadovybe. Partinio komiteto ir rektorato atstovai visada nusiteike bendrauti su studentais. Prašykite, reikalaukite patarimu, pagalbos, bendradarbiavimo, tiknelaukite jums primetamu renginiu.

Institute reikia pakeisti opinija pedagoginio darbo atžvilgiu. Kol kas mūsu institute déstytojas yra vertinamas tik už mokslini darbą, o tai, koks jis pedagogas - lieka antroje vietoje.

Moksliniai tyrimai parode, kad kai kuriose grupese iki 50 proc. studentu kai kuriu destytoju ǔsiemimuose nesupranta paskaitu turinio.

Ko laukia studentai iš destytojo? Kokie tipiškesni destymo trūkumai žiürint studentu akimis? Ignoruojamas institute studentas kaip subjektas. Bendraujama autokratiniu stiliumi. Net 88 proc. apklausty studentu pasisako už demokratine bendravimo atmosfera. 70 proc. studentu teigia, kad mažai ugdomas mątymas, reikalaujama tik iškalimo. Labai menkai ugdomas teigiamas požiūris i specialybę. Taip teige 83 proc. studentu. Nereikalaujama kürybiškumo (57,4 proc.) arba labai mažai jo reikalauja (29,9 proc.). Taigi nedaug dar persitvarkymo dvasios pedagoginiame procese. Koks čia persitvarkymas, jei apie 70 proc. studentu rengiasi egzaminui ir iskaitoms tik is netobulu užrašu.

Reika rimtai demokratizuoti santykius su studentais. Jie nori, kad destytojai veidu pasisuktu $\dot{z}$ ju sunkumus, poreikius, problemas, o ne vien iš aukšto, autokratiškai skelbtu jiems savo mokslo tiesas. Juk kaip tik demokratiškumo pradu santykiuose su studentais reikalauja naujas mastymas, asmenybes demokratizavimas.

Jaunimas ypač jautrus bet kokiai nacionalinei diskriminacijai. Institute dirba ir mokosi 15 tautybiu atstovai. Tarp studentu 77,8 proc. 
yra lietuviai, 22,2 proc. - kitu tautybiu, destytoju atitinkamai 86 proc. ir 14 proc.

Būtu gerai, kad "Inžinerija“ sužadintu kolektyvo poreiki ir nora aktyviau ir atviriau pasisakyti spaudoje, kelti i viešuma tai, kas negerai, ir tai, kas gerai. Matyt varžo ankstesni tabu, o nauji ipročiai dar nesusiformavo.

Daug svarbiu klausimu turi spręsti ir müsy instituto profsajungos organizacija. Dabartines kadencijos instituto profsajungos komitetas iš esmes pertvarke savo darbą. Profsajungos komitetas operatyviau sprendžia einamuosius klausimus, jo darbe daugiau viešumo, demokratiškumo" [4.76, p. 1-3].

Vilniaus inžineriniame statybos institute dar niekada nebuvo tokio audringo ataskaitinio rinkiminio susirinkimo. Jis prasidejo 15 val. $30 \mathrm{~min}$., o baigesi 3 valandą ryto.

Diskusijose kalbejo daugybè susirinkimo dalyvių.

Karinès katedros vyr. dèstytojas A. Tamošiūnas praneše, kad nuo spalio $12 \mathrm{~d}$. studentai boikotuoja karinio rengimo užsiemmimus, reikalauja sumažinti karinio rengimo trukmę iki 60 dienų. A. Tamošiūnas buvo paklaustas, ar studentai mieliau lankytų karinio rengimo paskaitas, jei būtų suformuoti nacionaliniai kariniai junginiai. İ tai nebuvo atsakyta.

"Ilgq laikq dirbu institute", - kalbejo prof. D. Maciulevičius. - Ilgq laikq mumyse tiesiog formuojamas buvo nepilnavertiškumo kompleksas. I destytoja žiürima taip, jei nenusižengei, nusižengsi ir t. t. Tokioje situacijoje nustojam gerbti save ir kitus. Daugiausia tai išplaukia iš administracijos. Štai universitete daug liberalesnes nuotaikos, gal todel ten ir tvarkos daugiau. Argi neaišku, jog kareiviniu režimas negali duoti geru vaisiu??"

„Viskas dalijama pagal simpatijas ir antipatijas. Jokios kritikos ir savikritikos! Baimes šmékla klaidžioja po instituta," - kalbejo aspirantas K. Gaulè.

Buvo daug ir kritiškai kalbama susirinkime apie besaikị mokslinių ataskaitų rašymą, apie tai, kad daugelis mokslininkų varžomi administravimo ir kt.

Kalbos buvo pačios ịvairiausios. Jos sukosi apie Sąjungos, respublikos, sostinès reikalus. Bet kai buvo imama kalbèti apie institutą, tuomet užvirdavo ypatingos aistros. Nieko nereikejo raginti, niekam nereikëjo siūlyti pasisakyti. Viena po kitos lèke valandos. Daugumai jos neprailgo. Taip kalbama nebuvo dar nei prieš metus, nei prieš kelis ménesius.

Buvo išrinktas naujos sudeties partinis komitetas. Sekretoriumi tapo K. Olšauskas.
Lapkričio $5 \mathrm{~d}$. VISI bendradarbiai palydejjo î paskutinę kelionę Liudviką Snudaitienę, daugiau nei 20 metų dirbusią VISI bibliotekoje, o nuo $1984 \mathrm{~m}$. - jos direktore, darbščią, nuoširdžią darbuotoją, kurią mègo ir vertino visas bibliotekos kolektyvas, gerbè destytojai ir studentai.

Lapkričio $23 \mathrm{~d}$. staiga mire buvęs daug metų Mechaninès technologijos fakulteto dekanu, Metalų technologijos katedros vedejas e. prof. p. Borisas Liaudis. LTSR saugumo šefą Kazimierą Liaudị, Boriso tevvą, lietuviai prisimena su siaubu, o Borisą Liaudị buvę bendradarbiai vertina pozityviai, gal tik apgailestaudami, kad jis taip ir neišmoko nors patenkinamai kalbèti lietuviškai.

Gruodžio 22 d. fakultetuose mokslininkai išrinko atstovus į VISI Mokslinio tyrimo sektoriaus mokslinę techninę tarybą: P. Didžpetrienę (Hidraulikos katedra), V. Kvedarą (Elektrotechnikos katedra), A. Baubli (Autotransporto ekonomikos katedra), N. Maciulevičių (Statybos valdymo sistemų laboratorija), A. Valiulį (Metalų technologijos katedra), B. Kuzmicką (Taikomosios matematikos ir mechanikos katedra), J. Skeivalą (Geodezijos katedra), J. Jakimavičių (Fizikos katedra), B. Užpolevičių (Gelžbetoninių konstrukcijų katedra), E. Zavadską (Statybos darbų technologijos katedra), Č. Ignatavičių (Pastatų konstrukcijų katedra), J. Vanagą (Urbanistikos katedra).

Pagal pareigybes į Tarybą buvo įtraukti prorektorius G. Marčiukaitis, MTS viršininkas A. Rimkevičius ir vyr. buhalteris J. Kliauza.

Jau po metu vykusiuose VISI rektoriaus demokratiškuose rinkimuose šios tarybos iškeltas kandidatas laimëjo rinkimus.

1989 m. pradžioje pradetas rengti naujas instituto statutas. Buvo numatyta jau kovo mènesi parengtą statuto projektą paskelbti „Inžinerijoje“, viešai svarstyti ir apibendrinus svarstymo rezultatus balandžio mènesi ji pateikti instituto Tarybai. Nors statutui rengti komisiją paskyre įsakymu rektorius A. Čyras, komisijos sudèčiai priešinosi LPS remimo VISI grupè. Jos lyderis A. Čižas teige, kad komisija yra sudaryta vien iš vadovu, todel keistina. Ilgainiui tos komisijos sudètis sąjūdiečių iniciatyva gerokai pakito.

Sausio $6 \mathrm{~d}$. „Tiesa“ išspausdino didelį VISI prorektoriaus G. Marčiukaičio straipsnį „Norime tikro technikos šuolio“. Jame desstoma, kaip ugdyti kūrybingus specialistus,

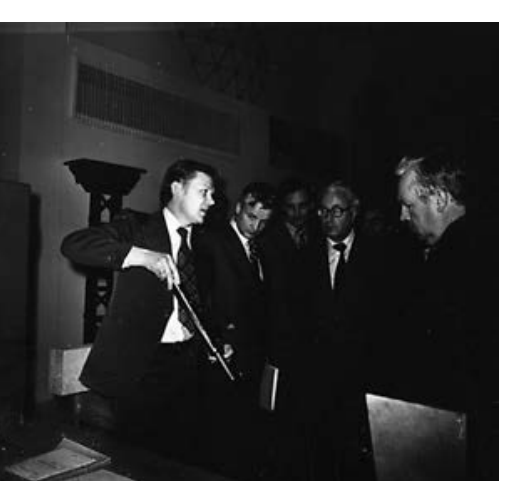

Doc. B. Užpolevičius demonstruoja savo sukurta prietaisa 
VILNIAUS

INŽINERINIS STATYBOS

INSTITUTAS

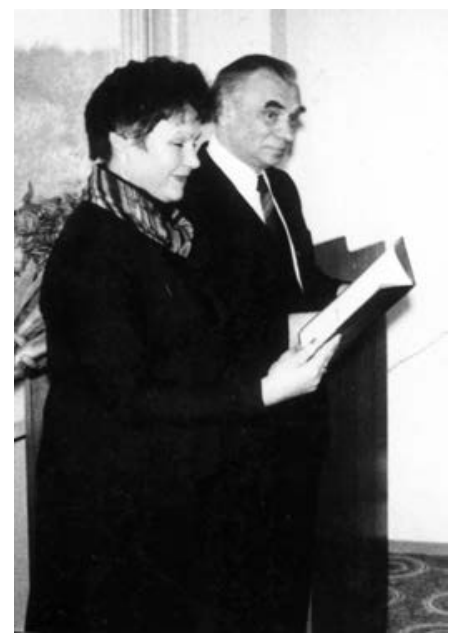

"Platformininkai"

M. Burokevičius ir S. Juoniené, kai dirbo VISI analizuojama, kodèl jauni, gabūs specialistai nenori dirbti mokslo ịstaigose. Autorius pateikè naujo visuomeninio judejjimo ịkūrimo tikslingumo vertinimą: „Yra siūlymu kovoti su techniniu biurokratizmu, realizuoti darbštuma, kurti Lietuvos techninio atgimimo sqjūdį. Vargu ar tai teisinga mintis, tuo labiau, kad turime universalu, išmintingq Sajüdi, sugebanti iskelti ir spręsti sudetingas problemas. Jo suvažiavime mokslininkai siūle daug racionaliu minčiu. Manau, atëjo laikas pradeti dirbti " $[4.77$, p. 2].

Kai Lietuvos persitvarkymo sąjūdžio veikla vis intensyvejo, noras ją sumenkinti, suskaldyti sąjūdiečiu vienybę buvo viena iš daugelio tuo metu okupantų naudoty priemonių. Dar praejusiems metams baigiantis okupantu šalininkai, kagebistai, atsibastę i Lietuvą rusakalbiai veikejjai susibūrè į kontrasąjūdišką organizaciją „Vienybè-JedinstvoJednośćc.

"Jedinstvo " paskelbé deklaraciją, kurioje pabrèžè, jog tvirtai laikosi marksizmo-leninizmo pozicijų, pripažista komunistų partijos vadovaujantị vaidmenị. Žadëjo be kompromiso kovoti su šovinizmo ir nacionalizmo apraiškomis, nuosekliai ginti lenininius internacionalizmo principus ir t. t.

"Jedinstvo" èmé organizuoti rusakalbių mitingus prieš Lietuvos trispalvę, prieš lietuvių kalbos paskelbimą valstybine kalba. Jedinstveninkai siekè sugrąžinti Lietuvą ị stalinizmo laikus, lietuvius paversti Lietuvoje „tautine mažuma“. Jie kurste didžiarusiškąji, slaviškąji šovinizmą. Deja, lietuvių jų gretose buvo, nors ir nedaug. Tai ant jų „platformos" užlipo buvę VISI destytojai - Mykolas Burokevičius, Stanislava Juonienè ir Giedrius Butkus. Tačiau su tokia „platforma“ galima buvo nuvažiuoti tik i „niekur“. Taip ir atsitiko, bet iki tol lietuviu tautai, ne be „mūsiškių “ dalyvavimo, buvo suteikta daug skausmo ir praradimu.

Bet gyvenimas Vilniaus inžineriniame statybos institute riedejo iprastu ritmu. Vyko studijų procesas, buvo daromi moksliniai tyrimai - daugiausia ūkiskaitiniai, posedžiavo rektoratas. Jo posedžiuose buvo reikalaujama pertvarkyti katedru darba, nors tai, kas buvo daroma, laikantis nustatytos iš aukščiau tvarkos, primine tik Krylovo kvartetą. Tik Sąjūdžio veikla suteike instituto gyvenimui daug žadančiu vilčiu, bet ar toms viltims bus lemta išsipildyti - niekas nebuvo tikras.

Vis delto rektoratas planuoja vasario mẻnesiui jau kitą posèdžių tvarką, kuriuose numatyti aptarti klausimai skamba neịprastai: naujo instituto statuto projektas; nauja profesorių ir destytojų darbo apmokejjimo tvarka; Vasario 16-osios minejjimas; Karinès katedros „bèdos“.

Taigi ir rektoratas pagaliau bando eiti koja kojon su gyvenimu.

Stengèsi eiti kartu ir partine organizacija. Jos iniciatyva Vilniaus inžineriniame statybos institute sausio mènesį buvo susirinkę aukštụjų mokyklų partijos komitetų sekretoriai aptarti rengiamų statutų. Kiekviena mokykla turejo savo specifiką, todèl buvo įdomu, kas kiekvienoje nuveikta.

Kalbejusieji tvirtino, kad partiniai komitetai dirba drauge su LPS grupemis, kad visiems rūpi aukštųjų mokyklų autonomija, ju gyvenimo demokratizavimas ir kt.

Renginys parode, kad valdantieji mokyklas nelinkę atiduoti daug valdžios kolektyvams, laviruoja, kaip išsaugoti kuo galingesnius valdymo svertus. Ju buvo siūloma formuoti tarybas, kuriose ne mažiau kaip puse būtu administracijos atstovai. Tokia pusine demokratizacija nebuvo priimtina LPS grupèms.

Sausio $23 \mathrm{~d}$. institute įvyko susirinkimas kandidatams į TSRS liaudies deputatų konferenciją iškelti. Sąjūdis rimtai žiūrejo į šiuos rinkimus, nes laike, kad išrinkti jo kandidatai gali padaryti didelę ịtaką Lietuvos žengimui ì nepriklausomybę.

I VISI atvyko LPS seimo narys filosofas Arvydas Juozaitis, vienas iš tų, kuriems siūle institutas kandidatuoti rinkimuose. Be jo, kandidatais į teritorinę apygardą buvo pasiūlyti rašytojas Jonas Avyžius ir VISI atstovai - docente Halina Kobeckaite, profesoriai Vytautas Liutikas ir Kazimieras Antanavičius.

I nacionalinę apygardą buvo pasiūlyti akademikas Eduardas Vilkas, profesorius Vytautas Liutikas ir VISI studentų profsąjungos komiteto pirmininkẻ Jūratė DindaitéKupliauskienè.

Po ịspūdingos A. Juozaičio kalbos VISI filosofijos katedros vedëjo pareigas èjęs $\mathrm{S}$. Arlauskas bandè nušalinti jo kandidatūrą. Bet susirinkusieji karštai pritare vyr. déstytojui L. Furmonavičiui, sakiusiam:

„Arvydas Juozaitis - laisvas žmogus. Nesuaugessu kreslu. Nesusitepęs kurdamas branduji 
socializma. Mums reikia tokiu, kurie kalbetu savaja, o ne didžiojo brolio verstine kalba, kurie nevažinetu Rytu kryptimi atsiklausti, kokia kalba mums kalbeti, kuo kvepuoti...".

„VISI kandidatai priimtini. Neskelbkim dvigubos morales - viena sau, kita - Sajungai, "- pasakè V. Būda.

I rinkiminę teritorinę apygardą Nr. 685 iškelti kandidatai slaptu balsavimu surinko po tiek balsų: A. Juozaitis - 179, doc. H. Kobeckaite - 63, prof. K. Antanavičius - 48, prof. V. Liutikas - 32, rašytojas J. Avyžius 3. Nors buvo nutarta, kad kelti galima du kandidatus, buvo išrinktas vienas.

I nacionalinę rinkiminę apygardą Nr. 225 iškelti kandidatai slaptu balsavimu surinko po tiek balsų: J. Kupliauskienè-11, V. Liutikas - 15, E. Vilkas - 172.

Išrinktas kandidatu ị rinkiminę teritorinę apygardą Nr. 685 - A. Juozaitis, kandidatu i nacionalinę rinkiminę apygardą Nr. 225 E. Vilkas $[4.78$, p. 2].

Taigi susirinkimas parode, su kuo eina VISI kolektyvas. Permainos respublikoje susilauke stipraus atgarsio ir institute.

Vasario 6 d. rektorate buvo kalbama apie būsimąji instituto statutą. Administracijos parengtą projektą pristate prorektorius A. Juzènas, bet LPS remimo VISI grupès lyderis A. Čižas pareiškè, kad statuto projektą parenge ir LPS instituto grupés nariai. Ju vardu kalbejęs V. Jasulaitis perskaite LPS tarybos rezoliuciją ir pastabas dèl A. Juzèno pristatyto statuto projekto. Rezoliucijoje buvo pažymeta, kad numatoma rinkimu i instituto tarybą sistema nedemokratiška, per ilgos vady kadencijos ir t. t.

Posedyje buvo daug ginčų. Bene pirmą kartą rektorate buvo labai drąsiai oponuojama rektoriaus nuomonè. Statuto projektą abi puses nutare bendromis jegomis tobulinti.

Vasario 9 d. rektorius A. Čyras išleido įsakymą „Dèl valstybinès kalbos vartojimo“. Tai jau reiške Sąjūdžio idejų laimejjimu pradžią Vilniaus inžineriniame statybos institute.

Politine prasme labai reikšmingas instituto gyvenime vasario $14 \mathrm{~d}$. paskelbtas „Inžinerijoje"Vasario 16-osios aktas, kurị priemè ir paskelbè Lietuvos Taryba $1918 \mathrm{~m}$.

Jaudinantis buvo Vasario 16-osios minëjimas instituto Didžiojoje auditorijoje. Visa auditorija kartu su akademiniu choru „Gabija“ entuziastingai giedojo senąjį Lietuvos himną Tautinę giesmę, „Užtrauksim naują giesmę, broliai“, „Lietuviais esame mes gimę“.
Prof. A. Čižas perskaite Lietuvos Tarybos 1918 m. vasario 16 d. aktą, doc. J. Žekevičius - ištraukas iš J. Basanavičiaus leistos „Aušros“, V. Kudirkos „Varpo“.

Isspūdingai skambëjo LPS Seimo Tarybos pirmininko Vytauto Landsbergio kalba, kurioje jis primine tą laisvejjimo, savo vertés pajautimo kelią, kuriuo Lietuva ejo i Vasario 16-ąją.

Auditorijoje kabojo trispalve, kuri nuo tos dienos jau neapleido instituto.

Kovo $3 \mathrm{~d}$. institute lankessi Lietuvos komunistu partijos Centro komiteto pirmasis sekretorius Algirdas Brazauskas. Jị, kaip kandidatą $\mathfrak{i}$ TSRS liaudies deputatus, pristate prof. A. Kudzys.

A. Brazauskas sake, kad dabartiniu persitvarkymo laikotarpio etapu reikia taip tvarkytis, kad turètume apčiuopiamų rezultatų. Jo nuomone, respublika turi tikslą - suverenitetą. Dar vienas svarbus dalykas - savarankiškumas. Su LPS nesą tikslo konfrontacijai. Vyriausybès ir LPS santykiai turị būti geri, reikalinga vienybè.

Kovo viduryje buvo paskelbta, ị kokias studiju formas bus vykdomas priemimas vasarą. Buvo nurodytos specialybès, bet kiek bus priimta žmonių studijuoti - šį kartą nepaskelbè. Matyt, buvo laukiama radikaliu permainu.

Tuo pat metu rektoriui A. Čyrui tarnybini raštą paraše VISI civilinès gynybos vadovas N. Nikitinas. Jis skundesi, kad civilines gynybos užsiemmimus lanko tik $20 \%$ studentu, nors mokymas vykdomas lietuvių kalba (!). Pasirodo, kad Architektūros, Statybos ir Statybos ekonomikos fakultetų studentai iš vis nebelanko CG paskaitų.

Prastejo padetis ne tik karybos mokslų, kurių destymas iki tol vyko rusų kalba. Blogejo ir politinių mokslų situacija.

Diplomantai pasiraše kreipimąsi į instituto vadovus dèl valstybinio mokslinio komunizmo egzamino ir pareikalavo:

1. Valstybini egzaminą vesti diskusijos forma, nagrinejant probleminius klausimus, kuriuos rengia destytojai kartu su studenty atstovais. 2. Egzaminų komisijos sudètị leisti pasirinkti pačioms grupems, suderinus su dekanatu. 3. Valstybinio egzamino pažymys turi būti ne mažesnis kaip visuomeninių mokslų pažymių vidurkis. 4. Mokslinio komunizmo sesijos egzaminą pakeisti nediferencijuota iskaita.

Balandžio $4 \mathrm{~d}$. partinio komiteto sekretorius $\mathrm{K}$. Olšauskas pasiūle išnagrinèti civilinès

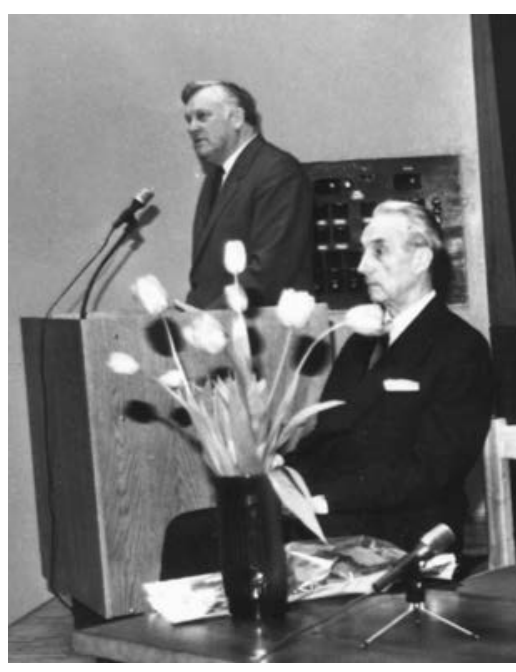

A. Brazauskas ir A. Kudzys

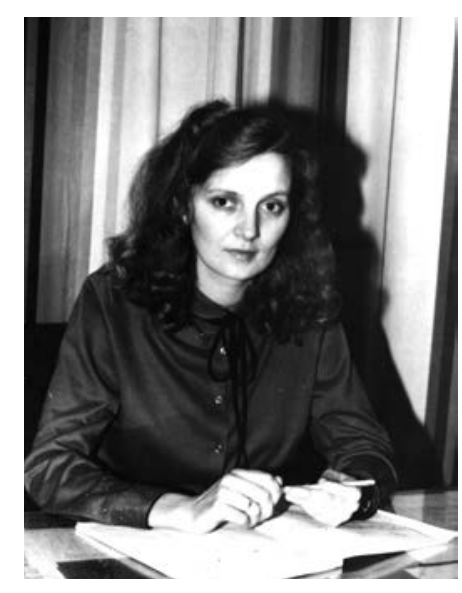

J. Dindaité-Kupliauskiené buvo išrinkta TSRS liaudies deputate

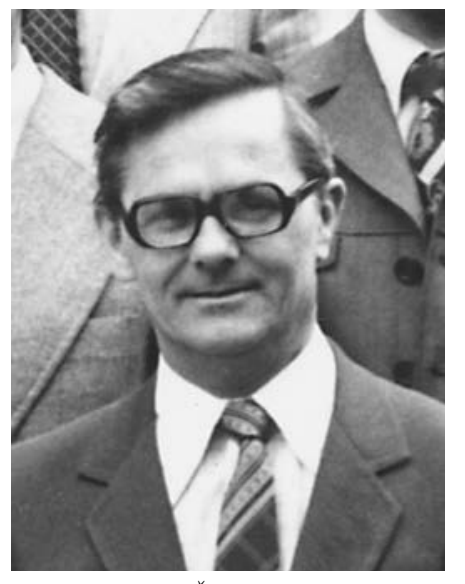

J. Žekevičius 


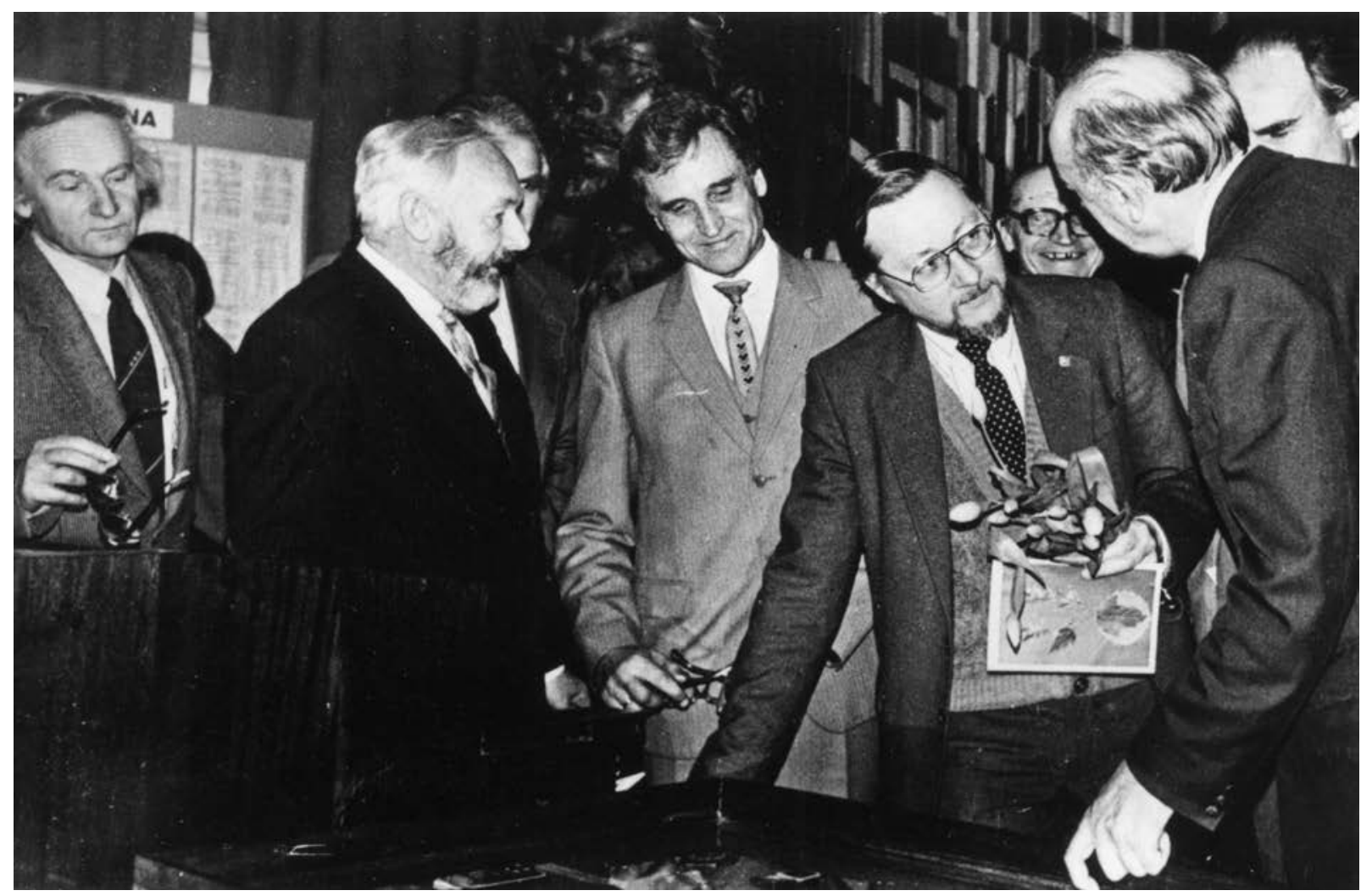

LPS pirmininkas V. Landsbergis svečiuose VISI, 1988 metais švenčiant Vasario 16-aja

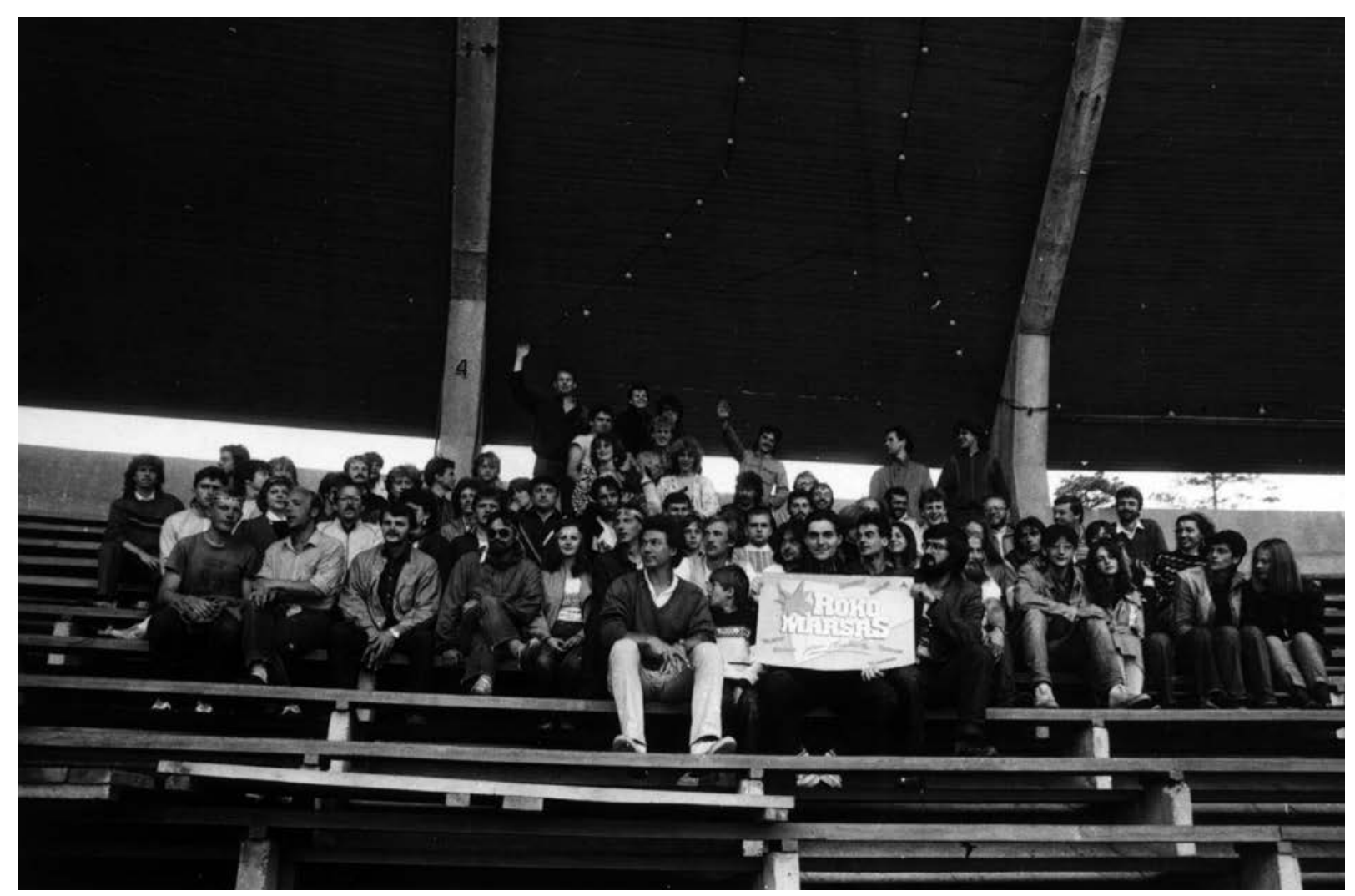

Tarp roko mařso dalyviu buvo dang VISI atstovu 
VILNIAUS

INŽINERINIS STATYBOS

INSTITUTAS

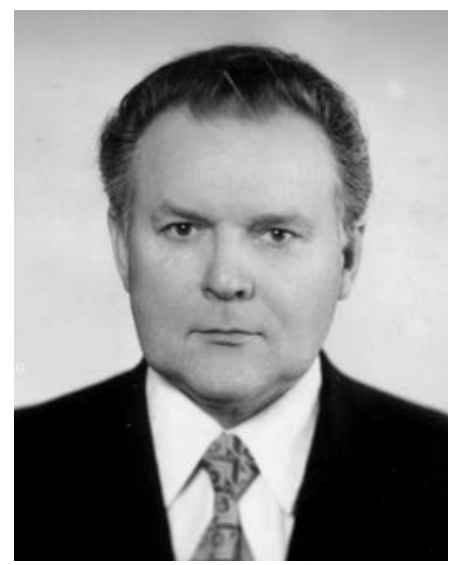

J. Dilba gynybos reikalus, bet apie mokslinio komunizmo egzaminą nekalbeta.

Balandžio $6 \mathrm{~d}$. tas pats K. Olšauskas paskelbè „Inžinerijoje“ straipsni „TSKP LKP CK XVII plenumo nutarimas ir pertvarkos bei demokratizacijos uždaviniai institute". K. Olšauskas, be kita ko, raše:

„Demokratinio centralizmo principas TSKP prieštarauja Respublikos politinio suvereniteto sampratai. Todel bütu tikslinga parengti LKP programa ir istatu projektus. Deramai juos apsvarsčius ir priemus, respublikine partine organizacija (veikiančia srities organizacijos teisemis) galima bütu reorganizuoti i savarankiškq Lietuvos Komunistu partija " [4.79, p. 1].

Pirmą kartą institute prabilta apie LKP ketinimą atsiskirti nuo TSKP.

Politinis gyvenimas institute tiesiog vire. Vyko Sąjūdžio renginiai, kitoniški nei anksčiau buvo partiniai susirinkimai, tarybos, rektorato posedžiai. Žmonès vis drąsiau reiške nuomonę įvairiausiais klausimais. Proletariato diktatūra braškèjo, nors iki tikros pergalès dar buvo toli.

Kovo $17 \mathrm{~d}$. atvirame partiniame susirinkime atmosfera kaito tuoj pat po sekretoriaus $\mathrm{K}$. Olšausko pranešimo, kurị jis su patosu baige šūkiu - „Liaudies planai - partijos planai“.

S. Arlauskas kviete džiaugtis, kad einama tautinio atgimimo keliu. E. K. Zavadskas kalbëjo apie opias socialines problemas, minëjo skurdų jaunųjų mokslininkų atlyginimą, dèl ko daugelis gabių žmonių palieka institutą. A. Jurkša sake, kad socializmą Lietuvai primete iš šalies, o ne pati Lietuva tą kelią pasirinko, kad gąsdinti tankais ar Karabachu - amoralu. Jis apgailestavo, kad LKP CK plenume neatsirado nè vieno, kuris būtu davęs atkirtį stalinistiniams A.Gabrèno, J. Gurecko išpuoliams. Stalinistus puole ginti VISI Karinès katedros vyr. destytojas A. Zaicevas. Jis kviete neatkurti savarankiškos LKP, nešaukti neeilinio LKP suvažiavimo. V. Brandišauskas atkirto A. Zaicevui sakydamas, kad, anot Lenino, nacionalizmas yra ne kas kita, o tik atsakas i rusiškąji socialšovinizmą.

I. Aleksaite teige, kad LKP CK plenume buvo išreikšta tokių nuomonių, nuo kurių gali pašiurpti. A. Lukoševičius pritare nuomonei, kad reikia sušaukti neeilini LKP suvažiavimą, o J. Dilba tiesiai šviesiai pareiškè, kad jam geda priklausyti partijai, kurios nariais yra J. Gureckas, V. Ivanovas, A. Zaicevas...

İvykių raida Lietuvoje ir institute darési vis radikalesne. Sajū dis tvirtai vedè tautą ne i suverenitetą, o ị nepriklausomybę. Aktyvi buvo ir LPS remimo VISI grupe.

1989 m. gegužès 15 d. rektorius A. Čyras išleido îsakymą, kuriuo, remdamasis Švietimo ministerijos kolegijos nutarimu, panaikino institute TSKP istorijos ir Mokslinio komunizmo katedras, o įsteige Politologijos katedrą. Šiai katedrai laikinai iki konkurso buvo priskirti: A. Marcelis, Z. Barkauskiene, E. Griškūnaite, V. Treigiene, N. Rybakovas, J. Kulakauskas, I. Vaitiekus, B. Stukiene, V. Jeruslanov, V. Brandišauskas, A. Blažiene, V. Tutkus, J. Juodagalvis, A. Jasmontas, R. Geleževičius, J. Srèbalius, E. Masalskiene, K. Monkevičius. Kai kurie iš jų buvo aktyvūs LPS nariai.

Tomis dienomis VISI Gelžbetoninių konstrukcijų katedros vedejjas A. Kudzys spaudoje suabejojo Vytauto Didžiojo universiteto atkūrimu. Jis raše:

„Aukštojo mokslo pertvarkos Lietuvoje tikslas - pagerinti visu sričiu specialistu rengima, palaipsniui stambinant ir kuriant naujas aukštasias mokyklas, tarp ju Kauno Vytauto Didžiojo universiteta. Noredami šc tiksla igyvendinti, privalome skubiai pašalinti iš aukštojo mokslo "vežimo" ratu visus pagalius. Pagrindinis pagalys yra demagogija, kuri vis dar viešpatauja aukštojo mokslo sistemoje.

Kai kolūkiečiai buvo alkani ir basi, tai išbujojo kolūkiu vadovai, turintys prietelius direktyviniuose organuose ir sugebantys gauti kitu saskaita papildomužemés ükio mašinu, trą̌u ir pašaru. Prasidejo, kaip rusaisako, "pokazuchu“" metas, tačiau ši demagogija nepagerino Lietuvoš̌emes ükio. Panašios „pokazuchos"pavyzdys yra skubiaisteigiamas Kauno Vytauto Didžiojo universitetas, kai norime dirbtinai parodyti Lietuvos aukštojo mokslo klestejima. Be to, aukštojo mokslo pertvarka ir nauju universitetu steigima daugiausiasprendžia Mokslu Akademijos ir kitu žinybu specialistai. Nejangi kelisimtai profesoriu ir keli tūkstančiai docentu, dirbančiu Lietuvos aukstosiose mokyklose yra tokiežiopli, kad is ju negalima sudaryti komisijos aktualiausiems müsu klausimams spręsti " $[4.80$, p. 2$]$.

Tame pačiame laikraštyje E. K. Zavadskas pradejo spausdinti prisiminimus apie tremtinių dalią Vorkutoje, kurioje jis ilgai gyveno, nuvykęs pas savo tevvą - tremtinị.

Birželio menesį rektorius A. Čyras patvirtino visų instituto katedrų destytojų etatus. 
Šis dokumentas rodo, kokios katedros ir kokio dydžio buvo paskutiniais sovietiniais 1989-1990 metais. Buvo tokios katedros ir ju etatai: Politologijos - 14,75; Filosofijos - 10; Politinès ekonomijos - 12; Lietuvių kalbos 8; Užsienio kalbų - 21; Estetikos - 8; Fizinio lavinimo - 20; Karinio parengimo - 21; Architektūros - 14; Dailes - 6,5; Urbanistikos - 8; Pastatu konstrukciju - 14,5; Matematikos - 30,5; Medžiagų atsparumo - 16; Statybinès mechanikos - 12; Gelžbetoninių konstrukciju - 15; Statybos darbų technologijos - 14; Pagrindų ir pamatu - 6,73; Metaliniu konstrukciju - 12; Darbo ir aplinkos apsaugos - 6,75; Statybos ekonomikos - 10; Statybos valdymo ir organizavimo - 12; Statybinių medžiagu - 7; Chemijos - 6; Autotransporto ekonomikos - 18; Miestų statybos - 6; Keliu - 9; Geodezijos - 21,2; Hidraulikos - 5; Vandentvarkos - 6; Šildymo ir vedinimo - 12; Elektrotechnikos - 11; Fizikos - 21; Metalų technologijos - 10; Automobilių transporto - 20; Mašinų gamybos technologijos - 9,25; Mašinų teorijos - 8; Braižybos - 22; Taikomosios matematikos ir mechanikos - 27; Statybos ir keliu mašinų -12.

1989 m. Vilniaus inžinerinis statybos institutas išleido 810 specialistų. Dieninị skyriu baige 535 , vakarini - 133 ir neakivaizdini - 142 žmonès.

$1989 \mathrm{~m}$. vasarą į institutą buvo numatyta priimti be stojamujų egzaminų, pagal atestatų balus. Daug jaunuolių grįžo iš sovietines armijos ir buvo priimti ị II kursą.

Rugpjūčio mènesį sužinota, kad Jūrate Kupliauskienè buvo išrinkta TSRS Aukščiausios Tarybos deputate.

Reikalingą straipsni, pavadintą „Išsaugokime“, „Inžinerijoje“ išspausdino profesorius E. K. Zavadskas. Jame kviete parodyti demesi savosios mokyklos istorijai.

VISI 20-mečio jubiliejaus išvakarèse rektorius A. Čyras palinkejjo studentams, destytojams, profesoriams ir visiems darbuotojams sekkmès Lietuvos atgimimo kelyje, džiaugsmo ir laimès kiekvieno gyvenime. Jis pareiške esąs įsitikinęs, kad visose gyvenimo srityse vyraus demokratija, viešumas, pagarba žmogui ir teisingumas.

Rugpjūčio 30 d. rektorius įsakymu panaikino parengiamajji skyriu prie VISI, kurio vedeju gerai dirbo ištisus 20 metų doc. P. Lukošius.

1989-1990 mokslo metų pradžia sutapo su instituto 20 metų jubiliejumi. Šventinis renginys vyko Vidaus reikalų ministerijos Kultūros rūmuose. Buvo sveikinimų, gražių ir piktokų kalbų, apdovanojimų, gražus meno kolektyvu koncertas. Bet susirinkusiųju nuotaika, nepaisant gausių ir energingų plojimų, buvo kažkaip nenatūrali. Buvo jaučiama, kad instituto laukia reikšmingos permainos.

Rugsejo $14 \mathrm{~d}$. rektorius A. Čyras išleido ìsakymą „Dèl komisijos instituto tarybai išrinkti sudarymo“. Komisijos pirmininku paskyre V. Liutiką - Matematikos katedros vedeją. Visi žinojo, kad būsimoji instituto taryba sudaroma, kad organizuotų ir pravestų rektoriaus rinkimus, kaip numate Statuto projektas. Bet gyvenimas įneše korektyvų. Madas diktavo Sajūdis.

Spalio $7 \mathrm{~d}$. Vilniuje įvyko Lietuvos mokslininkų steigiamasis suvažiavimas, kuris įkūrè Lietuvos mokslininkų sąjungą (LMS). I jos Tarybą buvo išrinkti du VISI atstovai: profesorius E. K. Zavadskas ir docentas B. Užpolevičius.

LMS suvažiavime desstęs VISI profesorius B. Kuzmickas kviete ryžtingai siekti, kad mokslininkai greičiau išsivaduotu iš mąstymo stereotipų ir autoritetų nelaisvès, kviete būti Lietuvos mokslo, ūkio ir tautos sąmonès atgimimo katalizatoriais.

1989 m. spalio 3 d. „Inžinerijos“ numeris buvo paskutinis, išleistas vyr. redaktores Halinos Kobeckaites. Ji entuziastingai pasinère į Lietuvos politini gyvenimą, o vyr. redaktore pradejo dirbti Reda Šmigelskienè. Abieju vyriausiųjų redaktorių darbas, leidžiant instituto laikrašti, vertinamas tikrai puikiai. Laikraštis „Inžinerija“ nepriekaištingai perteike tą audringą permainų laikotarpį ir tapo tikru instituto gyvenimo metraščiu.

Spalio viduryje susidariusi VISI iniciatyvinè studentu grupè paskelbè VISI studentų parlamento įstatų projektą. Jame buvo teigiama, kad Studentu parlamentas savarankiškas, atstovauja visiems studentams, savo veiklą grindžia Lietuvos konstitucija ir t. t. Projekte buvo numatyta rinkimuc $i$ parlamentą tvarka, organizaciné struktūra ir kt.

Studentu parlamentas ketino vykdyti tokias funkcijas: spręsti visus studentų socialinius klausimus, ginti studentu teises, dalyvauti derinant studijų tvarkaraštį, atestuojant destytojus ir t. t. Išrinktasis VISI studentu parlamentas jau spalio $25 \mathrm{~d}$. paskelbe kreipimąsi dèl tarnybos sovietinëje armijoje.

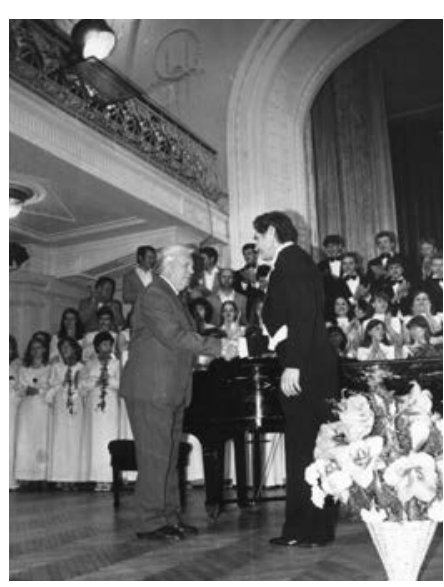

„Gabija“paminëjo 25-meti

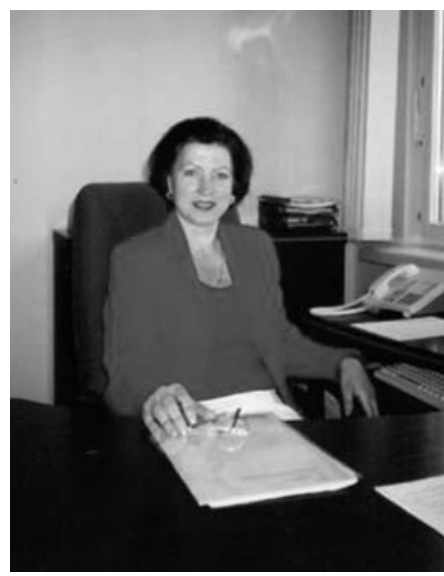

R. Varniene - VISI bibliotekos direktoré 1989-1992 m. 
VILNIAUS

INŽINERINIS STATYBOS

INSTITUTAS

ši naujoviškai sudaryta Taryba sprendè instituto radikalios pertvarkos klausimus, pateikiame visą jos sąrašą:

LIETUVOS TSR DEPUTATAMS,

TSRS LIAUDIES DEPUTATAMS,

VISI TARYBAI, LPS SEIMUI,

LIETUVOS ŽMONEMSS

Lietuvos žmones vis dažniau sukrečia žinios iš Tarybines armijos. Kankinimai, niekinimai, žudomi mūsu tautos sūnūs. Ne vienas lietuvis negali būti abejingas, tuo labiau tam negali būti abejinga studentija. VISI studentai, jausdami atsakomybe už kiekviena savo tautieti, tarnaujanti okupacineje armijoje, mano, kad praejusioje Lietuvos Aukšciausiosios Tarybos sesijoje šis klausimas nebuvo išsprestas ir to pasekoje rudeninio saukimo Lietuvos jaunuoliai vel privales eiti $\dot{z}$ "raudonaji pragara“. Todel LTSR Aukšciausiosios Tarybos sesijoje ivyksiančioje lapkričio $3 d$. turi būti priimtas sprendimas, kad $i$ okupacine SSSR armija nebütu šaukiamas ne vienas Lietuvos pilietis, ir atsisakiusiam tarnauti, remiantis tarptautine žmogaus teisiu deklaracija, Ženevos konvencija ir LTSR Aukšciausiosios Tarybos pripažintu müsu respublikos okupaciniu statusu, nebūtu taikoma jokia prievarta. Tuo mes irodysim savo tautos vienybe, o büdami abejingi patys sau tapsim savo tautos budeliais. Sesijos metu, lapkričio 3 diena palaikydamas pažangiasias LTSR Aukščiausiosios Tarybos ir TSRS liaudies deputaty jegas, galinčias teigiamai isspręsti šz klausima, VISI studentu parlamentas kviečia visus Lietuvos studentus ir destytojus neiti $i$ studijas ir dalyvauti pikete prie Aukščiausiosios Tarybos rūmu.

VISI studentu parlamentas

19891025

VISI taryba pritare instituto Studentu parlamento kreipimuisi ir siūle lapkričio 3 dieną paskaitas (laisvu susitarimu tarp destytoju ir studentu) perkelti i kitą laiką, kad destytojai ir studentai galetų nueiti prie Aukščiausiosios Tarybos rūmų išreikšti savo nuomonę dèl Lietuvos piliečių tarnybos TSRS armijoje.

\section{Demokratiškai išrinkta VISI taryba}

Spalio $25 \mathrm{~d}$. buvo paskelbti rinkimų i instituto Tarybą rezultatai, o rytojaus dieną Taryba susirinko ị pirmąji posedį. Iš viso buvo demokratiškai išrinkta 150 žmonių. Kadangi

\section{Inžinerines ekonomikos fakulteto deleguotieji:}

1. Albinas Gailius - Statybinių medžiagų $\mathrm{k}$-ros vedejjas, docentas

2. Vilhelmas Bagdonas - Statybos ekonomikos k-ros vedejjas, docentas

3. Albertas Šimenas - Statybinès ekonomikos k-ros docentas

4. Povilas Norkus - Chemijos k-ros vedejas, profesorius

5. Algis Juozas Grigas - Statybiniu medžiagų laboratorijos vedejjas

6. Adolfas Baublys - Autotransporto ekonomikos k-ros vedejas, profesorius

7. Ramūnas Palšaitis - Autotransporto ekonomikos k-ros docentas

8. Remigijus Pajeda - Autotransporto organizavimo ir valdymo laboratorijos vedejas

9. Petras Gailutis Adomènas - Autotransporto ekonomikos k-ros e. doc. pareigas

10. Kęstutis Valašimas - Statybos valdymo organizavimo k-ros vedejjas, e. doc. pareigas

11. Vidmantas Urbonas - Statybos valdymo sistemų laboratorijos vedejas

12. Juozas Bivainis - Statybos valdymo organizavimo $\mathrm{k}$-ros docentas

13. Nerijus Maculevičius - Statybos valdymo sistemų laboratorijos vyr. m. b.

\section{Miestu statybos fakulteto deleguotieji:}

14. Vytautas Jasulaitis - Kelių k-ros vedëjas, docentas

15. Kazys Sakalauskas - Miestų statybos fakulteto dekanas, docentas

16. Antanas Aloyzas Juzenas - vakarinio ir neakivaizdinio mokymo reikalų prorektorius, Keliu katedros docentas

17. Pranciškus Juškevičius - Miestų statybos $\mathrm{k}$-ros vedejjas, docentas

18. Marija Burinskiené - Miestų statybos k-ros e. doc. pareigas

19. Jonas Skeivalas - Geodezijos k-ros e. profesoriaus pareigas

20. Zenonas Kumetaitis - Geodezijos k-ros e. doc. pareigas

21. Petras Petruškevičius-Geodezijos k-ros docentas 
22. Algimantas Zakarevičius - Geodezijos $\mathrm{k}$-ros docentas

23. Skirmantas Skrinskas - Kelių laboratorijos vedejas

24. Juozas Jakimavičius - Fizikos k-ros vedejas, docentas

25. Juozas Algimantas Šatas - Fizikos k-ros docentas

26. Nijole Mykolaitienè-Fizikos k-ros docentè

27. Libertas Klimka - Fizikos k-ros docentas

28. Nijole Astrauskiené - Fizikos k-ros docentè

\section{Komunalinio ūkio fakulteto deleguotieji:}

29. Rokas Alvydas Liaukonis -Šildymo ir vedinimo k-ros profesorius

30. Vytautas Martinaitis - Šildymo ir vedinimo k-ros docentas

31. Zigmantas Jankauskas - Elektrotechnikos k-ros e. profesoriaus pareigas

32. Juozas Gediminas Valiukenas - Elektrotechnikos k-ros vedejas, docentas

33. Patricija Didžiapetriene - Vandentvarkos mokslo tiriamosios laboratorijos vyr. m. b.

34. Jonas Duoba - Komunalinio ūkio fakulteto dekanas, docentas

35. Vytautas Kazimieras Sakalys - Fizinio lavinimo $\mathrm{k}$-ros vedejjas, docentas

36. Irena Ona Marčiukaitiene -Fizinio lavinimo k-ros docente

37. Vytautas Jurgis Barisas - Fizinio lavinimo k-ros docentas

38. Romualdas Levickas - Fizinio lavinimo k-ros vyr. déstytojas

39. Dangira Paukštyte - Komunalinio ūkio fakulteto dispečerè

\section{Architektūros fakulteto deleguotieji:}

40. Romualdas Alekna - Dailès k-ros meistras

41. Česlovas Ignatavičius - Pastatų konstrukcijų k-ros vedëjas, docentas

42. Algimantas Jonas Nakas - Pastatų konstrukcijų k-ros docentas

43. Regina Gaušienè - Dailès k-ros e. doc. pareigas

44. Raimundas Arnas Dineika - Architektūros k-ros vedejas, docentas

45. Konstantinas Jakovlevas-Mateckis - Architektūros fakulteto dekanas, profesorius
46. Jurgis Vanagas - Urbanistikos k-ros vedejas, profesorius

Visuomenes mokslu katedros deleguotieji:

47. Eugenija Martinaitytè - Politinès ekonomijos $\mathrm{k}$-ros vedeja, docente

48. Jeronimas Grèska - Politinès ekonomijos k-ros e. profesoriaus pareigas

49. Aldona Baužienè - Politologijos k-ros vedëja, docentè

50. Albertas Marcelis - Politologijos k-ros profesorius

51. Rimgaudas Geleževičius - Politologijos $\mathrm{k}$-ros destytojas

52. Juozas Mureika - Filosofijos k-ros vedejas, profesorius

53. Halina Kobeckaite - Filosofijos k-ros docentè

Mechanines technologijos fakulteto deleguotieji:

54. Petras Audzijonis - Braižybos k-ros docentas

55. Pranas Gerdžiūnas - Braižybos k-ros docentas

56. Brunonas Gruzdys - Braižybos k-ros docentas

57. Alfonsas Venancijus Kuzmickas - Taikomosios matematikos ir mechanikos $\mathrm{k}$-ros docentas

58. Daumantas Maciulevičius - Taikomosios matematikos ir mechanikos k-ros vedejas, profesorius

59. Rimantas Belevičius - Taikomosios matematikos ir mechanikos k-ros e. doc. pareigas

60. Elena Strumskiené - Taikomosios matematikos ir mechanikos k-ros docente

61. Rimantas Kačianauskas - Taikomosios matematikos ir mechanikos k-ros e. doc. pareigas

62. Alvydas Pikūnas - Automobilių transporto $\mathrm{k}$-ros vedejas, docentas

63. Viktoras Tilindis - Automobilių transporto k-ros docentas

64. Juozapas Mindaugas Nemira - Automobilių transporto k-ros docentas

65. Česlovas Kęstutis Lukoševičius - Automobilių transporto k-ros docentas

66. Vytautas Turla - Mašinų teorijos k-ros vedejas, docentas

67. Arūnas Jakštas - Mašinų teorijos k-ros docentas 
VILNIAUS

INŽINERINIS STATYBOS

INSTITUTAS
89. Vidmantas Drobelis - Konstrukcijų bandymo laboratorijos vedejas

90. Jonas Juozaitis - Metalinių konstrukcijų k-ros vedëjas

68. Algirdas Vaclovas Valiulis - Metalu technologijos k-ros vedejas, docentas

69. Leonas Keblas - Metalų technologijos $\mathrm{k}$-ros docentas

70. Mečislovas Mariūnas - Mechaninès technologijos fakulteto dekanas, profesorius

71. Zigmas Kulaitis - Mašinų gamybos technologijos k-ros docentas

72. Bronislovas Spruogis - SKM k-ros vedejas, docentas

73. Marijonas Bogdevičius - SKM k-ros vyr. déstytojas

\section{Skaičiavimo centro deleguotieji:}

74. Violeta Ločeryte் - AIS sektoriaus viršininke

75. Algimantas Tamošaitis - Matematinio aprūpinimo skyriaus viršininkas

76. Ona Ramuté Turoniené - vyr. inžinieré programuotoja

\section{Bibliotekos deleguotieji:}

77. Regina Varniené - bibliotekos direktore

78. Ona Kuodienè - Komplektavimo skyriaus vyr. metodininkè

79. Marija Kačkuvienè- moksl. techn. inf. grupés vedëja

\section{Statybos fakulteto deleguotieji:}

80. Vytautas Liutikas - Matematikos k-ros vedejas, e. profesoriaus pareigas

81. Stasys Čirba - Matematikos k-ros docentas

82. Jonas Kleiza - Matematikos k-ros docentas

83. Eduardas Vakrina - Matematikos k-ros vyr. déstytojas

84. Juozas Raulinaitis - Matematikos k-ros docentas

85. Antanas Kudzys - Gelžbetoninių konstrukcijų k-ros vedejas, profesorius

86. Jonas Gediminas Marčiukaitis - mokslo reikalų prorektorius, profesorius

87. Povilas Vainiūnas - Statybos fakulteto dekanas, docentas

88. Arvydas Jurkša - Gelžbetoninių konstrukcijų k-ros docentas
91. Vladas Vaitkevičius - Metalinių konstrukciju k-ros docentas

92. Alfonsas Daniūnas - Metaliniu konstrukcijų k-ros vyr. destytojas

93. Gintas Lašas - Metalinių, medinių ir plastmasinių konstrukcijų laboratorijos vedejas

94. Antanas Algirdas Alikonis - Pagrindu ir pamatu $\mathrm{k}$-ros vedejjas, docentas

95. Bronius Sidauga - mokymo reikaly prorektorius, profesorius

96. Vytautas Kuliešius - Pagrindų ir pamatu katedros inžinierius

97. Liudmila Mauzienè - Užsienio kalbų $\mathrm{k}$-ros docente

98. Rūta Elžbieta Katalynaitè - Užsienio kalbų k-ros docente

99. Zinaida Stanevičiene - Užsienio kalbų k-ros docente

100. Kazimieras Rukšènas - Užsienio kalbų $\mathrm{k}$-ros vedëjas, docentas

101. Edmundas Kazimieras Zavadskas Statybos darbų technologijos k-ros vedejas, profesorius

102. Vladas Ćeslovas Kriukelis - Statybos darbų technologijos k-ros docentas

103. Vladimiras Glebovas - Statybos darbų technologijos k-ros e. doc. pareigas

104. Danielius Gužas - Darbo ir aplinkos apsaugos k-ros docentas

105. Rimantas Šukys - Šildymo ir vedinimo $\mathrm{k}$-ros inžinierius

106. Algirdas Eduardas Čižas - Medžiagų atsparumo k-ros vedëjas, profesorius

107. Jonas Algirdas Žekevičius - Medžiagu atsparumo k-ros docentas

108. Kęstutis Vislavičius - Medžiagų atsparumo k-ros docentas

109. Aleksandras Čyras - rektorius, Statybines mechanikos $\mathrm{k}$-ros profesorius

110. Antanas Krutinis - Statybinés mechanikos k-ros vedëjas, docentas

111. Antanas Patapavičius - Medžiagų atsparumo laboratorijos vedejas

112. Uljana Popkova - Lietuvių ir rusų kalbų k-ros vyr. dèstytoja

113. Juozas Stonys - Lietuvių ir rusų kalbų $\mathrm{k}$-ros vedejas

\section{Karinio parengimo katedros deleguotieji:}

114. Stanislovas Panavas - meistras 
115. Konstantinas Stanislovas Danaitis Karinio parengimo k-ros viršininkas, pulkininkas

116. Algirdas Tamošiūnas - Karinio parengimo k-ros vyr. destytojas

117. Sergijus Trapeznukovas - Karinio parengimo k-ros vyr. destytojas

118. Viktoras Pulinas - Karinio parengimo $\mathrm{k}$-ros destytojas

\section{Estetikos katedros deleguotieji:}

119. Juozas Sidaravičius - Estetikos k-ros vedejjas, e. doc. pareigas

120. Justinas Jonušas - Estetikos k-ros e. doc. pareigas

\section{Kvalifikacijos tobulinimo fakulteto deleguotieji:}

121. Ipolitas Zenonas Kamaitis - Kvalifikacijos tobulinimo fakulteto dekanas, e. prof. pareigas

122. Gintaras Aksomitas - Statybos k-ros e. doc. pareigas

\section{Administracijos deleguotieji:}

123. Vytautas Plakys - Mokymo skyriaus vedejas

124. Henrikas Giedrys - vyr. mechanikas

125. Jonas Narkevičius - vyr. energetikas

126. Virgilijus Bičkauskas - garažo viršininkas

127. Anatolijus Rimkevičius - MTS viršininkas

128. Jonas Kliauza - vyr. buhalteris

129. Vidmantas Suveizdis - bendrabučio Nr. 6 komendantas

130. Henrikas Marcinkevičius - I rūmy komendantas

131. Rimas Lekys - bendrabučio Nr. 3 komendantas

132. Vidmantas Bilinskas - Eksploatacinio skyriaus viršininkas

133. Kazys Petkevičius - centrinių rūmų komendantas

134. Stanislovas Kabulovas - II rūmų komendantas

135. Algirdas Žilinskas - Kapitalinès statybos grupès vadovas

136. Danute Godvaišiene - budetoja

137. Rimvydas Naujokas - Patentines paieškos grupès viršininkas

138. Alè Šlekienè - Kadrų skyriaus viršininkè
139. Kęstutis Briedis - Remonto skyriaus viršininkas

\section{Studenty deleguotieji:}

140. Rokas Knyva - AT-6/3 gr.

141. Dainius Burdulis - SI -6/1 gr.

142. Vygantas Subačius - AK-5/2 gr.

143. Artūras Arliukas - SKM-6/2 gr.

144. Kęstas Kieras - ATE-6/1 gr.

145. Irmantas Gailius - ATE-8/1 gr.

146. Rita Liubinaite $-\check{S} \mathrm{~V}-7 / 1 \mathrm{gr}$.

147. Algis Butrimavičius $-\mathrm{AT}-8 / 3$ gr.

148. Žilvinas Ragauskas $-\check{S} \mathrm{~V}-6 / 1$ gr.

149. Tautvydas Laucius $-\check{S} V-7 / 2$ gr.

Vilniaus inžinerinio statybos instituto Tarybos pirmininku buvo išrinktas prof. Algirdas Čižas, jo pavaduotoju - doc. Vytautas Jasulaitis.

Greitai buvo parengta ir patvirtinta instituto taryboje VISI rektoriaus rinkimu procedūra. Prasidejjo rektoriaus rinkimų kampanija.

Taigi naują rektorių turejo išrinkti net 150 asmenu taryba, kurioje buvo atstovaujama mokslininkms, darbuotojams ir studentams.

\section{Permainu procesas intensyveja}

Nors instituto kolektyvas gyveno jau permainu dvasia, rektoratas vis dar buvo inertiškas. Spalio $27 \mathrm{~d}$. rektoriaus įsakymu „Dèl vardinių stipendijų“ penkiems studentams buvo paskirtos Lenino stipendijos, po vieną - Dzeržinskio ir Angariečio. Neužteko drąsos šių trijų vardinių stipendiju jau nebeskirti, o daugiau skirti, tarkim, instituto tarybos stipendijų.

Blaškesi savo nuostatose ir instituto partinè organizacija. Spalio $27 \mathrm{~d}$. įvykusiame instituto partinès organizacijos atvirame susirinkime buvo priimtas pareiškimas, kuriame, be kita ko, klausiama: „Kas mes ir su kuo mes? Savo krašto patriotai ar paklusnūs svetimos valios vykdytojai? Lietuvos kürejai ar jos atkūrimo stabdytojai?" [4.81, p. 1].

Partinis susirinkimas vienbalsiai pareiškè, kad reikalauja visiškai savarankiškos Lietuvos komunistų partijos, kuri savo santykius su kitomis partijomis grịstu pariteto principu. „Mums, Lietuvos komunistams, atejo metas ryžtingai apsispręsti. LKP turi eiti su savo 
VILNIAUS

INŽINERINIS STATYBOS

INSTITUTAS gaminti nauja produkcija, taikyti naujas technologijas.

Neramina tai, kad kasmet mažeja mokslo

Tauta ir visais kitais pažangiai nusiteikusiais Lietuvos gyventojais ".

Susirinkimas išrinko Algirdą Čižąa ir Ramūną Palšaitị delegatais ị Lietuvos komunistų partijos XX suvažiavimą.

1989 m. ypač aktyvus įvairiausiose srityse buvo profesorius Edmundas Kazimieras Zavadskas. İvairiuose leidiniuose jis skelbia vieną paskui kitą iškart demesị patraukiančius publicistikos straipsnius visiems aktualiais klausimais.

Spalio $14 \mathrm{~d}$. Kaune, atkuriant Lietuvos inžinierių sąungą, E. K. Zavadskas energingai polemizavo šiuolaikinių inžinierių rengimo klausimais ir apie tai raše laikraštis „Inžinerinè mintis“. Dar birželio mènesị jis tame pačiame leidinyje spausdintame straipsnyje „Ar verta taip taupyti?" teigé, kad aukšta kvalifikacija nevertinama, klausé, kada pagaliau bus pradèta suprasti, kad be kūrybinių darbuotojų suinteresuotumo neimanoma jokia technikos pažanga. İsimintinas, ilgainiui tapęs postūmiu kai kuriems darbams buvo E. K. Zavadsko straipsnis „Išsaugokime...". Jis kviete dometis, branginti senąją istoriją, taip pat technikos mokslų istoriją.

Profesorius E. K. Zavadskas 1989 m. lapkričio $16 \mathrm{~d}$. instituto laikraštyje „Inžinerija " išdèste savo nuostatas tuometinès technikos mokslu padeties klausimu ir faktiškai pareiške ketinimą vesti institutą radikaliu pozityvių permainų keliu. $\mathrm{Pa}$ teiksime kai kurias šio didelio ir drąsaus straipsnio mintis:

„Lietuva nuolat atsilieka pagal bendra mokslininku skaičiu dešimčiai tūkstančiu gyventoju ne tik nuo kaimyniniu Latvijos bei Estijos.

Technikos mokslu, kaip ir kitu mokslu, tikslas - ieškoti nauju technikos sprendimu, nauju tiesu. Tačiau vis dažniau technikos mokslai tampa ministeriju ir žinybu tarnais. Jeigu mokslininku išaiškinamos tiesos nenaudingos žinyboms, jos dažniausiai atmetamos. Žinyboms naudinga užsakyti netgi milijardus kainuojančius antimokslinius projektus ir juos realizuoti praktikoje.

Administracinis-komandinis valdymo stilius neskatino didinti mokslininku ir inžinieriu kompetencijos. Kürybinis darbas buvo ir yra menkai apmokamas. Isigalejęs ekonominis mechanizmas neskatino gamybininku darbuotoju ivairiose technikos srityse. Pavyzdžiui, tik 7 proc. inžinieriu dirba mokslinj darba.

Lietuvoje kas 25 mokslo darbuotojas - moksly daktaras. Taigi technikos mokslu srityje vienam moksly daktarui tenka tik 50-60 mokslo darbuotoju. Yra technikos krypties moksliniu tyrimo institutu, kurie turi po viena daktara arba ne vieno... Iš 12-13 mokslo kandidaty tik vienas tampa mokslu daktaru.

Net ir gerai parengta darba sunku apginti del nevykusios moksliniu laipsniu suteikimo sistemos. Lietuvoje praktiškai nera moksliniu tarybu, galinčiu suteikti technikos daktaro laipsni, mažai yra ir tarybu, suteikiančiu technikos mokslu kandidato laipsni. Dangelis sričiu beveik neturi specialistu, turinčiu laipsnius. Kq kalbeti apie specialistus, jei analogiška padetis susidare ir su kai kuriu sričiu inžinieriais. Respublikoje neruošiami dangelio specialybiu inžinieriai. Beveik nesiunčiami arba nenoriai priimami mūsu abiturientai studijuoti retu specialybiu $\dot{z}$ šalies ir užsienio aukštasias mokyklas. Pavyzdžiui, mažai turime aviacijos, jüru laivininkystés, branduolines energetikos ir kitu specialistu.

Beveik dvigubai atsilikome nuo bendro šalies vidurkio leisdami knygas. Atsilikome ir nuo Latvijos ir Estijos. Tik kas šeštam Lietuvos gyventojui per metus isspausdiname moksline knygq. Ypač mažai išleidžiama literatūros iš technikos moksly srities.

Lietuvos aukštoji technikos mokykla yra apgailetinos padeties. Mokslui vystyti, materialei bazei plesti, skiriama labai mažai biudžetiniu lëšu. Kiek daug yra technikos moksly katedru be laboratoriju. Destytojai, turintys mokslinius vardus ir laipsnius, gauna prieškarinius atlyginimus. Vis toliau atidedamas ir numatytas simbolinis destytoju atlyginimu didinimas.

Destytojai moksliniam darbui gali skirti nedaug laiko, nes mūsu aukštosiose mokyklose jie dažnai turi iki 3 kartu dangiau savaitinin valandu negu užsienio saliu mokyklu destytojai. Paradoksalu, tačian kai kuriu katedru destytojai turi daugiau savaitiniu valandu net už viduriniu mokyklu mokytojus. Todel laukti aukśtu mokslo laimejimu, neturint laiko bei biudžetinio finansavimo, vargu ar realu.

Neskatinami rimtesni ilgalaikiai fundamentalūs tyrimai. Toliau smulkeja moksliniu 


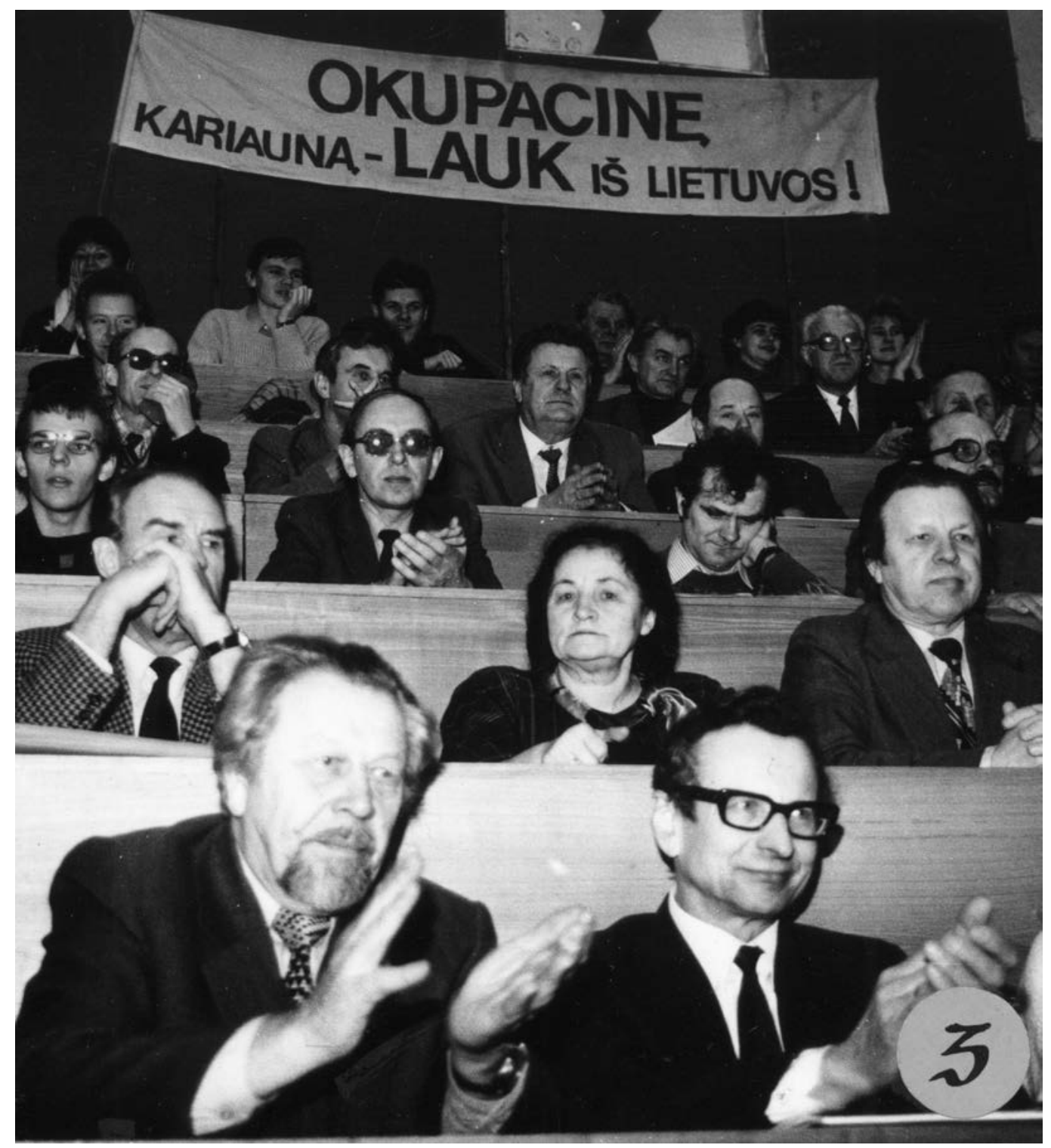

darbu pagal ükiskaitines sutartis tematika ir ju rezultatai.

Dabartiniu metu daug kalbama apie Lietuvos ekonomikos kelima, tačiau labai mažai technikos mokslu specialistu turi galimybę kelti kvalifikacija užsienyje, susipažinti su garsiu užsienio mokslo istaigu darbo patirtimi.

Siekiant teigiamu permainu, bütina keisti mokslo padeti valstybëje. Lietuvos TSR Aukščiausioji Taryba turetu tuoj pat patvirtinti aukstuju mokyklu priimtus statutus, turetu paruošti ir Mokslo istatyma, kuris leistu didinti jo svarba, nustatytu organizaciniu struktūru funkcionavimo principus, itvirtintu mokslininko teises ir pareigas. Šiam tikslui turi padèti ir mūsu kuriama Mokslininkusajunga. Akademiniam jaunimui reikalingas pavyzdys - destytojai mokslininkai, destytojai asmenybes, o ne žinybu pasamdyti konformistai. Vienu iš svarbiausiu uždaviniu tampa inžinerijos mokslu humanizavimas" [4.82, p. 1].
Laisvejjimo reiškiniai Lietuvoje kèle didelį susirūpinimą Maskvai. Vilniuje vis dažniau lankydavosi jos emisarai, siekdami tramdyti kylančias emocijas, siekdami kiek atsverti politinę Sąjūdžio įtaką visuomenei.

Sausio 10-ają svečio iš Maskvos sulauke ir VISI. Tai buvo TSRS liaudies švietimo komiteto pirmininkas akademikas G.Jagodinas. Vos ižzengęs i Didžiają auditoriją, akademikas suprato, kuo gyvena VISI. Auditorijoje studentai laike plakatus su iškalbingais tekstais: „Gorbačiovai, išvesk Raudonają Armiją iš Lietuvos“, „Russian occupants go home" ir t. t. Pirmiausia kalbejo VISI partinio komiteto sekretorius A. Kuzmickas, supažindinęs svečią su politine situacija Lietuvoje ir VISI komunistu nuostatomis tos situacijos atžvilgiu. V. Liutikas priminè susirinkusiems Lietuvos praradimus komunistu valdymo laikais, deportacijas ir kitus nusikaltimus. J. Mureika pabrěže,

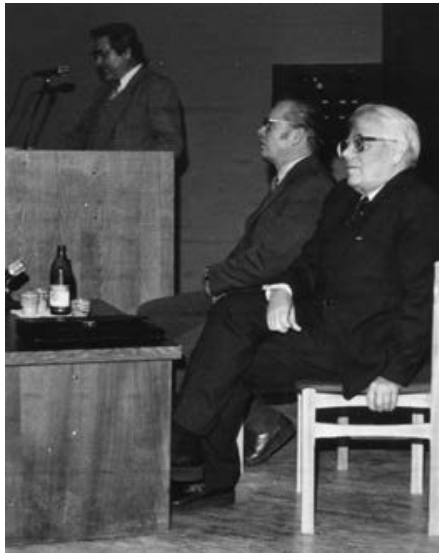

G. Jagodinas

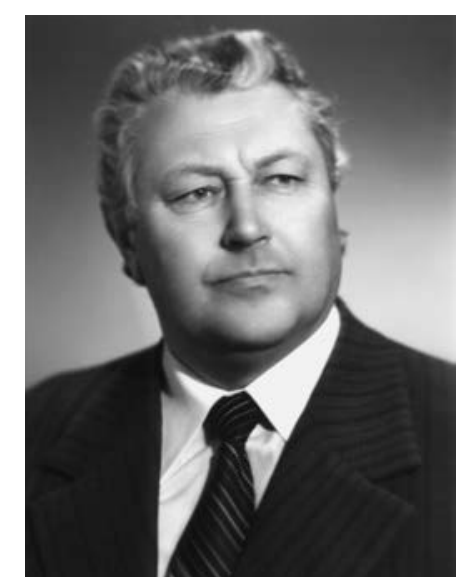

V. Liutikas 
VILNIAUS

INŽINERINIS STATYBOS

INSTITUTAS demokratinès santvarkos ir piliečių saugos bei gerovès būtina sąlyga.

ATGIMUSIAI LIETUVAINEPRIKLAUSOMYBE,

kad visa atsakomybe už liaudies nelaimes tenka TSKP. G. Jagodino kalba rode jo îsitikinimą, kad Lietuva 1940 m. savanoriškai istojo į TSRS. Jis tvirtino, kad neverta teisti žmones, kurie anksčiau prièmé vienokius ar kitokius sprendimus, nes buvęs kitas laikotarpis. Esą Gorbačiovas negali atsakyti už Stalino genocidą. Atvira buvo G. Jagodino nuomonè dèl rusų kalbos statuso. Jo manymu, kur tik ženge JAV ar Anglija, visur tautos turëjo kalbèti anglų kalba. Ši kalba buvo primetama prievarta. Svečio nuomone, rusų kalbos niekas prievarta neprimetinëjo. Jis teige, kad mažų tautų kalba išnyks, nes neturi ateities... (!?) [4.83, p. 1].

Sausio 11-ąją i Vilnių atvyko pats M. Gorbačiovas. Jis, anot „Gimtojo krašto“, bande itikinti Lietuvą, kad jai nereikia nepriklausomybès. Per tris viešnagès dienas "jis patobulino tautu apsisprendimo teise - nuo šiol panorejusi apsispresti tauta gales apsispręsti tik tada, kai... kitos tautos jai leis apsispresti (!) “ [4.84, p. 1].

Bet Lietuva leidimo jau neprašè. JAV žurnalistas B. Keleras savo reportaže laikraštyje „The New York Times“ sausio 13 d. rašè:

„Susidūręs su Lietuvos separatiniu judejimu, M. Gorbačiovas ragina palaukti naujos federacijos sukürimo. Joje jis žada lietuviams ir kitoms apsisprendusioms respublikoms realiu ekonominiu ir politiniu laisviu.

Kiekviename žingsnyje Baltijos respublikos gatvèse ir auditorijose M. Gorbačiovas susidūré su mandagiu, bet lediniu apsisprendimu lietuviu, kurie abejoja Gorbačiovo galimybemis igyvendinti savo pažadq" " $[4.85$, p. 3].

Ką gi, M. Gorbačiovas prisidejjo prie sovietines imperijos irimo, bet jam trūko istorinio įžvalgumo suvokti tautų laisvès troškimą, kuris vede i vieną tikslą - valstybinę nepriklausomybę. M. Gorbačiovo pažadai nebuvo priimtini Lietuvai ir tai tereiške jo politinius dividendus, kurie jam jokios naudos duoti jau negalejo.

$1990 \mathrm{~m}$. vasario $24 \mathrm{~d}$. buvo paskelbti rinkimai i Lietuvos TSR Aukščiausiąją Tarybą. „Sąjūdis“ vasario pradžioje paskelbè savo rinkiminę programą, kurioje pareiškè, kad „sieks atkurti nepriklausomą, demokratiškai tvarkomą Lietuvos valstybę, kūrybiškai vystyti ir igyvendinti programos nuostatas. Lietuvos nepriklausomybè yra tautos išlikimo,

\section{NEPRIKLAUSOMAI LIETUVAI - DEMOKRATIJA,}

\section{DEMOKRATIŠKAI LIETUVAI- ŽMONIŠKA GYVENIMĄ!}

\section{DEMOKRATIJA, NEPRIKLAUSOMYBE் IR GEROVE NEATSKIRIAMOS!}

Tuo pat metu Vilniaus inžineriniame statybos institute plètota diskusija rektoriaus rinkimų klausimu. „Inžinerija“ apklausè nemažai déstytojų - koks rektorius reikalingas institutui. Štai kai kurios pasisakiusiųjų mintys:

„Pirmiausia jis turi būti doras žmogus, savo Tèvynès Lietuvos patriotas ne dèl konjunktūros, $o$ iš j̧itikinimo, pasiryžęs del jos labo rizikuoti net savo kède <...>. Turètu büti šiek tiek ir bumanitaras" (V. Būda).

„Rektoriumi turètu büti veiklus žmogus, turintis gery organizaciniu sugebejimu, plačiu ryšiu ir vardą už instituto ribu" (A. Rimkevičius).

„Rektorius turi būti sąžiningas, demokratiškas, kompetentingas, naujoviu ieškotojas ir be abejo - objektyvus" (K. Rukšènas).

"Institutui reikalinga asmenybe“"(V. Plakys).

VISI taryba patvirtino VISI rektoriaus rinkimų procedūrą, kurioje labai detaliai aptarti kandidatų i rektoriaus postą iškelimo, ju aptarimo padaliniuose, balsavimo ir pareigu patvirtinimo klausimai. Ši procedūra numate tikrai demokratiškus rektoriaus rinkimus.

Sausio 25 d. „Inžinerija“ paskelbe iškeltų 3 kandidatų i VISI rektoriaus pareigas programas [4.86, p. 2].

\section{Kandidatu programos}

\section{Ekonomikos mokslu daktaro profesoriaus Kazimiero Antanavičiaus nuostatos}

Rektorius privalo vadovautis tik instituto, jo padaliniu ir studenty interesais. Jo pareiga - sudaryti geras salygas moksliniam ir pedagoginiam darbui. Darysime viska, kad tarpusavio santykiai būtu grindžiami abipuse pagarba, tolerancija ir meile žmogui. Svarbiausias rektoriaus uždavinys - puoselèti institute atmosfera, kurioje kiekvienas galetu 
laisvai reikšti mintis, kurioje nežeminamas žmogaus orumas, kur iniciatyva ir kürybiniai polekiai susilauktu pagarbos.

Mūsu uždavinys - rengti specialistus atgimusiai demokratinei Lietuvai, kuri taps lygiateisiu pasaulio tautu bendrijos nariu. Tik platu humanitarini issilavinima turintys, savo tautos mentaliteta jaučia, logiškai ir analitiškai mastyti gebantys inžinieriai gales sékmingai kurti nauja Lietuva, steigti savarankiškas firmas, dalyvauti tarptautineje veikloje. Todel pedagoginio darbo meistriškumas, pagristas dalyko žiniomis ir mokslo naujovemis, turi tapti svarbiausiuoju destytojo vertinimo kriterijumi. Reikia atmesti balais gristas lenktyniavimo sistemas. Asmenybiu $i$ balus nesutalpinsi.

Administracijos padaliniai turi atsisakyti savo „viršesnès“ padèties ir biurokratiniu manieru. Žinoma, reikia sutvarkyti ju atlyginimus.

Visuomeniniu disciplinu studijavimas turi būti orientuotas $i$ bendražmogiškąsias vertybes, skatinti jaunuoliu humanizma ir dvasinguma. Mokymas turi būti depolitizuotas. Visos partijos ir visuomeniniai judejimai institute veikia vienodais pagrindais.

Už studijas, už specialistu rengimo kokybe ir darbo drausme atsako fakultetai ir katedros. Rektoratas, nepažeisdamas statutu jam suteiktu teisiu, atlieka periodine specialistu rengimo kokybes analize. Turime pasiekti, kad mūsu absolventu diplomus pripažintu Europos šalys, o institutas bütu priimtas $i$ Europos technikos universitetu asociacija.

Turime užmegzti tvirtus nuolatinius ryšius su Vakary Europos, JAV, Kanados, Australijos aukštosiomis mokyklomis. Kviesti išeivijos lietuvius profesorius ir specialistus. Keistis specialistais, siusti mūsų darbuotojus $i$ stažuotes su užsienio universitetu stipendijomis.

Gabius studentus siustimokytis 1-3 metams užsienio aukštosiose mokyklose. Čia plačiai naudoti tarptautinius mokslo ir studentu fondus.

Integruoti moksla, mokyma, projektavima, gamyba. Plètoti bendrus mokslo tiriamuosius darbus ir kurti ükiskaitinius padalinius su $M A$ ir žinybiniais mokslo tyrimo institutais. Ikurti savus, komerciniais pagrindais veikiančius, projektavimo ir gamybinius eksperimentinius padalinius.

Moksliniams instituto padaliniams suteikti autonomines teises su savu biudžetu. Biudžetini finansavima mokslo darbams skirti konkurso tvarka, atsižvelgiant $i$ kandidatu bei daktary rengima.
Institute nerengti jokiu moksliniu darbo planu, kuriu vykdyma kontroliuoty administracijos padaliniai. Visa moksline veikla grindžiama sutartimis.

Turi büti iteisinta sukurtojo intelektinio produkto asmenine ar kolektyvine nuosavybe, ginamos autorinès teisés. Darbo užmokestis mokslineje veikloje neturi būti ribojamas.

Rektorius tures puoseleti socialini teisinguma visose instituto gyvenimo srityse, atmesti bet kokias privilegijas skirstant deficitines prekes ar gerybes. Rūpinsimes, kad visi instituto vidaus gyvenimo klausimai būtu sprendžiami apsvarsčius kolektyvuose.

Ypač svarbūs bus butu, gyvenamuju ir poilsio namy statybos klausimai.

Technikos mokslu daktaro profesoriaus Algirdo
Eduardo Čižo požiūris İ INSTITUTA

Jis ilgainiui turi tapti technikos universitetu (ne pavadinimas esmé), kurio pagrindiniai bruožai: 1) fundamentalus aukštos humanitarines kultūros technikos specialistu rengimas, 2) autoritetingas moksliniy technikos problemy sprendimas. Jo uždavinys - ne tik rengti specialistus, bet ir lavinti Lietuvos piliečius. Prestiža atgimstančioje Lietuvoje institutas gali pelnyti tik gerindamas savo tvarka, ugdydamas elgesio kultūrą.

\section{STUDENTUS}

Reikètu labiau remti žiniu trokštančius, visus mokyti savarankiškai STUDIJUOTI, reikia ieškoti būdu kuo anksčiau pagristai atsisakyti tinginiu ir nepajegiuju. Po bendro humanitarinio ir techninio parengimo studentas PATS sudaro savo studiju plana (institutas jam tik pataria). Po pagrindiniu studiju (4-4,5 metu) - podiplomines studijos (geriau ne tame pačiame universitete). Studentu savivalda, bet rimta, autoritetinga.

\section{DESTYTOJUS}

Destyti gali tik tas, kuris turi kūrybiniu siekiu, visu pirma - mokslo srityje. Labai svarbu rengti lietuviškus vadovelius, ne mažiau svarbi destytoju kalbos kultūra. Katedrai skiriamos disciplinos ir atitinkamai destytoju etatu skaicius, o katedros vedejas skirsto darbu apimti. Atmestinas dirbtinis menkaverčio biudžetinio mokslinio darbo planavimas, labiau skatintina destytoju veikla pagal prioritetines Respublikos mokslo programas.

\section{I ŽMOGU}

Instituto poreikiai derintini su dirbančiu žmoniu poreikiais. Kiekvienas vertintinas pagal darba ir iniciatyva. Kiekvienam - nustatyta darbo užduotis ir visiška atsakomybe už

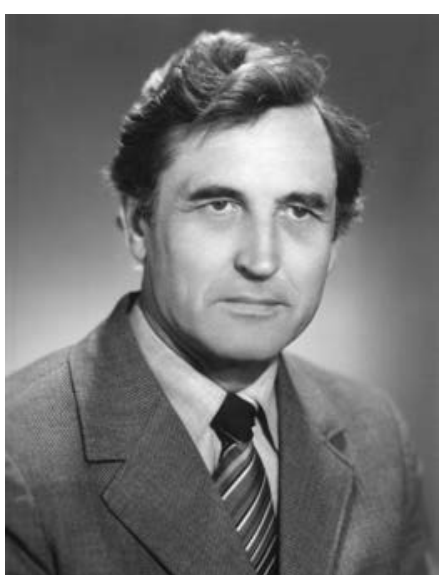

A. Čižas 
VILNIAUS

INŽINERINIS STATYBOS

INSTITUTAS

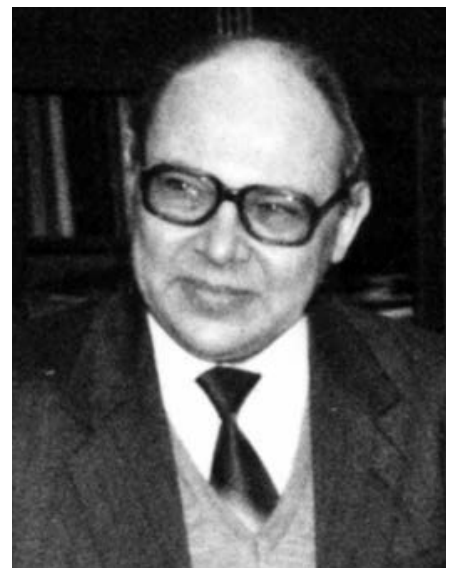

E. K. Zavadskas jos vykdyma. Papildomos užduotys papildomai apmokamos. Pagrindiniu darbu žmogus turetu uždirbti tiek, kad nereiketu blaškytis, kad visa energija tektu institutui. Demokratija neturi tapti anarchija. Kol yra deficito ir privilegiju, turi büti lygios teises ju igyti: bet ne lygiava. Todel reikia aiškiai reglamentuotu skatinimo kriteriju.

\section{PROREKTORIU KANDIDATUTRAS}

Jau ir pas mus galioja geras demokratinio valdymo principas: bet kurio vadovo darbo kadencija turi büti ribojama. Vien del to dauguma dabartiniu prorektoriu reikia keisti. Prieš renknt rektoriu ar prorektoriu, reikia pažinti asmeni, jo idejas, siekius. Taigi reikia išsamiai pasikalbeti ne tik su juo, bet ir su kitais apie ji. Bet tai gali tik naujas rektorius, o ne kandidatas. Büdamas kandidatu, galiu tik pradeti savaji saraša kandidatu i prorektorius: mokymo - J. Duoba, V. Jasulaitis, Z. Kamaitis, L. Lingaitis, K. Olsauskas, K. Valašimas, administracijos ir ükio - K. Briedis, J. Grabys, J. Kliauza. Mokslo reikalu prorektoriumi tapti turetu E. Zavadskas (jeigu nebus išrinktas rektoriumi).

I SAVE

Nesu pamiršęs savo amžiaus, bet jaučiuosi vienai kadencijai jegy ir sveikatos turis. $M a-$ nau, mano patirtis pakankama mokymo ir mokslo srityje, bet menka ükio srityje. Atrodo, sugebu išklausyti ir ivertinti kitu nuomone, bendrauti. Megstu ir suprantu humora. Kai kada būnu per daug liberalus, bet labai nemegstu vengiančiuju darbo.

Technikos mokslu daktaro profesoriaus Edmundo Kazimiero Zavadsko rektoriaus veiklos vizija

Mūsu bendras tikslas - kurti tautine prestižine autonomine aukštaja mokykla, gebančiq tenkinti Lietuvos ükio poreikius.

Uždaviniai: rengti plataus profilio aukštos kvalifikacijos inžinierius bakalaurus, inžinierius magistrus ir daktarus, spresti aktualias mokslo ir technikos problemas.

Kad šz tiksla pasiektume, turime:

1. STUDIJU SRITYJE: demokratizuoti, individualizuoti, humanizuoti, ekologizuoti studijas; integruoti mokymasi, moksla ir praktika; ugdyti asmenybes; puoseleti gimtają kalba, išmokyti užsienio kalbu, for- muoti paklausias specialybes; studentams leisti laisvai pagal sugebejimus konkurso keliu pasirinkti studiju lygi; sukurti pažangia kvalifikacijos keilimo sistema, specialistu atestacijos centra.

2. MOKSLO SRITYJE: skatinti kurtis kurybinius kolektyvus, ikurti katedrose aspirantūra, specializuotas tarybas moksliniams laipsniams ginti, ieškoti būdu formu partnerystei su užsieniu.

3. SOCIALINEJE SRITYJE: iš esmes pertvarkyti socialine politika, teikiant prioriteta darbuotoju užimtumo garantijoms, formuojant butu statybos fonda is ivairiu finansavimo šaltiniu, pertvarkant mokyklos statybos programa; darbuotoju krūvio ir atlygiu sistema, gerinant darbuotoju ir studentu buitines bei poilsio salygas.

Remiantis pagrindiniu mokyklos pertvarkos tikslu ir išvardytais uždaviniais: 1. Pertvarkyti instituta $\dot{z}$ technikos universiteta su koledžu sistema, išsaugant jau sukaupta potenciala. 2. Konkrečiq struktūra turi sukurti mokyklos kolektyvas drauge su užsakovais. 3. Vienyti instituto tarybos, instituto mokslines tarybos, studentu parlamento, politiniu partiju, visuomeniniy organizacijy ir rektorato pastangas. 4. Decentralizuoti ir demokratizuoti instituto valdyma (suteikti katedroms ir studentams savivalda).

Prorektoriais rinkčiausi: e. prof. p. Z. Kamaiti (Kvalifikacijos kelimo fakulteto dekana), prof. Z. Jankauska (Elektronikos katedra), doc. P. Juškevičiu (Miestu statybos katedros vedeja, Miestu statybos fakulteto tarybos pirmininka). Prašysiu administracija ir ükio padaliniu pareikstti savo nuomone dèl ükio reikalu prorektoriaus kandidatūros. Pasilieku teisę koreguoti prorektoriu darbo funkcijas, atsižvelgiant i būsimaja mokyklos struktūrą.

Iki rektoriaus rinkimu institute bendradarbiai karštai svarste kandidatu į rektorius galimybes, ginčijosi, kuris kandidatas tinkamiausias. Studentų parlamentas nenorejo sutikti su paskirta rinkimu diena, nes tuo metu dar buvo studentų atostogos. Bet galiausiai buvo susitarta rinkimu neatideti.

VISI rektoriaus rinkimai ivyko $1990 \mathrm{~m}$. vasario 7 d. Iš 150 tarybos narių rinkime dalyvavo 144.

Po pirmojo rinkimų turo daugiausia balų gavo E. K. Zavadskas - 72, K. Antanavičius 63, A. E. Čižas - 9.

Instituto tarybos patvirtinta VISI rektoriaus rinkimų procedūra teige, kad „Išrinktu laikomas tas kandidatas, kuris gavo daugiau 
kaip $50 \%$ balsų (skaičiuojama nuo dalyvavusių balsavime skaičiaus). Jeigu nè vienas kandidatas tiek balsų negavo, tame pačiame posedyje organizuojamas antrasis balsavimo turas, kuriame i biuletenius ịrašomi tik du kandidatai, kurie pirmajame ture gavo daugiausia balsų“.

Taigi E. K. Zavadskui būti išrinktam pirmame ture VISI rektoriumi pritrūko 1 balso. Buvo surengtas antras turas. Profesorius E. K. Zavadskas antrajame ture gavo 75 balsus, o profesorius K. Antanavičius - 69 . Taigi VISI rektoriumi nuo 1990 m. vasario 7 d. demokratiškai buvo išrinktas Edmundas Kazimieras Zavadskas.

Rektorius E. K. Zavadskas jau pirmąją darbo dieną iš savo kabineto pašalino Markso ir Lenino portretus, energingai ème formuoti savo komandą. Jo siūlymu buvo patvirtinti instituto prorektoriai.

Mokymo reikalų prorektoriais tapo t. m. k. doc. Ipolitas Zenonas Kamaitis ir t. m. k. doc. Algirdas Valiulis, mokslo reikalų prorektoriumi - t. m. k. doc. Pranciškus Juškevičius, administracijos ir ūkio reikalų prorektoriumi - inž. Juozas Grabys.

Buvo surengtas iškilmingas Vasario 16-osios minejimas Didžiojoje auditorijoje. Jame instituto kolektyvą pasveikinęs rektorius E. K. Zavadskas prisiminè šviesiąsias instituto asmenybes, pabrěžè norą, kad ir dabartiniai déstytojai būtų taip pat tokie, kad juos buvę studentai prisimintu visą gyvenimą. Minējime dalyvavęs Sąjūdžio Vilniaus miesto pirmininkas Aloyzas Sakalas kviete jaunimą issitraukti i kovą už nepriklausomą Lietuvą, pažymëjo, kad reikia labiau įvertinti tuos žmones, kurie bet kokiomis sąlygomis, pogrindyje ir atvirai iki šiol kovojo už laisvę. Profesorius Vytautas Kriščiūnas dalijosi prisiminimais apie nepriklausomos Lietuvos ekonominį, politinị ir kultūrinị gyvenimą, kvietè visus nesibaiminti žengiant laisvès keliu. Jo manymu, tauta pasiryžusi pakelti bet kokius išméginimus. Dalyvavęs minëjime Pasaulio lietuvių bendruomenès vicepirmininkas Algimantas Gureckas sake, kad lietuviai išeivijoje žavisi tautos susitelkimu, drausme, vadovų išmintimi.

Minejjimo dalyviams koncertavo VISI folklorinis ansamblis, vadovaujamas Evaldo Vyčino.

Vasario 24 d. įvyko rinkimai į Lietuvos Aukščiausiąją Tarybą. Juose triuškinančią pergalę laimèjo Sąjūdžio kandidatai.
Lietuva - LTSR.

\section{Lietuvos tokios NEBER !}

Kovo 10 dieną Vilniuje prasidejjo naujai išrinktos Lietuvos Respublikos Aukščiausiosios Tarybos pirmoji sesija, kurią pradejo Respublikos rinkiminès komisijos pirmininkas, buvęs Vilniaus universiteto rektorius Juozas Bulavas.

Antrajame sesijos posedyje kovo 11 dieną ìstatymu buvo patvirtintas oficialus mūsų valstybès pavadinimas - Lietuvos Respublika ir herbas - Vytis. Tos pačios dienos vakare parlamentarai, transliuojant televizijai, prièmé Lietuvos valstybès atkūrimo aktą:

„Lietuvos Respublikos Aukšciausioji Taryba, reikšdama Tautos valia, nutaria ir iškilmingai skelbia, kad yra atstatomas 1940 metais svetimos jegos panaikintas Lietuvos Valstybes suvereniu galiu vykdymas, ir nuo šol Lietuva vel yra nepriklausoma valstybe.

Lietuvos Tarybos $1918 \mathrm{~m}$. vasario $16 \mathrm{~d}$. Nepriklausomybes aktas ir $1920 \mathrm{~m}$. gegužes 15 d. Steigiamojo Seimo rezoliucija del atstatytos Lietuvos demokratines valstybes niekada nebuvo nustoje teisines galios ir yra Lietuvos valstybes konstitucinis pamatas.

Lietuvos valstybe pabrežia savo ištikimybe visuotinai pripažintiems tarptautines teises principams, pripažista sienu neliečiamuma,

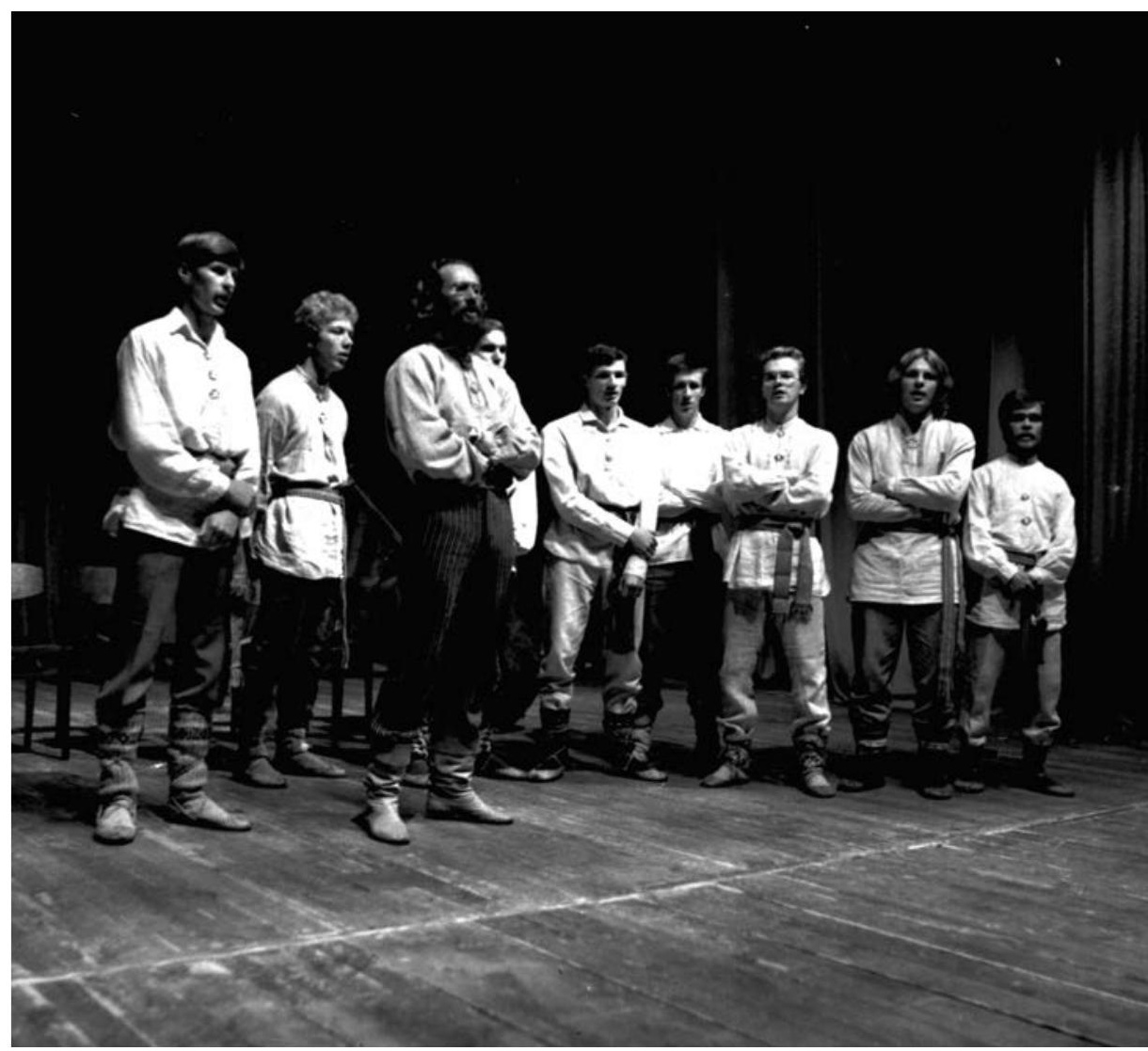

LIETUVA VELL LAISVA! $\longrightarrow$ 1990m. kovo $11 \mathrm{~d}$. 22 val. $45 \mathrm{~min}$.

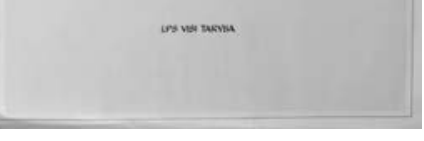


VILNIAUS

INŽINERINIS STATYBOS

INSTITUTAS

spektaklis, neįtiketinas, nors visų labai laukiamas vyksmas.

Lietuva vèl laisva! Lietuva vel nepriklausoma valstybè!

Rytojaus rytą visus, ateinančius į Vilniaus

kaip jis suformuluotas 1975 mety Europos saugumo ir bendradarbiavimo pasitarimo Helsinkyje Baigiamajame akte, garantuoja žmogaus, piliečio ir tautiniu bendriju teises.

Lietuvos Respublikos Aukšciausioji Taryba kaip suvereniu galiu reiškejja šiuo aktu pradeda realizuoti visa Valstybes suvereniteta " [4.87, p. 1].

Prigludusi prie televizorių ekranų visa Lietuva susijaudinusi seke posèdžio eigą. Visa tai atrode lyg trokštamas, fantastiškas inžinerinio statybos instituto centrinius rūmus, pasitiko VISI Sąjūdžio rèmimo grupès parengtas plakatas. Vieni kitiems spaudeme rankas, sveikinome su Nepriklausomybe.

Bet džiaugsmas buvo perpintas su nerimu.

Vilniaus gatvèse patruliavo sovietine kariauna, îtariai i i visus vykstančius procesus žiūrëjo rusakalbiai, iš akių buvo galima nujausti, kas su Lietuva, kas ne.

\section{Nutarta tapti Vilniaus technikos universitetu}

VISI rektorius E. K. Zavadskas „Inžinerijoje“ jau kovo $14 \mathrm{~d}$. praneša, kad „Mūsu aukštoji mokykla jau perorganizuojama $i$ Technikos universiteta. Müsu visu tikslas - tapti Europos technikos universitetu bendrijos nariu, rengti aukšto lygio technikos, architektūros specialistus " [4.88, p. 1].

Ten pat buvo paskelbta $1990 \mathrm{~m}$. priemimo studijuoti į VISI tvarka ir specialybès.

Architektūros fakultetas numate priimti studijuoti į architektūros specialybès dienines studijas.

Komunalinio ūkio fakultete buvo priimama į dvi specialybes: šilumos, dujų tiekimo ir védinimo specialybę (dieninés studijos) ir vandentiekio kanalizacijos, vandens ištekliu racionalaus naudojimo ir apsaugos specialybę (dieninès bei neakivaizdinès studijos) .

Mechaninès technologijos fakultete buvo keturios specialybès. Dieninę ir neakivaizdinę formą turëjo automobilių ir automobiliu ūkio specialybè bei kèlimotransportavimo, statybos kelių mašinų ir įrenginių specialybe. Suvirinimo įrenginių ir technologijos specialybès buvo tik dieninèse studijose. Mašinų gamybos technologijos specialybès buvo numatytos dieninèse ir vakarinèse studijose.

Miestu statybos fakultete buvo numatyta priimti tik į trijų specialybiu dienines studijas: komunalinès statybos ir ūkio, taikomosios geodezijos ir geležinkelių tiesimo. Buvo priimama ị dienines ir neakivaizdines automobilių kelių ir aerodromų statybos specialybes studijas.
Inžinerinès ekonomikos fakultetas skelbè priemimą į statybos ekonomikos ir valdymo bei transporto ekonomikos ir valdymo specialybiu dienines ir neakivaizdines studijas ir tik į dienines transporto valdymo ir pervežimų organizavimo specialybių studijas.

Statybos fakultete planuota priimti studijuoti dieniniame bei neakivaizdiniame skyriuose pramonines ir civilinès statybos specialybę ir tik į dienines studijas studijuoti statybinių gaminių ir konstrukciju gamybos bei statybos specialybių.

Kovo antroje puseje issiplieske polemika dèl 1989 m. instituto darbuotojų ir studentų atstovų susirinkimo priimto VISI statuto.

„Inžinerijoje“ doc. B. Užpolevičius rašè, $\mathrm{kad}$ „Dar nepraejo ne metai nuo tos dienos, kai instituto atstovu susirinkimas priemé Statuta, tačiau jau méginama keisti demokratija įteisinamus principus. Pavyzdžiui, pakeisti katedru vedeju ir dekanu kadenciju samprata, apriboti VISI tarybos nariu rotacija ".

Tame pačiame laikraštyje teisininkas doc. J. Sidaravičius teige: „Jei Statuta priima instituto darbuotoju ir studenty atstovy susirinkimas, tai tik jis gali ji keisti " [4.89, p. 1].

Gyvenimas parodè, kad instituto Sąjūdžio narių nuomone tąsyk nebuvo išgirsta. Instituto atstovų susirinkimas Statutui keisti nebuvo sušauktas.

Reikšmingas istorine prasme buvo 1990 m. gegužes 16 d. VISI mokslinès tarybos posedis. Taryba patvirtino dvieju ciklų studijas: bakalauro (4-5 metu) ir magistro 
(1-2 metų) ir svarbiausia - nutare reorganizuoti Vilniaus inžinerinį statybos institutą i Vilniaus technikos universitetą (VTU).

Tame pačiame posedyje buvusi Politinès ekonomijos katedra pavadinta Ekonomines teorijos katedra.

\section{Vilniaus inžinerinio statybos instituto veiklos reikšmé}

I Vilniaus inžinerinio statybos instituto veiklą dera žiūretti tiek tų laikų, tiek šių dienų akimis.

Sovietinès santvarkos sąlygomis, esant vadinamajam planiniam ūkiui, teko laikytis Maskvos sudarytų mokymo planų, ji buvo nustačiusi specialybes ir specializacijas. Tai ne visada atitiko reikmes, kurios būtų naudingesnès, reikalingesnès Lietuvai. Bet absoliuti dauguma profesorių, destytojų dirbo nuoširdžiai, profesionaliai ir VISI parengti specialistai buvo gerai vertinami.

Iki 1980 metų Vilniaus inžinerinio statybos instituto specialistu skaičius kasmet augo, bet kai brežnevinè stagnacija pasiekè savo piką, finansavimas mažejo, kasmet èmé mažèti studentų skaičiai, o išleidžiamų specialistų skaičiai beveik nekito (žr. grafikus).

VISI veiklos laikotarpiu daug užsièmimu laiko buvo skirta TSKP istorijai, Marksizmui-leninizmui, Politinei ekonomijai, Moksliniam komunizmui, kai fundamentiniams ir specialybes mokslams to laiko neužteko.

Vis delto VISI rektorato, dekanatų, katedru pastangomis studiju procesas buvo nuolat tobulinamas. Kiek įmanoma, leista lietuviška mokomoji literatūra, destytojai periodiškai kèle kvalifikaciją, dauguma vykdè mokslinius tyrimus, užsakomuosius darbus, gyne disertacijas.

Instituto studentų dauguma buvo lietuviai ir tai teigiamai veike Vilniaus gyventoju tautinį koloritą.

Vilniaus inžinerinio statybos instituto veiklos rezultatai, instituto prestižas tarp kitų respublikos aukštųjų mokyklų daugeliu požiūriu sietinas su rektoriaus, habilituoto daktaro, profesoriaus Aleksandro Čyro asmenybe.

Lietuvos mokslu akademijos tikrasis narys - akademikas A. Čyras tapo žymiausiu statybines mechanikos specialistu Lietuvoje ir labai vertinamu TSRS, sukūre savitą mokslinę mokyklą, kuri tapo žinoma daugelyje šalių.
A. Čyras naudojo naujausius mokslo ir technikos laimejjimus studentams mokyti. Jo iniciatyva VISI pirmas sovietijoje pradèjo naudoti elektronines skaičiavimo mašinas studiju procese.

A. Cyro nuopelnai, kad institutas pastate dideli pastatų kompleksą Studentų miestelyje, be kurio būtų neįmanomas šiandieninio universiteto darbas. Jo atminimą pelnytai gerbia Vilniaus Gedimino technikos universiteto bendruomene.

Vilniaus inžinerinio statybos instituto veikla buvo naudinga krašto ūkiui. Dauguma jo parengtu specialistu sèkmingai dirba ir šiandien įvairiose nepriklausomos, laisvos ir demokratines Lietuvos srityse.
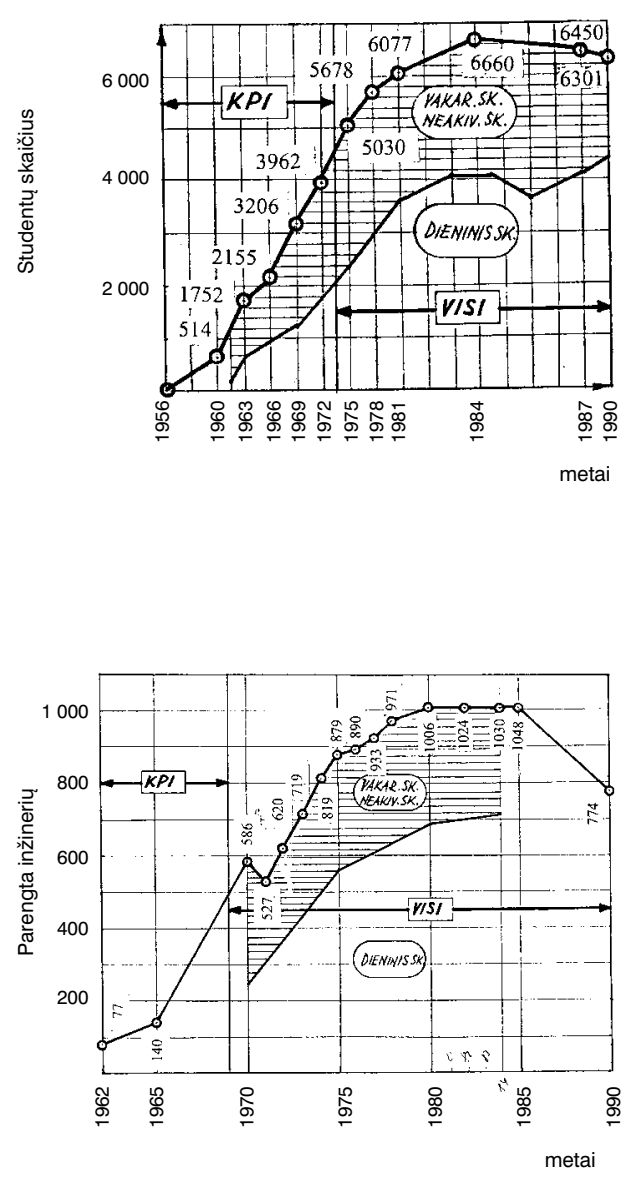



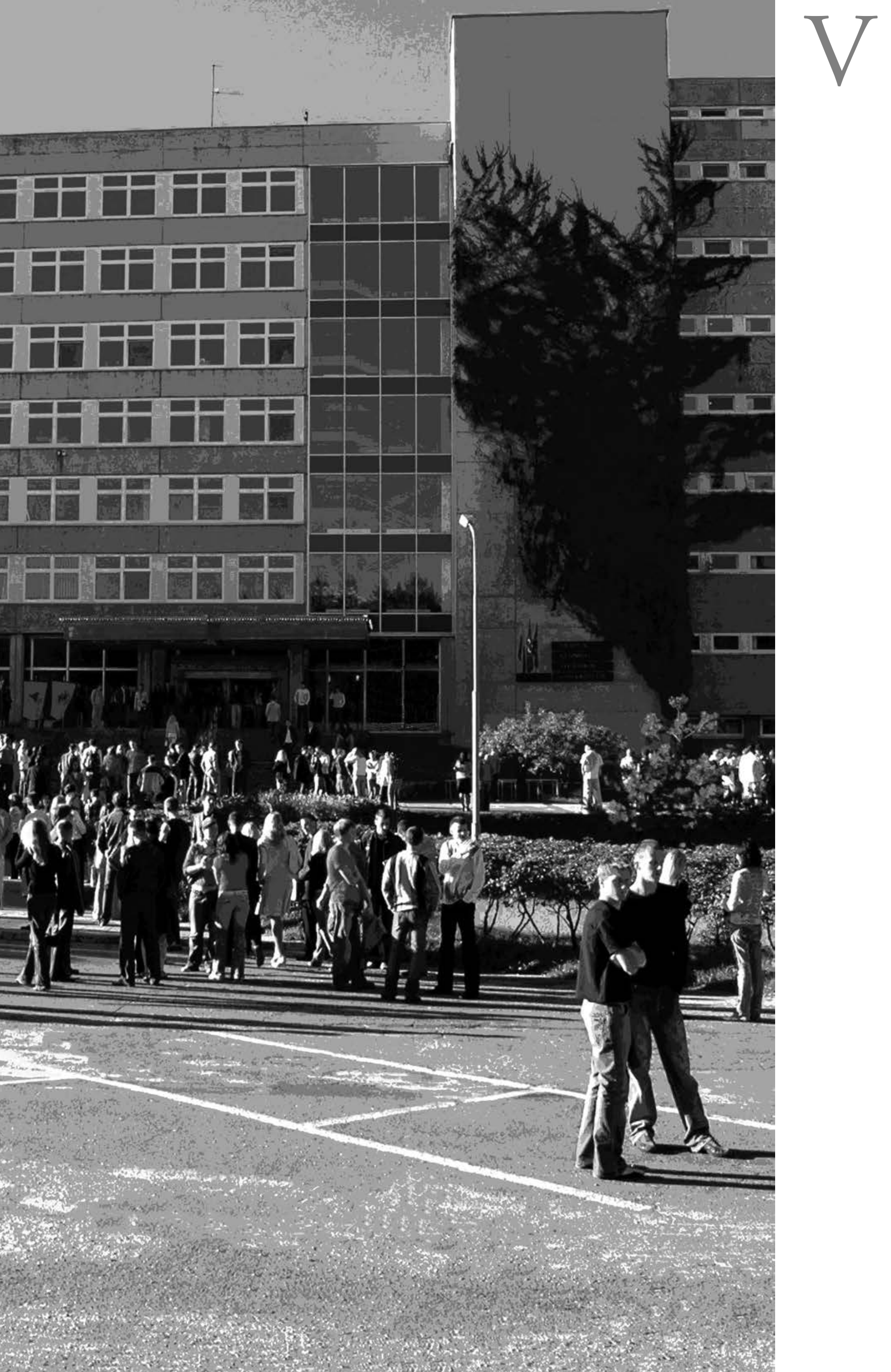




\section{VILNIAUS}

\section{TECHNIKOS}

\section{UNIVERSITETAS}

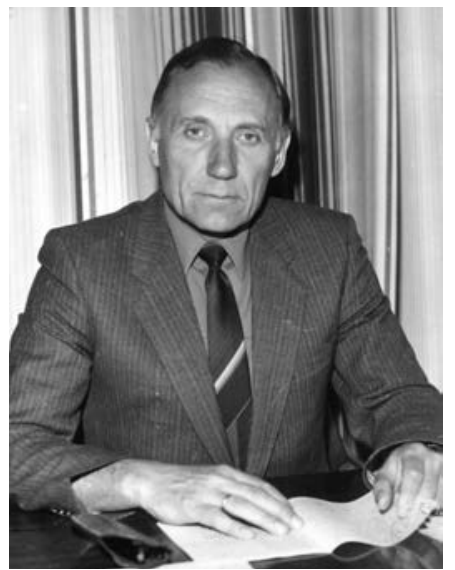

Mokymo reikalu prorektorius Z. Kamaitis

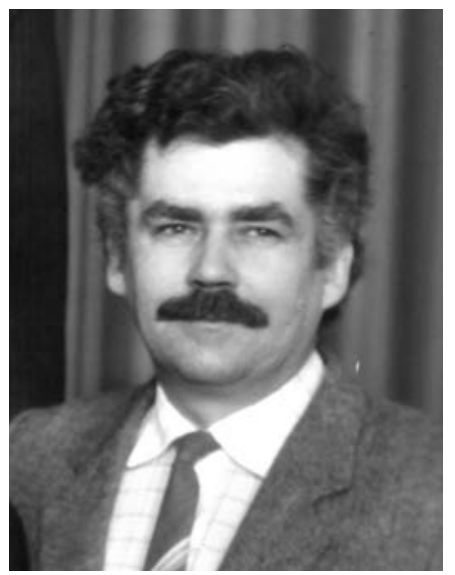

Mokslo reikaly prorektorius P. Juškevičius

\section{Vilniaus technikos universiteta iteisinant}

1990 m. birželio 13 d. VTU mokslinè taryba prièmé nutarimą „Dèl Vilniaus technikos universiteto struktūros". Nors universitetinis statusas dar Lietuvos valdžios nepripažintas, rektoriaus E. K. Zavadsko vedami mokyklos vadovai ima energingai pertvarkyti buvusį institutą $i$ technikos universitetą. Ilgainiui E. K. Zavadskas rašè, kad „Instituto pertvarkymas $\dot{i}$ technikos universiteta buvo bütinas. Ji atlikome laiku. Priešingu atveju jau $1990 \mathrm{~m}$. būtu sumažeje studentu, o veliau galejome tapti ir vienos aukštuju mokyklu filialu ar net fakultetu.

Pertvarkę instituta $i$ Technikos universiteta, išsangojome jau sukaupta mokslo ir kürybos potenciala. Kiekvienai katedrai sudareme salygas pačiai pasireikšti, ieškant büdu išgyventi labai sunkiu Lietuvai laikotarpiu <...>

Naujoji universiteto struktūra buvo kuriama kartu su visu mokyklos kolektyvu, rektoratas stengesi decentralizuoti ir demokratizuoti universiteto valdyma. Vis daugiau valdymo funkciju buvo perduodama dekanatams" [5.1, p. 4].

Bet Vilniaus technikos universitetas dar nebuvo pripažintas de jure. Technikos universiteto statusą turejo pripažinti Lietuvos Respublikos Aukščiausioji Taryba. Taigi vasarą Vilniaus aukštoji technikos mokykla pasitiko dar kaip neįteisintas universitetas. Pirmiausia tuo įtikinti reikejo Kultūros ir švietimo ministeriją, Mokslo ir studiju departamentą. Ministerija analizavo visas alternatyvas ir aiškinosi, ar aukštosios mokyklos, pretenduojančios gauti aukščiausios kategorijos mokymo ir mokslo įstaigos vardą, galès rengti specialistus Lietuvos mokslui, kultūrai, švietimui, ekonomikai, sveikatos apsaugai ir teisesaugai; ar gales pletoti fundamentini ir taikomajji mokslą; ar gales teikti mokslo laipsnius ir vardus; ar galès kelti baigusiųjų aukštąji mokslą kvalifikaciją, organizuoti ju perkvalifikavimą; ar gales rengti ir leisti mokslo darbus, vadovèlius, mokomąsias priemones bei kitus leidinius.

Visa tai galëjo spręsti buvęs Vilniaus inžinerinis statybos institutas, nuo gegužes $16 \mathrm{~d}$. pasiskelbęs Vilniaus technikos universitetu. Jis turejo tuomet per 6000 studentu, jame dirbo apie 500 desstytojų, tarp kurių buvo du Lietuvos mokslų akademijos tikrieji nariai, 40 profesoriu, daktaru, apie 350 docentų, mokslo kandidatų. Deja, visų žmonių pagrindinis rūpestis buvo ne mokyklos pertvarka, o Lietuvos likimas. Imperija pradëjo gležnutès nepriklausomos valstybès spaudimą.

I Lietuvą buvo gabenami nauji rusu kariniai daliniai - pagarsęję žiaurumu Kaukaze desantininkai. Sovietines kariaunos tanketès ir sunkvežimiai su ginkluotais kariškiais marširavo Vilniaus gatvemis, užiminejo civilinius objektus. Ginkluoti desantininkai dar kovo $27 \mathrm{~d}$. užgrobé LKP CK rūmus ir ten ikurdino „platformininkus“ - Lietuvos komunistų partijos (TSKP) vadeivą Mykolą Burokevičiu ir jo sèbrus. „Platformininkai“ organizavo provokacijas, priešiškus Lietuvos Respublikai mitingus, rengési nuversti teisètą Lietuvos valdžią.

Balandžio $12 \mathrm{~d}$. Vilniuje prie Arkikatedros įvyko daugiatūkstantine studentų manifestacija, remianti Lietuvos nepriklausomybę ir smerkianti sovietines kariaunos provokacijas. Manifestacijoje gausiai dalyvavo ir VISI (VTU) studentai bei dèstytojai.

Prasidejjusi Lietuvos ekonomine blokada dar labiau didino įtampą, o siautejusieji sovietiniai desantininkai kasdieną vis žiaurëjo. Jiems užgrobiant spaustuvę Maironio gatveje, lazdomis buvo mušami žmonès, kai kurie patyre rimtų traumų. Bet visos okupantų pastangos nedave lauktų rezultatų. Lietuvos žmones dar daugiau susibūrè, konsolidavosi. Balandžio pabaigoje Nacionalinis simfoninis orkestras surenge Katedros aikšteje koncertą, kuriame atliko Bethoveno 9-ąją simfoniją. I ši koncertą susirinko per 20000 žmonių. Ir 


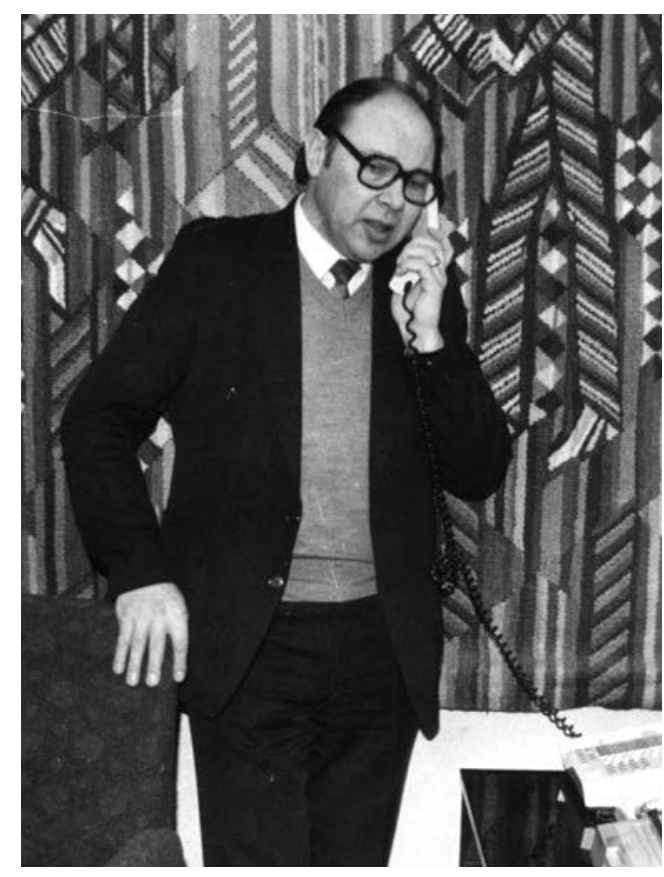

nors socialinè padetis buvo bloga - maisto produktus imta parduoti pagal talonus - lietuviu tauta buvo pasiryžusi vardan savo laisves ir nepriklausomybès bet kokiems išbandymams.

İvertindamas ekonominę situaciją rektorius E. K. Zavadskas nustate taupaus energijos išteklių naudojimo rūmuose tvarką, buvo ìvairiais būdais siekiama apsaugoti studentus nuo tarnavimo sovietineje armijoje.

Nepaisant ịtemptos politinès ir ekonominès padèties, VISI (VTU) studiju procesas buvo vykdomas kiek įmanoma normaliai. Vyko paskaitos, praktiniai darbai, diplomantai renge diplominius darbus. Tų dienų sunkumai tik žadino norą dar atkakliau dirbti.

1990 m. VISI (VTU) baige 774 jaunuoliai ir merginos: dienines studijas - 523, vakarines studijas - 140 ir neakivaizdines studijas 111. Tai buvo paskutinè Vilniaus inžinerinio statybos instituto laida, o kartu ir vienintele VISI (VTU) laida.

Jau nuo pat pasiskelbimo universitetu gegužes $16 \mathrm{~d}$. mokyklos vadovai labai daug dirbo studijuodami Vakaru valstybinio aukštojo mokslo ypatumus, konstravo savosios mokyklos būsimają studijų ir mokslo sistemą. Lankydamasis Kanadoje rektorius E. K. Zavadskas iš Toronto ir Monrealio McGill universitetu gavo visu studiju kalendorius su bakalaurų ir magistru rengimo programomis. I Vakarų valstybes buvo komandiruojami semtis patirties destytojai, deja, išvykas dar reikejo įforminti Maskvoje. Ypač daug nuveike, pertvarkant institutą i vakarietiško tipo technikos universitetą, prorektorius I. Z. Kamaitis, praeity stažavę- sis Prancūzijoje, dirbęs keletą metų Alžyre. Jis taip pat universiteto veiklos pradžioje aplanke ir Kanadą. Praverte ir kitų mokyklos asmenų sukaupta informacija užsienyje, buvo analizuota daug literatūroje randamy duomenų. Entuziazmas, kuriuo ypač pasižymëjo rektorius E. K. Zavadskas, uždege ir kitus. Tai leido greitai atlikti būtiniausius darbus, reikalingus institutui pertvarkyti i universitetą. Iškaboms pakeisti beliko sulaukti valdžios sprendimo.

Nuo 1990 m. rugsëjo $1 \mathrm{~d}$. buvo pereita prie dviejų pakopų studijų modulio, sudarytos pagal Vakarų šalių identiškų universitetų patirtị naujos studiju programos. Suprantama, atsižvelgta ir į Lietuvos poreikius.

Nuo naujuju 1990-991 mokslo metu veike keturi fakultetai, sustambinus anksčiau buvusius, o nuo spalio atgal iš KPI perimtas buvęs Automatizacijos fakultetas. Jis pavadintas Elektronikos fakultetu. Taigi VTU veiklos pradžioje turejo 5 fakultetus: Architektūros, Statybos, Inžinerinių komunikaciju, Mechanikos ir Elektronikos.

Inžinerinių komunikacijų fakultetas buvo sudarytas sujungus Miestų statybos ir Komunalinio ūkio fakultetus.

Buvo išnagrineta, koks humanitarinių, socialinių mokslų ciklas reikalingas universiteto specialistui rengti. Ši uždavinį spręsti buvo pavesta Filosofijos, Politologijos, Estetikos, Ekonomikos teorijos ir Kalbų katedroms.

Lietuvoje politinis gyvenimas kasdieną vis intensyvejo. Permainos buvo akivaizdžios visose srityse buvo imta vartoti lietuvių kalbą, demontuojami sovietiniai paminklai, jaunimas atsisakinejo tarnauti sovietinëje armijoje, labai aktyviai dirbo Lietuvos Vyriausybè. Buvo nutraukiama komunistu partijos pirminių organizacijų veikla. Tai buvo padaryta ir VISI (VTU).

Naujuosius mokslo metus pradejo 1230 pirmakursių, o rugsëjo $5 \mathrm{~d}$. rektorius E. K. Zavadskas paskelbe įsakymą, kuriuo buvo panaikinta Karine katedra.

İstojusiųjų studijuoti jaunimo kontingentas kaip visada buvo internacionalinis, bet ryškią daugumą sudare lietuviai. Iš 1230 pirmakursių 1025 buvo lietuviai, 87 lenkai, 85 rusai, 16 baltarusių, 4 žydai ir 13 kitu tautybių. VISI (VTU) buvo vyriška aukštoji mokykla. Pirmakursių vyrų buvo 980, o merginu -250 .

Labai sustiprëjo ryšiai su užsieniu. Pavasarị tautinių šokių ansamblis „Vingis“ apsilanke Kanadoje. Kartu vyko rektorius
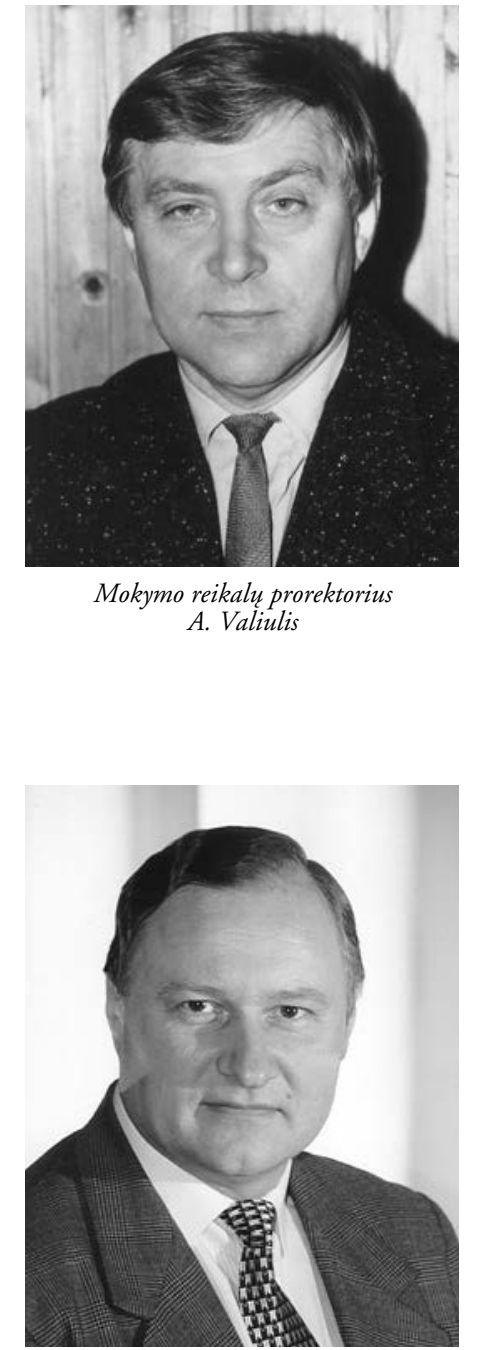

Administracijos ir ükio reikalu prorektorius J. Grabys 
VILNIAUS

TECHNIKOS

UNIVERSITETAS
E. K. Zavadskas, kuris su Toronto universiteto Technikos fakulteto dekanu taresi dèl bendradarbiavimo galimybių. Buvo užmegzti ryšiai ir Europoje bei Azijoje. VISI (VTU) pradëjo studijas 14 jaunuoliu iš Libano.

VISI (VTU) taryba nusprende pradetti rengti dalị studentų anglų ir prancūzų kalbomis. Paskui manyta tokius absolventus siųsti toliau studijuoti ị užsienį.

Mokslo bendruomenę jaudino klausimas - ar Lietuvoje igytas inžinieriaus diplomas tapo konvertuojamu. Šiuo klausimu „Tèvynès šviesoje“ raše E. K. Zavadskas. Jis teigè: „Kad mūsu inžinieriu diplomai taptu konvertuojami, bütina keisti aukštojo inžinerinio mokslo principa pereinant prie triju lygiu principo rengiant specialista. Dabartinis specialisto rengimas pagristas informacijos koncepcija. Atsakydami i klausimus - kas, kur, kada, nesuformuojame visaverčiu žiniu. Turima informacija dar nesudaro visu prielaidu gerai suprasti sprendžiama inžinerijos problema ir jos galimas kryptis.
Inžinerinejje praktikoje problemu kyla ịvairiose labai sudetingose situacijose. Deja, dauguma müsu rengiamu specialistu nebuvo išmokyti, kaip atskirti esminius problemos momentus. Tik analize, kurios pagrindas - pereiti nuo dalinio prie bendro, formuoja žinias. Tačiau ir žinios dar nera galutinis studiju rezultatas. Svarbiau užžinojima yra supratimas, leidžias atsakyti i klausimus, kodel.

Technikos universitetams kyla uždavinys pereiti prie triju lygiu studiju: informacija - žinojimas - supratimas.

Informacija - pradinis enciklopedinis paruosimo etapas, be kurio neimanomi kiti etapai. Žinojimas - mokejimas analizuoti, ieškoti ir rasti optimalu problemos sprendima. Aukšciausia išsilavinimo pakopa - galimybe suprasti. Tai ne tik problemos ar reiškinio supratimas, bet ir visos sistemos objektyvin desniu suvokimas. Tik tuo atveju, jeigu specialistas turi toki supratima, galima teigti, kad jo išsilavinimas - aukštasis.

Tokios triju pakopu inžinieriu studiju sistemos realizavimas reikalauja ne tik pakeisti turini, bet ir ieškoti is principo nauju destymo metodiku" [5.2, p. 31].

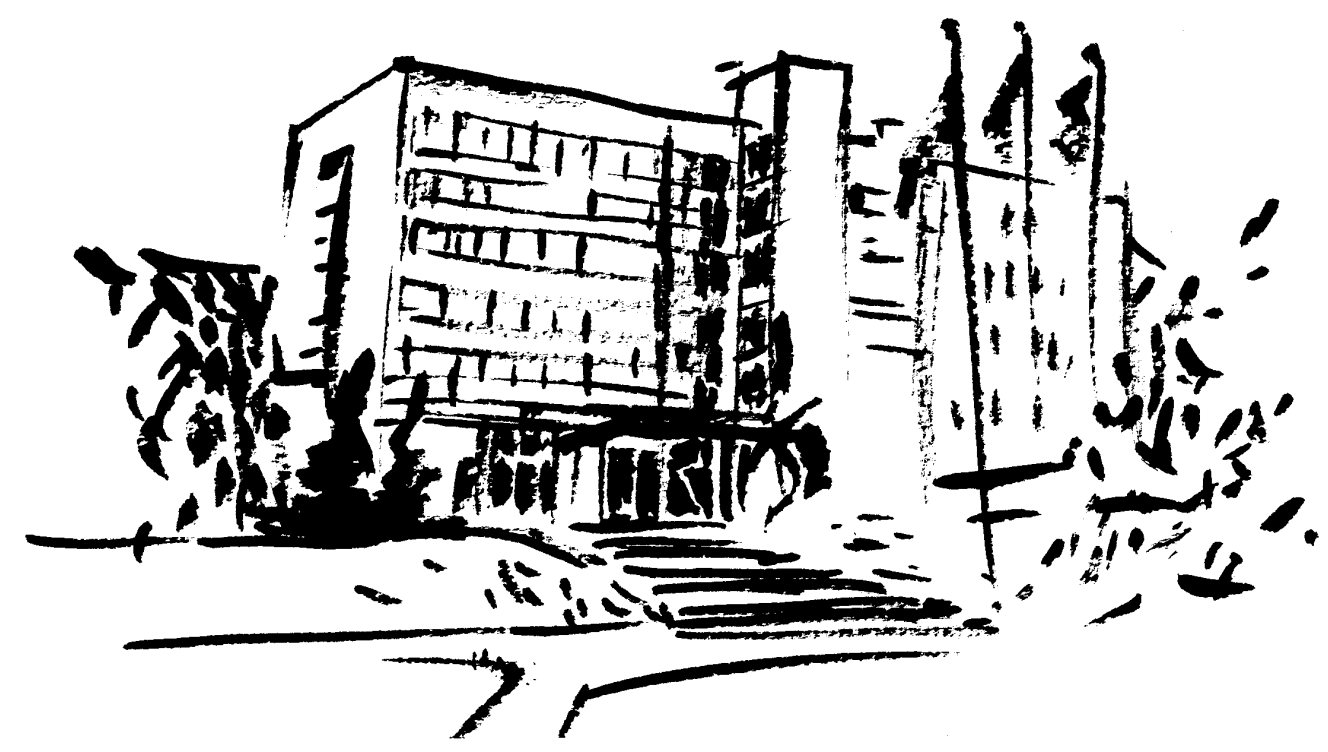

\section{Vilniaus technikos universiteto pripažinimas}

Rektorius E. K. Zavadskas atkakliai siekè paspartinti universiteto statuso pripažinimą. Jis skelbè straipsnius laikraščiuose, davè interviu radijui, televizijai, karštai įrodinejo universitetinio statuso būtinumą įvairiuose posedžiuose ar susirinkimuose. Ir jam pavyko įtikinti Lietuvos valdžią bei mokslo visuomenę, kad Vilniaus inžinerinis statybos institutas turi būti pripažintas technikos universitetu.

1990 m. spalio 31 d. Lietuvos Respublikos Aukščiausiosios Tarybos prezidiumas prièmé nutarimą „Dèl Kauno politechnikos instituto ir Vilniaus inžinerinio statybos instituto pavadinimų pakeitimo": 


\section{LIETUVOS RESPUBLIKOS \\ AUKŠČIAUSIOSIOS TARYBOS PREZIDIUMO}

\section{NUTARIMAS}

\section{DÉL KAUNO POLITECHNIKOS INSTITUTO IR VILNIAUS INŽINERINIO STATYBOS INSTITUTO PAVADINIMU PAKEITIMO}

Atsižvelgdamas i tai, kad mokymo proceso reorganizavimas Kauno politechnikos institute ir Vilniaus inžineriniame statybos institute atitinka technikos universitetu statusa, Lietuvos Respublikas Aukšciausiosios Tarybos Prezidiumas nutaria:

1. Pakeisti Kauno politechnikos instituto pavadinima ir vadinti ji Kauno technologijos universitetu.

2. Pakeisti Vilniaus inžinerinio statybos instituto pavadinima ir vadinti ji Vilniaus technikos universitetu.

3. Pavesti Švietimo, mokslo ir kultūros komisijai bei Mokslo ir studiju departamentui prie Lietuvos Respublikos Vyriausybes iki 1990 m. gruodžio 1 d. apsvarstyti Kauno technologijos universiteto ir Vilniaus technikos universiteto statutus ir pateikti juos tvirtinti Lietuvos Respublikos Aukšciausiajai Tarybai.

\section{LIETUVOS RESPUBLIKOS \\ AUKŠ ČIAUSIOSIOS TARYBOS \\ PIRMININKAS}

Vilnius, $1990 \mathrm{~m}$. spalio $31 \mathrm{~d}$.

1990 m. lapkričio 12 d. įvykusiame Vilniaus technikos universiteto rektorato posédyje buvo svarstoma, kaip greičiau integruotis į Vakaru aukštojo mokslo sistemą. Buvo nutarta: 1. Reorganizuoti studijas ir pereiti prie daugelyje šalių naudojamo triju pakopų modelio: bakalauras - magistras - daktaras. 2. İstoti į tarptautines asociacijas, tapti specialių programų nariais. 3. Pletoti bendradarbiavimą su VTU profilio Vakarų aukštosiomis mokyklomis. 4. Sudaryti akademines grupes, kuriose paskaitos būtų užsienio (pirmiausia anglų) kalba. 5. Rengti užsienio kalba specialistus kitoms šalims ir kt.

$1990 \mathrm{~m}$. ruduo buvo neramus. Sovietine kariauna elgesi vis į̌̌uliau. Minint lapkričio $7 \mathrm{~d}$. metines, A. Siaurusevičius raše: , ,automatais ginkluotu desantininku apsuptyje sangiai jausdamasis Mykolas Burokevičius pranašavo: „Politine santvarka Lietuvoje, sukurta dabartiniu Lietuvos vadovu, - laikinas reiškinys $\langle\ldots\rangle$, dabartinis autoritarinis režimas bus pakeistas demokratines socialistinès pakraipos santvarka". Bega metai, o Lietuvoje, kaip ir anksčiau, komunistai turi tiek jegos, kiek jos turi Raudonoji armija. 1918 m. Kapsukas kartu su Angariečiu, 1940-aisiais - Sniečkus, 1990 m. - M. Burokevičius savo tiesas skleidžia ir igyvendina svetimos kariuomenes padedami " [5.3 p. 1].
Desantininkai įsiveržè į konservatoriją, kai jos balkone įsitaise fotografai, o antrą sykį - kai ten buvo iškelta Leonido Brežnevo šmekkla, kurią rode „Šèpos" teatro aktoriai. Šturmo metu buvo daužomi langai, laužomi baldai, buvo sužeisti žmonès.

Rusijos imperija pasiskelbusiai nepriklausomai Lietuvai bande įbrukti naują Sąjungos sutartị, paremtą ne ekonomine, ne politine nauda, o tik šovinistine ideologija. Tuo pat metu sovietiniai kariškiai išdrįso šaudyti iš automatų ir kulkosvaidžių gyvenamajame rajone bei mušti žmones, kurie protestavo prieš sovietinès armijos buvimą Lietuvoje.

Visuomeneje kilo tam tikras nepasitenkinimas ir savąja valdžia. Iš demokratiškai išrinktos valdžios žmonès laukè daug daugiau nei iš autokratinès diktatorinès valstybès valdžios instituciju. Visuomenè manè, kad, išrinkusi savąją valdžią, ji turi teisę reikalauti, kad ta valdžia tarnautu būtent jiems, o ne piktnaudžiautu jos pasitikèjimu. $\check{Z}$ mones piktino jau nepriklausomos Lietuvos valdininkų atžagarumas, viršininkų nesiskaitymas, nesibaigiantis biurokratizmas, valdžiai teikiamos lengvatos bei privilegijos. Žmonés lygino buvusius su dabartiniais ir, deja, jau ne visada mate skirtumą. Daugèjo ìvairių protesto akcijų, kurios kèle sumaišti

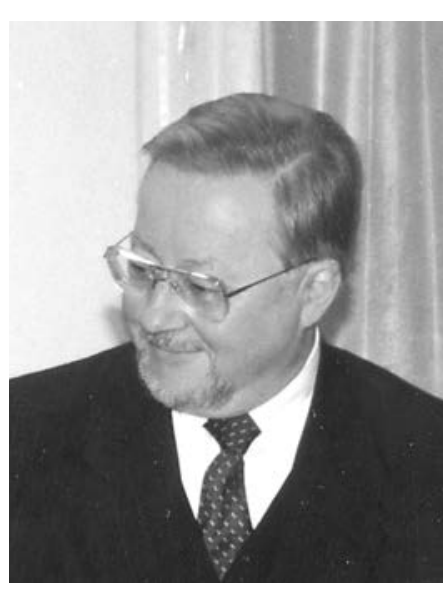

V. Landsbergis

\section{LANDSBERGIS}


VILNIAUS

TECHNIKOS

UNIVERSITETAS

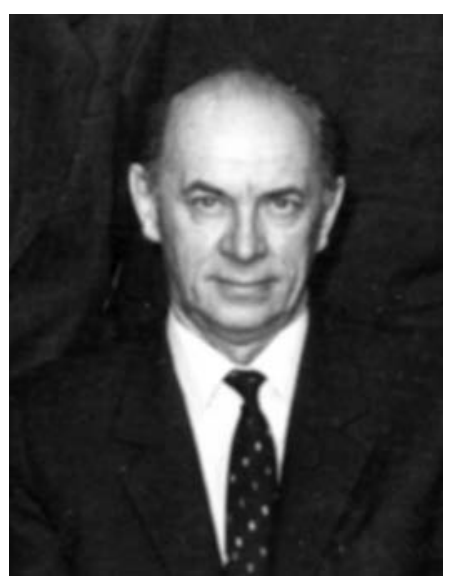

V. Jasulaitis

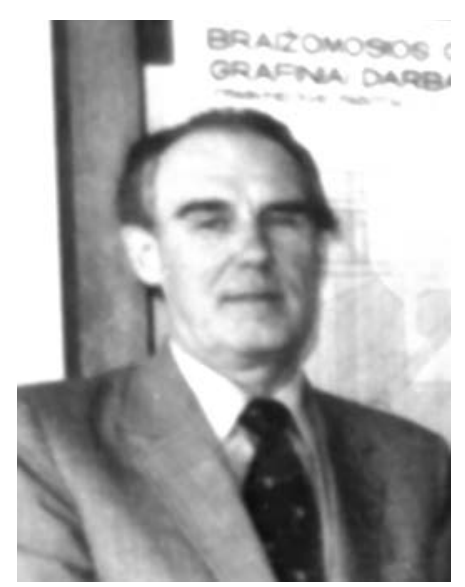

B. Gruzdys

visuomenëje ir tai galëjo destabilizuoti padèti, ko tik ir laukè okupanto kariauna. Vis pavojingesnès buvo organizuojamos jedinstvininku provokacijos. Desantininku padedami burokevičininkų LKP (TSKP) užiminëjo valstybinius pastatus, vede šlykščią propagandą per radiją ir televiziją. Buvo jaučiama, kad šali gali ištikti politine ir ekonomine katastrofa. Bet gresiančio pavojaus akivaizdoje absoliuti dauguma tautos nepalūžo, sunkiausiomis sąlygomis atkakliai dirbo ir už Lietuvos laisvę bei nepriklausomybę buvo pasiryžę kovoti visomis jègomis, visomis priemonemis.

Štai tokiomis aplinkybèmis buvo dirbama 1990 metams baigiantis. Vilniaus technikos universitetas toliau plète tarptautinį bendradarbiavimą, pasirašè sutartis su Madisono Viskonsino (JAV) universitetu, su Horsenso politechnika (Danija). Buvo parengti užsieniečių prièmimo ị VTU ir išvykstančiu ị užsienị nuostatai, priimta nauja stipendiju

\section{Tragiškos nepriklausomos Lietuvos dienos}

Tomis dienomis K. Prunskienés vadovaujama Vyriausybe smarkai padidino maisto produktų kainas. Ir nors buvo paskelbta, kad kiek didinamas biudžetinių ǐstaigų ir organizacijų darbuotojų darbo užmokestis, sovietine 5-oji kolona gavo signalą veikti. Prasidejo aršios jedinstvininkų provokacijos, sovietinè kariuomenè nepertraukiamai marširavo gatvèse, bandè užimti svarbius valstybinius pastatus. Iš Maskvos aidejjo grasinimai, prasimanymai, šmeižtas.

K. Prunskienei atsistatydinus, naujuoju Lietuvos Respublikos ministru pirmininku buvo patvirtintas buvęs VISI dèstytojas Albertas Šimenas. Dèl nesiliaujančiu sovietines kariaunos provokaciju Lietuvos Respublikos Aukščiausioji Taryba kreipesi į Lietuvos žmones kviesdama ginti savo valstybès parlamentą, kitus svarbius valstybinius pastatus. Kartu su visa tauta ginti savo šalies laisvę èmè ir Vilniaus technikos universiteto bendruomenè.

Tomis įtemptomis dienomis daug VTU darbuotojų dieną ir naktį budejo, saugodami Aukščiausiosios Tarybos ir tarpmiestines te- bei pašalpų skyrimo ir mokejjimo tvarka. Optimizmo netrūko. Visi jaute - kelio atgal jau nèra.

Pasitinkant Naujuosius - 1991 metus „Atgimimas“, be kita ko, rašè: „Anksčíau ar veliau švęim Naujuosius metus neskaičiuodami okupanty tanky ir ju nelaimingy kareiviu. Tükstanti kartu buvo teisus Senojo testamento išminčius: vanitas vanitatum et omnia vanitas. Tuštybiu tuštybe ir viskas tuštybe - tušcios parduotuves, smulkios intrigoskovojant deldidesnio patrioto vardo, nuplaukę kombipašarai ar ministro portfelis nera tiek verti, kad nuo ryto iki vakaro apie juos bütu galvojama " $[5.4$, p. 1].

1991 m. sausio 7 d. Vilniaus technikos universiteto rektorato posedyje buvo aptarti tolesni VTU veiksmai persitvarkant $\mathfrak{i}$ universitetą. Vyr. buhalteris J. Kliauza pristate lěšu fakultetams skirstymo, o prorektorius A. Valiulis - bakalauru studiju planų sudarymo principus. Prorektorius P. Juškevičius pateike leidybinio darbo nuostatų projektą. Rektorius E. K. Zavadskas kviete tik patenkinamai besimokančiu studentu „netempti“. Jis kviete rengti geriau nedaug, bet geru specialistų. legrafo stoties pastatus, keli dèstytojai budëjo pačiame parlamente. Budejimo ir organizaciniu štabu tapo VTU Studentų sąunga. Ji tarèsi su Vilniaus universitetu ir Vilniaus pedagoginiu institutu dèl bendru studentų veiksmų. Rektorius E. K. Zavadskas kviete saugoti ir VTU rūmus. Lietuvos radijas keletą kartų skaite VTU rektoriaus pranešimą, kad dèl Lietuvoje susidariusios padeties VTU studentu egzaminų sesija atidedama ir kad destytojai ir studentai eina ginti Lietuvos Respublikos objektu [5.5, p. 160].

Kai sausio 10 d. M. Gorbačiovas paskelbè ultimatumą, kuriuo reikalavo atkurti Lietuvoje tarybinę konstituciją, Lietuvos žmonès pasiryžo ginti savo šalies parlamentą. Kasdieną prie Aukščiausiosios Tarybos rūmų rinkosi tūkstančiai žmonių, kurie budejo ten dieną ir naktị. Rinkosi vilniečiai, važiavo autobusais žmonès iš visų Lietuvos miestų ir miestelių.

I parlamentą susirinkę krašto apsaugos savanoriai prisieke ginti Lietuvos parlamentą ir jo vadovus ir, jei reikes, tam reikalui nepagailes 
ir savo gyvybès. Tarp jų buvo ir VTU docentai Vytautas Jasulaitis bei Brunonas Gruzdys.

Sausio 12-ąją pas VTU rektorių E. K. Zavadską susirinko visų trijų didžiųjų aukštųjų mokyklų atstovai ir pasiskirste saugomais objektais.

Burokevičininkai paskelbè, kad sudaromas "nacionalinio gelbejjimo komitetas“, vienas jo vadeivu - J. Jermalavičius, kurị Vilniaus sovietinis karinis komendantas generolas V. Uschopčikas pareikalavo skirti ministru pirmininku, pareiške per platformininkų televiziją, kad „valdžios peremimo procesas jau prasidejo“.

Sausio 13 d. naktį sovietiniai tankai ir automatais ginkluoti kareiviai puole Lietuvos radijo ir televizijos pastatus, Televizijos bokštą Karoliniškèse. Žmonių minios apsupusios šiuos objektus neprileido kariaunos. Pasipyle šūviai ir iš automatų, ir iš tankų. Nuo kulkų, smūgių automatų buožemis, po tankų vikšrais žuvo 13 žmonių, šimtai buvo sužeisti. Tarp žuvusiųjų buvo ir VTU Elektronikos fakulteto pirmojo kurso studentas Rolandas Jankauskas.

Sausio 13-oji įejo į Lietuvos istoriją kaip diena, kai sovietine kariauna šaltakraujiškai žude beginklius taikius žmones, kaip diena, kai už laisvę buvo pralietas nekaltas kraujas. Tai tragiškas ir taurus Lietuvos žmonių kovos dèl tautos laisves puslapis. Lietuvos gyventojai skaudžiai išgyveno Tbilisio ir Baku tragedijas, buvo nepamiršę, kaip tankais sovietai sutraiške Vengrijos ir Čekoslovakijos laisvę. Sausio 13-oji irgi pareikalavo žmonių gyvybių. Tai dar viena deme ant sovietinès ir rusiškos imperijos per šimtmečius sukepusio nuo kraujo drabužio.

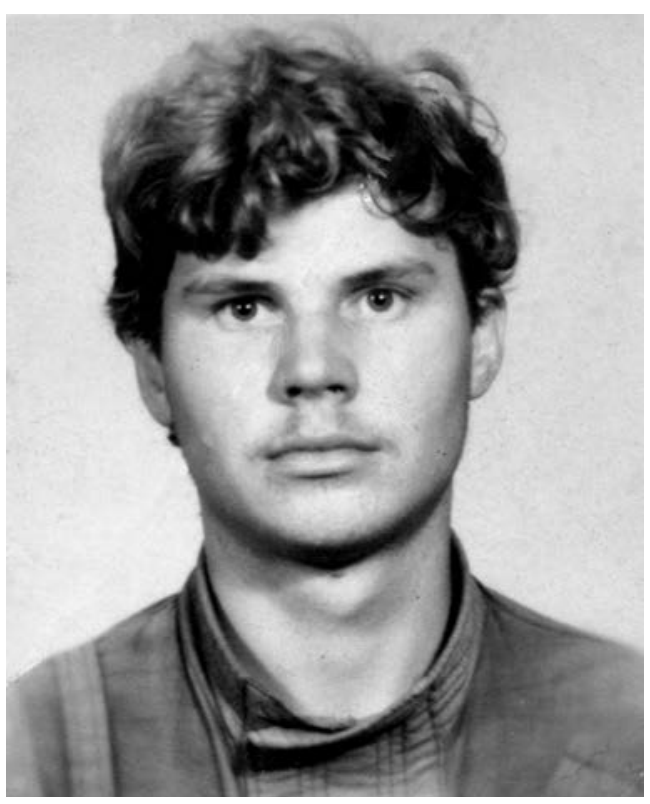

Viena šiurpios piktadarybes aukų - Rolandas Jankauskas per stojamuosius egzaminus savo rašinyje teigè: "Jaunimas - viso pasaulio ateitis ir dabartis. Mokytis ir kovoti reikia taip, kaip sako tavo sąmone, kaip reikalauja žmonija“. Šis Vilniaus technikos universiteto studentas po mirties apdovanotas Vyčio kryžiaus ordinu.

Mes jau rašeme apie VTU mišraus choro patriotizmo viešus precendentus sovietmečio metais. Pažymètina, kad keletą metų vienas chorvedžių buvo Br. Jankauskas, didvyrio Rolando Jankausko tèvas. Patriotu negimstama. Patriotas išugdomas. Čia labai didelè tèvu itaka. Garbe Rolando tèvams, išugdžiusiems dorą, drąsų Tèvynès gynëją, Vyčio kryžiaus kavalierių. Bet ar įmanoma apdovanojimu kompensuoti savo sūnaus netekties skausmą, ar todèl tapo jis mažesnis?

Laikas tolina tuos Sausio 13-osios kruvinuosius įvykius. Bet lietuvių tauta niekada nepamirš tų, kurie nepagailejo net savo gyvybès vardan Lietuvos laisvès ir nepriklausomybès.

Tuo metu, kai sovietiniai tankai puole Televizijos bokštą, paslaptingai dingo premjeras Albertas Šiménas. Manyta, kad ji pagrobe sovietiniai kagèbistai. Tokiomis aplinkybèmis Aukščiausioji Taryba premjeru paskyre Gediminą Vagnorių, Vilniaus inžinerinio statybos instituto absolventą, kurị laiką dèsčiusi Statybos ekonomikos fakultete.

Kiek vèliau A. Šimenas atsirado. Jo dingimo aplinkybès nebuvo išaiškintos. Gal todèl premjero poste liko G. Vagnorius.

Nors sovietine kariauna vis labiau siautëjo krašte, Lietuvos valdžia nuosekliai kūrè nepriklausomą demokratinę respubliką. Buvo priiminejami savos valstybes įstatymai, protestuojama prieš karinę sovietinę agresiją, pervadinamos miestų gatves, sportininkai paliko TSRS rinktines, ruošiama pinigu reforma, kuriama krašto apsauga ir t. t.

Nesustojo darbas ir Vilniaus technikos universitete, nors politinio gyvenimo aplinka turëjo didelę įtaką kasdienos darbams. $1991 \mathrm{~m}$. sausio $15 \mathrm{~d}$. TSRS centrines televizijos programa „Vremia“ pranešé, kad Vilniaus inžinerinis statybos institutas išbrauke 20 ne lietuvių tautybès studentu. Tai buvo prasimanymas, šlykštus melas, kurio tomis dienomis buvo ypač daug Maskvos propagandoje. Net mokyklos tikslaus pavadinimo sovietiniai gebelsai nežinojo. Rektorius E. K. Zavadskas nusiunte „Vremia“ programos vadovams protesto telegramą, kurioje pareikalavo paneigti melagingą informaciją, pabrěžęs, kad 


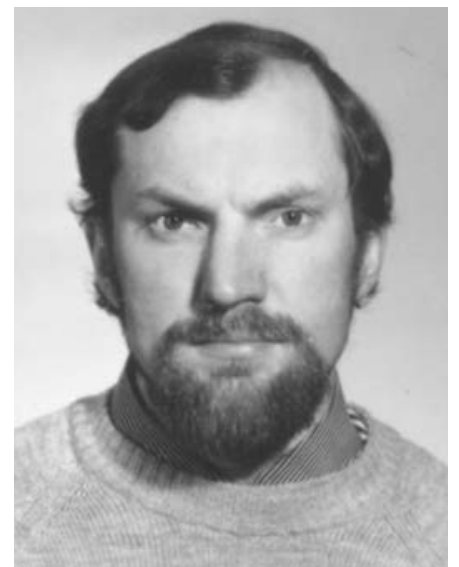

A. Šimenas

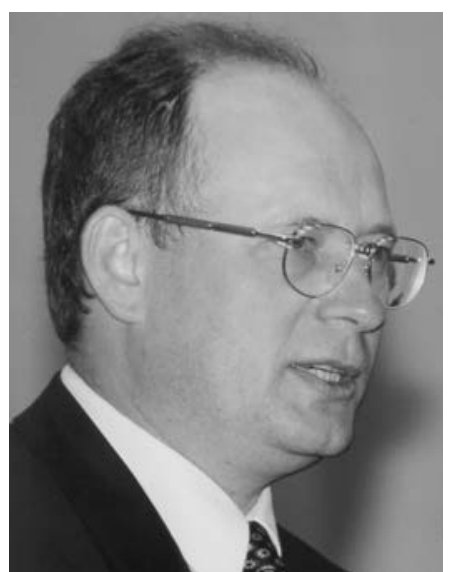

G. Vagnorius
VTU mokosi apie $20 \%$ ne lietuvių tautybès jaunuoliu, iš jų ir rusai. „Mums visi studentai vienodi“ - rašè rektorius.

Sovietine Maskvos valdžia tomis dienomis ieškojo įvairių pretekstų provoka-

\section{Universiteto dalykinès pertvarkos metas}

Pirmasis Lietuvoje, ėmęsis ryžtingai pertvarkyti studijų sistemą, Vilniaus technikos universitetas taip pat ryžtingai tvarke mokslo tyrimo darbų eigą.

$1991 \mathrm{~m}$. VTU pirmą kartą gavo valstybinę subsidiją mokslo tyrimo darbams finansuoti. Universiteto mokslininkai svarste kylančius uždavinius, prièmus Lietuvos mokslo ir studijų ịstatymą.

Elektronikos fakulteto siūlymu Radijo aparatūros technologijos katedra buvo reorganizuota ị Radijo elektronikos ir Radijo aparatūros katedras; Elektros įrenginių katedra pavadinta Automatikos katedra.

Statybos fakulteto siūlymu Chemijos ir statybinių medžiagų katedros buvo sujungtos, naujoji katedra pavadinta Statybiniu medžiagų katedra.

Kiek vèliau Autotransporto ekonomikos katedra buvo pavadinta Transporto valdymo katedra, o Metaly technologijos katedra Metalų technologijos ir suvirinimo katedra.

Kovo menesi buvo paskelbtos Vilniaus technikos universiteto priemimo taisykles. Jose buvo nurodyta, kad VTU studijos - dvieju pakopų: I pakopa - inžinieriaus bakalauro studijos, ju trukmè - 4 metai; II pakopa - inžinieriaus magistro studijos, ju trukmè - 1-2 metai.

Dieninèse studijose buvo numatyta 21 specialybè: architektūros, pramoninès ir civilines statybos, statybos (pedagoginio profilio), statybos dirbiniu ir konstrukciju gamybos, statybos ekonomikos ir valdymo, miestų statybos, automobilių kelių ir aerodromų statybos, geležinkeliu tiesimo, taikomosios geodezijos, vandentvarkos, šilumos, duju tiekimo ir vèdinimo, automobilių ir autoūkio, statybos ir kelių tiesimo mašinų bei įrenginių, suvirinimo įrenginių ir technologijos, mašinų gamybos technologijos, lokomotyvų ir jų ūkio, vagonų cijoms, skleide informacijos priemonèmis dezinformaciją, ji vis dar tikejosi užgesinti Lietuvoje kilusị išsilaisvinimo gaisrą. Imperinio mąstymo rusai niekaip negalejo suprasti, kodèl lietuviu tauta atsisako „didžiojo brolio" globos. Bet rusų imperinès ambicijos jau negalejo pakeisti lietuvių tautos nusistatymo - iškovoti laisvę ir gyventi savarankiškai. ir jų ūkio, transporto ekonomikos ir valdymo, pervežimų organizavimo ir valdymo, radioelektronikos ir automatikos.

Vakarines studijos buvo numatytos tik Mašinu gamybos technologijos specialybès, o neakivaizdinès -7 specialybių.

1990-1991 m. Vilniaus technikos universitete buvo tik 13 specialybių, studijavo 6192 studentai.

$1991 \mathrm{~m}$. kovo $21 \mathrm{~d}$. VTU visuotiniame mokslininkų susirinkime buvo priimtas Vilniaus technikos universiteto statutas.

Daugiausia rektoriaus E. K. Zavadsko iniciatyva buvo intensyvinami bendradarbiavimo ryšiai su užsienio mokyklomis. Buvo pasirašytos bendradarbiavimo sutartys, planuojama steigti su užsienio aukštosiomis mokyklomis ir firmomis eksperimentines imones, informacijos centrus, biurus. VTU podiplominių studijų centras įkūre bendrą biurą su austrų firma „Baltic Amadeus“, ir tai padejo spręsti kompiuteriu problemą.

1991 m. pavasari VTU ir Horsenso Politechnika (Danija) sutare įsteigti bendrą imonę „LITDANIJA“, kuri numate kelti studentų ir desstytojų kvalifikaciją bei pletoti komercinę veiklą.

Tą pati pavasarị rektorius E. K. Zavadskas ir prorektorius I. Z. Kamaitis apsilanke Libane. Buvo aptartos dešimties Libano jaunuoliu studijos VTU su ju tevais ir firmos, atsiuntusios studijuoti i Vilniu, vadovais. VTU vadovai susipažino su Libano aukštosiomis mokyklomis, specialistams keliamais reikalavimais.

1991 m. buvo ikkurtas VTU profesorių klubas, ketinęs oponuoti universiteto valdžios darbą, bet labai greitai to klubo veikla išblèso ir ilgainiui visai nutrūko.

$1991 \mathrm{~m}$. gegužes $20 \mathrm{~d}$. vykusiame VTU senato posedyje doc. V. Martinaitis pateike 
svarstyti naują studentu pažangumo vertinimo sistemą. Buvo pasiūlyta naudoti 10 balų vertinimo skalę tikintis, kad ji skatins studentus geriau mokytis. Numatyta studentus egzaminuoti tik raštu (išskyrus užsienio kalba). Visi egzaminų darbai turi būti saugomi katedrose vienerius metus. Buvo nutarta ịvesti siūlomą vertinimo sistemą. Kiek ji pasirode tobulesne už buvusiąją - ir šiandien nèra aišku. Bet ji nepasirodè ir blogesnè. İvesti ją reikëjo, nes tai buvo padaryta visose Lietuvos mokyklose.

\section{Pirmasis Garbès daktaras}

1991 m. gegužès 30 d. pirmą kartą mūsu mokyklos istorijoje buvo suteiktas Garbes daktaro vardas. Pirmuoju VTU Garbès daktaru tapo Leipcigo aukštosios technikos mokyklos habilituotas daktaras inžinierius Friedel Peldschus. VTU mokslo taryba įvertino jo didelius nuopelnus matematinių metodu kūrimo ir taikymo statybos technologijos srityje. Šis mokslininkas nagrinèjo lošimu teorijos taikymą statybos technologijos uždaviniams spręsti.

Friedel Peldschus kartu su VTU mokslininkais, daugiausia prof. E. K. Zavadsku, reguliariai organizuoja mokslinius kolokviumus tema "Statybos technologijos sprendimai“. F. Peldschus reguliariai vadovauja Lietuvos studentams diplomantams ir kt.

Gegužès ménesio pabaigoje Lietuvoje vyko 7-asis pasaulio lietuviu mokslo ir kultūros simpoziumas. VTU buvo surengti 4 sekciju posèdžiai. Statybinių medžiagų ir konstrukcijų sekcijai pirmininkavo prof. A. Kudzys, Statybos technologijos sekcijai - prof. E. K. Zavadskas, Urbanistikos ir architektūros sekcijai - arch. J. Vaškevičius ir Inžinerines komunikacijos ir susisiekimo sekcijai - doc. A. Juzènas.

VTU laikraštyje „Inžinerija“ doc. A. Jonaitis kviete kolegas stoti į naujai kuriamą desstytojų ir mokslininkų profesinę sąjungą. Jos steigiamasis susirinkimas įvyko gegužès 2 d. Anot A. Jonaičio, „Mūsu dauguma nusivyle senosiomis profesinemis sajungomis <...> Daugeliui, tikriausiai, kyla klausimas, ar reikalingos profesines sajungos müsu universitete? Anksčiau, kada egzistavo senosios profsajungos, buvo sudaryta regimybe, kad jos vienaip ar kitaip atstovauja müsy interesams, gina mus nuo administracijos. Veliau pradejome galvoti, kad müsu interesus gins mūsu pačì

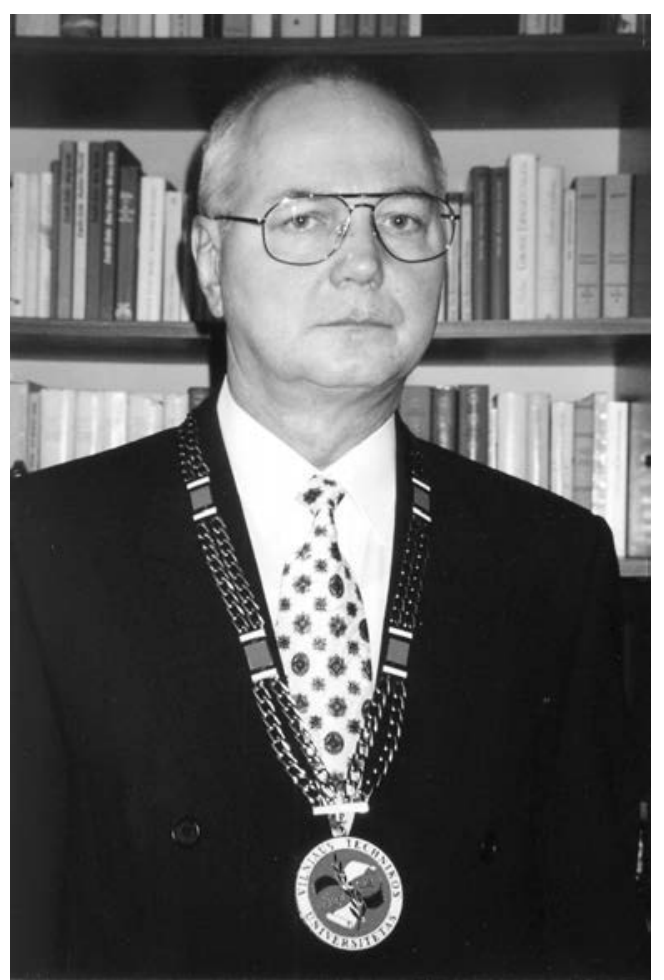

F. Peldschus

VTU Garbes daktaras
VILNIAUS TECHNIKOS

UNIVERSITETAS

232054, Vilnius, Sauléteklo at. 11,

Tel. 76-96-00, 76-37-60

Solita 61121406, 141874

Socialialo banko Lenino skyrius Vilntuje.

$199 \% 7 \cdot 16$ Nr. OII-12

По поводу ложного сообщения

в программе "Время" I5.0I.9I $\mathrm{r}$.

об исклочении иноязынных сту-

об исклочени иноязыныс сту-

но-строительном институте
Телевидение СССР Ilporpasma "Время" Телевизионная слугба новостеи ( $\mathrm{TCH}$ )

Редакция газеты "Комсомольская правда"

Програмана "Время" I5.0I.9I г. сообщила, что из Вильнюсского инкенерно-строительного института в течении последних дней по национальному признаку было исключено 20 инолзычных студенTOB.

3 а в

I. Информагия полностьо ложная.

2. Основанием для исключения ия университета является тольпо успеваемость или личное заявление об уходе по собственному желанио. Решая вопрос исключения начиональность студента никогда не имела никакого значения.

3. За период от I сентября I990 г. по I5.0I.I99I г. из Вильносского технического университета исключен 8I студент, из них I русский и I еврей. Все исключены по собственному желанир.

4. Вильносского инженерно-строительного института в настоящее время не существует, так как с 30 октября 1990 r. по решению Правительства Јитвы он реорганизован : Вильносский технический университет.

OT имени Вильнюсского технического университета категорически протестуем против распространения ложной информации, которая может способствовать нагнетанио недоверия между народами разных национальностей, проживагиих В Литве.

Ректор Вильносского технического университета

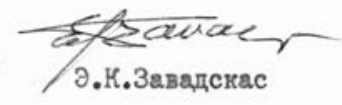


VILNIAUS

TECHNIKOS

UNIVERSITETAS

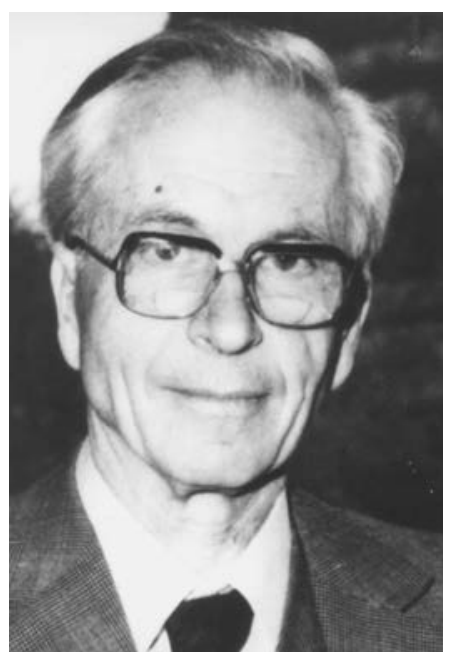

J. Argyris

VTU Garbes daktaras

išrinkta administracija ir jokios profsajungos bus nereikalingos. Dabar tikejimas naujosios universiteto valdžios teisingumu ir demokratiškumu blesta, nes daug sprendimu dèl mūsu interesu priimama kolektyvo neinformavus, su juo nepasitarus. Tai viena iš priežasčiu, kuri verčia burtis ż opozicija darbdaviui - profesines sajungas " [5.6, p. 3].

I įsteigtąją universiteto dèstytojų ir mokslininku profesines sąjungos tarybą buvo išrinkti A. Jonaitis, V. Juocevičius, A. Jurkša, P. Gerdžiūnas ir B. Valiūnas. Pirmininku tapo A. Jonaitis.

Bet šios profsąjungos realios veiklos pèdsakų nerasite. Buvo gražiai užsimota, bet... Horacijus yra sakęs "Nieko gyvenime nepasieksi be atkaklaus darbo". Atrodo, tai buvo pamiršę naujos profsąjungos šaukliai.

Birželio mènesị Vilniaus technikos universitete apsilanke garbingas svečias iš Danijos - Aalborgo universiteto rektorius Sven Caspersen su žmona. Jis su VTU valdžia aptare bendradarbiavimo tarp abieju universitetų plètojimo galimybes.

\section{Sovietinès valdžios ir komunistu agonija}

1991 m. liepos 31 d. Lietuvos žmones sukrète nauja tragedija. Sovietiniai galvažudžiai klastingai užpuole ir išžude Medininkų muitininkus. Tapo invalidu, bet liko gyvas tik vienas žmogus. Tai rode, kokia dar gležna mūsų laisve, kaip daug dar reikia padaryti, kad Lietuvos žmonès būtų saugūs. Nepraeis nè trys savaites, ir mūsų krašto lauks nauji išbandymai.

Rugpjūčio 19-osios rytą Tarybų Sąjungos radijas ir televizija praneše apie sovietijoje îvykdytą valstybès perversmą. Buvo paskelbta, kad prezidentas M. Gorbačiovas negali eiti pareigu ir jo igaliojimai atitenka viceprezidentui G. Janajevui. Buvo pranešta, kad visoje TSRS teritorijoje (o Maskvos manymu, jai tebepriklause ir Baltijos šalys) įvedama besąlygiška TSRS konstitucijos ir TSRS įstatymų viršenybè, laikoma, kad turi būti tuoj pat išformuotos valdžios ir valdymo struktūros, sukarintos formuotes, kurios veikia prieštaraujant TSRS konstitucijai ir
Beveik tuo pat metu lankèsi Štutgarto universiteto (Vokietija) Taikomuju skaičiavimų instituto direktorius John Argyris. Jam $1991 \mathrm{~m}$. birželio 28 d. VTU taryba, ivertinusi didelius nuopelnus kuriant ir taikant statybines mechanikos ir skaičiavimo matematikos metodus, suteikè VTU Garbès daktaro vardą.

$1991 \mathrm{~m}$. Vilniaus technikos universitetas išleido 788 absolventus. Dieninį skyrių baigè 513, vakarinị - 150 ir neakivaizdinį - 125 žmonès.

Vasarą Latvijos Liepojos mieste vyko 11oji "Gaudeamus“ švente. Joje dalyvavo visi trys didžiausi VTU meno kolektyvai: „Gabija“, „Vingis“ ir „Inžinerija“.

Nuo liepos $16 \mathrm{~d}$. vyko stojamieji egzaminai i VTU inžinieriaus bakalauro pirmajji kursą. Konkursas ị vieną vietą buvo 1,11 . İ dienines studijas buvo priimamas 761 jaunuolis: i Architektūros fakultetą - 38, Statybos fakultetą - 227, ị Inžinerinių komunikacijų fakultetą - 157, į Mechanikos fakultetą - 249, i Elektronikos fakultetą - 90. Dieninio skyriaus pirmakursiai 1991-1992 m. m. buvo 673 vyrai ir tik 88 merginos.

I vakarinị skyrių priimta 60 žmonių, ị neakivaizdinị skyrių - 78 .

TSRS įstatymams, laikoma, kad nebegalioja valdžios ir valdymo organu įstatymai ir nutarimai, kurie prieštarauja TSRS konstitucijai ir TSRS ịstatymams. Uždraudžiama organizuoti mitingus, eitynes, demonstracijas, įvedama masines informacijos priemoniu kontrole ir t. t.

Ir karinè mašina èmè veikti. Sovietai užgrobė Lietuvos didžiujų miestų radijo, televizijos stotis, ryšių mazgus. Visur patruliavo kariškiai. Vos vos tesigirdejo Parlamento radijo studijos balsas. Nejaugi tai jau demokratijos laidotuvès?

Lietuvos Aukščiausiosios Tarybos pirmininkas Vytautas Landsbergis tą pačią rugpjūčio 19-ąją kreipèsi ị pasaulio tautas ir laisvųjų šalių vyriausybes, į kitas tarptautines organizacijas:

„Lietuvos Respublikos žmoniu gyvybei ir visuomeninei tvarkai gresia soviety karinio smurto pavojus. Suteikite parama teisetai, visy žmoniu išrinktai Lietuvos valdžiai, kuri gina 
teisetuma ir stabiluma Lietuvoje. Pareikškite, kol nevelu, kad okupacines karines sovietu valdžios ivedimas Lietuvoje bus tolygus Hitlerio ir Stalino sanderio tęsimui ir itvirtinimui, kad Vakaru šalys netoleruos naujojo stalinizmo, o $u \check{z}$ agresijos pasekmes visa atsakomybe teks jos iniciatoriams ir vykdytojams. Lietuva laukia Jūsu žodžio, Jüsu apgynimo. Neleiskite, kad Budapešto ir Prahos tragedija pasikartotu prie atgimstancios Baltijos krantu“".

Pagrindas nerimui buvo didelis. Tik mažyte Islandija buvo pripažinusi Lietuvos Respubliką de jure. Didžiosios Vakarų valstybes reiške Lietuvai simpatijas, bet nei pripažino, nei kuo nors įsipareigojo. Daugybè Lietuvos gyventojų buvo pasiryžę kovai už laisvę, bet ką galëjom padaryti prieš milijonus karių turintį monstrą? Nuojauta buvo bloga, bet buvo suprasta, kad galesime pasipriešinti tik tuomet, jei visi būsime kartu. Tai įrode Sausio 13-oji.

Ačiū Dievui, pačioje Rusijoje prieš pučistus sukilo žmonès. Prasidejo protesto streikai, demonstracijos. Rusijos Federacijos prezidentas B. Jelcinas tapo kovos prieš perversmininkus vadovu. Masinis Rusijos visuomenès pasipriešinimas dave vaisių ir karine chunta žlugo. Lietuvos miestuose rusų kariškiai apleido užgrobtus ryšių objektus.

Rugpjūčio 23 d. Vilniuje, Lukiškių aikšteje, buvo demontuotas pagrindinis sovietinès valdžios ženklas - Lenino paminklas, o dieną anksčiau Maskvoje - F. Dzeržinskio paminklas. Tai reiške jau ir TSRS griūties pradžią. Prasidejjo intensyvus Baltijos šaliu valstybių nepriklausomybès pripažinimas.

\section{Pirmieji VTU studentai užsieniečiai}

Nuo 1991 m. rugsëjo 1 d. VTU pradëjo studijuoti 7 jaunuoliai iš užsienio. Trys libaniečiai pasirinko Architektūros fakultetą, keturi - Statybos.

1991 m. rugsejo 16-29 d. Krokuvoje ivvko 4-asis inžinierių rengimo tarptautinès asociacijos Rytų-Vakarų kongresas, kurio Vykdomasis komitetas nutare priimti Vilniaus technikos universitetą, atstovaujamą rektoriaus E. K. Zavadsko, tikruoju Tarptautines asociacijos nariu.

19910923 VTU senatas prièmé nutarimą dèl atsiskaitymų už studijas. Perlaikydamas egzaminus studentas turès užmokèti.
Gražius palaikymo žodžius siunte į VTU ir Vakaru mokslininkai. Labai prasmingas buvo mums tomis dienomis gautas laiškas iš VTU Garbès daktaro J. Argyrio:

Prof. Edmundui Zavadskui,

Vilniaus technikos universiteto rektoriui,

Studgartas, 1991 m. rugpjūčio 26 diena

Mielas Rektoriau, Profesoriau Zavadskai, aš šiomis dienomis esu labai pakiliai nusiteikęs dèl to, kad Baltijos valstybès bus pagaliau laisvos. İvykiai Sovietu Sajungoje suteiks laive Jūsu drasioms šalims. Aš labai žaviuosi Baltijos valstybemis ir linkiu joms paties geriausio.

Gal Jums idomu, kad po grižimo iš Vilniaus ắ parašiau išsamu laiška kancleriui Koliui, išreikšdamas savo nuoširdžia užuojauta ir stipriausia parama Baltijos valstybiu laisvei. Mano nuostabai jis atsake už savaitès ir pritare mano jausmams tiek oficialiais apmastymais, tiek pats ivertindamas Baltijos valstybiu europietiska charakteri.

Labai gailiuosi, kad Jūusu nebuvo (man Jūsu trūko) lankantis Vilniuje, bet, pasinaudodamas proga, reiškiu savo susižavejiima Jüsu didingu Technikos universitetu ir stipria akademine dvasia. Aš tvirtai tikiu, kad Jūsu šalis greitai taps mūsu bendru Europos namu nariu, kur laisvi žmonés lemia savo politine ir demokratine sistema.

\section{Nuoširdžiai Jūsu}

$$
\begin{aligned}
& \text { Em. Prof. Dr. Dr. h.c. } \\
& \text { mult. John ARGYRIS }
\end{aligned}
$$

Bet jau lapkričio mènesi, protestuojant Studentų sąjungai, šis nutarimas buvo gerokai sušvelnintas.

VTU biblioteka èmé teikti naują paslaugą - sudaryta galimybe naudotis automatizuotu Danijos bibliotekų katalogu.

1991 m. spalio 1 d. įkurta VTU doktorantūra, parengti jos nuostatai, į doktorantūrą priimti 24 asmenys.

Elektronikos fakulteto dekanu buvo išrinktas docentas Kazimieras Maceika, o Inžinerinių komunikacijų fakulteto dekanas Jonas Duoba išvyko dirbti pedagoginio darbo į Zambiją. VTU ịtrauktas į TEMPUS

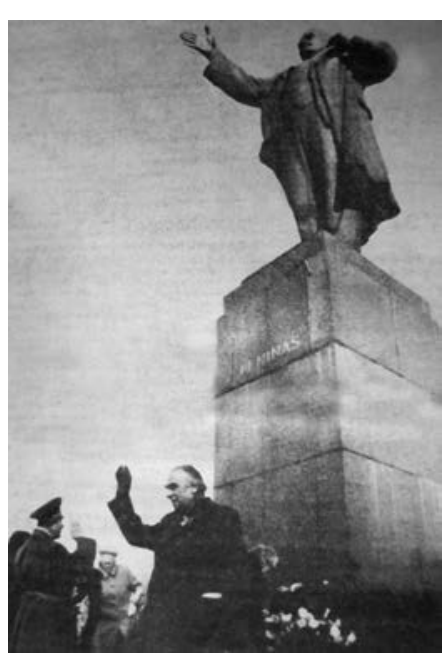

M. Burokevičius prie Lenino paminklo 
VILNIAUS

TECHNIKOS

UNIVERSITETAS

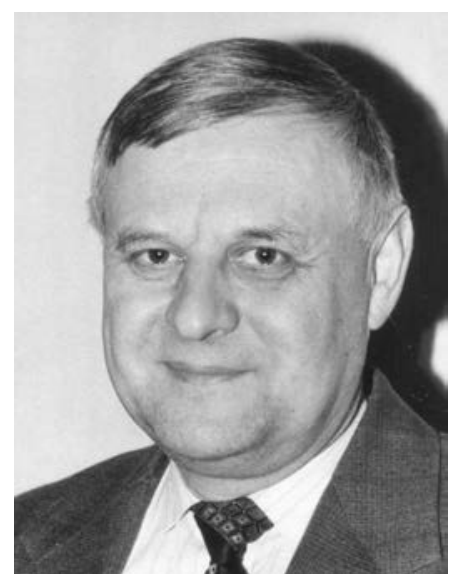

K. Maceika

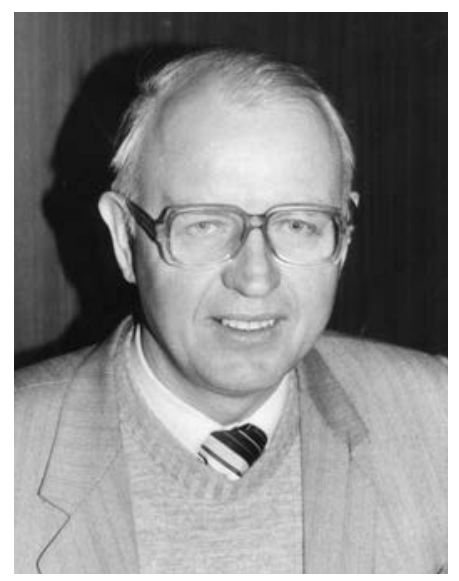

R. Ginevičius

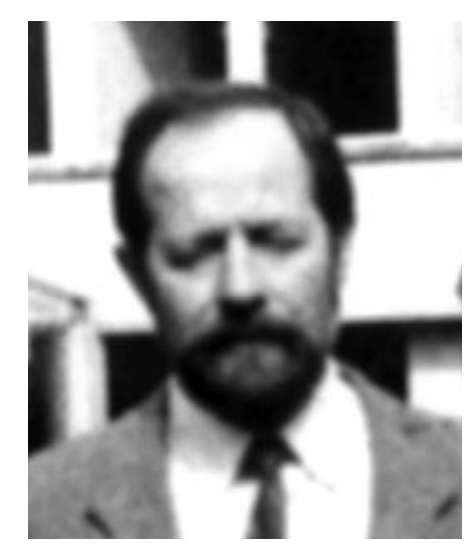

L. Furmonavičius programos vykdymą. Horsenso politechnika surenge Vilniaus technikos universitete parodą energijos taupymo klausimu. Lietuvos mokslo tarybos nariu tapo rektorius E. K. Zavadskas, o Lietuvos mokslų akademija jị išrinko nariu ekspertu.

Spalio pabaigoje Statybos ekonomikos katedros vedejju iki būsimų rinkimų buvo paskirtas doc. Romualdas Ginevičius.

İvykusiame Vidaus reikalų ministerijos Priešgaisrinès apsaugos departamento ir VTU vadovu susitikime buvo sutarta nuo 1992-1993 mokslo metu pradèti rengti priešgaisrinès apsaugos inžinierius bakalaurus. Buvo pranešta, kad abiejų isstaigų specialistai pradëjo rengti priešgaisrinès apsaugos inžinierių rengimo mokymo planą.

Maloni žinia atëjo VTU geotechnikams. Tarptautine gruntu mechanikos, pagrindu ir pamaty draugija priemé i cavo narius Lietuvos geotechnikos draugiją, kurios pirmininkas - VTU geotechnikos laboratorijos vedëjas inž. Liudvikas Furmonavičius.

Vietoj išvykusio dirbti į Afriką Jono Duobos Inžinerinių komunikacijų fakulteto taryba fakulteto dekanu išrinko docentą $\mathrm{Vy}$ tautą Martinaitį.

19911129 VTU senatas nutare įsteigti Lietuvos mokslininkų sąungos VTU skyrių.

Šventųjų Kaledų išvakarèse 19911223 VTU senatas nutare Geodezijos katedros pagrindu įkurti Geodezijos institutą.

1991 m. VTU sulaukè reikšmingos paramos iš užsienio, ypač Danijos mokyklų, kai kurių firmų, užsienio lietuvių. Igyta kompiuterinès technikos, techninès literatūros, sudarytos sąlygos mūsų destytojų bei studentu stažuotems ir praktikai. 1992 metus Technikos universitetas pradejo jau igijęs tam tikrą tarptautinį pripažinimą ir pozityvią perspektyvą.

1991 m. ataskaitoje VTU senatui rektorius prof. E. K. Zavadskas pažymëjo, kad VTU dirba 32 mokslo daktarai ir 308 mokslu kandidatai, docentai. Per tuos metus net i 17 šalių vyko 120 desstytojų ir 128 studentai.

Buvo ịkurtas VTU Pervežimų problemu institutas, aktyviai bendradarbiauta rengiant Lietuvos Respublikos mokslo ir studiju ịstatymą.

Tuoj po Naujųju 1992 metų pradžios buvo įkurtas Tarptautinių studijų centras.
Jo direktoriumi buvo paskirtas prof. Ipolitas Zenonas Kamaitis.

Sausio menesį Lietuvos Respublikos Vyriausybè prièmé nutarimą Nr. 52 „Dèl profesorių ir docentų rentos“. Po šio nutarimo VTU paliko didelis būrys mokslininku - net 38 , kurių dalis tikrai galëjo sèkmingai dar daug metų dirbti pedagoginị ir mokslinị darbą.

Vasario 3-7 d. VTU įvyko II tarptautine konferencija „Naujos statybines medžiagos, konstrukcijos ir technologijos statyboje“. Buvo perskaityti 155 pranešimai, iš jų 74 VTU mokslininkų.

\section{Buvo sunku, bet netrūko entuziazmo}

Pirmaisiais atkurtos nepriklausomybès metais Lietuva patyre daug sunkumų. İvairios organizacinès problemos, pertvarkos ekonomikos sudètingumas, finansų stoka - visa tai veikè visas šalies gyvenimo sritis. Be viso to, reikia prisiminti ir labai nepaprastą politinę padetį. Bet nepaisant visko, žmonès dirbo su dideliu entuziazmu, ieškojo problemų sprendimo, neprarado optimizmo. Vienas tokių entuziastų ir optimistu - VTU rektorius profesorius E. K. Zavadskas.

Jis raše daug straipsnių respublikos spaudoje, davè interviu, ypač kai buvo paskirtas Lietuvos mokslo tarybos nariu. Faktiškai jis gyne ne vien Vilniaus technikos universiteto, o visos Lietuvos aukštojo mokslo sistemos interesus. Su pavydetinu stropumu jis reagavo žiniasklaidos priemonèse i visas, tarkim, dienos aktualijas. Taip $1992 \mathrm{~m}$. vasarị interviu „Lietuvos aidui“" prof. E. K. Zavadskas aptare aktualiausią tuomet (ne mažiau aktualią ir dabar) problemą - aukštojo mokslo finansavimą. Jis sakè: „Opiausia - mokslo ir studiju finansavimo problema. Suprasdami sunkia ekonomine padeti, siekiame, kad aukštuju mokyklu finansavimas, issaugotas per daugeli dešimtmečiu, nors nebūtu sumažintas, kad išliktu suburtas ir valstybei svarbus mokslininku potencialas. Džiugu, kad praëjusiais metais Vyriausybe beveik nesumažino mokslo finansavimo. Manau, taip pasielgs ir šiemet. Juk mūsu mokslininkai dirbo labai sunkiomis salygomis. Praejusiais metais dalyvavau UNESCO surengtame rektoriu pasitarime Paryžiuje. Sužinojau, kad mūsu inžinieriui rengti skiriama 200 kartu mažiau lèšu negu išsivysčiusiose pasaulio šalyse. Gal per tolimas squvokas gretinu? Müsu universiteto profesoriai 
gauna mažesnius atlyginimus negu ju paruošti jauni absolventai, dirbantys gamyboje. Šios disproporcijos neišspręs ir paskutiniai, mokslininkams palyginti palankūs, Vyriausybes nutarimai. Tad nesmerkime aukštuju mokyklu destytoju, ieškančiu papildomo darbo kitur arba einančiu dirbti ten, kur geresne perspektyva gauti didesni atlyginima, buta, pasistatyti nama... Žinoma, gaila, kad aukštasias mokyklas palieka gabūs mokslininkai. Prieš metus jūsu laikraštyje kreipiausi j kolegas straipsniu "Profesoriai, sugrižkite!“ [5.7, p. 56].

Vasario 16-osios išvakarese sužinota, kad prof. habil. dr. Leonas Saulis apdovanotas Sausio 13-osios atminimo medaliu. O minint Vasario 16-ąją VTU apsilanke poetas Justinas Marcinkevičius.

Vasario $17 \mathrm{~d}$. VTU senatas nutare Architektūros fakultete įsteigti Teritorinio planavimo institutą.

Vis labiau stiprejo bendradarbiavimas su Danijos mokyklomis. Labai svarbi Technikos universitetui buvo gauta iš Danijos spausdinimo įranga, kuri padejo praplesti VTU mokslinès ir metodinès literatūros leidybą, pakelti jos technini lygi.

1992 m. kovo 11 d. Rygoje vykusiame Baltijos transporto akademijos steigiamajame susirinkime prezidentu išrinktas prof. Adolfas Baublys.

Balandžio $8 \mathrm{~d}$. Lietuvos mokslų akademijos prezidentas Juras Požèla ir VTU rektorius Edmundas Kazimieras Zavadskas pasiraše LMA ir VTU bendradarbiavimo sutarti.

VTU senatą vèl imta vadinti Taryba. Jos pirmininku vietoj A. Čižo buvo išrinktas fizikos ir matematikos mokslų daktaras profesorius Juozas Jakimavičius.

19920421 VTU moksline taryba nutare steigti Inovacini kompozitinių konstrukciju institutą Statybos fakultete ir Šilumos technikos institutą Inžinerinių komunikaciju fakultete.

1992 m. gegužes 27 d. VTU mokslinè taryba nutare pakeisti Inžinerinių komunikacijų fakulteto pavadinimą ir pavadinti ji Miestų inžinerijos fakultetu. Tame pačiame posèdyje nutarta ịsteigti Branduolinès hidrofizikos laboratoriją.

Birželio $26 \mathrm{~d}$. posèdyje VTU mokslinè taryba nutare kandidatu i Nacionaliniu premiju teikimo komitetą pasiūlyti prof. E. K. Zavadską. Tame pačiame posedyje nutarta Pagrindų ir pamatų katedrą pavadinti Geotechnikos katedra. Buvo nutarta įsteigti

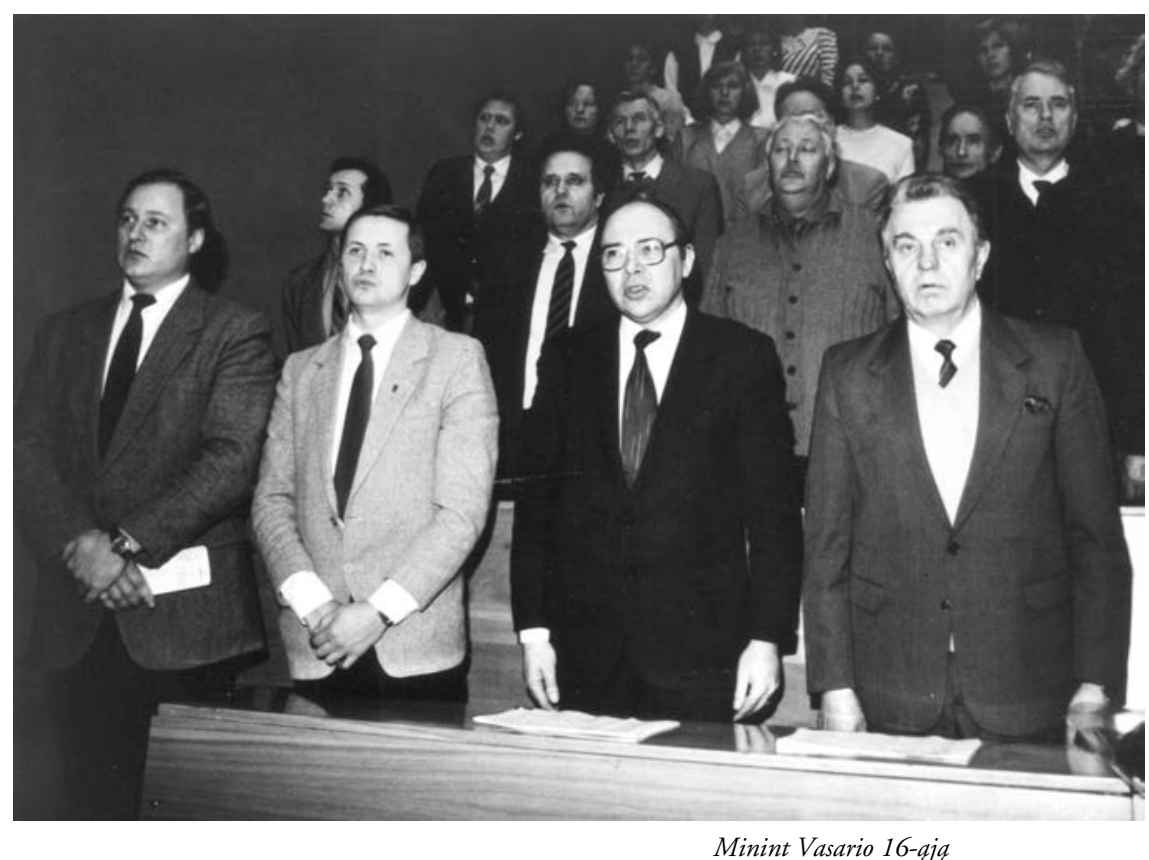

dar vieną mokslo laboratoriją - Statinių, konstrukcijų ir medžio.

1992 m. VTU išleido 680 specialistu. Dienini skyrių baige 494 žmonès, vakarinị skyrių - 111 ir neakivaizdinị skyrių -75 .

Liepos 2 d. Lietuvos Respublikos Aukščiausioji Taryba prièmè nutarimą „Dèl Vilniaus Technikos universiteto statuto“. Jo pirmasis punktas skelbia: Vilniaus technikos universitetas yra valstybinè aukštoji mokykla. Jis rengia specialistus su aukštuoju išsilavinimu, tobulina jų kvalifikaciją ir juos perkvalifikuoja, atlieka fundamentinius ir taikomuosius mokslo tyrimus, rengia mokslininkus. Statutas reglamentuoja uždavinius ir veiklos sritis, teisinę padetti, universiteto struktūrą, studijų formas, mokslinị ir metodinị darbą ir t. t.

Studentų priemimas į pirmąją studijų pakopą - $\mathfrak{i}$ inžinieriaus bakalauro studijų pirmąji kursą, numate, kad studentai pirmus dvejus metus studijuos bendrąsias mokslo ir bendrąsias technikos disciplinas pagal pasirinkto fakulteto studiju planus. Po dvejų sèkmingų metų studijų studentai turejo pasirinkti specialybę ar specializaciją. Buvo paskelbtos tokios specialybès: Architektūros fakultete - architektūra; Miestų inžinerijos fakultete - miestų inžinerija (specializacijos: keliai; miestų statyba; šilumos, duju tiekimas ir vedinimas); geodezija (topografija ir kartografija; inžineriné geodezija; kadastras ir geodezinès informacijos sistemos); Elektronikos fakultete - radioelektronika, automatika; Mechanikos fakultete - mechanika (specializacijos: mašinų gamyba; suvirinimo

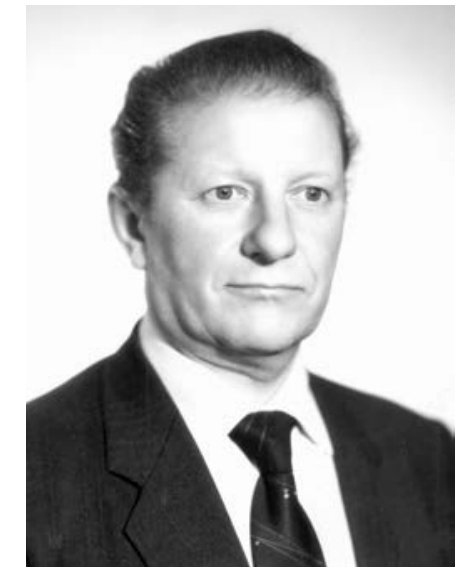

L. Saulis

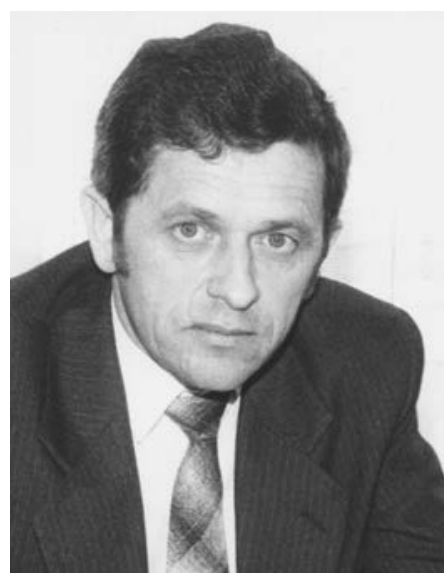

V. Martinaitis 
VILNIAUS

TECHNIKOS

UNIVERSITETAS

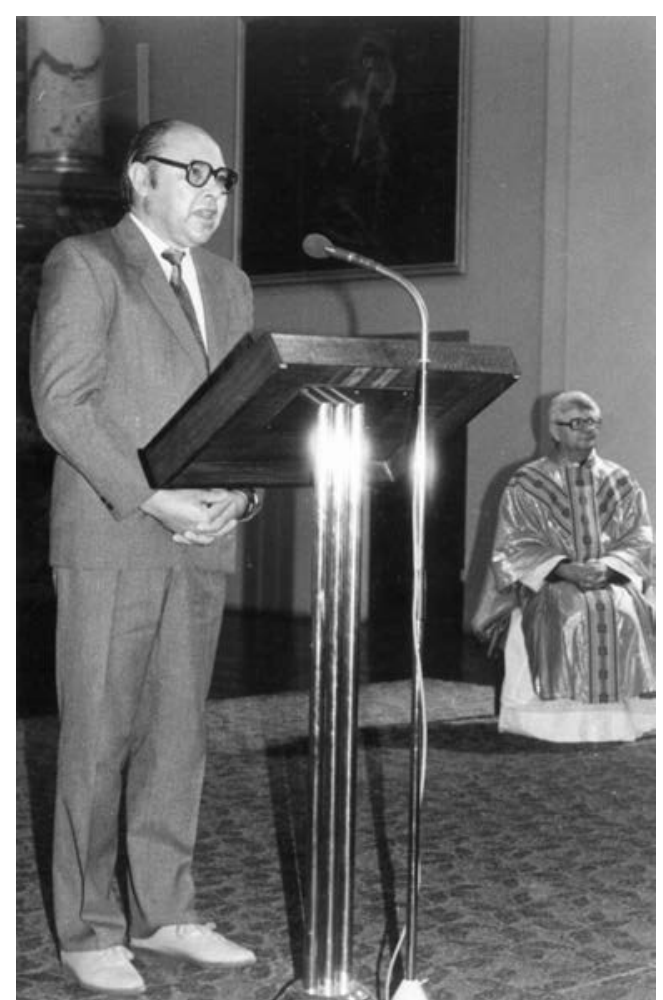

įrenginiai ir technologija; automobiliai; skraidymo aparatai ir varikliai; lokomotyvai ir vagonai; statybų ir kelių mašinos; mašinų gamybos vadyba; transporto vadyba); Statybos fakultete - statyba (specializacijos; statybos technologija ir menedžmentas; statinių konstrukcijos; statybos medžiagos ir dirbiniai), priešgaisrine sauga.

Po ketverių studijų metų, t. y. baigę pirmosios pakopos studijas, inžinieriai bakalaurai arba turintys anksčiau igytą inžinieriaus kvalifikaciją galëjo studijuoti antrojoje pakopoje - inžinieriaus magistro studijose, kurių trukmè - dveji metai.

Trečioji pakopa - doktorantūra, jos trukmè - 3-5 metai. İ doktorantūrą buvo numatyta priimti asmenis, baigusius inžinieriaus magistro studijas.

I pirmajį kursą $1992 \mathrm{~m}$. buvo priimta 590 vaikinų ir 115 merginų, iš viso 705 žmonès.

İspūdinga buvo 1992-1993 mokslo mety pradžia Šv. Kazimiero bažnyčioje, kurios rektorius Jonas Boruta pabrežè, kad ne mažiau svarbi žmogaus širdies ir sielos inžinerija.

J. Boruta kviete tarnauti Tèvynei, būtent tarnauti, kaupiant žinias ir igūdžius šiuo sunkiu metu. Ne vienas šių dienų studentas nueis dirbti i gamybą ir jam reikès ne vien tik išdidžiai vadovauti. Žmogus, nesuvokiąs kito žmogaus sielos, sakè kunigas, negali pasiekti geru rezultatu arba visa, ko jis siekia - tera laikina.

Nuoširdžiai, su jauduliu sveikino visus rektorius E. K. Zavadskas: „Mielieji Vilniaus technikos universiteto destytojai, studentai, svečiai! Leiskite nuoširdžiai padekoti Šv. Kazimiero bažnyčios rektoriui Jonui Borutai už suteikta garbę pradeti Naujuosius mokslo metus sioje šventoveje. Tai patvirtina, kad žmogaus dvasingumas yra susijes su mokslu, jis net pirmesnis, nes vaikas pirmiausia susipažista su Bažnyčia, su Dievo vardu.

Zmogaus dvasingumas sukuria atitinkama aplinka, jo dekka kiekviena vieta gali tapti šventove. Śiq akimirka prisimenu Vorkutos barakus, varganus tremtiniu būstus, kuriuose kunigai sukurdavo šviesu ir šventa dvasios lauka, tapdavusi vilties žvaigžde, saugojusi lietuvi nuo žüties. Tad ar ne simboliška Naujuosius mokslo metus pradeti Bažnyčioje - dvasios šventoveje? Šis mūsu tylus susikaupimas, malda - tarsi tyro vandens šaltinis, kuris pades mums gydyti okupacijos metu žaizdas, paskatins su didesne atsakomybe pažvelgti i Naujuju mokslo metu darbus.

O darbai laukia dideli. Vilniaus technikos universitetas jau iženge $\dot{z}$ Europos ir pasaulio universitetu šeima. Turime prigyti šioje šeimoje, tapti visaverčiais jos nariais. Visi turetume suprasti šiq tiesą, ypač pirmuju kursu studentai. Laisvai, nepriklausomai Lietuvai reikia geru inžinieriu. Ir kürybingu. Aviacijos, inžinerines fizikos, kitos specialybes pirmakart isteigtos Lietuvos aukštojoje mokykloje. Ir Jūs, brangūs studentai, pateisinsite jaunos, atsikuriančios valstybès didi pasitikejima.

Kreipiuosi z visus, kurie studijuoja ir dirba mūsu universitete, bükite vieningi, dori ir darbštūs. Saugokite savo garbę kiekviename žingsnyje. Tuo saugosime ir müsu universiteto garbę. Tik ka patvirtintas müsu universiteto Statutas. Jo nuostatos tebünie šventos.

Nelengvi laukia Naujieji mokslo metai. Bet nepamirškime: kuriame savo valstybe, statome savo namus, savo šventovę. Tegul müsu universitetas ir tampa mokslo šventove, kurioje gimtu šviesios, drasios mintys, kurioje bütu gera kiekvieno dvasiai, kurioje vyrautu kilnumas, dora.

Su Naujaisiais mokslo metais, mielieji. Geros kloties, asmenines laimes, sveikatos linkiu visiems Jums. Tegul mums padeda Dievas “ [5.8, p. 57-58]. 
Mokslo metu pradžioje VTU lankèsi venesuelietis Gediminas Orentas su sūnumi Kęstučiu. Jis pareiške, kad jo sena svajonè padèti Lietuvos studentams siekti mokslo. Tai buvo didelès paramos mūsų studentams pradžia. Ilgainiui Gediminas Orentas tapo vienu didžiausių VTU mecenatų.

Rugsëjo 16 d. laikinoji VTU taryba apsvarste rinkimų i naująją VTU tarybą taisykles ir prieme nutarimą del VTU tarybos rinkimu.

İvykusiuose rinkimuose i VTU tarybą išrinkta 50 žmonių: Architektūros fakultetas - prof. E. Bučiūte, doc. V. Dičius, doc. V. Stauskis; Elektronikos fakultetas - prof. A. Dambrauskas, prof. S. Štaras, prof.Z. Vainoris; Mechanikos fakultetas - prof. A. Baublys, prof. L. Lingaitis, prof. M. Mariūnas, prof. V. Vekteris, t. m. dr. O. Lukoševičienè, doc. L. Keblas, doc. M. Nemira, doc. A. Valiulis; Miestų inžinerijos fakulteto - prof. J. Skeivalas, prof. V. Vainauskas, doc. V. Jasulaitis, doc. P. Juškevičius, doc. V. Martinaitis, doc. A. Matuzevičius; Statybos fakulteto: prof. P. Baltrenas, prof. J. Kivilša, prof.A. Kazragis, prof. P. Norkus, prof. B. Sidauga, prof. J.Šimkus, prof. E. K. Zavadskas, doc. P. Vainiūnas; Bendrųjų moksly̨ centras - prof. J. Jakimavičius, prof. Z. Jankauskas, doc. P. Audzijonis,

\section{Planuojama rengti aviacijos specialistus}

Rektorato posedyje buvo svarstomas aviacijos specialistų rengimo klausimas, nes buvo siūloma, kad tokių specialistų rengimą turettų kuruoti viena aukštoji mokykla. Doc. J. Stankūno manymu, rengti aviacijos specialistus NVS šalyse nenaudinga, nes tikimasi, jog Lietuvos aviatoriai skraidys Vakaruose pagamintais lektuvais. Be to, toks specialistų rengimas labai brangiai kainuotu.

Buvo sudaryta darbo grupe, kuri turëjo suderinti aviatoriu pageidavimus ir VTU galimybes.

1992 m. spalio 25 d. įvyko Lietuvos Respublikos Seimo rinkimai. Šiuose rinkimuose balotiravosi net 5 VTU destytojai: V. Jasulaitis, A. Kunčinas, A. Šniukšta, J. Jonaitis ir V. Liutikas. İ Seimą buvo išrinkti Algirdas Kunčinas ir Vytautas Liutikas, gerai žinomi VTU bendruomenei. Sovietmečiu jie buvo partijos komiteto nariais, bet nebuvo fanati- doc. R. Bendorius, doc. A. Čiučelis, doc. E. Dagiene, doc. R. Masilionis, doc. J. Kaulakys, doc. A. Saulis, doc. J. Šliogeris; Humanitarinių mokslų centras - prof. B. Melnikas, prof. J. Stonys, doc. J. Bivainis, doc. R. Ginevičius, doc. A. Kunčinas, doc. A. Mačys, doc. P. Tamošauskas, doc. G. Počiauskienè.

Tarybos pirmininku buvo išrinktas prof. J. Jakimavičius, pavaduotoju doc. J. Juozaitis.

$1992 \mathrm{~m}$. rugsëjo $24 \mathrm{~d}$. VTU apsilankè Lietuvos nepaprastasis ir igaliotasis ambasadorius Venesueloje Vytautas Dambrava. Jis atveže magistrų stipendijoms 1200 dolerių, kuriuos surinko Gediminas Orentas.

VTU Garbes svečių knygoje V. Dambrava paraše: „Turiu garbę ir malonuma aplankyti Jüsu aukśtojo mokslo institucijos vadovybę ir susipažinti su Jūsu atliekamu nepaprastos svarbos darbu, kuriant Lietuvos gerovę ir užtikrinant akademines institucijos ateiti.

Perduodu geriausius sveikinimus Venesuelos vyriausybes ir Lotynu Amerikoje isikürusiu lietuviu vardu.

Aukite ir klestékite Tévynes pasididžiavimui".

Spalio $15 \mathrm{~d}$. rektorato posedyje buvo nutarta nuo 1993 m. rugsëjo $1 \mathrm{~d}$. ikkurti Aplinkos apsaugos katedrą.

kais. A. Kunčinui ir V. Liutikui tapus politikais, „Inžinerija“ klause A. Kunčiną, kaip jis vertina politini fanatizmą. A. Kunčinas, be kita ko, sakè: „Politikas turetu vengti dvieju kraštutinumu-politinio fanatizmo ir „vejarodines politikos". Seniau dirbantys mūsu universitete tikriausia dar prisimena puiku politinio fanatizmo pavyzdi-M. Burokevičiu, kurissugadino nemažai nervu ir sveikatos mūsu studentams ir destytojams. Politinis fanatikas nesugeba juertinti realios situacijos, jam vis dažniau rodosi, kadpasaulisyra toks, kokijis noretu matyti, one toks, koksyra is tikruju. Kada ideja yra svarbiau užpačius žmones, politinis fanatizmas atneša beprasmiu auku, praliejamas kraujas. Noréciau tiketi, kad tokiu fanatiku Lietuvoje nera daug, bet vis tenka sutikti žmoniu, dar tik linkstančiu ifanatizma. Jie nenori ar nesugeba isiklausyti i oponento argumentus, vienareikšmiškai šlovina viena ar kita autoriteta, apriori atmeta kitokias politines pažiūras, tuo pačiu pripažindami sau
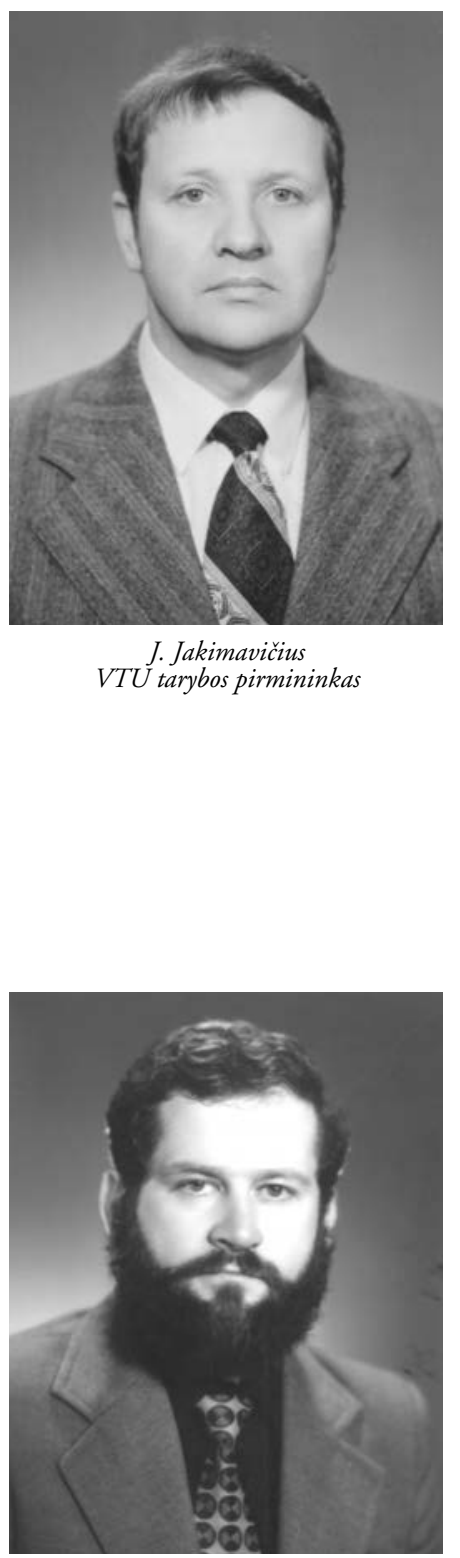

A. Kunčinas 
VILNIAUS

TECHNIKOS

UNIVERSITETAS

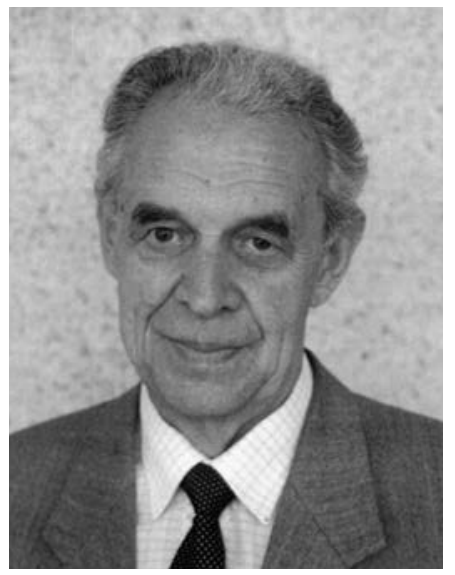

A. Žukauskas politines išminties, vieninteles tiesos monopo-

lic “[5.9, p. 1].

$1992 \mathrm{~m}$. VTU mokslininkai demonstravo ryškią pažangą. Padaugèjo monografijų - ju buvo išleista 11 , mokslo darbų rinkinių -7 . Už 890000 talonų buvo atlikta tiriamųju darbų pagal valstybinius užsakymus, o už 18,44 milijono talonų - ūkiskaitinių darbų. Tais metais rektorius E. K. Zavadskas buvo išrinktas Ukrainos technologinès kibernetikos akademijos užsienio nariu.

Nuo gruodžio $1 \mathrm{~d}$. Lietuvoje buvo pradètas mokslo laipsnių nostrifikavimas, t. y. gautų sovietmečiu mokslinių laipsnių pripažinimo procesas.

Naujuosius 1993 metus Vilniaus technikos universiteto bendruomenè sutiko su nerimu. Aukštasis mokslas buvo finansuojamas vis blogiau. 1992 m. aukštajam mokslui buvo skirti $7 \%$ valstybés biudžeto, o 1993 metams buvo numatyta tik $5 \%$. Mokslo visuomene žiniasklaidos priemonèse skelbe deklaracijas, memorandumus, protestus. Jau 1992 m. valstybès skiriamų lěšu vos pakako išmokèti varganiems atlyginimams, pastatu eksploatacinems išlaidoms, o dèl infliacijos lěšų jau trūko katastrofiškai. VTU net buvo priverstas prieš Naujuosius metus išleisti destytojus dvi savaites atostogauti vasaros atostogų sąskaita. Anot rektoriaus E. K. Zavadsko, aukštasis mokslas gavo teisę imtis komercijos, bet dèl biurokratų noro kontroliuoti, teikti nurodymus, kaip biudžetines lěšas naudoti, ja užsiimti labai sudetinga.

Tai buvo labai sunkus metas. Bet dèl VTU vadovu sumanios veiklos dauguma destytoju nepaliko universiteto, nors atlygis už sunkų ir reikalingą Lietuvai darbą buvo labai menkas.

Nepaisant sunkumų, buvo toliau pletojamas universiteto bendradarbiavimas su Vakarų šalių aukštosiomis mokyklomis. Sausio 25 d. rektorato posedyje VTU ryšiu su užsieniu skyriaus viršininkas Remigijus Čiupaila pranešè, kad penki VTU studentai turi galimybę 5 menesius tobulintis Danijoje, Olborgo universitete.

Buvo apsvarstytas Vilniaus mokslo parko steigimas kartu su Vilniaus miesto taryba, Lietuvos mokslų akademija, Vilniaus universitetu ir kt.
Vienas iš mokslo parko tikslų - sukurti infrastruktūrą, kuri skatintų, remtų ir konsultuotų įmones, gaminančias mokslui imlią produkciją. Parkas sudarytų sąlygas išbandyti ir ịdiegti naujausias idèjas bei atradimus mokslo ir technikos srityse, padetu mokslininkams, inžinieriams bei aukštos kvalifikacijos specialistams sukurti naujas darbo vietas.

Tame pačiame posedyje nutarta ịkurti nuolat veikiančią universiteto renginių darbo grupę. Rektoriaus įsakymu ją sudare šie asmenys: A. Nakas - pirmininkas, nariai: P. Baltrènas, L. Jankus, L. Ziberkas, G. Vežauskas, V. Plakys, B. Šaknys, V. Lujaniene, V. Šmigelskienè, A. Marašinskaitè, A. Rudminaitè, R. Muralienè.

Kasmet augo VTU bibliotekos literatūros fondas. 1993 m. pradžioje turèta beveik 800 tūkstančių leidinių.

$1993 \mathrm{~m}$. vasario $10 \mathrm{~d}$. VTU tarybos posedyje buvo patvirtinti VTU tarybos nuostatai.

VTU taryba - aukščiausias universiteto valdžios organas, kurios nutarimai privalomi visiems universiteto darbuotojams ir studentams. Jos nariais gali būti tik mokslininkai. Nuostatuose nuodugniai išdesstyti klausimai, priklausantys tarybos kompetencijai. Pateikta tarybos struktūra, jos darbo reglamentas.

Buvo apsvarstytas ir priimtas Vilniaus technikos universiteto struktūros projektas. Numatyta sukurti Aviacijos institutą fakulteto teisemis ir įsteigti Skrydžių valdymo ir Aviatechnikos katedras. Numatyta sukurti Verslo administravimo fakultetą ir šias katedras: Vadybos, Verslo ekonomikos, Humanitarinių ir socialinių mokslų, Kalbų ir Kūno kultūros. Bendrųjų mokslų centrą numatyta reorganizuoti į Fundamentinių mokslų fakultetą. Mechanikos fakultete planuota issteigti Aviainžinerijos katedrą.

Nutarta pakeisti kai kurių katedrų pavadinimus: Metalų technologijos ir suvirinimo -i Medžiagotyros ir suvirinimo; Mašinų teorijos - $\mathrm{i}$ Poligrafijos mašinų; Transporto valdymo - ic Pervežimo organizavimo; Automobilių transporto - $i$ Transporto mašinų; Braižybos - $\mathrm{i}$ Inžinerinès grafikos.

Vasarị Vilniaus technikos universiteto Garbès daktarais tapo LMA tikrasis narys Algirdas Žukauskas, Olborgo universiteto (Danija) rektorius prof. Sven Caspersen ir to paties universiteto profesorius Kai Borre, Vokietijos Lenna-Merseburgo miesto aukštosios technikos mokyklos prof. Peter Linnert. 
Kovo mènesį buvo paskelbtas prièmimas ¡ VTU bakalauro studiju pirmą kursą. I 14 specialybių iš viso buvo numatyta priimti 1000 žmonių: i architektūros specialybę 40 , automatiką -50 , i gaisrinę saugą -50 , i geodeziją -30 , į inžinerinę fiziką -20 , ị inžinerinę informatiką - 30, į mechaniką - 260, i miestų inžineriją -145 , ị radioelektroniką 105 , ị skraidymo aparatų pilotavimą -15 , i skrydžių valdymą -15 , ị statybą -190 , i verslo administravimą -50 .

Reikia pažymèti įdomią specializaciju gamą. Tarkim, radioelektronikos specialybè teikè galimybę pasirinkti penkias specializacijas: radioelektronikos, elektronines aparatūros, aviacinès elektronikos, fizikinès radioelektronikos ir kompiuterizuotų radioelektroninių sistemų. Automatikos specialybes specializacijos: robototechninès sistemos, mikroprocesorinès technologinių procesų val-

\section{Pradètos Garbès daktaru inauguracijos}

Balandžio $14 \mathrm{~d}$. Bonifratrų bažnyčioje ivvyko S. Caspersen, K. Borre ir P. Linnert inauguracijos VTU Garbès daktarais procedūra. Jiems buvo įteikti VTU Garbès daktaro diplomai dalyvaujant Danijos ir Vokietijos ambasadoriams, daugeliui svečių iš užsienio ir Lietuvos aukštujjų mokyklų. Olborgo universiteto profesorius K. Borre išrūpino ir perdave Vilniaus technikos universitetui vertingą geodezinę techniką: keturis GPS imtuvus, du fotografines įrangos komplektus ir du kompiuterius. Sèkmingai bendradarbiaujama su Geodezijos katedros profesūra.

Kiek vèliau VTU Garbès daktaro diplomas buvo įteiktas LMA akademikui Algirdui Žukauskui.

1993 m. gegužè 10-13 d. vykusioje VTU tarptautinëje statybos mokslu konferencijoje dalyvavo net 25 svečiai iš užsienio, atvykę iš Vokietijos, Anglijos, Norvegijos, Lenkijos, Kanados, Švedijos, Prancūzijos, Danijos ir kt.

Lietuva buvo priimta dalyvauti TEMPUS programoje $1991 \mathrm{~m}$. İ šią programą įsijungè ir Vilniaus technikos universitetas. Pagal TEMPUS programą VTU gavo 16 kompiuterių. Keturios VTU katedros kartu su užsienio partneriais parenge keletą bendradarbiavimo projektų. dymo sistemos, aviacijos elektros įrenginiai, elektros įrenginiai ir jų eksploatavimas.

Mechanikos fakultetas surengè prièmimą i naują specialybę - biomechaniką. Biomechanikai - tai ortopediniu priemonių, invalidų vežimèlių ir reabilitacijos įrangos bei panašios medicinos technikos kūrimo, gamybos ir remonto organizavimo inžinieriai.

Lietuvos aviacijai reikalingiems specialistams rengti nuo pavasario ima veikti VTU Aviacijos institutas. Buvo numatyta priimti norinčius igyti inžinieriaus piloto, skrydžių vadovo, aviacijos inžinieriaus mechaniko bei aviapervežimų organizavimo ir valdymo specialisto kvalifikaciją.

Reikalingos kraštui bei įdomios buvo ir kitos specialybès, specializacijos. Svarbu, kad ju paklausa garantavo visiems absolventams darbo vietas.

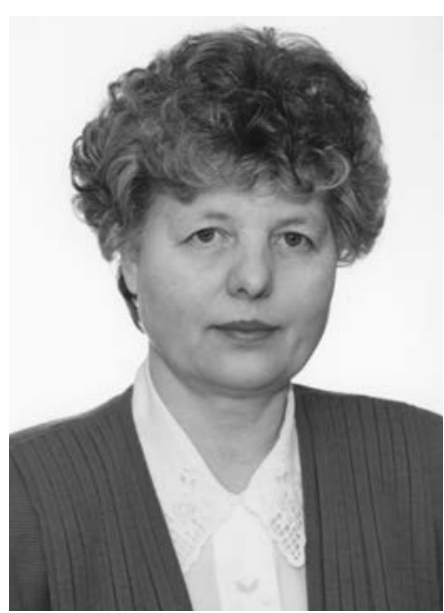

R. Žemkiené

Personalo skyriaus direktoré nuo $1993 \mathrm{~m}$.
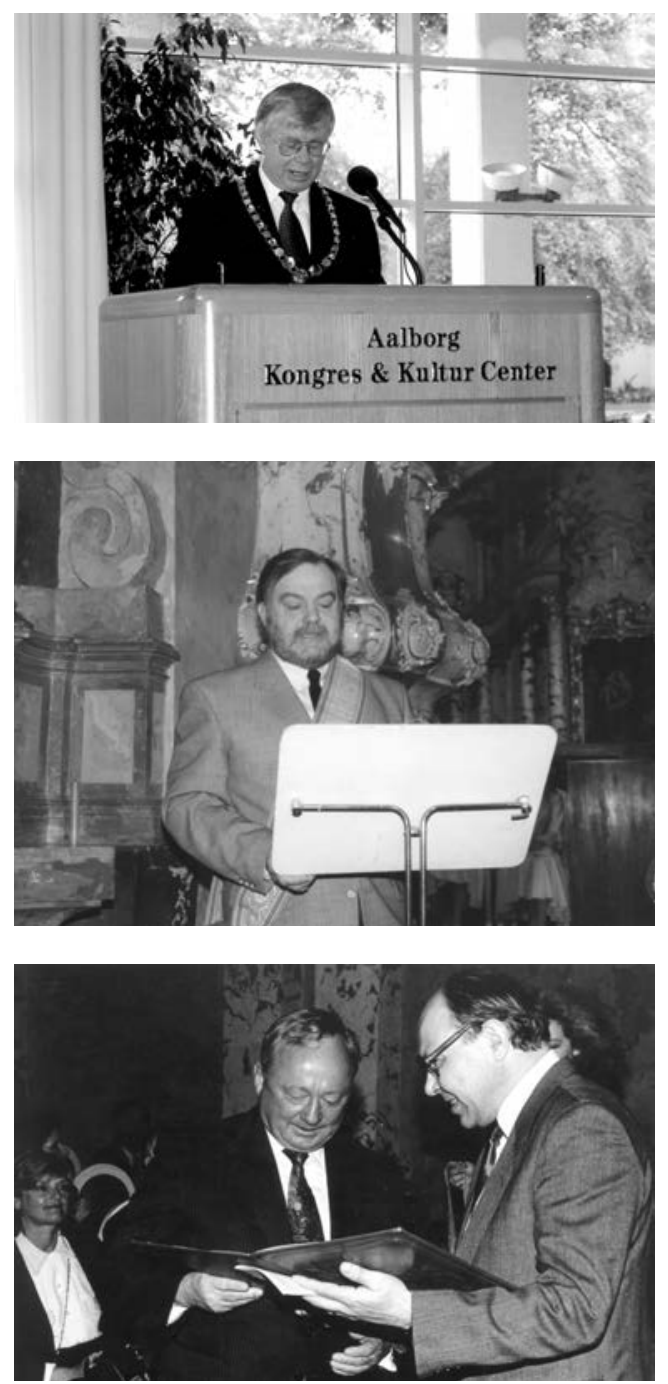

VTU Garbès daktarai

S. Caspersen

K. Borre 
VILNIAUS

TECHNIKOS

UNIVERSITETAS

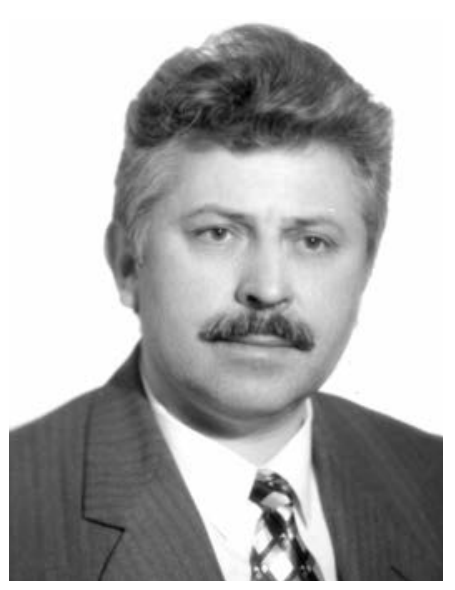

V. Plakys

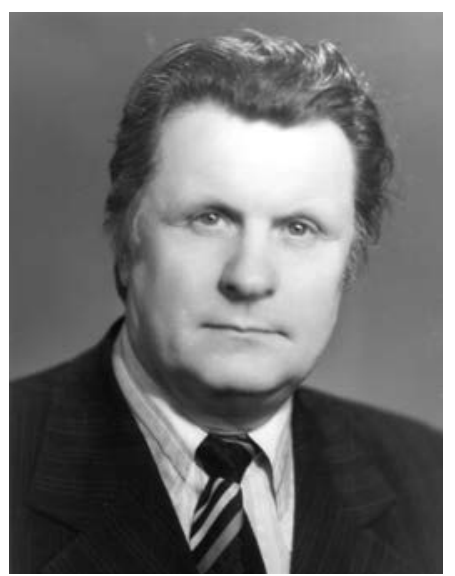

V. Sakalys
Balandžio mènesį Vilniaus miesto meru tapo VTU Kelių katedros vedejas doc. Vytautas Jasulaitis.

Balandžio 29 d. habilitacinị darbą „Pastatų ir jų gelžbetoninių konstrukcijų atnaujinimas, stiprinimas ir apsauga nuo korozijos sintetinemis dervomis" apgyne I. Z. Kamaitis. Darbą labai gerai įvertino habilitacinis komitetas, kuriam pirmininkavo prof. E. K. Zavadskas.

Gegužès menesį rektorato posedyje Mokslo ir studiju skyriaus vedejjas Vytautas Plakys praneše apie studijų kreditų, koeficientu sistemos ir etatų paskirstymo problemas. Nuo 1993-1994 mokslo metų studentu ir destytojų darbo apimtị buvo numatyta matuoti kreditais.

Gegužès menesį VTU studentai gausiai dalyvavo Vilniaus universiteto stadione surengtoje sporto šventeje, skirtoje pagerbti Dariaus ir Girèno skrydžio per Atlantą 60-meti.

Labai gerai pasirode Statybos fakulteto trečiakursis Vladas Jurgilas, laimëjęs $1 \mathrm{my}$ lios begimą. Estafeteje VTU sportininkai buvo antri.

Šventę organizuojant daug ir nuoširdžiai padirbejo VTU Sporto klubo pirmininkas doc. V. Sakalys, Kūno kultūros katedros vedejas A. Mačys, Vadybos fakulteto dekanas R. Ginevičius.

Birželio 9-10 dienomis VTU Architektūros fakultetas, Dailes akademija ir Architektu sąjunga suorganizavo tarptautinę mokslinę konferenciją „Architektūros mokykla pasikeitimų periodu“.

Vilniaus technikos universiteto doktorantūroje studijas tęse 62 jaunuoliai. Technikos universitetas jau disponavo teise suteikti habilituoto daktaro laipsni statybos, mechanikos, elektronikos ir elektrotechnikos specialistams. VTU gavo teisę teikti docento mokslo vardus visose socialiniu, humanitariniu, gamtos ir technikos mokslų bei profesoriu vardus - ekonomikos, vadybos, architektūros ir visose technikos srityse. Taigi VTU prestižas labai išaugo.

1993 m. VTU išleistų specialistų derlius buvo gerokai didesnis nei prieš metus. Iš viso baige 1023 žmonès: dienini skyriu 825 , vakarinị skyrių - 108 ir neakivaizdinị skyriu -90 .
Vasarą sèkmingai vyko priemimas ị pirmajji kursą. Iš viso priimti 1303 jaunuoliai ir merginos: į Architektūros fakultetą - 61, Statybos fakultetą - 245, Miestų inžinerijos fakultetą - 240, Mechanikos fakultetą - 295, Elektronikos fakultetą - 167, Verslo vadybos fakultetą - 113, Fundamentaliụjų mokslų fakultetą - 64, Aviacijos institutą - 62 ir $\mathfrak{i}$ Tarptautinių studiju centrą - 56 .

I verslo vadybos specialybès vieną vietą stojo 8 pretendentai. Net 40 proc. stojančiujų i VTU - merginos, daugiausia ịstojusiųju - vilniečiai.

Po kelerių metų pertraukos vèl atvère duris Vilniaus technikos universiteto istorijos muziejus.

\section{Tarptautinis architektūros fakulteto studentu laimejimas}

1993 m. tarptautiniame studentų architektų darbų konkurse Vašingtone (Jungtinès Amerikos Valstijos) VTU Architektūros fakulteto studenty Tomo Grunskio, Aliaus Vosyliaus ir Sigito Rimkevičiaus konkursinis projektas (vadovas Algis Vyšniūnas) laimëjo 3 vietą.

Kiekvienais metais JAV aukštujjų architektūros mokyklų asociacija skelbia konkursą studentams urbanistams. Šio konkurso tema - „Gyvenamoji statyba mieste“. Konkurse dalyvavo per 1400 studentu iš 29 šalių, atstovavusių 138 mokykloms. Užduotis - „Suprojektuoti naują vidutinio aukštų skaičiaus (5-8 aukštų) gyvenamųjų namų kompleksą su pagalbiniais pastatais 750 1000 gyventojų susiformavusioje istorineje aplinkoje. Vieta pasirenkama konkurso dalyvių gyvenamojoje vietoje“.

VTU Architektūros fakulteto studentai tokią vietą pasirinko Šiaulių miesto Lieporių rajone. Jų trečiąją vietą laimëjęs darbas buvo ivertintas 1000 dolerių premija. Bet svarbiausia, šis laimëjimas rode apie gerą VTU Urbanistikos katedros rengiamų specialistų lygi, ką reikejjo laikyti viso Architektūros fakulteto gražiu tarptautiniu parisitatymu Vakarų pasauliui.

Rugsëjo 1-osios proga rektorius E. K. Zavadskas „Inžinerijoje“ sveikino studentus, dèstytojus ir darbuotojus ir raše:

„Jums, büsimiesiems inžinieriams, teks kurti, projektuoti Lietuvos ateiti. Kad ir ka statytumèt-paprasta pirkia, rümus, tiltus, kad ir ka konstruotumet-mašinas, lekktuvus, visa tai 


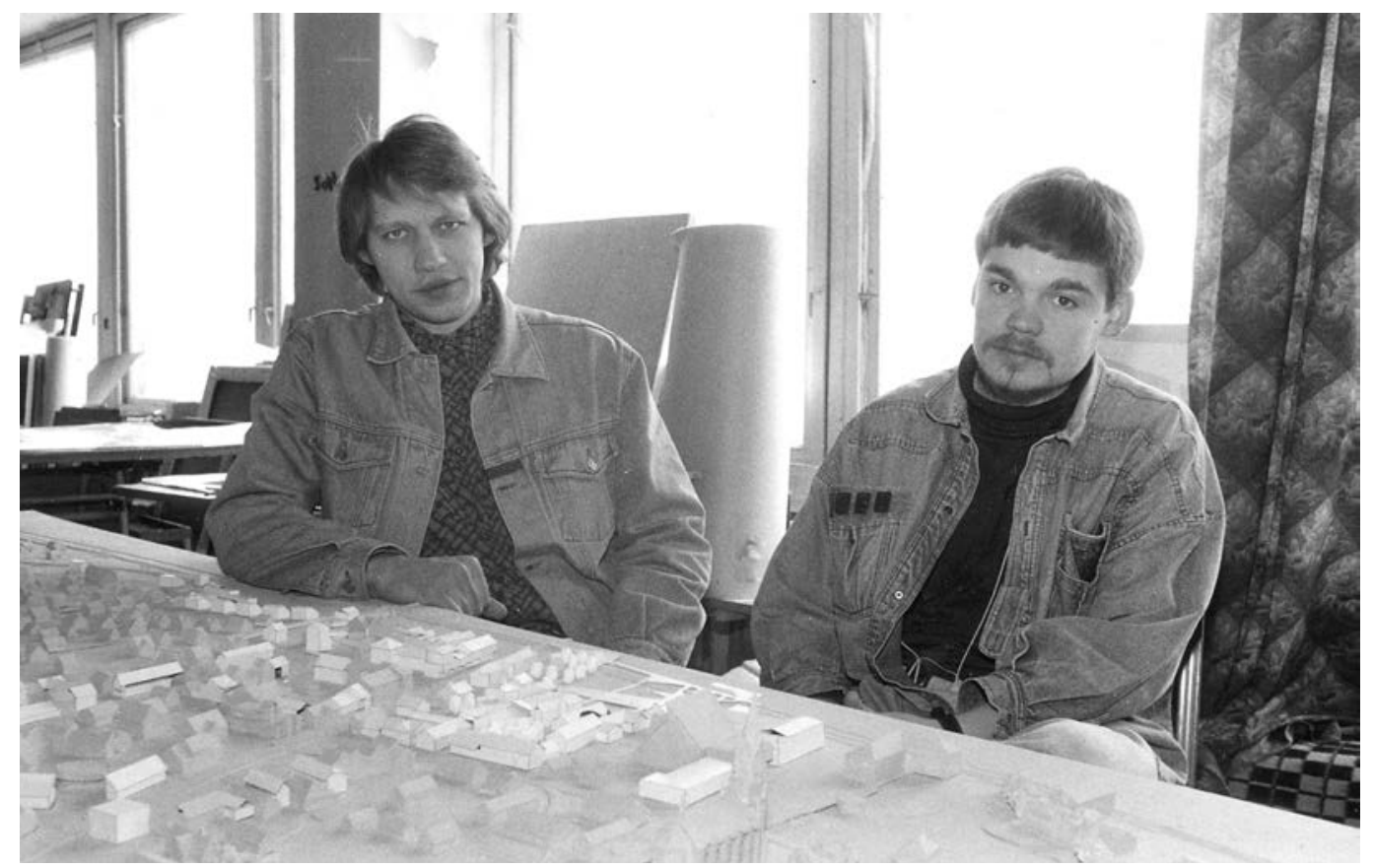

tarnaus Lietuvos žmonems. Savos, daug iškentëjusios, o dabar jau laisvos Tevynès dukroms ir sūnums teks naudotis Jüsu kürybos vaisiais.

Mūsu tautos šviesulys profesorius Zigmas Žemaitis raše: ,...lietuviu tauta turi didinga praeiti, jai skirta tureti ir kilnia vertinga ateiti்". Sie žodžiai, tarti 1935 metais, skamba lyg pasakyti siandien. Ilgi okupacijos metai nesunaikino müsu tautos vilties kurti kilnia vertinga ateiti. Ši viltis turetu tapti müsu visu siekimu. Vardan jos verta daug ko atsisakyti, atsideti mokslui ir kürybai.

Tad j darba, mielieji! Būkime kaip gera darni šeima, kurioje dalijasi vieni su kitais ne vien duonos kąniu, bet ir mintimis bei svajonemis. Padekime vieni kitiems šiame nelengvame mūsu valstybès Lietuvos atkūrimo laikotarpyje " [5.10, p. 1].

Po dviejų savaičių - dar viena švente Vilniaus technikos universitete.

Rugsèjo 13-ąją Lietuvos aviacijos liniju mokymo centro salëje susirinkę VTU garbūs svečiai savo kalbose minëjo užgimstant naujaji Lietuvos aviacijos etapą. Aviacijos instituto pirmakursiams tą dieną buvo įteikti studentų pažymëjimai.

Aviacijos instituto direktorius doc. Jonas Stankūnas pabrèžè, kad Lietuvai reikalinga sava aviacijos sistema, savi specialistai. Užsienyje rengti vieną lakūną kainuotų kone VTU metų biudžetą!

Rektorius E. K. Zavadskas sakè: „Šiandien Jüs tampate pirmaisiais atgimusios Lietuvos aviacijos studiju studentais. Jüs būsite pirmoji lakūnu laida. Atvirai pasakysiu: Jūsu laukia labai itemptos studijos. Abejingu, tikiu, tarp Jüsu nebus, nes Jüs suprantate, kad nuo Jüsu pastangu priklausys Lietuvos valstybes aviacijos ateitis ir rytdiena " [5.11, p. 1].

Rugsèjo $24 \mathrm{~d}$. VTU apsilanke žymus JAV lietuvių visuomenès atstovas lietuvių namotyros mokslo pradininkas dr. inž. Jurgis Gimbutas, daug metų gražiai bendradarbiavęs su VTU muziejų kuratoriais. Jo deka VTU mokslo istorikai gavo galimybę geriau pažinti JAV lietuvių inžinierių darbus, jų patriotinę visuomeninę veiklą. I VTU, J. Gimbutui tarpininkaujant, atkeliavo ne vieno žymaus JAV lietuvių inžinieriaus archyvai.

19931125 Vilniaus technikos universitete vyko Baltijos šalių rektorių konferencija. Joje aptarti mokyklų bendradarbiavimo klausimai. 1993 m. VTU Aviacijos institutui iš JAV buvo nupirkti mokomieji lekktuvai. Jiems lěšs išrūpintos nepaprastomis pastangomis ir tai buvo didelis VTU vadovų laimëjimas.

\section{Nauji VTU mokslininku laimëjimai}

1993 metu pabaigą vainikavo žinia apie Lietuvos valstybines premijos paskyrimą habilituotam technikos daktarui, Lietuvos mokslų akademijos tikrajam nariui Aleksandrui Čyrui ir jo mokiniams - docentams technikos daktarams Juozui Nagevičiui, Juozui Atkočiūnui, Antanui Krutiniui, Romanui Karkauskui ir Stanislovui Kalantai.

Mokslinio darbo rezultatai 1993 m. apskritai buvo geri.
Studentai architektai

S. Rimkevičius ir T. Grunskis (bei A. Vosylius) tarptautiniame konkurse Amerikoje 1993 m. laimejo premiją

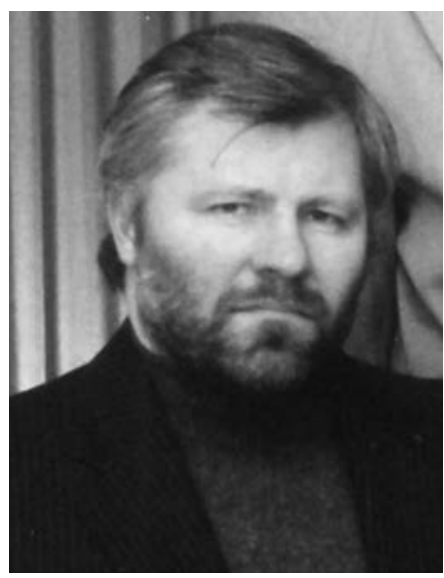

A. Vyšniūnas

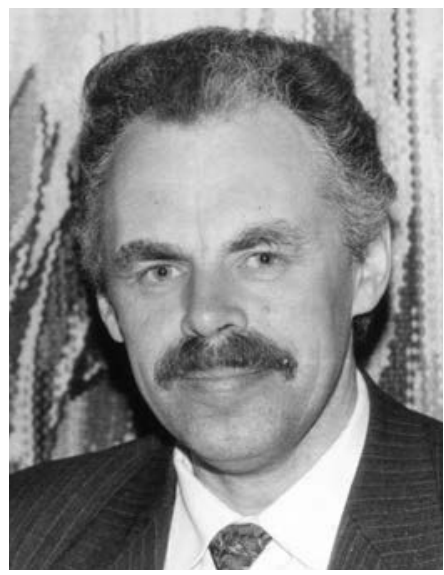

J. Stankūnas

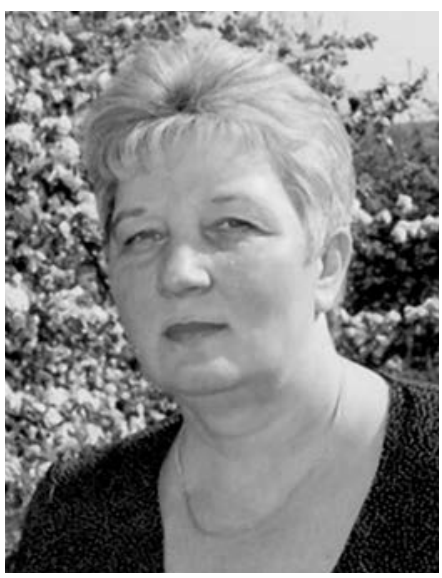

M. Baranauskiene

VTU bibliotekos direktore 1993-1996 m. 


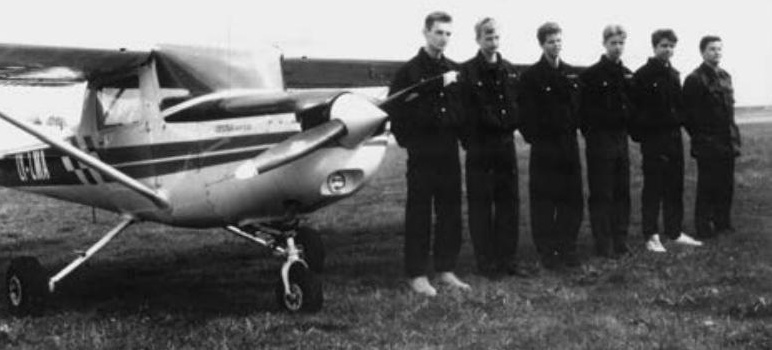

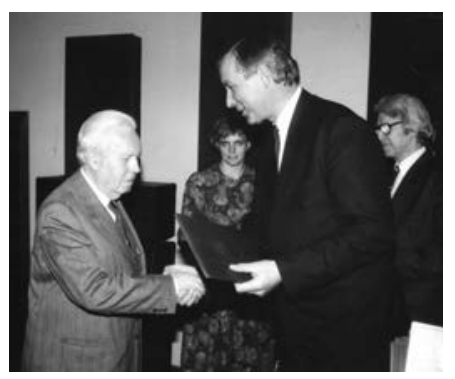

Ministras Pirmininkas A. Šleževičius jteikia premija A. Cyrui
Statybinès mechanikos katedra Iš kairès ̣̂ dešine pirmoje eilëje: doc. dr. J. Žukas, doc. dr. R. Fliotoviene, akademikas prof. habil. dr. A. Cyras, katedros vedejas doc. dr. A. Krutinis, doc. dr. S. Kalanta;

antroje eileje:

reikalų tvarkytojas R. Ašmenskas, doc. dr. L. Rimkus, doc. dr. A. Norkus, doc. dr. R. Karkauskas, doc. dr. V. Skaržauskas; trečioje eileje: doc. dr. J. Nagevičius, doc. dr. J. Atkočiūnas
Viršuje dešinëje -

Studentai priešskridymo praktika
VTU darbuotojai apgyne 10 daktaro disertaciju. Habilituotais daktarais tapo Ipolitas Zenonas Kamaitis (Tarptautinių studiju centras), Renius Žeromskas (Automobiliu transporto katedra), Genadijus Kulvietis (Inžinerinès informatikos katedra), Vytautas Kazimieras Augustaitis (Poligrafinių mašinu katedra), Algirdas Smilgevičius (Automatikos katedra), Romualdas Mačiulaitis (Statybinių medžiagu katedra), Narimantas Kazimieras Paliulis (Vadybos katedra), Juozas Bivainis (Vadybos katedra) ir Petras Gailutis Adomenas (Transporto vadybos katedra). Už kūrybinius darbus pripažinti profesorių vardai architektams Vytautui Jurgiui Dičiui, Raimundui Arnui Dineikai ir Algimantui Nasvyčiui. Be to, Technikos universitete daug disertaciju gyne atvykę iš kitų institucijų ir kitų šalių. Daktaro disertacijas VTU gyne Austrijos, Vokietijos, Monako piliečiai. VTU suteikti daktaro ir habilituoto daktaro diplomai buvo nostrifikuoti užsienyje.

VTU mokslininkų pajegos èmè atsigauti, nes priemus Lietuvos Vyriausybés potvarki dèl mokslininkų rentos ir ị pensiją išejus net kelioms dešimtims VTU mokslininkų profesorių ir docentų, mokslininkų gretos buvo praretejusios.

Bet mokslas Lietuvoje per pirmuosius nepriklausomybes metus taip ir netapo prioritetiniu valstybeje. Kai kurie tai Seimo, tai Vyriausybės nariai skleidè nuostatas, kad Lietuvai „,nereikia tiek aukstuju mokyklu, mokslinio tyrimo institutu, dvieju simfoniniu orkestru, tiek daug biblioteku ir t. t." [5.12, p. 196]. Kovos su tokiomis fariziejiškomis nuotaikomis avangarde buvo (ir tebera) profesorius Edmundas Kazimieras Zavadskas. Bet kuriame forume, spaudoje, visose kitose žiniasklaidos priemonese jis nuosekliai ir atkakliai siekè apginti aukštąjį mokslą nuo įvairiausių užsipuolimų, net prasimanymų. Tai, kad per daug metu Vilniaus technikos universitetas buvo sèkmingai pletojamas - didžiausi nuopelnai tenka rektoriui E. K. Zavadskui.

1994 m. sausio 11 d. VTU iqvyko mokslinè konferencija „Statybos aukštojo mokslo raidos Lietuvoje momentai“, o vasario $20 \mathrm{~d}$. vel svečiavosi garsus gamtosaugininkas, JAV lietuvis Valdas Adamkus.

Vasario $17 \mathrm{~d}$. rektorius E. K. Zavadskas Technikos universiteto tarybos posedyje vienbalsiai buvo perrinktas kitai ketveriu metų kadencijai. Mokslo reikalų prorektoriumi tapo prof. Juozapas Audvydas

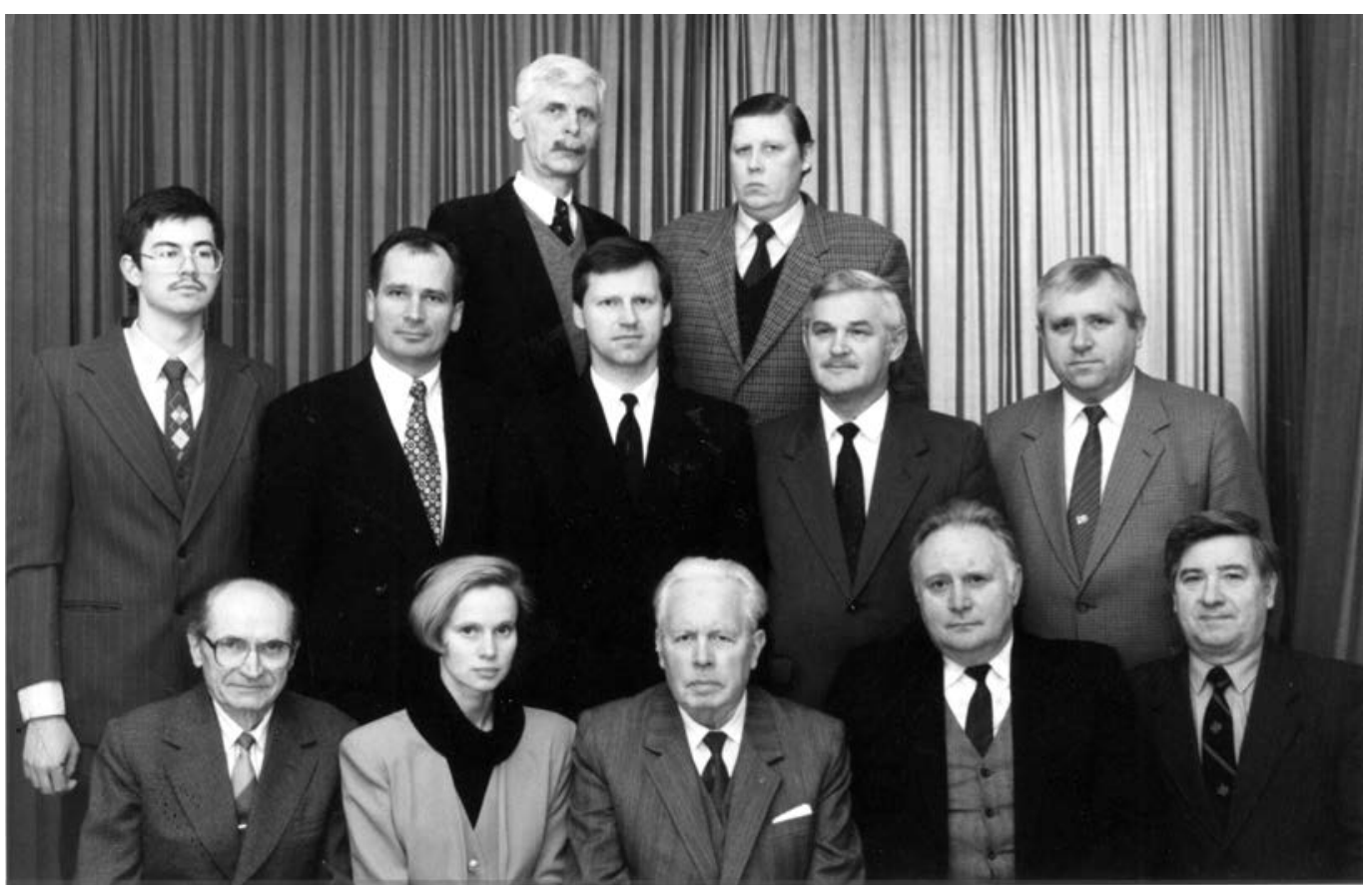




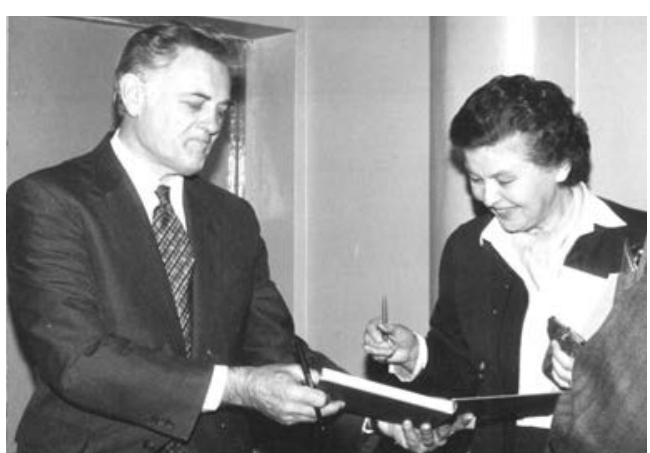

Staškevičius, o mokymo reikalų - doc. Alfonsas Daniūnas. Doc. Algirdas Valiulis patvirtintas prorektoriumi - rektoriaus pavaduotoju.

1994 m. Fundamentaliųjų mokslų fakultete, kuris buvo izurtas 1993 m. (dekanas A. Čiučelis), steigiamos inžinerinès informatikos ir bioinžinerijos specialybès.

Miestų inžinerijos fakultete įsteigiama nekilnojamojo turto vadybos specialybe. Visuose fakultetuose isteigta labai daug specializacijų, kurios pasirenkamos nuo trečio kurso.

I kuriamas Transporto fakultetas (dekanu išrenkamas prof. R. Žeromskas).

Lietuvos mokslų akademijos nariu korespondentu išrenkamas VTU rektorius habilituotas daktaras profesorius Edmundas Kazimieras Zavadskas. Vyriausybès telegramoje 19940316 rašoma: „Širdingai sveikinu Jus, išrinktą Lietuvos mokslų akademijos nariu korespondentu, ir linkiu naujų laimëjimų mokslo baruose garsinant mūsų šalies vardą. Respublikos prezidentas Algirdas Brazauskas“.

\section{Daugeja renginiu}

Suaktyvëjo Studentų sąjunga, kai VTU Studentu atstovybès prezidentu išrenkamas Elektronikos fakulteto studentas Mindaugas Kiznis, viceprezidentu - Miestų inžinerijos fakulteto studentas Darius Bazaras.

„Architektų dienos - 94" buvo ypatingos Vilniaus senamiesčio tvarkymo akcija. Tris dienas VTU ir VDA studentai kuopé, tvarke ir gražino prie pat bastèjos stūksantį bene prieš 15 metų apleistos mokyklos pastatą Subačiaus ir Strazdelio gatvių sankryžoje. Išvežta apie 70 tonų šiukšlių, su išmone ir humoru išdažytas pastato fasadas. Akcijos tikslas - priminti visuomenei ir valdžiai katastrofišką daugelio senamiesčio pastatų būklę.

1994 m. balandžio mèn. i VTU susirinkę įvairių sričių specialistai ịkūrè „Bičiulių klubą": steigiamojoje deklaracijoje teigiama, kad klubo nariai rems VTU vykdomą mokslo ir studiju pertvarką, pades aukštajai mokyklai. Prezidentu išrinktas Vincas Kaziela (Skrydžiu valdymo tarnybos techninis direktorius), viceprezidentais - Algimantas Gapšys („Precizikos“ generalinis direktorius), Jonas Jakimavičius (Statybininkų asociacijos generalinis direktorius), Gediminas Orentas (UAB „Ornaga“ prezidentas, Venesuelos lietuvis).

19940622 pasirašyta sutartis tarp VTU ir Varšuvos aukštosios gaisrininkų mokyklos. Numatyta bendradarbiauti gaisrinès saugos mokslinių tyrimy ir specialistų rengimo srityse.

1994 m. gegužès 26 d. įvyko naujai perrinkto Technikos universiteto rektoriaus, profesoriaus habilituoto daktaro, Mokslų akademijos nario korespondento Edmundo Zavadsko inauguracijos iškilmes. Tai buvo tikra švente. Iškilmèse dalyvavo daug svečiu iš užsienio ir Lietuvos. Pagerbiant VTU rektorių išreikštas ir viso VTU kolektyvo darbo ìvertinimas.

Sveikinimą prof. E. K. Zavadskui atsiunte Lietuvos Respublikos Prezidentas Algirdas Brazauskas. Inauguracijos proga rektoriu sveikino Lietuvos Respublikos Seimo nariai, aukštųjų mokyklų rektoriai, Lietuvos mokslų akademijos vadovai, ministeriju, organizacijų atstovai, užsienio svečiai, VTU profesoriai, destytojai ir studentai.

Per ketverius metus VTU nueitas kelias pristatytas 1994 metu gegužę išleista E K. Zavadsko publikacijų knyga: „Vilniaus technikos universitetas: praeitis, dabartis,

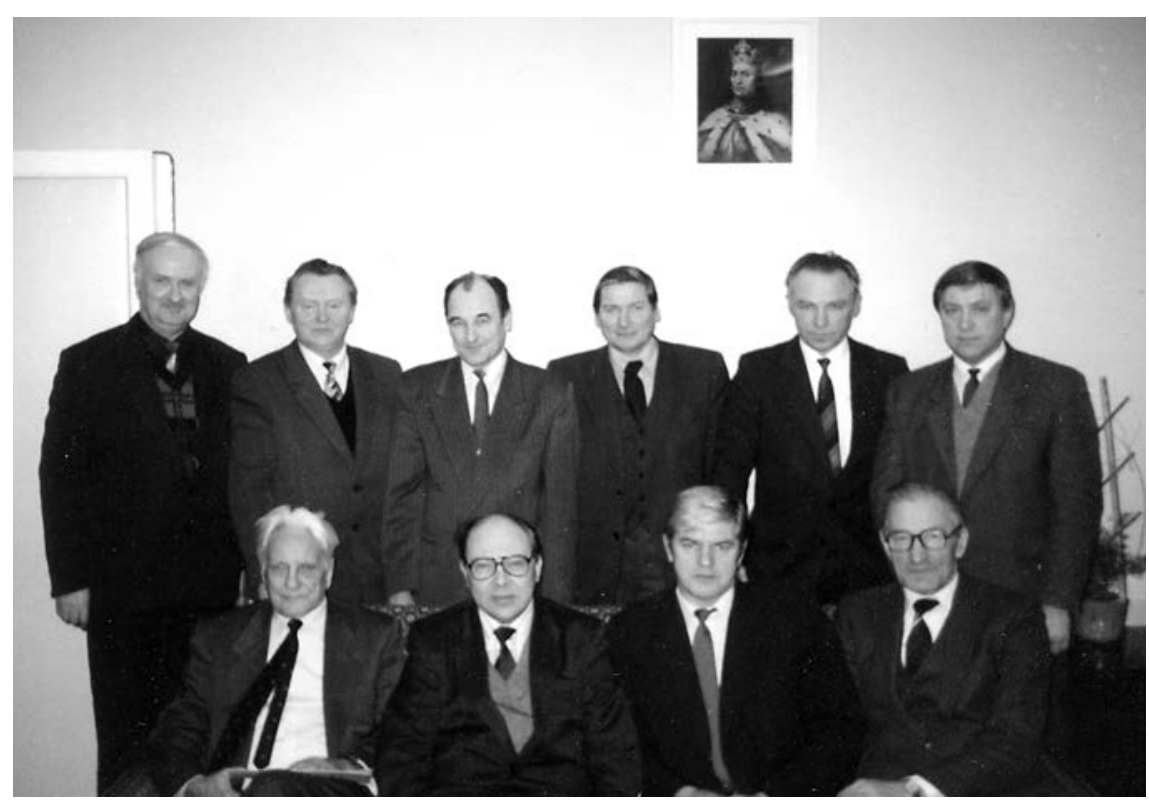

Kairëje -

V. Adamkus ir P. Didžiapetriené

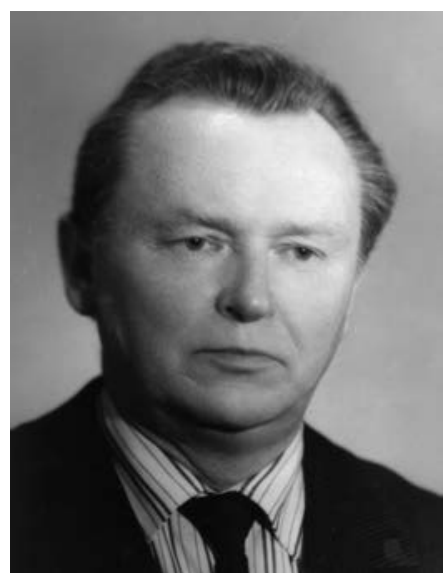

J. A. Staškevičius

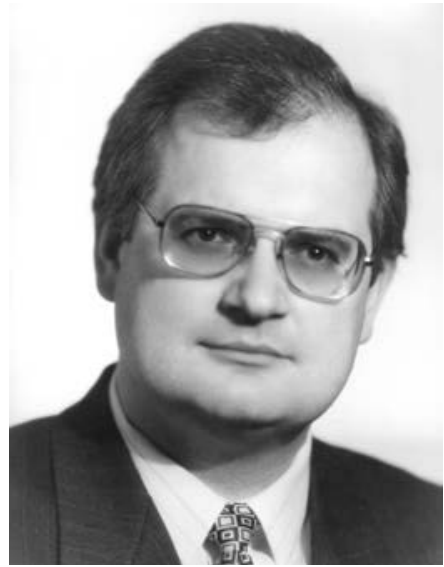

A. Daniūnas

\section{Bičiulių klubas}

Iš kairés ju dešine pirmoje eileje: G. Orentas, E. K. Zavadskas, V. Kaziela, G. Gapšys;

antroje eileje:

A. Nakas, J. A. Staškevičius,

P. Vainiūnas, J. Jakimavičius,

R. Kubilius, A. Valiulis 
VILNIAUS

TECHNIKOS

UNIVERSITETAS
通

ateitis". VTU istorijos muziejuje buvo įrengta E. K. Zavadsko spausdintu darbu ekspozicija, skirta jo gimimo 50-osioms metinèms.

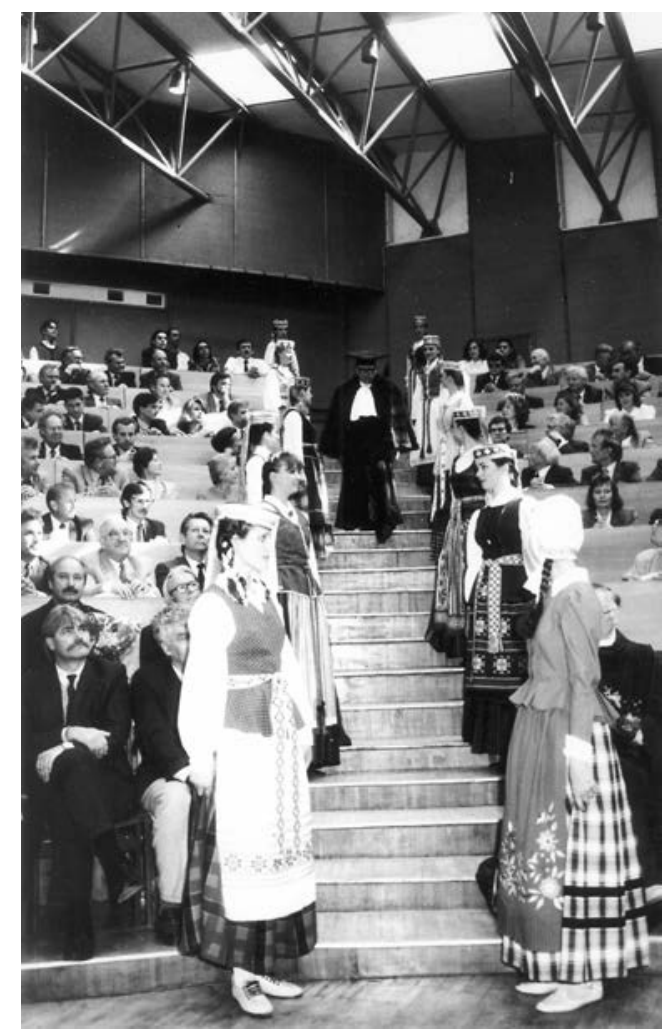

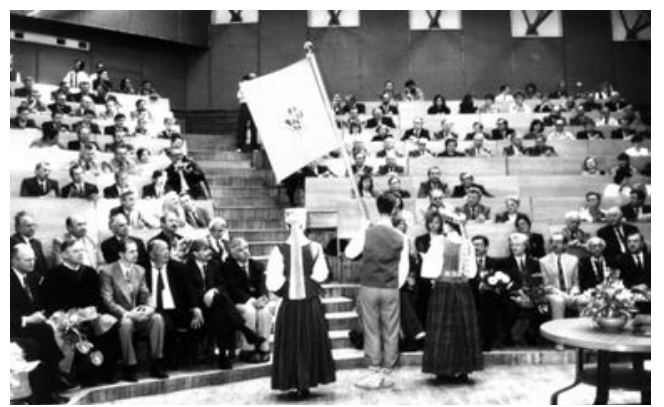

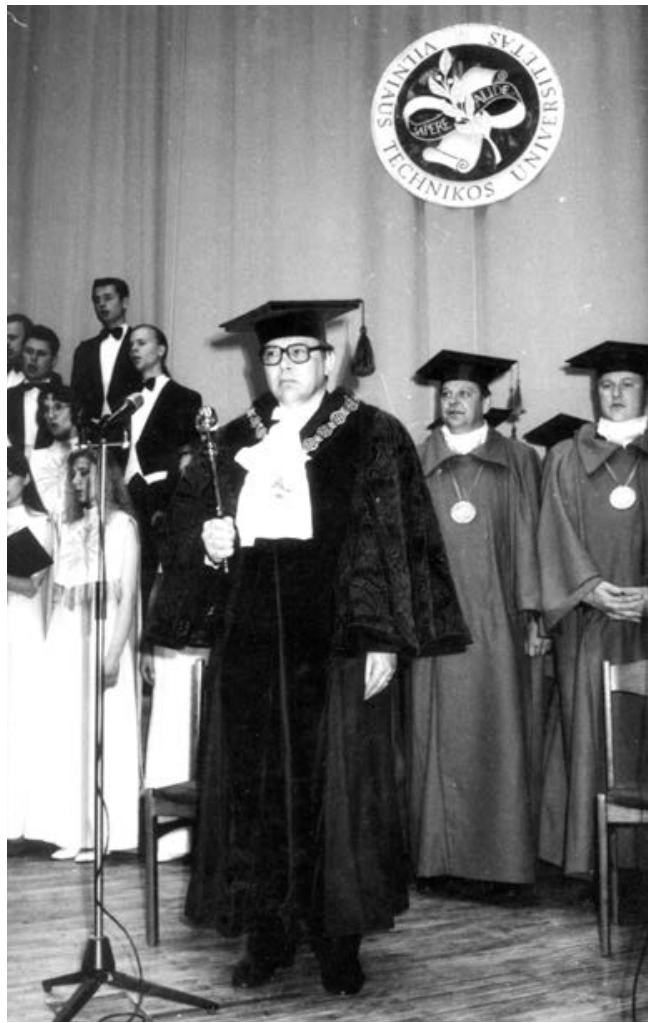

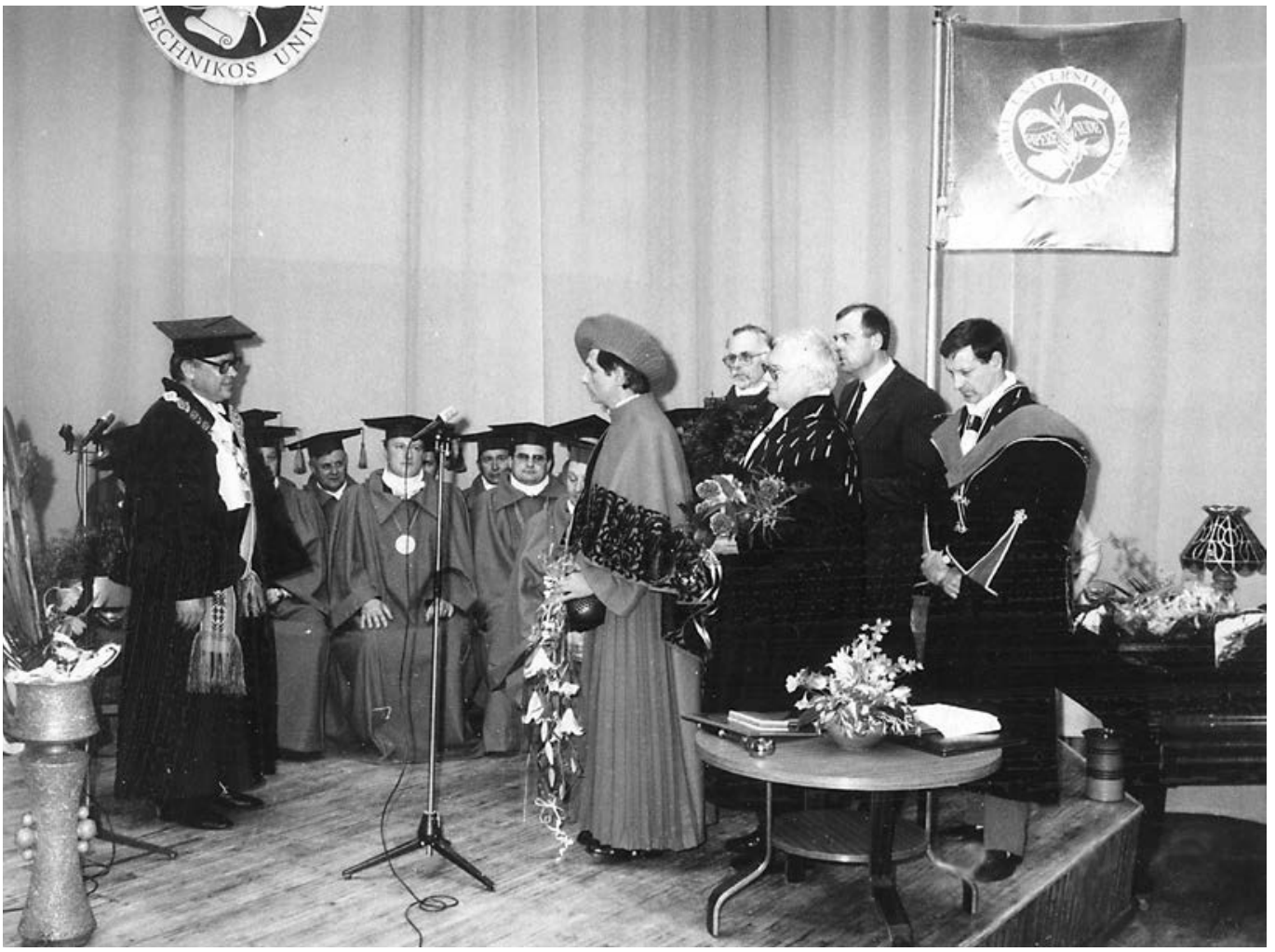




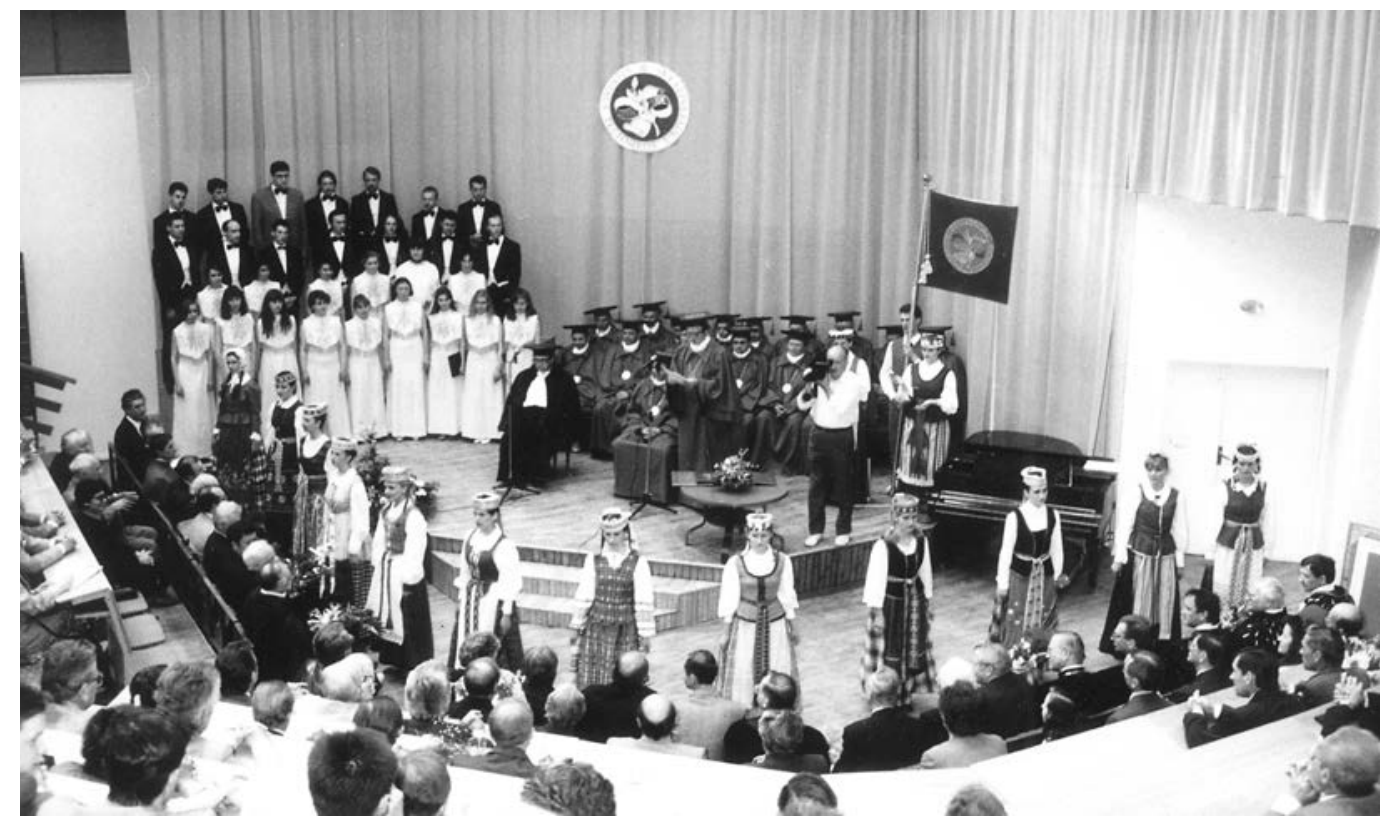

Rektoriaus inauguracijos proga VTU rektorato nariai pasipuoše togomis. Jas, VTU herbą, skeptrą ir vèliavą, sukūre dailininke Irena Vabalienè.
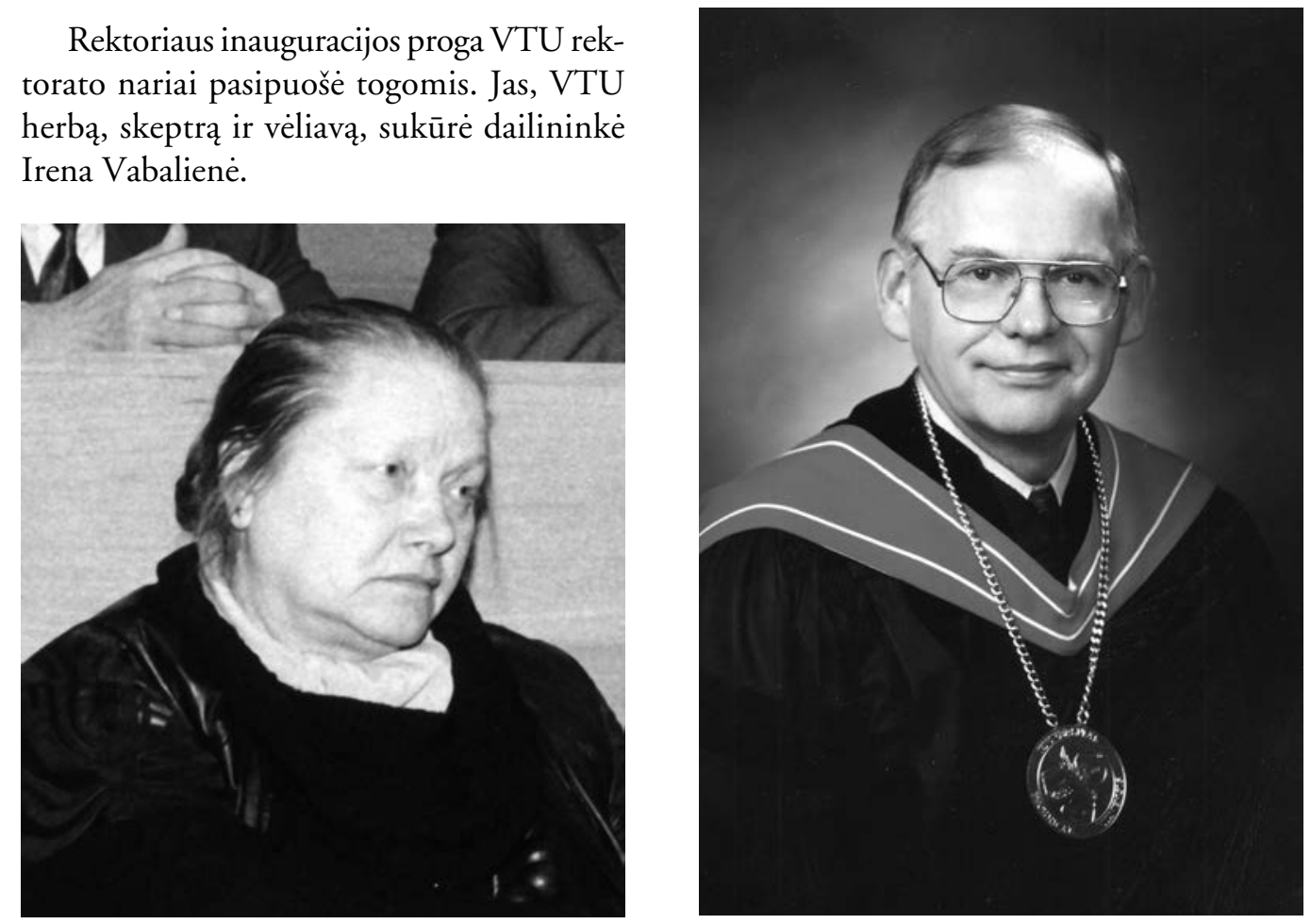

Išilmiu metu Garbes daktaro diplomas iteiktas New Jersey valstijos universiteto (JAV) profesoriui, habilituotam daktarui Valentinui Sernui-žymiam fizikui, šilumos mainu specialistui, labai padedančiam universitetui

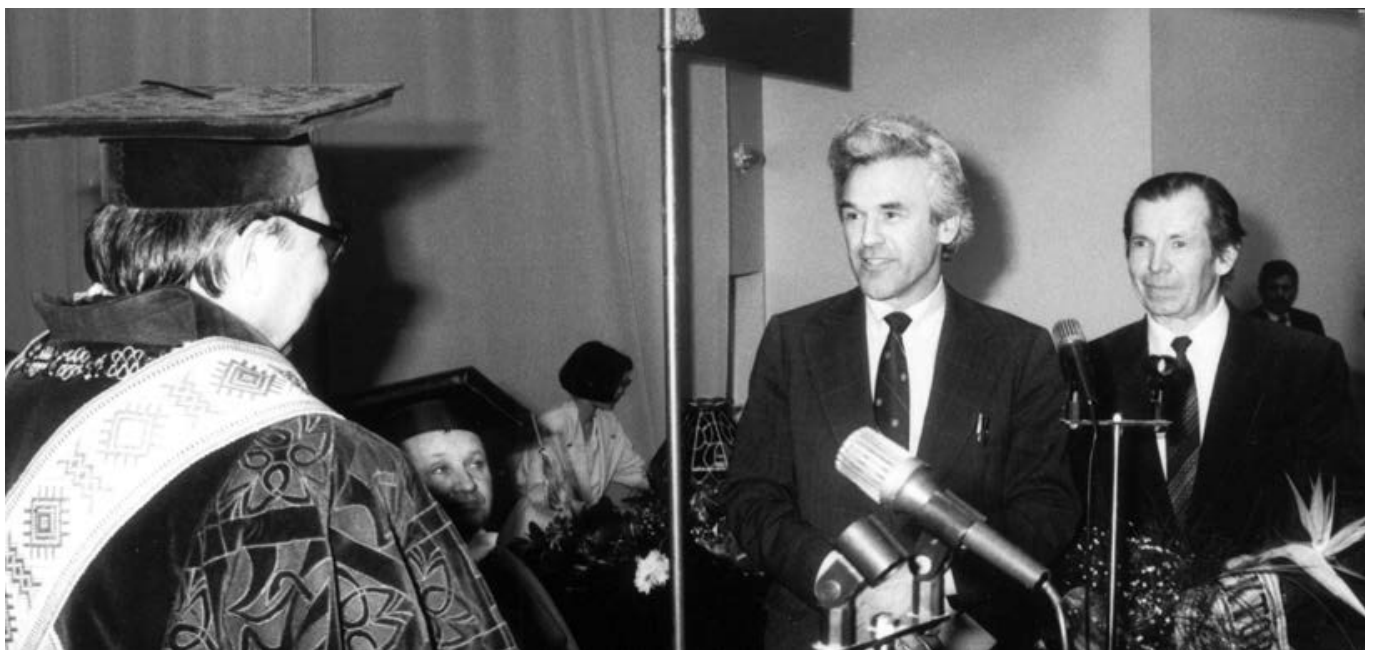


VILNIAUS

TECHNIKOS

UNIVERSITETAS
Viř̌uje dešinëje -

J. E. Lietuvos Respublikos Prezidentas Algirdas Brazauskas VTU Garbes daktaras
Reikšmingas VTU prestižo patvirtinimas $1994 \mathrm{~m}$. rugsejo mènesị atejo iš Lenkijos. Profesorius habilituotas daktaras, Lietuvos mokslų akademijos tikrasis narys Aleksandras Čyras buvo išrinktas Lenkijos mokslu akademijos užsienio nariu.

Rugsëjo 22-23 dienomis VTU Miestu inžinerijos fakultete vyko tarptautine mokslinè konferencija „Miesto inžinerija ir aplinka“.

Dar vienas šventinis renginys vyko 1994 m. spalio 21 d., kai VTU tarybos iškilmingame posedyje buvo įteiktas VTU Garbess daktaro diplomas Lietuvos Respublikos Prezidentui Algirdui Mykolui Brazauskui. Tai padaryta už didelius A. M. Brazausko nuopelnus statybos ir ekonomikos mokslui, Lietuvos aukštajam mokslui, Lietuvai, Vilniaus technikos universitetui.

Gera žinia atejo iš Australijos. Čia vykusiose II pasaulio meistrų žaidynèse, startavęs 45-49 metų amžiaus grupejje, VTU Medžiagu atsparumo katedros docentas Kęstutis Vislavičius laimèjo du medalius.

Lapkričio pradžioje Vilniaus technikos universitete apsilankęs JAV ambasadorius Lietuvoje J. Swichartas pažymëjo, kad „Lietuvos tikslas - prisijungti prie Europos, tapti Europos Sajungos nare. Tam reikia talenty ir labai aukšto lygio žiniu. Ir pasiekti tai nebus lengva: sunki ekonomine padetis, resursu trükumas. Tačiau mokslo ir technikos srityje galima

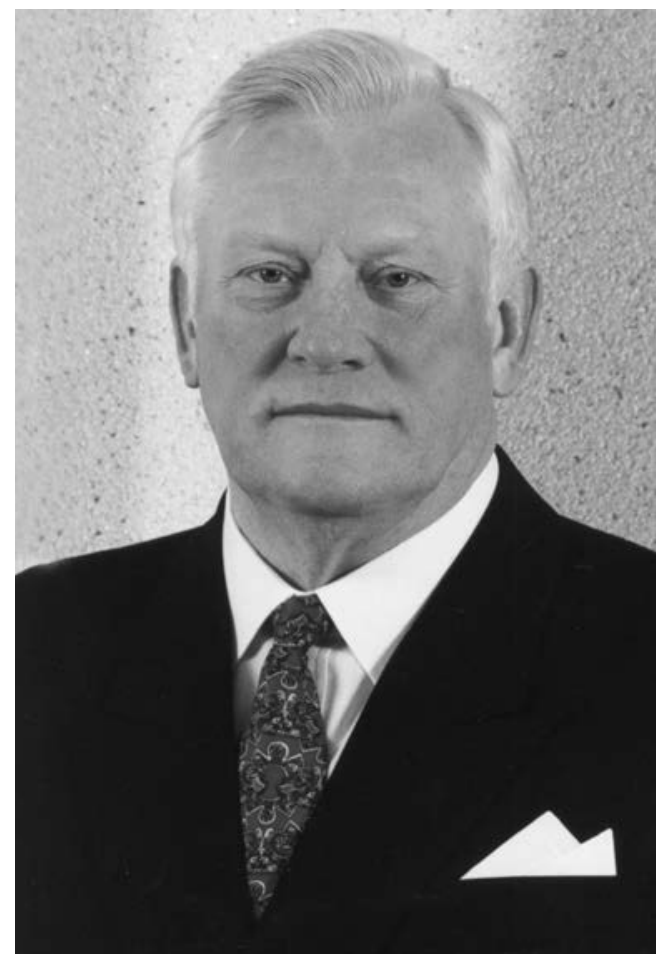

labai daug nuveikti, jeigu yra geru ir atsakingu darbuotoju“. Tokių darbuotojų rengimas Lietuvai - kilnus ir svarbiausias Vilniaus technikos universiteto uždavinys.

1994 m. spalio 14-16 d. vykusiame Pasauliniame inžinierių rengimo kongrese Kaire dalyvavo VTU rektorius E. K. Zavadskas. Jis skaite pranešimą „Studiju restruktūrizavimas Vilniaus technikos universitete". Ilgainiui jis buvo paskirtas dirbti tarptautiniame patareju komitete, kuris turëjo organizuoti identišką kongresą JAV, Minesotos universitete.

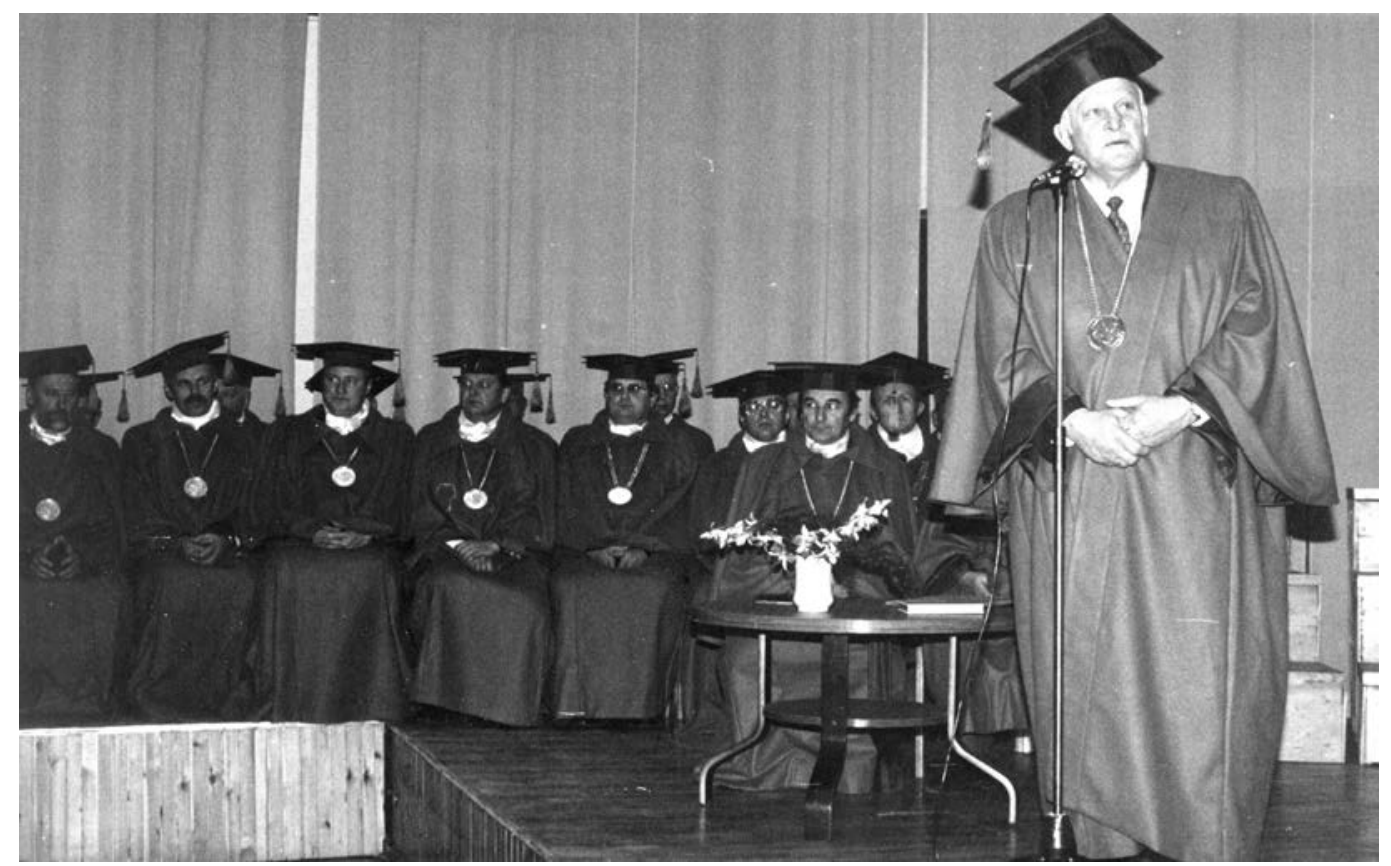


1994 m. buvo nutarta pakeisti Miestų inžinerijos fakulteto pavadinimą ir vadinti ji Aplinkos inžinerijos fakultetu.

VTU istorijos muziejuje kelis menesius veike izžymių inžinierių lietuvių veiklos paroda: Jurgio Gimbuto (JAV) ir Juozo Danio (Kanada). Su jais užsimezgè gražūs bendradarbiavimo ryšiai. Ilgainiui žymaus hidrotechniko J. Danio-Daniliausko darbu parodą VTU surenge Lietuvos architektūros muziejuje, o dar vèliau - Klaipèdos jūrų muziejuje.

Tais metais habilituotais daktarais tapo Algimantas Miškinis (Architektūros katedra), Eduardas Kirjackis (Matematikos katedra) ir Rimantas Belevičius (Teorinès mechanikos katedra).

1994 m. gruodžio 15 d. VTU ir Lietuvos karo akademija pasiraše bendradarbiavimo sutarti. Numatyta bendrai naudotis turimomis techninemis priemonemis, laboratorijomis, bazemis, keistis literatūra.

\section{Pagal studentų skaičiu VTU - trečias}

1995 m. sausio $27 \mathrm{~d}$. bendradarbiavimo sutartis pasirašyta tarp VTU ir Lietuvos policijos akademijos. Pasirašant sutartị dalyvavęs Seimo narys J. Tartilas pažymejo, kad „kai $d u$ žmones vienas kitam paduoda rankas, jie stipresni negu du“.

Dažnai VTU lankosi Vokietijos ambasadorius Lietuvoje Reihartas Krausas. 19950118 atvykęs į Technikos universitetą kartu su VFR piliečiu baronu Rolandu fon Grotusu, R. Krausas kalbëjo apie Lietuvos integracijos į Europos ekonomiką būtinybę, apie bendradarbiavimo formas.

$1995 \mathrm{~m}$. sausio $20 \mathrm{~d}$. pasaulinio garso mokslininko Teodoro Grotuso vaikaičiai viešejo VTU Architektūros fakultete. Teodoro tevai kilę iš Lietuvos. Rolandas ir Harri Grotusai, kompiuterines įrangos verslininkai, atvežè ir padovanojo VTU Architektūros fakultetui modernų kompiuterí, skirtą architektūros projektams rengti. Kartu su kompiuteriu izžymiojo Teodoro Grotuso (1795-1822) septintosios kartos vaikaičiai padovanojo ir tobuliausią Vokietijoje architektūrinio projektavimo programą.

Architektūros fakultete surengtose iškilmese dalyvavo ir Lietuvos mokslų akademijos prezidentas Benediktas Juodka.

Abiturientams skirtame „Inžinerijos“ laikraštyje rektorius $\mathrm{E}$. K. Zavadskas pažymëjo, kad pagal studentų skaičių VTU yra trečioji Lietuvos aukštoji mokykla. Tik VTU rengia lakūnus, skrydžių valdymo specialistus, priešgaisrinès saugos inžinierius, automobilių transporto ir geležinkelių transporto inžinierius, geodezininkus.

19950208 Lietuvos Vyriausybès nutarimu VTU Aviacijos institutui perduotas buvęs Lietuvos avialiniju administracinis pastatas (Rodūnios kelias 8). Metu pabaigoje iškilmingai atidengta šių, pavadintų Penktaisiais, VTU rūmais iškaba.

1995 m. pradžioje VTU mokèsi 4020 studentų. VTU galima tapti bakalauru, o dar po vienerių studiju metų - igyti diplomuoto inžinieriaus kvalifikaciją arba tęsti studijas magistrantūroje bei igyti inžinieriaus magistro laipsni, o dar vèliau studijuoti doktorantūroje ir ginti mokslų daktaro disertaciją.

$1995 \mathrm{~m}$. VTU praturtejo patalpomis ir kitose Vilniaus vietose: Naugarduko gatvëje ìsikūre Elektronikos fakultetas ir Plytinès gatvëje - Transorto inžinerijos fakultetas. 1995 m. vasario mènesị sužinota, kad 1994 metų Lietuvos Respublikos mokslo premija paskirta VTU profesoriui habilituotam daktarui Pranui Baltrenui už darbus oro užterštumo dulkèmis mažinimo klausimu.

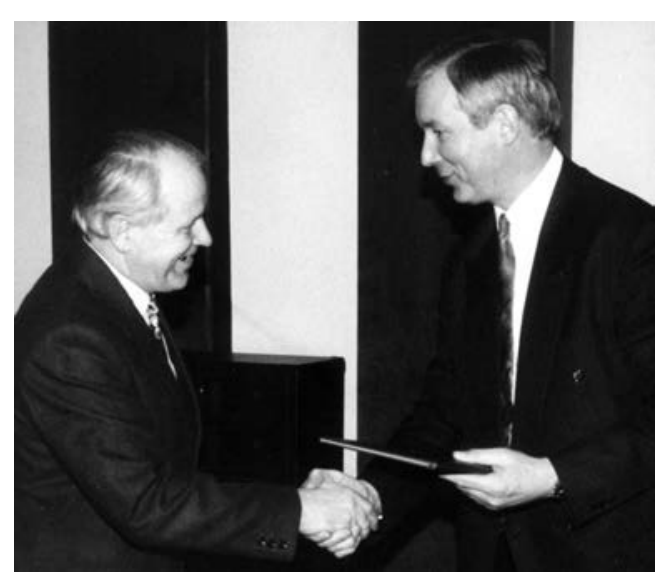

Tą patị mènesį prasidëjo mokslinè konferencija "Lietuvos mokslas ir pramone“", kurią organizavo Kauno technologijos universitetas. Šioje konferencijoje, kuri vyksta kasmet, buvo numatyta „ivertinti mokslo ir pramonés bükle Lietuvoje, aptarti büdus, kaip moksliniu tyrimu rezultatus ir jais remiantis sukurtas naujas technologijas greičian idiegti i pramone, apsvarstyti konkrečiu mokslo krypčiu naujausiu tyrimu rezultatus, taip pat panagrineti specialistu rengimo problemas bei mokslo ir studiju instituciju galimybes integruotis i ekonomikos pletojimo procesa" (iš spaudos konferencijos).

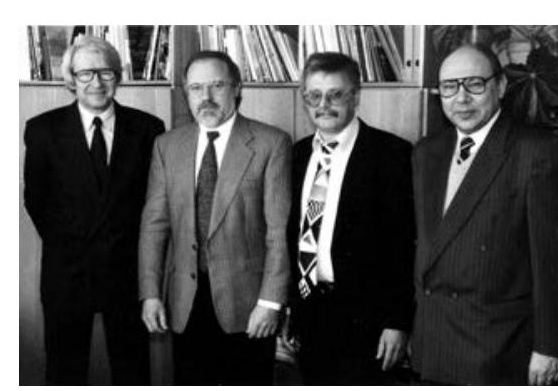

LMA prezidentas B. Juodka ir rektorius E. K. Zavadskas su T. Grotuso vaikaičiais

Premjeras A. Šleževičius iteikia premiją P. Baltrenui

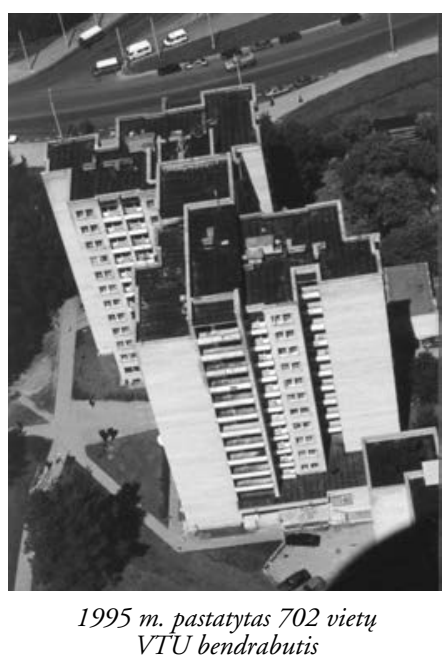


VILNIAUS

TECHNIKOS

UNIVERSITETAS

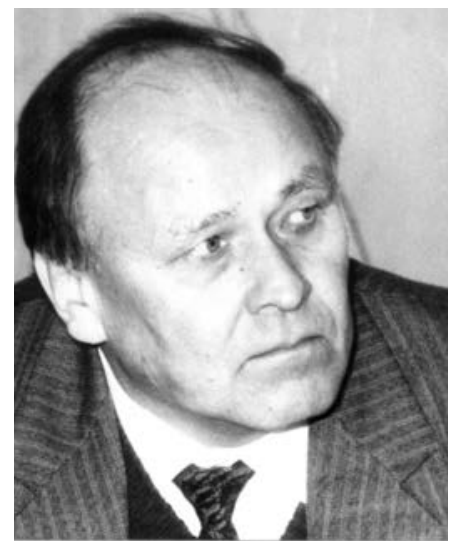

A. Ciučelis

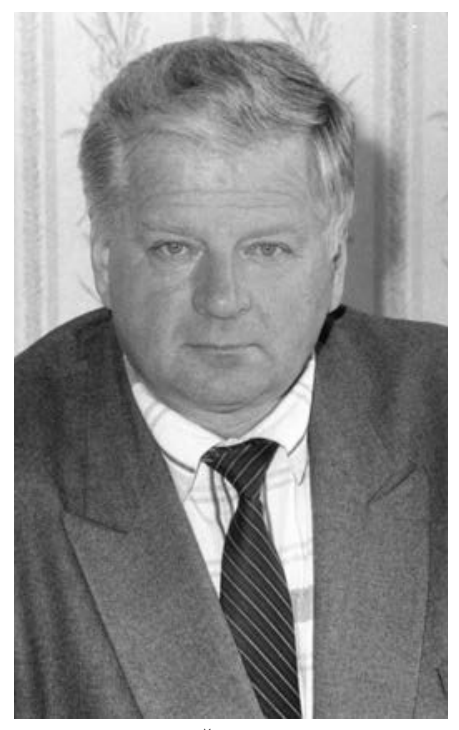

R. Žeromskas
Reikšminga Vilniaus technikos universitetui buvo trijų Lietuvos universitetu atlikta VTU daktaro disertacijas gynusių užsieniečiu vadybos mokslo srityje darbų ekspertizè. Visos 6 pateiktos disertacijos pripažintos atitinkančios daktaro disertaciju reikalavimus, drauge paneigtos abejonés dèl VTU kompetencijos.

Balandžio mènesi prie VTU Darbo ir gaisriness saugos katedros pradejo veikti Žmonių saugos mokslo institutas. Jame vykdomi darbai turi padèti išaiškinti traumų, ligų, gaisrų ir avariju priežastį bei numatyti reikalingas profilaktikos priemones. Rengiami norminiai aktai, taisyklès, instrukcijos ir kiti darbų saugos srities dokumentai.

VTU Geodezijos katedros specialistai, nuo 1995 m. pavasario kartu su Norvegijos firma „Fjel-langer Wideroe“, Projektavimo ir restauravimo institutu ir kt. pradejo kurti Vilniaus kompiuterizuotą geoinformacinę sistemą.

1995 m. studentų darbų konkurso Vašingtone 3-ioji premija teko VTU Architektūros fakulteto magistrui Algimantui Pliučui.

Gegužès 2-3 d. Verslo vadybos fakultete vyko tarptautine konferencija „Verslas ir vadyba 95“, o 10-13 d. - „Naujos statybinès medžiagos, konstrukcijos ir technologijos". Pastarojoje dalyvavo 264 mokslininkai, 68 - iš 18 užsienio šalių. Šioje konferencijoje pirmą kartą Lietuvos istorijoje buvo skaitomi pranešimai gaisrines saugos sekcijoje. Aviacijos institute vyko mokslinè konferencija „Aviacijos plètra Lietuvoje“, Elektronikos fakultete - „Elektroniniai informacijos keitikliai“.

Gegužès mènesį VTU gavo Anglijos vyriausybes ir britų korporacijos dovaną - metodinès medžiagos rinkini. Tai 202 paskaitu konspektai, 2100 schemų ir brèžinių, 1000 skaidrių, 21 vaizdo kasete, kelios mokomosios kompiuteriu programos. Ši metodinè medžiaga padès sueuropinti konstruktorių, gamintojų ir statytojų rengimo procesą.

Gegužè 25 dieną ivyko iškilmingas VTU tarybos posedis, kuriame paminèta data, kai prieš penkerius metus VISI mokslo taryba nutare reorganizuoti VISI ị VTU. Šventini pranešimą perskaite rektorius E. K. Zavadskas, dalyvavo daug garbingų svečių.

Aplinkosaugos klausimams geriau spręsti sudaryta ir 19950425 pasirašyta bendradar- biavimo sutartis tarp Lietuvos Respublikos aplinkos apsaugos ministerijos ir VTU. Kiek veliau šioje srityje nutarta bendradarbiauti ir pasirašyta sutartis su Voronežo technologijos akademija (Rusija).

Birželio $7 \mathrm{~d}$. vykusioje mokslinëje konferencijoje „Lietuvos transportas“ dalyvavo 154 transporto specialistai, valdžios atstovai.

1995 m. birželį diplomų VTU absolventams įteikimo ceremonijoje dalyvavo Lietuvos Respublikos Prezidentas Algirdas Brazauskas. Jis įteike diplomus geriausiems magistrams. 1995 m. VTU išleido jau ketvirtają magistrų laidą, kurią sudaro 91 magistras. 1995 m. VTU suteike 437 bakalauro ir 302 inžinieriaus diplomus. Per 5 metus VTU parenge 199 magistrus.

Lietuvai reikšminga tai, kad VTU Aviacijos institutas $1995 \mathrm{~m}$. išleido pirmuosius 25 diplomuotus inžinierius, 15 bakalaurų. Statybos fakultetas išleido pirmuosius 19 gaisrinès saugos inžinerijos bakalaurų.

Nuo 1956 iki 1995 m. Vilniaus aukštoji technikos mokykla išleido 24433 inžinerijos specialistus: KPI Vilniaus filialas - 1945 , VISI - 18023 ir VTU - 4465.

VTU rektorato patalpose buvo atidaryta architekto Alfonso Keturkos akvarelių paroda ir, deja, jai dar tebeveikiant parodos autoriaus netekome. A. Keturka (1919-1995) beveik 50 metų dirbo pedagogini architektų rengimo darbą, suprojektavo keletą pastatų, statinių. Vis delto ryškiausias jo darbų pedsakas lieka gausiose nuostabaus grožio akvarelèse.

Aplinkos apsaugos katedra sulaukè vertingos labdaros iš JAV aplinkos apsaugos agentūros. Ją suorganizavo tautietis Vacys Šaulys. Siuntoje buvo 350 mokslinių leidinių, ivvairių tarptautinių organizacijų leidžiamų biuletenių ir kt. literatūros.

19950724 iškilmingai atidarytas 702 vietų naujai pastatytas VTU bendrabutis. Šešerius metus (!) trukusi bendrabučio statyba buvo baigta 5-ųjų pasaulio lietuvių žaidynių išvakarese. Tarp šių žaidynių dalyvių buvo ir keletas VTU sporto veteranų.

\section{Antraji universitetini penkmeti pradedant}

Nuo 1995-1996 mokslo metu pradžios Vilniaus technikos universitete pradèjo veikti Transporto specialistų mokymo centras. Jis įsteigtas VTU drauge su Lietuvos susisiekimo ministerija ir Švedijos kompanija 
„ASG Transport Development AB/Swede

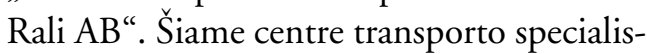
tai mokomi profesionaliai dirbti transporto rinkoje, jis turi konsultuoti vyriausybès institucijas, rengiančias su transportu susijusius įstatymus bei plètojančias veiksmingą transporto infrastruktūrą.

1995 m. rugsejji buvo apžvelgtas VTU treju metu darbas vykdant TEMPUS programą. 22 desstytojai tobulinosi Danijos, Anglijos ir Ispanijos aukštosiose mokyklose. 60 studentu 3-4 menesius studijavo Horsense, Glamorgane ir Valensijoje. VTU igijo kompiuterinès įrangos, įvairiu programų, matavimo prietaisų beveik už 120 tūkst. ECU.

1000 doleriu ižymaus JAV architekto J. Muloko (1907-1983) premija paskirta VTU Architektūros fakulteto diplomantei Astai Petrauskaitei (vadovas J. Anuškevičius).

19950729 aviacijos šventes metu VTU Aviacijos institutui mokymo tikslams aviacijos kompanija „AVIA BALTIKA“ padovanojo sraigtasparni MI-2.

Rugsejo 17-22 d. VTU rektorius E. K. Zavadskas su Lietuvos vyriausybine delegacija, vadovaujama Lietuvos Prezidento Algirdo Brazausko, lankesi Rumunijoje ir Turkijoje.

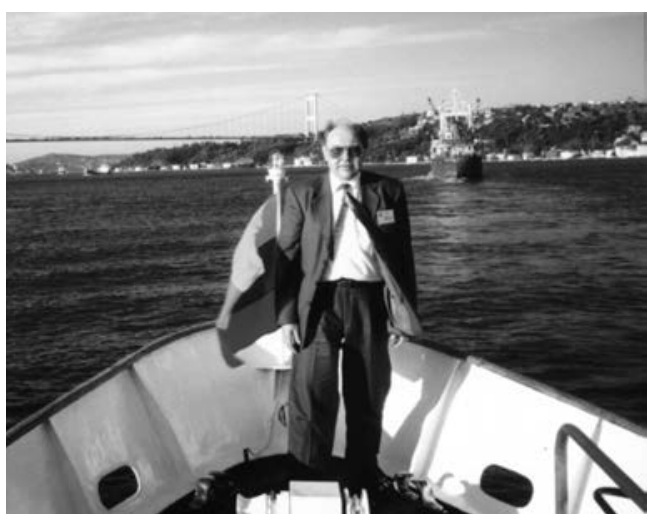

Spalio 4-5 d. VTU kartu su Lietuvos geotechnikos draugija surengè tarptautinę mokslinę konferenciją.

Spalio $31 \mathrm{~d}$. Nacionalineje filharmonijoje iškilmingai pamineta VTU penkeriu metų sukaktis. 1990 m. spalio $31 \mathrm{~d}$. Lietuvos Aukščiausiosios Tarybos pirmininkas Vytautas Landsbergis pasiraše dokumentą, kuriuo VISI buvo suteiktas universiteto statusas. Minejjime dalyvavo Lietuvos Prezidentas A. Brazauskas, daug Vyriausybès narių, aukštųjų mokyklų rektoriai, VTU bičiuliai.

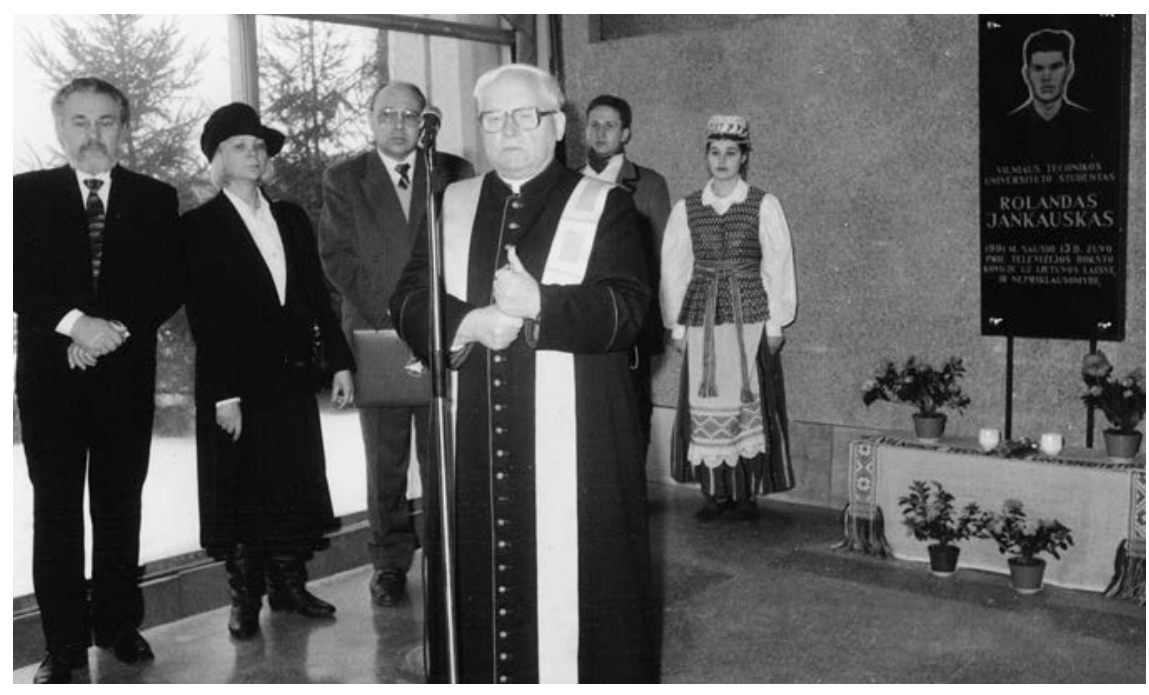

R. Jankausko memorialines lentos atidengimas

Gruodžio 4-5 d. VTU buvo vienas iš tarptautinès konferencijos „Baltijos jūros regiono vizija bei strategija 2010-iesiems metams ir jo reikšmè Centrinei ir Rytų Europai“" organizatorių.

1995 m. gruodžio pabaigoje iš Švedijos buvo pargabenta ir Vilniaus aerouosto teritorijoje sumontuota diferencine kosminè navigacine stotis. Ja naudojasi Geteborgo Shalmerso universitetas, VTU Aviacijos institutas ir VTU Geodezijos katedra, vykdydami geodezinius žemés plutos stebejimus, jai padedant tikslinamos navigacijos sistemoje naudojamos koordinates. Taigi ji labai pravers ir lekktuvų skrydžiu patikimumui didinti, garantuoti lèktuvų nusileidimo saugumą.

1995 m. habilituoto daktaro mokslini laipsnị gavo Raimondas Kirvaitis (Radioelektronikos katedra) ir Jonas Stankūnas (Aviacijos institutas).

1996 metus Vilniaus technikos universitetas pradejo nors ir su dideliais finansiniais sunkumais, bet pakiliai ir optimistiškai. Sustiprëjo VTU pozicijos Lietuvos mokslo taryboje. Jos nariais yra VTU profesoriai habilituoti daktarai E. K. Zavadskas, P. Baltrenas, R. Žeromskas ir I. Z. Kamaitis. Mokslų akademijos nariai ekspertai yra VTU profesoriai habilituoti daktarai A. Baublys, A. J. Staškevičius ir I. Z. Kamaitis.

Technikos universitetas leidžia vis daugiau monografijų, vadovèlių, labai padaugejo specialybių ir specializacijų. VTU absolventų diplomai pripažįstami Baltijos ir arabų valstybèse. Gerai vertinami VTU baigę specialistai ir Lietuvoje.

1996 m. sausio 13 d. VTU Centrinių rūmų vestibiulyje buvo atidengta memorialinè lenta (dailininkas Stanislovas Jagminas)

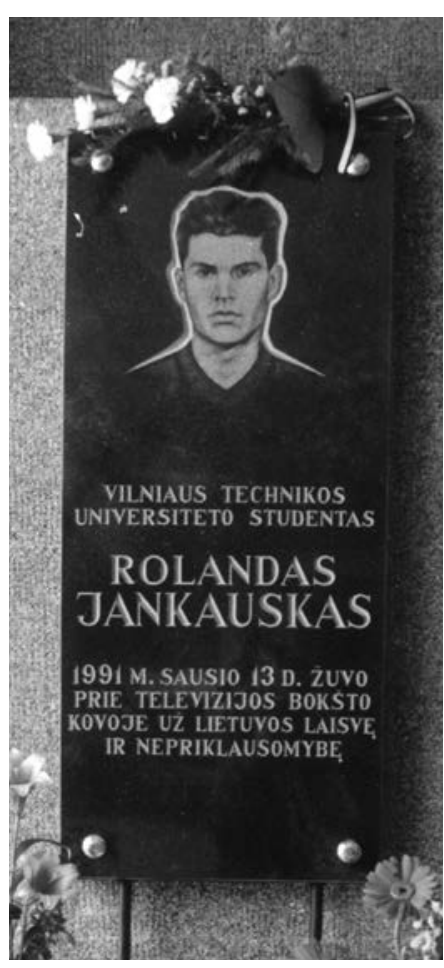

R. Jankauskui atminti 
VILNIAUS

TECHNIKOS

UNIVERSITETAS vimu ir 05 auditorijoje surinko pavyzdinị lango stendą. $\breve{S} \mathfrak{i}$ stendą firmos atstovai padovanojo Technikos universitetui.

Tą patị kovo ménesí, pakeliui į Bolo-

buvusiam technikos universiteto studentui Rolandui Jankauskui, tragiškai žuvusiam prieš penkerius metus prie Vilniaus televizijos bokšto. Iškilmėse kalbèjo Seimo deputatas J. Tartilas, monsinjoras K. Vasiliauskas, rektorius E. K. Zavadskas ir kt. Dalyvavo ir R. Jankausko tèvai.

1996 m. vasario 7 d. VTU Mechanikos fakultete aktų saleje vykusiame renginyje dalyvavo V. Landsbergis.

Vasario ménesị VTU ịvyko jau antroji, tapusi tradicine, proto muge „Intelektas 96“. Tokiose mugese įvairių firmų atstovai, tiesiogiai bendraudami su diplomantais ir studentais, ieško inžinerijos ir verslo vadybos specialistų, kurie, baigę savo studijas, ateitų dirbti i firmą. $1996 \mathrm{~m}$. mugeje dalyvavo 14 firmų ir 120 studentų. Mugeje didžiausio pasisekimo sulauke jaunuoliai, gerai mokantys užsienio kalbą bei išmanantys darbą kompiuteriais.

19960209 Paryžiuje Serži Pontua (Cergy-Pontoise) universiteto administracinès tarybos pirmininkas B. Rultas ir VTU rektorius E. K. Zavadskas pasirašè bendradarbiavimo sutartị. Joje numatyta bendrai analizuoti oro taršos, miesto transporto, energijos taupymo, vandenų valymo, betono ilgaamžiškumo, kompiuterinio projektavimo metodikos bei kitas temas. Bus keičiamasi studentais, destytojais. Šiame bendradarbiavime labai svari organizacine Aplinkos inžinerijos fakulteto docento daktaro Vytauto Martinaičio veikla.

Jau metų pradžia buvo gera mokslininkams. Vytautas Giniotis (Skrydžių valdymo katedra) ir Vladislava Stankūnienè (Verslo ekonomikos katedra) tapo habilituotais daktarais.

19960223 VTU rektorius E. K. Zavadskas „Respublikos“ dienraštyje paskelbe straipsni „Ar reikia mažinti inžinierių rengimą?", kuriame įtikinamai parodé, kad techninè ir drauge ekonomine pažanga Lietuvoje daug priklauso nuo inžinierių darbo, kad inžinierių rengimo skaičiaus jokiu būdu negalima mažinti, kad būtina kurti naujas, turinčias perspektyvą ir paklausias inžinerines specialybes.

19960327 Danijos firmos „VELUX International A/S" atstovai surenge seminarą VTU, kuriame supažindino su moderniomis stogo langu konstrukcijomis bei jų monta- nijos universitetą, Romoje lankesi VTU prorektoriai A. J. Staškevičius, A. Valiulis ir Aviacijos instituto direktorius J. Stankūnas. Ten jie susitiko su prelatu Algimantu Bartkumi, kuriam įteike VTU padekos raštą ir juostą už demesį Technikos universiteto studentams.

1996 m. balandžio 2-4 d. studiju prorektorius A. Daniūnas ir TSC direktoriaus pavaduotojas A. Rimkevičius dalyvavo Azijos šalių būsimųjų studentų mugeje Pakistano sostinëje Karačyje. Šioje mugëje visas dienas per TV buvo rodomas filmas apie VTU, stenduose skelbiama informacija apie Technikos universitetą, priemimo ị ji sąlygas, specialybes. VTU ekspozicija, papuošta Lietuvos trispalve, sulauke didelio demesio.

199605 16 VTU rektorius E. K. Zavadskas bei Metalinių ir medinių konstrukcijų katedros vedëjas A. Kvedaras lankèsi Didžiosios Britanijos plieno konstrukcijų institute. Be to, lietuviai aplanke prestižinị Sario universitetą, kurio rektorius profesorius Patrikas Dowlingas labai palankus VTU, remia literatūra, priima stažuotojus, linkęs plèsti ryšius su Technikos universitetu.

1996 m. gegužès 23-25 d. Vilniaus technikos universitete vyko Europos inžinierių rengimo asociacijos (SEFI) seminaras praktiniams igūdžiams formuoti ir ugdyti. Tokie seminarai anksčiau vyko Stokholme, Berlyne, Notingeme, Miškolce, Kopenhagoje ir kt., o 1997 m. vyks Norvegijoje. Seminaro surengimas Vilniuje rodo, kad VTU yra aukštai kotiruojamas Europoje.

19960528 iš Monrealio į Vilnių atskrido du sportiniai lèktuvai „Cesna-172“. Jie gražiai papilde VTU Aviacijos instituto skrydžiu praktikų bazès jau anksčiau igytų 6 lèktuvų ir 1 sraigtasparnio eskadrilę.

Tą pačią dieną „Lietuvos"viešbučio konferencijų salëje vyko tarptautinè konferencija „Kelių eismo saugumas ir aplinkos apsauga“. Ją surengè VTU ir Varšuvos automobilių transporto institutas. 


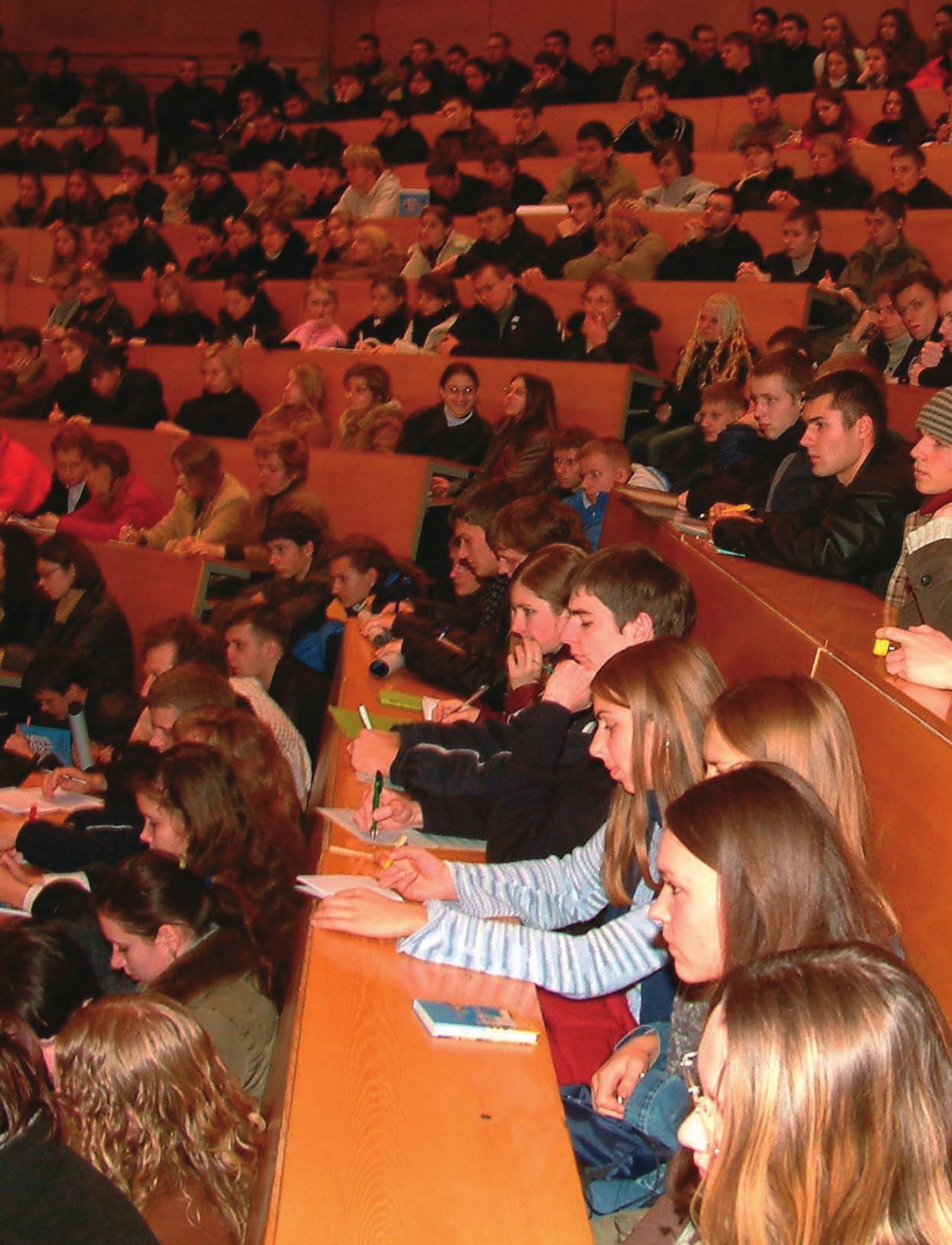






\title{
VILNIAUS
}

\section{GEDIMINO TECHNIKOS}

\section{UNIVERSITETAS}

\author{
Lietuvos Didžiojo kunigaikščio Gedimino vardas - Vilniaus technikos \\ universitetui
}

Lietuvos Respublikos Vyriausybès nutarimu (1996 m. rugpjūčio 21 d. Nr. 991) Vilniaus technikos universitetui suteiktas Lietuvos Didžiojo kunigaikščio Gedimino vardas.

Dar tarpukario laikotarpiu, kai buvo ketinama steigti Politechnikos institutą, Lietuvos inžinierių draugija siūle „suteikti jam Didžiojo Lietuvos kunigaikščio Gedimino, pirmojo Lietuvos miestų statytojo ir amatu įkūrëjo Lietuvoje, vardą". Lietuvai 1939 m. atgavus savąją sostinę, buvo minčių steigti Politechnikos institutą Vilniuje, bet krašto sovietine okupacija neleido to padaryti.

Atsižvelgiant ị praeityje išreikštus visuomenès lūkesčius, Vilniaus technikos universitetas kreipési i Vyriausybę dèl Lietuvos Didžiojo kunigaikščio Gedimino vardo suteikimo šiai aukštajai mokyklai.

VTU nuopelnai mokslui neabejotini. Čia buvo rengiami humanitarinių, socialinių, tiksliųjų, gamtos ir technikos mokslų - iš viso 21 specialybès bakalaurai arba inžinieriai. Technikos universitetas taip pat renge daugelio technikos sričių magistrus, 12-os mokslo krypčių daktarus: čia buvo apginti 9 mokslo krypčių habilituoto daktaro darbai.

1996 m. rugsëjo 3 d. 16 val. Lietuvos nacionalinëje filharmonijoje įvyko naujujuc mokslo metų atidarymas ir iškilmingas aukštosios technikos mokyklos Vilniuje - Vilniaus Gedimino technikos universiteto keturiasdešimties metu jubiliejaus minejjimas.

VTU bendruomenę ta proga pasveikino rektorius prof. E. K. Zavadskas, kurio iniciatyva ir pastangomis buvo įkurtas Vilniaus technikos universitetas. Jo pasiūlymu VTU buvo suteiktas garbingas ir ipareigojantis LDK Gedimino vardas. Rektorius savo sveikinime raše:

"Džiaugiuosi, galedamas šiais metais pasveikinti Jus su neeiliniais, naujais 1996-1997 mokslo metais. Juk šie metai mūsu aukśtajai mokyklai-jau 40-ieji, jubiliejiniai. Turime garbingus Universiteto ir Gedimino vardus, kurinos iškovojome tik visos müsu aukštosios mokyklos bendrijos pastangomis - destytoju, darbuotoju, studentu pasiaukojamu ir sažiningu darbu, nepaliaujamu žiniu ir geroves mūsu universitetui siekimu.

Šiais metasi gausus mūsu universiteto studentu būrys pasipilde gabiais, žiniu ištroškusiais jaunuoliais ir merginomis. Viliuosi, jog jie isilies $\dot{z}$ mūsu universiteto bendrijos gretas, garsindami universiteta ne tik geru mokymusi, bet ir moksline išradybine veikla, sportiniais ar meniniu saviveiklos kolektyvu laimëmais. Linkiu Jums, brangūs studentai, maloniu studiju metu, o Jums, mieli profesoriai ir destytojai - ištvermès ir geranoriškumo, lydint jaunaja karta mokslo pasaulio link..." [6.1, p. 1].

Universiteto 40-ies metu jubiliejaus šventę pradejo VGTU tarybos pirmininkas prof. L. Saulis. Jis paskelbe atvykusių garbingų svečių pavardes - atvyko Lietuvos Respublikos Prezidentas, Vilniaus Gedimino technikos universiteto Garbès daktaras Algirdas Brazauskas, Seimo deputatai, Vyriausybes nariai. Tarp svečiu - Lietuvos Respublikos švietimo ir mokslo ministras, profesorius Vladislavas Domarkas, monsinjoras Kazimieras Vasiliauskas, Vilniaus Gedimino technikos universiteto Garbes daktaras, akademikas Algirdas Žukauskas, Lietuvos aukštuju mokyklų rektoriai, užsienio valstybiu ambasadoriai arba ju atstovai Lietuvoje. Daug svečių atvyko iš užsienio valstybių aukštųjų mokyklų, su kuriomis turime sudarę bendradarbiavimo sutartis. Tai Poznanès technologijos universiteto rektorius, profesorius Eugeniusz Mitkowski ir profesorius Oleg Kaplinski, Varšuvos technikos universiteto rektorius, profesorius Marek Dietrich, Radomo technikos universiteto rektorius, profesorius Wieslaw Wasilewski, Kelcu technikos universiteto prorektorius, profesorius Roman Nadolski, Cergy-Pontoise (Prancūzija) universiteto 


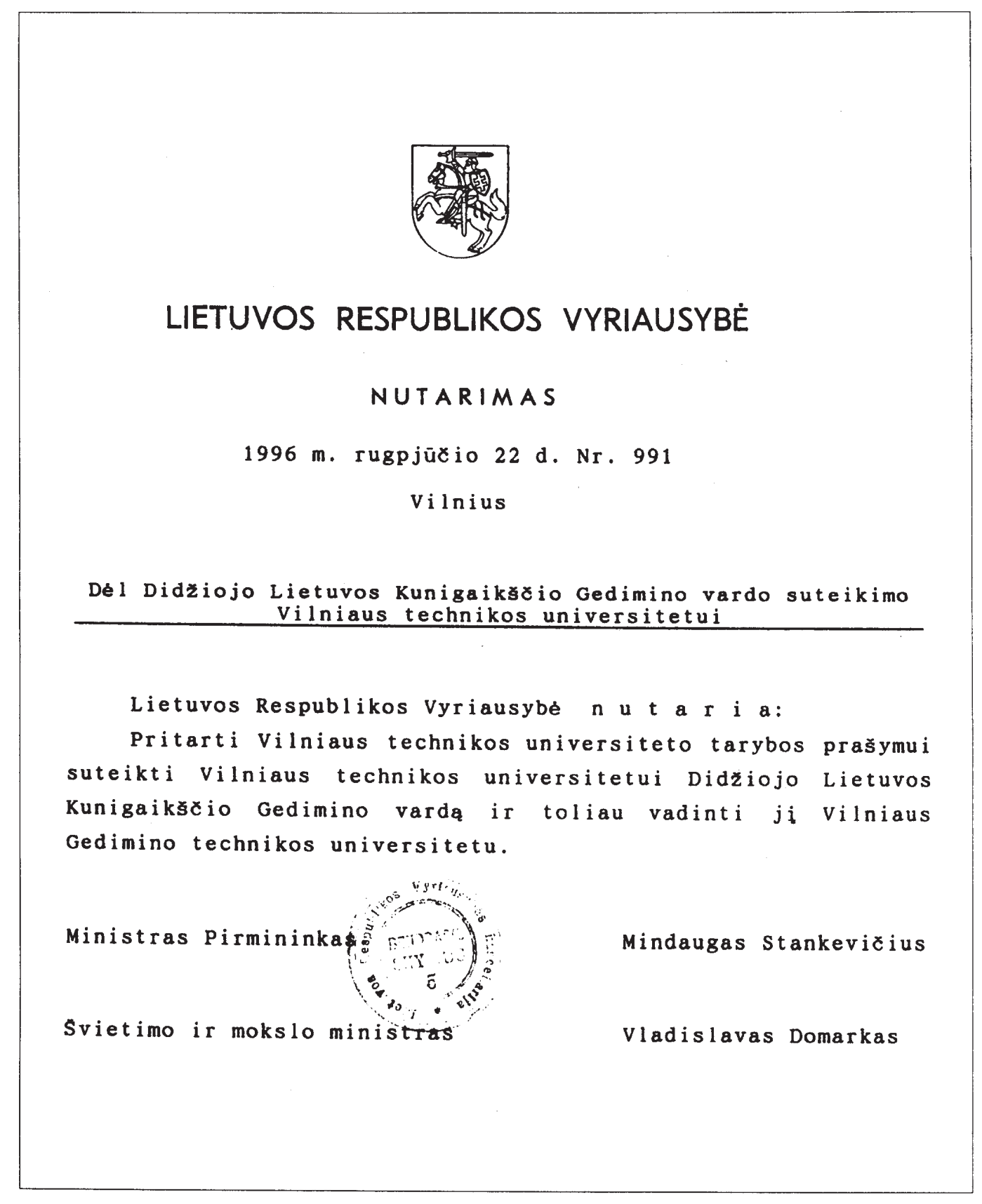

prorektorius, profesorius Rober Vivian ir jo vadovaujama septynių žmonių delegacija, Leipcigo aukštosios technikos, ekonomikos ir kultūros mokyklos profesorius, mūsu universiteto Garbès daktaras Friedel Peldschus, Veimaro Statybos universiteto prorektorius, profesorius Frank Werner ir profesorius Erik Raue, Olborgo universiteto (Danija) profesorius Erik Bejder, Šiaures Amerikos lietuviu bendriju ilgametis vadovas, diplomuotas inžinierius Vytautas Birieta iš Kanados, Viskonsino valstijos (JAV) Medisono universiteto profesorius ir Pietvakariu Viskonsino architektu draugijos prezidentas, architektūros daktaras Raimundas Matulionis. Dalyvavo įvairių organizacijų, akcinių bendrovių vadovai, VTU remejjai ir bičiuliai.
Šventinị pranešimą perskaitè Vilniaus Gedimino technikos universiteto rektorius, Lietuvos mokslu akademijos narys korespondentas, habilituotas daktaras, profesorius Edmundas Kazimieras Zavadskas. Apžvelgęs aukštosios technikos mokyklos vystymąsi per 40 metu, išvardijęs technikos universiteto pasiektus laimejjimus mokslo, mokymo, bendradarbiavimo srityse, paskatinę visus pletoti kultūrinį aktyvumą bei mokslą kaip kultūros dalị, rengti gerus specialistus savarankiškam darbui, E. K. Zavadskas pabrežè, kad „mes, Universitetu bendrijos profesoriai, destytojai, studentai, absolventai, pirmiausia turime atsiminti esa Lietuvos piliečiai ir nuo müsu pačiu priklausys müsu valstybès ateitis".

Susirinkusius sveikinęs Respublikos Prezidentas A. Brazauskas pasidžiauge, jog 
VILNIAUS

GEDIMINO

TECHNIKOS

UNIVERSITETAS

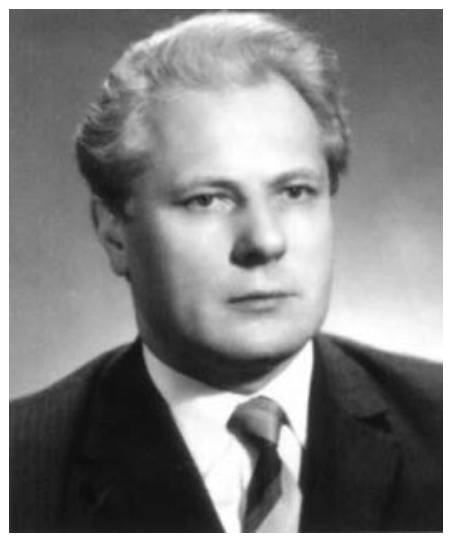

V. Statulevičius

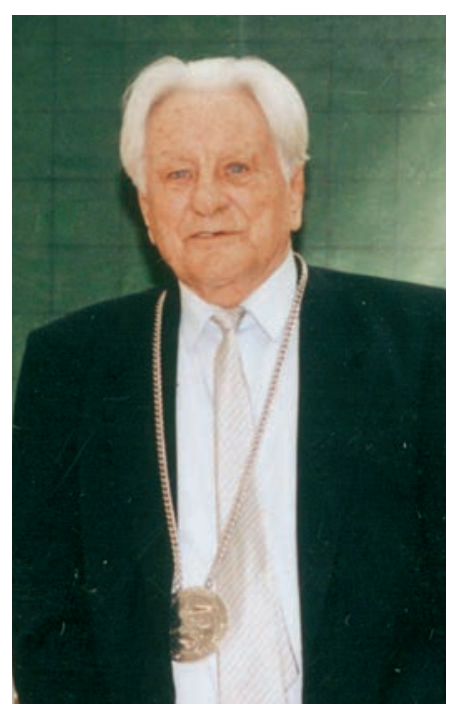

G. Orentas

Dešinëje apačioje:

40-mečio minëjimas Filharmonijoje šiandien Vilniuje turime tvirtą inžinierių branduoli ir palinkejo tolesnio sèkmingo bendradarbiavimo, tarpusavio supratimo bei palaikymo. Kalbëjo Lietuvos švietimo ir mokslo ministras, profesorius V. Domarkas, palinkëjęs universitetui "tokios pat dinamikos, tokio pat plataus veiklos baro, kaip buvo paskutiniais metais ". Sveikinimo žodį Mokslu akademijos vardu tare profesorius, akademikas, VTU Garbès daktaras A. Žukauskas.

Monsinjoras K. Vasiliauskas savo sveikinamąją kalbą skyre dabartiniam jaunimui: „Tikiuosi, kad technikos universitete studijuojantis jaunimas taps ne tik gerais specialistais, bet ir visaverčiais žmonemis, kuriu pareiga -už tiesq, už geri, už groži kovoti “, - pasake monsinjoras. Visų rektorių vardu kalbëjo Muzikos akademijos rektorius prof. J. Antanavičius. „Š aukstoji mokykla atlaikys visas negandas - mes to ir linkime" - pabrežè profesorius.

Ministeriju padèkos raštai ir apdovanojimai buvo įteikti daugeliui mūsų universitetui nusipelniusių profesorių, docentų, darbuotojų.

Profesorius A. J. Staškevičius paskelbè rektorato nutarimą apie apdovanojimą medaliu „Už nuopelnus Vilniaus Gedimino technikos universitetui“ ir įteike juos ilgamečiam šios aukštosios mokyklos rektoriui, prof. habil. dr. A. Čyrui, Tarptautinių studiju centro direktoriui, prof. habil. dr. Z. Kamaičiui, Mechanikos fakulteto dekanui, prof. habil. dr. M. Mariūnui, ūkio direktoriui J. Grabiui bei Informacijos ir ryšių direkcijos direktoriui doc. dr. A. Nakui.

Garbès nario vardo apdovanojimai iškilmingai įteikti akademikui V. Statulevičiui, „Lietuvos avialiniju“" generaliniam direktoriui S. Dailydkai, $A B$ „Lietuvos geležinkeliai“ generaliniam direktoriui $S$. Labučiui, akcinès bendroves „Biofa“ generaliniam direktoriui prof. habil. dr. Vladui Algirdui Bumeliui. Garbès mecenato - verslininkui, Venesuelos lietuviui, VTU Bičiulių klubo viceprezidentui G. Orentui.

Vilniaus Gedimino technikos universiteto Garbès daktaro vardai iškilmingai suteikti Didžiosios Britanijos Sario universiteto vicekancleriui (rektoriui) ir prezidentui, profesoriui P. J. Dowling (D. Britanija) ir Poznanès technologijos universiteto prof. habil. dr. O. Kaplinski (Lenkija).

Statybos fakulteto dekanas P. Vainiūnas ir Verslo vadybos fakulteto dekanas R. Ginevičius supažindino šventes dalyvius su prof. P. J. Dowling ir prof. O. Kaplinski biografijomis, išvardijo jų mokslinius laimejjimus bei nuopelnus Vilniaus Gedimino technikos universitetui, Garbes daktarai buvo apsiausti VGTU togomis, pasake kalbas.

Šventès metu iškilmingai buvo imatrikuliuoti - įšventinti į studentus VGTU pirmakursiai. Prof. E. K. Zavadskas, skeptru palietęs kiekvieno iš scenoje esančių pirmakursių

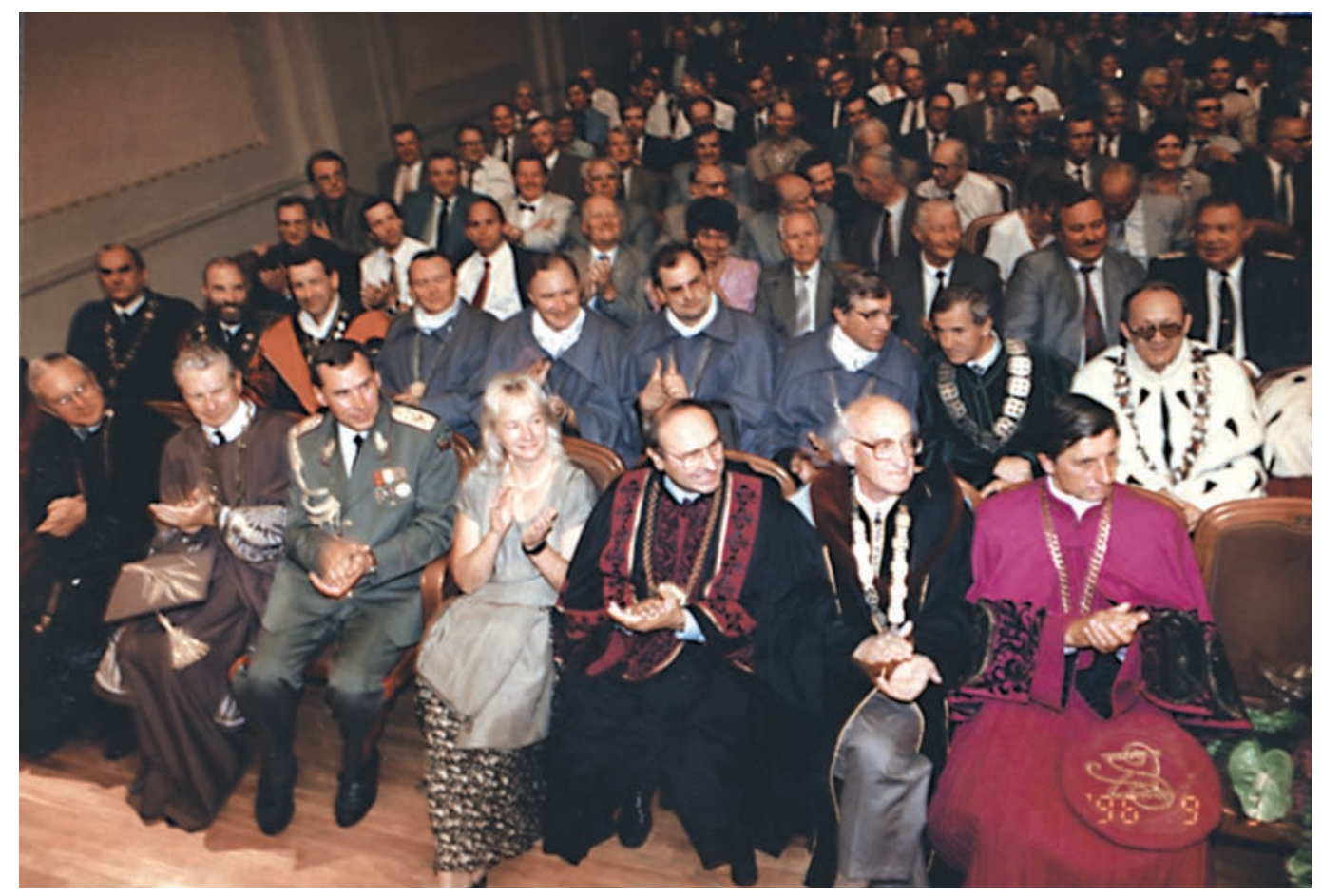




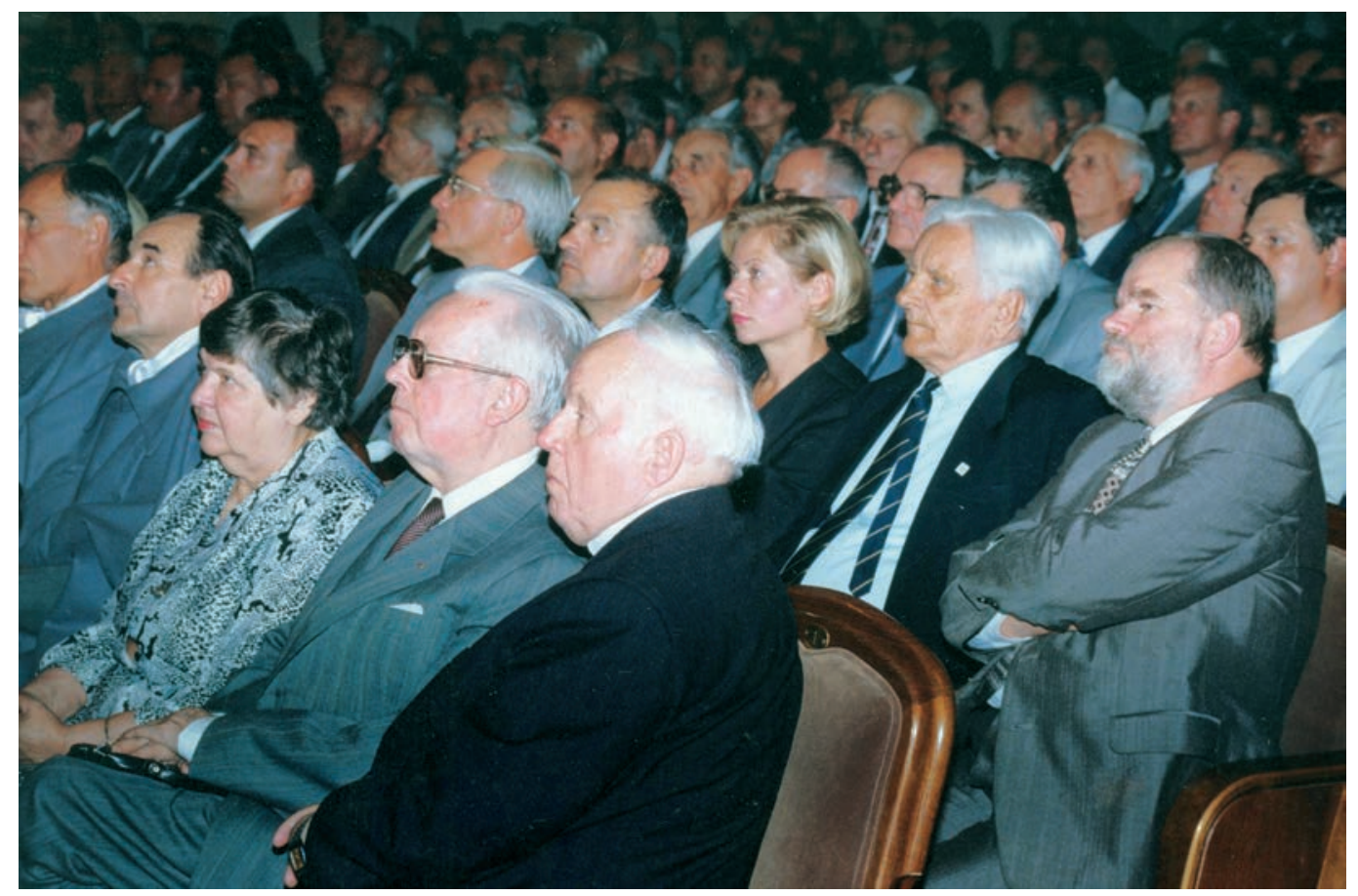

atstovų petị, įteike jiems studento pažymëjimus ir palinkejo sèkmés studijose.

Iškilminga Vilniaus Gedimino technikos universiteto 40-mečio švente baigesi ansamblio „Hiperbole““, kuris susikūre šioje aukštojoje mokykloje, koncertu, palydètu gausiais aplodismentais. Dainos, prieš dešimt metu skambëjusios po mūsų aukštosios mokyklos skliautais, vèl suskambo... Suskambo naujai, pažadinusios susirinkusių širdyse ir praëjusių dienų ilgesị, ir per tuos metus neišblessusi vienybés jausmą - visi buvome ir esame šios mokyklos vaikai... [6.2, p. 2].

Rugsèjo 11-ąją susirinkusiems ì posèdi Vilniaus Gedimino technikos universiteto tarybos posedžių saleje VGTU rektorius prof. habil. dr. E. K. Zavadskas iškilmingai įteikè apdovanojimus, įvertinančius šiu žmonių indèli universiteto, šalies labui. Juk „viskas prasideda nuo žmoniu - nuoširdžiai dirbančio ir daug padarančio kolektyvo"padèkojo universiteto rektorius. Vilniaus Gedimino technikos universiteto garbes ir padèkos raštai bei atminimo medaliai įteikti administracijos, ūkio padalinių, mokslo laboratoriju darbuotojams.

Minint aukštosios technikos mokyklos Vilniuje - Vilniaus Gedimino technikos universiteto keturiasdešimties metu jubilieju universitete buvo paskelbtas geriausių mokslininku konkursas. VGTU rektoratas nuoširdžiai pasveikino jo nugalètojus - profesorius, habilituotus mokslų daktarus Zenoną Kamaitį, Joną Skeivalą, Raimundą Čiegị,
Leoną Saulį, Mečislovą Mariūną, Vladą Vekterị, Edmundą Kazimierą Zavadską, Gediminą Marčiukaitį, Adolfą Baublį, Aleksandrą Vytautą Rutkauską; docentus, habilituotus daktarus - Algimantą Pošką, Rimantą Kačianauską, Vytautą Giniotį; docentus, daktarus - Rimantą Buivydą, Romualdą Ginevičių.

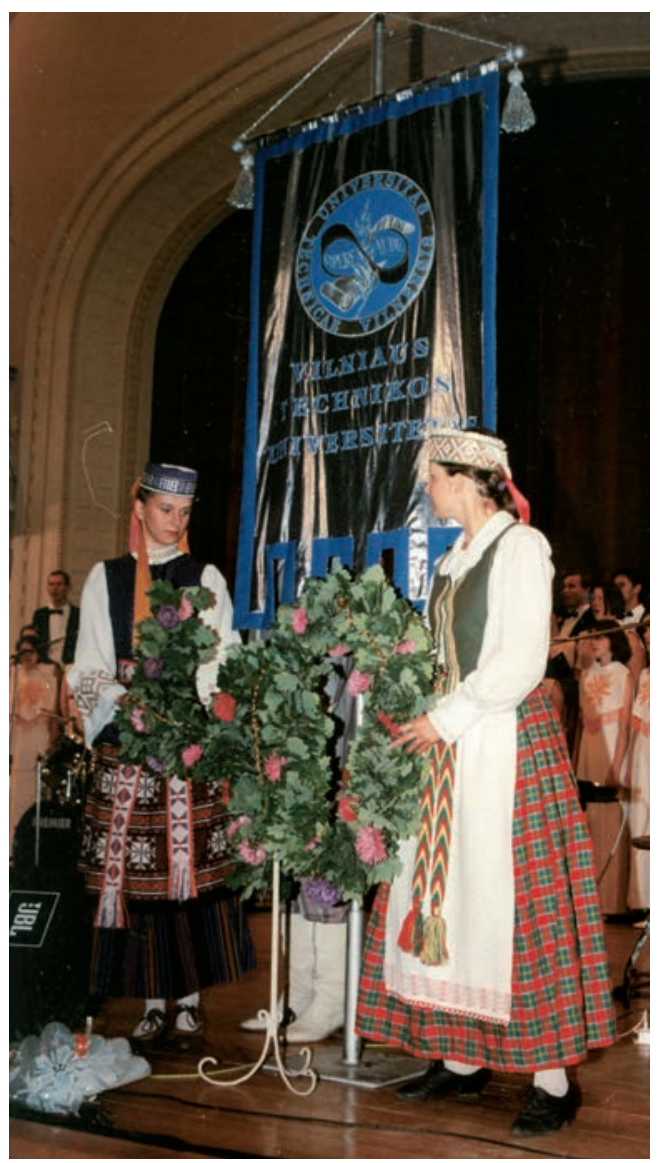


VILNIAUS

GEDIMINO

TECHNIKOS

UNIVERSITETAS

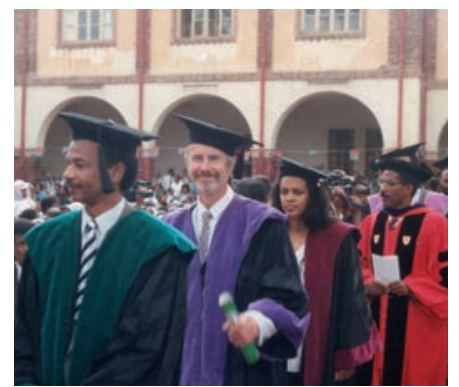

Nuo 1994 m. pirmasis iš Lietuvos Jungtiniu Tautu savanoris doc. V. Stragys (centre) déstè Eritrëjoje
Viršuje dešinëje P. J. Dowling VGTU Garbes daktaras

Dešinëje - O. Kaplinski VGTU Garbes daktaras

\section{Bendradarbiavimas pletojamas toliau}

Rugsëjo pradžioje, pradedant naujus mokslo metus, Vilniaus Gedimino technikos universitete pasirašytos bendradarbiavimo sutartys dar su dviem užsienio šalių universitetais - Sario universitetu ir Poznanés technologijos universitetu.

Sutartis tarp Vilniaus Gedimino technikos universiteto ir Sario universiteto numato ryšius mokslinių tyrimų srityje, keitimąsi informacija ir rezultatais, abieju universitetu studentų, magistrantų bei doktorantų, taip pat specialistų mainus.

Bendradarbiavimo sutartis tarp Vilniaus Gedimino technikos universiteto ir Poznanès technologijos universiteto numato bendradarbiauti mokslinès tiriamosios veiklos, studiju pletros, mokslininkų ir pedagogų rengimo srityse. Kartu numatoma atlikti aktualias mokslinių tiriamųjų darbų temas, keistis naujausia informacija, mokymo patirtimi, metodine medžiaga - studiju programomis, konspektais, savomis kompiuterinemis programomis.

VGTU studentai dalyvavo Statybos ir urbanistikos bei Energetikos ministeriju paskelbtame konkurse individualaus gyvenamojo namo projektui sukurti. Paskatinamosiomis premijomis du VGTU studentu darbai: Vido Turauskio darbas „Karkasinio gyvenamojo namo statybos projektas" (vadovas - doc. dr. J. R. Šimkus) ir Juozo Arbušausko „Karkasinio gyvenamojo namo inžinerine įranga" (vadovas - doc. dr. M. Gedgaudas).

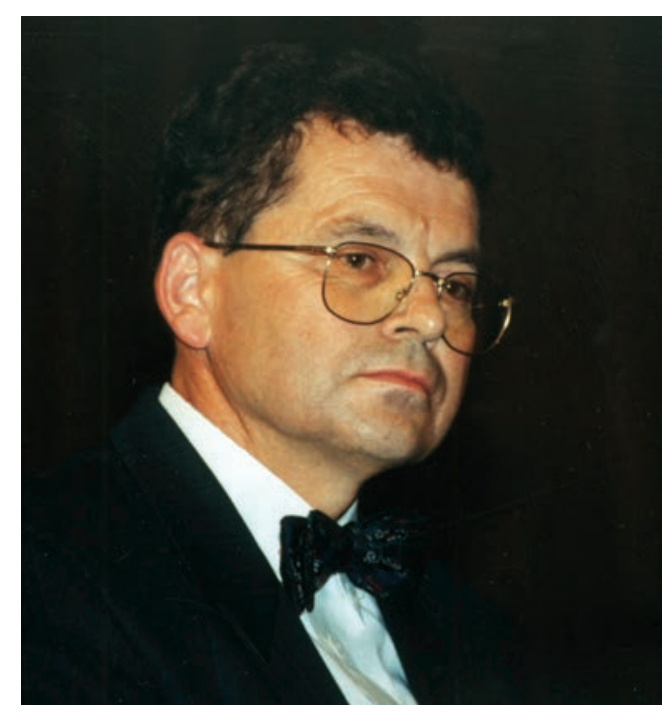

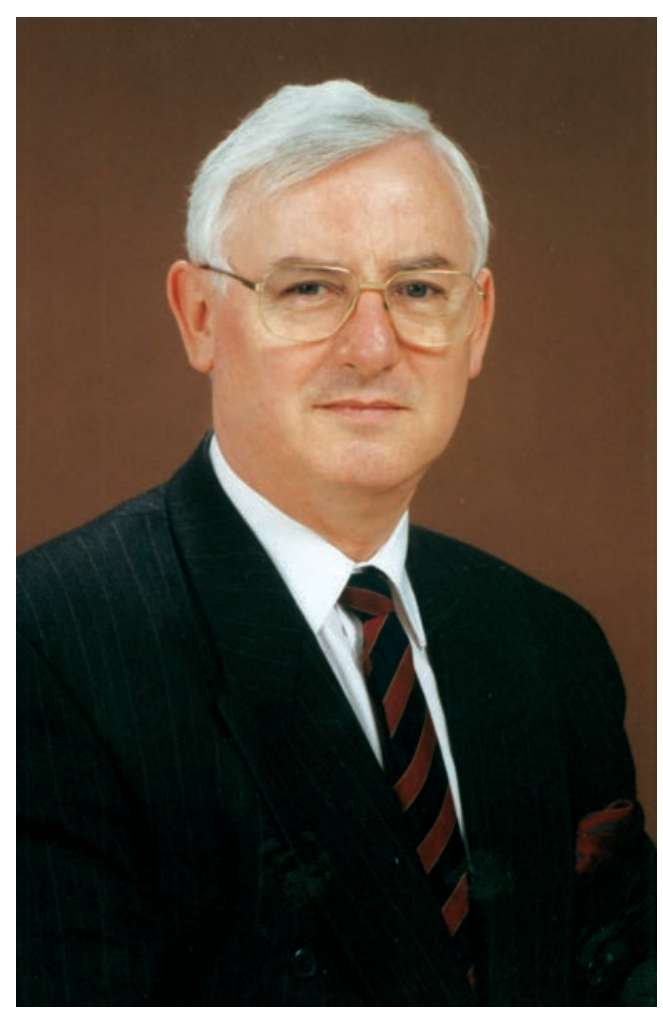

Rugsejji Vilniaus Gedimino technikos universiteto Aviacijos institute pirmiesiems penkiasdešimčiai 3-iojo ir 4-ojo kursų orlaivių pilotavimo specialybès studentų Lietuvos Respublikos civilinès aviacijos direkcijos inspekcijos atstovai iškilmingai ịteike lakūno mejejo licencijas. Tad pirmieji Lietuvoje parengti pilotai išlaike egzaminą - pripažinti oficialiai, įvertinti dokumentu.

Rengti pilotus daug padejo Aviacijos instituto direktoriaus pavaduotojas skrydžiams Leonas Jonys, turëjęs jau dešimtmečiais skaičiuojamą skraidymo stažą ir tarptautinị lakūno instruktoriaus pripažinimą.

Ukrainos ir Lietuvos valstybinių himnų skambëjimu rugsëjo $24 \mathrm{~d}$. prasidëjo iškilmingas universiteto Tarybos posedis Vilniaus Gedimino technikos universitete. Tą dieną Ukrainos Prezidentui, profesoriui, habilituotam daktarui Leonidui Kučmai įteiktas Vilniaus Gedimino technikos universiteto Garbes daktaro diplomas ir regalijos.

L. Kučma yra daug nuveikęs kosmoso raketų technikos ir medžiagų technologijų srityse. Profesorius gerai žinomas pasaulyje atsparumo teorijos ir kevalų mechaninès irties specialistas, jo mokslinių darbų sąrašas gerokai viršija pusę šimto. Tarp jų - stambūs, fundamentalūs darbai, monografija „Kosmoso raketų hermetiškumas“. Prof. L. Kučma dirbo techniniu vadovu Baikonūro komplekse, kosmoso aparatų gamybos 
komplekso „Pivdenne“ generaliniu direktoriumi. Mokslininkas apdovanotas Lenino ir Ukrainos valstybinemis premijomis, yra Ukrainos inžinerinès akademijos akademikas, be to, jam suteikti daugelio pasaulio šaliu - Italijos, Brazilijos, Argentinos, Čiless, Kinijos, Suomijos ir Indonezijos - aukščiausi valstybiniai apdovanojimai.

Suteikdama Garbés daktaro vardą profesoriui, akademikui Leonidui Kučmai, Vilniaus Gedimino technikos universiteto bendrija pažymëjo ne tik profesoriaus nuopelnus technikos mokslui, bet ir didžiuli jo indèli, pletojant draugystes ir bendradarbiavimo ryšius tarp Ukrainos ir Lietuvos.

L. Kučma buvo 11-asis VGTU Garbès daktaras. Iki jo VGTU Garbès daktarais tapo F. Peldschus, P. Linnert, J. Argyris, K. Borre, S. Caspersen, V. Šernas, P. J. Dowling, O. Kaplinski, A. Žukauskas ir A. M. Brazauskas.

Rugsëjo ménesį Vilniaus Gedimino technikos universitete vyko antroji tarptautine moksline konferencija „Miestų inžinerija ir aplinka“, kurioje dalyvavo Lietuvos, Didžiosios Britanijos, Rumunijos, Jugoslavijos, Suomijos, Šveicarijos, Vokietijos, Latvijos, Rusijos ir kt. valstybių mokslininkai.

Spalio $1 \mathrm{~d}$. Vilniaus Gedimino technikos universiteto tarybos posedyje svarstytas ir patvirtintas VGTU tarybos darbo planas 1996-1997 m. m., numatantis pagrindines Tarybos veiklos gaires.

Tarybos posedyje profesoriaus pedagoginis mokslo vardas suteiktas: doc. habil. dr. Raimundui Kirvaičiui (Radioelektronikos katedra) doc. habil. dr. Jonui Stankūnui (Aviacijos institutas); docento pedagoginis mokslo vardas suteiktas vyr. asist. dr. Romualdui Kliukui (Medžiagų atsparumo katedra); dvidešimčiai šiais metais priimtu doktorantu patvirtinti doktorantūros komitetai.

Iškeltos VGTU mokslininku kandidatūros Lietuvos mokslo premijai gauti: prof. habil. dr. Dmitrijaus Styro (darbų ciklas „Branduolinès hidrofizikos tyrimų eksperimentiniai ir teoriniai pagrindai, jų procesų ir anomalių efektų žemëje prognozes") ir Lietuvos MA nario korespondento, prof. habil. dr. Edmundo Kazimiero Zavadsko (darbu ciklas „Statybos projektų daugiakriterinis įvertinimas ir technologinių sprendimų daugiatikslè selektonovacija“).

Už darbą rengiant universiteto jubiliejaus minëjimą buvo padèkota Informacijos ir ry-

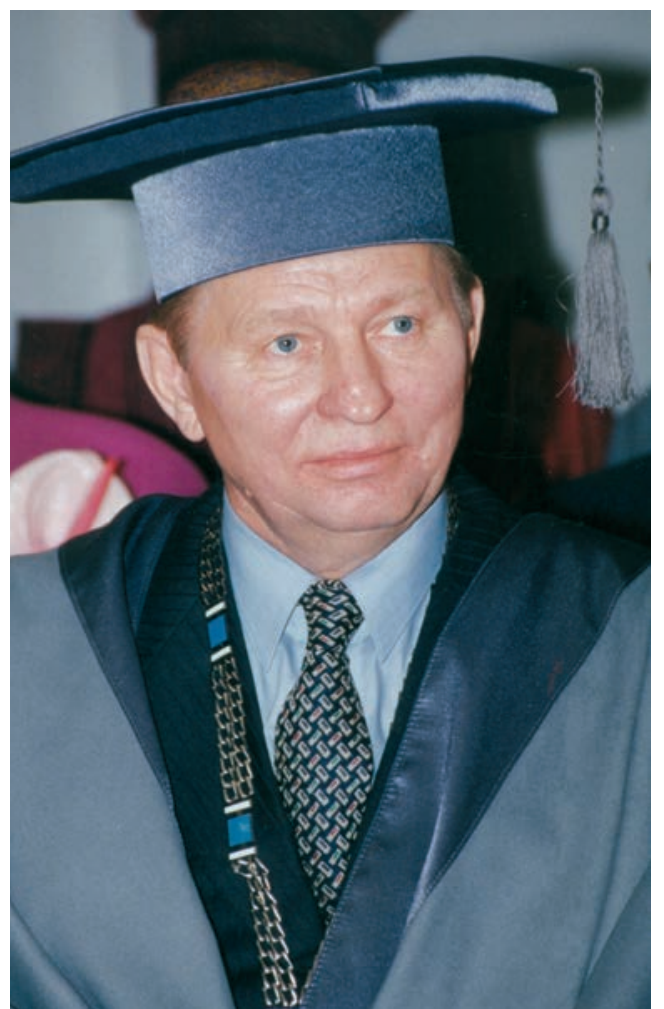

L. Kučma

VGTU Garbès daktaras

šių direkcijos darbuotojams: direktoriui doc. dr. A. Nakui, reikalų tvarkytojai J. Valeckienei, dailininkems R. Muralienei ir A. Rudminaitei, režisierei D. Kilimonytei, choro „Gabija“ vadovei R. Viskantaitei, „Inžinerijos“ redakcijos vyr. redaktorei $\mathrm{M}$. Akstinaitei ir redaktorei D. Buivydienei bei Vaizdo ir garso technikos priemonių laboratorijos darbuotojams - vedejui V. Kučinskui ir fotografui A. Jauniui.

Spalio ménesị Vilniaus plokštelių studija išleido pirmąją Vilniaus Gedimino technikos universiteto choro „Gabija“ dainų ir giesmių kasetę. Joje - harmonizuotos lietuvių liaudies dainos, įvairi religinè muzika.

Mokslines ir mokomosios techninès literatūros fondus papildè naujas „Vokiečiulietuvių ir lietuvių-vokiečių kalbų automobilizmo terminu žodynas“. Jị sudare Antanina Žitkute, išleido Mokslo ir enciklopediju leidykla. Žodyno rengejus konsultavo Vilniaus Gedimino technikos universiteto Automobiliu transporto katedros doc. dr. Leonas Gastila, lietuviškąją žodyno dalį sukirčiavo Terese Morta Valiuvienè.

Europos menų, mokslų ir profesijų akademija 1996 m. akademiko vardą suteikè Lietuvos ambasadoriui Italijoje ir Graikijoje Romanui Podagèliui. Jis įrašytas ị Akademikų ordino sąrašą.

Romanas Podagèlis $1966 \mathrm{~m}$. baige KPI Vilniaus filialą, igijo statybos inžinieriaus

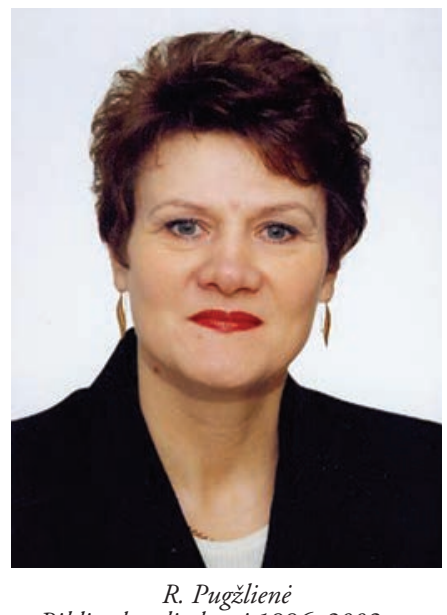

Bibliotekos direktore 1996-2002 m. 
VILNIAUS

GEDIMINO

TECHNIKOS

UNIVERSITETAS
Dešinëje apačioje:

Europos menu, moksly ir profesiju akademiko diplomo itteikimas R. Podagéliui archeologinių tyrimų ir konservavimo darbų nuolatinès mokslinès tarybos narys.

Spalio pabaigoje įvyko VGTU rektoriaus prof. habil. dr. E. K. Zavadsko ir Studentu atstovybes prezidento Evaldo Birgiolo bei programų direktoriaus Dariaus Bazaro susitikimas. Buvo aptarti aktualūs technikos universiteto studentų gyvenimo klausimai. Pastebeta, kad reikia išsaugoti studentu poilsio vakaru organizavimo vietas, kaip reiketų spręsti organizacines patalpų įrengimo problemas. Nutarta, kad reikia imtis neatidèliotinų priemonių, siekiant užkirsti kelią mokamo mokslo įvedimui. Buvo nagrineta ir studentų dalyvavimo masiniuose renginiuose problema, aptartos destytoju „nevaldiško" požiūrio ị studentų švietimą formavimo galimybès.

Tenka pripažinti, kad to meto VGTU studentų atstovybes veikla buvo ryški. Jos vadovai turejo autoritetą tarp visų studentų ir buvo vertinami už dalykišką veiklos pobūdį tiek pačių studentų, tiek universiteto vadovybès.

Lapkričio 21-22 d. Vilniaus Gedimino technikos universiteto Aviacijos institute vyko tarptautine konferencija „Aviacija-96“, skirta Lietuvos lakūno Stepono Dariaus 100-osioms gimimo metinèms pamineti.

Pranešimus konferencijoje skaitè LR susisiekimo ministerijos sekretorius A. Šakalys, Civilines aviacijos direkcijos generalinis direktorius A. Šileika, aviakompanijos
Lietuvos architektu sajungos veikloje, buvo Vilniaus žemutinès pilies (Valdovų rūmų)

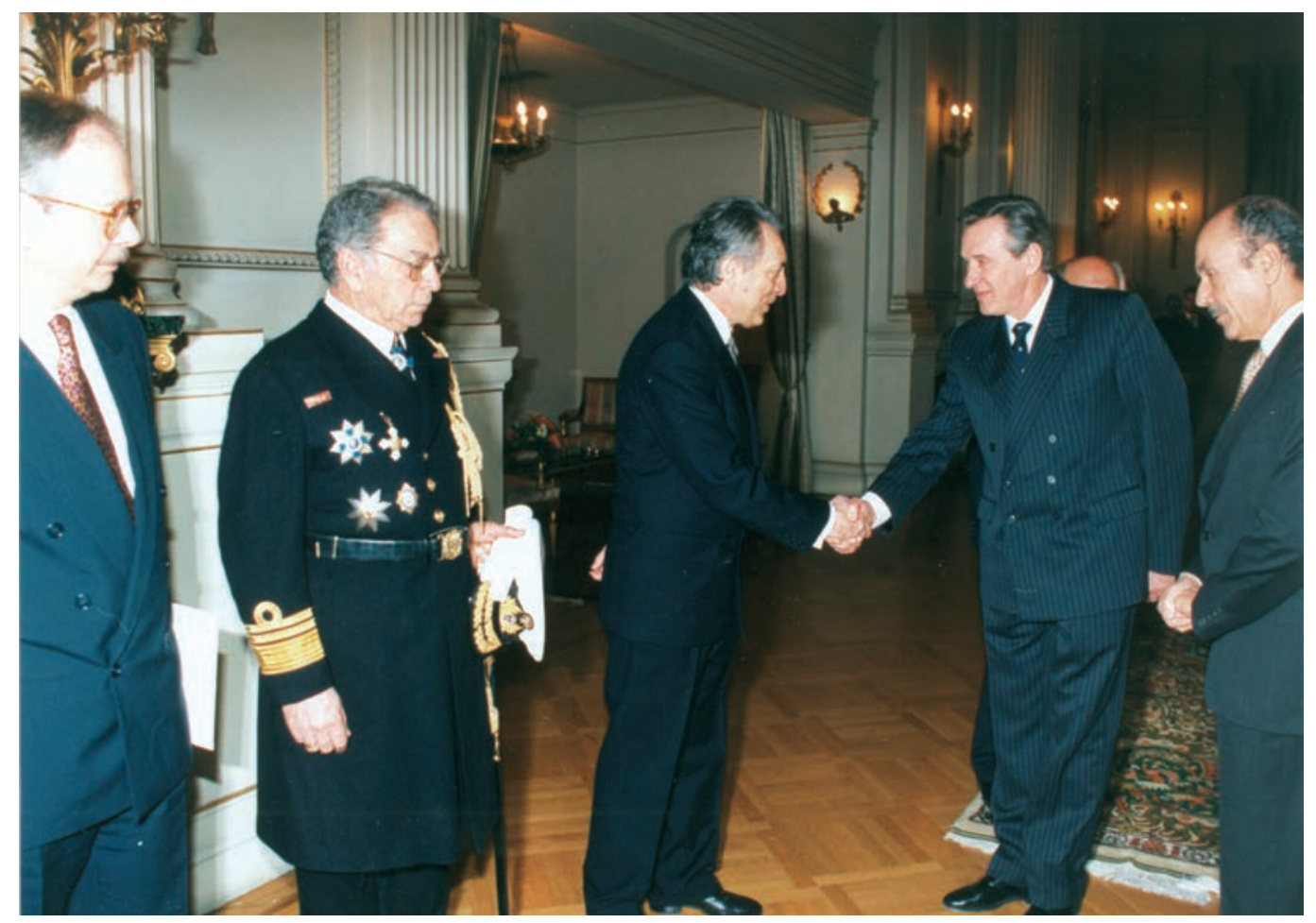


„Lietuvos avialinijos“" generalinis direktorius S. Dailydka, VGTU Aviacijos instituto specialistai, Vilniaus Gedimino technikos universiteto mokslininkai, aviacijos specialistai iš 8 užsienio valstybių - Suomijos, Lenkijos, Italijos, Nepalo, Anglijos, Švedijos, Estijos, Latvijos.

Lapkričio $22 \mathrm{~d}$. VGTU studentai ir destytojai turejo progą išgirsti kolegų iš Gdansko politechnikos (kitaip vadinamos Politechnikos akademijos) kamerinio choro (vadovas Mariusz Mroz) ir mušamųjų instrumenty ansamblio „Jeunesses Musicales“ (vadovas Piotr Sutt) įspūdingą koncertą.

\section{Rektoriaus viešnagè Italijoje}

Gruodžio 16 d. Italijoje, Florencijos mieste, Vilniaus Gedimino technikos universiteto rektoriui, profesoriui, habilituotam daktarui, LMA nariui korespondentui Edmundui Kazimierui Zavadskui įteiktas Europos menų, mokslų ir profesijų akademijos garbès akademiko diplomas. Garbès akademiko vardas prof. E. K. Zavadskui suteiktas už nuopelnus vystant šalies aukštąji mokslą, integruojant jị i Vakarų Europos valstybiu bendriją.

Europos menų, mokslų ir profesiju akademija - tai tarptautine nepolitine ir nesiekianti pelno asociacija, kurios tikslas - pletoti socialinę ir kultūrinę veiklą, suburti kvalifikuotus ir gerai žinomus meno, mokslo ir profesinès veiklos žmones. Europos menų, mokslų ir profesiju akademija teikia privilegijas naujovems, žmoniškumui, bendrajai etikai, minties laisvei, pažangai ir papročiams.

1996 m. gruodžio 18 d. Vilniaus Gedimino technikos universiteto rektorių, prof. habil. dr. E. K. Zavadską priemé popiežius Jonas Paulius II.

Metų pabaigoje mūsų absolventą Gediminą Vagnorių, vèl tapusį Lietuvos Vyriausybès Premjeru, pasveikino VGTU vadovai. Premjeras atsiunte padèkos laišką rektoriaus E. K. Zavadsko ir Tarybos pirmininko L. Saulio vardu, kuriame rašè:

„Aš savo ruožtu sieksiu, kad Vyriausybe sudarytu salygas mokslo ir studiju institucijoms produktyviai dirbti, sunkiomis ekonominio gyvenimo reformos salygomis išsaugoti efektyviai dirbanti mokslo pedagogini potenciala.

Vyriausybe skatins prioritetinius, tarptautinio lygio, reikšmingus Lietuvos pažangai ir

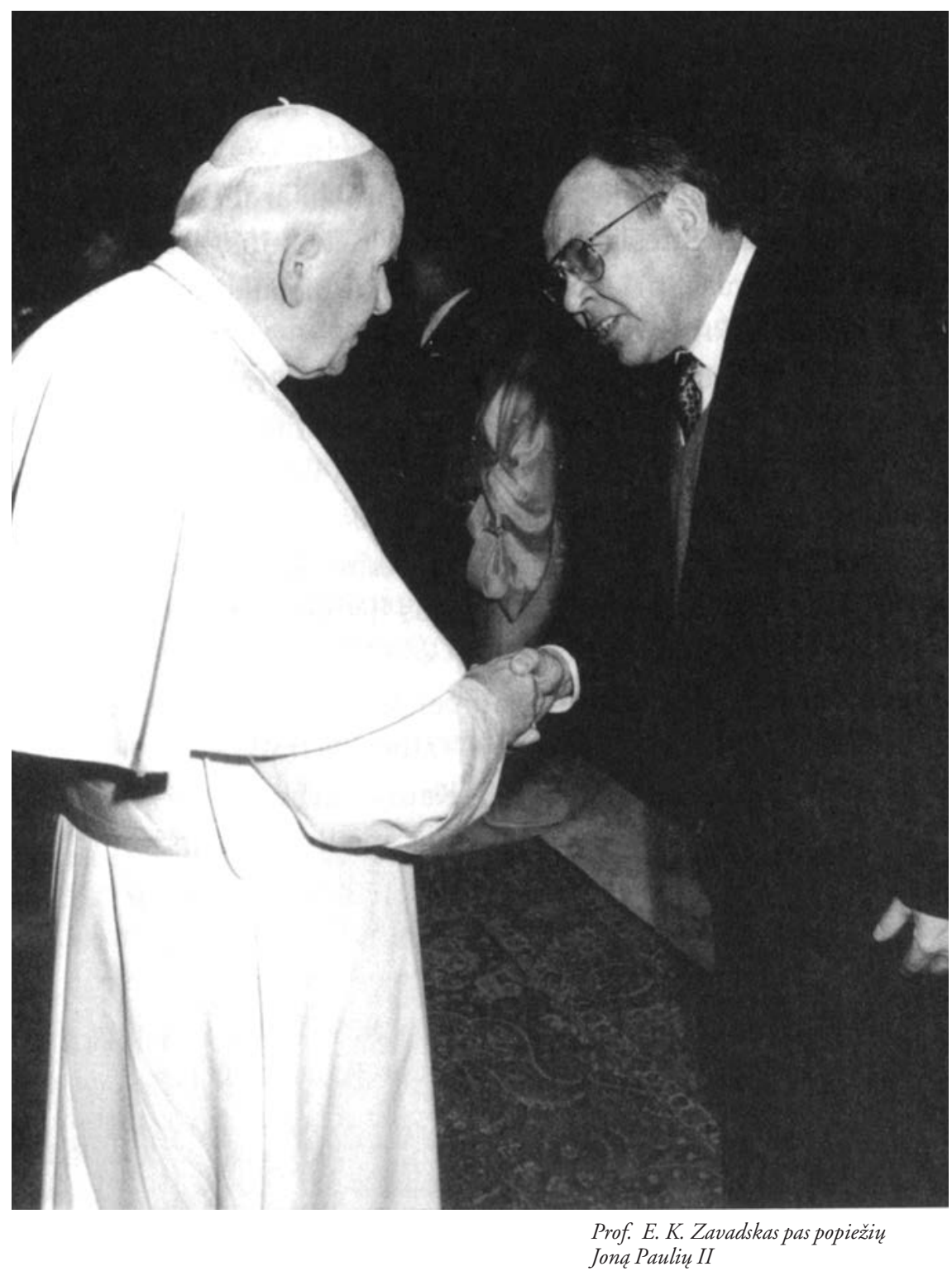

prisidedančius prie integravimosi ¿ Vakaru Europos struktūras tyrimus.

Linkiu, kad mūsu lükesčiai pildytusi “.

Per rinkimus į Lietuvos Respublikos Seimą buvo išrinktas VGTU Užsienio ryšių direkcijos direktorius doc. dr. Remigijus Ćiupaila, o Fundamentinių mokslų fakulteto dekanas doc. dr. Algirdas Čiučelis - i Vilniaus miesto valdybą.

1996 metai buvo sèkmingi universitetui. I pirmąji kursą buvo priimti studijuoti 2053 jaunuoliai ir merginos: $1719-\mathrm{i}$ dieninị skyrių (iš kurių 303 klausytojai), $334-i$ neakivaizdinị skyriu (iš kurių 172 klausytojai). Pagrindinèse studijose studijavo 5775 studentai. Tais metais pagrindines studijas baige tik 369 žmonès. Taip buvo dèl to, kad 1992 m. buvo labai sumažejęs studentų prièmimas, beveik nebuvo konkurso.

1990-1997 m. technikos universiteto parengtų specialistų skaičių dinamika pateikta lentelëje. 
VILNIAUS

GEDIMINO

TECHNIKOS

UNIVERSITETAS
Viršuje dešineje -

Lenteleje-specialistai, parengti 1990-1997 m
Habilitacinius darbus apgynè Algimantas Juozas Poška (Automatikos katedra), Ramūnas Palšaitis (Transporto vadybos katedra), Rimantas Kačianauskas (Teorinès mechanikos katedra), Vytautas Giniotis (Skrydžiu valdymo katedra), Juozas Atkočiūnas (Statybinès mechanikos katedra), Alfonsas Kazys Skrinska (Šildymo ir védinimo katedra), Vytautas Kazimieras Augustaitis (Poligrafiniu mašinų katedra), Raimundas Kirvaitis (Radioelektronikos katedra), Jonas Stankūnas (Skrydžių valdymo katedra).

Naujuosius 1997 metus VGTU bendruomenè pasitiko su viltim, kad gyvenimas kitais metais taps geresnis, kad bus daugiau džiaugsmingų minučių. Ir metai prasidëjo geromis naujienomis.

1997 m. sausio 10 d. už drąsą ir pasiaukojimą Lietuvos Respublikai Vilniaus Gedimino technikos universiteto doc. Vytautas Jasulaitis apdovanotas Sausio 13-osios atminimo medaliu.

1997 m. sausio 21 d. Vilniaus miesto meru buvo išrinktas doc. dr. A. Čiučelis, Vilniaus Gedimino technikos universiteto Fundamentinių mokslų fakulteto dekanas.

Sausiui baigiantis sužinota, kad Vilniaus Gedimino technikos universiteto rektoriui, prof. habil. dr. E. K. Zavadskui už darbų ciklą „Statybos projektų daugiakriterinis ìvertinimas ir technologinių sprendimų daugiatikslè selektonovacija“" paskirta Lietuvos mokslo 1996 metu premija.

1997 m. vasario 6-7 d. Vilniaus Gedimino technikos universitete vyko tarptautine konferencija „Nekilnojamojo turto vertinimas ir investicijos Centrinëje ir Rytu Europoje pereinant i laisvosios rinkos ekonomiką“. Konferencijos tikslas - suburti pripažintus turtinių operacijų ekspertus ir pasidalyti žiniomis bei patyrimu apie nekilnojamojo turto rinkų veikimą visoje Centrineje ir Rytu Europoje. Pranešimus konferencijoje numato skaityti specialistai, susirinkę i Vilnių net iš 5 kontinentų, 12 pasaulio šalių.

Nekilnojamojo turto vertinimo ir investicijų klausimai buvo nagrinëjami ịvairiais aspektais, svarstomos privatizavimo, turto valdymo, finansu, vertinimo, nuosavybès, investiciju, apmokestinimo, informacijos technologijos pritaikymo ir interneto naudojimo, taip pat mokymo procesų problemos.

\begin{tabular}{|c|c|c|c|c|}
\hline \multirow{3}{*}{ Metai } & \multicolumn{4}{|c|}{ Parengta specialisty } \\
\hline & \multirow{2}{*}{ iš viso } & \multicolumn{3}{|c|}{$i s ̌ j u$} \\
\hline & & $D$ & $V$ & $N$ \\
\hline 1990 & 774 & 523 & 140 & 111 \\
\hline 1991 & 788 & 513 & 150 & 125 \\
\hline 1992 & 680 & 494 & 111 & 75 \\
\hline 1993 & 1023 & 825 & 108 & 90 \\
\hline \multirow{3}{*}{$\begin{array}{l}1994 \\
\text { iš ju: } \\
\text { inžin. } \\
\text { bkl. }\end{array}$} & 1235 & 1063 & 81 & 91 \\
\hline & 807 & 635 & 81 & 91 \\
\hline & 428 & 428 & - & - \\
\hline \multirow{3}{*}{$\begin{array}{l}1995 \\
\text { iš ju: } \\
\text { inžin. } \\
\text { bkl. }\end{array}$} & 643 & 466 & 64 & 113 \\
\hline & 138 & - & 50 & 88 \\
\hline & 505 & 466 & 14 & 25 \\
\hline \multirow{3}{*}{$\begin{array}{l}1996 \\
\text { iš ju: } \\
\text { inžin. } \\
\text { bkl. }\end{array}$} & 533 & 369 & 42 & 122 \\
\hline & 193 & 29 & 42 & 122 \\
\hline & 340 & 340 & - & - \\
\hline \multirow{3}{*}{$\begin{array}{l}1997 \mathrm{~m} . \\
\text { planas: } \\
\text { iš ju: } \\
\text { inžin. } \\
\text { bkl. }\end{array}$} & 720 & 673 & 7 & 40 \\
\hline & 47 & - & 7 & 40 \\
\hline & 673 & 673 & - & - \\
\hline
\end{tabular}

Vilniaus aukštųjų mokyklų studentų pirmenybèse sèkmingai startavo mūsų „Inžinerijos" komanda, įveikusi Lietuvos karo (75:66), Muzikos (127:29) akademijas, Vilniaus universitetą (84:79) ir Pedagogini (59:56) universitetą. Ir nors kiek nelauktai pralaimejusi Lietuvos policijos akademijos krepšininkams, komanda tapo Lietuvos studentų krepšinio lygos čempionato I rato nugalètoja Vilniaus zonoje ir sostinès aukštųjų mokyklų studentų 1996 metų čempione. Mūsų komanda buvo apdovanota medaliais, I laipsnio diplomais, itteikta taurè. Antroji vieta atiteko VU komandai, trečioji - VPU krepšininkams.

VGTU komandoje žaide komandos kapitonas Viktoras Gasiūnas, Remigijus Mikènas, Saulius Mikelionis, Arūnas Kerulis, Nerijus Statkus, Vytautas Valaitis, Nerijus Tautvaišas, Ramūnas Žemaitis, Vytautas Ramanauskas, Arūnas Balasevičius, Žilvinas Žydelis, Liudas Rimkus. Komandą treniravo Kęstutis Grigaliūnas.

1997 m., minint Vasario 16-ąją, paminètos Vytauto Didžiojo universiteto 75-osios metinès. "Jei nebütu Lietuvoje universitetu, nebütu ir valstybès. Šis pirmasis tikrai lietuviškas universitetas, išugdęs lietuviškosios inteligentijos kartas, padejo išlikti lietuviu dvasiai, išsaugoti nepriklausomybès siekius", - pažymèjo Vilniaus Gedimino technikos universiteto rektorius, profesorius E. K. Zavadskas iškilmingame VGTU 
tarybos posedyje, skirtame Lietuvos valstybès atkūrimo dienai ir Kauno universiteto 75-mečiui pažymèti.

Pažymint Lietuvos valstybès atkūrimo dieną ir Kauno universiteto 75-metị VGTU profesoriai ir docentai, baigę arba studijavę Kauno (Vytauto Didžiojo) universitete, apdovanoti medaliu „Už nuopelnus Vilniaus Gedimino technikos universitetui" ir Vilniaus Gedimino technikos universiteto Garbès raštu už ilgameti gerą mokslinį ar kūrybinį pedagoginị darbą.

Medaliu „Už nuopelnus Vilniaus Gedimino technikos universitetui“" apdovanoti: prof. dr. Mykolas Kosčiauskas, doc. dr. Leonas Gastila, prof. habil. dr. Kazimieras Šešelgis, prof. dr. Jonas Šimkus, prof. dr. Jokūbas Kivilša, prof. habil. dr. Antanas Kudzys, prof. dr. Bronius Sidauga, prof. habil. dr. Vincas Vainauskas, prof. habil. dr. Zenonas Vainoris, prof. habil. dr. Daumantas Maciulevičius, prof. habil. dr. Algirdas Čižas, prof. Arnas Dineika, prof. habil. dr. Kostantinas Jakovlevas-Mateckis, doc. dr. Romualdas Jonušas, doc. dr. Evaldas Palšaitis, doc. Vaclovas Pranaitis, doc. Romualdas Sakalauskas, doc. dr. Pranas Mikšta.

Vilniaus Gedimino technikos universiteto Garbès raštu už ilgametį gerą mokslinị ar kūrybinį pedagoginį darbą apdovanoti: doc. dr. Jurgis Dyčmonas, doc. dr. Jurgis Dilba, doc. dr. Kęstutis Lukoševičius, doc. dr. Linas Vidugiris, doc. dr. Jonas Budrys, doc. dr. Henrikas Gilys, doc. dr. Kęstutis Baškys, doc. dr. Ipolitas Nickus, doc. dr. Vytautas Tulevičius, doc. dr. Vytautas Viršilas, doc. dr. Juozas Žukas, dr. Ričardas Garalevičius, doc. Justinas Šeibokas, doc. dr. Vilius Šulga, doc. dr. Gintautas Vasionis.

Pranešta, kad 1997 m. mūsų universitete pradèta diegti nauja pažangi sistema stipendijoms ir atlyginimams moketi. Naudojant plastikines „Globus“ mokëjimo korteles atlyginimai ir stipendijos mokami per Žemès ūkio banką, su kuriuo Vilniaus Gedimino technikos universitetas pasiraše sutartị.

Vasario vidury Panevežyje vyko Lietuvos uždaru patalpu suaugusių ir jaunimo lengvosios atletikos čempionatas. Šauniai jame pasirodè VGTU lengvaatlečių komanda, tarp šalies aukštųjų mokyklų komandų užèmusi III vietą. Nugalèjo Kauno kūno kultūros instituto lengvaatlečiai, antri - Vilniaus pedagoginis universitetas.

Individualiai čempione tarp jaunimo tapo Aplinkos inžinerijos fakulteto antrakurse

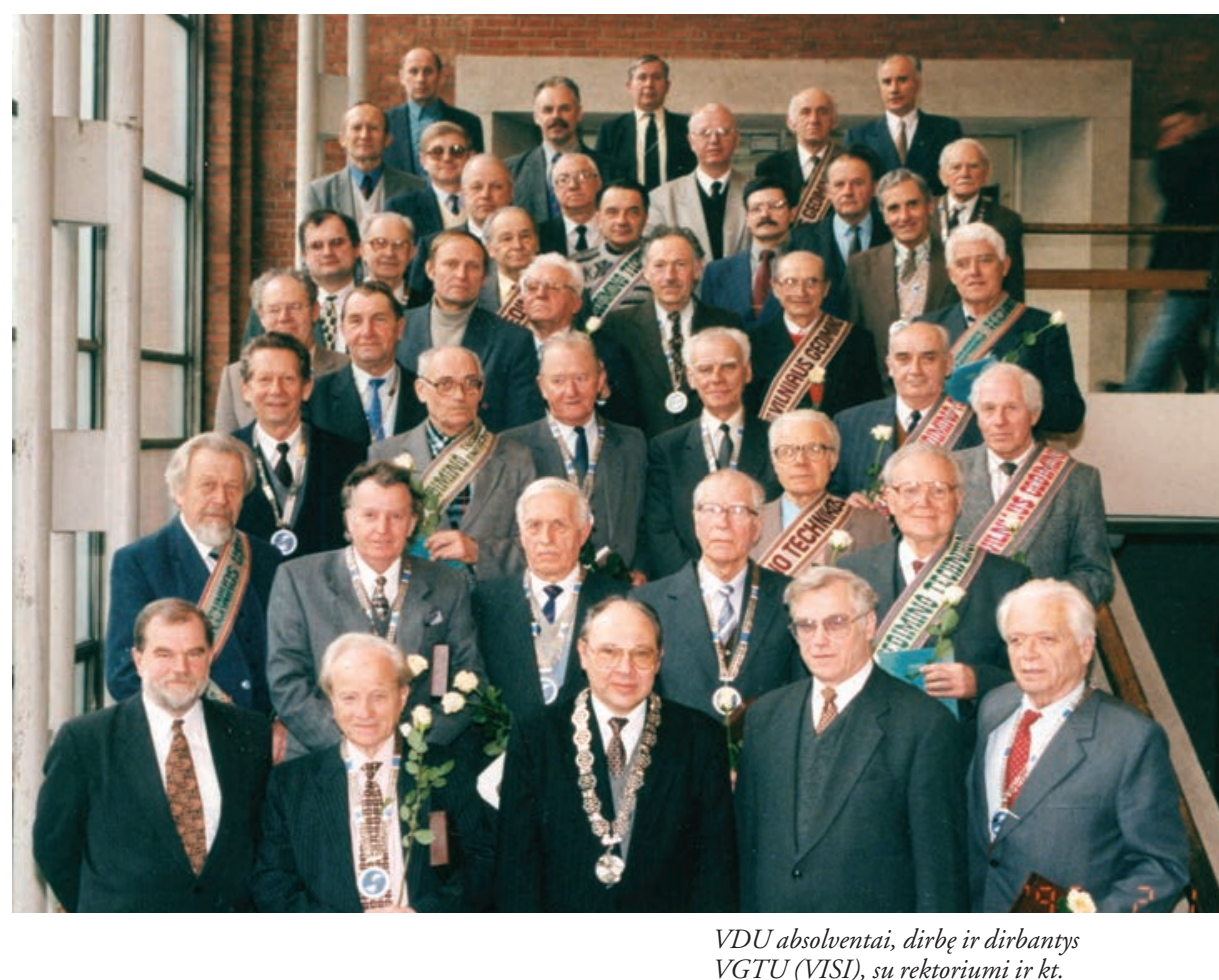

V. Vinskutè, trišuoliu nušokusi $12,12 \mathrm{~m}$. Šuolio į tolį rungtyje ji buvo antra $-5,40 \mathrm{~m}$.

Čempiono vardą tarp jaunimo iškovojo to paties fakulteto antrakursis Modestas Urbonavičius, nustūmęs rutuli 13,13 m.

1997 m. vasario 20 d. Geodezijos katedros biografija praturtejo svarbiu faktu: VGTU taryba nutare pakeisti pavadinimą ir vadinti ją Geodezijos ir kadastro katedra. Tai padaryti skatino pasikeitusios studijų programos, šalies ūkio poreikiai bei noras įsilieti ị Europos Sąungą.

\section{0-asis „Inžinerijos“ numeris}

1997 m. vasario - kovo mèn. išrinkti nauji Studentų atstovybès parlamentarai: prezidentas - Evaldas Birgiolas, viceprezidente - Lina Šleinotaite, valdybos pirmininkas - Mindaugas Kiznis, buhaltere - Natalija Šèmis, programų direktorius - Darius Bazaras, Užsienio skyriaus kuratore - Lina Šleinotaitè, masinių renginių kuratorius - Vilius Ambrazevičius.

Darius Bazaras „Inžinerijoje“ įdomiai apibūdino studentų visuomeninę poziciją:

„Studentai visais laikais buvo aktyviausia visuomenes dalis. Tai irode ir 1990-1993 mety mitingu periodas, Televizijos bokšto, Seimo gynimas, paskutiniai juykiai Kaune, kai policija sumuše studenta. Jo kolegos organizavo protesto akcija, kuri irode studentu vienybe ir jega. Šitai kai kam pameteja ideja, 
VILNIAUS

GEDIMINO

TECHNIKOS

UNIVERSITETAS

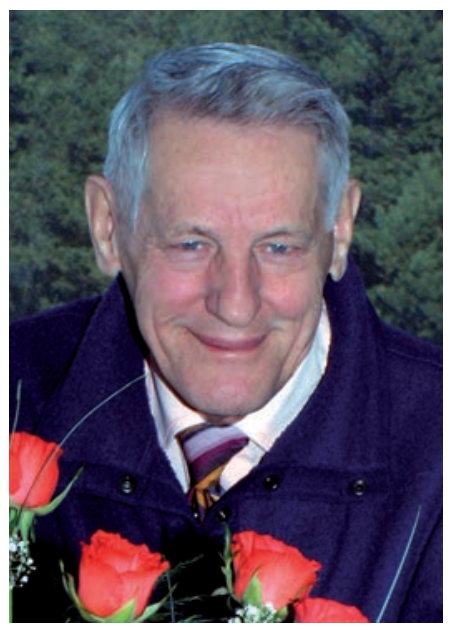

„Inžinerijos" vyr. redaktorius J.Norkevičius

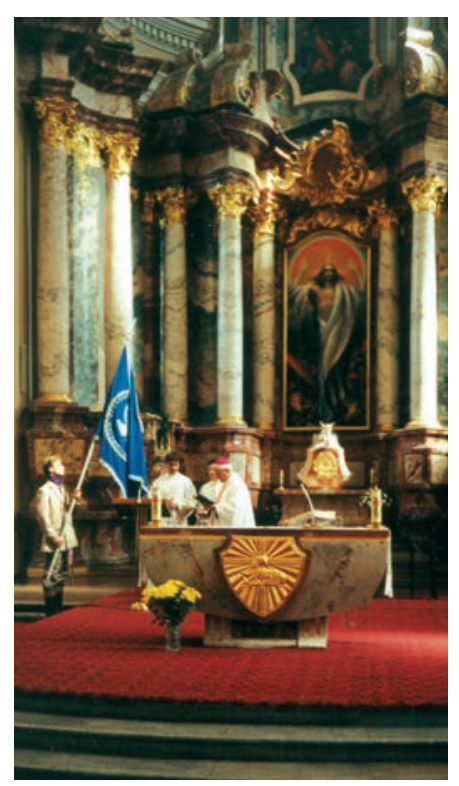

VGTU veliavos pašventinimas Šv. Kazimiero bažnyčioje kad studentai gali padeti igyvendinti ir jo sumanymus. Todel studentu organizacija neretai "aplanko" ivairūs visuomenés veikejai, kurie pateikia juairiausius projektus. Gal ir neblogai, kai sulaukiama idomiu siūlymu. Tik visa beda - dauguma ju studentus mato ne kaip partnerius, bet kaip darbo įranki... Tai dar karta irodo, kad studentas yra vertinamas ne kaip asmenybe, bet tik kaip dalis kažko" [6.3, p. 9].

Gegužès viduryje buvo išleistas 1000-asis „Inžinerijos" numeris. Laikraščio leidejus ir skaitytojus ta proga pasveikino rektorius E. K. Zavadskas:

"Rodos, taip neseniai rankose laikeme pirmaji "Inžinerijos" numeri. Džiaugemès, tikèjomés. Puoselejome gražias viltis. $O$ šiandien jau skaitome tūkstantajz šio laikraščio numeri. Ir vèl džiangiamès, kad „Inžinerija “ visa laika buvo naujos informacijos skleideja, demesinga müsu universiteto gyvenimo metraštininke.

Anglu patarle sako, jog geras priekalas küjo nebijo. Šie žodžiai tinka "Inžinerijai“ - tiksliai apibüdinantys jos kasdienos veikla.

Sveikindami „Inžinerija“" tükstantojo numerio išleidimo proga, linkime jai ir toliau likti visu laukiamunuoširdžziu, turiningu pašnekovu. Didelèskürybinès sèkmes!" [6.4, p. 1].

Prisiminimų žiupsneli jubiliejiniam numeriui pateike doc. A. Lubys. Be kita ko, jis rašè:

"Keitesi „Inžinerijos" vyriausieji redaktoriai. Su viena iš ju man teko ilgiau bendradarbiauti. Tai buvo filosofijos daktare, docente Halina Kobeckaité - aukštos kultūros, dideles erudicijos, gilaus strateginio mastymo asmenybe. 10 metu iki M. Gorbačiovo "perestroikos"su ja bei kitais bendraminčiais pradejome pertvarka VISI, sprendeme savaitraščio „Inžinerija “, taip pat psichologinio klimato, tarpusavio santykiu, bendravimo gerinimo ir kitas problemas.

Skaičiau „Inžinerija“" nuo jos pirmojo iki dabar - tūkstantojo - numerio. Gyvendamas Afrikoje, Prancūzijoje, Rusijoje ir kitur rašiau apie vadyba, Paryžiu, Prancüzijos ekonomika, kultūra, moksla ir švietima. Šiuos straipsnius ir dabar galima rasti laikraščio komplektuose" [6.5, p. 4].

Pačioje balandžio pabaigoje ị tarptautinę konferenciją „Verslas ir vadyba '97“, kurią surenge Vilniaus Gedimino technikos universitetas, susirinko mokslininkai iš Vokie- tijos, Čekijos, Lenkijos, kitų šalių. Ir ne tik mokslininkai. Šikart aktualios temos suvede draugen ir firmu atstovus, praktikus. Buvo aptariamos ne tik verslo ir vadybos problemos Lietuvoje, ekonominés reformos ir rinkos raida, bet ir verslo kultūros klausimai, inovacijų plètojimo Rytų ir Vidurio Europos šalyse tyrimų kryptys.

Konferencijoje perskaityta apie 70 pranešimų.

Vasaros pradžioje Aukštadvario bazejje vyko 2-osios kaimiškosios septynkoves varžybos, kuriose dalyvavo ir Lietuvos Respublikos Prezidentas Algirdas Brazauskas. Prezidentas išbande jègas mesdamas kūjị, diską, ietị, stūmè rutuli bei jị mete per galvą, per šoną, iš apačios. Nors aukštos vietos neužèmé, prezidentas sakè nesigailįs, kad dalyvavo varžybose.

1997 metais VGTU baige 1034 žmonès. 640 absloventu gavo bakalauro diplomą, 72 - inžinieriaus. Dienines studijas baigè 669, vakarines - 5 ir neakivaizdines - 38 . Tais metais pirmąsias bakalaurų laidas išleido Fundamentinių mokslų ir Verslo vadybos fakultetai.

\section{Iteiktas 500-asis magistro diplomas}

LR Vyriausybès Ministras Pirmininkas Gediminas Vagnorius, universiteto rektorius Edmundas Zavadskas 500-ąji magistro diplomą įteikè Metalinių ir medinių konstrukcijų katedros absolventui Dariui Narmontui, kuris baigiamajam darbui panaudojo Boisbuchet (Prancūzija) studentiškos bazès statybos praktikoje igytas žinias, sukauptą patirtį apie metalinių dygliuotų plokštelių pritaikymą statybose.

Rugpjūtį skaudi žinia pasiekè VGTU. Tragiškai žuvo Lietuvos mokslų akademijos viceprezidentas, Technikos mokslų skyriaus pirmininkas, akademikas, habilituotas daktaras, profesorius, VGTU Garbes daktaras Algirdas Žukauskas.

1997 metais studijuoti ị VGTU pirmąji kursą buvo priimti 1542 jaunuoliai, kurie tapo studentais ir 371 - klausytojais.

1997-1998 mokslo metu atidarymas įvyko sostines Šv. Kazimiero bažnyčioje.

Vyskupas Jonas Boruta pašventino VGTU vèliavą, "Gabijos" choras su gera nuotaika giedojo Šv. Mišiose. Vyskupas sakè:

„Visuomenés pesimizmas mažai pagristas. Mes tikrai turime labai gražaus jaunimo, 


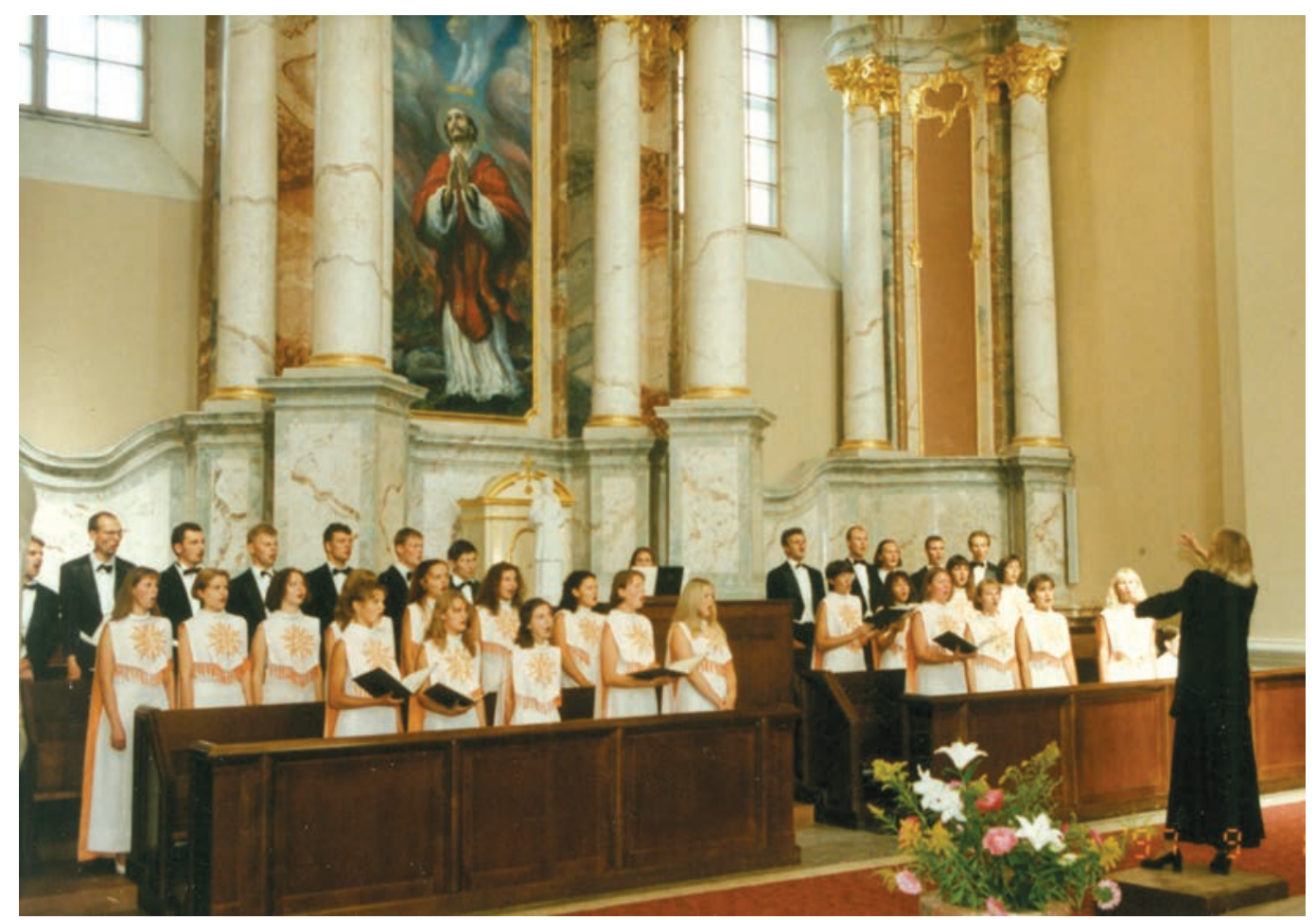

žinančio, kas yra atsakomybè, ir žiūrinčio ij moksla daug rimčiau, negu prieš keleta metu ar sovietmečiu, kai studentai sédédavo aukštosiose mokyklose, noredami tik laika prastumti “ [6.5, p. 1].

Vyskupą J. Borutą papildè rektorius E. K. Zavadskas:

„Gyvenimas parode, kad müsu studentai nelieka nuоšaly nиo kasdienos juykiu, politiniu aktualiju. Kiekvieno destytojo pareiga - mokyti akademini jaunima visa tai kritiškai apmastyti, daryti savas išvadas. Ir tai vyksta savaime. Gilios ir objektyviai perteikiamos destomo dalyko žinios stiprina, plečia studento požiūri z gyvenima, ugdo kritiška logini mastyma" [6.6, p. 1].

Rugsèjo mènesị VGTU èmé leisti jau šeštąji mokslo tarptautinį žurnalą - „Nekilnojamojo turto vertinimas ir investicijos", spausdinamą anglų kalba.

Naujasis žurnalas pradetas leisti neatsitiktinai. Tokio leidinio pageidavo pavasari vykusios tarptautinès konferencijos dalyviai, kurie aptare nekilnojamojo turto vertinimo ir investiciju rinkos sąlygomis klausimus. Vilniaus Gedimino technikos universitetas ne tik išgirdo pageidavimą, bet ir ėmèsi iniciatyvos, kad mokslininkai, praktikai gautu leidinį, kuris gvildentų nūdienai itin svarbius ir reikšmingus klausimus.

Žurnalo redaktoriai - VGTU rektorius, habil. dr. prof. E. K. Zavadskas, Napiero (Didžioji Britanija) universiteto prof. Brianas
Sloanas bei vilnietis mokslininkas dr. A. Kaklauskas. Be šių mokslininkų, redakcinei tarybai priklauso Australijos, Baltarusijos, Bulgarijos, Estijos, JAV, Jugoslavijos, Kroatijos, Latvijos, Lenkijos, Rusijos, Ukrainos, Vengrijos, Vokietijos aukštųjų mokyklų, mokslo institucijų bei keturi VGTU mokslininkai.

1997 m. rugsejo 25 d. Vilniaus Gedimino technikos universiteto tarybos posedyje priimtas nutarimas - švenčiant Architektūros katedros 75-metį ir pažymint joje dirbusio ižymaus architekto Vytauto LandsbergioŽemkalnio nuopelnus Lietuvai, universiteto 05 auditoriją pavadinti architekto Vytauto Landsbergio-Žemkalnio vardu.

Auditoriją puošia šio ir architektūrai, ir pedagogikai, ir žmonèms nusipelniusio profesionalo portretas, jo projektuotu pastatu brežiniai, nuotraukos, pasakojančios apie jo gyvenimą ir kasdienos veiklą.

Iškilmèse dalyvavo bei kartu su E. K. Zavadsku atidenge vardines auditorijos iškabą LR Seimo pirmininkas prof. Vytautas Landsbergis, šio žymaus architekto sūnus. Susirinkusiems jis šiltai, nuoširdžiai papasakojo apie savo tèvą, jo gyvenimą, pažiūras, architektūrinę ir pedagoginę veiklą. Pateikiame jo kalbos ižzangą:

"Mieli kolegos, man labai džiugu pasveikinti Architektūros katedra su sukaktimi. Aš irašiau pora žodžiu i Jüsu stora knyga ir, kaip tyčia, taip ir pasirašiau - architekto sūnus Vytautas Landsbergis. Isties dekkingas esu, kad
$S v$. Kazimiero bažnyčioje gieda "Gabija“ (vad. R. Viskantaite)

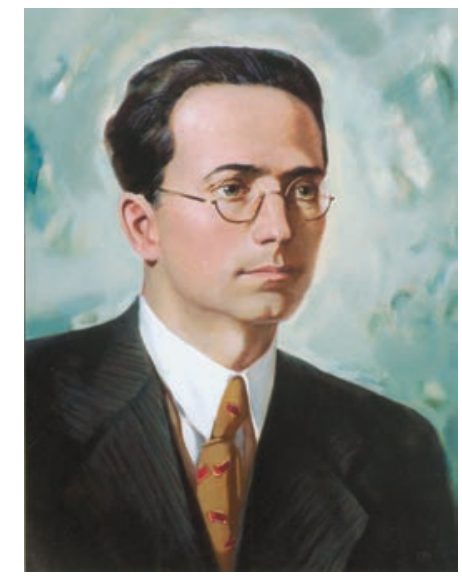

V. Landsbergis-Žemkalnis Dail. J.Grigorovičius 
VILNIAUS

GEDIMINO

TECHNIKOS

UNIVERSITETAS

Dešinëje:

G. Vagnoriaus inanguracijos momentai

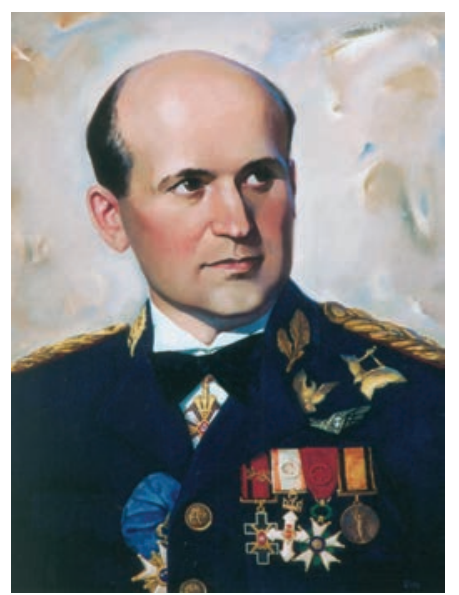

A. Gustaitis Dail. J.Grigorovičius atidaroma mano tevo vardo auditorija. Tegu tas vardas, ši iškaba, visiems, kurie eis koridoriumi, ir kurie ten dirbs, primena ta žmogu, architekta, patriota, kurio darbai turbüt tikrai gali būti pamokantys jauniems būsimiems Lietuvos architektams " [6.7, p.1].

Apie savitos lietuviškos architektūros mokyklos gimimą, jos kelią bei architektus, dirbusius Architektūros katedroje, pranešimą perskaite VGTU Architektūros katedros vedejas doc. Leonidas Ziberkas.

1997 m. spalio 30 d. VGTU centrinëje auditorijoje inauguruotas Vilniaus Gedimino technikos universiteto Garbès daktaru Lietuvos Respublikos Ministras Pirmininkas Gediminas Vagnorius. Vilniaus Gedimino technikos universiteto taryba, pripažindama Lietuvos Respublikos Ministro Pirmininko dr. Gedimino Vagnoriaus nuopelnus ekonomikos mokslui ir šalies mokslo pletrai, 1997 m. liepos 1 d. suteike jam VGTU Garbès daktaro vardą. Jis - dvyliktasis universiteto Garbes daktaras, tačiau vienintelis, baigęs šią aukštąją mokyklą, čia pradejęs savo mokslinę biografiją.

Lietuvos Respublikos Ministrui Pirmininkui dr. G. Vagnoriui įteiktas Garbes daktaro diplomas. VGTU tarybos pirmininkas prof. habil. dr. L. Saulis ir rektorius prof. habil. dr. E. K. Zavadskas apgaube ji iškilminga toga bei įteikè medalị už nuopelnus Vilniaus Gedimino technikos universitetui.

Garbès daktaras savo inauguracinëje kalboje sakè:

„Leiskite nuoširdžiai padekoti už suteikta garbingq varda. Nejaučiu, jog būčiau ji užsitarnavęs. Tokio Jüsu ivertinimo negalèciau sieti su tiesiogine moksline veikla, kuri nutrūko 1990 metais, ar tik su savo asmeniu, nes šalies pertvarkymo darbuose aktyviai dirbo dešimtys ir šimtai specialistu. Man ypač malonu, jog valstybes atkürimo reikalams sukurtoms vyriausybinems darbo grupems vadovavo ir Vilniaus Gedimino technikos universiteto destytojai ir aukletiniai, jog visuomenines santvarkos permainoms müsu VISI (taip jis anksčiau vadinamas) buvo pasirengęs ne blogiau už kitas aukštasias mokyklas. Labai noretusi už visa tai padekoti atskirai kiekvienam iš Jüsu.

Ši garbingq varda galéciau priimti ne kaip kokios nors veiklos pripažinimo ženkla, bet tik kaip Jūsu man duodama papildoma ipareigojima ateičiai - visas kuklias žinias ir likusius energijos išteklius pagal išgales panaudoti prasmingiems bendriems darbams arba kaip draugiška perspejima pernelyg ilgai neužsibüti valstybes tarnybose" $[6.8$, p. 3$]$.

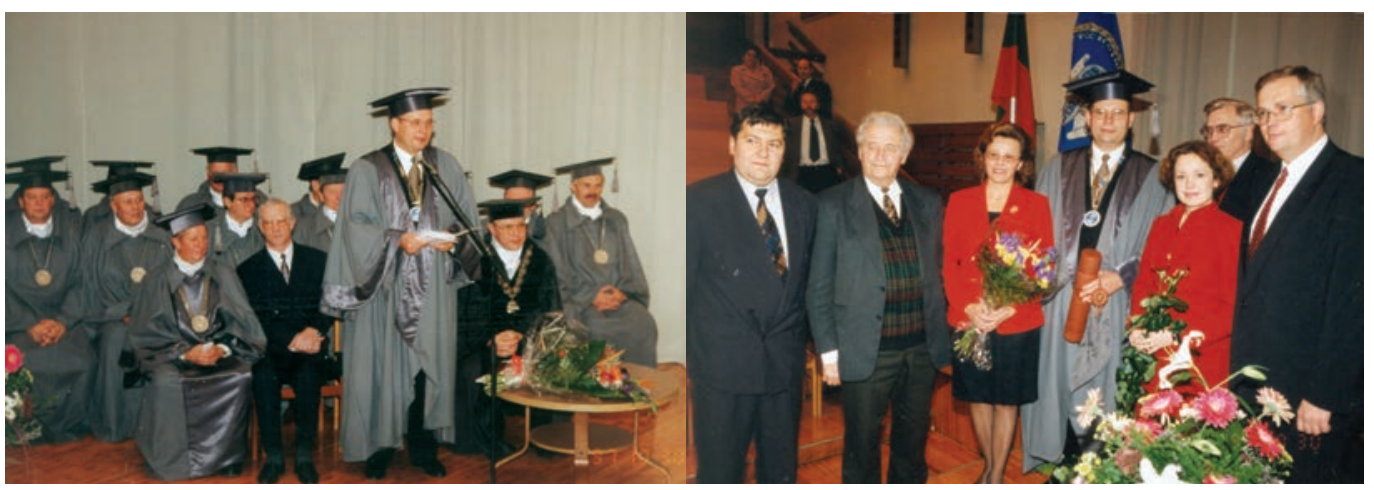

\section{Aviacijos institutui - Antano Gustaičio vardas}

1997 m. lapkričio 13 d. Vilniaus Gedimino technikos universiteto taryba, pažymit didelius brigados generolo, aviacijos konstruktoriaus ir lakūno Antano Gustaičio nuopelnus Lietuvos aviacijai, A. Gustaičio 100-ųjų gimimo metinių proga nutare suteikti VGTU Aviacijos institutui Antano
Gustaičio vardą ir toliau vadinti ji Antano Gustaičio aviacijos institutu.

Gruodžio $10 \mathrm{~d}$. VGTU centrinëje auditorijoje (03) įvyko susitikimas su Lietuvos Respublikos Seimo pirmininku, kandidatu i Lietuvos Respublikos Prezidentus Vytautu Landsbergiu. 
VGTU statybos mokslų muziejuje buvo atidaryta paroda „Architektas, inžinierius Vytautas Landsbergis-Žemkalnis ir jo darby konstruktoriai" bei pristatyta Algimanto Nako to paties pavadinimo knyga.

1997 metams baigiantis Verslo vadybos fakulteto dekanas R. Ginevičius „Inžinerijoje" rašè, kad Tarptautinis studijų kokybès vertinimo centras gerai ịvertino fakulteto studijų programas, o kai kuriuos jų komponentus pavadino pavyzdiniais.

Vilniaus Gedimino technikos universiteto ženklas $1997 \mathrm{~m}$. buvo įregistruotas $\mathrm{LR}$ valstybiniame patentų biure ir išduotas ženklo liudijimas Nr. 24178. Tai reiškia, kad ši ženklą saugo Lietuvos Respublikos prekių ir paslaugu ženklų įstatymas, kad VGTU ženklas yra įrašytas į Lietuvos Respublikos prekių ir paslaugu ženklų registrą. Ši ženklą-herbą sukūre dailininke Irena Vabaliene.

Gruodžio $31 \mathrm{~d}$. po sunkios ligos mire daug metų dirbęs VGTU (VISI) Matematikos katedros vedeju profesorius Vytautas Liutikas. 1992-1996 m. jis buvo Lietuvos Respublikos Seimo nariu. Prezidentas A. Brazauskas apie V. Liutiką sake: „Savo gyvenima paskyręs jaunosios kartos ugdymui, $V$. Liutikas pasiliks visu atmintyje kaip vienas iš švietimo pertvarkos iniciatoriu, turintis aktyvia pozicija visuomeniniame-politiniame gyvenime“.

Sutinkant Naujuosius 1998 m. VGTU pasveikino Lietuvos Respublikos Prezidentas

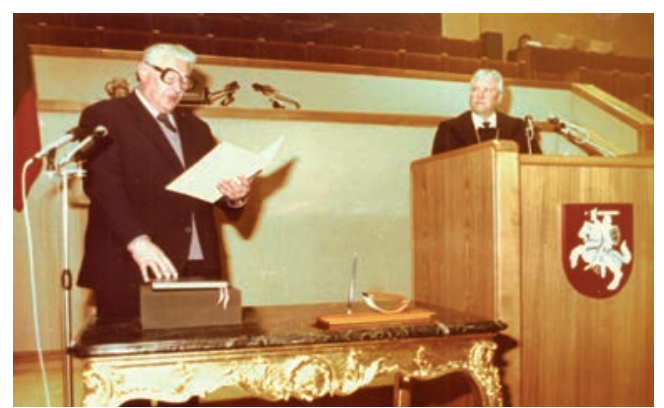

Algirdas Brazauskas, Lietuvos Respublikos Ministras Pirmininkas Gediminas Vagnorius ir kt. G. Vagnorius kvietè nepagailèti pastangų, kad 1998-ieji - jubiliejiniai Lietuvos valstybès metai - būtų sèkmingi visiems tèvynainiams.

1998 m. sausio 3 dieną, baigdamas aštuoniasdešimt trečiuosius metus, po ilgos sunkios ligos mire VGTU profesorius, habilituotas daktaras, ilgametis Urbanistikos katedros vedejas Kazys Šešelgis.

VGTU neteko šviesaus, garbingo Žmogaus, Lietuvos architektūros patriarcho, sukūrusio plačiai išgarsëjusią teritorijų planavimo, urbanistikos mokyklą, išauginusio ištisą plejadą mokslininku - daktarų ir habilituotų daktarų.

Pirmoje sausio puseje VGTU pirmasis prorektorius doc. Algirdas Valiulis Baltijos valstybių (Lietuvos, Latvijos, Estijos) ir Švedijos technikos universitetu (Lundo, Linčiopingo, Stokholmo) strateginio konsorciumo BALTEC steigiamojo komiteto pirmasis susitikimas.

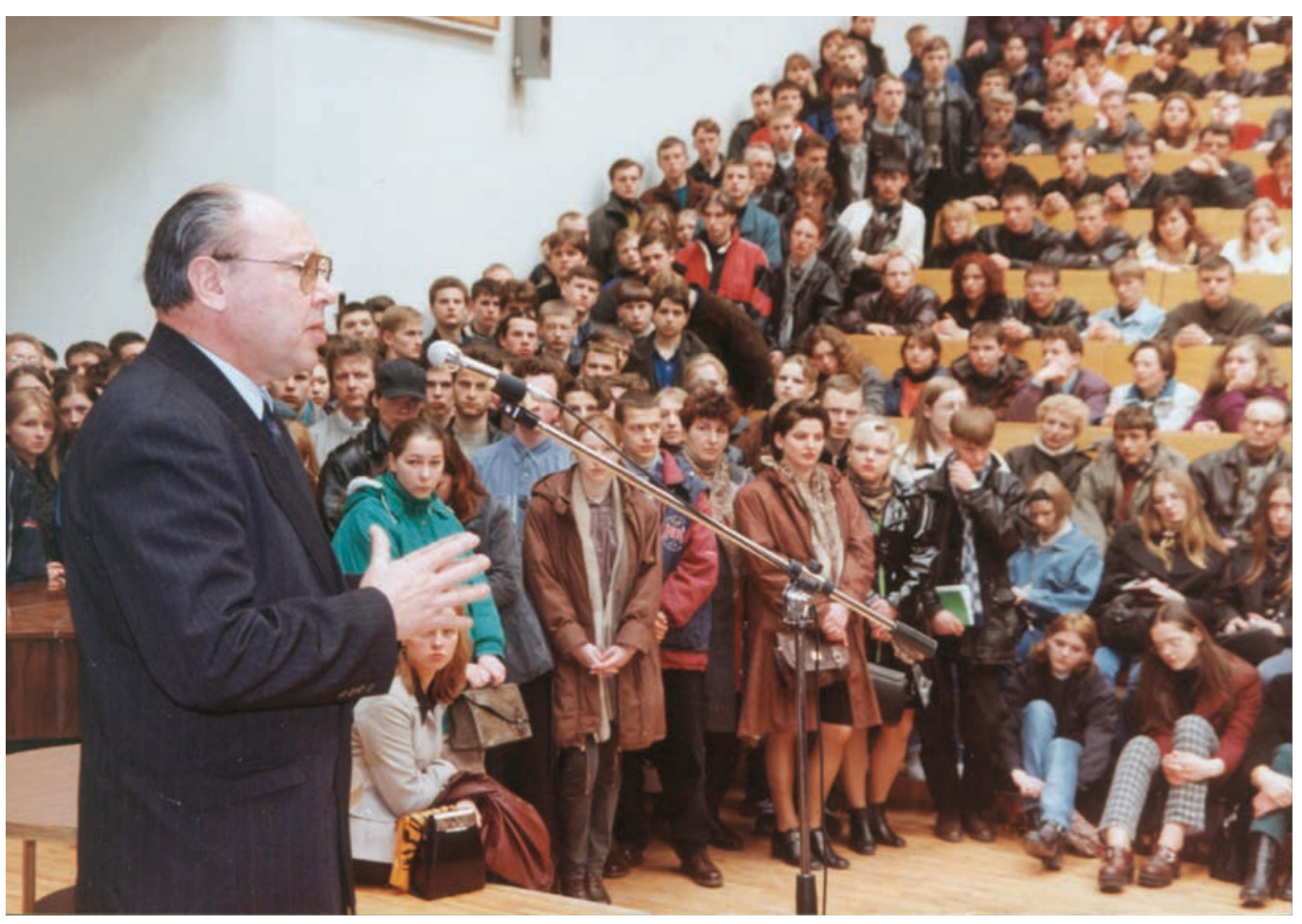


VILNIAUS

GEDIMINO

TECHNIKOS

UNIVERSITETAS

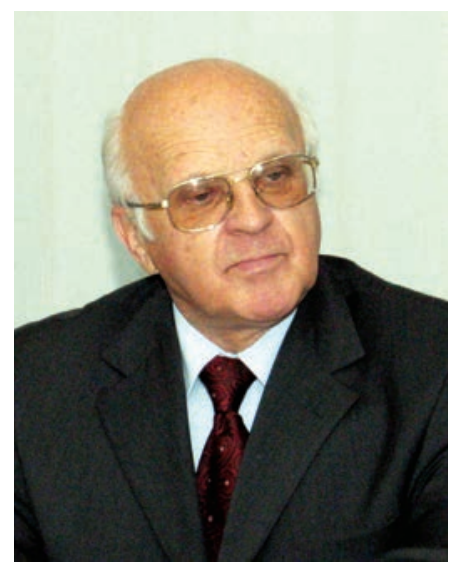

A. Š Šrtakauskas VGTU Garbés narys

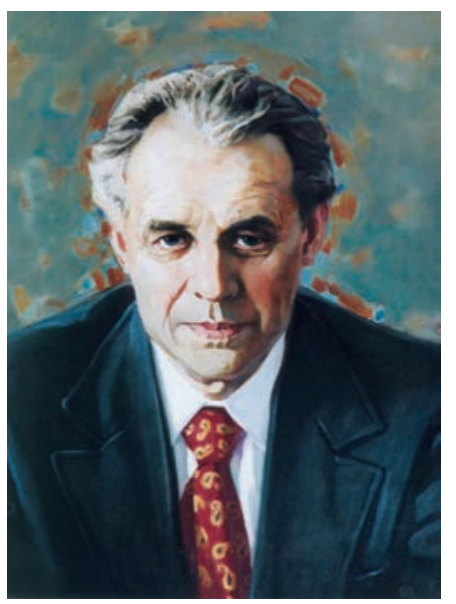

A. Žukauskas VGTU Garbes daktaras
Viršuje dešinèje -

Monsinjoras K. Vasiliauskas VGTU Garbés narys
Ketinimų protokolas įkurti ši konsorciumą minetų institucijų pasirašytas $1997 \mathrm{~m}$. gegužę Kaune. Šio konsorciumo įkūrimo tikslas - plètoti technikos universitetu bendradarbiavimą universitetų vadybos ir infrastruktūros vystymo, tarpuniversitetinių tinkly kūrimo, studentų, akademinio ir administracinio mokymo kokybès gerinimo, bendru orientuotų problemų tyrimų pletros, konferenciju ir seminarų rengimo srityse.

Tolesneje perspektyvoje šis bendradarbiavimas turejo išsivystyti įvirtualų „Baltijos technologijos ir gamtos mokslų universitetą“, jungiantị šalių apie Baltijos jūrą technikos universitetus.

Vasario mènesį VGTU Garbès nario vardai buvo suteikti monsinjorui Kazimierui Vasiliauskui ir Lietuvos statybininku asociacijos prezidentui Adakrui Šeštakauskui. VGTU taryboje buvo sakoma, kad monsinjoras Kazimieras Vasiliauskas jau penkerius metus gražiai, turiningai bičiuliaujasi su mūsu universitetu. Jis dalyvavo daugelyje mūsu renginių, pašventino pirmąją mūsų vèliavą, Sausio 13-osios didvyrio Rolando Jankausko memorialinę lentą. Jo nepaprastos šilumos ir geranoriškumo kupinus žodžius girdejome organizuojant judejimą „Pagražinkime Lietuvą" bei atidarant akademiko Algirdo Žukausko vardo Šilumos mainų mokomąją laboratoriją.

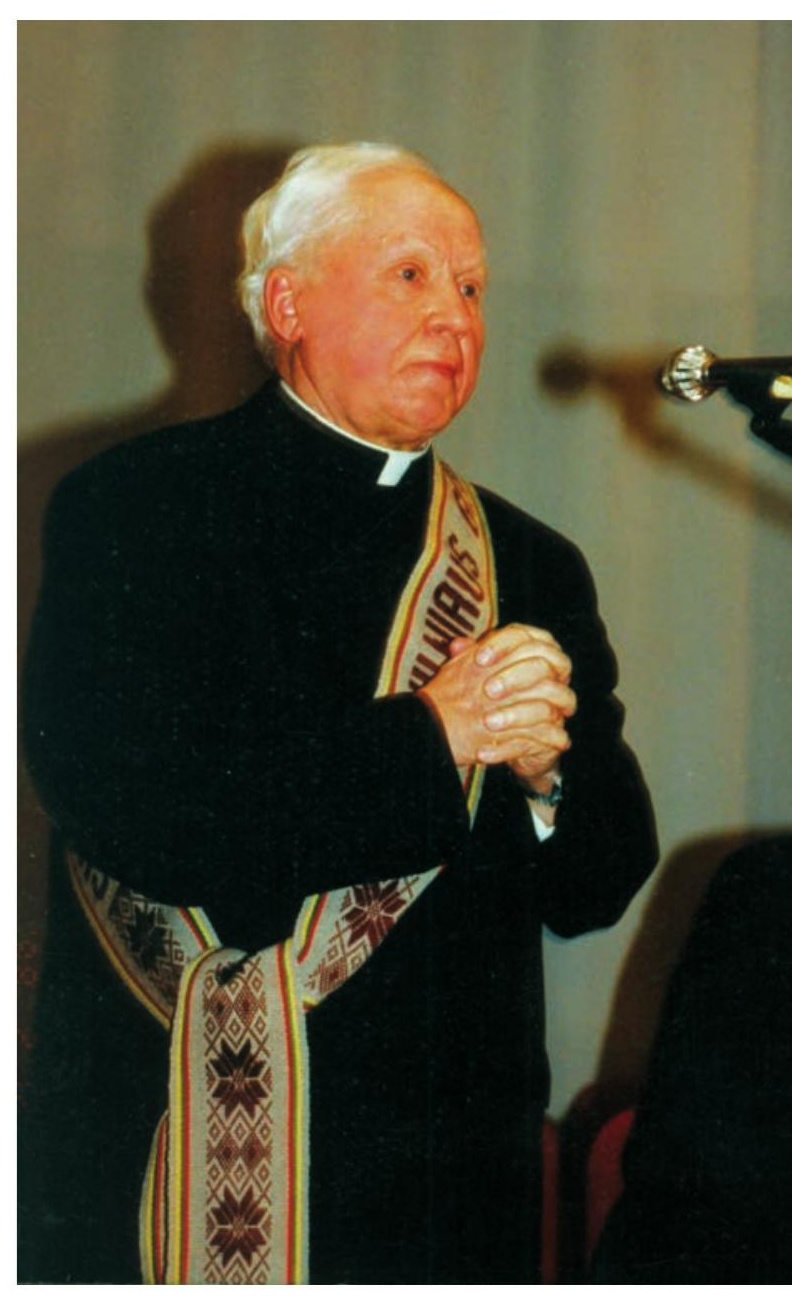

Lietuvos statybininkų asociacijos prezidentas Adakras Šeštakauskas nuolat dalyvauja mūsų renginiuose, padeda spręsti studentų praktikų organizacinius klausimus, remia mūsų reprezentacinę leidybą.

\section{Rektorius E. K. Zavadskas - dar vienai kadencijai}

1998 m. vasarị baigèsi prof. E. K. Zavadsko rektoriavimo kadencija. VGTU senatas surenge naujus rektoriaus rinkimus vasario $24 \mathrm{~d}$. Kandidatais i rektoriaus postą užsiregistravo trys asmenys: jau ejęs rektoriaus pareigas Lietuvos mokslu akademijos narys korespondentas prof. habil. dr. Edmundas Kazimieras Zavadskas, akademikas prof. habil. dr. Antanas Kudzys ir dr. doc. Rimantas Čechavičius.

Visų triju kandidatų rinkiminès programos turëjo esminiu skirtumy tiek turinio, tiek apimties atžvilgiu.

E. K. Zavadskas savo programoje suformulavo technikos universiteto misiją, uni- versiteto tarybos ir rektoriaus uždavinius, pagrindinius rektoriaus veiklos tikslus. Jis numate stiprinti universiteto bendruomenę, remdamasis demokratijos ir humanizmo idèjomis.

A. Kudzys ketino tvirtai laikytis principo, kad būtų viena nuo kitos atskirtos universiteto ir vykdomosios institucijos bei pripažinti, kad pagrindinè valdžia universitete svarbos tvarka priklauso visuotiniam mokslininku susirinkimui, universiteto tarybai ir fakultetu taryboms.

R. Čechavičius teigè, kad „universitete ypač svarbu puoseleti žmogaus laisvę, gerbti jo oruma, skatinti iniciatyva $\langle\ldots\rangle$. Universitete 
bütina nuomoniu ivairove, tolerancija ir pagarba kitokiai minčiai. Universitetas turi büti demokratijos židiniu: jo rektorius, dekanai turi büti renkami visuotiniuose susirinkimuose, $k u$ riuose balso teise turi tureti ne tik mokslininkai, bet ir pedagogu bei studentu atstovai ".

Taryba neįžvelgè A. Kudzio ir R. Čechavičiaus programose naujumo ar originalumo. Rektoriaus E. K. Zavadsko praktinè 8 metų vadovavimo universitetui veikla įrode jo didelę potenciją dar ketveriems metams. Tarybos slapto balsavimo rezultatai buvo įtikinami: už E. K. Zavadską - 40 balsų, už A. Kudzị - 3 balsai, už R. Čechavičiu - 0 balsų.

Prieš keletą savaičių vykusiame Tarybos posedyje rektorius E. K. Zavadskas pateike paskutinių kadencijos metu ataskaitą, kurioje pabrežè, kad pirmineje programoje numatyta ir vienbalsiai priimta universiteto strategija praktikoje tik išplèté, o ne pakeitè pagrindinius tikslus. Tai-studentų skaičiaus didinimas, daugiapakopés studiju sistemos ittvirtinimas, studijų sistemos ir programų tobulinimas, humanizavimas, fundamentiniu pagrindų išplètimas, tarptautinès patirties taikymas ir bendradarbiavimo plètimas, nauju studiju programų įvedimas, įvertinant šalies poreikius aktualiems moksliniams tyrimams plètoti - pastangos siekti atviro Vilniaus technikos universiteto.

Švietimo ir mokslo ministerijoje buvo užregistruotos 41 pirmosios studiju pakopos programa (specialybès, neįskaitant specializacijų) ir 61 specializacija, 35 magistrantūros programos ir 33 specializuotų profesiniu studijų programos.

$1990 \mathrm{~m}$. reformos pradžioje buvo 19 programų, 1991 m. - tik 6, 1992 m. - tik 7. Paskui, siekiant kuo geriau patenkinti šalies poreikius, programų sparčiai daugëjo.

$1997 \mathrm{~m}$. buvo turimos 78 magistrantūros studijų ir 51 specializuotų profesinių studiju programos (specializacija). VGTU renge humanitarinių (architektūra), socialinių, matematikos, gamtos ir plataus spektro technikos mokslų visų studijų pakopų specialistus.

Kasmet didejo mokslo tiriamųjų darbų ir paslaugu apimtys: per ketverius metus jos išaugo beveik keturis kartus. VGTU mokslininkai ịsitrauke ir sèkmingai dirbo įvairiose tarptautinèse programose, pateikè konkrečiu siūlymų porai tarptautinių programų projektų. Buvo surengta 10 tarptautinių konferenciju, 1 tarptautinis seminaras, 1 tarptautinis kolokviumas, 10 respublikinių mokslinių

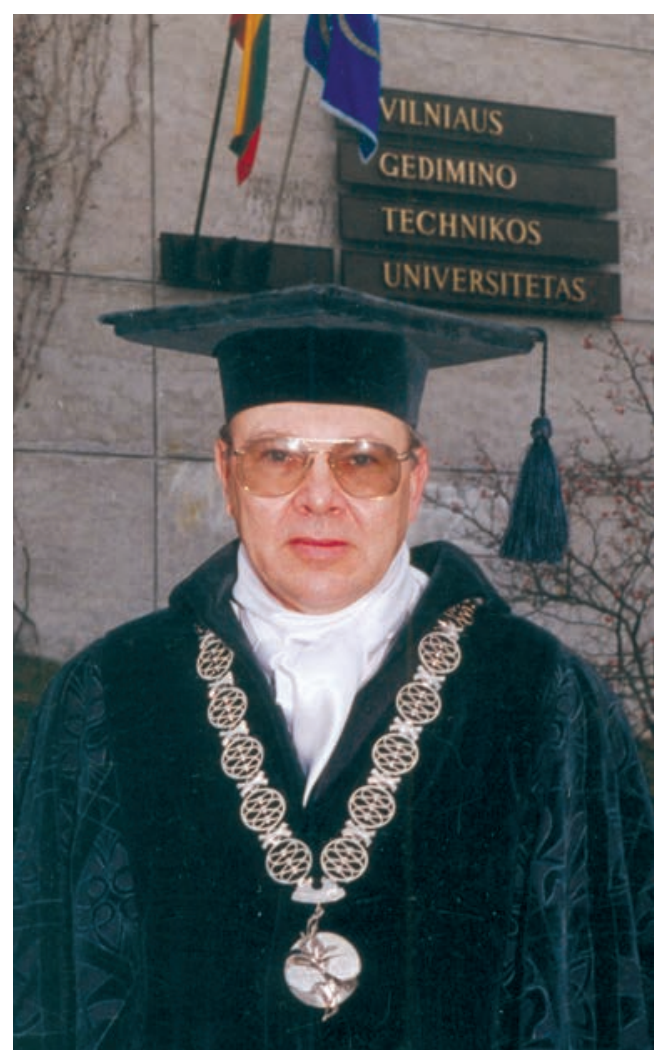

Rektorius E. K. Zavadskas išrinktas naujai kadencijai konferenciju ir 1 respublikinis seminaras. Daugèjo dvišalių tarptautinių bendradarbiavimo sutarčių, išsiplète ju geografija.

Ir visi kiti Vilniaus Gedimino technikos universiteto veiklos rodikliai rode pažangą, novatoriškumą. Visa tai ir nuleme praktiškai vieningą VGTU tarybos narių pasirinkimą rektoriumi dar vienai kadencijai išrinkti prof. E. K. Zavadską.

\section{Gerbiami nusipelne tautai ir technikai}

Rektoriaus novatoriškumui galima priskirti ir jo entuziastingą norą pagerbti Lietuvos technikos pažangai, lietuvių tautai daug nusipelniusias asmenybes.

Vasario $12 \mathrm{~d}$., minint Lietuvos valstybes atkūrimo dienos aštuoniasdešimtmeti, į VGTU atvyko visų labai mégiamas ir gerbiamas monsinjoras Kazimieras Vasiliauskas, Lietuvos Respublikos Seimo pirmininko pavaduotojas Arvydas Vidžiūnas, socialinès apsaugos ir darbo ministrė Irena Degutienè, viceministras Rimantas Karvelis, Lietuvos Respublikos Prezidento patarejas Arvydas Matulionis. Renginyje Vasario 16-osios 80-mečio proga pranešimą perskaite A. Vidžiūnas. VGTU tarybos pirmininkas prof. Leonas Saulis perskaite $1998 \mathrm{~m}$. vasario $5 \mathrm{~d}$. Tarybos nutarimą, kuriuo monsinjorui Kazimierui Vasiliauskui

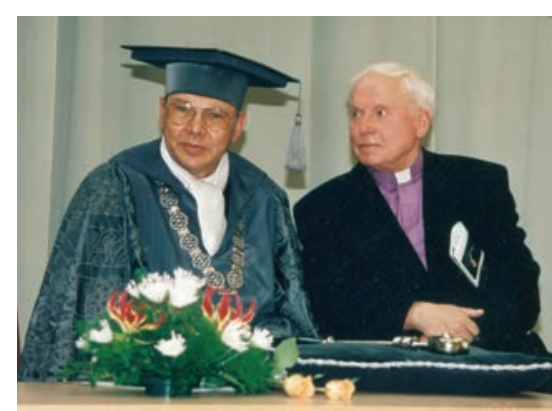

E. K. Zavadskas ir K. Vasiliauskas 
VILNIAUS

GEDIMINO

TECHNIKOS

UNIVERSITETAS
Viršuje dešinèje -

$P$. Vileisio auditorijos atidarymas Vasario 16-aja už nuopelnus VGTU buvo suteiktas šio universiteto Garbès nario vardas. Monsinjoras K. Vasiliauskas, nuoširdžiai padèkojęs, pasakojo, kaip jam teko švęsti Vasario 16-ąją lageryje, kaip giedodavo Lietuvos himną, kviete mylèti tiesą, grožį ir gèrị, linkëjo visiems vienybès. Renginio metu buvo atidaryta vieno didžiausių kovotojų už tautinị atgimimą, už Lietuvos laisvę ir nepriklausomybę, žymaus geležinkelių ir tiltų statytojo, kelių inžinieriaus Petro Vileišio auditorija. Kalbëjęs apie P. Vileišį A. Nakas pabrežè, kad Petras Vileišis nenuilstamai žadino tautini atgimimą, savo lešomis lietuviškos spaudos draudimo laikais lietuvių kalba išleido apie šimtą įvairaus turinio knygelių, leido pirmąj̨ lietuvišką dienraštic „Vilniaus žinios“, rèmé lietuvių kultūrinius renginius, siekè lietuvinti Vilnių, materialiai remè žymius atgimimo veikejjus, tokius kaip Joną Basanavičių, Antaną Smetoną ir kt.

P. Vileišio auditoriją pašventino monsinjoras K. Vasiliauskas, rektorius E. K. Zavadskas ir Tarybos pirmininkas L. Saulis atidenge auditorijos iškabą. Auditorijoje kabo dailininko J. Grigorovičiaus nutapytas portretas, įrengta inžinieriaus darbų ekspozicija.

Rektoriui E. K. Zavadskui palaikant ar paties iniciatyva VGTU dabar yra daug šaliai nusipelniusių žmonių vardais pavadintų auditorijų ar laboratorijų. Tai yra puikiausia

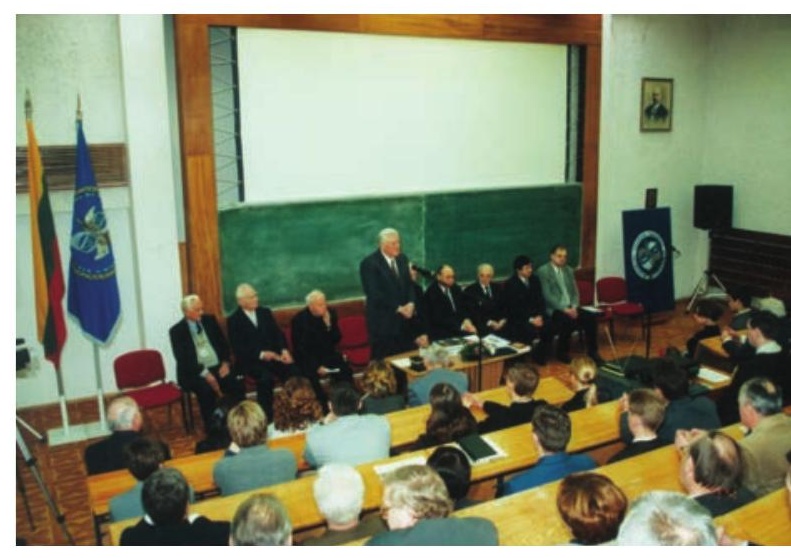

patriotizmą ugdanti priemonè. Ji studentams žadina norą domètis savojo krašto praeitimi, savosios tautos laimejimais. Antraip, anot B. Railos, "Jis mokes tik žavetis ir girtis svetimais blizgučiais ir savo tautai bus tuščias pasipūtelis ar visai ja nutrūks. Iš tokio mūsu tauta mažai teturés naudos, ypač jos sunkiaisiais laikais..." [6.9, p. 419].

Gražią iniciatyvą parode Statybos fakultetas. Viena VGTU antro kurso grupe kai kurias disciplinas (modulius) pradèjo studijuoti prancūzų kalba. Studijų prancūzų kalba tikslas - gana gerai išmokti prancūzų, ypač techninę, kalbą, vyresniuose kursuose dalyvauti tarptautinèse studiju programose TEMPUS, SOCRATES, LEONARDO, veliau tęsti studijas Prancūzijos ar Belgijos universitetuose - planuojamos semestro trukmés studijos užsienyje, geriau pasirengti darbui Lietuvoje steigiamose bendrose su prancūzais imonèse.

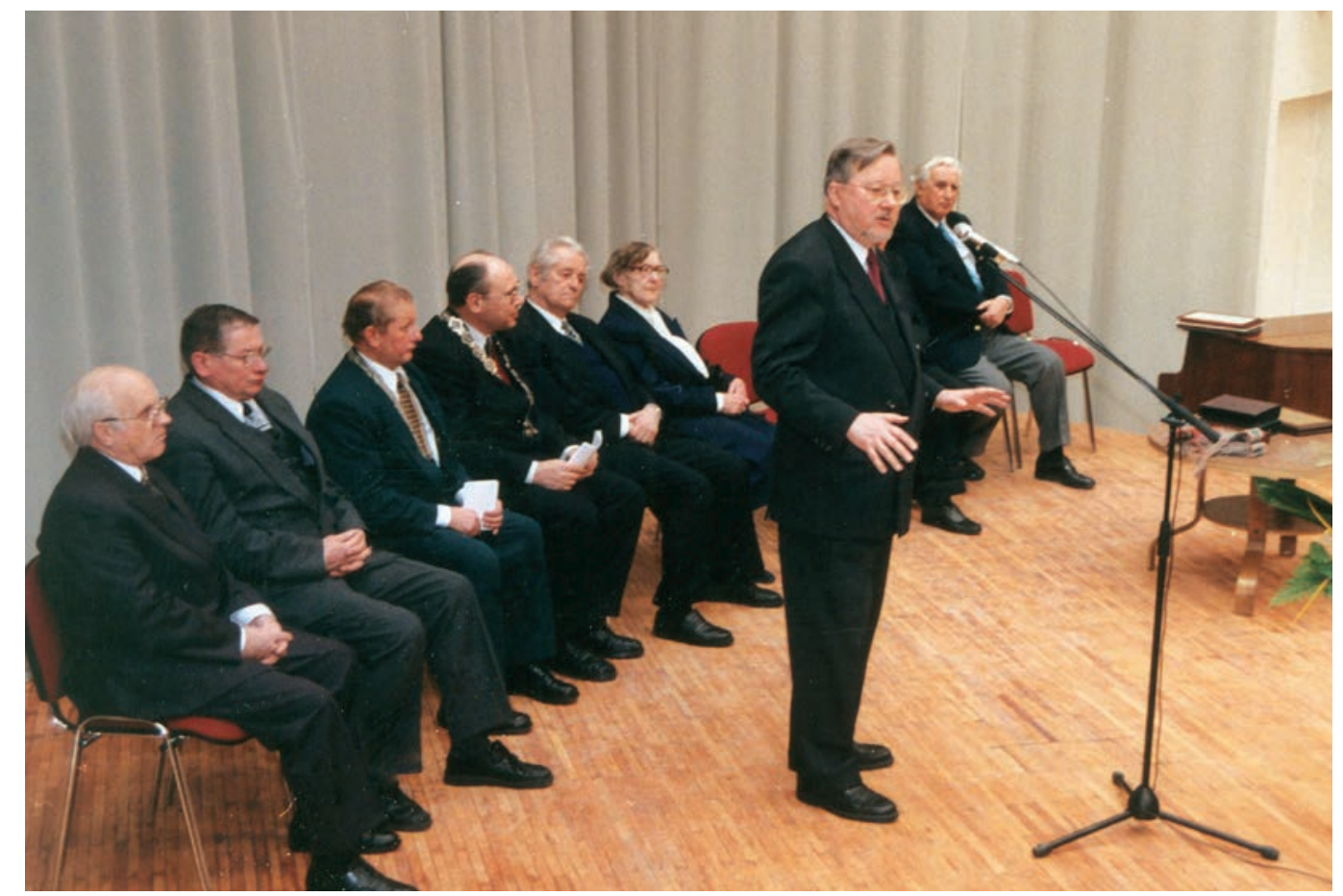




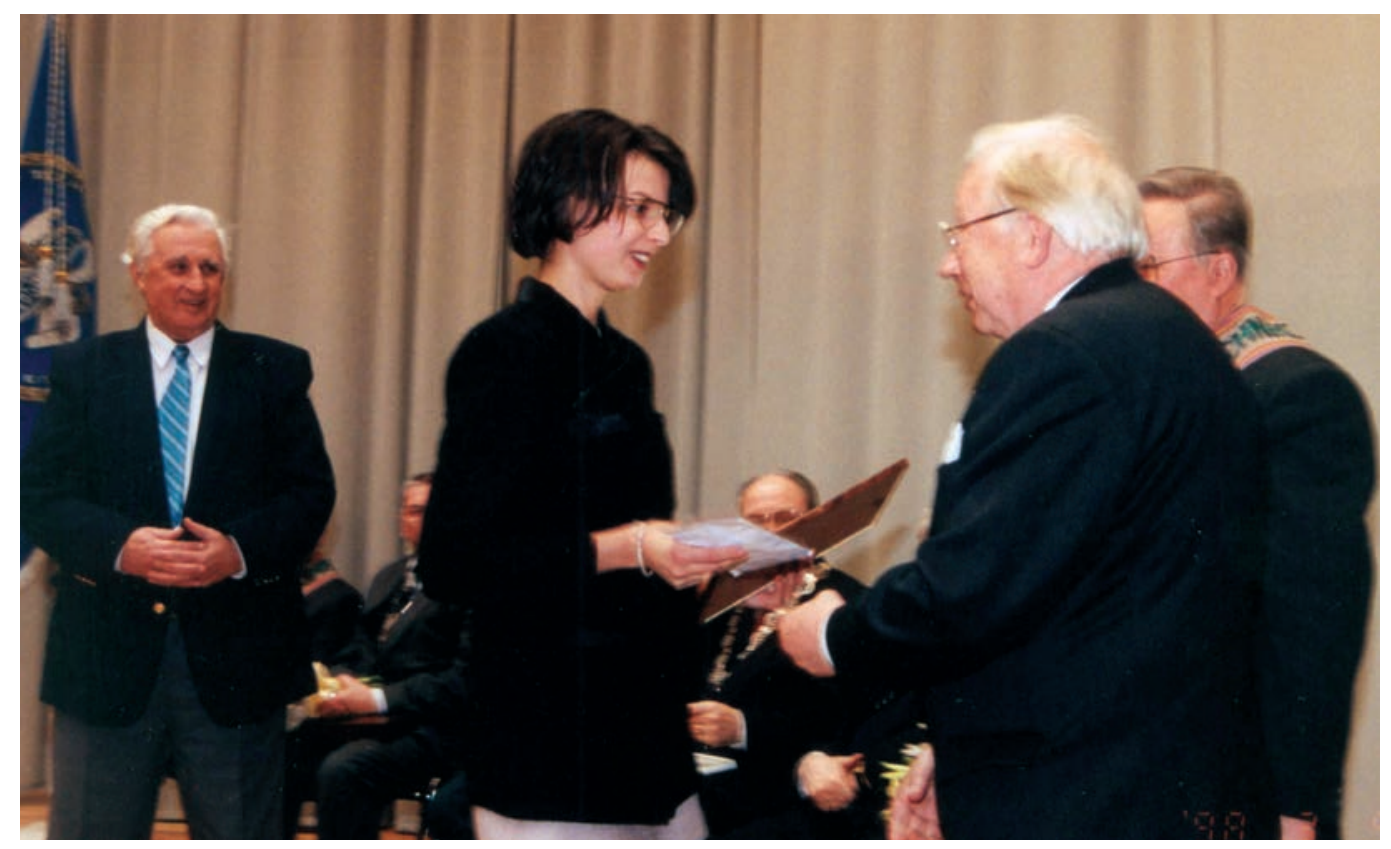

G. Žemkalnis j̇teikia stipendija

R. Vaineikytei
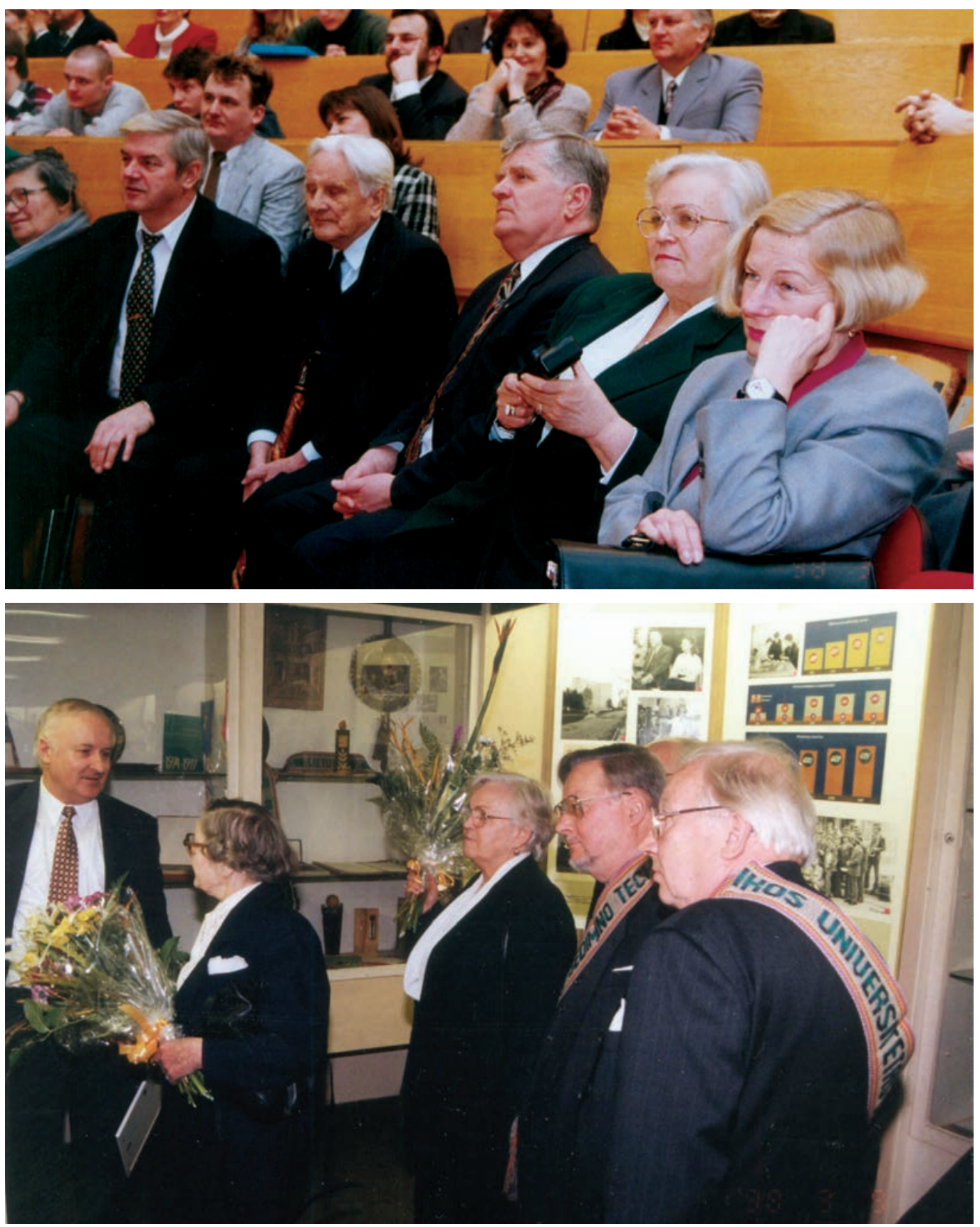

Svečiai aplanke VGTU

Statybos moksly muzieju

\section{Minejjimo metu}


VILNIAUS

GEDIMINO

TECHNIKOS

UNIVERSITETAS
Buvo ir daugiau gražių studentų laimèjimų. Šauniai pasirodè VGTU lengvaatlečiai Lietuvos lengvosios atletikos uždarų patalpu čempionate. Verslo vadybos fakulteto antrakursè Dalia Leonavičiūte tapo šuolių į aukštị čempione, AGAI antrakursis Mindaugas Staleriūnas laimëjo $800 \mathrm{~m}$ bègimo bronzos medalį.

İspūdingas buvo Vilniaus Gedimino technikos universitete Kovo 11-osios - Lietuvos Nepriklausomybès atkūrimo dienos minèjimas. Jame dalyvavo Lietuvos Respublikos Seimo pirmininkas Vytautas Landsbergis, švietimo ir mokslo ministras Zigmas Zinkevičius, Pasaulio lietuvių bendruomenès atstovas Seime Gabrielius Landsbergis, žymūs Lietuvos architektai Leonardas Vaitys, Algimantas Nasvytis ir kt.

Tą dieną profesoriui Vytautui Landsbergiui ir Lietuvos statybininkų asociacijos prezidentui Adakrui Šeštakauskui buvo įteiktos VGTU Garbès nario regalijos. Medaliu „Už nuopelnus Vilniaus Gedimino technikos universitetui" buvo apdovanotas tos pačios asociacijos generalinis direktorius Jonas Jakimavičius.

Izžymaus Lietuvos architekto Vytauto Landsbergio-Žemkalnio vaikų kartu su Lietuvos architektų sąjunga ịsteigta Vytauto Landsbergio-Žemkalnio fondo stipendija buvo paskirta VGTU magistrantei Rusnai Vaineikytei už darbą „Rekreacinis kompleksas Šventojoje“ (vadovas prof. V. Dičius). Ji ir buvo įteikta renginio metu.

\section{Mokslo premija elektronikams}

Kovo menesi buvo dar vienas labai malonus universitetui įvykis. 1997 metų Lietuvos mokslo premija buvo įteikta šešiems VGTU Elektronikos fakulteto mokslininkams už darbą „Plačiajuosčiai elektroniniai ittaisai informacijos apdorojimo sistemoms (teorija, modeliavimas ir taikymas)“. Šio darbu ciklo autoriai - Z. Vainoris, R. Kirvaitis, S. Štaras, J. Stankūnas, R. Martavičius, J. Skudutis.

İvyko VGTU vadovybès permainų. Mokslo prorektoriumi buvo patvirtintas prof. habil. dr. Rimantas Kačianauskas, studijų prorektoriumi - doc. dr. Alfonsas Daniū- nas, infrastruktūros ir užsienio ryšių prorektoriumi - doc. habil. dr. Algirdas Valiulis, administracijos prorektoriumi - doc. dr. Arūnas Komka.

1998 m. balandį išleista „Inžinerija“, skirta abiturientams. Joje rektorius prof. E. K. Zavadskas šiltai kreipesi ị abiturientus, atskleisdamas inžinieriaus profesijos žavesį, pristatydamas didelę VGTU rengiamų specialybių ir specializaciju gamą. Rektorius, baigdamas straipsnį, raše: „Pasirinkęs viena iš müsu universiteto siūlomu studiju programu (specialybę), Tu, mielas abituriente, gerai pasirengsi savarankiškam gyvenimui. Neabejoju, kad gavus inžinieriaus ar kita mūsu universiteto išduodama diploma, tavo gyvenimas taps idomus ir turiningas. Visa kasdienè veikla busnaudinga müsu tautai, valstybei “ $[6.10$, p. 2].

Gegužès $28 \mathrm{~d}$. VGTU įvyko iškilmingas susirinkimas, kuriame buvo paminetas Lietuvos Sąjūdžio įkūrimo dešimtmetis. Susirinkime dalyvavo LRS pirmininkas Vytautas Landsbergis

„Tiketi ateitimi - jaunu žmoniu jausmas. O Sajūdis, visi jo dalyviai tikejo ateitimi, todel mus visus užliejo jaunystés banga, nepaisant kiek kam tada buvo metu", - akcentavo Seimo pirmininkas.

Rektoratas ir Taryba aktyviausius universiteto sąjūdiečius - profesorius A. Čižą, R. Dineiką, E. K. Zavadską, docentus, asistentus L. Furmonavičių, V. Būdą, K. Valašimą, A. Čiučeli, S. Glebų, B. Užpolevičių, V. Jasulaitį, Z. Pociu, J. Srébalių, A. Kaminską, J. Lekevičių, K. Vislavičių apdovanojo knygomis, kuriose jų autorius $V$. Landsbergis noriai pasirašè.

Iškilmingas susirinkimas, skirtas Sąūidžio dešimtmečiui paminèti, baigesi vieno iš aktyviausių šio visuomeninio judejjimo dalyvių, Kovo 11-osios Nepriklausomybes Akto signataro prof. Kazimiero Antanavičiaus atminimo lentos atidengimu. Velionio gyvenimą ir veiklą apibūdino doc. R. Ginevičius.

Iškilmingame susirinkime taip pat dalyvavo Seimo kancleris Jurgis Razma. Kartu su visais dainavo ir "Gabijos" choristai $[6.11$, p. 2].

Gegužès pabaigoje Aukštadvaryje vyko tradicinès lengvaatlečių varžybos. Rungtyniavo Lietuvos metiku veteranai VGTU rektoriaus taurei laimeti. Tarp dalyvių buvo daug sporto veteranu - buvusių čempionų ir rekordininkų. Tik kaip svečias ši kartą dalyvavo Prezidentas Algirdas Brazauskas, dažnas šių varžybų dalyvis. 


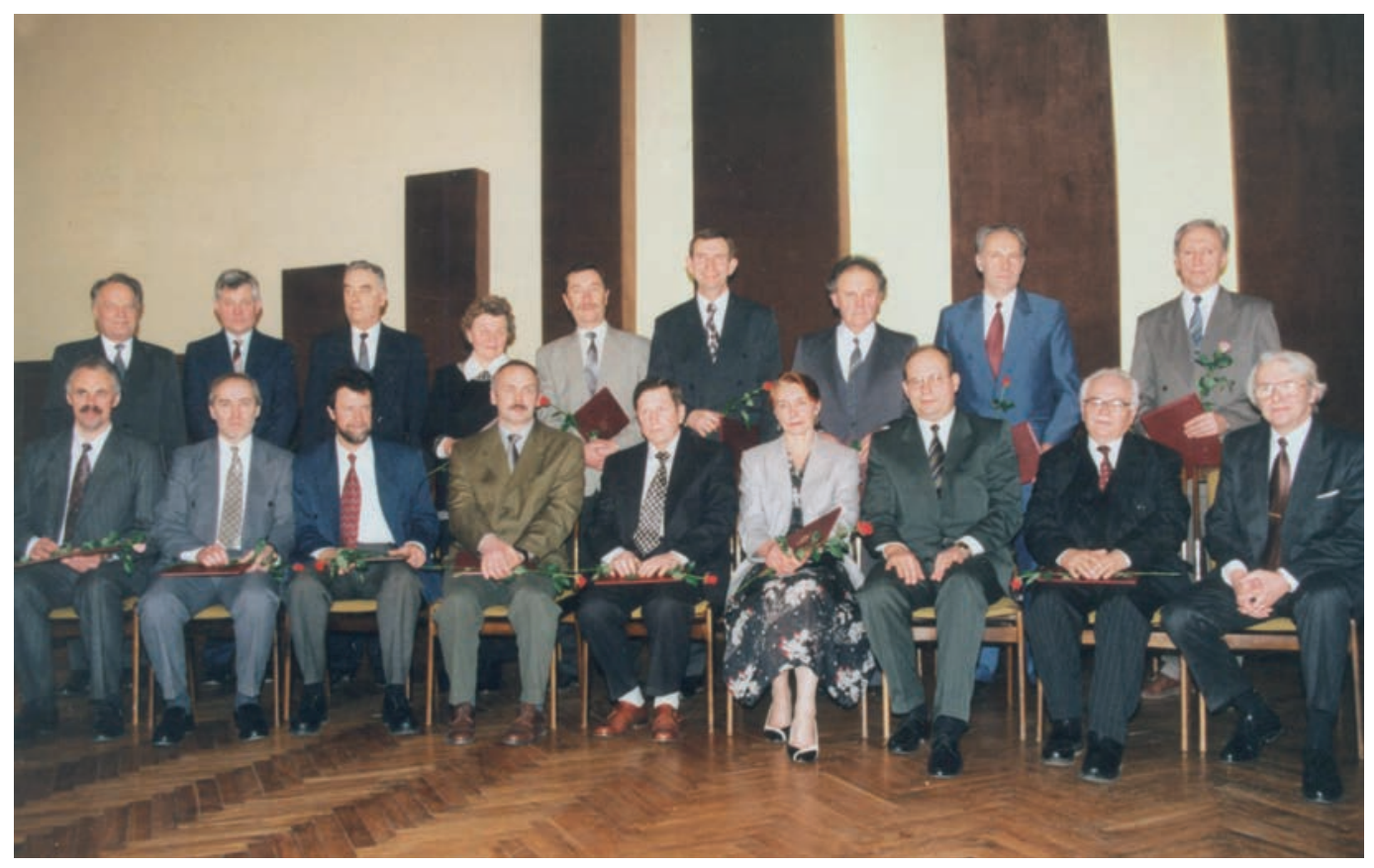

1998 metų Lietuvos studentų krepšinio lygos čempionate VGTU komanda laimëjo bronzos medalius. VGTU pralenke tik LKKI ir VU rinktines.

1998 m. Vilniaus Gedimino technikos universiteto pagrindines studijas baige 825 žmonés, antros pakopos studijas - 358 žmonès, o iš viso 1183 jaunuoliai ir merginos. Daugiausia absolventų parengè Verslo vadybos fakultetas - 246. Aplinkos inžinerijos fakultetą baige 211, Statybos - 193, Transporto inžinerijos - 135, kitus - 60-90 žmonių.

Vasarą, vykdant priemimą i pirmajị kursą, studentais tapo 2921 žmogus.

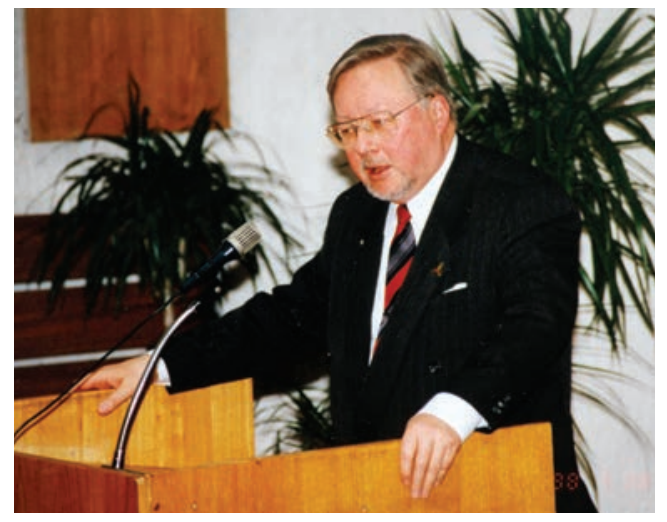

Rugpjūčio 12-18 dienomis VGTU vyko 7-oji Vilniaus tikimybių teorijos ir matematines statistikos konferencija. S̨i kartą ji buvo
1997 m. mokslo premiju laureatai su premjeru G. Vagnoriumi ir LMA prezidentu B. Juodka.

VGTU atstovai:

1-oje eilëje (iš kairès): J. Stankūnas (1), R. Martavičius (2), R.Kirvaitis (3), J. Skudutis (5);

2-oje eileje: Z. Vainoris (7), S. Štaras (9)

\section{Landsbergis}

Švenčiant Sajūdžio 10-meti VGTU

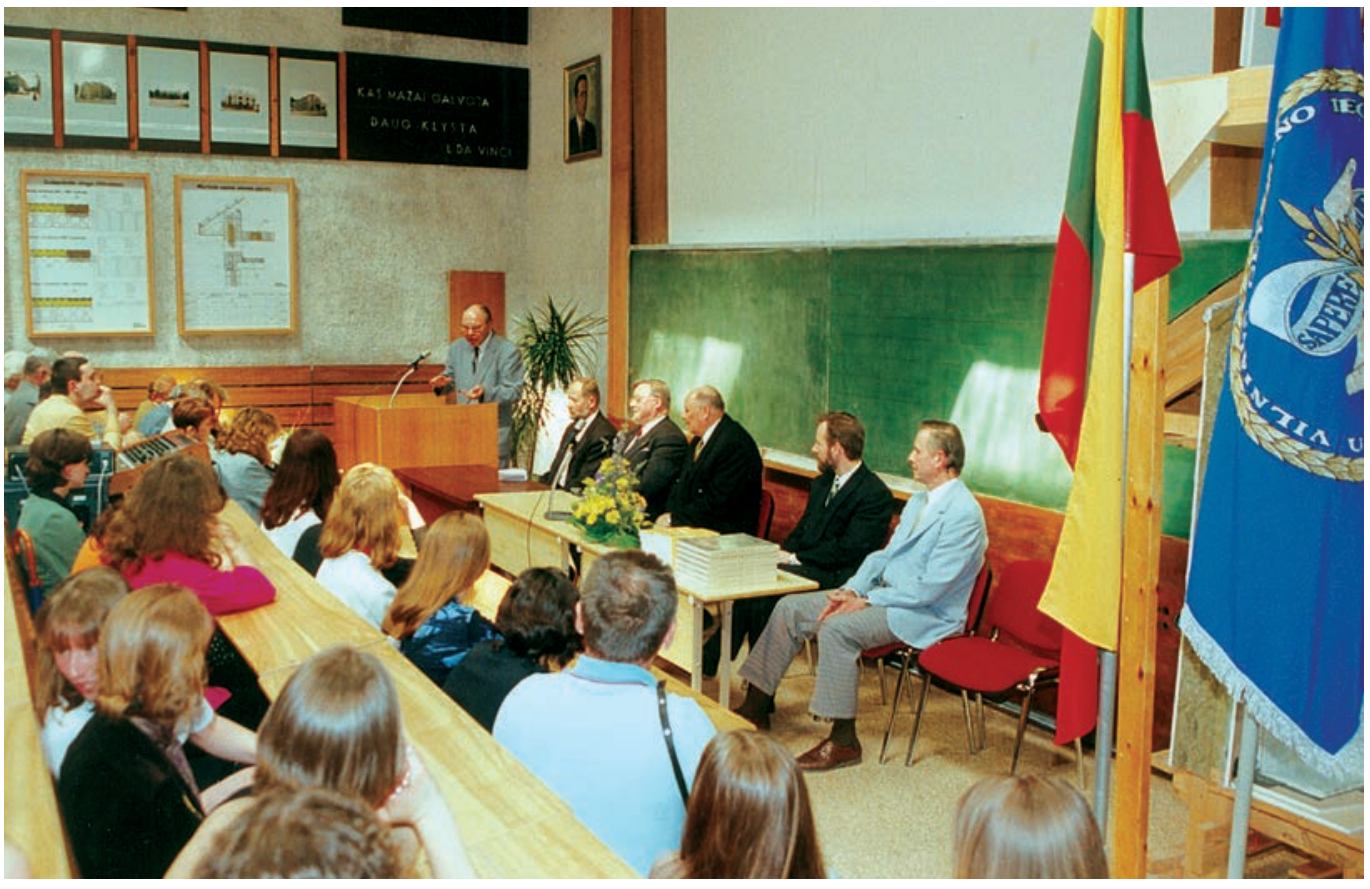


VILNIAUS

GEDIMINO

TECHNIKOS

UNIVERSITETAS

Konferencijos prezidiumas

V. Adamkus sveikina ižymybe J. Kubilin

Viršuje dešinèje -

Matematikus sveikina

J. E. LR Prezidentas V. Adamkus surengta kartu su 22-uoju Europos statistiku kongresu. Konferencija sulauke apie 400 dalyvių. Be lietuvių, sulaukta matematikų iš 37 šalių. Gausiausios delegacijos buvo Rusijos, JAV, Vokietijos, Didžiosios Britanijos, Prancūzijos. Po vieną dalyvị atvyko iš Kipro, Mongolijos, Kuveito.

Tarptautinę matematikų konferenciją savo apsilankymu pagerbè Lietuvos Respublikos Prezidentas Valdas Adamkus.
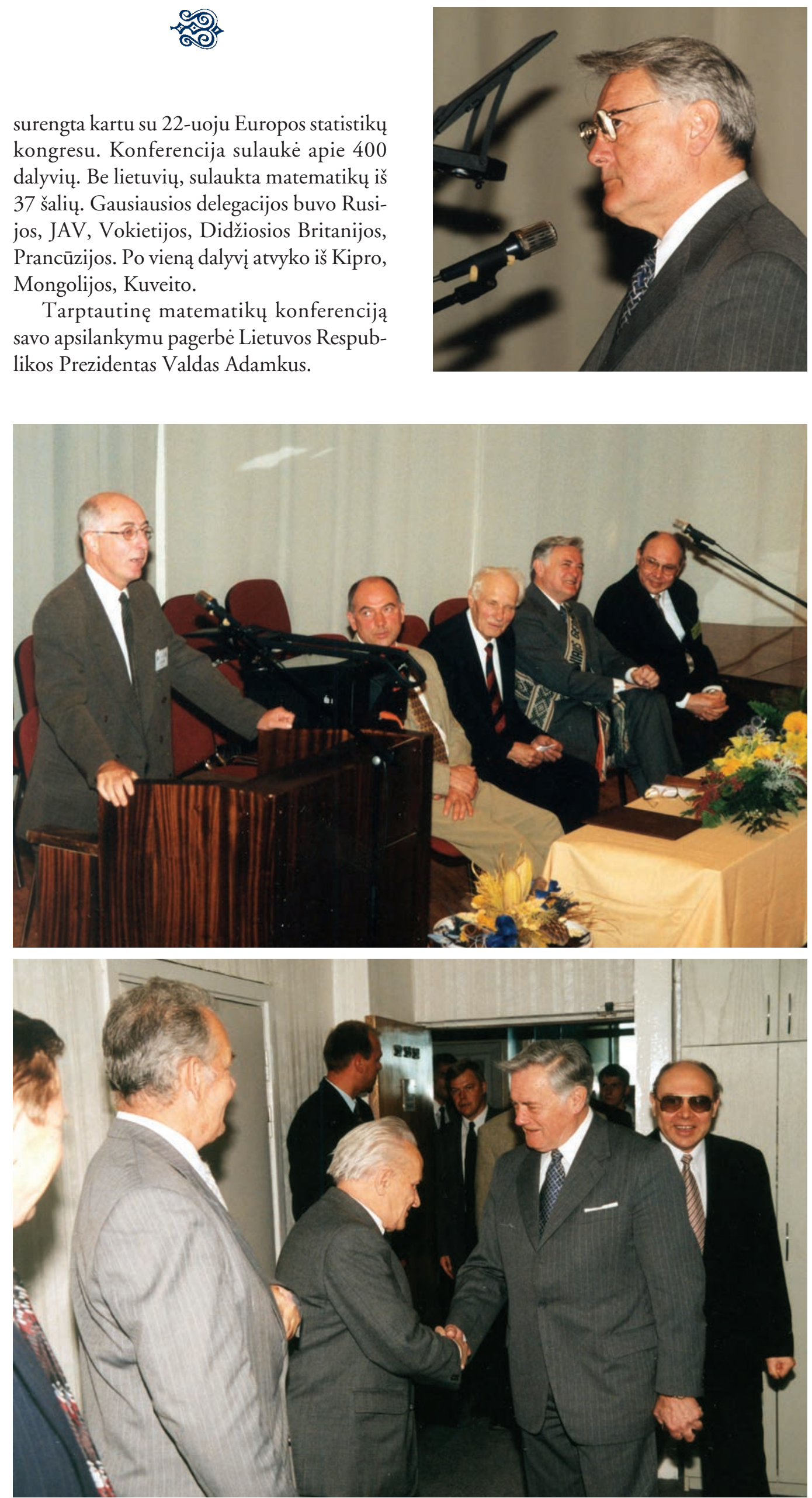


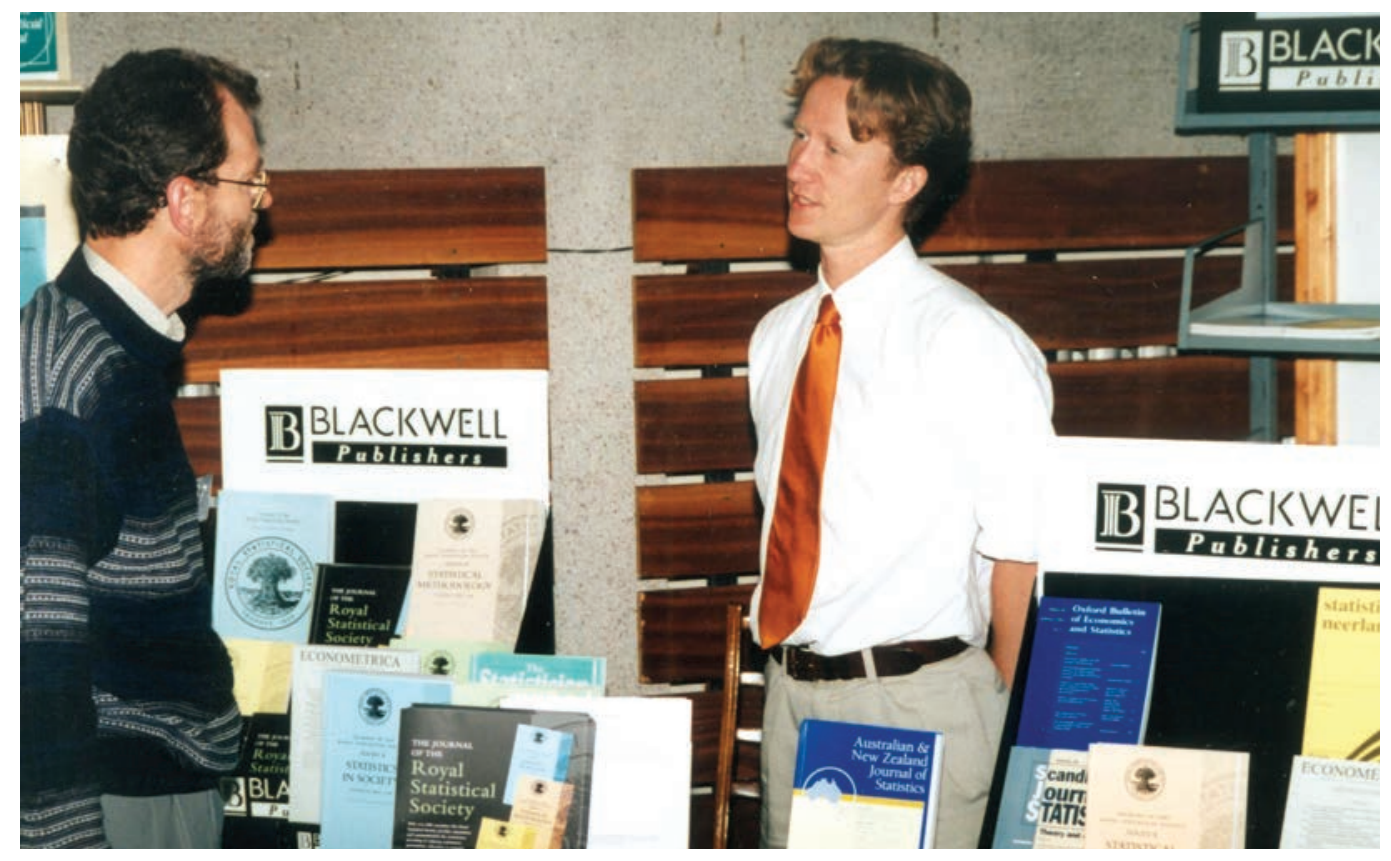

Dalis Konferencijos ekspozicijos

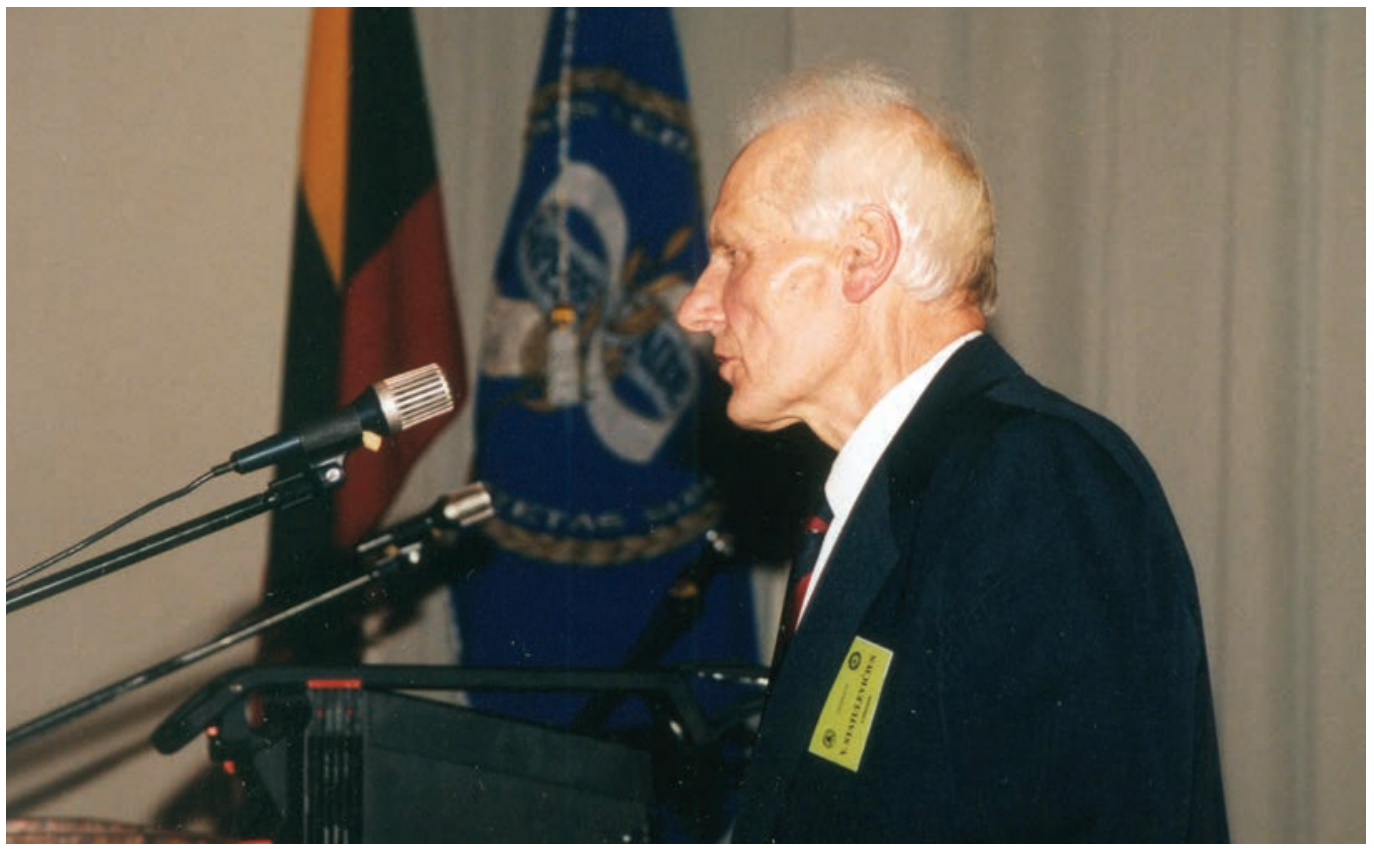

Konferencijos sumanytojas ir

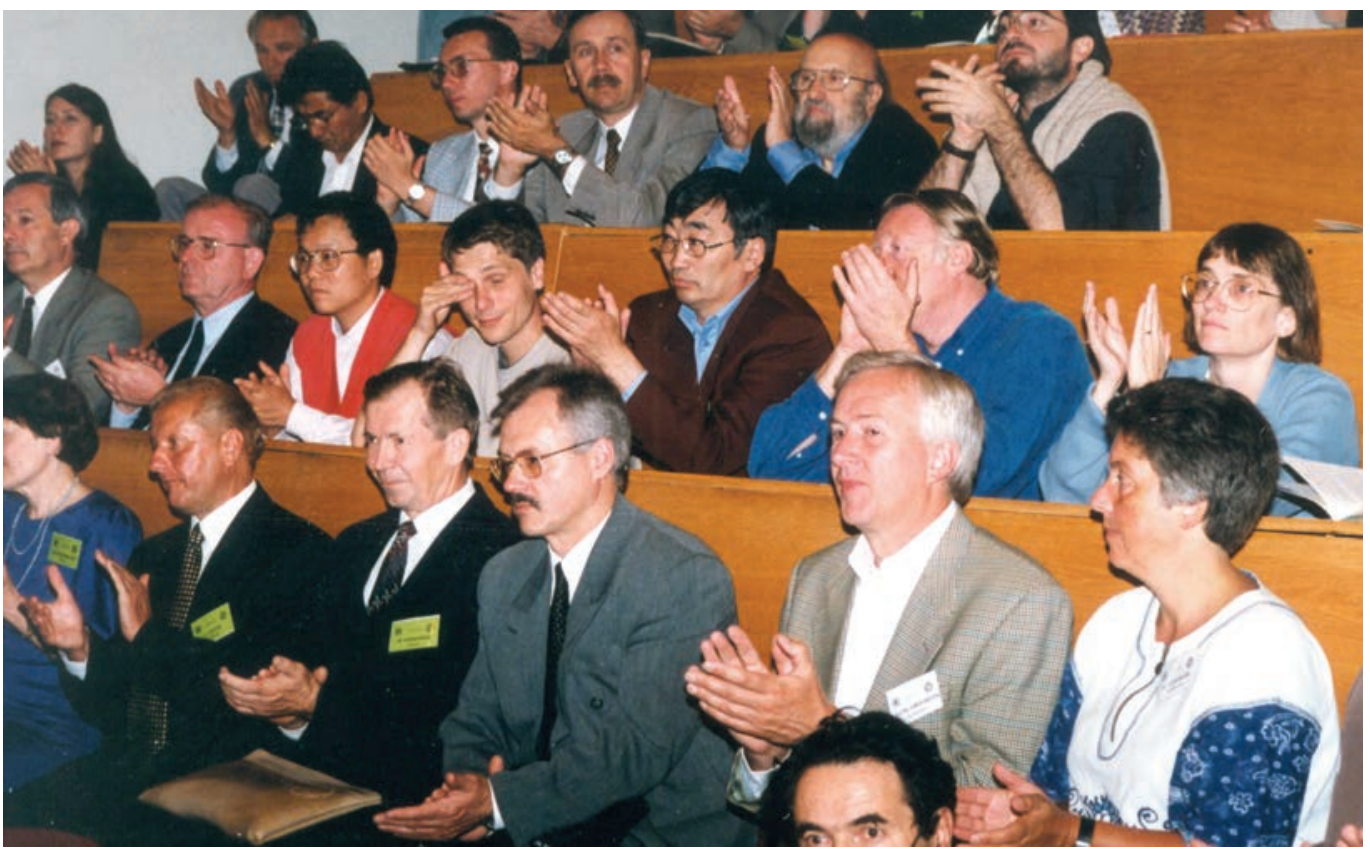


VILNIAUS

GEDIMINO

TECHNIKOS

UNIVERSITETAS

Pirmasis „Gedimino universiteto “ numeris
Rugsèjo 1-ąją vykusioje pirmakursių imatrikuliacijos šventeje dalyvavo Vilniaus miesto meras Rolandas Paksas. Buvo pasidžiaugta, kad 1427 jaunuoliai ir merginos tapo VGTU studentais, o 361 - klausytojais. Dar 193 priimti į neakivaizdinị skyrių. Rektorius E. K. Zavadskas linkejjo studentams užsispyrimo, ištvermès, darbštumo įveikiant vis naujas pakopas, siekiant savo galutinio tikslo -igyti pasirinktą profesiją ir specialybę. Jis primine, kad laukia įtemptas ir įdomus darbas, kad reikia studijuoti, o ne studentauti, kviete rasti laiko ir koncertams, spektakliams, domètis menu ir sportu. Tą dieną pasidžiaugta ir Vilniaus Gedimino technikos universiteto pradèto leisti publicistinio žurnalo „Gedimino

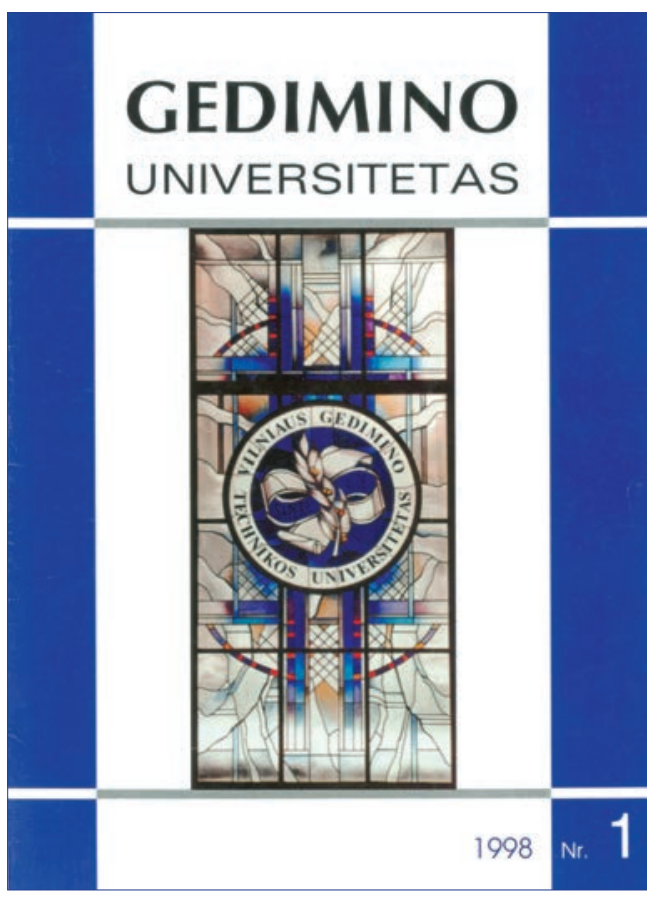

\section{Sprendžiant susikaupusias problemas}

Daug problemų susikaupè VGTU Antano Gustaičio aviacijos institute. Nepaisant ypač didelių direktoriaus prof. Jono Stankūno pastangu, rektoriaus E. K. Zavadsko, palaikančio institutą, dèmesio, nebuvo sprendžiamas instituto normalaus finansavimo klausimas. Problema buvo apsvarstyta VGTU taryboje ir priimtas istorinès vertes pareiškimas, kuriame sakoma:

"Aviacija yra Lietuvos tautines savimo"Gedimino universiteto“ redkolegija su rektoriumi

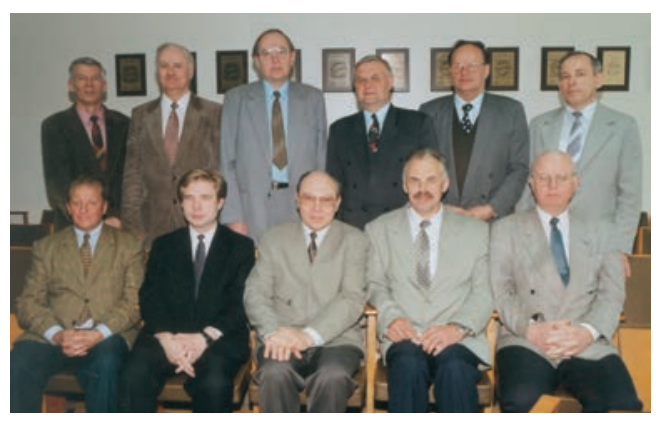

universitetas" pirmuoju numeriu. Prisimintos ir vasaros netektys: mire profesorius Daumantas Maciulevičius bei docentas Alvydas Šniukšta.

1998 m. spalio 1 d. VGTU studijavo: Aplinkos inžinerijos fakultete-683, Fundamentinių mokslų fakultete -508 , mechanikos fakultete -1036 , Statybos fakultete 1611 , Transporto inžinerijos fakultete -1 068, Verslo vadybos fakultete - 1208 , Antano Gustaičio aviacijos institute -355 ir Tarptautiniu studiju centre -76 žmonès. Iš viso VGTU turejo 8256 studentus.

VGTU buvo vyriškas universitetas: vyrų buvo $62,4 \%$, merginu $-37,6 \%$.

Pagal tautybes pasiskirstymas buvo toks: lietuviai sudare $83,6 \%$, rusų buvo $8 \%$, lenku $-5,3 \%$ ir 3,2\% - kitu tautybių.

Studiju programos daugiausia buvo technologijos mokslų -88 . Trys studiju programos buvo humanitarinių, 13 - socialinių ir 5 - fizinių mokslų. Technologijos mokslus studijavo 5703 asmenys, humanitarinius 321 , socialinius -1784 ir fizinius -448 .

VGTU pagrindinèse studijose studijavo daugiausia vilniečiai ir Vilniaus apskrities gyventojai - 54,5\%, iš Alytaus apskrities $8,4 \%$, Panevėžio apskrities $7,5 \%$, Utenos apskrities $-7,4 \%$. Kitų apskričių 1,3-6\%.

tautinio patriotizmo šaltinis. Lietuvoje ji turi gilias tradicijas, kuriu šaknys yra dar $1650 \mathrm{~m}$. dienos šviesa išvydusiame Kazimiero Semenaviciaus mokslo veikale "Didysis artilerijos menas", vienu pirmuju pasaulyje iškelusiame daugiapakopes raketos skrydžio ideja. Žymin Lietuvos aviacijos konstruktoriu ir didvyrišku lakūnu dèka aviacija mūsu šalyje yra labai populiari. Mes vieninteliai tarp Baltijos valstybiu issaugojome nacionaline aviacijos kompanija ir pirmieji suformavome karines oro pajegas. Ver- 
tinant patogia Lietuvos geografine padeti, nacionaline aviacija turiperspektyva tapti pajegia Lietuvos transporto sistemos sudetine dalimi, sukurti apie save aviacijai talkinančiu versly industrija su daugybe kvalifikuoto darbo vietu. Lietuvoje perspektyvūs ir lengvuju skraidymo aparatu konstravimas bei gamyba. Aviacijos pletrai reikalingi aukštos kvalifikacijos aviacijos specialistai

Vertinant krašto poreikius ir konkrečius Lietuvos Vyriausybes užsakymus 1993 m. Vilniaus technikos universitete ikurtas Aviacijos institutas. Jame rengiami orlaiviu pilotavimo, skrydžiu valdymo, aviacines mechanikos, aviacines elektronikos, aviaciniu elektros irrenginiu ir oro vežimu vadybos specialistai Lietuvos civilinei ir karo aviacijai. Per labai trumpa laika, panaudojus Vilniaus Gedimino technikos universiteto, Lietuvos karo akademijos ir aviacijos imoniu pajegumus, suformuotas pedagoginis kolektyvas ir minimali mokomoji baze. Už valstybes ilgalaikems investicijoms skirtus 2 milijonus litu irengta kompiuteriniu treniruokliu klase, nupirkti 9 mokomieji lektuvai. Aviakompanijai "Lietuvos avialinijos" ir LR civilines aviacijos direkcijai padedant, naudoti gauti pastatai ir mokomieji orlaiviu pilotavimo bei skrydžiu valdymo treniruokliai.

Aviacijos institutas jau išleido penkias aviacines mechanikos bakalauru, po dvi orlaiviu pilotavimo ir skrydžiu valdymo inžinieriu, dvi diplomuotu inžinieriu lakūnu, dvi diplomuotu inžinieriu skrydžiu vadovu, tris aviacines mechanikos, vienq aviacines elektronikos ir keturias oro vežimu vadybos diplomuotu inžinieriu laidas. Institute jau rengiami mokslo magistrai ir daktarai. Kasmet organizuojamos tarptautines mokslines konferencijos.

Specialistai rengiami turint konkrečius Susisiekimo ir Krašto apsangos ministeriju užsakymus. VGTU Antano Gustaičio aviacijos institute parengti specialistai dirba aviakompanijoje "Lietuvos avialinijos", Karinese oro pajegose, Vidaus reikalu ministerijos aviacijos padalinyje ir bendrojoje aviacijoje <...>

VGTUAntano Gustaičio aviacijos instituto uždaviniai daugiausia realizuojami tik Vilniaus Gedimino technikos universiteto pastangomis, nuolat stingant lèsu ir esant neišspręstiems instituto bazes formavimo klausimams. Vienintele universitetine Lietuvos aviacijos mokykla neturi nuosavos skraidymu bazes. Institutui nuolatos tenka büti prašytoju. Nepaisant kiekvienaismetais rengiamu ir teikiamy Vyriausybei instituto finansavimo projektu bei pletros programu, $f$ nansavimas nera pakankamas <...>

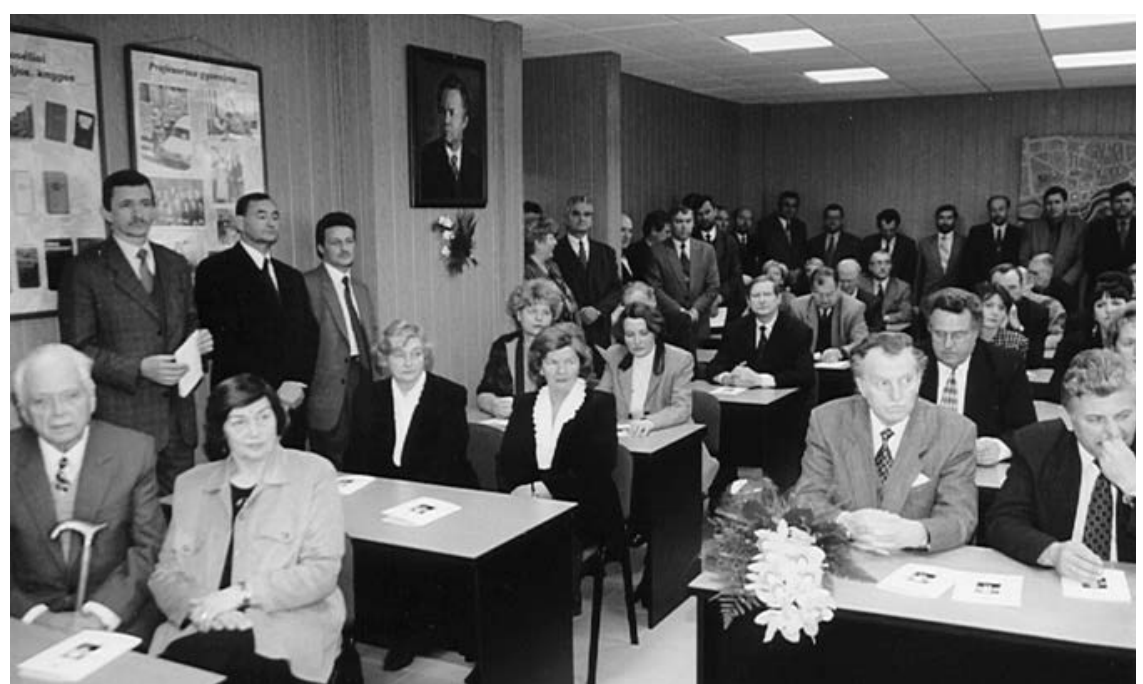

V. Šeštoko auditorijos atidarymas

Jausdama atsakomybę už Lietuvos technine pažanga ir specialistu perspektyvioms ükio šakoms rengima, Vilniaus Gedimino technikos universiteto taryba atsakingai pareiškia, kad aviacijos, kaip vienos is techniniu ir technologiniu požiūriu dinamiškiausiai besivystančiu transporto šaku, ateitis priklausys tik nиo parengtu specialistu profesinio lygio ir ju pasiruosimo atitikimo tarptautiniams reikalavimams. Mes reiškiame vilti, kad Lietuvos Respublikos Prezidentas, Lietuvos Respublikos Seimas ir Lietuvos Respublikos Vyriausybe rems Lietuvos aviacija, turinčia gilias tradicijas ir priims reikalingus nutarimus VGTU Antano Gustaičcio aviacijos instituto finansavimo ir mokomosios bazes kürimo problemoms išspręsti.

VGTU tarybos pirmininkas

habil.dr. prof. L. Saulis"

Spalio mènesị savo veiklos penkmetị švente VGTU Verslo vadybos fakultetas. Iškilmés vyko V. A. Graičiūno auditorijoje, kuriai jo vardas suteiktas minint 100-ąsias pasaulinio garso vadybos mokslininko, nužudyto sovietiniame konclageryje, gimimo metines. Fakulteto dekanas doc. Romualdas Ginevičius pranešè, kad vadybos mokslo pradininkui pagerbti įsteigtos Vytauto Andriaus Graičiūno 7 stipendijos -5 pagrindinių ir 2 magistrantūros studijų.

Verslo vadybos fakultetas įsteige ir mirusio profesoriaus, Atkuriamojo Seimo signataro Kazimiero Antanavičiaus stipendijas: 3 pagrindinių studijų ir 1 - magistrantūros.

25-metį švente laikraštis „Inžinerija“. Prie redakcijos vairo buvo doc. Irena Gaidamavičienè (1970-1972; 1986-1987 m.), doc. Halina Kobeckaite (1976-1986 m.), Arvydas Kriaunevičius (1993-1994 m.), Marija Akstinaite (1994-1998 m.). Nuo 1998 m. pavasario-Julius Norkevičius.

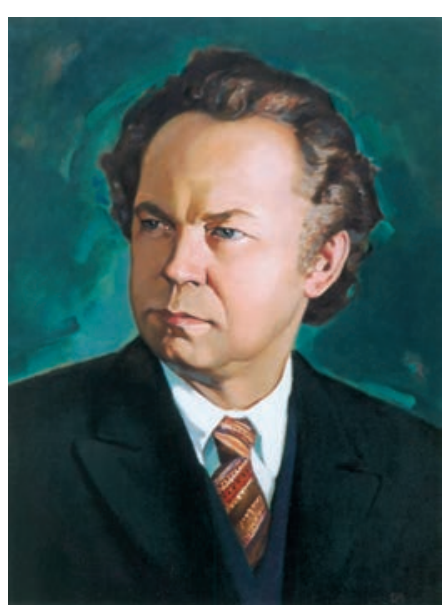

V. Šeštokas Dail. J. Grigorovičius

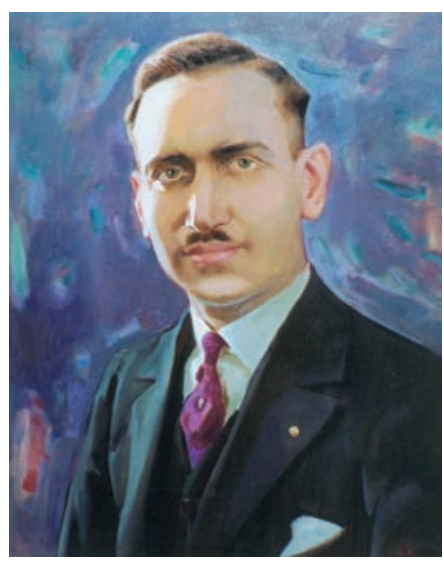

V. A. Graičiūnas Dail. J. Grigorovičius 
VILNIAUS

GEDIMINO

TECHNIKOS

UNIVERSITETAS

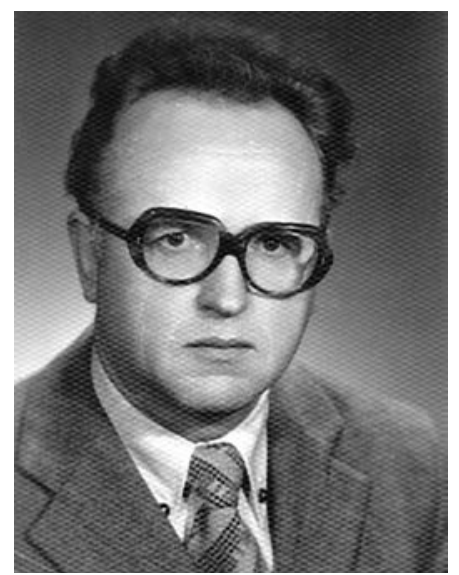

A. Ažubalis

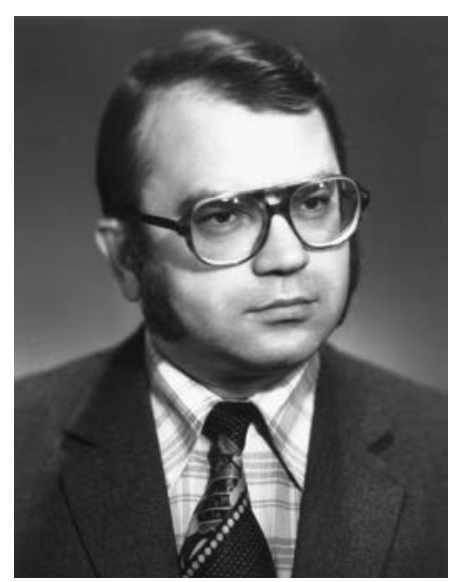

A. Baublys - Transporto mokslo instituto direktorius

\section{Intensyveja tarptautinis} bendradarbiavimas

Spalio pabaigoje Elektronikos fakultetą aplanke projekto partneriai iš Danijos, Vokietijos ir Didžiosios Britanijos. Taip pat ívyko naujos modernios klases, skirtos dirbti internete, atidarymas.

Gruodžio mėnesį dekanas R. Ginevičius, dalyvaudamas Lietuvos ūkio ir kultūros dienose Vokietijoje, suderino sutarties tekstą tarp VGTU Vadybos fakulteto ir Štralzundo aukštosios mokyklos analogiško fakulteto. Taip pat susitarta dèl dviejų VGTU Verslo vadybos fakulteto studentų išsiuntimo studijuoti 1998-1999 m. m. pavasario semestre (studijų išlaidas apmokèjo priimanti pusè).

Susitarta dèl Štralzundo aukštosios mokyklos destytojų, profesorių dalyvavimo žurnalo „Inžinerinè ekonomika ir vadyba“, kurị planuoja leisti Verslo vadybos fakultetas, redkolegijos darbe.

Suderintas klausimas dèl Štralzundo aukštosios mokyklos profesorių ir destytojų dalyvavimo VGTU Verslo vadybos fakulteto organizuojamose tarptautinèse konferencijose. Susitarta del bendro dalyvavimo SOCRATES programoje (per metus bus keičiamasi po penkis studentus ir po vieną déstytoją).

Vilniaus Gedimino technikos universitetas toliau koncentravo mokslinius tyrimus pagal prioritetines fundamentiniu ir taikomųjų tyrimų veiklos sritis. Tokiu prioritetinių mokslo krypčių VGTU turëjo 10: 1. Statybinių medžiagų, konstrukcijų ir statybos technologiju tyrimas, kūrimas ir taikymas; 2. Informacinių technologijų, statistinès analizès ir fizinių procesų modeliavimo metodu kūrimas ir taikymas; 3. Integracijos į Europos Sąjungą socialinių, ekonominių bei technologinių problemų tyrimai ir inžinerijos sistemu harmonizavimas ir restruktūrizavimas; 4. Eksperimentiniai ir teoriniai aplinkos sistemu tyrimai ir aplinkos apsaugos technologijų kūrimas; 5 . Architektūros ir urbanistikos objektu, jų projektavimo metodų ir statybos bei teritoriju planavimo sistemos tyrimai atsižvelgiant ị socialinius ir ekonominius pokyčius; 6. Transporto sistemos veiklos strategijos tyrimai ir ịvairiu transporto technologiju kūrimas; 7. Geodezijos, kartografijos technologijų ir fizikinių dydžių matavimo metodų ir priemonių tyrimas, kūrimas ir taikymas; 8. Elektros ir elektroninių įtaisų kūrimas, optimizavimas ir tobulinimas; 9. Mechaninių ir biomechaninių sistemų, technologinių procesų tyrimas, projektavimas ir tobulinimas; 10. Energijos tiekimo ir vartojimo sistemų tyrimas, vertinimas ir optimizavimas.

$1998 \mathrm{~m}$. mokslinius tyrimus vykde 60 habilituotu daktarų ir profesorių bei 279 daktarai ir docentai. Didžiausia mokslo problema - laboratoriju ịranga labai nusidèvejusi, trūksta lešų.

$1998 \mathrm{~m}$. buvo įsteigti du nauji universitetiniai mokslo padaliniai - Mokslotyros centras ir Transporto mokslo institutas bei vienas fakultetinis padalinys - AGAI Aviacijos mokslo laboratorija.

VGTU turejjo 197 doktorantus, 139 iš ju studijavo technologijos mokslus.

Tais metais habilituoto daktaro disertaciją apgyne Algirdas Ažubalis iš socialinių mokslų srities - „Matematika lietuviškoje mokykloje XIX a. pr. - 1940 m." Pedagoginis profesoriaus mokslo vardas buvo suteiktas R. Martavičiui, B. Spruogiui, V. Giniočiui, O. G. Rakauskienei, V. J. Stauskiui ir A. V. Valiuliui.

VGTU mokslininkai dalyvavo keturiose Europos Komisijos mokslo programose, vienoje - NATO mokslo programoje, penkiose - Šiaurès šalių mokslo programose ir kt. Beveik $24 \%$ padidëjo užsakomųjų darbų apimtys, palyginti su 1997 m. Daugiausia ju turejo Aplinkos inžinerijos fakultetas.

VGTU 1995-1998 metais moksliniuose žurnaluose ir leidiniuose paskelbè 2315 straipsnių, iš jų užsienyje - 395 .

$1998 \mathrm{~m}$. VGTU surenge 6 tarptautines mokslines konferencijas. Jose bei įvairiose kitose mokslo konferencijose VGTU mokslininkai perskaite beveik 700 pranešimų.

Toliau stiprejo VGTU biblioteka. Buvo sukurta „Naujosios VGTU bibliotekos koncepcija“, kurioje atlikta bibliotekos privalumų, galimybių, trūkumų analize, apibrèžta bibliotekos, kaip mokymo ištekliu centro, misija, paslaugos, kurias gali teikti biblioteka, struktūriniai bibliotekos pokyčiai. Naujas bibliotekos pastatas buvo suvoktas kaip erdve, skirta studentų savarankiškam darbui ir studijoms, moksliniams kontaktams, seminarams, konferencijoms. VGTU bibliotekos fondą sudare 676960 egzempliorių beveik 150000 pavadinimų knygų.

Metų pabaigoje mirusio VGTU profesoriaus Vaclovo Vytauto Šeštoko vardu buvo 
pavadinta Aplinkos inžinerijos fakulteto viena auditorija.

Pradžiugino VGTU futbolininkai. Lietuvos aukštųjų mokyklų mažojo futbolo čempionate jie laimejo pirmąją vietą (treneris - Albertas Tarulis).

Universiteto taryba (1998 m. gruodžio 16 d.), ịvertindama didelius inžinieriaus dr. Jurgio Gimbuto nuopelnus, vykdant lietuvių liaudies architektūros tyrimus, plètojant namotyros mokslą ir didelị indèli i Lietuvos mokslo istoriją, suteike jam Vilniaus Gedimino technikos universiteto Garbès daktaro vardą.

Lietuvos namotyros mokslo pradininkas inž. dr. Jurgis Gimbutas su VGTU bendradarbiavo nuo 1993 m., kai buvo pakviestas dalyvauti mokslinëje konferencijoje „Aukštojo statybos mokslo raidos Lietuvoje momentai“. Po to jis ne kartą aplanke VGTU, skaite įdomius pranešimus architektūros klausimais. Jo dèka universitetas palaike gražius dalykinius ryšius su kai kuriais JAV, Kanadoje gyvenančiais lietuviais architektais, statybos ar hidrotechnikos inžinieriais, jų šeimų nariais.

Dr. J. Gimbutas atsiunte daug autentiškos medžiagos, susijusios su lietuvių inžinieriu darbais ir ju biografijomis. Jis skyre lěšu fakulteto studentu geriausiems kaimo sodybos projektams pažymeti.

\section{Neužmirštama Sausio 13-oji}

1999 m. pradžioje apie Sausio 13-osios ìvykius „Inžinerijoje“ prisiminè VGTU tarybos pirmininkas prof. Leonas Saulis:

„Sausio 13-oji nepaprastai reikšminga data mūsu tautai, valstybei. Tragiškos $1991 \mathrm{~m}$. sausio dienos visam pasauliui parode lietuviu tautos susiklausyma, ryžta ir pasiankojima apginti ir j̇virtinti atgauta laisvę, itikino, kad Kovo 11-osios Nepriklausomybes akto paskelbimas - neatsitiktinis. Priešingai, ỉrode visam pasauliui, kad lietuviu tauta politiškai subrendusi Laisvei ir Nepriklausomybei.

Man giliai ż atminti isireže toks epizodas. Okupantams isiveržus i Televizijos bokšta ir tankams nubloškus laisves gynejus, pasigirdo vienos merginos rauda. Sirdi draskanti rauda. Ta bežade jaunos merginos rauda savotiškai perdave visu bokšto gynejju neapykanta okupantams.

Laisves, Nepriklausomybes sieke, už ja kovojo visi tautiečiai - ir tie, kurie müru stojo prieš sovietu tankus prie Televizijos bokśto, ir tie, kurie saugojo Parlamenta, Vyriausybe, ir, sakykime, gyvenantys Australijoje, Kanadoje, JAV. Tomis Sausio dienomis visu lietuviu, visos tautos siekiai buvo bendri, nepaprastai vieningi. Tada mums pasiseke, nes turejome išmintinga, drasu, nepaprastai ryžtinga vadova prof. Vytauta Landsbergì " [6.12, p. 1].

Metų pradžioje įvyko Architektūros fakulteto dekano rinkimai. Postą paliko prof. Vytautas Dičius, o dekanu buvo išrinktas Urbanistikos katedros docentas daktaras Eugenijus Staniūnas.

Gražiai ir nepaprastai iškilmingai paminèta Vasario 16-oji - Lietuvos valstybes atkūrimo diena. Prasmingu ižzangos žodžiu minëjimą pradëjo Tarybos pirmininkas habil. dr. prof. Leonas Saulis. Jo mintis savotiškai pratęse prof. Ramutis Šimaitis. Cituodamas įvairius dokumentus, signatarų, mūsų tautai didžiai nusipelniusių visuomenès veikejų prisiminimus, jis susirinkusiems primine sunkų, vargingą, bet nepaprastai prasmingą kelią $i$ Lietuvos valstybingumo atkūrimą, ì Nepriklausomybes dieną. Buvo prisimintos ir aukos, sudettos ant Tèvynès laisves aukuro.

Rektorius prof. habil. dr. Edmundas Kazimieras Zavadskas perskaite prezidentūros sveikinimo telegramą, adresuotą prof. Ramučiui Šimaičiui apdovanojimo LDK Gedimino ordinu proga. Rektorius savo, taip pat visos universiteto bendruomenés vardu apdovanotajam profesoriui palinkëjo daug sveikatos, visokeriopos sèkmés, stiprybes toliau darbuojantis mylimos Tèvynès labui.

Prieš Vasario 16-osios minejimą buvo pasirašyta tarpusavio bendradarbiavimo sutartis su „Lietuvos aidu“. Dienraščio vyriausiasis redaktorius Rimantas Varanauskas, bendroves direktore Lina Belevičiené, rektorius prof. Edmundas Zavadskas prisiminè šio laikraščio indèli, skelbiant mūsų šalies nepriklausomybę bei jąstiprinant, plètojant. Trumpai buvo apibūdinti nūdienos dienraščio pagrindiniai siekiai, tematika, ko tikimasi ir laukiama iš mūsu mokslininkų, studentų pasirašius bendradarbiavimo sutartį su universitetu [6.13, p. 1].

Kovo mènesị Vilniaus tarptautiniame oro uoste nusileido naujas VGTU Antano Gustaičio aviacijos instituto mokomasis lèktuvas CESSNA-310R. Lèktuvą pilotavo instituto direktoriaus pavaduotojas skrydžiams Leonas Jonys ir amerikiečių lakūnas Antoni Eyre. Tai buvo jau dešimtasis instituto mokomasis lèktuvas.

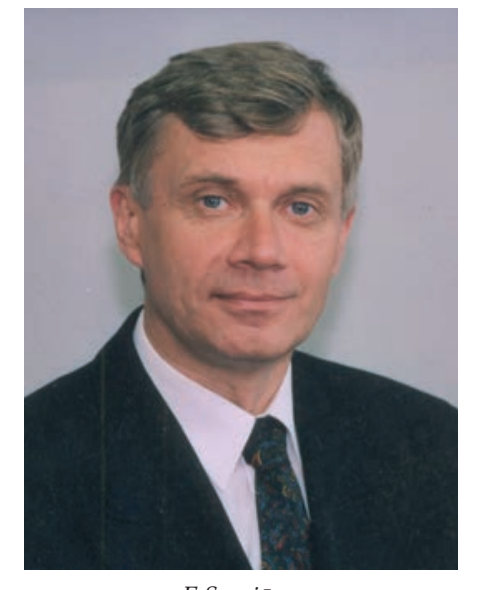

E.Staniūnas

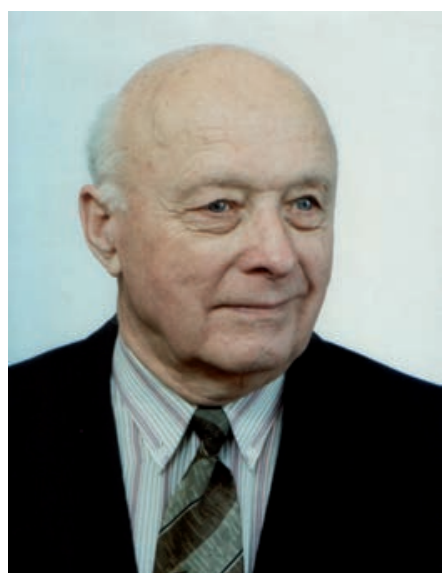

R. Šimaitis 
VILNIAUS

GEDIMINO

TECHNIKOS

UNIVERSITETAS

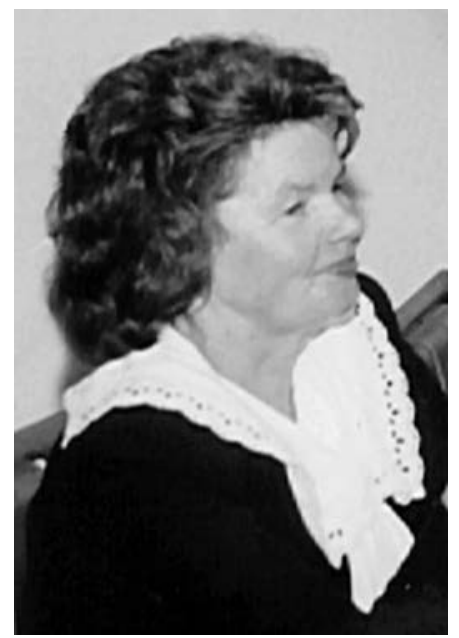

1999 m. jkurtas VGTU Mokslotyros centras. Jo direktore paskirta dr. V. Lujaniene
Naują mokslinę monografiją išleido „Technikos“ leidykla. Tai doc. habil. dr. Romualdo Ginevičiaus „Imonių veiklos diversifikacija“. Autorius monografijoje nagrinëjo įvairius svarbiausius įmonių augimo strategijos aspektus. Knyga prasideda išsamiu įmonés pletros, augimo dydžio ir jos matu supratimo pristatymu, ju tarpusavio ryšiu. Paskui aptariami įmones augimo strategijos klausimai, nusakomos jos veiklos diversifikacijos prielaidos, tikslai, išanalizuojamas strateginis rinkos segmentavimas. Mokslininkas išsamiai išnagrinejo įmonių veiklos diversifikacijos rūšis ir jų tarpusavio ryšius. Vertingas leidinio skyrius, kuriame analizuojama įmonių veiklos diversifikacijos raida 1900-1990 metais. Verslo vadybos fakulteto dekanas Romualdas Ginevičius monografijoje ypatingą dèmesį skyre įmonès veiklos bei jos augimo strategijos kiekybiniam įvertinimui ir planavimui, siūlydamas savo metodiką, kuri, kaip rodo monografijoje pateikti skaičiavimai, yra tobulesne, palyginti su esamomis.

Kaip visuomet, buvo paminèta Lietuvos Nepriklausomybès atkūrimo diena. Iškil-

\section{Daug reiškia tarpusavio bendravimas}

Dar vienas minëjimas buvo skirtas Lietuvos karo aviacijos 80-mečiui, kuri surenge AGAI. Ta proga buvo pristatyta LMA ir VGTU išleista Algimanto Liekio knyga „Lietuvos karo aviacija (1919-1940)“.

İdomių minčių apie destytojo ir studento santykius universiteto laikraštyje išdèstè rektorius E. K. Zavadskas:

„Studentas siekia žiniu. Profesorius padeda šiuos gražius siekius igyvendinti. Šiame siekyje labai dang reiškia gražus tarpusavio bendravimas. Ar jau galime kalbeti, kad egzistuoja draugiški, savitarpio supratimo santykiai tarp müsu universiteto destytoju ir studentu?

Profesoriaus, docento, destytojo pasakyti žodžiai, adresuotistudentui, turi didele itaką. Ir ne tikstudentui. Negeranoriskos, pagiežingos, piktos pastabos gali sužlugdyti būsimojo habilitacinio darbo autoriu. Mokslo krypties ar doktorantūros komiteto nariu neapgalvoti žodžiai doktorantui taip pat gali tureti neigiama ìtaka. mingas minèjimas buvo surengtas neseniai gautuose rūmuose - Trakų ir Pylimo gatvių sankryžoje. Renginyje dalyvavo Kovo 11-osios akto signatare Nijolè Oželyté, koncertavo "Gabija“ ir „Vingis“.

Gana tolimoje praeityje buvusių grafų Tiškevičiu rūmų aktų saleje emocingai ir kerinčiai kalbejo N. Oželytè. Ji sakè, kad nesvarbu nei pavardès, nei vardai tų, kurie pasiraše paminetą aktą. Kaip ir neverta kalbeti apie tuos, kurie tvirtino, kad atkurta nepriklausomybè popierine, o dabar užima aukštus postus.

„Kur kas svarbiau, kas ivyko Kovo 11-osios diena, svarbi vidine savijauta-lygirlaimejome, lyg ir iškovojome. Bet ar kiekvienas jau tapome laisvas?! O ar nepriklausomybe savaime jau yra vertybe?? Kartu büdami Baltijos kelyje, Sausio 13-osios dienomis sugebame pakilti, atitrükti nuo kasdienos rietenu, bet kai išsiskirstome-vel liekame kiekvienassau. Taigalnepakankamai išnaudojame nepriklausomybes suteikta galimybę büti laisvi?

Bütina visu atsakomybe, noras ir pareiga daryti gera kitam, siekti ir išnaudoti visas galimybes daryti gyvenima šviesesni, prasmingesni. Tik tada pajusime, kad nepriklausomybe ne tik atvede i savus namus, betkiekvienas juosepasijutome laisvas, dvasiskai pakyletas " [6.14, p. 1].

Studentaspiktupastabu ǐsgirsta dar daugiau. Neretas destytojas per paskaitas ar pratybas savo negera nuotaikq išlieja studentams. Ir nesusimąsto, koks jo pasakytužodžiu poveikis<...>

Labai gaila, kad dar ir dabar mūsu universitete yra nemažai destytoju, kuriems svetima geru santykiu su studentais samprata. Kuriems trūksta geranoriškumo, supratingumo ir objektyvumo, vertinant studentu žinias. Dažnai jaunam pirmakursiui užtenka, kad nors karta neobjektyviai ivertintu jo žinias, kad nusvirty rankos, dingtu noras siekti žiniu, mokslo aukštumu. Ir atvirkšciai, jei destytojas padrasina studenta, negaili jam gero žodžio, atsiranda didelis noras ỉrodyti, ka gali, siekti aukštesniu tikslu" [6.16, p. 3].

1999 m. gegužę VGTU (VISI) absolventas Rolandas Paksas buvo paskirtas Lietuvos Respublikos Ministru Pirmininku. Universitetui tai buvo didele garbé, nes R. Paksas ne tik baige Statybos fakultetą, bet kurị laiką ir 
dèstè būsimiems statybininkams, dirbdamas valandiniu desstytoju Architektūros fakulteto Pastatų konstrukcijų katedroje.

VGTU vyko 6-oji tarptautine konferencija „Naujos statybinès medžiagos, konstrukcijos ir technologijos", kurioje dalyvavo 305 mokslininkai, tarp jų 154 iš užsienio šalių. Buvo perskaityti 188 pranešimai.

Gegužè $18 \mathrm{~d}$. îvyko VGTU tarybos iškilmingas posedis, skirtas pasaulinio garso statybos ir hidrotechnikos inžinieriaus Vytauto Izbicko auditorijos atidarymui. Pranešimą, gausiai iliustruotą nuotraukomis, dokumentais, apie inžinierių Vytautą Izbicką perskaite doc. A. Nakas. Pranešejas akcentavo, jog Vytautas Izbickas - vienas žymiausių lietuvių statybos ir hidrotechnikos inžinieriu - projektavo, techniškai prižiūrèjo ar konsultavo dideles ir unikalias pramonès ir energetikos statybas beveik visuose pasaulio žemynuose. Gyvendamas užsienyje jis tapo ne tik pasaulinio garso specialistu, bet ir ižymiu JAV lietuvių bendruomenès veikeju. Savo profesiniais darbais jis garsino lietuvių tautą, savo visuomenine veikla sieke Lietuvos laisves ir nepriklausomybès. Iškabą ir vardinę auditoriją pašventino monsinjoras Kazimieras Vasiliauskas, grojo Muzikos akademijos styginiu kvartetas.

Birželio mènesi gauta žinia, kad Vilniaus Gedimino technikos universitetas tapo Europos universitetu asociacijos (CRE) nariu.

Vilniaus miesto meru buvo išrinktas VGTU (VISI) absolventas Juozas Imbrasas, o pirmuoju vicemeru - Fundamentiniu mokslų fakulteto dekanas doc. Algirdas Čiučelis, buvęs prieš kurị laiką ir miesto meru.

Birželio menesio antroje puseje nustatytas 1999 metu absolventų derlius. Studijas baige 1096 bakalaurai, 450 magistru ir 106 specializuotų profesorių studijų absolventai, iš viso 1694 žmonès.

Tūkstantojo magistro diplomo savininke tapo Mechanikos fakulteto biomechanikos studiju programos absolvente Rima Sakalauskaitè.

Vilniuje įvyko tradicine Baltijos šalių studentų meno kolektyvų šventè „Gaudeamus XII".

Vasarą studijuoti i VGTU pirmajji kursą buvo priimti 3506 žmonès. Daugiausia prièmé Statybos fakultetas - 666, nedaug atsiliko Aplinkos inžinerijos fakultetas - 585, Transporto inžinerijos - 493, Verslo vadybos -481 ir t. t.
Naujuosius mokslo metus VGTU pradëjo geros nuotaikos. Prieš 30 metų tapęs savarankiška mokykla, Vilniaus Gedimino technikos universitetas išaugo, sustiprejjo ir sukūre tvirtą pagrindą tolesnei produktyviai veiklai. 1969 m. VGTU (VISI) buvo 4365 studentu, o 1999 m. - 9252 studentai. Buvo 5 fakultetai, o po 30 metu jų buvo 8 ir dar Aviacijos institutas bei Tarptautinių studijų centras.

Vilniaus Gedimino technikos universitetas tapo prestižine Lietuvos aukštąja mokykla, turinti gerą vardą tiek šalyje, tiek užsienyje.

\section{Pradetas leisti VGTU metraštis}

Rugsejo pradžia pažymèta dar vienu ryškiu įvykiu. Išleistas VGTU Mokslotyros centro leidinys „Metai ir dienos. VGTU 1990-1993 m.". Knygos sudarytojai prof. E. K. Zavadskas ir dr. V. Lujaniené šiame metraštyje apžvelgè pagrindinius įvykius. $\mathrm{Pa}-$ teikiami universiteto tarybos, rektorato priimti nutarimai, universiteto bendruomenès nuveiktas darbas reorganizuojant Vilniaus inžinerinį statybos institutą $i$ Technikos universitetą. Knygos sudarytojai pateike ir pagrindinius dokumentus (Statutą, įvairius nuostatus), kuriuos parenge sudarytos komisijos, grupes, atskiri skyriai. Jie parode ir dokumentų kaitą. Knygoje „Metai ir dienos“ sukaupta medžiaga turi neįkainojamą vertę istorijai ir pades kiekvienam skaitytojui, plačiajai visuomenei prisiminti tą audringą periodą ir tuos pokyčius, kuriuos išgyveno Vilniaus Gedimino technikos universitetas ir jo bendruomene.

Rugsejo 20-25 d. Vilniaus Gedimino technikos universitete įvyko tapusi tradicine „Gedimino savaite“".

Monsinjoras Kazimieras Vasiliauskas aukojo šventas mišias Šv. Mikalojaus bažnyčioje už mirusius VGTU profesorius, destytojus, darbuotojus ir studentus. Buvo padètos gèles prie Gedimino paminklo, veike parodos, vyko studentų blickonkursai, meno kolektyvu pasirodymai, vakaronès.

Tą savaitę vyko mokslo istorikų konferencija "Technikos mokslų raida Lietuvoje“, kurioje dalyvavo daug žymių praeities inžinierių, 1941 m. sukilimo dalyvis, sudarytosios Lietuvos Vyriausybès ministras prof. Adolfas Damušis. Konferenciją pagerbe ir Lietuvos mokslo tarybos pirmininkas prof. Kęstutis Makariūnas, kuris į VGTU Garbès svečių knygą ịraše tokius žodžius:

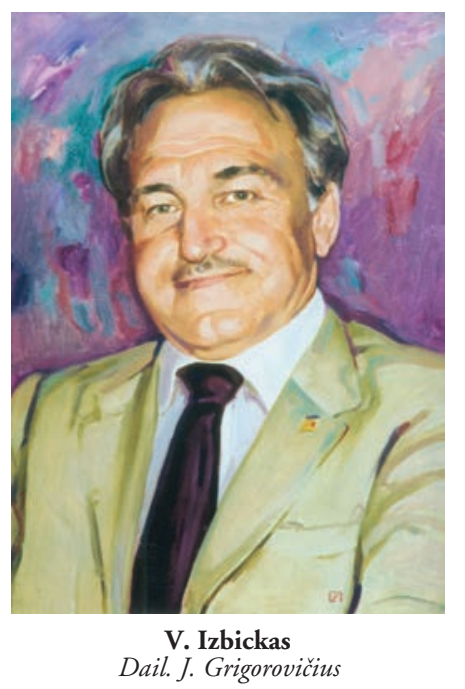


VILNIAUS

GEDIMINO

TECHNIKOS

UNIVERSITETAS

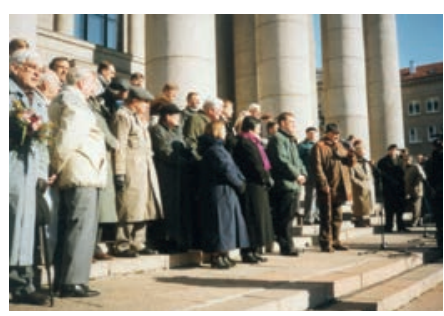

G. Orentas kalba mitinge priě̌ „Williams
"Nelengvais mokslui ir aukštajam mokslui laikais pirmiausia noretusi palinketi Vilties. Linkejimai butu tušti žodžiai, jeigu aukštosiose mokyklose nebütu ugdomi aukšto išsimokslinimo pilietiški žmonès, kurie būtu tvirtai nusistate patys kurti ne tik savo, bet ir šalies ateitį. Linkiu VGTU sèkmes, telkiant demesi darbui ypač sia linkme, daryti vis didesni poveiki salies mokslinei ir techninei kultūrinei, be ko nei valstybe, nei tauta netures ateities ".

Rugsëjo 23 d. ịvyko iškilmingas VGTU tarybos posedis, kuriame Garbes daktaru buvo inauguruotas JAV lietuvis dr. inž. Jurgis Gimbutas. Buvo apdovanoti sodybos projekto konkurso Architektūros fakultete laimetojai.

Gedimino savaites dienomis vyko sporto varžybos, vaizdo filmų pristatymai, žygiai dviračiais ir kt.

Spalio $4 \mathrm{~d}$. Lietuvos architektų sąjunga pirmininku išrinko VGTU Architektūros katedros profesorių Vytautą Dičių. Jis žadejjo revoliucijų nedaryti, nes jos per brangiai kainuoja. Stengsis daryti tai, kam ji ịpareigojo suvažiavimas. Bandys daryti įtaką valdžiai, kad architektams būtų suteikta daugiau galimybių rengti įstatymus teritorinio planavimo, architektūros, urbanistikos problemu klausimais. Teige sieksiąs, jog prie Aplinkos ministerijos būtų įkurtas Urbanistikos ir architektūros departamentas. Tuomet įstatymų rengimui architektai tikrai galètų daryti itaką.

Tą patį rudenį buvo nutarta įkurti VGTU teatro studiją. Režisieriumi pradejjo dirbti Olegas Kesminas. Buvo paskelbtas priemimas, į kurị gausiai susirinko įvairių fakultetu ir kursu studentai.

Vilniaus universiteto pakviesti, apie 3 tūkst. sostinès aukštuju mokyklu studentu, destytojų susirinko ị Nepriklausomybės aikšteje vykusị mitingą „Gelbẻkime Lietuvos ūki, jei norime išgelbeti Lietuvos mokslą ir švietimą“. Mitinge dalyvavo nemažai mūsu universiteto auklètinių. Kalbètojai piktinosi, kad mažinamos léšos mokslui, studijoms, nepritare sutarties su „Williams" pasirašymui. Mitinge emocingai ir įtikinamai kalbejo ir VGTU Garbès mecenatas Gediminas Orentas.

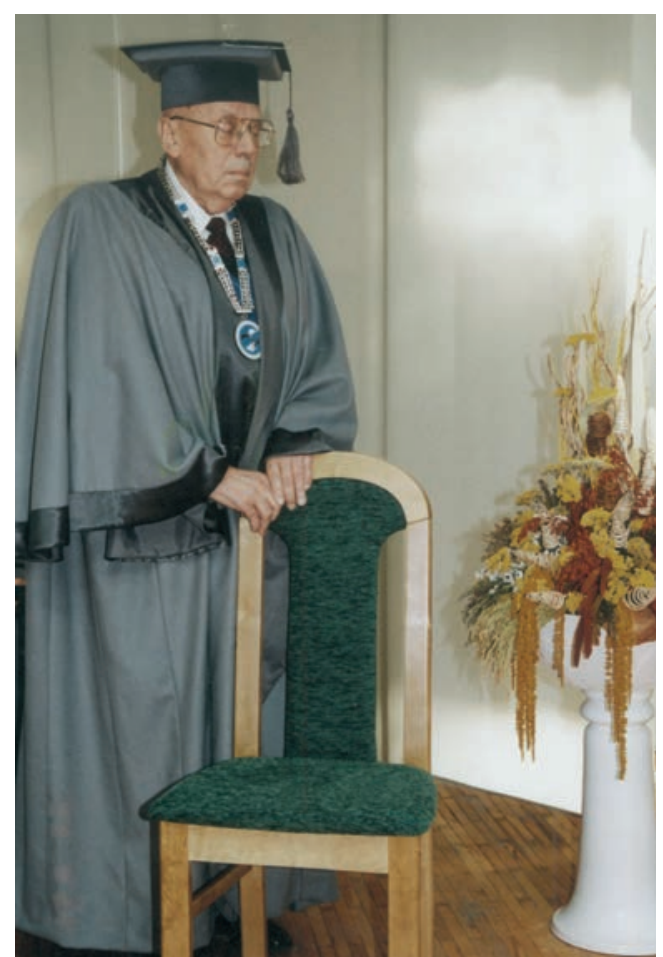

Giotebergo (Švedija) Čalmerso universitete vyko 3-iasis Baltijos regiono šalių inžinierių mokymo seminaras, organizuotas kartu su UNESCO tarptautinių inžinierių mokymo centru. Jame pranešimą tema „Aukštosios mokyklos ir ūkio struktūrų bendradarbiavimas ūkio reformų proceso sąlygomis" skaite VGTU prorektorius prof. A. V. Valiulis.

Spalio 12-15 d. VGTU dalyvavo „Litexpo" vykusioje tarptautineje parodoje „Statyba-99“. Ne vienas parodos lankytojas stabteledavo prie Architektūros fakulteto surengto sodybos konkurso nugalètojų J. Zimkutes, D. Lauciaus, R. Amšiejaus projektų.

Lietuvos rektoriai apsilanke pas Prezidentą Valdą Adamkų, kuris pritare rektorių pozicijai, kad valstybes biudžeto išlaidos švietimui kitais metais neturetų būti mažinamos.

VGTU taryba Garbès nario vardą suteikè Varšuvos automobiliu transporto instituto direktoriui Česlovui Lepkovskiui ir Lietuvos VRM Priešgaisrinès apsaugos ir gelbejimo departamento vadovui pulkininkui Kaziui Zulonui.

1999 m. pabaigoje buvo įkurtas Gedimino klubas. Jis skirtas visoms universiteto bendruomenès visuomeninems organizacijoms: profesorių, bičiulių, moterų, mokslo istoriku ir kitiems klubams, teatro studijai, studentu atstovybei ir t. t.

VGTU Nepertraukiamojo mokymo centras èmé teikti įmonèms naują paslaugą - mokyti ir konsultuoti personalą įdiegti kokybès vadybos sistemas pagal ISD-900 standartą. 
$\mathrm{Na}$, o 1999 metai baigési žinia, kad vienas „Vingio“vadovų, choreografas Ričardas Tamutis pelne Kultūros ministerijos premiją už savo naujausią kūrinį - šokį „Antele““.

\section{Žengiant i XXI amžiu}

2000 metai - paskutiniai XX amžiaus metai. Visi tikisi, kad ateinantis XXI amžius bus geresnis ir Lietuvai, ir visam pasauliui.

Bet kol kas pasaulis ne toks, kokio noretume. Kraujas liejasi, krinta aukos Azijoj, Europoj, Lotynų Amerikoj. Ryški technologinè pažanga - bene savaitemis tobulëja kompiuteriai, kasmet vis demonstruojami naujo stiliaus automobiliai, nuolat atsiranda naujuc buities prietaisų ir t. t., ir t. t. Tačiau daugelio žmonių gyvenimas ne gerëja, o dažniau ir prastëja. Kas bus toliau - nežinia.

Ir vis dèlto! Lietuva savo ateitį mato Europos Sąungoje, ji tikisi gyventi saugiai, jei bus priimta i NATO. Nors letai, bet po truputi, gereja ekonominis ir socialinis eilinių Lietuvos gyventojų gyvenimas. Atgyja ir žemés ūkis. Važiuojant iš Vilniaus Klaipedos kryptimi mažëja apleistų žemés plotų, gal tik arčiau sostinès daugybè hektarų piktžolių. Džiugina intensyvëjančios statybos. Sostinès gyventojai ima didžiuotis augančiais dangoraižiais. Bet... daug ịvairaus amžiaus žmonių krečia šiukšliadèžes ieškodami maisto, žmonès daugiausia skundžiasi mažais atlyginimais, didejančiomis būsto eksploatacijos kainomis ir kt. Tačiau nèra to blogo, kas neišeitų i gera.

Jaunimas ima suprasti, kad nereikia nei iš gamtos, nei iš dangaus laukti malonių. Pažanga, geresnis gyvenimas gali būti pasiektas tik savo žiniomis, savo energija ir darbu. Ir vis daugiau jaunimo atsisuka i mokslą, i universitetus, akademijas, institutus, kolegijas, mokyklas. O tai jau teikia vilties, kad visuomenè, kuri grindžia savo šiandienąžinių troškimu, turi ateitį.

XXI amžius, be abejo, bus ne tik vilčių išsipildymo, bet ir praradimų amžius. Išlieka branduolinio ginklo pavojus, terorizmo agresija, epidemijų grésmé, bet tikèkime - pasaulị gali ir tikrai išgelbès nuo baisiausių dalykų būtent technologine pažanga. Žmonès tampa ramūs, geranoriški, kai visi bent jau patenkinamai gyvena.

2000 m. sausio 3 d. ịvykusiame Vilniaus Gedimino technikos universiteto rektorato posedyje rektorius prof. habil. dr. Edmundas Kazimieras Zavadskas pasveikino visus rektorato narius reikšmingos datos proga ir palinkëjo tvirtybès, užsispyrimo atlaikyti laukiamus sunkumus. Rektorius sake, kad išgyvensime, jei būsime supratingi, drausmingi ir kūrybingi. Jis išreiške optimizmą, kad Gedimino universitetas buvo ir bus, nepaisant to, kad aukštojo mokslo finansavimas mažinamas net 18 \%, kad nepadengiamos 1999 metų išlaidos ir biudžeto skolos. Rektorius kvietè taupyti, nurodè būtiniausias taupymo priemones artimiausiu metu.

Sausio $19 \mathrm{~d}$. atsisveikinome su vienu veteranu, dirbusiu dar pirmaisiais mokyklos kūrimosi metais - docentu Algimantu Petru Samulevičiumi. Jis 12 metų buvo Mašinų gamybos katedros vedeju, atliko daug mokslo darbų, svarbių gamybai.

Po 10 dienų, sausio 29 d., dar viena netektis. Mire buvęs Ekonomikos katedros vedejas docentas Albinas Martinaitis. Jis buvo labai produktyvus mokslininkas, didelès erudicijos žmogus, kolekcionierius, puikus pedagogas.

Naudingą Lietuvos sostinei darbą atliko VGTU Geodezijos instituto darbuotojai. Jie sudare Vilniaus miesto šiaurinès ir vakarinès dalies skaitmenini GIS bazinį žemèlapị. Jo duomenų bazès, formuojamos stereomodeliais ir diskeliais, metų pradžioje perduotos sostinès savivaldybès įmonei „Vilniaus planas“.

$2000 \mathrm{~m}$. Vyriausybe suformavo naujos sudeties Lietuvos mokslo premijų komitetą, kurio pirmininku patvirtintas prof. habil. dr. Kęstutis Makariūnas. Technologijos mokslų sekcijai pirmininkauti buvo pavesta VGTU rektoriui prof. habil. dr. E. K. Zavadskui. I atskirų sekcijų komisijas buvo įtraukti trys VGTU atstovai: prof. habil. dr. P. Baltrenas, prof. habil. dr. L. Saulis ir prof. habil. dr. R. Ginevičius.

Tarptautinį laimejjimą pasiekè mūsų geotechnikai. VGTU Geotechnikos laboratorija kartu su Prancūzijos, Norvegijos kompanijomis, Britanijos ir Ispanijos tyrimų centrais, Vokietijos Darmštato universitetu ir viena Anglijos firma laimëjo konkursą polinių pamatų technologijoms tobulinti.

Pasitinkant Vasario 16-ąją gera žinia atẻjo iš Prezidentūros. Lietuvos Didžiojo kunigaikščio Gedimino ordinais apdovanoti buvęs rektorius akademikas prof. habil. dr. Aleksandras Čyras ir rektorius LMA narys korespondentas prof. habil. dr. Edmundas Kazimieras Zavadskas. Gedimino ordino medalis teko Statybos fakulteto dekanui dr. doc. Povilui Vainiūnui.
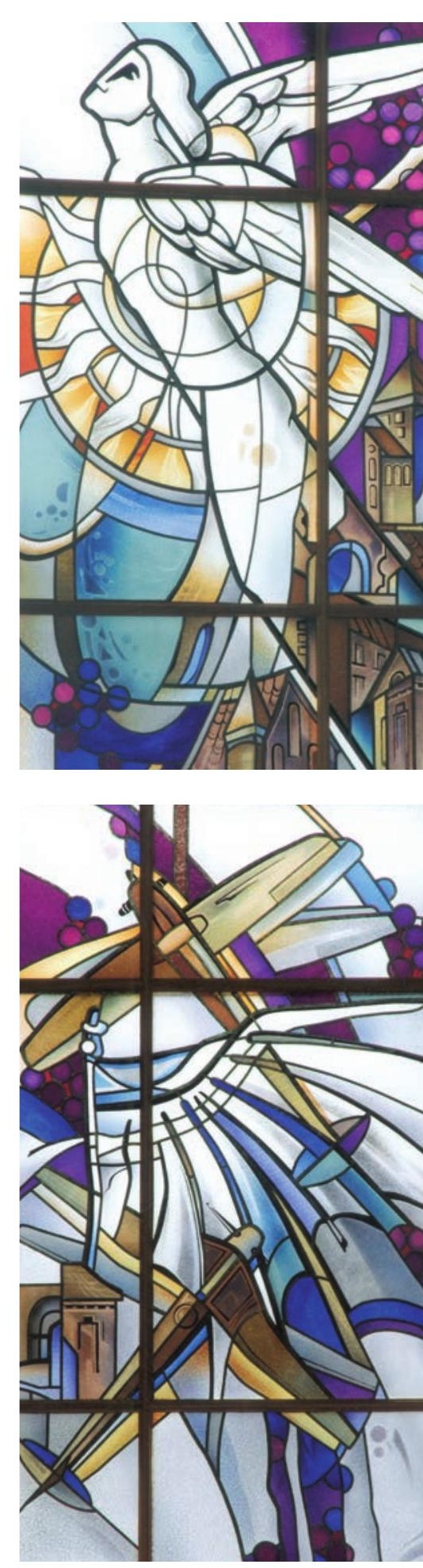

AGAI patalpose irengti vitražai. Dailininke E.Utariene 


\section{VILNIAUS}

GEDIMINO

TECHNIKOS

UNIVERSITETAS

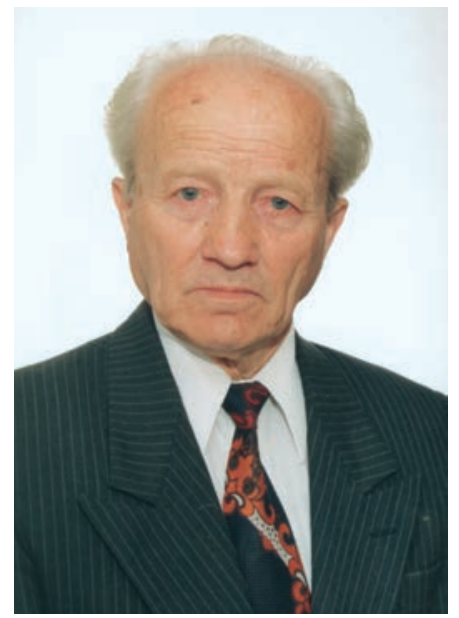

V. Vainauskas

Viršuje dešinëje -

Gavus valstybès apdovanojimus

(iš kaires): P. Vainiūnas, A. Cyras,

E. K. Zavadskas
Nuo vasario 23 d. Sauletekio rūmuose prie Didžiosios auditorijos veike Kinijos ambasados įrengta paroda apie Makao. Parodos atidaryme Kinijos ambasadorius Guan Hengguang kalbëjosi su rektorato nariais, aptare kartu su VGTU studijuojančiais kinais studentais kai kuriuos jų studijų ir gyvenimo Vilniuje klausimus. Rektorius E. K. Zavadskas supažindino svečius su Technikos universiteto istorija, struktūra, studiju programomis. Kinijos ambasadorius siūle artimiausioje ateityje aptarti gludesnio bendradarbiavimo bei studiju plettros galimybes.

Džiugią naujieną praneše Lietuvos mokslo premiju komitetas. Technologijos moksly srityje premija paskirta VGTU prof. habil. dr. Vincui Vainauskui už darbų ciklą „Geodezijos, fotogrametrijos ir kartografijos moksly teorijos ir praktikos pletra (1957-1998)“.

Lietuvos Nepriklausomybès atkūrimo dešimtmečio minējimas Vilniaus Gedimino technikos universitete buvo ypatingas. I ji atvyko Lietuvos Respublikos Prezidentas J. E. Valdas Adamkus. Jis sakè: „...šis dešimtmetis - per trumpa laiko atkarpa, kad gerai suvoktume, kas ivyko 1990-aisiais. Ateities istoriku laukia nelengvos müsu Lietuvos studijos. Bet kai kurie faktai jau šiandien aiškūs. Svarbiausias iš ju-atkurta ir apginta istorine valstybe. Visu gyvenimo sričiu permainos siandien lemia ir spartina šalies grižima $\dot{i}$ demokratiniu valstybiu bendrija, $\dot{z}$ liberaliosios $\mathrm{Va}$ karu demokratijos erdvę. Kiekvienam Lietuvos piliečiui - kiekvienam iš mūsu tai reiškia teise ir laive naudotis Vakary demokratijos laimejimais.

Suprantama, totalitarinio palikimo, buvusio laiko inercijos atsisakymas ir grižimas $\dot{z}$ pilietine bendruomene - sunkūs išméginimai ne tik žmogui, bet ir valstybei, visai Rytu bei Vidurio Europai<...>

Apgailestauju, kad visq atkurtos laisves desimtmeti per daug jegu skirta ir dabar skiriama tarpusavio kovai ir per mažai-kūrybai. Turiu galvoje politini, visuomenini - visa viešaji Lietuvos gyvenima. To padarinys - daugybe nebaigtu darbu, ipusetu, nebaigtu ar net nepradetu reformu. Daug pykčio ir nepasitikejjimo, skurdo ir nevilties slegiamu žmoniu.

Ir vis delto tikiu ateities Lietuva. Šiandienine "vargo mokykla" - tai bütina grižimo ì normaly gyvenima dalis. Prieš dešimt metu bu-

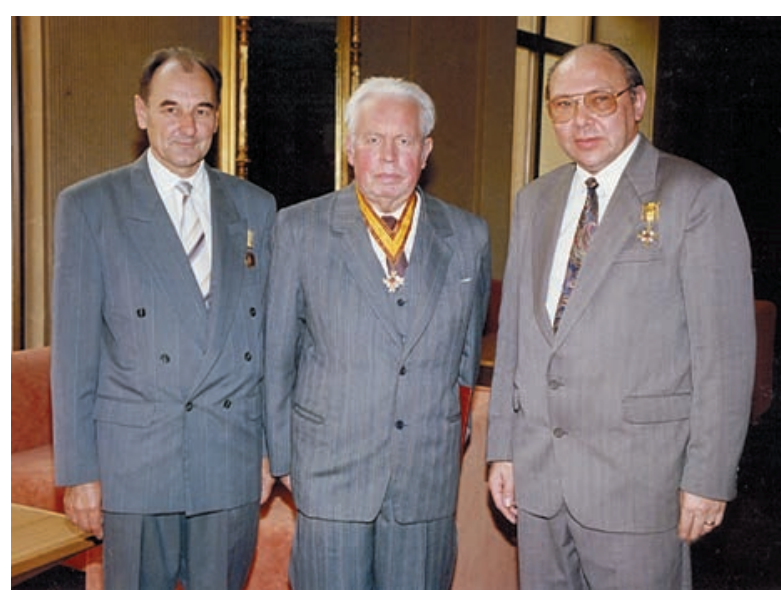

vome visuomene, neturinti ka prarasti. Šiandien esame kurianti visuomene, ateities vardan turinti jueikti permainu baime ir kiekvieno iš müsu sieloje isišaknijusia inerciją. Esame tauta ir valstybe, pajegi tai padaryti “[6.16, p. 1-3].

Iškilmingam susirinkimui pirmininkavęs VGTU tarybos pirmininkas prof. L. Saulis pažymëjo, kad Vilniaus Gedimino technikos universitetas, sparčiai atlikęs struktūrinius pertvarkymus, tapo brandžiu, šiandienos reikalavimus atitinkančiu universitetu, kuriam, kaip ir nepriklausomybes atkūrimui, sukako dešimtmetis.

Rektorius prof. E. K. Zavadskas pasidžiauge laimejimais, bet apgailestavo, kad dèl šalies ekonominès padèties aukštųjų mokyklų padètis apgailètina, kai neskirtas būtinas ju minimaliai egzistencijai finansavimas, kai priversti dirbti be bibliotekos, kad visuomenè neobjektyviai informuojama apie mūsų veiklą, kai bandoma parodyti, kad per tuos dešimt metų lyg ir neįvyko jokių teigiamų reformų, o jos tik dabar prasides, parengus Lietuvos universitetu bendruomenès kontraversiškai vertinamą Aukštojo mokslo ịstatymą. Dabar svarbu išsaugoti tai, kas pasiekta, ir negalima pritarti klastingiems pareiškimams, kad Lietuvoje per daug universitetu. Lietuvos universitetams reikia tik garantuoto finansavimo, kuo didesnio pastovumo ir kuo mažiau reformu.

Renginio metu dr. Algimantas Liekis pristate knygą „Profesorius Kazimieras Antanavičius".

Iškilmių pabaigoje šiltai buvo sutiktas rektorato nutarimas apdovanoti J. E. Lietuvos Respublikos Prezidentą Valdą Adamkų VGTU medaliu „Už nuopelnus Vilniaus Gedimino technikos universitetui“. Tokiais medaliais buvo apdovanoti ir Tarybos pirmininkas prof. L. Saulis bei studiju prorektorius doc. A. Daniūnas. 
Kovo ménesị buvo ir daugiau malonių akimirkų. Architektų rūmuose duris atvèré „Technikos“ knygynas, pirmąji spektakli parodè Teatro studija, pirmuosius žingsnius žengè "Gedimino" klubas, trečią vietą Lietuvos studentų salès futbolo čempionate laimëjo VGTU rinktinè.

Sulaukta dar vieno VGTU mokslininku tarptautinio pripažinimo. Aktyviausi VGTU „Framework 5 “ programos dalyviai buvo pakviesti dirbti į Briuselį. Tai Aplinkos inžinerijos fakulteto prof. P. Baltrenas ir Statybos fakulteto doc. A. Gailius. Abu jie dabar jau galëjo kvalifikuotai konsultuoti universiteto kolegas, rengiant „Framework 5 “ programai naujus pasiūlymus.

Tarptautinį VGTU pripažinimą reiške Baltijos jūros regiono technikos universitetų konsorciumo „BALTECH“ pasitarimas, įvykęs Vilniaus Gedimino technikos universitete. Prof. A. V. Valiulis rašè, kad pasitarime buvo svarstomas nauju, bendru visiems 7 -iems universitetams magistro programų rengimas, aptartas studentų mainų, déstymo ir studiju kokybes vertinimas, mokomujų priemonių rengimas ir kt.

Naujas duomenų bazes įsigijo VGTU biblioteka. Penkios naujos duomenu bazès gautos kompaktinių diskų forma. Bazèse galima atlikti paiešką pagal temą, straipsnio autoriaus pavardę, straipsnio pavadinimą bei periodinio leidinio pavadinimą.

Prie Lietuvos mokslu akademijos kovo $29 \mathrm{~d}$. buvo įkurta Transporto tyrimų taryba, kurios pirmininku išrinktas narys ekspertas prof. Adolfas Baublys - VGTU Transporto instituto direktorius.

Balandžio ménesi Antano Gustaičio aviacijos institutas pasipuoše dailininkès Editos Utarienés vitražais. Jos sukurti vitražai - centrinių rūmų vestibiulyje, AGAI ir vèliau VGTU bibliotekoje reikšmingai humanizavo patalpas, sukūre dvasingą aplinką, praturtino iki tol kuklius patalpu interjerus.

Buvo pradèta rengti nauja VGTU Statuto redakcija. Tą darbą turejjo padaryti sudaryta darbo grupe: prof. P. Adomenas, prof. J. Atkočiūnas, prof. P. Baltrenas, prof. R. Belevičius, prof. J. Bivainis, SA prezidentas E. Birgiolas, prof. A. Česnys, doc. A. Čiučelis, prof. A. Čižas, doc. A. Daniūnas, prof. R. Ginevičius, prof. R. Kačianauskas, doc. V. Martinaitis, prof. L. Saulis, prof. S. Štaras ir prof. E. K. Zavadskas.

Gegužès menesį džiugino VGTU studentai laimëjimais Lietuvos aukštųjų mokyklų

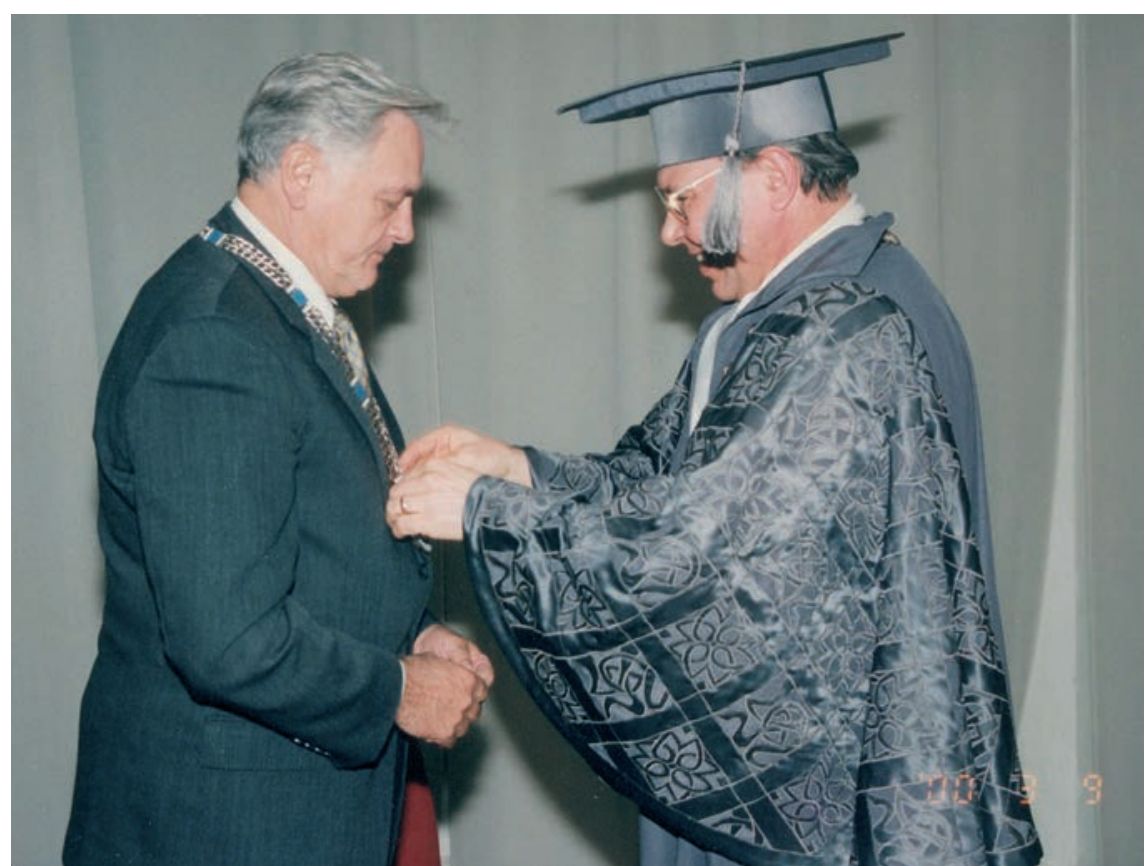

Rektorius apdovanoja J. E. Prezidento medaliu „Už nuopelnus Vilniaus Gedimino technikos universitetui"

studentų medžiagų mechanikos ir atsparumo respublikineje olimpiadoje. VGTU studentas V. Vadlūga (AT-7) antrus metus iš eilès laimejjo pirmąją vietą, o antras buvo A. Vika (TI-8).

Gražiai pasirodè Lietuvos studentų krepšinio čempionate VGTU komanda, iškovojusi 2-ąją vietą. Joje žaidè V. Gasiūnas, D. Černeckis, A. Kerulis, D. Bimba, R. Mikenas, M. Usevičius, N. Statkus, N. Tautvaišas, T. Monkevičius, R. Šerenas ir M. Lumpickas. Treneris - K. Grigaliūnas.

Studentu atstovybès prezidentu vietoj palikusio postą E. Birgiolo birželį buvo išrinktas Evaldas Vaitelis, Transporto inžinerijos ketvirto kurso studentas.

2000 m. birželį VGTU išleido gražų absolventų būrị - lygiai 2 000. Pagrindines studijas baige 1326 žmonès, II pakopos studijas (magistrantūrą ir specialiąsias profesines studijas) - 674 žmones. Aplinkos inžinerijos fakultetą baigè 322, Architektūros - 110, AGAI - 112, Elektronikos - 136, Fundamentinių mokslų - 154, Mechanikos - 184, Statybos - 349, Transporto inžinerijos - 241, Verslo vadybos -386 ir Tarptautinių studijų centrą - 6 žmones.

Nuo 1995 m. išleidžiamų specialistų skaičiu augimas kiek lettejo, bet vèliau ryškiai didëjo.

Verslo vadybos tūkstantąji diplomą gavo Laima Baliukonytè. Jos magistrantūros darbas buvo ịvertintas 10 balų. Diplomą jai itteikè LRS naré, socialinés apsaugos ir darbo ministre Irena Degutienè.

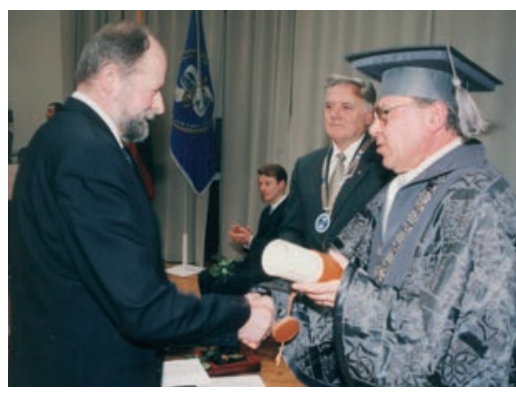

Apdovanojamas Sajūdžio VGTU grupes lyderis L. Furmonavičius 
VILNIAUS

GEDIMINO

TECHNIKOS

UNIVERSITETAS

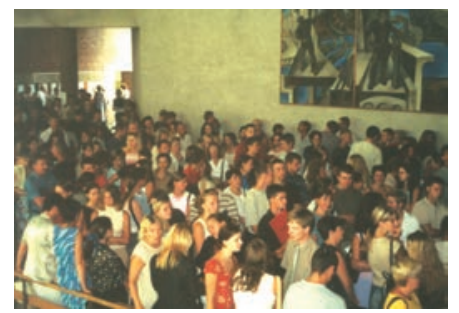

Atviru duru dienq

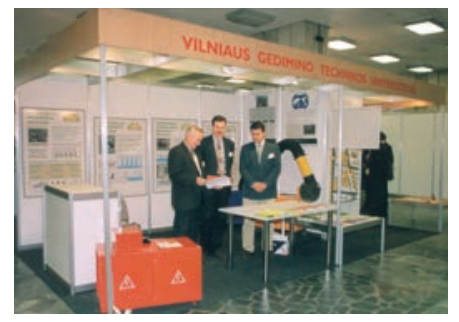

VGTU ekspozicija parodoje Sporto rūmuose

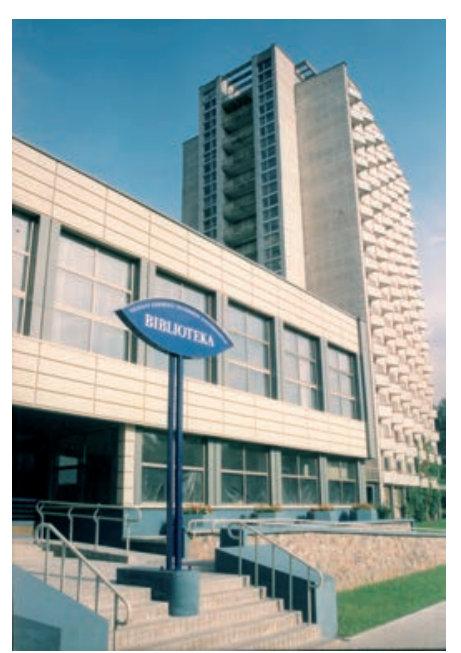

Prie naujosios bibliotekos

Viršuje dešinëje -

A. Srreiberis

VGTU Garbès daktaras

Minẹjimas Rotušeje
Vasarąi VGTU studijas buvo prïmta 3880 jaunuolių ir merginų. I pagrindines studijas ịstojo 2 635, o ị II pakopos studijas - 1245 žmonès. Daugiausia priemé Statybos fakultetas -790 , Verslo vadybos fakultetas -627 , Aplinkos inžinerijos fakultetas - 612, Transporto inžinerijos fakultetas -561 ir t. t.

Rugsèjo 1-osios - Mokslo žinių ir laisvès dienos proga rektorius E. K. Zavadskas kviete pirmakursius būti atsakingus už savo pasirinkimą. "Kiekviena profesija ir specialybe pamilstama, kai skiriama daug valandu, dienu, menesiu ir metu gilinantis i jos paslaptis. Daugelis mūsupirmakursiu yra iprate, kad jais nuolatos kas nors rüpintusi. Pirmiausia didžiausia dali rūpesčiu prisiimdavo tevai. Labai lengva gyventi, kai kažkasprisiimaatsakomybęužmūsu finansinius reikalus, ivairius isipareigojimus ir emocinę büsena, sveikata. Tačiau daugelis tapusiuju studentais privales pasirūpinti savimi ir kuo greičiau tai supras, tuo bus geriau ir jiems, ir visai universiteto bendruomenei, ir net visai visuomenei "[6.17, p. 3].

Visas Lietuvos mokyklas pasveikinęs švietimo ir mokslo ministras Kornelijus Platelis (VGTU absolventas) rašè:

„Rugsejo 1-oji-Laisvès diena. Prieš septynerius metus mūsu žeme paliko paskutiniai Sovietu sajungos kareiviai. Tai buvo milžiniškas jaunos valstybès diplomatijos laimejjimas. Ji visada dera prisiminti pradedant mokslo metus laisvoje ir nepriklausomoje šalyje. Pažinimas ir laisve - tai du neatsiejami dalykai, neegzistuojantys vienas be kito " $[6.18$, p. 1].

Rugsëjo viduryje Vilniaus Gedimino technikos universiteto biblioteka, o ir visa universiteto bendruomene paminëjo didelès reikšmès įvyki. Atidaryta nauja moderni VGTU biblioteka. Buvo igyvendinta rektoriaus E. K. Zavadsko idejja vietoj buvusiu parduotuves ir valgyklos įrengti šiuolaikinę biblioteką. Pastato rekonstrukcijos projektą parenge ir "kietą" autorinę priežiūrą vykdè architekte prof. dr. Elena Nijolè Bučiūte. Darbus vykde UAB „Giedra“. Monsinjoras Kazimieras Vasiliauskas, pašventinęs bibliotekos patalpas, tare įsimintinus žodžius: „Tegul neblesta meile knygai. Džiugu, kad kavine, kuriu dabarmūsu sostineje pakankamai yra ant kiekvieno kampo, pertvarkyta i biblioteka, kurioje vyks širdžiu ir proto puota. Laiminu sienas, bet omeny turiu čia dirbančius žmones " [6.19, p. 1 ir 3].

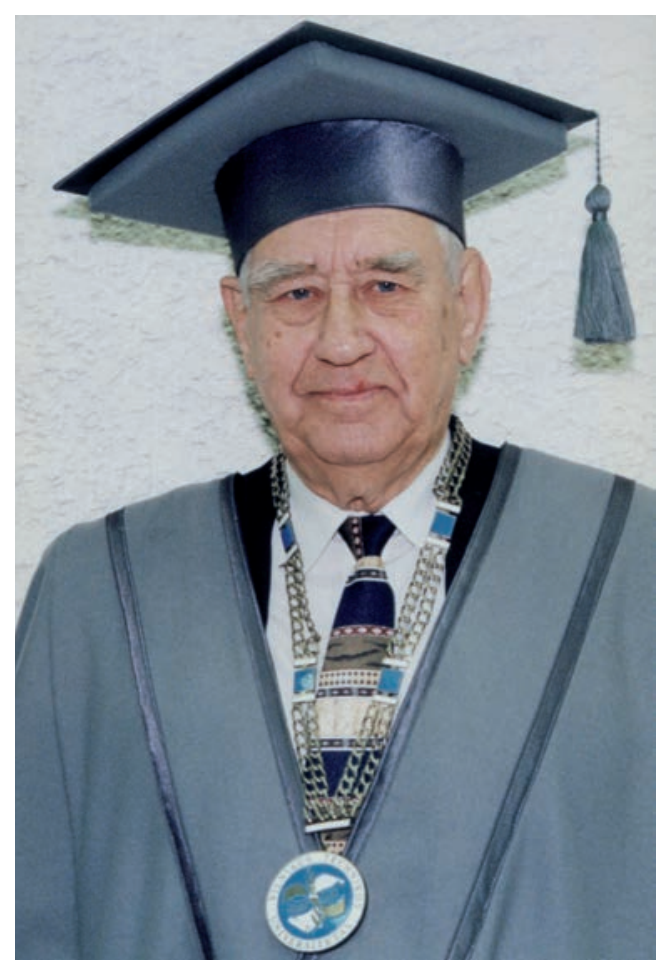

Bibliotekoje, kurios direktore Regina Pugžlienè nestokojo iniciatyvų, jau buvo pradeta diegti nauja bibliotekinè sistema ALEPH 500. Bibliotekoje buvo įrengtas moderniausias Lietuvoje kompiuterinis tinklas, 135 darbo vietos, igyta 15 kompiuterių ir 2 serveriai. Po keleto metų buvo tikimasi tureti per 100 kompiuteriu.

İkurtuvių šventeje dalyvavo LRS švietimo, mokslo ir kultūros komiteto pirmininkas dr. Ž. Jackūnas, Švietimo ir mokslo viceministras dr. A. ̌̌alys, aplinkos ministras dr. D. Lygis, Vilniaus vicemeras habil. dr. A. Kudzys ir kt.

Spalio 19-28 d. buvo surengta tradicine tapusi Gedimino universiteto savaite, kurios pagrindinis akcentas - VGTU 10-mečio minejjimas miesto Rotušeje. Vilniaus gyventojams ir svečiams įspūdị padare AGAI lekktuvų skrydis virš Katedros aikštes akcijos prie Gedimino paminklo metu.

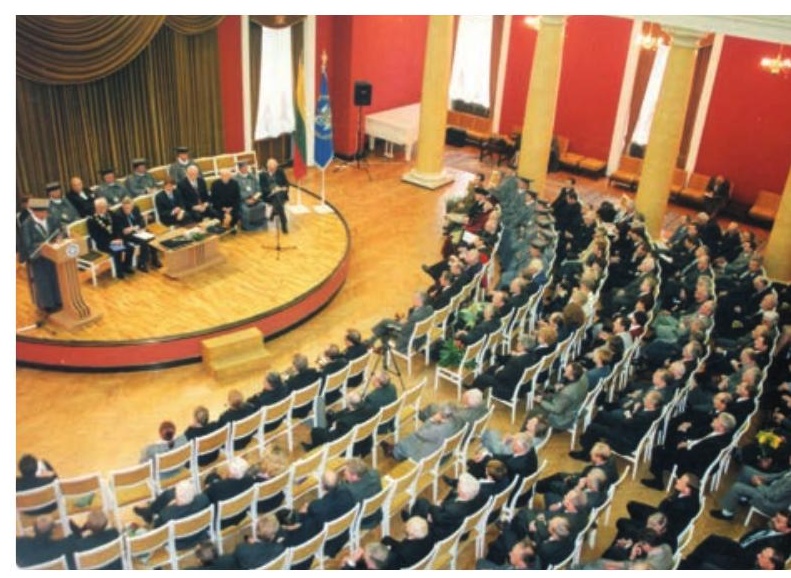


Savaitès dienomis inžinieriaus Vytauto Izbicko auditorijoje įvyko Tarybos posèdis, kuriame VGTU Garbès daktaru buvo inauguruotas maskvietis Andriejus Šreiberis. Jis per 30 metu bendradarbiavo su VGTU (VISI) mokslininkais, daug pagelbejjo ne vienam doktorantui, rengusiam disertacijas, buvo ne vieno jų oponentu.

\section{Jos puošia universiteta}

İspūdingą savo darbų parodą rektorato prieigose surengè VGTU profesionales dailininkès Asta Rudminaite ir Ramunè Muraliene. Tai buvo tik nedidele dalis universitetui jų atliktų darbų. I dvidešimti parodos stendu tilpo tik patys gražiausi, įdomiausi darbai. Rektorius abi dailininkes apdovanojo VGTU dešimtmečio medaliais.

VGTU dešimtmečio minëjime Vilniaus rotušeje dalyvavo Prezidentas, VGTU Garbès daktaras Algirdas Brazauskas, Ministras Pirmininkas, VGTU absolventas Rolandas Paksas, VGTU Garbès narys monsinjoras Kazimieras Vasiliauskas, LRS narys, VGTU docentas Algirdas Kunčinas, VGTU Garbes mecenatas Gediminas Orentas, VGTU Garbes narys akademikas Vytautas Statulevičius, Statybininku asociacijos prezidentas, VGTU Garbès narys Adakras Šeštakauskas ir daugelis kitų garbingų žmonių. Šventini pranešimą perskaite rektorius prof. E. K. Zavadskas.

„Šiandiena galime pasidžiaugti ir pripažinti, kad mūsu universitetas yra kitokia aukštoji mokykla, nei buvo prieš dešimtmeti ir net prieš 2-3 metus, -sakèpranešejas. -Jos kiekybinis ir kokybinis augimas yra lengvai pastebimas bei visuomenes vertinamas. Iki 10200 išaugo studijuojančiuju skaičius. Kelis kartus padidejo studiju programu, kurias gali pasirinkti jaunimas, skaičius. Išaugo destytoju mokslo daktaru ir habilituotu mokslo daktaru skaičius. Didžiuliais tempais plečiasi universiteto tarptautinis bendradarbiavimas. Dešimtis kartu padidejo pasirašytu bendradarbiavimo sutarčiu skaičius. Išango studentu mainai su pasaulio aukštosiomis mokyklomis. I universiteta kasmet stoja vis daugiau abiturientu. Stojančiuju skaičiai ir konkursai, palyginti su kitomis aukštosiomis mokyklomis, atspindi realu müsu universiteto jvaizdi “. Rektorius savo šventiniame pranešime kalbëjo ir apie sunkią aukštujjų mokyklų šiandienos būklę, nuolatos mažinamą finansavimą, skubiai priimtą, bet taisytiną įstatymą, kuris reglamentuoja mokslą, aukštąsias studi-

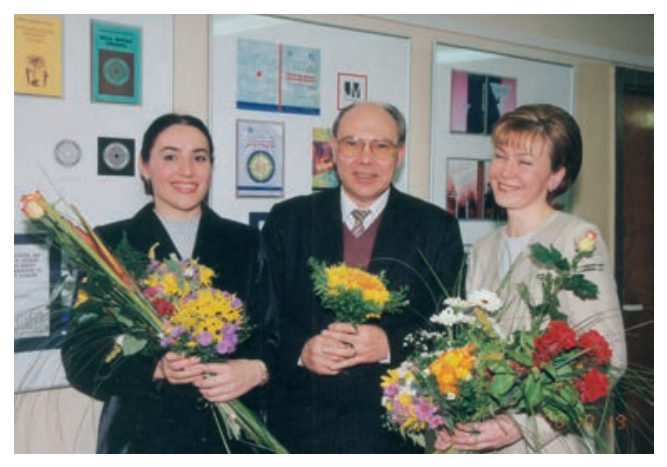

Iš kairès: A. Rudminaite, E. K. Zavadskas, R. Muraliené

jas, šio dokumento siūlomas reformas, nepamatuotą kritiką šalies universitetų adresu. Prisiminta, jog finansuojant aukštąsias mokyklas beveik neatsižvelgiama į studijų programų sudètingumą ir būtiniausias sąnaudas. „Mūsu universitetas jau ištvere daugybę išbandymu. Beveik neskiriant papildomo finansavimo, atliko milžiniška reforma, restruktūrizavima, ikūure kelis naujus fakultetus, sukūrè dešimtis nauju studiju programu ir parengè šaliai tūkstančius reikalingu specialistu ".

Tarybos pirmininkas L. Saulis ir rektorius E. K. Zavadskas pasveikino Rolandą Paksą, antrą kartą tapusį Lietuvos Respublikos Ministru Pirmininku ir apdovanojo ji jubiliejiniu atminimo medaliu. Renginio metu VGTU Garbes daktarais buvo inauguruoti Varšuvos aukštosios mokyklos rektorius prof. Ježi Volaninas ir Kauno technologijos universiteto profesorius Danielius Eidukas. Švente baigesi, ir jau kitą dieną tęsèsi VGTU mokslininkų kasdieniai darbai.

Lapkričio menesį buvo išleistas Vinco Vainausko parengtas „Kartografijos ir geodezijos terminų aiškinamasis žodynas". Šis terminų žodynas parengtas vadovaujantis JAV Gynybos kartografavimo departamento išleistu žodynu, skirtu veiksmingam bendradarbiavimui tarp daugelio įvairių valstybių vartotojų. Jis turejo palengvinti spręsti skubius dabarties uždavinius ir atverti duris i pasaulini matavimo inžinerijos mokslo lobyną. Žodyno paskirtis dvejopa. Visu pirma - tai dvikalbis žodynas. Antra - jis yra aiškinamasis. Tai buvo pirmas bandymas sudaryti šios mokslo ir praktikos šakos dvikalbị žodyną.

Net dvi dienas vyko mokslo istoriku konferencijos „Technikos moksly̨ raida Lietuvoje" posedžiai. Jos plenariniame posèdyje buvo pristatytos dvi naujos knygos: E. K. Zavadsko ir V. Lujanienés sudaryta „Dienos ir darbai“ ir A. Nako „Inžinierius Vytautas Izbickas“.

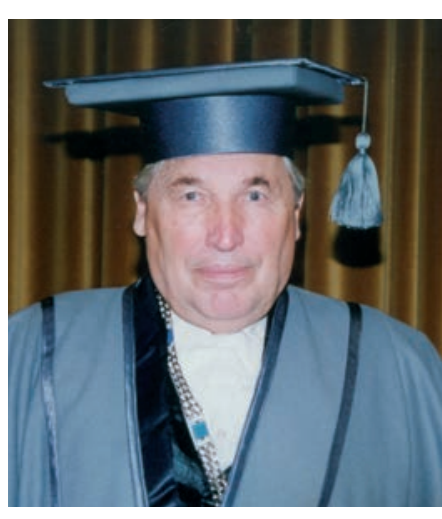

D. Eidukas VGTU Garbès daktaras

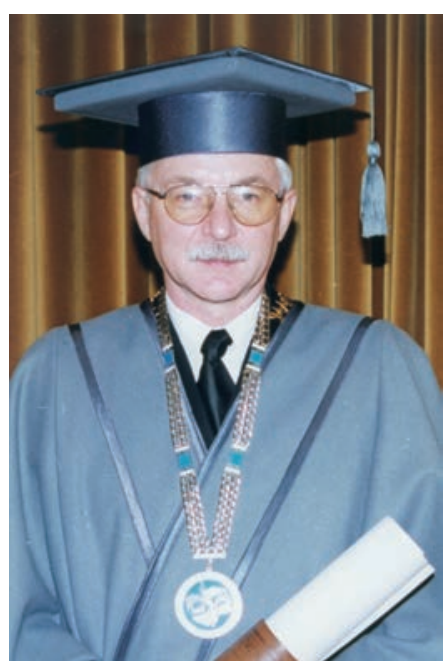

I. Volaninas VGTU Garbés daktaras 
VILNIAUS

GEDIMINO

TECHNIKOS

UNIVERSITETAS

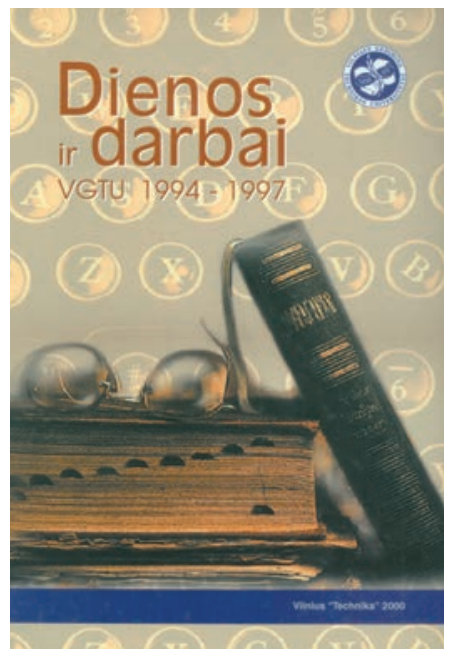

Viršuje dešinëje -

D. H. Milneris

VGTU Garbes narys
2000 metams baigiantis, sužinota, kad tarptautines programos „Framework5“ aplinkosaugos srities projektų ekspertas, VGTU Aplinkos apsaugos katedros vedejas prof. habil. dr. Pranas Baltrenas patvirtintas Lietuvos standartizacijos departamento Technikos komiteto „Aplinkosauga“ pirmininku. Komitetui buvo pavesta rūpintis, kad Lietuvos aplinkosaugos dokumentai, standartai atitiktų tarptautinių ir Europos standartų reikalavimus.

Gražiai paskutinius XX amžiaus metus baigè VGTU lengvaatlečiai. „Baltijos taurès“ varžybose VGTU komanda buvo trečia, o APU-0 gr. Studente Jūratè Strumskytè laimëjo $800 \mathrm{~m}$ bègimo varžybas.

Švenčiu proga į VGTU bendruomenę kreipesi rektorius E. K. Zavadskas ir Tarybos pirmininkas L. Saulis.

„Gerbiami kolegos! Studentai, visi darbuotojai!

Tegul Kaledu ir Naujuju Metu švenčiu tyla, prasmingas susikaupimas atveria Jüsu širdis džiangsmui, pripildo jas tikejimo savimi ir kitais, kad turetume kuo pasidalyti sušeimos nariais, bičiuliais, bendradarbiais, pradedamitrečiajz tūkstantmeti. Linkime, kadXXI amžiuje kiekvieno Jūsu nuolatinis, ištikimas palydovas būtu sveikata, meile, gražus tarpusavio supratimas ir sutarimas šeimoje, darbe, kasdienos sèkme ir ramybe, pedagoginis optimizmas ".

Lietuvos Respublikos Seimas dar 2000 m. spalio ménesi patvirtino naujos redakcijos VGTU statutą, kuris buvo parengtas, atsižvelgiant ị naująji Aukštojo mokslo įstatymą. Metams baigiantis Senato nariais buvo išrinkti:

1. Prof. habil. dr. E. K. Zavadskas, rektorius. 2. T. Butkus, AMm-9, A. Gustaičio aviacijos institutas. 3. D. Jančiulyte, VV-8/1, Verslo vadybos fakultetas 4. M. Lipnevič, 11-8/1, Fundamentinių mokslų fakultetas 5. K. Mečinskaite, PV-8, Mechanikas fakultetas 6. E. Vaitelis, TPPm0 , Transporto inžinerijos fakultetas 7 . Prof. habil. dr. P. Baltrenas, Aplinkos inžinerijos fakultetas. 8. Doc. dr. D. Čygas, Aplinkos inžinerijos fakultetas. 9. Prof. habil. dr. Z. Kamaits, Aplinkos inžinerijos fakultetas. 10. Doc. habil. dr. V. Martinaitis, Aplinkos inžinerijos fakultetas. 11. Prof. habil. dr. A. Zakarevičius, Aplinkos inžinerijos

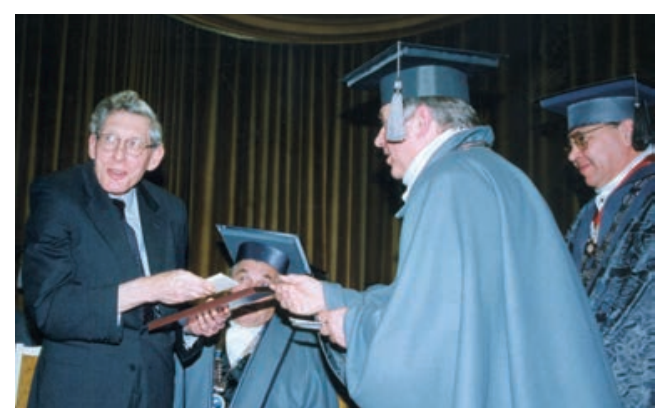

fakultetas. 12. Prof. dr. R. Buivydas, Architektūros fakultetas. 13. Prof. L. Ziberkas, Architektūros fakultetas. 14. Prof. habil. dr. P. G. Adomènas, Fundamentinių moksly fakultetas. 15. Prof. habil. dr. R. Belevičius, Fundamentinių mokslų fakultetas. 16. Prof. habil. dr. A. Česnys, Fundamentinių mokslų fakultetas. 17. Prof. habil. dr. R. Čiegis, Fundamentinių mokslų fakultetas 18. Doc. dr. A. Čiučelis, Fundamentinių mokslų fakultetas. 19. Prof. habil. dr. R. Kačianauskas, Fundamentinių mokslų fakultetas. 20. Prof. habil. dr. M. K. Leonavičius, Fundamentinių mokslų fakultetas. 21. Prof. habil. dr. L. Saulis, Fundamentinių moksly̨ fakultetas. 22. Doc. dr. M. Šukšta, Fundamentinių mokslų fakultetas. 23. Prof. habil. dr. R. Kirvaitis, Elektronikos fakultetas. 24. Prof. habil. dr. R. Martavičius, Elektronikos fakultetas. 25. Prof. habil. dr. A. Poška, Elektronikos fakultetas. 26. Prof. habil. dr. J. Skudutis, Elektronikos fakultetas. 27. Prof. habil. dr. M. Mariūnas, Mechanikos fakultetas. 28. Prof. habil. dr. A. V. Valiulis, Mechanikos fakultetas. 29. Prof. habil. dr. V. Vekteris, Mechanikos fakultetas. 30. Prof. habil. dr. J. Atkočiūnas, Statybos fakultetas. 31. Doc. dr. P. Čyras, Statybos fakultetas. 32. Prof. habil. dr. A. Kaklauskas, Statybos fakultetas. 33. Doc. habil. dr. G. Kaklauskas, Statybos fakultetas. 34. Prof. habil. dr. A. K. Kvedaras, Statybos fakultetas. 35. Doc. dr. V. Stragys, Statybos fakultetas. 36. Doc. dr. R. Vadlūga, Statybos fakultetas. 37. Doc. dr. P. Vainiūnas, Statybos fakultetas. 38. Doc. habil. dr. M. Bogdevičius, Transporto inžinerijos fakultetas. 39. Prof. habil. dr. L. Lingaitis, Transporto inžinerijos fakultetas. 40. Prof. habil. dr. R. Palšaitis, Transporto inžinerijos fakultetas. 41. Doc. dr. A. Pikūnas, Transporto inžinerijos fakultetas. 42. Prof. habil. dr. R. Ginevičius, Verslo vadybos fakultetas. 43. Prof. habil. dr. B. Melnikas, Verslo vadybos fakultetas. 44. Prof. habil. dr. N. Paliulis, Verslo vadybos fakultetas. 45. Prof. habil. 
dr. V. Pruskus, Verslo vadybos fakultetas. 46. Prof. habil. dr. A. V. Rutkauskas, Verslo vadybos fakultetas. 47. Prof. habil. dr. A. J. Staškevičius, Verslo vadybos fakultetas. 48. Dr. R. Tamošiūnienè, Verslo vadybos fakultetas. 49. Prof. habil. dr. J. Stankūnas, Antano Gustaičio aviacijos institutas.

I VGTU senato pirmininko postą buvo pasiūlyti 4 kandidatai, habilituoti daktarai profesoriai: Rimantas Belevičius, Romualdas Ginevičius, Raimundas Kirvaitis ir Leonas Saulis. Komisijos pirmininkas prof. M. Mariūnas paskelbẻ balsavimo rezultatus: už R. Belevičių balsavo 14, už R. Ginevičių 19, už R. Kirvaitį - 6, už L. Sauli - 10 senatorių.

Taigi iš karto Senato pirmininkas neišrinktas, nes nè vienas kandidatas nesurinko 50 proc. +1 balsų. I antrą turą pateko $\mathrm{R}$. Belevičius ir R. Ginevičius. Po trumputès pertraukèles balsavimo komisijos pirmininkas paskelbè, jog Senato pirmininku išrinktas Verslo vadybos fakulteto dekanas prof. habil. dr. Romualdas Ginevičius, už kurị balsavo 28 senatoriai. Už prof. Rimantą Belevičių antrame ture balsavo 20 senatorių.

Plojimais buvo pasveikintas naujasis Senato pirmininkas prof. R. Ginevičius. Rektorius prof. E. K. Zavadskas Senato vardu palinkëjo pirmininkui sèkmès, stiprybès, ištvermès, įteikè gèlių puokštę bei užkabino medali „Už nuopelnus Vilniaus Gedimino technikos universitetui“, kuris dèl profesoriaus stažuotès nebuvo laiku įteiktas. Padèkota ir gèlèmis apdovanoti buvęs Tarybos pirmininkas prof. Leonas Saulis, pirmininko pavaduotojas prof. Petras Adomenas, rinkimų komisijos pirmininkas doc. Romualdas Vadlūga, Tarybos reikalų tvarkytoja Aldona Bruzgelionienè.

Senato pirmininkas prof. Romualdas Ginevičius padekojo visiems už pasitikejjimą ir išreiške viltį, jog bendrai dirbant bus sèkmingai atliktos universiteto bendruomenei keliamos funkcijos [6.20, p. 2].

Prof. habil. dr. Romualdas Ginevičius nuo 1993 m. dirbo İmonių ekonomikos ir vadybos katedros vedeju ir Verslo vadybos fakulteto dekanu. Prie abiejų pareigų dar prisidejo VGTU Senato pirmininko darbas.

2001 m. sausio 13 d. sukako dešimt metų nuo kruvinųjų 1991 m. ìvykių, kai begriūnanti Sovietų Sąunga nežabotu teroru sieke sulaikyti lietuvių tautą, ryžtingai stojusią i laisvès ir nepriklausomybès kelią.

Pasitinkant Sausio 13-osios įvykių dešimtąsias metines, prie televizijos bokšto žuvusio
Elektronikos fakulteto pirmakursio Rolando Jankausko atminimui įamžinti VGTU centriniuose rūmuose (dabar vadinamų Sauletekio rūmų centriniame korpuse) memorialinè lenta buvo atnaujinta, gražiai sutvarkyta aplinka.

Anot buvusio Lietuvos Respublikos Seimo nario J. Tartilo, „studentas Rolandas Jankauskas-pavyzdys ne tik jūsu aukštajai mokyklai, bet ir visos Lietuvos akademiniam jaunimui. Šimtmečiais stoves lenta, primenanti šio jaunuolio auka mūsu Tèvynei " [6.21, p. 59].

2001 m. sausio 23 d. Vilniaus Gedimino technikos universitete ìvyko Kauno technologijos universiteto ir VGTU vadovų susitikimas. Nors abu universitetai tarp savęs konkuruoja, abu svarbias problemas gali sèkmingiau spręsti turedami bendrą poziciją. Tai diktavo pats gyvenimas, kai buvo mažinamas universitetų finansavimas, kai teko kovoti su kai kurių biurokratų inspiruotomis neteisingomis nuostatomis. Iš KTU atvyko rektorius R. Bansevičius, Senato pirmininkas R. P. Žilinskas, prorektoriai V. Ostaševičius, R. Šiaučiūnas, N. Navickas, P. Baršauskas. VGTU atstovavo rektorius E. K. Zavadskas, Senato pirmininkas R. Ginevičius, prorektoriai R. Kačianauskas, A. V. Valiulis, A. Daniūnas, A. Komka. Universitetų vadovai taresi, kaip bendrai naudotis laboratorine įranga tiek mokslo, tiek studiju reikalams, kaip efektyviau keistis leidžiama literatūra, nagrinejo galimybes kartu rengti vadovelius ar monografijas. Sutarta pasikeisti duomenų bazemis apie turimus prietaisus, aparatus ir įrenginius. Manyta, kad kai kuriuos unikalius laboratorinius darbus studentai galètų atlikti nuvažiavę i kitą universitetą, jei tik ten yra įrengta atitinkamai aprūpinta laboratorija. Esant galimybèms šitiems tikslams buvo numatyta efektyviau naudoti šiuolaikines ryšio technologijas. Pažymèta, kad būtina intensyviau pasinaudoti lygiagrečiosios architektūros kompiuteriu, esančiu VGTU skaičiavimo centre. Susitikime kalbèta, kad VGTU lygiagrečiųjų skaičiavimų kompiuterine baze turètų daugiau naudotis visa Lietuva. Akcentuota, kad reikia rengti bendras nuotolinių studijų programas.

Sutarta naujausiems mokslo ir technologijų laimëjimams skleisti organizuoti abiejų universitetų magistrantų ir doktorantų bendras vasaros mokyklas, kad tikslinga kartu su Lietuvos mokslų akademija organizuoti renginį technologijų pažangai, jos integravimo i mūsų kraštą galimybèms aptarti.

Susitikimo dalyviai džiaugèsi jau esamu abiejų universitetų bendradarbiavimu. Kaip

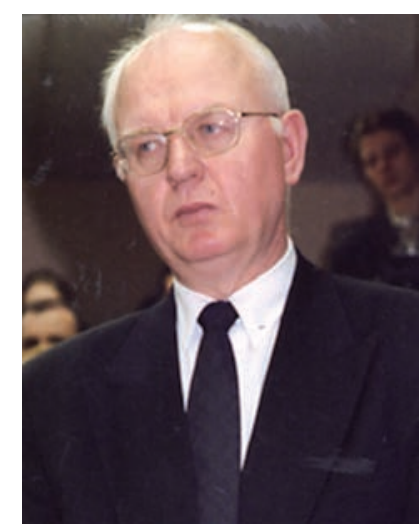

R. Ginevičius Senato pirmininkas 
VILNIAUS

GEDIMINO

TECHNIKOS

UNIVERSITETAS

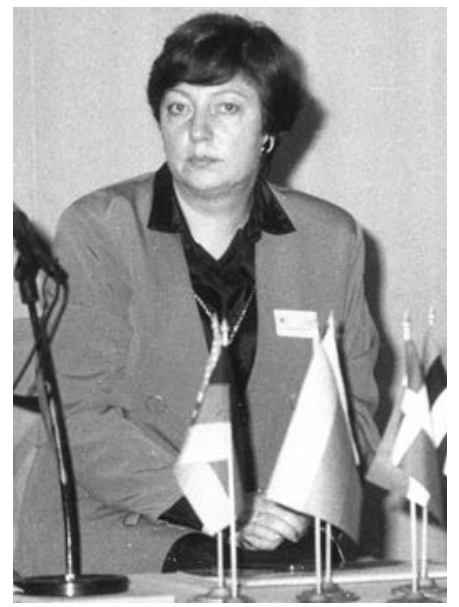

M. Burinskiene, pirmojo elektronine vadovélio autore pavyzdys nurodytas neseniai KTU ir VGTU bendrai parengta ir išleista knyga apie statybos mokslo ir studijų raidą Lietuvoje. Kartu raginta rasti naujus bendradarbiavimo laukus bei siekti, kad destytojų ir studentų skaičiu santykis būtų toks, kokio reikia inžinieriams rengti. Buvo pateikta ir daugiau gražaus bendradarbiavimo pavyzdžių, ypač dirbant doktorantūros komitetuose, keičiantis oponentais ir kt.

VGTU Garbès svečiu knygoje KTU rektorius prof. R. Bansevičius užrašè: „Šiandien Lietuvai ypač svarbus dvieju pagrindiniu technologijos krypties universitety VGTU ir KTU-bendradarbiavimas. Ne konkuruoti, bet bendradarbiauti! - tegul šis devizas plečia müsu santykius" [6.22, p. 1-2].

Metų pradžioje Miestų statybos katedros darbuotojai, vadovaujami doc. dr. M. Burinskienès, pateikè parengtą vadovèlį, kuriame analizuojami mūsų kraštui svarbūs teritorijų tvarkymo, želdinimo, susisiekimo organizavimo ir inžinerinès infrastruktūros projektavimo, įrengimo ir remonto klausimai. Tai pirmasis VGTU stambus vadovelis universitete, išleistas elektronine versija.

Pasitinkdamas Vasario 16-ąją VGTU rektoratas įsteige dar dvi vardines stipendijas - Stepono Kairio ir Petro Vileišio. Steponas Kairys - Vasario 16-osios signataras, žymus aplinkos inžinierius, pirmojo vadovèlio „Kanalizacija“ autorius, buvęs Vytauto Didžiojo universiteto profesorius. Petras Vileišis - vienas žymiausių XIX amžiaus pabaigos - XX amžiaus pradžios lietuvių atgimimo veikëjų, ǐžymus geležinkelių ir tiltu statytojas, buvęs Lietuvos Respublikos susisiekimo ministras.

Taigi nuo šiol VGTU turëjo 11 vardiniu stipendiju: L. D. K. Gedimino, S. Grinkevičiaus, A. Gustaičio, S. Kerbedžio, D. Maciulevičiaus, L. Grincevičiaus, K. Semenavičiaus, V. A. Graičiūno, K. Antanavičiaus, S. Kairio ir P. Vileišio. Ju dydis - 2,5 MGL (minimalaus gyvenimo lygio).

Puikūs leidiniai gule ant skaitytojų stalo tuoj po Naujųju metų. Tai prof. A. V. Valiulio sudarytoji „Dešimt Vilniaus Gedimino technikos universiteto reformos ir kūrybos metų. 1990-2000" bei KTU ir VGTU statybos mokslininkų parengta „Statybos mokslų ir studijų raida Lietuvos universitetuose“.
Reikšmingas Lietuvos technikos inteligentijai įvykis vyko VGTU vasario $13 \mathrm{~d}$. Visuomenei buvo pristatytas pirmą kartą Lietuvos istorijoje leidžiamos "Technikos enciklopedijos" pirmasis tomas. Šios enciklopedijos Redaktoriu tarybos pirmininkas yra VGTU rektorius prof. E. K. Zavadskas, o tarybos nariai, be kitu, yra VGTU profesoriai A. Čižas, P. Baltrenas, Z. Kamaitis, A. Smilgevičius, S. Štaras, A. V. Valiulis ir doc. A. Nakas. Daugelis VGTU mokslininkų rašo šiai enciklopedijai straipsnius, yra jos recenzentai. Todèl renginyje dalyvavęs Mokslo enciklopediju leidybos instituto direktorius Rimantas Kareckas dèkojo mūsų universitetui už reikšmingą pagalbą leidžiant „Technikos enciklopediją“. Teigiamai vertino mūsų mokslininkų darbą Fizikos ir technologijos mokslų redakcijos vedejja Irena Valiuliené, mokslinè redaktore Janina Kuliešienè. Numatyta išleisti keturis „Technikos enciklopedijos" tomus.

Vasario 15 d. mūsų universiteto bendruomenès atstovai susirinko į Petro Vileišio auditoriją paminèti Lietuvos valstybes atkūrimo dieną. Renginyje dalyvavo Prezidentas VGTU Garbès daktaras Algirdas Brazauskas, VGTU Garbès nariai monsinjoras Kazimieras Vasiliauskas ir Lietuvos statybininku asociacijos vadovas Adakras Šeštakauskas, VGTU Garbès mecenatas Gediminas Orentas, garsus Lietuvos mokytojas, ilgametis $\mathrm{Pa}-$ svalio Petro Vileišio gimnazijos direktorius Juozas Dulskis ir kt. Prelegentai akcentavo, kad vis daugiau jaunimo siekia mokslo, prisimine švietimo ir mokslo problemas, aptare ateities perspektyvas. Šventes išvakarese studentams, kuriems už gerą mokymąsi buvo paskirtos vieno žymiausių lietuvių tautinio atgimimo veikëjų, kelių inžinieriaus Petro Vileišio ir socialdemokratų partijos įkūrëjo, Vasario 16-osios signataro Stepono Kairio vardines stipendijos, buvo įteikti stipendiju pažymejjimai. Renginio metu buvo pristatyta Algimanto Nako ir Valdo Pruskaus išleista knyga „Petras Vileišis. Inžinierius. Kultūrininkas. Verslininkas“, kurią parenge „Technikos" leidykla. Knyga išleista 150-ųju Petro Vileišio gimimo metiniu proga.

Dažnos buvo VGTU mokslininkų kelionès į užsienį, stiprëjo VGTU ir užsienio universitetu bendradarbiavimas. Branduolines hidrofizikos laboratorijos vedejas prof. D. Styra lankesi Olborge (Danija) pagal TATENA'os programą. Čia skaite pranešimus apie Baltijos jūros užterštumą dirbtinès 
kilmès radionuklidais ir jos savivalą bei apie Žemés anomalių reiškinių prognozę pagal kietojo kosminio spinduliavimo srauto nestabilumą. Be to, profesorius susipažino su naujomis universiteto laboratorijomis, aptare bendradarbiavimo su hidrofizikos ir hidraulikos mokslininkais pletotés klausimus.

„Technikos" leidykla vokiečių kalba išleido prof. E. K. Zavadsko knygą „Mehrkriterielle entscheidungen im bauwesen“(„Daugiakriteriniai sprendimai statyboje“).

Doc. Rimantas Kalinauskas Varniuose, Žemaičių vyskupystès muziejuje, pristate savo

\section{Vèl valstybès premijos}

Kovo 8 d. Mokslų akademijoje iškilmingai įteiktos Lietuvos nacionalinès mokslo premijos. Vieną iš ju gavo ir mūsų universiteto profesoriai habilituoti daktarai Adolfas Baublys ir Ramūnas Palšaitis. Mokslo premiju Technologijos mokslų sekcijos pirmininkas universiteto rektorius prof. Edmundas Kazimieras Zavadskas, pristatydamas laureatus, akcentavo, jog premija ịvertintas ilgametis mokslininkų triūsas, apibendrintas darbe „Lietuvos transporto sistemos formavimo strategija: teoriniai ir metodiniai aspektai (1988-1999)“.

Mūsų universiteto organizuotame Lietuvos nepriklausomybes atkūrimo Kovo 11-osios dienos minejime dalyvavo ilgametis VLIK’o (Vyriausiojo Lietuvos išlaisvinimo komiteto) prezidentas, Seimo narys Kazys Bobelis. Jis nuoširdžiai pasidžiauge, kad buvo pakviestas î šią šventę, kad galejo pasidalyti didelio nerimo mintimis. Atsisveikindamas Universiteto garbès svečiu knygoje įrašè:

„Visa mūsu Tautos ateitis priklauso nuo išsilavinusio, tautiniai subrendusio jaunimo. Jūsu universitetas ši gyvybini Lietuvos ateities isipareigojima labai garbingai atlieka.

Linkiu sèkmés augti, stiprèti ir toliau mūsu jaunima aukleti patriotiniai ir tautiniai. Seimo narys dr. Kazys Bobelis ".

Gražių laimèjimų pasiekè jaunieji VGTU mokslininkai. Arnui Kačeniauskui už darbą „Klampaus nespūdaus skysčio tekejjimo srityje su laisvuoju paviršiumi modeliavimas baigtinių elementų metodu" ir doktorantui Raimundui Rigertui už darbą , Sijos ir kolonos junginys: plieninio rèmo pusiau standžių knygą „Energotropiniai žmogiškumo pagrindai“. Tai labai originali knyga ir nuostabu, kad ją parengè Inžinerinés informatikos katedros docentas.

Tarp VGTU studentų netrūksta drąsių ir atkaklių žmonių. Paaiškëjo, kad „Balticum“ čempionate VGTU Turistų klubo nariai E. Černiauskas, A. Jankevičiūtè, V. Kišonaitè, D. Rusakevičius, A. Rusakevičienè, R. Mozūraité, M. Mikalajūnas, E. Saženytė atliko IV sudetingumo žygi Altajaus Pietų bei Šiaures Čiujos kalnagūbrias ir laimejo trečiąją vietą.

mazgų elgsena" paskirta mokslų akademijos 2000 m. jaunųjų mokslininkų premija.

Aštuntus metus Lietuvos muzikų rémimo fondas kartu su Vilniaus aukštųjų mokyklų rektoriais kviete studentus, desstytojus, visus, kurie neabejingi muzikai, ị Šv. Jonų bažnyčioje vykstančius koncertus. Juos lankẻ nemažai ir mūsų universiteto studentų, desstytojų, darbuotojų. Balandžio 2-ąją ìvyko baigiamasis koncertas. „Alma Mater musicalis" projekto aštuntųjų metų ciklą užbaige Lietuvos muzikos akademijos studentų simfoninis orkestras. Meno vadovo ir dirigento Roberto Šerveniko vadovaujamas kolektyvas nemažai koncertuoja Lietuvoje, užsienyje ir visur gerai vertinamas. Šiltai, gausiais plojimais ji sutiko ir klausytojai, susirinkę $i$ Šv. Jonų bažnyčią. Lietuvos muzikų rèmimo

Iteikus premija (iš kaires): R. Palšaitis, V. Adamkus, A. Baublys

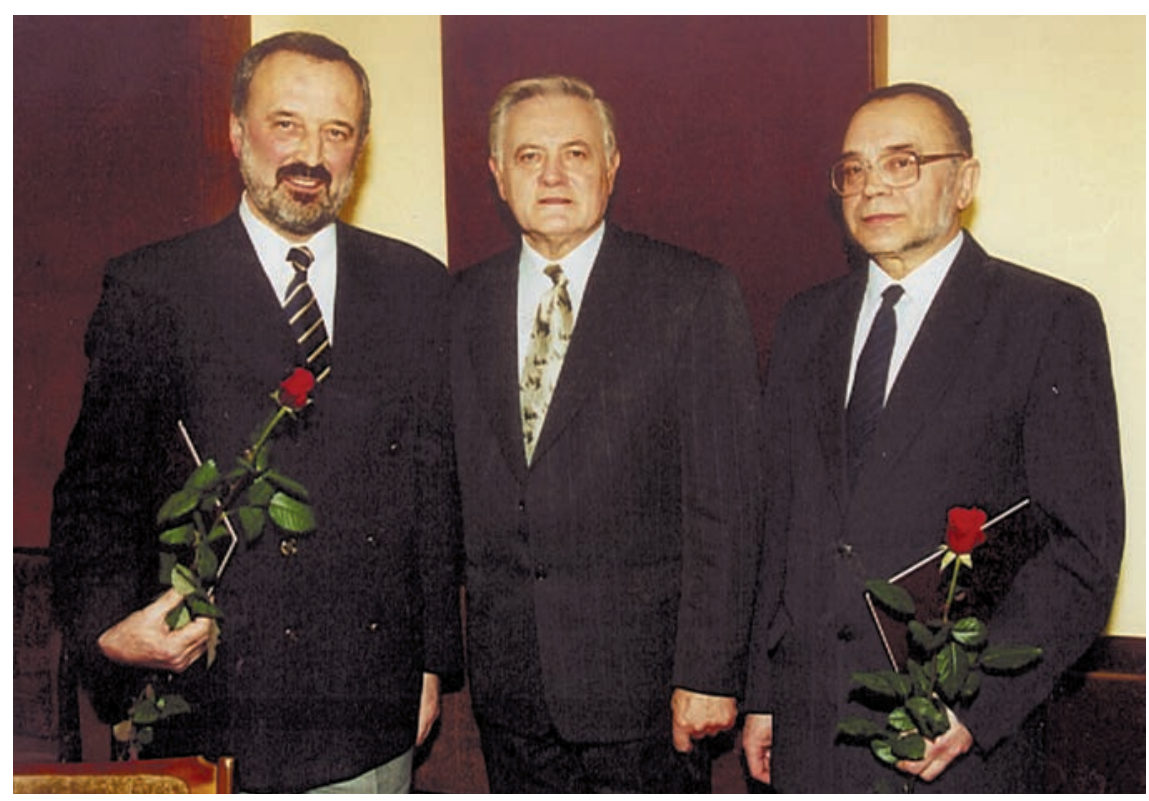


VILNIAUS

GEDIMINO

TECHNIKOS

UNIVERSITETAS

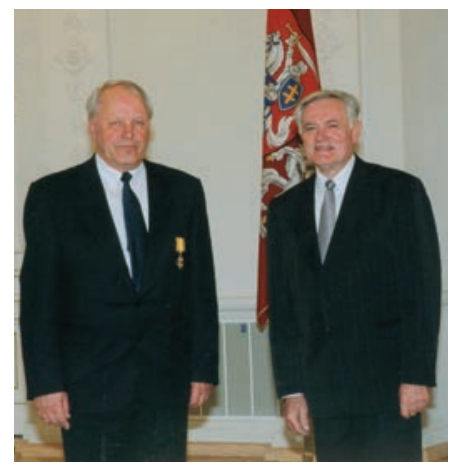

P. Baltrena apdovanojus LDK Gedimino ordinu fondo vadove Liucija Stulgiene, pasibaigus koncertui, dekkojo atlikèjams, nuolatiniams koncertų lankytojams ir pakviete visus aktyviai dalyvauti kitų metu projekte, kuris bus ne mažiau turiningas ir įdomus.

Stiprumo mechanikos mokslo laboratorija gavo Nacionalinio akreditacijos biuro medžiagų mechaninių bandymų srities akreditavimo pažymejjimą.

Tai pirmoji universitetine akredituota laboratorija, kuri įsteigta $1962 \mathrm{~m}$. Joje dirba, bandymus atlieka habilituotas daktaras, trys mokslo daktarai, du eksperimentatoriai, turintys aukštąjj išsilavinimą, metrologas, elektronikas, mechanikas. Laboratorija atlieka medžiagų ir konstrukcijų tiek statinès, tiek ciklines irties mokslo tiriamuosius ir taikomuosius darbus. Jiems naudoja tris unikalius kintamojo apkrovos ženklo pulsatorius, devynias įvairaus galingumo universalias tempimo-gniuždymo mašinas. Turima ir kompiuteriné programinè ịranga eksperimentu rezultatams apdoroti. Daug pagyrimo žodžiu teko buvusiam ir dabartiniam laboratorijos vedejjams prof. Mindaugui Leonavičiui, doc. Marijonui Šukšstai.

Aukštas postas Lietuvos mokslų akademijoje teko VGTU rektoriui LMA nariui korespondentui prof. E. K. Zavadskui. Akademijos visuotinis susirinkimas balandžio ménesi jị išrinko Technikos skyriaus pirmininko pavaduotoju bei Statybos ir transporto sekcijos pirmininku. Lenkijos mokslų akademijos Statybos ir hidrotechnikos inžinerijos komitetas išrinko ji užsienio nariu.

Gražų apdovanojimą pelnè VGTU bibliotekos direktore Regina Pugžlienè. Už nuopelnus darbe ir ilgametị darbą Nacionalines Lietuvos biblioteku savaites metu jai buvo paskirta 2000 metu bibliotekininko UAB „Bibliotekų kolektoriaus“ specialioji premija.

„Palepès“ teatras-studija gegužès 1-7 d. dalyvavo Vilniuje vykusiame tarptautiniame universitetų teatrų forume „Universitetas ir jaunimo kultūra: ieškome autoriaus, ieškome herojaus“. „Palepe“" rode du spektaklius: A. Simonavičiūtes "Čia ir dabar" ir studentiškų istorijų mozaiką „Bobiada“.

Gegužę VGTU vyko VII tarptautine konferencija „Naujos statybinés medžiagos, konstrukcijos ir technologijos", kurioje dalyvavo apie 300 mokslininkų iš 21 užsienio šalies.

Universitete įvyko tradicinis, dabar jau aštuntasis, tarptautinis kolokviumas „Racionalūs sprendimai statyboje". Jame dalyvavo apie 50 Vokietijos, Lenkijos ir Lietuvos mokslininkų. Vienas pagrindinių šio kolokviumo iniciatoriu ir organizatoriu - prof. E. K. Zavadskas. Kolokviumo metu jam buvo įteiktas Rusijos inžinerijos akademijos užsienio nario diplomas. Tai reikšmingas Lietuvos mokslininko pripažinimas.

Lietuvos aukštųjų mokyklų studentų medžiagų mechanikos ir atsparumo respublikineje olimpiadoje puikiai pasirode VGTU studentai ir laimëjo pirmąsias vietas. Nugalètojų komandą sudarè: A. Vika (TTI-8), V. Vadlūga (AT-7), P. Bagdonas (S-9/1), T. Žigina (CI-9/4) ir A. Stonys (SKP-8/1). Pirmąja buvo Tatjana Žigina, kuri ir paskelbta olimpiados laimètoja.

$2001 \mathrm{~m}$. birželio $21 \mathrm{~d}$. Lietuvos moksly̨ akademijoje įvyko narių ekspertų rinkimai. Jais tapo trys VGTU profesoriai: A. V. Valiulis, R. Kačianauskas ir A. Baublys.

Didelį specialistų būrị kraštui parengè ir birželi išleido Vilniaus Gedimino technikos universitetas. Iš viso išleisti 2134 absolventai. 1350 baige pagrindines studijas, 701 - magistrantūros studijas ir 83 - specialiąsias profesines studijas. Statybos fakultetas parenge 425, Aplinkos inžinerijos fakultetas - 366, Verslo vadybos fakultetas -351 , Transporto inžinerijos fakultetas - 272, Mechanikos fakultetas - 240, Fundamentinių mokslų fakultetas - 139, Elektronikos fakultetas - 138, AGAI - 109, Architektūros - 91 ir Tarptautinių studiju centras -3 specialistus.

2001 m. vasarą visada prisimins Aplinkos apsaugos katedros vedejas habil. dr. prof. Pranas Baltrenas, kurị Lietuvos Respublikos Prezidentas apdovanojo LDK Gedimino ordinu. Jị P. Baltrénas pelnė už vaisingą mokslinę veiklą, daugybę išradimų ir leidinių.

$2001 \mathrm{~m}$. VGTU jau antri metai dalyvavo vykdant bendrajji priemimą $i$ aukštąsias mokyklas. I pagrindines dienines studijas buvo priimta 2350 jaunuolių, neakivaizdines - 473. Iš viso 2823 žmonès. I magistrantūros studijas priimti 1126 žmonès, specialiąsias profesines studijas - 1210 žmonių. Iš viso i pirmąji kursą priimta 4033 jaunuoliai ir merginos.

İ dienini skyrių stota daugiausia iš Vilniaus miesto ir apskrities. Didžiausias kon- 
kursas buvo ị Verslo vadybos, Architektūros ir Aplinkos inžinerijos fakultetus.

Rugsejo 1-osios proga ị universiteto bendruomenę kreipesi rektorius $\mathrm{E}$. K. Zavadskas straipsniu "Gedimino universitete“. Pažymejęs, kad sulaukème pirmųjų naujojo šimtmečio ir tūkstantmečio mokslo metu pradžios, prisiminęs daugybę istorinių faktų ir pasidžiaugęs VGTU laimejjimais, rektorius primine tuometinius sunkumus:

"Didžiausia problema šiuo metu tampa Lietuvos valdančiuju instituciju - Prezidento, Seimo, Vyriausybés - požiūris j̇ aukštuju mokykly ateiti, pirmiausia ju finansavimo problema. Deja, jau keleri metai kasmet finansavimas, skirtas vienam studentui, mažinamas, mažai atsižvelgiama ir $\grave{i}$ żvairiu studiju programu sqanaudas. Tačiau tuo pat metu kai kurie valstybiniu instituciju atstovai nepamirsta reguliariai priekaištauti aukštosioms mokykloms dèl rengiamu absolventu parengimo lygio, dèl destytoju spaudoje skelbiamu mokslo darbu kokybes bei tarptautinio lygio. Lietuvos žiniasklaidoje vykdoma visuomenes ir aukštuju mokykly supriešinimo kampanija, nepagristai sumenkinant universitetu laimejimus. Teigiama, kad ligi šiol jokiu permainu dar neįuyko. Nutylima, kad siiuo metu egzistuojanti teisine baze net nesudaro galimybiu studentams atlikti praktiku, o destytojams - privalomai kelti kvalifikacijos, tam gaunant papildomu atostogu. Prioritetai švietimui ir mokslui deklaruojami žodžiais, bet nepagrindžiami veiksmais.

Prie šalies vairo stoja vis naujos Vyriausybes, o požiūris j̇a aukštaji moksla praktiškai pasilieka toks pat. Jam taikomas liekamasis finansavimo principas. Labai noretusi tiketis, kad sis požiüris neliks ilgalaikis ir jau šiais metais, planuojant $2002 \mathrm{~m}$. valstybès biudžeta, pasikeis “ $[6.22$, p. 3].

\section{VGTU atidaryta K. Baršausko auditorija}

$2001 \mathrm{~m}$. rugsëjo 14-25 d. VGTU surengè tradicinemis tapusias "Gedimino universiteto dienas“. Jų metu įvyko pirmakursių imatrikuliacijos aktas, buvo atidaryta profesoriaus Kazimiero Baršausko fizikos auditorija, VGTU Garbès daktaru inauguruotas Reino Frydricho Vilhelmo universiteto Bonoje profesorius Erichas Veisas.

Dienų metu buvo aukotos Šv. Mišios Šv. Mikalojaus bažnyčioje už mirusius profesorius, dèstytojus, darbuotojus ir studentus, prie Gedimino paminklo padeta gelių. Vyko daug kitokių priemoniu - koncertai, parodos, sporto varžybos ir kt.

İspūdinga buvo tarptautine konferencija „Technikos humanizavimas“, daug pranešimų buvo perskaityta mokslinejje konferencijoje „Mokslo ir technikos raida Lietuvoje“. Tarptautinę konferenciją „Technikos humanizavimas" globojo Lietuvos Respublikos Prezidentas Valdas Adamkus. Ji buvo skirta Lietuvos ir Lenkijos diplomatinių santykių atkūrimo dešimtmečiui.

Konferenciją atidare rektorius E. K. Zavadskas.

Buvo perskaitytas J. E. Prezidento Valdo Adamkaus sveikinimas, o po to sveikinimo kalbą pasake monsinjoras Kazimieras Vasiliauskas. Jis sakè, kad konferencija nagrinejja labai aktualią žmonijai technikos humani- zavimo problemą. $\breve{S}$ i tema esanti kiekvieno inteligento širdies hobis. Taip pat kalbëjo, kad Katalikų Bažnyčia siekia šalinti prieštaravimus tarp ịvairių tikybų, kad būtinas įvairių tautų bendradarbiavimas, draugiški, geranoriški santykiai. Pasakojo apie gyvenimą sovietiniuose kalejimuose, lageriuose, apie tremties metus, bendravimą su žymiuoju disidentu Andrejumi Sacharovu. Monsinjoras buvo labai išbalęs, kalbëjo su didesnemis nei paprastai pauzemis, bet išbuvo visą plenarini posedị.

Konferencijos plenarinio posedžio pabaigoje monsinjoras Kazimieras Vasiliauskas buvo apdovanotas Lenkijos Lietuvos bičiulių klubo žurnalo „Lithuania“ ir Lietuvos „Kultūros barų“ žurnalo įsteigtu medaliu „Integralus humanizmas“. Ši medalị steigèjai skiria už humanistinių amžinųjų vertybių propagavimą visuomeninio ir privataus gyvenimo srityse. Tokiu medaliu buvo apdovanoti konferencijos dalyviai - Lenkijos ambasadorius Jerzy Bahras, VGTU senato pirmininkas Romualdas Ginevičius, Vroclavo technologijos universiteto rektorius Andžejus Mulakas, žinomi Lietuvos žurnalistai Gediminas Zemlickas, Artūras Matusas, Vytautas Markevičius ir kt. Jau anksčiau tokiais medaliais buvo apdovanotas VGTU rektorius E. K. Zavadskas ir Lenkijos Lietuvos bičiulių

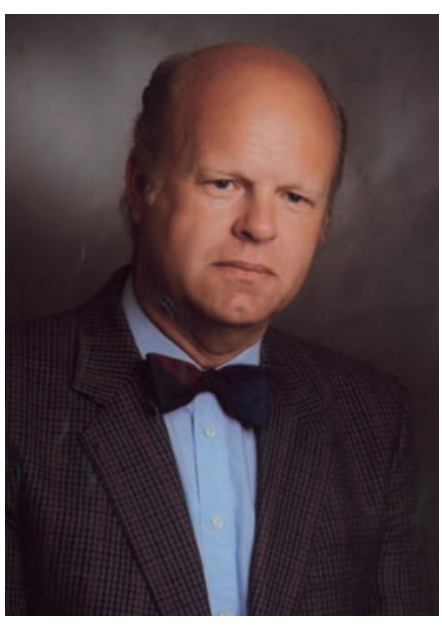

E. Veisas VGTU Garbès daktaras 
VILNIAUS

GEDIMINO

TECHNIKOS

UNIVERSITETAS klubo pirmininkas bei minetos konferencijos organizatorius Leonas Brodovskis. Pasibaigus konferencijos plenariniam posèdžiui Monsinjoras ilgokai kalbejosi su daktaru Leonu Brodovskiu, jo žmona Danute, kitais svečiais. Su visais atsisveikinęs, palydetas „Gedimino universiteto" redaktorès Astos Verbickienès, jis išskubejo atgal ị ligoninę. Tai buvo paskutinis Monsinjoro apsilankymas Vilniaus Gedimino technikos universitete. Po triju savaičiu ji aplankème, deja, jau pašarvotą didžiausioje Lietuvos šventoveje - Arkikatedroje bazilikoje. Monsinjoras mire $2001 \mathrm{~m}$. spalio $14 \mathrm{~d}$.

Vilniaus Gedimino technikos universitetas $2001 \mathrm{~m}$. spalị turejjo 10907 studentus: 8696 - pirmosios pakopos studiju, 2211 antrosios pakopos studiju.

$2001 \mathrm{~m}$. technologijos mokslų studijų programos sudare $82,7 \%$, socialinių mokslų $-11,5 \%$. Pagrindinèse studijose studijavo 87 užsienio studentai.

Neblogi buvo mokslinio darbo rezultatai. Automobiliu katedros doc. dr. Alvydas Pikūnas apgyne habilitacinį darbą „Lietuvos kelių transporto materialinių ir energetiniu sąnaudų, žalingo poveikio aplinkai bei visuomenei mažinimo problemos".

Keturi habilituoti daktarai gavo profesoriaus mokslinį vardą: M. Bogdevičius (me- chanikos inžinerija), R. Baušys (mechanikos inžinerija), G. Kaklauskas (statybos inžinerija), A. H. Marcinkevičius (mechanikos inžinerija).

Toliau augo užsakomųju mokslo darbų apimtys. $2001 \mathrm{~m}$. jų atlikta už 3,9 mln. Lt. Daugiausia tokių darbų atliko Geodezijos mokslo institutas.

VGTU mokslininkai $2001 \mathrm{~m}$. parenge ir išleido 11 monografijų, 13 vadovèlių, daug kitų leidinių, paskelbè beveik 1000 mokslinių straipsnių. Sparčiai èmè didèti straipsnių skaičius užsienio mokslo žurnaluose su svorio koeficientu (ISI). Mokslinèse konferencijose perskaityta beveik 1000 mokslinių pranešimų tarp jų užsienyje - beveik 40. Gauti 5 išradimų patentai.

VGTU $2001 \mathrm{~m}$. déstè 777 déstytojai, iš jų $14 \%$ buvo habilituoti daktarai, profesoriai. VGTU turëjo 1254 kompiuterius. 2001 metu geriausiu VGTU sportininku buvo išrinktas Statybos fakulteto Nekilnojamojo turto vadybos specialybès antrojo kurso studentas Aistis Šlajus. Jis dukart iškovojo Lietuvos suaugusių vasaros bei tiek pat kartų žiemos teniso varžybų čempiono vardą, tapo čempionu dvejetų varžybose, buvo Lietuvos suaugusių rinktinès nariu.

Gražiai pasirode pereinamosios „Baltijos" taurès varžybose VGTU lengvaatlečiai. Varžybose Rygoje Jūrate Strumskyte (MEU/1 gr.), Linas Šalkauskas (CI1/4 gr.) laimëjo $1000 \mathrm{~m}$ begimus, o Audrius Jonušis (FMU/0) - trišuolio varžybas.

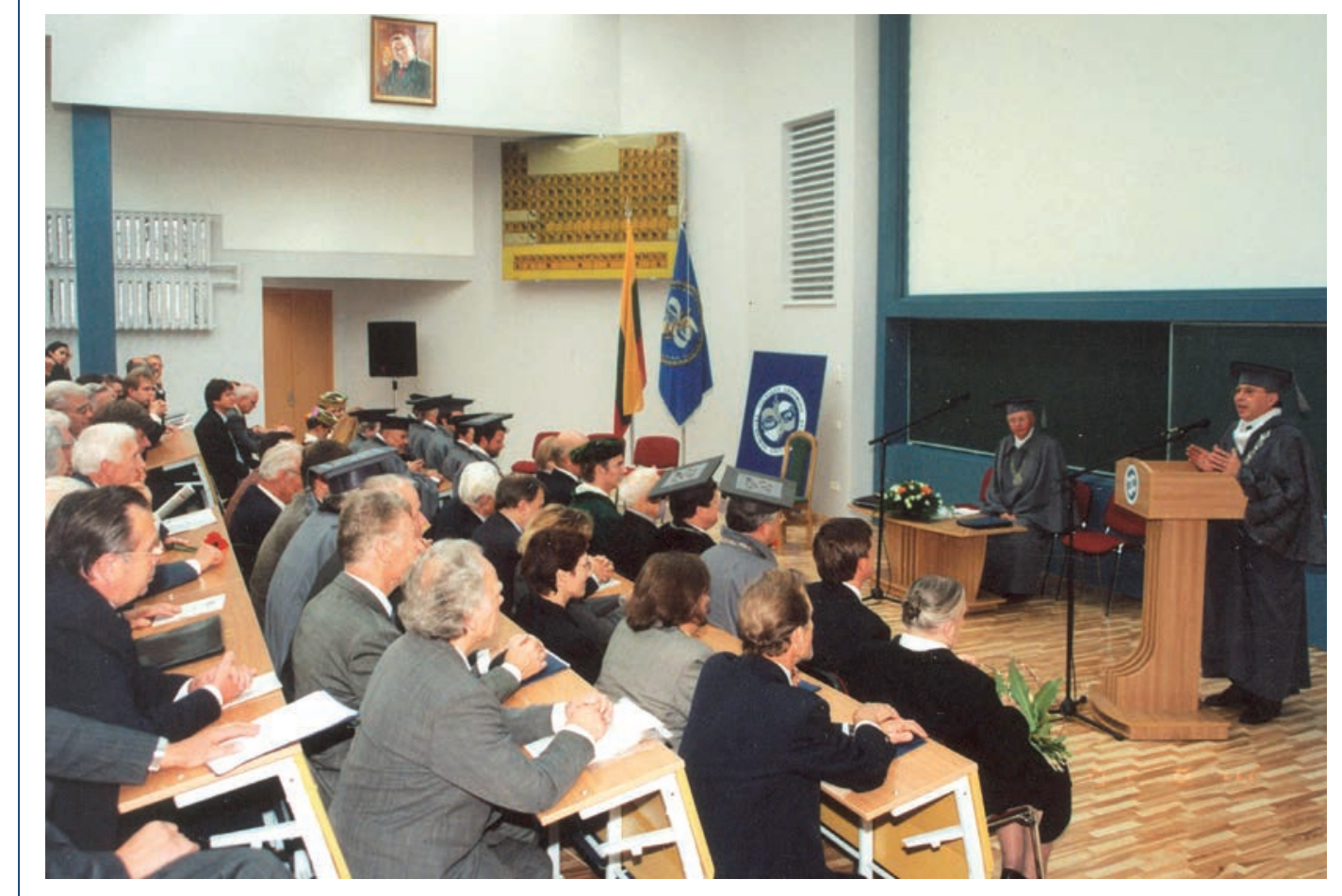


VGTU bendruomenè su pakilia nuotaika sutiko 2002 metus.

Nebuvo pamiršta Sausio 13-oji. Apsilankyta Antakalnio kapinése, padèta gèlių ant Rolando Jankausko kapo ir prie paminklinès lentos VGTU rūmuose, uždegtos žvakutès.

\section{Aukštas E. K. Zavadsko veiklos ịvertinimas}

Sausio $24 \mathrm{~d}$. didelès iškilmès buvo Poznanés technologijos universitete, kurių metu Vilniaus Gedimino technikos universiteto rektorius, Lietuvos mokslų akademijos narys korespondentas, habilituotas daktaras profesorius Edmundas Kazimieras Zavadskas buvo inauguruotas mineto garsaus Lenkijos universiteto Garbès daktaru.

Prof. E. K. Zavadskas daug metų bendradarbiavo ir toliau bendradarbiauja su Poznanès technologijos universiteto mokslininkais, rengia tradicinius kolokviumus, dalyvauja mokslinèse konferencijose, oponuoja disertacijas. Poznanès mokslininkai aukštai įvertino prof. E. K. Zavadsko indèlį sprendžiant dirbtinio intelekto taikymo statyboje problemas. E. K. Zavadskas sukūrè daugiatikslio resursu taupymo, technologinių variantų parinkimo metodus pagal sistemiškumo ir kompleksiškumo principus.

Prof. E. K. Zavadskas daug nuveike stiprindamas Vilniaus ir Poznanès universitetų dalykinį bendradarbiavimą. Lenkai gerai įvertino E. K. Zavadsko nuostatą, kad kalbant apie Lietuvos ir Lenkijos valstybių santykius, reikia daugiau kalbèti apie tai, kas sieja lietuvių ir lenkų tautas kūrybingam, lygiateisiam ir abipusiškai naudingam bendradarbiavimui, nuoširdžiai bičiulystei, ugdo tarpusavio pagarbą.

Pažymėtina, kad Lenkijos universitetai nesuteikia Garbès daktarų vardų „lengva ranka“. Teikiantis Garbès daktaro vardą Poznanès universitetas siunčia trims žymiausiems tos pačios krypties Lenkijos universitetams medžiagą apie kandidatą ir priima sprendimą suteikti Garbès daktaro vardą tik tuomet, jei visi trys atsiliepimai yra teigiami ir su atitinkama rekomendacija.

Taigi Poznanés technologijos universiteto Garbès daktaro vardas ypač garbingas. Jis, be to, reiškia ir aukštą Garbés daktaro mokslinès veiklos įvertinimą.

Po kelių ménesių Vilniaus Gedimino technikos universitete lankèsi Poznanès technologijos universiteto delegacija, vadovaujama rektoriaus prof. habil. dr. profesoriaus

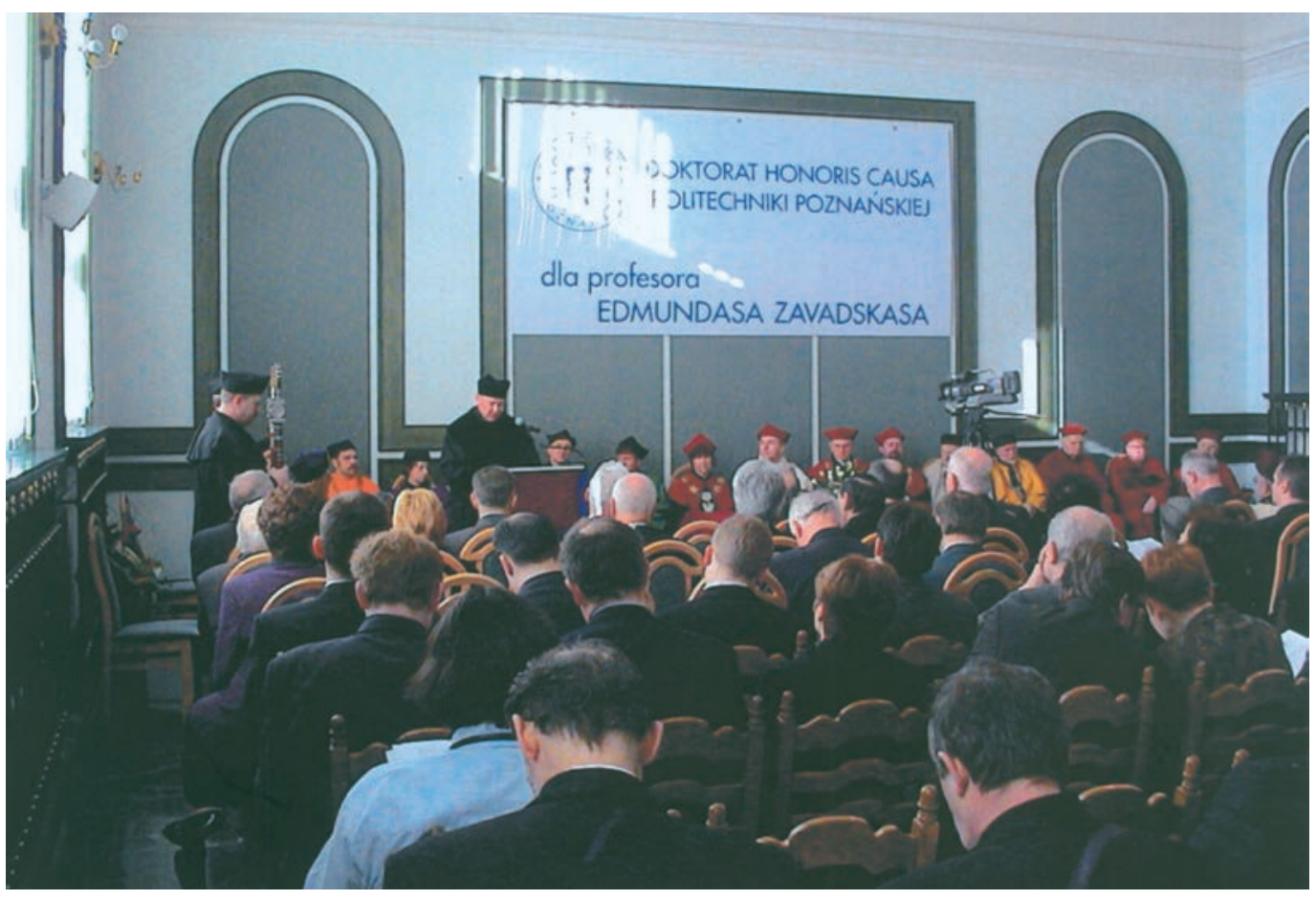


VILNIAUS

GEDIMINO

TECHNIKOS

UNIVERSITETAS
Ježio Dembčinskio. Jis pabrèžè, kad prof. E. K. Zavadsko pripažinimas Poznanès technologijos universiteto Garbès daktaru labai reikšmingas. Lenkijoje toks pripažinimas labai vertinamas ir apskritai nėra dažnas. Per 82 universiteto gyvavimo metus tik 21 mokslininkui buvo suteiktas Poznanès technologijos universiteto Garbès daktaro vardas.

$2002 \mathrm{~m}$. vasario pradžioje maloni žinia gauta iš Vokietijos. Tarptautine Šiaurès Vokietijos informatizavimo akademija prie Jungtinių Tautų organizacijos išrinko savo viceprezidentu VGTU senato pirmininką prof. Romualdą Ginevičių.

Dar vienas gražus epizodas - gauta programine įranga naudoti išimtinai studiju reikalams. Ją universitetui padovanojo absolvento dr. Gintario Aksamito vadovaujama UAB „AGA“. Tai bendrove, kurios veiklos sritis - kompiuterine grafika ir automatizuotas projektavimas, programines ir techninès irrangos aprūpinimas, mokymo ir konsultavimo klausimai. Tai tauri absolvento akcija, rodanti dékingumą ir rūpestị savąja Alma Mater. Anot O. Balzako, dekingumas įrodomas darbais. Suprantama, universitetas liko dèkingas.

Vasario 16-osios minejime, kuriame dalyvavo LRS vicepirmininkas Vytenis Andriukaitis, buvo pranešta, kad 2001 metu Lietuvos mokslo premija paskirta VGTU prof. habil. dr. Ipolitui Zenonui Kamaičiui.
Premija I. Z. Kamaičiui paskirta už darbų ciklą „Pastatų ir inžinerinių statinių būkles tyrimai, renovacija ir ilgaamžiškumo didinimas (1970-2000 m.)“.

I. Z. Kamaitis per daugiau kaip 30 metu atliko daug teorinių, eksperimentinių ir natūrinių tyrimų, kurių rezultatai buvo taikomi statomuose ir eksploatuojamuose objektuose. Jis vadovavo įvairiu projektų rengimui, per 30 svarbių objektų remontams. Jis suformavo statybinių polimerinių kompozitu - kliju, mastiku, skiediklių ir betonu - gavimo ir gamybos technologiją, pagal kurią juos galima naudoti konstrukcijoms remontuoti, stiprinti ir apsaugoti nuo korozijos. I. Z. Kamaitis sukūrè supleišëjusių gelžbetoninių konstrukcijų remonto technologiją, ištyre konstrukcijų su užtaisytais ịvairiais plyšiais elgseną ir pasiūle metodiką konstrukcijų parametrams apskaičiuoti, ịvertinant įvairių apkrovų įtaką, visa tai apibendrino keliose monografijose.

Dar viena gera žinia - E. K. Zavadskas ir A. V. Valiulis parenge ir leidykloje "Technika“ išleido knygą - „Universitetas pletros ir tobulejimo kelyje“. Senato pirmininkas R. Ginevičius j̨žangos žodyje taikliai apibūdino šią VGTU leidyklos 704 mokslo literatūros knygą:

„Nuo pat VGTU ikūrimo jame puoselejama tradicija apibendrinant, sisteminant jvykin esme, ju etapus, fiksuoti jo pletra ir kaita. Ir tai daro asmenys, kurie kasdiena su tuo susiduria, kuriems tenka priimti sprendimus ir, žinoma, kuriems tenka didžiausia atsakomybè už aukštosios mokyklos ateitį " $[6.24$, p. 4].
Nacionaline mokslo premija jteikus I. Z. Kamaiciui (is kaires): P. Baltrenas, I. Z. Kamaitis, E. K. Zavadskas, R. Ginevičius, A. Nakas

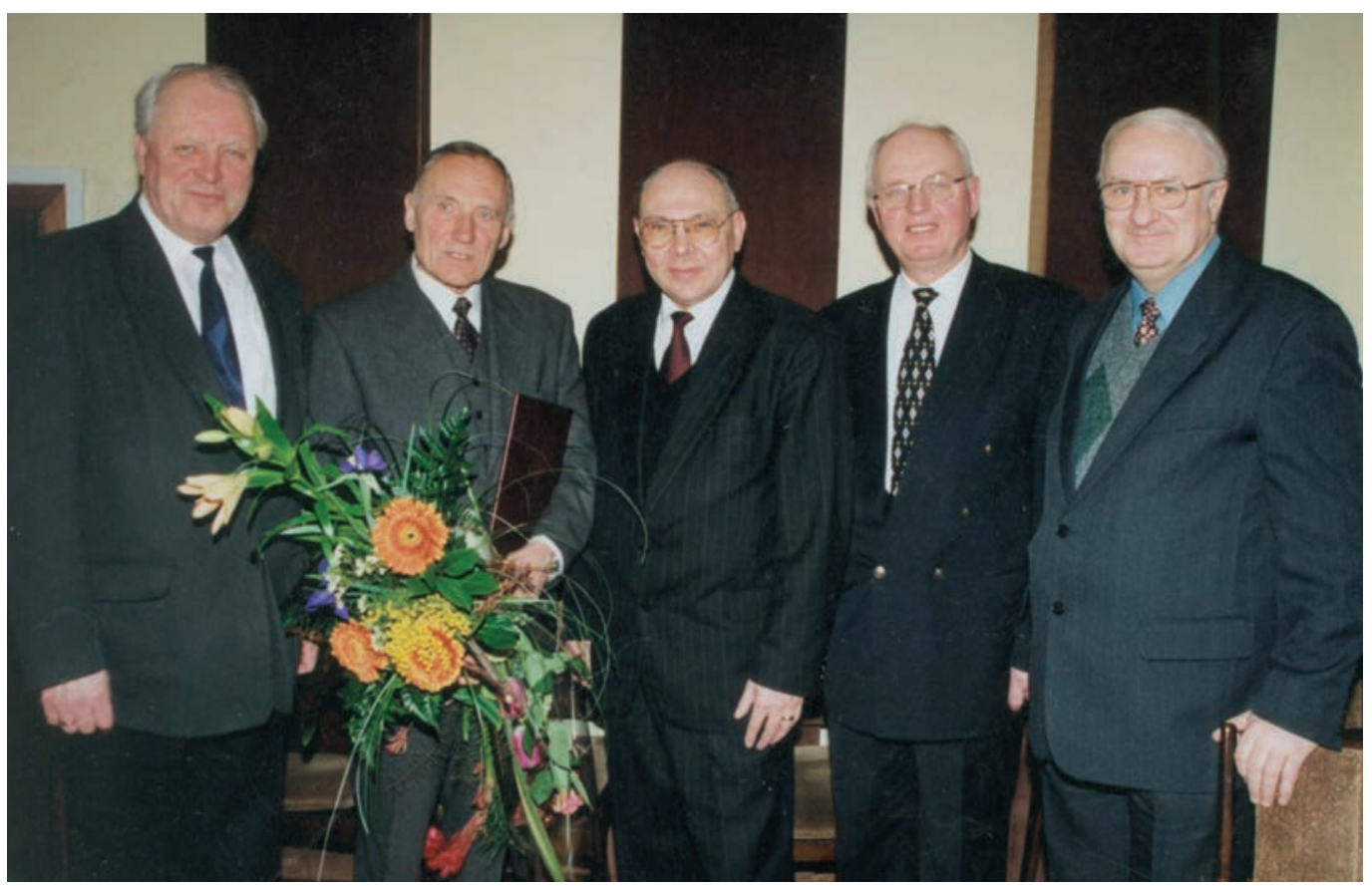


Vasario 28 d. Europos Komiteto prie Lietuvos Vyriausybes generalinis direktorius P. Auštrevičius VGTU senato posedžiu salëje gana nuobodokai kalbëjo apie vykstančias derybas dèl Lietuvos narystés Europos Sąjungoje. Prelegentui trūko motyvacijos kalbamu klausimu, neatrode, kad Lietuvos vyriausiasis derybininkas karštai siekia Lietuvos integracijos į Vakarų Europos bendriją. Matyt, taip nebuvo, bet, kaip sakoma, kalbai "trūko chemijos“.

Minint Kovo 11-ąją, vyko iškilmingas VGTU senato ir Lietuvos mokslų akademijos Technikos skyriaus jungtinis posedis.

Rektorius E. K. Zavadskas pirmiausia kalbejo apie Kovo 11-osios svarbą Lietuvos gyvenime, prisiminé sudètingus pirmuosius atkurtos nepriklausomybes metus, tų metų universiteto gyvenimą.

Naujajji VGTU Garbès daktarą akademiką habilituotą daktarą profesorių Kazimierą Ragulskị rektorius E. K. Zavadskas apibūdino kaip neturinį analogo Lietuvoje mokslininką, parengusį per 200 mokslo daktarų, padariusi apie 2000 išradimų, kurių dauguma patentuoti, parašiuși šimtus mokslinių straipsnių, dešimtis knygų.

Prof. B. Spruogis, vienas K. Ragulskio mokinių, pabrežè, kad akademikas sukūre precizinès vibracinès technikos mokslinę mokyklą, yra kelių tarptautinių ir trijų Lietuvos valstybinių premijų laureatas, pasaulinès išradybos parodos aukso medalio laimetojas.

Daug VGTU mokslininku yra akademiko K. Ragulskio mokiniai, tarp jų: A. Kavolèlis,
M. Mariūnas, V. Augustaitis, B. Spruogis, G. Kulvietis, R. Kanapėnas, R. Jonušas, J. Solominas, V. Dovydenas, J. Jurevičius, V. Turla, L. Zubavičius, J. Astrauskas, A. Jakštas, K. Slivinskas ir kt.

Kovo 15-ąją - buvusiam VISI rektoriui akademikui Aleksandrui Čyrui būtų sukakę 75 metai. Jo atminimui pagerbti VGTU surengè mokslinę konferenciją „Šiuolaikinès statybines mechanikos problemos", o VGTU Senato nutarimu buvo įsteigta akademiko Aleksandro Čyro stipendija ir jo vardo auditorija. Konferencijoje pranešimus skaite profesoriai J. Atkočiūnas, A. Čižas, A. Borkovski, A. Žiliukas, A. Kudzys, R. Kačianauskas ir kt. Auditorija pasipuošè J. Grigorovičiaus puikiai nutapytu A. Čyro portretu, A. Rudminaite ir R. Razmiene gražiai įformino A. Nako parengtus A. Čyro darbų ekspozicijų stendus.

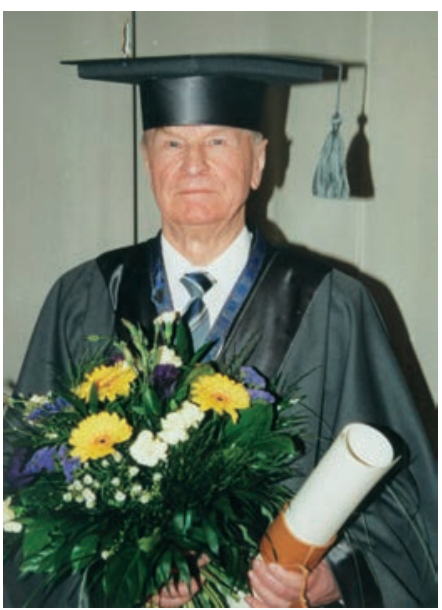

K. Ragulskis

VGTU Garbes daktaras

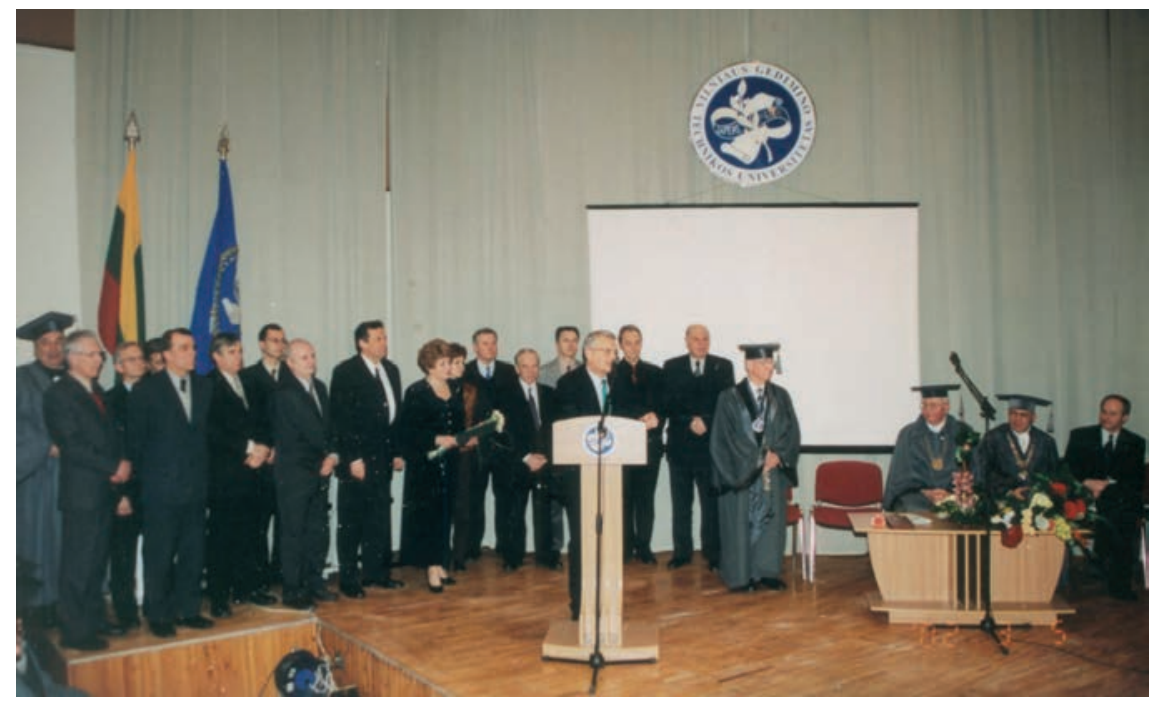

K. Ragulskio

inauguravimo Garbes daktaru momentas

\section{VGTU taryba - priežiūros ir globos institucija}

Balandžio pradžioje pirmą kartą susirinko suformuotoji Vilniaus Gedimino technikos universiteto taryba. Universiteto taryba pagal VGTU statutą yra universiteto visuomeninés priežiūros ir globos institucija. Be kita ko, ji vertina, kaip naudojamas universiteto turtas, valstybès ir kitos lèšos. Vertina, kaip universitetas prisideda prie valstybès plètros ir kt. Taryba svarsto universiteto lěšu sąmatas, jų vykdymą. Ji skelbia Senato ar rektoriaus rinkimus.

Švietimo ir mokslo ministro įsakymu dar 2000 metais universiteto taryba buvo sudaryta ketverių metų kadencijai tokios sudeties:
- nariai, skirti Senato - P. Daščioras, VGTU studentų sąungos atstovas; R. Ginevičius, VGTU senato pirmininkas; R. Kirvaitis, VGTU profesorius, Elektronikos fakulteto dekanas; P. Vainiūnas, VGTU Statybos fakulteto dekanas; E. K. Zavadskas, VGTU rektorius;

- nariai, skirti švietimo ir mokslo ministro ir Vilniaus Gedimino technikos universiteto susitarimu - A. Čiučelis, Vilniaus miesto savivaldybès tarybos narys; J. Dieninis, Lietuvos žemés ūkio banko valdybos pirmininko pavaduotojas; Z. Kumetaitis, Nacionalinès žemès tarnybos prie Žemès ūkio ministerijos Geodezijos ir kartografijos 
VILNIAUS

GEDIMINO

TECHNIKOS

UNIVERSITETAS

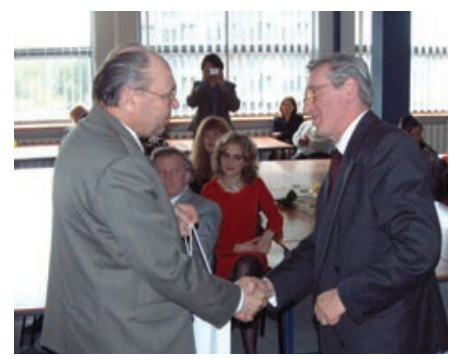

Susitikimas su ambasadoriumi R. Podagèliu VGTU bibliotekoje $2002 \mathrm{~m}$.

\section{VGTU taryba}

Išskaires - 1-oje eileje:

R. Ginevičius,

J. Dieninis, E.K. Zavadskas;

2-oje eileje:

P. Daščioras, R. Kirvaitis, A. Tarvydas, A. Čiučelis, Z. Kumetaitis;

3-ioje eileje:

J. Ivoška, A. Šeštakauskas, P. Vainiūnas, E. Mažeikis, T. Milaknis departamento direktorius; T. Milaknis, AB „Alna“ generalinis direktorius; A. Tarvydas, Lietuvos parodu centro LITEXPO direktorius, Vilniaus prekybos, pramonès ir amatu rūmų tarybos narys;

- nariai, skirti švietimo ir mokslo ministro - A. Gaižutis, akademikas, Lietuvos mokslų akademijos viceprezidentas; J. Ivoška, advokatas; E. Mažeikis, pulkininkas, Lietuvos kariuomenès karinių oro pajegu vadas; A. Ramonas, LR Seimo švietimo, kultūros ir mokslo komiteto patarëjas; A. Šeštakauskas, Lietuvos statybininkų asociacijos prezidentas, Lietuvos pramonininku konfederacijos valdybos ir prezidiumo narys.

Taryba pirmininku išrinko doc. dr. J. Dienini.

Štai ši Taryba balandžio menesio pradžioje nutare, kad Vilniaus Gedimino technikos universiteto rektoriaus rinkimai skelbiami $2002 \mathrm{~m}$. birželio $20 \mathrm{~d}$. Buvo paskelbtas viešas konkursas rektoriaus pareigoms užimti.
Rektorius E. K. Zavadskas, atsakydamas i "Gedimino universiteto " redaktoriaus klausimą, suformulavo, kokiomis savybemis turètų pasižymèti rektorius:

„.... rektorius pirmiausia turètu büti demokratiskas, nevengiantis bendrauti su universiteto bendruomenes nariais žmogus. Rektoriui labai svarbu büti veikliam, nuolat domettis salies politika, ekonomika, pasaulio, Europos, šalies aukštojo mokslo politika, büti komunikabiliam, nevengti dalyvauti visuomenineje veikloje, lankytis suvažiavimuose, konferencijose, priemimuose, nevengti skaityti pranesimu, kalbeti juairiuose renginiuose, kartu atstovauti universitetui, bendruomenei. Labai svarbu, kad rektorius nevengtu bendrauti ziniasklaidos priemonemis: kalbetu per radija, televizija, rašytu ¿ laikraščius, žurnalus <...>. Rektorius turi sugebeti sukurti gera prorektoriu kolektyva ir pats dirbti kolektyve " [6.25, p. 2-3].

Tenka pripažinti, kad įvardytomis savybėmis rektorius E. K. Zavadskas tikrai pasižymejo. Ir ne tik įvardytomis. Tai buvo vadovas - ideju generatorius, be galo energingas, emocingas, atkaklus. Ir neužmiršdamas universitete svarbiausio posto,

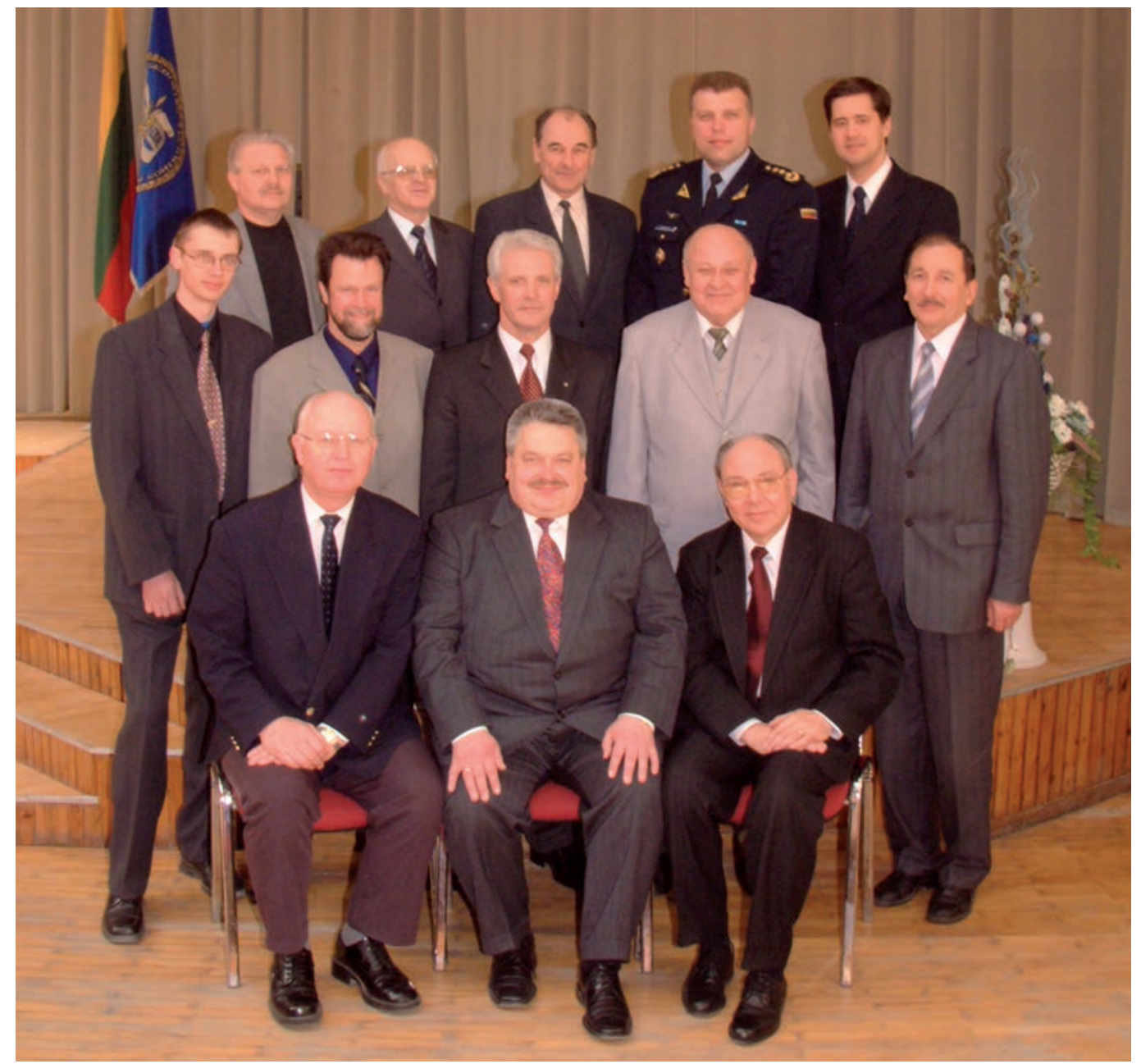


jis neprarado savo geriausiųju savybių, todèl buvo ir lieka didelis autoritetas universiteto bendruomenëje.

Išradingai dirbo VGTU bibliotekos kolektyvas. Baigiantis balandžiui Lietuvoje vyko Nacionaline bibliotekų savaite. Jos metu universiteto biblioteka nemokamai išdavinëjo skaitytojo bilietą, nereikalavo mokèti delspinigių už paveluotai grąžintą knygą. Paskutinę akcijos dieną biblioteka surenge įspūdingą renginį. Iškilmingai buvo pristatytas Editos Utarienés sukurtas vitražas „Pažinimo medis", kuris bibliotekos interjerą padare puošnų ir dvasingą, filosofiškai prasmingą. Čia dideli nuopelnai tenka ir tuometinei bibliotekos direktorei Reginai Pugžlienei, nuosekliai ir atkakliai siekusiai paversti biblioteką modernia ir puošnia, tokia, kurioje kartą apsilankius, kiltų noras lankytis dar ir dar. Malonu pažymetti, kad novatorišką Reginos Pugžlienès veiklą sèkmingai tęsia ir ją pakeitusi vadove Rimute Abramčikienè bei ją supančios kolegès.

Tame pačiame renginyje apie savo darbą idomiai pasakojo ambasadorius Romanas Podagèlis, ilgametis Lietuvos Respublikos atstovas Italijoje, Graikijoje ir Maltoje. Dr. R. Podagèlis - mūsų absolventas, daug metu dèstęs VISI, buvęs Gelžbetoninių konstrukciju katedros docentas.

Balandžio $27 \mathrm{~d}$. VGTU pagerbè svečią iš Šveicarijos. Už nuopelnus plètojant Šveicarijos universitetų ryšius su VGTU daktarui Maksui Šveiceriui, daug padejusiam mūsu doktorantams ir magistrantams, buvo suteiktas VGTU Garbès nario vardas.

Gegužès pradžioje Vilniaus Gedimino technikos universitete visą savaitę vyko trečiasis tarptautinis universitetų teatrų forumas. Jame dalyvavo studentų teatrai iš Airijos, Ispanijos, Kroatijos, Latvijos, Vengrijos ir Lietuvos. VGTU „Palepe““ rodè du spektaklius. Rektorius E. K. Zavadskas, sveikindamas forumo dalyvius, pabreže tokios veiklos svarbą, kaip humanizmo idëjų nešeju. „Humanizmo idejos neturi sienų tarp valstybių ir tautu", - sakè rektorius.

Gražiai buvo atstovaujama universitetui tarptautinëje mokslo, aukštųjų technologiju ir studiju parodoje „Mokslas 2002“. Ekspoziciją puikiai įrengti padejjo VGTU atstove Laimute Bernotiené, koncertavo „Vingis“ su savo kapela.

Parodų centre LITEXPO vykusioje konferencijoje pranešimus skaite VGTU Senato pirmininkas profesorius R. Ginevičius, aka-

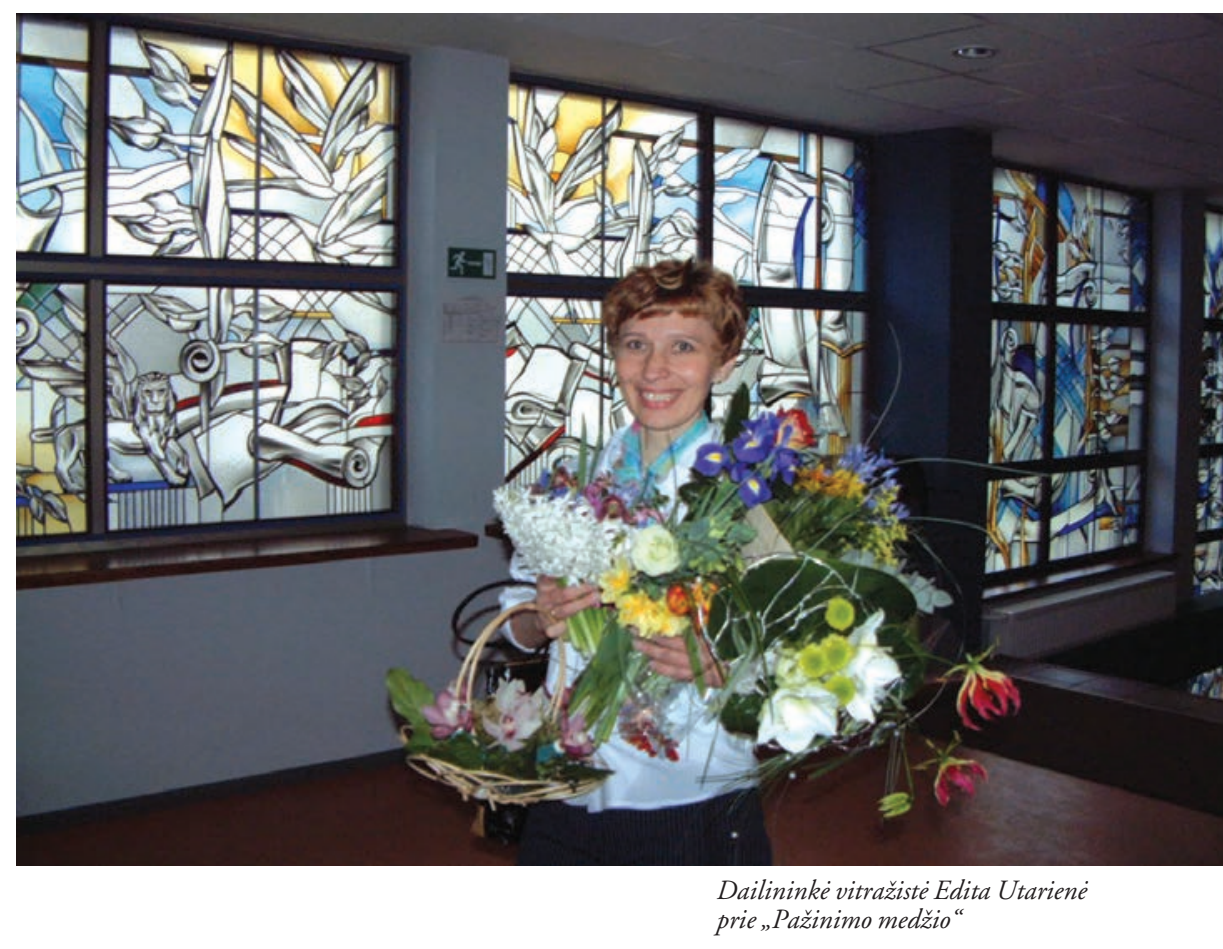

demikas J. Kulys, profesoriai J. Stankūnas ir R. Čiegis.

Gegužes pabaigoje universitete vyko 5-oji tarptautine mokslinè konferencija „Aplinkos inžinerija“. Joje skaityta 217 pranešimų.

VGTU studentai vèl pasirodè geriausiai A. Čyro auditorijoje įvykusioje Lietuvos medžiagų mechanikos olimpiadoje. Čempionu tapo VGTU TTI-8 gr. studentas A. Vika. T. Žigina (MUV-9 gr.) ši kartą buvo antra.

Pirmąji 2002 m. pusmeti VGTU profesūros atstovai nemažai demesio skyre užsienio kelionems. Japonijoje, Saporo mieste, ,vykusiame kelininkų kongrese dalyvavo Aplinkos inžinerijos fakulteto Kelių katedros docentai Donatas Čygas ir Alfredas Laurinavičius. Danijoje, Lundo universitete, vykusiame BALTECH konsorciume, posedžiavo prorektorius profesorius Algirdas Valiulis. Mènesį Prancūzijoje stažavosi doc. Valentinas Skaržauskas, o Vokietijoje, Štralzundo mieste, paskaitas skaite Mechanikos fakulteto dekanas prof. Mečislovas Mariūnas.

2002 m. sukako 100 metu nuo buvusio Specialiųjų konstrukcijų katedros vedejo profesoriaus Anatolijaus Rozenbliumo gimimo.

Anatolijus Rozenbliumas - ižymus statybų konstruktorius, pedagogas ir mokslininkas. Jis kartu su ižymiu Lietuvos architektu Vytautu Landsbergiu-Žemkalniu yra suprojektavęs daug garsiausių tarpukario Kauno pastatų. Ypač A. Rozenbliumas išgarsëjo, kai per trumpą laiką suprojektavo legendinę

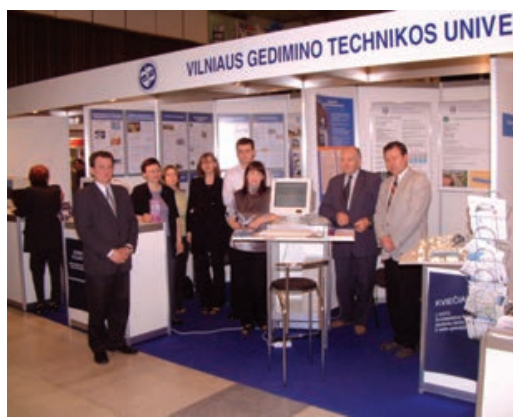

VGTU darbuotojai prie parodos stendo 
VILNIAUS

\section{GEDIMINO}

TECHNIKOS

UNIVERSITETAS

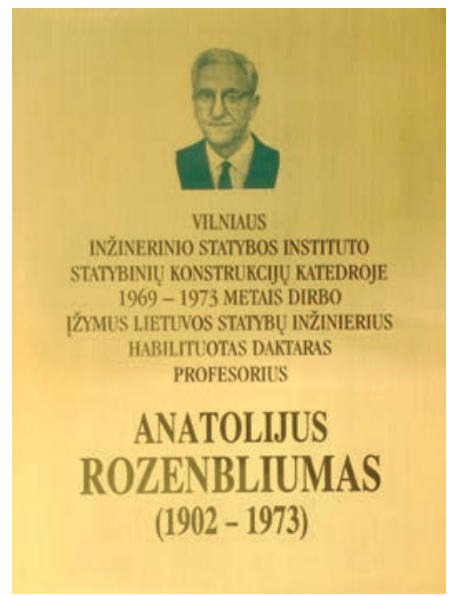

Atminimo lenta A. Rozenbliumui Statybos fakultete

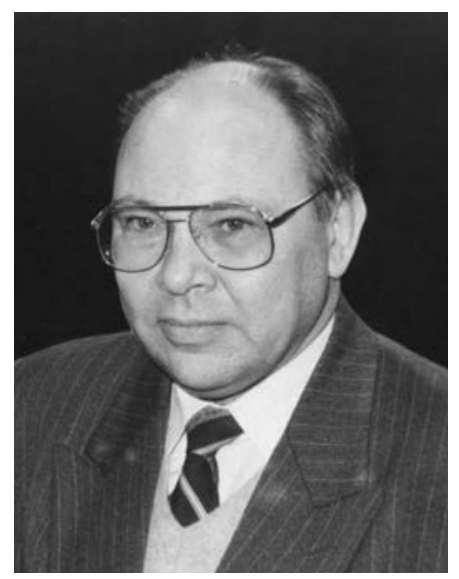

Pirmasis prorektorius E. K. Zavadskas

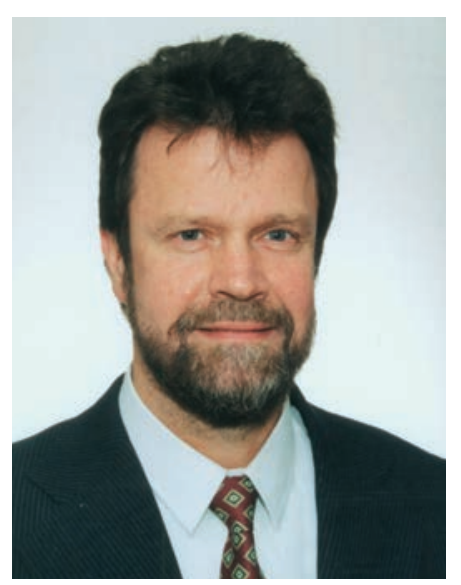

Mokslo prorektorius R. Kirvaits
Kauno Sporto halę, kurioje Lietuvos krepšininkai tais pačiais metais laimëjo Europos čempionų vardą.

Dideli A. Rozenbliumo nuopelnai statybinių konstrukcijų moksle. Jis sukūre originalią gelžbetoninių konstrukcijų deformaciju skaičiavimo teoriją, išugde keliolika technikos mokslų kandidatų, daktarų. Aukšto specialistu pripažinimo sulauke jo vadovèlis „Mūrinès konstrukcijos“, kuris lietuvių kalba buvo išleistas Lietuvoje ir rusų kalba - Maskvoje.

Profesoriaus Anatolijaus Rozenbliumo šimtmečio proga VGTU vyko šiai progai skirta moksline konferencija, buvo pristatyta Algimanto Nako knyga „Profesorius Anato- lijus Rozenbliumas“, prie buvusio jo darbo kabineto Statybos fakultete buvo atidengta jam skirta atminimo lenta, ant profesoriaus kapo padètos gèlès.

2002 m. gegužès 29 d. mirè VGTU Aplinkos apsaugos katedros profesorius prof. habil. dr. Ramutis Šimaitis, jaunysteje pogrindyje kovojęs su sovietine okupacija. Už tai buvo nuteistas 10 metu griežto režimo pataisos darbų. Vèliau tapo mediku, dirbo mokslinio tyrimo institute. Nepaisant praeities, $1984 \mathrm{~m}$. tapo habilituotu daktaru. Nuo 1992 m. dirbo VGTU. Apdovanotas DLK Gedimino ordinu.

Šauniai pasirodè Lietuvos aukštųjų mokyklų studentų teniso čempionate Kaune VGTU rinktinè. Ji laimejo pirmąją vietą, o Aistis Šlajus, SNTV/0 gr. studentas, tapo čempionu vieneto ir dvejeto varžybose.

\section{Prof. habil. dr. Romualdas Ginevičius - rektorius}

2002 m. birželio 20 d. įvykusiuose VGTU rektoriaus rinkimuose kandidatavo du profesoriai habilituoti daktarai - Romualdas Ginevičius ir Algirdas Vaclovas Valiulis. Abu - tos pačios mokyklos absolventai, abu iki tol užèmè reikšmingas pareigas universitete. R. Ginevičius - VGTU senato pirmininkas, Verslo vadybos fakulteto dekanas, İmonių ekonomikos ir vadybos katedros vedejas. A. V. Valiulis - VGTU senato narys, infrastruktūros ir užsienio ryšių prorektorius, Medžiagotyros ir suvirinimo katedros vedëjas, Lietuvos mokslų akademijos narys ekspertas.

Abu kandidatai paskelbe savo rinkimines programas.

R. Ginevičius akcentavo, kad pagrindinis universiteto uždavinys - profesinis kvalifikuotu specialistu rengimas, kryptingas studijuojančiųų pilietiškumo, jų tautinès savimonés, atsakomybes ir pareigos jausmo savo valstybei, savajam universitetui ugdymas.

A. V. Valiulis skelbè panašias nuostatas: rengti šalies ūkiui ir kitoms sritims kompetentingus pasaulio ir Europos standartus atitinančius specialistus, ugdyti asmenybę, puoselèti nacionalinę kultūrą ir kt. Jis akcentavo universitetų tvarką, paremtą programiniu veiklos organizavimu ir finansavimu, siūle stambinti studiju programas, diegti universitete kokybès valdymo sistemą.

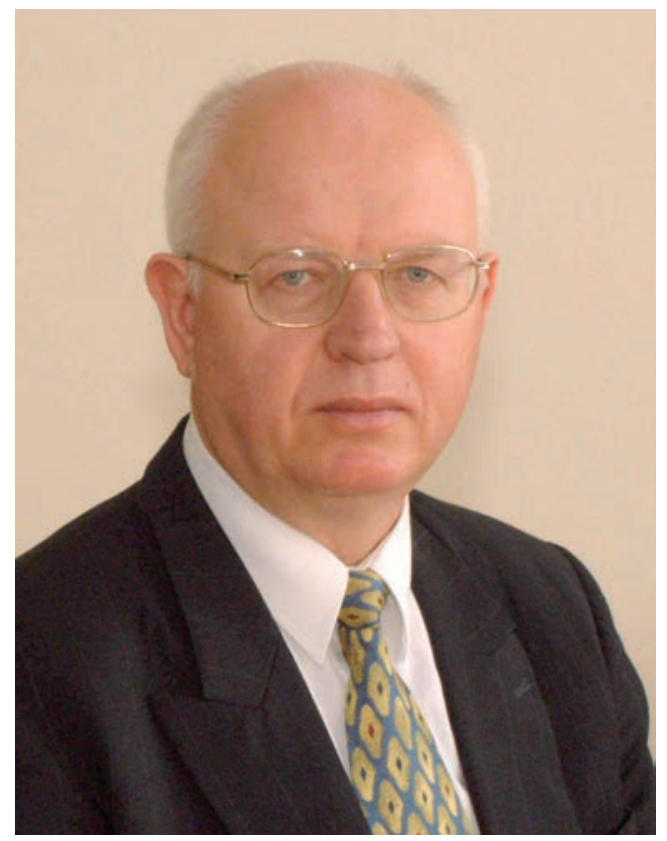

İvykusiuose rinkimuose balsavo 48 VGTU senatoriai: už Romualdo Ginevičiaus kandidatūrą balsavo 30, prieš - 16, už Algirdo Valiulio kandidatūrą balsavo 16, prieš - 32 . Taigi VGTU rektoriumi 2002-2006 metu kadencijai buvo išrinktas habilituotas daktaras profesorius Romualdas Ginevičius. Jis pateike Senatui kandidatus i prorektorių ir naujai steigiamą kanclerio postus.

Senatas slaptu balsavimu patvirtino pirmuoju prorektoriumi prof. E. K. Zavadską, mokslo prorektoriumi - prof. R. Kirvaiti, 
studiju prorektoriumi - doc. A. Daniūną, infrastruktūros ir užsienio ryšiu prorektoriumi - prof. A. V. Valiuli, kancleriu - doc. A. Komką.

Tame pačiame posedyje Verslo vadybos fakulteto dekanu Senatas patvirtino prof. habil. dr. Aleksandrą Vytautą Rutkauską.

Iki rugsëjo $1 \mathrm{~d}$. VGTU rektoriaus pareigas ejo prof. E. K. Zavadskas.

$2002 \mathrm{~m}$. universitetą baige $2208 \mathrm{ab}-$ solventai: pagrindines studijas - 1334 , magistrantūros studijas -818 ir specialiąsias profesines studijas - 56 .

Aplinkos inžinerijos fakultetą baige 336, Architektūros fakultetą - 85, Elektronikos fakultetą - 142, Fundamentinių mokslų fakultetą - 171, Mechanikos fakultetą - 282, Statybos fakultetą - 434, Transporto inžinerijos fakultetą - 177, Verslo vadybos fakultetą - 375, AGAI - 93, Tarptautinių studiju centrą - 13 žmonių.

Daugiausia išleista verslo vadybos specialistų - 233, transporto inžinerinès ekonomikos ir vadybos - 122, inžinerines informatikos - 113, statybos valdymo - 105 .

Diplomus įteikè, absolventus sveikino, linkëjo sèkmès, ragino visą gyvenimą mokytis, tobulinti kasdienos veiklos igūdžius Seimo narys Andrius Kubilius, Universiteto tarybos pirmininkas, LŽŪ banko valdytojo pavaduotojas Jonas Dieninis, VGTU Garbes narys, Statybininku asociacijos prezidentas Adakras Šeštakauskas, susisiekimo ministras Zigmas Balčytis, sostinès meras Artūras Zuokas, VGTU Garbes narys, Priešgaisrinès apsaugos ir gelbejjimo tarnybos direktorius Kazys Zulonas ir kiti.

$2002 \mathrm{~m}$. rugsëjo 1-ąją ì prie VGTU centrinių rūmų susirinkusius tūkstančius studentų kreipessi pradeję̧s eiti universiteto rektoriaus pareigas prof. habil. dr. Romualdas Ginevičius. Pasveikinęs visus naujųjų mokslo metų proga rektorius pasakẻ savo pirmąją imatrikuliacinę kalbą:

„Šiandiena yra tik dvi alternatyvos - arba eiti i prieki, išsiskirti iš kitu tarpo savo žiniomis, erudicija, sugebejimu spresti sudetingas situacijas, tobulu ǔ̌sienio kalbu mokëjimu, arba plaukti pasroviui, tapti "pilka mase" ir nugyventi pilka gyvenima. Viskas Jüsu rankose! Jeigu Jums pakaks ryžto, nuovokos ir Jūs suprasite, kad studijos universitete - tai tramplinas $\dot{z}$ gyvenimo aukštumas, Jūs pasuksite pirmuoju keliu. Jeigu Jüs gyvensite ša akimirka, nebūsite savo gyvenimo „strategu" - suksite antruoju.
Im $m$ üs universiteta ateina abiturientai savo mokslu vidurinese mokyklose, valstybiniu egzaminu laikymo rezultatais irode, kad jie yra geriausi, nepabūge inžinerijos, technologijos studiju. Tai teisingas pasirinkimas. Atgyjanti salies pramone, didejantys statybu mastai teikia nauju, geresniu darbo galimybiu. Patirtis rodo, kad rimtai studijuojant müsu universitete galima tapti visokeriopai isssilavinusiu specialistu, galinčiu dirbti plataus profilio darbus. Šiandien Lietuvoje sunku rasti jmone, departamenta ar ministerija, kur atsakingu pareigy neity mūsy aukletiniai. Šiq mokykla baige ir dauguma universiteto vadovu, profesoriu, docentu.

Studiju metu nereiketu užsisklęsti savo kiaute, dometis vien tik specialybes dalykais, tapti "technokratu“ blogaja šio žodžio prasme. Specialistas inteligentas turi tureti ne tik puikiu dalykiniu sugebejimu, bet ir pasižymeti tvirta morale, kultūra, išmanyti politika, gilintis $\dot{j}$ socialinius ir humanitarinius mokslus, suprasti mena. Priminsiu, jog labai svarbu išmanyti ekonomika ir vadyba. Juk Jūs - busimieji imoniu, istaigu vadovai, o pagrindinis bet kurios imones veiklos tikslas - ekonominis rezultatas. Šie mokslo metai sudetingiausi bus pirmakursiams. Jie ipratę, kad jais rūpintusi tevai, broliai, seserys, mokytojai. Atejus i universiteta, toks gyvenimas baigiasi: teks patiems priimti sprendimus ir atsakyti už savo veiksmus. Kita vertus, siandienos gyvenimas - tai kova už būvį. Noréčiau, kad universitetas Jums bütu ne vien tik žiniu, bet ir gyvenimo mokykla. Norint ja išeiti kuo greičiau, reikia büti aktyviems, nes tik tokiu atveju ateina patyrimas. Nereikia bijoti suklysti, tai žmogiška. Tuo labiau, kad universitete dirba geranoriški profesoriai, destytojai, dekanatu darbuotojai, kurie ir patars, ir pades.

Sèkmés visiems mūsu bendrijos nariams siais mokslo metais!"

2002-2003 mokslo metus pradëjo 11696 Vilniaus Gedimino technikos universiteto studentai: pagrindinių dieninių studijų - 7621 , pagrindinių neakivaizdinių studiju - 1864 , magistrantūros dieninių studijų - 1720 , magistrantūros vakarinių studiju - 263, magistrantūros neakivaizdinių studijų - 180 ir specialiųjų profesinių studijų -48 .

Mokslo metu pradžioje tarp studijuojančiųjų lietuviai sudare 73,6 \%, lenkai $-6,2 \%$, rusai $-5,7 \%$, kitų tautybių arba nenurodžiusių tautybes - 14,5\%. Taigi VGTU dominavo lietuvių tautybès studentai.

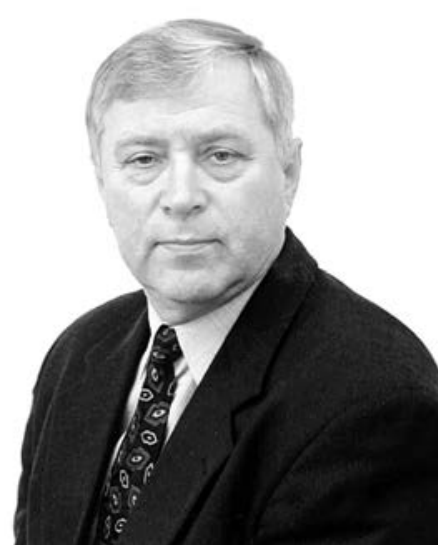

Infrastruktūros ir užsienio ryšiu prorektorius $A$. V. Valiulis
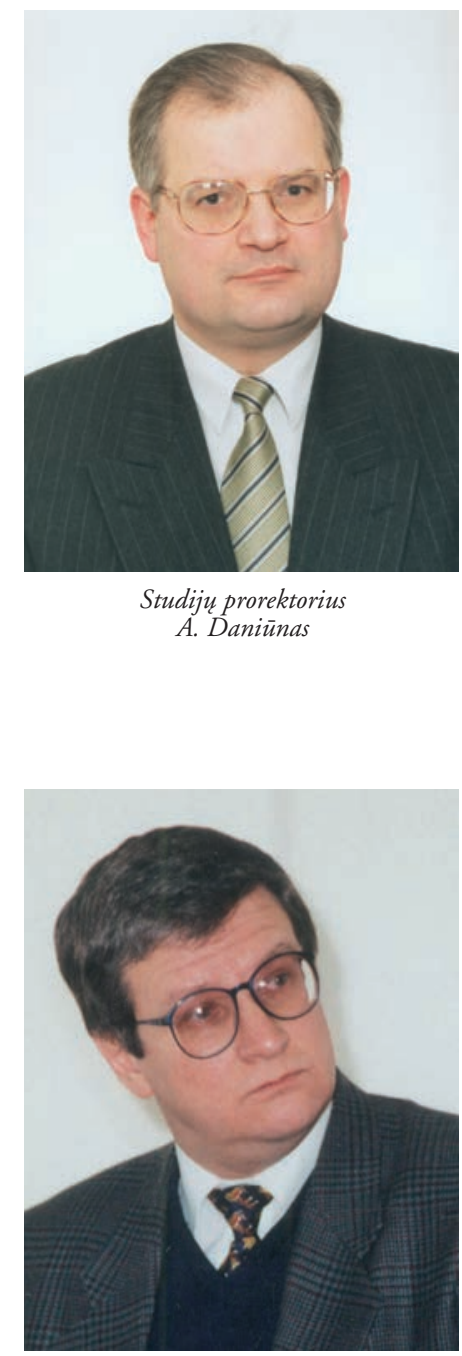

Kancleris A. Komka 
VILNIAUS

GEDIMINO

TECHNIKOS

UNIVERSITETAS

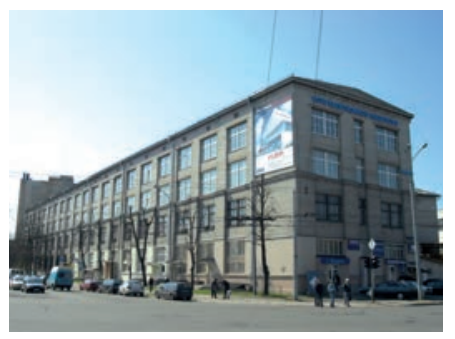

Elektronikos rūmai

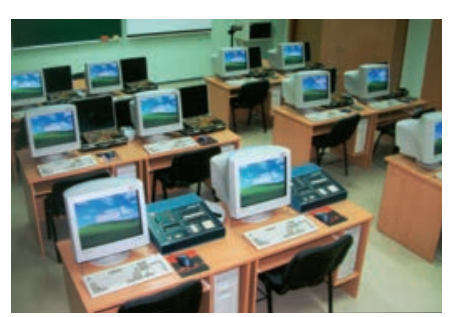

Kompiuteriu klaseje
Viršuje dešinëje -

buvess ir naujasis rektoriai atidaro naujasias elektroniku patalpas
$2002 \mathrm{~m}$. išliko didelis įregistruotų studiju programų ir specializacijų (pakraipų) skaičius - 105. Praktiškai šis skaičius nekito jau šešerius metus. Daugiausia buvo technologiju mokslų srities studiju programų -87 .

VGTU studentų, $2002 \mathrm{~m}$. įstojusių i VGTU pagrindines studijas užsienio kalba, daugiausia studijavo angliškai. Tokių studentų buvo $73,7 \%$, vokiečių kalba mokèsi $19,5 \%$, prancūzų $-3,6 \%$, rusų $-3,2 \%$.

Dieninių studijų studentų dauguma buvo iš Vilniaus apskrities ir Vilniaus miesto.

Tarptautinių studiju centras prièmé studijuoti jaunuolius iš penkių užsienio valstybių: iš Turkijos -4 , iš Pakistano - 22, iš Libano, Turkmenistano ir Baltarusijos - po 1 , iš viso 29 žmones.

64,23\% pagrindinių studijų studentu buvo vyrai. Antros pakopos studijose vyru buvo kiek mažiau $-58,62 \%$.

\section{Elektroniku ikurtuvès}

$2002 \mathrm{~m}$. rugsëjo 1-oji buvo ypatinga Elektronikos fakulteto destytojams, darbuotojams ir studentams. Fakultetas galutinai paliko buvusius unitu vienuolyno rūmus ir įsikūrè Naugarduko g. 41. Elektronikos fakulteto pirmakursius, profesūrą su mokslo metu pradžia sveikino švietimo ir mokslo ministras Algirdas Monkevičius, universiteto pirmasis prorektorius prof. Edmundas Kazimieras Zavadskas, buvęs dekanas, dabar mokslo prorektorius prof. Raimundas Kirvaitis, dekane doc. Roma Rinkevičiené. Dešimtą valandą švietimo ir mokslo ministras ir rektorius perkirpo juostelę ir pakviete visus susirinkusiuosius pasižvalgyti po naująsias Elektronikos fakulteto patalpas, kurios buvo įrengtos biudžeto ir remeju - Telekomo ir UAB „Festo“ - lèšomis.

$2002 \mathrm{~m}$. Elektronikos fakultetas prième studijuoti i pirmąji kursą 380 žmonių. Ju studijos prasidejo jau puikiai irrengtose patalpose.

Prorektorius, buvęs fakulteto dekanas prof. R. Kirvaitis iškilmese sake, jog 40 metu bazilijonų vienuolyne gyvavęs fakultetas išleido ì gyvenimą beveik 4000 kvalifikuotu specialistų - inžinierių, bakalaurų, magistrų ir mokslo daktarų. Tačiau jau dešimt

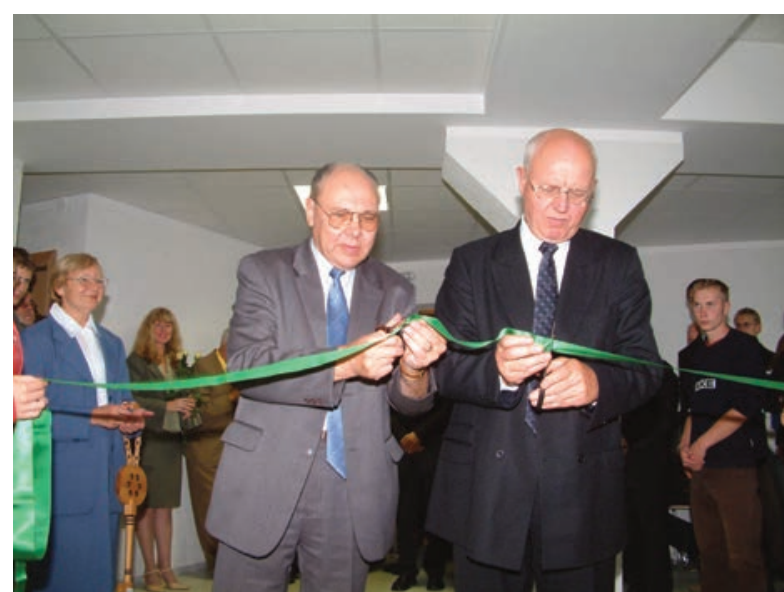

metų fakultetas buvo tik bazilijonų rūmų nuomininkas. Vykdydama restitucijos aktą, LR Vyriausybè grąžino rūmus tikriesiems jų savininkams - bažnyčiai. Todèl daugiau kaip prieš 6 metus prasidejjo Naugarduko gatveje renovuojamo pastato projektavimas, maždaug prieš 4 metus - ir pastato renovavimo darbai. Kalbetojas dekojo universiteto vadovybei ir pirmiausia buvusiam ilgamečiam universiteto rektoriui prof. Edmundui Kazimierui Zavadskui, šalies Vyriausybei. Dèkota ir darbus rūmuose vykdžiusiems ir vykdantiems gen. rangovui „Arkada“ (direktorius Rimas Piliponis, statybos darbų vadovas Zigmas Jakimavičius). Už darbų priežiūrą padèkota universiteto kapitalinès statybos direktoriui dr. Pranui Malinauskui. Nebuvo pamiršti ir ALVALIO baldininkai (direktorius Vaidas Malinauskas), kompiuterinę ir organizacinę techniką bei prietaisus teikusių firmų vadovai.

Daug padèkos žodžių išsakyta rèmëjams. UAB „Festo“ Lietuvos skyriaus direktoriaus Alfonso de Laato iniciatyva įrengta automatikos ir robotu technikos elementų laboratorija, Lietuvos telekomo vadovų iniciatyva jau porą metų veike moderni ryšių technikos laboratorija. Kartu išsakytas įsitikinimas, kad nemažès Vyriausybès rūpestis ir pagalba, kad pradèti darbai būtų kuo greičiau baigti.

Su ịkurtuvių švente Elektronikos fakulteto bendruomenę sveikino ir linkejjo sèkmès, glaudesnio ir rezultatyvaus bendravimo su remejjais, verslininkais, kuriant Naugarduko rūmuose „stiprų elektronikos technologijų kampą“ "švietimo ir mokslo ministras dr. Algirdas Monkevičius, rektorius prof. Romualdas Ginevičius, pirmasis prorektorius prof. Edmundas Kazimieras Zavadskas, universiteto kancleris doc. Arūnas Komka, remèjai Alfonsas de Laatas, „Alnos“ generalinis direktorius, universiteto Tarybos narys Tomas 
Milaknis, LRT generalinis direktorius, fakulteto aukletinis Valentinas Milaknis, prof. Zenonas Vainoris ir kiti [6.26, p. 2-3].

Rugsejo $17 \mathrm{~d}$. buvo surengti Gedimino universiteto dienos renginiai. Centriniuose rūmuose buvo atidaryta turistų klubo parengta paroda „İspūdžiai iš kelionių", VGTU bibliotekos rūmuose - naujų leidinių paroda. Iš Trakų gatveje esančiu rūmų buvo surengta studentų eisena į Katedros aikštę, kur prie Gedimino paminklo ansamblis „Vingis“" parode gražią tautinių šokių kompoziciją, rektorius R. Ginevičius padejo prie paminklo gèlių, palinkèjo sèkmès VGTU bendruomenei, buvo išklausyti Vilniaus mero A. Zuoko linkèjimai. Efektingai atrode VGTU Antano Gustaičio aviacijos instituto mokomųjų lèk-

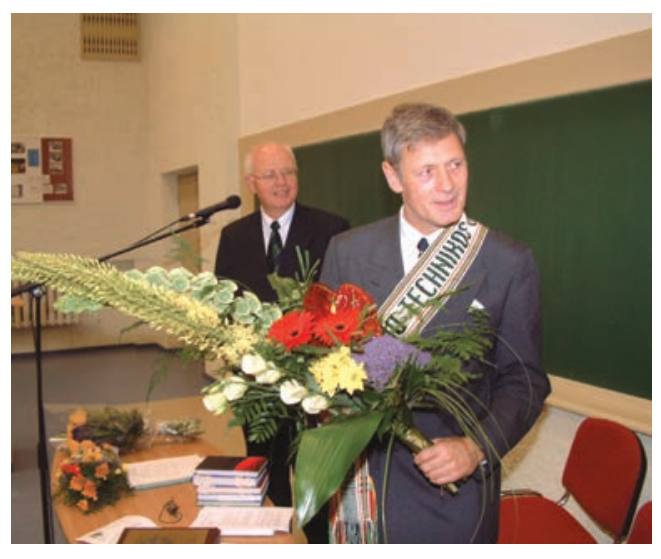

tuvų eskadrilès skrydis virš Katedros aikštès. Tą dieną buvo ir daugiau ịdomių renginių, kuriuos vainikavo studentų vakaronè „Karolinos" klube.

\section{Prof. dr. Donatas Čygas - Senato pirmininkas}

Rugsèjo ménesị ịvykusiame VGTU senato posedyje, buvusiam Senato pirmininkui R. Ginevičiui tapus rektoriumi, įvyko naujo Senato pirmininko rinkimai.

Kandidatais ị Senato pirmininko postą buvo pasiūlyti Aplinkos inžinerijos fakulteto dekanas prof. dr. Donatas Čygas ir Matematines statistikos katedros vedejas prof. habil. dr. Leonas Saulis. D. Čygas gavo 27 balsus, L. Saulis -10 .

Taigi nuo $2002 \mathrm{~m}$. rugsëjo $11 \mathrm{~d}$. Vilniaus Gedimino technikos universiteto senato pirmininku tapo prof. Donatas Čygas.

„Dékoju visiems, kurie manimi pasitikëjo, ir pasistengsiu pateisinti senatoriu viltis. İsitikines, jog rasime bendra kalba, kad Senatas ir toliau sékmingai, produktyviai dirbtu ", - sake prof. Donatas Cygas.

Rugsèjo 20 d. universitete lankèsi mūsų šalyje viešęjęs Lenkijos Respublikos Seimo pirmininkas Marekas Borovskis ir jo vadovaujamos delegacijos nariai. Lenkijos Seimo pirmininkas sakè, jog jam didelè garbe lankytis mūsų universitete, susitikti su modernios aukštosios mokyklos vadovais, mokslininkais. Garbusis svečias pasirašè universiteto Garbès svečiu knygoje, įteikè rektoriui vertingų suvenyrų, primenančiu bendrus Lietuvos ir Lenkijos siekius. Marekas Borovskis A. Graičiūno auditorijoje studentams, profesūrai skaite paskaitą „Lenkija ir Lietuva - bendri iššūkiai, bendra ateitis“. Ji skirta Lenkijos ir Lietuvos tautu

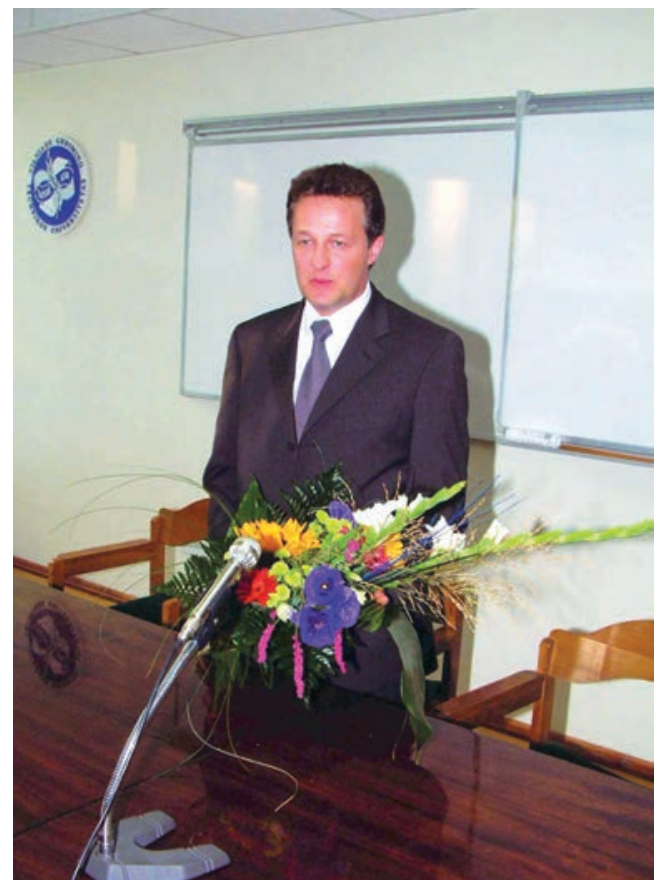

vietai šiandienos pasaulyje, svarbiausiems nūdienos reikalams - integracijai į Europos Sajungą, narystei NATO, bendrai kovai su terorizmu, abiejų šalių ekonomikos plètrai, stabiliai ilgalaikei demokratijai. Ypač akcentuota mokslo, žinių plètra, švietimo, išsilavinimo reikšmè tautos ir šalies ateičiai.

Rugsèjo pabaigoje Palangoje vyko XII tarptautine moksline konferencija „Elektromagnetiniai trikdžiai 2002“. Ją organizavo Kauno technologijos, Vilniaus Gedimino technikos ir Bialystoko (Lenkija) technikos universitetai. 


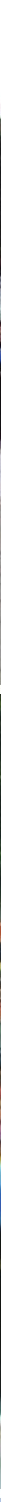


VILNIAUS

GEDIMINO

TECHNIKOS

UNIVERSITETAS

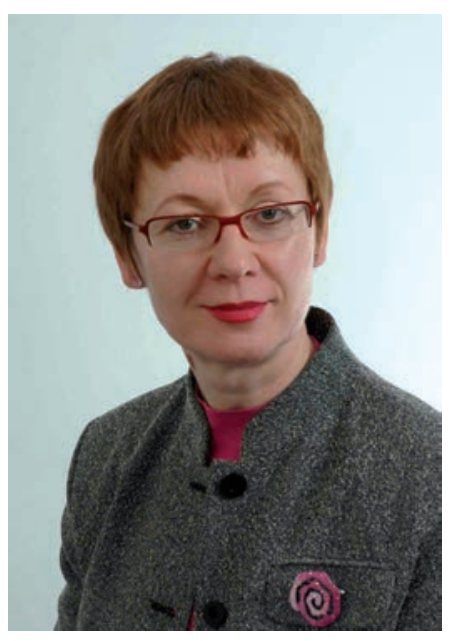

R. Abramčikiené VGTU bibliotekos direktore nuo $2002 \mathrm{~m}$
Konferencijoje nagrinèti elektromagnetinio suderinamumo, trikdžių telekomunikacijose, elektromagnetinių procesų modelia- vimo bei apsaugos nuo viršitampių ir žaibų klausimai. Dalyviai gavo gerai parengtą pranešimų medžiagos leidinị.

Šešiose sekcijose dalyvavo daugiau kaip 30 mokslininkų, kurie skaite 29 pranešimus. VGTU Elektronikos fakultetui atstovavo 6 dèstytojai, kurie perskaite 4 pranešimus.

Prof. habil. dr. R. Rinkevičienè - pirmoji moteris dekanè mūsu mokyklos istorijoje

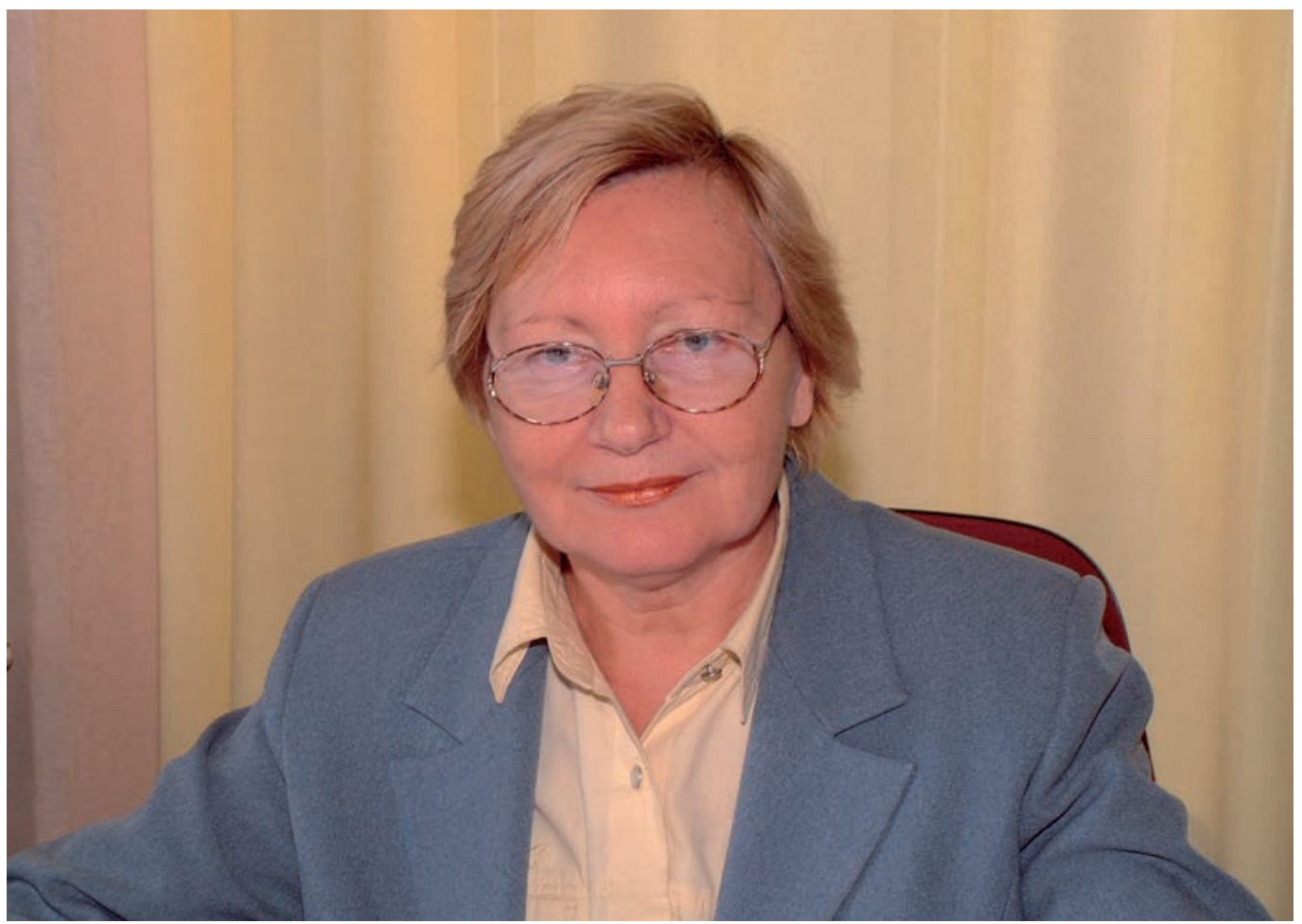

Elektronikos fakulteto dekane vietoj tapusiu prorektoriumi prof. R. Kirvaičio buvo išrinkta prof. habil. dr. Roma Rinkevičienè. Ji buvo dirbusi prodekane, žinoma mokslo visuomenei automatinio valdymo specialiste, gera pedagogé.

Spaliui baigiantis, VGTU bibliotekos direktore Regina Pugžliene paliko savo postą. Ji išvyko gyventi ị JAV. Aštuoniolika metų Regina Pugžlienè dirbo universiteto bibliotekoje. Ji perejo visus karjeros laiptelius nuo paprastos bibliotekininkes iki direktorès. Pastaruosius šešerius metus sèkmingai vadovavo gausiam moterų ir kelių vyrų kolektyvui. Reginos Pugžlienés direktoriavimo metais biblioteka persikèle į naujas, erdvias ir modernias patalpas, skaitytojai aptarnaujami naudojantis naujausiomis nūdienos technologijomis.

Iš direktores Reginos Pugžlienes pareigas peremé jos pavaduotoja Rimute Abramčikienè.
Nuo spalio 24 d. vyko 5-oji Lietuvos jaunųjų mokslininkų konferencija „Lietuva be mokslo - Lietuva be ateities“. Dirbo 12 sekcijų: „Humanitariniai ir socialiniai mokslai XXI“, „Aplinkos apsaugos inžinerija“, „Elektronika ir elektrotechnika“, „Statyba“, „Mechanika, medžiagu inžinerija, pramonès inžinerija ir vadyba“, „Matematika ir informatika“, „Bioinžinerija ir bioinformatika“, „Fizika ir fizine kompiuterija“, „Aviacijos technologija“, „Asmenybe ir kultūra“ (studentų), „Transportas“. Būsimieji architektai savąją konferenciją pavadino „K. Šešelgio skaitymai“. Doktorantai, magistrantai parengè keletą šimtų turiningu, įdomių, pranešimų.

Spalio $30 \mathrm{~d}$. ịvykusiame iškilmingame Senato posédyje VGTU Garbès nario regalijos itteiktos visos Lenkijos Lietuvos myletojų draugijos pirmininkui, žurnalo „Lithuania" vyriausiajam redaktoriui, technikos 
humanizavimo propaguotojui, vienam iš garbès medalio „Integralusis humanizmas“ steigejui dr. Leonui Brodovskiui.

Garbès nario regalijos įteiktos ir Lietuvos Ministro Pirmininko patarejui Algirdui Vapšiui už nuolatinį demesi ir paramą rengiant puikios kvalifikacijos statybų specialistus.

Iškilmingame posedyje dalyvavo ir kalbëjo Lenkijos ambasadorius Lietuvoje prof. Ježis Baras.

Lapkričio 9-ąją Vilniaus Gedimino technikos universitete surengta Mokslo diena. Jos metu vyko mokslininkų susitikimai su abiturientais, buvo aplankomos mokslo laboratorijos, Skaičiavimo centras, Geodezijos mokslo institutas. Buvo surengta „Technikos" leidinių mugè.

\section{Rektoriaus R.Ginevičiaus inauguracija}

Didele švente universiteto bendruomenei tapo lapkričio $15 \mathrm{~d}$. įvykusi naujojo Vilniaus Gedimino technikos universiteto rektoriaus prof. Romualdo Ginevičiaus inauguracija.

Buvęs rektoriumi beveik 13 metų prof. E. K. Zavadskas, be kita ko, sake:

„Šiandiena galima pasidžiaugti, kad Vilniaus Gedimino technikos universiteto rektoriumi išrinktas visuomeniškai aktyvus mūsu universiteto bendruomenés narys, mūsu aukštosios mokyklos absolventas, visa gyvenima pasky-
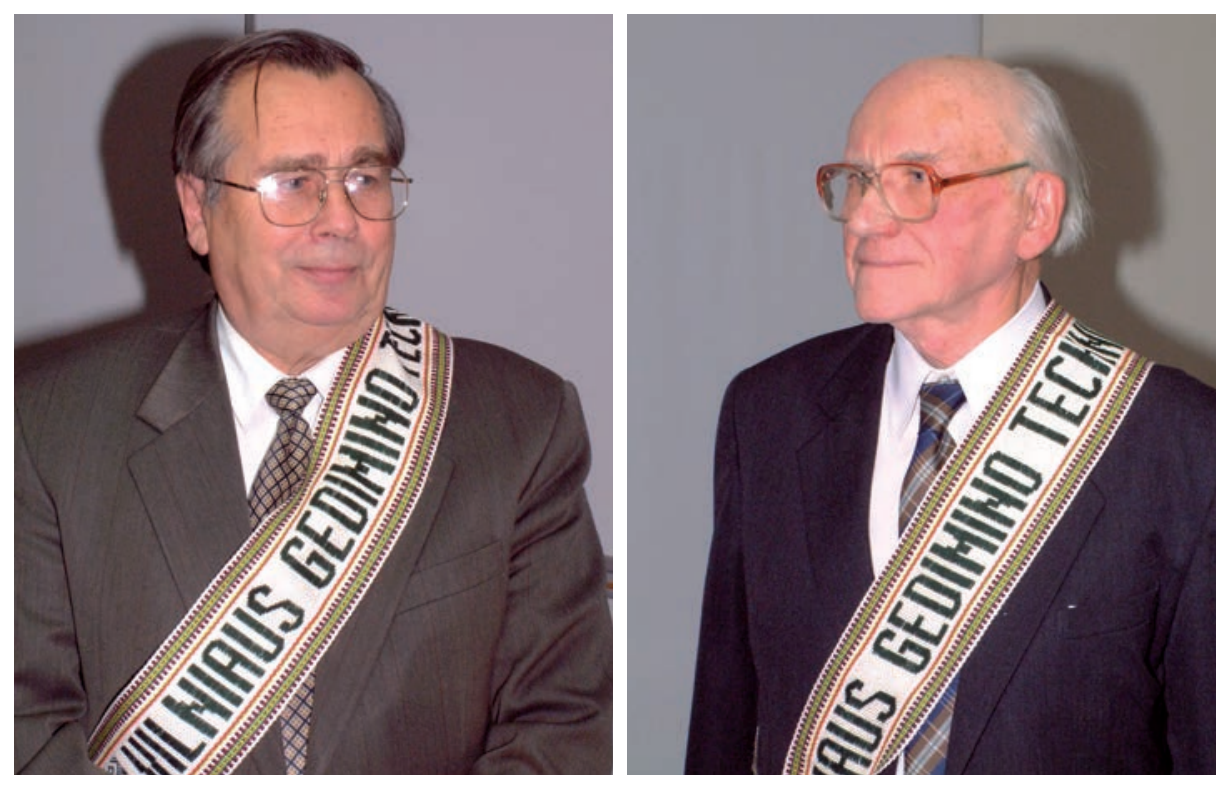

Kairëje - VGTU Garbès narys A. Vapšys, dešinëje -

VGTU Garbès narys L. Brodovskis ręs savo Alma Mater. Profesorius, habilituotas socialiniu moksly daktaras, inžinierius ekonomistas Romualdas Ginevičius yra puikus mokslininkas, pedagogas ir vadybininkas, turintis didele vadovo patirti, nes yra ejes beveik visas universitetams büdingas vadovaujančiasias pareigas: prodekano, katedros vedejo, Verslo vadybos fakulteto dekano, universiteto Senato pirmininko. Universiteto bendruomenés nariai turejo galimybiu per daugeli metu isitikinti būsimojo rektoriaus kompetencija. Esu dekingas visiems,

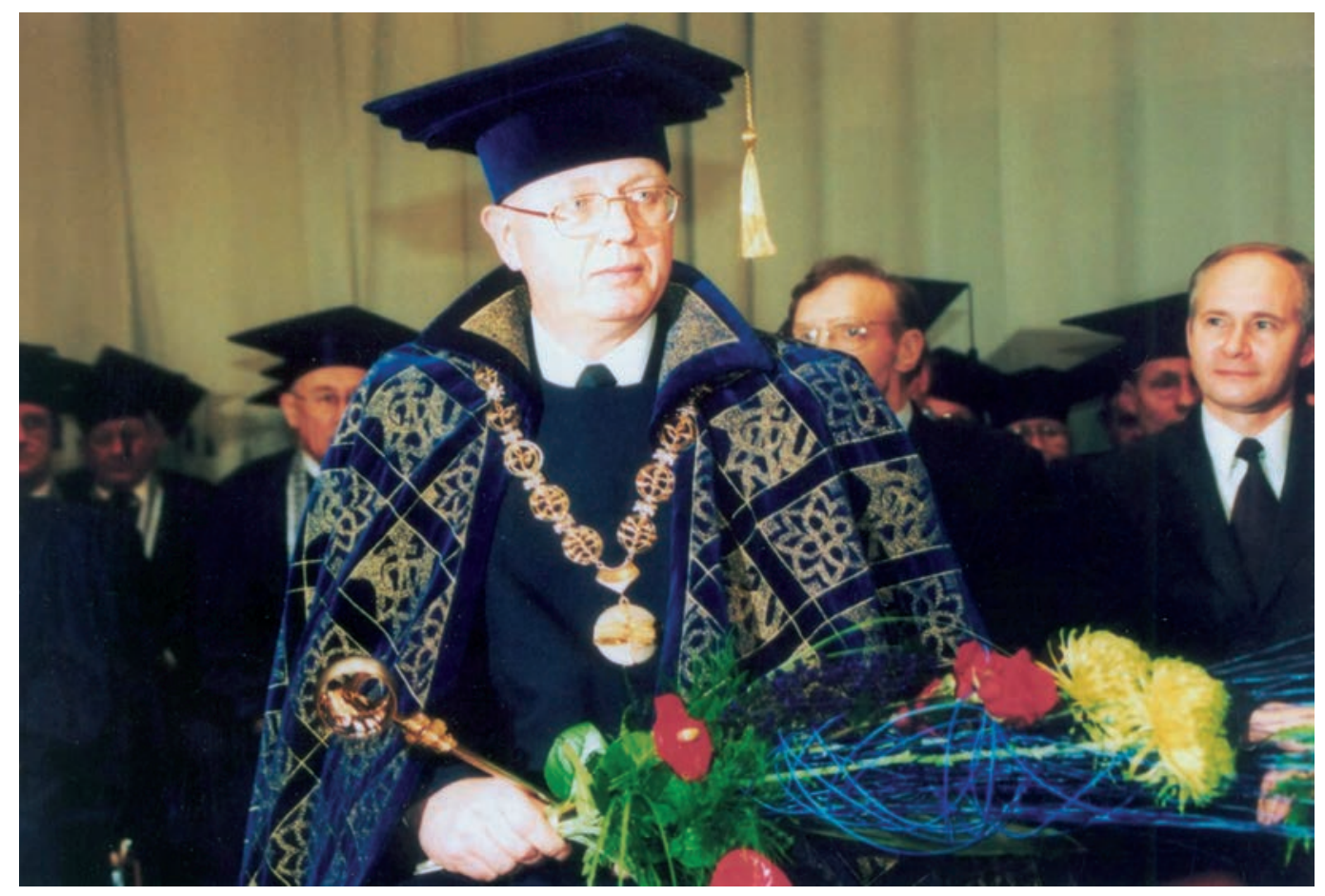


VILNIAUS

GEDIMINO

TECHNIKOS

UNIVERSITETAS
Rektoriaus inauguravimo švente buvo transliuojama internete.
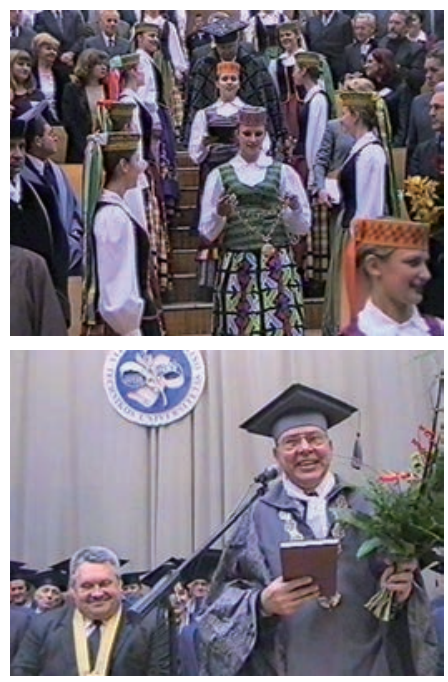

šiuos dvylika su puse metu remusiems pažangias idejas ir nepaprastai daug dirbusiems, siekiant jas realizuoti. Kartu dekoju ir vienminčiui, ir bendražygiui profesoriui Romualdui Ginevičiui, taippat daug prisidejusiam prie Gedimino technikos universiteto kürimo. Džiangiuosi, kad universiteto valdžios atributai isiandien itteikiami valingam, gabiam, vedliam ir turinčiam labai reikalingu diplomatiniu sugebejimu kolegai ".

Senato pirmininkas prof. D. Čygas pabrèže, kad išrinktas rektoriumi prof. R. Ginevičius yra "puikus žmogus, sugebantis kiekviena išklausyti, besistengiantis kiekvienam padeti ir patarti, daug pasiekęs mokslininkas ir pedagogas, gabus administratorius. Šiuos jo asmenybès bruožus juertino ir Lietuvos Respublikos Vyriausybe, pakvietusi profesoriu nuo siu metu pavasario vadovanti Privatizavimo komisijai.

Vilniaus Gedimino technikos universiteto bendruomene, atidavusi universiteto vaira $i$ tvirtas profesoriaus habilituoto daktaro Romualdo Ginevičiaus rankas, tikisi, kad jis nepriekaistingai atliks akademinei visuomenei nüdienos iškeltus uždavinius ir universiteto laivas sparčiai, sekmingai plauks $\dot{z}$ naujas studiju bei mokslo aukštumas. Linkime gerbiamam rektoriui visokeriopos sèkmès “.

Didelę kalbą pasakè rektorius prof. R. Ginevičius. Baigdamas ją sakè:

„Aš tvirtai pareiškiu, kad dirbdamas Vilniaus Gedimino technikos universiteto rektoriumi visus savo sugebejimus, visa savo energija skirsiu mūsu universiteto, viso mūsu krašto labui. Sakoma, kad neimanoma tampa imanoma, kaižmonesstoja juiena greta, kai žmonés veikia kartu. Aštikiuosisklandaus bendradarbiavimo su visa mūsu universiteto bendruomene, tikiu gražia mūsu universiteto ateitimi ".

Renginyje perskaityti Lietuvos Respublikos Prezidento Valdo Adamkaus ir Ministro Pirmininko Algirdo Brazausko sveikinimai rektoriui. Sveikino LRS pirmininko pavaduotojas A. Skardžius, švietimo ir mokslo ministras A. Monkevičius, Vilniaus apskrities viršininkas G. Paviržis, Lietuvos mokslo tarybos pirmininkas prof. K. Makariūnas, daugelio užsienio universitetų rektoriai ir kt.

Rektoriui renginio metu buvo įteiktos valdžios regalijos: medalionas su puošnia grandine ir skeptras. Rektorius vilkejo prabangia toga, sukurta dailininkès Irenos Vabalienès.

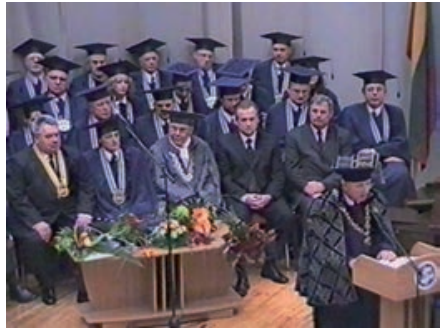

\section{0-osios „Vingio“ ansamblio metinès}

Gruodžio ménesį savo keturiasdešimtąsias veiklos metines pažymejjo dideliu koncertu Rusų dramos teatre VGTU tautinių šokių ansamblis „Vingis“. Per koncertą buvo prisiminti, plojimais ir gèlemis pagerbti ne tik šiandienos universiteto tautinių šokių ansamblio „Vingis“ vadovai, bet ir jị kūrusieji, anksčiau dirbusieji A. Gineitis, J. Mykolaitis, V. Pūgžlys, G. Věžauskas, B. Navickaite, $\mathrm{V}$. Bukenaite. Pačiais bendriausiais potepiais papasakota ansamblio istorija, koncertine veikla.

Šventinį koncertą parengè ansamblio „Vingis“ meno vadove Rimute Zaleckaité, choreografas Ričardas Tamutis, orkestro vadovas Antanas Jonušas. Jų režisūra, šokëjų meistriškumas, nuoširdumas sukūre pakilią, šiltą, jaunatvišką nuotaiką, kuri visą laiką buvo jaučiama ir scenoje, ir saleje.

Per keturiasdešimt savo gyvavimo metų ansamblis koncertavo daugiau kaip 700 kartų. Visomis iškilmingomis progomis pasirodo savajame universitete, dalyvauja respublikinèse ir Pasaulio lietuvių dainu šventese, nepraleido ne vieno "Gaudeamus“ koncerto, aplanko šalies miestus, keliauja po svečias šalis. Vingiečiai jau pabuvojo ir 
šoko Lenkijoje, Čekijoje, Vengrijoje, Estijoje, Latvijoje, Vokietijoje, Kanadoje, Anglijoje, Airijoje, Belgijoje ir kitur.
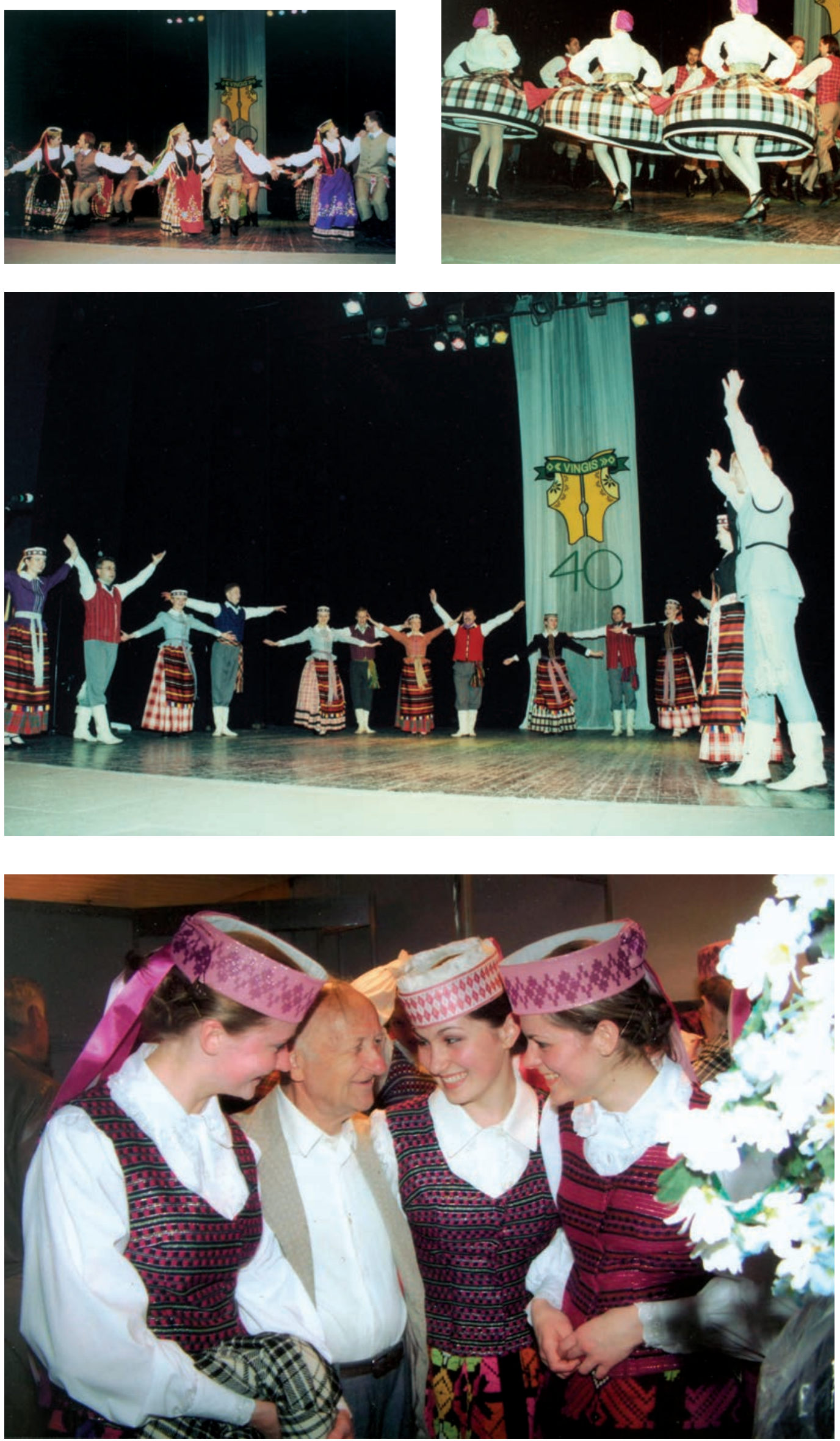
VILNIAUS

GEDIMINO

TECHNIKOS

UNIVERSITETAS
Viršuje dešinëje -

Lietuvos universitetu rektoriu konferencijos posedžiai vyksta ir VGTU

\section{Intensyveja mokslininku veikla}

2002 metais nuo vasaros iki žiemos daug keliavo VGTU mokslininkai.

Prof. A. V. Valiulis dalyvavo 140-osioms Rygos technikos universiteto metinems skirtoje mokslineje konferencijoje, Helsinkio technologiju universitete vykusiame BALTECH konsorciumo valdybos posedyje, Vokietijos miestuose - Vismare ir Vesemundeje vykusiame 6-ajame Baltijos šalių regiono seminare inžinerinio mokymo klausimais.

Prof. M. Mariūnas dalyvavo Vroclave (Lenkija) vykusioje biomechaniku tarptautineje konferencijoje.

Prof. A. Skrinska lankèsi Ispanijoje ir Europos saules energijos naudojimo tyrimy centre, atliko mokslinius tyrimus.

Doc. V. Stragys dalyvavo Atenuose (Graikija) vykusiame Europos statybos inžinieriu tarybos posedyje.

Čestakovoje (Lenkija) vykusioje tarptautineje konferencijoje pastatų ir statinių gaisrinès saugos klausimais dalyvavo doc. R. Šukys ir prof. P. Čyras.

Prof. A. Kvedaras dalyvavo Ciombra (Portugalija) universitete vykusioje tarptautineje konferencijoje plieninių konstrukciju klausimais.

Prof. A. Čižas dalyvavo Europos kokybès vertinimo agentūrų tinklo seminare, kuris įvyko Norvegijoje Tromso mieste.

Tai tik dalis užsienio kelionių, kuriose dalyvavo mūsų mokslininkai. Nepriklauso-

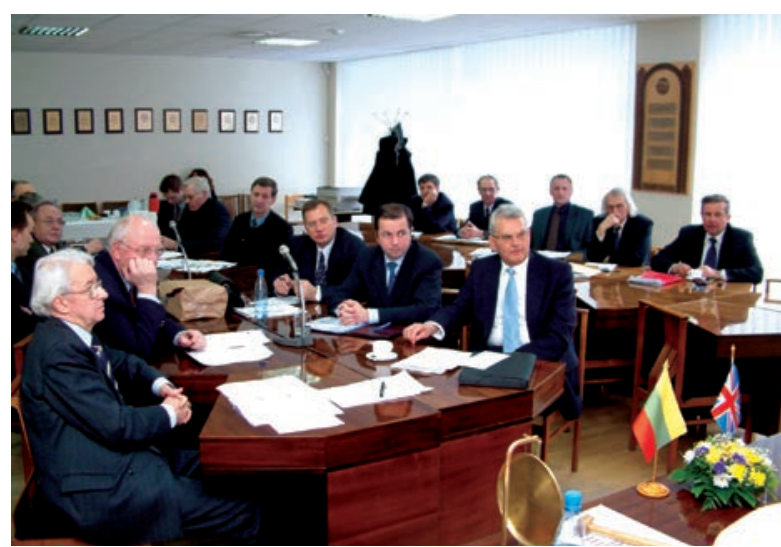

mybès metais atsivèrusios galimybès leido mūsų mokslininkams laisvai semtis Vakarų mokslininkų patyrimą, remtis jų laimejimais ir visa tai naudoti savo krašto labui.

2002 metais vyko universiteto mokslo infrastruktūros pokyčiai: prie VGTU buvo prijungtas Termoizoliacijos institutas, ịsteigti du nauji universitetiniai padaliniai - Gynybos technologijų ir Inovacijų centrai, du nauji fakultetiniai padaliniai - Telekomunikaciju mokslo centras ir Fizinès medžiagotyros laboratorija. VGTU tapo viešosios įstaigos "Visoriu technologinis parkas" steigeju ir dalininku.

Per 2002 metus universitete buvo apgintos 28 daktaro ir 1 habilituoto daktaro disertacijos (geodezininkas P. Petroškevičius).

Už $4 \mathrm{mln}$. Lt atlikta užsakomųjų darbų, iš jų darbų už $1,7 \mathrm{mln}$. Lt atliko Aplinkos inžinerijos fakultetas.

VGTU mokslininkų lěšos, vykdant tarptautinius projektus, sudare apie 900 tūkst. Lt. Tai netenkino universiteto vadovybes.

Buvo paskelbti 957 moksliniai straipsniai, padaugejo straipsnių su ISI. Pastarųjų daugiausia paskelbe Fundamentinių moksly

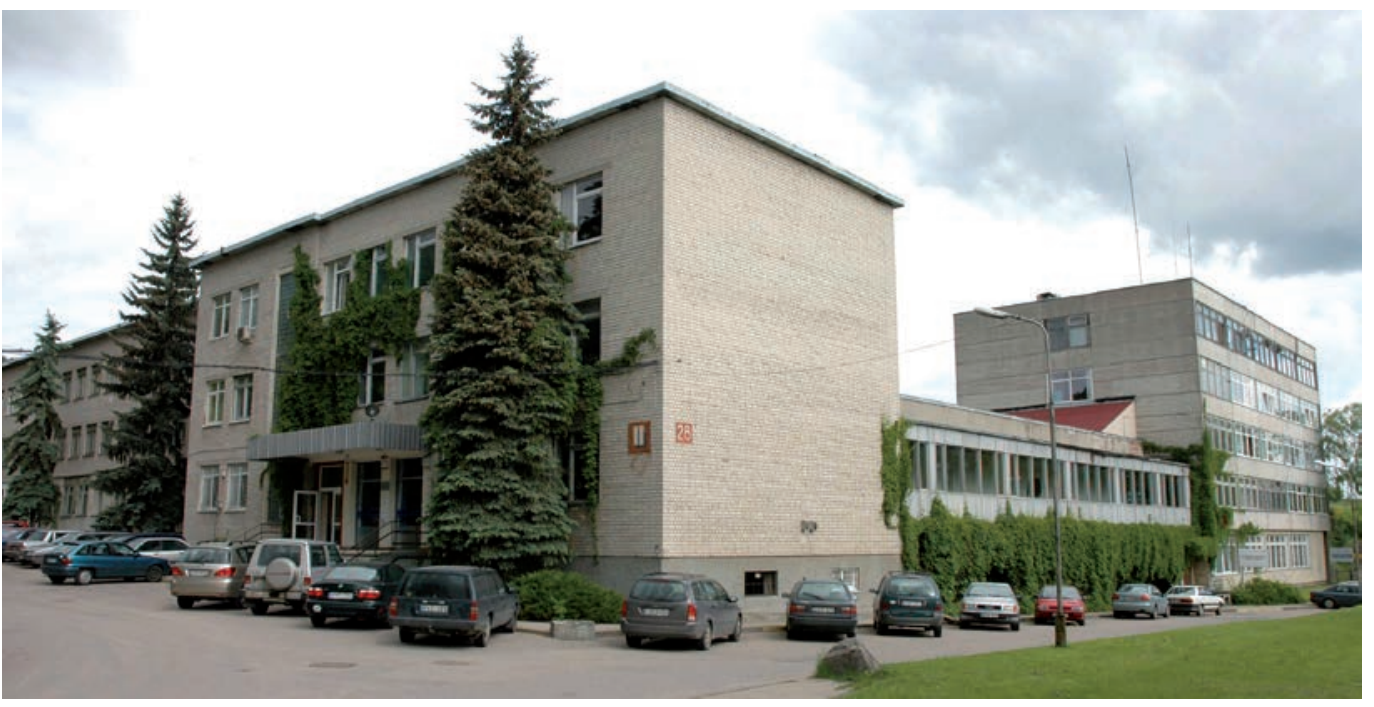


fakulteto mokslininkai. Buvo išleista 17 monografijų, 5 vadovèliai, 55 mokomosios knygos ir kt.

Universitete $2002 \mathrm{~m}$. surengtos 4 tarptautines mokslinès konferencijos ir 24 konferencijos bei seminarai. Gauti 4 išradimu patentai.

Universitetas dalyvavo keturiose parodose: „Hanoverio muge 2002“, ir parodose Lietuvoje „Mokslas 2002“, „TransBaltica 2002“, „Nekilnojamasis turtas. Investicijos“.

Doktorantūroje studijavo 211 doktorantų, daugiausia - technologijos mokslus.

2002 m. universitete dirbo 115 habilituotų daktarų, profesorių, 427 docentai ir daktarai, 83 lektoriai, 169 asistentai ir 59 mokslo darbuotojai. Iš viso 833 žmonès.

Nuo 2002 m. gegužès VGTU bibliotekoje knygos skaitytojams išduodamos tik automatizuotai, o spalio mèn. įdiegta patobulinta bibliotekines informacijos sistemos ALEPH 500.14 .2 versija. Visa tai sutrumpino knygos kelią pas skaitytoją.

Bibliotekos skyrių vedejjos A. Striogiené ir A. Diržauskienè laimèjo finansinę paramą išvykti i Helsinkio technologijos universiteto ir Norvegijos mokslo ir technologijų universiteto bibliotekas. Komplektavimo skyriaus vedejja $S$. Urbonavičiene lankèsi Frankfurto knygu mugèje. Užmegzti nauji kontaktai, pasisemta patirties.

Biblioteka nuolat rengia leidinių, temines parodas ir kt.

$2002 \mathrm{~m}$. leidykla „Technika“ suredagavo ir išleido 9 monografijas, 6 mokslo darbus ir leidinių serijas, 19 konferencijų medžiagu rinkinių, 2 vadovèlius, 51 mokomąji metodinį leidinị ir kt.

Metų pabaigoje geriausiu VGTU sportininku buvo išrinktas Valerijus Petrulievičius, $400 \mathrm{~m}$ bègimo Lietuvos čempionas, Elektronikos fakulteto III kurso studentas.

Jau pirmąji Naujujjų 2003 metų šeštadieni Vilniaus Gedimino technikos universitete vyko atvirų durų dienos renginiai. Universiteto vadovai - rektorius R. Ginevičius, studiju prorektorius A. Daniūnas, Prièmimo komisijos atsakingasis sekretorius R. Kliukas - pasakojo gausiai susirinkusiems iš visos Lietuvos moksleiviams apie VGTU, apie studijų jame ypatumus, isstojimo tvarką, galimus pasikeitimus prièmimo ị aukštąją mokyklą taisyklese.

Atviru durų dienos Nepriklausomybès metais Vilniaus Gedimino technikos universitete labai populiarios. Susidomëjimas

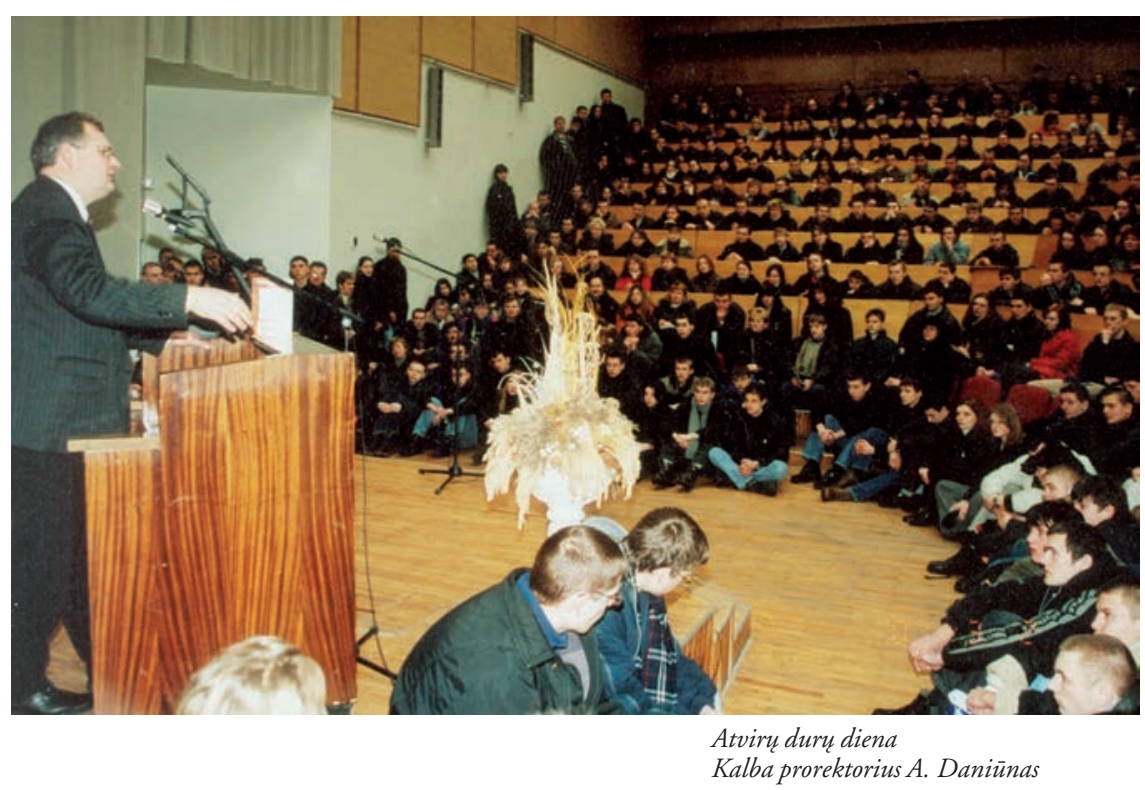

studijomis VGTU nuo 1995 m. nuolat augo. Atvirų durų dienomis ị Didžiąją auditoriją, turinčią apie 250 sedimų vietų, susirenka per 500 ir daugiau žmonių. Jaunimas aplanko mokymo bei mokslo laboratorijas, lankosi universiteto fakultetuose ir institutuose, kur suteikiama detalesnè informacija apie specialybes, specializacijas, įsidarbinimo baigus studijas galimybes.

Iškilmingai buvo paminetas Darbo ir gaisrines saugos katedros dešimtmetis.

VGTU rektorius prof. Romualdas Ginevičius sake, jog tai sektinas pavyzdys kitiems universiteto padaliniams, kaip ryšius su darbdaviais panaudoti studijų materialinei bazei turtinti, studentų mokomosioms gamybinems praktikoms organizuoti. Už nuolatinị rūpestį ir pagalbą rengiant gaisrinès saugos specialistus universitetas medaliu „Už nuopelnus Vilniaus Gedimino technikos universitetui“" apdovanojo departamento direktorių, VGTU garbès narị Kazį Zuloną, o departamento darbuotojus Remigijų Baniulį, Giedrių Bagdoną, Mečislovą Griškevičių, Gintarą Paulauską, Vladimirą Suslavičių - padèkos raštais, universiteto vardinemis juostomis.

Ilgametis Darbo ir gaisrinès saugos katedros vedejjas prof. Petras Čyras, gaisrinès saugos specialistu rengimo pradininkas, pagarbiai vadinamas Tèvu. Jo indèlis ị gaisrinę saugą dešimtmečio proga ịvertintas valstybinès priešgaisrinès gelbëjimo tarnybos pasižymëjimo ženklu „Ugniagesio gelbètojo žvaigždè". Vidaus reikalų ministerijos pirmojo laipsnio atminimo ženklu „Tèvynès labui“ apdovanoti Statybinių medžiagų katedros vedejas prof. Romualdas Mačiulaitis bei Darbo ir gaisriness saugos katedros vedejas doc. Ritoldas Šukys. 
VILNIAUS

GEDIMINO

TECHNIKOS

UNIVERSITETAS

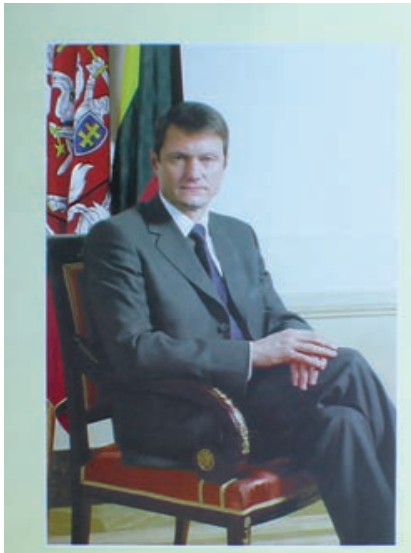

ROLANDAS PAKSAS
Sukakčiai skirtose iškilmèse prisiminta katedros istorija, džiaugtasi mokslo bei kasdienés veiklos laimejjimais, kartu aptarti ir aktualūs darbo, specialistų rengimo gerinimo klausimai. İdomių minčių apie tai išsake pirmasis prorektorius prof. Edmundas Kazimieras Zavadskas, Priešgaisrinès apsaugos ir gelbejjimo departamento direktorius Kazys Zulonas, departamento direktoriaus pavaduotojas Remigijus Baniulis, Ugniagesiu rengimo centro vadovas Mečislovas Griškevičius, pirmosios laidos absolventas majoras Valdas Krulikauskas ir kiti [6.27, p. 3].

Sausio 13 d. Vilniaus Gedimino technikos universiteto bendruomene pagerbè tos tragiškos dienos aukų atminimą. Prie Rolando Jankausko memorialinès lentos Centriniuose rūmuose ir jo kapo buvo padèta gyvu gèlių, degè žvakutès.

\section{Istatymu privalo laikytis visi vadovai}

Nepriklausomos Lietuvos septintuoju prezidentu buvo išrinktas mūsų mokyklos absolventas statybos inžinierius Rolandas Paksas. Ta proga ji pasveikino VGTU rektorius R. Ginevičius ir Senato pirmininkas D. Čygas. Palinkejjo, kad būtų sulaukta krašto gerovès kilimo, brandžios santarves, kad gerètų žmonių socialinè padètis, kad Prezidentas skirtų daug demesio mokslo ir studijuc pletrai.

Buvo neslepiamas VGTU bendruomenès didžiavimasis, kad universiteto absolventas R. Paksas tapo Lietuvos Respublikos Prezidentu. Deja, žmonés ne visada tokie, kokie atrodo. Tas pasididžiavimo jausmas dingo, kai paaiškèjo, kad R. Paksas pažeide įstatymus ir kilo skandalas, pasibaigęs apkalta. Buvęs du kartus Vilniaus miesto meru, du kartus Ministru Pirmininku ir metus laiko Prezidentu, Rolandas Paksas, kai paaiškejjo dorove ir îstatymais neparemti veiksmai, buvo atstatydintas iš Prezidento pareigų ir apleido šalies politinị elitą.

Rašytojas H. Balzakas yra rašęs: „Tiesa panaši i kartu gerima, nemalonaus skonio, bet ǔ̌tat gražinanti sveikata" " $[6.28$, p. 84].

Sausio mènesį leidykla „Technika“ išleido A. Nako ir J. Norkevičiaus knygą „Bičiulystès puslapiai“. Kiek vèliau, pri- statydamas šią knygą skaitytojams, doc. Marijonas Šukšta raše:

„Nuo universiteto véliavos pašventinimo užsimezge ryšiai su monsinjoru atneše mums labai daug džingiu ir šviesiu akimirku. Monsinjoras Kazimieras Vasiliauskas tapo visu žymesniu universiteto ivvykiu dalyviu. Knygoje tai labai detaliai ir kruop̌šciai aprašyta. Bet tai ne didžiausia šios knygos verté. Svariausia, mano manymu, ne chronologija ir susitikimo detales, bet monsinjoro mintys, išsakytos šiu susitikimu metu. Jas verta paskaityti tiek jaunam, dar gyvenimo patyrimo neturinčiam studentui, tiek gyvenimo patirties turtingiems technikos moksly atstovams. Savo mintimis monsinjoras, neneigdamas technikos revoliucijos svarbos ir privalumu, mus ispeja apie piktnaudžiavima. jos vaisiais, apie dvasios sudaiktejima, apie atsitraukima nuo dvasiniu dalyku, apie nemokejima džiangtis ir myleti. Jo mintys - tai ne ikyrūs pamokslavimai ar seniokiški pabambëjimai. Tai greičiau problemiško mūsu technikos amžiaus esé.

Knygoje labai išryškinti monsinjoro ispejjimai apie pavojus, kurie atsiranda sumaterialejusiame gyvenime. Autoriams pavyko atskleisti harmoninga šio žmogaus požiüri z sudètingas šiuolaikinio technizuoto pasaulio problemas, atskleisti jo humanistiniu isitikinimužavesi, jo begaline meile ir pasiaukojima žmonems.

Knyga labai svarbi ir kitu požiūriu. Tai tam tikra prasme ir istorinis jauno universiteto metraštis. Istorija yra vertybe, kuria reikia saugoti ir puoseleti. Autoriams tai pavyko " [6.29, p. 3].

Nacionalinis akreditacijos biuras VGTU Geodezijos instituto kalibravimo laboratorijai išdave dokumentą, kad laboratorija atitinka Lietuvos bei tarptautinius standartus, kad ji gali daryti elektroninių tolimačių kalibravimą. Tai labai svarbus laimëjimas, leidęs toliau pletoti VGTU geodezininkų mokslo ir praktikos darbus.

Universiteto bendruomenei ypač malonu, kai VGTU absolventai nepamiršta savosios Alma Mater, ja didžiuojasi, ją remia. Vienas tokiu absolventu - bendrovès „AGA“ direktorius dr. Gintaris Aksamitas. Baigiantis sausiui jis vel apsilanke universitete ir padovanojo Architektūros, Aplinkos inžinerijos, Mechanikos ir Statybos fakultetams bei Antano Gustaičio aviacijos institutui daug komplektų įvairios kompiuterių programinès įrangos. „AGA“ bendrovei igyvendinti dovanojimo akciją padejo užsienio kompanijos, kurioms „AGA“ atstovauja mūsų šalyje. 
Stiprejo ir glaudūs VGTU ryšiai su užsieniu, buvo pasirašomos bendradarbiavimo sutartys, keičiamasi vizitais, mokslo laimëjimais, dalyvaujama vieni kitų moksliniuose seminaruose ar konferencijose. Sausio menesi

\section{Gimtoji kalba - valstybingumo požymis}

Vasario 11 d. VGTU Petro Vileišio auditorijoje buvo iškilmingai paminèta Vasario 16-oji. Rektorius R. Ginevičius kalbëjo, kad prieš 85 -erius metus atkūrus Lietuvos valstybę, tuometiné ekonominè socialine situacija buvo daug kuo panaši i į šių dienų. Rektorius piktinosi, kad pastebimas siekis iš mokslo kalbos išguiti lietuvišką žodi, keičiant jị anglišku. Jis sakè, kad dr. Jonas Basanavičius, Lietuvos nepriklausomybès patriarchas, teige, kad gimtoji kalba yra vienas iš valstybingumo įvertinimo požymių. Čia galima pažymèti, kad, anot Arvydo Juozaičio, kosmopolitizmas, globalizacija kelia dideli pavojų tautos išlikimui. Nereaguoti ị tai būtų neatsakinga. Tai, kad universiteto vadovas šiuo klausimu išreiškè nepasitenkinimą - jau geras ženklas, jis teikia vilčių, kad mūsų universitete lietuvių kalba bus gerbiama ir puoselëjama.

Dalyvavęs minëjime svečias - Kovo 11osios akto signataras Gediminas Ilgūnas rektoriaus R. Ginevičiaus buvo pagirtas už tai, kad jis, būdamas LRS komiteto pirmininku, remė idëją pertvarkyti institutą $i$ universitetą, padejjo parengti Statutą.

"Kiekviena epocha, kiekviena tauta turi žmoniu, kurie ypatinga reži irežzia savo krašto gyvenime ", - pabrèže renginio svečias. Šitaip jis iqvardijo ir Vasario 16-osios signatarus, iš jų išskirdamas inžinierių Steponą Kairį, kuris visą laiką liko ištikimas savo įsitikinimams, politinèms pažiūroms.

Gediminas Ilgūnas priminè, kad nepriklausomos Lietuvos ideją pirmasis viešai išsake $1863 \mathrm{~m}$. sukilimo vadas Antanas Mackevičius. Išsamiai apžvelgè nueitą kelią iki Vasario 16-osios akto, apie kilusius nesutarimus Lietuvos Taryboje. Ypač akcentavo Stepono Kairio ir jo bendraminčių Stanislovo Narutavičiaus, Jono Vileišio, Mykolo Biržiškos vaidmeni, kad paskelbta Lietuvos nepriklausomybè nebūtų saistoma jokiais ryšiais su užsienio valstybèmis.

Rektoriaus ir svečio kalbas palydejo studentès Ievos Džervutes padeklamuotos buvo pasirašyta bendradarbiavimo sutartis su Niurtingeno (Vokietija) aukštąja mokykla, kurioje įsipareigota bendradarbiauti ir vykdyti mainus mokslo, studijų ir informacinese srityse.

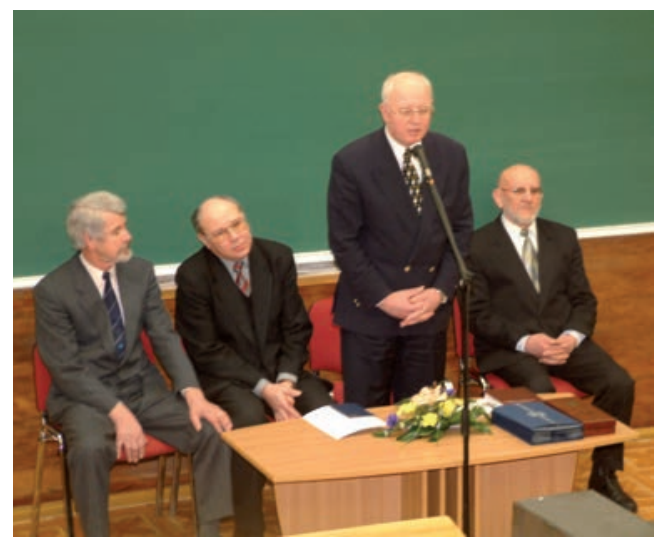

Justino Marcinkevičiaus eilès apie tèvynę, tautinių šokių ansamblio „Vingis“ kapelos vadovo Antano Jonušo pagrota Maironio „Lietuva brangi“ melodija. Solistai Česlovas Nauseda, Pranas Zaremba, Antano Jonušo birbynei pritariant, padainavo tris lietuvių liaudies dainas. Dainininkai susirinkusiuosius kviete jiems pritarti, ir siūlymas buvo išgirstas [6.30, p. 3].

Vasario ménesį įvyko dar vienas reikšmingas renginys - parodų centre LITEXPO vykusi tarptautine aukštojo mokslo ir profesinio mokymo paroda „Studijos-2003“. Šioje parodoje VGTU fakultetai ir institutai pristate daug medžiagos apie studijų programas, absolventų įsidarbinimą, studentų laisvalaikį. VGTU ekspoziciją apžiūrejjo šalies vadovas V. Adamkus, Seimo Pirmininkas A. Paulauskas, premjeras A. Brazauskas ir kt.

Kompiuterizacija VGTU jau seniai tapo visuotine VGTU mokslo tyrimuose, studijose. Žengia ji ir į kitas sritis. Tautinių šokių ansamblio „Vingis“ šokejjas Andrius Marma parengè kompaktinị diską apie ansamblio istoriją, o akademinis choras „Gabija“ $i$ CD įraše geriausias visų laikų dainas.

Vasarị pasikeite Studentų atstovybès vadovas. Vietoj buvusio SA prezidento Pauliaus Daščioro buvo išrinkta Kristina Mečinskaitè.
Minëjimo metu (iš kairess):

V. Stragys, E. K. Zavadskas, R. Ginevičius, G. Ilgūnas 


\section{VILNIAUS}

GEDIMINO

TECHNIKOS

UNIVERSITETAS

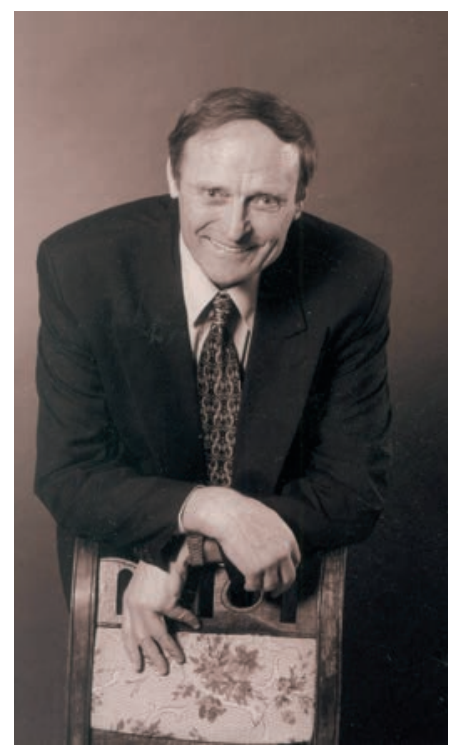

V. Stauskis

\section{Dar dvi mokslo premijos}

Puikų mokslinį laimëjimą pasiekè VGTU atstovas V. Stauskis. Jam buvo paskirta 2002 metų Lietuvos mokslo premija. Taip įvertintas prof. habil. dr. Vytauto Stauskio darbų ciklas „Salių akustikos tyrimai, inžineriniai sprendimai ir jų realizavimas (1977-2001 m.) “.

Mokslinè V. Stauskio veikla skirta žiūrovų salių akustinių savybių, konstrukcijų, garso izoliacijos, transporto triukšmo mažinimo tyrimams. Šiuos klausimus laureatas nagrinejo ir daktaro disertacijoje, ir habilitaciniame darbe.

Prof. Vytautas Stauskis pamegta tema paraše per 130 moksliniu straipsnių, dvi monografijas (viena iš jų anglų kalba). Yra septynių architektūrines akustikos srities išradimų bei vadovèlio „Architektūrine akustika“ autorius. Jis - Lietuvos akustiku asociacijos Architektūrines akustikos skyriaus pirmininkas, Tarptautinio akustikos ir vibracijos instituto bei Prancūzijos akustikų asociacijos užsienio narys.

Lietuvos mokslu akademijos tikrajam nariui VGTU Chemijos ir bioinžinerijos katedros vedejjui prof. Juozui Kuliui mokslo premija paskirta (kartu su kitais) už darbų ciklą „Ksenobiotikų oksidacinès-redukcinès transformacijos ir citotoksiškumo mechanizmų tyrimai 1988-2001 matais"

Ne mažesnis dèmesys nei mokslui Vilniaus Gedimino technikos universitete skiriamas ir studijoms. Studijų prorektorius A. Daniūnas universiteto laikraštyje kreipèsi į abiturientus, kviesdamas studijuoti VGTU, ir apžvelge rengiamų specialistų poreikį šalyje. Jis raše:

„Mano manymu, dažnai užmirštame ar tiesiog per mažai skiriame demesio pamastymams, ka veiksime baigestudijas, ar rasime kur pritaikyti žinias, igytas universitete, ar gausime darba pagal savo kvalifikacija. Štai kodèl pačioje pradžioje atkreipiau demesi z jkelbimus. Jie labai gerai charakterizuoja, kokiu specialistu reikia Lietuvoje. Žinant, kad ekonomikos lygis müsu šalyje kils, minètu specialistu poreikis tikrai dides. Taigi jaunieji kolegos dar karta permastykite, sudekkite visus už ir prieš ir apsispreskite. Nuoširdžiai linkiu, kad jūsu pasirinkimas būtu teisingas ir atneštu jums ateityje sekmę. Jei pasirinksite studijas Vilniaus Gedimino technikos universitete, manau, neapsiriksite.

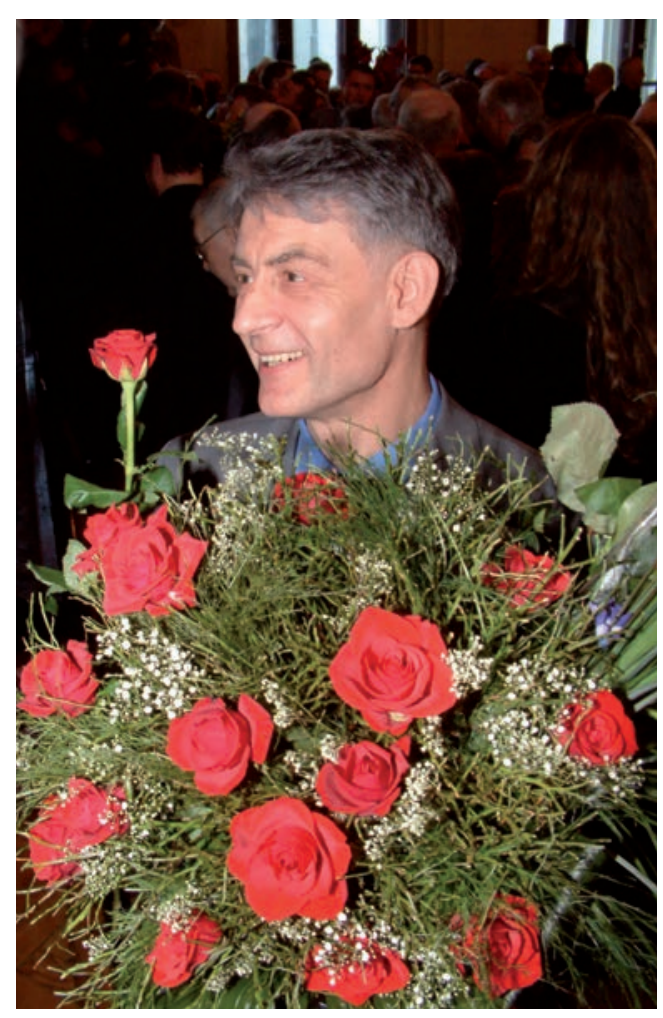

Baigusieji universiteta turety tureti sias savybes: tureti pakankamai atitinkamos srities žiniu; gebeti dirbti komandoje, grupeje; greitai prisitaikyti prie aplinkos pokyčiu, mokèti generuoti idejas, moketi spręsti ne tik teorines problemas, bet ir pritaikyti žinias praktikoje. Ar tenkina müsu universitete organizuojamos studijos šiuos reikalavimus? Manome, kad taip. Mūsu absolventai turi pakankamai žiniu, jie yra iniciatyvuss, geba prisitaikyti prie aplinkos, greitai igyja pasitikejima darbe, ganai greitai kyla karjeros laiptais " $[6.31$, p. 1,3$]$.

Dar labiau sustiprejjo VGTU Skaičiavimo centras. Lygiagrečiųjų skaičiavimų laboratorija kovo pabaigoje surenge naujojo asmeninių kompiuterių klasterio „VILKAS“ pristatymą.

2003 m. tai buvo galingiausias Lietuvoje lygiagretusis kompiuteris. Asmeniniu kompiuteriu klasteris „VILKAS“ - tai 10 dviprocesiniu SMP technologijos Intel architektūros asmeninių kompiuterių, sujungtų i lokalų tinklą, naudojant Ethernet duomenų perdavimo technologiją, bei valdomų specializuota programine įranga.

Klasterio pristatyme išsakytas noras plètoti lygiagrečiuosius skaičiavimus Lietuvoje, skatinti naujų specialistų rengimą bei steigti Lygiagrečiųjų skaičiavimų asociaciją, kuri jungtų universitetų ir mokslo institucijų šios srities specialistus.

Pavasari, kaip jau tapo tradicija, vyko VGTU „Karjeros diena“. Joje dalyvavo 
38 įmonès ir organizacijos. Renginiu labai domejosi ir visų fakultetų studentai, kurie norëjo sužinoti darbdavių reikalavimus jauniems specialistams, darbo ir kitas sąlygas.

Balandi gera žinia atejo iš Lenkijos. Visos Lenkijos Lietuvos bičiulių klubo visuotinis susirinkimas Garbès nariu išrinko prof. E. K. Zavadską už siekius humanizuoti techniką, ugdyti visapusiškai išsilavinusius specialistus.

Pasižymejo ir VGTU jaunieji mokslininkai. Lietuvos mokslų akademija už geriausius $2002 \mathrm{~m}$. jaunųjų mokslininkų darbus premijavo kai kurių universitetu jaunuosius mokslininkus, tarp jų ir VGTU Tiltų ir specialiųjų statinių katedros dr. Darių Bačinską. Du kiti - M. Samofolovas ir T. Rekašius apdovanoti Pagyrimo raštais. Dr. Dariaus Bačinsko premijuotas darbas - „Lenkiamy gelžbetoninių elementų ilgalaikio deformavimo integralinis modelis “.

Balandžio 26-oji - Pasaulinès intelektines nuosavybès diena. Ši diena $2003 \mathrm{~m}$. buvo paminèta iškilmingai. Tai padaryta todèl, kad aukštai ịvertinti VGTU išradejjų darbai. Už intelektinés veiklos plettrą, už patentuotu išradimu gausą Pasaulinè intelektinès nuosavybès organizacija mūsų universitetą apdovanojo diplomu. Ši garbų apdovanojimą rektoriui prof. Romualdui Ginevičiui įteike mūsų šalies atstovas minètoje organizacijoje Rimvydas Naujokas.

Gegužès pradžioje pirmojo laipsnio diplomą $V$ tarptautiniame vaikų ir jaunimo chorų festivalyje-konkurse jaunimo choru kategorijoje „Gabija“ laimëjo pirmojo laipsnio diplomą. Vadovaujamas meno vadoves Rasos Viskantaites VGTU mišrus choras „Gabija“ ryškiai tobulejo ir buvo galima tiketis dar didesnių laimejimų.

Vis daugiau gražiu rezultatų dave tarptautinis bendradarbiavimas. Užsienio mokslininkų, daugiausia nuveikusių padedant VGTU jauniesiems mokslininkams siekti mokslo aukštumų, veikla buvo įvertinta VGTU senato.

Gegužès 16 d. iškilmingame Senato posedyje buvo įteiktos VGTU Garbès daktaro regalijos Napiero universiteto (Škotija) profesoriui Brianui Sloanui ir Baltarusijos nacionalinio technikos universiteto profesoriui Ivanui Leonovičiui. B. Sloanas gražiai ir abipusiškai naudingai bendradarbiauja su Statybos technologijos ir vadybos bei Statybos ekonomikos ir nekilnojamojo turto katedromis, o I. Leonovičius - su Kelių katedra.

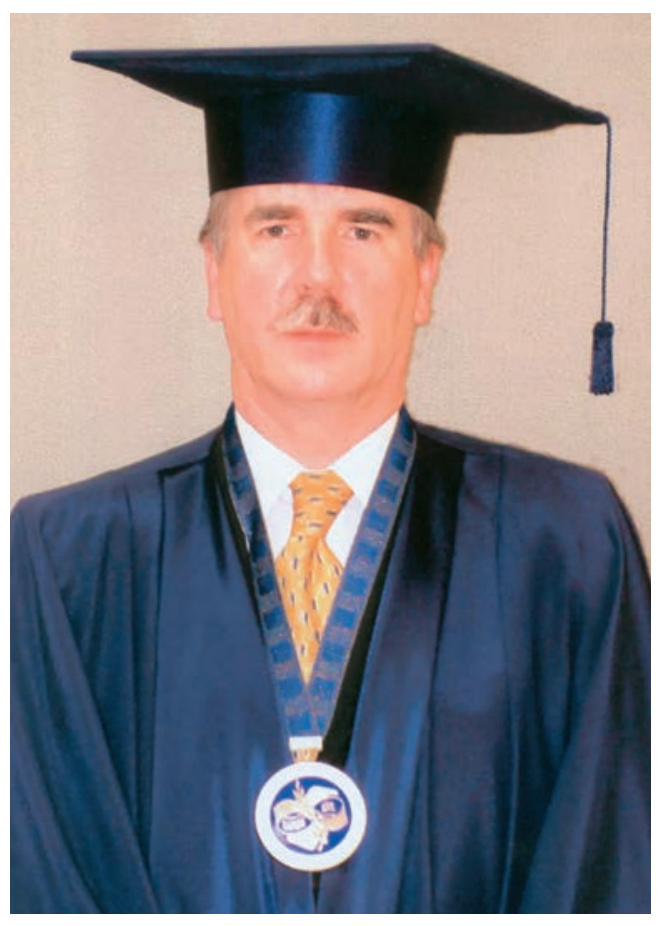

B. Sloanas

VGTU Garbes daktaras

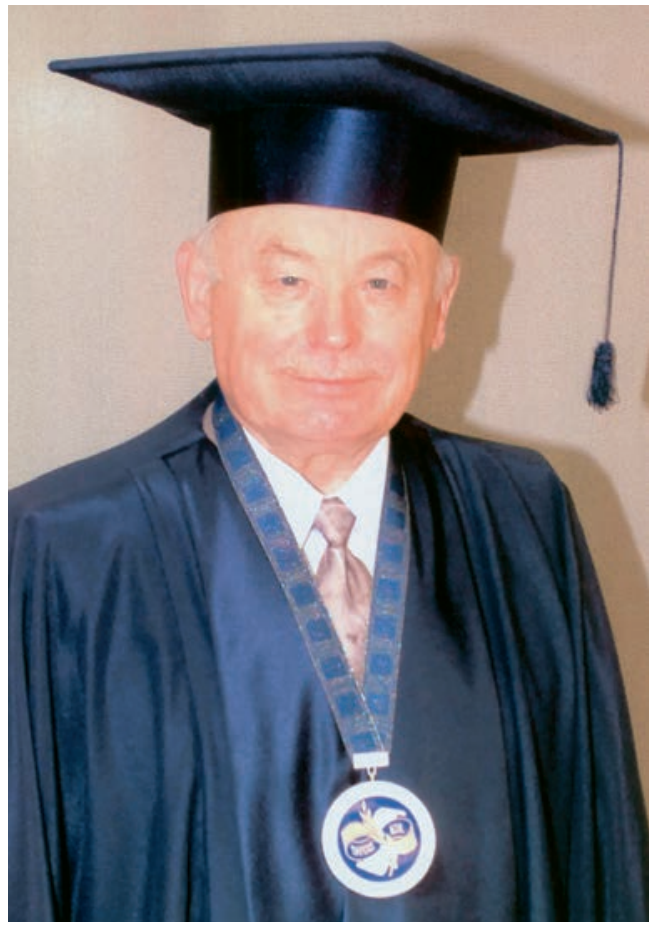

I. Leonovičius

VGTU Garbes daktaras
2003 m. gegužę gražiai buvo pagerbtas užsienyje ir VGTU atstovas. Varšuvos technologijos universiteto Statybos fakulteto tarybos posedyje VGTU Statybos fakulteto dekanui prof. dr. Povilui Vainiūnui buvo įteiktos Varšuvos technologijos universiteto Garbes profesoriaus regalijos.

Garbes profesoriaus vardu įvertinta ne tik moksline, pedagogine, bet ir aktyvi visuomenine prof. Povilo Vainiūno veikla. Jis - nuolatinès tarptautinès konferencijos „Naujos statybines medžiagos, konstrukcijos ir technologijos "bei tarptautinių simpoziumų statybos specialistų rengimo klausimais mokslinio 


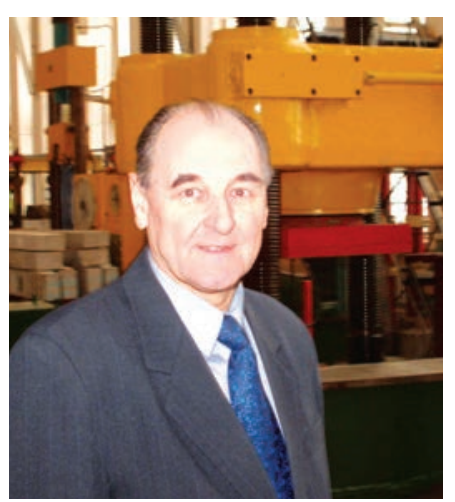

P. Vainiūnas

POLITECHNIKA WARSZAWSKA

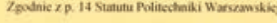

Prof, dr n.t. Povilas Vainiunas

HONOROWEGO PROFESORA Wyddialu Indyaierī Ladowej
Politechniki Warscawshiej

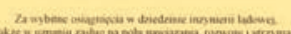

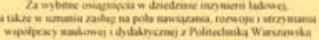

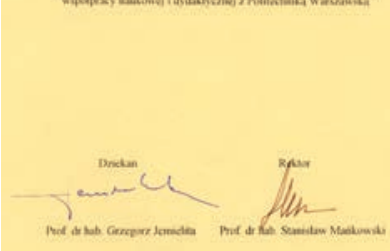

Su J. Kairiu VGTU Žiniasklaidos ir renginiu direkcijos darbuotojos

gis Kairys. Skraide ir VGTU AGAI absolventai, buvo demonstruojamas radijo bangomis valdomas lekktuvo modelis.

Kasmet birželio mènesị Vilniaus Gedi-

komiteto pirmininkas ir narys, Europos šaliu Statybos fakultetu asociacijos tarybos narys, Tarptautines tiltų ir pastatų statybos asociacijos individualus narys, taip pat Statybos fakulteto kaip kolektyvinio nario atstovas, šios asociacijos Lietuvos grupes pirmininkas, Lietuvos centrinés statinio projekto, statinio projekto vykdymo priežiūros ir statinio projekto bei statinio ekspertizes vadovu profesinių žinių patikrinimo komisijos pirmininkas, Lietuvos statybininku asociacijos prezidiumo narys. Profesorius yra aktyvus ir mūsų universiteto Tarybos, Senato narys.

Pasižymejo ir mūsų sportininkai. Kaune vykusiose SELL žaidynèse SNTV-0 gr. studentas Aistis Šlajus tapo teniso varžybų čempionu.

Gegužès 23 d. Antano Gustaičio aviacijos institutas iškilmingai paminëjo savo veiklos 10-metị. Kyviškių aerodrome instituto darbuotojus, universiteto vadovus sveikino $\mathrm{Su}-$ sisiekimo ministerijos, aviacijos įmonių, karo oro pajėgu atstovai, instituto remëjai ir kt. Skraide karinių oro pajègu lèktuvai bei kuri laiką studijavęs mūsų mokykloje geriausias pasaulio akrobatinio skraidymo lakūnas Jur- mino technikos universitete labai gyva ir šventiška. Diplomų įteikimas - ypač įsimintina diena kiekvieno studento gyvenime. $T a ̨$ dieną pasveikinti gaunantị universiteto diplomą ateina tevai, broliai, seserys, uošviai, bičiuliai, o dažnai - ir vaikai ant mamos ar tèvelio rankų. Tai viena reikšmingiausių švenčių universitete. Šurmulys kyla visuose universiteto rūmuose. Dažniausiai diplomų itteikti atvyksta ir šalies vadovai, ministrai, parlamentarai.

2003 metų derlius - 2338 Vilniaus Gedimino technikos universiteto parengti specialistai. Pagrindines studijas baige 1474 , magistrantūros -838 ir specialiąsias profesines - 26 žmonés. Per visą aukštosios technikos mokyklos Vilniuje gyvavimo laiką buvo parengta per 28000 specialistu.

Vasarą sèkmingai buvo suformuotas naujas pirmakursių kontingentas. Iš viso priimti studijuoti 4198 jaunuoliai ir merginos: ị pagrindines studijas - 2970 , i magistrantūros studijas - 1194 ir ì specialiąsias profesines studijas -34 .

2003-2004 mokslo metų pradžioje Vilniaus Gedimino technikos universitetas

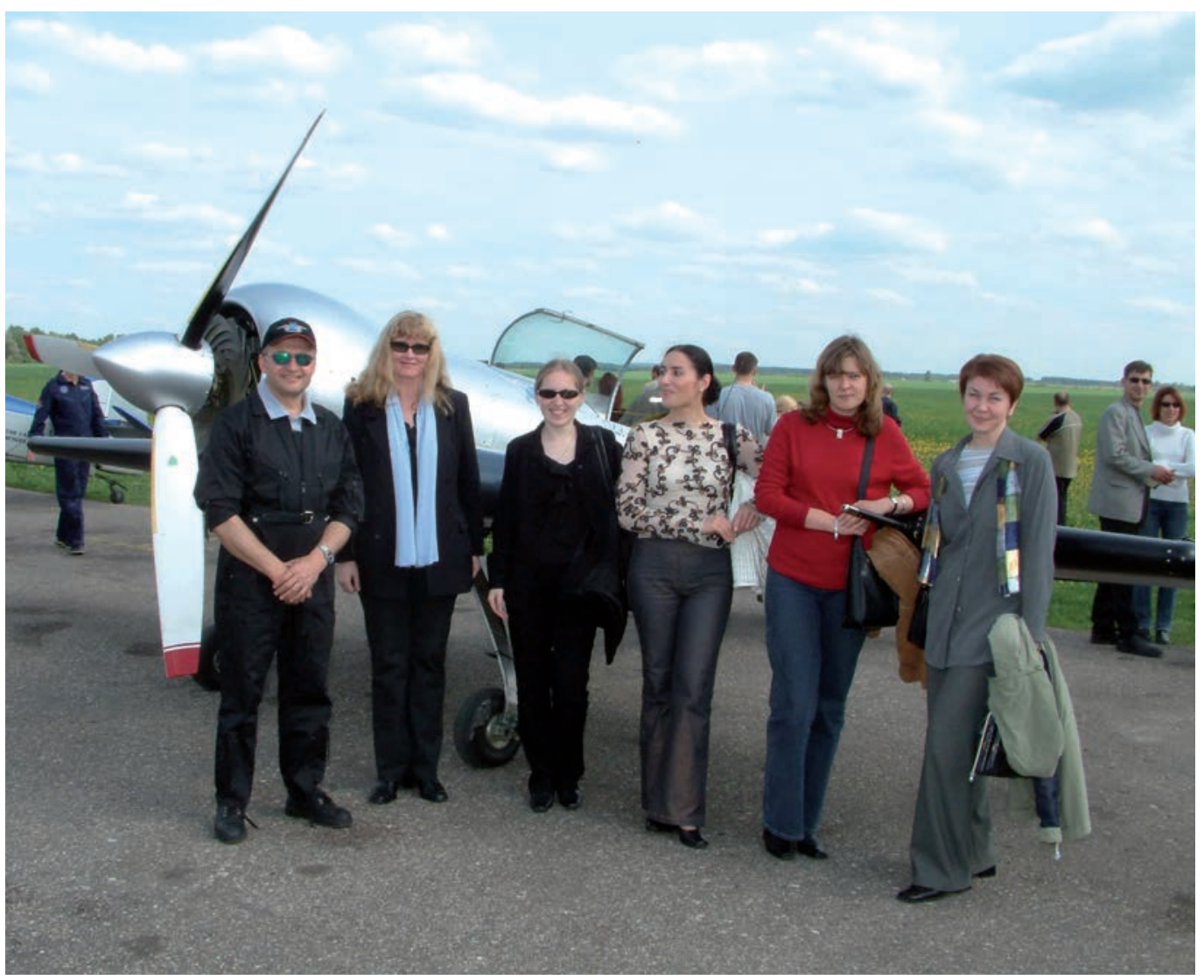


turejo 12798 studentus: lietuvių - 72,3 proc., lenku ir rusų - po 6,2 proc., kitu tautybiu - 15,4 proc. Universitetas toliau moteriškejjo, bet liko vyriškas: vyrų buvo 8333 , o moteru - 4465.

Rugsèjo 1-ąją prie VGTU Sauletekio rūmų įvyko pirmakursių imatrikuliacija. Studentus, profesūrą, visus universiteto darbuotojus mokslo metu pradžios proga sveikino universiteto rektorius prof. habil. dr. Romualdas Ginevičius. Jis primine, kad universitetinemis studijomis baigiasi pirmasis žmogaus gyvenimo etapas. Jis yra esminis kitiems dviem, nes nuo to, kaip bus jiems pasiruošta, taip bus žengiama toliau - arba ìdomiai, prasmingai, turiningai, solidžiai, arba pilkai, neįdomiai, su nuolatiniais nepritekliais.

Piramidès viršūnëje lieka geresni, ištvermingesni, grimzta tie, kurie tokiai kovai nepasiruošę, neapsiginklavę. Jaunų žmonių ginklai šioje kovoje - gilios žinios, išskirtiniai gebejimai, tam tikros būdo savybès. Tai galima igyti tik ilgai, įtemptai ir sistemingai dirbant. Nepaprastai augant gyvenimo tempui ir informacijos kiekiui, didžiausiu deficitu tampa laikas. Tik prasmingai ir efektyviai ji naudojant galima neatsidurti gyvenimo šalikelëje. Studijų metai būtent ir skirti sukurti žinių ir savybių, būtinų sèkmingai tolesnei veiklai, potencialą.

Nuo rugsejo $1 \mathrm{~d}$. pradejo veikti VGTU Humanitarinis institutas. Šio padalinio nuostatuose pasakyta, kad instituto tikslas - diegti ir puoseleti humanistines vertybes, sudaryti sąlygas universitete pletotis humanitarinei kultūrai rengiant techninio ir kito profilio specialistus. Sito sieks Filosofijos ir politologijos, Kūno kultūros, Lietuvių kalbos, Užsienio kalbų katedrų, Edukologinių tyrimų, Estetinio ugdymo, Kalbu mokymo centru, Kompiuterines lingvistikos laboratorijos, Sporto, Turizmo klubų, meno kolektyvu bendruomenès. Kasdienos veikla jos sieks didinti humanitarinių, socialinių dalykų įtaką studento asmenybei, jo pilietiškumui ugdyti, skiepyti meilę savo kraštui, skatinti rūpesti savo sveikata kaip vertybe. Taip pat svarbus instituto uždavinys - formuoti etinę, estetinę, meninę kalbos bei kūno kultūrą. Pagal savo kompetenciją instituto padaliniai prisidès prie bakalaurų, specializuotų profesinių, magistrų ir doktorantų studiju, rengs, siūlys humanitarinių, socialinių studiju modulius. Katedrų darbuotojai, jų kolektyvai vykdys humanitarinių, socialinių mokslų srities fun- damentinius ir taikomuosius mokslo tyrimus. Jiems apibendrinti ir paskleisti organizuos mokslininkų susirinkimus, respublikines bei tarptautines konferencijas, seminarus, pasitarimus. Institutas leis mokslinę literatūrą, humanitarinio profilio žurnalą. Jo mokslininkai rengs vadovelius, metodines ir kitas mokomąsias priemones. Nuostatai leidžia institutui nustatyta tvarka siūlyti suteikti humanitarines ir socialines srities pedagoginius vardus, ịpareigoja aktyviai prisidetti ir visokeriopai padeti organizuoti studentu, viso universiteto bendruomenés renginius.

Naujam padaliniui patiketa vadovauti prof. habil. dr. Povilui Tamošauskui.

Architektūros fakulteto dekanu pradejjo dirbti fakulteto dekano rinkimus fakulteto Tarybos posedyje laimëjęs prof. dr. Rimantas Buivydas, žinomas architektūros teoretikas, turintis nemažą administracinio darbo patyrimą.

Elektronikos fakultetas vèl džiaugèsi studentais. Fakultetui buvo perduotas puikiai įrengtas dar vienas (ketvirtas) aukštas. Jame irengtos auditorijos, laboratorijos, darbo kabinetai.

Geros žinios rugsëjy gautos iš Rusijos. Profesoriui E. K. Zavadskui Garbès daktaro vardą informatikos srityje suteike Rusijos valstybinis A. Gerceno pedagoginis universitetas, o profesoriui P. Baltrenui Garbès daktaro vardą suteikè Sankt Peterburgo valstybines miško technines akademijos mokslo taryba.

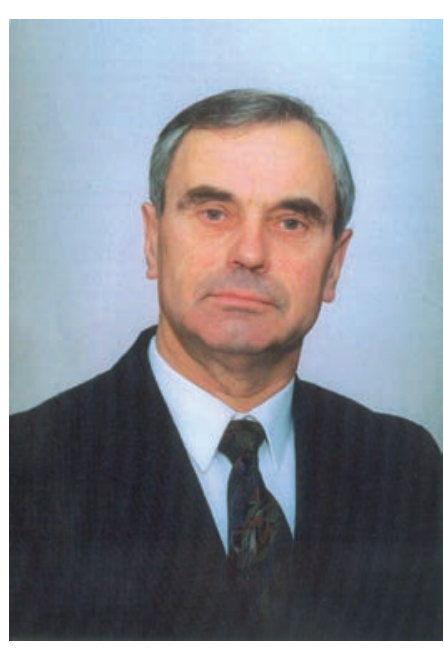

P. Tamošauskas

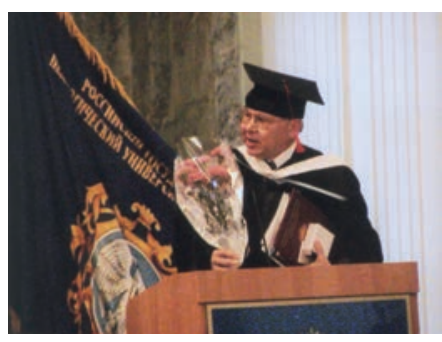

E. K. Zavadskas - Peterburgo A. Gerceno universiteto Garbes daktaras

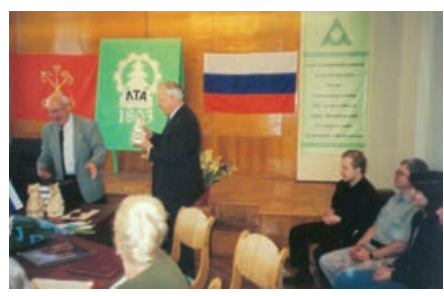

P. Baltrenas - Peterburgo miško akademijos Garbes daktaras

Kasmiet VGTU vyksta „Karjeros dienos“

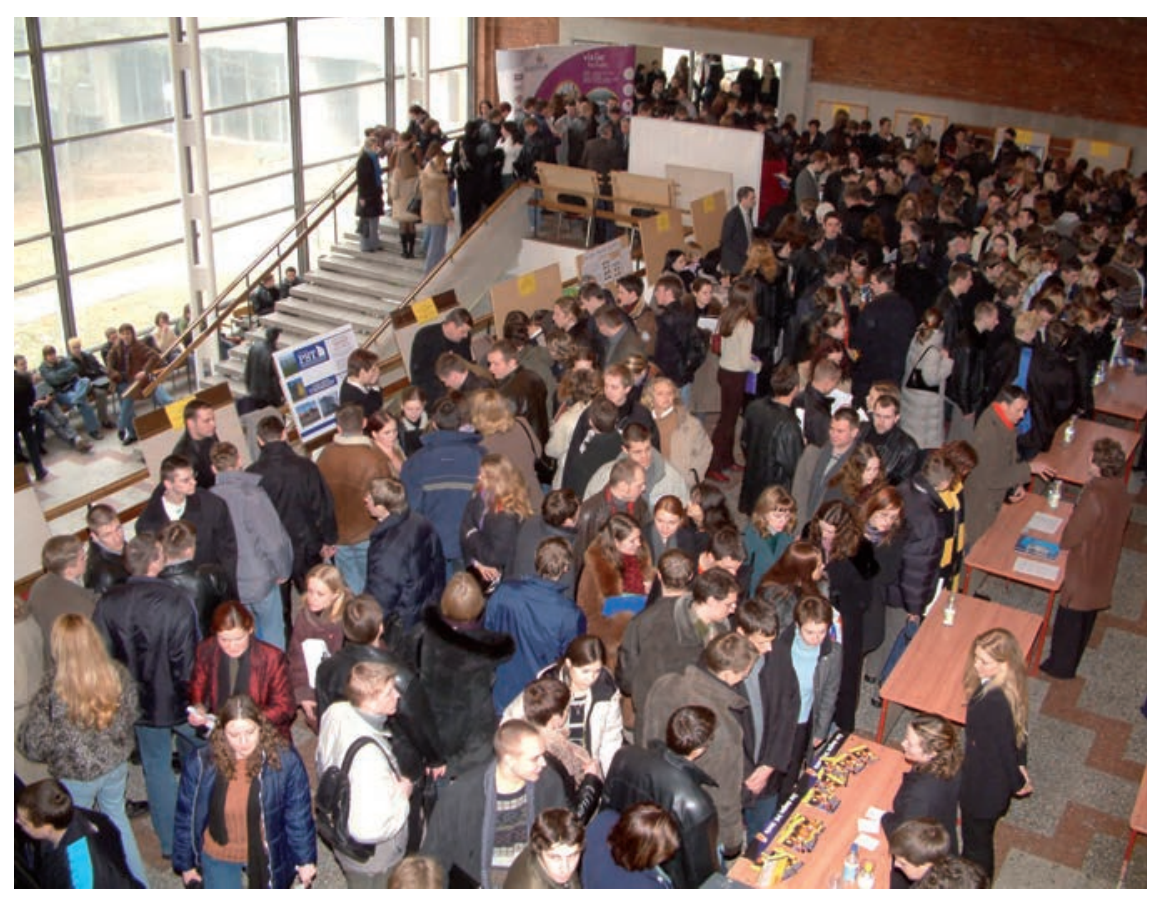


VILNIAUS

GEDIMINO

TECHNIKOS

UNIVERSITETAS

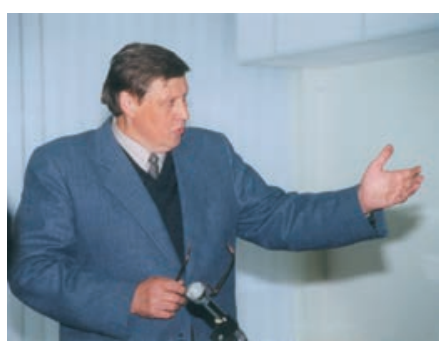

J. Atkočiūnas
VGTU mokslininkus aukštai įvertino Valstybinè atominès energetikos saugos inspekcija, davusi mūsų universitetui licenciją, kuria suteikiama teise Lietuvos Respublikos branduolinès energetikos srityje vykdyti mokslinius, technologinius tyrimus ir saugos įvertinimus.

VGTU senatas pritare ketinimui ịsteigti prie Architektūros fakulteto Meninio ugdymo centrą.

Tradiciškai vyko Gedimino universiteto dienos. Katedros aikšteje įspūdingą koncertą surengè „Gabijos“ choras, atlikęs odę Vilniui ir jo ịkūrèjui.

Rugsëjo ménesį VGTU vykusioje Lietuvos mokslo istorikų konferencijoje buvo paminètas lietuvio gelžbetoninių konstrukcijų mokslinių tyrimų Lietuvoje pradininko, pir-

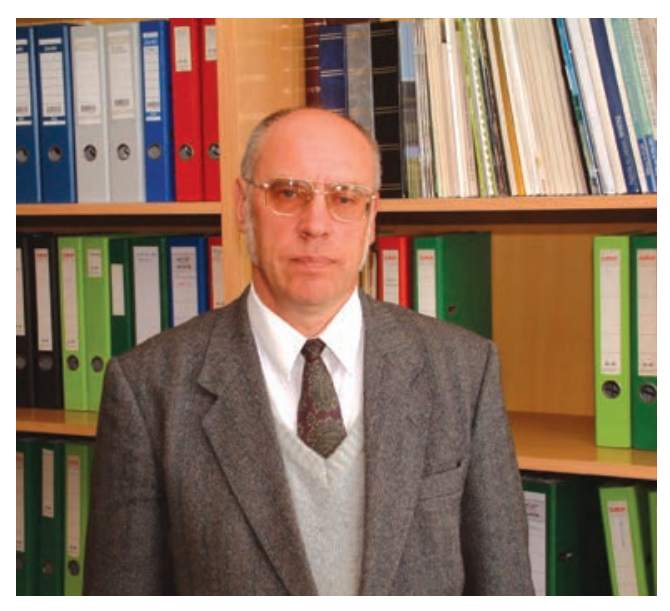

R. Buivydas

mosios gelžbetonio mokslo disertacijos autoriaus Jono Kuodžio gimimo 100-osios metinès. Statybos mokslo muziejuje buvo įrengta J. Kuodžiui skirta ekspozicija. Iškilmingame konferencijos plenariniame posedyje dalyvavo J. Kuodžio dukra su vyru ir J. Kuodžio sūnus, atvykę iš JAV.

\section{Vilniaus meras A. Zuokas - VGTU Garbès narys}

VGTU senatas, įvertindamas Vilniaus mero Artūro Zuoko pastangas plètoti studentų miestelio infrastruktūrą, jo rūpestị gausinti visuomeninį transportą Sauletekio alëja, pastangas igyvendinti „Sauletekio slenio" projektą, kuris integruotu verslo ir mokslo interesus, suteike Artūrui Zuokui Vilniaus Gedimino technikos universiteto Garbès nario vardą.

Džiaugsmingas $2004 \mathrm{~m}$. ruduo buvo Architektūros fakulteto destytojams, darbuotojams ir studentams. Keletą metų dirbę apšiurusiose, buvusių patalpų šeimininkų nualintose patalpose, jie įženge i i puikiai suremontuotas auditorijas, braižyklas ir katedras. Kaip ir dera universiteto estetikos flagmanui, Architektūros fakultetas nuo šiol dalị savo patalpų turejo moderniai įrengtas, skoningai apipavidalintas, funkcionaliai tobulas. Praeis dar keletas metų ir buvusių grafo Tiškevičiaus rūmų kompleksas, reikia tikètis, visas taps VGTU pasididžiavimo objektu.

Spalio mènesį Lietuvos Respublikos Seimas, atsižvelgdamas į Lietuvos Vyriausybès teikimą, paskyre Lietuvos mokslo tarybos nariu Statybines mechanikos katedros vedeją habilituotą daktarą profesoriu Juozą Atkočiūną. Šio be galo pareigingo, principingo

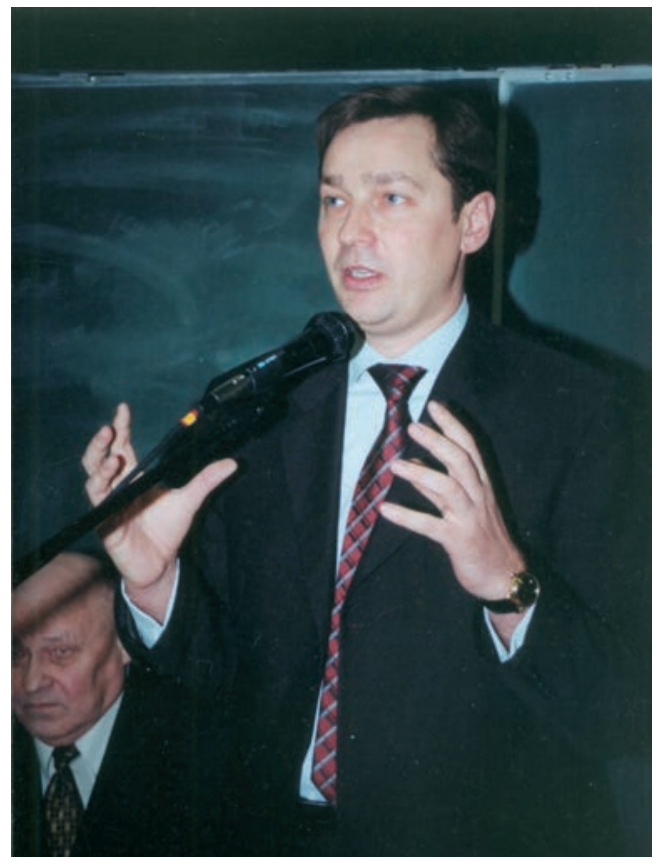

žmogaus, puikaus pedagogo ir mokslininko paskyrimas ị Lietuvos mokslo tarybą reiške aukštą prof. J. Atkočiūno veiklos įvertinimą. Jis užima dar vienas svarbias pareigas - yra VGTU senato pirmininko pavaduotojas.

Vilniaus Gedimino technikos universiteto studentai, kurie gauna vardines stipendijas, pelno didelę ne tik studentų, bet ir destytoju 
pagarbą. Tokių stipendiatų nebūna daug. $2003 \mathrm{~m}$. tokias stipendijas rektoratas paskyre 33 bakalaurantams ir 11 magistrantų. Visų šių stipendijų liudijimai iškilmingai įteikti kiekvienam susitikime su VGTU rektoriumi prof. R. Ginevičiumi, Senato pirmininku prof. Donatu Čygu, prorektoriais ir fakultetu dekanais.

Bendraudami su rektorato nariais ir vardiniais stipendiatais prie kavos puodelio, pirmūnai papasakojo, kaip jie pasieke puikių žinių vertinimo rezultatų, apie kai kurias studiju problemas, ką, jų manymu, deretu pagerinti.

Toks nuoširdus universiteto vadovų ir studentų bendravimas teikia vadovams daug gerų minčių studijų procesui gerinti. Tuo pat metu studentai ima geriau pažinti universiteto galimybes ir ima suvokti, kur jie neteisūs.

Rudeniui baigiantis Vilniaus Gedimino technikos universitete vyko tarptautinés organizacijos „Universitetu aljansas už demokratiją“ 14-oji metine konferencija „Nauju aukštojo mokslo sistemų link“. Šio aljanso forumai plètoja demokratiją ne tik universitetų, bet ir kiekvienos šalies gyvenime. Konferencijoje dalyvavo apie du šimtus dalyvių iš Jungtinių Amerikos valstijų, Centrinès ir Rytų Europos, Nepriklausomų valstybiu sandraugos. Aljanso prezidentas dr. J. Ryder džiaugesi konferencijos parengimu, pažymëjo naujieną tokių konferencijų darbe - studentu sekciją ir diskusijų apskritąji stalą. Gerai buvo ivertinti konferencijos dalyvių iš VGTU pranešejai. Prof. A. V. Valiulio pranešimas „Profesines žinios ir verslumas: nauji darbdavių reikalavimai“, prof. R. Ginevičiaus bei A. Valiulio pranešimas „Žiniomis ir igūdžiais grindžiamo inžinierių ugdymo link“, filologès Astos Radzevičienès pranešimas „Žmoniškujjų išteklių ugdymas universitete: internacionalizavimo pamokos" sulauke išskirtinio konferencijos dalyviu demesio, o diskusiju audrą sukèle Irena Alperyté, skaičiusi pranešimą „Studento reintegravimosi procesas, sugrižzus po studijų JAV“.

Lapkričio mènesį rektorius R. Ginevičius Kaliningrade pasiraše bendradarbiavimo sutartị su Kaliningrado valstybiniu technikos universitetu. Šs universitetas turi beveik 7000 studentu, devynis fakultetus, keturiasdešimt studiju programų. Jame désto 65 profesoriai, habilituoti daktarai ir 300 daktarų. Buvo numatyti abiejų universitety mainai paskaitoms skaityti, bendri moksliniai seminarai, konferencijos ir kt.
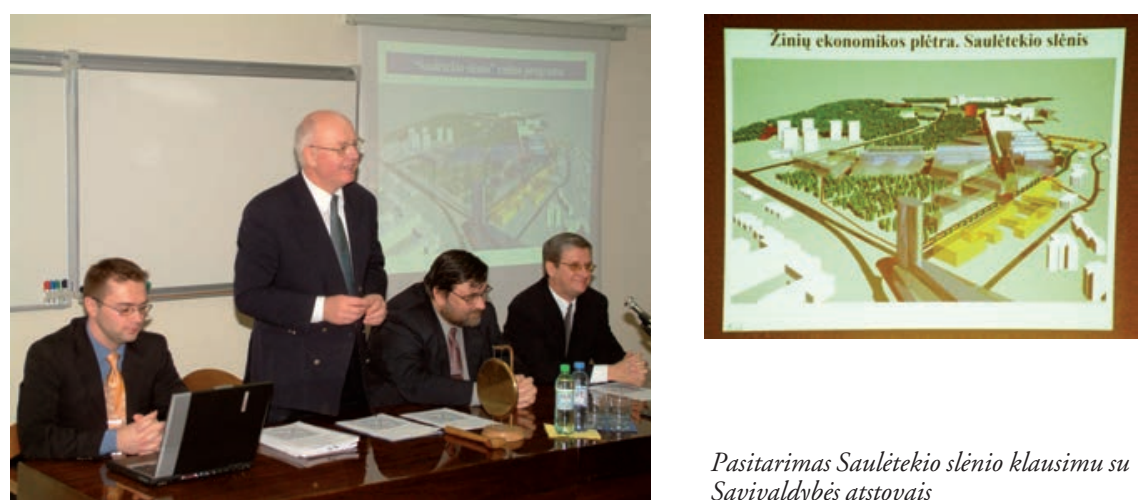

Pasitarimas Sauletekio slenio klausimu su Savivaldybes atstovais

Pariteto pagrindais bendradarbiavimas su Rusijos universitetais pageidautinas ir įmanomas. Nepriimtinas tik buvęs diktatas, kuris, norime tiketi, daugiau neegzistuos.

„Kauno diena“" (2003 11 21) išspausdino probleminį rašinị „Žaidimo taisyklès pagal absurdo metodiką", aptariantį, kaip ir kodel dèl biurokratinių atestacijos nuostatų nemažai garbių mūsų šalies mokslininkų, dèstytoju yra nepelnytai nuvertinti ir pažeminti. Keliama mintis - užuot vaikiusis moksliniu publikacijų ISI leidiniuose, geriau deretų rengti paskaitų auditą ir už tai desstytojui skirti papildomų balų.

Reikšmingas VGTU laimëjimas - pasirašyta sutartis su Štralzundo (Vokietija) aukštąja technikos mokykla dèl dvigubų diplomų išdavimo. Tai rodo, kad užsienyje teigiamai vertinamos studijos Vilniaus Gedimino technikos universitete. Malonu, kad gerai vertinamos ne tik studijos, bet ir mūsų šalies kultūra, gyventojai, malonu, kad Lietuva tampa patraukli ne tik vokiečiams, bet ir daugeliui kitų šalių studentų, kurių nemažai kasmet renkasi studijas VGTU.

Tarptautinëje verslo sistemy modeliavimo konferencijoje

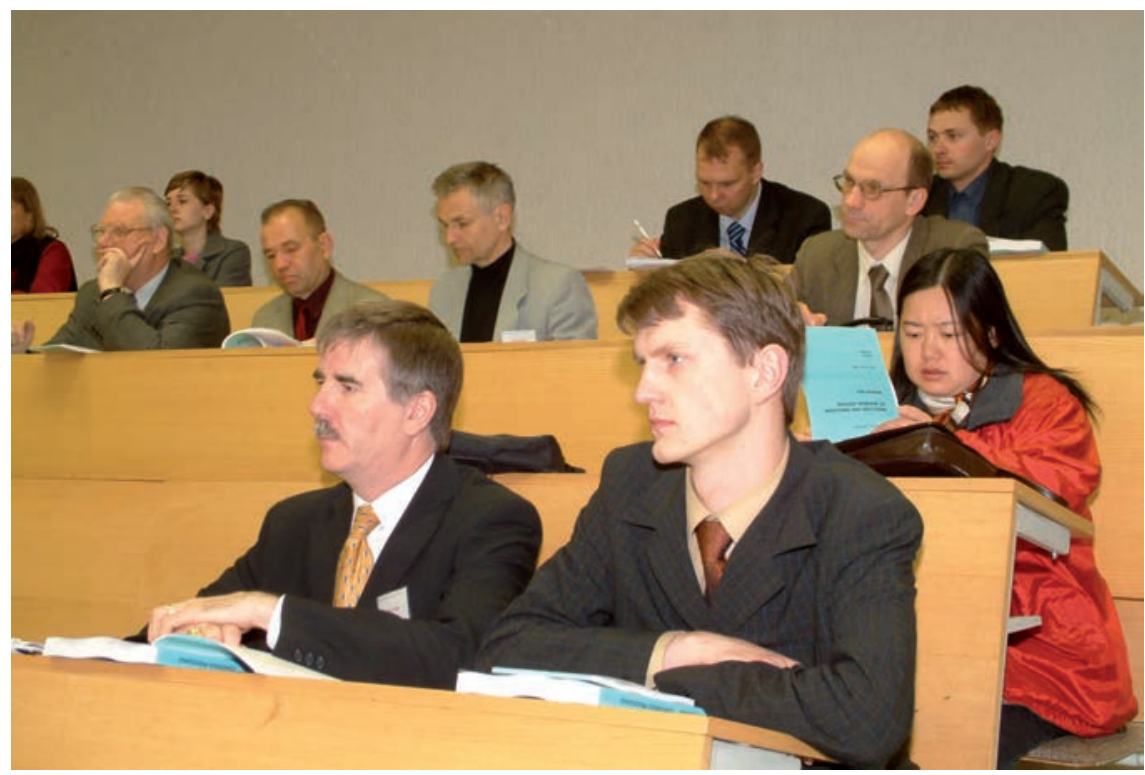


VILNIAUS

GEDIMINO

TECHNIKOS

UNIVERSITETAS
Dar viena gera žinia gauta gruodžio pradžioje. Rusijos inžinerines akademijos suvažiavimas VGTU rektorių prof. habil. dr. R. Ginevičių išrinko užsienio nariu akademiku.

2003 m. pabaigoje VGTU biblioteka paskelbè, kad per 30 metu i ISI mokslo publikaciju duomenų bazę buvo įrašytos 123 universiteto mokslininkų publikacijos. Jos buvo cituotos 67 kartus. Ne Lietuvos autoriai, deja, šias publikacijas citavo tik 13 kartu. VGTU vadovai reagavo ì problemą išmintingai ir buvo priimta mokslinių publikaciju skatinimo sistema, kuri ilgainiui radikaliai pagerino mokslininkų darbo rodiklius šiuo klausimu.

Naujųju metų išvakarese buvo surengta graži VGTU bendruomenès švente prie Kalèdinès eglutes. Kaip sakè rektorius R. Ginevičius, tokiu švenčių reikia organizuoti ir daugiau, nes jos kelia nuotaiką, padeda pasirengti intensyviam darbui.

2003 metai buvo sèkmingi ir VGTU mokslininkams.

VGTU atliko užsakomųjų mokslo darbų beveik už $7 \mathrm{mln}$. Lt. Už dalyvavimą tarptautiniuose projektuose gauta per 400 tūkst. Lt.

Per 2003 m. mūsų universitete apginta 30 daktaro ir 5 habilituoto daktaro disertacijos. Doktorantūroje studijavo 217 doktorantų.

Pagerèjo moksliniai straipsniai, 25 iš ju ittraukti ị ISI duomenų bazę.

VGTU buvo surengtos 28 mokslinès konferencijos ir seminarai. 4 konferencijos buvo tarptautines. Mokslinese konferencijose mūsų mokslininkai perskaite 582 pranešimus. Mūsų organizuotose mokslinèse konferencijose 143 pranešimus perskaite užsienio mokslininkai.

VGTU ir toliau pirmavo išradybineje veikloje. Buvo gauti 3 išradimu patentai.

2003 m. VGTU mokslininkai didžiausią demesi skyre Europos komisijos 5-osios ir 6-osios bendrosios moksliniu tyrimu, technologiju pletros ir demonstracinés veiklos programoms, paprastai žymimoms FP5-6. VGTU turejo 16 vykdomų projektų. Iš šių projektų daugiausia lešsc uždirbo projektas „TOPIC“, kurị vykdé Geotechnikos mokslo laboratorijos mokslininkai, vadovaujami vieno žymiausių mūsų krašto geotechnikų Liudviko Furmonavičiaus.
Dalyvavimas FP5-6 projektuose teikia tiek universitetui, tiek autoriams tarptautini pripažinimą, todèl ši darbą dirbantys mokslininkai ne tik pagiriami, bet ir labai skatinami.

Naujieji 2004 metai Lietuvoje prasidejo nekokios nuotaikos. Lietuvos nepriklausomybę mūsų tauta pasirinko su šviesiausiomis viltimis, visi buvo ịsitikinę, kad šalis savo šalị plettos laikydamasi sąžiningumo, dorovès principur. Buvo tikimasi, kad valstybëje vyraus teisingumas, išmintis, pasiaukojimas. Deja. Krašte suklestëjo korupcija, dalis visuomenés gyvena skurde, vos ne kas savaitę kyla politinio gyvenimo skandalai. Seimas pradejo apkaltą Respublikos Prezidentui Rolandui Paksui, įtarimai dèl kyšiu ęmimo pareikšti Seimo nariams Vyteniui Andriukaičiui, Vytautui Kvietkauskui, Arvydui Vidžiūnui. Kaltinimas seka kaltinimą daugybei valstybes tarnautojų ir t. t., ir pan. Atrodytu, Lietuva uždus nuo galingų, baisių korupcijos monstro gniaužtų.

Betgi dauguma Lietuvos žmonių, nepaisydami valdžią krečiančių skandalų, daug ir dorai dirba, nors ir ką sakysi, kraštas tvarkosi, stiprëja, savo paprastų žmonių prakaitu kuria savo ateitį. Atkakliu paprastų žmonių darbu auga bendrasis vidaus produktas. Dirbantys paprasti žmonès nusipelno didžiausios pagarbos, kad vis délto Lietuva žengia modernios valstybes link.

Sunkiomis sąlygomis šiandien gyvena Lietuvos mokslas, aukštosios mokyklos, universitetai. Bet ir šiame bare šalis nenuleidžia rankų. Išaugo studijuojančių skaičiai, mokslininkai didelemis pastangomis ir pasiaukojimu randa naujas „nišas“ moksliniuose tyrimuose, mūsų mokslo rezultatai vis plačiau deklaruojami pasaulinèse informacinèse priemonèse. Visa tai būdinga ir Vilniaus Gedimino technikos universiteto bendruomenei. Tai teikia gražių vilčiu ateičiai.

Sausio ménesị Architektūros fakulteto Pastatų konstrukcijų katedros vedëjas, bene žymiausias Lietuvoje akustikos specialistas, habilituotas daktaras profesorius Vytautas Stauskis gavo išradimo „Prieštriukšminis rezonansinis ekranas" patentą. Išradimas leidžia efektyviau kovoti su transporto keliamu triukšmu, gali būti naudojamas ir kitoms su triukšmu susijusioms problemoms spręsti.

Sausio pabaigoje Fundamentiniu mokslų fakulteto doktorante Vitalija Avdejenkova, prieš kelis metus studijavusi VGTU 


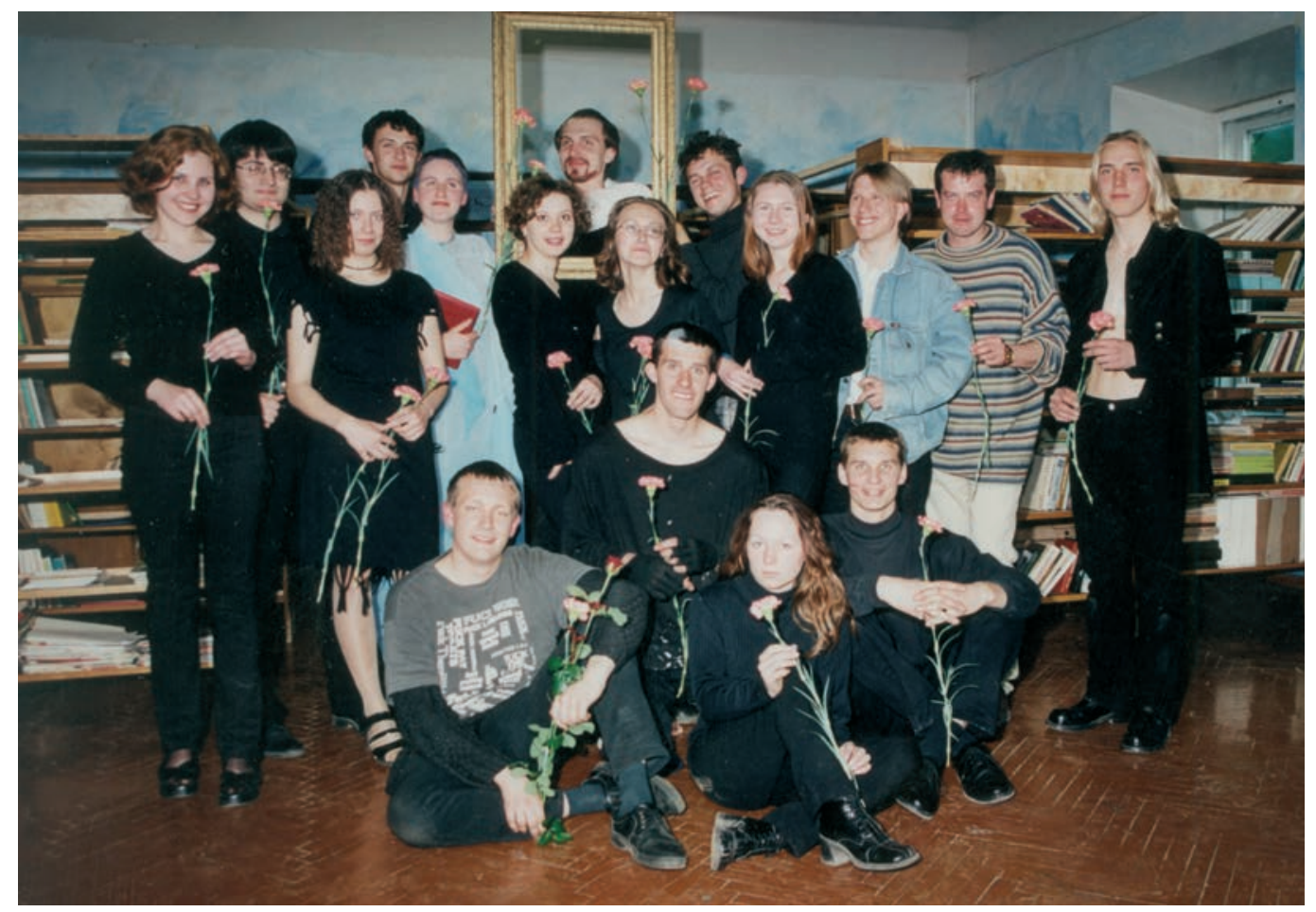

2004 m. VGTU teatras-studija „Palepe“ paminëjo 5-meti

taikomosios statistikos magistrantūroje, o nuo 1999 metu - Matematinés statistikos katedros doktorantūroje, apgynè matematikos daktaro disertaciją. Prof. Leonas Saulis, vadovavęs darbui, raše „Inžinerijoje“, kad V. Avdejenkova pasirinko nūdienos padiktuotą temą apie bendrojo vidaus produkto modeliavimą. Kodel ji aktuali? Atliekant tarpvalstybinius lyginimus, vertinant kiekvienos šalies ekonominę pažangą, naudojami sąskaitų rodikliai, kurių svarbiausias - bendrasis vidaus produktas (BVP). Jis naudojamas šalims lyginti ivvairiais aspektais, ịvairiems santykiniams rodikliams formuoti.

Matematinio modeliavimo svarbą pabrěže ir akademikas, VGTU Garbès daktaras Kazimieras Ragulskis. Jis rašè:

„Dèl žmoniu klaidu, nekompetencijos, nesažiningumo daroma didžiule žala progresui. Gyvybiškai svarbu mobilizuoti Lietuvos patriotines intelektines pajegas, kad, nustatant perspektyvas, priimant svarbiausius visuomenes klausimu sprendimus, atliekant prognozavima, būtu gauta optimaliu rezultatu. Čia svarbus vaidmuo ir tenka matematiniam modeliavimui".

Vis intensyvejo VGTU tarptautinis bendradarbiavimas.

Doc. dr. Česlovas Aksamitauskas ir doc. dr. Vida Maliené skaite paskaitas Bochumo (Vokietija) taikomųu mokslų universitete.

Elektronikos fakultete lankessi JAV Texas instruments firmos Europos universitetų va- dovas Robertas Owenas su kolegomis ir supažindino su naujausia firmos produkcija, padovanojo fakultetui kompaktinius diskus su informacine ir studijų medžiaga.

Maloni žinia iš JAV pasieke prof. J. Parasonị. Jis buvo išrinktas Amerikos biografijų instituto tarybos patareju.

VGTU Antano Gustaičio aviacijos institute apsilanke prancūzų delegacija, kuri konsultavo instituto darbuotojus, kaip pasirengti darbui pagal Europos Jungtines aviacijos administracijos (JAA) reikalavimus.

\section{Isteigtas Absolventu ir bičiuliu klubas}

Gerai yra turèti bičiulių užsienyje, bet netrūksta jų ir Lietuvoje. Ryšiams su mūsų aukštosios mokyklos per visą istoriją parengtais absolventais, mūsų remejais ir apskritai technikos universitetui palankiais žmonemis stiprinti, $2004 \mathrm{~m}$. vasario $4 \mathrm{~d}$. universitete buvo įsteigtas Absolventų ir bičiulių klubas. Buvo priimti klubo ịstatai ir išrinkta 9 asmenu VGTU absolventu ir bičiulių klubo valdyba: R. Podagèlis, G. Lygnugarienè, A. Avulis, E. K. Zavadskas, R. Busila, V. Kontrauskas, D. Ruseckas, E. Rečiūnas ir A. Usoniené. Klubo prezidentu valdybos nariai išrinko 1966 m. KPI Vilniaus filialo absolventą, gelžbetoninių konstrukcijų specialistą, Lietuvos užsienio reikalų ministerijos ambasadoriu ypatingiems pavedimams doc. dr. Romaną Podagèlị. Prieš keliolika metų 
VILNIAUS

GEDIMINO

TECHNIKOS

UNIVERSITETAS dirbęs mūsų mokykloje, R. Podagèlis pasižymëjo kaip puikus organizatorius, principingas žmogus, geras destytojas, Lietuvos patriotas.

Kovo ménesį Gedimino universitete apsilanke iž̌ymūs svečiai: minint Kovo 11 ąją - Lietuvos nepriklausomybes atkūrimo dieną iškilmingame minejjime dalyvavo Lietuvos Respublikos Seimo pirmininko pirmasis pavaduotojas Česlovas Juršènas, o minint Pasaulinès žemés dieną - Prezidentas Valdas Adamkus. Č. Juršènas kalbëjo, kad Lietuvos Konstitucija visiems piliečiams suteikia daug teisių. Žmonès jomis naudojasi. Bet yra ir problemu. Dar beveik neegzistuoja gamybine, verslo demokratija. Spaudoje, per radiją, televiziją, mitinguose, susitikimuose kalbetojai kritikuoja prezidentą, premjerą, Seimą, valdininkus, bet niekas blogo žodžio nesako apie darbdavị ar jo iqgaliotą vadovą, neužsimenama apie konkrečioje įmoneje ar ịstaigoje pasitaikančius trūkumus, negeroves. Č. Juršènas pabrežè, kad dabar daug kokybiškesne tarptautine Lietuvos situacija, ji dar daugiau pageres, kai tapsime NATO ir Europos Sajungos nariais.

Rektorius R. Ginevičius savo kalboje akcentavo atsakomybes už savo darbą, savo veiksmus svarbą.
Pasaulinès žemès dienos minëjimą suorganizavo VGTU Aplinkos apsaugos institutas ir Aplinkos apsaugos katedra. Dalyvaujant svečiams medyje prieš Sauletekio rūmus buvo iškelti inkilai, kalbeta apie inkilų iškèlimo tradicijas Lietuvoje, Pasaulinès žemès dienos prasmę.

Prezidentas V. Adamkus gyre universitetą už jo dèmeși aplinkosaugai, apgailestavo, kad Lietuvoje dažnai nepaisoma aplinkosaugos reikalavimų, nesprendžiamos kai kurios aktualios jos problemos.

Kovo 11-osios proga LR Prezidentas Rolandas Paksas atsiunte Vilniaus Gedimino technikos universitetui sveikinimą, kuriama sakoma: „Te kasdieniai mūsų darbai stiprina atgimusią Tẻvynę ir žmonių pasiryžimą gyventi laisves, demokratijos, geroves valstybeje“. Deja, R. Pakso ryšiai su didžiojo Rytu kaimyno atstovais buvo tiek artimi, jog Seimas nustate Lietuvos Respublikos Prezidentą Rolandą Paksą dèl savo ryšių esant pažeidžiamą, o tai kelia pavojų šalies nacionaliniam saugumui. Balandžio 6 d. Lietuvos Respublikos Seimas baige apkaltos procesą valstybès vadovui ir Rolandas Paksas buvo nušalintas nuo Prezidento pareigu. Apmaudu - netekome absolvento-prezidento.

2004 m. kovo 29 d. Lietuva tapo Šiaurès Atlanto aljanso (NATO) nare. Tą pačią dieną Belgijos karinių oro pajęgų naikintuvai, įsikūrę prie Šiaulių esančiame Zoknių aerodrome, emé saugoti trijų Baltijos valstybių -
VGTU absolventų ir bičiulių klubo vadyba

Is kaires:

V. Kontrauskas, A. Avulis, D. Ruseckas, E. Rečiūnas, A. Usoniene, R. Podagèlis, G. Lygnugarienè, E. K. Zavadskas, R. Busila

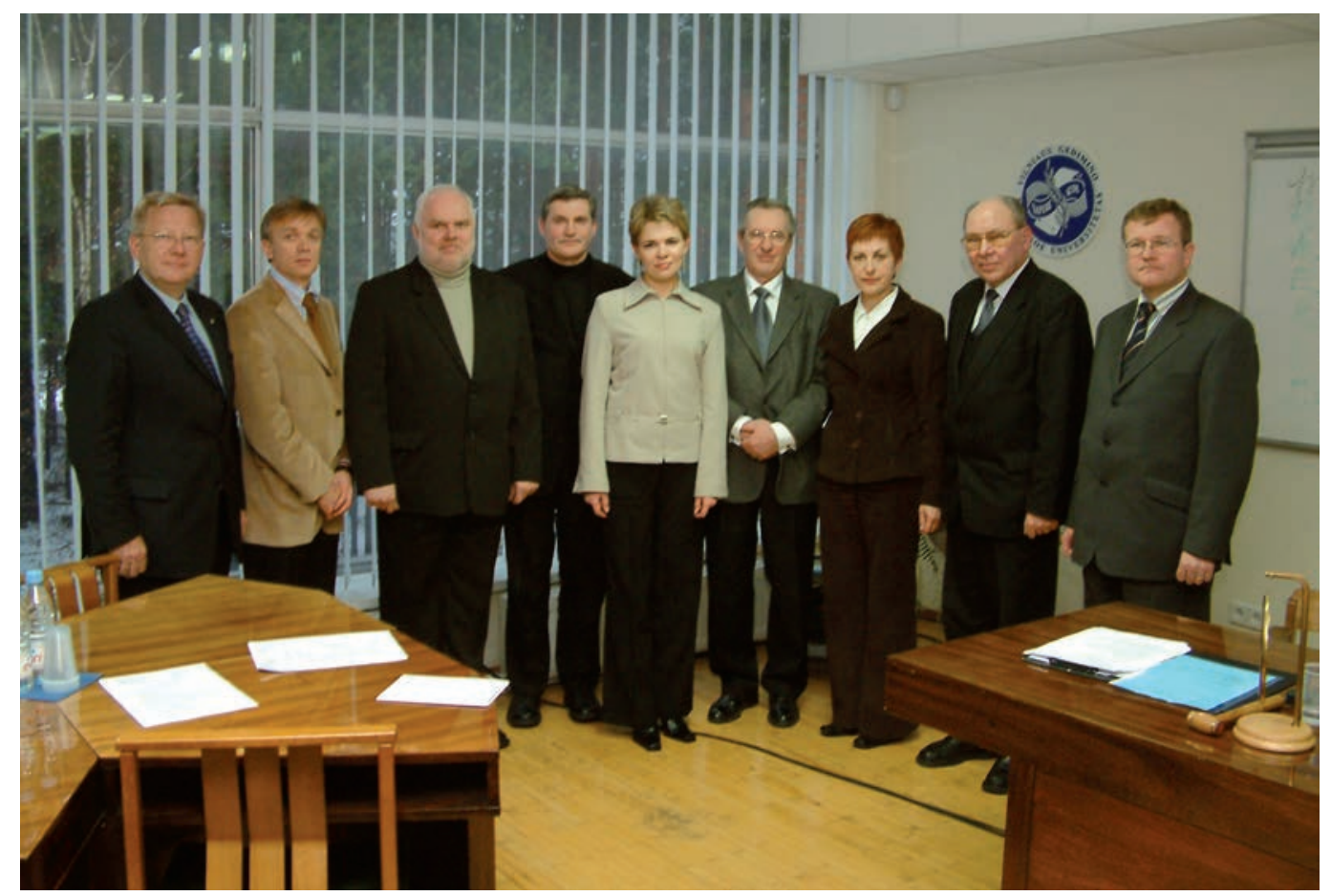


Lietuvos, Latvijos ir Estijos - oro erdvę. Pasijutome saugesni, bet neturime pamiršti, kad šalies saugumas daugiausia dalimi priklauso nuo mūsų pačių pasiryžimo gyventi laisvoj ir nepriklausomoj valstybejj, nuo mūsų pasiryžimo bet kuria kaina ginti savo žemę, savo šalies laisvę. Čia didelis vaidmuo tenka visų rūšių mokykloms, kurių uždavinys - rengti ne tik gerus specialistus, bet ir ugdyti savosios šalies patriotus.

Mènesio pabaigoje išradejo patento liudijimą gavo profesoriai Bronislovas Spruogis ir Marijonas Bogdevičius bei doktorantai Arvydas Matiliauskas bei Vygandas Mištinas. Jie visi sukūre vamzdyno vidumi žingsniuojanti robotą.

Balandžio ménesị gauta dar viena maloni žinia. Prof. habil. dr. E. K. Zavadskas ir prof. dr. D. Čygas buvo išrinkti Baltarusijos architektūros akademijos užsienio nariais.

Tarptautinis bendradarbiavimas pletojamas ir Rytu bei Vakarų kryptimi. Balandi tarptautinio projekto „TOPIC“ vadovas Liudas Furmonavičius dalyvavo tarptautinèje konferencijoje „Geotechninès inžinerijos laimëjimai“", Miuncheno tarptautineje statybos industrijos mugèje „Bauma-2004“ ir susipažino su naujausiomis polių įrengimo technologijomis.

Prorektorius A. V. Valiulis dalyvavo Zakopaneje (Lenkija) vykusioje tarptautineje konferencijoje „Mechaninès ir medžiagų inžinerijos laimëjimai“.

Gegužès mènesį VGTU bendruomene nuoširdžiai sveikino per 12 metų buvusi rektoriumi, instituto į universitetą reformavimo iniciatorių ir atkakliausią igyvendintoją, LDK Gedimino ordino kavalierių, šalies mokslo premijos laureatą, Lietuvos moksly akademijos nari korespondentą, prof. habil. dr. Edmundą Kazimierą Zavadską gražaus jubiliejaus - 60-mečio - proga. E. K. Zavadskas pelnytai yra apdovanotas valstybès, daugelio šalies ir užsienio instancijų. Bet jubiliatui didžiausia laimé, neabejojame, - patirti didelę ir pelnytą pagarbą savosios universiteto bendruomenès kurią, priešakyje eidamas, sèkmingai vedè pažangos link. Vilniaus Gedimino technikos universitetas įsitvirtino šalies universitetų avangarde ir dideli nuopelnai pirmiausia tenka buvusiam VGTU vadovui.

Birželio 9 d. VGTU Garbès nario regalijos buvo įteiktos Ukrainos nacionalinio aviacijos universiteto profesorei Galinai Suslovai, kurios dèka užmegztas dalykinis bendradarbia-

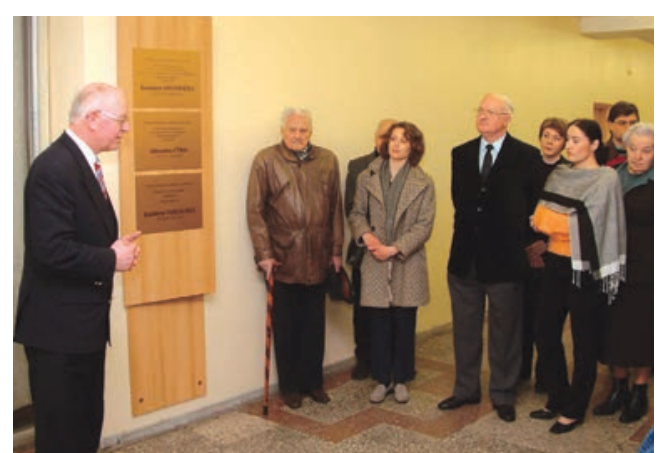

vimas tarp VGTU ir Ukrainos nacionalinių aviacijos universitetu.

2004 m. Vilniaus Gedimino technikos universitetas išleido 2346 specialistus: 1466 pagrindinių studijų, 863-magistrantūros studijų ir tik 17 - specialiųjų profesinių studijų. Pastarųjų studijų absolventų skaičius tolygiai mažëjo jau nuo 1995 metų.

$2004 \mathrm{~m}$. pavasarị Chemijos ir bioinžinerijos katedros doc. dr. Juozo Jankausko bei Vandentvarkos katedros doc. dr. Marinos Valentukevičienès išradimas „Natūralaus absorbento naudojimas gamtiniam vandeniui valyti “ ir Aplinkos apsaugos katedros vedejo prof. habil. dr. Prano Baltreno, doc. dr. Česlovo Ignatavičiaus bei dr. Gytauto Ignatavičiaus išradimas „Mechaninis mèginių iš skirtingu grunto sluoksnių paemimo įrenginys" gavo patentus.

Atkūrus Lietuvos nepriklausomybę Technikos universiteto mokslininkai pirmąją patentinę paraišką pagal naująji LR patentų isstatymą pateike 1995 metais. Iki 2006 m. iš viso buvo paduotos 35 patentinès paraiškos išradimams, kuriuos sukūre 48 išradëjai.

VGTU išradimai buvo eksponuoti keturiose „HANNOVER MESSE“ parodose, o 2003 m. universitetas, kaip mineta, apdovanotas Pasaulinès intelektinès nuosavybès organizacijos prizu.

VGTU dirba 40 išradejuu, produktyviausi iš jų yra: prof. habil. dr. P. Baltrènas - 12 išradimų, prof. habil. dr. A. Kazragis - 5 išradimai, doc. dr. A. Gailius - 4 išradimai, prof. habil. dr. V. Giniotis - 4 išradimai.

Šaunią pergalę Lietuvos orientavimosi sporto čempionate iškovojo Verslo vadybos fakulteto studentas Paulius Kudriavcevas.

Birželi VGTU Aukštadvario bazejje buvo surengta universiteto bendruomenès šventè. Rektorius R. Ginevičius, sveikindamas gausiai susirinkusius ị renginị, sakè, kad bendruomenès švente - tai gražus ir didžiai prasmingas mokslo metų pabaigos akcentas. Per metus rezultatyviai padirbeję, turime 
VILNIAUS

GEDIMINO

TECHNIKOS

UNIVERSITETAS teisę turiningai pailsèti. Jis linkëjo giedros nuotaikos bei linksmai, gražiai bendraujant praleisti poilsio dieną gamtos prieglobstyje. Susirinkusiuosius sveikino aerobikos šokëjos, parasparnių trijule, Antano Gustaičio aviacijos instituto lekktuvų eskadrilè. Rektoriaus taurę laimëjo Aplinkos inžinerijos fakulteto komanda. Švente baigèsi vakarone, kurioje universiteto bendruomenę linksmino „Radastos" ir "Raskilos“ ansambliai. Šventeje puikiai pasirode VGTU bibliotekos kolektyvas. Jų „Bibliobobos“, parodijavusios įvairias „personas“, įsteigusios „Draugystés bufetą“ ir kt., paliko neužmirštamą įspūdị.
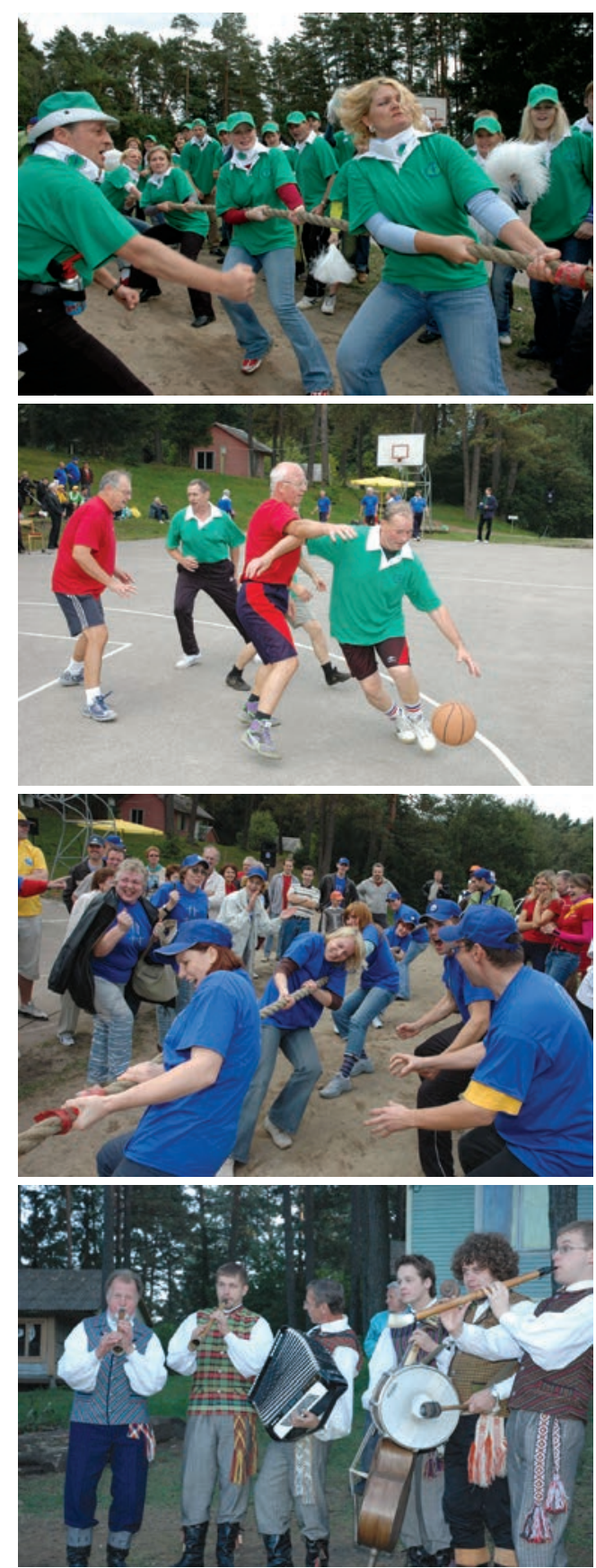

Birželio $30 \mathrm{~d}$. į pirmojo šaukimo sesijos paskutini posedį susirinko VGTU senatas. Jo pirmininkas D. Čygas universiteto laikraščio redaktoriui sakè, kad rugsèji pradèsiančio dirbti Senato vienas svarbiausių uždavinių - siekis, kad priimti nutarimai būtų vykdomi, kad Senato rekomendacijos taptu kiekvieno bendruomenès nario kasdienès veiklos būtinybe. Senatas sieks laiku ir operatyviai reaguoti į universiteto bendruomenę slegiančias problemas ir bendrai ieškoti kelių joms spręsti.

Kasmet, Lietuvos valstybès karaliaus Mindaugo karūnavimo dieną, Lietuvos Respublikos Prezidentas teikia apdovanojimus Lietuvai nusipelniusiems žmonems. $2004 \mathrm{~m}$. liepos 6 d. bus ypač įsimintina VGTU Darbo ir gaisrines saugos katedros kūrejui ir buvusiam ilgamečiam jos vadovui profesoriui Petrui Čyrui. Jam laikinasis prezidentas Artūras Paulauskas įteike Lietuvos Didžiojo kunigaikščio Gedimino ordino Karininko kryžių.

Už nuopelnus Lietuvos valstybei ir už pastangas garsinti Lietuvos vardą pasaulyje Lietuvos Didžiojo kunigaikščio Gedimino ordino Riterio kryžiumi buvo apdovanotas VGTU infrastruktūros ir užsienio ryšiu prorektorius, Medžiagotyros ir suvirinimo katedros vedejas profesorius Algirdas Vaclovas Valiulis. Apie 15 metu eidamas atsakingas pareigas, A. V. Valiulis produktyviai dirbo ir mokslinį darbą, daug nuveike kitais klausimais. Paraše ar sudare dešimtị knygų, paskelbẻ daug mokslinių ir publicistinių straipsnių, ryškūs jo atlikti VGTU tarptautinio bendradarbiavimo pletros darbai.

Reikšmingą Vilniaus Gedimino technikos universitetui straipsnį vasarą išspausdino populiarus Lietuvoje „Veido“ žurnalas.

2004 m. vasarą Vilniaus Gedimino technikos universitetas vykde priemimą i 42 studiju programas. Buvo priimti 2937 žmonès ị pagrindines studijas, 1370 - į magistrantūrą ir $13-\mathrm{i}$ specialiąsias profesines studijas, iš viso 4320 žmonių.

Aplinkos inžinerijos fakultetas prièmé 678 žmones, Architektūros fakultetas - 147, Elektronikos fakultetas - 429, Fundamentinių mokslų fakultetas - 469, Mechanikos fakultetas - 496, Statybos fakultetas - 833, Transporto inžinerijos fakultetas - 483, Verslo vadybos fakultetas - 647, A. Gustaičio aviacijos institutas - 108, Tarptautinių studijų centras -30 . 


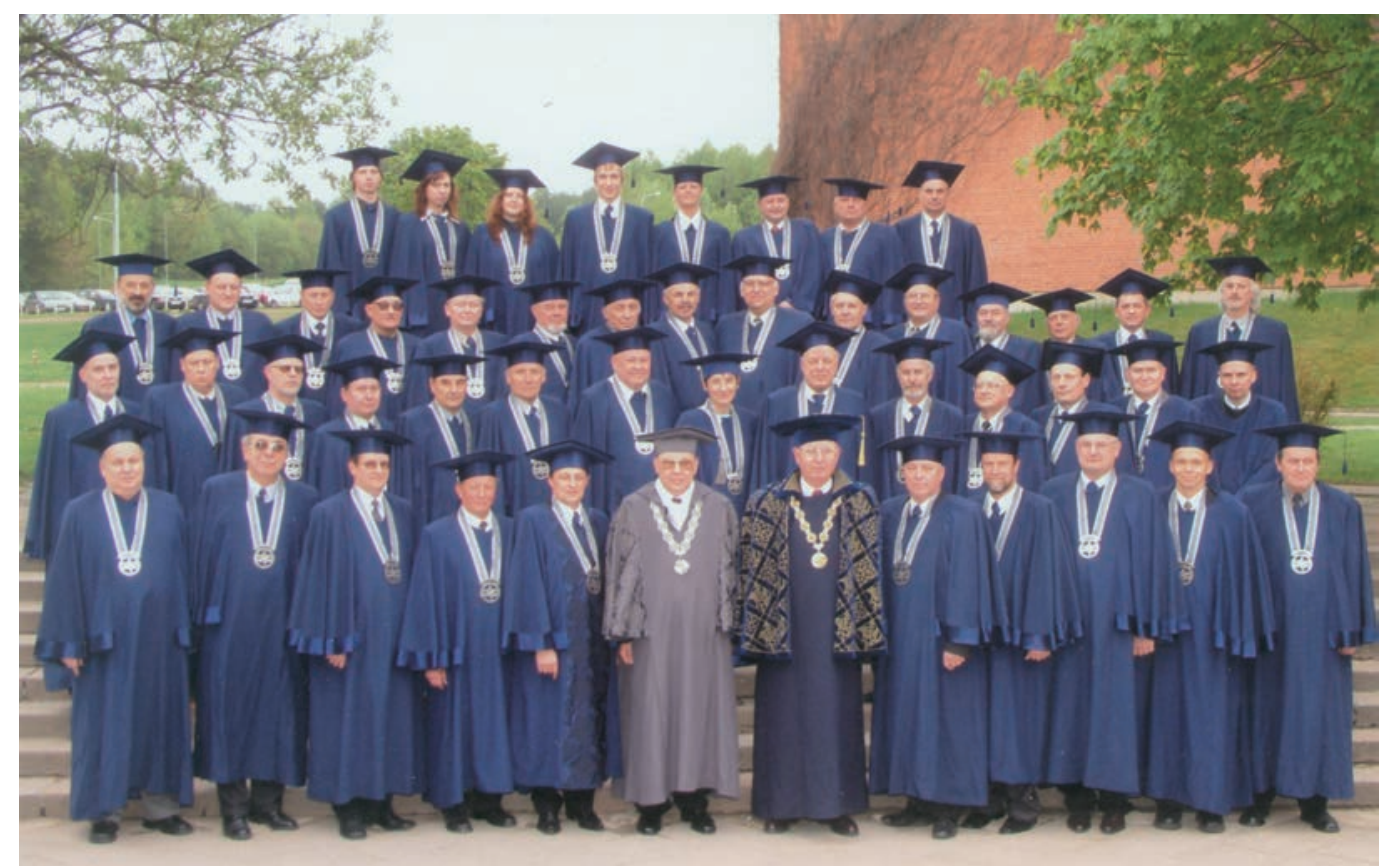

Malonu, kad vis dažniau buvo sužinoma apie naują VGTU mokslininkų ryšiu plètrą.

Liepos menesi i $\mathrm{VGTU}$ atvyko svečiu iš Danijos ir Vokietijos. VGTU Garbès daktaras danas Kai Bore ir vokietis Giunter Chein (Miuncheno universiteto Geodezijos ir navigacijos instituto direktorius) supažindino VGTU Geodezijos ir kadastro katedros bei Geodezijos instituto mokslininkus su naująja europine GSP programa, patare, kaip ją sèkmingai igyvendinti savo darbuose.

Verslo vadybos fakulteto İmoniu ekonomikos ir vadybos katedros docentes R. Korsakiene ir $\mathrm{M}$. Tvaronavičiene, laimëjusios konkursą, dalyvavo Austrijos Steyr mieste vykusiose Europos mokslo dienose organizaciju ekonomikos ir firmų teorijos klausimais. Abi mūsų dalyvès gavo sertifikatus, pažyminčius sèkmingą jų dalyvavimą Europos mokslo dienose. Bet svarbiausia - abi mokslininkes sukaupe naudingos informacijos klausimais, susijusiais su ekonomikos įtaka firmos veiklai, firmos sprendimams, ką gaminti sau ir ką kitiems ir kt.

Rugsèjo 1-ją prie Sauletekio rūmų centrinio korpuso įvyko tradicine naujųjų mokslo metų atidarymo šventè.

Rektorius R. Ginevičius, sveikindamas gausiai susirinkusius pirmojo kurso studentus, pabrèžè, kad 2004-2005 mokslo metu pirmakursiai yra pirmieji, kurie įstojo i VGTU, Lietuvai jau esant Europos Sąjungos nare, pažymejjo, kad inžinerinès studijos populiareja, kad Gedimino universiteto rengiami specialistai paklausūs. Rektoriaus manymu, gerą verslininką gali parengti tik aukštoji technikos mokykla. Be to, inžinerinés studijos suformuoja toki žmogaus mąstymą, kuris leidžia tapti ir politiku. Daugelis VGTU absolventų sèkmingai kopia profesinès karjeros laiptais. Bet tam reikia daug jègu, ištvermès. Rektorius kviete pirmakursius derinti studijas ir studentavimą, linkejo sèkmingų studijų ir nedaryti klaidų.

Paskui buvo imatrikuliuoti visų fakultetų pirmojo kurso studentai. Rektorius kiekvienam jų spaude ranką ir skeptru liesdamas petị , „ǐ̌ventino “ isstojusiųjų atstovus, o kartu ir visus pirmakursius ị studentus.

Dalis studentų ir destytojų dalyvavo Arkikatedroje bazilikoje mokslo metų pradžiai aukotose Šv. Mišiose, o vakare - šventiniame koncerte prie Lietuvos Respublikos prezidentūros S. Daukanto aikšteje.

Rugsejo 27-30 d. įvyko tradicinès Gedimino dienos. Daugumą renginių suorganizavo VGTU Studentu atstovybè. Buvo renkamas metu destytojas, vyko "monopolio“ žaidimai, „kulinaru šou“, karaokè konkursai, buvo dalijama milžiniška pica, vyko kitos atrakcijos.

Pagal tradiciją surengta akcija Katedros aikšteje prie Gedimino paminklo. Senato saleje buvo apdovanoti geriausi praejusių mokslo metu sportininkai. Teatras-studija "Palepee“ rodè spektaklius, choras „Gabija“ koncertavo, vyko studentu vakaronès, sporto varžybos ir kt. Ypatingą susidomejjimą kèle gaisrinès saugos specialybès studentų varžybos prie Sauletekio rūmų auditorinio korpuso. prof. habil. dr. A. V. Rutkauskas, prof. habil. dr. B. Melnikas, doc. dr. A. Komka, prof. habil. dr. L. Saulis, prof. dr. D. Čygas, prof. habil. dr. E. K. Zavadskas, prof. habil. dr. R. Ginevičius, prof. habil. dr. A. V. Valiulis, prof. habil. dr. R. Kirvaitis, doc. dr. A. Daniūnas, prof. habil. dr. G. Kaklauskas, prof. dr. L. P. Ziberkas;

2-oje eileje (iš kairés):

prof. habil. dr. R. Martavičius, prof. habil. dr. J. Atkočiūnas, doc. dr. M. Sukšta,

prof. habil. dr. M. Mariūnas, prof. dr. E. Vainiūnas, prof. habil. dr. I. Z. Kamaitis, doc. dr. A. Čiučelis, doc. dr. R. Tamošiūniene, prof. habil. dr. P. Baltrenas, doc. dr. V. V. Stragys, prof. habil. dr. V. Pruskus, prof. habil. dr. V. Vekteris, prof. habil. dr. A. Poška, prof. habil. dr. A. Kaklauskas;

3-ioje eileje (iš kairès):

prof. habil. dr. R. Palšaitis, prof. habil. dr. M. Bogdevičius, prof. habil. dr. J. Skudutis, prof. habil. dr. A. K. Kvedaras, prof. habil. dr. A. J. Staškevičius, prof. habil. dr. P. G. Adomenas, prof. dr. R. Vadlūga, prof. habil dr. J. Stankūnas, prof. habil. dr. A. Česnys, prof. habil. dr. A. Pikūnas, prof. habil. dr. L. P. Lingaitis, prof. habil. dr. N. Paliulis, prof. habil. dr. A. Zakarevičius, prof. habil. dr. V. Martinaitis, prof. habil. dr. R. Belevičius; 4-oje eileje (iš kairès): stud. L. Stankevič,

stud. L. Rakštyte, stud. K. Mečinskaitė, stud. M. Olšauskas, stud. E. Baltrenaité, prof. habil. dr. R. Kačianauskas, prof. habil. dr. M. K. Leonavičius, prof. habil. dr. P. Tamošauskas

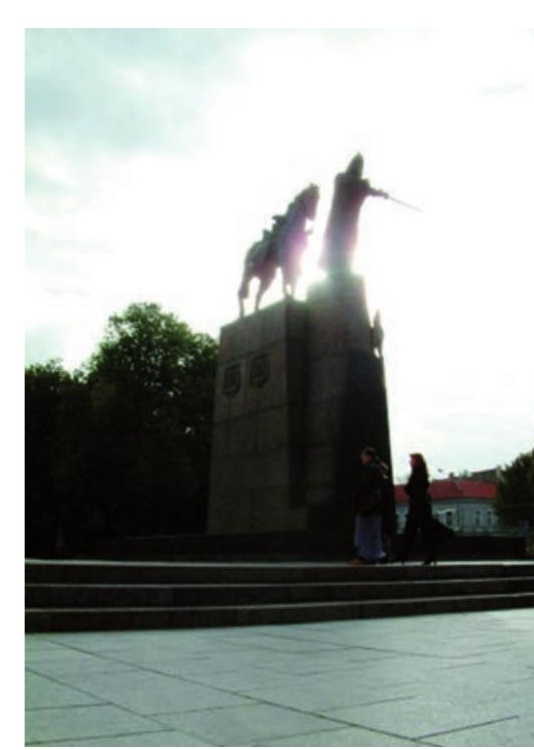


VILNIAUS

GEDIMINO

TECHNIKOS

UNIVERSITETAS

VGTU Gedimino dienos 20040928

Nuotraukose dešinëje -

studentai rinko Metu destytojus, parodomoji gaisro gesinimo rungtis
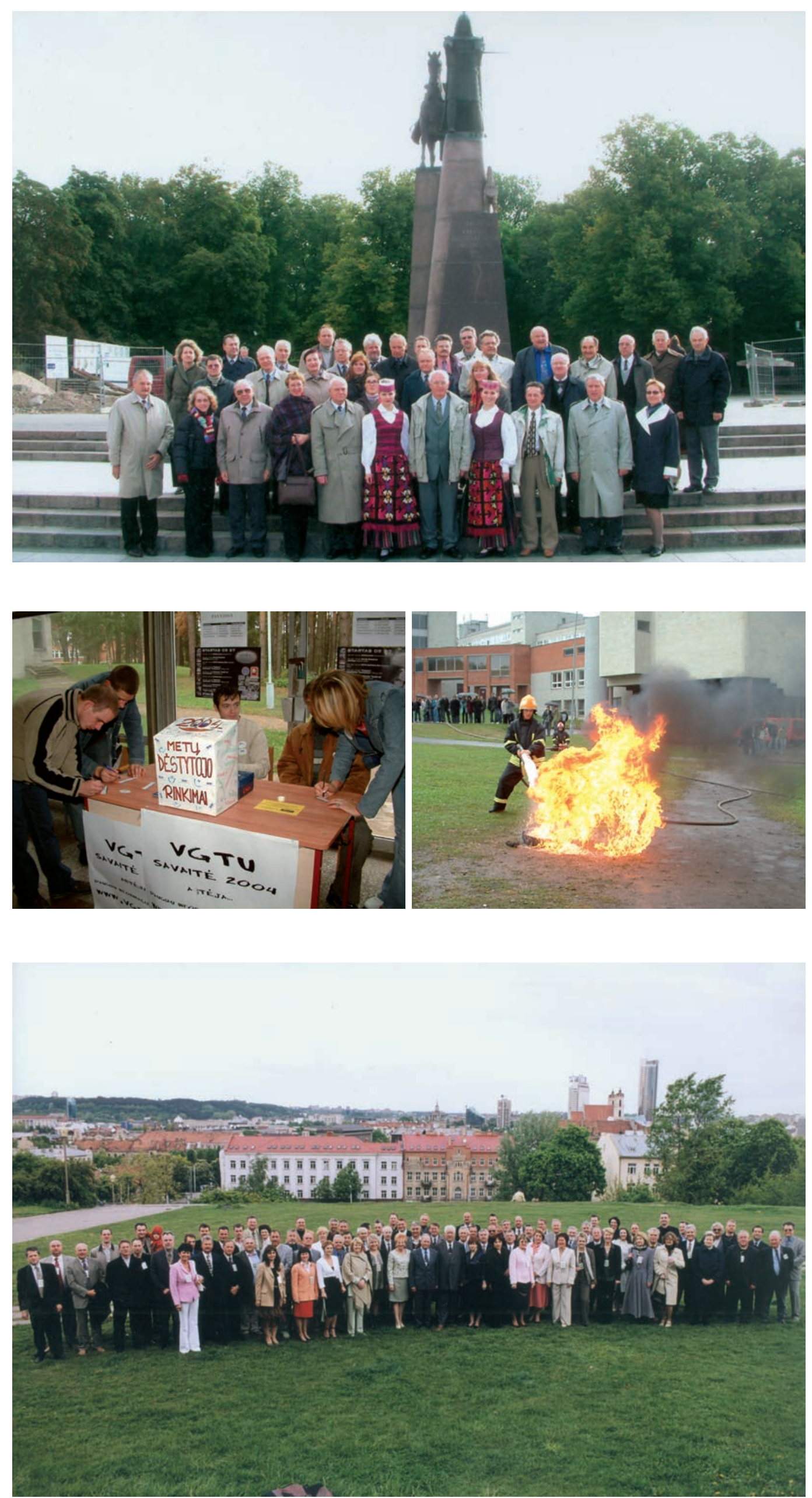

VISI pučiamuju orkestras "Inžinerija“ buvo vienas geriausiu Lietuvoje.

$2004 \mathrm{~m}$. Vilniuje susitiko buve orkestro dalyviai. Centre - maestro Justinas Jonušas 
Rugsèjo 29 d. Didžiojoje auditorijoje vyko iškilmingas VGTU senato posedis, kurio metu VGTU Garbes daktaru buvo inauguruotas Ukrainos nacionalinio aviacijos universiteto rektorius Vitalijus Babakas.

Prof. habil. dr. V. Babakas - Ukrainos mokslų akademijos narys korespondentas, Informacinių diagnostikos sistemų instituto direktorius, Ukrainos nusipelnęs mokslo ir technikos veikejas, Ukrainos valstybines mokslo ir technikos premijos laureatas, nuo 1988 m. - Ukrainos nacionalinio aviacijos universiteto rektorius. Jis labai produktyvus mokslininkas, paskelbęs per 200 mokslo publikaciju, turintis 30 išradimų ir patentų, parašęs 3 monografijas ir 16 vadovelių.

V. Babaką su VGTU sieja glaudūs ryšiai. Jis daug padejo kuriant Antano Gustaičio aviacijos institutą, keliant AGAI destytoju kvalifikaciją, aprūpinant institutą reikalinga mokomąja metodine literatūra, skelbiant mokslinius straipsnius.

Platūs V. Babako tarptautiniai ryšiai dažnai padejjo VGTU mokslininkams praplèsti savojo instituto tarptautini bendradarbiavimą.

Tame pačiame VGTU senato posedyje buvo prisimintos Vilniaus inžinerinio statybos instituto ịkūrimo 35-osios metinès. Apie tai pranešimą perskaitè rektorius R. Ginevičius. Baigdamas pranešimą rektorius sakè:

"Gedimino universitete šiandien studijuoja 14000 studentu, desto per 900 profesoriu ir destytoju. Nors palengva, bet stiprëja mūsu finansine padetis ir materialine baze. Mes su viltimi žvelgiame jateiț, nepaisydami skeptiku deklaruojamu minoriniu natu. Ateitis priklauso žiniu visuomenei, ir mes turime daryti viska, kad tokia visuomene būtu sukurta kuo greičiau. Manau, kad tai paskatins mūsu naryste Europos Sajungoje, nuolat gerejjanti krašto ekonomika, krašto saugumas, dalyvaujant Šiaures Atlanto šaliu bendrijoje.

Bet realizuoti visas viltis galime tik nuolatiniu, atkakliu ir sažiningu darbu. To ir linkiu visiems mums, gerbiamieji kolegos! " [6.32, p. 4].

Trisdešimt penktujjų metinių proga ilgiausiai ir produktyviai dirbusieji šioje aukštojoje mokykloje apdovanoti Padekkos raštais.

Šventès baigesi, ir Gedimino universiteto mokslininkai bei darbuotojai paniro į kasdienos darbus.

Buvo iprasta, kad daugiausia stojama studijuoti į Statybos fakultetą. Bet Statybos fakultetas gausus ne tik studentų. Fakulteto

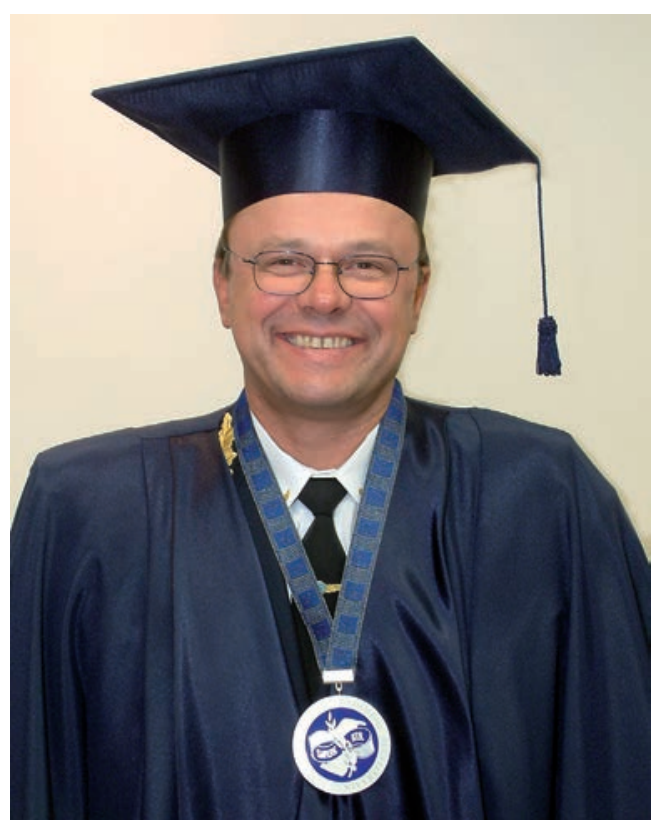

V. Babakas

VGTU Garbès daktaras mokslininkai labai produktyvūs mokslinëje veikloje, literatūros leidyboje. 2004 m. spalị šio fakulteto nariai Gedimino klube Lietuvos statybos inžinierių Vilniaus klubo nariams pristate parengtas ir išleistas tris knygas: J. Gajausko ir kt. „Statybos inžinieriaus žinynas“, R. Sakalausko „Statybininko prisiminimai“ ir E. K. Zavadsko, F. Peldšaus bei L. Ustinovičiaus „Lošimų teorija statybos technologijoje ir vadyboje“.

Rektorius R. Ginevičius, kalbèdamas apie pristatomas knygas, pabrěžè, kad kiekviena knyga viena kitą papildo. „Tai klasika, pažanga, žmogus," - sakè rektorius.

Rektorius R. Ginevičius ir mokslo prorektorius R. Kirvaitis spalio ménesị dalyvavo tarptautines konferencijos „Žinių ekonomika - prabanga ar nacionalines strategijos būtinybé" apskritojo stalo diskusijoje „Aukštojo mokslo reforma žinių ekonomikai“, kurioje buvo karštai polemizuojama su pagarséjusiais radikalizmu profesoriais V. Daujočiu ir A. Janulaičiu.

Spalị VGTU mokslininkai dažnai vyksta į užsienị.

Ukrainoje (Sevastopolyje) tarptautinëje mokslinëje konferencijoje „XXI amžiaus mašinų gamyba ir technosfera" dalyvavo doc. O. Prentkovskis ir prof. H. Sivilevičius. Joje už skaitytą pranešimą „Transporto priemonès judëjimas nelygiu keliu" Olegas Prentkovskis buvo apdovanotas pirmojo laipsnio diplomu.

Chemijos ir bioinžinerijos katedros vedejjas prof. J. Kulys vyko ị Taliną dalyvauti Europos akademijos pasitarime „Tyrimai ir 
VILNIAUS

GEDIMINO

TECHNIKOS

UNIVERSITETAS
Viršuje dešinëje -

"Niujorkas" nakti išsimokslinimas Europoje: regioninis meistriškumas ir platesnes Europos erdvès perspektyvos".

Medžiagu atsparumo katedros vedejjas prof. R. Kačianauskas Gdanske dalyvavo „Framework 5“ programos remiamo kompetencijos centro „Miestų statyba ir reabilitacija" tarybos posedyje, kuriame aptare bendradarbiavimo galimybes, tiriant Vilniaus istorinio paveldo pastatus.

Matematinio modeliavimo katedros vedejjas prof. R. Čiegis lankèsi Taline ir Miunchene, kur technikos universitetuose oponavo disertacijas.

Informacinių sistemų mokslo laboratoriju vedejjas prof. O. Vasiliecas Bulgarijoje dalyvavo tarptautinëje mokslinëje konferencijoje „Inžinerinių ir mokslinių tyrimų sistemų automatizavimas".

Vienu ar kitu tikslu užsienyje lankėsi dar daug kitu universiteto mokslininkų. Buvo svečių iš užsienio ir Vilniaus Gedimino technikos universitete. Visa tai labai naudinga visai VGTU bendruomenei, nes sukauptos iš kelionių žinios, naujos ir senos pažintys su užsienio mokslininkais padeda mūsų universitetui dalykiškai integruotis į Europos Sąjungos mokslo visuomenę, padeda lengviau taikyti Vakarų standartus, kitus norminius dokumentus tiek gamyboje, tiek moksliniuose tyrimuose.

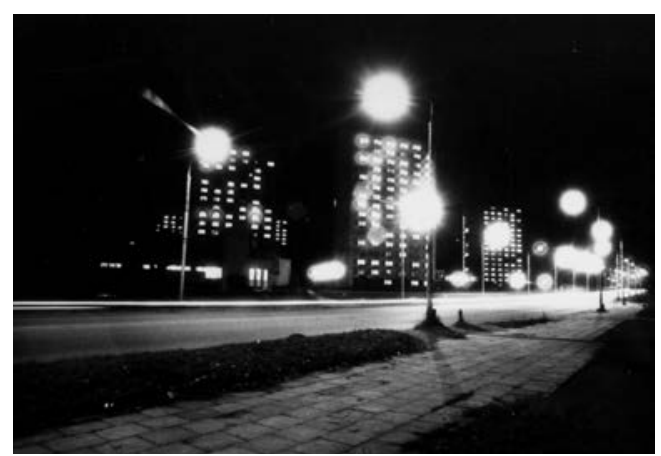

Svarbus yra VGTU bendradarbiavimas ir su gamybos įmonems. Jis duoda abipusę dalykinę naudą. Tokio glaudaus bendradarbiavimo pavyzdys yra VGTU ir Lietuvos statybininku asociacijos susitarimas. $2004 \mathrm{~m}$. spali tarp VGTU ir LSA buvo pasirašytas bendradarbiavimo priemonių planas, galintis būti pavyzdžiu ir kitiems tokiems susitarimams.

Dokumente išdèstyti konkretūs universiteto ir asociacijos îsipareigojimai, prognozuoti laukiami rezultatai, numatyta, kas atsakingas už kiekvieno įsipareigojimo vykdymą. Svarbiausias universiteto įsipareigojimas - nuolat kartu su Statybininkų asociacija tobulinti mokslo ir studiju procesą, taikant naujausius statybos bei pramonés laimejjimus, diegiant vientisą studijų, nuotolinio mokymo, nuolatinio specialistų tobulinimo sistemą. Iš čia seka ir studiju programų, kai kurių temų destymo laiko tikslinimo, gamybinès bei ikidiplomines praktikos organizavimo darbai. Universitetas kartu su asociacijos atstovais

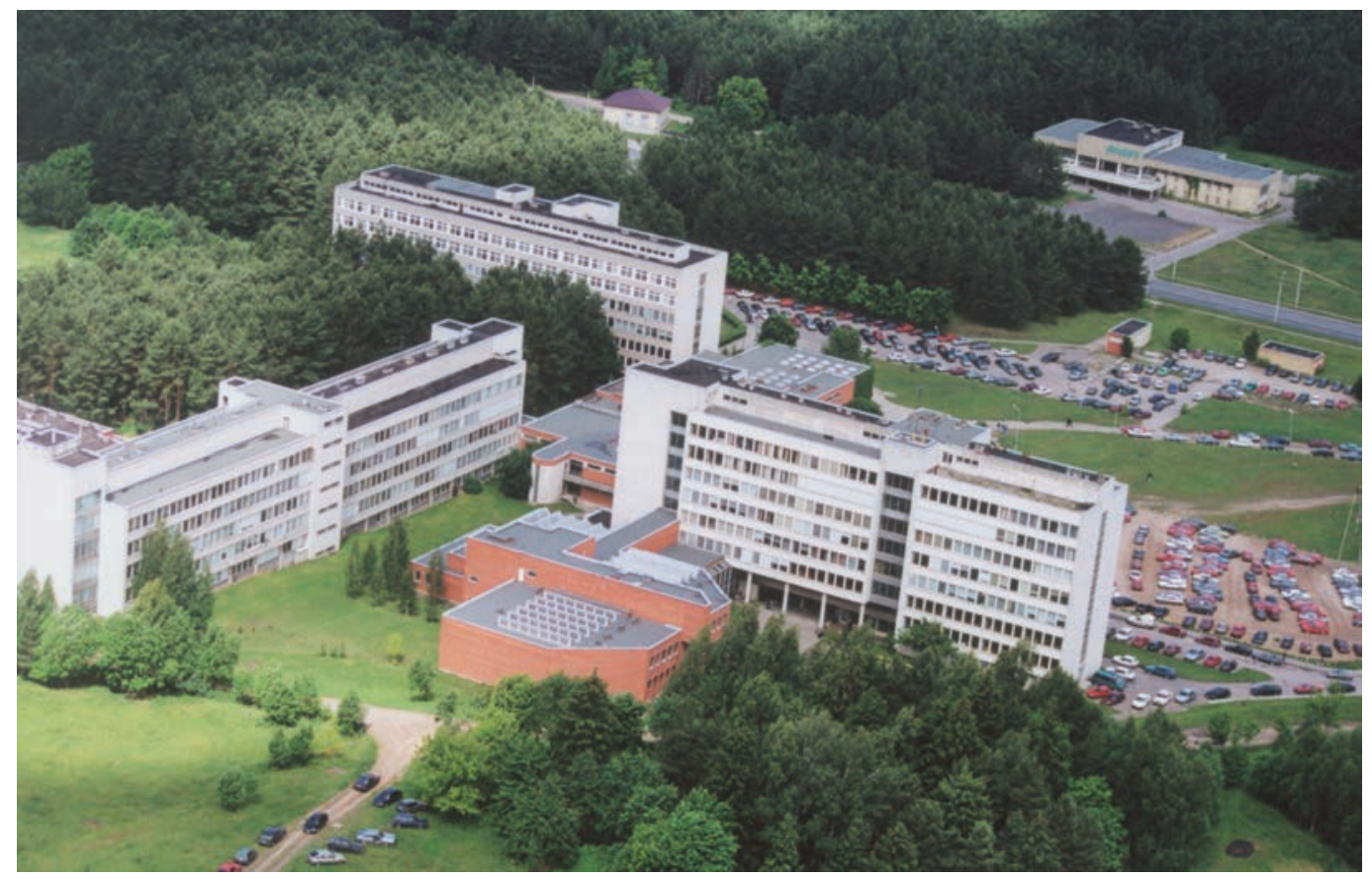


žada derinti naujas studijų programas, jų profiliavimą ir specialistų rengimo planus, kviesti juos skaityti paskaitų. Sudarant studentų baigiamųjų darbų temų sąrašus, atsižvelgti i asociacijos siūlomą tematiką, informuoti bendradarbiavimo partnerius apie organizuojamas mokslines konferencijas, kviesti juos dalyvauti rengiant ir vykdant tarptautinius projektus. Taip pat issipareigota kviesti asociacijos įmones $i$ universiteto organizuojamas Karjeros dienas, teikti joms visokeriopa pagalbą ieškant jaunų specialistų, rekomenduoti gabiausius studentus dirbti asociacijos imonèse.

Statybininkų asociacija įsipareigoja informuoti universitetą apie specialistų poreikį statybos įmonèms, palaikant glaudžius ryšius su VGTU Integracijos ir karjeros direkcija, kviesti mokslininkus dalyvauti jų organizuojamuose seminaruose bei specialistu tobulinimo kursuose. Asociacija žada remti universitetą i̊sigyjant technines priemones, įrengiant mokomąsias laboratorijas, perkant mokslo ir mokymo metodikos medžiagą.

Nepamiršti ir gamybinès praktikos organizavimo klausimai, kvalifikuoti jų vadovai. Statybos inžinerijos krypties asociacijos įmonése apie 50-60 proc. antrojo kurso studentų galetų atlikti keturių savaičių gamybinę praktiką statybos darbų technologijos procesams suvokti, apie 50-60 proc. trečiojo kurso studentų - keturių savaičių gamybinę organizacinę praktiką ir 50-60 proc. pirmojo kurso magistrantų - keturių savaičių gamybinę organizacinę vadybos praktiką. Partneriai pasiryžę tarp asociacijos narių platinti universiteto mokslinę, periodinę literatūrą, sudaryti palankias sąlygas doktorantams dalyvauti eksperimentiniuose tyrimuose, būti aktyviems Absolventų ir bičiulių klubo veikloje bei baigiamųjų darbų gynimo komisijų darbe [6.33, p. 1].

Spalio pabaigoje suaktyvëjo VGTU absolventu ir bičiulių klubo veikla. Absolventų ir bičiulių klubo nariais gali būti ne tik universiteto absolventai, bet ir asmenys, kurie yra neabejingi šiai aukštajai mokyklai. Asmuo, siekdamas tapti klubo nariu, susipažįsta su klubo îstatais, užpildo prašymą, sumoka stojamąji mokestị. Tapęs nariu, asmuo igyja visas teises: dalyvauti universiteto ir klubo renginiuose, inicijuoti ir organizuoti renginius, dalyvauti svarstant klubo veiklos klausimus, naudotis sprendžiamojo balso teise susirinkimuose, reklamuoti savo įmonę, organizaciją klubo internetiniame puslapyje ir VGTU leidiniuose, prisijungti prie klubo narių duomenų bazès ir kt. Absolventų ir bičiulių klubo darbui sèkmingai vadovauja jo prezidentas doc. Romanas Podagèlis. Jam nuoširdžiai talkininkauja Integracijos ir karjeros direkcijos vadovè Arūnè Usonienè.

2004 metų ruduo buvo sèkmingas Vilniaus Gedimino technikos universiteto techninių sporto šakų atstovams. Antano Gustaičio aviacijos instituto studentas Lietuvos klubinès klasès sklandymo varžybose iškovojo bronzos medalị, o pilotas instruktorius Linas Rūtelionis dalyvavo Pasaulio standartinès kategorijos akrobatinio skraidymo čempionate. Tarp startavusių lietuvių L. Rūtelionis šiose varžybose buvo antras. AGAI pirmojo kurso studentas Maksimas Timofejevas kosminio aviamodeliavimo pasaulio čempionate laimëjo sidabro medalị. Be to, jis buvo apdovanotas taure ir diplomu. M. Timofejevas vaikystëje lankè Vilniuje Jaunųjų technikų stoties modeliavimo būrelį ir „užsidege“" aviamodeliavimu. Jis - daugkartinis Lietuvos čempionas. Antroji vieta tarp 200 aviamodeliuotojų iš 18 pasaulio šalių - labai didelis laimejimas. AGAI atstovai gerai pasirode ketvirtajame lekktuvų ralio Lietuvos čempionate. Čempionais tapo AGAI 1-oji komanda - Linas Rūtelionis ir Tomas Mekionis. Antri buvo Dainius Jazdauskas ir Saulius Briedis - AGAI absolventai. Lietuvos precizinio skraidymo čempionate Linas Rūtelionis ir Donatas Latvènas laimejo sidabro ir bronzos medalius, o čempionu tapo AGAI absolventas Dainius Jazdauskas.

Taigi AGAI darbuotojai, studentai ar absolventai savo laimejjimais garsina Antano Gustaičio aviacijos institutą, Vilniaus Gedimino technikos universitetą.

Lapkritį sužinota, kad prof. Pranas Baltrenas yra išrinktas Europos gamtos mokslų akademijos akademiku. Tai gražus darbštaus mokslininko aplinkosaugininko veiklos ivertinimas.

2004 metams baigiantis daug VGTU mokslininkų vyko ị užsienį, daug užsienio mokslininkų atvyko pas mus. Lietuvos mokslų grandų dèmesio sulaukè Lietuvos jaunųjų mokslininkų konferencija „Lietuva be mokslo - Lietuva be ateities“. Plenariniame jaunųjų mokslininkų konferencijos posedyje ši kartą dalyvavo Lietuvos mokslų akademijos viceprezidentas akademikas Algis Piskarskas. Pranešimus, skirtus jauniesiems mokslininkams, skaitè prof. E. K. Zavadskas, prof. A. Šileika, akad. L.Telksnys, prof. J. V. Vaitkus, 
prof. R. Jucevičius, prof. R. Rudzkis ir prof. L. P. Lingaitis. Tokias konferencijas organizuojant didelį darbą atlieka VGTU mokslo prorektorius R. Kirvaitis, Mokslotyros centro vyresnioji mokslo darbuotoja V. Lujanienè. Visi konferencijoje perskaityti pranešimai visuomet išleidžiami atskira knyga.

Gruodžio 9 d. Vilniaus Gedimino technikos universitete įvyko tradicine Lietuvos mokslo istorikų konferencija „Mokslo ir technikos raida Lietuvoje“. Joje perskaityta keliasdešimt pranešimų.

\section{Automobilu keliu mokslo laboratorijos akreditacija}

Gražiais darbais gali pasigirti Lietuvos kelininkai. Malonu, kad šiame procese dalyvauja ir VGTU - vieninteliai Lietuvoje rengiame aukštos kvalifikacijos kelių specialistus. VGTU Kelių katedros mokslininkai atlieka daug kelių ir miesto gatvių statybos, remonto technologijų ir konstrukcijų tyrimų, kelių medžiagų bandymus ir kt.

Metų pabaigoje maloni žinia pasiekè Kelių katedrą - buvo gautas Automobilių keliu mokslo laboratorijos akreditacijos diplomas. Ši laboratorija buvo įsteigta 1999 m. kartu su Vilniaus miesto savivaldybe. Akreditavimo proga Aplinkos inžinerijos fakultete buvo surengtas posedis, kuriame dekanas prof. D. Čygas pabrěže, kad tai ketvirtoji VGTU akredituota laboratorija. Trys iš ju - Aplinkos inžinerijos fakultete. Šis fakultetas pirmauja VGTU daugelyje sričių, tarp jų pagal užsakomuosius mokslo tyrimus. Rektorius R. Ginevičius sakè, kad tai sektinas pavyzdys visų fakultetų, mokslo padalinių vadovams ir darbuotojams.

Be akreditacijos pažymejjimo, Automobilių kelių mokslo laboratorija turi dar du Aplinkos ministerijos atestatus. Vienas suteikia teisę atlikti dalinę statinio projekto ekspertizę, techninę statinio ekspertizę bei finansinę ekonominę statinio ekspertizę susisiekimo statiniu grupei. Darbo sritis statinių konstrukcijos. Kitas - teisę atlikti statinio dalies projektavimo darbus, vykdyti statinio statybos techninę priežiūrą. Statiniu kategorijos - ypatingi statiniai. Statiniu grupès - susisiekimo komunikacijos: automobiliu (valstybines ir vietinés reikšmès) keliai ir miesto gatves, geležinkelio ir oro transporto bei pésčiųjų judejimo vietos, tarp ju - inžineriniai statiniai ir pastatai šių komunikaciju reikmèms tenkinti (išskyrus viešojo naudojimo pastatus). Projektavimo darbo sritis: konstrukcine, pasirengimo statybai ir statybos darbų organizavimo, ekonominè.

Rezultatai pristatomi aukšto rango tarptautinèse konferencijose, skelbiami prestižiniuose moksliniuose žurnaluose, konferencijų ir kongresų recenzuojamuose darbuose. Atskirai galima pažymetti didžiuli šių darbų indèli rengiant nepriklausomos Lietuvos automobilių kelių ir gatvių normatyvinių dokumentų bazę.

Laboratorijai išduotas akreditavimo pažymëjimas suteikia galimybę gauti dar daugiau užsakomųjų darbų. Kartu besąlygiškai ịpareigoja užtikrinti šių darbų atlikimo kokybę. Toks aukštas laboratorijos ịvertinimas prisidés prie Lietuvos automobilių kelių ir gatvių dangų kokybes gerinimo, jų funkcionavimo trukmès didinimo, mokesčiu moketoju pinigu taupymo $[6.34$, p. 3$]$.

Rektoriaus R. Ginevičiaus Senatui pateiktoje ataskaitoje pabrèže, kad $2004 \mathrm{~m}$. Vilniaus Gedimino technikos universitetas ženge didžiulį žingsnį mokslo srityje. Jis teige, kad mokslas yra universitetinių studiju kokybes sąlyga.

VGTU mokslininkų laimèjimus liudija pagrindiniai pasiekti rodikliai: turime doktorantūros teisę 15 mokslo krypčių, apgintos 32 daktaro disertacijos (didžiausias doktorantūros efektyvumas Lietuvoje), ìvyko aštuonių mokslininkų habilitacijos procedūros, suteiktas vienas profesoriaus pedagoginis vardas, aštuoniems daktarams - docento pedagoginiai vardai.

Pernai atlikta užsakomųju darbų ir paslaugų beveik už 6,4 mln. Lt, iš jų Aplinkos inžinerijos fakultetas - už 2,6 mln. Lt. Iš žsakovu gautos lěšos pasiskirste taip: iš valstybiniu instituciju - 34 proc., iš ūkio subjektų - 34 proc., iš savivaldybių -8 proc., už tarptautinius projektus - 16 proc., iš Valstybinio mokslo ir studiju fondo -8 proc. 
Dvigubai daugiau negu ankstesniais metais lěšų gauta už dalyvavimą tarptautiniuose projektuose.

Bendras publikacijų skaičius padidejjo 20 proc. ir siekè beveik 1,5 tūkstančio. „Labai svarbus rodiklis, - sake rektorius, - straipsniu su ISI indeksu dinamika: 2003 m. - 25, $2004 \mathrm{~m}$ - 35. Dar ryškesne ISI vadinamuju "procidingy" moksliniu darbu dinamika: 2002 m. - 7, 2003 m. - 25, 2004 m. - 135. 2003-2004 m. už publikuotus straipsnius uždirbta per 4,0 mln. Lt. Islleista 13 monografiju, 50 kitokio pobüdžio knygu, surengtos 28 konferencijos ir seminarai, buvome aktyvūs išradybineje veikloje. Tik gaila, kad sioje veikloje nevienodai aktyviai dalyvauja visu fakultetu, katedru bei laboratoriju mokslininkai. Pamažu daugëja publikaciju autoriu, ir tai džingina. Apskritai mokslas negali būti epizodinis: kai daroma nuolat, gaunami reikšmingi rezultatai".

Universiteto vadovas paragino visus būti aktyvesnius siekiant dalyvauti nacionaliniuose projektuose ir pasidžiaugè, kad aktyviai plečiasi išorëje veikiančių fakultetu sąrašas. Jo nuomone, metų fakultetu galima laikyti Architektūros fakultetą, kuris atkūre doktorantūros teisę, pradejo aktyviai organizuoti ịvairaus lygmens konferencijas ir, kas labai svarbu, gauti milijoninius užsakymus iš miestų savivaldybių (doc. Algis Vyšniūnas, Urbanistikos katedra).

\section{Kultūros premijos}

2005 metų pradžioje sužinota apie dviejų VGTU darbuotoju gautas premijas. Lietuvos Respublikos kultūros ministerija premiją „ „Ǔ̌ aktualiausius ir ryškiausius publicistikos kūrinius" paskyre Vilniaus Gedimino technikos universiteto Architektūros pagrindų ir teorijos katedros destytojui Almantui Samalavičiui. A. Samalavičius „Kultūros baru“ “žurnale paskelbe daug straipsnių tautinių stereotipų, Rytų ir Vidurio Europos kultūrinio tapatumo klausimais. Jis taip pat nagrinejo kolektyvinès bei individualios atminties pokomunistineje visuomeneje problemas. A. Samalavičius pirmasis Lietuvoje nagrinëja kultūros atminties problematiką.

Telšiu rajono savivaldybe ir Karolinos Praniauskaites centrinès bibliotekos Martyno Mažvydo premiją gavo VGTU Žiniasklaidos ir renginių direktoriaus pavaduotojas, laikraščio „Inžinerija“ vyriausiasis redaktorius Julius

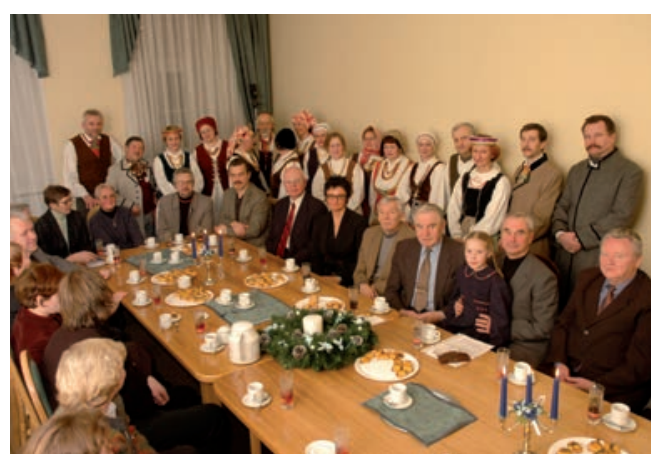

„Gedimino klube" periodiškai vyksta idomus renginiai
Norkevičius už daugelį metų atliekamą savojo krašto kraštotyros darbą.

Abi premijos - A. Samalavičius ir J. Norkevičiaus - reikšmingos Technikos universitetui, nes humanistines srities darbų VGTU nèra daug.

VGTU mokslininkai susiję ir su branduolinès energetikos tematika. Šiai sričiai pletoti reikšminga pasirašyta bendradarbiavimo sutartis tarp VGTU ir Valstybines atominès energetikos saugos inspekcijos (VATESI). Sutartį pasiraše universiteto rektorius prof. Romualdas Ginevičius ir VATESI viršininkas Saulius Kutas. Šalys įteisino vykstanti bendradarbiavimą branduolinès energetikos srityje, tobulinant branduolinès energetikos objektų saugą. VATESI įsipareigojo sudaryti sąlygas VGTU specialistams bendruose projektuose, kvalifikacijos kèlimo renginiuose, naudotis tyrimams reikalingu VATESI turtu. Universitetas įsipareigojo konsultuoti ir teikti ekspertinę bei techninę paramą. Taip pat atlikti darbus konstrukcijų mechanikos ir skaitinio modeliavimo, medžiagotyros ir suvirinimo technologiju, statybiniu technologijų ir konstrukcijų, darbo ir priešgaisrinès saugos, branduolinès hidrofizikos srityse. Sutarties koordinatoriumi paskirtas Medžiagų atsparumo katedros vedejjas prof. Rimantas Kačianauskas, kuris yra ir VATESI Mokslinès techninès paramos organizaciju koordinacinès tarybos pirmininkas [6.36, p. 3].

Sausio 13 diena kasmet prisimenama kaip 1991 metais žuvusių kovoje už laisvę didvyrių diena. VGTU atstovai aplanke Antakalnio kapines ir ant Rolando Jankausko kapo padẻjo gèlių, uždegè žvakutes. I̦simintiną kalbą apie nepamirštamus sausio įvykius pasake prof. E. K. Zavadskas.

Gauta žinia, kad nuo 2005 m. VGTU Transporto mokslo institutas priimtas ị Europos transporto tyrimų institutų asociaciją. 1998 m. įkurtas Transporto mokslo institutas, negaudamas biudžetinio finansavimo, 
VILNIAUS

GEDIMINO

TECHNIKOS

UNIVERSITETAS

Viršuje dešinëje -

Vaizdo studija

Vaizdo studijos atidarymas

Iš kairès: A. Monkevičius, R. Motuzas, R. Ginevičius

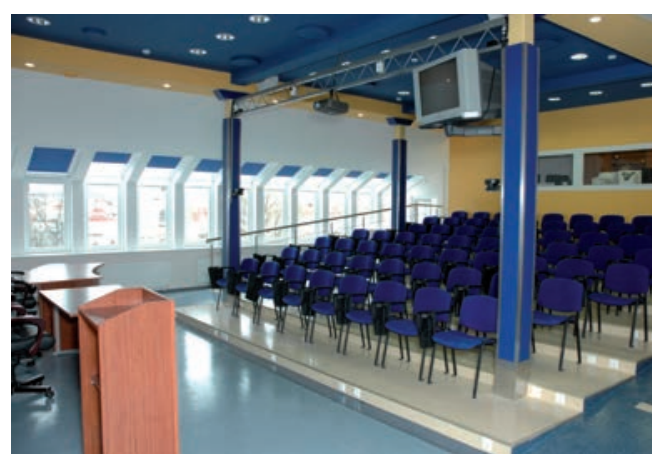

sèkmingai vykdo transporto sistemos veiklos strategijos ir prognozavimo, ivvairių transporto rūšių technologijų tobulinimo plettros bei kitus tyrimus. Jo darbuotojai dalyvauja kuriant transporto sistemos veiklą reglamentuojančių îstatymų ir poịstatyminių aktų projektus. Institutas taip pat telkia Lietuvos transporto mokslininkus fundamentaliems darbams bei tikslinems programoms vykdyti.

2005 m. pradžioje Architektūros rūmuose buvo pristatyta naujai įrengta moderni, aprūpinta naujausia technine įranga VGTU vaizdo studija. Renginyje dalyvavo Lietuvos švietimo ir mokslo ministras Remigijus Motuzas, Seimo narys Algirdas Monkevičius, Lietuvos rektorių konferencijos pirmininkas Vytautas Kaminskas, VGTU rektorato nariai, Architektūros fakulteto šeimininkai. Naujoji vaizdo studija pades plètoti, tobulinti nuotolinị mokymą, užtikrins aukštesnę studiju kokybę. Ministras R. Motuzas pabrèžè, kad koordinuojant ir vykdant programas „Informacines technologijos mokslui ir studijoms" ir „Lietuvos mokslo ir studiju kompiuteriu tinklas" nekyla jokių nesutarimų tarp ministerijos, aukštųjų mokyklų, mokslo institucijų. Tai vienintele perspektyvi sritis, kuri gali mus suartinti, suglaudinti ir igyvendinti daugelį svarbių kitos srities projektų. Studijų prorektorius doc. Alfonsas Daniūnas sakè, jog įrengti šią vaizdo studiją skatino du nūdienos padiktuoti tikslai: nuotolinio

mokymo plètra ir mūsų universiteto siekis užtikrinti aukštesnę studijų kokybę, gerinti studijų materialinę bazę, aprūpinti ja naujausia šiuolaikiškos technologijos įranga. Nuotolinių studijų centru priklausančioje ir prižiūrimoje vaizdo konferencijų studijoje sudaromos puikios galimybes transliuoti, klausytis ar dalyvauti vienu metu skirtingose vietose vykstančiose paskaitose, seminaruose, konferencijose, pristatymuose ir gynimuose. Nuotolinių studijų centrui priklausančioje ir prižiūrimoje klasëje transliuojamos vaizdo konferencijos, paskaitos, kursai ir seminarai, nuotoliniu būdu egzaminuojami studijuojantieji VGTU studentai.

2005 m. sukurta papildoma virtuali Nuotolinių studijų centro tarnybiné stotis ir įdiegta programinè įranga, skirta pasaulinius nuotolinio mokymosi kursų rengimo standartus SCORM (Sharable Con-tent Object Reference Model) atitinkančiai virtualiai mokymosi terpei IBM Lotus Learning Management System Aitthoring Tool palaikyti. Joje integruoti įrankiai leidžia organizuoti nuotolines

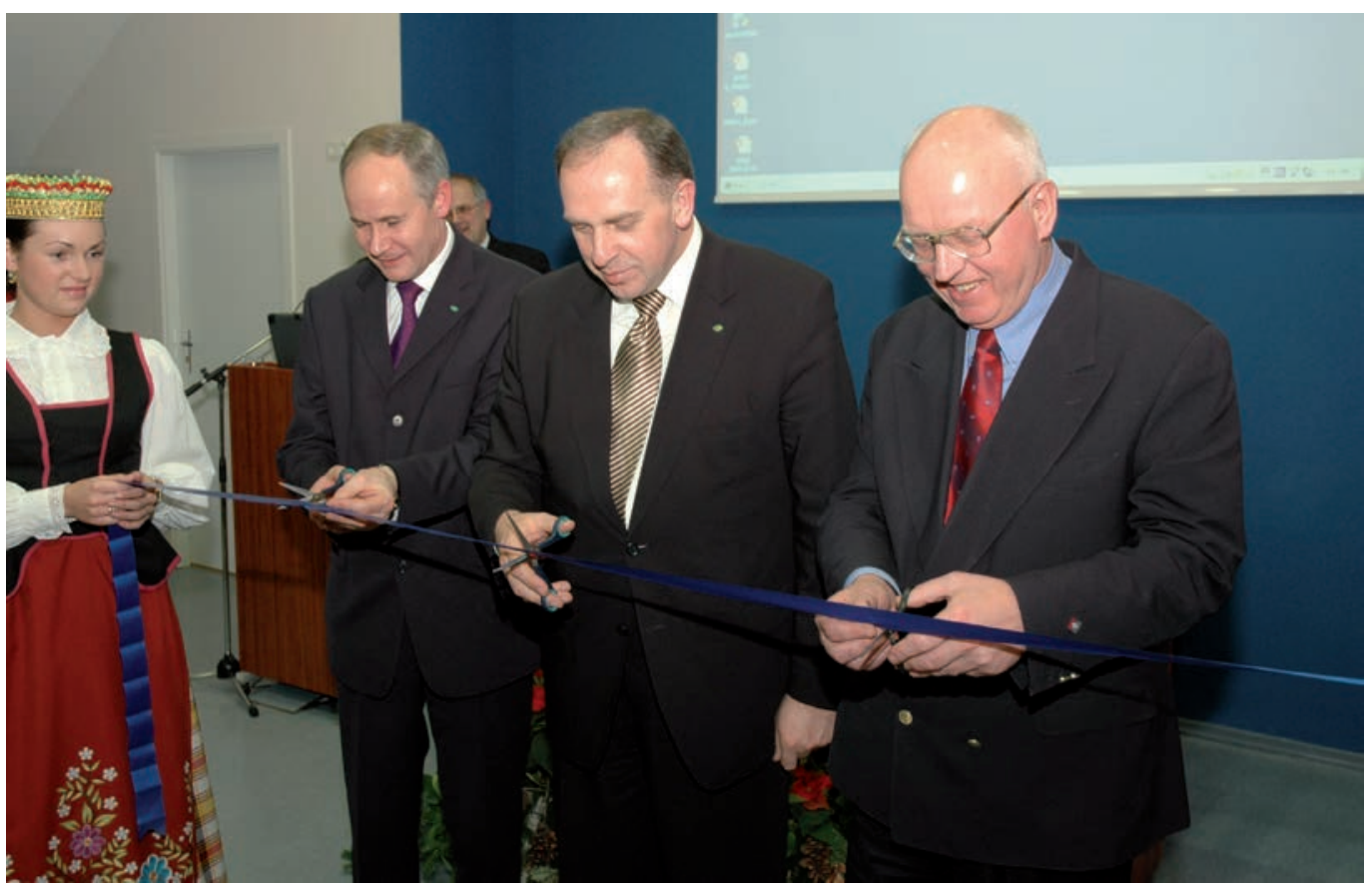


studijas internetu, tam naudojant tokias priemones, kaip diskusijos, pokalbių kambariai, žodynai, elektroninis paštas, kalendoriai, testai, savikontroles klausimynai ir kt. Tikimasi, kad visiškai baigus visus diegimo, derinimo ir bandymo darbus, bus sudarytos sąlygos ne tik naudotis minetomis galimybemis, bet ir teikti, eksploatuoti nuotolinių studijų modulius, parengtus naudojant kitą programinę irrangą [6.36, p. 10].

\section{Bičiuliai susitiko „Hanner“ dangoraižyje}

2005 m. vaisinga veikla pasižymèjo VGTU absolventų ir bičiulių klubas, kurio prezidentas yra Romanas Podagèlis. Buvo organizuojami dažni klubo renginiai, davę naudos ju dalyviams. Sausio menesi klubo nariai apsilanke „Hanner“ verslo centre, kurio valdybos pirmininkas yra VGTU absolventas Arvydas Avulis. I renginị susirinko per 20 klubo narių. Susitikimo šeimininkas A. Avulis papasakojo apie „Europos“ pastatu kompleksą, kurį sudaro verslo, prekybos centrai ir gyvenamasis daugiaaukštis namas. Iš dangoraižio 31-ojo aukšto susirinkusieji pasigrožèjo Vilniaus žiemos panorama. Kadangi svečiai buvo daugiausia inžinieriai, A. Avulis išsamiai supažindino su verslo pastato konstrukcine sandara, moderniomis apsaugos priešgaisrinèmis priemonèmis, efektyvia oro vedinimo sistema, automobilių laikymo galimybemis.

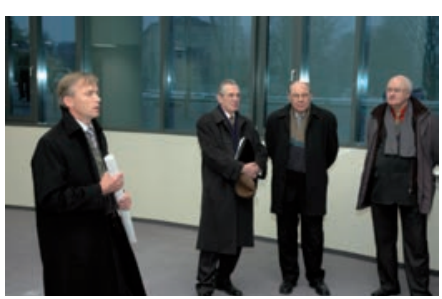

„Hanner" vadybos pirmininkas A. Avulis pasakoja apie pastatu kompleksa

„Europa“"

Architektas - VGTU Architektūros katedros doc. A. Ambrasas

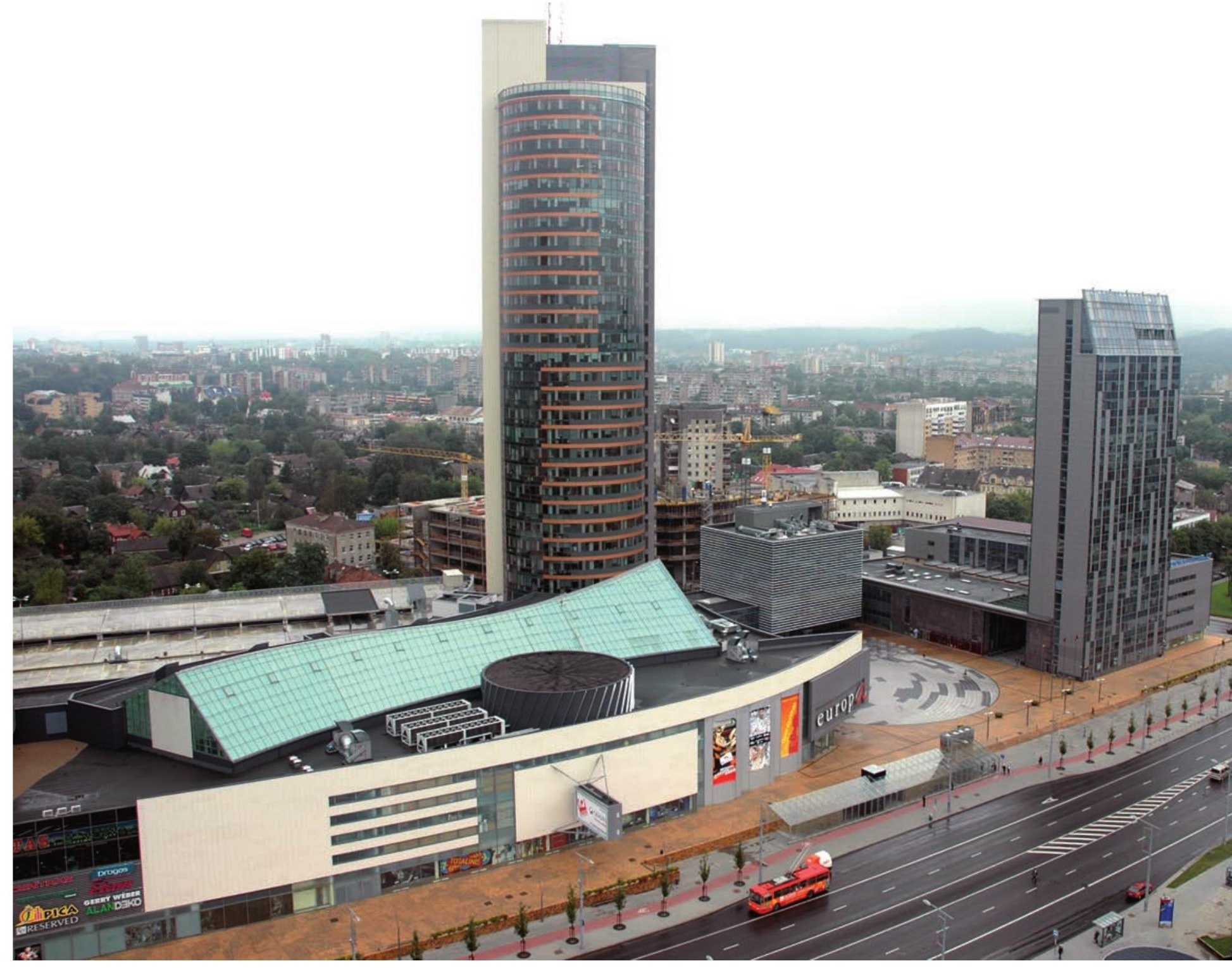


VILNIAUS

GEDIMINO

TECHNIKOS

UNIVERSITETAS
Po ekskursijos įvyko nuoširdi diskusija apie verslo, mokslo ir studiju problemas, kalbeta ir apie būsimą 2006 m. Vilniaus Gedimino technikos universiteto jubilieju - veiklos 50-ąsias metines. Rektorius prof. habil. dr. Romualdas Ginevičius, prorektoriai, kai kurie kiti susitikimo dalyviai pasidžiauge, kad šalies Vyriausybès 2004-2008 m. programa numato nuosekliai didinti mokslo ir kt. sričių finansavimą. Tai teikia vilčių universiteto darbui gerinti. Sausị Aplinkos ministerija apsvarste Statybos fakulteto Gelžbetoninių ir mūrinių, Metalinių ir medinių konstrukcijų katedrų mokslininkų paruoštas pirmąsias
Lietuvos istorijoje nacionalines visų statybinių konstrukcijų (betoninių, gelžbetoninių, mūrinių, metalinių, aliuminio, medinių, silikatbetonio ir armocemenčio) projektavimo normas.

Tai labai didelis ir atsakingas darbas - juk reikëjo apibendrinti visą sukauptą mūsų ir kitose šalyse konstrukcijų skaičiavimo, projektavimo patyrimą ir, vadovaujantis pagrindiniais Euronormų projektavimo principais, sukurti projektavimo reglamentus, tinkamus pereinamajam laikotarpiui, kol bus galutinai parengtos visos Euronormos. Deja, tokie atsakingi šaliai darbai nèra tinkamai įvertinami. Teigiama, kad jie šaliai duoda menkesnę naudą, negu užsienyje paskelbtas straipsnis anglų kalba, kuris kažin ar kada pasieks Lietuvos statybininkus.

\section{Svečiuose istorikas akademikas E. Gudavičius}

$2005 \mathrm{~m}$. vasario $16 \mathrm{~d}$. universitete įvyko renginys, skirtas Vasario 16-ajai - Lietuvos valstybes atkūrimo dienai - paminèti. Renginyje dalyvavo Lietuvos mokslų akademijos tikrasis narys, Nacionalines ir Lietuvos mokslo premijos laureatas Edvardas Gudavičius, VGTU Garbès mecenatas Gediminas Orentas, universiteto vadovai, destytojai, darbuotojai, studentai. Izžymusis istorikas E. Gudavičius apžvelgè mūsų tautos istoriją, papasakojo, kaip ateita iki Vasario 16-osios, akcentavo istorinę šios datos reikšmę. Svečias atsake į daug klausimų. Renginyje 90-mečio proga buvo pasveikintas VGTU mecenatas G. Orentas. Pasveikinti mokslininkai, pelnę Lietuvos mokslo premijas: LMA narys korespondentas, habilituotas daktaras, profesorius E. K. Zavadskas, habilituotas daktaras profesorius A. Kaklauskas, habilituotas daktaras profesorius J. Vanagas ir Lietuvos mokslu akademijos korespondentas, habilituotas daktaras profesorius V. A. Bumelis.

Technologijos moksly srities premiją pelne profesoriai Edmundas Kazimieras $\mathrm{Za}$ vadskas ir Artūras Kaklauskas už darbų ciklą "Statybos šakos modeliavimas (metodai, modeliavimas, sprendimu paramos ir informacines sistemos, internetinès technologijos, praktiniai taikymai (1996-2003 m.)".

Iš keturių taikomosios mokslinès veiklos (eksperimentinès pletros) premijuotu darbų - du mūsiškiai. Tai Urbanistikos katedros profesorius Jurgis Vanagas, pelnęs mokslo premiją už darbų ciklą „Vilniaus ir Kauno dvimiestis: Lietuvos didmiesčiu urbanistines sandaros ir pletros modeliavimas (1969-2003 m.)“. Premija įvertintas ir mūsų universiteto Senato ir UAB „SICOR Biotech" direktoriu komiteto pristatytas Bioinformatikos mokslo laboratorijos vedëjo prof. Vlado Algirdo Bumelio ir jo kolegu Mykolo Maurico, Vytauto Naktinio, Jono Henriko Pesliako biomedicinos mokslo darbu ciklas „Terapiniai rekombinantiniai baltymai ir jų naudojimas medicinoje (1983-2003 m.)“.

Vasario pabaigoje - kovo pradžioje VGTU prorektorius A. Daniūnas, studiju programu koordinatore B. Tamulaitiené, TSC vadybininke R. Bubliené dalyvavo Kinijos LR sostineje Pekine surengtoje parodoje-mugeje. Studijomis VGTU domejosi kinai mokiniai ir ju tevai. Daugiausia kinai nori studijuoti verslą, informatiką, mechaniką, architektūrą. Po parodos VGTU atstovai susitiko su Lietuvos ambasadoriumi KLR A. Žurausku ir aptare kinų galimybes studijuoti Lietuvoje.

2005 m. kovo 11-osios proga „Inžinerijoje“ J. Norkevičius paskelbè medžiagą apie studentų apklausą: ką jie žino apie Kovo 11-ąją ir ką ši švente reiškia jiems, ju tèvams, draugams, giminems. Absoliuti dauguma studentų atsake, kad jiems Kovo 

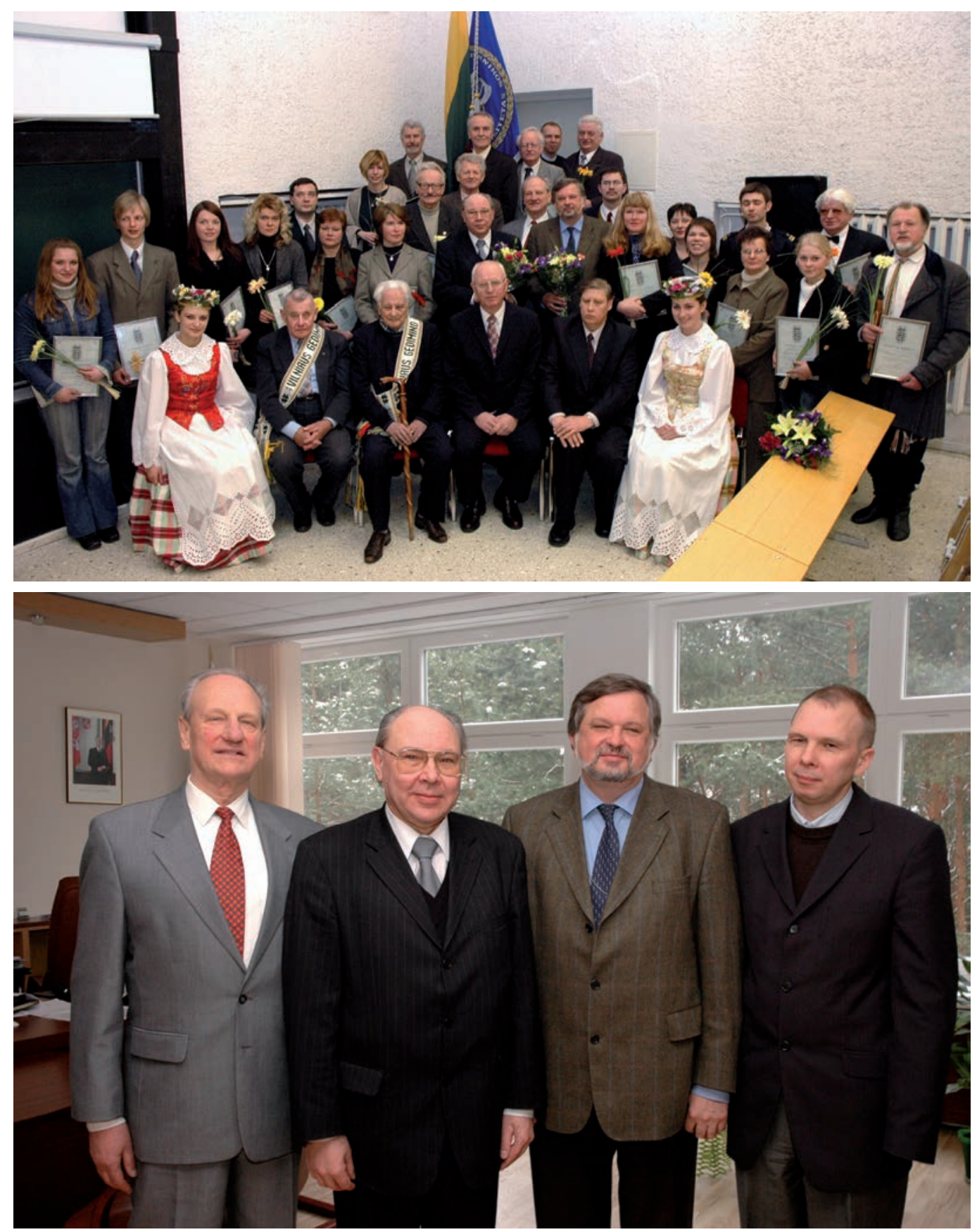

LMA iteikus nacionalines mokslo premijas. Iš kairés: J. Vanagas, E. K. Zavadskas, V. A.Bumelis, A. Kaklauskas

11-oji - labai reikšminga data. Anot R. Bučylos, „Kai žmogus laisvas ir nepriklausomas, jis gali visapusiškai išreikšti save, savo mintis ir idejas“, o anot T. Vailionio, „...atgave nepriklausomybe, nors labai letai ir sunkiai, pradëjome tikètis geresnio ir nevaržomo gyvenimo“. A. Ustinovičius teigia: „Gera, kai esi laisvos ir nepriklausomos Lietuvos pilietis “.

2005 m. kovo 18 d. mūsu universitete apsilanke Gruzijos švietimo ir mokslo ministras A. Lomaia, lydimas savo šalies konsulo. Svečias papasakojo VGTU vadovams apie Gruzijos švietimo ir mokslo problemas, domëjosi, kaip panašios problemos sprendžiamos Lietuvoje. Ji domino studijų programų akreditavimas, studijų ir universiteto kitų darbo baru kompiuterizavimas, užsienio studentų studijos, Bolonijos proceso principu igyvendinimas VGTU. Susitikime pas rektorių prof. R. Ginevičiu dalyvavo prorektoriai, kancleris, kai kurių fakultetų dekanai, Tarptautinių studijų centro direktorius.

2005 m. kovo 22 d. Architektūros rūmuose buvo atidaryta dailès ir architektūros kūrinių galerija. Joje periodiškai bus eksponuojami VGTU ir kitu aukštujju mokyklu darbuotojų, studentų, menininkų kūrybos darbai.

Jau po savaites buvo atidaryta dar viena nauja galerija VGTU bibliotekoje, kurioje numatyta ekspozicijas keisti kas mènesi. 
VILNIAUS

GEDIMINO

TECHNIKOS

UNIVERSITETAS

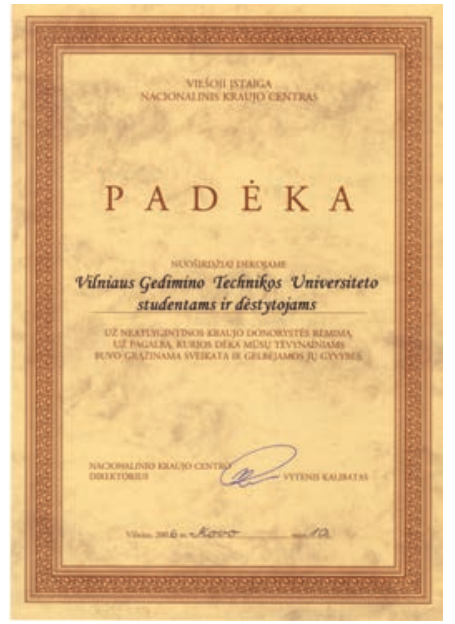

Padeka VGTU donorams

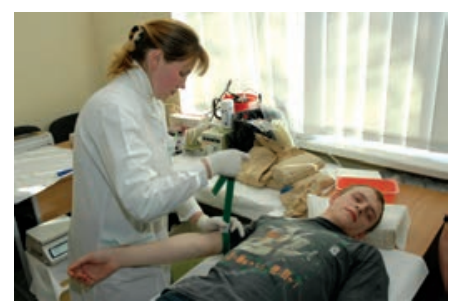

Remigijaus Kuto. Periodiškai atnaujinama programine įranga, stiprèja materialinè bazè.

Skaičiavimo centro lygiagrečiųjų skai-

Labai malonu, kad gerai vertinami Vilniaus Gedimino technikos universiteto jaunųjų mokslininkų darbai. Lietuvos mokslų akademijos prezidiumas paskyre premijas jaunųjų mokslininkų ir studentų darbų konkurso nugaletojams, tarp kurių buvo ir VGTU atstovai.

Technikos mokslų skyriaus premija skirta Vandentvarkos katedros docentei dr. Marinai Valentukevičienei už darbą „Adsorbcijos procesų naudojimas šalinant nepageidaujamas medžiagas iš gamtinio vandens".

Aukštųjų mokyklų studentų mokslinių darbų konkurso Technikos mokslų skyriaus premija skirta Mechanikos fakulteto magistrui Valentinui Varnauskui už darbą „Suvirinimo elektrodu glaisto komponentų įtaka prilydyto metalo savybèms".

Švietimo ir mokslo ministras paskyre Lietuvos atstovus ir ekspertus Europos Sajungos 6BP specialiųjų programų komitetuose. Tarp jų - ir trys mūsų universiteto mokslininkai.

Programos „Europos mokslinių tyrimy erdves sujungimas ir stiprinimas" komitete temos „Aeronautika ir erdves tyrimai“ Lietuvos atstovu paskirtas prof. habil. dr. Jonas Stankūnas, Antano Gustaičio aviacijos instituto direktorius. Tos pačios programos komitete temos „Subalansuotoji plètra, globalūs pokyčiai ir ekosistemos" potemio „Tvarusis paviršiaus transportas" ekspertu paskirtas prof. habil. dr. Ramūnas Palšaitis, Transporto vadybos katedros vedejas. Programos „Europos mokslinių tyrimų erdves struktūrizavimas" komitete temos „Ž mogiškieji ištekliai ir mobilumas" Lietuvos atstovu paskirtas doc. dr. Liudas Rimkus, Mokslo direkcijos direktoriaus pavaduotojas.

Net 248 Vilniaus Gedimino technikos universiteto studentai ir darbuotojai dalyvavo Nacionalinio kraujo centro surengtoje gerumo akcijoje ir tapo donorais - dave kraujo, kuris tikriausiai ne vienam žmogui išgelbëjo gyvybę.

Už ypatingą pagalbą, padedant igyvendinti donorystés akciją, Nacionalinis kraujo centras dekojo VGTU fakultetų donorams, dekanams, dèstytojams, kancleriui Arūnui Komkai bei Darbuotojų saugos ir sveikatos skyriaus vedejui Feliksui Katinui.

Nuolat tobuleja VGTU Skaičiavimo centras, vadovaujamas direktoriaus doc. dr. čiavimų laboratorija pristate modernizuotą VGTU asmeninių kompiuterių klasterį „,Vilkas". Jis papildytas dideles spartos tinklo komutatoriais, atnaujinta sistemine programine įranga, leidžianti efektyviau administruoti vartotojus bei skirstyti klasterio išteklius užduotims vykdyti.

Dabar tai viena galingiausių lygiagrečiujų skaičiavimų sistemų Lietuvoje, turinti 26 procesorius su 26 GB operatyviosios atminties bei 5,6 TB išorinès atminties diskais. Atlikus klasterio greitaveikos testus, pasiektas pikinis 130,4 Gflops slankiojo kablelio operacijų apdorojimo greitis. Šie rezultatai desningi. Tai dešimties metų kryptingo darbo, plètojant lygiagrečiuosius skaičiavimus mūsų universitete, rezultatas. Šiuos faktus, pristatydamas atnaujintą klasteri, pateike Matematinio modeliavimo katedros vedejjas prof. Raimondas Čiegis.

Gražaus jubiliejaus proga buvęs Architektūros fakulteto dekanas prof. habil. dr. Konstantinas Jakovlevas-Mateckis buvo apdovanotas Lietuvos architektų sąjungos Garbès žymeniu „Už nuopelnus Lietuvos kraštovaizdžio architektūrai“.

Parengta ir patvirtinta nuotolinių studiju modulių kokybès įvertinimo sistema, kuri leis sudaryti sąlygas efektyvesnems nuotolinems studijoms. Patvirtinta Vilniaus Gedimino technikos universiteto nuotolinių studiju modulių medžiagos akreditavimo bei jos prilyginimo mokomosios literatūros leidiniams laikinoji tvarka. Pagal šią tvarką $2005 \mathrm{~m}$. rudenį buvo akredituoti pirmieji nuotolinių studijų moduliai.

$2005 \mathrm{~m}$. balandžio $5 \mathrm{~d}$. Lietuvos mokslų akademijoje vyko jos prezidento rinkimai. I LMA prezidentus balotiravosi ir VGTU Chemijos ir bioinžinerijos katedros vedejas akademikas Juozas Kulys. Savo rinkimų programoje jis rašè:

„Mano, kaip Moksly akademijos prezidento, veiklos tikslai sutampa su bendriausiais MA tikslais: telkti mokslines pajegas svarbiausioms Lietuvos mokslo, kultūros, kalbos, ükio bei socialines pažangos problemoms spressti; skatinti ir palaikyti Lietuvoje aukšta moksliniu tyrimu ir studiju lygi; ugdyti mokslininku asmenybes ir individualybes, büti Lietuvos mokslininku intelektiniu centru; skatinti ir vykdyti bendrus ivairiu disciplinu fundamentinius tyrimus; ska- 
tinti ir padeti organizuoti mokslini Lietuvos ir kitu saliu mokslo centru bendradarbiavima; būti mokslo ekspertu mokslo ir studiju, technikos, ükio, kultūros, socialinès raidos, aplinkos apsangos, sveikatos apsangos ir kitais klausimais " $[6.37$, p. 2].

Lietuvos moksly akademijos prezidentu buvo išrinktas Zenonas Rokus Rudzikas. Fizikas, habilituotas daktaras, akademikas, Lietuvos mokslo, Källen (Švedija), A. Jucio premijų laureatas Zenonas Rokus Rudzikas yra parašęs daugiau kaip 280 mokslinių publikacijų teorines fizikos ir jos taikymų srityje klausimais. Jis taip pat yra 5 monografiju, spausdintų Vilniuje, Leningrade, Taline, Maskvoje, Kembridže, autorius arba bendraautoris. Mokslininkas skaite pranešimus ir paskaitas JAV, Kanados, Italijos, Didžiosios Britanijos, Švedijos, Vokietijos ir kitu valstybių mokslo centruose. Jau 1992 m. „istojo“ i NATO, o 1994 m. - i ES, vadovaudamas ju finansuojamiems tarptautiniams projektams. Prezidentas turi ne vienerių metu vadovavimo patirtį, yra daugelio mūsų šalies, Europos ir tarptautinių organizacijų narys bei vadovas.

Akademiką Zenoną Rokų Rudziką, išrinktą MA prezidentu, universiteto bendruomenes vardu pasveikino rektorius prof. Romualdas Ginevičius ir Senato pirmininkas prof. Donatas Čygas.

Vèl puikiai pasirode VGTU „Vingio“ šokejai ir muzikantai, vadovaujami Rimutes Zaleckaites, Ričardo Tamučio ir Antano Jonušo.

Balandžio 16-17 d. vykusiame dainų ir liaudies šokių festivalyje „Kadagys-2005“ mūsų universiteto tautinių šokių ansamblis apdovanotas I laipsnio diplomu. Taip pat už geriausiai atliktą kūrinị skrabalais dainų ir šokių ansamblių kategorijoje apdovanojimas itteiktas vingiečiui Elektronikos fakulteto studentui Augustinui Ruibiui.

Šeštajame jaunimo teatrų forume, kurį organizavo Universitetų teatrų asociacija kartu su VU ir VGTU, mūsų teatras „Palepé“, režisuojamas Olego Kesmino, rode Sauliaus Šaltenio bei Nigel Wiliams spektaklius

Forumas vyko devizu „Mano erdve“. Tai iprasminta suvokimu - „Teatras kaip dvasine architektūra", tai požiūris ị dvasinès kultūros paveldo objektus kaip į erdvę, kurioje galima realizuoti savo menines fantazijas. Malonu, kad VGTU teatras nuolat ieško naujovių, kad studentai-artistai yra dideli šio meno žanro entuziastai.

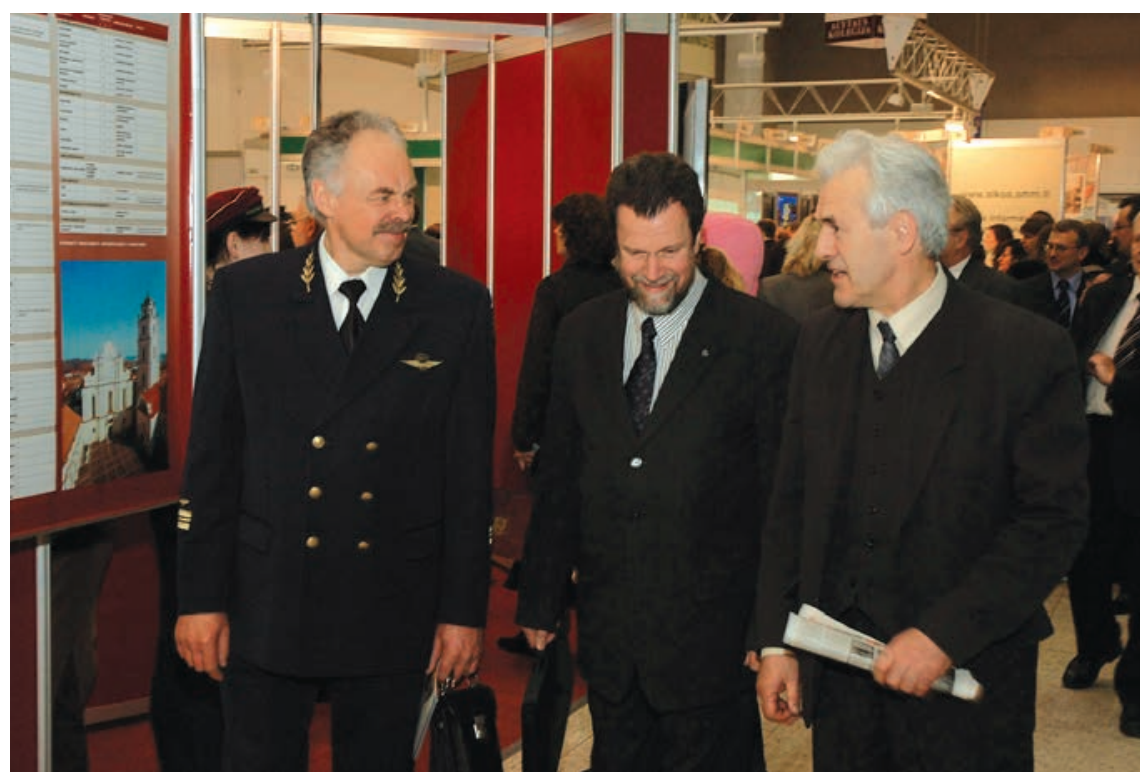

LMA prezidentas Z. R. Rudzikas (pirmas is dešines) su VGTU profesoriais R. Kirvaičiu ir J. Stankūnu

VGTU studentai puikiai pasirodo ir kaupdami žinias, kurios lems jų profesini pasirengimą.

2005 metų Lietuvos universitetų studentų medžiagų mechanikos ir atsparumo respublikinëje olimpiadoje, kuri vyko Šiauliuose, Vilniaus Gedimino technikos universiteto CI-3/1 gr. studente Žydra Šernaite laimejo pirmąją vietą. Ketvirtas buvo CI-3/2 gr. studentas Arnas Sudeikis.

2005 m. gegužès 7 d. Gedimino klube buvo pamineta Spaudos atgavimo, kalbos ir knygos diena. Susirinkusieji stebejosi pastaraisiais metais pasikeitusiu spaudos požiūriu ị kasdienos darbus. Anksčiau laikraščiai, žurnalai sistemingai supažindindavo

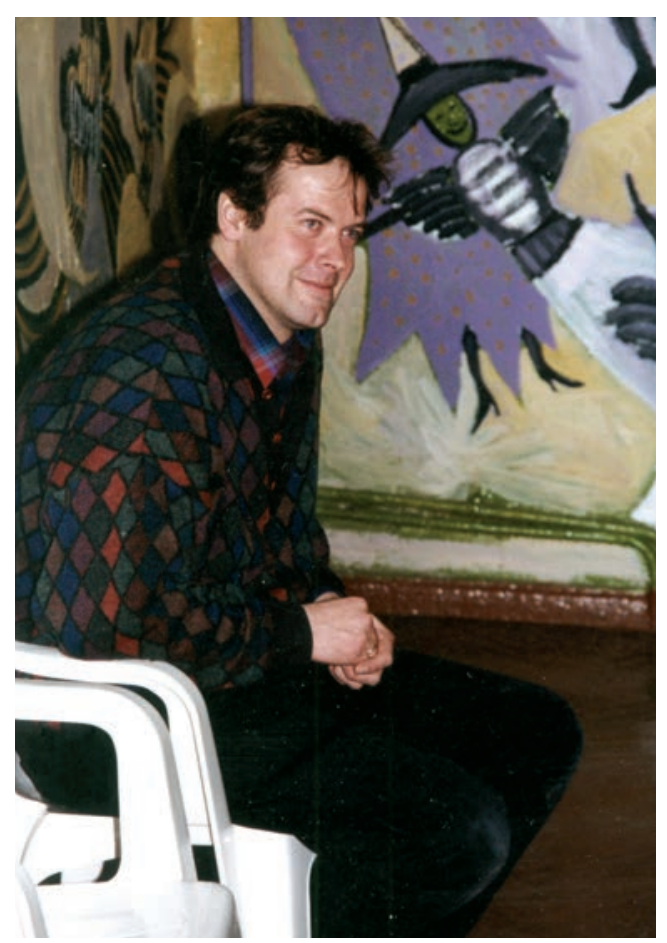

O. Kesminas - teatro-studijos „Palepéc režisierius 
VILNIAUS

GEDIMINO

TECHNIKOS

UNIVERSITETAS su studijų, mokslo naujovèmis, įvairiais išradimais, studentu ir mokslininkų veikla, o dabar šitai beveik nedaroma. Tai kelia mokslo ịstaigu susirūpinimą. Mokslotyros centro direktorius dr. A. Liekis pristate savo parengtą trilogiją „Lietuvos tautos - lietuviu kalbos likimas“. Renginyje dalyvavo „Mokslo ir gyvenimo" vyr. redaktorius J. Baldauskas, „Mokslo Lietuvos“ vyr. redaktorius G. Zemlickas, „Statybos ir architektūros“ vyr. redaktorius J. Stražnickas, „Mokslo ir technikos" redaktoriaus pavaduotoja G. Krikščiukaitienè, žurnalistas D. Šniukas, keli rektorato nariai ir kt.

2005 m. gegužę VGTU apsilanke Kinijos Liaudies Respublikos nepaprastoji ir igaliotoji ambasadore Yang Xiuping, kartu viešejo ambasados pirmasis sekretorius An Jingxin ir spaudos atašè Ding Tao. Susitikime su VGTU rektorato nariais kinai aptare bendradarbiavimo su Kinijos aukštosiomis mokyklomis pletros galimybes.

$2005 \mathrm{~m}$. birželio $8 \mathrm{~d}$. universiteto vadovai susitiko su Lietuvos pramonininkų konfederacijos prezidentu B. Lubiu. Kartu su juo atvyko kiti konfederacijos vadovai: M. Aleliūnas, R. Jasinavičius, A. Federavičius ir E. Nazelskis. Susitikime aptartos inžinieriu rengimo problemos, galima konfederacijos parama universitetui. B. Lubys pasiraše VGTU Garbés svečių knygoje.
Birželio mènesị îvykusiame iškilmingame Senato posedyje VGTU Garbès daktaru buvo inauguruotas Štralzundo aukštosios mokyklos profesorius Šlomo Šafiras. Jo deka abi mokyklos intensyviai keičiasi žiniomis, dèstytojais, studentais, kultūros pramogomis. Pasirašyta sutartis dèl dvigubų diplomų teikimo, igyvendinamas projektas dèl bendros knygu serijos „Projektų valdymas“, leidžiamas bendras tarptautinis mokslo žurnalas „Journal of Business Economics and Management". Š. Šafiras sakè: „Džiugu, kad mūsu aukštosios mokyklos sekkmingai bendradarbiauja, ir būsiu labai laimingas, jei ir toliau galéciau bent kukliai prisideti prie bendros abieju šaliu geroves kūrimo".

Gegužès pabaigoje vyko VGTU Aplinkos inžinerijos fakulteto suorganizuota 6-oji tarptautinè mokslinè konferencija „Aplinkos inžinerija“, Konferencijos organizacinio komiteto pirmininkas doc. Č. Aksamitauskas sake, kad „bene svarbiausias šio mokslinio renginio išskirtinis bruožas-gerokai išsipletusi konferencijos dalyviu geografija. Pirmojoje turejome tik keleta pranešeju iš užsienio, o šiemet sulaukeme pranešeju iš dvidešimt triju šaliu. Jie netolygiai pasiskirste i jekcijas. Pavyzdžiui, Miestu transporto sistemu sekcijoje pranešimus skaité net keturiolikos ǔssienio šaliu mokslininkai. Be artimiausiu mūsu kaimynu - Baltarusijos, Estijos, Latvijos, Lenkijos - mokslininku kiekviena karta konferencijoje dalyvauja ir Austrijos, Čekijos, Olandijos, Kazachstano, Rusijos, Suomijos, Švedijos, Vokietijos ir kitu Europos šaliu atstovai, besidomintys aplinkos

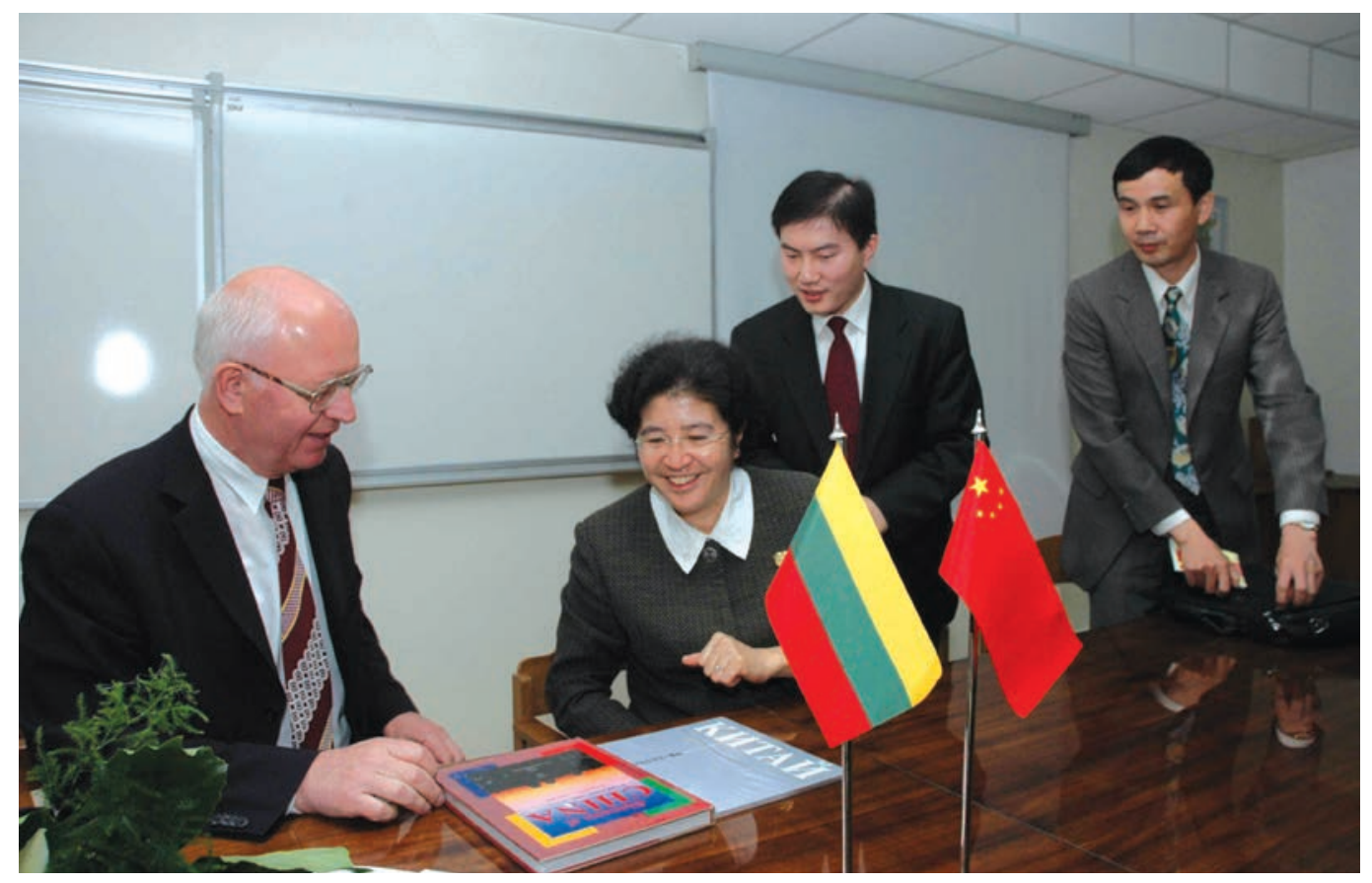


inžinerijos klausimais. Šiemet pirma karta idomiu pranešimu sulaukeme iš Jungtines $\mathrm{Ka}$ ralystes, Ispanijos, Italijos, Prancüzijos, Slovenijos mokslininku“", - teige konferencijos „Aplinkos inžinerija“ organizacinio komiteto pirmininkas doc. Česlovas Aksamitauskas. Jo nuomone, kitas išskirtinis bruožas - kaskart sparčiai didejjantis dalyvių skaičius. $1994 \mathrm{~m}$. ì pirmąją minètos tematikos konferenciją susirinko šimtas penkiasdešimt mokslininkų, aplinkos inžinerijos praktikų, o šiemet sulaukta beveik pusketvirto šimto dalyvių.

Šis gausus būrys, pasiskirstęs ị Aplinkos apsaugos, Vandentvarkos ir hidraulikos, Miestų transporto sistemų, Keliai ir geležinkeliai, Geodezijos ir kadastro technologijos sekcijas, perskaitè daugiau kaip du šimtus penkiasdešimt pranešimų aktualiais nūdienos padiktuotais aplinkos inžinerijos klausimais.

Konferenciją organizavo Tarptautinè matininkų asociacija, Tarptautine ekologijos ir gyvybès saugos akademija, Lietuvos moksly akademija, Baltijos kelininkų, Lietuvos vandens tiekejų asociacijos, Vilniaus Gedimino technikos universitetas. Tačiau praktiškai beveik visi svarbiausi organizaciniai rūpesčiai gulè ant Aplinkos inžinerijos fakulteto dekanato, katedrų darbuotojų pečių. Konferencija sulaukè dvidešimt triju rèmëjų paramos.

2005 m. birželį mèn. VGTU pasirašè bendradarbiavimo sutartị su Lietuvos pramoninkų konfederacija. Sutartį pasiraše rektorius prof. R. Ginevičius ir konfederacijos prezidentas doc. B. Lubys.

Pasak pramonininkų vadovo, sparčiai diegiant i gamybą naujausias technologijas, kyla poreikis keisti ir studiju technologijas. „Vien išsilavinusio, intelektualaus žinovo nepakanka. Negalime tokio specialisto, atejusio iš universiteto, mokyti dar 3-5 metus pažinti praktine gamybą. Mūsu gamyklose dažnai stažuojasi studentai iš Vakaru. Tam reikia skatinti ir mūsu studentija“, - sake . Lubys. Pasak jo, po keleto metų į užsienį dirbti vyks jau ne medikai ir architektai, o inžinieriai, ju stygių pradedame justi Europoje. Tai skatino pramonininkus atsigręžti ị jiems specialistus rengiančias institucijas. Pasirašytos bendradarbiavimo sutartys su Rektoriu konferencija, dviem šalies universitetais leis prisidèti prie nūdienos reikalavimus atitinkančiu specialistų rengimo.

Birželio mènesị Vilniaus Gedimino technikos universitetas kartu su Matematikos ir informatikos institutu, Vilniaus universi-

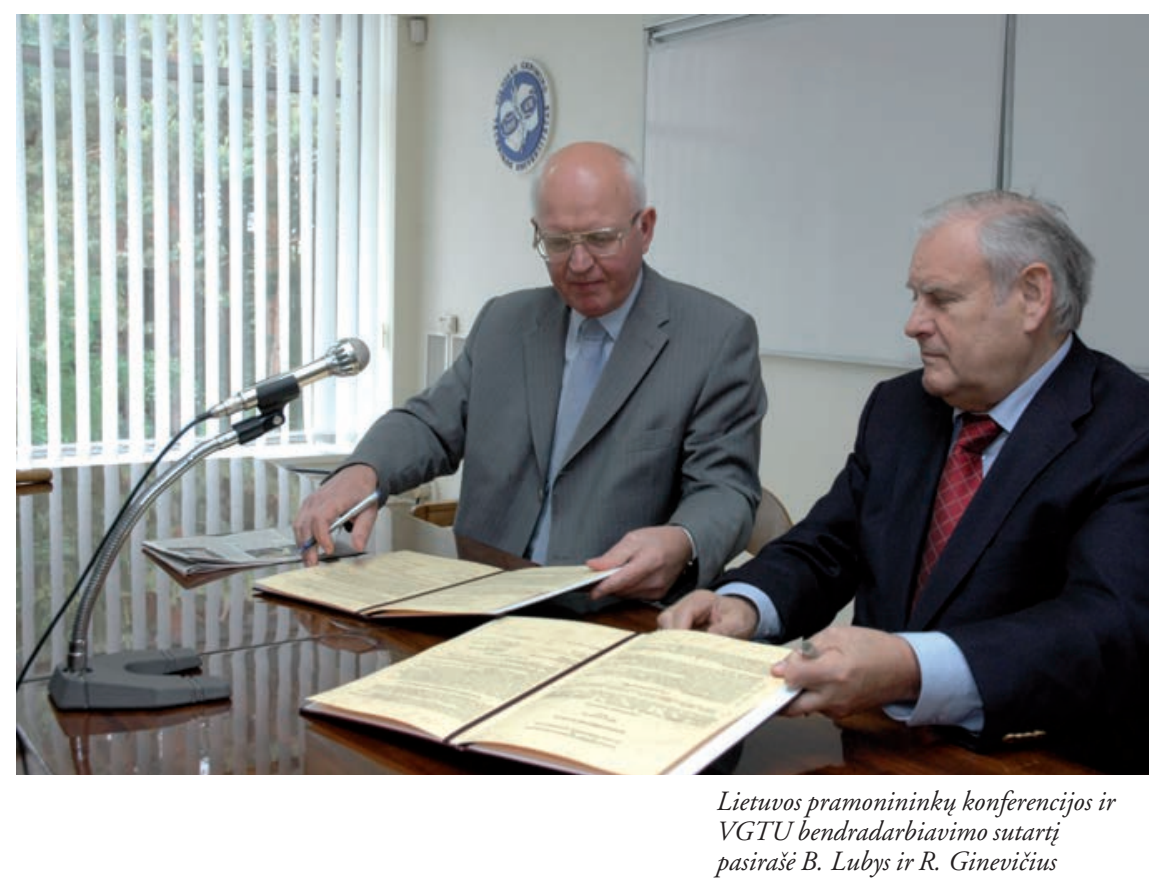

tetu surengè dešimtąją tarptautinę mokslinę konferenciją „Matematinis modeliavimas ir analizé". İ ją atvyko 190 mokslininkų iš 20 šalių. Konferencijos dalyviai jau šeštą kartą susirinko Lietuvoje. Šiemet jie posedžiavo Trakuose. Tris kartus šią konferenciją rengè Latvijos ir kartą-Tartu universitetai. Ši statistika rodo, kad Matematinio modeliavimo katedros darbuotojų ir vedejo prof. Raimondo Čiegio konferencijos organizavimo patirtis teigiamai įvertinta ir tarptautiniu mastu.

VGTU, Matematikos ir informatikos instituto, VU mokslininkai aktyviai dirba skaičiavimo metodų, matematinio modeliavimo, lygiagrečiųjų algoritmų sudarymo, jų naudojimo srityse. Ju darbai gerai žinomi užsienyje. Konferencijoje aptarti aktualūs skaičiavimo metodų, lygiagrečiųjų algoritmų, diferencialinių lygčių, matematinio modeliavimo, statistinio modeliavimo klausimai.

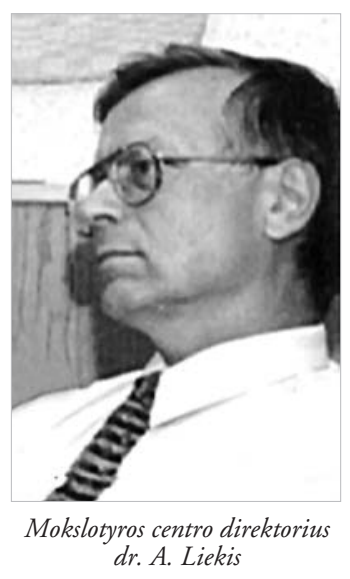

\section{Premijos vadovéliu autoriams}

Birželio 13 d. Švietimo ir mokslo ministerijoje buvo apdovanoti Aukštojo mokslo vadovèlių konkurso laureatai. Tarp konkurso nugaletojų buvo ir VGTU vadovelių rengejjai. Antrąją premiją gavo Fundamentinių mokslų fakulteto Matematinio modeliavimo katedros vedejjas prof. Raimondas Čiegis (už vadovèlį „Diferencialinių lygčių skaitiniai sprendimo metodai“). Antroji premija taip pat skirta Statybos fakulteto Darbo ir gaisrines apsaugos katedros darbuotojams Petrui Čyrui, Vilmantui Girniui, Kaziui Algirdui Kaminskui, Vytautui 
VILNIAUS

GEDIMINO

TECHNIKOS

UNIVERSITETAS

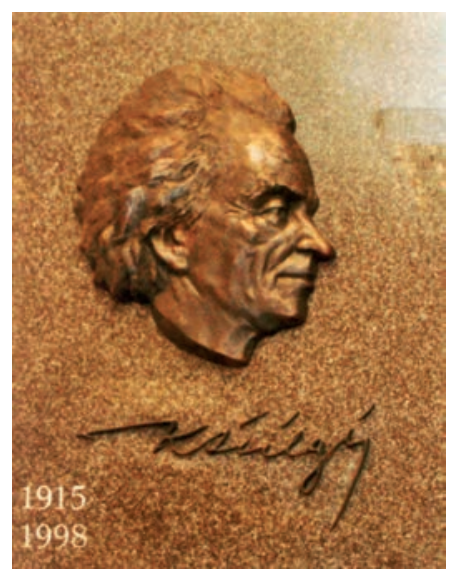

Architektūros fakultete atidengta atminimo lenta

prof. habil. dr. Kazimierui Šešelgiui
Viršuje dešinëje -

Diplomu iteikimo šventé
Nainiui, Ritoldui Šukiui, Juozapui Tartilui už knygą „Profesinè sauga ir sveikata. Ergonomikos principai“. Trečiąsias premijas gavo net du mūsų universiteto Architektūros fakulteto mokslininkai - Vytautas Jonas Stauskis už vadovelį „Architektūrine akustika" bei Jurgis Vanagas už vadoveli „Miesto teorija“. Trečioji premija skirta ir vadovelio "Matavimo teorija ir praktika“ autoriams - Vladui Vekteriui, Rimantui Mykolui Kanapenui bei kitiems Fundamentinių mokslų fakulteto darbuotojams. Paskatinamosios premijos iteiktos Transporto inžinerijos fakulteto darbuotojams už vadovèlius „Riedmenų diagnostika“, „Transporto ekonomika“.

Kaip visada, pakiliai ir iškilmingai vyko diplomų įteikimo savaite. Auditorijos buvo perpildytos diplomantų ir svečių. Aplinkos inžinerijos fakultetas diplomus įteike saviesiems diplomantams šio fakulteto pastangomis įrengtame amfiteatre šalia fakulteto korpuso. Renginyje dalyvavo ne tik 414 fakulteto diplomantų, bet ir labai gausus studentu ir svečiu būrys. Pažymètina, kad Aplinkos inžinerijos diplomantai buvo pasipuošę fakulteto togomis.

VGTU pagrindines studijas 2005 metais baige 1798 jaunuoliai ir merginos, magistrantūrą - 958, specialiąsias profesines studijas - 12. Iš viso VGTU išleido 2768 specialistus.

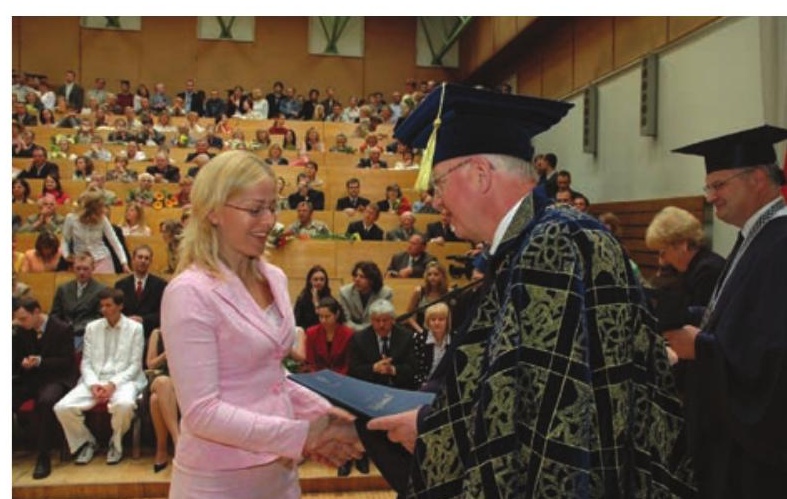

2005 m. vasarą i VGTU pagrindines studijas buvo priimtas 3491 žmogus, ị magistrantūrą - 1271 , ị specialiąsias profesines studijas - tik 14. Iš viso VGTU pirmajame kurse nuo rugsëjo turëjo studijuoti 4776 žmonès.

2004-2005 mokslo metais išaugo užsienio studentų skaičius, atvykstančių į VGTU pagal SOCRATES/ERASMUS programą.

SOCRATES/ERASMUS programos dalyviai išvyksta dalinių studijų, kurios užsienio aukštojoje mokykloje trunka 3-12 mènesių, o paskui tęsiamos mūsų universitete. VGTU partnerès šioje programoje yra net 98 Europos aukštojo mokslo institucijos.

Be šios programos, mūsų studentai studijuoja užsienyje ir pagal dvišales VGTU sutartis su užsienio partneriais. Universitetas yra pasirašęs daugiau kaip 50 tokių sutarčių, pagal kurias su Vokietijos, Lenkijos, Švedijos, Danijos, Rusijos, Čekijos ir kitų šalių universitetais bendradarbiaujama jau ne vienerius metus.

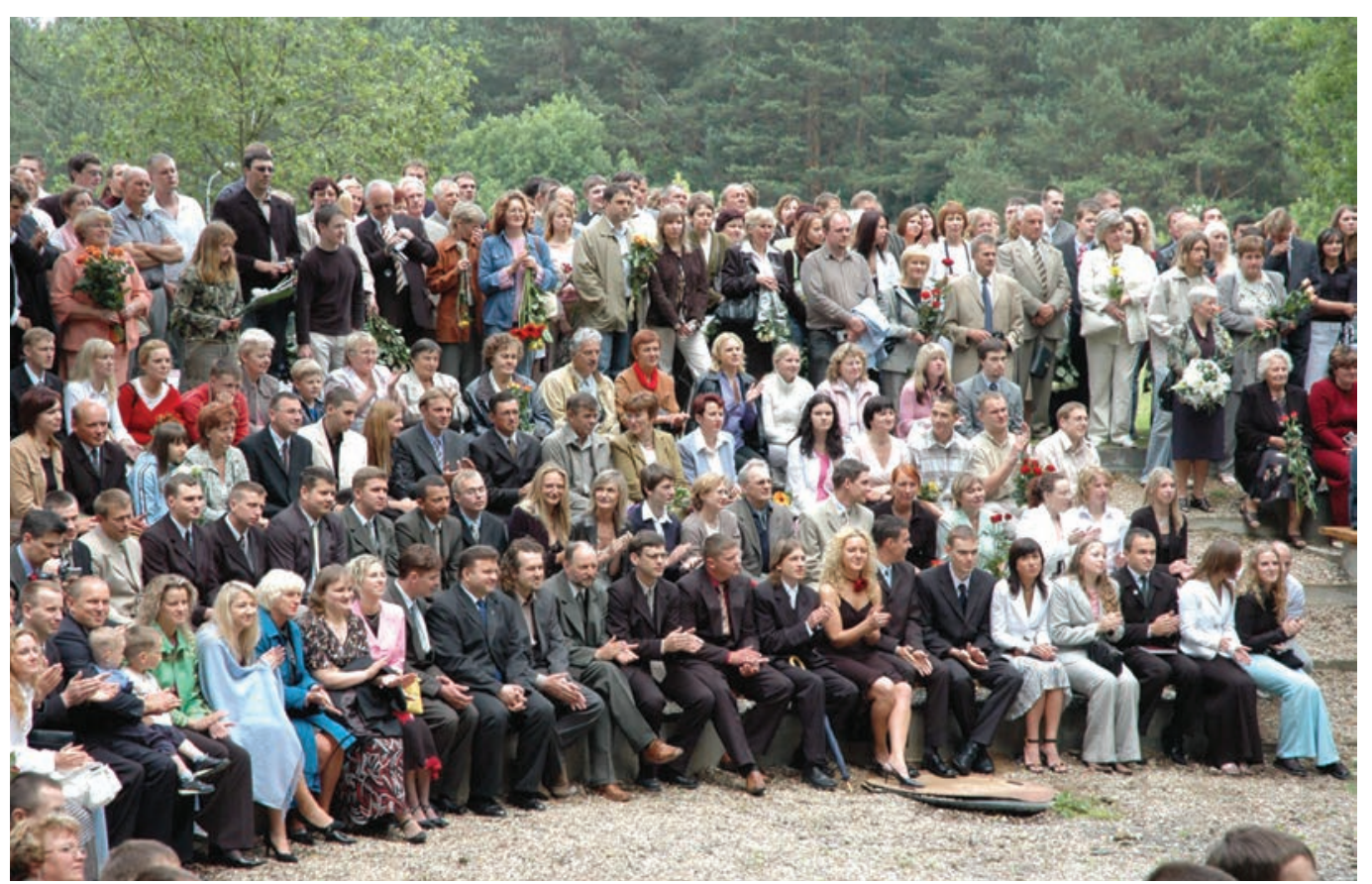


Taip pat kasmet apie 30 VGTU studentų atlieka praktikas pagal kitas dvišales universiteto sutartis ar praktiku programas (LEONARDO DA VINČI, laeste) [6.38, p. 2].

2005-2006 mokslo metu pradžia Vilniaus Gedimino technikos universitete buvo iprastiné. Pirmojo kurso studentai susirinko prie Sauletekio rūmų centrinio korpuso. Prie jo plevesavo Lietuvos, Europos Sajungos ir VGTU veliavos. Rektorato nariai stovejo naujų fakultetų vèliavų fone.

Šventę pradejo studijų prorektorius doc. Alfonsas Daniūnas. Jis visus pasveikino su Rugsejo pirmąja ir susirinkusiems pirmakursiams pristate universiteto rektorių prof. Romualdą Ginevičių, Senato pirmininką prof. Donata Čygą, fakultetu, institutu, Tarptautinių studijų centro vadovus. Paskui praneše apie priemimo į pirmąji kursą rezultatus, papasakojo apie stojančiujjų konkurso ypatumus.

Universitetą gausiausiai papildè Vilniaus apskrities gyventojai. Dieninèse studijose mokysis 41,6 proc. šios apskrities abiturientų, o iš ju 29,6 proc. tikri vilniečiai, î pagrindinių studijų pirmą kursą ịstojo 84,6 proc. baigusiųjų mokyklas lietuvių kalba. Daug lietuviškesnis tapo Elektronikos fakultetas: iš 384 priimtųjų i pirmą kursą 99,7 proc. yra lietuvaičiai. Tik jie šiemet studijuos Fundamentinių mokslų fakultete. Šito anksčiau niekada nebuvo. Rusai, lenkai, kitu tautybiu atstovai šiemet sudaro 7,1 proc. dieninių studiju visų pirmakursių.

„Džiugu, kad šitoks gausus ir gerai pasirengusiu abiturientu bürys pasirinko mūsu

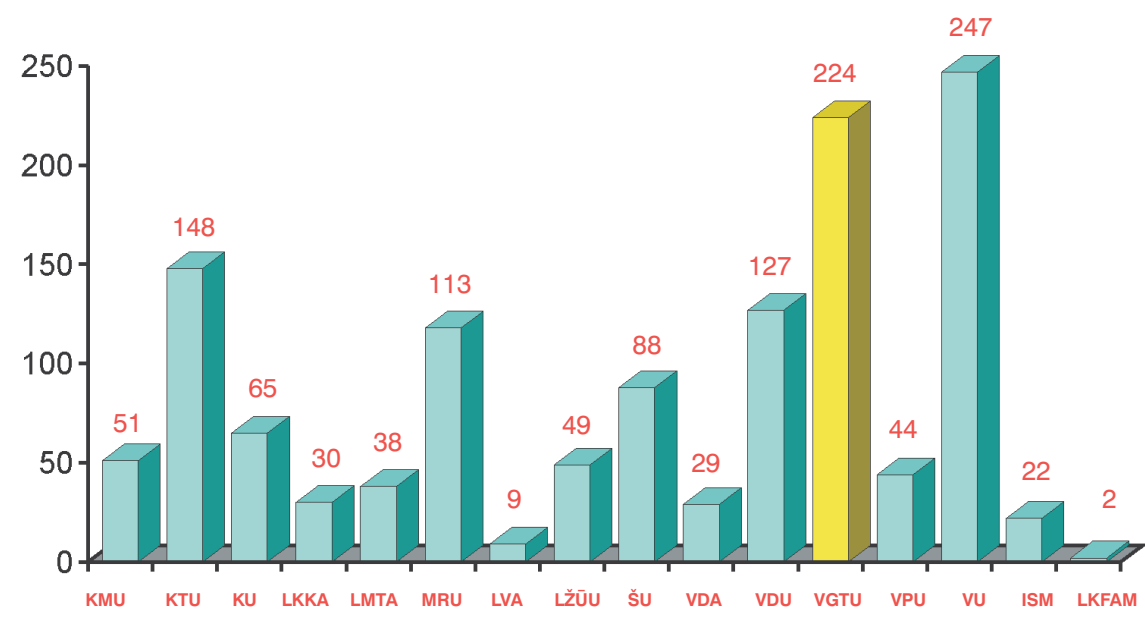

Lietuvos aukštuju mokyklu studijuojančiuju skaičius pagal SOCRATES/ERASMUS

universiteta“, - pasidžiauge rektorius prof. Romualdas Ginevičius, pradedamas sveikinimo žodic.

Universiteto vadovas, pasveikinęs mokslo metų pradžios dalyvius ir palinkëjęs jiems visokeriopos sèkmés, bendrais bruožais aptare technikos studiju ypatybes, ragino nuo pat pirmos dienos rimtai studijuoti, o ne studentauti, priminè mūsų universiteto absolventų įsidarbinimo galimybes, siūlè nuo pat pirmųjų studijų dienų ịsitraukti į mokslinę veiklą, būti aktyviais meno kolektyvų dalyviais, nepamiršti vidurineje, gimnazijoje pamégto sporto.

2005-2006 mokslo metais pasikeitè ne vienas universiteto padalinio vadovas. Studijų programos koordinatore, Chemijos ir bioinžinerijos katedros lektore Birute Tamulaitiene paskirta Tarptautinių studiju centro direktore, rektorato nare. Statybos

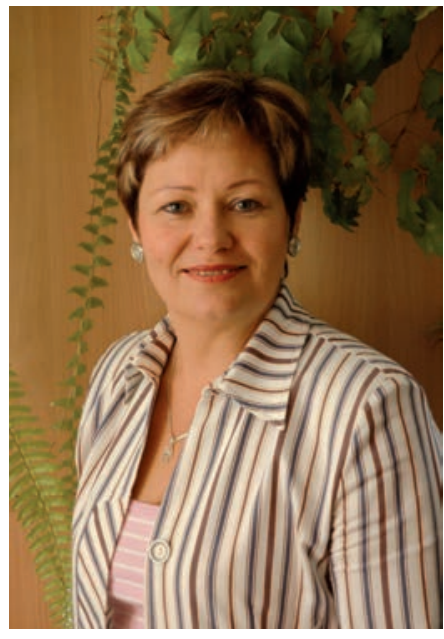

B. Tamulaitiené

Tarptautiniu studiju centro direktore

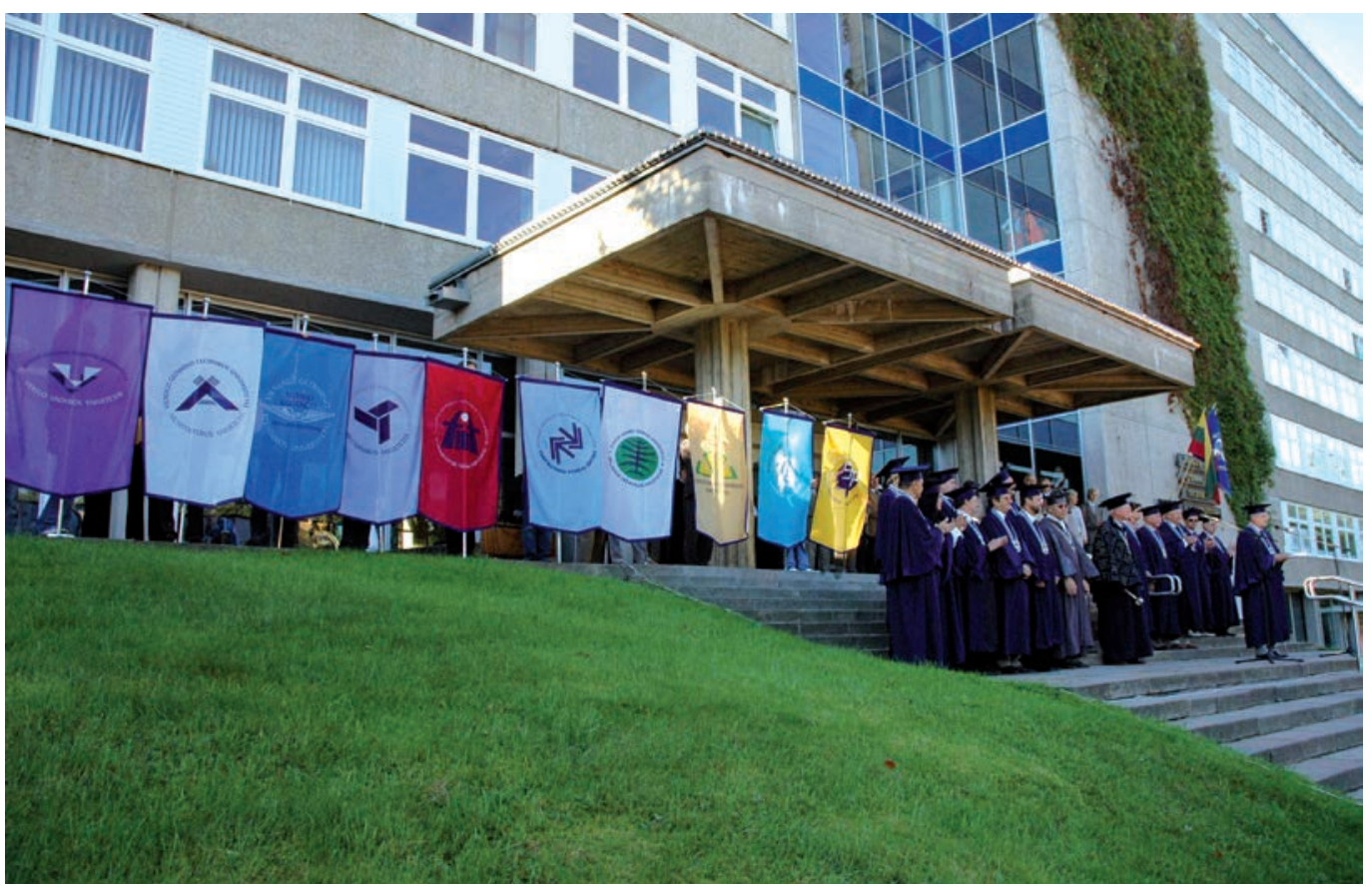


VILNIAUS

GEDIMINO

TECHNIKOS

UNIVERSITETAS
Viršuje dešinëje -

Ukrainos nacionalinis aviacijos universitetas suteike Garbès daktaro varda

$R$. Ginevičiui, oJ. Stankūna apdovanojo $\check{S} v$. Stanislovo Komandoro kryžiumi fakulteto prodekanu tapo Gelžbetoninių ir mūrinių konstrukcijų katedros doc. dr. Arnoldas Šneideris; Transporto inžinerijos prodekanu - Transporto vadybos katedros doc. dr. Darius Bazaras; Aplinkos inžinerijos fakulteto prodekane paskirta Aplinkos apsaugos katedros doc. dr. Rasa Vaiškūnaité.

Ūkio direkcijai vadovauja buvęs mūsų universiteto absolventas, vadybos ir verslo administravimo magistras Romanas Jagèlo, ne vienerius metus dirbęs ịvairiose ūkinès veiklos bendrovese.

VGTU senatas penkerių metų kadencijai patvirtino penkis katedrų vedejus. Geodezijos ir kadastro katedrai vadovauja doc. dr. Česlovas Aksamitauskas, prof. habil. dr. Vytautas Martinaitis tapo Šildymo ir vedinimo katedros vedeju, prof. habil. dr. Julius Skudutis - Kompiuterių inžinerijos katedros vedejju, prof. habil. dr. Artūras Kaklauskas - Statybos ekonomikos ir nekilnojamojo turto vadybos katedros vedeju, prof. habil. dr. Josifas Parasonis - Inžinerinès architektūros katedros vedeju.

Rugsèjo mènesị dar vieną apdovanojimą pelnè Statybos fakulteto dekanas prof. Povilas Vainiūnas. Lietuvos statybininkų asociacija ji apdovanojo statybininko garbès ženklu.

Reikšminga žinia atskriejo iš Kijevo. Ukrainos nacionalinis aviacijos universitetas suteike Garbès daktaro vardą Vilniaus Gedimino technikos universiteto rektoriui. Rugsèjo pabaigoje Ukrainos nacionaliniame aviacijos universitete įvyko habilituoto daktaro profesoriaus Romualdo Ginevičiaus inauguravimo Garbès daktaru iškilmès.

Jau po kelių dienų - dar viena gera žinia. Ši kartą iš Minsko. Prof. R. Ginevičius, prof. E. K. Zavadskas ir prof. D. Čygas tapo Tarptautinés organizavimo ir valdymo akademijos tikraisiais nariais-akademikais.

Svarus ir reikšmingas apdovanojimas iteiktas VGTU Antano Gustaičio aviacijos instituto habilituotam daktarui profesoriui Jonui Stankūnui. Ukrainos nacionalinis aviacijos universitetas ji apdovanojo Tarptautinio Šv. Stanislovo ordino komandoro kryžiumi.

Visi šie garbingi ir aukšti VGTU mokslinès, pedagoginès ir vadybinès veiklos ịvertinimai reikšmingai stiprina mūsų universiteto prestižą, sudaro prielaidas tolesniam abipu-

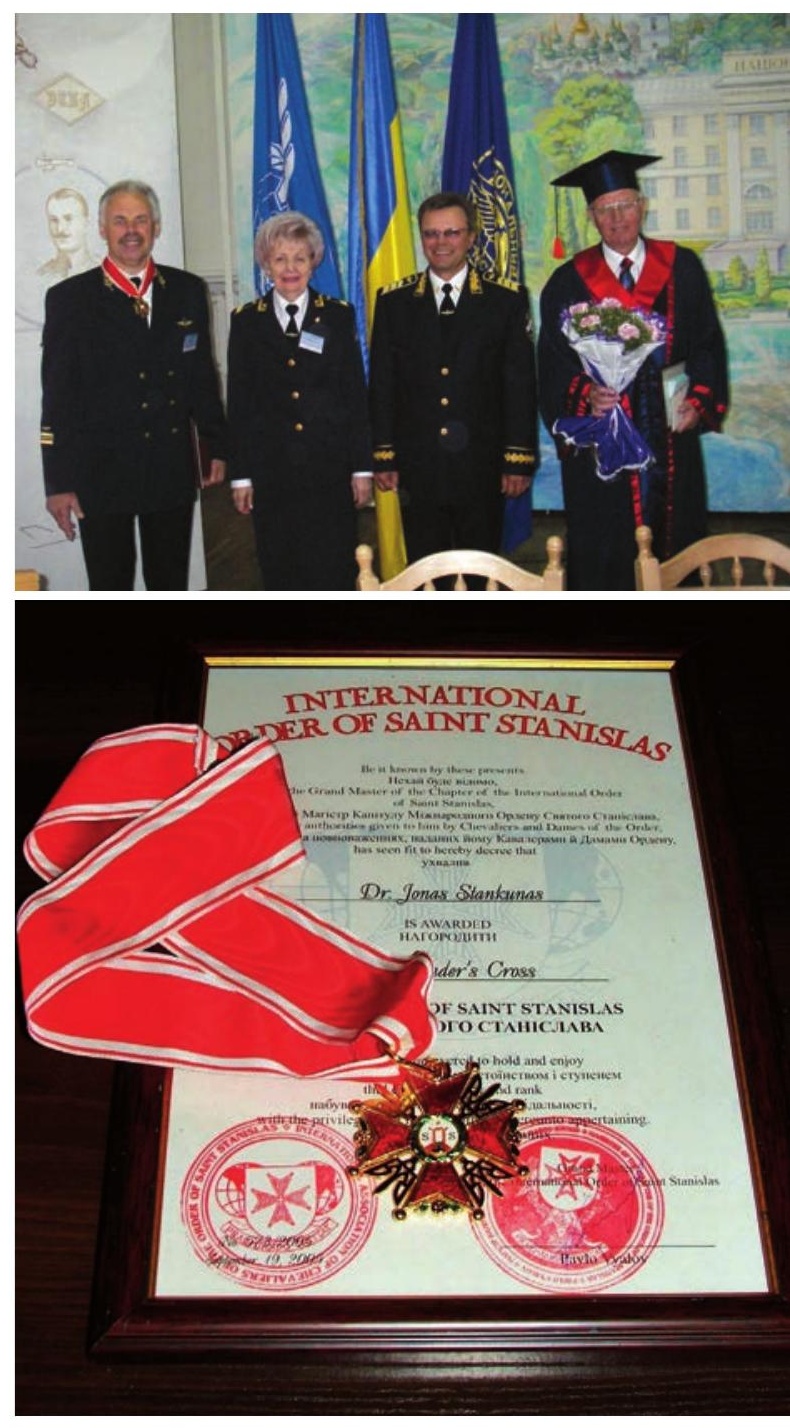

siškai naudingam tarptautiniam universitetų bendradarbiavimui.

Malonus apdovanojimas įteiktas Miestų statybos bei Architektūros pagrindų ir teorijos katedrų profesoriui habilituotam daktarui Konstantinui Jakovlevui-Mateckiui. Jis už mokslines publikacijas kraštovaizdžio architektūros srityje apdovanotas pirmąja premija ir aplinkos ministro padekos raštu „Už kūrybinę energiją ir sèkmę puošiant ir planuojant mūsų kraštą, puoselejjant kraštovaizdžio architektūrą".

Universiteto imtynininkų rinktinè dalyvavo Vilniaus miesto dziudo imtyniu čempionate. Treneris Algirdas Šulinskas džiaugèsi, kad pirmas vietas iškovojo Mechanikos fakulteto pirmojo kurso M-5/2 grupes studentas Ignas Petkevičius (svorio kategorija iki $60 \mathrm{~kg}$ ) ir Statybos fakulteto S-5/9 grupès studentas Rolandas Kovalevičius (svorio kategorija - iki $66 \mathrm{~kg}$ ).

Baigiantis spaliui, pasikeitè mūsų universiteto studentų visuomeninés organizacijos vadovas. Ne vienerius metus jai vadovavusi 
Lina Pabedinskaitė Studentų atstovybès prezidento regalijas perdave buvusiam viceprezidentui, Transporto inžinerijos fakulteto antrakursiui Justui Nugarui.

2005-2006 mokslo metais VGTU studijavo 60 studentų, atvykusių pagal SOCRATES/ERASMUS programą. Daugiausia iš Ispanijos, Vokietijos, Austrijos. Visi jie nuoširdžiai buvo priimti ị VGTU studentų bendruomenę ir jau patyre studentiškų krikštynų "džiaugsmą". Krikštijamieji turejo galimybę pristatyti savo nacionalinius, kultūrinius skirtumus, parodyti sportinius sugebëjimus surengtose „Olimpinèse žaidynèse“.

Studentai visą semestrą studijuos įvairiuose fakultetuose. Daugiausia - Verslo vadybos, Aplinkos inžinerijos fakultetuose.

Malonų pranešimą spalio ménesį gavo VGTU Lygiagrečiujų skaičiavimų laboratorija. Agentūra „Factum“ " prie Kultūros fondo užregistravo naują Lietuvos rekordą - didžiausią skaičiavimų spartą: 62,81 milijardu operacijų per sekundę su 64 bitų ilgio slankiojo kablelio skaičiais.

Šis rekordas pasiektas Lygiagrečiųjų skaičiavimų laboratorijoje esančiu 26 mazgu asmeniniu kompiuteriu klasteriu „Vilkas“. Greičio testas atliktas „High Performance Linpack" programa. Siekiant rekordo, rasta optimali klasterio mazgu programinès įrangos konfigūracija. Tai leido maksimaliai išnaudoti klasterio išteklius bei pasiekti Lietuvos rekordą.

Šiame darbe aktyviai dalyvavo laboratorijos darbuotojai dr. D. Mažeika, dr. V. Starikovičius bei prof. habil. dr. R. Čiegis, kuriam ir kilo ideja, jog Lietuvoje turetu būti registruojami galingiausi kompiuteriai. $[6.39$, p. 3].

Lapkriti Antano Gustaičio aviacijos institute vyko Baltijos valstybiu aeronautikos mokslo ir pramones atstovy seminaras „Bepiločiai aparatai taikiems tikslams“, kuriame aptartos tarptautinio tinklinio projekto UAVNET parengtos bepiločių aparatų plètros strategines kryptys, Baltijos valstybių galimybès dalyvauti bepiločių orlaivių kūrimo programose, europinių ir nacionalinių aeronautikos technologinių platformų kūrimo eiga ir perspektyvos.

Universiteto bendruomené gražiai pagerbè ilgamečius savo darbuotojus. Personalo direkcijos direktorei Reginai Žemkienei universitetas - pirma ir kol kas vienintele darboviete. Tik per čia praleistus daugiau kaip keturiasdešimt metų jai teko eiti įvairias pareigas. Ir visur dirbo stropiai, sąžiningai. Reginos Žemkienes ilgametis darbas ịvertintas Švietimo ir mokslo ministerijos Padekos raštu.

Jonas Žemkus, nors ir su pertraukomis, taip pat ilgametis universiteto darbuotojas. Garbingos sukakties proga jis apdovanotas medaliu „Už nuopelnus Vilniaus Gedimino technikos universitetui“".

Dažnos ir vaisingos yra VGTU rektoriaus R. Ginevičiaus užsienio kelionès.

Kaip Lietuvos aukštujų mokyklų rektorių delegacijos narys prof. R. Ginevičius lankèsi Kazachstane. Śios šalies ekonomika pletojama intensyviai ir sèkmingai, todèl ši valstybè sulaukia užsienio šalių dèmesio. Buvo aplankyti svarbiausi Kazachijos universitetai. Juose studijos pritaikytos prie tarptautinių standartu.

Ne vienai studijų programai dèstyti kviečiami JAV, Didžiosios Britanijos, Prancūzijos, Ispanijos, Vokietijos ir dar kity šalių profesoriai, geriausi savos srities specialistai. Kasmet beveik trys tūkstančiai universiteto studentų ilgesniam ar trumpesniam laikui vyksta mokytis bei stažuotis į užsienio šaliu aukštąsias mokyklas.

Rektorius R. Ginevičius rašè:

„Euroazijos nacionalinio L. N. Gumilevo universiteto šiu metu biudžetas - daugiau kaip vienas milijonu doleriu. Beveik tiek pat turima lěsu studentu siuntimui mokytis ǔ̌sienyje, ju bei destytoju stažuotems. Universiteto profesürai, kaip visiems šalies biudžetiniams darbuotojams alga padidejo 32 proc. Studentu stipendijos siemet taip pat padidintos du kartus.

Viešnage baigesi bendradarbiavimo sutarties prašymu. Šeimininkai su mūsu universiteto mokslininkais noretu vykdyti bendrus mokslo tyrimus, organizuoti bendras konferencijas, keistis destytojais, studentais. Sutartyje ypač akcentuojamas bendradarbiavimas pletojant nuotolines, magistrantūros, doktorantūros studijas. Partneriu isipareigojimu vykdymas daug priklausys nuo fakultetu, katedru, laboratoriju, kitu mokslo padaliniu tiesioginiu ryšiu.

Lankiausi Alma Atos technikos universitete, ir po pokalbio su vadovais pasirašeme bendradarbiavimo sutartį. Taip pat pasirašyta bendradarbiavimo sutartis su Kazachijos nacionaliniu Abajaus pedagoginiu universitetu, turinčiu giminingu fakultetu. Šiuose dokumentuose, be bendru moksliniu tyrimu, konferenciju, keitimosi moksline informacija, daug demesio skiriama keitimuisi studentais.

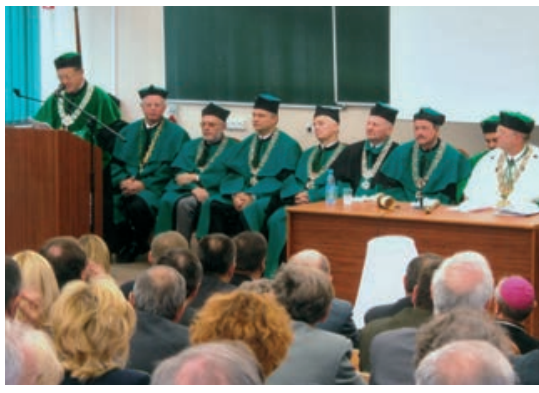

Rektorius R. Ginevičius Bialystoko Politechnikos naujuju mokslo mety atidarymo renginyje $2003 \mathrm{~m}$. 
VILNIAUS

GEDIMINO

TECHNIKOS

UNIVERSITETAS

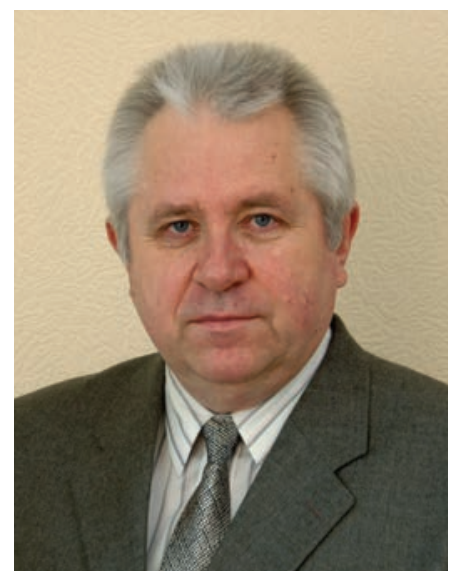

V. Skaržauskas

Mokslo direkcijos direktorius

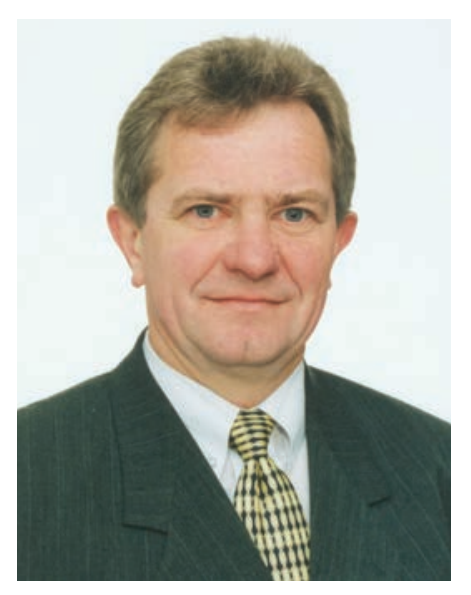

R. Kutas

Skaičiavimo centro direktorius
Lietuvos universiteto rektoriams gera ispūdi taip pat paliko Alma Atos valstybinis Abajaus, Alma Atos D. A. Kunajevo, Kazachijos nacionalinis agrarinis, Kazachijos nacionalinis Abajaus pedagoginis, Tarptautinis verslo universitetai, kuriems šalies valdžia skiria ne mažiau demesio, kaip ir Euroazijos nacionaliniam L. N. Gumilevo universitetui. Todel ir čia turtingi mokymo kabinetai, laboratorijos, bibliotekos" [6.40, p. 1-3].

Rektorius R. Ginevičius gruodį lankèsi Lenkijoje ir su Varšuvos technikos universitetu pasiraše bendradarbiavimo sutartị.

Metams baigiantis Lietuvoje daug polemizuota aukštojo mokslo būkles klausimu. Lietuvos universitetų rektorių konferencijos (LURK), Lietuvos pramonininkų konfederacijos (LPK) ir Lietuvos studentų sąjungos (LSS) darbo grupe parenge Aukštojo mokslo sistemos pletros plano projektą. Jis parengtas atsižvelgiant į Europos Parlamente (EP) svarstomas nuostatas, Lietuvos ịstatymus ir įvertinant dabartinę Lietuvos aukštojo mokslo būklę. Alternatyvų planą yra parengusi LR švietimo ir mokslo ministerijos darbo grupè. Tačiau LURK ekspertai atkreipe demesi, kad keletas šio plano teiginių pažeidžia LR Konstituciją ir šiuo metu veikiančius ịstatymus.

Rektorių konferencijos nariai diskutavo dèl studentų studijų krypties ir studiju programų pasirinkimo motyvacijos didinimo, kitais svarbiais universitetams klausimais.

2005 m. Vilniaus Gedimino technikos universitete vykdomuose moksliniuose tyrimuose dalyvavo 824 mokslo darbuotojai pedagogai, iš ju - 608 mokslininkai su mokslo laipsniais ir 216 kitų tyrejų. Katedrose ir mokslo padaliniuose dirbo 53 etatiniai mokslo darbuotojai, užimdami 46 etatus, 19 mokslo padalinių administracijos darbuotojų (10 etatu) ir 30 mokslo padalinių technikos ir pagalbinių darbuotojų (23 etatai). Mokslinè veikla buvo pletojama penkiuose universitetiniuose mokslo institutuose, dviejuose mokslo centruose ir dviejose mokslo laboratorijose; keturiuose fakultetiniuose mokslo institutuose ir viename mokslo centre, šešiolikoje fakultetiniu ir katedrinių mokslo laboratorijų, taip pat 59 katedrose.

2005 m. įvyko kai kurių universiteto mokslo infrastruktūros pokyčių. 2005 m. pavasarị buvo įsteigtas Gynybos technolo- gijų centras. 2005 m. lapkričio 23 d. Senato posedžio nutarimu buvo likviduoti trys nevykdantys aktyvios veiklos mokslo padaliniai: Žmonių saugos mokslo institutas, Turto vertinimo mokslo centras ir Aviacijos mokslo laboratorija.

$2005 \mathrm{~m}$. universitete apgintos 38 daktaro disertacijos, iš jų 2 disertacijas apgyne eksternai iš kitu instituciju. Tai geriausias rezultatas per paskutinius penkerius metus. Penkios disertacijos apgintos dar nepasibaigus doktorantūros laikui, keturias disertacijas apgyne eksternu baigusieji doktorantūrą VGTU ankstesniais metais. Iš 342005 m. apgynusių disertacijas VGTU doktorantų 25 šiuo metu dirba mūsų universitete.

Kaip ir ankstesniais metais, buvo vykdomos VGTU ir kitų institucijų mokslininku habilitacijos procedūros. Sèkmingai perëję šią procedūrą devyni mokslų daktarai (aštuoni iš VGTU) igijo teisę užimti profesoriaus arba vyriausiojo mokslo darbuotojo pareigas.

2005 m. VGTU senatas aštuoniems habilituotiems mokslų daktarams ir perejjusiems habilitacijos procedūrą daktarams suteike profesoriaus pedagoginį vardą, trylikai mokslo daktarų - docento pedagoginị vardą. Visi jie - VGTU destytojai.

Geru rezultatu pasiekta publikuojant mokslo darbus. Bendras publikacijų skaičius mokslo žurnaluose ir leidiniuose padidejo nedaug: nuo 1456 straipsnių 2004 m. iki 1491 straipsnių 2005 m. Tačiau kasmet vis daugiau straipsnių publikuojama žurnaluose, įrašytuose į JAV Mokslinès informacijos instituto (Institute of Scientific Information - ISI) pagrindinių žurnalų sąrašą: $2002 \mathrm{~m}$. buvo paskelbta 14 tokių straipsnių, $2003 \mathrm{~m}$. -25 , $2004 \mathrm{~m}$. -35 ir 2005 m. -45.

VGTU mokslininkai, vieni ir kartu su bendraautoriais iš kitų institucijų, $2005 \mathrm{~m}$. parenge ir išleido 9 monografijas, 2 žodynus ir 26 kitokio pobūdžio knygas.

$2005 \mathrm{~m}$. universitete surengtos $28 \mathrm{kon}-$ ferencijos ir seminarai, iš ju 5 tarptautinès konferencijos. Konferencijose dalyvavo 2032 mokslininkai. VGTU mokslininkai jose perskaite 815 pranešimų, 317 pranešimų perskaitè svečiai iš užsienio [6.36, p. 45-46].

Rektorius R. Ginevičius metinëje universiteto darbo ataskaitoje pabrèzè, kad VGTU turi doktorantūros teisę 15 mokslo krypčių, 44 doktorantūros programas. Užsakomųjų darbų mastas - nuo $3 \mathrm{mln}$. Lt $2002 \mathrm{~m}$. išaugo iki $10 \mathrm{mln}$. Lt $2005 \mathrm{~m}$. 
Daugiausia užsakomųjų darbų atliko Kelių (su laboratorija), Urbanistikos (su laboratorija), Elektroninių sistemų, Gelžbetoninių ir mūrinių konstrukcijų, Transporto technologinių įrenginių ir kitos katedros. Vykdant tarptautinius projektus nepralenkiama lydere yra prof. A. Kaklausko vadovaujama Statybos ekonomikos ir nekilnojamojo turto vadybos katedra.

Gausëja išradimų. $2005 \mathrm{~m}$. paduotos 4 patentines paraiškos ir gauti 5 išradimų patentai. Už išradimus mūsų profesorius Bronislovas Spruogis šiemet buvo apdovanotas Pasaulinès intelektinès nuosavybés organizacijos aukso medaliu.

Apie išaugusią mokslininkų kompetenciją byloja ir dalyvavimas įvairiose tarptautinèse programose. Vykdyta arba vykdoma 40 tarptautinių mokslo programų projektų, iš ju 17 - Europos Komisijos. Kasmet ì tarptautines programas isitraukia vis daugiau mokslininkų.

Pastaraisiais metais VGTU yra įsitvirtinusi tarp pirmaujančių aukštojo mokslo institucijų pagal SOCRATES/ERASMUS programos studentų ir desstytojų mainus.

Vien 2005 mokslo metais pagal SOCRATES programą studijuoti į užsienị buvo išsiųsti 224 mūsų studentai, o mokytis pas mus atvyko 68 užsienio šalių studentai.

VGTU studentai 2004-2005 m. turejo galimybę išvykti pas vieną iš daugiau kaip 120 partnerių 21 Europos šalyje. Pagal SOCRATES/ERASMUS programą skaityti paskaitų, dalyvauti priežiūros ar organizacinèse išvykose vyko 95 VGTU darbuotojai, o VGTU studentams paskaitas skaite 33 dèstytojai iš užsienio. Bendras 2005 m. VGTU vykdomu SOCRATES projektų finansavimas viršijo $2 \mathrm{mln}$. Lt. Dvišalių sutarčių pagrindu bendradarbiaujama su 62 aukštojo mokslo institucijomis iš 23 šalių.

Labai išaugo kompiuterizacijos lygis. 8,5 studento tenka vienas kompiuteris. Studiju reikmèms fakultetuose ir Skaičiavimo centre įrengta 41 kompiuterių klasé, jose yra 673 darbo vietos. Nuo 2005 m. visiems pagrindinių studijų pirmo kurso studentams suteikti el. pašto adresai, jais naudojasi 9250 studentų. Palyginti su 2002 m., el. pašto adresų skaičius išaugo daugiau kaip tris kartus.

Rektorius R. Ginevičius teigè, kad „sieksime, jog mūsu universitetas būtu šiuolaikiškas, taptu reikšmingu Lietuvos mokslo ir kultūros židiniu, visuomenes progreso varikliu, nenusi-

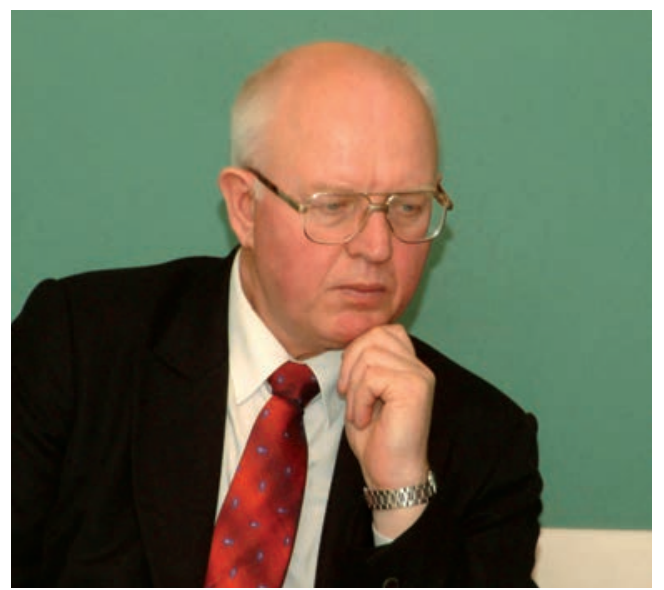

Svarstant rektoriaus ataskaita

leidžiančiu geriausiems šalies ir užsienio universitetams " [6.41, p. 27-28].

2006 metus Lietuva pasitiko su viltimis ir nerimu. Greitai sueis treji metai, kaip esame NATO nare, dveji metai, kaip esame Europos Sąjungoje. Vis dar turime vilčių, kad vietoj lito bus įvestas euras, nors dorai niekas nepaaiškina šio reikalo privalumų ar trūkumų. Bet nesibaigiantys mūsų krašte politikų skandalai, stiprejančios Rusijos imperialistines užmačios verčia nerimauti.

Taip, Rusijos imperializmo apologetai Michalkovas, Prochanovas, Leontjevas ir kt. per įvairiausius Rusijos televizijos kanalus akiplešiškai tvirtina apie „istino ruskich zemliach na Severo Zapade“, iškreipdami ne tik istorinę tiesą, bet ir neslepdami savo imperialistinių ketinimų.

Tačiau pasaulis jau gerokai pasikeitęs. Nors negalime ramiai stebeti minetųjų didžiojo kaimyno politikos apraišku, vis delto turime vilties, kad skiriantis mus nuo jo NATO skydas sutramdys bet koki agresijos proveržį. Lietuvos istorijos pamokos mus moko, kad Lietuva niekada neturi pamiršti

B. Spruogis apdovanojamas WIPO aukso medaliu

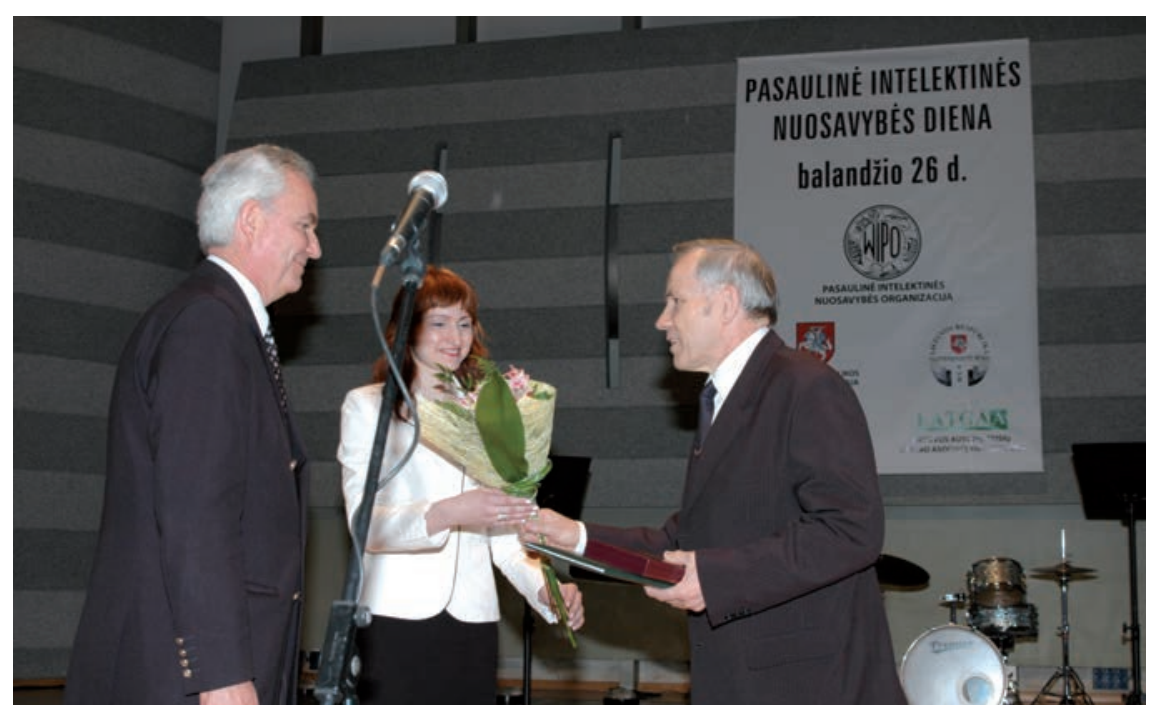


VILNIAUS

GEDIMINO

TECHNIKOS

UNIVERSITETAS

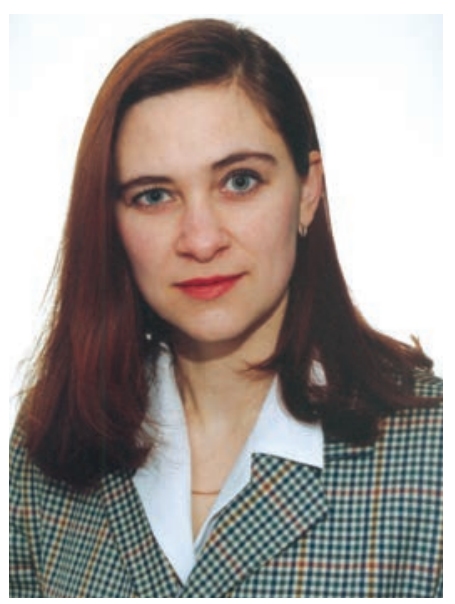

A. Radzevičiené

Užsienio ryšiu direkcijos direktoré

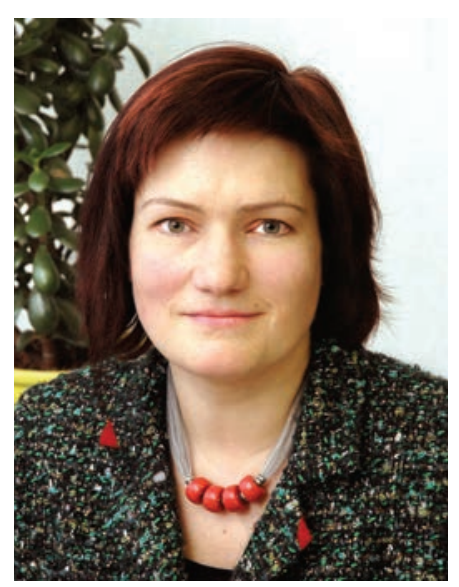

E. Dagiene

Leidyklos "Technika" direktore ginti savojo krašto savo jëgomis. Tik politiškai stabili, ekonomiškai tvirta, vieninga tauta gali neabejoti savo krašto saugumu. Todèl savąji jaunimą ugdydami išsimokslinusį, patriotišką, turesime daug saugesnę valstybę, daug gražesnį gyvenimą sukursime visiems Lietuvos gyventojams. Sprendžiant šiuos tikslus, ypač reikšmingas universitetu, tarp jų ir Vilniaus Gedimino technikos universiteto, vaidmuo.

2006 metai Vilniaus Gedimino technikos universitetui - jubiliejiniai. Rugsëjo $1 \mathrm{~d}$. sueina 50 metų nuo tos dienos, kai Vilniuje pradëjo darbą aukštoji technikos mokykla Kauno politechnikos instituto Vakarinio fakulteto Vilniaus skyrius, ilgainiui tapęs savarankiška prestižine Lietuvos aukštąja mokykla - Vilniaus Gedimino technikos universitetu. Metų pradžioje imta rimtai rengtis iškilmingai paminèti jubiliejų, bet neužleisti ir kasdienos darbai.

Kaip visada, nebuvo pamiršti 1991 m. Sausio 13-osios įvykiai. Buvo pagerbti žuvusieji tautos laisvès gynejai, ant buvusio Elektronikos fakulteto studento Rolando Jankausko kapo padèta gèlių, uždegtos žvakutes. Prisiminti ir kiti mūsų universiteto žmonès, ypač pasižymejję ginant Lietuvos Parlamentą. Tai Vytautas Jasulaitis, Brunonas Gruzdys, Vacius Mališauskas, Kazimieras Algirdas Kaminskas ir daugelis kitų. Žvelgiant atgal, drąsiai galima tvirtinti, kad Technikos universitetas buvo vienas iš laisves gynimo bastionų Vilniuje. Toje kovoje - įvairiose akcijose - dalyvavo dauguma VGTU desstytojų ir darbuotojų, daugelis studentų. Šiai tuomet rizikingai veiklai tiesiogiai vadovavo pats rektorius - prof. E. K. Zavadskas. Mūsų universiteto žmonių tomis dienomis parodytas patriotizmas - garbingas Vilniaus Gedimino technikos universiteto puslapis.

Lietuvos ekonomikai stiprëjant, šalies pramonès įmonems, norinčioms dirbti pasaulinès konkurencijos sąlygomis, reikia vis daugiau geru specialistų. Beprasmiška rengti daug neperspektyviu specialybiu specialistų, jei jų įsidarbinimo galimybès ribotos. Specialistų paklausą geriausia jausti ir rengti gerus specialistus, gebančius greitai adaptuotis darbo vietoje, jei yra glaudus gamybos, verslo organizacijų ir universitetu bendradarbiavimas. Todel Vilniaus Gedi-

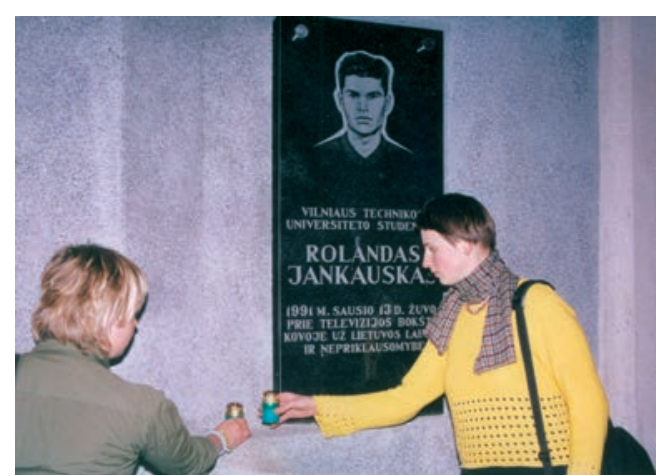

mino technikos universiteto vadovai skiria tam rimtą demesį.

$2006 \mathrm{~m}$. sausi VGTU pasirašè bendradarbiavimo sutartį su „Eikos“ imonių grupe. Iš 54 „Eikoje“ dirbančių administracijos darbuotojų net 31 - VGTU absolventas. „Eikos statyboje " iš 44 darbuotojų 19 - VGTU absolventai. Pasirašytoje sutartyje numatyta sudaryti praktikos sąlygas „Eikos“ ir „Eikos statybos" rinkodaros, pardavimų, finansų ir gamybos skyriuose. Pasak VGTU rektoriaus prof. habil. dr. Romualdo Ginevičiaus, ši sutartis yra geriausias pavyzdys, kaip realiai galima užtikrinti kvalifikuotų specialistų rengimą. „Rinkos poreikiai ir technologijos keičiasi greičiau nei akademines programos. Studiju metu rinkos ekspertu perteiktos praktinès žinios jaunimui suteikia konkurencini pranašuma darbo rinkoje ir pasitikejimo savimi kaip specialistais", - įsitikinęs universiteto vadovas. „Eikos“direktorius Robertas Dargis pabrežè, jog „proto nutekejimo “ i užsienị kontekste pasirašytu dokumentu siekiama atskleisti karjeros galimybių Lietuvoje perspektyvas gabiausiems studentams, „idarbinti labiausiai praktikos metu pasižymejjestudentai bus finansiškai paskatinti. Büdami vienu aktyviausiu rinkos dalyviu, mes esame suinteresuoti dalintis praktine patirtimi, kad aukštasias mokyklas baigtu realiam darbui pasirengespecialistai ", - teigia sutarties iniciatorius R. Dargis [6.42, p. 2].

Metų pradžioje reikšmingos permainos padarytos VGTU „Technikos“ leidykloje. Jos direktore tapo Eleonora Dagiene. Suformuoti trys skyriai: Leidybos (vedeja Nina Gilytè), Maketavimo (vedëja Audroné Gurklienè) ir Elektroninès leidybos (vedëja Jevgenija Petkuvienè). Anot E. Dagienès, leidykla „Technika“ yra jau tinkamas autoriaus pagalbininkas, siekiantis tapti dar geresniu. Nuolat tobulejanti „Technikos“ leidyklos produkcija patvirtina šiuos direktorès žodžius.

Puikiai aukštųjų mokyklų studentų sambo imtynių čempionate pasirode VGTU komanda, laimejjusi komandinę pergalę. 
Atskirose svorio kategorijose nugalètojais tapo Ignas Petkevičius M-5/2 gr. studentas ir Tomas Mečkovskis - S-5/7 gr. studentas. Tai pagirtino trenerio Alberto Sulinsko darbo rezultatai.

Sausio mènesį Antano Gustaičio aviacijos instituto direktorius prof. habil. dr. Jonas Stankūnas buvo išrinktas Nacionalinio aeronautikos technologines platformos kūrimo tarybos pirmininku.

Vasario 23-25 d. VGTU dalyvavo tarptautineje aukštojo mokslo, profesinio mokymo ir kvalifikacijos kèlimo parodoje. Mūsų universitetas plačiai pristate pirmosios ir antrosios pakopų studijas, fakultetus, institutus, centrus, priemimo į juos sąlygas, praejusiu metų įstojimo konkursus, studentų mainus ir studijas užsienio kalba, tęstines studijas, užsienio kalbų kursus, mūsų absolventų įsidarbinimo galimybes bei mokslo projektus. Tuo pat metu vyko ir Vilniaus knygų muge. Mugès dienomis leidyklos direktore Eleonora Dagiené gavo dokumentą, patvirtinantį, kad „Technikos“ leidykla tapo Lietuvos akademinių leidyklų asociacijos nare. Ši asociacija vienija KMU, KTU, KU, LVA, LKKA, ŠU, VPU, VDU, M. Romerio universiteto, Vilniaus ir Kauno kolegiju leidejus. İstatuose numatyta, kad nariai gins vieni kitu interesus, bendraudami su valstybès institucijomis, tarptautinemis organizacijomis, kitomis leidybos, gamybos ir prekybos ịmonemis. Taip pat derins neperiodinių leidinių ir žurnalų leidybos bei platinimo interesus, teiks asociacijos nariams paslaugas ir turimą informaciją, koordinuos, organizuos ir rems leidejjų dalyvavimą šalies ir tarptautinèse knygų mugèse. Susivienijus bus lengviau pletoti elektroninę leidybą - įdiegti skaitmenines technologijas, parengti nemažai elektroninių vadovelių, kitos mokomosios medžiagos. Leidejjai ketina igyvendinti ambicingus projektus, efektyviau kelti akademinès leidybos lygit, kartu rūpintis jos pletra, dalytis įvairia kita patirtimi [6.43, p. 1].

Puikiai atstovavo Vilniaus Gedimino technikos universitetui mūsų jaunieji mokslininkai Lietuvos mokslų akademijos tradiciniame mokslinių darbų konkurse.

Jaunųjų mokslininkų mokslinių darbų 2005 m. konkurso Technikos mokslų skyriuje nugalètoju tapo Medžiagotyros ir suvirinimo katedros asistentas Irmantas Gedzevičius. Jo darbas - „Metalinių purkštujju dangų struktūros ir savybių priklausomybès nuo technologinių parametrų tyrimas“.
Studentų mokslinių darbų 2005 m. konkurso nugalettojais tapo trys mūsiškiai: Matematikos, fizikos ir chemijos mokslų skyriuje Matematines statistikos katedros doktorantas Viktoras Chadyšas, o Technikos mokslų skyriuje - Statybines mechanikos katedros magistrantas Valentin Jankovskij ir Aplinkos apsaugos katedros doktorantas Mindaugas Kvasauskas.

Džiugino universiteto bendruomenę savo kultūriniais renginiais VGTU biblioteka. Ši kartą joje buvo surengta japonų medžio raižinių paroda. Parodą atidarant dalyvavo Japonijos ambasados laikinasis reikalų patiketinis, VGTU vadovai ir kt.

\section{„Aukso paukštè“ - „Vingiui“}

Prieš septynerius metus Lietuvos liaudies kultūros centras kartu su Pasaulio lietuviu dainų šventès fondu mejejeju meno kolektyvams ir jų vadovams îsteige prizą ,Aukso paukšte“. Dèl jos varžosi šokių ir tautinès muzikos, folkloro, chorai ir vokaliniai ansambliai. Šokių ir tautinès muzikos ansamblių grupëje geriausiu 2005-ųjų metų mégëjų meno kolektyvu pripažintas ir mūsų universiteto jaunimo tautinių šokių ansamblis „Vingis“. „Aukso paukštes" įteikimo iškilmès ir laureatų koncertas vyko Nacionaliniame dramos teatre. „Vingi“", gavusį „Aukso paukšstę“, sveikino infrastruktūros ir užsienio ryšiu prorektorius, buvęs šio ansamblio šokejas prof. Algirdas Vaclovas Valiulis. Jis koncerto organizatoriams, žiūrovams primine, kad $1962 \mathrm{~m}$. pirmieji entuziastai pradejo repeticijas, o rudenį surenge ir

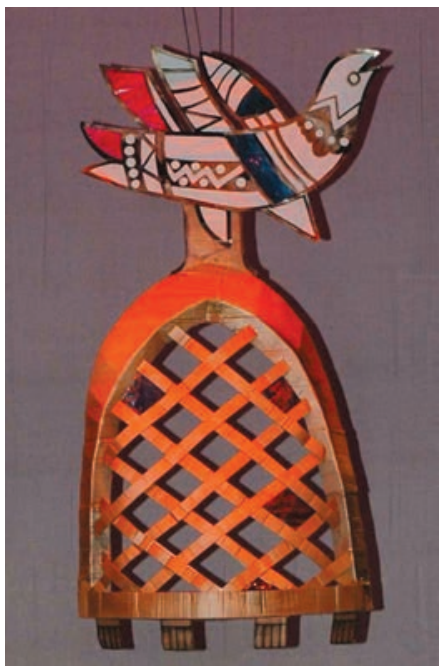

„Aukso paukšté

„Vingio" meno vadovai Iš dešines:

R. Zaleckaite, R. Tamutis,

A. Jonušas ir R. Stančiauskas

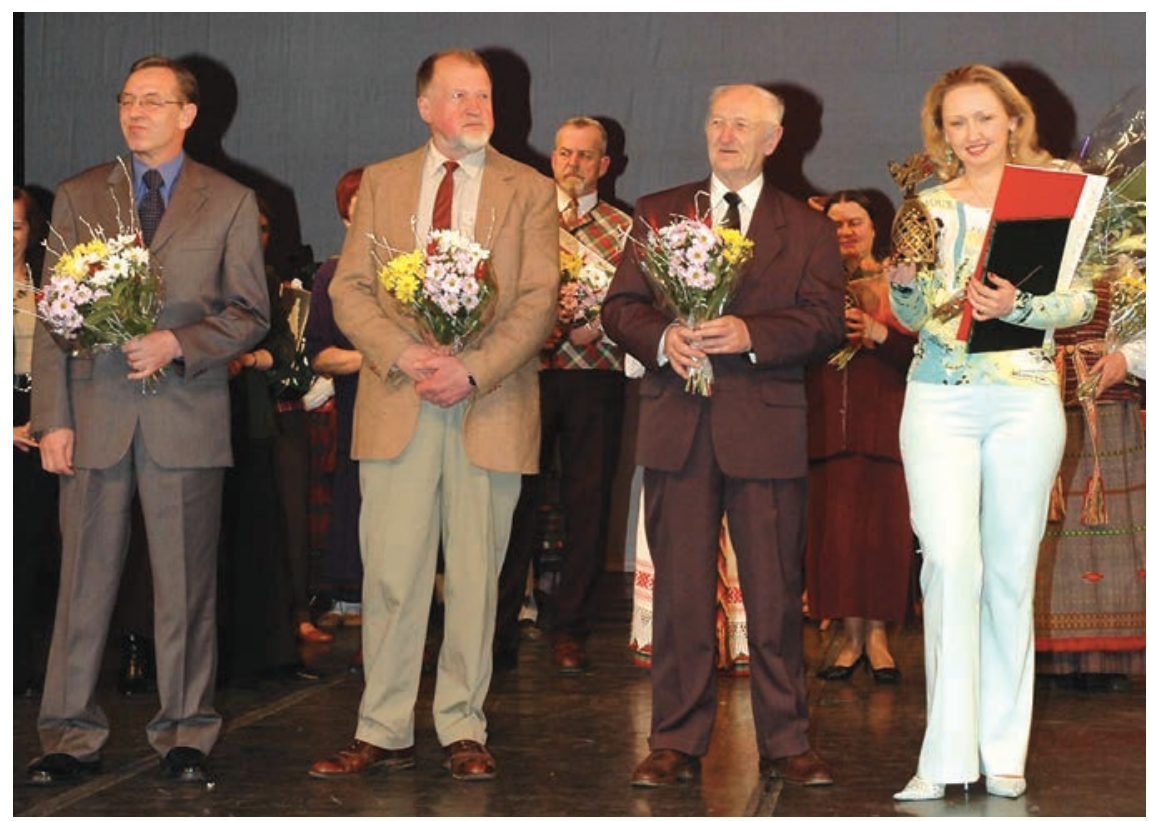


VILNIAUS

GEDIMINO

TECHNIKOS

UNIVERSITETAS

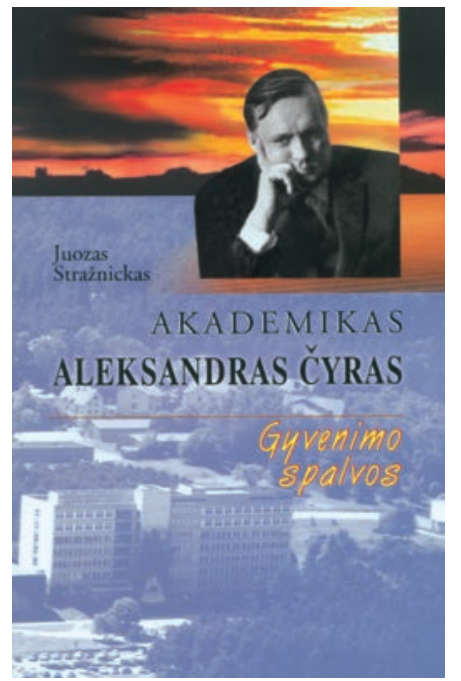

Viršuje -

„Vingis"2005 m. koncertavo Rusijoje

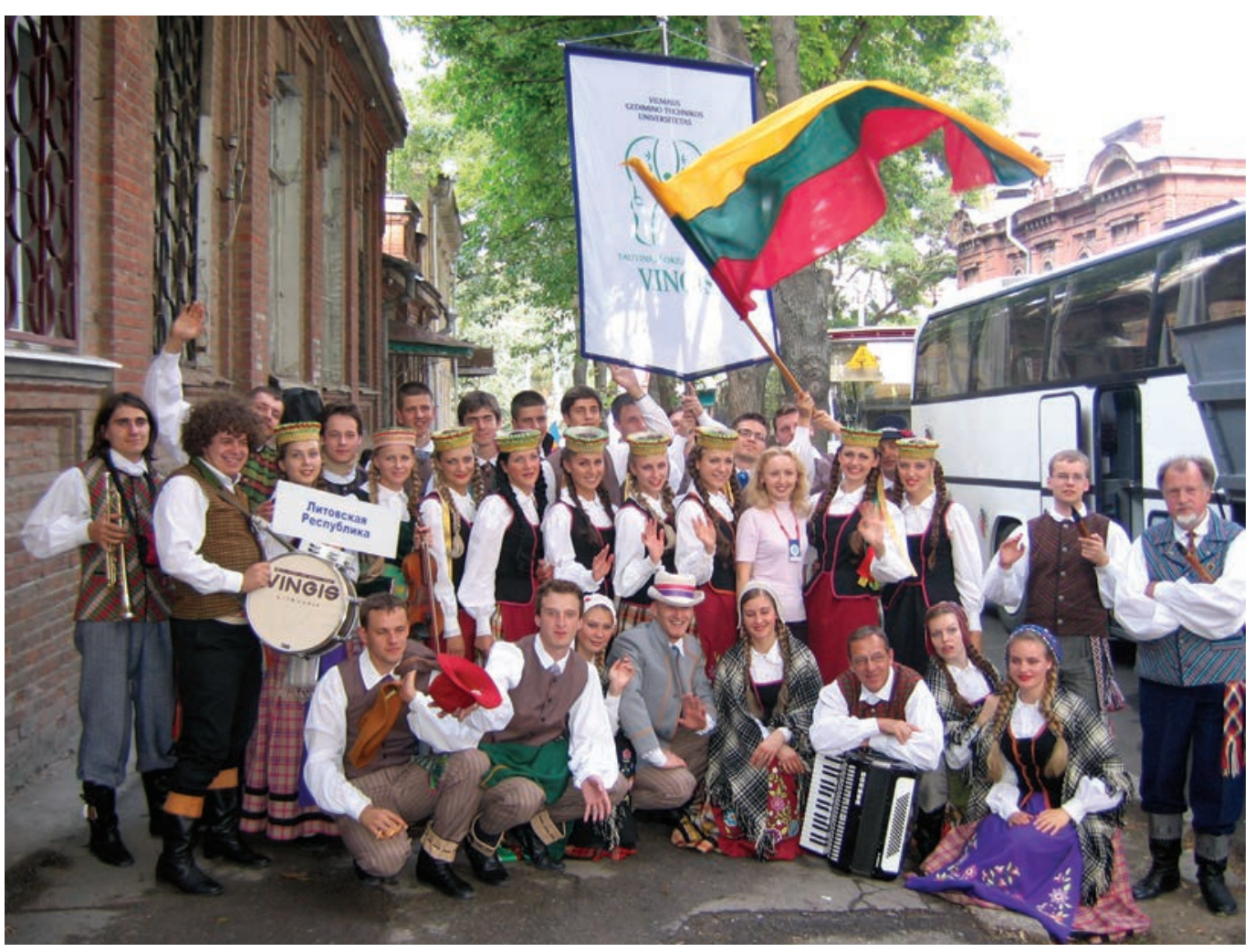

pirmąji koncertą. Ir taip pamažu ta nedidelè srovelè išsivingiavo ị didelị, plačiai žinomą „Vingiّ", visu pastebimą, besididžiuojanti garbingu apdovanojimu. Tai nuoširdūs ne vienerių metų Rimutés Zaleckaites, choreografo Ričardo Tamučio, instrumentinés grupès vadovo Antano Jonušo darbo rezultatai.

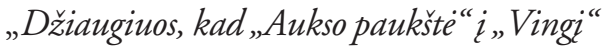
atkeliavo universiteto jubiliejiniais metais. Tai geriausia, kokia mes galejome parengti, kolektyvo dovana savajai Alma Mater penkiasdesimtmečio sukakties proga ", - sake ansamblio vadovè Rimute Zaleckaite, padekojusi šokèjams, muzikantams už meilę šokiui, tautinei muzikai ir universiteto vadovybei už demesi ir visokeriopą paramą [6.44, p. 1$]$.

Toliau buvo pletojamas bendradarbiavimas su kaimynais lenkais. Viešeję Lenkijoje VGTU senato pirmininkas prof. D. Čygas, mokslo prorektorius prof. R. Kirvaitis ir kt. aptare bendradarbiavimo galimybes su Vroclavo technologijos universiteto Aplinkos ir Civilines inžinerijos fakultetais. Buvo pasirašyta sutartis, pagal kurią vyko destytoju ir darbuotoju mainai.

Aukštųjų mokyklų bendrųjų vadovèlių leidybos komisija vertino vadoveliu leidybos reikalus - kalbos taisyklingumą, išraiškingumą, vadovèlių maketą, dizainą, poligrafinę kultūrą. Vienu geriausiu išrinktas ir VGTU leidyklos „Technika“ išleistas vadovelis. Už nepriekaištingai suredaguotą prof. R. Čiegio vadoveli „Lygiagretieji algoritmai ir tinklinès technologijos" švietimo ir mokslo ministras Padekos raštu apdovanojo leidyklos "Technika“ vyresniąją redaktorę Ritą Malikenienę.

Pavasarị vèl pradžiugino mūsų sportininkai. Lietuvos aukštujjų mokyklų stalo teniso čempionate VGTU komanda laimëjo visus susitikimus ir tapo nugaletoja. Komandoje žaide AAT-3 gr. studentas A. Skirgaila, S 3/4 gr. studentas V. Švedas, $S$ 5/8 gr. studentas V. Medaikis ir S 5/6 gr. studentas M. Buda. Dideli nuopelnai priklauso ir ilgamečiam VGTU rinktinès treneriui doc. Henrikui Sausenavičiui, visuomeninkui, dideliam šios sporto šakos entuziastui.

\section{Knyga apie akademika A.Čyra}

„Technikos“ leidykla išleido Juozo Stražnicko monografiją „Akademikas Aleksandras Čyras. Gyvenimo spalvos“. Tai išsamus, gausiai dokumentais, prisiminimais ir nuotraukomis praturtintas pasakojimas apie aukštosios technikos mokyklos steigëją mūsų šalies sostinëje, Vilniaus inžinerinio statybos instituto rektoriu, optimaliosios statybinès mechanikos kūreją. Minint A. Čyro gimtadienį, kovo mènesi J. Stražnicko knyga pristatyta skaitytojams. Rektorius R. Ginevičius pažymejo, kad Aleksandro Čyro pavarde aukso raidemis 
įrašyta universiteto Atminimo memoriale. Universiteto jubiliejaus proga prie ięjimo ì Sauletekio rūmus atsiras pirmojo rektoriaus biustas. Nuo 2002 metų pažangiausiems studentams skiriama jo vardo stipendija. Prisiminimais pasidaliję akademikai Jonas Kubilius, Antanas Kudzys, profesoriai Henrikas Zabulis, Edmundas Kazimieras Zavadskas, docentai Juozas Nagevičius, Romualdas Sakalauskas lyg susitarę sake, jog pristatomos knygos herojus - neeilinè, valdinga ir nepaprastai darbšti asmenybé, pasaulinio garso mokslininkas, garsiosios optimizacinès statybinès mechanikos

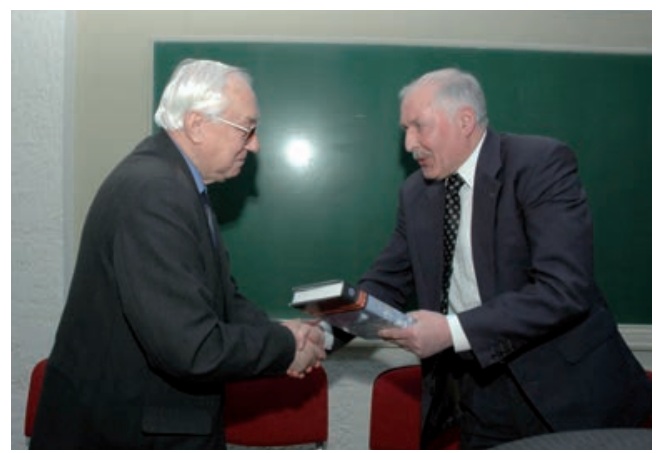

J. Stražnickas jiteikia knyga A. Cyro broliui Petrui Cyrui mokslo mokyklos, kurią per tris dešimtmečius „baige“" 46 profesoriaus mokiniai, ịkūrëjas.
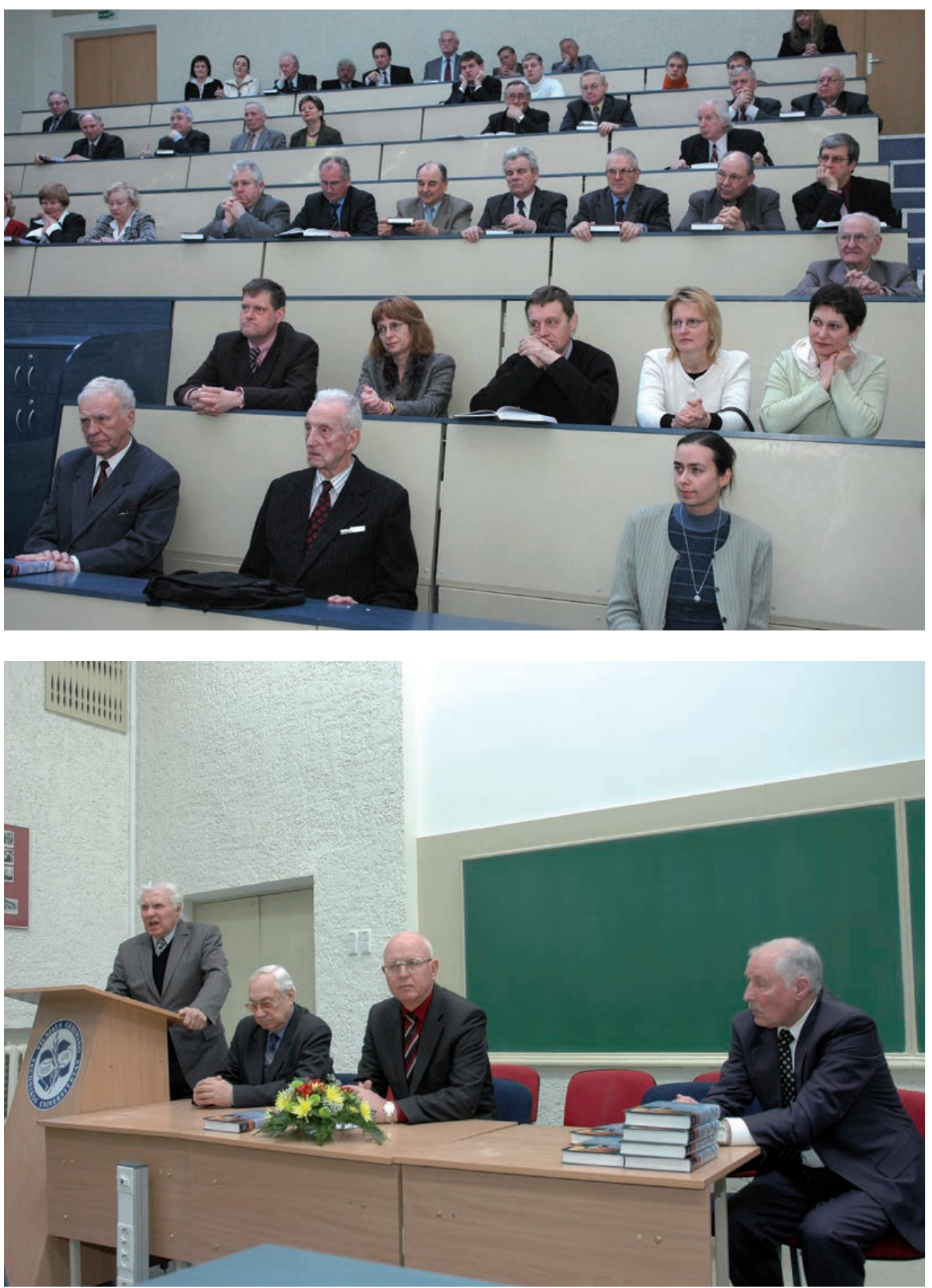
VILNIAUS

GEDIMINO

TECHNIKOS

UNIVERSITETAS
Viršuje dešinëje -

K. D. Frohner

VGTU Garbés daktaras
Lietuvos sambo 2006 metų sunkaus svorio čempionu tapo VGTU studentas Tomas Mečkovskis (S-5/7 gr.). Jis iškovojo pirmąją vietą ir absoliučioje svorio kategorijoje.

$2006 \mathrm{~m}$. balandį buvo nustatyti VGTU mokslinių monografijų vidinio konkurso nugaletojai. Pirmoji vieta paskirta Geodezijos ir kadastro katedros prof. habil. dr. P. Petroškevičiui už monografiją "Gravitacijos lauko poveikis geodeziniams matavimams", antroji vieta - Tiltų ir specialiụju statiniu katedros prof. habil. dr. G. Kaklauskui už monografiją „Integral Flexural Constitutive Model for Deformational Analysis of Concrete Structures", trečioji vieta - prof. dr. Z. Daunorai, doktorantei S. Kirvaitienei, doc. dr. Algiui Vyšniūnui už monografiją „Vilniaus miesto vizualinio identiteto apsauga ir pletros principai“.

Buvo paskelbti ir aukštojo mokslo vadovelių VGTU konkurso nugalètojai. Pirmoji vieta paskirta prof. habil. dr. J. Atkočiūnui ir doc. dr. J. Nagevičiui už vadoveli „Tamprumo teorijos pagrindai“, antroji vieta - prof. habil. dr. E. K. Zavadskui, doc. dr. A. Karablikovui, prof. dr. V. Kriukeliui (mirusiam), doc. dr. H. Nakui, doc. dr. R. Sakalauskui ir doc. dr. J. R. Šimkui už vadoveli „Pastatų statybos technologija“ bei prof. habil. dr. E. K. Zavadskui, doc. dr. P. Mikštai, doc. dr. R. Sakalauskui ir doc. dr. Šimkui už vadovèli „Statybos organizavimas“, trečioji vieta - prof. habil. dr. R. Barauskui, prof. habil. dar. R. Belevičiui ir prof. habil. dr. R. Kačianauskui už vadoveli „B „Baigtinių elementų metodo pagrindai“.

Visi konkursu nugaletojai apdovanoti piniginemis premijomis. Tarptautini apdovanojimą - „Swiss Baltic Net Graduate Award" - pelne Elektronikos fakulteto doktorantas V. Jasonis. 500 Šveicarijos franku jam paskirta už praejjusių metų mokslines konferencijas.

Didejjantị jaunimo dèmesį moksliniam darbui rodo vis aktyvesnis jaunųjų mokslininku dalyvavimas mokslinèse konferencijose. Tarkim, 9-ojoje jaunųjų mokslininku konferencijos „Mokslas - Lietuvos ateitis“ Aplinkos apsaugos inžinerijos sekcijos darbe dalyvavo net 115 jaunųjų mokslininku, tarp jų - 22 dalyviai iš užsienio - Rusijos, Lenkijos, Slovakijos, Latvijos.

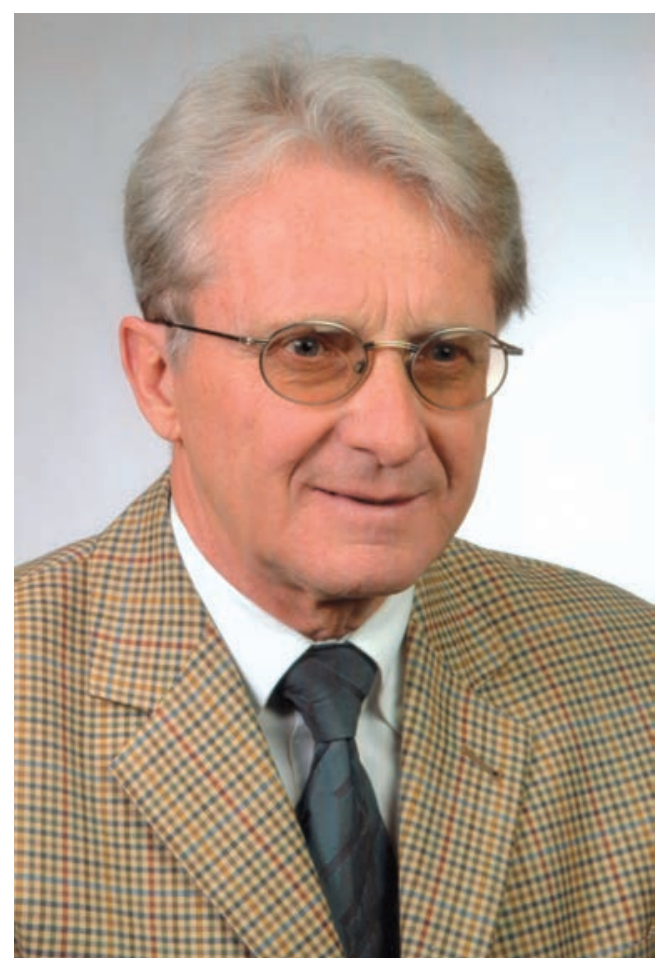

$2006 \mathrm{~m}$. balandis praturtino ir VGTU profesoriu gretas. Profesoriaus diplomai Senato posedyje buvo įteikti Donatui Čygui, Alfredui Laurinavičiui, Leonidui Sakalauskui, Albertui Čaplinskui. Tame pačiame Senato posedyje Hamburgo-Harburgo technikos universiteto Ergonomikos instituto vadovui prof. dr.-inž. Klaus-Dieter Frohner suteiktas VGTU Garbès daktaro vardas.

\section{VGTU darbo apžvalga}

Rektorius prof. habil. dr. Romualdas Ginevičius pabande apibendrinti Vilniaus Gedimino technikos universiteto darbo pastarojo laikotarpio rezultatus, tam naudodamas VGTU bei kitų universitetų rodiklius, kurie buvo paskelbti žurnale „Veidas“:

„Kompleksinio lyginimo lenteles rezultatai rodo, kadinformaciniu technologijuspecialybëje VGTU užima antraja, bioinžinerijos - antraja, elektronikos - pirmaja, statybos - antraja, transporto inžinerijos-pirmają ir vadybos - pirmaja vieta. Sitiekpirmuju - antrujuvietunè vienam universitetui neskirta <...> I Idomus dar vienas aspektas. "Veido"lenteleje išvardyta 10 specialybiu. Ju pavadinimai rodo, kad tai šiuo metu paklausiausios specialybès. Saraše aštuonis kartus paminetas VU, šesis - Vilniaus Gedimino technikos universitetas, penkis - KTU, keturis VDU, tris-MRU ir du-KMU. Šie skaičiai irgi liudija apie universitetu reagavima i rinkos poreikius. Gerikiekybiniai rezultatai liudija ir 
apie kokybę, nes kiekybei ir kokybè müsu veikloje lemia viena kita " $[6.45$, p. 3].

Rektorius pabrežè, kad nors pagal 2005 metų stojimo ir prièmimo rezultatus buvome antri po Vilniaus universiteto, pagrindinį dèmesį būtina atkreipti ị studijų kokybę, kurią lemia desstymo lygis, materialinè studijų bazè, studiju programų kokybè. Prof. R. Ginevičius išanalizavo visų šių trijų veiksnių būklę ir akcentavo, kad destymo kokybei gerinti dar reikia daug padaryti. Materialinè studijų baze be rimto finansavimo iš esmés negali būti pagerinta. Dabar apsieinama tik kosmetinemis priemonemis. Studiju programos didesnio rūpesčio nekelia. Tai liudija jų atestacija, taip pat ir tarptautinè.

Rektorius pažymëjo, kad dauguma dèstytoju dirba profesionaliai, sąžiningai ir pasiaukojamai, o tokių, kurie neatitinka reikalavimu - tik vienetai.

Rektorius R. Ginevičius džiaugèsi įspūdingais, palyginti su ankstesniais metais, VGTU mokslininkų darbo rezultatais. Vadinamųju „Master list" moksliniu straipsnių 2005 m. paskelbta 46, t. y. beveik 4 kartus daugiau nei $2001 \mathrm{~m}$. Dar daugiau išaugo „ISI proceeding“ tipo straipsnių: $2005 \mathrm{~m}$. jų paskelbta net 110 . Bendras visų mokslinių straipsnių skaičius i̊spūdingas - per 1500. Užsakomųjų mokslo darbų atlikta už $10 \mathrm{mln}$. litų. Mokslinès produkcijos gausa pasižymi Kelių, Aplinkos apsaugos, Geodezijos ir kadastro, Statybos ekonomikos ir nekilnojamojo turo vadybos, Transporto vadybos, Imonių ekonomikos ir vadybos katedros. Malonu, kad VGTU mokslininkų straipsniai vis dažniau patenka i Lietuvos mokslo tarybos patvirtintus tarptautinių mokslo duomenų bazių sąrašus.

Užsakomųjų mokslo tiriamųjų darbų daugiausia įvykde Kelių katedros ir jos laboratorijos, Urbanistikos katedros ir jos laboratorijos, Elektroninių sistemų, Gelžbetoninių ir mūrinių konstrukcijų, Transporto technologinių irrenginių katedros mokslininkai.

Sèkmingiausiai su tarptautiniais projektais dirba Statybos ekonomikos ir nekilnojamojo turto vadybos katedra (vedejas A. Kaklauskas). Rektoriaus manymu, daugelio katedru mokslininkai nèra pakankamai aktyvūs ir atkaklūs rengdami paraiškas struktūriniams fondams, kuriuos gavus atsiranda lěšų, labai reikalingų esamai laboratorinei bazei atnaujinti ar naujai įrangai įsigyti.

Rektorius džiaugiasi, kad vis daugiau jaunųjų mokslininkų, apgynę daktaro diser- taciją, lieka dirbti VGTU. Tai gerina universiteto desstytojų amžiaus kitimą - stabilizavosi destytojų amžiaus vidurkis, universitetas neteko senëjimo tendencijos.

Desstytojų mokslinè kvalifikacija aukšta turintys mokslo laipsnius ir vardus sudaro per 65 proc. $2005 \mathrm{~m}$. buvo apgintos 38 daktaro disertacijos, keletas perejo habilitacijos procedūrą profesoriaus vardui gauti.

Rektorius gyre leidyklą „Technika“, VGTU biblioteką ir Skaičiavimo centrą.

Bendras leidyklos „Technika“ leidinių skaičius nuo pusantro tūkstančio $2002 \mathrm{~m}$. išaugo iki pustrečio tūkstančio $2005 \mathrm{~m}$. Leidykla dirba gerai, naują impulsą ji igavo, kai buvo patobulinta jos struktūra ir vadovauti èmè buvusi jos darbuotoja Eleonora Dagiené. Prie spręstinų klausimų reikètų priskirti universiteto leidiniu platinimo ir pardavimo aktyvinimą. Tam leidykloje įsteigta vadybininko pareigybè.

VGTU biblioteka pagrịstai pripažinta viena pažangiausių šalyje ir bene pažangiausia tarp visų Lietuvos universitetų bibliotekų. Jos kolektyvas yra labai darbingas, energingas ir kūrybingas. Tolesnei jos plètrai reikia išspręsti patalpų, esančių šiame pastate, išlaisvinimo ir įrengimo klausimus. Šiuo metu VGTU turi galingiausius skaičiavimo išteklius Lietuvoje. Tai leidžia vykdyti rimtus mokslinius tyrimus ir skelbti prestižines publikacijas. Sparčiai gerèja aprūpinimas kompiuteriais skaičiuojant tiek vienam darbuotojui, tiek vienam studentui.

Kaip matyti iš rektoriaus R. Ginevičiaus pateiktos medžiagos, Vilniaus Gedimino technikos universitetas gali tvirtinti, kad jame sèkmingai igyvendinamos nacionalinès Lisabonos strategijos nuostatos, Bolonijoje pasirašyta Europos mokslo ministru jungtine deklaracija. VGTU nuolat siekia prisideti prie europines aukštojo mokslo erdvès, kūrimo, siekia prisitaikyti prie nuolat kintančiu poreikių, visuomenès reikalavimų, mokslo laimejimų. Daug padaryta, kad VGTU būtų atviras pasauliui, konkurencingas.

Malonu, kad VGTU mokslininkai vis dažniau yra tarp apdovanojamųjų. Balandžiui baigiantis, Vilniaus kongresų rūmuose minint Tarptautinę intelektinès nuosavybès dieną VGTU prof. habil. dr. Bronislovui Spruogiui buvo įteiktas Pasaulinès intelektinès nuosavybès organizacijos (WIPO) aukso medalis. Jị ir WIPO sertifikatą B. Spruogis gavo už per daugelį metų padarytus beveik 200 išradimų.
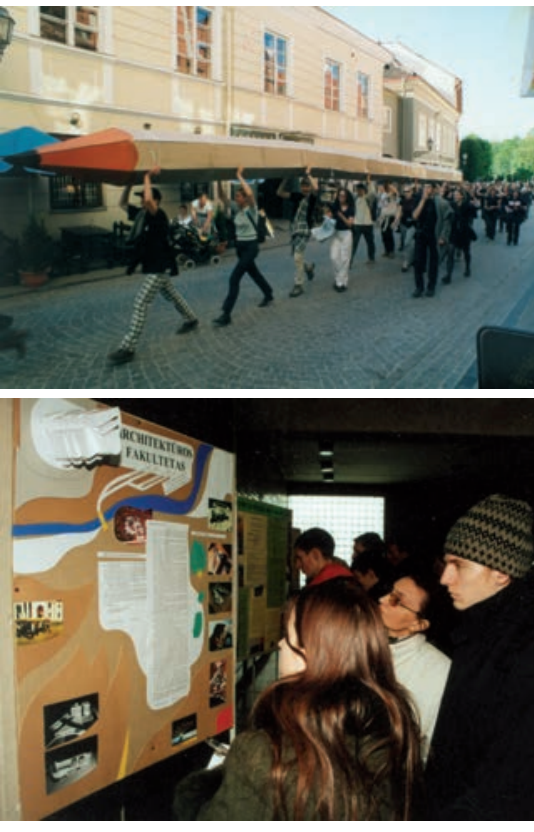

Architektu dienu vaizdai 
VILNIAUS

GEDIMINO

TECHNIKOS

UNIVERSITETAS
Aukštojo mokslo vadoveliu konkurso pirmosios premijos laimetojai su ministerijos vadovu Is kaires:

R. Martavičius,

R. Kirvaitis, R. Motuzas
Pažymėtina, kad toks apdovanojimas Lietuvos išradejjui buvo įteiktas pirmą kartą.

Jau po menesio išradejjai nudžiugino dar kartą. VGTU Biomechanikos katedros prof. habil. dr. Rimantas Kanapenas sukūrè lazerini gydymo prietaisą, skirtą įvairioms ligoms gydyti. Jis pagristas steriliu neinvaziniu lazerio spindulių ir magnetinio lauko kompleksiniu poveikiu žmogaus biologiniams audiniams ir kraujui. Šis lazerinis prietaisas (LMP-010 M) yra patentuotas ir sertifikuotas 25 Europos Sąjungos šalyse.

VGTU profesūra puikiai ịvertinta už aukštojo mokslo vadovèlių rengimą. $2006 \mathrm{~m}$. birželi Lietuvos švietimo ir mokslo ministro issakymu pirmaja premija apdovanoti vadovélio „Analogine elektronika“ (išleisto $2003 \mathrm{~m}$.) autoriai prof. habil. dr. Raimundas Kirvaitis ir prof. habil. dr. Romanas Martavičius. Trečioji premija už vadoveli „Automatiniu valdymo sistemų optimizavimas“ (2003 m.) paskirta prof. habil. dr. Algirdui Dambrauskui. Dvi paskatinamosios premijos paskirtos už vadovèli „Elektrinių riedmenų priežiūra ir patikimumas" (2001 m.) - prof. habil. dr. Leonui Lingaičiui ir už vadoveli „Krovinių vežimas" (2002 m.) - prof. habil. dr. Adolfui Baubliui.

Jau daug metų VGTU mokslininkai vykdo įvairius tiriamuosius darbus Lietuvos sostinei. Pažymètinas mūsų geodezininkų, transportininkų, architektų ir aplinkosaugos specialistu gražus ir abipusiškai naudingas bendradarbiavimas su Vilniaus savivaldybe. Siekiant efektyviau panaudoti Vilniaus Gedimino technikos universiteto mokslininku kūrybini potencialą sostinès labui, tarp Vilniaus miesto savivaldybes ir VGTU buvo pasirašyta bendradarbiavimo sutartis.

Sutartyje numatyta, kad VGTU mokslininkai padès gerinti Vilniaus infrastruktūrą, atliks reikalingas miesto pletrai ekspertizes, vykdys savivaldybès darbuotojų tęstinį mokymą, kels kvalifikaciją, dalyvaus bendruose

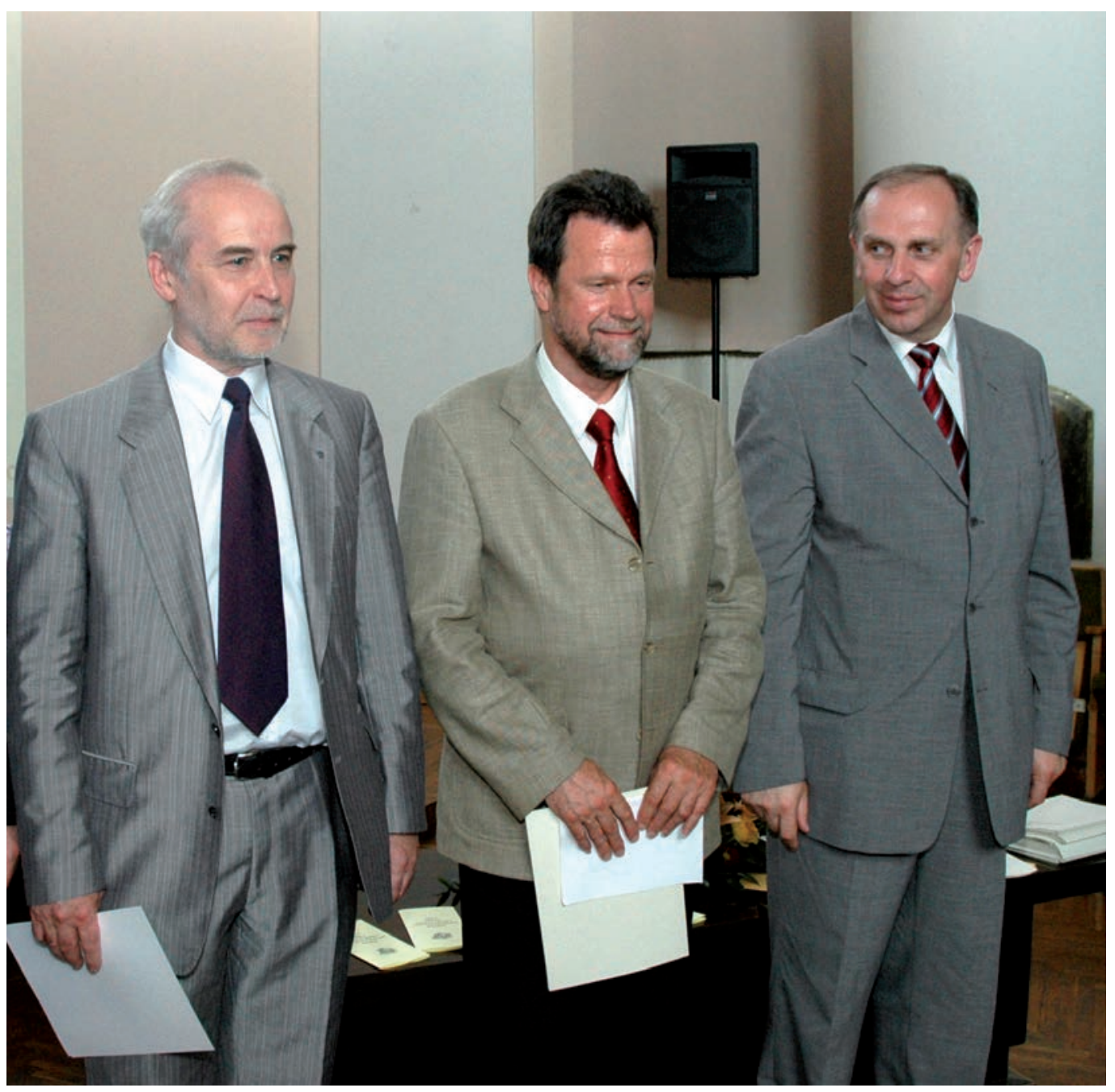


šalies ir tarptautiniuose sostinès plètros projektuose. Sutarti pasirašè rektorius R. Ginevičius ir meras A. Zuokas. Mažai turime VGTU atstovu politinese partijose, todèl universiteto bendruomenè dèmesingai išlydëjo ị Lietuvos Respublikos Seimą keletą metų buvusią Ekonomikos direkcijos vadovę Etelą Karpickienę. Taip jau susikloste, kad VGTU ekonomikos tvarkytoju pareigos kyla: Anatolijus Rimkevičius dabar - Vidaus reikalų ministerijos sekretorius, Arūnas Komka - VGTU kancleris, o štai Etela Karpickienè - Seimo nare. VGTU Ekonomikos direkcijos direktore paskirta Vilija Remeikienè.

Vilniaus Gedimino technikos universiteto senatas dar balandi paskelbè rektoriaus rinkimu reglamentą ir atskirą konkursą rektoriaus pareigoms užimti. Reglamente, be kita ko, sakoma, kad kandidatus i rektoriaus pareigas gali siūlyti universiteto padaliniai, pavieniai moksliniai pedagoginiai darbuotojai arba kandidatai gali siūlyti patys save.

Profesorių habilituotą daktarą Romualdą Ginevičių kandidatu į VGTU rektoriaus pareigas iškèle (antrajai kadencijai) net 11 universiteto padalinių. Jis buvo vienintelis kandidatas ị rektoriaus postą. $2006 \mathrm{~m}$. birželio $1 \mathrm{~d}$. „Inžinerijoje“ buvo paskelbtos kandidato i rektorius programinès tezés, kuriose prof. R. Ginevičius išdestė savo nuostatas svarbiausiais universiteto veiklos klausimais: studijų, mokslo, ūkio ir kt.

\section{Profesorius $R$. Ginevičius išrinktas VGTU rektoriumi antrajai kadencijai ir LURK prezidentu}

2006 m. birželio 7 d. VGTU senato posedyje įvykusiuose rektoriaus rinkimuose už prof. habil. dr. Romualdo Ginevičiaus išrinkimą rektoriumi balsavo 44 senatoriai, 3 balsavo prieš ir 2 susilaike. Prof. habil. dr. R. Ginevičius išrinktas Vilniaus Gedimino technikos universiteto rektoriumi penkeriu metų kadencijai, t. y. iki 2011 metų vasaros.

Rektorių R. Ginevičių sveikino senatoriai, bendradarbiai. Rožiu puokštę rektoriui itteike Studentu atstovybes prezidentas Justas Nugaras. Daugelyje aukštujjų mokyklų
SA konfrontuoja su rektoriais, o VGTU SA dalykiškai, kartais aštriai polemizuoja su universiteto vadovybe, bet ta polemika vyksta tarpusavio pagarbos ir supratimo dvasia. Tai padeda rektoratui ir Studentų atstovybei rasti abipusiškai naudingus sprendimus.

Prof. R. Ginevičiaus gebejjimas ne tik reikliai vadovauti, bet ir šiltai bendrauti su kolegomis bendradarbiais greitai buvo pastebetas šalies rektorių konferencijoje. Todel neatsitiktinai prof. Romualdas Ginevičius $2006 \mathrm{~m}$. birželio $16 \mathrm{~d}$. yra išrinktas

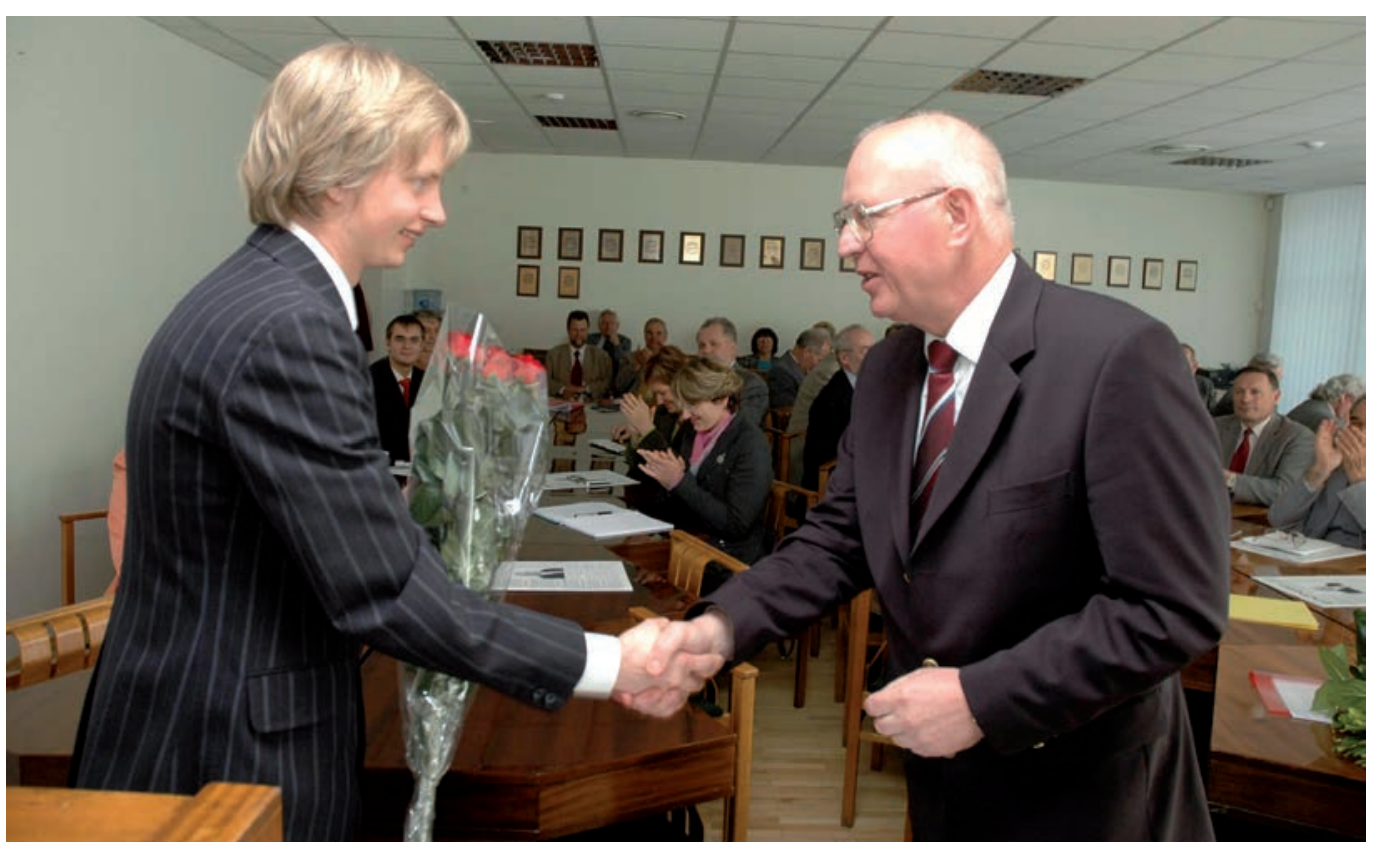

Studentu atstovybes prezidentas J. Nugaras sveikina rektoriu R. Ginevičiu 
VILNIAUS

GEDIMINO

TECHNIKOS

UNIVERSITETAS
LR Seimo pirmininkas V. Muntianas jteikia diplomus 2006 m. absolventams
Lietuvos universitetų rektorių konferencijos prezidentu.

Netrukus Senatas patvirtino rektoriaus pasiūlytus kandidatus į prorektorių ir kanclerio postus. Prorektoriais toliau dirba prof. habil. dr. Edmundas Kazimieras Zavadskas, prof. habil. dr. Raimundas Kirvaitis, doc. dr. Alfonsas Daniūnas. Pirmą kartą prorektoriumi dirba doc. dr. Liudvikas Rimkus. Kancleriu liko doc. dr. Arūnas Komka.

Birželio mènuo - universitetinio „derliaus" ir diplomy įteikimo metas.

2006 m. Vilniaus Gedimino technikos universitetas išleido 2707 absolventus. Pagrindines studijas baige 1856 žmones: Aplinkos inžinerijos fakultetą - 279, Architektūros fakultetą - 67, Antano Gustaičio aviacijos institutą - 45, Elektronikos fakultetą - 191, Fundamentinių mokslų fakultetą - 177, Mechanikos fakultetą - 162, Statybos fakultetą - 255, Transporto inžinerijos fakultetą -273 , Verslo vadybos fakultetą -403 ir Tarptautinių studijų centrą -4 .

Magistrantūros studijas baigè 849 žmonès, daugiausia - Statybos fakultetą - 193, Verslo vadybos fakultetą - 162 ir Aplinkos inžinerijos fakultetą -125 .

Per 50 Vilniaus aukštosios technikos mokyklos - KPI Vilniaus filialo, Vilniaus inžinerinio statybos instituto, Vilniaus technikos universiteto ir Vilniaus Gedimino technikos universiteto - veiklos metu iš viso išleista 45987 specialistai: pagrindinių studiju 38 140, magistrantūros studiju - 6989 ir specialiųju profesinių studiju - 858. Gyvenimas ịrodé, kad ịsteigti suverenią aukštąją technikos mokyklą Lietuvos sostineje buvo puikus sprendimas. Dar daugiau - tai buvo naudinga visai Lietuvai, jos ekonomikai ir kultūrai. Vilniaus Gedimino technikos universitetas tapo prestižine, viena geriausių ir didžiausių šalies aukštųjų mokyklų, kurios parengti specialistai savo darbu kuria Lietuvos ateiti.

\section{Pažangos kryptimi - vietoj epilogo}

Vilniaus Gedimino technikos universiteto 50-mečio jubiliejus paskatino knygos autorių nors stambiais rakursais apžvelgti sostinès aukštosios technikos mokyklos raidą. Ši mokykla neatsirado plyname lauke, jos ištakos susijusios pirmiausia su Kauno politechnikos institutu, tarpukario Lietuvos Vytauto Didžiojo universitetu ir 425 metus atšventusiu senuoju Vilniaus universitetu.

50 metų žmogui - labai didelis jo gyvenimo tarpsnis, o aukštajai mokyklai - brandos metai. Per šį laikotarpị Vilniaus aukštoji technikos mokykla, pradejusi veiklą turédama 75 studentus ir 10 destytojų, išaugo iki trečios pagal dydį Lietuvos aukštosios mokyklos - Vilniaus Gedimino technikos universiteto ir tapo vienu prestižinių Lietuvos universitetu.

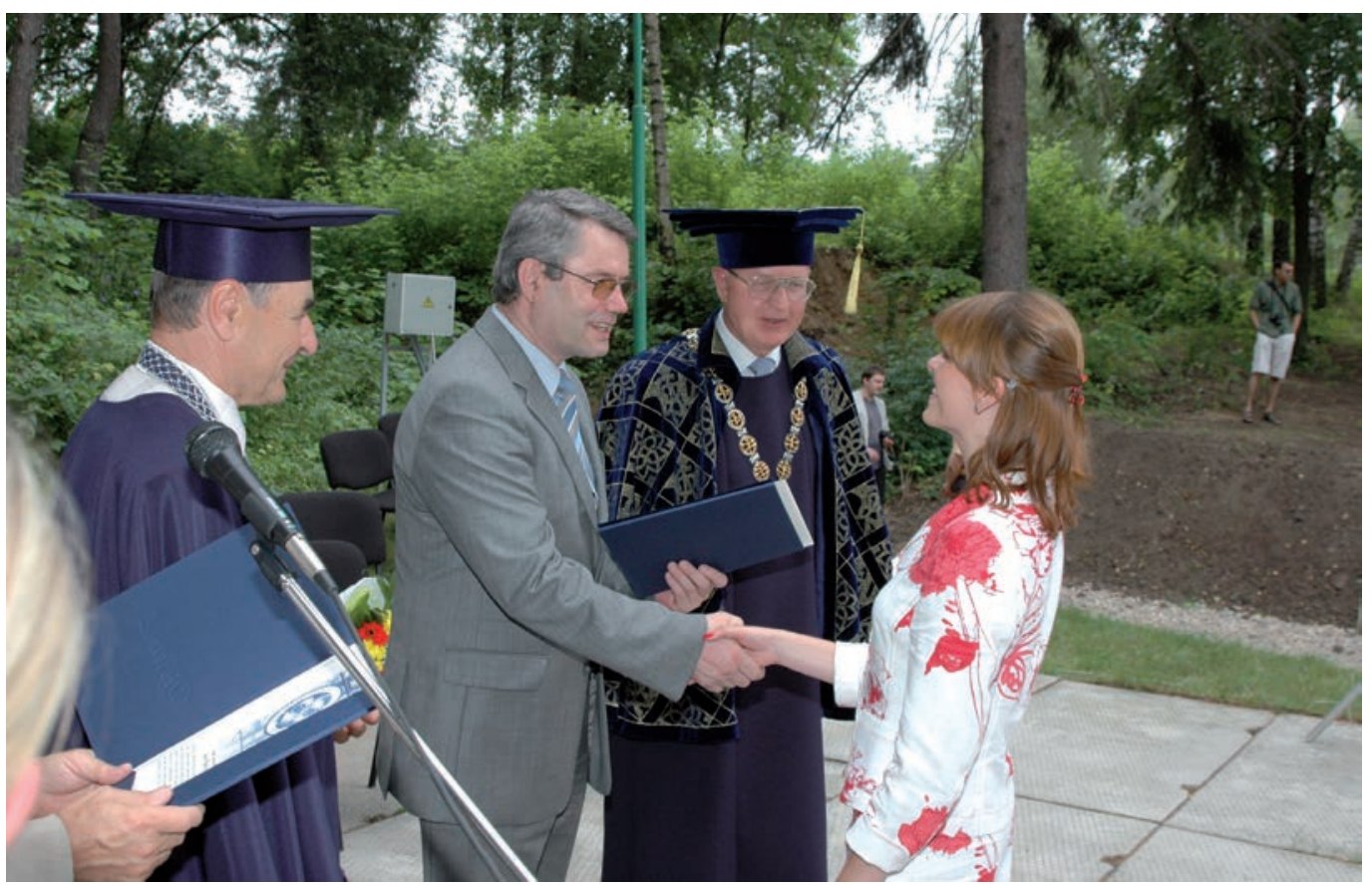


Jubiliejiniais metais Vilniaus Gedimino technikos universitete studijuoja per 15000 studentų pagal 88 studiju programas: pagrindinių studijų - 40, magistrantūros studiju 43, specialiuju studiju - 5. Studiju programos periodiškai nustatomos atsižvelgiant Lietuvos ūkio pokyčius ir specialistų poreikị. Todel VGTU specialistų paklausa yra didele. Mūsų absolventai praktiškai neturi ịsidarbinimo problemų. Studijų programų lankstumas leidžia parengti ir profesionalius gamybininkus, ir potencialius mokslininkus.

2006 m. birželị „Veido“ žurnale akademikas E. Vilkas taikliai apibūdino Lietuvos aukštojo mokslo padètị ir jo problemas. Jis rašo, kad universitetai jau ne mažiau kaip antrą dešimtmeti gyvena bado dieta. Materialinè bazè visiškai nuskurdusi, mokslininko profesijos prestižas nusmukęs dèl menku pragyvenimo perspektyvų ir socialinio statuso, studentai uždarbiauja pragyvenimui ir neturi kada studijuoti, be to, geresnius destytojus ir studentus pavilioja Europos ir Amerikos universitetai. E. Vilko manymu, nereikia kaltinti universitetu, kad jie atsilieka specialistu rengimo kokybe, moksline produkcija ir jos naudojimu, kol yra minetosios sąlygos. Jis teigia, kad vis dèlto aukštojo mokslo lygis Lietuvoje yra daug aukštesnis, negu jis turètų būti pagal finansavimo lygị ir daugeliu atvejų nenusileidžia vakarietiškajam. Tą liudija faktai, kad Lietuvoje parengti specialistai randa darbą Vakaruose [6.46, p. 10]. Mes žinome daug pavyzdžių, kai VGTU absolventai sèkmingai dirba Vokietijoje, Anglijoje, Suomijoje ir kitose išvystytose valstybèse.

Technikos universitetuose studijuoti nèra lengva. Daugiausia studentų iš tokių universitetų iškrinta pirmame, antrame kurse, neivveikę aukštosios matematikos, fizikos, chemijos. Dovanai diplomai nedalijami. Norint tapti konkurencingu specialistu, reikia daug ir atkakliai dirbti.

Specialisto parengimo kokybè daugiausia priklauso nuo destytojų kvalifikacijos ir pedagoginio talento. Aukštesnị dèstymo lygị lemia dèstytojo dirbamo darbo intensyvumas, geros kokybès stažuotès, galimybè naudotis naujausiais informacijos šaltiniais literatūra, internetu ir kt. Kai kurių dalykų desstytojai privalètų turèti inžinerinio ar verslininko darbo patirtị. Vis delto specialistui parengti reikšmingas ir pedagoginis desstytojo meistriškumas. Asmeninis kontaktas su geru mokslininku, patyrusiu ir sąžiningu desstytoju

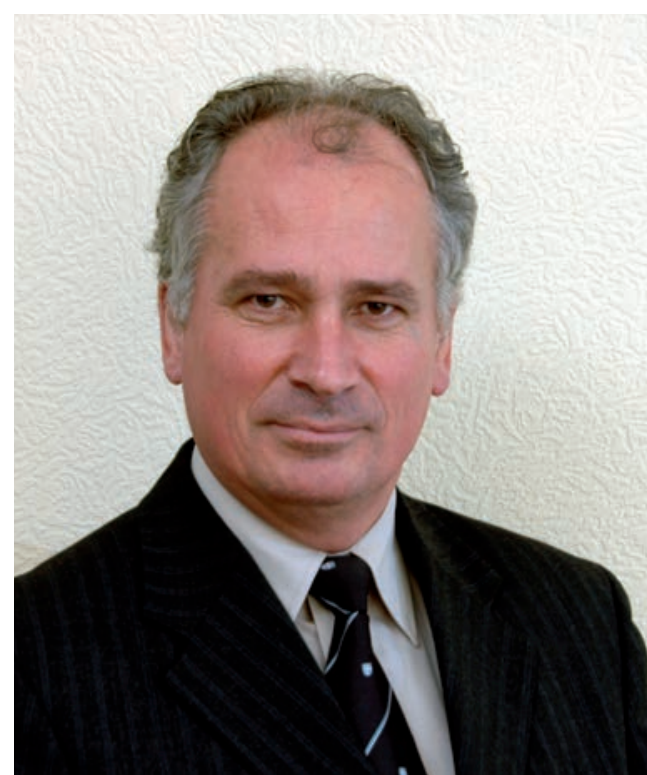

Prorektorius L. Rimkus

įkvepia būsimajam absolventui ne tik mokslo pažinimo troškimą, bet ir inžinerinio, vadybinio darbo reikalingumo suvokimą, profesijos žavesi, o kartais ir romantiškumą.

Vilniaus Gedimino technikos universitete dirba daug puikių destytojų, pasižyminčiu aukšta moksline reputacija, didaktine išmintimi, sąžiningu darbu. Jie sudaro universiteto akademinès bendruomenès daugumą, dèl jų atsidavimo turime gražių laimëjimų tiek rengiant specialistus, tiek vykdant mokslinius tyrimus. Jie sugeba rengti ne tik gerus specialistus, bet ir ugdo juos kaip piliečius, kaip giliai mąstančias asmenybes.

Sèkmingam studijų procesui reikia daug literatūros. Todèl nepaprastai svarbi šiam procesui yra biblioteka. VGTU biblioteka jau veikia per 40 metu ir tapo viena moderniausių šalyje. Jos fonduose yra beveik 600 tūkstančių leidinių, jų pavadinimų - per 120 tūkstančių. Profesionalūs ir kūrybingi per 60 bibliotekos darbuotojų nuolat tobulina bibliotekos darbą, diegia modernias naujoves. Iš skaitytojams skirtų 374 darbo vietų 38 yra kompiuterizuotos. Biblioteka prenumeruoja per dešimtį duomenų bazių, kuriomis naudojasi ir déstytojai, ir studentai. Sukurtos déstytojų ir mokslininkų publikacijų, VGTU žurnalų ir kt. lokalių duomenų bazès.

Studiju procese vis daugiau taikomos informacinès technologijos bei telekomunikacijos. Studiju reikmèms fakultetuose ir Skaičiavimo centre įrengta 41 kompiuterių klasè ir 673 darbo vietos. Čia vyksta informacinių technologijų bei kompiuterinès grafikos užsiemimai. Magistrantai ir bakalaurantai turi galimybių skaičiuoti IBM SP superkompiuteriu 
VILNIAUS

GEDIMINO

TECHNIKOS

UNIVERSITETAS
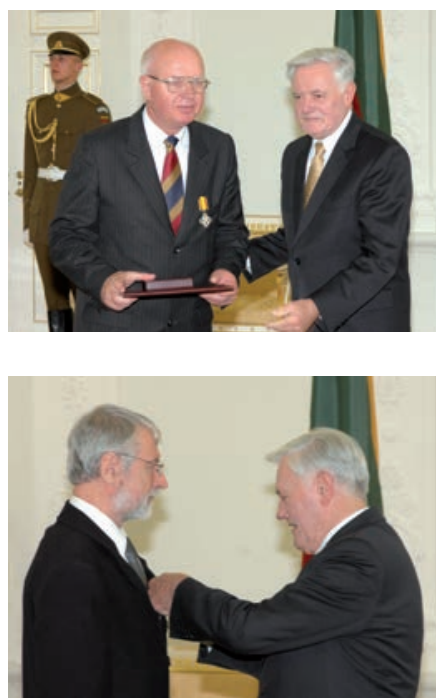

2006 m. liepa profesoriai

$R$. Ginevičius ir V. Dičius apdovanoti LDK Gedimino ordinu
VGTU daug dèmesio ir lěšu skiria mokslo ir mokomosios literatūros leidybai. Apie 60 \% leidžiamų leidinių sudaro mokslo knygos ir žurnalai, $40 \%$ - vadoveliai ir mokomosios knygos. Vadoveliai yra pagrindine priemoné. Jų svarba studijuojant labai didele, jei jie savo turiniu atitinka laiko kriterijus ir yra aukštos kokybès. VGTU vadoveliai daugiausia atitinka šiuos reikalavimus, tad dažnai yra premijuojami.

Pagerëjo VGTU leidžiamos literatūros ne tik mokslinè, bet ir estetine bei technine kokybe. Tai gero „Technikos“ leidyklos darbo rezultatas. Vien per pastaruosius penkerius metus "Technika" išleido 35 mokslines monografijas, 33 vadovelius, apie 300 mokomujju knygu, 11 moksliniu publicistiniu leidinių, leidžia dešimtį periodinių mokslo žurnalų, taip pat mokslo darbų, konferencijų straipsnių rinkinius ir t. $\mathrm{t}$.

Apie naujus universiteto uždavinius, kylančius Lietuvai tapus Europos Sąungos nare raše VGTU rektorius prof. R. Ginevičius. Jei mūsų studentai turès galimybę kaupti kreditus įvairiuose Europos universitetuose, jie perims ir įdiegs naujausias technikos, technologijos, ekonomikos ir vadybos žinias, taps konkurentiški ir vidaus, ir užsienio rinkose. Tik tokiu atveju Vilniaus Gedimino technikos universitetas bus žinomas, ir netrūks norinčiųjų jame studijuoti $[6.47$, p. 1$]$.

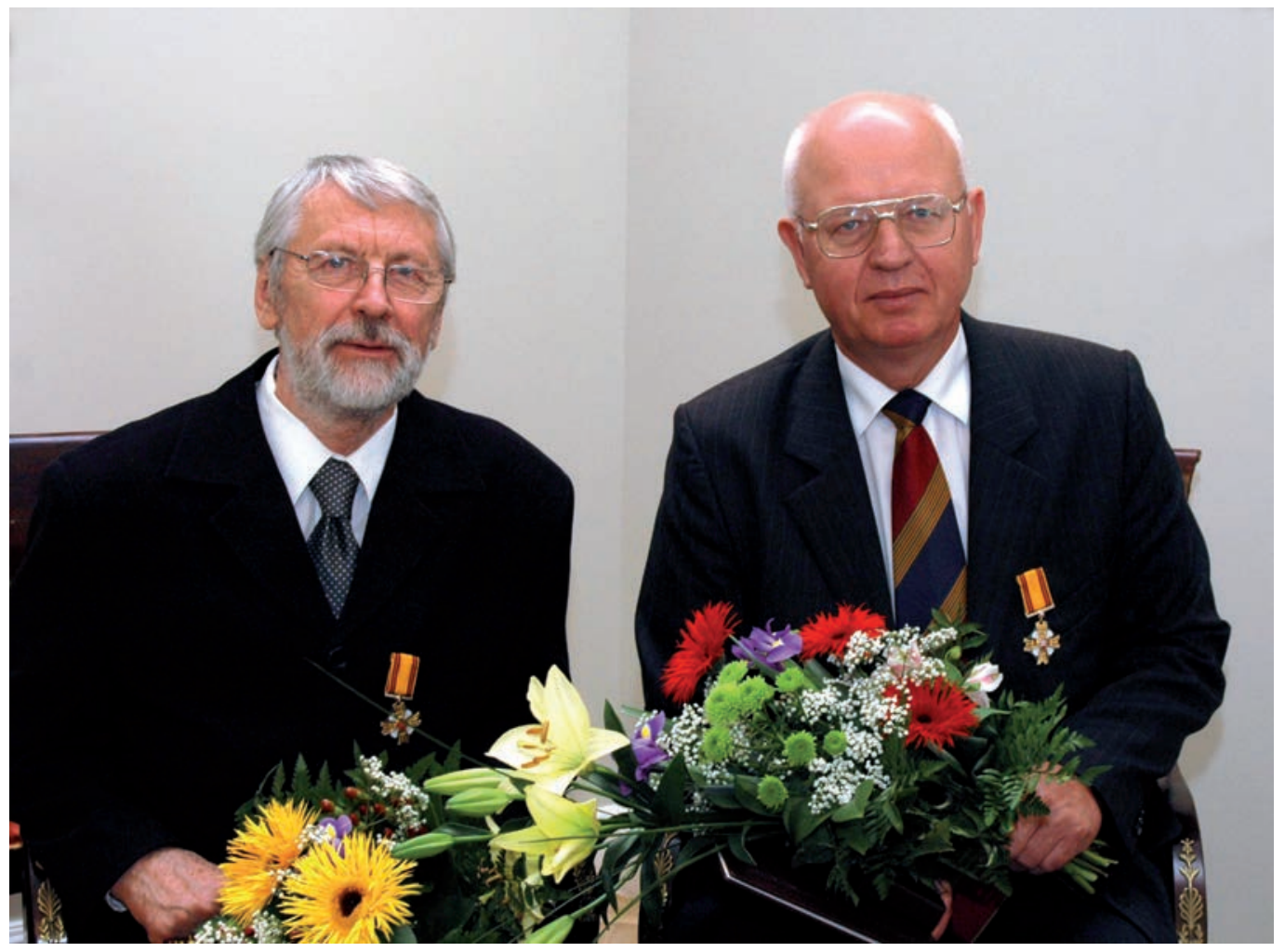


Vilniaus aukštojoje technikos mokykloje pirmiausia buvo pletojami technikos mokslai. Labiausiai pasižymëjo statybinès mechanikos, statybinių konstrukcijų, mechaninių sistemy̨ dinamikos, elektronikos sričiu atstovai. Véliau išpletoti ir fundamentinių mokslų - matematikos, chemijos, fizikos tyrimai. Per 50 metų atlikta labai daug naudingų kraštui taikomųjų mokslinių darbų.

Vilniaus Gedimino technikos universiteto 50-mečio jubiliejaus išvakarese mokslinius, tyrimus vykdo per 600 mokslininkų, turinčiu mokslo laipsnius, ir per 200 kitu tyrëjų.

VGTU pagrindines pareigas eina per 80 habilituotų mokslo daktarų ir per 360 mokslo daktarų. Tai galingas mokslinis potencialas, kurio pajegumą rodo periodiškai gaunamos nacionalines mokslo premijos, nuolat ginamos disertacijos, vis didejanti užsakomųjų mokslo darbų gausa, dalyvavimas tarptautiniuose projektuose. Turime per ketvirti tūkstančio doktorantų, kurių absoliuti dauguma sèkmingai vykdo mokslo darbus. Daugiausia darbų yra iš technologijos moksly̨ srities, bet ypač malonu, kad VGTU doktorantai gina disertacijas jau ir iš fundamentinių mokslų, konkrečiai - iš matematikos. Dabar Gedimino universitetas turi teisę organizuoti doktorantūrą ir teikti daktaro mokslo laipsnius 15-oje mokslo krypčių.

Vienas svarbiausių mokslininko veiklos rodiklių yra jo mokslines publikacijos. Vienas svarbiausiu kriterijų, vertinant universitetu mokslinę veiklą bei mokslinių publikacijų vertingumą, yra mokslinių straipsnių spausdinimas tarptautinëje mokslineje spaudoje, ypač leidiniuose, ịrašytuose į JAV Mokslinès informacijos instituto pagrindinị žurnalų sąrašą (ISI Master List). Malonu, kad tokiu VGTU mokslininkų publikacijų sparčiai daugëja.

Tenka pripažinti, kad taikomuosiuose moksluose - technikoje, technologijoje - vis labiau siaureja specializacijos, vis daugiau ivvairių šakų specialistai siaurina savo pažinimo sriti, kartu siaurina ir savo akiratị. Todèl Vilniaus Gedimino technikos universitete rimtas dèmesys skiriamas studentų dvasiniam ugdymui. Išauklètu žmogumi neįmanoma apsimesti. Išsiauklejjęs, dvasiškai turtingas žmogus ir yra inteligentas. Paprastai jis doras, jam svetimi kompromisai su savo sąžine, jis nèra gobšus, neklimpsta ị konjunktūrinị konformizmą. VGTU profesūra siekia ugdyti dorovinius įsitikinimus, pagarbą sąžiningam darbui, neabejingumą kultūrai. Čia svarbus vaidmuo tenka universiteto meno kolektyvams - „Gabijai“, „Vingiui“, „Palepei“. VGTU vadovybe sudaro studentams galimybę lankyti puikius Alma Mater Musicalis koncertus ir kt.

Per 50 metu Vilniaus Gedimino technikos universitetas parenge beveik 50000 specialistu. Dauguma jų buvo lietuviai ir ịsidarbino Vilniuje bei Vilniaus krašte. Tai pozityviai veike šio krašto lietuvinimą. VGTU absolventu yra ir visoje Lietuvoje. Absoliuti dauguma jų dorai ir gerai dirba ir dirbo, nemažai jų užima aukštus postus, valstybès, gamybos, verslo sferose, pasiekę puikių mokslo laimëjimų.

VGTU (VISI Statybos fakulteto) absolventas Rolandas Paksas buvo išrinktas Lietuvos Respublikos Prezidentu, du kartus buvo Ministru Pirmininku, Vilniaus miesto meru. Galima tik apgailestauti, kad padaryta rimtų klaidų, kurios lèmè nesèkmingą tolesnę Rolando Pakso karjerą.

Lietuvos Respublikos Ministru Pirmininku du kartus buvo ir Statybos-ekonomikos fakulteto absolventas Gediminas Vagnorius.

Daug absolventų buvo arba yra Lietuvos Respublikos Seimo nariais, Lietuvos Respublikos ministrais, departamentų vadovais ir t. t.

Mūsų absolventai yra ir dauguma dabartinių VGTU vadovų. Habilituotas mokslų daktaras, profesorius, VGTU rektorius Romualdas Ginevičius baige KPI Vilniaus filialą 1969 m., Lietuvos mokslų akademijos narys korespondentas, habilituotas mokslų daktaras, VGTU pirmasis prorektorius Edmundas Kazimieras Zavadskas baige KPI Vilniaus filialą 1967 m., mokslų daktaras, docentas, VGTU studijų prorektorius Alfonsas Daniūnas baige VISI 1978 m., mokslų daktaras, docentas VGTU pletros prorektorius Liudvikas Rimkus baigè VISI 1977 m., mokslų daktaras, docentas, VGTU kancleris Arūnas Komka baige VISI 1978 m.

Vilniaus Gedimino technikos universiteto bendruomenè džiaugiasi, kad daug universiteto profesorių apdovanoti DLK Gedimino ordinais ir medaliais.

Didžiuojamés universiteto žmonių kūrybiniais laimëjimais. Malonu, kad daugelis naujų puikių Lietuvos ir sostinés pastatų autoriai yra VGTU absolventai.

Mus džiugina pradèta dar vieno - labai svarbaus Gedimino universitetui - pastato statyba Sauletekio alejoje. Jis sudarys geresnes 
VILNIAUS

GEDIMINO

TECHNIKOS

UNIVERSITETAS studijų ir mokslo tiriamojo darbo sąlygas, sukurs dar modernesnị VGTU ịvaizdị.

Manome, kad Vilniaus Gedimino technikos universiteto studentu atstovybe dalykiškai gilinasi į studentų problemas ir padeda vadovybei jas spręsti ne konfrontuodama, bet atvirai ir aiškiai destydama abipuses pozicijas, ieškodama tinkamo sprendimo. Žvelgiant $i$ 50 metu mokyklos praeiti, galima padaryti išvadą, kad aukštosios technikos mokyklos ìkūrimas Vilniuje buvo strategiškai teisingas, laiku priimtas sprendimas, tiek tenkinant specialistu poreiki, tiek siekiant lietuvinti Lietuvos sostinę. Pasiaukojamo ir atkaklaus darbo rezultatas - Vilniaus Gedimino technikos universitetas - dar prieškario technikos srities inteligentijos svajonè.

Vilniaus Gedimino technikos universitetas pasiekè gražiu darbo rezultatų: esame trečiasis universitetas pagal studentų skaičių ir pirmasis pagal absolventų įsidarbinimą. Universitetas tapo prestižine Lietuvos aukštąja mokykla, kurioje tobulai derinamas mokslas ir studijos, kuri kasmet išleidžia didelį pulką bakalaurų, magistrų, daktarų. Išaugo tarptautinis VGTU autoritetas, plečiasi tarptautinis bendradarbiavimas.

Niekas negalètų paneigti didelių nuopelnų, tenkančių buvusiems ir esamiems VGTU vadovams, kuriantiems ir pletojantiems šią aukštąją mokyklą, darantiems ją šiuolaikinę, modernią. Tai rektoriai Aleksandras Čyras, Edmundas Kazimieras Zavadskas, Romualdas Ginevičius. Jų pastangomis ir išmintimi buvo konsoliduojama mokyklos bendruomene vis didesniems tikslams pasiekti, jie atkakliai gyne VGTU interesus visose aukštesnès valdžios struktūrose.

Vilniaus Gedimino technikos universiteto destytojai, mokslininkai, darbuotojai, studentai gerai supranta, kad Lietuvos kelią i gražesni gyvenimą kloja mokslas, studijos, žiniu troškulys, suvokimas, kad neturinčios didelių gamtinių išteklių valstybès ateitis - žinių visuomene. Todel VGTU bendruomene remia Bolonijos deklaracijos inicijuotą Europos aukštojo mokslo erdvès kūrimą, siekia, kad Bolonijos proceso laimejjimai kuo greičiau būtų igyvendinami ir Lietuvoje. VGTU taip pat turi laimejjimų - vieni pirmųjų i̇diegème

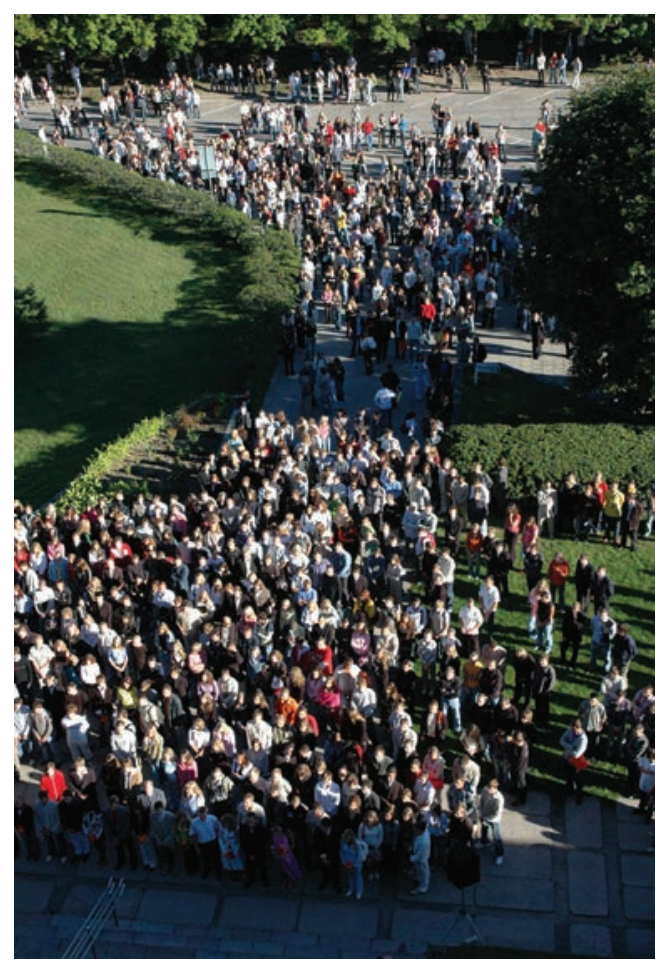

daugiapakopę studiju sistemą, išplètojome tarptautinius dèstytojų ir studentų mainus.

Vilniaus Gedimino technikos universitetas yra atviras visam pasauliui, jame kasmet daugejja studentų iš užsienio.

Lietuva jau prieš kelerius metus ratifikavo Lisabonos konvenciją dèl išsilavinimo pripažinimo. Puiku, kad mūsų studentai jau gauna vadinamuosius dvigubus diplomus. Netoli tas laikas, kai pasaulyje bus pripažįstami visi VGTU išduoti diplomai. Bet tam reikés dar daugiau ir daugiau dirbti, didesnè turès būti finansine valstybès parama.

Mokslo ir kultūros žmonès visais laikais buvo tarp tų, kurie kūre Lietuvą - Tautą ir Valstybę. Tik išsilaisvinusi tauta stipri - toks buvo daugelio Lietuvos mokslo ir kultūros asmenybiu veiklos moto $[6.48$, p. 5]. "Sapere aude“ (Siek išminties) - toks užrašas yra Vilniau Gedimino technikos universiteto ženkle-herbe. Tai ir yra mūsų bendruomenès moto.
Viršuje dešinëje Rugsejo 1-aja 


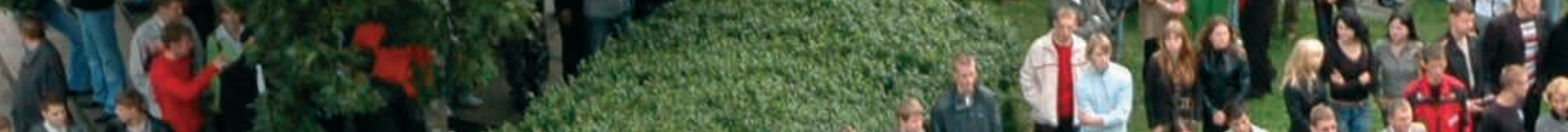

F.

I) 1

and

(x) (1) 10070

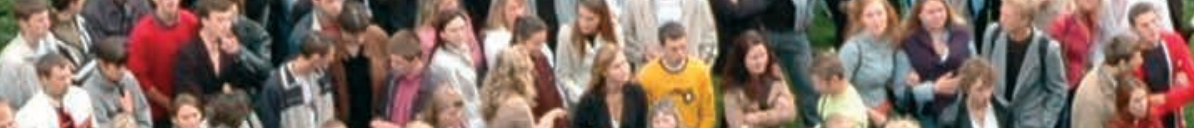

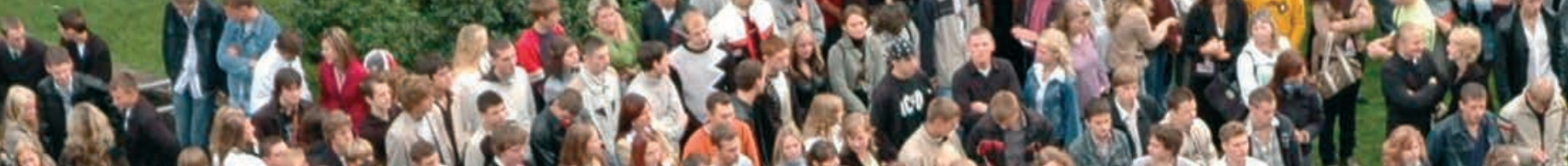
31-10)

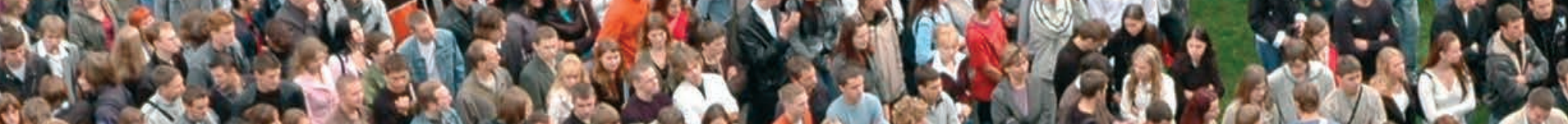

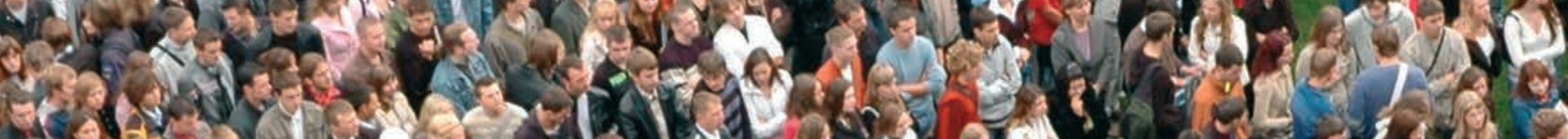

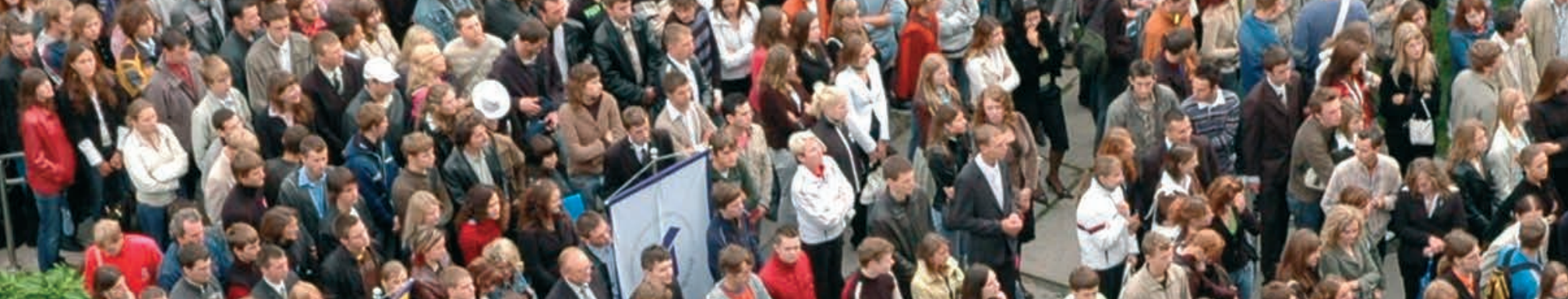
2.0.

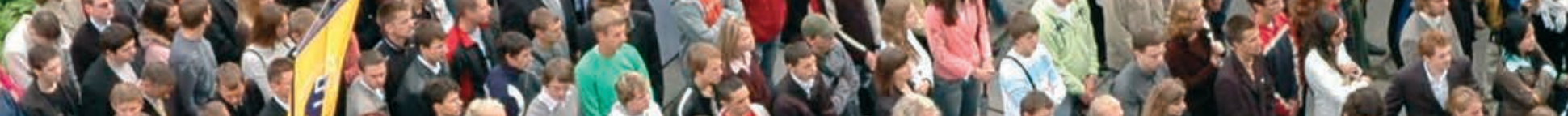

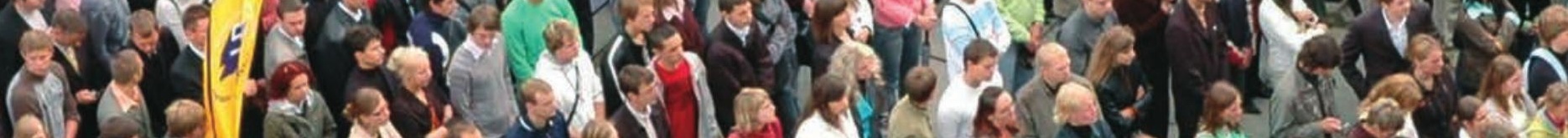
If

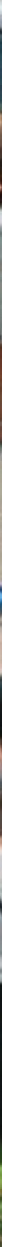





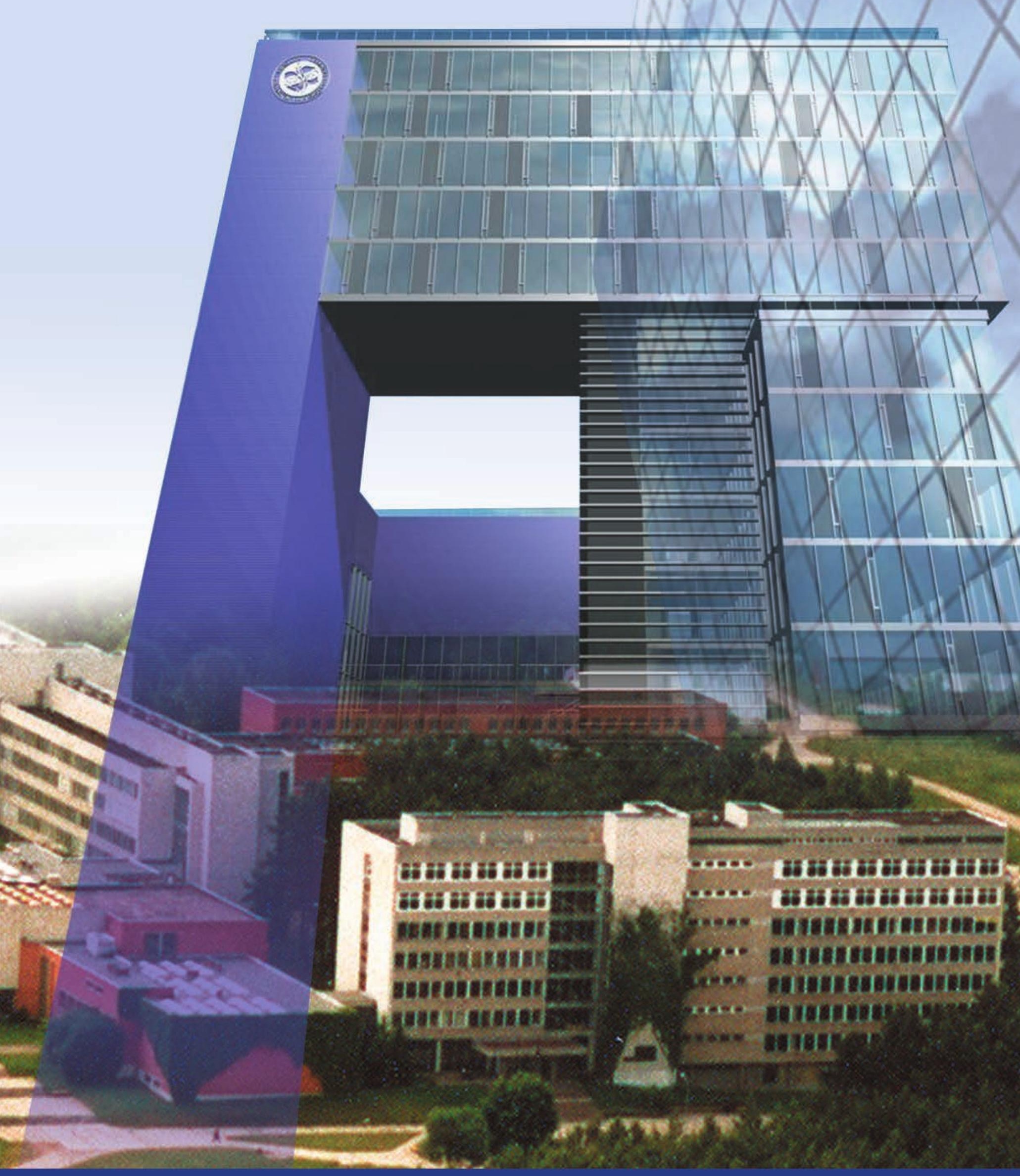




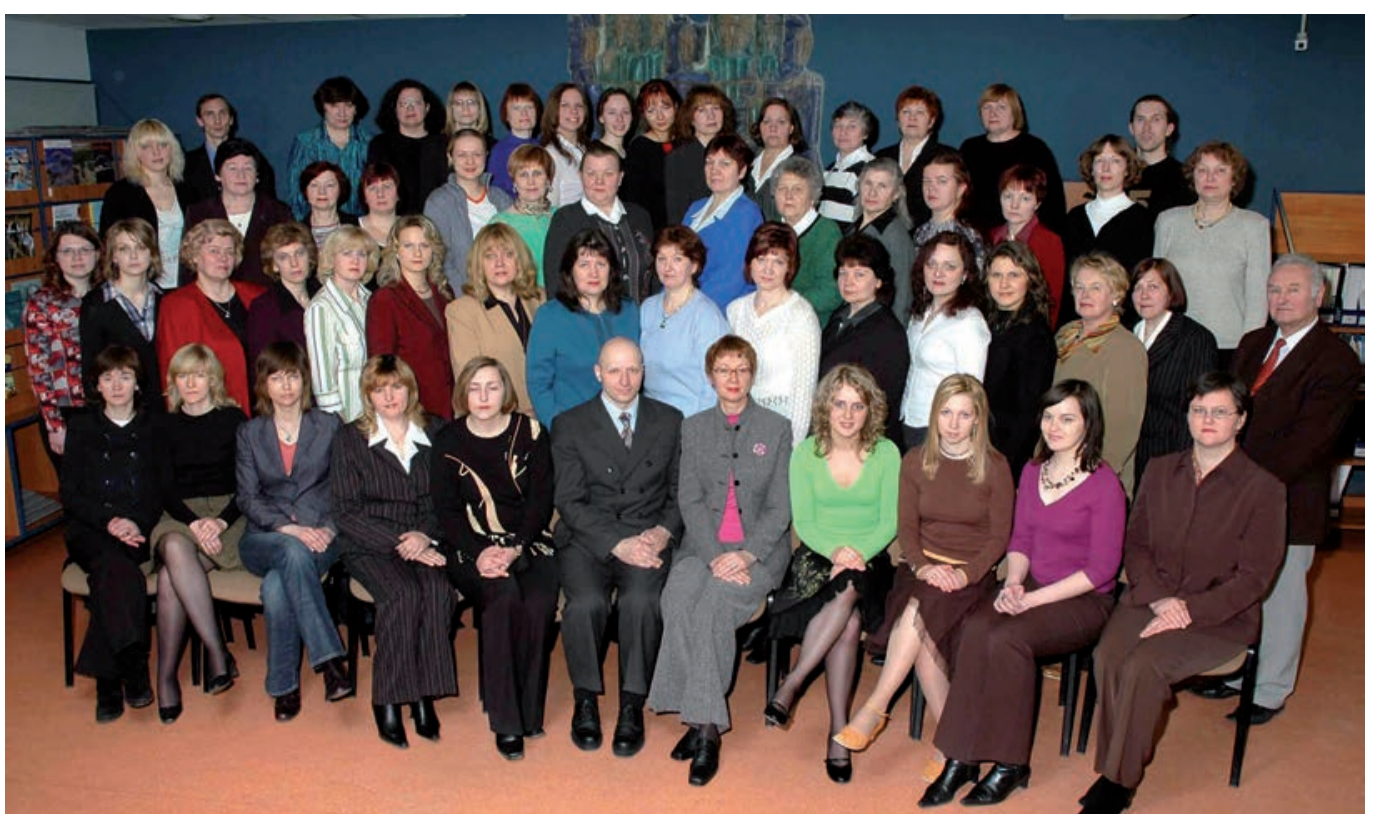

Iš kaires j dešine pirmoje eileje:

vyresn. bibliotekininkè Laima Siudikienè, Komplektavimo skyriaus vedèja Sigutè Urbonavičienè, vyresn. bibliotekininkè Vilma Vaicekiūtienè, valytoja Lucija Sužiedèliené, vyriaus. bibliotekininke Audra Bujaitè, direktorès pavaduotojas ūkio reikalams Vytautas Prunskus, bibliotekos direktore Rimute Abramčikiené, direktores pavaduotoja Edita Vaitkevičiūte, Skaitytojų aptarnavimo skyriaus vedëja Ingrida Kasperaitiené, Skaityklų aptarnavimo skyriaus vedeja Vaida Sobeckyte, Bibliografijos ir informacijos skyriaus vedëja Aurelija Striogiene;

antroje eileje:

vyresn. bibliotekininkė Liana Jakubovič, bibliotekininke Vykinta Janušytė, rūbininkè Valerija Petrašiūniené, valytoja Ana Miliunec, vyresn. bibliotekininkė Janina Kesyliené, vyresn. bibliotekininké Natalija Popkova, vyresn. bibliotekininkè Lilija Mosiejienè, vyriaus. bibliotekininkè Ona Juršaitè, vyresn. bibliotekininkè Elena Telyčènienè, vyresn. bibliografè Ramunẻ Soloduchiené, vyresn. bibliotekininkè Genè Kesylytè, vyresn. bibliotekininkè Raimonda Čèsnienè, vyresn. bibliotekininke Jovita Mučinyte, vyresn. bibliografe Galina Tuguši, vyresn. bibliotekininke Jovita Spečiūnienè, budètojas Algimantas Leleika;

trečioje eileje:

bibliotekininkè Aušra Golšanskaitè, vyresn. bibliotekininkè Tatjana Čygienè, vyresn. bibliotekininkè Eugenija Juknevičienè, vyresn. bibliotekininkẻ Nijolè Gaideliené, kompiuterinių tinklų administratorius Vaida Plauškaite, vyresn. bibliotekininkè Vaidilute Rimšelienè, budètoja Irena Vasaroviené, rūbininkè Renyte Bakanavičiene, budètoja Aldona Čičeliené, budètoja Genovaite Letkauskiené,

Fondų saugojimo skyriaus vedejja Jelena Bogdanova, Literatūros tvarkymo skyriaus vedëja Gelmina Vaikšnorienè, vyresn. bibliotekininkè Lolita Agapoviené, vyriaus. bibliotekininkè Dalia Užusienytė;

ketvirtoje eileje:

vyresn. bibliotekininkas Linas Balaišis, vyresn. bibliotekininkè Aldona Dilnikienè, vyresn. bibliotekininkè Sigutė Deramerienè, vyriaus. bibliotekininkẻ Vitalija Antanavičiené, vyresn. bibliotekininkè Irina Klimiato, vyresn. bibliotekininkè Aistè Pranckute, bibliotekininke Gabija Kochanskaite, bibliotekininke Ana Bartoševič, vyresn. bibliotekininkè Vida Dumpiene, vyresn. bibliotekininkè Nijolè Stankevičiūtè, vyresn. bibliotekininkè Roza Sorkina, vyresn. bibliotekininkè Gražina Andriūniené, vyresn. bibliotekininke Danguole Povilaitiené, Automatizacijos sektoriaus vedëjas Viktor Pozlevič 
STUDIJU

DIREKCIJA

VAIZDO

IR GARSO

TECHNINIU PRIEMONIU

LABORATORIJA

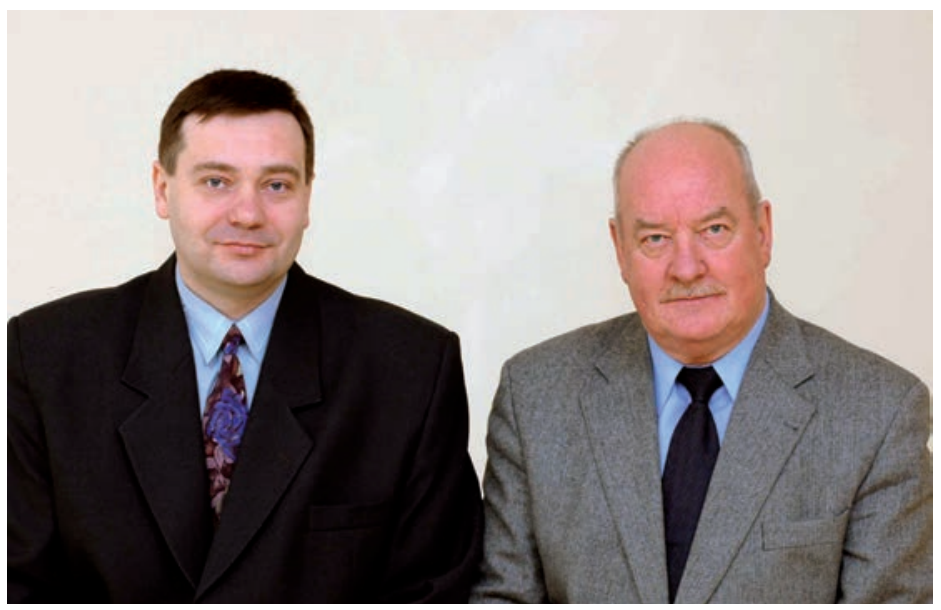

Iš kairés i dešinę:

inžinierius Edmundas Kapusta,

laboratorijos vedëjas Vaidotas Romualdas Kučinskas 


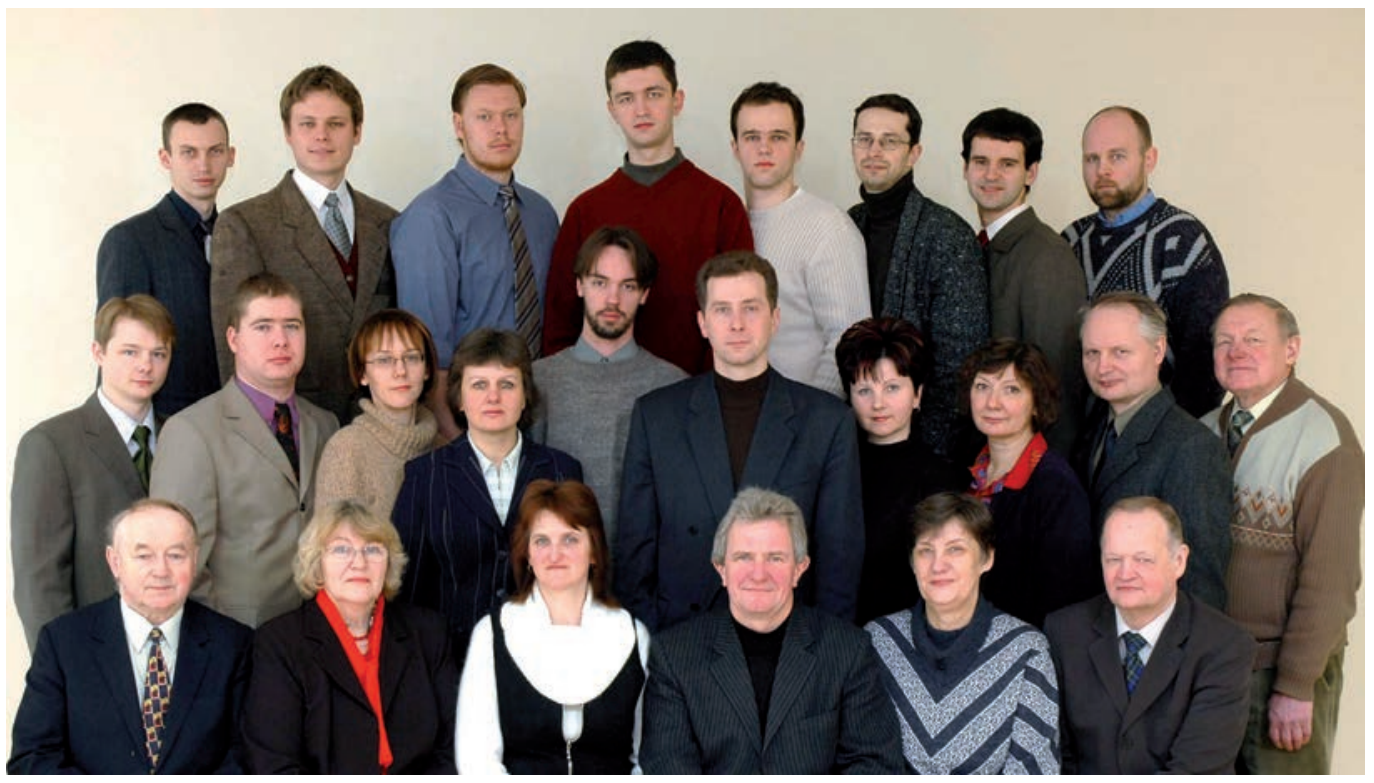

Iš kaires j dešine pirmoje eilëje:

operatorius Jonas Bačinskas, operatore Elena Genè Chaliulina, reikalų tvarkytoja Lijana Daunoraite, direktorius doc. dr. Remigijus Kutas, Techninès eksploatacijos ir programinès įrangos grupès vedëja Janina Zapolskiené, Komunikacijų ir ryšiu grupes vedëjas Vytautas Baravykas;

antroje eileje:

vyresn. programuotojas Arūnas Oškutis, kompiuterių tinklo administratorius Mindaugas Štaras, VGTU tinklalapio grupès vedejja Aušra Misiūnienè, operatorè Nijolè Strumiliené, operatorius Petras Urbanavičius, Lygiagrečiųjų skaičiavimų laboratorijos vedëjas doc. dr. Dalius Mažeika, operatore Jolanta Kavalevskiené, vyresn. programuotoja Laima Bajorūnaité, programuotojas Algirdas Maknickas, meistras Jonas Dzedulionis;

trečioje eilejje:

programuotojas Viktoras Karalius, programuotojas Robertas Radžvilas, kompiuterių tinklo administratorius Giedrius Mackevičius, tinklo administratorius Filip Savin, vyresn. programuotojas Lukas Subačius, paralelinio kompiuterio administratorius dr. Vadimas Starikovičius, vyresn. mokslo darbuotojas dr. Arnas Kačeniauskas, vyresn. programuotojas Česlav Vilkevič

NUOTOLINIU STUDIJU CENTRAS

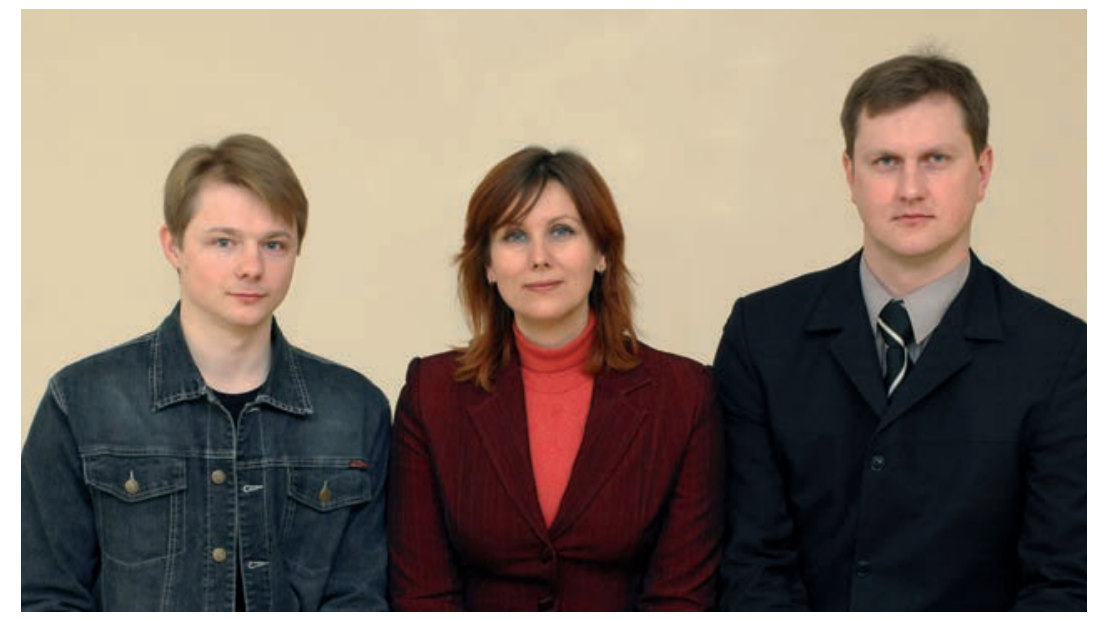

Iš kaires j dešinę:

programuotojas Arūnas Oškutis, vyresn. programuotoja Lina Gorbunova, direktorius dr. Vaidotas Trinkūnas 
MOKSLO

DIREKCIJA

KAPITALINÉS

STATYBOS

DIREKCIJA

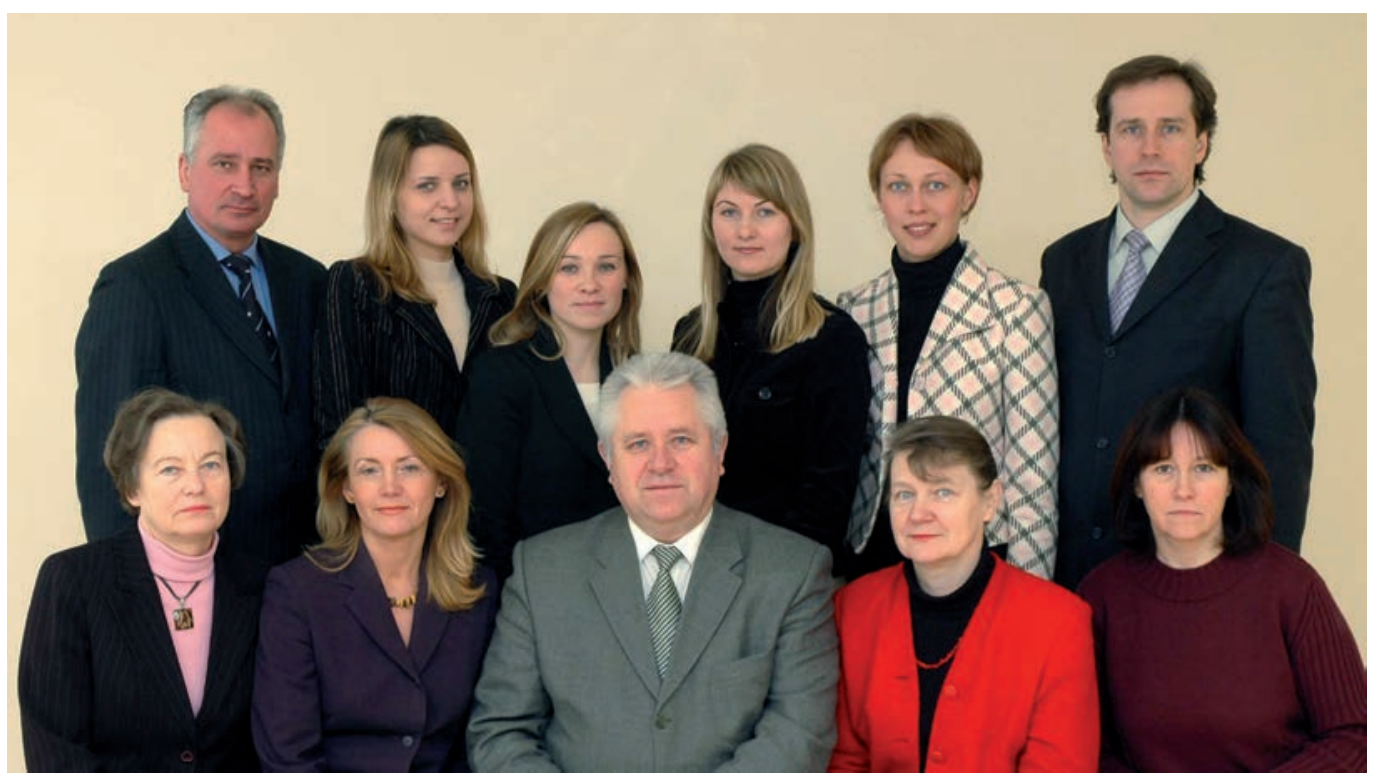

Iš kairés j dešine pirmoje eilëje:

Doktorantūros ir habilitacijos skyriaus vyr. vadybininkè Aldona Bruzgelioniené, Informacijos ir marketingo grupès vedëja Žibute Adomavičiené, direktorius doc. dr. Valentinas Skaržauskas, Intelektinès nuosavybès skyriaus vedëja Vaiva Laukaitiené, vyr. vadybininkè Rima Palioniene;

antroje eileje:

buvęs direktoriaus pavaduotojas doc. dr. Liudvikas Rimkus, vyr. vadybininké Lina Papinigyté, vadybininke Giedrè Molyté, vadybininkẻ Inga Belevičiūté, vadybininké Laura Bernotaite, Doktorantūros ir habilitacijos skyriaus vedejjas doc. dr. Šarūnas Mikaliūnas

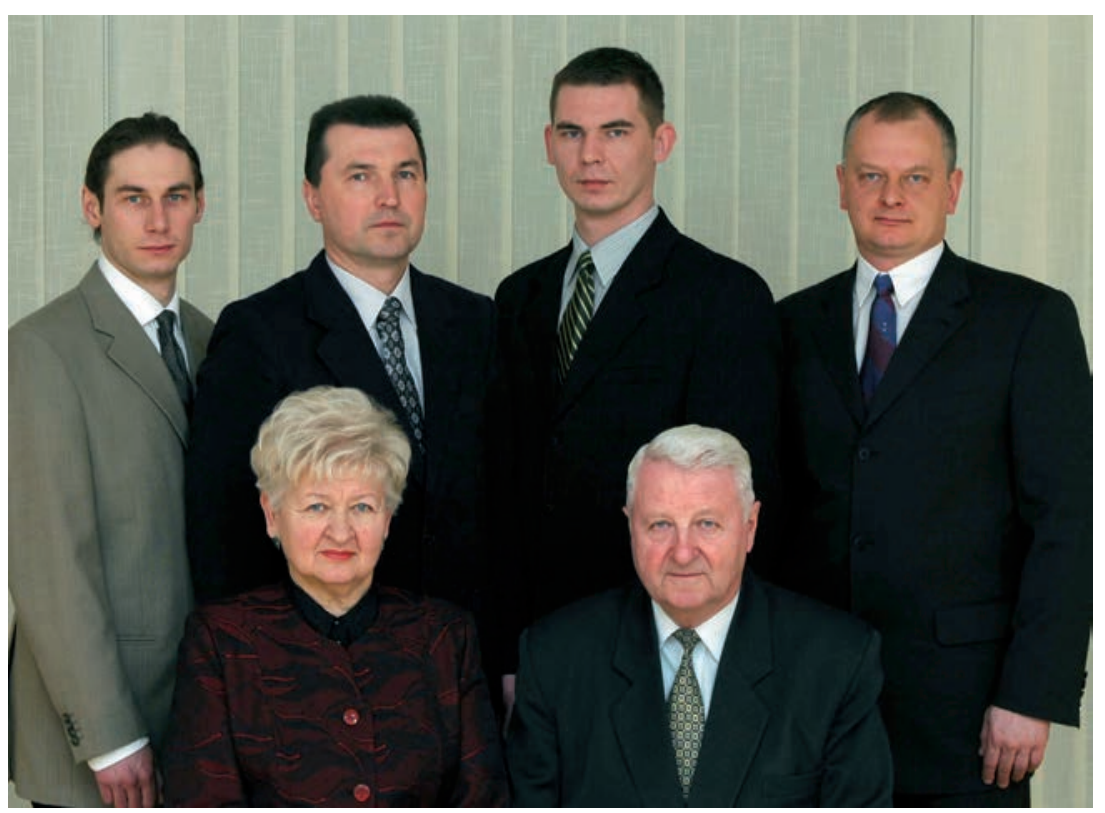

Iš kaires j dešine pirmoje eileje:

sąmatininke Birute Pagaliene, direktorius doc. dr. Pranas Malinauskas; antroje eileje:

techninès priežiūros inžinierius Darius Kalibatas, bendrosios techninès priežiūros vadovas Svajūnas Karvelis, techninès priežiūros inžinierius Arūnas Barvidas, bendrosios techninès priežiūros vadovas Artūras Marcinkevičius 
UŽSIENIO RYŠIŲ DIREKCIJA

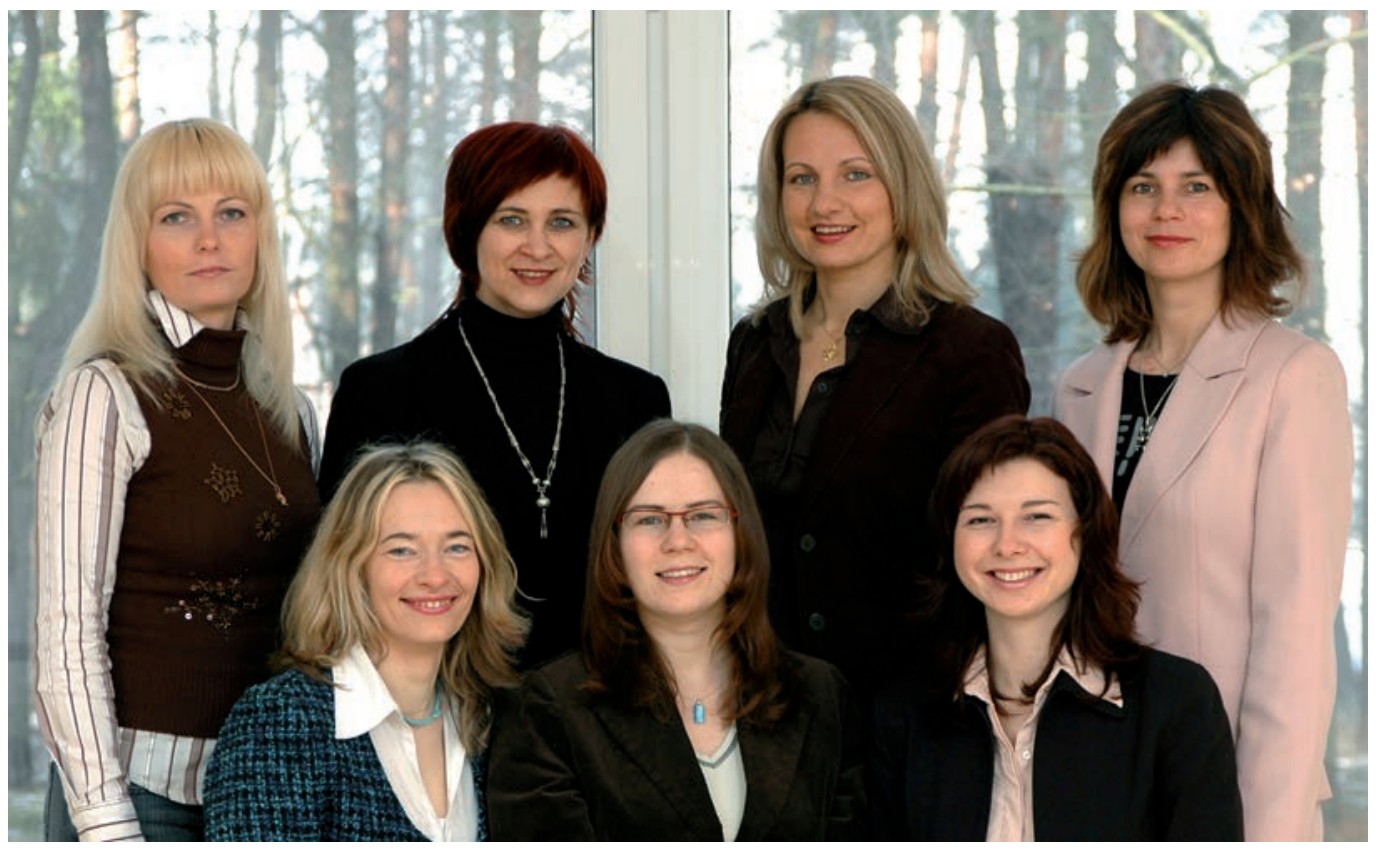

Iš kaires j dešine pirmoje eilëje:

tarptautinių ryšių koordinatore Austëja Ikamaite, SOCRATES programos grupés vedëja Lilija Gončaroviené, Tarptautinių programų grupès vedëja Valentina Omelčenko;

antroje eileje:

vadybininke Vilma Getautytè, direktore Asta Radzevičienè, SOCRATES programos grupès konsultantė Dalia Bložienè, direktorés pavaduotoja Aušra Peledienè

TARPTAUTINIS STUDIJU CENTRAS

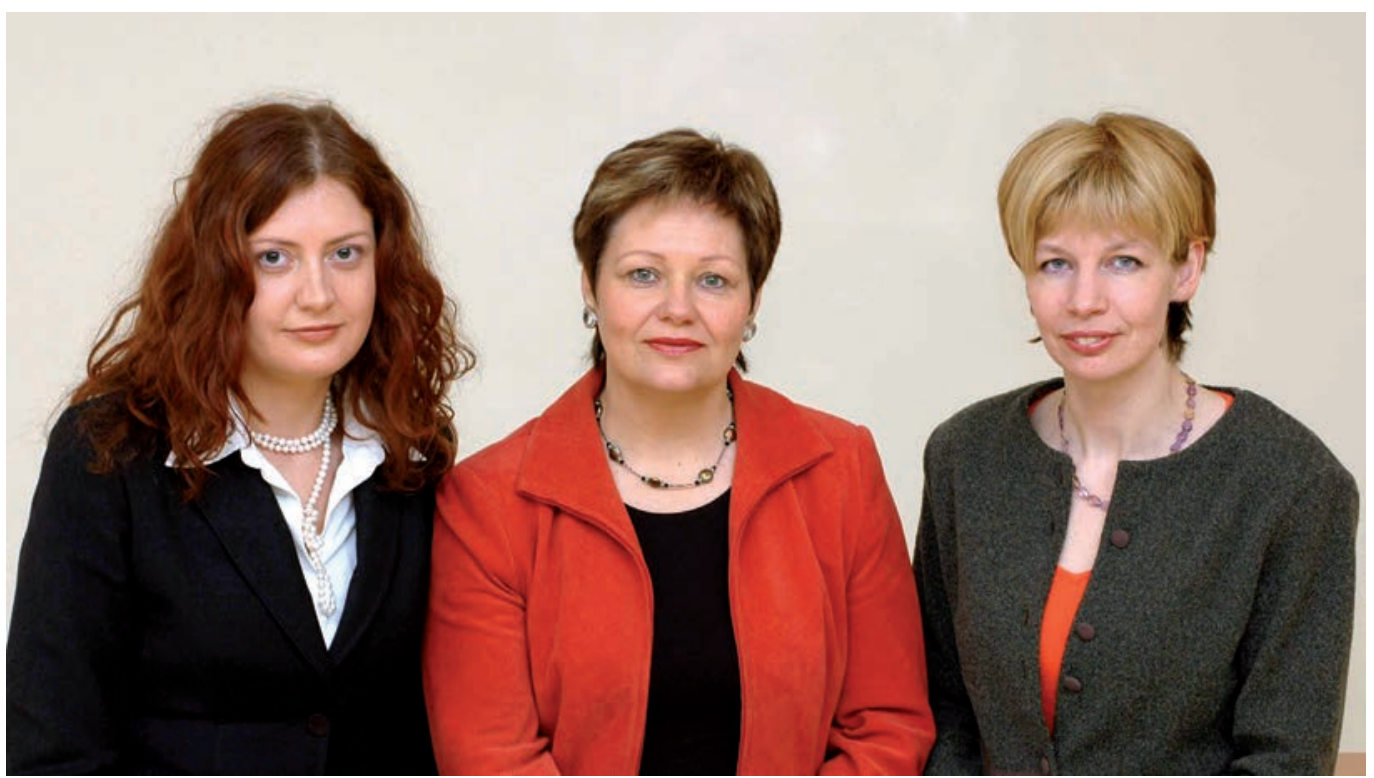

Iš kaires j dešinę:

vadybininkè Raimonda Bubliené, direktorè Birutè Tamulaitienè, vadybininkè Ina Gujienè 
PERSONALO DIREKCIJA

\section{RAŠTINE்}

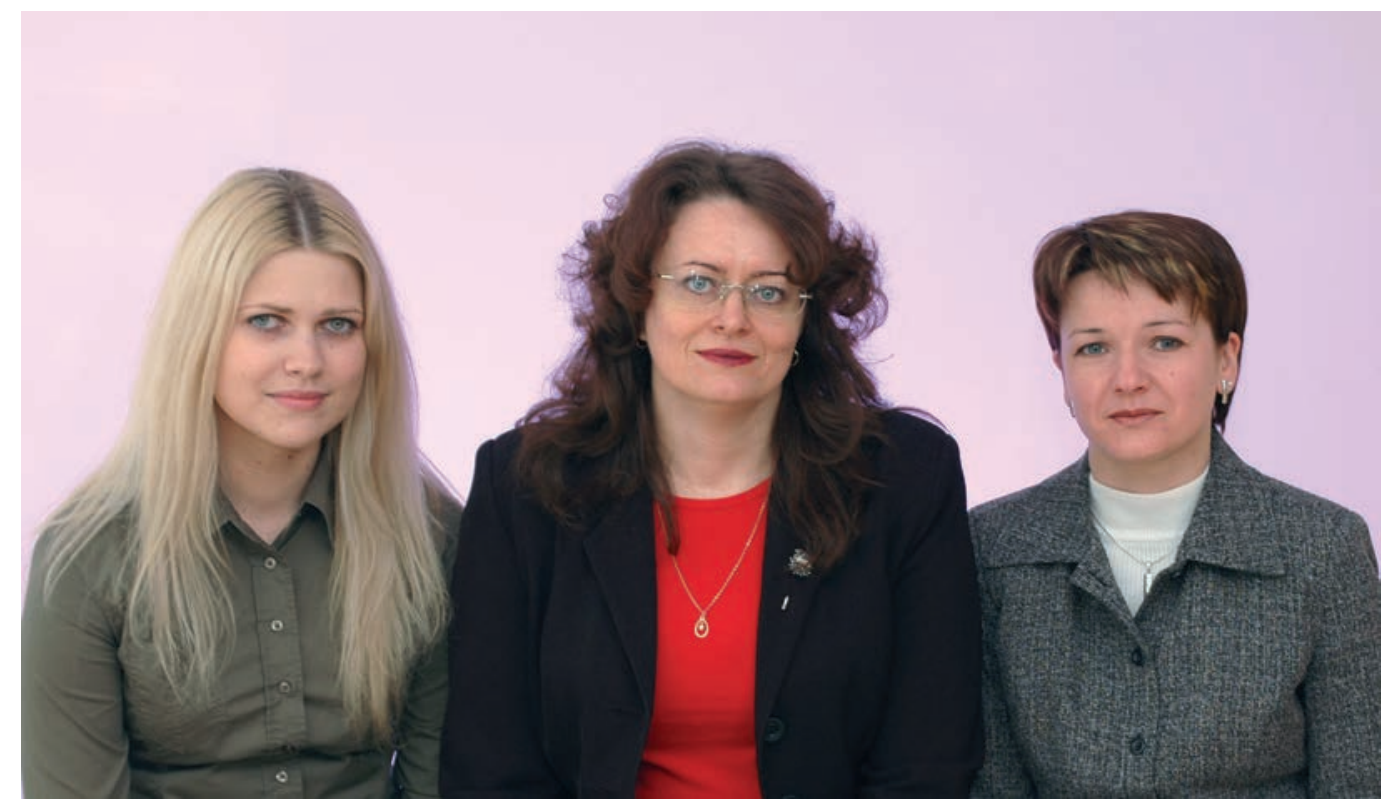

Iš kaires j c dešinę:

inspektorè Loreta Kačinskytè, vedëja Jolanta Marcinkevičienė, inspektore Alma Kavaliauskiene 
ŽINIASKLAIDOS IR RENGINIU DIREKCIJA
INTEGRACIJOS IR KARJEROS DIREKCIJA

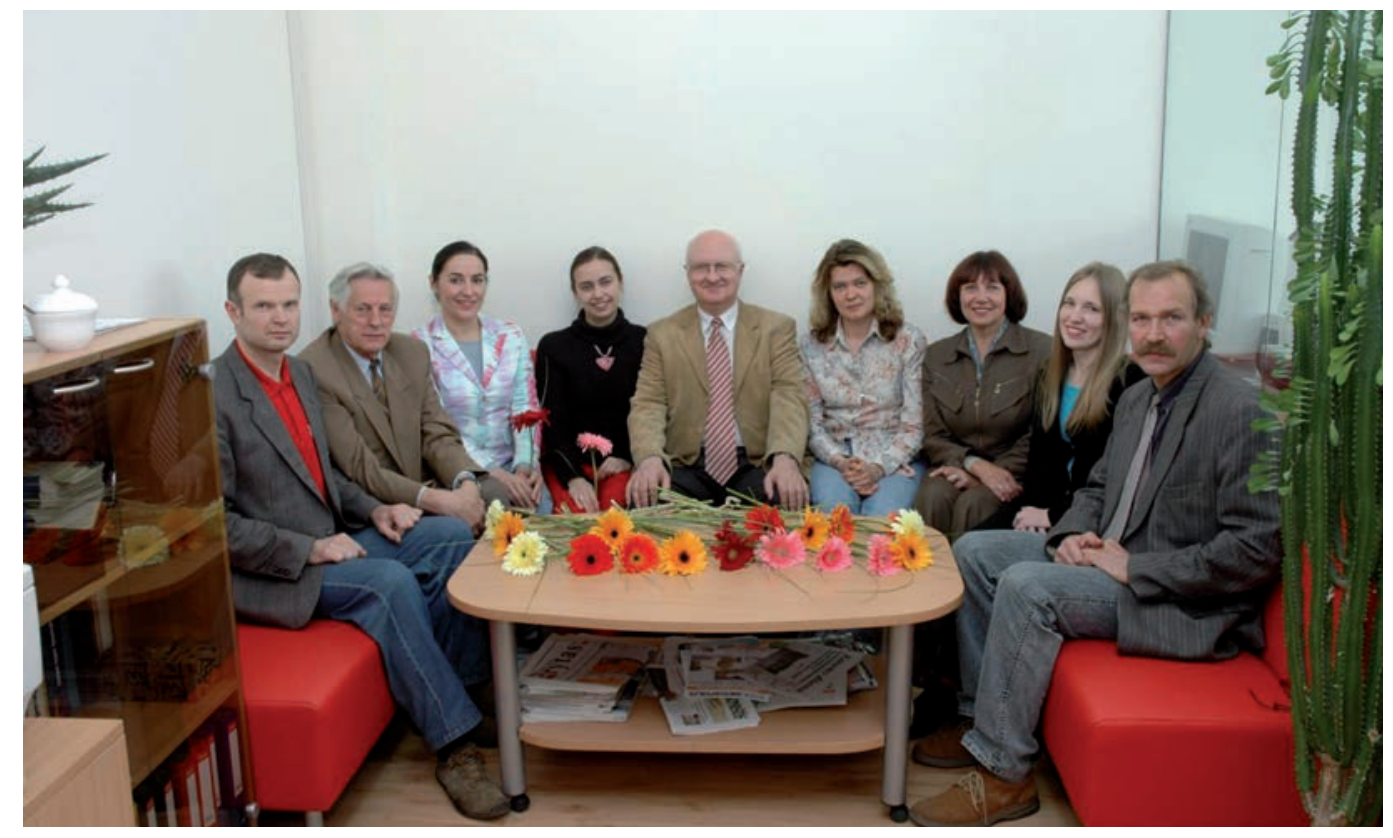

Iš kaires j c dešinę:

technikas Gintaras Urbanavičius, VGTU laikraščio „Inžinerija“ redaktorius Julius Norkevičius, dailininke Asta Rudminaite, VGTU žurnalo „Gedimino universitetas“ redaktore Asta Verbickiené, direktorius doc. dr. Algimantas Jonas Nakas, reikalų tvarkytoja Rasa Karnilaite, direktoriaus pavaduotoja Vanda Zubelytè, VGTU muziejaus tvarkytoja Jolanta Šiugždaitè, fotografas Aleksas Jaunius

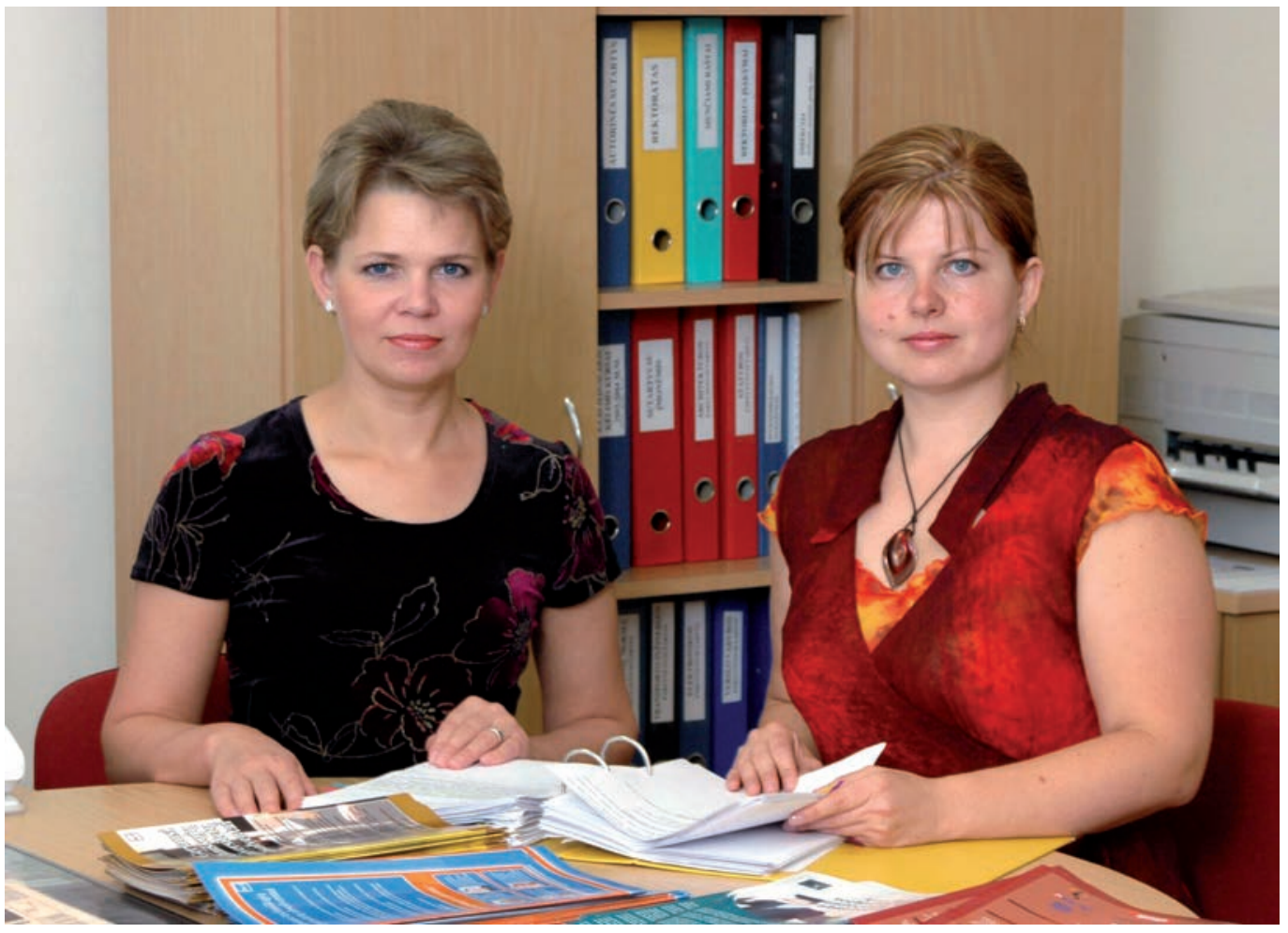

Iš kaires $\dot{y}$ dešinę:

direktore Arūnè Usoninè, vyresn. vadybininkè mgr. Inga Veževičienè 
INFORMACINIŲ SISTEMU SKYRIUS

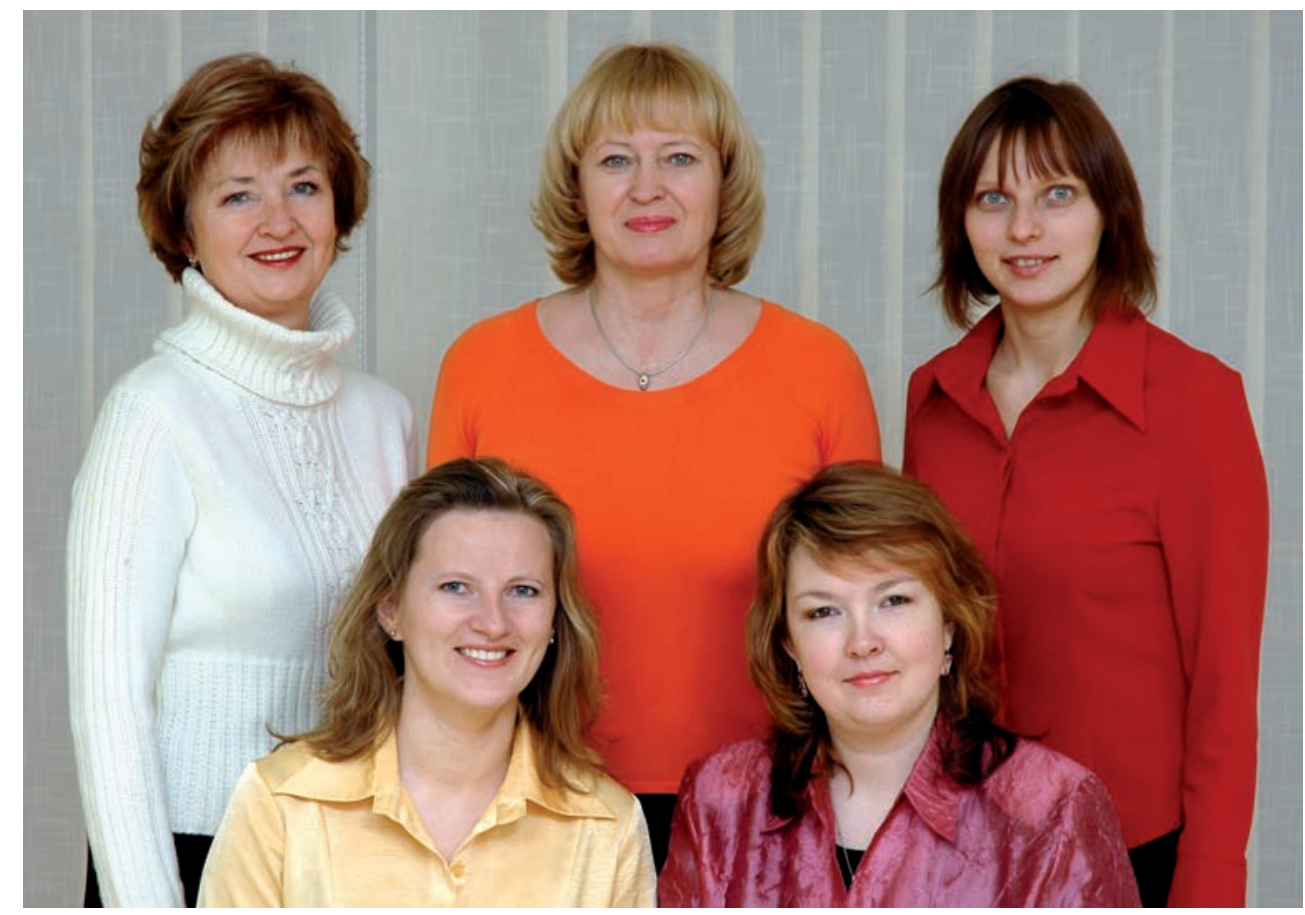

Iš kaires i dešine pirmoje eileje:

administratore Edita Juodvalkiené, reikalų tvarkytoja Jelena Grankova;

antroje eileje:

reikalų tvarkytoja Vitalija Nakienè, vedëja Dale Bulašiené, reikalų tvarkytoja Milda Viteikienè

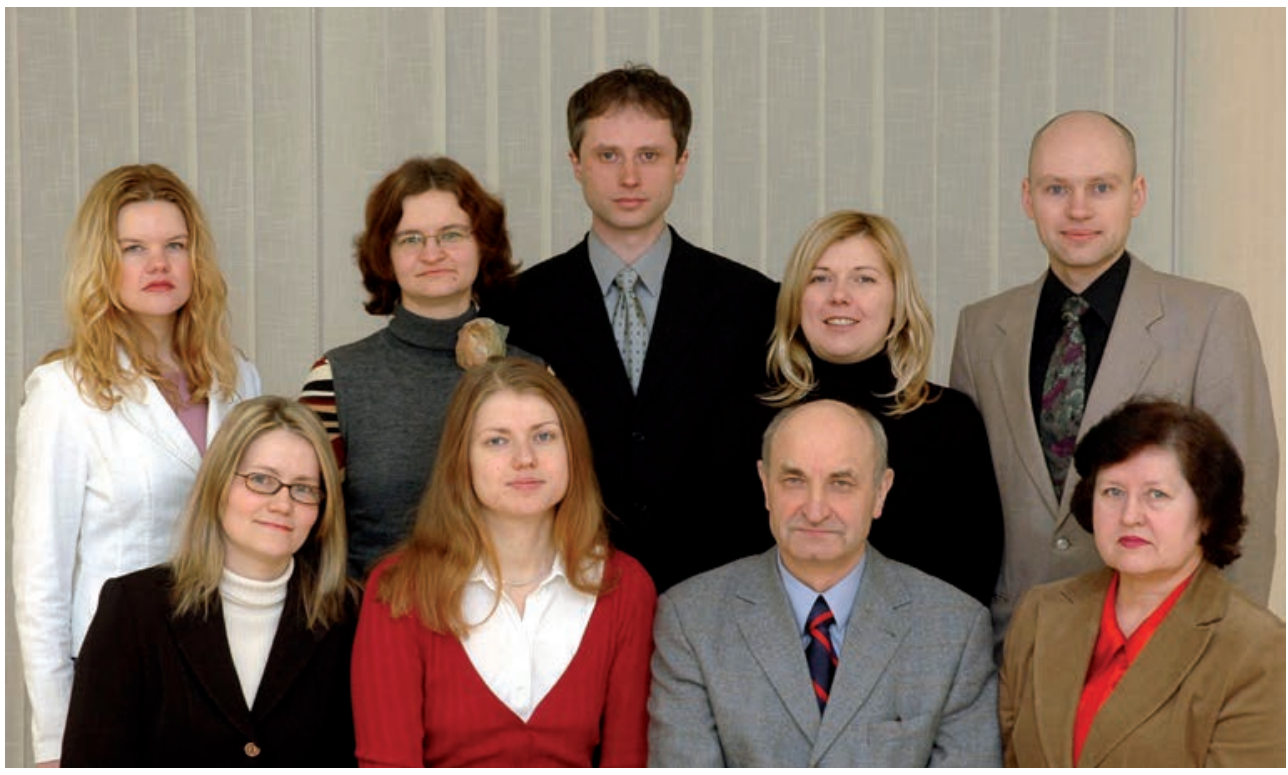

Iš kaires j dešinę pirmoje eileje:

programuotoja mgr. Vilda Braukylienè, vyresn. inžiniere programuotoja mgr. Valdona Judickaite, kanclerio padejjëjas doc. dr. Jonas Daunoravičius, inžiniere programuotoja Laimutè Valikoniené;

antroje eileje:

programuotoja mgr. Jevgenija Čikun, inžiniere programuotoja mgr. Milda Marija Baravykaite, programuotojas mgr. Egidijus Rauba,

vyresn. inžiniere programuotoja mgr. Edita Galinyte, vedëjas mgr. Darius Braukyla 
EKONOMIKOS

DIREKCIJA

TEISĖS

DIREKCIJA

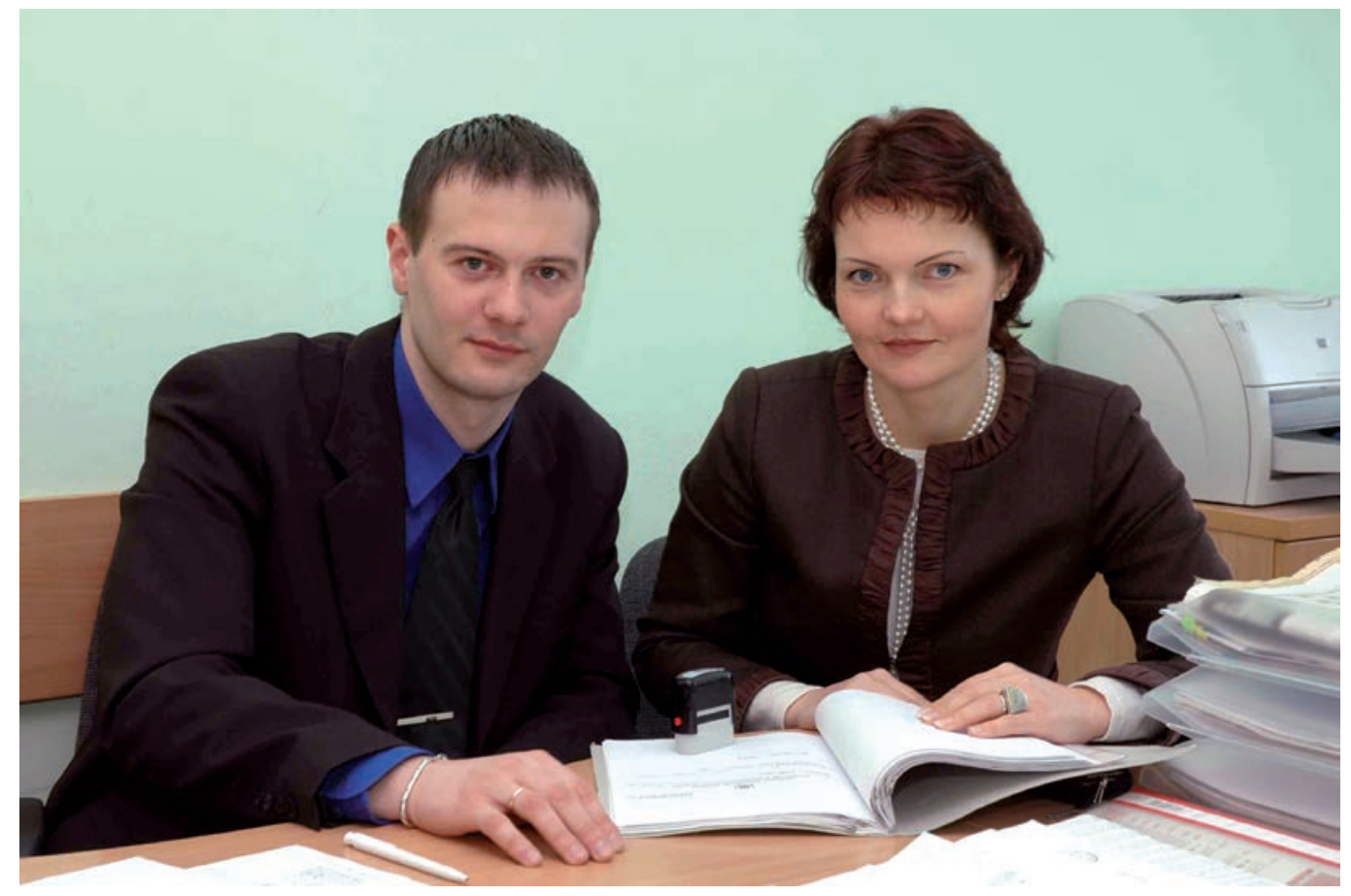

Teisininkas Algis Tuminas ir direktore Violeta Keršulienè 


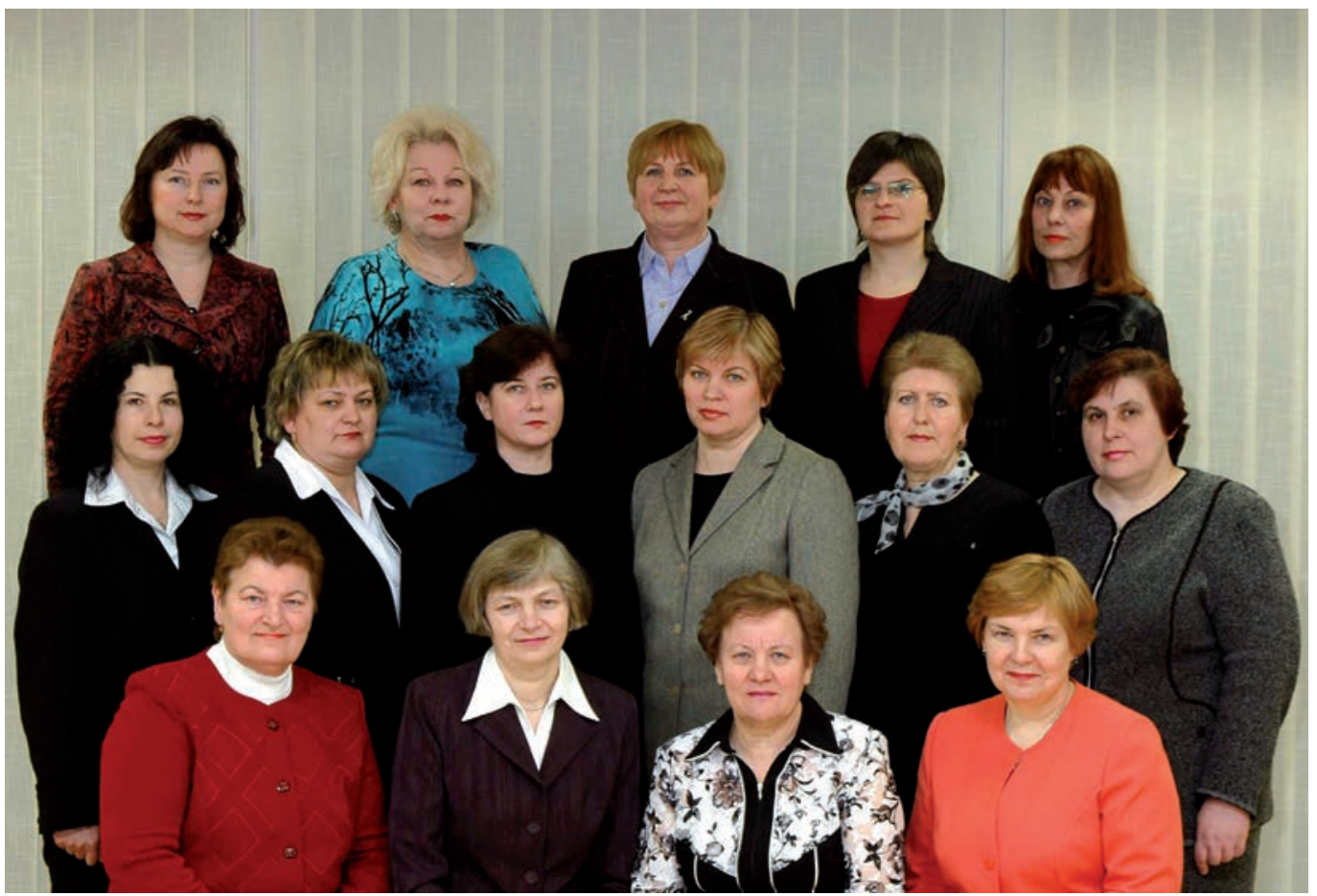

Iš kairés j̣ dešine pirmoje eilëje:

vyresn. kasininkè Elvyra Jundienè, vyr. buhaltere Giedre Ružinskienè, Turto apskaitos grupés vedëja Vaclova Petkevičienè, vyr. buhalterès pavaduotoja Virgute Papinigiené;

antroje eileje:

grupès vedëja Audronė Garunkštienè, buhalterè Angelè Subačienè, Pajamų ir tarptautinių projektų apskaitos grupès vedëja Lidija Grigaliūnienè, buhalterè Ona Padegimienė, buhaltere Antanina Tijūnèlienė, vyresn. buhalterẻ Janina Skrickaja;

\section{trečioje eileje:}

vyresn. buhaltere Rita Dragūnaite, buhaltere Violeta Sakalienė, buhaltere Stasė Jundiené, vyr. buhalterès pavaduotoja Aldona Voicekènaite, buhalterè Nina Kuzinienè

DARBUOTOJU SAUGOS IR SVEIKATOS SKYRIUS

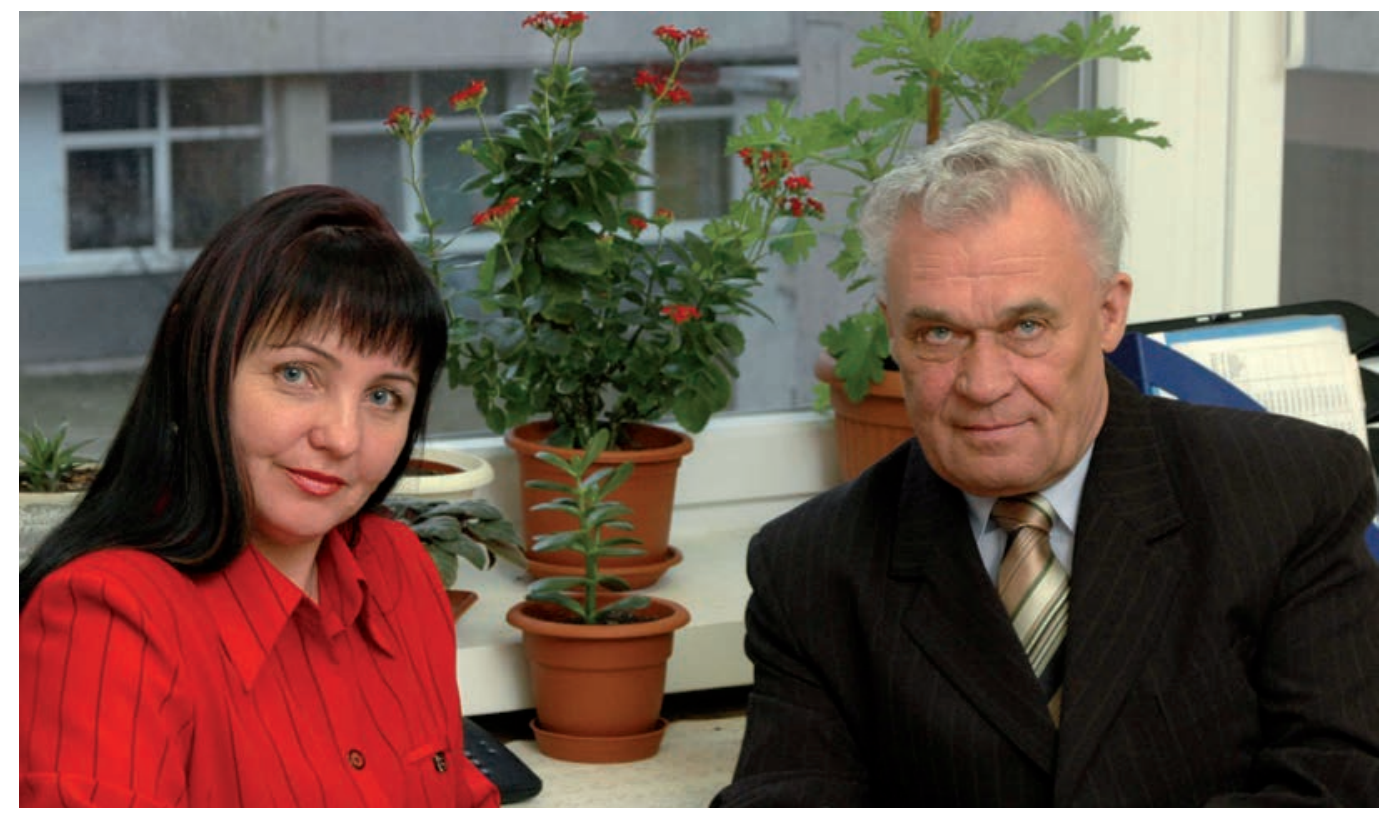

Darbuotojų saugos ir sveikatos inspektorè Danutė Zarembiené, skyriaus vedëjas Feliksas Algimantas Katinas 
LEIDYKLA „TECHNIKA“
KNYGYNAS „TECHNIKA“

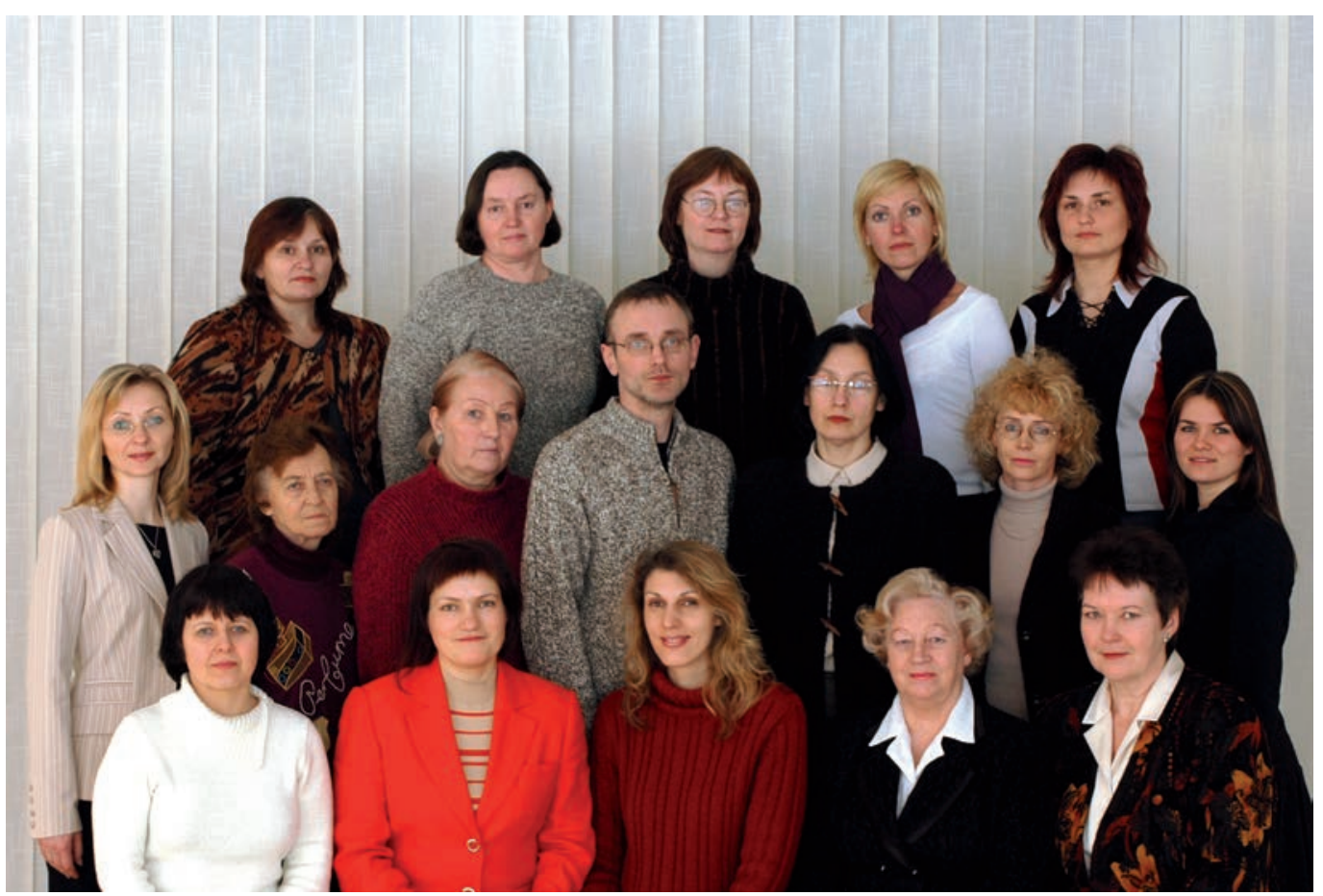

Iš kaires j dešine pirmoje eileje:

maketuotoja Vilija Aleksandravičiené, direktore Eleonora Dagiené, operatorè Miglè Kaltenyté, Leidybos skyriaus vedejja Nina Gilytė, Maketavimo skyriaus vedëja Audroné Gurkliené;

antroje eileje:

vyresn. redaktoré Rita Malikèniené, vyresn. redaktoré angl. Almuté Teresèlè Gurskiené, vyresn. redaktore Stase Kirkienè, vadybininkas Dainius Saltenis, vyresn. redaktore Violeta Kočiūnaité, vyresn. redaktorè Nijolè Žuvininkaité, maketuotoja Viktorija Šapkina;

trečioje eilejje:

vyresn. redaktorè Laimute Kerteniené, maketuotoja Loreta Urbanavičiené, vyresn. redaktore Viktorija Tamoševičienè, vyresn. redaktore Aušra Kovalkovienè, Elektroninès leidybos skyriaus vedèja Jevgenija Petkuvienè

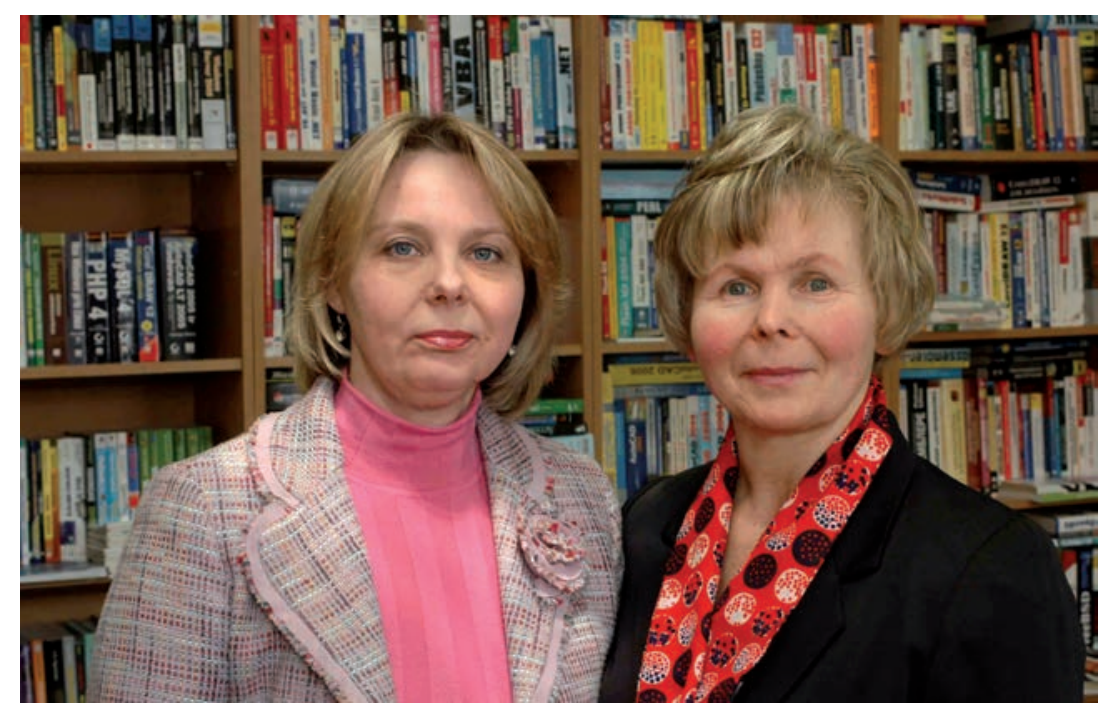

Iš kairés j dešinę:

vadybininkė Laimute Zakaržauskiené, vedèja Eugenija Norvilienė 
ŪKIO

DIREKCIJA

TRANSPORTO SKYRIAUS DARBUOTOJAI

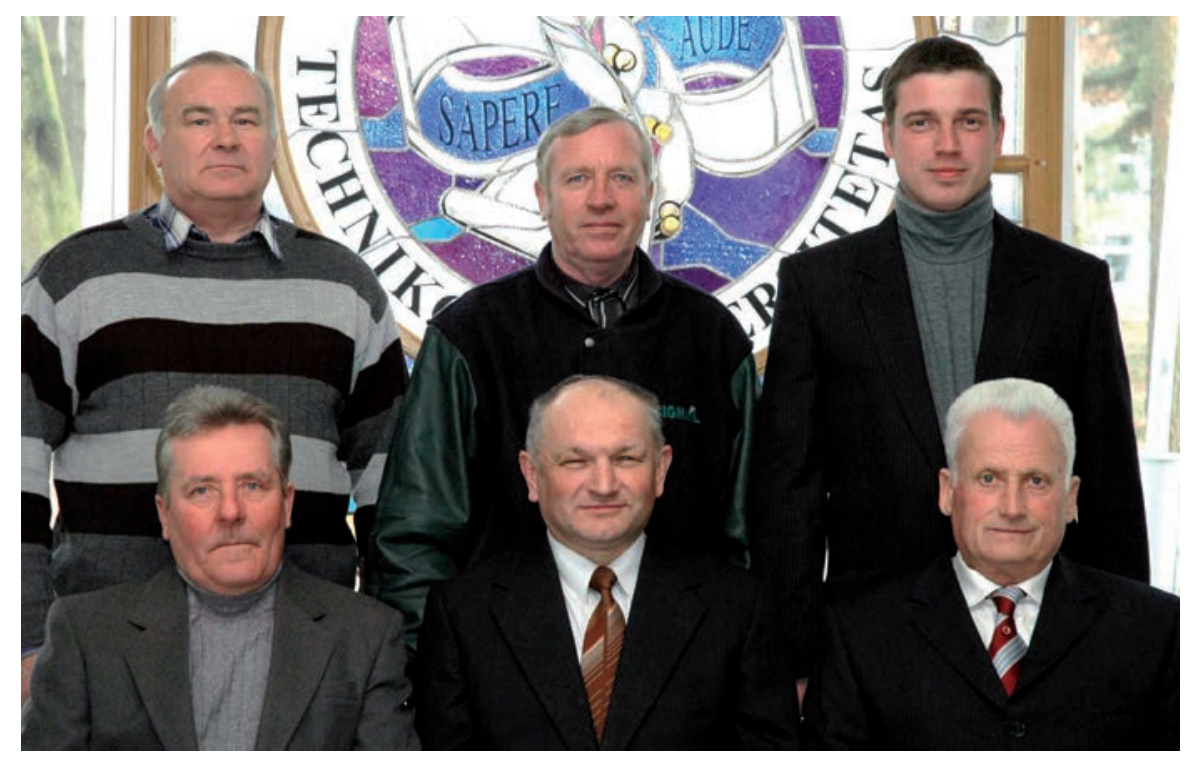

Iš kaires j dešine pirmoje eilëje:

vairuotojas Romas Čygas, Transporto skyriaus vedejjas Henrikas Motiejūnas, vairuotojas Jan Runevič;

antroje eileje:

vairuotojas Aleksandras Vorobjovas, vairuotojas Vytautas Braškus, vairuotojas Edgaras Ragenas 
ÜKIO DIREKCIJOS PASTATŲ PRIEŽIŪROS IR EKSPLOATAVIMO TARNYBA
ARCHYVAS

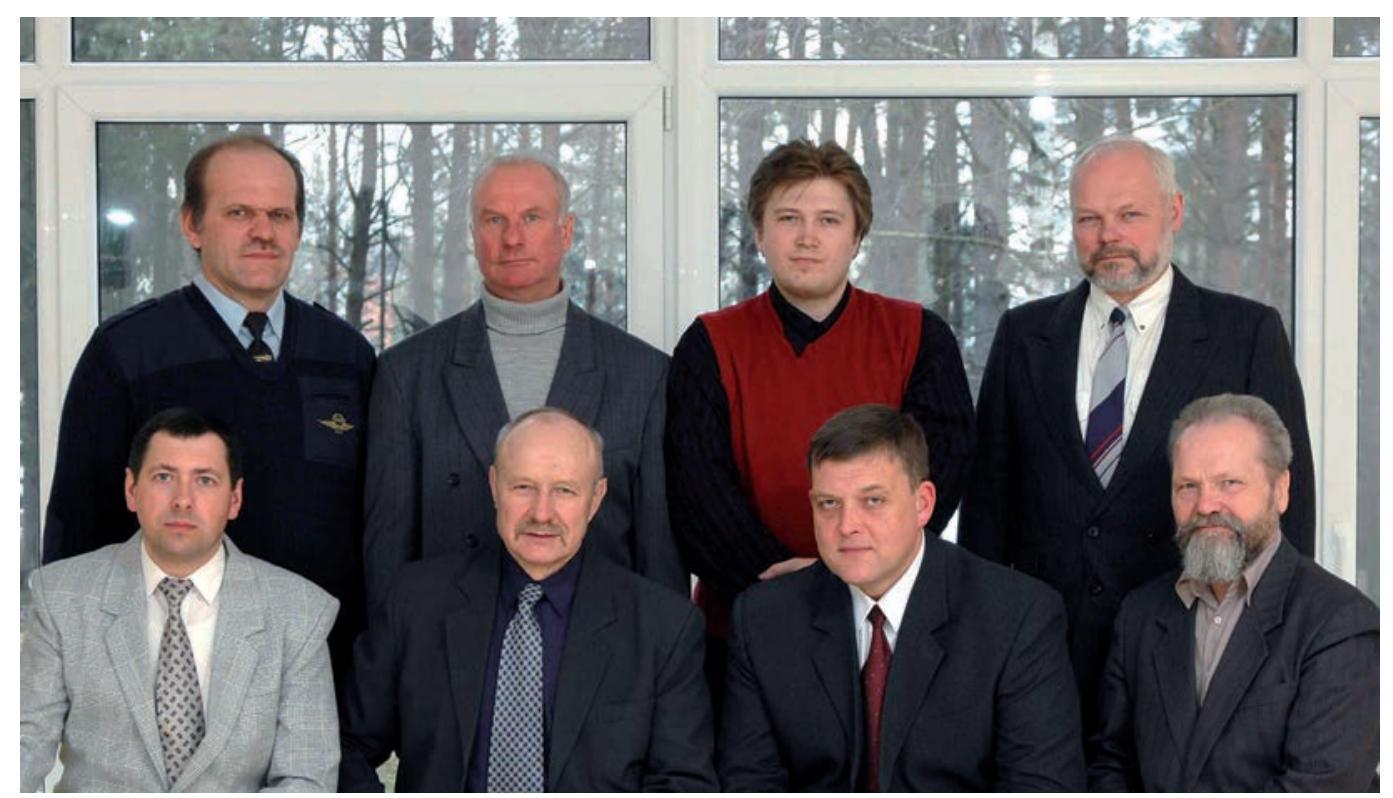

Iš kairés j dešine pirmoje eilëje:

Sauletekio rūmų (I ir II laboratorinio korpusų) ūkvedys Gintautas Sinkevičius, Pastatų priežiūros ir eksploatavimo tarnybos viršininkas Kazys Andrijauskas, Saulètekio rūmų (Centrinio ir I auditorinio korpusų) ūkvedys Gintautas Karnila, Mechanikos rūmų ūkvedys Ivan Samochvalov;

antroje eileje:

Aviacijos rūmų ūkvedys Ryšald Petruševski, Transporto rūmų ūkvedys Stasys Kalesnykas, Turto valdymo grupes vadybininkas Emilis Dovidauskas, Saulètekio rūmų (II korpuso ir II auditorinio korpuso) ūkvedys Gediminas Karvelis

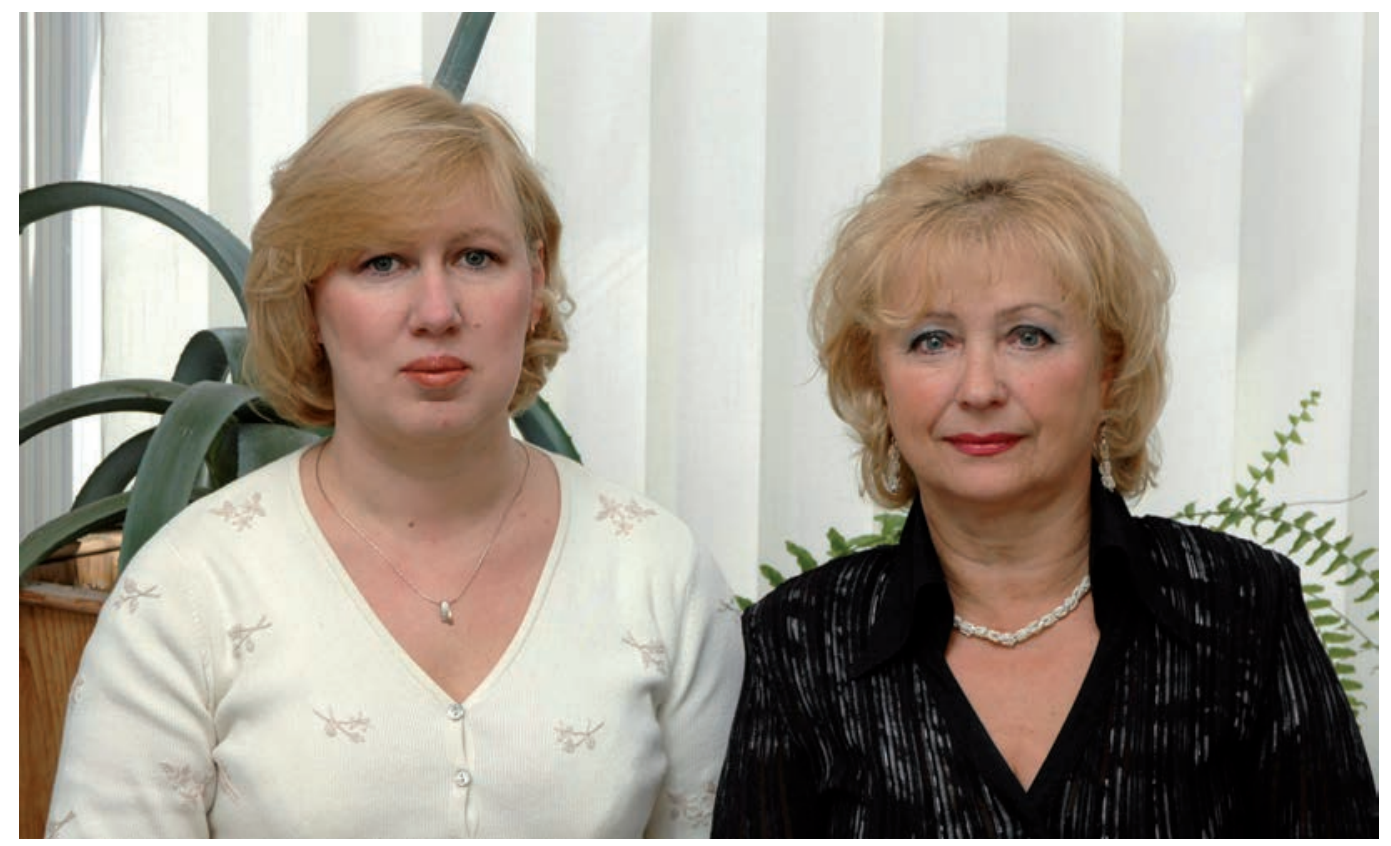

Iš kaires j dešinę:

archyvare Daiva Gaižauskienè, vedèja Olga Starkovskienè 


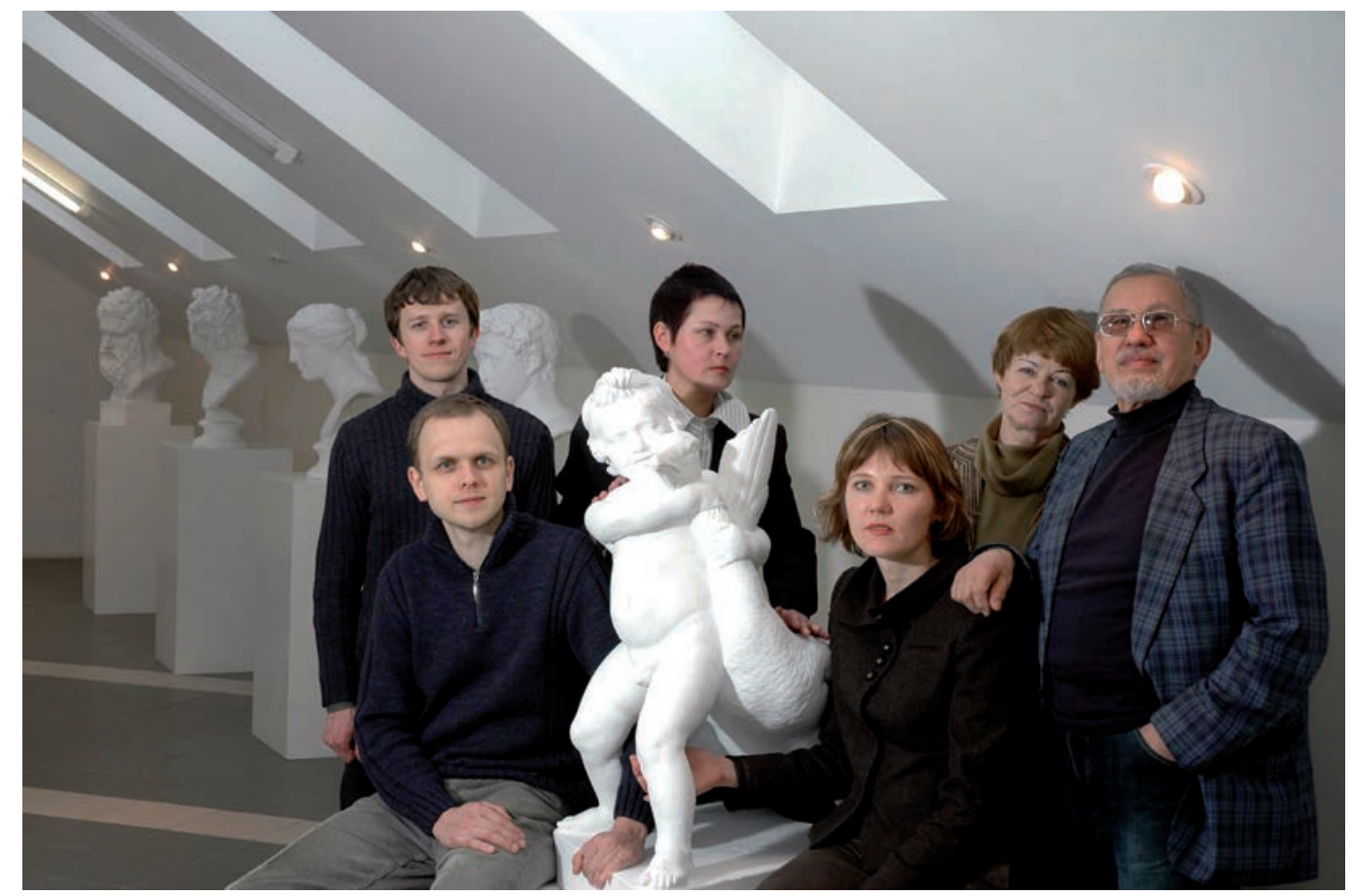

Iš kairés i dešinę:

dailininkas Rimantas Milkintas, architektas Gediminas Navickas, dailininke Dalia Zebenkiené, MUC direktore dr. Egle Navickiené, architekte Justina Savickiené, dizaineris Vladas Butrimas 


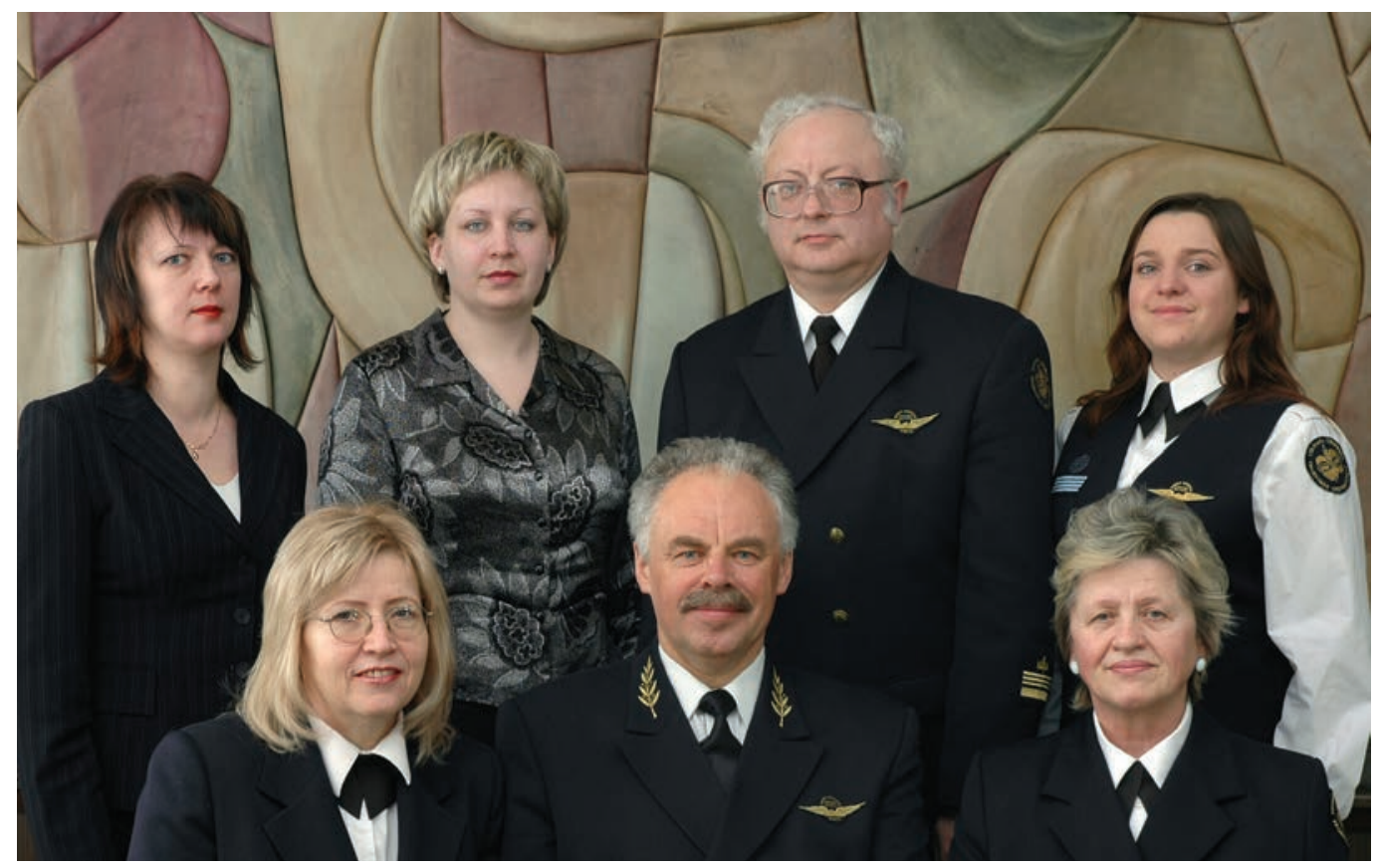

Iš kairés j dešine pirmoje eilëje:

redaktore Margarita Apanavičiené, direktorius prof. habil. dr. Jonas Stankūnas, direktoriaus pavaduotoja ūkio reikalams inž. Aldona Rakovskiené Antroje eilëje: vadybininke Vilija Skaržinskaite, vadybininkè Inga Lavrinavičiené, direktoriaus pavaduotojas mokymo reikalams doc. dr. Romualdas Malinauskas, SA atstove AGAI Rimante Mizaraite

Antano Gustaičio aviacijos institutas įkurtas 1993 m. Jame yra trys katedros, skrydžių valdymo praktikos bazè. Jai priklauso 12 darbo vietų kompiuterių klase, lektuvų „Jak-42“ ir „An-2“ treniruoklių laboratorija, skrydžių valdymo mokymo laboratorijos. Mokymo procese naudojamasi ir aviacijos įmoniu mokymo bei gamybinèmis bazemis - LAL mokymo centru, Civilinès aviacijos direkcijos Skrydžių valdymo centru. Skrydžių praktika atliekama KASP Dariaus ir Gireno atskirosios aviacijos eskadrilès aerodrome Kyviškèse, Paluknio aeroklube, Vilniaus tarptautiniame oro uoste bei KOP I aviacijos bazes kariniame oro uoste Zokniuose. 
AVIACIJOS

PRIETAISU

KATEDRA

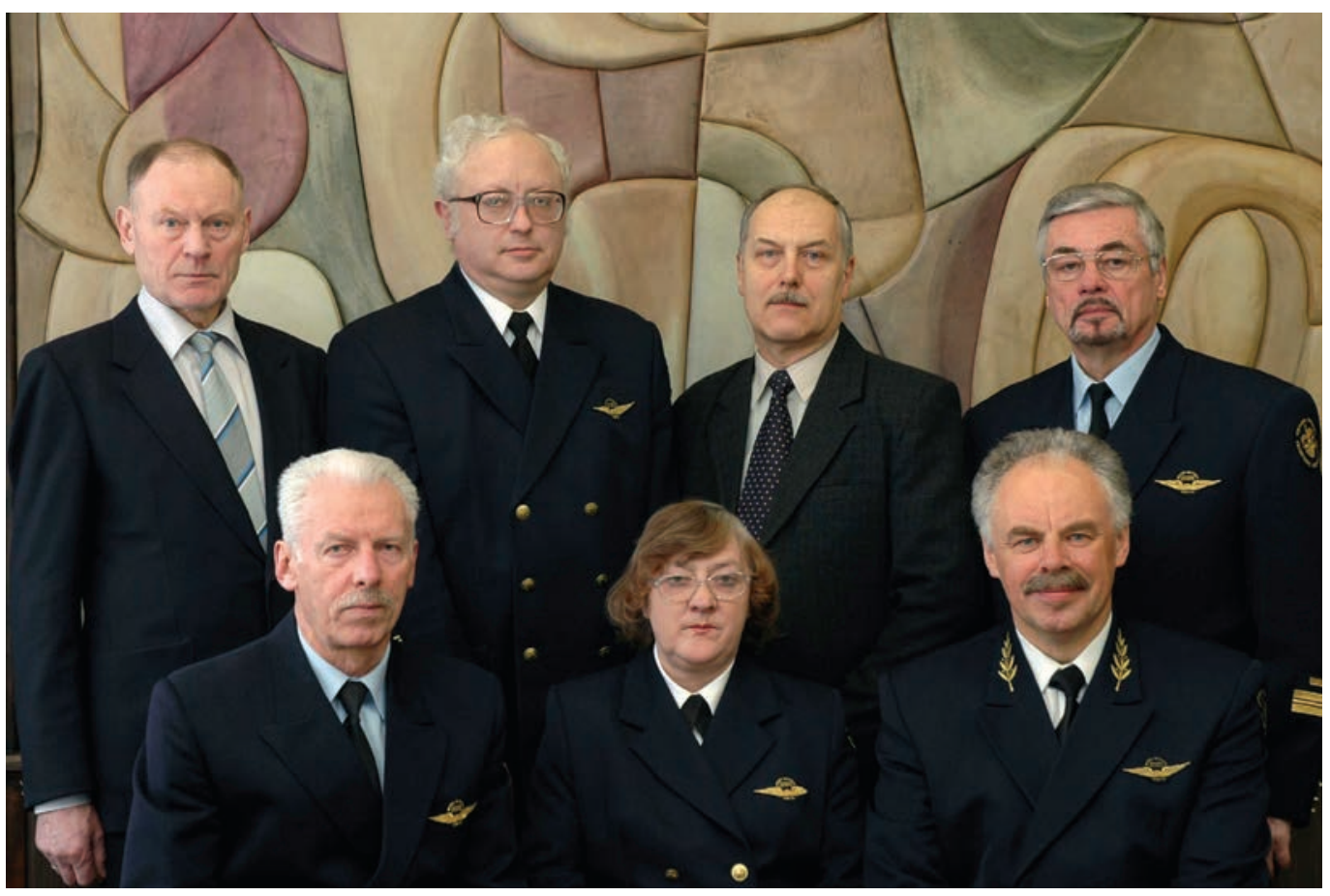

Iš kaires j dešine pirmoje eileje:

katedros vedëjas doc. dr. Algimantas Jakučionis, reikalų tvarkytoja Elvira Ona Palaimiené, prof. habil. dr. Jonas Stankūnas;

antroje eilëje:

doc. dr. Bronius Karaliūnas, direktoriaus pavaduotojas mokymo reikalams dr. doc.

Romualdas Malinauskas, asistentas Antanas Savickas, prof. habil. dr. Eugenijus Pileckas

Katedra ịkurta reorganizavus Skrydžių valdymo katedrą. 1997 m. gegužè 26 d. VGTU rektoriaus isakymu Nr. 643-PG paskyrus katedros vedëją, Aviatechnikos katedra pradëjo funkcionuoti nuo 1997 m. birželio 1 d. 2000 m. katedra pavadinta Aviacinių prietaisų katedra. 


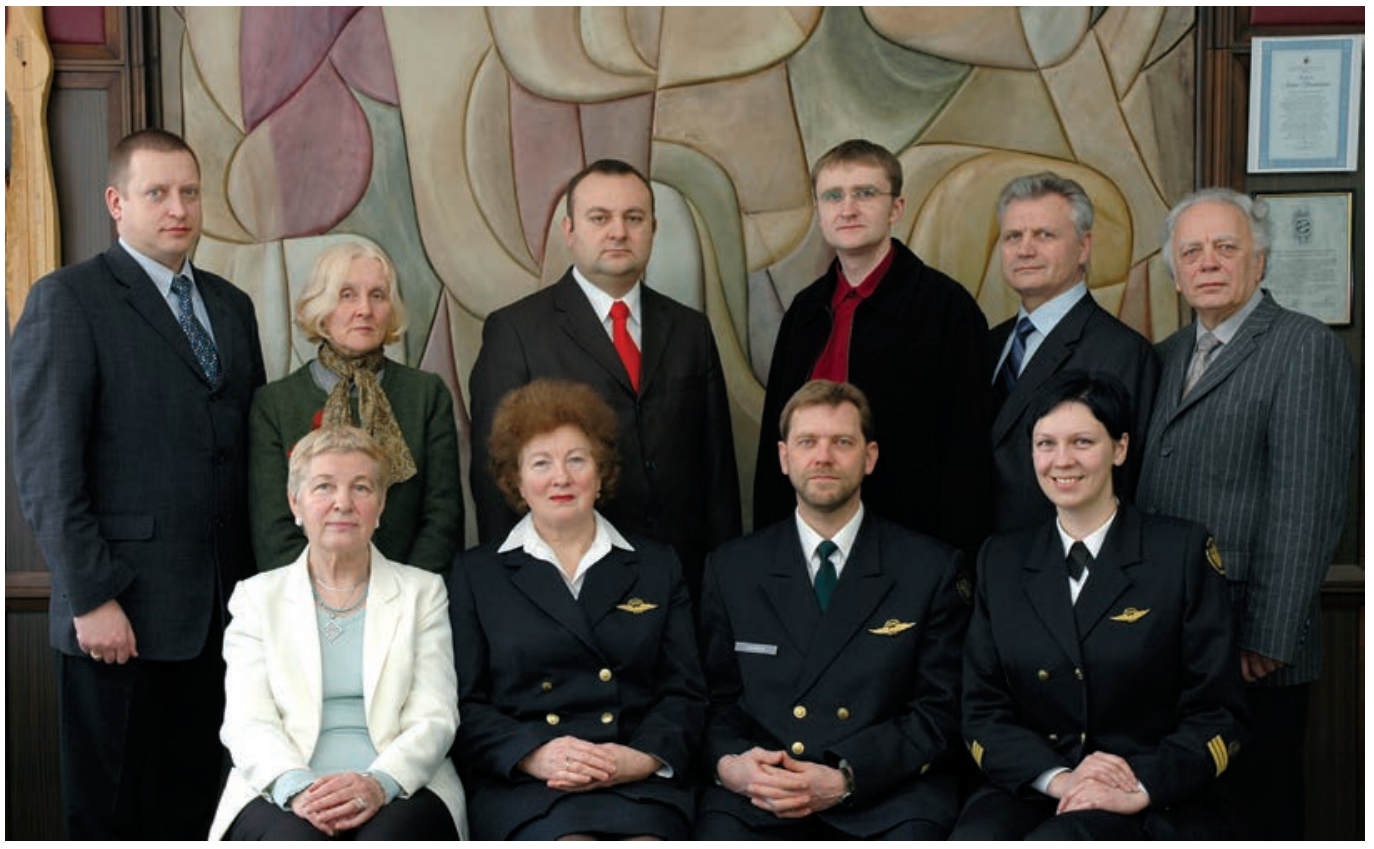

Is kaires j dešine pirmoje eileje:

asistente Nijolè Ona Žegūniené, reikalų tvarkytoja Vita Nijolè Urbonavičienė, katedros vedëjas doc. dr. Darius Ereminas, asistente mgr. Karolina Vaitonyté;

antroje eileje:

asistentas mgr. Nerijus Maleckas, asistente Regina Čepaitytė,

lektorius dr. Valentinas Jaruševičius, asistentas Aurimas Puskunigis, asist. Domas Balandis, prof. habil. dr. Algimantas Zakarevičius

Aviacijos technologijų katedra ịkurta 1993 m. spalio mèn. Tai profiliné Aviacijos instituto katedra. Ji rengia orlaivių pilotavimo, skrydžių valdymo inžinierius (4 mokslo metai) ir diplomuotus inžinierius skrydžių vadovus bei diplomuotus inžinierius pilotus, oro vežimų vadybos magistrus. İstojusieji i ̨ orlaivių pilotavimo ir skrydžių valdymo specialybių grupes, kuriose dèstoma anglų kalba, I kurse mokosi Tarptautiniame studijų centre. Stojantieji ị orlaivių pilotavimo specialybę (amžiaus riba 18-25 metai) turi gauti medicinos pažymą, patvirtinančią, kad jų sveikata atitinka 1 klasès reikalavimus, į skrydžiu valdymo specialybę -3 klases reikalavimus, pereiti psichologinį profesinio tinkamumo ir fizinio pajegumo testus, kurių išvados turi būti teigiamos. Katedroje dirba 4 profesoriai, 2 docentai, 2 vyr. asistentai eina (ne pagrindines pareigas), 16 asistentų eina (ne pagrindines pareigas). 2000 m. Skrydžių valdymo katedra pavadinta Aviacijos technologijų katedra. 


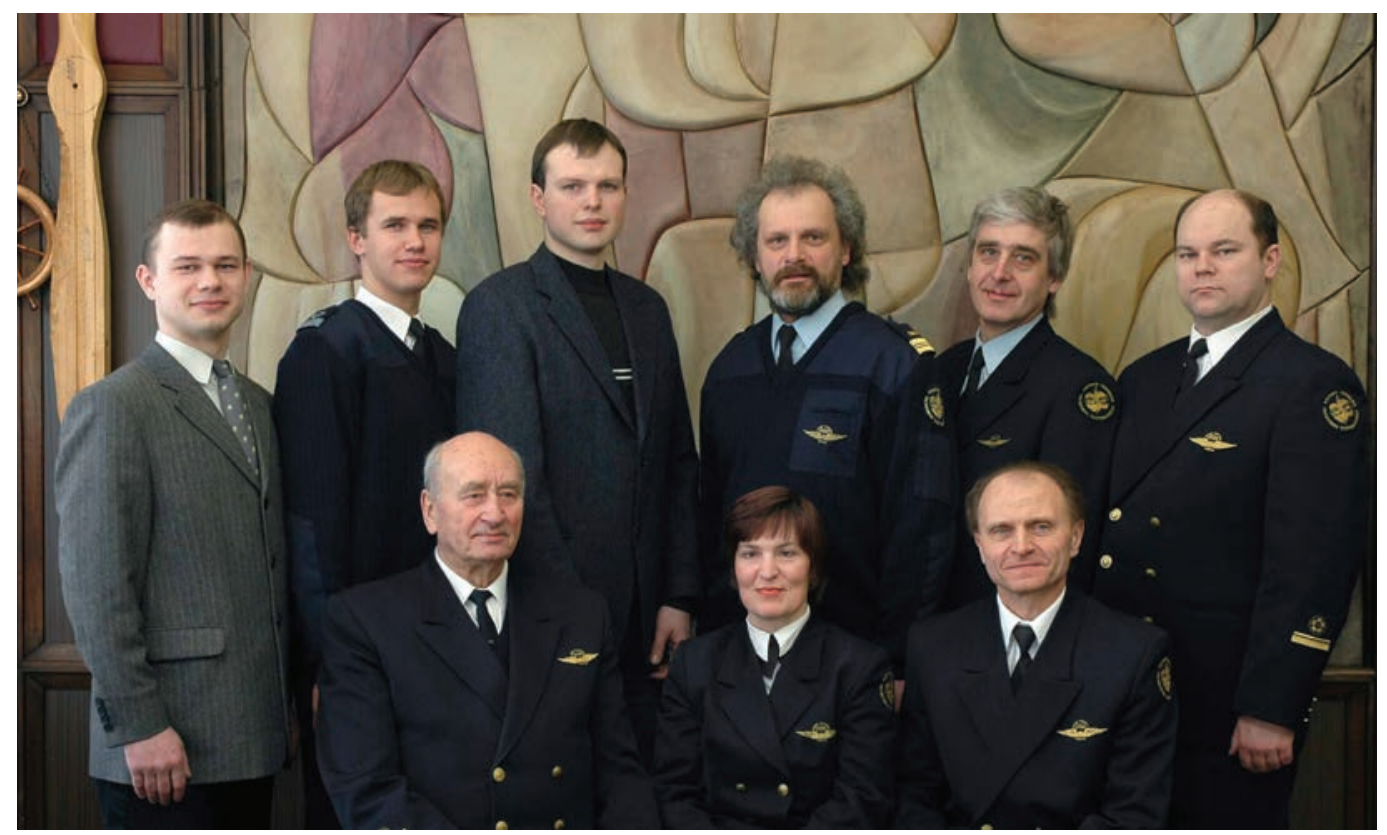

\section{Iš kaires j dešinę pirmoje eilëje:}

doc. Juozas Zujus, reikalų tvarkytoja Elvita Marcinkevičiené, katedros vedëjas doc. dr. Eduardas Lasauskas;

\section{antroje eileje:}

asist. mgr. Vincas Šnirpūnas, asist. mgr. Algimantas Deikus, lab. vedejas bkl. Paulius Lipnickas, asist. Kęstutis Leonavičius, asist. Bronius Merkys, asist. Saulius Janavičius

Aviacinès mechanikos katedra įsteigta 1993 m. kovo mèn. Mechanikos fakultete. Pradžioje ji buvo vadinama Aviainžinerijos katedra. Nuo pirmųjų katedros mokslo metų katedros vedëju buvo paskirtas aviatorius doc. dr. Juozas Zujus. 1994 m. rektorato sprendimu katedra buvo perduota Aviacijos institutui. Nuo 1997 m. Antano Gustaičio aviacijos institute orlaivių techninès diagnostikos ir orlaivių patikimumo disciplinas dėsto žinomas Kauno technologijos universiteto profesorius, Lietuvos mokslų akademijos narys - ekspertas Antanas Žiliukas. 1999-2001 m. katedrai vadovavo prof. habil dr. Eugenijus Pileckas - 48 išradimų, dviejų monografijų ir daugiau nei šimto mokslinių straipsnių autorius. $2001 \mathrm{~m}$. katedros vedëju paskirtas dr. Eduardas Lasauskas. Aviacinès mechanikos katedra yra profilinè, apima pagrindines aviacinès mechanikos sritis - orlaivius ir jų variklius. Svarbiausios desstomosios disciplinos: orlaivių konstrukcija, aviacinių variklių teorijos ir konstrukcijos pagrindai, orlaivių patikimumas ir technine priežiūra, jų patikimumas ir technine diagnostika, reaktyvinių variklių reguliavimo sistemos ir kt. AGAI, neturedamas nuosavos mokymo bazes aviacijos inžinieriams mechanikams rengti, naudojasi Mechanikos fakulteto, „Lietuvos avialinijų“, Prienų AB „Sportinè aviacija“ ir kitų geranoriška parama turimomis techninèmis bazemis bei laboratorijomis. Institute rengiami bakalaurai ir magistrai turi galimybes susipažinti su aviacijos technika, eksploatavimo, priežiūros, kontrolès priemonemis, orlaivių ir variklių priežiūros organizavimu, darbais skrydžių saugumui ir patikimumui užtikrinti ir kt. Mūsų absolventai dirba įvairiose Lietuvos aviakompanijose, karinèse oro pajegose, Vidaus reikalų ministerijos aviacijos padalinyje, studijuoja magistrantūroje, doktorantūroje, atlieka Jurgio Kairio orlaivių priežiūrą. Pastaruoju metu vis daugiau ịsitraukia ị pedagoginį darbą ir rengia jaunuosius aviacijos mechanikos specialistus. 
APLINKOS

INŽINERIJOS

FAKULTETO

ADMINISTRACIJA

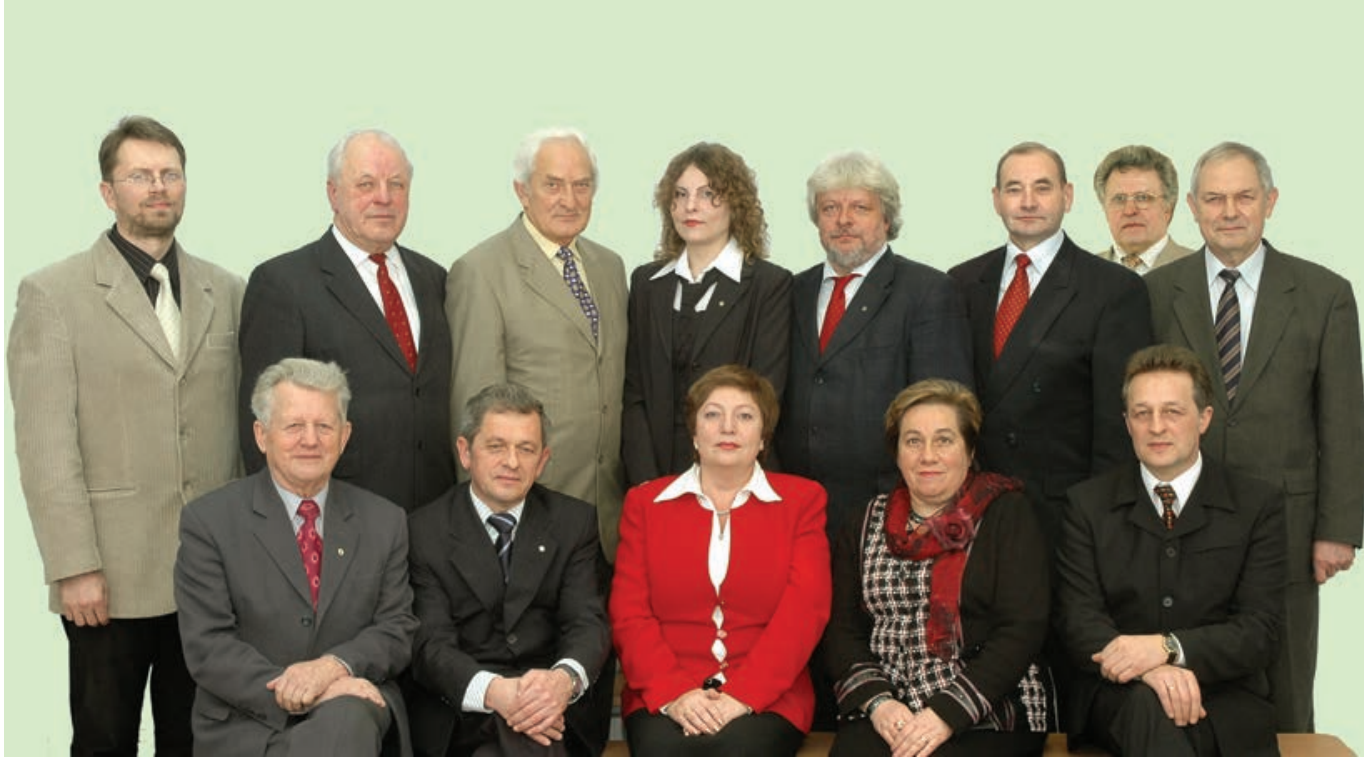

Iš kairès j̇ dešine pirmoje eileje:

fakulteto tarybos pirmininkas, Šildymo ir vedinimo katedros prof. habil. dr. Alfonsas Skrinska; Šildymo ir vedinimo katedros vedejas prof. habil. dr. Vytautas Martinaitis; Miestų statybos katedros vedejja, Teritorinio planavimo instituto direktore prof. dr. Marija Burinskiené; fakulteto studijų prodekané, studiju komiteto pirmininkè, Šildymo ir védinimo katedros doc. dr. Sabina Paulauskaité; fakulteto dekanas, Kelių katedros profesorius dr. Donatas Čygas;

antroje eileje:

fakulteto studijų ir ūkio reikalų prodekanas, Šildymo ir vedinimo katedros doc. dr. Kęstutis Čiuprinskas; Aplinkos apsaugos katedros vedëjas, Aplinkos apsaugos instituto direktorius prof. habil. dr. Pranas Baltrènas; Hidraulikos katedros vedejjas prof. dr. Antanas Lukianas; fakulteto mokslo ir ryšių su užsieniu prodekane, Aplinkos apsaugos katedros doc. dr. Rasa Vaiškūnaité; Kelių katedros, Automobilių kelių mokslo laboratorijos vedejjas prof. dr. Alfredas Laurinavičius; Geodezijos ir kadastro katedros vedëjas doc. dr. Ceslovas Aksamitauskas; fakulteto neakivaizdinių studiju prodekanas, Keliu katedros doc. dr. Antanas Aloyzas Juzenas; Geodezijos instituto direktorius prof. habil. dr. Petras Petroškevičius

Dabartinio fakulteto pradininku laikomas Miestų statybos fakultetas, įsteigtas 1968 m. kaip Kauno politechnikos instituto Vilniaus filialo fakultetas. 1969 m. pertvarkius filialą ị Vilniaus inžinerinị statybos institutą, fakultetas išlaike savo vardą iki $1990 \mathrm{~m}$. Fakultete buvo rengiami taikomosios geodezijos, miestų statybos, automobilių kelių inžinieriai.

Iš Kauno politechnikos instituto į VISI perkèlus šilumos, dujų tiekimo ir védinimo bei vandentvarkos specialybes, 1987 m. įsteigtas Komunalinio ūkio fakultetas. Toks fakultetas gyvavo iki $1990 \mathrm{~m}$. 1990 m. sujungus Miestų statybos ir Komunalinio ūkio fakultetus, įsteigtas Inžinerinių komunikacijų fakultetas. Šitaip fakultetas buvo vadinamas iki 1992 m. Nuo 1992 m. iki 1995 m. buvo vadinamas Miestų inžinerijos fakultetu.

Nuo šios datos fakultetas vadinamas Aplinkos inžinerijos fakultetu. Šiandien tai antras pagal dydį VGTU fakultetas, kuriame rengiami 4 pakopu specialistai: bakalaurai, diplomuoti inžinieriai, magistrai ir daktarai. 


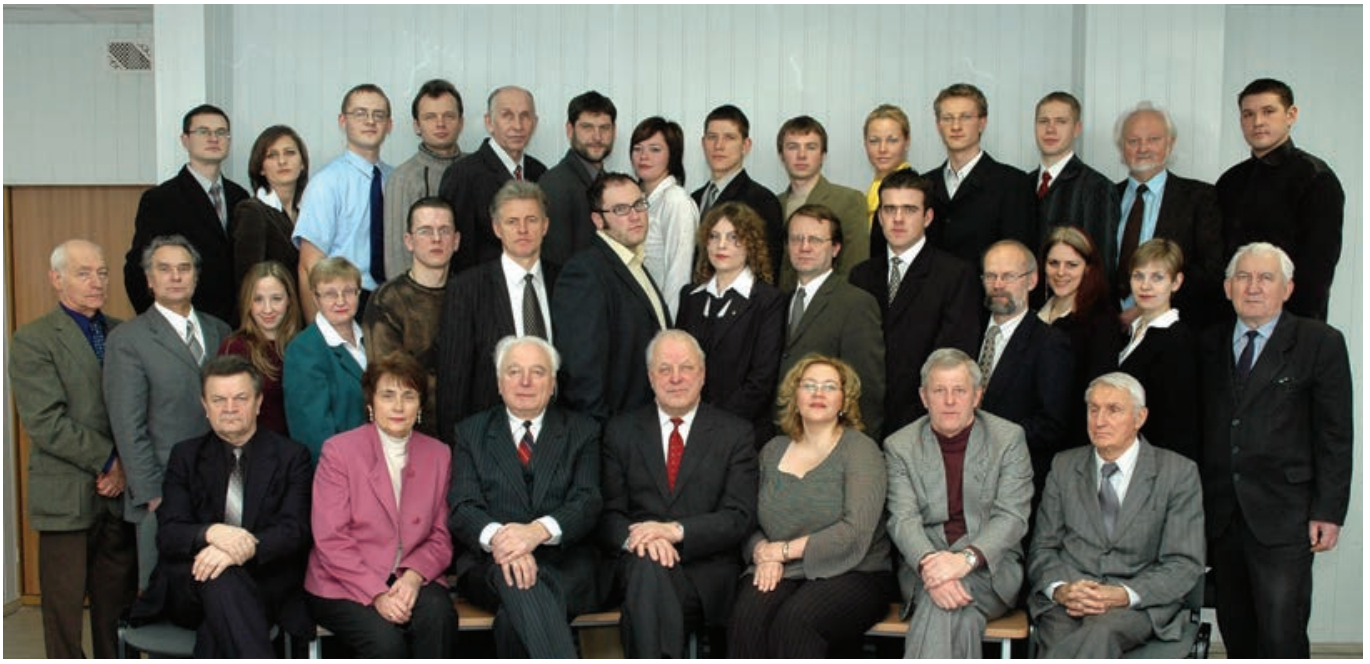

\section{Iš kairés j dešine pirmoje eilëje:}

doc. dr. Bronius Jaskelevičius, doc. dr. Rasele Girgždienè, prof. habil. dr. Donatas Butkus, katedros vedëjas prof. habil. dr. Pranas Baltrenas, doc. dr. Aušra Zigmontiené, doc. dr. Raimondas Leopoldas Idzelis, prof. habil. dr. Petras Vaitiekūnas;

antroje eileje:

doc. dr. Davidas Ščupakas, lab. vedëjas doc. dr. Adomas Vagonis, asist. dokt. Evelina Brannvall, asist. Vida Zubkaitiené, reik. tvarkytojas Algimantas Budreika, doc. dr. Stasys Motiejūnas, dokt. Danas Budilovskis, doc. dr. Rasa Vaiškūnaite, doc. dr. Saulius Vasarevičius, asist. dokt. Raimondas Grubliauskas, doc. dr. Vytautas Oškinis, asist. dokt. Kristina Greičiūte, asist. dokt. Agnè Kazlauskiené, doc. dr. Zenonas Venckus;

\section{trečioje eileje:}

doc. dr. Vaidotas Vaišis, vyr. laborante Jolanta Graudinytè, Mantas Pranskevičius, doc. dr. Dainius Paliulis, doc. dr. Juozas Justinas Blynas, doc. dr. Egidijus Petraitis, asist. dokt. Audroné Jankaite, asist. Gintas Stankus, asist. dokt. Mindaugas Kvasauskas, asist. dokt. Edita Baltrenaite, Linas Vaitkevičius, asist. dokt. Alvydas Zagorskis, doc. dr. Aloyzas Girgždys, Tomas Januševičius

Aplinkos apsaugos katedra įkurta 1993 m. rugsëjo mèn. Jos ištakos - tuometine Statybos fakulteto Darbo ir aplinkos apsaugos katedra. Pirmuosius metus pagrindinių universitetinių studijų programa buvo vadinama „Pramonés aplinkosauga“, o nuo 1997 metu - „Aplinkos apsaugos inžinerija“. Aplinkos apsaugos inžinerijos studiju programa aprépia įvairias aplinkos apsaugos problemas: oro valymo technologijas, atliekų tvarkymo sistemos ypatybes, aplinkos monitoringo sistemas, pramonés ir transporto aplinkosaugą ir kt., o pastaruoju metu - ir aplinkos apsaugos vadybą. Nuo $1993 \mathrm{~m}$. pradètos rengti Aplinkos inžinerijos magistrantūros studijos. Sèkmingai užbaigus magistrantūros studijas, tolesnes studijas galima tęsti doktorantūroje arba dirbti pagal igytą kvalifikaciją valstybinèse ir privačiose aplinkosaugos tarnybose ir pan. Pagrindinių studijų ir magistrantūros studiju studentai kasmet dalyvauja AAK iniciatyva organizuojamoje respublikinèje jaunųjų mokslininkų konferencijoje „Aplinkos apsaugos inžinerija“. Nuo 1995 m. VGTU Aplinkos apsaugos katedra pradëjo organizuoti Aplinkos ministerijos sistemoje dirbančių valstybés tarnautojų valstybinių aplinkos apsaugos inspektorių kvalifikacijos kèlimo kursus. Nuo $2002 \mathrm{~m}$. kvalifikacijos kèlimo kursų organizavimą peremé Aplinkos apsaugos institutas. 


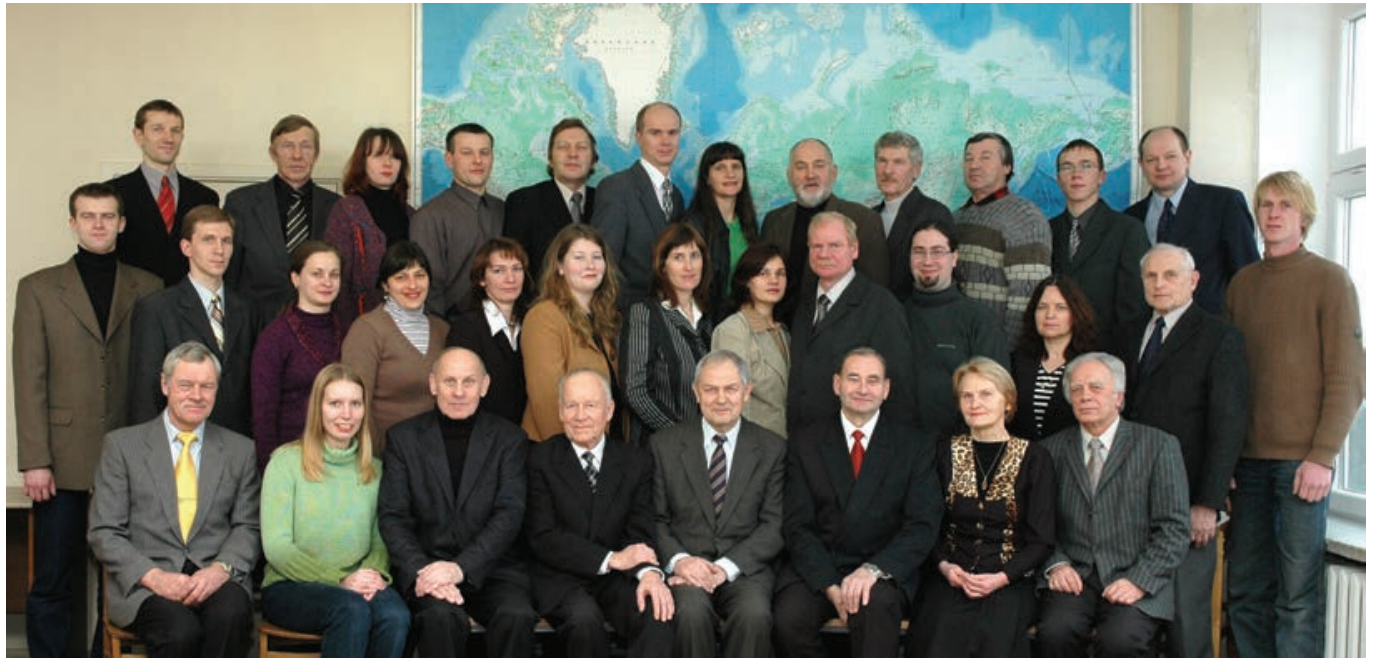

\section{Iš kairés j dešine pirmoje eilëje:}

doc. dr. Algimantas Gasilionis, dokt. Irina Jonauskienė, prof. habil. dr. Jonas Skeivalas, doc. dr. Stasys Kazakevičius, prof. habil. dr. Petras Petroškevičius,

katedros vedëjas doc. dr. Vladislovas Česlovas Aksamitauskas, lekt. Jadvyga Stepanoviené, prof. habil. dr. Algimantas Zakarevičius;

antroje eileje:

dokt. Bomantas Bručas, doc. dr. Arminas Stanionis, dokt. Danute Zmitrovičienè, dokt. Asta Anikèniené, inž. Evelina Zigmantienè, reikalų tvarkytoja Silvija Gečytė, asist. Eglè Tumeliené, doc. dr. Jūrate Sužiedelytė-Visockiené, doc. dr. Raimundas Putrimas, tech. asist. Marius Petniūnas, doc. dr. Birute Ruzgiene, prof. habil. dr. Vytautas Giniotis, inž. Aldas Neseckas;

\section{trečioje eileje:}

dokt. Kęstutis Čypas, lekt. Algirdas Neseckas, dokt. Rūta Puziené,

dokt. Romuald Obuchovski, doc. dr. Boleslovas Krikštaponis, asist. Arūnas Būga, metodininkè Edita Aleknienè, lab. vedejjas Povilas Viskontas, inž. Algirdas Butkus, inž. Albinas Petniūnas, technikas Dominykas Šlikas,

doc. dr. Eimuntas Kazimieras Paršeliūnas

1969 m. ̨̣kūrus Vilniaus inžinerinị statybos institutą, Geodezijos katedra perkelta ị Vilnių iš Kauno ir tolesne jos veikla susijusi su Vilniaus inžineriniu statybos institutu ir Vilniaus Gedimino technikos universitetu.

1997 m. Geodezijos katedros imta vadinti Geodezijos ir kadastro katedra. Katedrai vadovavo doc. dr. A. Ražinskas (1969-1980), doc. dr. V. Tulevičius (1980-1990), doc. dr. A. Zakarevičius (1990-1995), prof. habil. dr. J. Skeivalas (1995-1998), doc. dr. E. Paršeliūnas (1998-1999), nuo 1999 m. prof. habil. dr. A. Zakarevičius, nuo 2005 m. doc. dr. V. Č. Aksamitauskas.

Iki nepriklausomybès atkūrimo geodezijos mokslui pletotis buvo sudarytos nepalankios sąlygos, nes buvusioje Sovietų Sąjungoje geodezija priklause vienai iš ypač slaptų sričių.

Atkūrus nepriklausomybę, organizuotos dviejų pakopų studijos: bakalauro ir magistro. Pagal šią studiju programą jau yra parengta per 200 geodezijos bakalauru, 92 magistrai, 25 diplomuoti inžinieriai. Šiuo metu aštuoni doktorantai studijuoja doktorantūroje.

Magistratūros studijose parengti pirmieji Lietuvoje geografinių informacinių sistemų, geodezinių tinklų specializacijų magistrai.

$1993 \mathrm{~m}$. Geodezijos katedra pradëjo rengti nekilnojamojo turto vadybos bakalaurus (pastaruoju metu šie specialistai rengiami Statybos fakultete). Iki $2000 \mathrm{~m}$. parengtas 71 nekilnojamojo turto vadybos bakalauras.

Nuo 1996 m. pradèta rengti dvieju geodezijos studiju pakraipų specialistus: geodezijos ir kartografijos bei nekilnojamojo turto kadastro. Pirmieji nekilnojamojo turto kadastro studiju pakraipos bakalaurai baigiamuosius darbus gynè 2001 metais. 


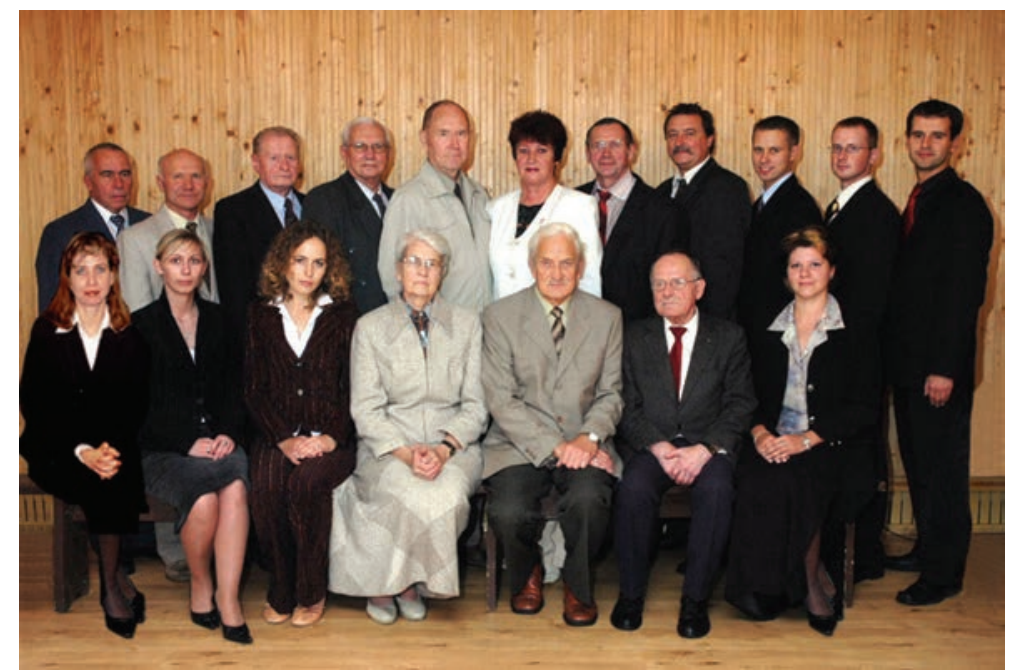

\section{Iš kairès j dešine pirmoje eilëje:}

doc. dr. A. Dolgopoloviene, mgr. R. Ruminaite, dokt. O. Survilaite, asist. D. Jankauskiene, katedros vedëjas prof. dr. A. Lukianas, asist. J. Kunigèlis, doc. dr. L. Bagdžiūnaitè-Litvinaitiené;

antroje eileje:

doc. dr. R. Pekus, doc. dr. V. Šaulys, lab. vedëjas V. Riauba, prof. habil. dr. N. Ždankus, katedros reikalų tvarkytoja A. Barkauskaitè, doc. habil. dr. S. Vaikasas, prof. habil. dr. A. Česnulevičius, dokt. G. Sabas, dokt. M. Stankevičius, doc. dr. A. Kačeniauskas

Hidraulikos katedra kaip savarankiškas padalinys veikia nuo $1969 \mathrm{~m}$.

Katedros vedëjais dirbo: 1969-1980 m. ir 1989-1993 m. - doc. dr. K. Baškys, 1980-1987 - doc. dr. M. Gedgaudas, 1987-1989 m. - doc. dr. K. Blažys, 1993-2000 m. - doc. dr. R. Alekna, nuo 2000 m. iki dabar - doc. dr. A. Lukianas.

Per katedros gyvavimo istoriją joje dirbo daugelis patyrusių ir žinomų šalyje mokslininkų ir hidrotechnikos specialistų: doc. dr. K. Baškys, doc. dr. J. Duoba, doc. dr. V. Marčènas, doc. dr. R. Alekna, D. Jankauskienè, J. Kunigelis ir kiti. 


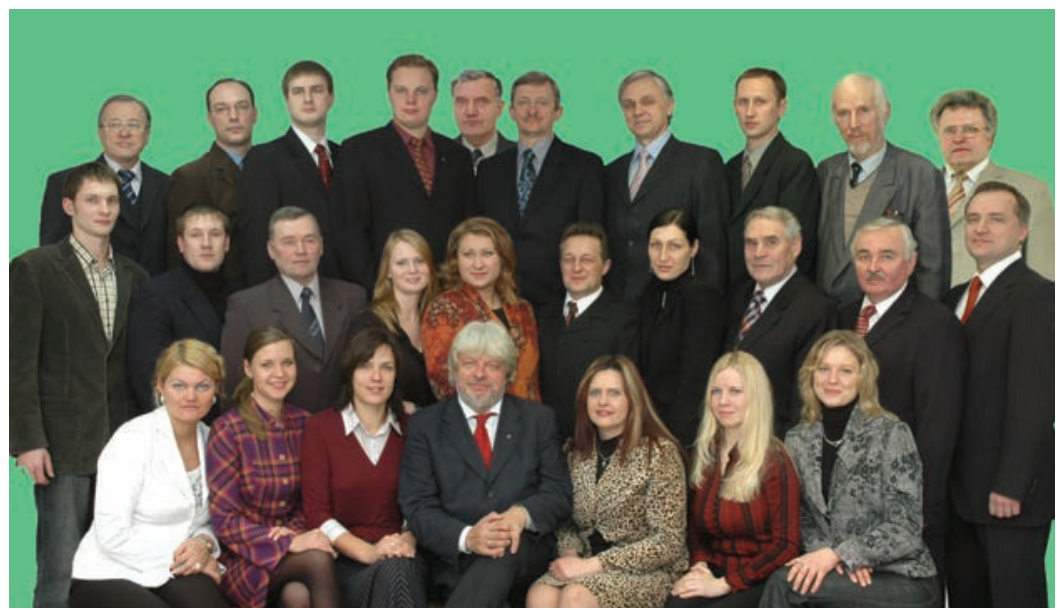

Iš kairés j̇ dešine pirmoje eileje:

vadybininke bkl. Lina Banyte, laborantè Laura Žiliūtè, doc. dr. Inesa Povilaitienè, katedros vedejjas prof. dr. Alfredas Laurinavičius, doc. dr. Daiva Žilioniené, dokt. Lina Juchnevičiūté, dokt. Kornelija Ratkevičiūté;

antroje eileje:

laborantas Irmantas Šiupinius, techn. asist. bkl. Alfredas Butenas, inž. Albinas Stankevičius, dokt. inž. Faustina Tumėnienè,

reikaly̨ tvarkytoja mgr. Lina Kniukštaite, Senato pirmininkas, Aplinkos inžinerijos fakulteto dekanas prof. dr. Donatas Čygas, asist. dr. Laura Černiauskaite, doc. dr. Kazys Sakalauskas, doc. dr. Kazys Petkevičius, lekt. dr. Skirmantas Skrinskas;

trečioje eileje:

doc. dr. Igoris Podagèlis, asist. mgr. Remigijus Rezgaitis, inž. bkl. Viktoras Vorobjovas, kokybès vadybininkas dokt. Audrius Vaitkus, asist. Rimantas Babickas,

doc. dr. Kęstutis Skerys, Lietuvos automobilių kelių direkcijos prie Susisiekimo ministerijos generalinis direktorius doc. dr. Virgaudas Puodžiukas, dokt. Rolandas Oginskis,

doc. dr. Julius Christauskas, doc. dr. Antanas Aloyzas Juzėnas

Inžinieriai kelininkai Kauno politechnikos institute buvo rengiami 1951-1969 m. Nuo 1969 iki 1990 m. juos rengè Vilniaus inžineriniame institute, į kurị Kelių katedra ir buvo perkelta iš Kauno. 1967-1977 m. Kelių katedros vedëju dirbo doc. dr. (nuo 1983 m. - prof. habil. dr.) Steponas Rokas. Vèliau kelių katedros vedejjais dirbo: 1977-1987 m. - doc. dr. Kazimieras Sakalauskas, 19871993 m. - doc. dr. Vytautas Jasulaitis, nuo 1995 m. - prof. dr. Alfredas Laurinavičius.

Nuo 1949 iki 2005 m. parengti 1503 inžinieriai, iš jų: automobilių kelių specialybès - 1430, geležinkelių - 73. Nuo $1994 \mathrm{~m}$. pagal naują studijų sistemą parengti 299 bakalaurai ir 240 magistrų. 1969 m. katedrai persikèlus iš Kauno politechnikos instituto ị naują Vilniaus inžinerinį statybos institutą, jos istorija susieta su šia mokykla. Doc. dr. E. Palšaitis katedroje dirbo nuo 1950 iki 1993 m., doc. Linas Vidugiris katedroje dirbo iki 1994 m.; nuo 1962 iki 1967 m. jis buvo Kelių katedros vedeju. Didelį indèlį į kelių mokslo plètrą inneše prof. habil. dr. Steponas Rokas.

Nuo 1967 iki 1977 m. jis - katedros vedëjas, 1983 m. pirmasis iš pokario metų katedros darbuotojų apgynęs technikos mokslų daktaro (dabar habilituoto daktaro) disertaciją. Katedroje dirbo docentai daktarai: Vytautas Jasulaitis, Henrikas Sausenavičius, Vincas Stragys bei inžinieriai Juozas Šerys, Stasys Pekšys, Anicetas Bagdonas ir Gerimantas Tarvydas.

1984-1989 m. disertacijas gyne prof. S. Roko mokiniai: H. Sivilevičius (Maskvoje), K. Petkevičius (Maskvoje), K. Skerys (Charkove), A. Laurinavičius (Maskvoje), I. Podagèlis (Odesoje). Jie sèkmingai dirbo Kelių katedroje ir jos laboratorijoje. Nuo 1997 m. disertacijos Vilniuje (VGTU) buvo ginamos praktǐ̌kai kasmet: 1977 m. - D. Čygas, 1998 m. -S. Skrinskas, 2000 m. -V. Puodžiukas, 2003 m. D. Žilionienè (pirma moteris Lietuvoje kelininkè daktare), $2004 \mathrm{~m}$. - I. Povilaitienè (pirma moteris Lietuvoje geležinkelininkè daktarè), 2004 m. - L. Černiauskaitė, 2005 m. -A. Braga. Šiuo laikotarpiu katedros vedejjas buvo 1977-1987, 1993-1996 m. - doc.dr. Kazys Sakalauskas, 1987-1993 m. - doc. dr. Vytautas Jasulaitis, nuo 1995 m. iki dabar - prof. dr. Alfredas Laurinavičius. 


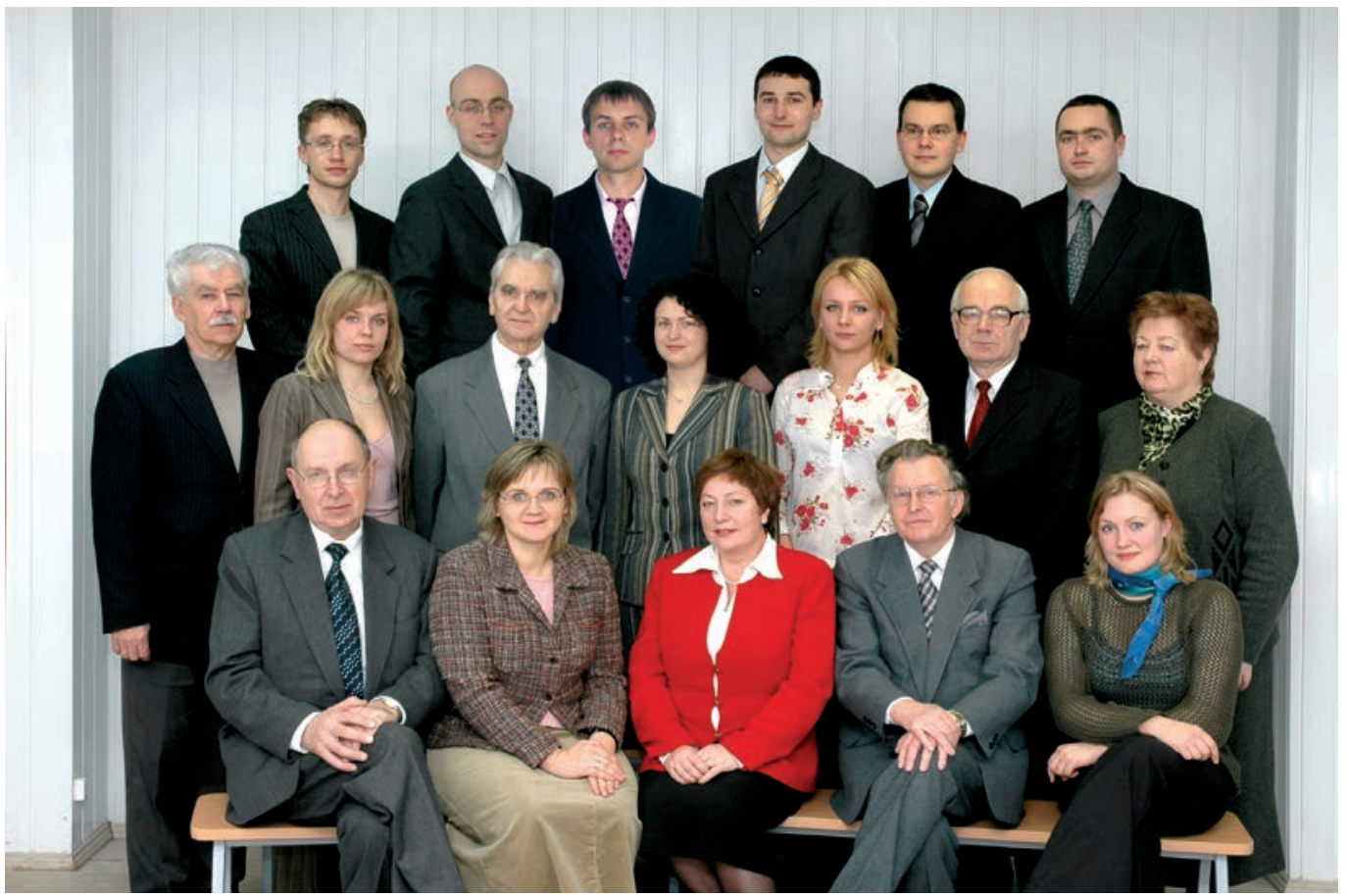

Is kaires j dešine pirmoje eileje:

doc. dr. G. Paliulis, dr. A. Mačerinskiené, katedros vedëja prof. dr. M. Burinskiené, prof. habil. dr. K. Jakovlevas-Mateckis, mgr. R. Skripkienè;

antroje eileje:

prof. habil. dr. P. Juškevičius, dokt. K. Jauneikaite, doc. dr. A. Rimkus, dokt. R. Ušpalytė-Vitkūniené, mgr. J. Venckauskaite, doc. dr. A. Klibavičius, reikalų tvarkytoja A. Bešeniené;

\section{trečioje eileje:}

lekt. D. Misiūnas, dokt. J. Zaborskas, technikas Ž. Grabauskas, technikas V. Palevičius, doc. dr. V. Grigonis, dokt. M. Jakimavičius

Miestų statybos katedra įkurta KPI Vilniaus filiale 1965 m. Pirmasis Miestų statybos katedros vedejjas - prof. tech. m. dr. Vytautas Kriščiūnas (1908-1991). Miestų statybos katedra savo įkūrimo pradžioje buvo įvairialypé, čia buvo desstomos bendrosios statybos, geodezijos, statybinių konstrukcijų, santechnikos ir profilinès miestų statybos disciplinos - miestų transportas, gatvès ir keliai, miestų planavimas. Pirmoji miestų statybos trylikos inžinierių laida baigè KPI Vilniaus filialą $1967 \mathrm{~m}$. gruodžio menesị.

Ypač išsiplète ir suaktyvejo Miestų statybos katedros veikla nuo 1971 m., kai nuo jos atsiskyrè Pastatų konstrukcijų katedra. Miestų statybos katedrai pradejo vadovauti technikos mokslų daktaras profesorius Vaclovas Vytautas Šeštokas (1931-1984).

Po prof. V. Šeštoko mirties nuo 1984 iki 1990 m. Miestų statybos katedrai vadovavo arch. dr. doc. P. Juškevičius. 1990-1996 m. katedrai vadovavo doc. dr. Antanas Klibavičius. Šiuo metu katedrai jau septynerius metus kūrybingai vadovauja prof. Marija Burinskiené.

Miestų statybos katedra per daugiau nei 38 metu gyvavimo laikotarpị savo mokslinę ir pedagoginę veiklą siejo su miestų infrastruktūros plètra bei teritoriju tvarkymu. Daugiausia démesio buvo skiriama miesto susisiekimo sistemoms, jų darbo analizei, įvertinimui bei teikiami pasiūlymai jas tobulinti. Pastarąjį dešimtmetį ypač išsiplète miestų statybos katedros mokslinès veiklos tematika, atsižvelgiant į Europos Sajungos mokslines kryptis. Moksliniai katedros darbai vykdomi pagal miestų savivaldybių užsakymus, yra sujungti į , „Miesto subalansuotos plètros“ temą, apimančią būsto, susisiekimo sistemų, inžinerinių komunikacijų, miesto tvarkymo, aplinkos formavimo ir humanizavimo, racionalaus energetinio planavimo, sanitarinio miesto valymo, pagristos bei tolydžiai pletojamos miesto infrastruktūros plètrą. 


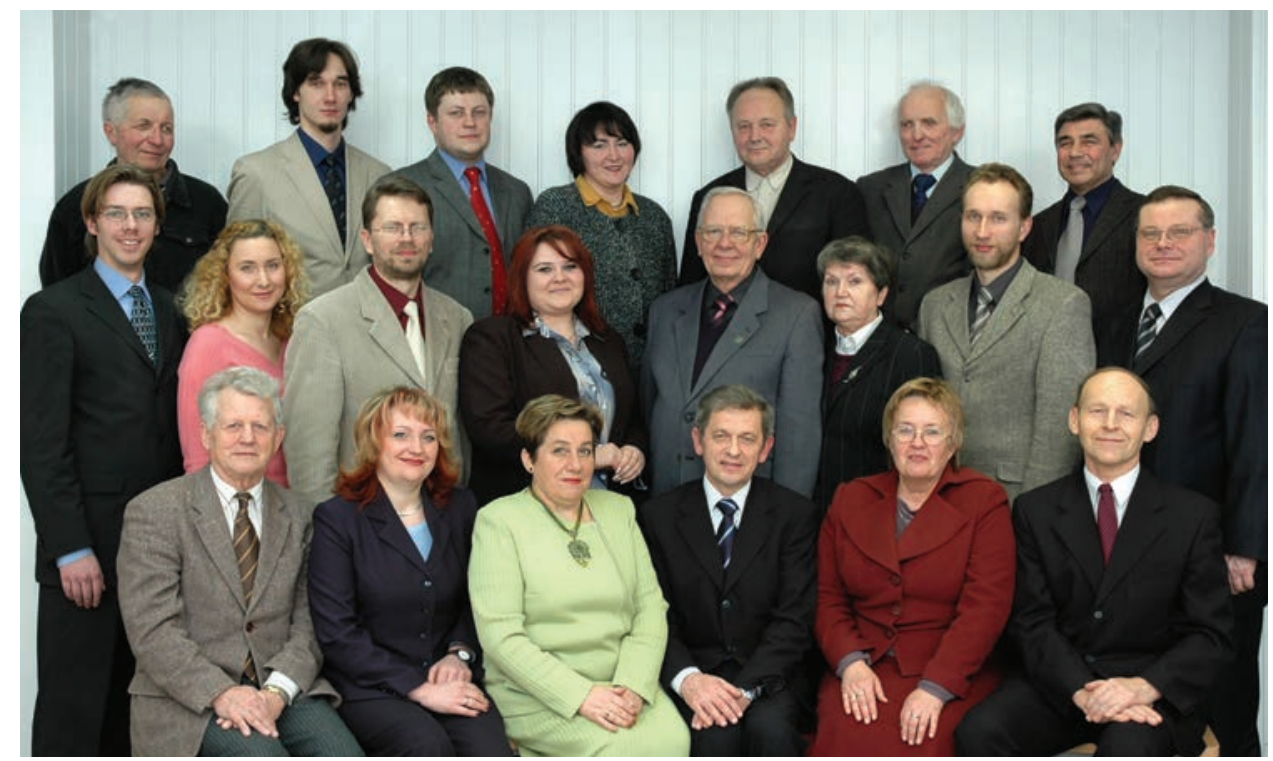

Iš kaires j dešine pirmoje eileje:

prof. habil. dr. Alfonsas Kazys Skrinska, katedros reikalu tvarkytoja Genrika Rynkun, doc. dr. Sabina Paulauskaite, katedros vedejjas prof. habil. dr. Vytautas Martinaitis, lekt. Sigute Čeplinskaite, prof. dr. Egidijus Saulius Juodis;

antroje eileje:

dokt. Darius Biekša, dokt. Violeta Sosnovskaja, doc. dr. Kęstutis Čiuprinskas, vadyb. Margarita Gelbūdaite, doc. dr. Aloyzas Algimantas Šakmanas, doc. dr. Nijole Juzefa Vegyte, doc. dr. Artur Rogoža, doc. dr. Petras Urbonas; trečioje eileje:

lab. Romualdas Sribike, lekt. Kęstutis Valančius, lekt. Giedrius Šiupšinskas, lekt. Jolanta Čiuprinskienè, techn. asist. Algirdas Kindurys, techn. asist. Edvardas Miliukas, lab. vedëjas Vincas Janulis

Tokiu pavadinimu katedra veike KPI nuo 1961 m., o jos dèstytojus perkẻlus iš Kauno į Vilnių, VISI katedra issteigta $1988 \mathrm{~m}$. rugsèjo $1 \mathrm{~d}$.

Katedra profilinè - rengia termoinžinerijos mokslo magistrus ir daktarus.

Katedros vedejais Vilniuje dirbo: 1988-1990 m. - doc. dr. Marijonas Gedgaudas, 1990-1991 m. doc. dr. Vytautas Martinaitis, 1991-1997 m. - doc. dr. Edvardas Tuomas, 1997-2002 m. - prof. habil. dr. Alfonsas Skrinska, nuo 2002 m. iki dabar - prof. habil. dr. Vytautas Martinaitis.

1998 m. katedros Šilumos mainų mokomajai laboratorijai suteiktas tragiškai žuvusio akademiko Algirdo Žukausko vardas.

Nuo 1988 m. katedroje dirbo doc. D. Rachlevičiene, doc. E. Juodis, prof. A. Liaukonis, doc. S. Paulauskaite. Nuo 1989 m. atvyko dirbti iš Kauno doc. B. Narbutis, doc. E. Tuomas. 19870901 îsteigus Komunalinio ūkio fakultetą, studiju prodekane kviečiama dirbti Šildymo ir védinimo katedros doc. S. Paulauskaite, kuri šias pareigas eina jau daugiau nei 15 metų.

Tragiškai žuvus akad. A. Žukauskui, jo gimimo 75-mečio proga 1998 m. papildytai ir suremontuotai Šilumos mainų mokomajai laboratorijai suteiktas A. Žukausko vardas. 1999 m. pakartotinai gaunama energetikos ir termoinžinerijos mokslo krypties doktorantūros studijų teisè. Tais pačiais metais Kęstutis Čiuprinskas pirmas VGTU apgyne Energetikos ir termoinžinerijos mokslo krypties daktaro disertaciją, o netrukus pradeda dirbti Aplinkos inžinerijos fakulteto prodekanu. $2000 \mathrm{~m}$. katedros doc. dr. Vytautas Martinaitis apgyne habilituoto daktaro disertaciją. 
VANDEN-

TVARKOS

KATEDRA

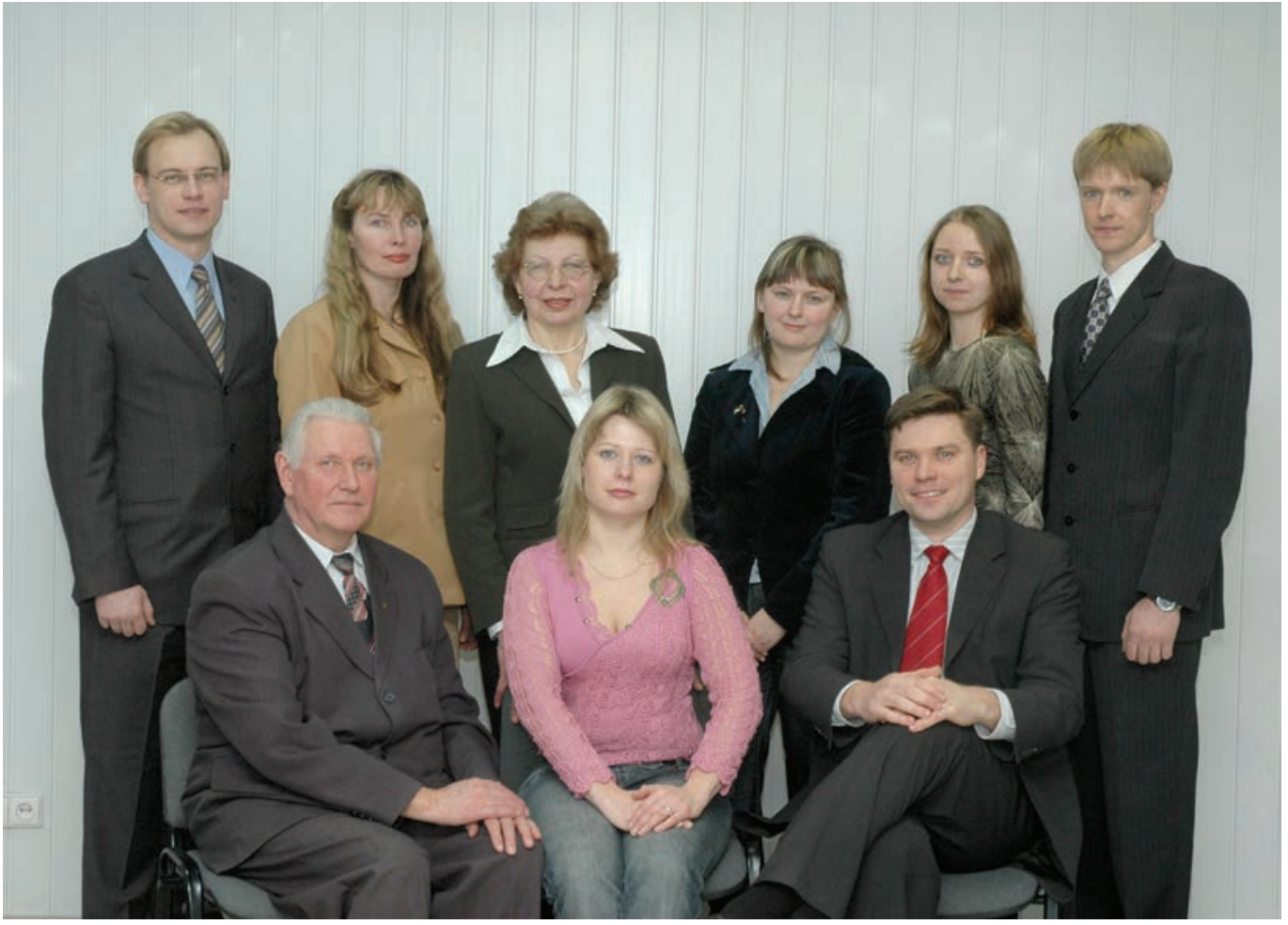

\section{Iš kairès j dešine pirmoje eilëje:}

katedros vedëjas prof. dr. Algirdas Bronislovas Matuzevičius, reikalu tvarkytoja Vaida Larionoviené, doc. dr. Regimantas Dauknys;

antroje eileje:

Antroje eileje: doc. dr. Mindaugas Rimeika, doc. dr. Aušra Mažeikienè, lekt. Zita Paulauskiené, doc. dr. Marina Valentukevičiené, laborantė Aistė Dapkevičūte, lab. vedëjas Tomas Žemaitis

Katedros veiklos pradžia susijusi su Lietuvos universiteto Technikos fakultete $1922 \mathrm{~m}$. įsteigtu Statybos skyriumi. Šiame skyriuje buvo įkurtas Santechnikos kabinetas, kuris 1940 m. rugpjūčio 15 d. buvo pertvarkytas ị Miestų sanitarijos katedrą. Ši data laikoma Vandentvarkos katedros isteigimo diena.

1965 m. katedra pavadinta Vandentiekio ir kanalizacijos ir iki 1989 m. pavadinimo nekeite.

Vilniaus inžineriniame statybos institute pirmieji studentai į vandentvarkos specialybę buvo priimti 1985 metais. Specialybes dalykams destyti 1988-1989 m. dalis KPI Vandentiekio ir kanalizacijos katedros déstytojų buvo perkelti ị šio instituto Hidraulikos katedrą. Vandentvarkos katedra čia îsteigta $1989 \mathrm{~m}$. rugsëjo $1 \mathrm{~d}$.

Katedra rengia aplinkos inžinerijos vandentvarkos krypties bakalaurus, diplomuotus inžinierius ir magistrus. Be to, veikia aplinkos inžinerijos ir kraštotvarkos doktorantūra.

Katedroje dèstomi šie dalykai: vandentvarka, pastatų vandentiekis ir nuotakynas, vandens mikrobiologija, vandentieka, nuotèkų šalinimas, vandens ruošimas, nuotékų valymas, kt.

Katedra turi Vandentvarkos mokomąją laboratoriją, kompiuterinę klasę, kuria naudojasi doktorantai ir magistrantai.

Nuo katedros įsteigimo jos vedejjais dirbo: 1940-1945 m. - doc. Steponas Kairys, 1945-1956 m. ir 1961-1975 m. - prof. Stasys Vabalevičius, 1956-1961 m. - prof. Bronius Petrulis, 1975-1988 m. doc. Ginutis Kutas, 1989 -2002 m. - doc. Algirdas Bronislovas Matuzevičius.

Šiuo metu katedrai vadovauja prof. Algirdas Bronislovas Matuzevičius. 


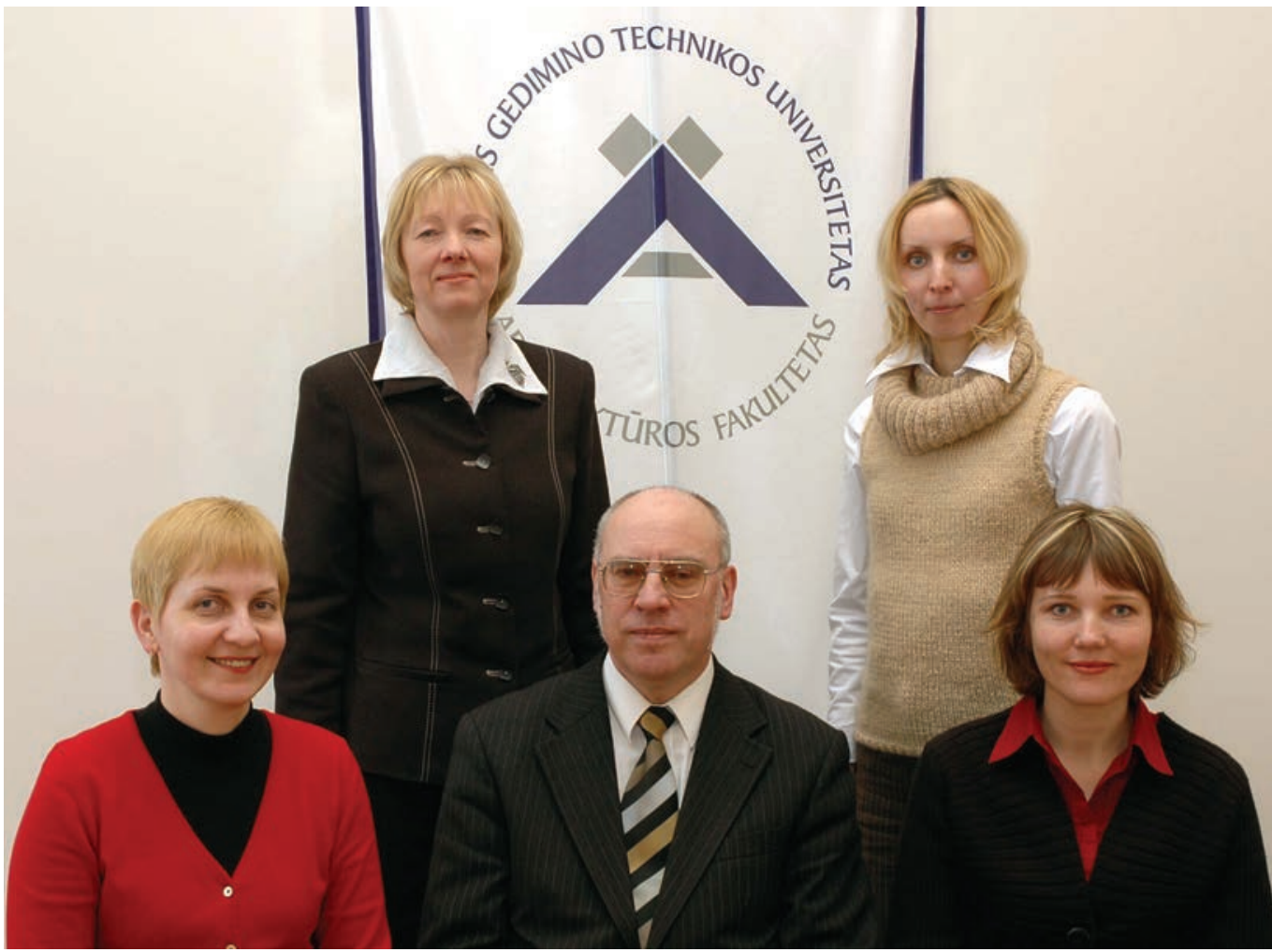

Iš kairès j dešine pirmoje eileje:

studiju prodekané doc. dr. Edita Riaubiené, dekanas prof. dr. Rimantas Buivydas, mokslo prodekane doc. dr. Egle Navickiene;

antroje eileje:

administratore Vida Šimulionytè, vadybininkè Jolanta Kozič

VGTU Architektūros fakulteto istorija tiesiogiai siejama su Kauno Vytauto Didžiojo universitetu. 1946 m. fakultetas įkurtas kaip administracinis mokymo ir mokslo padalinys, buvusị Statybos fakultetą pertvarkius ị du savarankiškus - Architektūros ir Statybos - fakultetus. Pirmuoju dekanu 1946-1949 m. buvo doc. S Stulginskis, nuo 1949 m. - doc. S. Sčesnulevičius.

$1951 \mathrm{~m}$. Kauno universiteto technikos fakultetų pagrindu suformuotas Kauno politechnikos institutas (KPI), vèl sujungus Architektūros ir Statybos fakultetus. Po 20 metų, t. y. 1971 m. Architektūros fakultetas ,atgijo “ Vilniaus inžineriniame statybos institute, iš Kauno perkèlus Architektūros, Gyvenviečiu palnavimo ir Grafinių darbų katedras. Priemimas ị architektūros specialybés pirmajji kursą pradètas dar $1970 \mathrm{~m}$. rudenị Vilniuje, dar nepersikèlus visoms profilinems katedroms. Atkurto Architektūros fakulteto dekanu 1971-1972 m. tapo prof. Jurgis Vanagas. 1972-1987 m. fakultetui vadovavo prof. Antanas Spelskis, kuris pokario metais dirbo Architektūros katedroje Kaune, o vèliau - Vilniaus dailès institute (1970 m. jis grižo ị VISI Architektūros katedrą). Nuo 1987 m. dekano pareigas ëjo prof. Konstantinas Jakovlevas-Mateckis. 1991-1999 m. Architektūros fakulteto dekanu buvo prof. Vytautas Dičius, 1999-2003 m. - doc. dr. Eugenijus Staniūnas, o nuo $2003 \mathrm{~m}$. Architektūros fakultetui vadovauja prof. dr. Rimantas Buivydas.

Šiandien VGTU Architektūros fakultete studijuoja daugiau nei 500 studentų. Fakulteto pedagoginį personalą sudaro 57 dẻstytojai, iš jų 12 profesorių ir 15 docentų. Kiekvienais metais Architektūros fakultetas išleidžia apie 70 architektūros bakalaurų ir apie 50 architektūros magistrų. Architektūros specialistai rengiami pagal dvipakopę studijų sistemą: po ketverių pagrindinių studijų metu igyjamas bakalauro kvalifikacinis laipsnis, o dar po dvejų metų magistrantūros studijų - architektūros magistro laipsnis. Galimos ir trečiosios pakopos studijos - doktorantūra - humanitarinių mokslų daktaro laipsniui igyti. 


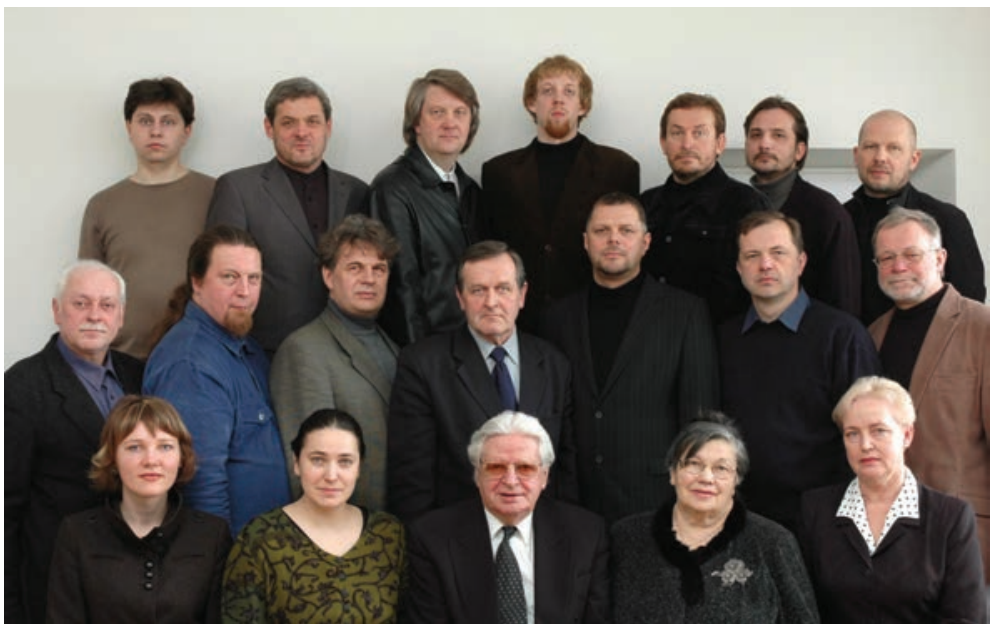

Iš kaires j dešine pirmoje eilëje:

doc. dr. Eglè Navickiené, doc. dr. Lada Markejevaite, prof. Justinas Šeibokas, prof. dr. Nijolè Elena Bučiūté, reikalų tvarkytoja Danuta Stankovskaja;

antroje eileje:

vadybininkas Jonas Kairelis, doc. dr. Kęstutis Lupeikis, doc. Gintautas Blažiūnas, katedros vedejas prof. Leonidas Pranas Ziberkas, doc. Saulius Mikštas, doc. Audrius Ambrasas, doc. Alvydas Žickis;

trečioje eileje:

asist. Virginijus Gerdvilis, doc. Linas Naujokaitis, prof. Gintaras Čaikauskas, vadyb. mgr. Arnoldas Gabrènas, doc. Sigitas Kuncevičius, lekt. Saulius Pamerneckis, doc. Rolandas Palekas

Architektūros katedra Kaune veikẻ jau nuo 1922 m., kai 1971 m. Vilniaus inžineriniame statybos institute buvo ịsteigtas Architektūros fakultetas. Architektūros katedrą sudarẻ dauguma dėstytojų, persikelusiu iš KPI.

1971 m. Vilniaus inžinerinio statybos instituto Architektūros katedroje dirbo 10 etatinių dèstytojų, iš kurių 6 atsikèle kartu su katedra iš Kauno, tai - A. Lukošaitis, S. Abramauskas, A. Keturka, A. Vaivada, V. Kasputis ir L. Ziberkas, taip pat iki tol epizodiškai katedroje dirbęs architektas V. Dičius ir tų metų absolventas A. Uljanovas bei du vilniečiai - A. Spelskis ir V. Vaitkus.

1973-1975 m. katedroje pradeda dirbti V. Baranauskas, A. Dineika, Z. Liandzbergis, E. Staniūnas, V. Kundrotas, 1978 m. grįžta J. Baršauskas.

1985 m. į katedrą pakviečiama E. N. Bučiūtè, 1986 m. - J. Šeibokas, K. Jakovlevas-Mateckis, Č. Mazūras, A. Uljanovas (grižo po 12 metų pertraukos), 1988 m. - G. Čaikauskas ir G. Gasperaitis, 1989 m. - R. Buivydas, 1990 m. - S. Kuncevičius ir R. Palekas, 1991 m. - J. Jurevičienè.

1993-1994 m. keičiamos studiju programos ir dvejus metus (1994 ir 1995 m.) išleidžiami architektūros bakalaurai (4 metų studijos) ir tradiciniai (5 metų studijos) diplomuoti architektai. $1995 \mathrm{~m}$. 19 absolventu gauna paskutinius diplomuoto architekto diplomus. Tais pačiais metais priimami ị pirmą kursą pirmieji magistrantai, 11 iš kurių 1996 m. apgina magistro tezes ir gauna architektūros magistro diplomus.

2002 m. vykdant Architektūros fakulteto restruktūrizaciją ir įkūrus Architektūros pagrindų ir teorijos katedrą, i j ją iš Architektūros katedros buvo perkelti: prof. dr. R. Buivydas (naujos katedros vedejas), doc. J. Jurevičiene, asist D. Vrubliauskas, jaun. moksl. dr. V. Petrušonis, dokt. E. Riaubiené.

1999 m. į katedrą pakviečiamas architektas L. Naujokaitis; 2003 m., išejus prof. E. N. Bučiūtei, metus laiko katedroje dirbo architektai A. Asauskas ir A. Lagunovičius; $2004 \mathrm{~m}$. išejus ilgamečiam katedros vedëjui prof. R. A. Dineikai, į katedrą pakviečiamas architektas A. Ambrasas, o 2005 m. išejus prof. J. Šeibokui - arch. S. Pamerneckis ir dokt. V. Gerdvilis.

2003-2004 m. katedros darbuotojai architektai K. Lupeikis, E. Navickienè ir L. Markejevaite apgynè menotyros daktaro disertacijas.

1971-2005 m. Architektūros katedra išleido 706 diplomuotus architektus. 322 architektūros bakalaurus ir 162 architektūros magistrus. Tarp jų nuo $1998 \mathrm{~m}$. architektūros bakalauro diplomus gavo 6 , o magistro -9 užsienio šalių piliečiai.

Katedros vedëjais dirbo: A. Luošaitis (1948-1974), A. Spelskis, A. Dineika, L. Ziberkas. 
ARCHITEKTŪROS

PAGRINDŲ IR

TEORIJOS

KATEDRA

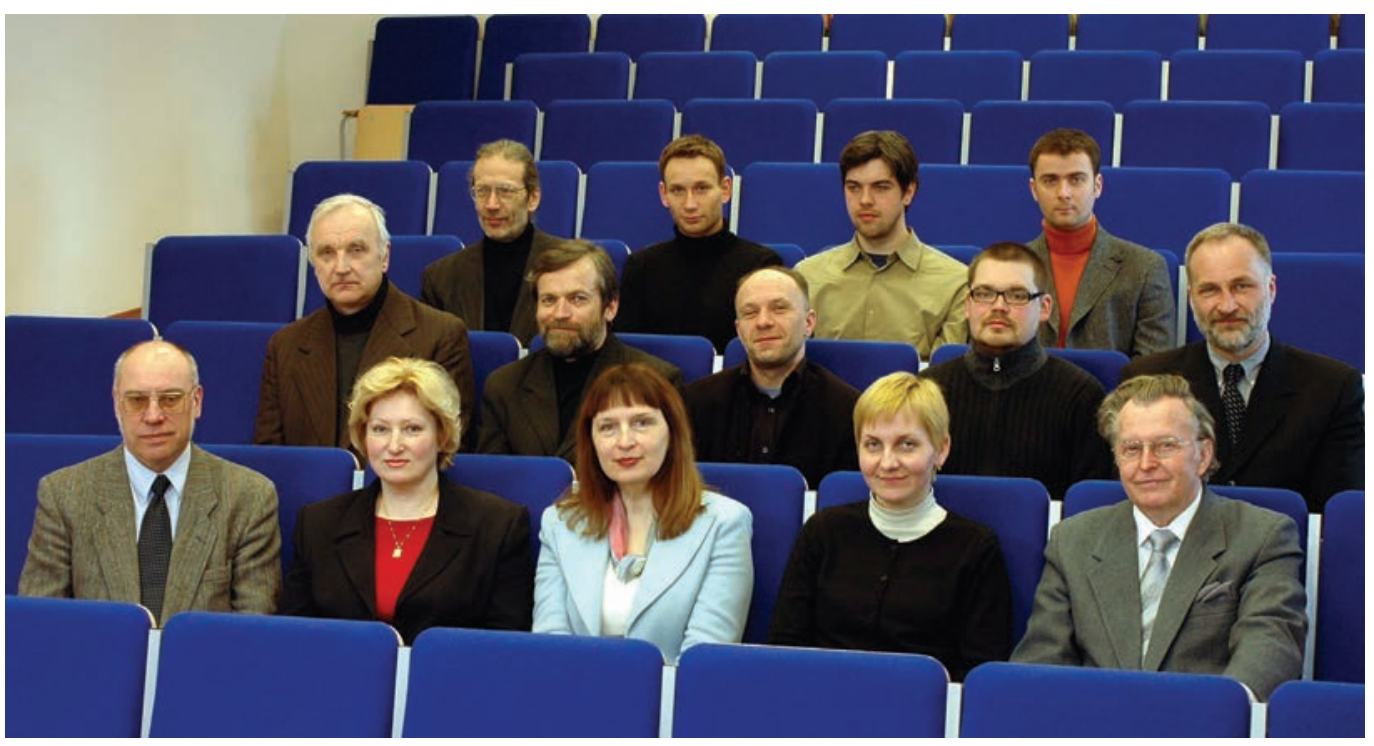

Iš kaires j dešinę pirmoje eileje:

AF dekanas, katedros vedejjas prof. dr. Rimantas Buivydas, katedros reikalų tvarkytoja Dalia Gaižauskiené, doc. dr. Jūrate Jurevičienè, AF Studiju prodekanė, doc. dr. Edita Riaubiené, prof. habil. dr. Konstantinas Jakovlevas-Mateckis;

antroje eileje:

Antroje eileje: Evaldas Purlys (Paminklų restauravimo projektavimo instituto vadovaujantysis architektas), doc. dr. Vytautas Petrušonis, doc. dr. Almantas Liudas Samalavičius, doc. dr. Tomas Gruskis, doc. Dalius Vrubliauskas;

trečioje eileje:

vadybininkas Leonas Pivoriūnas, dokt. Albertas Lagunavičius, dokt. Martynas Valevičius, dokt. Albinas Mocevičius

Architektūros pagrindų ir teorijos katedra buvo ịkurta $2002 \mathrm{~m}$. rugsëjo mėnesị. Jos įkūrëjas ir pirmasis vedejas - prof. dr. Rimantas Buivydas. 


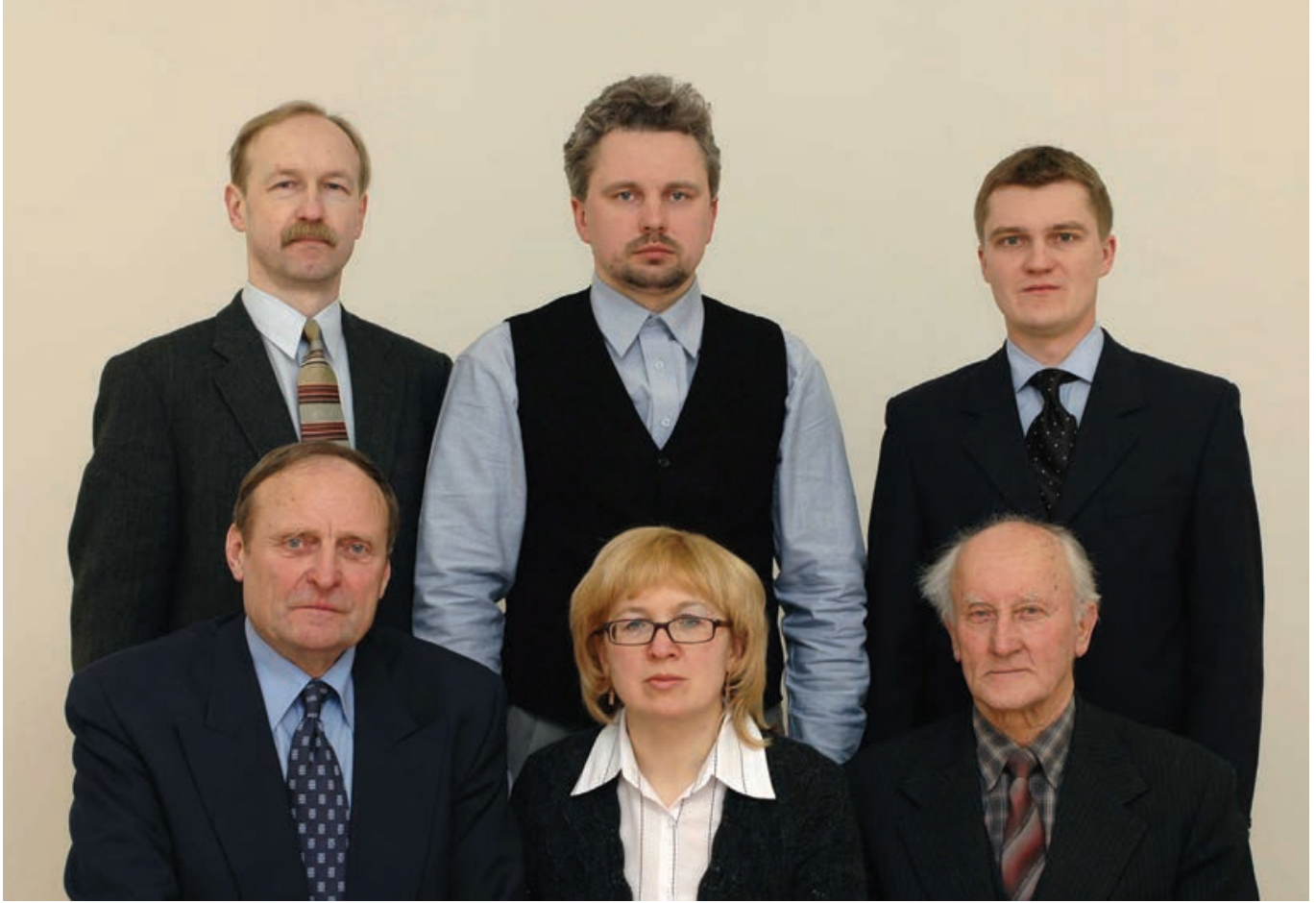

Iš kaires j dešinę pirmoje eileje:

katedros vedejas prof. habil. dr. Vytautas Jonas Stauskis, reikalų tvarkytoja Audroné Jašinskiené, mokymo meistras Povilas Alekna;

antroje eileje:

Antroje eileje: doc. dr. Gintaris Cinelis, dr. Arūnas Čekanavičius, dr. Marius Mickaitis

Katedros veiklos pradžia Vilniuje - 1960 m., kai KPI Vilniaus vakariniame fakultete buvo įkurta Statybos katedra. 1965 m. jau KPI Vilniaus filiale katedra skilo į dvi: Statybos ir Miestų statybos katedras. Joje dirbo dèstytojai, kurie, ịsteigus Vilniaus inžinerinį statybos institutą, sudare Architektūros fakulteto Pastatų konstrukcijų katedros branduolį. Dalis dèstytojų persikèle iš KPI.

Katedros vedejju nuo 1960 iki 1976 metų dirbo docentas (vèliau profesorius) daktaras Vytautas Kriščiūnas. 1976-1986 m. vedëjavo doc. dr. Algimantas Nakas, 1986-1996 doc. dr. Česlovas Ignatavičius, 1996-2000 prof. habil. dr. Josifas Parasonis, nuo 1996 m. - prof. habil. dr. Vytautas Stauskis. 2002 m. prof. habil. dr. Vytautui Stauskiui suteikta Nacionalinè mokslo premija. 


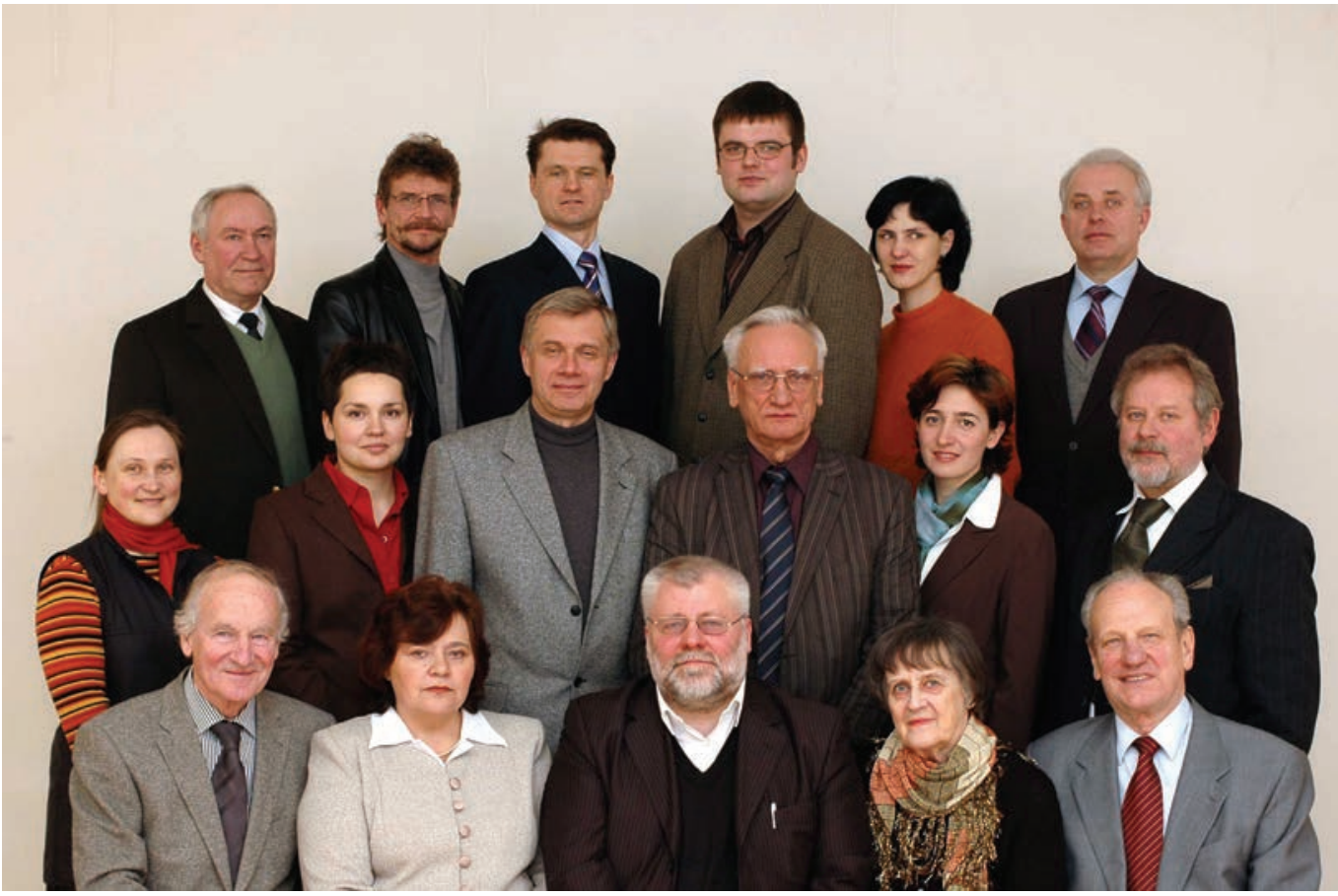

Iš kaires j dešinę pirmoje eilejje:

prof. Algimantas Nasvytis, reikalų tvarkytoja Sofija Stupak, katedros vedëjas doc. Algis Vyšniūnas, doc. Irena Marija Daujotaité, prof. habil. dr. Jurgis Vanagas;

antroje eileje:

doc. dr. Dalia Dijokiené, dokt. Giedre Ingrida Laukaitytè-Malžinskiené, doc. dr. Eugenijus Kęstutis Staniūnas, prof. dr. Zigmas Jonas Daunora, doc. dr. Inesa Alistratovaite, lekt. Česlovas Šliažas;

\section{trečioje eileje:}

Vadybininkas Genadijus Popkovas, lekt. Saulius Motieka, doc. dr. Gintaras Stauskis, asist. Mykolas Kurtinaitis, dokt. Egle Truskauskiene, doc. dr. Sigitas Dereškevičius

1971 m. Vilniaus inžineriniame statybos institute ịkūrus Architektūros fakultetą, ịsteigta Gyvenviečių planavimo ir tvarkymo katedra. Jos destytojai buvo perkelti iš Kauno politechnikos institute veikusios to paties pavadinimo katedros. Katedros vedejju dar nuo 1949 metų buvo prof. Kazimieras Šešelgis, šias pareigas Vilniuje ejęs iki 1980 metų. 1980-1993 m. katedros vedeju dirbo prof. Jurgis Vanagas.

Nuo 1993 m. katedra vadinama Urbanistikos katedra. 1993-2002 m. katedros vedëju dirbo Zigmas Jonas Daunora. Nuo 2002 m. katedrai vadovauja doc. Algis Vyšniūnas.

$2004 \mathrm{~m}$. prie Urbanistikos katedros įkurta Urbanistinès analizès mokslo laboratorija. 


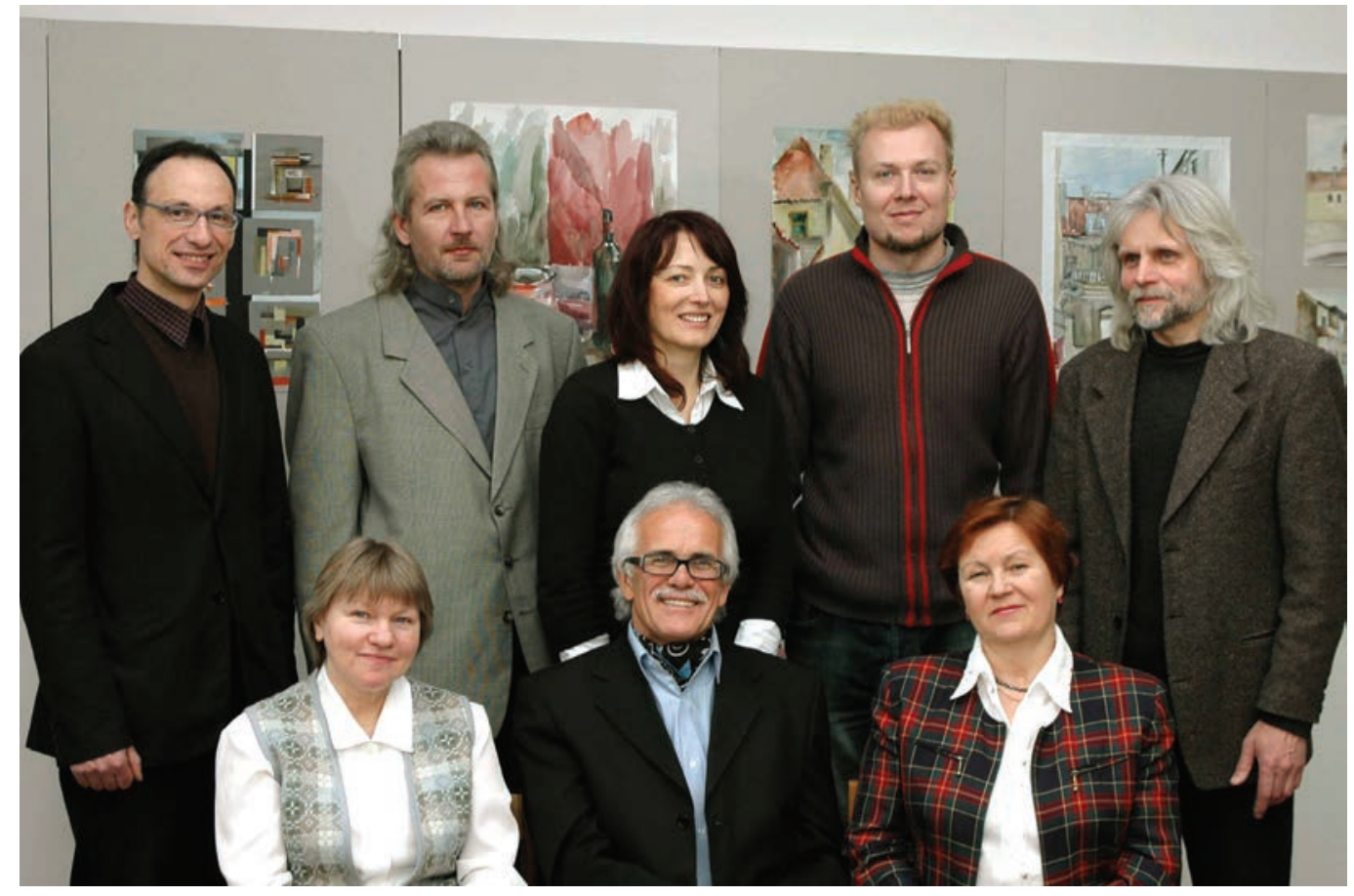

Iš kaires j dešine pirmoje eileje:

vadybininke Svetlana Ragoza, katedros vedëjas prof. Jonas Anuškevičius, reikalų tvarkytoja Uljana Popkova;

\section{antroje eileje:}

doc. dr. Audrius Novickas, doc. Valdas Bubelevičius, asist. Lilija Puipiene, asist. Darius Linartas, doc. Vidmantas Gylikis

1970 m. perkeliant iš Kauno politechnikos instituto ị Vilnių Statybos fakultetą ir steigiant Architektūros fakultetą VISI, čia buvo perkelta Grafinių darbų katedra, pavadinta Dailes katedra. 1997 m. katedros pavadinimas buvo pakeistas ị Architektūrinès grafikos.

Buvę ir esami katedros vadovai: 1970-1988 - Alfonsas Janulis; 1988-1995 Linas Julijonas Jankus; 1995-1997 - Regina Gaušiene; nuo 1997 m. - Jonas Anuškevičius.

Katedroje yra dirbę iškilūs dailininkai: monumentalistas Stasys Ušinskas, tapytojas Jonas Čeponis; taip pat skulptorius Alfonsas Janulis, taikomosios grafikos specialistas Vytautas Bačenas, inžinierius architektas Henrikas Bogdanas, grafike Danute Narvydaité, tekstilininkè Donata Žemaitienė, skulptorius Gediminas Žuklys, menotyrininke Rita Mikučionytė. 
ELEKTRONIKOS

FAKULTETO

DEKANATAS

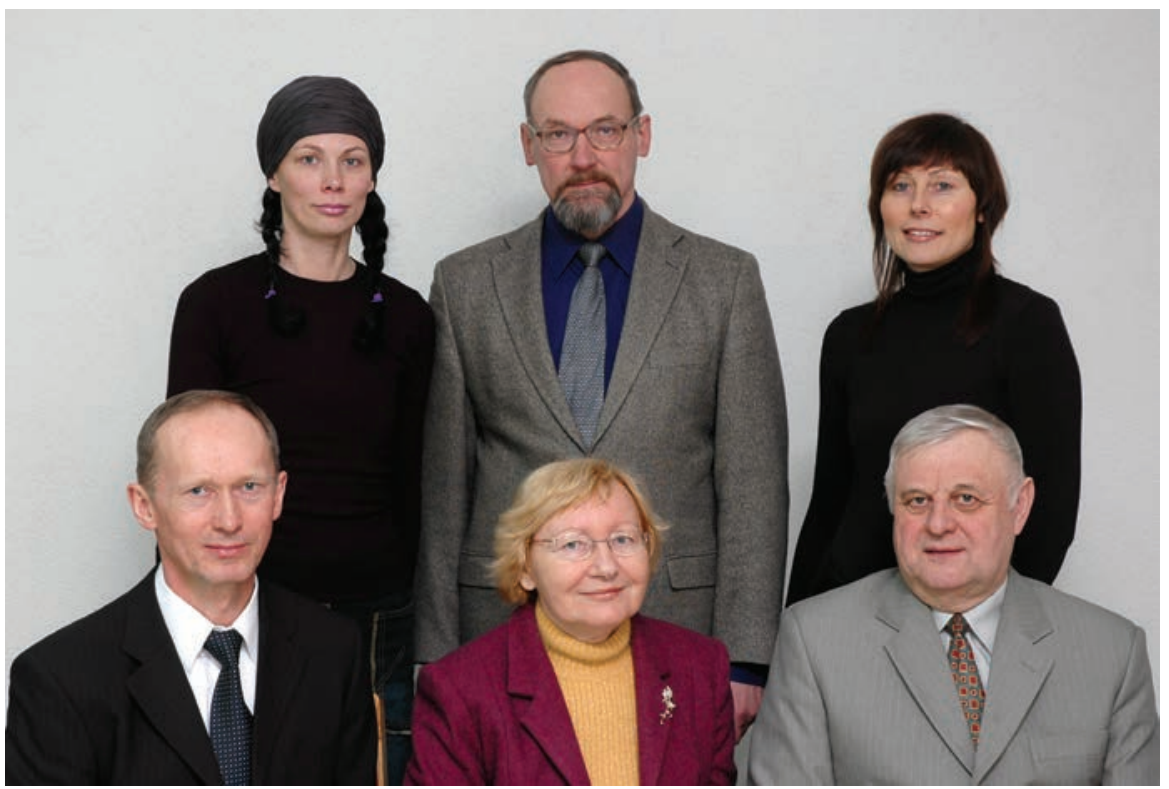

Iš kaires j dešine pirmoje eilejje:

mokslo prodekanas doc. dr. Vytautas Urbanavičius,

dekané prof. habil. dr. Roma Rinkevičiené,

magistrantūros prodekanas doc. dr. Kazimieras Vytautas Maceika;

antroje eileje:

vadybininkè Jūratè Savarauskaité, pagrindinių studiju prodekanas doc. dr. Ričardas Visvaldas Pocius, administratore Daiva Rimkiené

1961 m. įkurtame Kauno politechnikos instituto Vilniaus filiale išleistos dvi elektros energijos tiekimo specialybés inžinierių laidos. $1962 \mathrm{~m}$. liepos $1 \mathrm{~d}$. atsirado Prietaisų gamybos fakultetas su pirmuoju dekanu S. Marazu ir prodekanu L. Janulioniu. $1964 \mathrm{~m}$. fakultete veike keturios katedros.

Fakultete yra Automatikos, Elektrotechnikos, Elektroninių sistemų ir Kompiuterių inžinerijos katedros. Jose dirba 50 desstytojų: 10 profesorių, habil. daktarų; 28 docentai, daktarai; 12 doktorantų.

$1961 \mathrm{~m}$. įkurtame Kauno politechnikos instituto Vilniaus filiale išleistos dvi elektros energijos tiekimo specialybès inžinierių laidos. $1962 \mathrm{~m}$. liepos $1 \mathrm{~d}$. atsirado Prietaisų gamybos fakultetas su pirmuoju dekanu S. Marazu ir prodekanu L. Janulioniu. $1964 \mathrm{~m}$. fakultete veikè keturios katedros: Bendrosios fizikos, Elektrotechnikos, Matematikos ir Radijo aparatūros technologijos. Tuo metu fakultetas dieniniame skyriuje renge garso technikos, radijo aparatūros konstravimo ir gamybos inžinierius, o vakariniame - elektros pavarų ir pramonès įrenginių automatizavimo specialistus, radijo aparatūros konstruktorius ir technologus. 1966 m. nuo Elektrotechnikos katedros atsiskyrusi Skaičiavimo technikos ir matematikos katedra renge matematinių skaičiavimo mašinų ir programavimo inžinierius. Nuo 1967 m. lapkričio 1 d. fakulteto dekanu tapo Č. Teišerskas. 1966-1969 m. laikotarpiu veikè Radioelektronikos katedra, vadovaujama doc. J. Stanaičio.

Dideli pokyčiai įvyko $1969 \mathrm{~m}$. İkurtame Vilniaus inžineriniame statybos institute fakultetas pavadintas Automatizacijos fakultetu. Jame buvo trys katedros: Elektrotechnikos, Elektros pavaru ir Radijo aparatūros technologijos. Fakultete liko tik vakarinis skyrius. Dieninio skyriaus studentai ir dalis desstytojų išvyko į Kauną ir ten įkūrè KPI Radijo aparatūros konstravimo katedrą. Todèl vienu metu fakultetas buvo vadinamas Vakariniu. $1978 \mathrm{~m}$. kovo $6 \mathrm{~d}$. fakulteto dekanu tapo doc. Z. Vainoris, tačiau greitai jis buvo pakviestas dirbti i Aukštojo mokslo ministeriją. Jo pareigas pereme ir iki $1991 \mathrm{~m}$. fakultetui vadovavo doc. A. Seilius. Vyriausybès nutarimu $1987 \mathrm{~m}$. fakultete vèl atidarytas dieninis skyrius ir jis tapo KPI Vilniaus fakultetu. Jame buvo dvi profilines ir viena bendroji katedra. Autonomiškai organizuotos radijo aparatūros konstravimo ir gamybos bei elektros ịrenginių ir autonatizavimo specialybių inžinierių studijos dieniniame ir vakariniame skyriuose.

$1991 \mathrm{~m}$. fakultetas sugrižo į Vilniaus technikos universitetą ir tapo Elektronikos fakultetu. Jo dekanu išrinktas doc. K. Maceika. Šiuo laikotarpiu susiformavo dviejų specialybių: automatikos ir radioelektronikos triju pakopų - bakalaurų, magistrantūros ir doktorantūros - studijos su galimybe pasirinkti įvairias specializacijas.

Kiekvienais metais į fakultetą įstoja apie 160 studentų. Per 37 metus fakultetas yra išleidęs 3000 radioelektronikos ir automatikos inžinierių, 521 bakalaurą, 107 magistrus. 


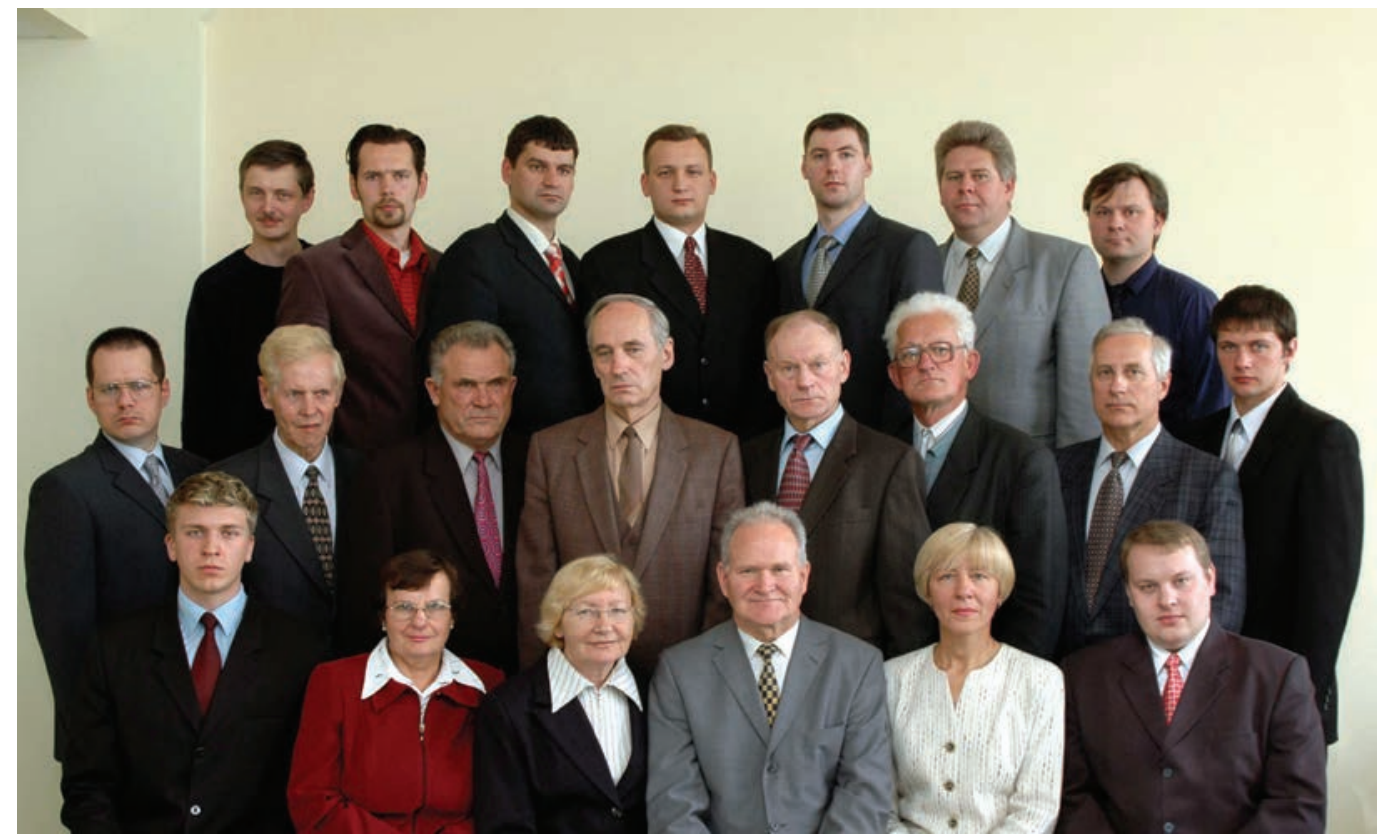

Iš kairès j̇ dešine pirmoje eilejje:

laborantas Robertas Janickas, katedros reikalų tvarkytoja inž. Zita Kunickaite, EF dekane prof. habil. dr. Roma Rinkevičiene, katedros vedejjas prof. habil. dr. Algimantas Juozas Poška, doc. dr. Zita Savickiené, meistras dokt. Saulius Lisauskas;

antroje eileje:

techn. asist. dokt. Dinas Šulskis, prof. habil. dr. Algirdas Dambrauskas, doc. dr. Lionginas Radzevičius, prof. habil. dr. Algirdas Smilgevičius, doc. dr. Bronius Karaliūnas, meistras inž. Justinas Stonys, doc. dr. Edvardas Matkevičius, laborantas Jonas Kriaučiūnas; trečioje eileje:

doc. dr. Dainius Udris, dokt. Vytautas. Rinkevičius, lektorius dr. Kęstutis Jasiūnas, doc. dr. Žydrūnas Čeponis, doc. dr. Audrius Ilgevičius, lab. vedëjas asist. Alvydas Šlepikas, asist. dr. Jonas Zubaitis

Katedra ịkurta 1967 m., nuo 1991 m. - VGTU Automatikos katedra. $1988 \mathrm{~m}$. ịsteigtas dieninis šios specialybès skyrius ir studentai priimti į I kursą. 


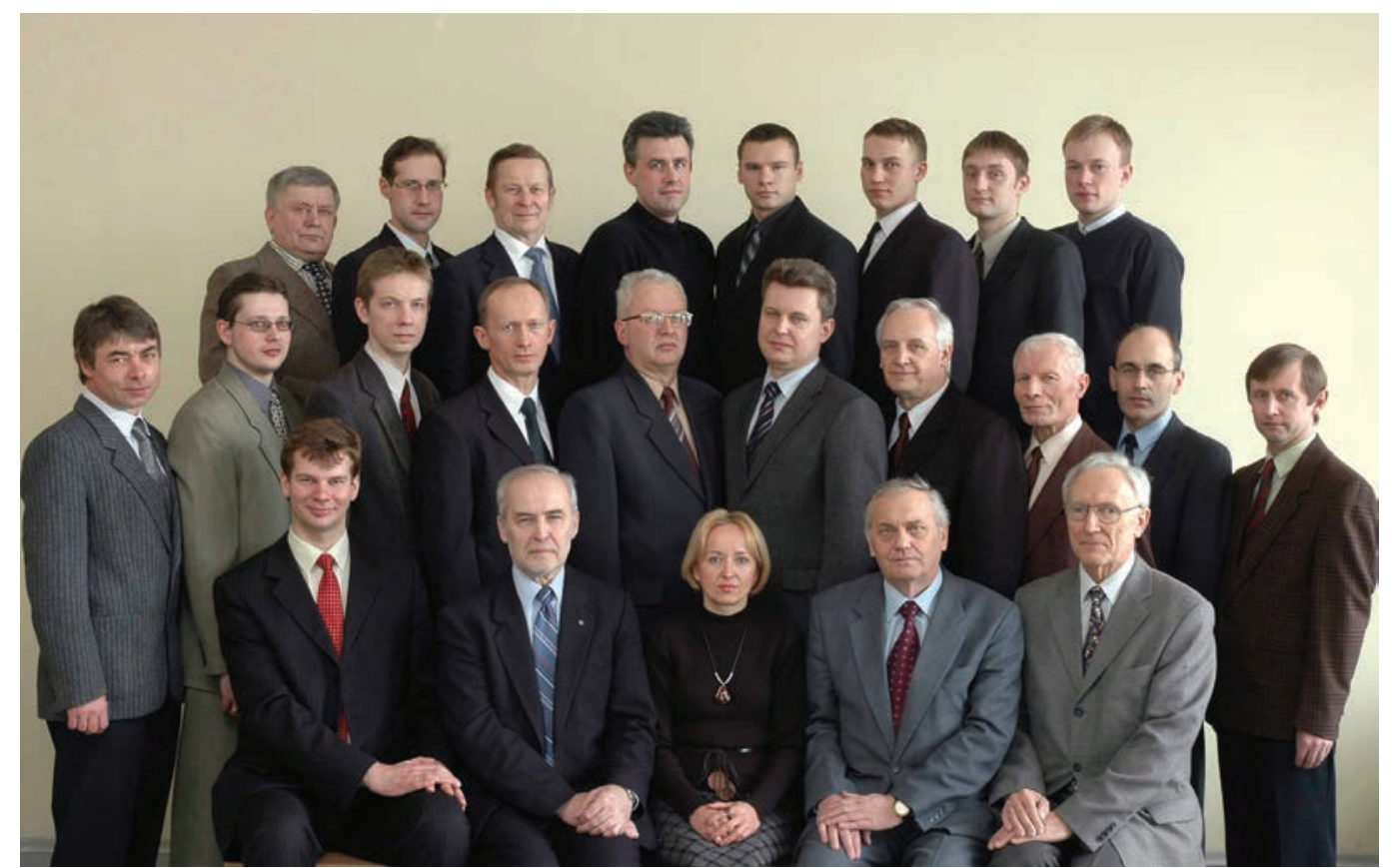

Iš kairès j̇ dešine pirmoje eileje:

doc. dr. A. Ušinskas, katedros vedejas prof. habil. dr. R. Martavičius,

reikalų tvarkytoja R. Raguckienė, doc. dr. A. Seilius, prof. habil. dr. S. Štaras;

antroje eileje:

asist. mgr. A. Malinauskas, dokt. T. Burokas, dokt. E. Žitkevičius, doc. dr. V. Urbanavičius, doc. dr. R. Pupeikis, doc. dr. D. Navakauskas, doc. dr. V. Mališauskas,

laboratorijų vedëjas K. Žičius, dr. D. Seliuta, techn. asist. A. Giržadas;

trečioje eileje:

meistras K. Aukštikalnis, doc. dr. A. Jurjevas, doc. dr. A. M. Montvilas, doc. dr. A. Geižutis, dokt. D. Grigaitis, mgr. D. Matuzevičius, dokt. A. Serackis, dokt. K. Bartnykas.

1964 m. buvo įkurta Radijo technologijos katedra. 1966 m. ši katedra suskilo į dvi - Radijo technologijos ir Radioelektronikos. 1991 m. atkurta Radioelektronikos katedra. 2000 m. Radioelektronikos katedros vedejju išrinktas prof. R. Martavičius. 
ELEKTRO-

TECHNIKOS

KATEDRA

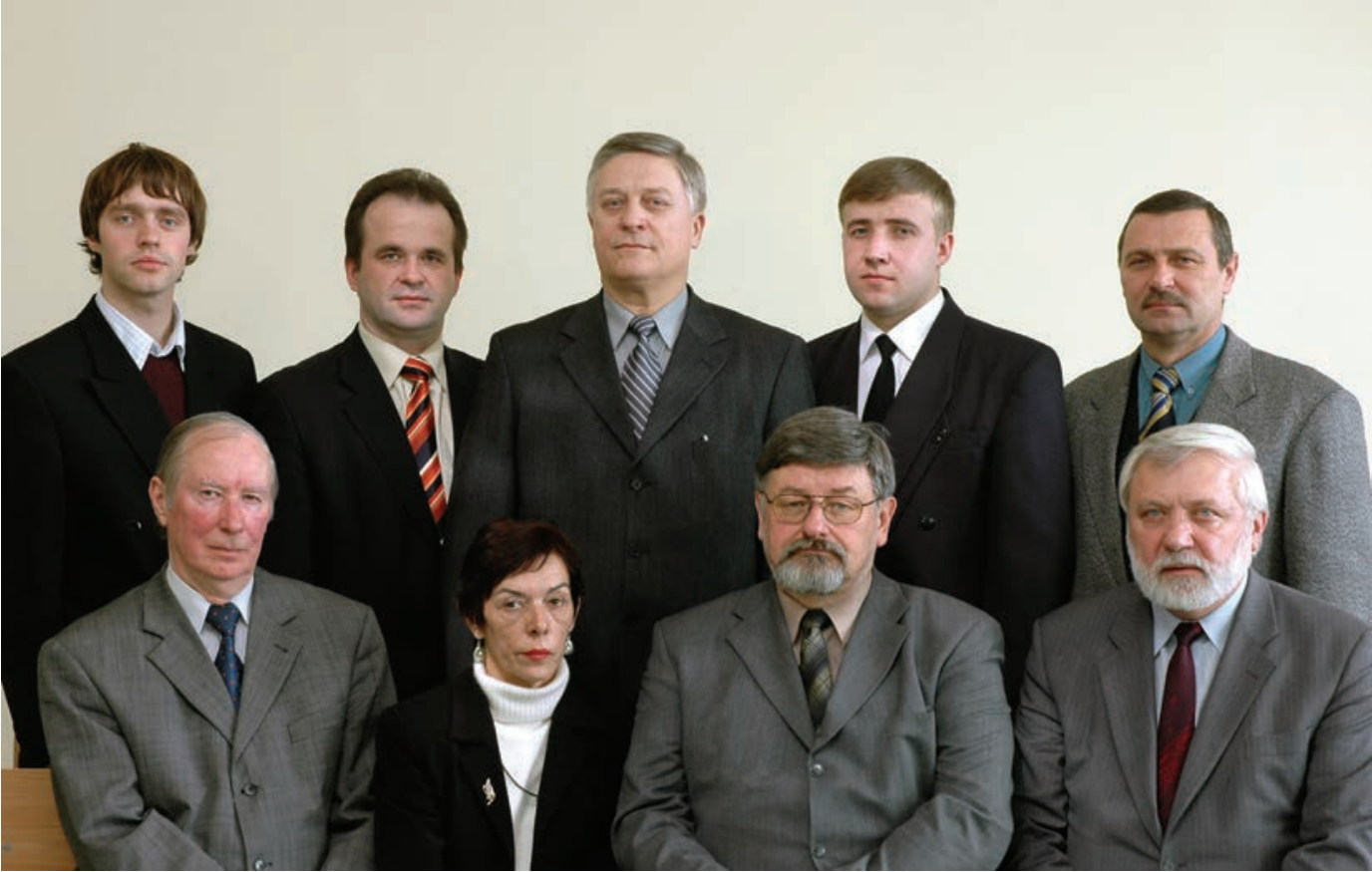

Iš kaires j dešine pirmoje eilëje:

prof. habil. dr. Zigmantas Jankauskas, reikalų tvarkytoja Birute Basokiené, katedros vedejas prof. dr. Vygaudas Kvedaras, doc. dr. Valentinas. Zaveckas; antroje eileje:

dokt. Saulius Bartkevičius, doc. dr. Jurij Novickij, doc. dr. Laimis Laurinavičius, meistras Ričardas Masiulionis, lab. vedejjas asist. Saulius Barauskas

Elektrotechnikos katedra įsteigta $1960 \mathrm{~m}$. Kauno politechnikos instituto Vilniaus vakarinį skyriuje. Katedra desto elektros grandinių teoriją, elektrotechniką, elektrotechniką ir elektros tinklus, technologinių procesų automatizavimą, automatikos elementus, gamybinę ir priešgaisrinę automatiką, mikroprocesorinę techniką.

Katedros vedëjais dirbo: 1956-1967 m. - doc. dr. S. Marazas, 1967-1975 m. - doc. dr. V. Česonis, 1975-1976 m. - doc. dr. G. Valiukenas, 1976-1985 m. - doc. dr. Z. Jankauskas, 1985-1990 m. - doc. dr. G. Valiukenas, nuo 1990 m. - prof. habil. dr. Z. Jankauskas. 


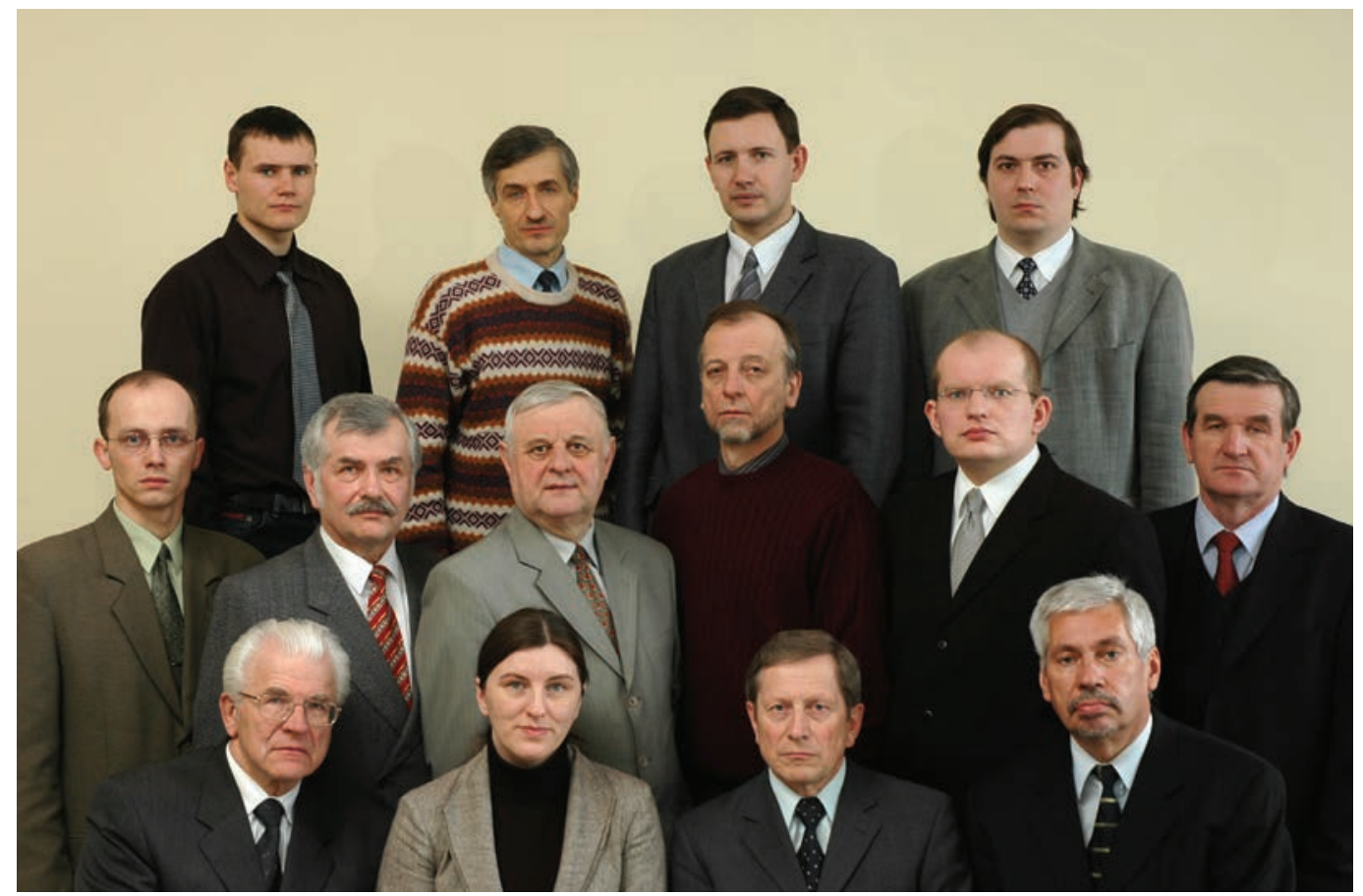

Iš kaires j dešine pirmoje eileje:

prof. habil. dr. Albinas Jonas Marcinkevičius, reikalų tvarkytoja Jolanta Saudargaite, katedros vedejjas prof. habil. dr. Julius Skudutis doc. dr. Julius Skardžius;

antroje eileje:

doc. dr. Darius Povilauskas, doc. dr. Algirdas Gražulevičius, doc. dr. Kazimieras Maceika, doc. dr. Algirdas Baškys, dokt. Vaidas Jasonis, prof. habil. dr. Romualdas Navickas;

trečioje eilejje:

dokt. Nerijus Paulauskas, vedëjas Arvydas Stankevičius doc. dr. Vladislavas Daškevičius, doc. dr. Gediminas Gražulevičius

1964 m. buvo įkurta Radijo aparatūros technologijos katedra. 1966 m. nuo Radijo aparatūros technologijos katedros atskilo doc. J. Stanaičio vadovaujama Radioelektronikos katedra. 1969 m. KPI Vilniaus filialas buvo reorganizuotas ị VISI. Dieninio skyriaus studentų grupes ir dalis katedrų dèstytojų buvo perkelti į KPI. VISI liko viena - Radijo aparatūros technologijos katedra. $1991 \mathrm{~m}$. Radijo aparatūros technologijos katedra padalyta ị dvi - Radioelektronikos ir Radijo aparatūros katedras. 2000 m. Radijo aparatūros katedros vedëju išrinktas prof. J. Skudutis. 2004 m. Radijo aparatūros katedra pavadinta Kompiuterių inžinerijos katedra. 
FUNDAMENTINŲ

MOKSLŲ

FAKULTETO

DEKANATAS

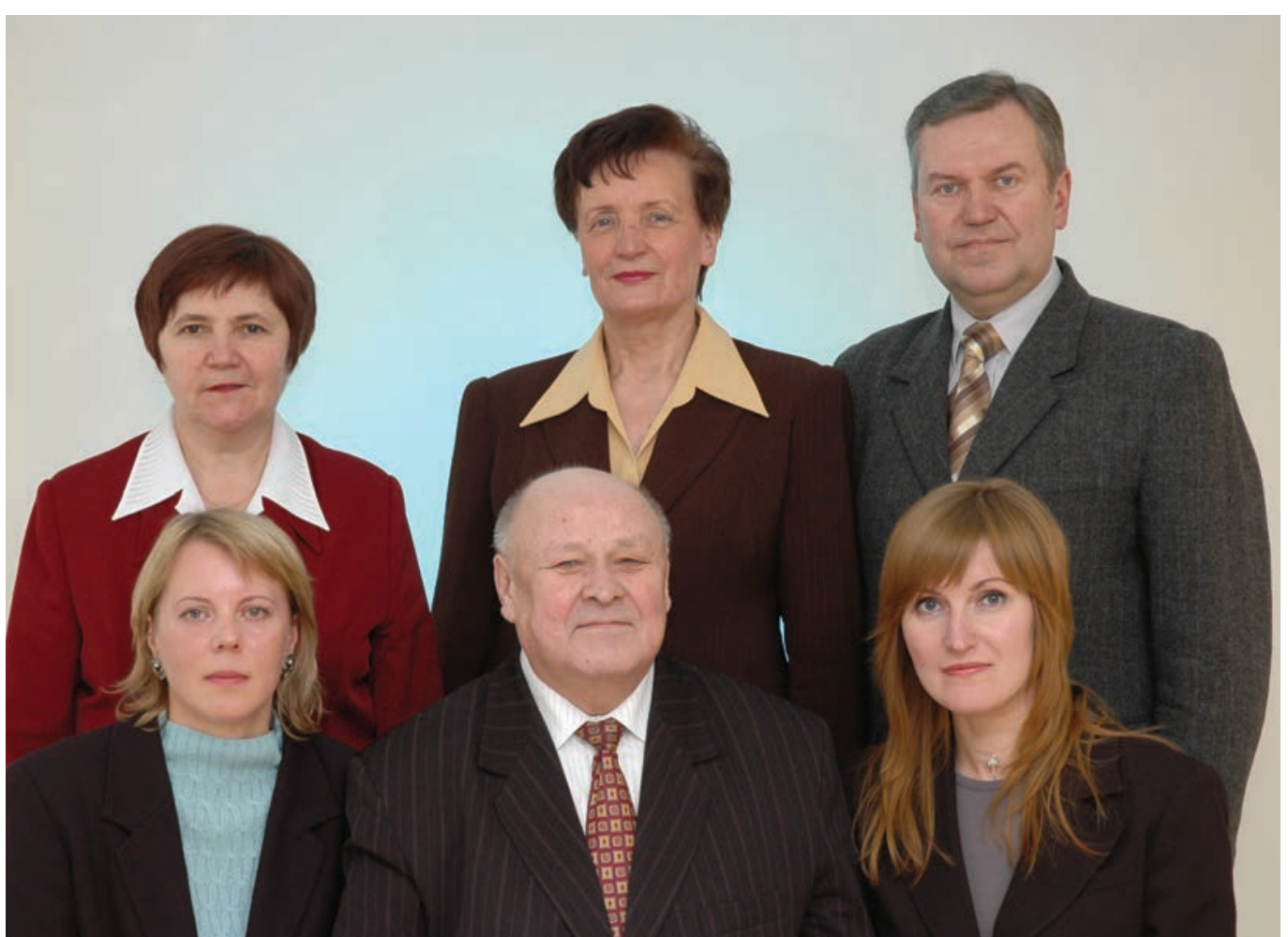

Iš kaires j dešine pirmoje eilëje:

vadybininke Loreta Valaityte, dekanas doc. dr. Algirdas Čiučelis, administratore Daiva Triukaite;

\section{antroje eileje:}

prodekané doc. dr. Elena Zalieckiené, prodekanè prof. dr. Jadvyga Keriené, prodekanas doc. dr. Algirdas Sokas

Fundamentinių mokslų fakultetas (FMF) įkurtas 1993 m., prijungus prie jo bendrųjų mokslų katedras: Fizikos, Matematikos, Inžinerinès grafikos, Teorinès mechanikos, Inžinerinès informatikos ir Medžiagų atsparumo. Tais pačiais metais ị fakulteto inžinerinés informatikos specialybę buvo priimta 64 bakalaurai ir 34 magistrantai, kitais metais į bioinžinerijos specialybę - 25 bakalaurai. Mokymui organizuoti buvo pasitelkti žymiausi respublikos specialistai, pasirašyta bendradarbiavimo ir darbo sutartis su Matematikos ir informatikos, Biotechnologijos institutais bei UAB „Biofa“. Šių institutų direktoriai - prof. V. Statulevičius (vèliau prof. M. Sapagovas), prof. V. Bumelis geranoriškai padejo formuoti dèstytojų kolektyvus. Prof. V. Bumelis daug paremè ir materialiai, perduodamas fakultetui chromatografijos, mikrobiologijos ir biochemijos laboratorijas su visa įranga. Ju verté siekia daugiau nei 200000 Lt. Kartu su Biotechnologijos institutu ir Italijos paramos fondu įrengta šiuolaikinè genų inžinerijos mokomoji laboratorija.

1994 m. į bioinžinerijos specialybę buvo priimti pirmieji studentai. Šiuo metu įkurta profilinè Chemijos ir bioinžinerijos katedra. VGTU lešomis ir padedant „Biofai“ bei Biotechnologijos institutui buvo įsigyta laboratorijų įranga. Rengiant šios specialybes studentus dalyvauja žymiausi specialistai - tai profesoriai V. Bumelis, V. Laurinavičius, habilituoti daktarai A. Pauliukonis, K. Sasnauskas, S. Klimašauskas, doc. R. Marcišauskas ir kiti. Sukaupta laboratorine įranga ir destytojų kolektyvas visiškai pajègus rengti šios srities specialistus, ką akivaizdžiai įrodè ir pirmoji bioinžinierių laida. Visų absolventų rengimas yra tinkamo lygio, todèl dauguma jų i̇stojo i̇ magistrantūrą.

Fakultetas palaiko mokslinius ryšius su Veimaro statybos ir architektūros universitetu, Štutgarto universiteto Kompiuterių taikymo ir statybinès mechanikos institutu, Milano, Birmingemo, Tusono, Briuselio, Varšuvos ir kitomis aukštosiomis mokyklomis. Užsienyje kasmet apsilanko apie 30 mūsų dėstytojų bei studentų pagal ịvairias programas. Aktyviai bendradarbiaujame su respublikos vidurinemis ir aukštosiomis mokyklomis. 
TELE-

KOMUNIKACIJU

INŽINERIJOS

KATEDRA

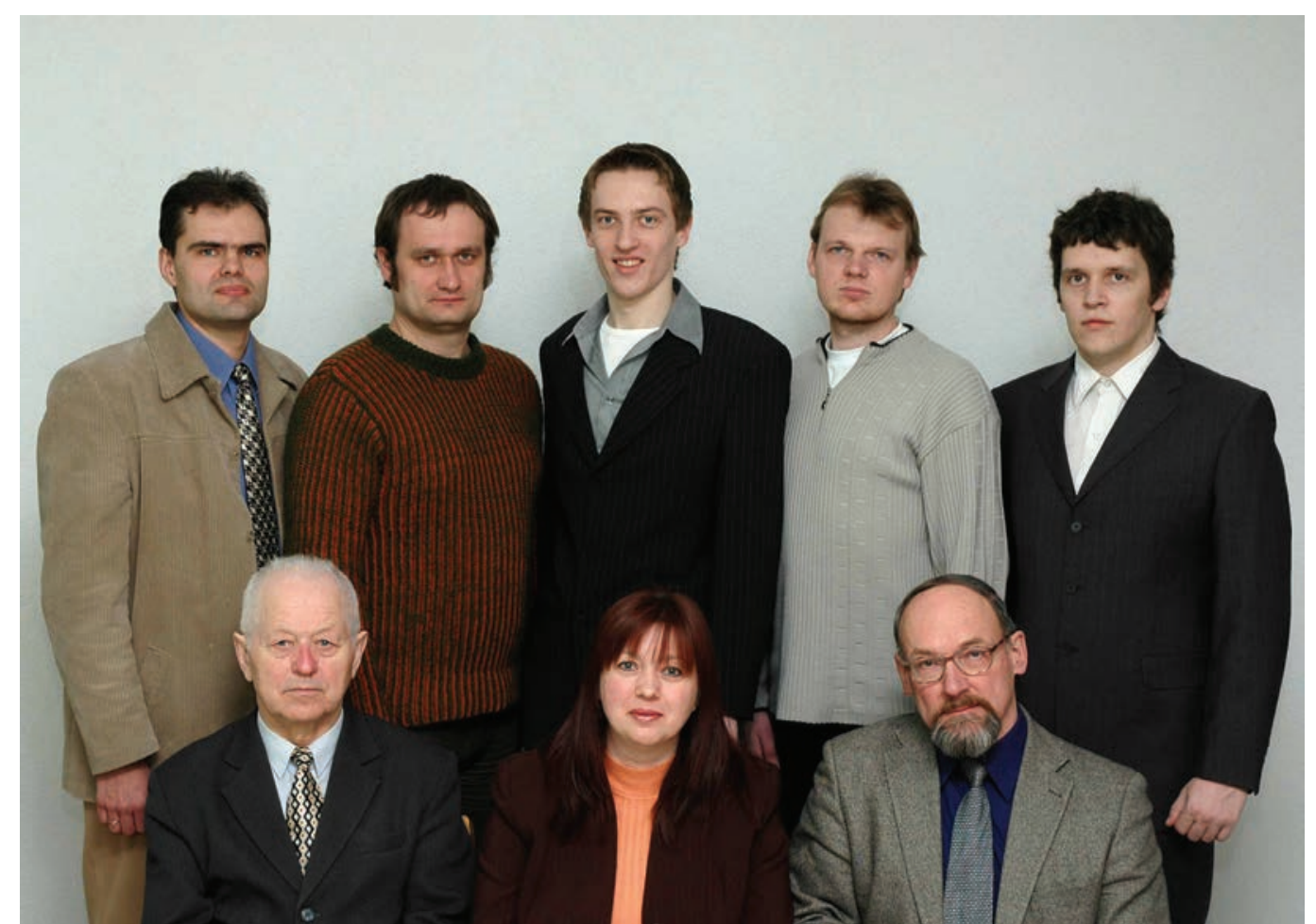

Iš kaires j dešine pirmoje eileje:

prof. habil. dr. Algimantas Kajackas, reikalų tvarkytoja Violeta Butkevičiené, doc. dr. Ričardas Pocius;

antroje eileje:

doc. dr. Šarūnas Paulikas, dokt. Lukas Pavilanskas, techn. asist. Gediminas Montvilas, lab. vedëjas, dokt. Darius Guršnys, dokt. Aurimas Anūkaitis

2002 m. ịkurta Telekomunikacijų inžinerijos katedra. 2002 m. katedros vedejju paskirtas prof. habil. dr. A. Kajackas. 
CHEMIJOS IR BIOINŽINERIJOS KATEDRA

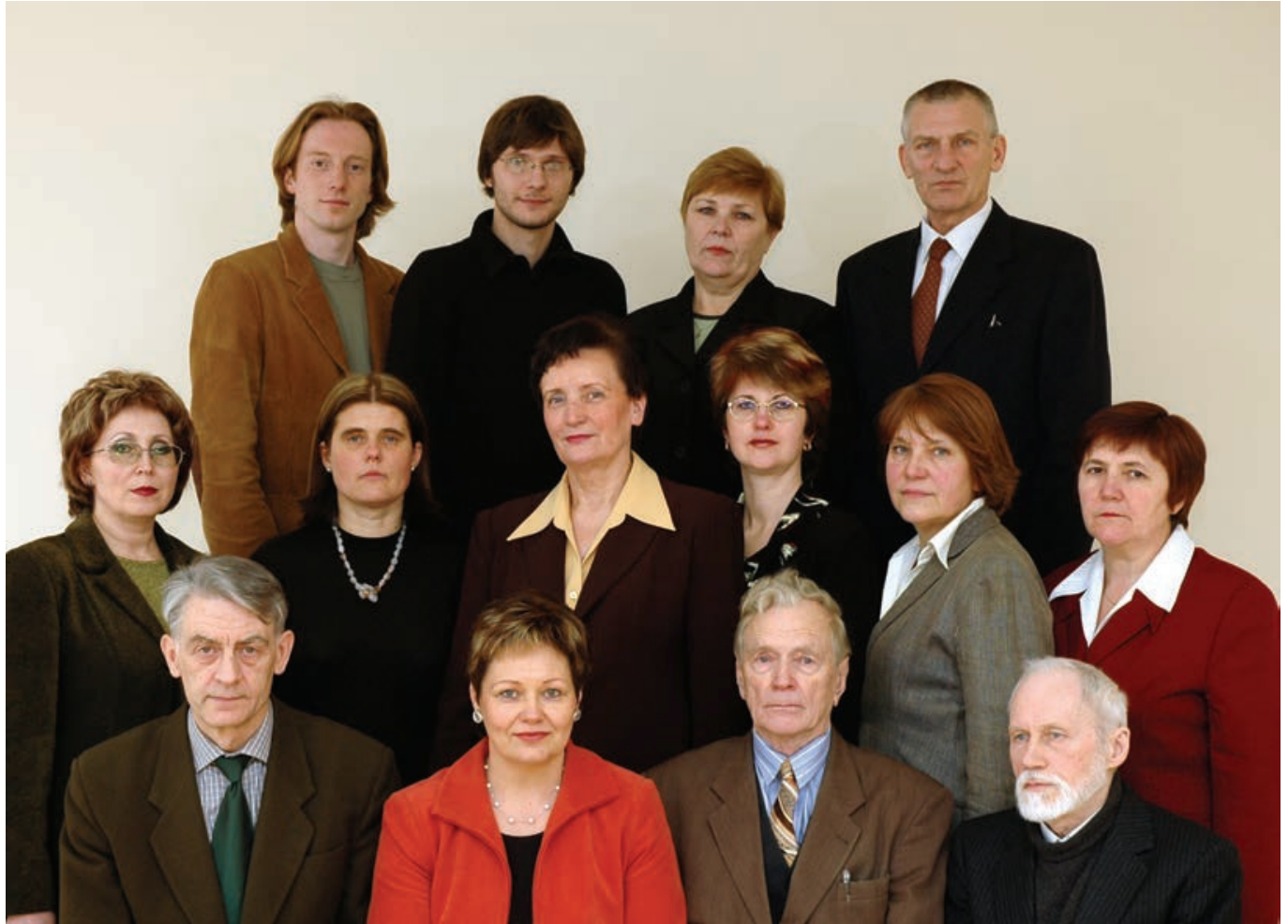

Iš kaires j dešine pirmoje eilejje:

prof. habil. dr. J. Kulys, lektore B. Tamulaitienè, prof. habil. dr. A. Kazragis, doc. dr. A. Juška;

antroje eileje:

lab. vedëja R. Gražènienè, vyresn. m. d. J. Sereikaite, prof. J. Kerienè, vyresn. laborante V. Voišniene, reikaly̨ tvarkytoja D. Kiršiené, doc. dr. E. Zalieckiené; trečioje eileje:

lab. vedëjas Ž. Dapkūnas, jaun. moksl. darb. M. Morkūnas, vyresn. laborante K. Jakeliūniené, doc. dr. J. Jankauskas

1963 m. Kauno politechnikos instituto Vilniaus filiale buvo įsteigta Chemijos katedra, kurios vedëju buvo paskirtas doc. Ipolitas Nickus. $1969 \mathrm{~m}$. KPI Vilniaus filialas tampa savarankišku Vilniaus inžineriniu statybos institutu, o Chemijos katedra - viena iš jo sudètinių dalių. Nuo 1974 m. katedros vedëju tapo žymus Lietuvos mokslų akademijos Chemijos ir cheminès technologijos instituto mokslininkas, analizinés chemijos specialistas prof. Povilas Norkus. Katedros moksliniai tyrimai bei darbai orientuojami cheminès analizės kryptimi, kuriami brangiųjų metalų kiekybinio nustatymo metodai. 1991 m. Chemijos katedra ịtraukta ị Statybinių medžiagų katedros sudètị. Katedros vedëju paskiriamas doc. Albinas Gailius, o nuo 1995 m. vedëjo pareigas eina prof. Algimantas Kazragis. Šiuo laikotarpiu katedroje atliekami naujų šilumos izoliuojamųjų statybinių medžiagų kūrimo bei tyrimo darbai. 1996-02-15 Statybinių medžiagų katedra suskyla ir įkuriama dabartinè profilinè Chemijos ir bioinžinerijos katedra, rengianti bioinžinerijos specialistus. Katedros vedëjo pareigas eina prof. Algimantas Kazragis. 2001-05-01 katedros vedeju paskiriamas Lietuvos mokslų akademijos tikrasis narys, prof. habil. dr. Juozas Kulys. Katedroje plètojami moksliniai darbai prioritetinese biotechnologijos, bioinformatikos, biologinio modeliavimo srityse. $2001 \mathrm{~m}$. katedroje ikuriama Bioinformatikos mokslo laboratorija, kuriai vadovauja laboratorijos vedëjas LMA narys korespondentas, prof. habil. d. Vladas Algirdas Bumelis. Šiuo metu katedroje dirba 7 profesoriai habilituoti daktarai, 23 docentai daktarai. 


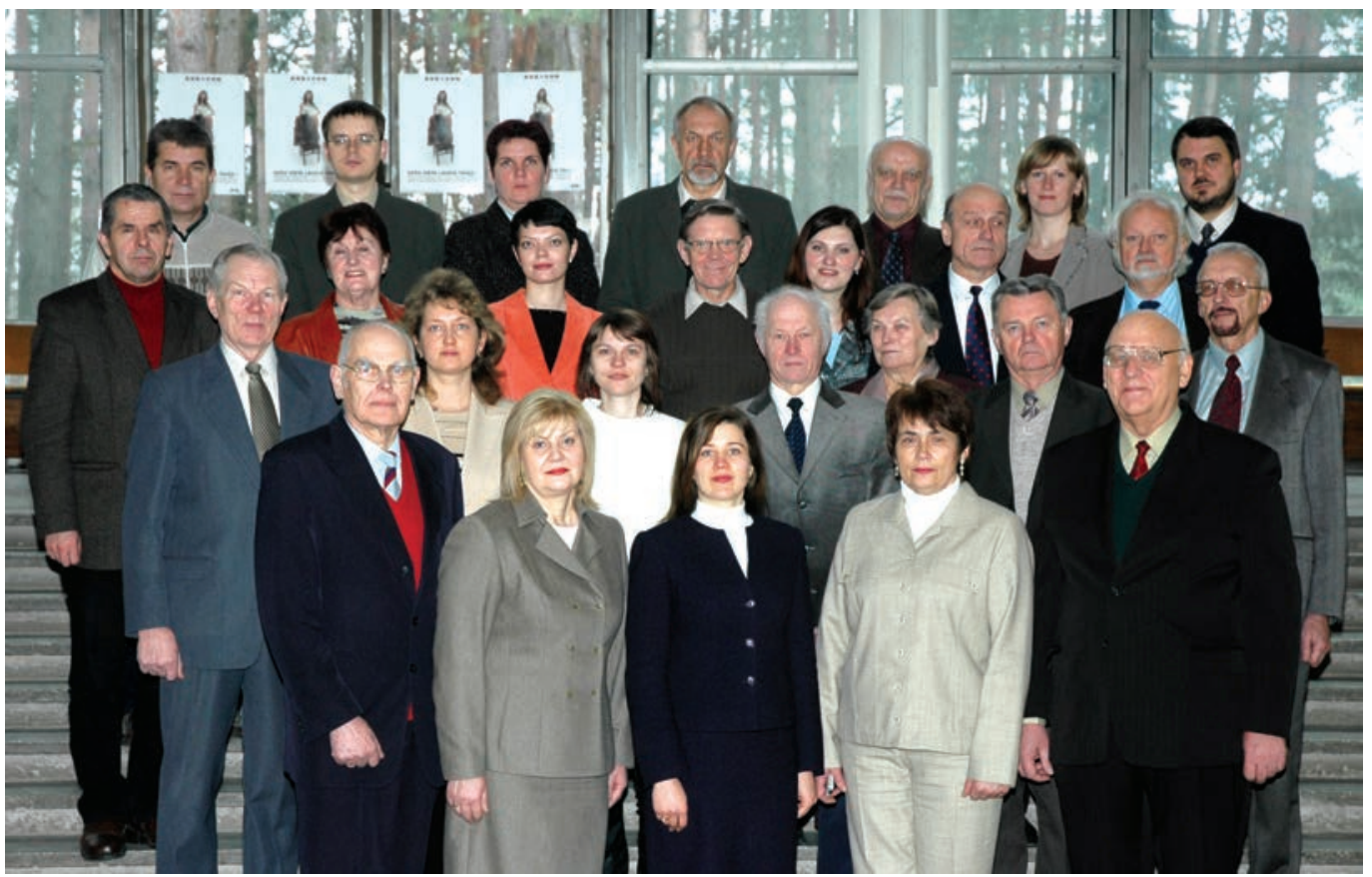

Iš kairès j̇ dešine pirmoje eileje:

doc. dr. Antanas Urbelis, doc. dr. Nijolè Astrauskiené,

doc. dr. Gražina Grigaliūnaitè-Vonsevičiené, doc. dr. Raselè Girgždienè,

katedros vedëjas prof. habil. dr. Antanas Česnys;

antroje eileje:

prof. habil. dr. Evaldas Garška, reikalų tvarkytoja inž. Jelena Petrušenko,

dokt. Sonata Tolvaišiene, mokslo lab. vedëjas habil. dr. Eugenijus Šatkovskis,

lekt. Regina Banienè, prof. habil. dr. Dmitrijus Styro, doc. dr. Aleksejus Bogdanovičius;

trečioje eileje:

doc. dr. Valdas Špakauskas, inž. Valentina Syrusiene, dokt. Jolanta Stupakova,

doc. dr. Stanislovas Aloyzas Karpinskas, dokt. Vaida Valuntaite,

doc. dr. Bronislovas Martinènas, doc. dr. Aloyzas Girgždys;

ketvirtoje eileje:

jaun. moksl. darb. Viktor Zagatskij, dokt. Dainius Jasaitis, dokt. Asta Daunaravičené, mok. Lab. vedëjas Leonidas Kuliominas, doc. dr. Rimgaudas Adolfas Bendorius, dokt. Milda Pečiuliené, vyriaus. moksl. darb. dr. Paulius Miškinis

Fizikos katedros, kaip savarankiško aukštosios technikos mokyklos padalinio, užuomazgą sudare Kauno politechnikos instituto Vilniaus filialo Elektronikos katedros Fizikos metodinès komisijos (sudarytos 1964 m.) darbuotojai. Jos vadove buvo vyr. déstytoja Hilda Gutmaniené.

Pirmuoju Fizikos katedros vedeju nuo 1965 iki 1975 m. buvo Vilniaus universiteto absolventas doc. dr. Edmundas Mauza. Vèliau katedrai vadovavo doc. dr. Antanas Urbelis (nuo 1975 iki 1985 metų) ir prof. hab. dr. Juozas Jakimavičius (nuo 1985 iki 1995 metų). Nuo 1995 m. katedrai vadovauja prof. hab. dr. Antanas Česnys.

Nuo 1970 m. iki 1989 m. katedra buvo VISI Miestų statybos fakulteto, nuo 1990 m. - Bendrųju mokslų centro, o nuo $1993 \mathrm{~m}$. balandžio - VGTU Fundamentinių mokslų fakulteto padalinys. 1970 m. prie katedros įkurta Branduolinès hidrofizikos mokslo laboratorija. Laboratorijai vadovauja doc. dr. A. Girgždys.

2002 m. prie katedros įkurta Fizikinès medžiagotyros mokslo laboratorija. Laboratorijai vadovauja habil. dr. Eugenijus Šatkovskis. 


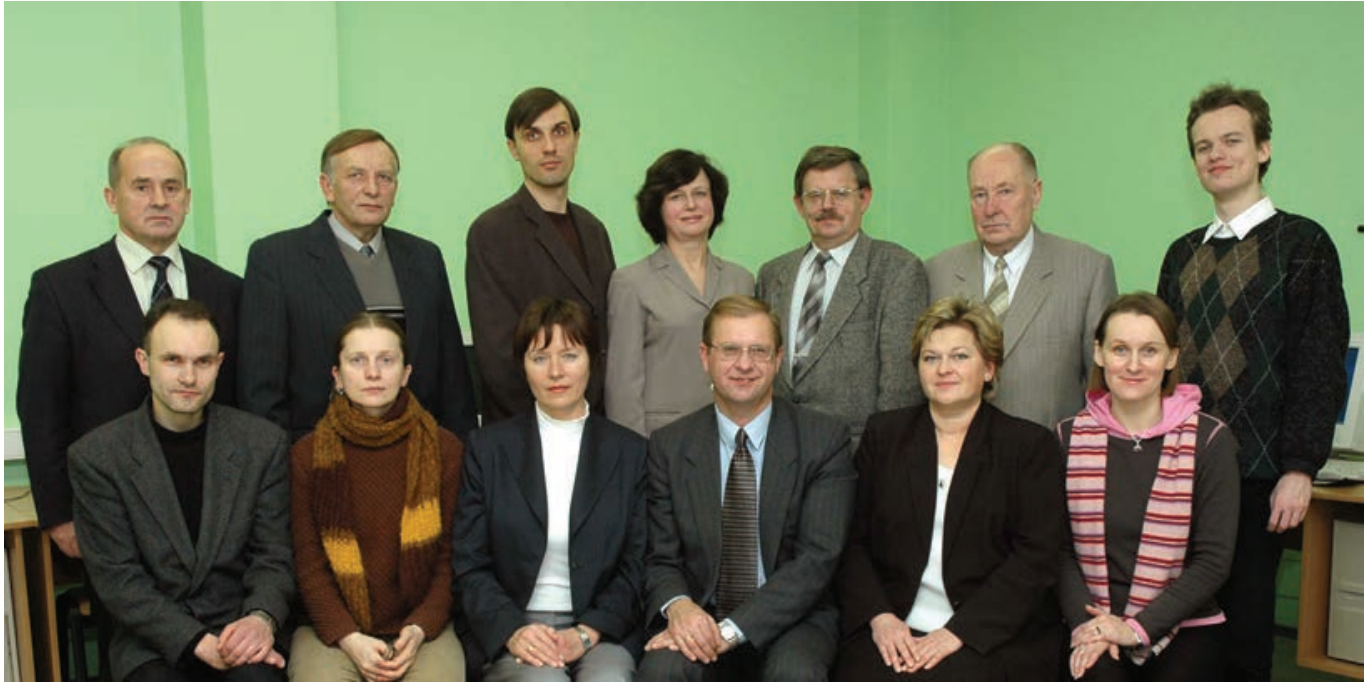

\section{Iš kairés j dešine pirmoje eilëje:}

asist. mgr. Vaidas Guogis, doc. dr. Girūta Kazakevičiūtė-Januškevičienè, lekt. Birutė Juodagalviené, katedros vedejjas prof. habil. dr. Romualdas Baušys, doc. dr. Daiva Makuteniené, lekt. dr. Rytè Žiūriené;

antroje eileje:

doc. dr. Vytautas Slivinskas, doc. dr. Antanas Leonas Lipeika, doc. dr. Linas Gabrielaitis, reikalų tvarkytoja Kristina Braškuvienè, doc. dr. Petras Audzijonis, lekt. Pranas Motiejūnas, meistras Artūras Kriukovas

Katedra ịkurta 2001 m. Nuo pat ịkūrimo katedrai vadovauja prof. habil. dr. R. Baušys. 


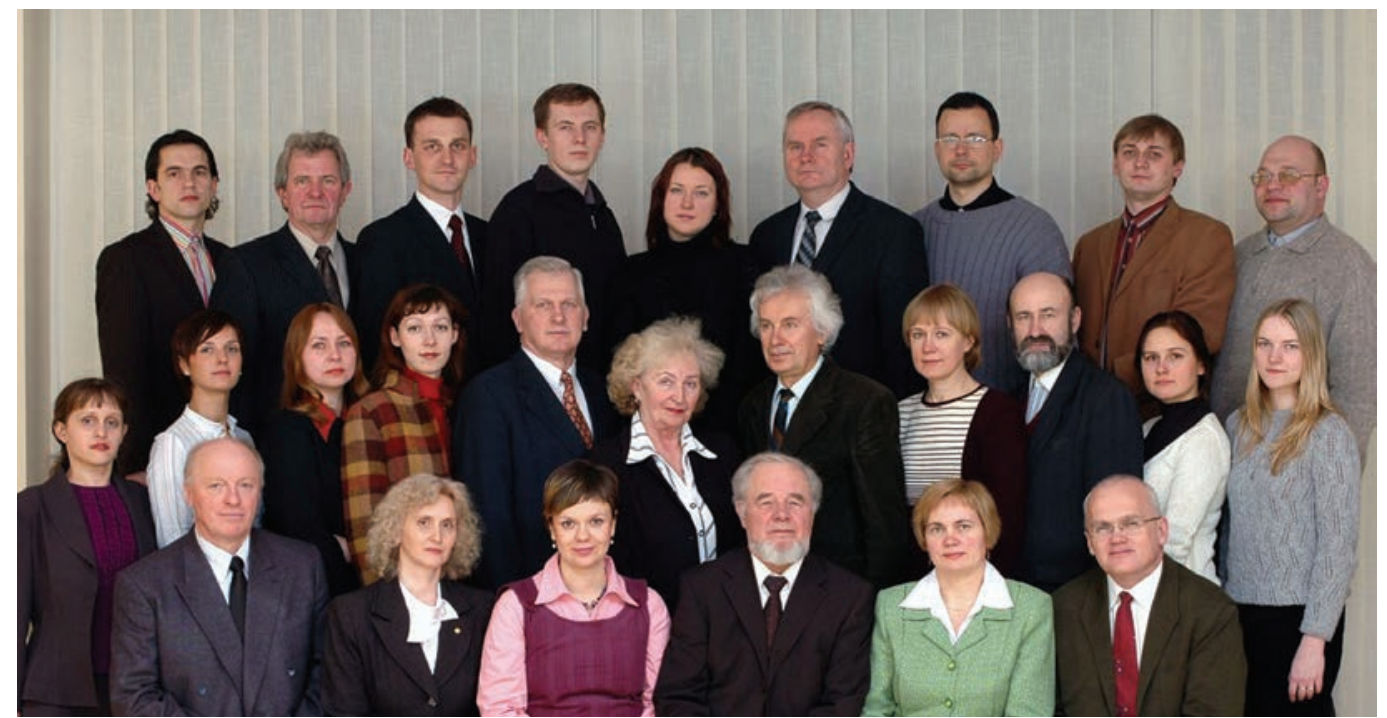

Iš kaires j̇ dešine pirmoje eileje:

prof. dr. Olegas Vasilecas, lekt. Nijole Čeikienè, reikalų tvarkytoja Karina Čiurliené, katedros vedejas prof. habil. dr. Petras Gailutis Adoménas, doc. dr. Nijolè Batarliené, prof. habil. dr. Antanas Čenys;

antroje eileje:

doc. Ana Usovaite, lekt. Birute Pliuskuviené, asist. Rasa Juodagalvytè, asist. Diana Būgaite, doc. dr. Algimantas Čepulkauskas, lekt. Emilija Garbonienè, doc. dr. Algis Saulis, doc. dr. Audroné Lupeikiené, doc. dr. Juozas Vyšniauskas, dokt. Ieva Sliesoraityté, asist. Jolanta Aleknaite;

trečioje eileje:

asist. Andrej Tunevič, doc. dr. Remigijus Kutas, asist. Artūras Šriupša, doktorantas Sergejus Sosunovas, lekt. Jelena Mamčenko, doc. dr. Juozas Laučius, doc. dr. Algirdas Laukaitis, lekt. Rolandas Griškevičius, doc. dr. Arūnas Ribikauskas

Informacinių sistemų katedros pirmtakè buvo Inžinerinès informatikos katedra, įkurta 1987 m. Jos istorija dar labai trumpa, tačiau prisiminti ją įdomu. Bendrojo pobūdžio informatikos kursas buvo vadinamas įvairiai - skaičiavimo technika, skaičiavimo mašinos ir programavimas, informacinès technologijos. Didžiausias šio kurso entuziastas ir propaguotojas buvo prof. D. Maciulevičius. Jo vadovaujamoje Taikomosios matematikos ir mechanikos katedroje buvo suburti šios disciplinos destytojai.

1990 m. reorganizavus Taikomosios matematikos ir mechanikos katedrą buvo įsteigta Informatikos katedra. Ji ịejo ị Mechaninès technologijos fakulteto sudetį. Pirmuoju katedros vedèju buvo išrinktas doc. A. Saulis. I naują katedrą perëjo desstytojai, mokę studentus informatikos pagrindų. Daugumos šių destytoju mokslinio darbo kryptis tuo metu nebuvo suformuluota, ją kiekvienas galejo suprasti savaip. Keletas dèstytojų ir katedros vedëjas svarste apie informatikos kryptį ir informatikos specialybès įvedimą universitete. Tam tikslui noreta pakviesti gerų specialistų, pirmiausia iš MA matematikos ir informatikos instituto.

1993 m. įkurtas Fundamentinių mokslų fakultetas, o jame ,atsidūrusi“ katedra pavadinta Inžinerinès informatikos. Pradèti rengti bakalaurai, sudarytos kelios įvairių specializacijų magistrantų grupés. Nuo 1993 m. Inžinerinès informatikos katedra pradëjo rengti inžinerinès informatikos studentus. Nuo 1998 m. katedrai vadovauja profesorius, habilituotas daktaras Petras Gailutis Adoménas. Inžinerinès informatikos disciplinos déstomos visų universiteto specialybių studentams pirmame ir antrame kursuose. Studentai sužino apie kompiuterių paskirtį, tipus, struktūrą, techninę ir informacinę irrangą. Susipažžsta su duomenų struktūromis, algoritmavimu ir algoritminemis kalbomis. 1999 m. inžinerinès informatikos katedros bazëje sukurtos dvi katedros: Informacinių sistemų ir Informacinių technologijų. Pagrindine priežastis - kelis kartus padidejjęs studentų priemimas ị informatikos pagrindines studijas, be to, išaugęs magistrantų skaičius. 


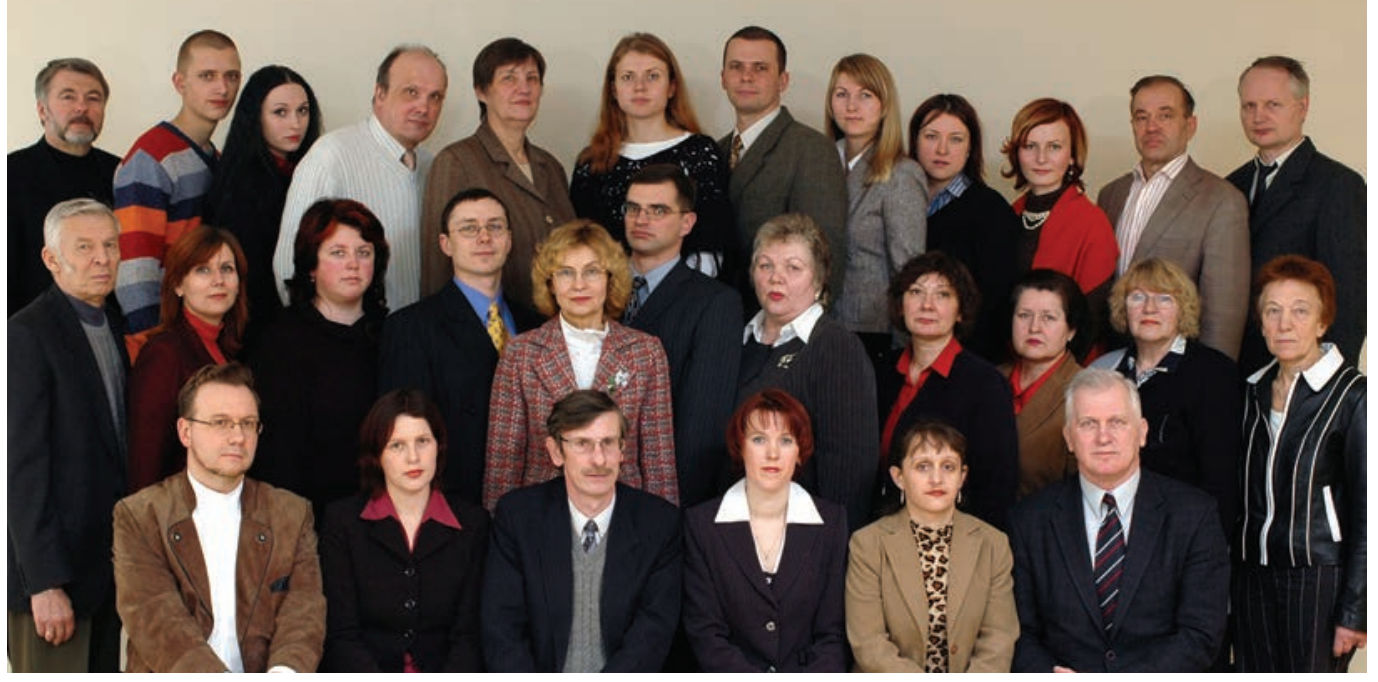

Iš kairès j dešine pirmoje eileje:

doc. dr. Saulius Valentinavičius, dokt. asist. Inga Tumasoniene,

katedros vedëjas prof. habil. dr. Genadijus Kulvietis, doc. dr. Irma Šileikienė, doc. dr. Ana Usovaite, doc. dr. Algimantas Čepulkauskas;

antroje eileje:

doc. dr. Rimantas Kalinauskas, asist. Lina Gorbunova, dokt. asist. Jelena Stankevič, asist. Audrius Kabašinskas, doc. dr. Regina Kulvietienè, dokt. asist. Mindaugas Rybokas, reikalų tvarkytoja Danute Dapkevičienè, asist. Laima Bajorūnaite, asist. Laima Valikoniené, asist. Elena Genè Chaliulina, doc. dr. Janina Radvilavičiūte;

trečioje eileje:

doc. dr. Alfredas Busilas, meistras Jurgis Mikučionis, asist. Kristina Buronkaite, doc. dr. Saulius Minkevičius, lekt. Janina Zapolskienė, dokt. Valdona Judickaite, asist. Tomas Kaminskas, dokt. Inga Belevičiūte, dokt. lekt. Jelena Mamčenko, dokt. asist. Živilè Patravičiūté, prof. habil. dr. Leonidas Sakalauskas, asist. Algirdas Maknickas

1990 m. buvusi Mechaninès technologijos fakultete Taikomosios matematikos ir mechanikos katedra skilo ị dvi: Teorinès mechanikos ir Informatikos katedras. 1993 m. įsteigus Fundamentiniu mokslų fakultetą Informatikos katedra pavadinta Inžinerinès informatikos katedra. Jos vedèju dirbo habil. dr. prof. Genadijus Kulvietis, o nuo 1998 m. - prof. habil. dr. Petras Gailutis Adoménas. 1999 m. Inžinerines informatikos katedra padalyta į Informacinių sistemų ir informacinių technologiju katedras. Informaciniu technologiju katedros vedëju dirba prof. habil. dr. Genadijus Kulvietis. 


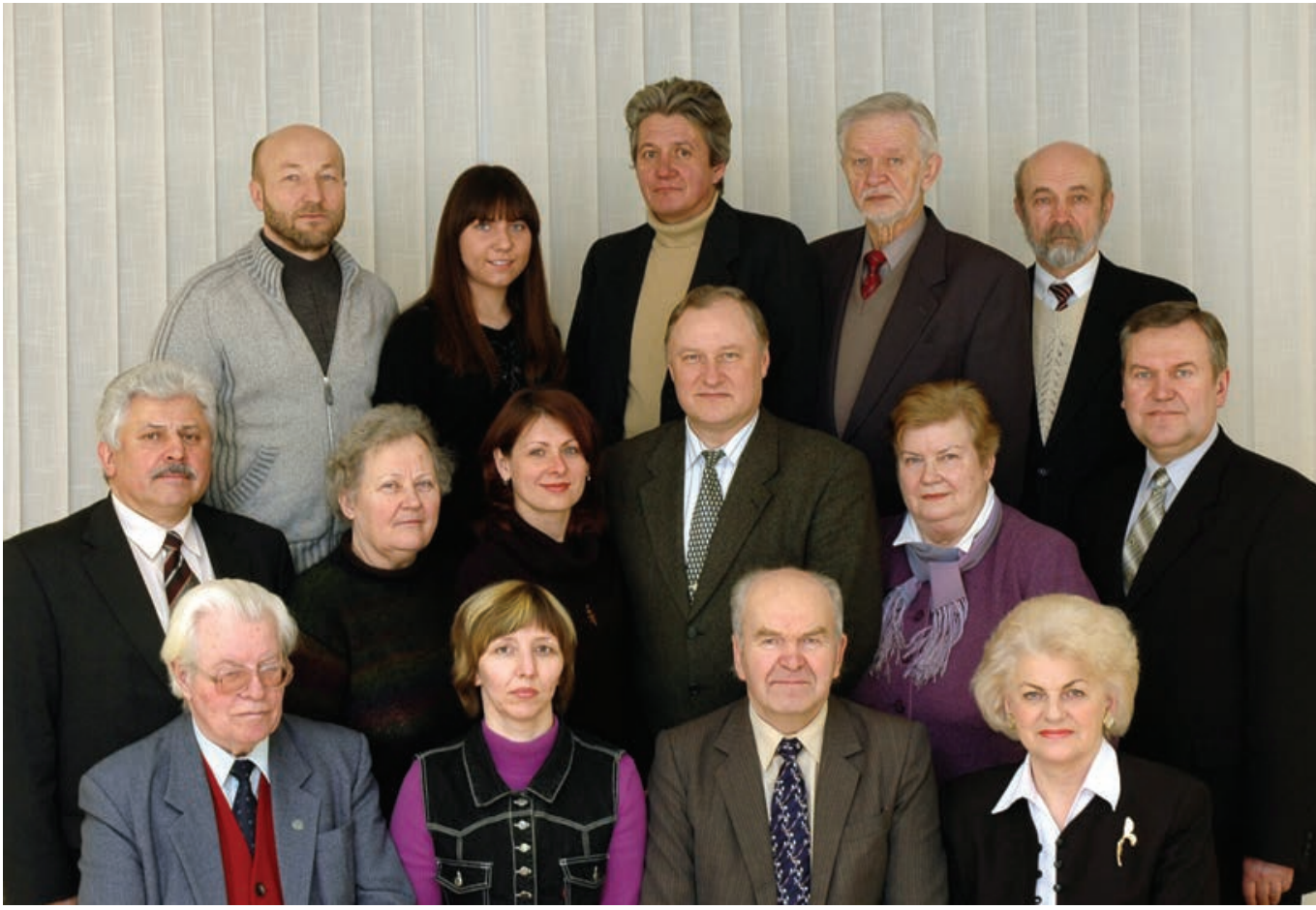

Iš kairés j̇ dešine pirmoje eileje:

lekt. Vytautas Lemke, reikalų tvarkytoja Jūratè Vinogradova, katedros vedëjas doc. dr. Pranas Gerdžiūnas, lekt. Zina Sofija Rimkevičiené;

antroje eileje:

lekt. mgr. Vytautas Plakys, lekt. Stase Donata Uljanoviené, doc. dr. Sonata Vdovinskiene, lekt. Juozas Grabys, lekt. Juta Tekle Tatjana Maroziené, doc. dr. Algirdas Sokas;

trečioje eileje:

doc. dr. Rymantas Kvietkauskas, vyresn. laborante Ana Vinogradova,

instruktorius Džiugas Radvila, lekt. Tadas Saulius Urnevičius, doc. dr. Jonas Zemkauskas

Inžinerinès grafikos katedra ịsteigta $1961 \mathrm{~m}$. Iki $1992 \mathrm{~m}$. ji buvo vadinama Braižybos katedra. Per paskutinį dešimtmetị katedros vedejjais buvo: doc. dr. J. Charitas iki 1971 m., doc. dr. H. Gylys 1972-1977 m., doc. dr. Raslanas 1977-1987 m., doc. B. Zabotka 1987-1993 m., doc. dr. P. Audzijonis 1993-1996 m., doc. dr. P. Gerdžiūnas - nuo 1996 m. iki dabar.

Inžinerinès grafikos katedroje grafinès disciplinos destomos Architektūros, Statybos, Transporto inžinerijos ir Mechanikos fakultetų technikos specialybių pagrindinių studiju pirmųjų ir antrųju kursų studentams.

Nuo 1993 m. Inžinerinès grafikos katedroje yra magistrantūros studijos, kuriose rengiami inžinerines ir kompiuterines grafikos specialybes magistrai.

Lietuvai integruojantis į Europos Sajungą tapo svarbus norminių dokumentų (šiuo atveju - techninių brěžinių standartų) suderinimas pagal pasaulinius ir Europos Sajungos reikalavimus. Grupé katedros darbuotojų analizuoja ir rengia techninių grafinių dokumentų Lietuvos standartus.

Nuo 1996 m. katedra yra Tarptautinès inžinerinès ir kompiuterinès grafikos ir braižomosios geometrijos asociacijos (ICECGDG) narys. 


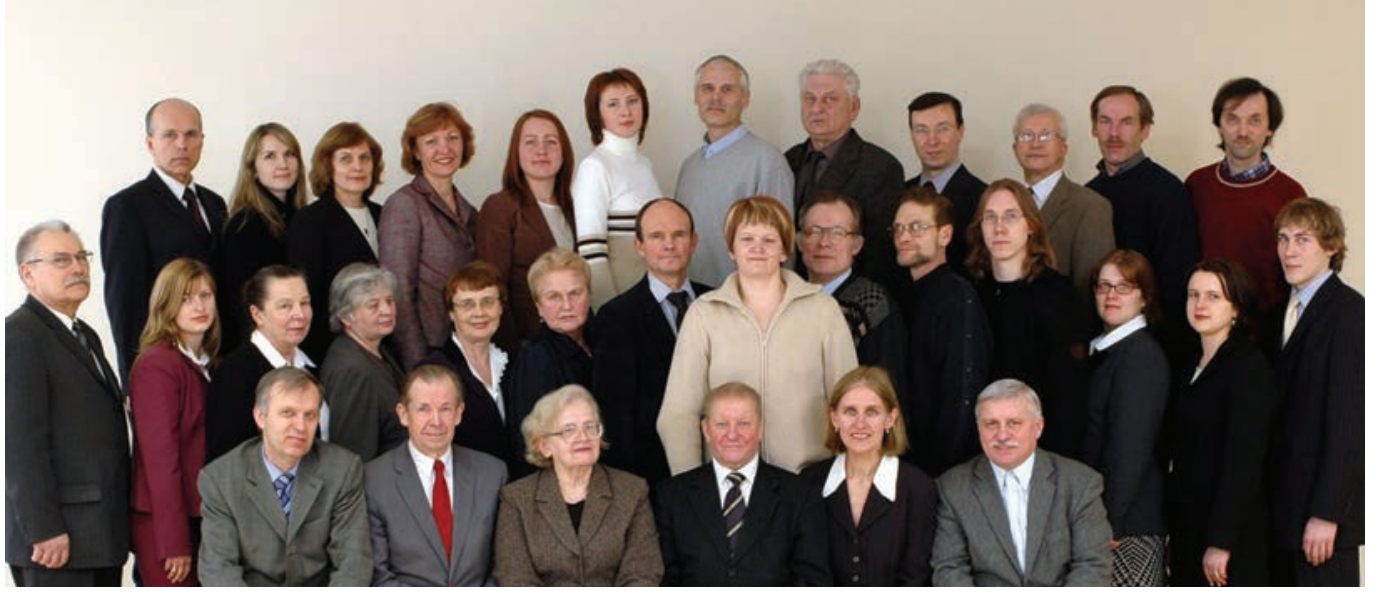

Iš kairès j dešine pirmoje eileje:

prof. habil. dr. Rimantas Rudzkis, prof. habil. dr. Mifodijus Sapagovas, doc. dr. Sigute Vakriniené, prof. habil. dr., katedros vedejjas Leonas Saulis, doc. dr. Birute Kryžienè, prof. habil. dr. Kęstutis Kubilius;

antroje eileje:

lekt. Eduardas Vakrina, dokt. Svetlana Danilenko, doc. dr. Stanislava Nerute Kligiené, lekt. Vale Stankevičiené, techn. asist. Romualda Agota Podviezkiene, doc. dr. Danute Bagdoniené, doc. dr. Rimas Banys, dokt. Elena Račiulaityte, doc. dr. Feliksas Motiejus Mišeikis, lekt. dr. Kazimieras Samaitis, dokt. Tomas Rekašius, doc. dr. Dovile Deltuviené, doc. dr. Audronè Jasaitienè, dokt. Viktoras Chadyšas;

trečioje eileje:

prof. habil. dr. Jonas Kazys Sanklodas, dokt. Ana Čuvak, doc. dr. Danute Krapavickaite, katedros reik. tvark. Milda Kubilienè, dokt. Jurgita Židanavičiūte, asist. Rūta Simonavičiené, doc. dr. Marijus Radavičius, doc. dr. Antanas Žemaitis, doc. dr. Žilvinas Kalinauskas, doc. dr. Valentinas Podvezko, doc. dr. Stasys Čepulenas, lekt. dr. Arūnas Grigelionis

1993 m. Vilniaus technikos universitete buvo įkurtas Fundamentinių mokslų fakultetas. Buvusi Matematikos katedra $1995 \mathrm{~m}$. lapkričio $15 \mathrm{~d}$. buvo reorganizuota į Matematines statistikos ir Matematinio modeliavimo katedras. Matematinès statistikos katedros pedagoginį personalą daugiausia sudare tikimybiu teorijos ir matematinès statistikos specialistai: doc. D. Bagdoniene, doc. B. Kryžiene, doc. V. Podvezko, prof. L. Saulis, doc. Vakriniene, doc. A. Žemaitis. Katedros personalą papilde Matematikos ir informatikos instituto mokslininkai: akad. V. Statulevičius, prof. K. Kubilius, prof. R. Rudzkis, prof. H. Pragarauskas, prof. M. Sapagovas, prof. J. Sunklodas, doc. N. Kligiené, dr. S. Čepulenas, doc. M. Radavičius, dr. B. Kaminskiene, doc. R. Banys, doc. D. Krapavickaitè $1996 \mathrm{~m}$. gegužès $28 \mathrm{~d}$. Matematinès statistikos katedros vedëju išrinktas prof. habil. dr. Leonas Saulis.

1996 m. katedroje įkurta taikomosios statistikos studiju programos „Statistiniai metodai finansuose ir ekonomikoje" specializacijos magistrantūra, į kurią kasmet priimama 15-20 pagrindines studijas baigusių bakalaurų.

$2003 \mathrm{~m}$. gauta teise steigti jungtinę Vilniaus Gedimino technikos universiteto ir Matematikos ir informatikos instituto fizinių mokslų srities (P000) matematikos mokslo krypties (01P) doktorantūrą. Pastaruoju metu katedroje yra 7 pirmųjų-ketvirtųjų metų doktorantai.

Katedros darbuotojai mokslinius straipsnius skelbia prestižiniuose žurnaluose.

Nuo 1996 m. Matematines statistikos katedroje veikia „Taikomosios matematikos" seminaras. Vadovas - prof. L. Saulis. Nagrinejjami matematinių-statistinių metodų taikymai technikoje, medicinoje, finansuose ir ekonomikoje.

1998 m. liepos 14 d. Vilniaus Gedimino technikos universitetui suteikta teise teikti pedagoginius docento ir profesoriaus mokslo vardus matematikos mokslo kryptyje (01P). 


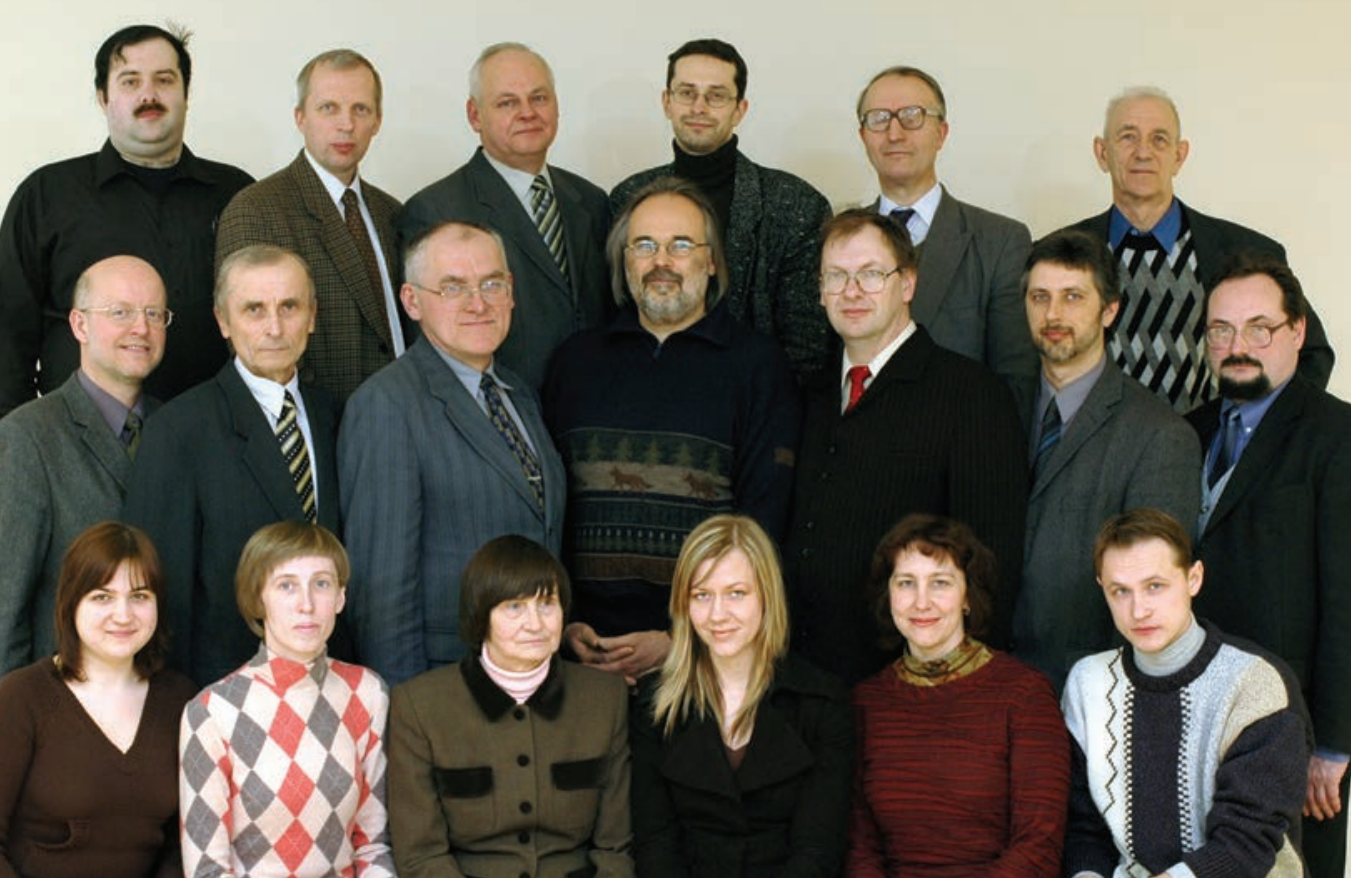

Iš kairés j dešine pirmoje eilëje:

asist. reikalų tvarkytoja Inga Laukaityté, doc. dr. Teresė Leonavičiené, lekt. Janina Jauriené, asist. Gerda Jankevičiūté, doc. dr. Olga Štikonienè, asist. Vaidas Keblikas;

antroje eileje:

doc. dr. Regimantas Čiupaila, doc. dr. Stasys Čirba, doc. dr. Mečislovas Meilūnas, doc. dr. Eugenijus Paliokas, doc. dr. Artūras Štikonas, doc. dr. Jevgenijus Kirjackis, doc. dr. Aleksandras Krylovas;

trečioje eilejje:

doc. dr. Igoris Belovas, katedros vedëjas prof. habil. dr. Raimondas Čiegis, doc. dr. Jonas Kleiza, doc. dr. Vadimas Starikovičius, doc. dr. Vincas Valavičius, prof. habil. dr. Eduardas Kirjackis

KPI Vilniaus filiale 1962 m. ikurtoji Matematikos katedra 1995 m. suskilo į Matematinio modeliavimo ir Matematinès statistikos katedras.

Matematinio modeliavimo katedros vedejju nuo pat katedros įsteigimo dirba prof. habil. dr. Raimondas Čiegis. 


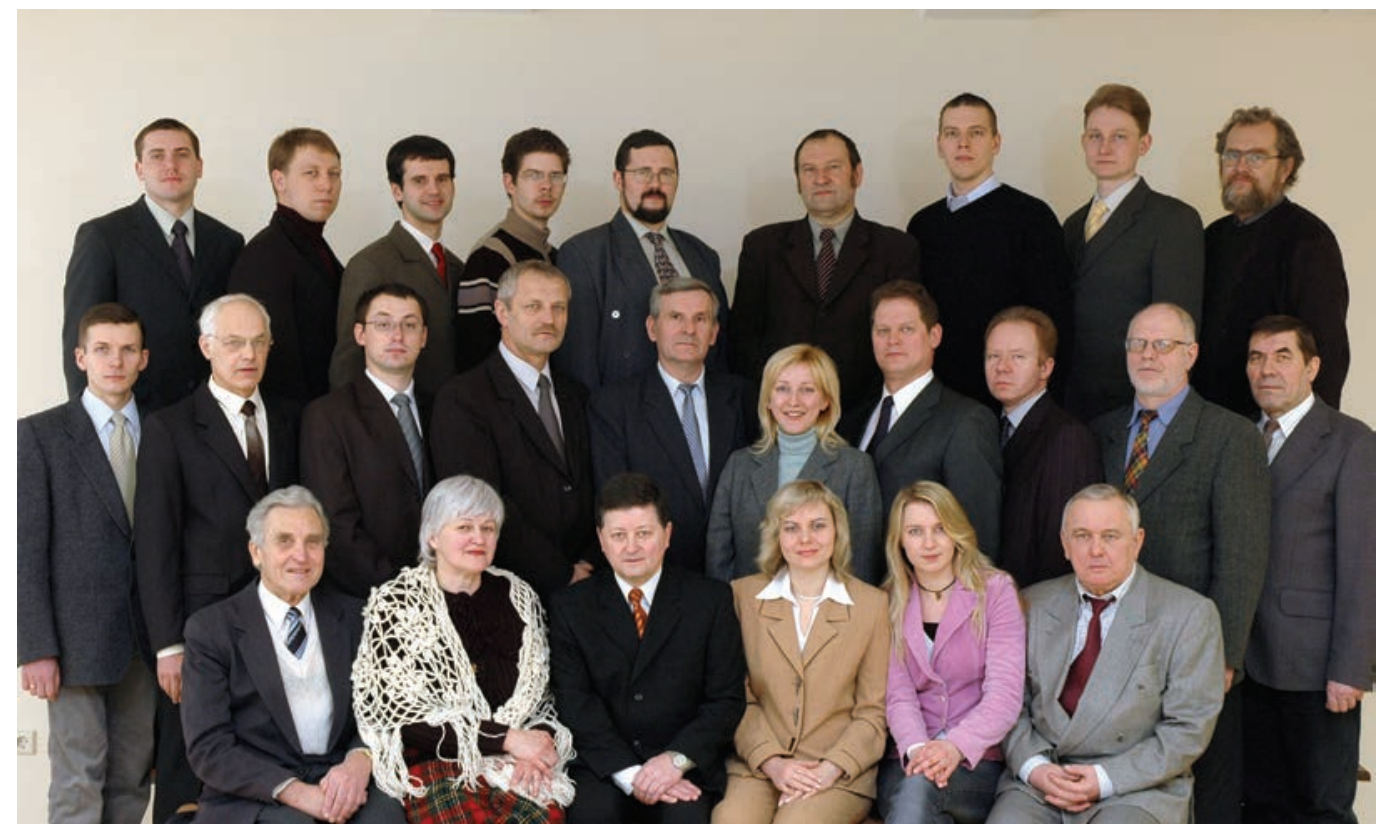

Iš kaires $\dot{i}$ dešine pirmoje eilejje:

prof. habil. dr. A. E. Čižas, asistentė J. Matulionienè, katedros vedejjas prof. habil. dr. R. Kačianauskas, reikalų tvarkytoja M. Zabulioniené, doktorantė G. Misiukaite, prof. habil. dr. M. K. Leonavičius;

antroje eileje:

dokt. G. Petraitis, doc. dr. A. Krenevičius, asist. dr. V. Žarnovskij, doc. dr. K. Vislavičius, doc. dr. S. Stupak, dokt. J. Selivonec, doc. dr. R. Kliukas, doc. dr. A. Jaras, doc. dr. M. Šukšta, metrologas V. Kozlovski;

\section{trečioje eileje:}

dokt. J. Tretjakovas, dokt. V. Vadluga, doc. dr. A. Kačeniauskas, dokt. L. Tumonis, vyresn. mokslo darb. dr. E. Stupak, lab. vedëjas A. Patapavičius, dokt. Aleksejus Jefimovas, dokt. J. Kimso, vyr. eksperimentatorius A. Speičys

1976 m. rugpjūčio 1 d. buvo įsteigta Vilniaus inžinerinio statybos instituto Statybos fakulteto Medžiagų atsparumo katedra. Pirmuoju katedros vedeju tapo prof. habil. dr. Algirdas Eduardas Čižas. 1990 m. katedra tapo kuriamo Vilniaus technikos universiteto Fundamentinių mokslų fakulteto padaliniu.

Aštuoniolika metų - nuo 1976 iki 1994 m. - Medžiagų atsparumo katedros vedëju buvo prof. habil. dr. Algirdas Eduardas Čižas; vienerius metus - nuo 1994 iki 1995 m. - doc. dr. Marijonas Šukšta, trejus metus - nuo 1995 m. iki 1998 m. - prof. habil. dr. Rimantas Kačianauskas, vienerius metus - nuo 1998 m. iki 1999 m. - doc. dr. Kęstutis Vislavičius, dvejus metus nuo 1999 m. iki 2001 m. - doc. dr. Stanislav Stupak. Nuo 2001 m. rugsèjo 1 d. katedrai vel vadovauja prof. habil. dr. Rimantas Kačianauskas. 


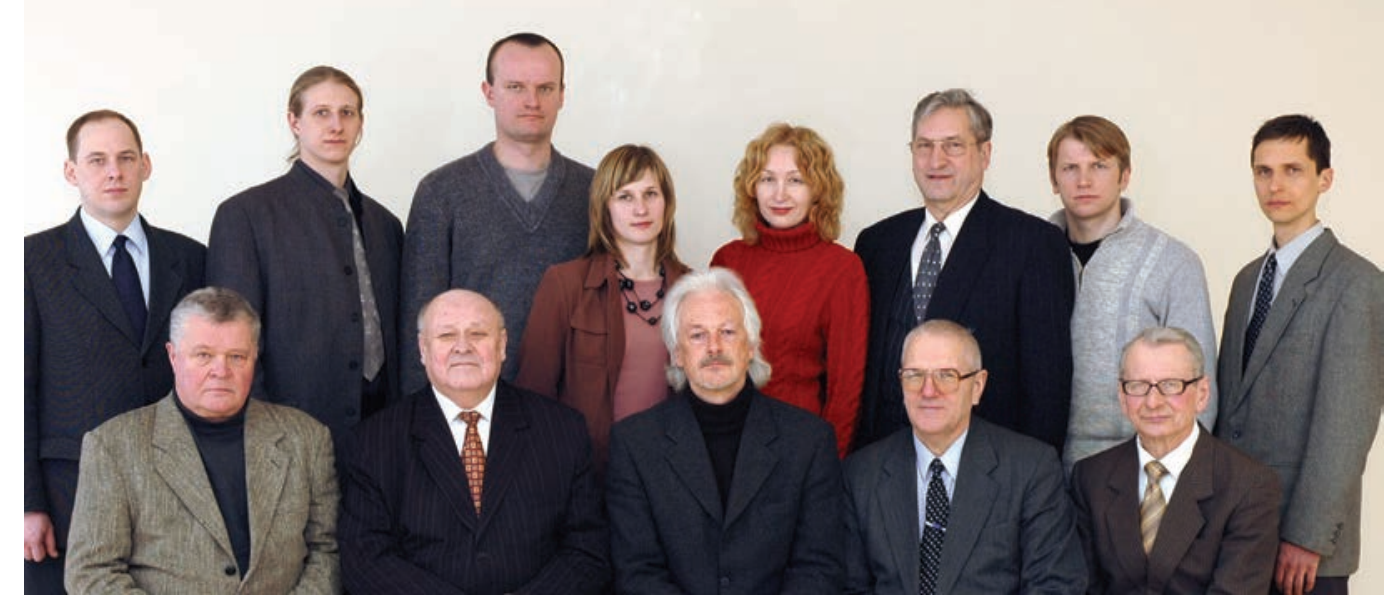

Iš kairès j dešine pirmoje eileje:

doc. Jonas Gaspariūnas, FMF dekanas doc. Algirdas Čiučelis, katedros vedejjas prof. habil. dr. Rimantas Belevičius, doc. Leonidas Syrus, doc. Petras Baradokas;

antroje eileje:

doc. Edvard Michnevič, dokt. Paulius Ragauskas, dokt. Miroslavas Salètis, reikalų tvarkytoja asist. Aušra Narkevičienè, asist. Elena Glèbienè, lektor. Algimantas Rimdžius, doc. Dainius Rusakevičius, dokt. Dmitrij Šešok

Teorinès mechanikos katedra taip vadinama nuo $1990 \mathrm{~m}$.

Sunku pasakyti, kada yra Teorines mechanikos katedros gimtadienis. Katedra tokiu pavadinimu tuometinio Technikos universiteto, Fundamentinių mokslų centre (vèliau - fakultete) atsirado 1990 metais, ị dvi dalis pasidalijus Taikomosios matematikos ir mechanikos katedrai. Ši pirmtake visą laiką buvo dvilypè: puse katedros darbuotojų desste teorinès mechanikos dalykus, o kita - bendrosios informatikos, programavimo, anksčiau - ir skaičiavimo metodų dalykus. Teorinè mechanika buvo destoma ir dar ankstesnèse - nuo $1960 \mathrm{~m}$. Kauno politechnikos instituto Vilniaus vakarinio fakulteto Taikomosios mechanikos katedroje, o nuo $1961 \mathrm{~m}$. - Vilniaus inžinerinio statybos instituto Mechanikos-matematikos katedroje, iš kurios galiausiai $1970 \mathrm{~m}$. atsirado Taikomosios matematikos ir mechanikos katedra. Taigi katedros ištakos siekia dar $1960 \mathrm{~m}$.

Nuo 1962 m. iki 1990 m. katedrų, destančių mechanikos dalykus, vedèju buvo prof. D. Maciulevičius. Jam vadovaujant buvo suformuotos teorinés mechanikos dèstymo mūsų universitete tradicijos. Véliau katedrai vadovavo doc. A. Čiučelis ir doc. J. Kasnauskas, o nuo 1995 m. katedros vedejju yra prof. R. Belevičius. 
HUMANITARINIS INSTITUTAS

FILOSOFIJOS IR POLITOLOGIJOS KATEDRA

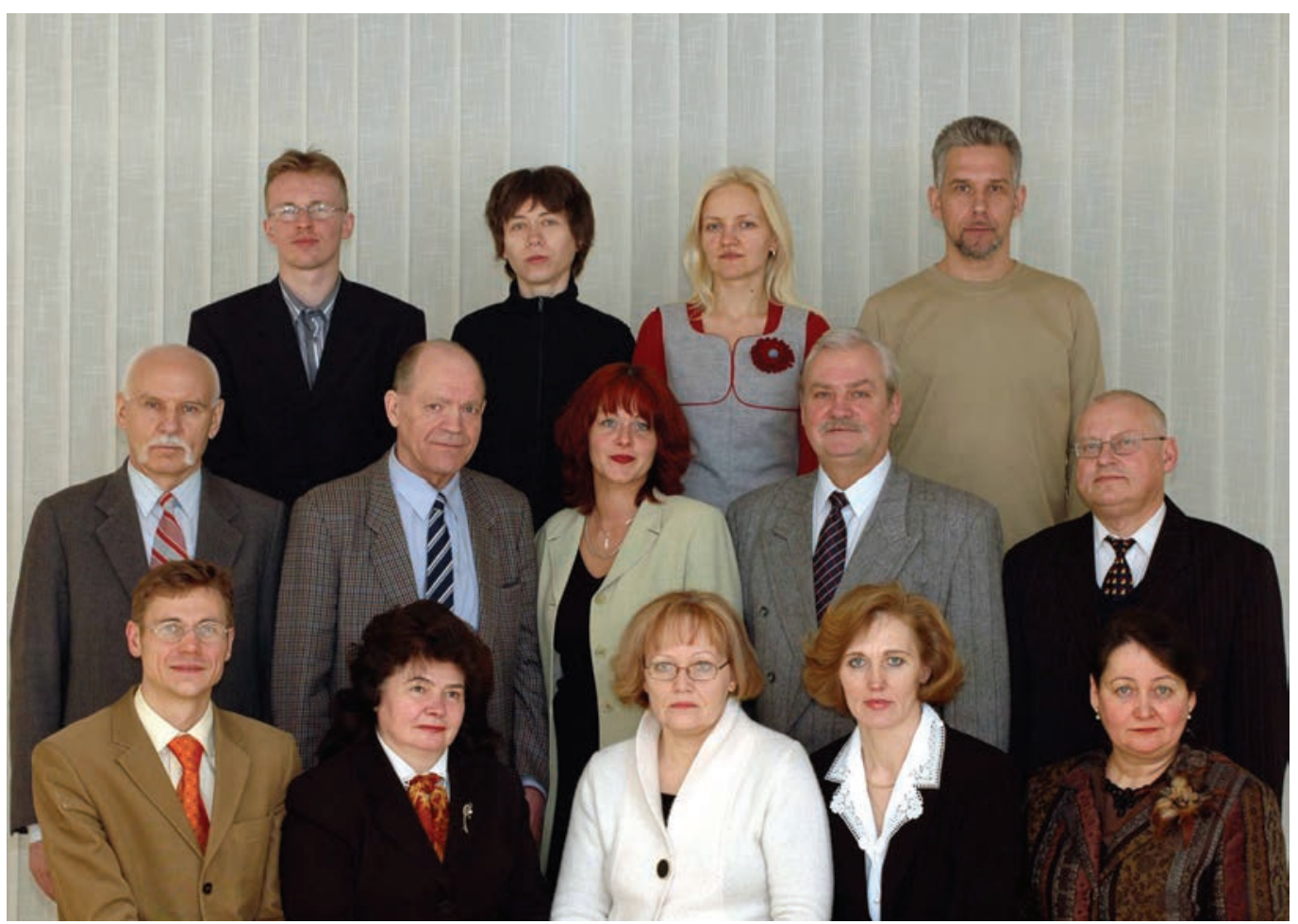

Iš kaires j dešine pirmoje eilejje:

doc. dr. Tomas Kačerauskas, doc. dr. Vilija Grincevičienè, doc. dr. Laima Monginaite, lektoré Vitalija Kecioryte, doc.dr. Dalia Eidukiené;

antroje eileje:

doc. dr. Aleksandras Jasmontas, doc. dr. Kazimieras Monkevičius,

reikalu tvarkytoja Tatjana Mamajeva, lekt. Rimantas Biržys, prof. habil. dr. Valdas Pruskus; trečioje eilejje:

lekt. dr. Mindaugas Briedis, doc. dr. Nida Vasiliauskaite, jaunesn. moksl. darb. Aušra Gavenaite, doc. dr. Arūnas Mickevičius

1961-1992 m. m. buvo: Marksizmo-leninizmo, Filosofijos, TSKP istorijos, Politinès ekonomijos, Mokslinio komunizmo, Estetikos ir teises, Politologijos katedros. Tai buvo savarankiškos katedros, kuriose destomos šios disciplinos: TSKP istorija, politine ekonomija, filosofija, mokslinis komunizmas, estetika, etika, pedagogika, politologija, teisé.

1992-07-01 Politologijos katedra reorganizuota ị Humanitarinių ir socialinių mokslų katedrą, kuri nuo 1993-03-31 tapo Verslo vadybos fakulteto padaliniu.

Nuo 1994 m. katedroje yra edukologijos magistrantūra.

2001-07-02 Humanitarinių ir socialinių mokslų katedra pavadinta Filosofijos ir politologijos katedra.

2003-06-25 Filosofijos ir politologijos katedra tapo Humanitarinio instituto padaliniu. 


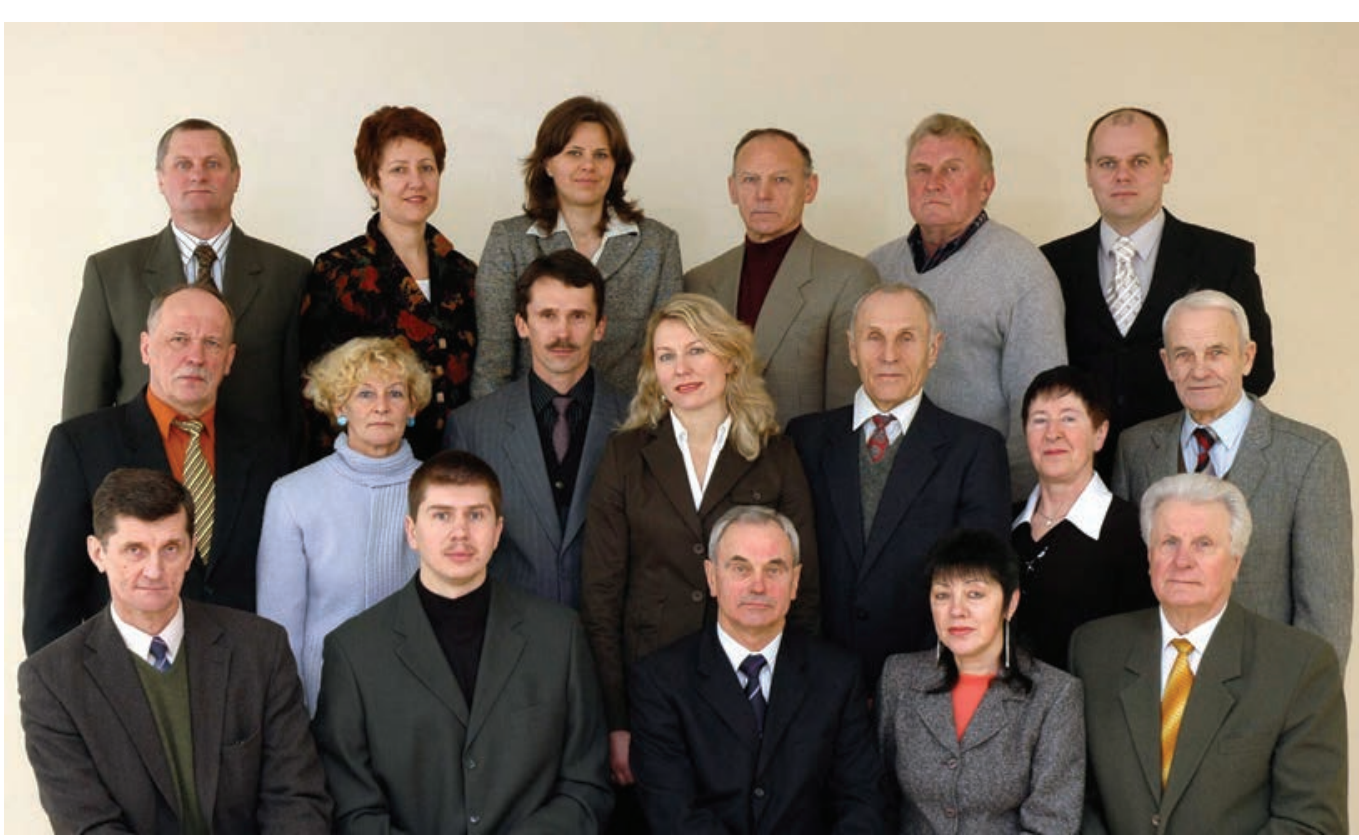

Iš kaires j dešine pirmoje eilëje:

treneris pedagogas Jonas Adomaitis, treneris pedagogas Gintaras Šerkšnas, katedros vedëjas prof. habil. dr. Povilas Tamošauskas, reikalų tvarkytoja Vale Šliažiené, doc. Vytautas Sakalys;

\section{antroje eileje:}

lekt. Jonas Pečiūra, asist. Vytautè Kazlauskienè, asist. Vitalijus Podlužnas, asist. Valda Morkūniené, doc. Jonas Adamonis, lekt. Elena Zitikiené, doc. Vytautas Barisas; trečioje eileje:

lekt. Algirdas Šulinskas, asist. Daiva Višinskiené, sporto ir turizmo klubo „Inžinerija“ vedëja Raminta Kuktaite, treneris pedagogas Antanas Černiauskas, docentas Anastazas Špokas, doc. Stanislavas Dadelo

1965 m. buvo įkurta KPI Vilniaus filialo Fizinio lavinimo katedra. Jos vedeju buvo paskirtas ižymus Lietuvos krepšininkas Vytautas Kulikauskas, èjęs vedëjo pareigas iki 1980 m. Paskui katedrai vadovavo doc. Vytautas Sakalys, nuo 1991 m. - doc. Arvydas Mačys.

1993 m. įsteigtam Verslo vadybos fakultetui priskirta Kūno kultūros katedra. Taip ji pavadinta $1991 \mathrm{~m}$.

2003 m. îsteigtam Humanitariniam institutui priskirtajai Kūno kultūros katedrai vadovauja prof. habil. dr. Povilas Tamošauskas, kartu dirbantis ir instituto direktoriumi. 
LIETUVIŲ

KALBOS

KATEDRA

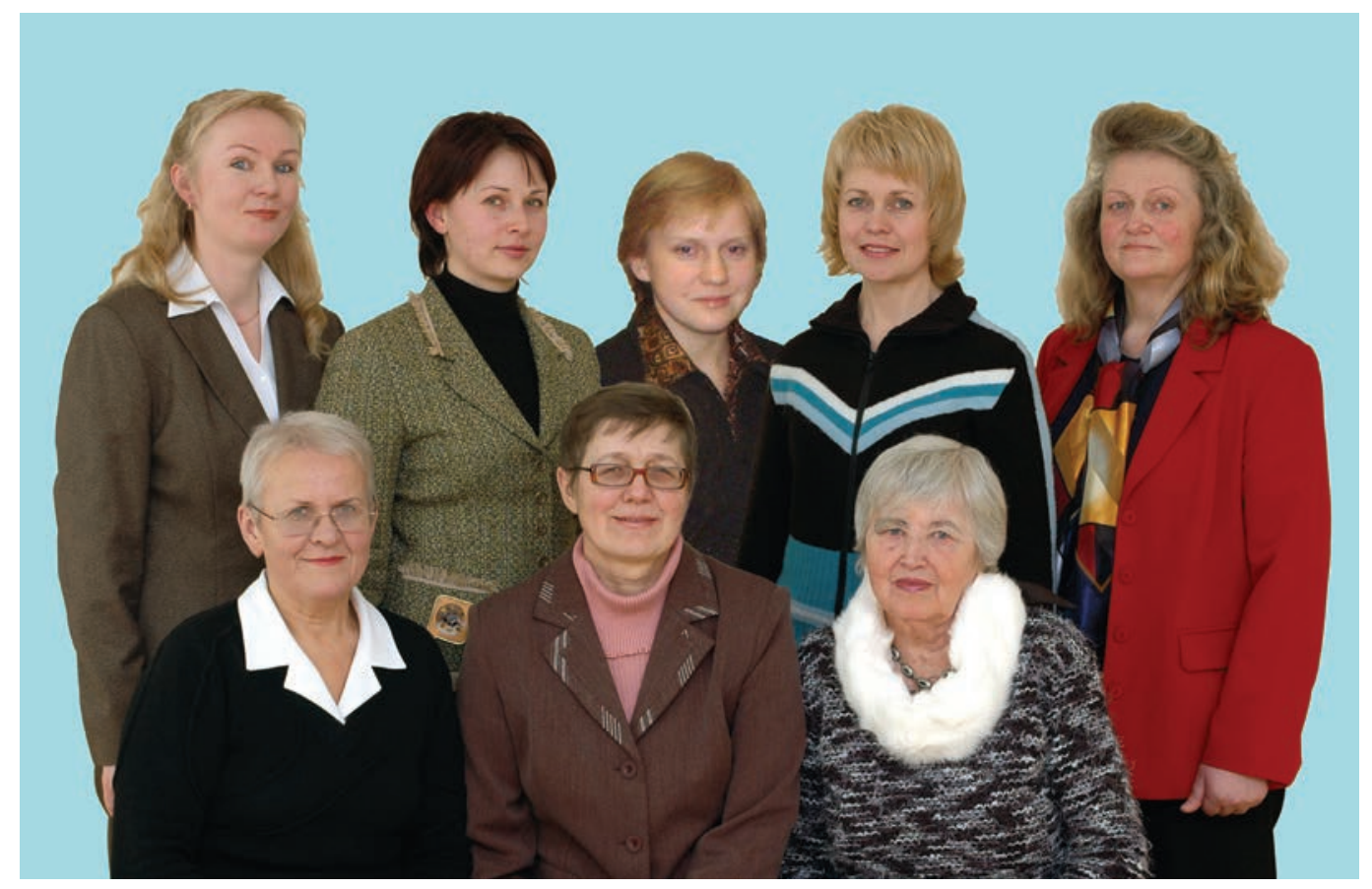

Iš kaires j dešine pirmoje eileje:

reikalų tvarkytoja Rūta Darbutiené, katedros vedëja doc. dr. Angele Kaulakiené, doc. dr. Leonora Domininka Barzdžiukiene;;

antroje eileje:

lekt. Angelika Petrètienè, lekt. Lina Rutkiené, lekt. Vita Krasauskaite, doc. dr. Vilija Celiešiené, lekt. Regina Žukiené

VGTU rektorato 1997-10-21 posedžio nutarimu buvusi Kalbų katedra buvo reorganizuota ị Užsienio kalbų katedrą ir Lietuvių kalbos katedrą. Lietuvių kalbos katedros vedejju buvo paskirtas prof. habil. dr. Juozas Stonys, kuris katedrai vadovavo iki $2001 \mathrm{~m}$. liepos ménesio.

Nuo 2002 m. spalio Lietuvių kalbos katedrai vadovauja doc. dr. Angele Kaulakienè.

Lietuvių kalbos katedra palaiko glaudžius ryšius su Lietuvių kalbos institutu, Valstybine lietuvių kalbos komisija. A. Kaulakienè yra šios komisijos, jos Koordinavimo tarybos, Terminologijos pakomisess, Specialybès kalbos kultūros programų rengimo pakomisès narè.

Lietuviu kalbos katedros darbuotojai aktyviai bendradarbiauja su mokslo („Filologija“, „Kalbos kultūra“, „Terminologija”) ir mokslo populiarinamųjų („Gimtoji kalba“, „Fizikų žinios“) leidinių redakcinemis kolegijomis. 
UŽSIENIO

KALBU

KATEDRA

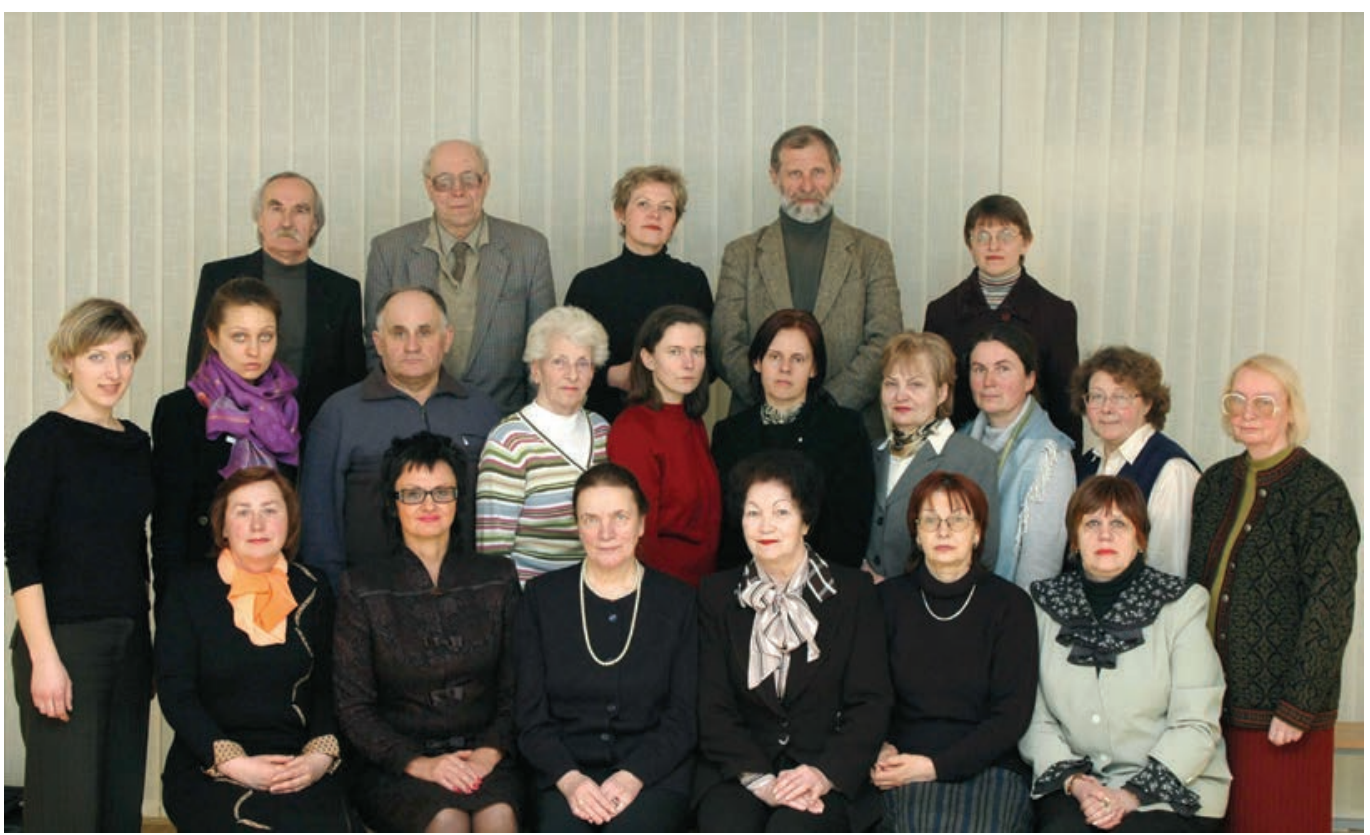

Iš kaires j dešine pirmoje eilëje:

asist. Nijolè Netikšienè, lekt. Vanda Birutè Ginevičienè,

katedros vedëja doc. dr. Laimute Kitkauskiené, doc. dr. Liudmila Mauziené,

Kalbų mokymo kompiuterinès laboratorijos vedëja Elena Vislavičienè,

asist. Vida Asanavičiené;

antroje eileje:

asist. Giedre Knizikevičiūte, asist. Kristina Juodinyté, doc. dr. Aleksandras Velička, doc. dr. Rūta Elžbieta Katalynaitè, lekt. Rasa Sklizmantaitè, asist. Genovaite Snuviškienè, lekt. Viktorija Norvaišiene, lekt. Regina Juškiene, asist. Olga Miščenko, asist. Evelina Baravykiene;

trečioje eileje:

lekt. Jonas Mickonis, lekt. Algis Starkus, lekt. Irena Miculevičiene, lekt. Zigmantas Vytautas Banelis, lekt. Auksė Marmiené

1960 m. KPI Vilniaus filiale įkuriama Kalbų mokymo komisija, kuriai vadovauja dėstytoja Aldona Ona Glemžienè. 1963 m. KPI rektoriaus prof. dr. K. Baršausko ịsakymu Nr. 182 Vilniaus filiale steigiama Kalbų katedra. Vedëja - Aldona Ona Glemžienè. 1969 m. reorganizavus KPI Vilniaus filialą i Vilniaus inžinerinị statybos institutą, Kalbų katedra priskiriama Statybos fakultetui. 1977 m. Kalbų katedra padalinta ị Užsienio kalbų bei Lietuvių ir rusų kalbų katedras. Užsienio kalbų katedros vedejja - doc. dr. A. O. Glemžienè (iki 1979 m.). 1979 m. Užsienio kalbų katedrai vadovavo doc. dr. Kazimieras Rukšènas (iki 1992 m.). 1992 m. katedros sujungtos ir pervadintos Kalbų destymo centru. 1993 m. Centras pavadintas Kalbų katedra. Vedejja - doc. dr. Liudmila Mauzienè (iki 1997 m.). Katedra priklauso Verslo ir vadybos fakultetui. 1997 m. įsteigtos Užsienio kalbų ir Lietuvių kalbos katedros. 1997-2001 m. Užsienio kalbų katedros vedeju dirba doc. dr. Kazimieras Rukšènas. 1997 m. rudenį ịkuriama Užsienio kalbų katedros kalbų mokymo kompiuterine laboratorija. Vedëja inž. Elena Vislavičienè. 2002 m. šios katedros laikinuoju vedëju dirba doc. dr. Aleksandras Velička. Nuo 2002 m. rudens Užsienio kalbų katedros vedejja konkursiniu būdu išrenkama doc. dr. Laimute Alfonsa Kitkauskinè. 


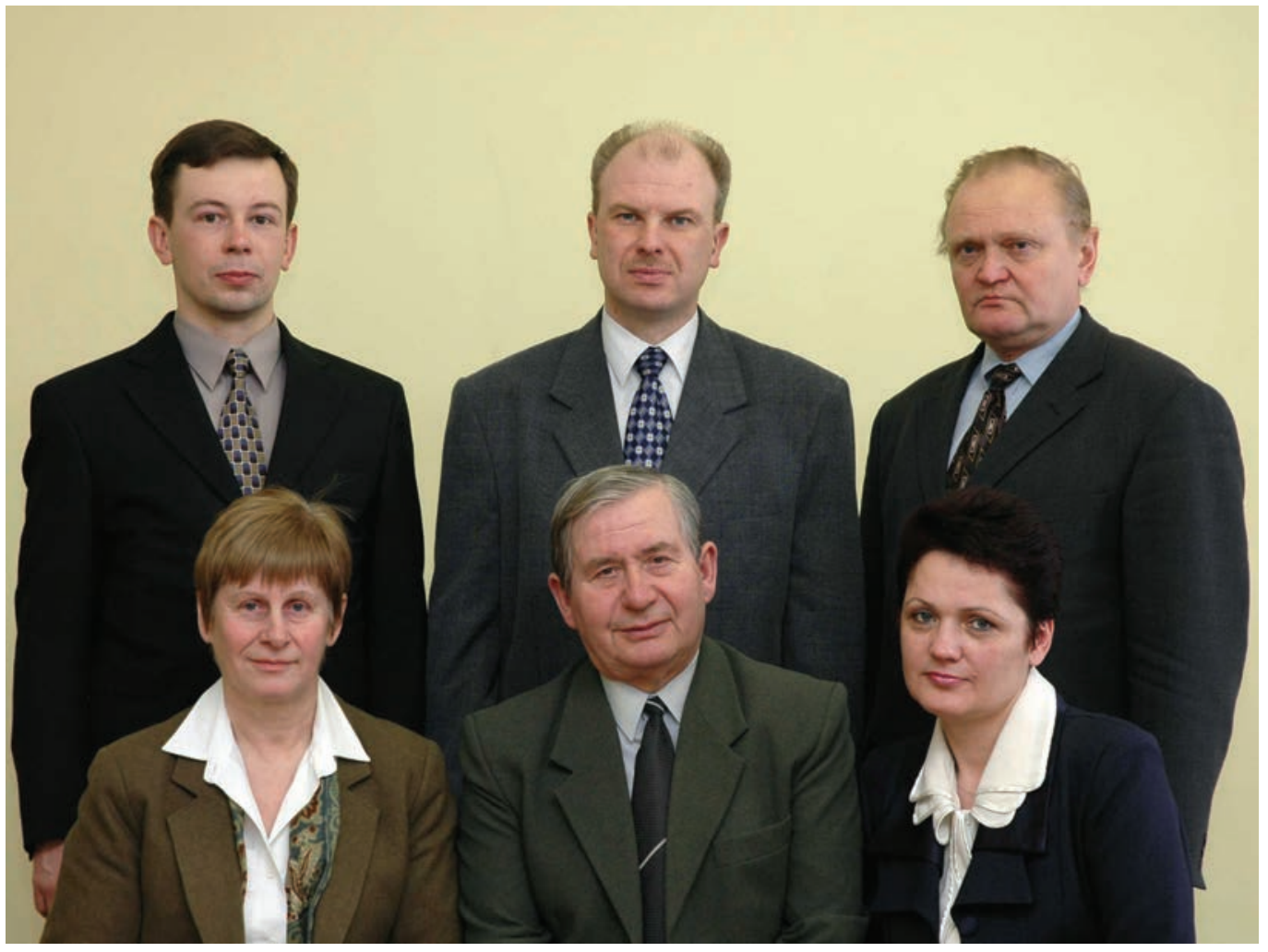

Iš kaires j dešinę pirmoje eilejje:

administratore Ale Lygiene, dekanas prof. habil. dr. Mečislovas Mariūnas, vadybininkè Nijole Krikščiūniene;

\section{antroje eileje:}

mokslo prodekanas doc. dr. Irmantas Gedzevičius,

magistrantūros prodekanas doc. dr. Audrius Čereška, studiju prodekanas doc. dr. Arūnas Jakštas

Mechanikos fakultetas yra vienas iš seniausių fakultetų universitete. Mechanikos fakulteto pradžia - 1956 metai, kai buvo ịkurtas KPI vakarinio fakulteto Vilniaus skyrius. 1960 m. KPI vakarinio fakulteto Vilniaus skyrius pertvarkytas ị vakarinị KPI Mechanines technologijos fakultetą, kuriame buvo pramoninès ir civilinès statybos specialybe. Nuo $1961 \mathrm{~m}$. jis tampa KPI Vilniaus filialo Mechaninès technologijos fakultetu, kuriame studentai pradèti mokyti ir dieniniame skyriuje. 1969-1990 m. tai - Vilniaus inžinerinio statybos instituto Mechanines technologijos fakultetas. 1990 m. fakultetas pavadintas Vilniaus technikos universiteto Mechanikos fakultetu. Iki 1994 m. fakultetas buvo didžiausias tuometiniame Technikos universitete.

Dabar fakultete yra 5 katedros: Mašinų gamybos, Medžiagotyros ir suvirinimo, Poligrafinių mašinų, Biomechanikos ir Pramonés įmonių valdymo.

Fakultete dirba 84 darbuotojai: 37 mokslininkai, iš jų 8 prof. habil. dr.; 1 habil. dr.; 28 doc. dr. Doktorantūroje studijuoja 19 doktorantų. 
BIO-

MECHANIKOS

KATEDRA

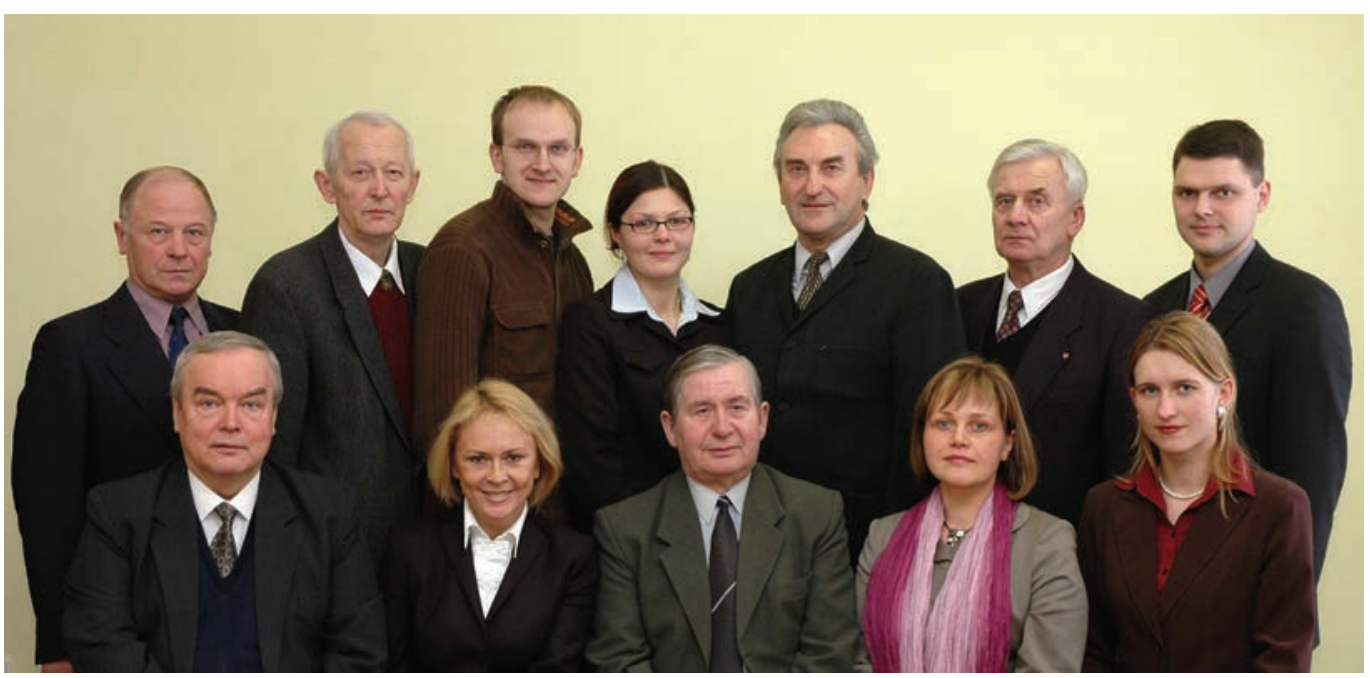

Iš kaires j dešine pirmoje eilëje:

prof. habil. dr. Viktoras Vasilionkaitis, doc. dr. Viktorija Sliesoraitiene, katedros vedëjas prof. habil. dr. Mečislovas Mariūnas, doc. dr. Andžela Šešok, dokt. Giedre Uzdilaite;

antroje eileje:

lekt. Rimantas Antanas Batakys, vedejjas Vytautas Einoris, asist. dr. Julius Griškevičius, reikalų tvarkytoja asist. Kristina Daunoravičiene,

prof. habil. dr. Rimantas Mykolas Kanapenas, lekt. dr. Juozas Vincas Astrauskas, dokt. Irmantas Trimonis

Biomechanikos katedra ịkurta 1996 metais. Katedros profilį nulemè kvalifikuotų inžinerijos specialistų stygius medicinos, reabilitacinès, kompensacinès technikos, protezų ir ortezų projektavimo, gamybos ir eksploatacijos bei neiggaliụjų integravimo į visuomenę problemoms spręsti. Be nurodytų problemų, rengiami specialistai nagrinëja žmogaus ir jo organų judesių kinematiką, kinetiką ir dinamiką, jų parametrų įvertinimo metodus, matavimo ir duomenų apdorojimo techniką, susipažįsta su implantų medžiagomis, jų taikymu, su naujausiais gydomosios terapijos metodais ir techninèmis priemonemis. Jie supažindinami su žmogaus anatomija, fiziologija, elektromagnetiniais procesais ir biolaukais žmogaus organizme, medicinine psichologija ir kitais vidaus bei aplinkos procesais. Katedra, rengdama specialistus, glaudžiai bendradarbiauja su medikais anatomais, chirurgais ir reabilitologais. Specialistai rengiami pagal bakalaurų ir magistrų studijų programas. Katedros vedejjai: 1997-2001 m. doc. dr. J. V. Astrauskas; nuo 2001 m. iki šiol - prof. habil. dr. M. Mariūnas. 


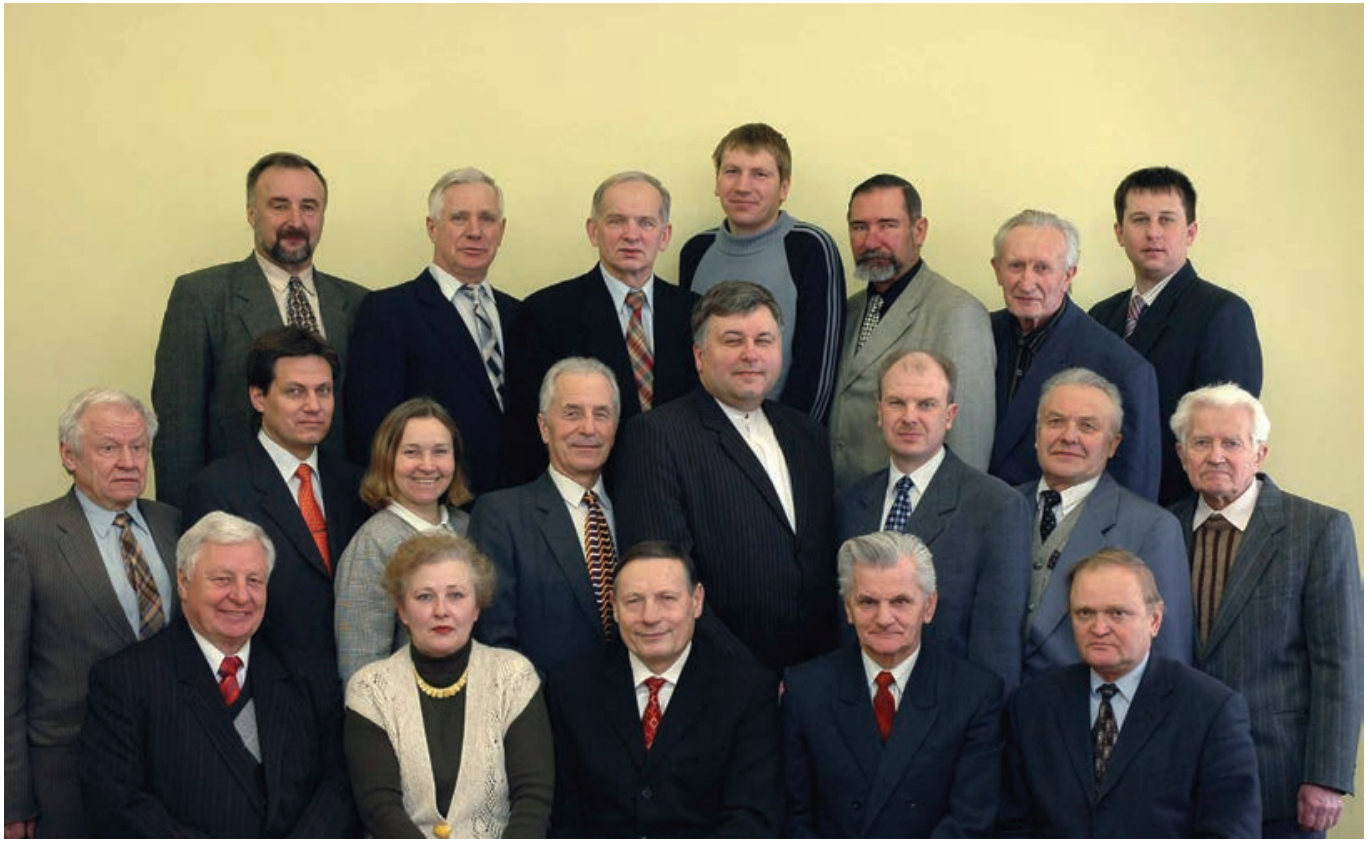

Is kaires j dešine pirmoje eileje:

ekt. dr. Rimantas Pranas Budrys, meistrè Valentina Šapalova,

katedros vedejjas prof. habil. dr. Vladas Vekteris,

prof. habil. dr. Andrejus Henrikas Marcinkevičius,

doc. dr. Arūnas Jakštas;

\section{antroje eileje:}

mokomosios laboratorijos vedëjas inž. Vladas Vytautas Paplauskas, doc. dr. Gintas Viselga, reikalų tvarkytoja inž. Irena Survilaite, doc. dr. Vytautas Pauža, doc. dr. Vytautas Bučinskas, doc. dr. Audrius Čereška, doc. dr. Evaristas Algirdas Totoraitis,

meistras Dainius Jonas Gudauskas;

trečioje eilëje:

doc. dr. Vytautas Striška, prof. habil. dr. Albinas Kasparaitis, doc. dr. Kastytis Slivinskas, dokt. Artūras Kilikevičius, doc. dr. Mindaugas Jurevičius, meistras Arbert Zykov, doc. dr. Vadim Mokšin

Katedra įsteigta 1965 metais.

1965 m. KPI Vilniaus vakariniame skyriuje buvo įkurta Mašinų gamybos procesų automatizavimo katedra, kuri 1967 m. buvo pavadinta Mašinų gamybos technologijos katedra, o 1991 m. - Mašinų gamybos katedra.

Katedros vedejjai: 1965-1973 m. - doc. dr. Romualdas Jonušas, 1973-1984 m. - doc. dr. Algimantas Samulevičius, 1984-1990 m. - prof. habil. dr. Mečislovas Mariūnas, nuo 1990 m. iki dabar - prof. habil. dr. Vladas Vekteris. 
MEDŽIAGO-

TYROS IR

SUVIRINIMO

KATEDRA

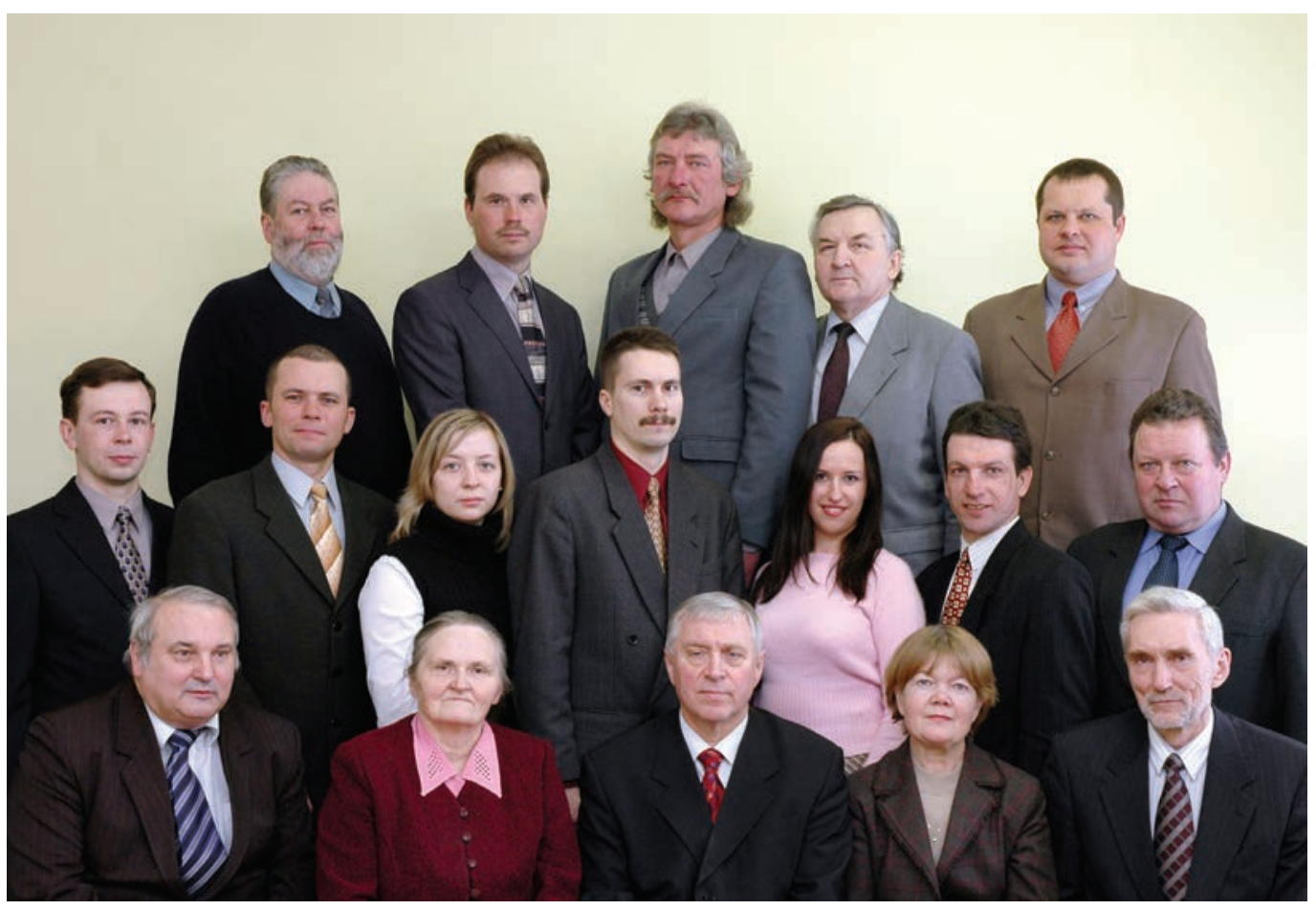

Iš kaires j dešinę pirmoje eilejje:

doc. dr. Ivanas Višniakas, reikalų tvarkytoja Vladislava Juodeliené, katedros vedejas prof. habil. dr. Algirdas Vaclovas Valiulis, asistente Danute Ščekaturoviene, doc. dr. Jonas Bendikas;

antroje eileje:

doc. dr. Irmantas Gedzevičius, meistras Tomas Kaminskas, meistre Rasa Vaikšnoraite, doc. dr. Nikolaj Višniakov, meistre Jūrate Budreikaitè, doc. dr. Vitalijus Rudzinskas, lab. vedëjas Leonas Vičiulis;

trečioje eilëje:

doc. dr. Jevgenijus Ščemeliovas, doc. dr. Olegas Černašejus, meistras Gintaras Krisiūnas, asist. Česlovas Kazakevičius, dokt. Valentinas Varnauskas

Katedra ịkurta 1960 m. Iš pradžių tai buvo Kauno politechnikos instituto Vilniaus filialo Metalų apdirbimo katedra. 1969 m. įsteigus Vilniaus inžinerinį statybos institutą buvo pavadinta Metalų technologijos katedra, rengianti suvirinimo specialybès inžinierius. Nuo 1990 m. pavadinta Metalų technologijos ir suvirinimo katedra, nuo 1993 m. - Medžiagotyros ir suvirinimo katedra. Šiuo metu katedra rengia medžiagotyros ir suvirinimo specialybès bakalaurus, magistrus ir medžiagų inžinerijos daktarus.

Katedros vedejjai: 1960-1974 m. - t. m. k. doc. Borisas Liaudis, 1975-1985 m. - doc. dr. Algimantas Šriupša, 1986-1989 m. - doc. dr. Algirdas Vaclovas Valiulis, 1990-1997 m. - doc. dr. Leonas Keblas, 1997-1998 m. - doc. dr. Valentas Juodelis, 1998-1999 m. - doc. dr. Stasys Glèbus, 1999-2001 m. - doc. dr. Jevgenijus Ščemeliovas, nuo 2001 m. iki dabar - prof. habil. dr. Algirdas Vaclovas Valiulis. 


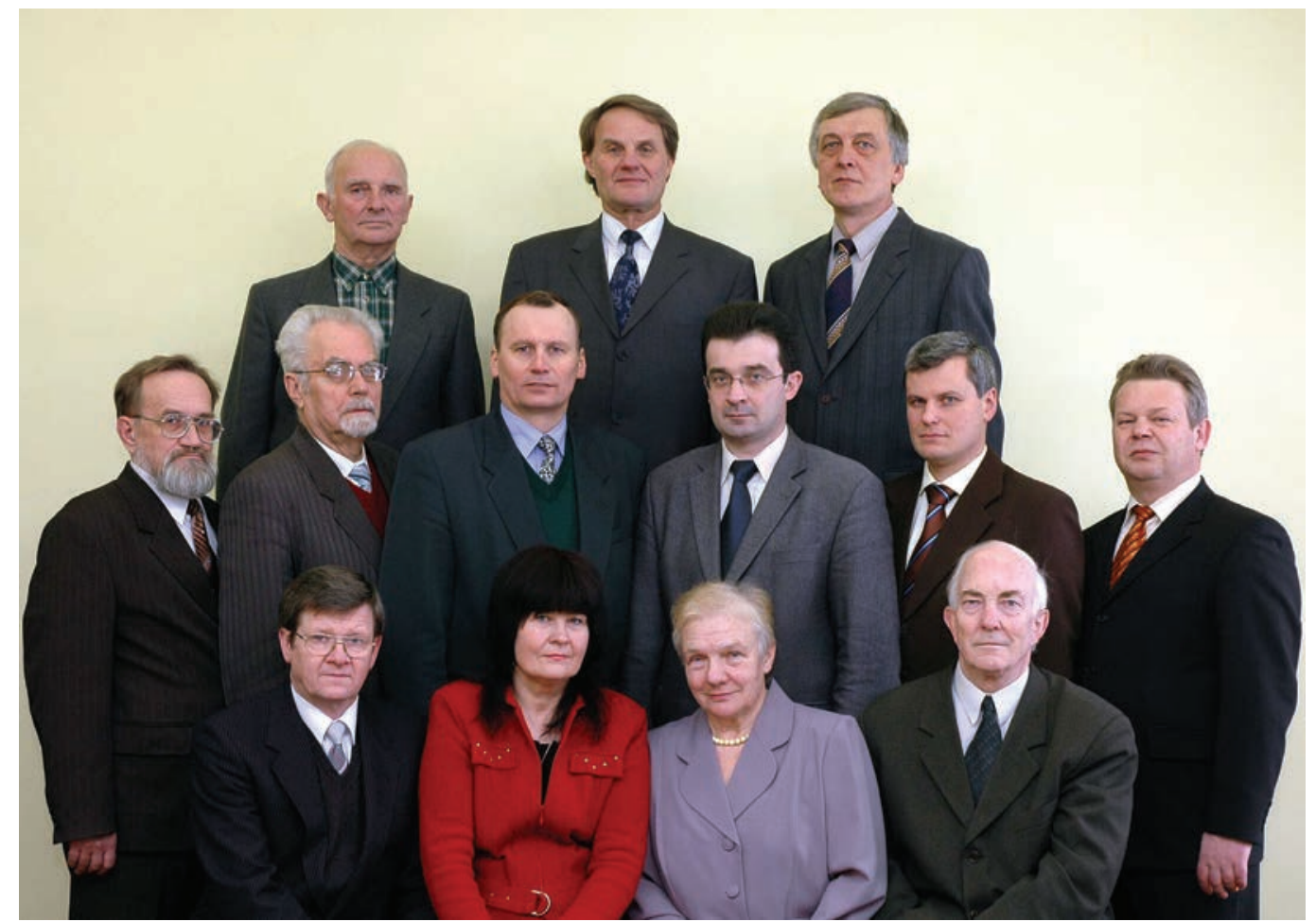

Iš kairès j̇ dešine pirmoje eilejje:

katedros vedejjas doc. (e. prof. p.) dr. Vytautas Turla, reikalų tvarkytofa fil. Raimonda Bobiniené, asist. inž. Marija Mudèniené, prof. habil. dr. Vytautas Kazimieras Augustaitis;

antroje eileje:

lekt. dr. Vladimir Gičan, doc. dr. Donatas Jonas Sidaravičius, doc. dr. Rimas Maskeliūnas, doc. dr. Igor Iljin, doc. dr. Nikolaj Šešok, doc. dr. Eugenijus Jurkonis;

trečioje eileje:

poligrafinių mašinų mok. lab. vedëjas inž. Aleksandras Skapas, doc. dr. Leonas Zubavičius, taikomosios mechanikos ir mašinų elementų mok. lab. vedëjas Virgilijus Krisiūnas

Poligrafinių mašinų katedra įkurta 1993 m., reorganizavus bendrąją techninę Mašinų teorijos katedrą, kuri savo ruožtu buvo ịkurta $1962 \mathrm{~m}$. rugsëjo $1 \mathrm{~d}$. Poligrafinių mašinų katedrą įkurti VGTU skatino tai, kad sovietmečiu poligrafijos specialistai, turintys aukštajj̨ išsilavinimą, Lietuvoje nebuvo rengiami.

Katedros vedejais dirbo: 1962-1970 m. - doc. dr. D. Maciulevičius, 1970-1987 m. - prof. habil. dr. A. Kavolelis, nuo 1987 m. iki dabar - dr. doc. V. Turla. 


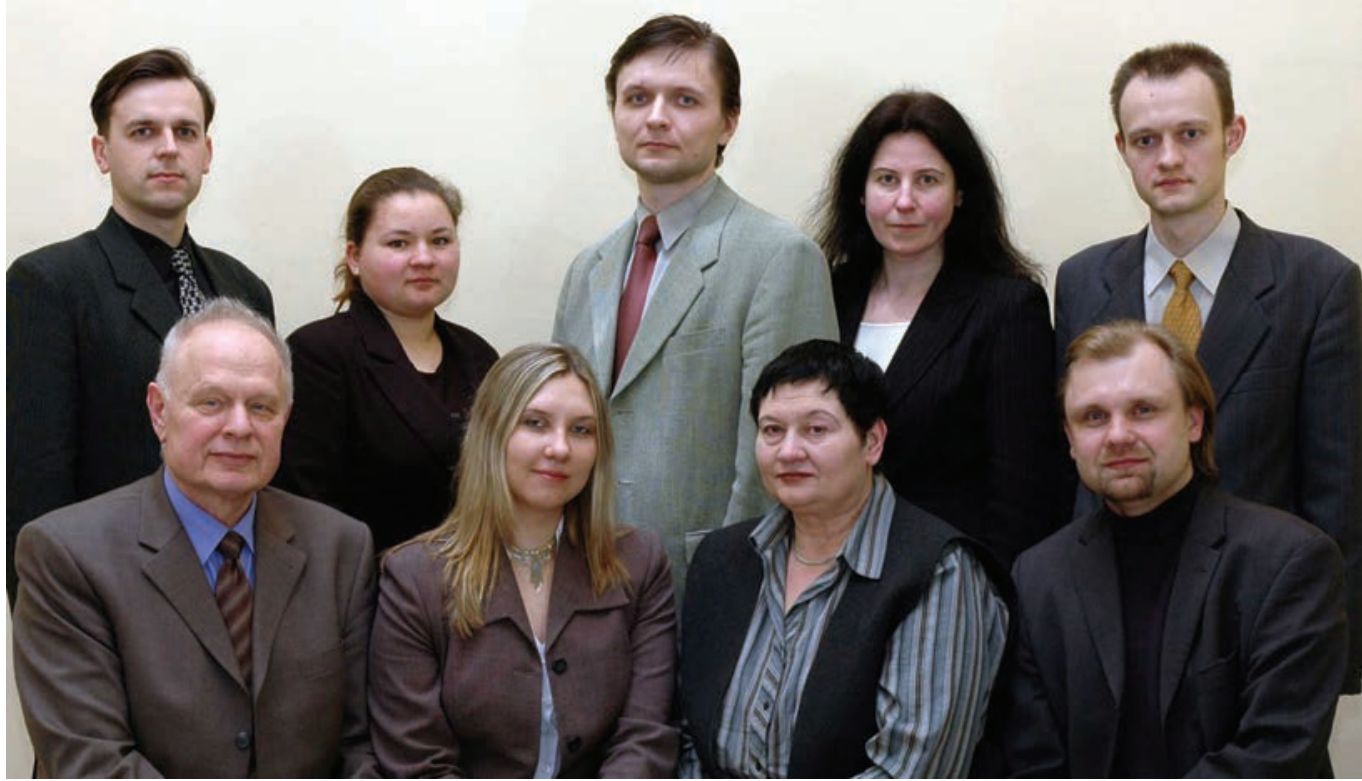

Iš kaires j dešne pirmoje eileje:

doc. dr. Bronius Jančiauskas, asistentė Edita Kazlauskiené, doc. dr. Irena Zabielavičiené, katedros vedejjas doc. dr. Rolandas Strazdas;

antroje eileje:

dokt. Donatas Bertašius, reikalų tvarkytoja Rasa Vaitiekauskaite,

doc. dr. Eligijus Toločka, doc. dr. Dalia Treigiene, dr. Augustinas Maceika

Mechanikos fakulteto Pramonés įmonių valdymo katedra įsteigta $1996 \mathrm{~m}$. spalio $29 \mathrm{~d}$. Pramonès imonių valdymo katedra rengia pramonés inžinerijos bakalaurus, pramonès inžinerijos mokslo magistrus, vadybos ir verslo administravimo magistrus.

Katedra per aštuonerius savo gyvavimo metus išleido 177 bakalaurus, 129 magistrus, studijavusius pramonès įmonių vadybą, ir 64 magistrus, anglų kalba studijavusius pramonés inžineriją ir vadybą.

İsteigtos katedros pirmieji etatiniai darbuotojai buvo doc. dr. A. Lubys ir vyr. asist. dr. I. Zabielavičienè. Šiuo metu katedroje dirba jau 15 dèstytojų.

Katedros vedejais dirbo: 1997-1999 m. doc. dr. A. Lubys, 1999-2005 m. doc. dr. B. Jančiauskas, nuo 2005 m. iki dabar - doc. dr. R. Strazdas 


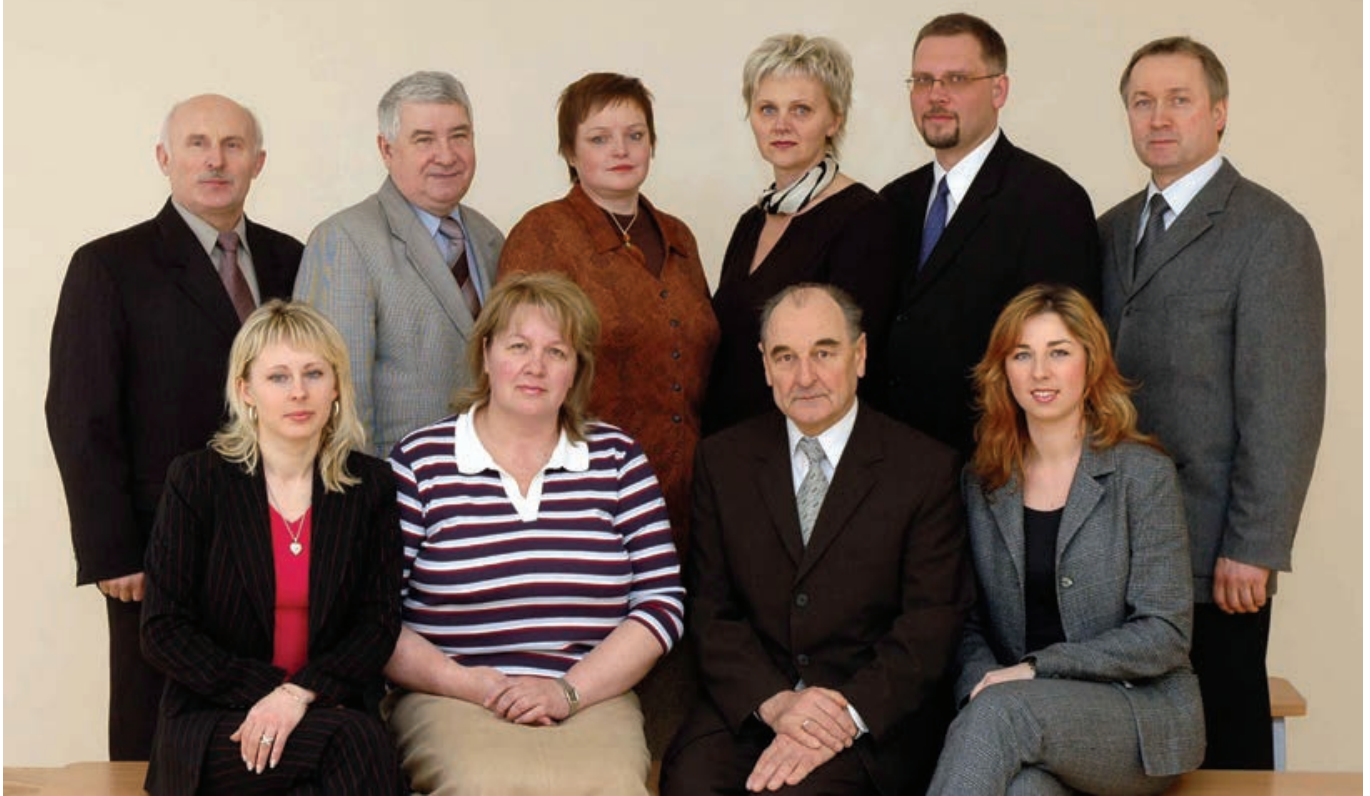

Iš kaires j dešine pirmoje eileje:

vadybininke Rita Lenčiauskienè, administratore mgr. Alma Vaitoniené, dekanas prof. dr. Povilas Vainiūnas, vadybininkè mgr. Jurgita Ramanauskaité; antroje eileje:

prodekanas doc. dr. Algirdas Jonas Notkus, prodekanas prof. dr. Stanislovas Kalanta, vadybininkè Dalia Kamblevičienè, vadybininkė Ligita Elona Sliesoraitiené, prodekanas doc. dr. Arnoldas Šneideris, prodekanas doc. dr. Algirdas Juozapaitis

Statybos inžinierių rengimo pradžia Lietuvoje ir Statybos fakulteto atsiradimas susiję su Aukštųjų kursų Kaune įkūrimu 1920 m., vèliau - su Technikos fakultetu Lietuvos universitete, o nuo 1930 m. - Vytauto Didžiojo universitete. 1940 m. fakultetas savo statusą igijo ir dabartinị pavadinimą gavo Kauno Vytauto Didžiojo universitete. 1969 m. Statybos fakultetas persikèle ị Vilnių ir tapo naujai įkurto Vilniaus inžinerinio statybos instituto dalimi.

Statybos fakulteto dekanais dirbo: 1970-1980 m - doc. dr. Viktoras Krušinskas, 1980-1987 m. prof. habil. dr. Algirdas Čižas, nuo1987 m. iki dabar - prof. dr. Povilas Vainiūnas. 
DARBO IR GAISRINĖS SAUGOS KATEDRA

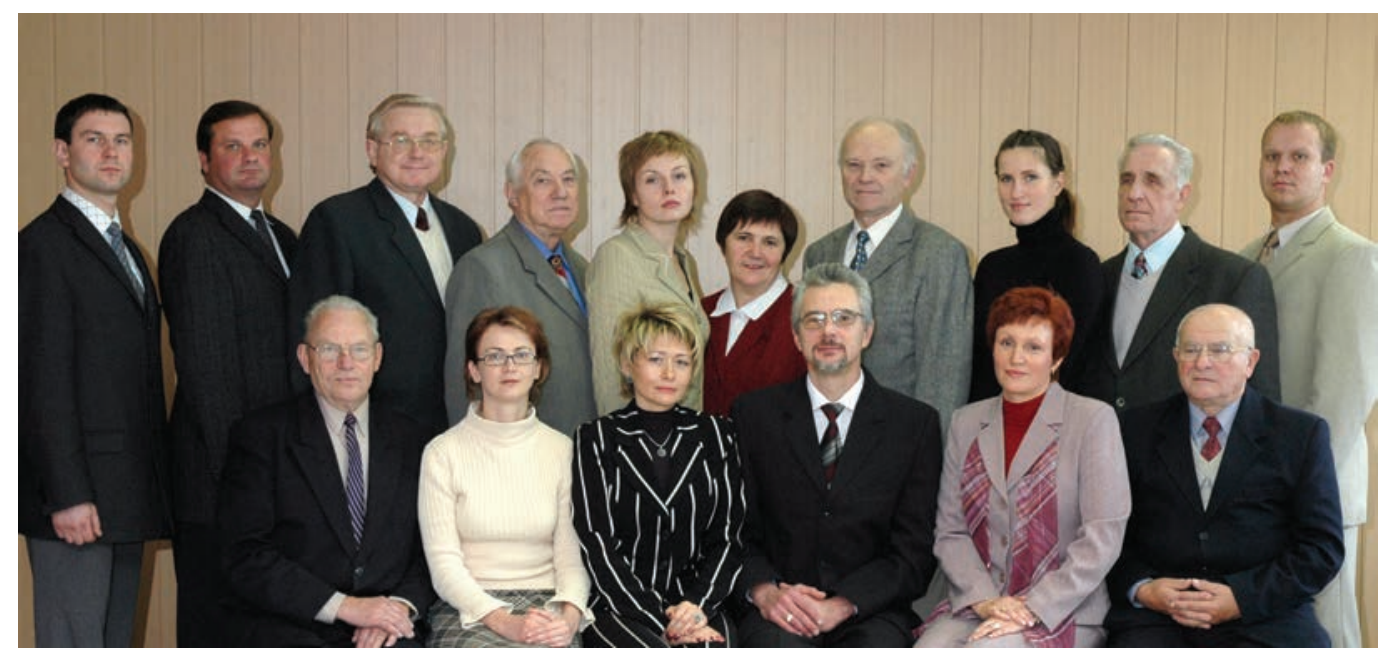

Iš kaires j dešine pirmoje eileje:

doc. dr. Vytautas Nainys, jaunesn. mokslo darbuotoja Ela Jarmolajeva, lab. vedejja Valentina Leonova, katedros vedejjas doc. dr. Ritoldas Sukys, reikalų tvarkytoja Natalija Baraškova, lekt. Romualdas Dubonis;

antroje eileje:

dr. Andrius Žukas, dr. Valmantas Girnius, prof. habil. dr. Romualdas Mačiulaitis, doc. dr. Petras Čyras, dokt. Audra Stankiuviené, doc. dr. Elena Zalieckiené, doc. dr. Kazys Algirdas Kaminskas, laborante Asta Žydelyte, techn. asistentas Jonas Mašnauskas, dokt. Donatas Gurevičius

1985 m. birželio 18 d. ịsteigta Darbo ir aplinkos apsaugos katedra. Tai ir buvo dabartinés Darbo ir gaisrines saugos katedros gimtadienis.

Pirmuoju katedros vedeju skiriamas doc. dr. Petras Čyras. Jis šias pareigas èjo ilgiausiai -iki $2002 \mathrm{~m}$. 1995-1996 m. keturis mènesius katedrai vadovavo habil. dr. Romualdas Mačiulaitis.

$2002 \mathrm{~m}$. Darbo ir gaisrinès saugos katedros vedëju išrenkamas doc. dr. Ritoldas Šukys. 1992 m. katedrai suskilus ị dvi, susikūre nauja Darbo ir gaisrinès saugos katedra.

$1992 \mathrm{~m}$. rugsejo $1 \mathrm{~d}$. pradètos studijos pagal naują gaisrines saugos programą.

Pirmais studiju metais degimo ir gesinimo teorijos laboratorinius darbus studentai atlikdavo departamento Gaisrinių tyrimų centre.

Mokomąją praktiką katedros studentai atlieka Priešgaisrinès apsaugos ir gelbëjimo departamento Ugniagesių gelbètojų mokykloje. Vèlesniais studijų metais dvi gamybines praktikas atlieka Priešgaisrinès apsaugos ir gelbejjimo departamento padaliniuose.

1995 m. išleista pirmoji 19 absolventų gaisrinès saugos bakalaurų laida.

$1996 \mathrm{~m}$. Darbo ir gaisrinès saugos katedroje buvo pradètos ergonomikos studijos.

$2002 \mathrm{~m}$. pradèti rengti saugos inžinerijos magistrai.

Katedros darbuotojai gilinasi į gaisrų ir nelaimingu atsitikimų priežastis ir prevenciją. Šia tema jie parašè ne vieną mokslinị straipsnị, metodines rekomendacijas, skaite pranešimus šalies ir tarptautinèse konferencijose.

Kasmet katedros mokslininkai atlieka kvalifikacinius ir užsakomuosius mokslo tiriamuosius darbus.

1995 m. prie katedros įkurtas universitetinis Žmonių saugos mokslo institutas.

Per visus katedros darbo metus jau išleista 10 bakalaurų ir viena saugos inžinerijos ir aštuonios ergonomikos magistrų laidos. I̦ savarankišką veiklą išlydèti 344 gaisrinès saugos bakalaurai ir 11 saugos inžinerijos bei 45 ergonomikos magistrai. 
GELŽBETONINIŲ IR MŪRINIŲ

KONSTRUKCIJU

KATEDRA

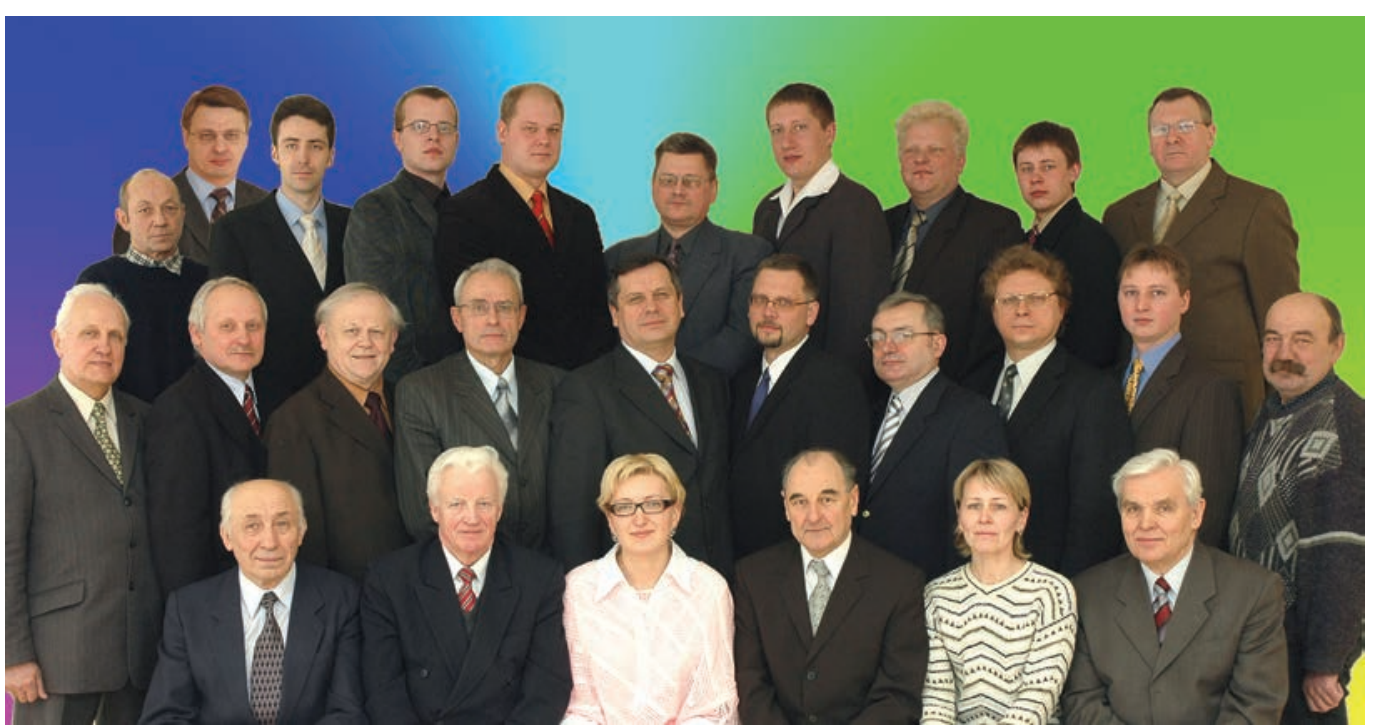

Iš kaires j dešine pirmoje eilëje:

doc. dr. Romualdas Vadlūga, prof. habil. dr. Gediminas Marčiukaitis, techninè asistentė Daiva Jurènienè, katedros vedëjas prof. dr. Povilas Vainiūnas, reikalų tvarkytoja Rima Juršenniené, doc. dr. Petras Pukelis;

antroje eileje:

doc. dr. Vidmantas Jokūbaitis, doc. dr. Juozas Valivonis, doc. dr. Benediktas Užpolevičius, doc. dr. Arvydas Jurkša, doc. dr. Vytautas Papinigis, doc. dr. Arnoldas Šneideris, doc. dr. Bronius Jonaitis, doc. dr. Egidijus Rytas Vaidogas, asist. Linas Juknevičius, meistras Vadim Lazutkon;

trečioje eileje:

meistras Vitolis Kučinskas, doc. dr. Vladimir Popov, dokt. Remigijus Šalna, dokt. Tomas Skuturna, dokt. Dainius Šakinis, meistras Juozas Gervè,

dokt. Mindaugas Grigonis, lab. vedejjas dr. Gintaras Jurkenas,

dokt. Žydrūnas Kuodis, laborantas Jonas Šeferis

1922-03-24 patvirtinus Lietuvos universiteto statutą, Technikos fakultetą sudare 17 katedrų, tačiau jų sąraše konstrukcinių katedrų nebuvo. Artimiausia pagal profilį buvo tiltų katedra, kuriai buvo pavesta desstyti akmeninius, medinius, geležinius ir gelžbetoninius tiltus ir rengti projektus.

Gelžbetonio disciplinai buvo skirta vienodai mokomojo laiko statybos, mechanikos, elektrotechnikos ir chemines technologijos specialybès studentams.

Tarybų Sąungai okupavus Lietuvą, Statybos fakultete vietoje Tiltų katedros įkurta Tiltų ir geležinių konstrukcijų katedra. Katedrai vadovavo doc. J. Kuodis. Jis pirmasis iš Lietuvos gelžbetonininkų $1936 \mathrm{~m}$. Vienos aukštesniojoje technikos mokykloje apgyne technikos mokslų daktaro disertaciją.

1944-08-01 Raudonoji armija vel okupavo Kauną. Nors karas tebesitęsè, rugpjūčio 4 d. atkurtas VDU. Statybos fakultete buvo 14 katedrų. Tarp jų - gelžbetoninių konstrukcijų ir tiltų (vyr. desst. A. Rozenbliumas) bei Metalinių konstrukcijų ir tiltų (doc. A. Bistrickas).

Vilniuje, KPI vakariniame skyriuje, atidarytame 1956 m., gelžbetoninių konstrukcijų disciplina buvo destoma Statybos katedroje.

Statybos katedra nuo 1965 m. rugsëjo 1 d. padalyta į dvi: Miestų statybos (vedëjas doc. V. Kriščiūnas) ir Statybinių konstrukcijų (vedejjas prof. A. Kudzys).

Pertvarkius KPI Vilniaus filialąi Vilniaus inžinerinį statybos institutą (VISI), nuo statybinių konstrukcijų katedros $1969 \mathrm{~m}$. buvo atskirta jos dalis (déstytojai, dèstę metalines, medines ir plastmasines konstrukcijas) ir pavadinta Specialiųjų konstrukcijų katedra (vedëjas prof. A. Rozenbliumas).

Nuo 1972 m. statybinių konstrukcijų katedra pavadinama Gelžbetoninių konstrukcijų katedra, kuri tapo vieninteliu koncentruotu moksliniu ir mokymo padaliniu gelžbetoninių ir mūrinių konstrukcijų srityje Lietuvoje. Todel 1998 m. ji buvo pavadinta Gelžbetoninių ir mūrinių konstrukcijų katedra. 


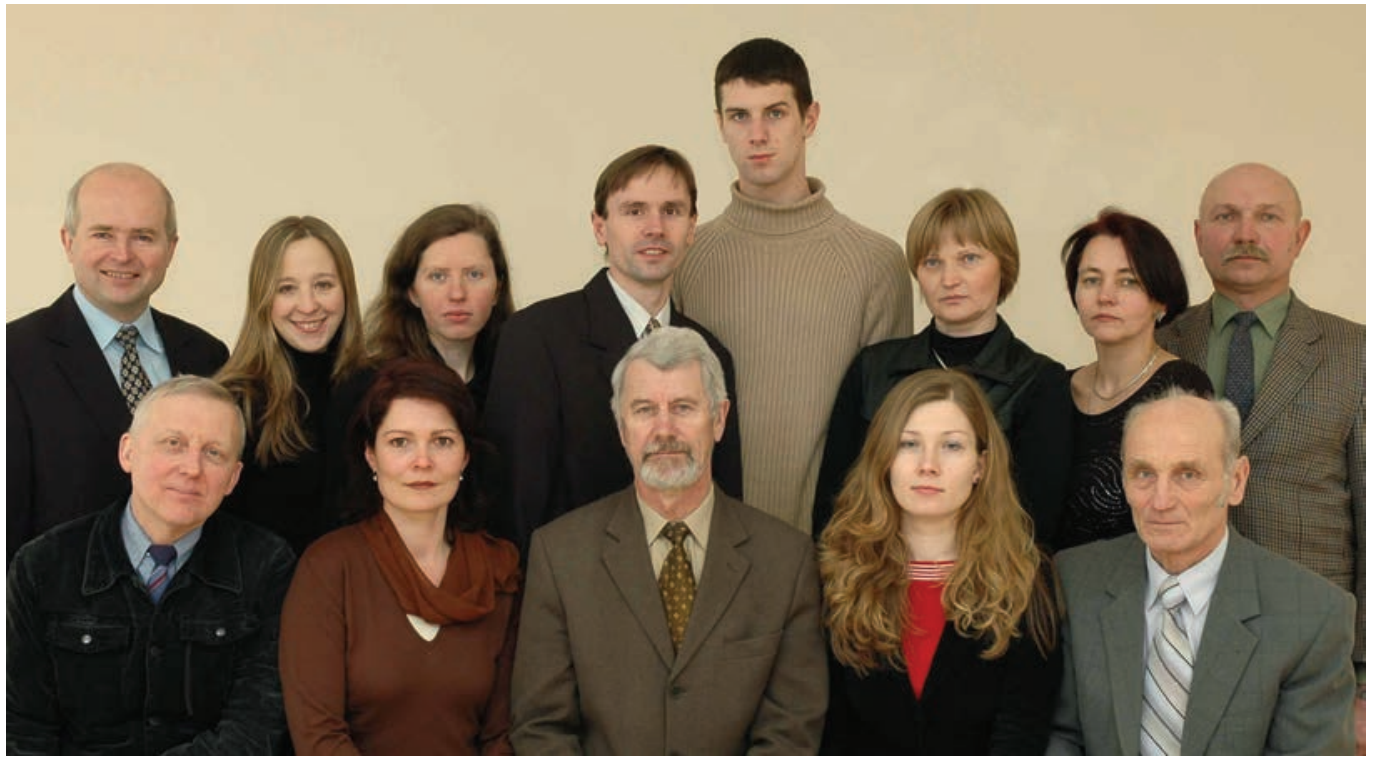

Iš kairès j dešine pirmoje eileje:

doc. dr. Jurgis Medzvieckas, vadybininkè Elena Matulevičiené,

katedros vedejjas doc. dr. Vincentas Stragys, dokt. Neringa Vervečkaite, doc. dr. Jonas Amšiejus;

antroje eileje:

doc. dr. Rimas Mackevičius, doc. dr. Evelina Brannvall, doc. dr. Danute Sližyté, doc. dr. Darius Markauskas, laborantas Simas Sidauga, asist. Sabina Prušinskiené, reikalų tvarkytoja Alina Lukšeniené, lab. vedëjas Zenonas Juška

Geotechnikos katedros veiklos pradžia yra 1940 m., kai Kaune, Vytauto Didžiojo universitete, buvo issteigta Inžinerinés geologijos katedra. Po $1950 \mathrm{~m}$. reformos ji buvo KPI, $1970 \mathrm{~m}$. perkelta i VISI ir pavadinta Pagrindų ir pamatų katedra. $1992 \mathrm{~m}$. VGTU ši katedra pavadinta Geotechnikos katedra. $1968 \mathrm{~m}$. katedroje įsteigta žinybinè Pagrindų ir pamatų mokslo laboratorija, $1971 \mathrm{~m}$. ji taip pat perkelta ị VISI, nuo $1992 \mathrm{~m}$. vadinama geotechnikos mokslo laboratorija. Katedros vedejai - prof. Mykolas Kaveckis (1950-1968), prof. Jonas Šimkus (1968-1980), prof. habil. dr. Antanas Alikonis (1980-1996), nuo 1996 m. - doc. dr. Vincentas Stragys. Pedagoginis katedros darbas - pagrindinès bakalauro ir magistrantūros studijos. Bakalauro studijose destomos trys pagrindines geotechnikos disciplinos: inžinerinè geologija, gruntų mechanika, pagrindai ir pamatai. Skaitomos ir pasirenkamos specialiosios disciplinos. Katedroje yra geotechnikos specialybes doktorantūra. Katedros iniciatyva nuo $1968 \mathrm{~m}$. vyksta Baltijos geotechnikos konferencija. Ji rengiama kas 3-5 metai vis kitoje Baltijos šalyje. $2000 \mathrm{~m}$. Pernu (Estija) vyko devintoji konferencija.

Dauguma katedros desstytojų aktyviai bendradarbiauja su užsienio studijų ir mokslo institucijomis. V. Stragys stažavosi Tronheimo (Norvegija) aukštojoje technikos mokykloje ir Geotechnikos institute (1980). Déste Lusakos (Zambija) universitete (1989-1991). Kaip Jungtinių Tautų savanoris dalyvavo Asmaros (Eritrëja) universitete atkuriant inžinerines studijas (1994-1996). Yra SOCRATES/ERASMUS teminių tinklų projekto EUCEET vykdytojas. J. Medzvieckas $1993 \mathrm{~m}$. Danijos geotechnikos institute išklausè kursą „Geotechninis projektavimas pagal EC7“, 1996 m. Kembridžo universitete - kursą ,,Geotechninis projektavimas naudojant baigtinių elementų programą „,SAGE CRISP“". L. Furmonavičius yra dviejų monografijų ir dviejų išradimų bendraautoris, Lietuvos geotechnikos draugijos steigejas (1990 m.), pirmasis draugijos prezidentas. Jo rūpesčiu draugija priimta i Tarptautinę gruntų mechanikos ir geotechnikos inžinerijos draugiją (ISSMGI), jis yra tos draugijos 18-ojo technikos komiteto (poliniai pamatai) narys. Jo pastangomis Geotechnikos laboratorija tapo programos FRAMEWORK-5 temos „Techniškai optimali polių koncepcija“ vykdytoja. 
INŽINERINĖS

ARCHITEKTŪROS KATEDRA

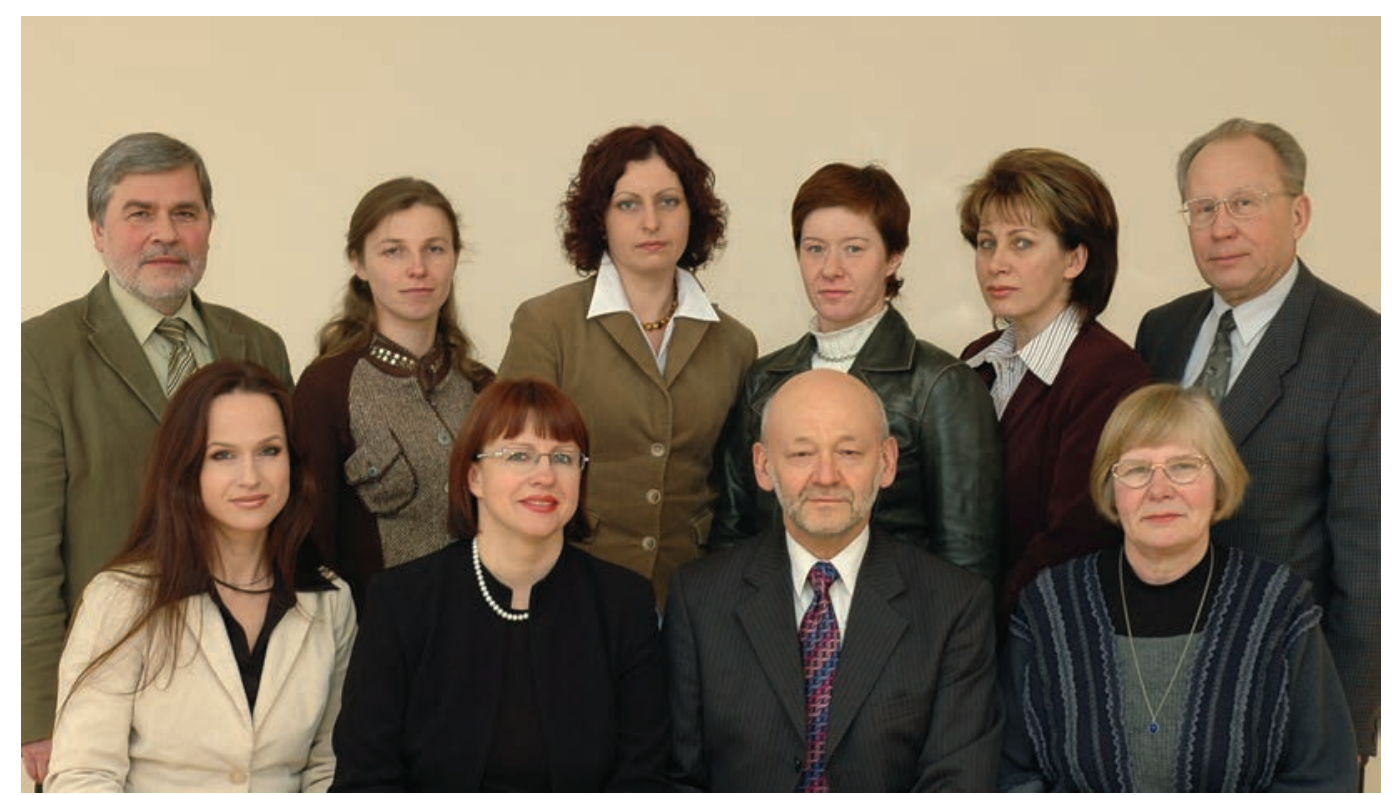

Iš kairés j dešine pirmoje eileje:

asistente Meda Dilinskiené, doc. dr. Audronè Endriukaityté, katedros vedejjas prof. habil. dr. Josifas Parasonis, doc. Regina Gaušiené; antroje eileje:

doc. Juozapas Šipalis, dokt. Inga Garnytė-Sapranavičienè, dokt. Jūrate Mačiulytė, doc. dr. Aiste Andriušyté, reikalų tvarkytoja Irena Freitakiené, lekt. Liudvikas Antanas Skaržinskas

Inžinerinès architektūros katedra įsteigta $2000 \mathrm{~m}$. liepos 4 d. VGTU tarybos posedžio nutarimu ir funkcionuoja nuo $2000 \mathrm{~m}$. rugsèjo $1 \mathrm{~d}$. Katedra yra profilinè. 


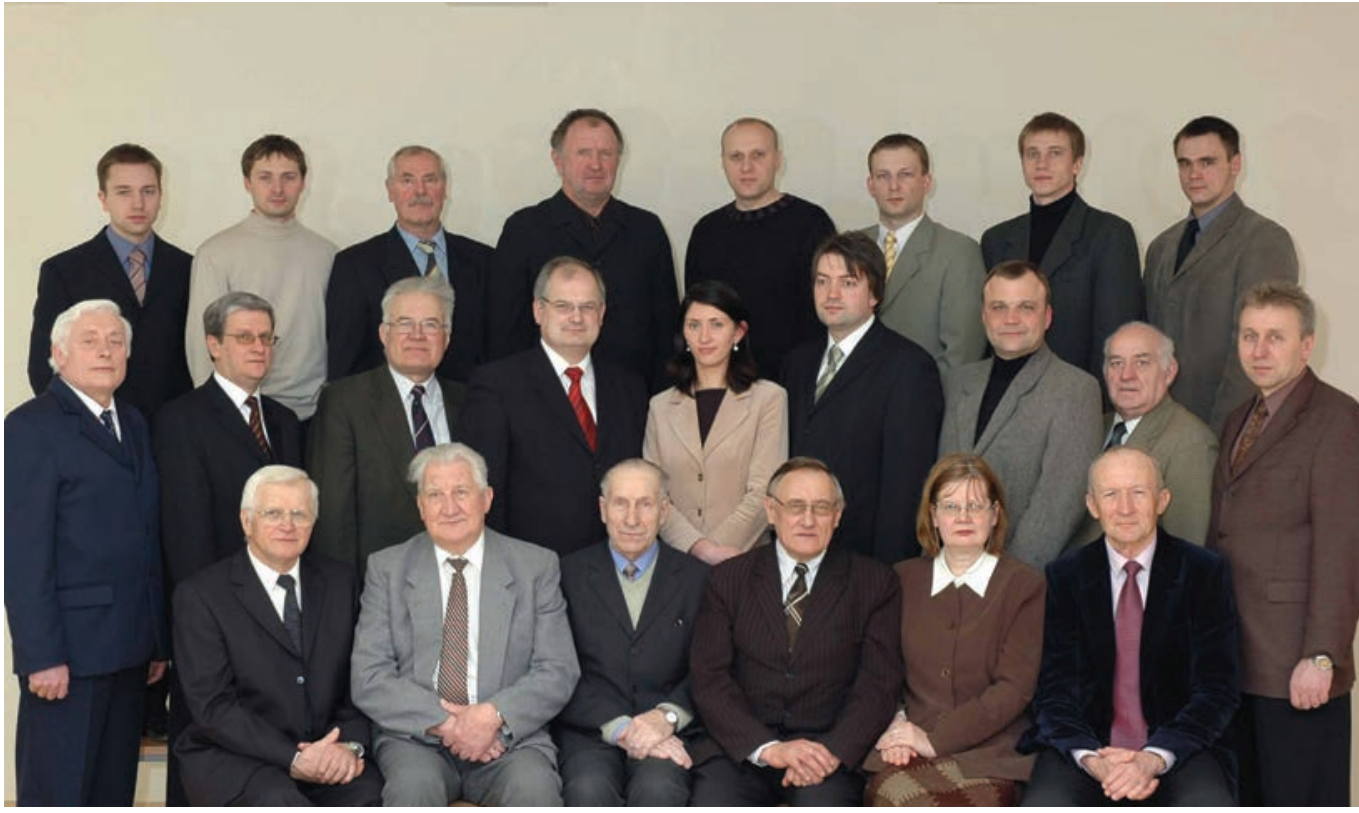

Iš kaires j dešine pirmoje eilëje:

doc. dr. Vladas Vaitkevičius (emeritas), doc. dr. Algirdas Valentinavičius (emeritas), doc. dr. Kazimieras Šapalas (emeritas), katedros vedejas prof. habil. dr. Audronis Kazimieras Kvedaras, reikalų tvarkytoja Nijolè Dzikaite, doc. dr. Jonas Juozaitis (emeritas);

antroje eileje:

doc. dr. Balys Valiūnas, VGTU kancleris doc. dr. Arūnas Komka, doc. dr. Rimantas Čechavičius (emeritas),

VGTU studijų prorektorius doc. dr. Alfonsas Daniūnas, vadybininkè Rima Miklušyte, asist. dr. Kęstutis Gurkšnys, doc. dr. Gintas Šaučiuvenas, inž. Jonas Arūnas Pranevičius (emeritas), prof. dr. Antanas Šapalas; trečioje eilëje:

dokt. Paulius Bagdonas, doc. dr. Vaidotas Šapalas, lab. vedëjas Algirdas Juzulènas, meistras Jonas Kozičius, doc. dr. Viačeslavas Šaraškinas, dokt. Žygimantas Blaževičius, dokt. Saulius Kavaliauskas, dokt. Artiomas Kuranovas

Metaliniu ir medinių konstrukcijų katedra Vilniaus Gedimino technikos universitete veikia nuo 1995 m., kai buvo pakeistas buvęs Metaliniu konstrukciju katedros pavadinimas, suteiktas jai 1972 m. Taip buvo pavadinta Specialiụjų konstrukciju katedra, 1969 m. rugpjūčio 1 d. įsteigus Vilniaus inžinerinį statybos institutą. Katedra yra profilinè. Ji specializuota metalinių, medinių ir kompozitinių konstrukcijų ir tiltų kursams pagrindinių akademinių ir profesinių, specializuotųjų profesinių, magistrantūros ir doktorantūros studijų studentams dèstyti tas specialybes, kurių programose numatyti šios srities dalykai. Be to, katedra vadovauja baigiamiesiems ir diplominiams darbams bei projektams, magistrantūros tezėms, doktorantų disertacijoms.

Katedros vedejjais buvo: 1969-1972 m. prof. habil. dr. Anatolijus Rozenbliumas, 1973-1979 m. doc. dr. Algirdas Valentinavičius, doc. dr. 1979-1984 m. - Kazimieras Šapalas, 1984-1989 m. doc. dr. Vladas Vaitkevičius, 1989-1994 m. - doc. dr. Jonas Juozaitis, nuo 1994 iki dabar - doc. dr. Audronis Kazimieras Kvedaras. 


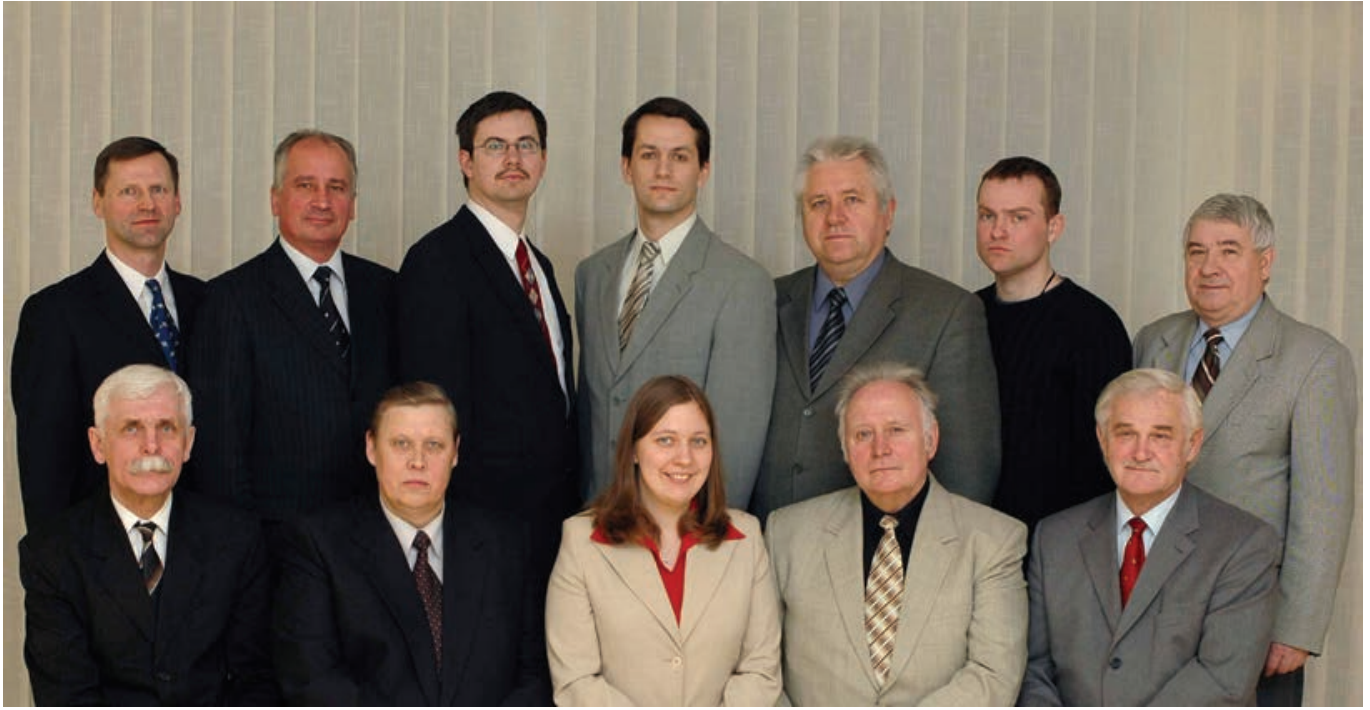

Iš kaires j dešine pirmoje eileje:

doc. dr. Juozas Nagevičius, katedros vedëjas prof. habil. dr. Juozas Atkočiūnas, doc. dr. Dovile Merkevičiūté, doc. dr. Antanas Krutinis, prof. dr. Romanas Karkauskas;

antroje eileje:

prof. dr. Arnoldas Norkus, doc. dr. Liudvikas Rimkus,

reikalų tvarkytojas Remigijus Ašmenskas, dokt. Artūras Venskus,

doc. dr. Valentinas Skaržauskas, jaunesn. mokslo darb. Andrius Grigusevičius,

prof. dr. Stanislovas Kalanta

Mechanikos mokslo pradžia Lietuvoje glaudžiai susijusi su Vilniaus universitetu, ikkurtu 1579 m. Universitete buvo skaitomas kietųjų kūnų ir skysčiu mechanikos kursas.

Nepriklausomoje Lietuvoje statybinès mechanikos plètoté susijusi su 1922-02-16 d. ịsteigtu Lietuvos universitetu Kaune. Lietuvos Seimo 1922-04-12 nutarimu universiteto Technikos fakultete ikuriamas Statybos skyrius ir Statybinès mechanikos katedra.

Pradedant 1960 m. statybinès mechanikos mokslo centras pamažu persikelia ị Vilnių. 1969 m. ik kurtas Vilniaus inžinerinis statybos institutas (dabar VGTU), kuriame savo veiklą plètojo lietuviškos optimizacinès statybinès mechanikos pradininko A. Čyro vadovaujama Statybinès mechanikos katedra. Jam vadovaujant apgintos 27 mokslų daktaro disertacijos, o D. Maciulevičius (1969), A. Čižas (1974), A. Borkowski (1978), R. Kačianauskas (1996) ir J. Atkočiūnas (1996) tapo habilituotais daktarais. Optimizuojant konstrukcijas buvo taikoma matematinio programavimo dualumo teorija ir metodai, rezultatai buvo skelbiami „Lietuvos mechanikos rinkinyje“(1978-1989). VGTU Statybines mechanikos katedra organizavo tarptautines konferencijas „Optimizacijos ir patikimumo problemos statybinëje mechanikoje“ (1973, 1975, 1979, 1983, 1988). Nuo $1991 \mathrm{~m}$. Statybinès mechanikos katedra kuruoja tarptautinių konferencijų „Naujos statybinés medžiagos, konstrukcijos ir technologijos“ sekciją „Konstrukcijų optimizacija ir nauji skaičiavimo metodai“.

1972-1987 m. Statybines mechanikos katedrai vadovavo prof. A. Čyras, kuris 1985 m. buvo išrinktas tikruoju Lietuvos mokslų akademijos, o 1994 m. - Lenkijos mokslų akademijos užsienio nariu.

1987-1997 m. katedrai vadovo doc. A. Krutinis. 1993 m. grupei jos mokslininkų - A. Čyrui, R. Karkauskui, A. Krutiniui, J. Atkočiūnui, S. Kalantai ir J. Nagevičiui - už statybinés mechanikos kompiuterizuoto mokymo vadovèlių komplektą paskirta Lietuvos valstybinè mokslo premija. 1997 m. katedros vedëju išrinktas prof. J. Atkočiūnas. 
STATYBINIŲ

MEDŽIAGŲ

KATEDRA

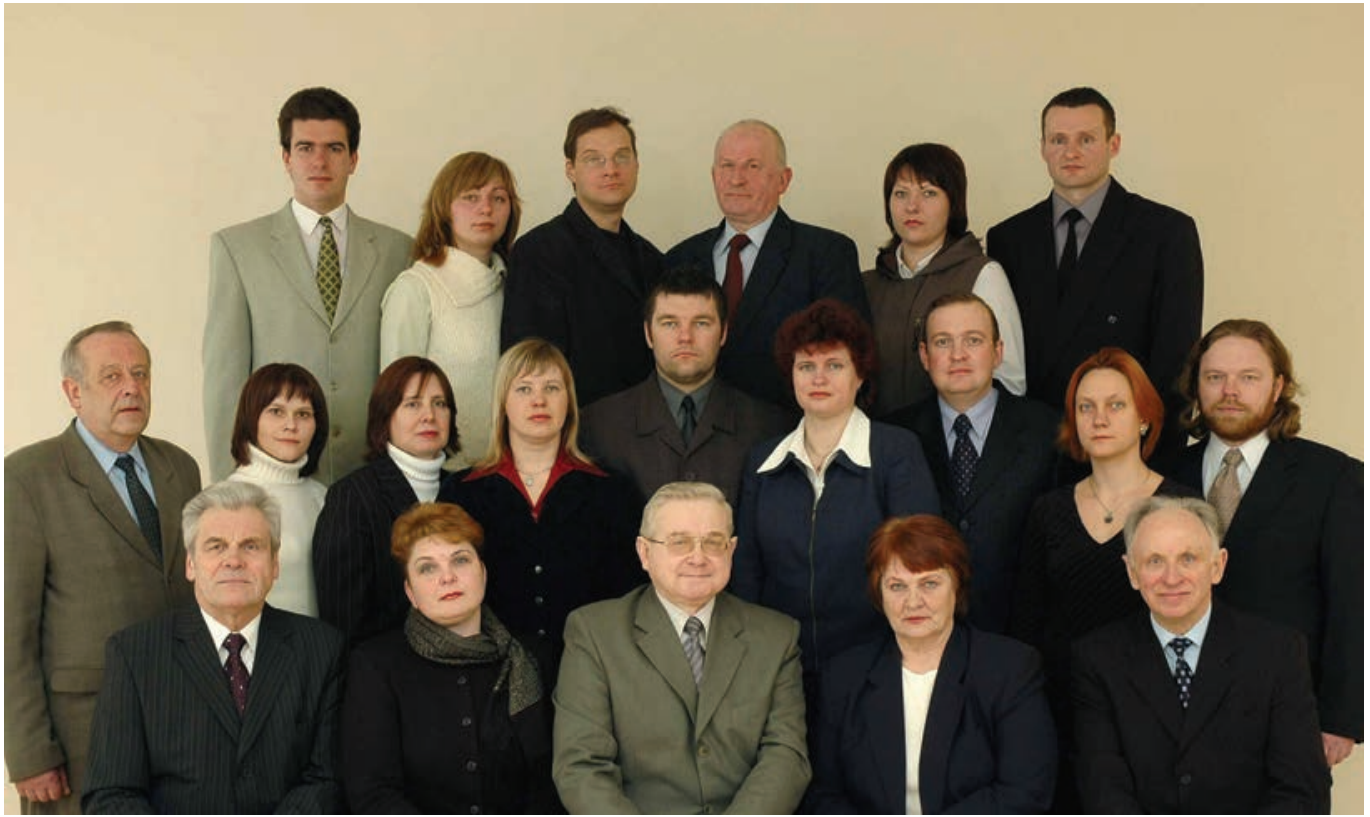

Iš kaires j dešine pirmoje eilëje:

prof. dr. Albinas Gailius, vadybininkè Irena Judickienè,

katedros vedejjas prof. habil. dr. Romualdas Mačiulaitis,

mok. lab. vedejja inž. Elvyra Atkočiūtè, doc. dr. Algimantas Pranas Naujokaitis;

antroje eileje:

doc. dr. Fabijonas Petrikaitis, dokt. Olga Kizinievič, doc. dr. Asta Kičaite,

doc. dr. Džigita Nagrockiené, asist. dr. Rimvydas Stonys,

reikalų tvarkytoja inž. Antanina Červokienè, dokt. Andrius Buska,

doc. dr. Ramune Žurauskienè, doc. dr. Valdas Balkevičius;

trečioje eileje:

doktorantas Sergejus Gaidučis, dokt. Jurgita Malaiškienè,

moksl. Darb. dr. Darius Zabulionis, mok. lab. meistras Edmundas Dirma,

mok. lab. laborantė Jolanta Grigelevičienè, asist. dr. Sigitas Vëjelis

Vilniuje statybinių medžiagų disciplina aukštojoje mokykloje pradèta destyti 1962 m. tuometinio Kauno politechnikos instituto Vilniaus filialo Chemijos katedroje. $1972 \mathrm{~m}$. Statybinių medžiagu laboratorija iš Chemijos katedros buvo perkelta į Statybos technologijos katedrą. İ šią katedrą perkelti ir statybinių medžiagų dalyko destytojai. 1975 m. buvo ịsteigta Statybinių medžiagų katedra.

Statybinių medžiagų katedros vedèjais įvairiais jos veiklos laikotarpiais buvo: 1975-1986 ir 1990-1995 m. - doc. dr. Albinas Gailius, 1986-1990 m. - doc. dr. Algimantas Pranas Naujokaitis, 1995-1996 m. - prof. habil. dr. Algimantas Kazragis, nuo 1996 mety iki dabar - prof. habil. dr. Romualdas Mačiulaitis.

1993 m. katedroje studijas baigè 19 pirmųjų inžinierių technologų.

1995 m. magistro tezes apgyne pirmieji du magistrantai. Jų kasmet daugëja.

1997 m. buvo parengtos ir patvirtintos naujos pagrindinių studijų bakalaurų ir magistrų programos

2001 m. sukuriamos naujos studijų kryptys. Bakalaurų ir magistrų programos Statybos medžiagos ir dirbiniai priskiriamos statybos inžinerijos studiju krypčiai. Studiju programa Statybinès medžiagos magistrams priskiriama medžiagų mokslo studijų krypčiai.

$2005 \mathrm{~m}$. Statybos fakultete Statybinių medžiagų katedroje viena mokomųjų laboratorijų pavadinta profesoriaus Prano Jodeles vadru.

Statybinių medžiagų mokslo pradininku Lietuvoje laikomas profesorius Pranas Juodele (1871-1955). Jie ne tik pirmasis iš vietinių žaliavu pradëjo kurti statybines medžiagas, jų technologijas, tirti jas, bet ir rūpinosi Lietuvos statybinių medžiagų gamybos problemų sprendimu, daug dèmesio skyrẻ statybines medžiagas išmanačių aukštos kvalifikacijos specialistų rengimui. 


\section{STATYBOS}

EKONOMIKOS IR NEKILNOJAMOJO TURTO

VADYBOS

KATEDRA

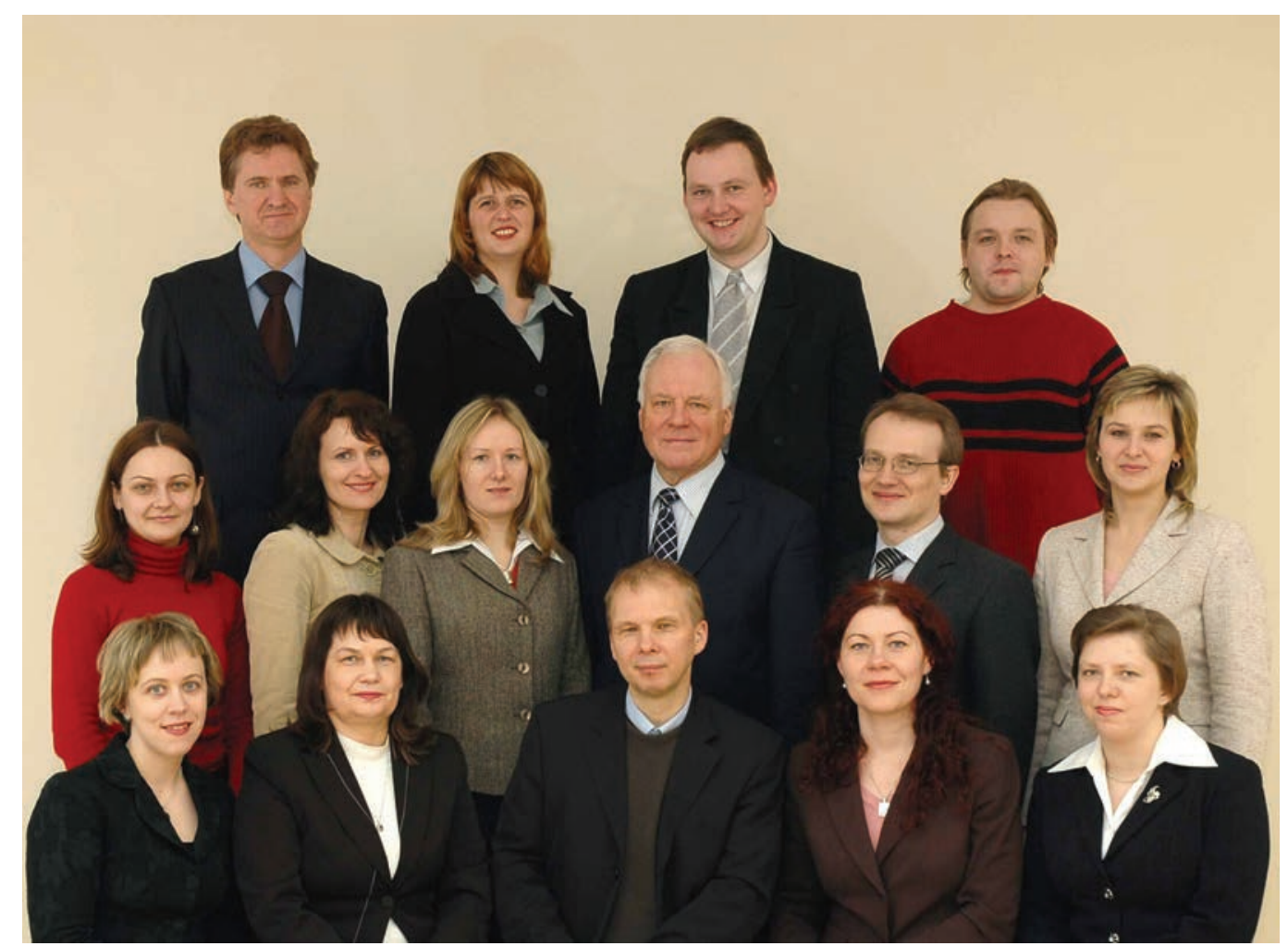

Iš kaires j dešine pirmoje eilejje:

reikalų tvarkytoja Jurga Naimavičené, vadybininke Silva Rimkuviené, katedros vedëjas prof. habil. dr. Artūras Kaklauskas, doc. dr. Nerija Banaitiené, doc. dr. Natalija Lepkova;

antroje eileje:

tyrèja Aistè Mickaitytè, asit. Loreta Kanapeckienè, lab. vedëja Neringa Gudiené, doc. dr. Gintautas Satkauskas, doc. dr. Audrius Banaitis, dokt. Vita Urbonavičiene;; trečioje eilëje:

doc. dr. Saulius Raslanas, asist. Eva Trinkūnienè, dokt. Mindaugas Krutinis, doc. dr. Andrius Gulbinas 
STATYBOS

TECHNOLOGIJOS

IR VADYBOS

KATEDRA

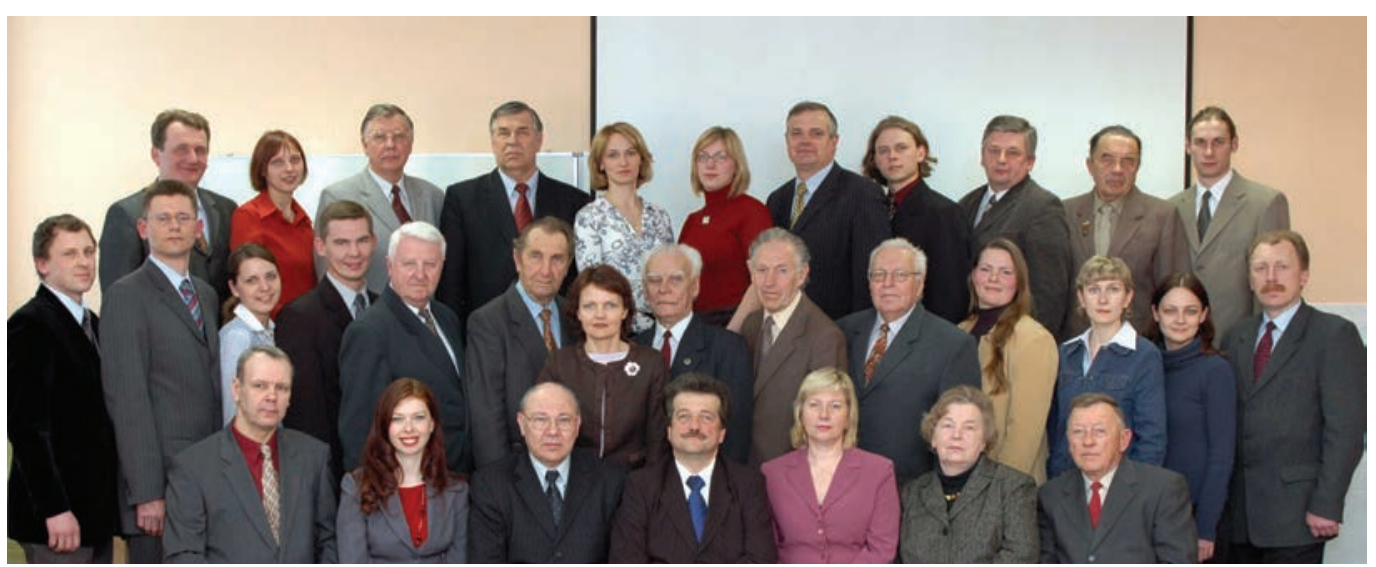

Iš kaires j dešine pirmoje eilëje:

vyresn. moksl. darb. dr. Zenonas Turskis, dokt. Galina Ševčenko, katedros vedejas prof. habil.dr. Edmundas Kazimieras Zavadskas, vyriaus. moksl. darb. prof. habil. dr. Leonas Ustinovičius, katedros reikalų tvarkytoja mgr. Aldona Liubertiené, vadybininkè inž. Regina Krutiniené, doc. dr. Andrejus Karablikovas;

antroje eileje:

doc. dr. Paulius Gaučas, doc. dr. Jonas Šaparauskas, mokymo lab. vedëja mgr. Lina Papinigytè, dokt. Arūnas Barvidas, doc. dr. Pranas Malinauskas, doc. dr. Pranas Mikšta, dokt. Violeta Keršuliené, doc. dr. Romualdas Sakalauskas; doc. dr. Henrikas Nakas; doc. dr. Romualdas Šimkus, dokt. Jolanta Tamošaitiené, doc. dr. Jurgita Antuchevičiené, dokt. Aistė Mickaityte, doc. dr. Gintautas Ambrasas;

trečioje eilëje:

doc. dr. Romualdas Tamošaitis, dokt. Milda Viteikiené,

vyresn. moksl. darb. doc. dr. Česlovas Ignatavičius, doc. dr. Algirdas Andruškevičius, doc. dr. Tatjana Vilutiené, dokt. asist. Edita Šarkienė, doc. dr. Vladislavas Kutut, dokt. asist. Darius Migilinskas, doc. dr. Titas Dëjus, doc. dr. Ričardas Garalevičius, dokt. Darius Kalibatas

1970 m. nuo Statybos ekonomikos katedros atsiskyre Statybos darbų technologijos katedra, kuri 1993 m. buvo pavadinta Statybos technologijos ir vadybos katedra. Katedros vedejais buvo: 1987-1990, 1990-2002 VTU-VGTU rektorius, nuo 2002 m. iki dabar - prof. habil. dr. Edmundas Kazimieras Zavadskas, 1990-1992 m. - doc. dr. Vladas Kriukelis, 1992-1996 m. - doc. dr. Romualdas Šimkus, 1996-2001 m. - prof. habil. dr. Artūras Kaklauskas.

Katedros dèstytojai, be tradicinių disciplinų (statybos procesų technologijos, statybos organizavimo), dèsto: statybos marketingą, statinių eksploatavimą ir renovaciją, matematinių metodų taikymą statyboje, finansų vadybą, kontraktus statyboje, verslo ekonomiką, kokybès valdymo sistemas, operacijų tyrimų metodus, auditą ir apskaitą bei kitas statybos inžinierių praktinei veiklai būtinas disciplinas. 1999 m. katedra pradejo rengti dvejų metų nekilnojamojo turto vertinimo magistrus.

Katedros kolektyvas aktyviai dalyvauja mokslo tiriamuosiuose darbuose.

Per dešimt metų (1990-2000 m.) katedros darbuotojai yra išleidę penkias monografijas; 2001$2004 \mathrm{~m}$. - septynias monografijas.

Katedra redaguoja ir leidžia mokslo žurnalą „Ūkio technologinis ir ekonominis vystymas“. $2004 \mathrm{~m}$. pradètas dèstyti disciplinos „Sprendimų paramos sistemos" paskaitų ciklas doktorantams. 


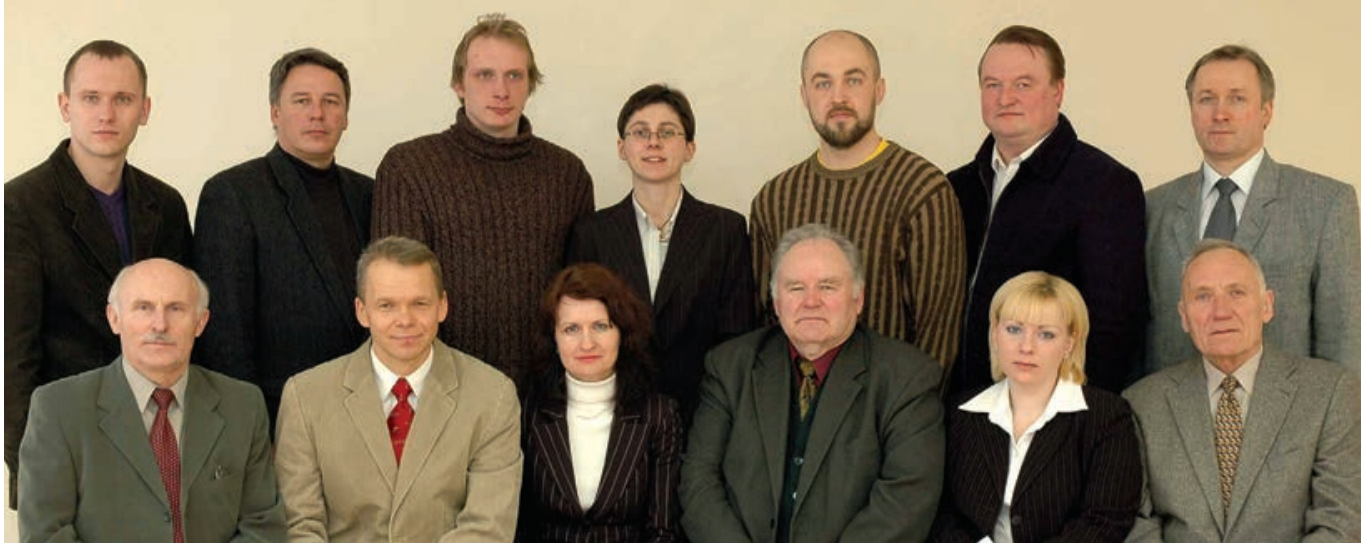

Iš kaires j dešine pirmoje eilëje:

doc. dr. A. Notkus, katedros vedejas prof. habil. dr. G. Kaklauskas, reikalų tvarkytoja L. Kanapeckiené, prof. dr. E. Dulinskas, dokt. T. Grigorjeva, prof. habil. dr. Z. Kamaitis;

antroje eileje:

dokt. D. Jatulis, dokt. G. Viršilas, dokt. R. Girdžius, jaunesn. moksl. darb. dr. R. Zamblauskaite, dokt. V. Gribniak, doc. dr. D. Bačinskas, dr. doc. A. Juozapaitis

Statybos fakultete $1997 \mathrm{~m}$. buvo pradètos Energetikos ir transporto statybos studijos. $2001 \mathrm{~m}$. pradejo studijuoti pirmieji Tiltų ir viadukų studijų programos magistrantai. $2001 \mathrm{~m}$. vasarą įkurta nauja Tiltų ir specialiųjų statinių katedra.

Būsimieji tiltininkai VGTU rengiami kaip plataus profilio statybininkai, jie studijuoja ne tik tiltus, bet ir kitus specialiuosius statinius bei pastatus, gali tobulinti žinias tiltų pakraipos magistrantūroje.

Katedros vedëju išrinktas profesorius G. Kaklauskas. 


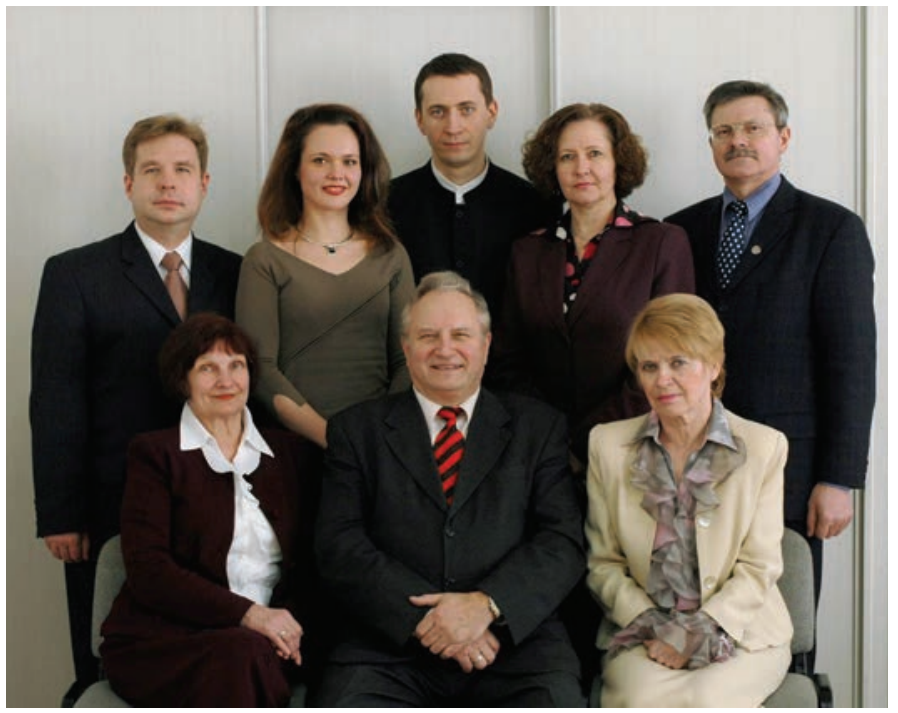

Iš kaires j cešine pirmoje eilëje:

neakivaizdinio skyriaus vadybininkè Domicele Katiniené, dekanas prof. habil. dr. Leonas Povilas Lingaitis, dieninio skyriaus vadybininke Elvina Burbiené;

antroje eileje:

mokslo prodekanas doc. dr. Darius Bazaras, vadybininke Olga Lingaitienè, neakivaizdinių studijų prodekanas doc. dr. Giedrius Garbinčius,

administratore Alè Dadurkiené, dieninių studijų prodekanas Vilius Garbinčius

Transporto inžinerijos fakultetas įkurtas $1994 \mathrm{~m}$. Vilniaus technikos universiteto tarybos nutari$\mathrm{mu}$ ir pavadintas Transporto fakultetu (TF). Jam priskirtos Mechanikos fakulteto (MF) katedros: Automobilių transporto - AT, vietoj MF buvusios Transporto mašinų katedros, Kelių tiesimo mašinu - kaip ir anksčiau trumpinama SKM, vietoj MF buvusios Statybos ir kelių mašinų katedros, ir Transporto vadybos - TV, vietoj MF buvusios Pervežimų organizavimo katedros. Kartu su fakultetu įkuriama Geležinkelių transporto (GT) katedra

Fakulteto taryba $1994 \mathrm{~m}$. balandžio $18 \mathrm{~d}$. Transporto fakulteto dekanu išrinko Automobilių transporto katedros prof. habil. dr. Renių Žeromską.

1996 m. vasarą i Plytinés g. 27 išsikelia dvi TF katedros: Transporto vadybos ir Transporto technologinių įrenginių (TTI ) - taip 1995 m. pervadinta Keliu tiesimo mašinų katedra.

1995 m. fakultetas pervadinamas Transporto inžinerijos fakultetu (TIF). Studiju programos peržiūrimos ir atnaujinamos, pakeičiami ir ju pavadinimai: Transporto inžinerija ir Transporto inžinerine ekonomika ir vadyba.

Inžinerijos studijų programos $2006 \mathrm{~m}$. vel sujungiamos ị vieną - Transporto inžineriją su specializacijomis.

1998 m. balandžio 18d. baigiasi dekano R. Žeromsko kadencija. Jị pakeičia Geležinkelių transporto katedros vedëjas prof. habil. dr. Leonas Povilas Lingaitis.

Fakultetas aktyviai dalyvauja tarptautiniuose projektuose. Fakultetas organizuoja tarptautines mokslo konferencijas "Transbaltica“. Leidžia recenzuojamą periodinį mokslo darbų žurnalą „Transportas“. Dalis fakulteto disciplinų destoma anglų kalba.

Absolventai - reti darbo biržos svečiai. Daugelis gauna geras pareigas valstybinèse ir privačiose įmonèse bei ịstaigose, nes turi gerą žinių bagažą ir yra išmokę kūrybiškai dirbti. 


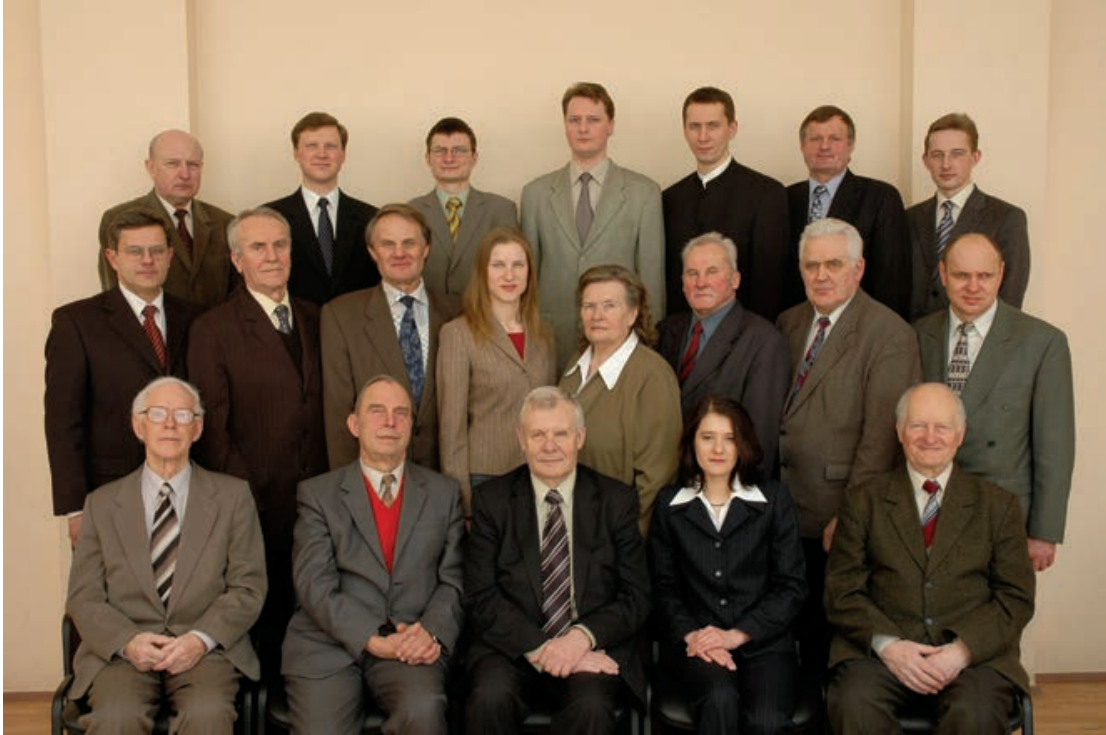

Iš kaires j dešinę pirmoje eileje:

doc. dr. Kęstutis Lukoševičius, prof. habil. dr. Algis Butkus,

katedros vedejjas prof. habil. dr. Alvydas Pikūnas, reikalų tvarkytoja Vilija Saulyté,

lekt. Romualdas Brazys;

antroje eileje:

doc. dr. Valdas Valiūnas, doc. dr. Valentinas Mickūnaitis, doc. dr. Leonas Zubavičius, doktorantė Jurgita Kinderyte, prof. habil. dr. Ona Lukoševičienè, doc. dr. Viktoras Tilindis, techn. asist. Rimgaudas Ambrazevičius, doc. dr. Valentinas Mitunevičius;

trečioje eileje:

lekt. dr. Zenonas Bogdanovičius, doc. dr. Robertas Pečeliūnas, doc. dr. Saugirdas Pukalskas, doc. dr. Saulius Nagurnas, doc. dr. Giedrius Garbinčius, lab. vedëjas Jonas Lasinskas, doc. dr. Edgar Sokolovskij

1922-1940 m. Lietuvoje Vytauto Didžiojo universiteto Technikos fakultete buvo rengiami plataus profilio inžinieriai. $1944 \mathrm{~m}$. nauju pavadinimu atkurtame Kauno valstybiniame universitete isteigiama Transporto katedra. $1950 \mathrm{~m}$. po universiteto reorganizacijos ši katedra buvo perkelta i Kauno politechnikos institutą ir pavadinta Automobilių katedra. Kauno politechnikos instituto Vilniaus filiale automobilių inžinieriai vakariniame skyriuje pradèti rengti rusų kalba nuo $1963 \mathrm{~m}$. 1969 m. minètas filialas pertvarkomas ị atskirą aukštą̧ą mokyklą - Vilniaus inžinerinị statybos institutą (nuo 1997 m. - Vilniaus Gedimino technikos universitetas), ị kurị 1970 m. iš Kauno atkeliama Automobilių katedra. Joje iki 1984 m. išleidžiami automobilių eksploatacijos, kelių ir statybos mašinų profilio inžinieriai. Kaune 1945-1970 m. šių inžinierių parengta 423, o Vilniuje 1964-1995 m. - 1520. 1984-1991 m. įkūrus ir atsidalijus Kelių ir statybos mašinų (vèliau - Transporto technologinių įrenginių) ir Geležinkelių transporto katedroms, katedroje buvo rengiami tik diplomuoti automobilių eksploatacijos inžinieriai.

1990 m. Lietuvai atgavus nepriklausomybę visuose technikos mokslų fakultetuose dèstomoji kalba - lietuvių. Užsieniečiams organizuojamos grupès dèstomąja anglų ir lietuvių kalbomis. Mokymo planai pertvarkomi pagal Vakarų valstybiu pavyzdį, ịvedant kreditus. 


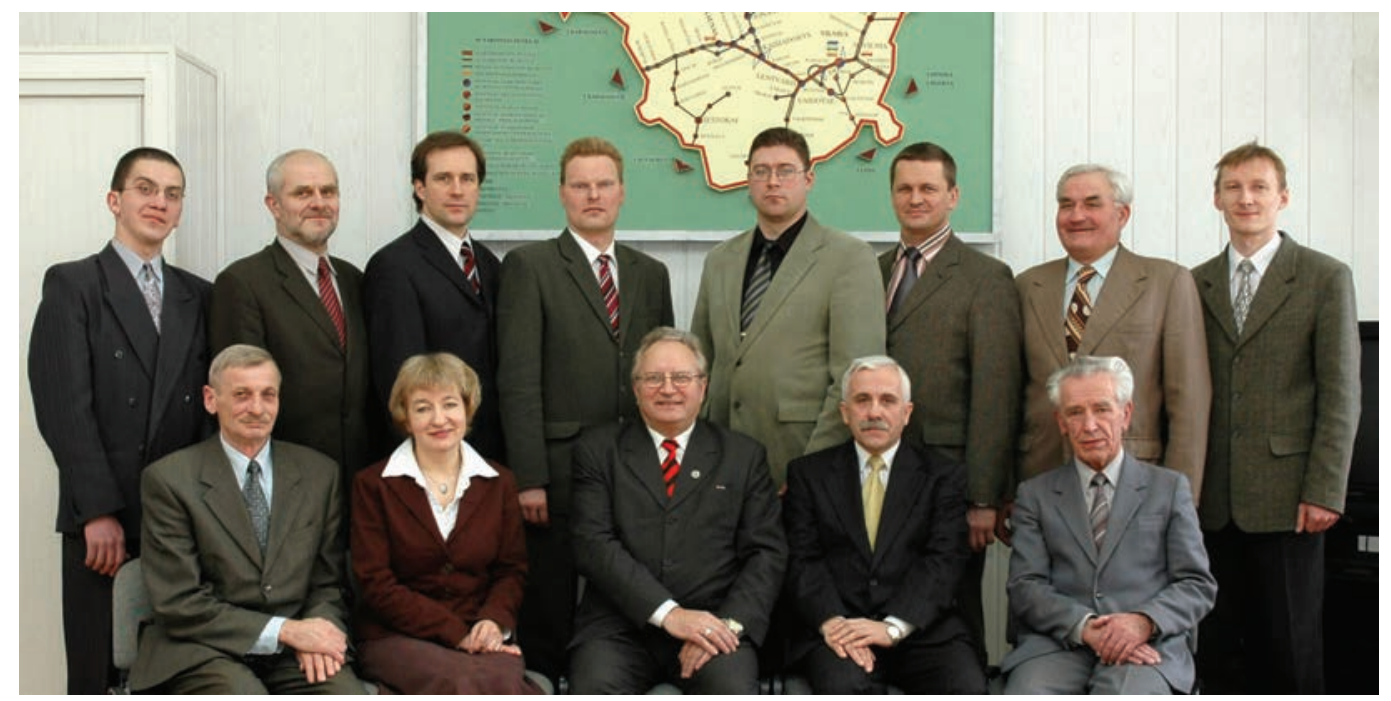

Iš kairè j dešine pirmoje eileje:

doc. dr. Stasys Glebus, reikalų tvarkytoja inž. Virginija Bobiniené,

katedros vedëjas prof. habil. dr. Leonas Povilas Lingaitis,

asist. inž. Lionginas Liudvinavičius,

Geležinkelių transporto mok. lab. vedëjas inž. Antanas Kundelis;

antroje eileje:

dokt. Vidmantas Juršenas, doc. dr. Rimantas Subačius, doc. dr. Šarūnas Mikaliūnas, doc. dr. Gediminas Vaičiūnas, meistras inž. Stasys Steišūnas, doc. dr. Gintautas Bureika, meistras inž. Albertas Griška, dokt. Viačeslav Petrenko

Katedra pradëjo savo veiklą 1994 m. rugsëjo $1 \mathrm{~d}$. Katedros įkūrëjas ir pirmasis vedëjas buvo prof. habil. dr. Leonas Povilas Lingaitis. Nuo 1998 m. iki 2001 m. katedrai vadovavo doc. dr. Rimantas Subačius. Nuo $2001 \mathrm{~m}$. iki šiol katedrai vadovauja prof. L. P. Lingaitis.

Didelį indèli į katedros veiklą ir studentų mokymą yra įnešę tokie dèstytojai, kaip doc. dr. Juozapas Mindaugas Nemira (1994-2002 m.), destęs studentams termodinamiką ir šilumokaitą, šilumos ir masès mainus bei daug prisidëjęs prie naujų mokymo programų kūrimo; puikus geležinkelio transporto specialistas asist. Algirdas Kliore (1997-2002 m.), studentams dèstęs geležinkelio eismo saugą; prof. habil. dr. Leonidas Sakalauskas (1997-2002 m.), magistrantams destęs Masinio aptarnavimo teoriją; dr. Alfonsas Katkus(1996-2002 m.), bakalaurams dèstęs transporto konstrukcines ir eksploatacines medžiagas.

Pirmasis Geležinkelių transporto mokomosios laboratorijos vedejjas buvo Jonas Mulevičius (19941996 m.), nuo 1996 m. laboratorijos vedëju dirba inž. Antanas Kundelis.

Per devynerius metus katedra išleido 164 bakalaurus, 18 diplomuotų inžinierių ir 77 magistrus. Apgintos dvi daktaro disertacijos.

Geležinkelių transporto inžinerijos programą studijuojantiems studentams organizuojamieji susitikimai su $A B$ „Lietuvos geležinkeliai“ atstovais, taip pat su šią studijų programą baigusiais ir $A B$ „Lietuvos geležinkeliai“ dirbančiais absolventais. III kurso studentai gamybinę praktiką atlieka Lietuvos geležinkeliams priklausančiose įmonèse, kur jie ieško medžiagos ir pasirenka būsimo baigiamojo darbo temą. Studentams priskirti praktikos vadovai gamybininkai suteikia medžiagą ir konsultuoja tiek praktikos, tiek būsimojo baigiamojo darbo klausimais.

Studentų praktiniams sugebejjimams ugdyti organizuojamieji laboratoriniai darbai vyksta Vilniaus lokomotyvų depe. Geležinkelių transporto laboratorijos kompiuterių klasëje studentai prognozuoja geležinkelių transporto energetikos rodiklius, tobulina ju prognozavimo metodikas, optimizuoja eismo organizavimo sistemas, lokomotyvų brigadų sudarymo tvarką.

Bakalauru ir inžinierių kvalifikacinio laipsnio suteikimo komisijoms nuo 1995 m. skirtingais laikotarpiais pirmininkavo $\mathrm{AB}$ „Lietuvos geležinkeliai“ lokomotyvų remonto depo viršininkas Silistinas Razgus, $\mathrm{AB}$ „Lietuvos geležinkeliai“ Technikos tarnybos viršininkas Alfredas Zubkevičius, šiuo metu pirmininkauja $A B$ „Lietuvos geležinkeliai“ Krovinių vežimo valdybos Riedmenų skyriaus viršininkas Virgilijus Jastremskas. 
TRANSPORTO

TECHNOLOGINIU

İRENGINIŲ

KATEDRA

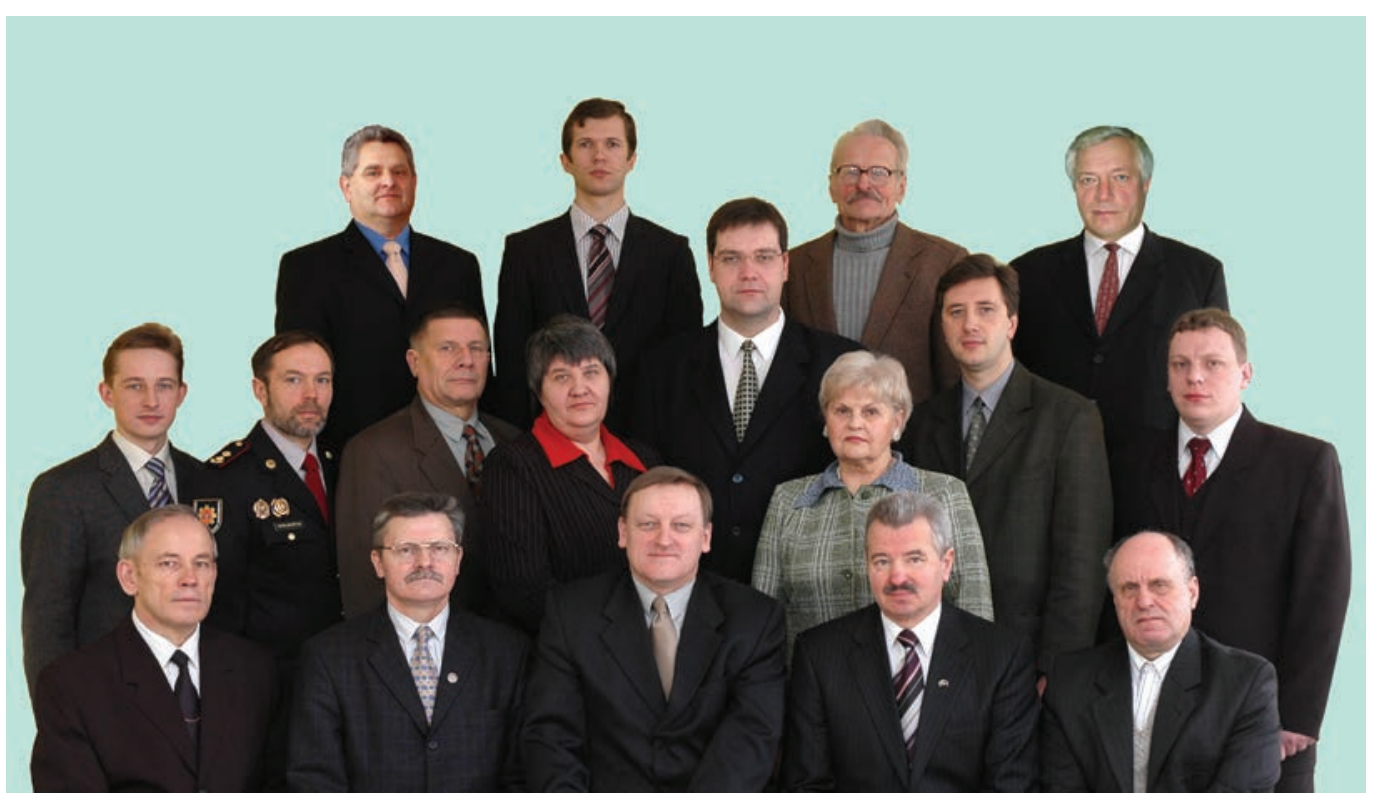

Iš kaires j dešine pirmoje eileje:

prof. habil. dr. Bronislovas Spruogis, doc. dr. prodekanas Vilius Bartulis, katedros vedejjas, prof. habil. dr. Marijonas Bogdevičius, prof. habil. dr. Henrikas Sivilevičius, doc. dr. Jurgis Jurevičius;

antroje eileje:

doc. dr. Edgar Sokolovskij, asist. dokt. Valdimiras Suslavičius,

bakalaurų baigiamųjų darbų atestacinès komisjos pirmininkas inžinierius Algimantas

Kleinas, reikalų tvarkytoja ir lab. vedëja inžiniere Laima Dabulevičiené,

jaun. moksl. darb. mgr. Arvydas Matiliauskas, vyr. laborantė Genute Puziniené,

doc. dr. Olegas Prentkovskis, moksl. darb. dr. Oleg Vladimirov;

trečioje eileje:

bakalaurų baigiamųjų darbų atestacinès komisjos pirmininkas mgr. Juozas Kondrotas, dokt. asist. Rasimundas Junevičius, lab. meistras Vladas Bielinskas, bakalaurų baigiamųjų darbų atestacinés komisjos pirmininkas mgr. Jonas Puluikis

Transporto technologinių įrenginių katedra įkurta $1985 \mathrm{~m}$. Vilniaus inžinerinio statybos instituto Mechaninès technologijos fakultete. Tada katedra buvo vadinama Statybos ir kelių mašinų katedra. Jos pirmasis vedejjas buvo doc. dr. Bronislovas Spruogis.

Nuo 1991 iki 1995 metu jau Vilniaus technikos universitete Mechanikos fakultete katedra vadinama Kelių tiesimo ir statybos mašinų katedra.

1994 m. įsikūrus Transporto inžinerijos fakultetui, katedra buvo pavadinta Transporto technologinių įrenginių katedra. Nuo 1995 m. katedrai vadovauja doc. dr. (nuo 2000 m. - prof. habil. dr.) Marijonas Bogdevičius.

Katedros absolventai dirba privačiose ir valstybinèse įmonese, kuriose naudojamos, projektuojamos transporto mašinos ir technologiniai įrenginiai bei statybos technika, transporto mašinų priežiūros ir prekybos, eismo saugumo, vamzdynų transporto ir degalinių ūkio srityse, kelių policijos, muitinès, gaisrinès saugos ir gelbëjimo padaliniuose, oro ir laivų uostuose. 


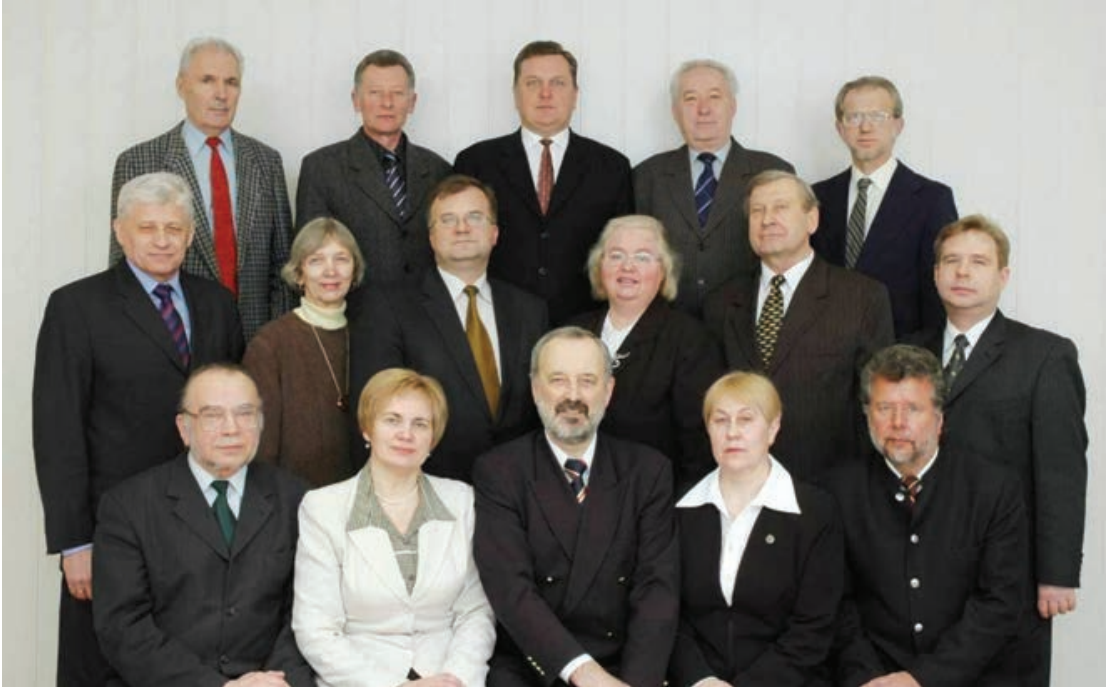

Iš kaires j dešine pirmoje eileje:

prof. habil. dr. Adolfas Baublys, doc. dr. Nijolè Batarliené, katedros vedejas prof. habil. dr. Ramūnas Palšaitis, reikalų tvarkytoja Vida Vasiliene, prof. dr. Jonas Butkevičius; antroje eileje:

doc. dr. Algirdas Šakalys, technin. asist. Nijolè Valčackiené, doc. dr. Alminas Mačiulis, doc. dr. Daiva Griškevičiené, doc. dr. Algirdas Juozapas Griškevičius, doc. dr. Darius Bazaras;

trečioje eileje:

doc. dr. Rimantas Limba, doc. dr. Andrius Kęstutis Vyskupaitis, doc. dr. Jonas Lazauskas, doc. dr. Mindaugas Mazūra, lab. vedejas Vladas Ivankovas

Katedra įsteigta 1965 m. Katedros pavadinimas iki šiol keitesi keletą kartų: 1965 m. - Gamybos ekonomikos katedra; 1969 m. - Pramonés ekonomikos katedra; 1981 m. - Autotransporto ekonomikos katedra; 1992 m. - Pervežimų organizavimo katedra; 1994 m. ir iki šiol - Transporto vadybos katedra.

Katedros vedejjai:

1965-1972 m. - ekon. m. kand. doc. Albinas Martinaitis; 1972-1979 m. - techn. m. kand. doc. Konstantinas Sasnauskas; 1979-1982 m. - ekon. m. kand. doc. Romualdas Baltrušaitis; 1982-1997 m. - prof. habil. dr. Adolfas Baublys;

Nuo 1997 m. iki šiol - prof. habil. dr. Ramūnas Palšaitis.

Prie katedros 1983 m. įsteigta mokomoji laboratorija, o 1986-1997 m. prie katedros veiké Žinybinè automobilių transporto organizavimo ir valdymo laboratorija.

2001 m. prof. habil. dr. A. Baubliui ir prof. habil. dr. R. Palšaičiui už mokslo darbų ciklą „Lietuvos transporto sistemos formavimo strategija: teoriniai ir metodiniai aspektai (1988-1999 m.) " paskirta technologijos mokslų srities valstybiné mokslo premija.

Katedra yra profilinè. Rengiami Transporto inžinerines ekonomikos ir vadybos studiju programos bakalaurai ir magistrai, veikia doktorantūra. 


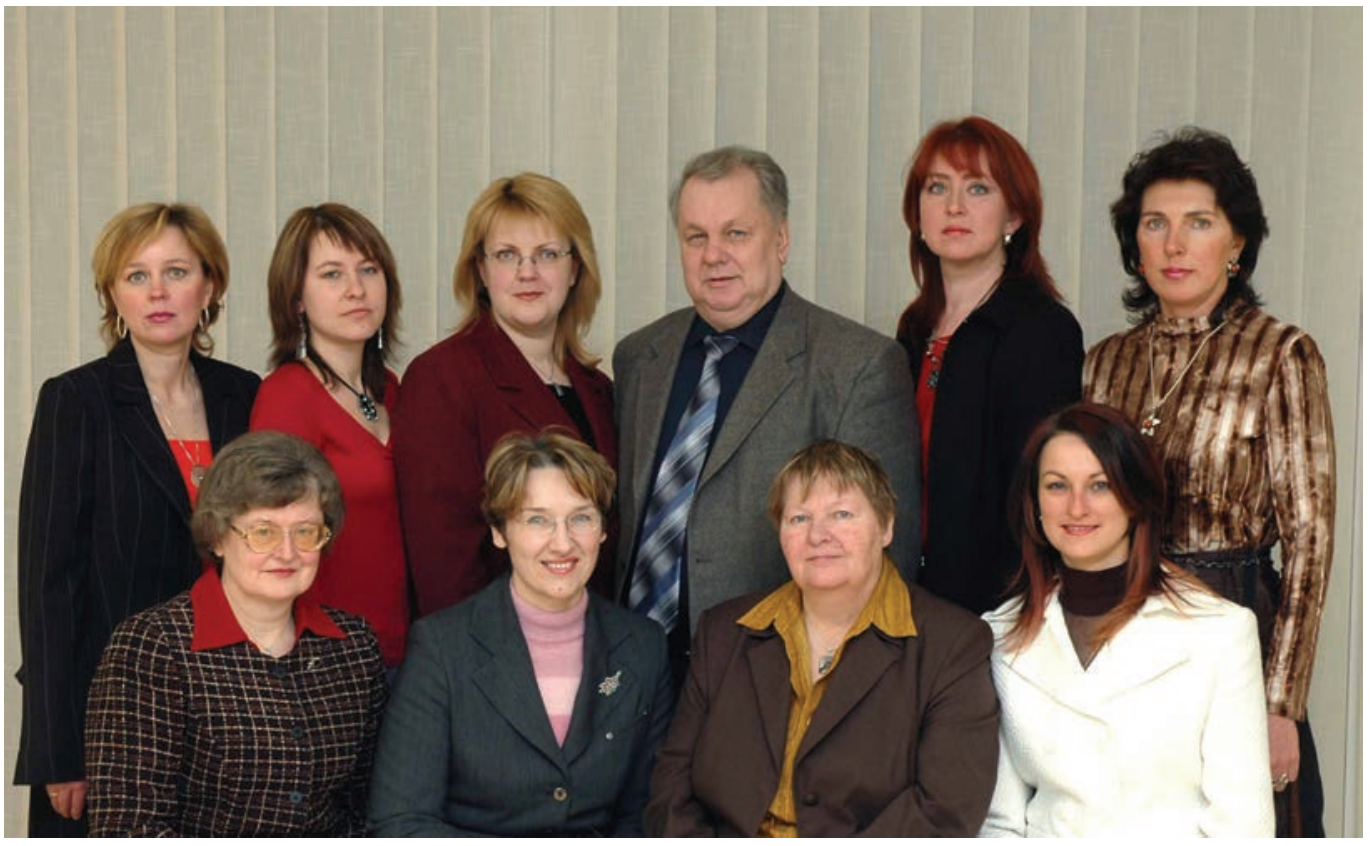

Iš kaires j dešine pirmoje eileje:

pagrindinių studiju prodekanè doc. dr. Laima Šečkuté, magistrantūros studijų prodekané doc. dr. Rima Tamošiūniené, mokslo prodekané doc. dr. Arnoldina Pabedinskaité, neakivaizdinio ir vakarinio skyrių prodekanè doc. dr. Algita Miečinskiené; antroje eileje:

vadybininke Daiva Versekèniené, vadybininke Diana Pachomovaite, administratore mgr. Vaida Blazarenaite, dekanas prof. habil. dr. Aleksandras Vytautas Rutkauskas, vadybininke Egle Mikuževičiūtè, vadybininke mgr. Gražina Jurgiliené

Fakultetas įkurtas 1993 m. vasario 10 d. Šiuo metu fakultete yra 6 katedros: Finansų, İmonių ekonomikos ir vadybos, Socialines ekonomikos ir vadybos, Tarptautinès ekonomikos ir vadybos, Teisés, Verslo technologijų; 1 moksline laboratorija - Verslo projektavimo ir aplinkos ekonomikos.

$2004 \mathrm{~m}$. gruodžio $30 \mathrm{~d}$. duomenimis, fakultete pagrindines (ne pagrindines) pareigas ëjo ir mokslinëje veikloje dalyvavo 83 (27) tyrejai, iš ju 66 (19) mokslininkai: 40 (4) habilituotų daktarų, 26 (15) daktarai. Doktorantūroje studijavo 41 doktorantas.

Verslo vadybos fakulteto destytojai desto vadybos, strateginio valdymo, imonių valdymo ir organizavimo, valdymo informatikos, kokybès vadybos, marketingo, logistikos, personalo vadybos ir valdymo psichologijos, vadovo darbo, matematinių vadybos metodų, nekilnojamojo turto vadybos, inovacijų ir investicijų vadybos, valdymo teorijų ir kitus dalykus. 


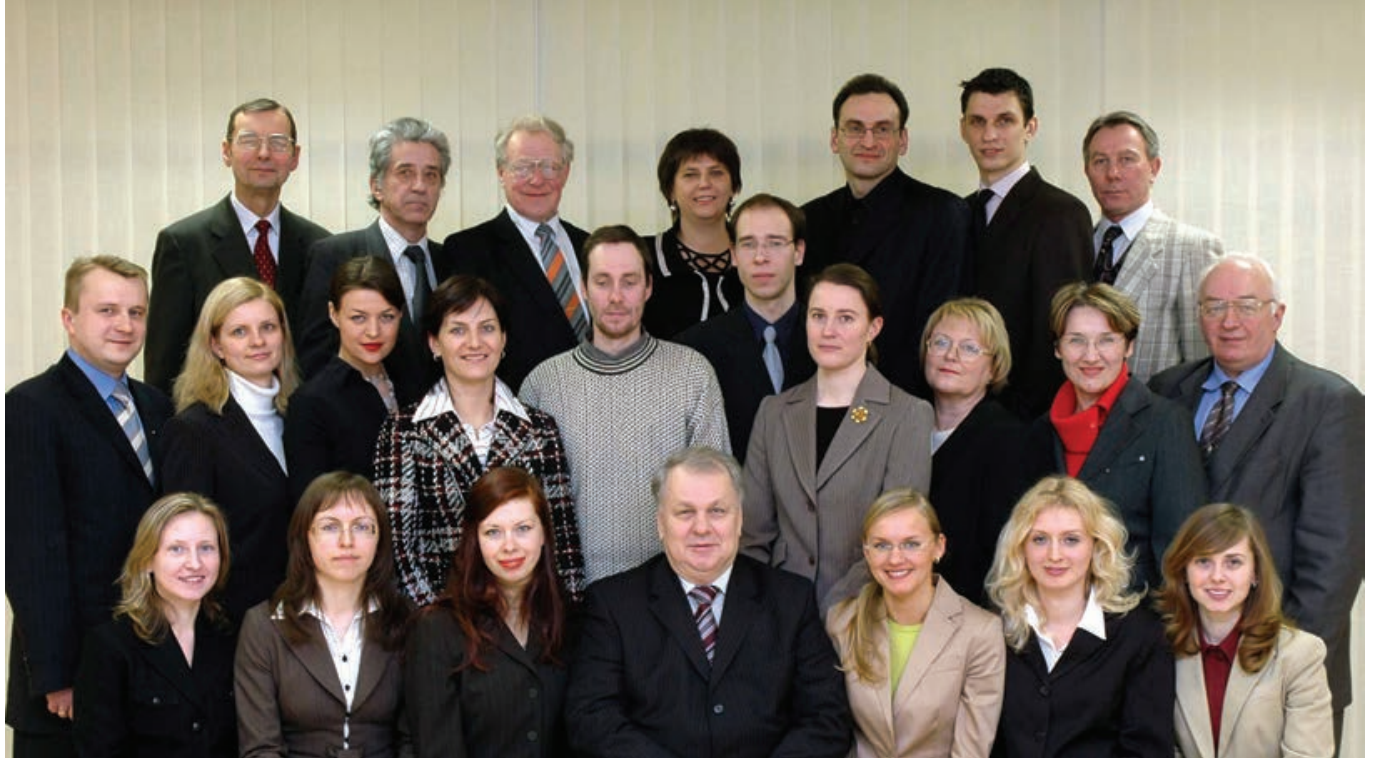

Iš kaires j dešinę pirmoje eilëje:

asist. Violeta Janovič, techn. asist. Asta Filipovič, asist. Galina Ševčenko, katedros vedejjas prof. habil. dr. Aleksandras Vytautas Rutkauskas, asist. dokt. Ingrida Trumpaite, reikalų tvarkytoja Jelena Borisova, asist. dokt. Irena Kucko;

antroje eileje:

dokt. Vytautas Lingaitis, dokt. Regina Jasilioniene, asist. dokt. Laura Kaleininkaite, asist. dr. Aurelija Mažintiené, doc. dr. Artūras Stepanovas,

dokt. Tomas Ramanauskas, asist. dr. Raimonda Martinkute,

doc. dr. Eugenija Martinaityte, doc. dr. Rima Tamošiūnienè, doc. dr. Viktoras Filipavičius; trečioje eileje:

doc. dr. Stasys Valentinavičius, doc. dr. Vytautas Pranas Sūdžius,

lekt. dr. Vytautas Ignacas Grigutis, doc. dr. Daiva Jurevičiené, asist. Renaldas Vilkancas, dokt. Skirmantas Šidlauskas, lekt. doc. dr. Jonas Žaptorius

1993 m. vasarị susikūrè Verslo vadybos fakultetas, ị kurio sudèti iejo Verslo ekonomikos katedra. Katedros vedëjas - prof. habil. dr. A. V. Rutkauskas. $2001 \mathrm{~m}$. Verslo ekonomikos katedra buvo perorganizuota, ir taip atsirado Finansų katedra, kurios vedejju paskirtas prof. habil. dr. A. V. Rutkauskas. 2004 m. lapkritį Finansų katedra buvo pervadinta Finansų inžinerijos katedra. 


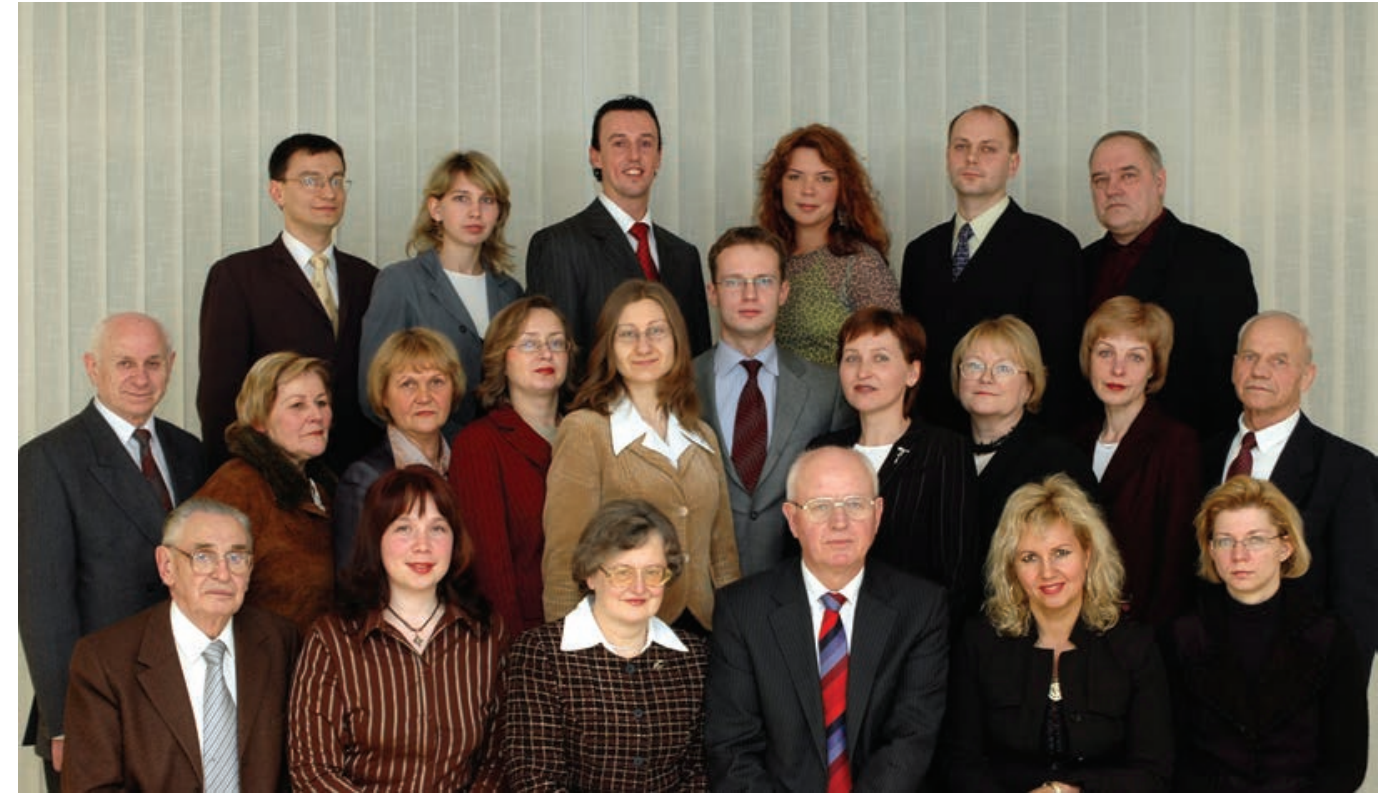

Iš kaires j dešinę pirmoje eileje:

lekt. Algimantas Jurgis Jonaitis, asist. Aušra Liučvaitiene, doc. dr. Laima Šečkute, katedros vedëjas prof. habil. dr. Romualdas Ginevičius, prof. dr. Manuela Tvaronavičiené, e. doc. p. dr. Renata Korsakiene;

antroje eileje:

lekt. doc. Juozas Silickas, doc. dr. Aldona Garškiené, vadybininke Rūta Dilbiené, e. doc. p. dr. Asta Stankevičienė, dokt. Vida Vaitkūnaite, dokt. Viktoras Zubrecovas, asist. Jolanta Paunksniené, doc. dr. Eugenija Martinaityte, reikalų tvarkytoja Irena Grigoniene, doc. dr. Vytautas Aukščiūnas;

trečioje eileje:

dokt. Audrius Dzikevičius, asist. Kristina Kalašinskaite, dokt. Šarūnas Bruzge, dokt. Ilona Kutut, dokt. Dovydas Mikelis, lekt. dr. Valentinas Kazlovas

Katedra įkurta 2001 m., Verslo vadybos fakultete Vadybos katedrą ir Ekonomikos katedrą reorganizavus ị penkias katedras: İmonių ekonomikos ir vadybos, Verslo technologijų, Socialinès ekonomikos ir vadybos, Tarptautinès ekonomikos ir vadybos, Finansu. 
SOCIALINĖS

EKONOMIKOS

IR VADYBOS

KATEDRA

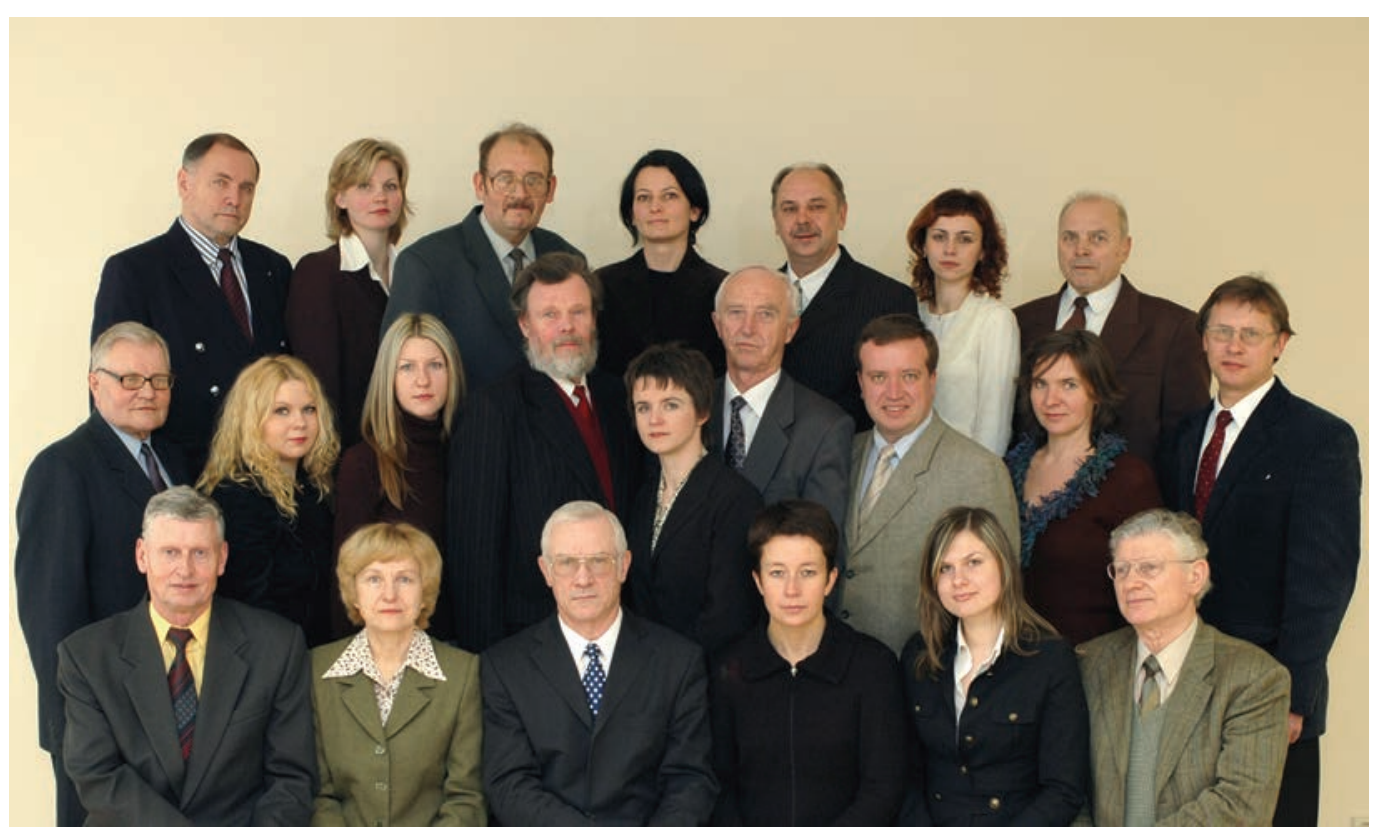

Iš kaires j dešine pirmoje eilëje:

prof. habil. dr. Algis Žvirblis, reikalų tvarkytoja Terese Krasauskiené, katedros vedejas prof. habil. dr. Juozas Bivainis, doc. dr. Inga Blažiené, vadybininke Giedre Staskevičiūte, prof. habil. dr. Algis Šileika;

antroje eileje:

doc. dr. Stepan Zaicev, dokt. Virgilija Zinkevičiūtè, dokt. Rasa Zabarauskaite, prof. dr. Fabijus Saulius Butkus, asist. Maryte Alminauskiene, asist. Romualdas Liukaitis, dr. Vladislavas Petraškevičius, dokt. Daiva Andriukaitiene, dokt. Rolandas Drejeris;

trečioje eileje:

dr. Jurgis Samulevičius, dokt. Ilona Skačkauskiené, doc. dr. Algirdas Jakutis, asist. Jolita Ramanauskiené, doc. dr. Valentinas Dubinas, dokt. Živile Tunčikiené, doc. dr. Česlovas Purlys

Katedra įsteigta $2001 \mathrm{~m}$. birželio mènesį. Prof. J. Bivainis katedrai vadovauja nuo jos įsteigimo dienos. 


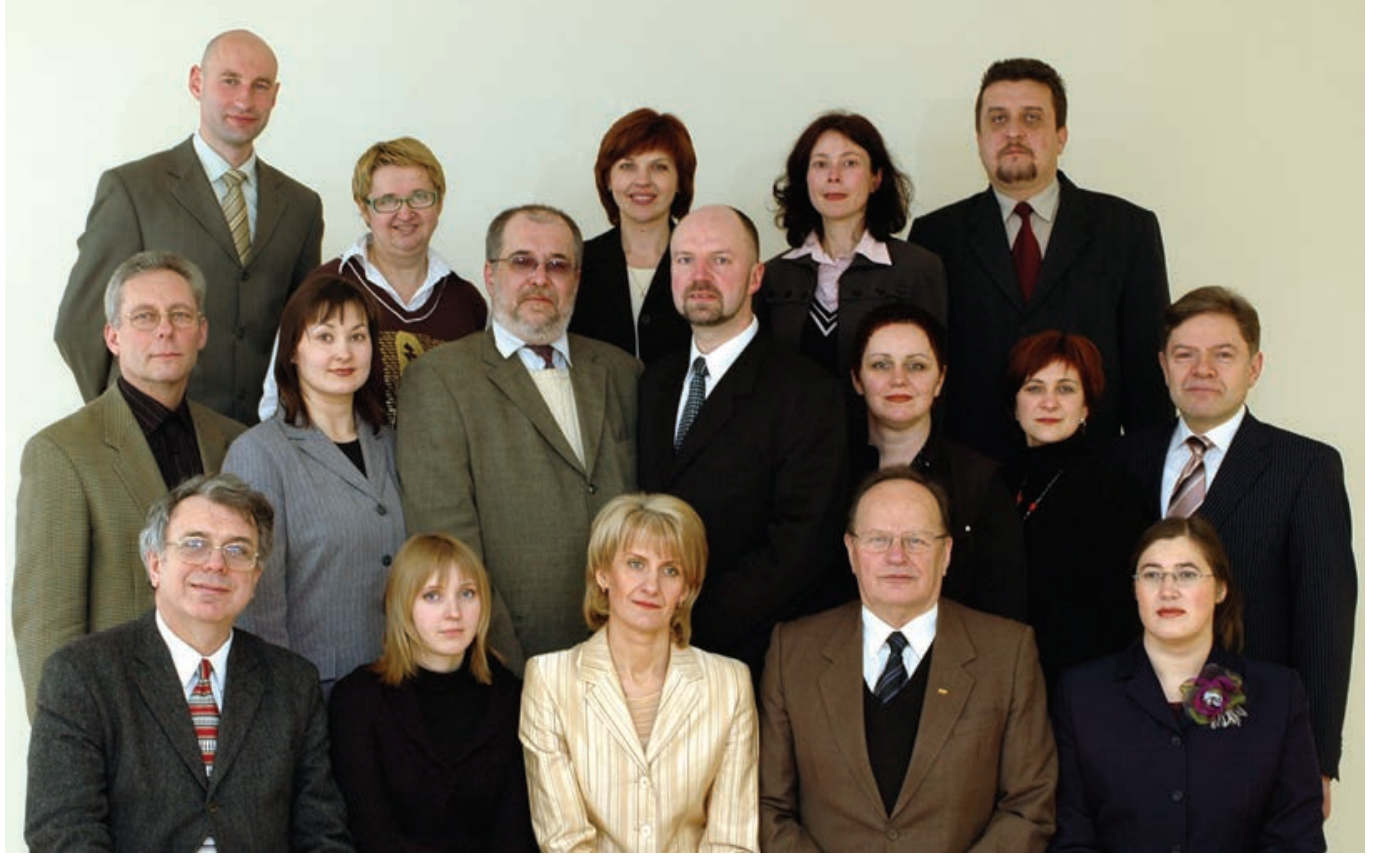

Iš kaires i dešine pirmoje eilejje:

katedros vedejjas prof. habil. dr. Borisas Melnikas, asist. Audroné Kvedariené, asist. Vida Pipiriené, doc. dr. Antanas Lubys, asist. Diana Volungevičiené; antroje eileje:

doc. dr. Algirdas Miškinis, vadybininke Nora Martinkeniené, doc. dr. Algis Kabaila, dokt. Gintaras Čepas, asist. Liudmila Lobanova, dokt. Asta Radzevičiené, prof. dr. Eugenijus Chlivickas;

trečioje eilejje:

asist. T. Razdauskas, asist. Irena Alperyte, asist. Liuda Maciukevičiené, doc. dr. Rasa Smaliukiené, doc. dr. Arvydas Jakubavičius 


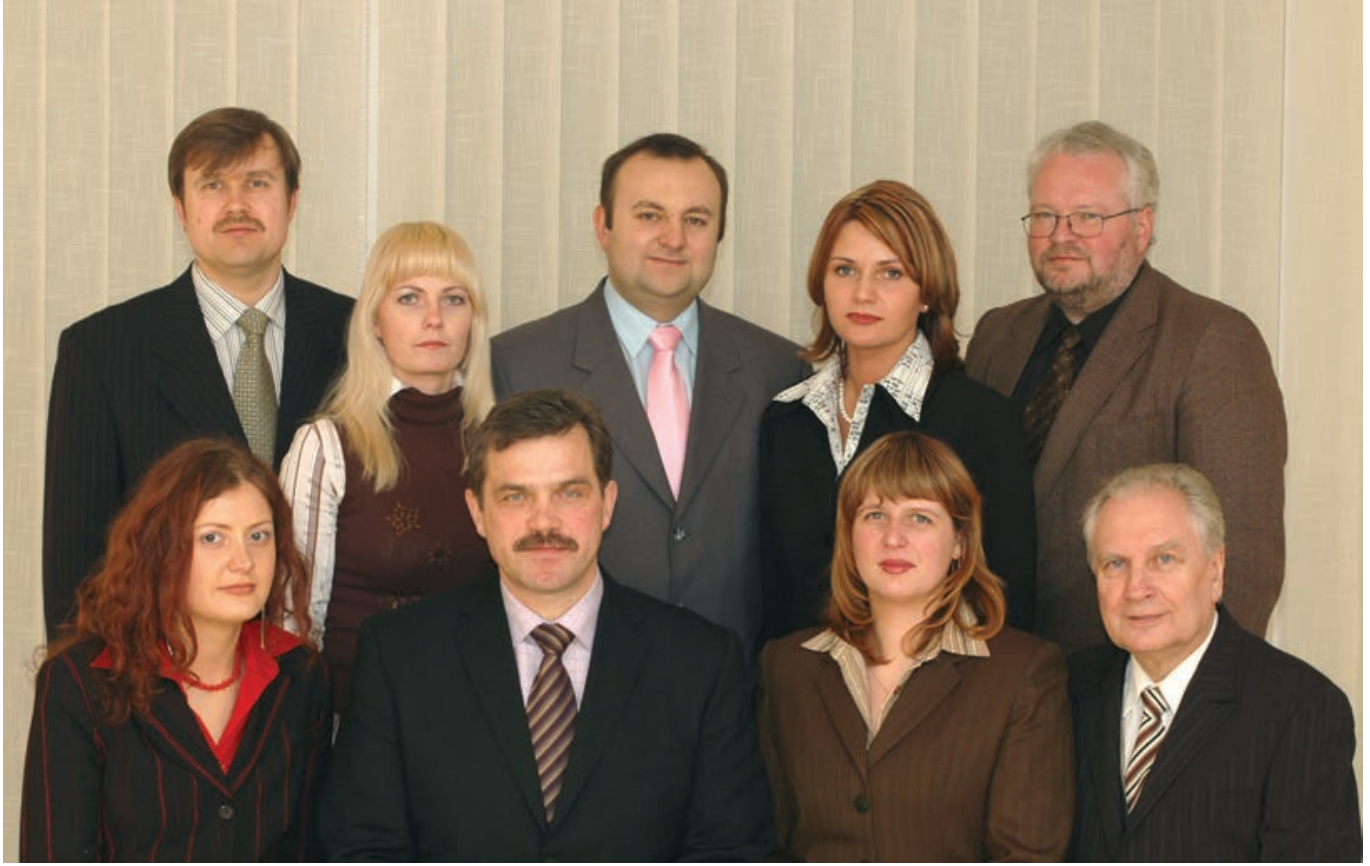

Iš kaires j dešine pirmoje eileje:

lekt. Raimonda Bublienè, katedros vedëjas doc. dr. Sigitas Mitkus, lekt. Eva Trinkūniené, doc. dr. Kazimieras Liudvikas Valančius;

antroje eileje:

asist. Artūras Subačius, lekt. Vilma Getautytè, doc. dr. Valentinas Jaruševičius, reikalų tvarkytoja Vaida Zemlickiene, asist. Astijus Rutkauskas

Teisès katedra įsteigta $1993 \mathrm{~m}$. Jos vedëju buvo teisès mokslų daktaras, docentas Juozas Sidaravičius, o jam mirus katedros vedèju pradèjo dirbti doc. dr. Sigitas Mitkus.

Nuo 1993 m. teises disciplina įvesta kaip privaloma visiems studijuojantiems universitete. İsteigus Verslo vadybos fakultetą, įvesti tokie specializuoti teisès dalykai, kaip ūkinè ir darbo teisè, žemès teise, žemés ir nekilnojamojo turto teise, valstybinè teise, administracine teisè ir kt. Magistrantūros studijose dèstoma ekologinè teisè, finansinè teisè, tarptautinè teisè, darbo teisè ir kt. 
VERSLO

TECHNOLOGIJU KATEDRA

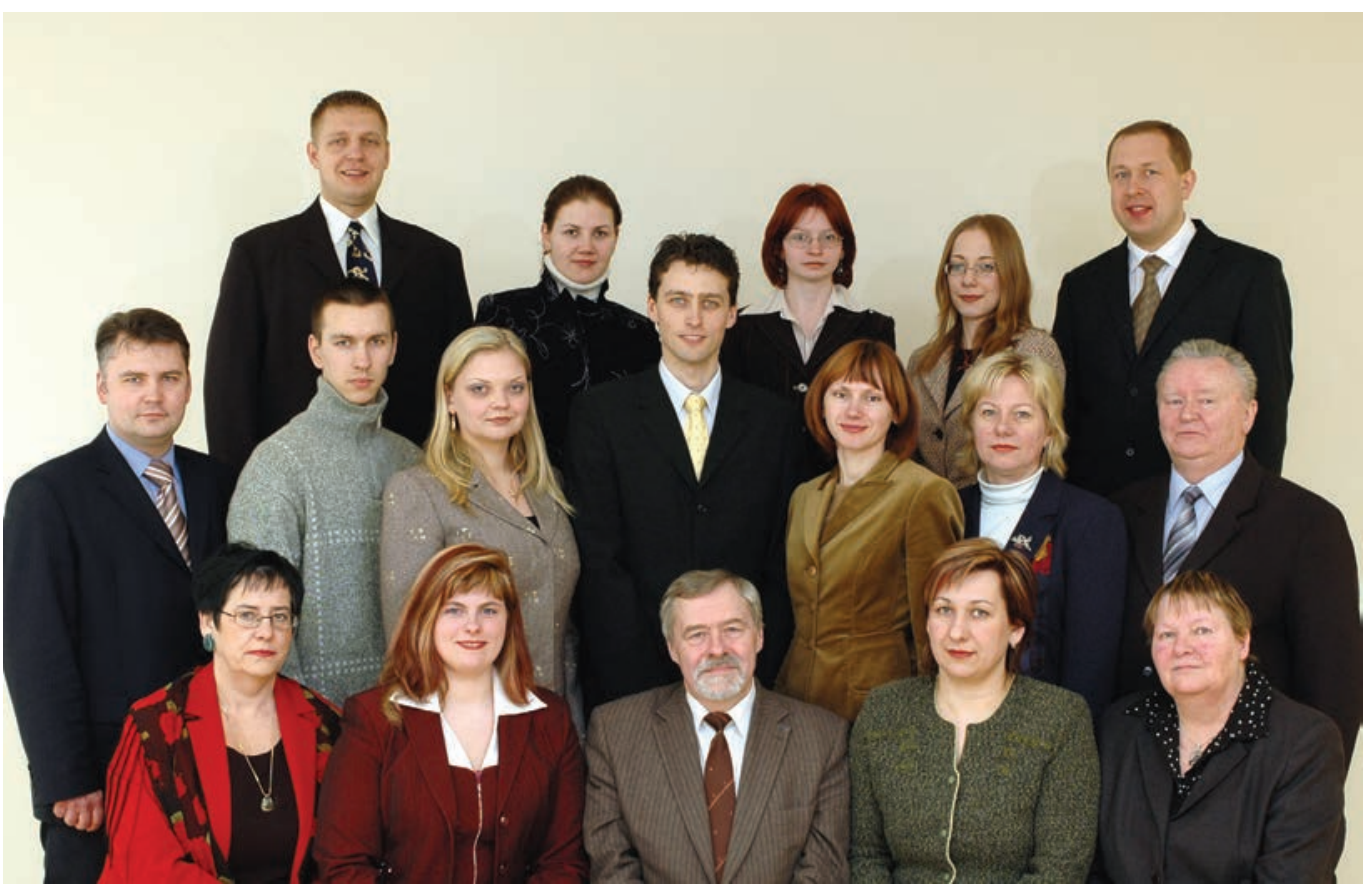

Iš kaires j dešine pirmoje eileje:

lekt. mgr. Nina Šukeliene, katedros reikalų tvarkytoja Jurgita Ginavičiené, katedros vedëjas prof. habil. dr. Narimantas Paliulis, vadybininkẻ Vida Sviackevičiené, doc. dr. Arnoldina Pabedinskaite;

antroje eileje:

asist. dr. Linas Šaulinskas, laborantas Marius Gibavičius, asist. dr. Vida Elskyte, asist. mgr. Romualdas Vitkauskas, asist. mgr. Vita Marytė Janušauskiené, asist. mgr. Aldona Liubertienė, prof. habil. dr. Juozapas Audvydas Staškevičius; trečioje eileje:

dokt. Giedrius Čyras, dokt. Jurgita Raudeliūnienè, dokt. Nelè Jurkènaité, dokt. Margarita Friman, doc. dr. Juozas Merkevičius

Katedra ịkurta 2001 m., Verslo vadybos fakulteto Vadybos katedrą ir Ekonomikos katedrą reorganizavus ị penkias katedras: İmonių ekonomikos ir vadybos, Verslo technologijų, Socialinès ekonomikos ir vadybos, Tarptautines ekonomikos ir vadybos, Finansų.

Katedra rengia aukštos kvalifikacijos vadybos specialistus - bakalaurus, magistrus ir doktorantus. 2002 m. du Verslo technologiju katedros magistrantai laimëjo apdovanojimus Europos komiteto prie LRV organizuotame geriausio diplominio darbo Lietuvos ekonominés integracijos ị Europos Sąjungos bendrąją rinką tema konkurse. Jurgita Raudeliūniené - I vieta, Romualdas Vitkauskas - paskatinamoji premija.

Katedra vykdo mokslo tiriamuosius darbus, vykdo tarptautinius ir užsakomuosius projektus bei konsultuoja: ITT įtakos įmonių veiklai ir žmonių gyvensenai tyrimų, informacinių valdymo sistemų kūrimo ir diegimo, įmonių reorganizavimo (reinžinerijos), valdymo sistemų kūrimo ir tobulinimo, inovatyvių technologijų diegimo, visuotinès kokybes valdymo sistemų kūrimo ir tobulinimo, logistikos sistemų kūrimo ir tobulinimo srityse. 

IVAIRŪS

KŪRYBINIAI

DARBAI 
Architektè E. N. BUČIUTE்

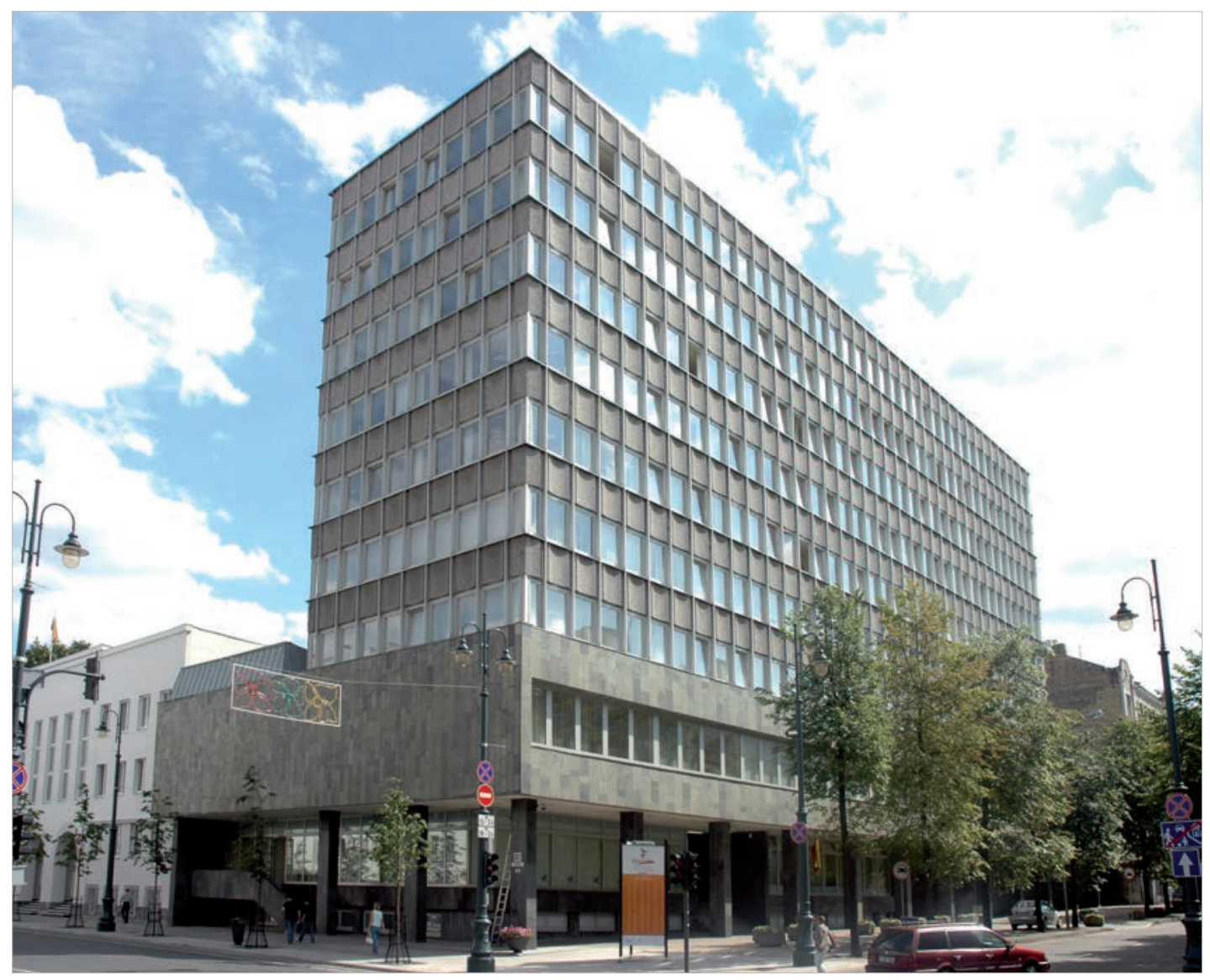

Prof. E. N. Bučiūté. Valstybinio plano komiteto rümai Vilniuje

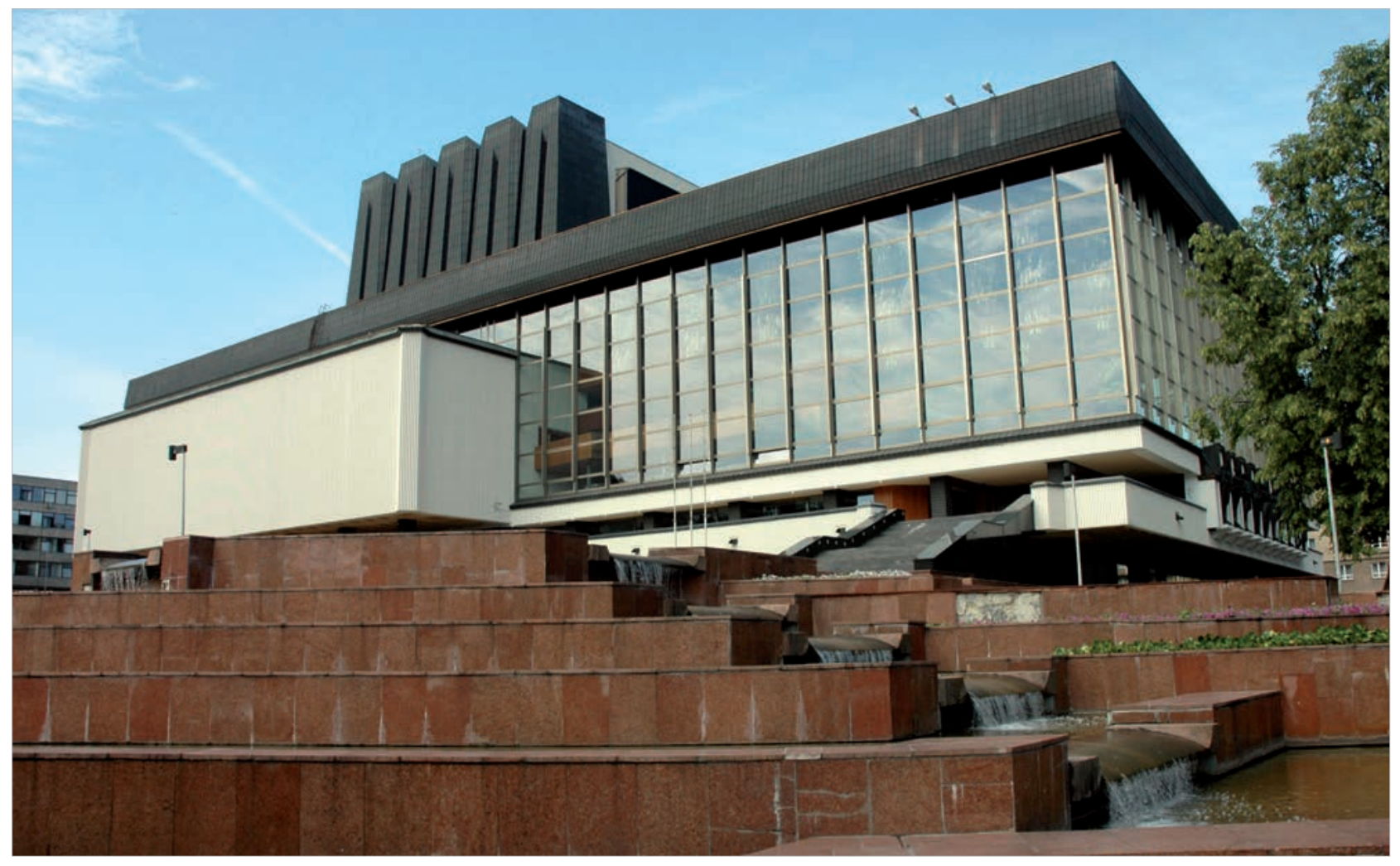

Prof. E. N. Bučiùtè. Operos ir baleto teatro rümai Vilniuje 


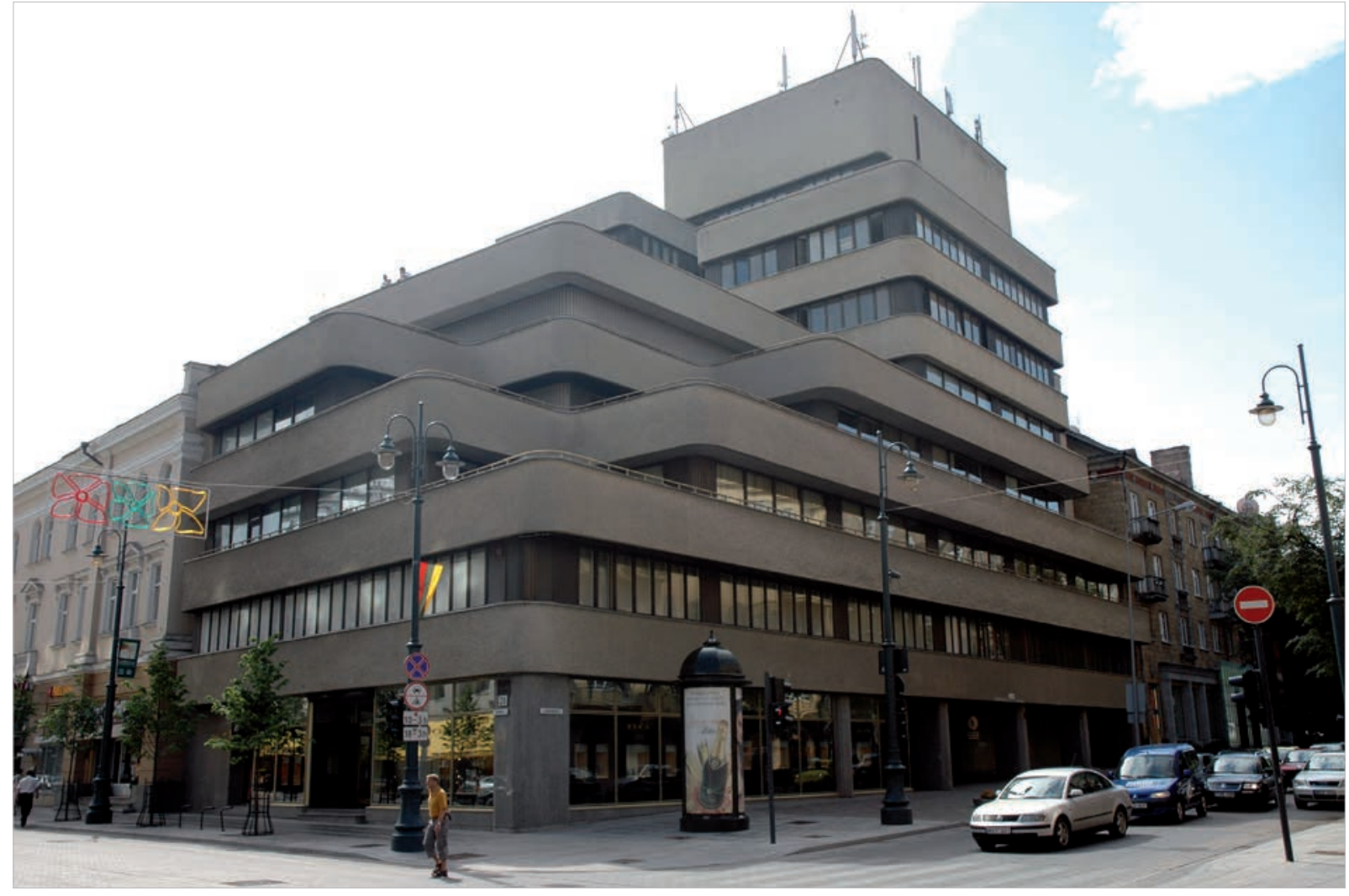

Prof. J. Šeibokas. Lietkoopsajungos rūmai Vilniuje

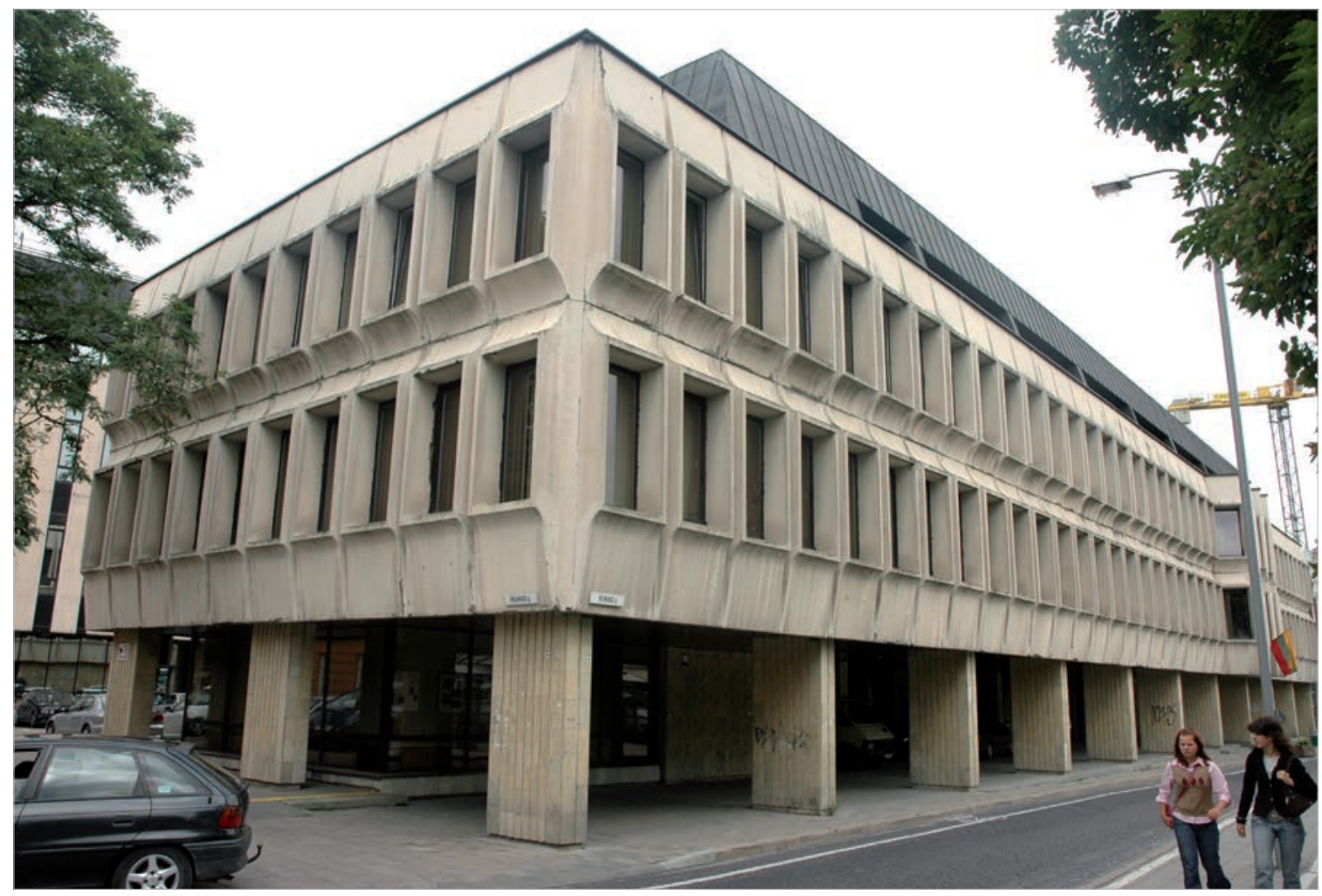

Prof. J. Šeibokas. Ryšiu ministerijos rümai Vilniuje 


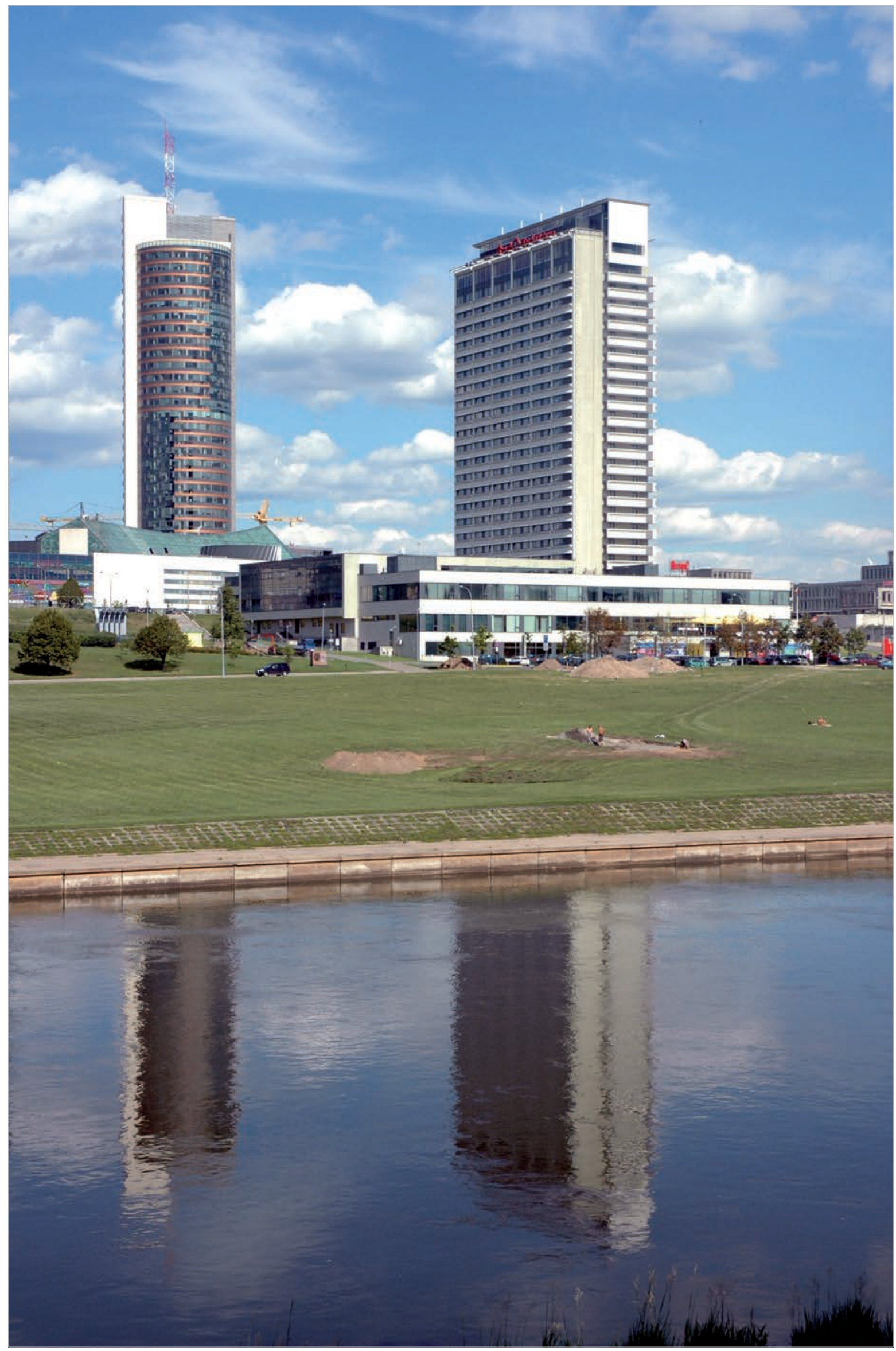

Prof. A. Nasvytis, V. Nasvytis. „Lietuvos" viešbutis Vilniuje 
Architektai E. TAMOŠEVIČIUS, A. DINEIKA

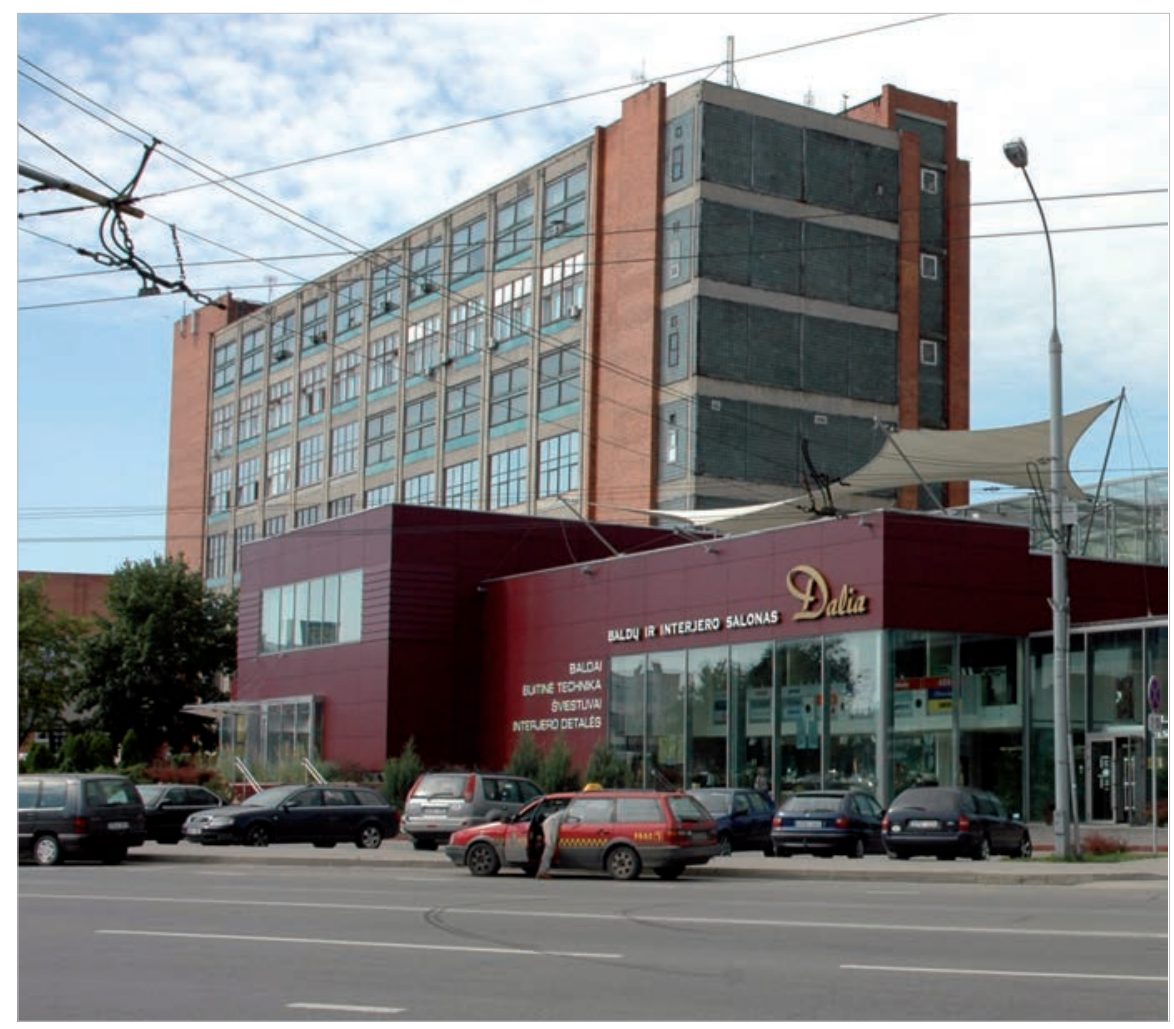

Prof. A. Dineika. Pramonés pastatas Vilniuje (2-ame plane)

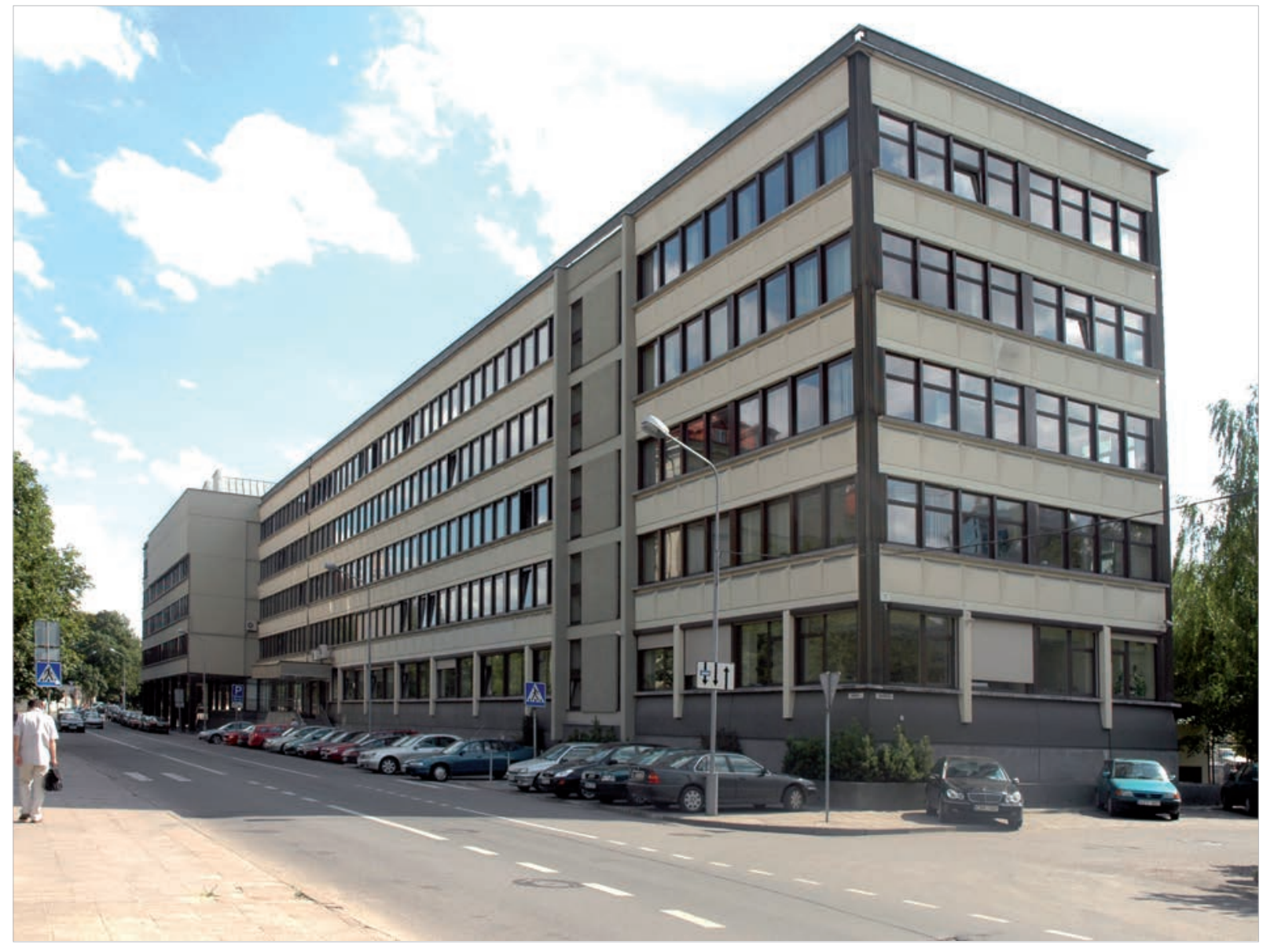

Doc. E. Tamoševičius. Tiekimo organizacija Vilniuje 


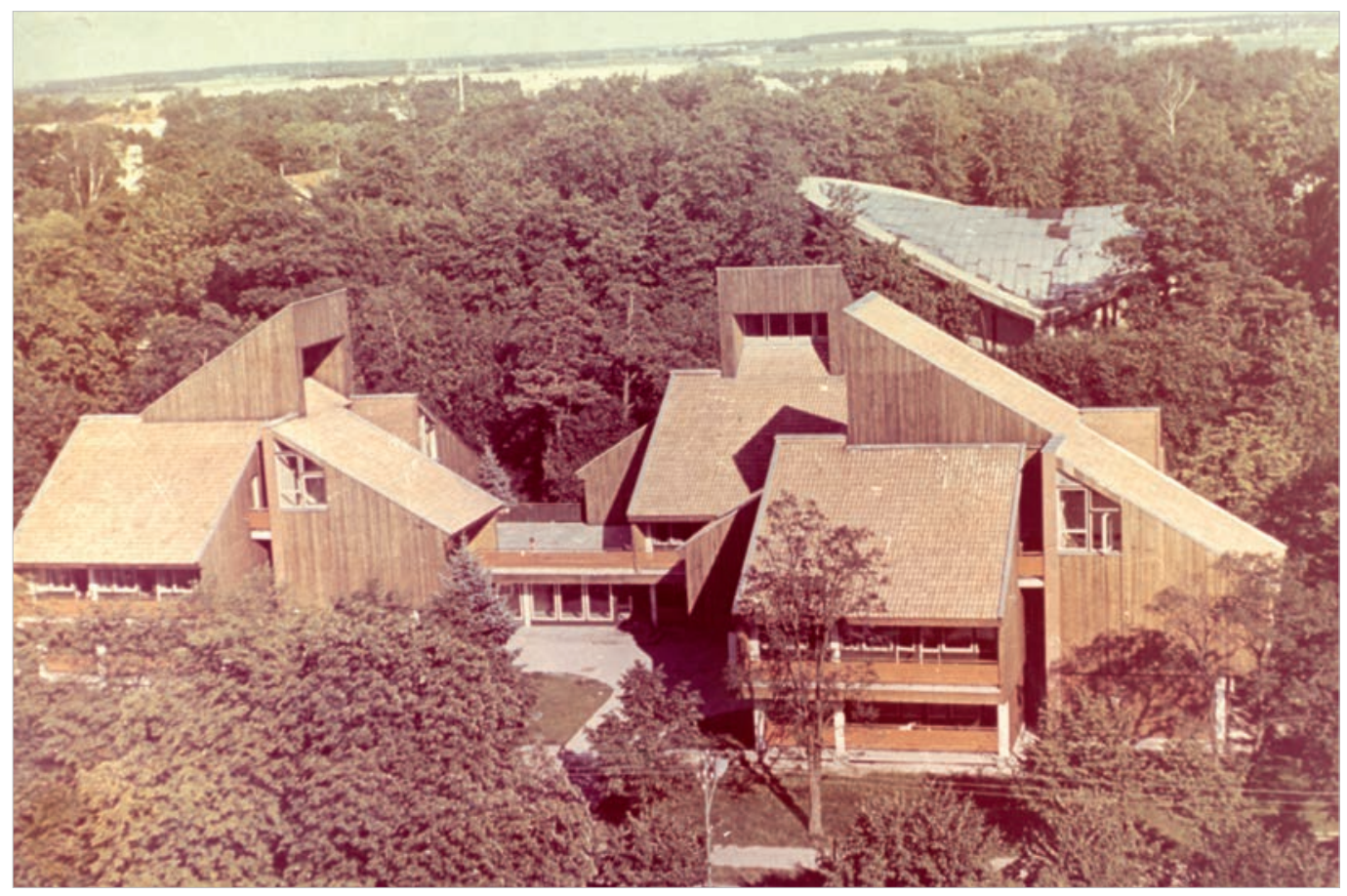

Prof. V. Dičius, L. Ziberkas. Lietuvos moksly akademijos poilsio namai Palangoje

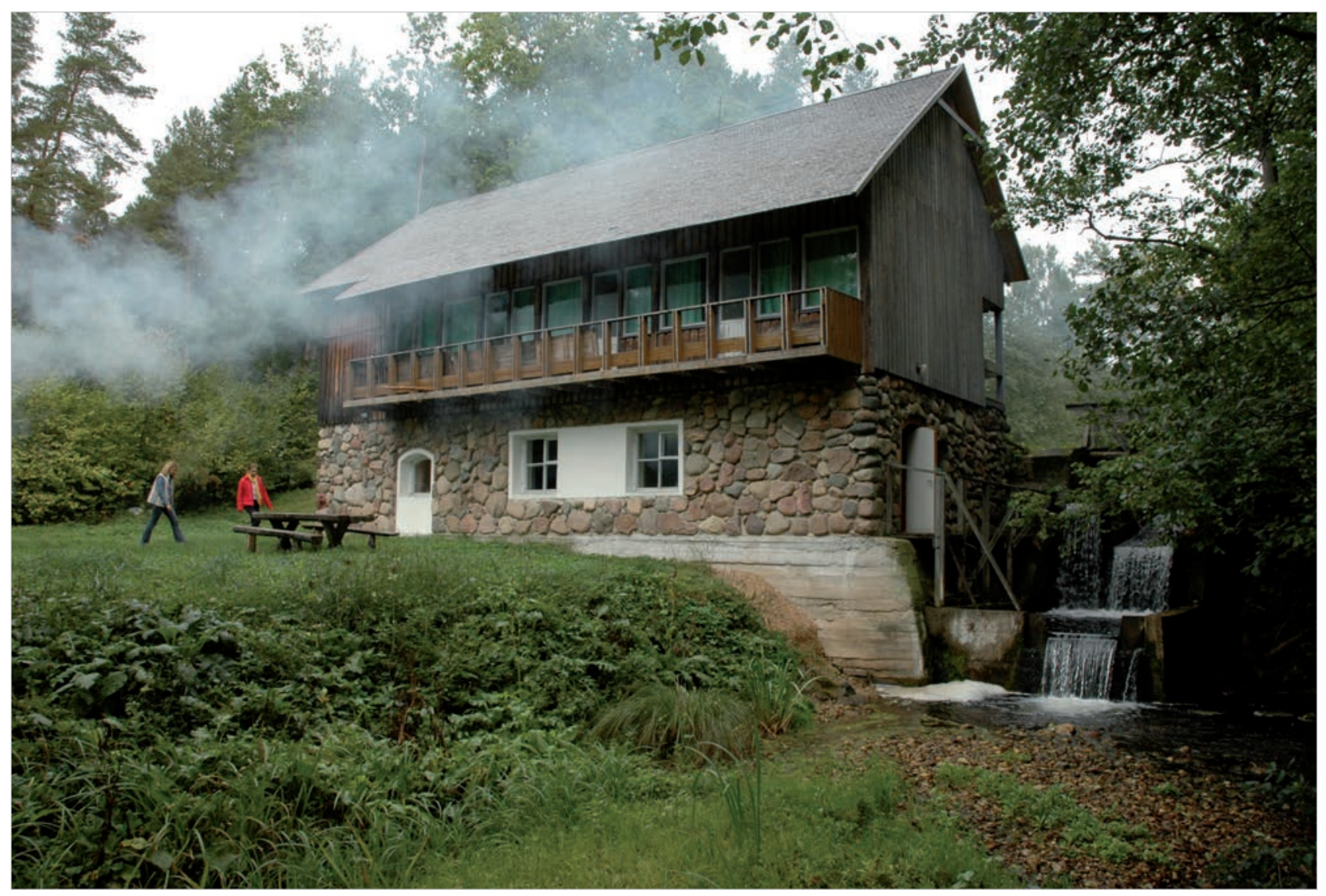

Prof. V. Dičius. VGTU praktiku baze Aukstaitijos nacionaliniame parke prie Kirdeikin 


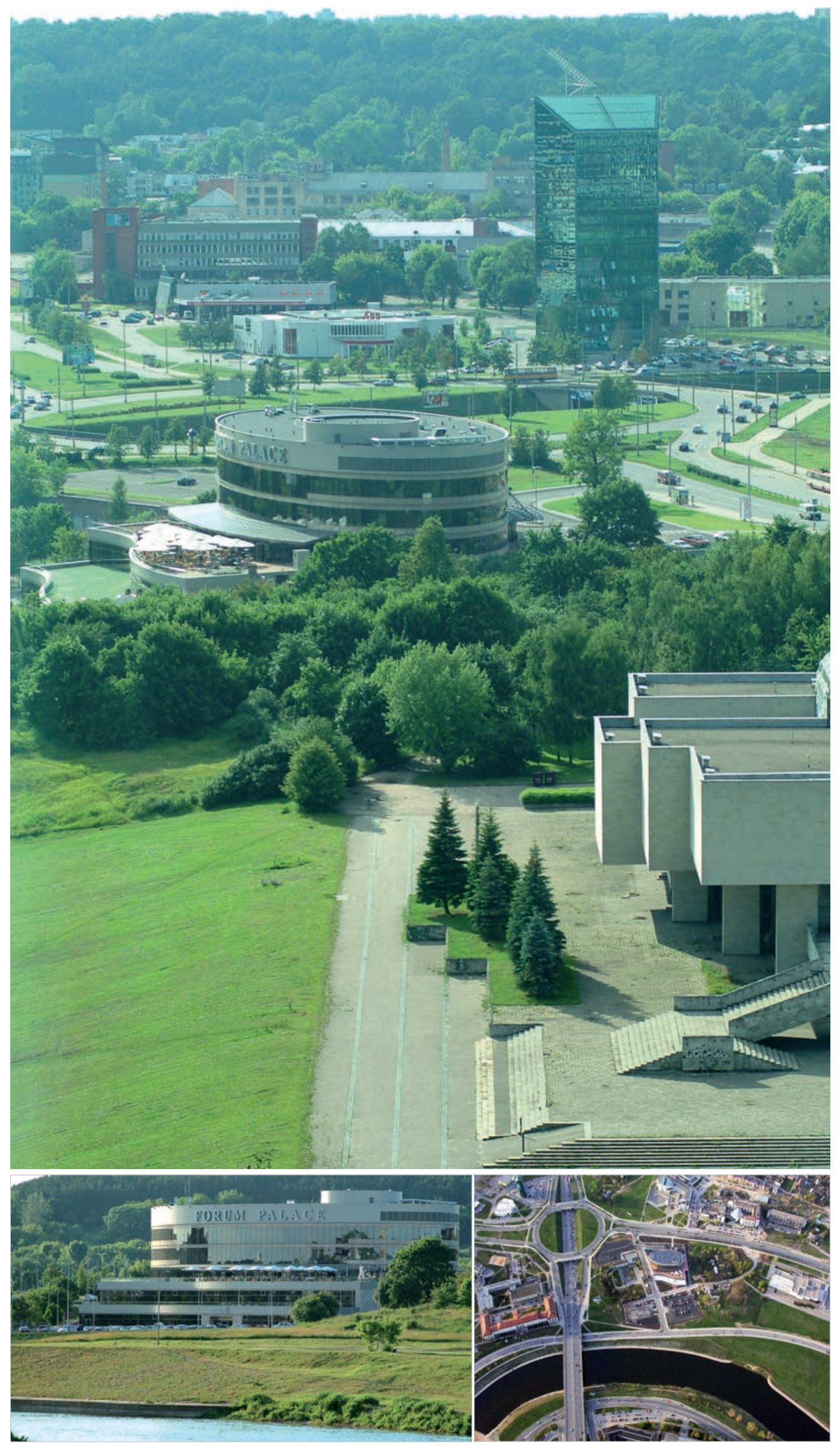

Doc. G. Čaikauskas. „FORUM PALACE“ rümai Vilniuje 
Architektas R. PALEKAS

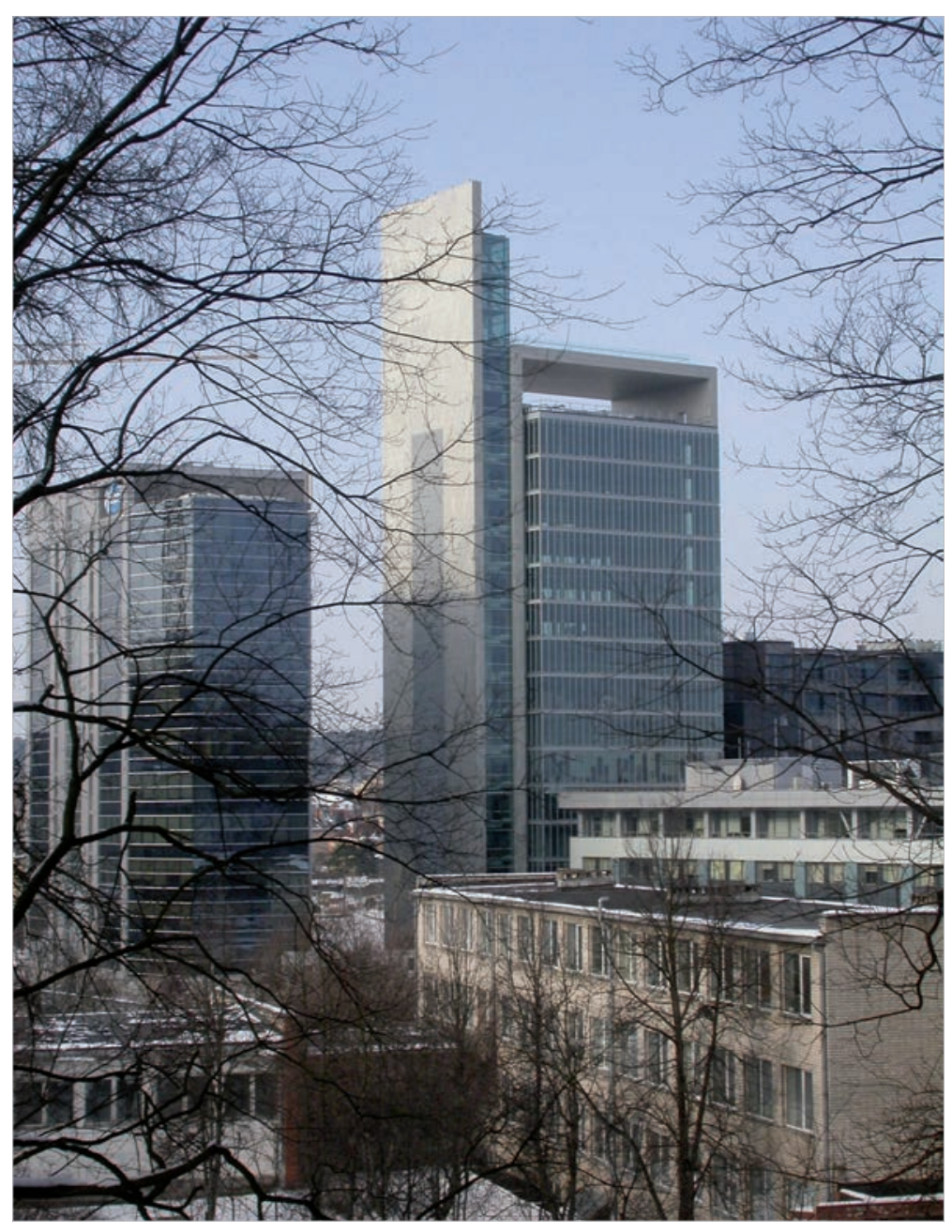

Doc. R. Palekas. Biuru pastatas Vilniuje

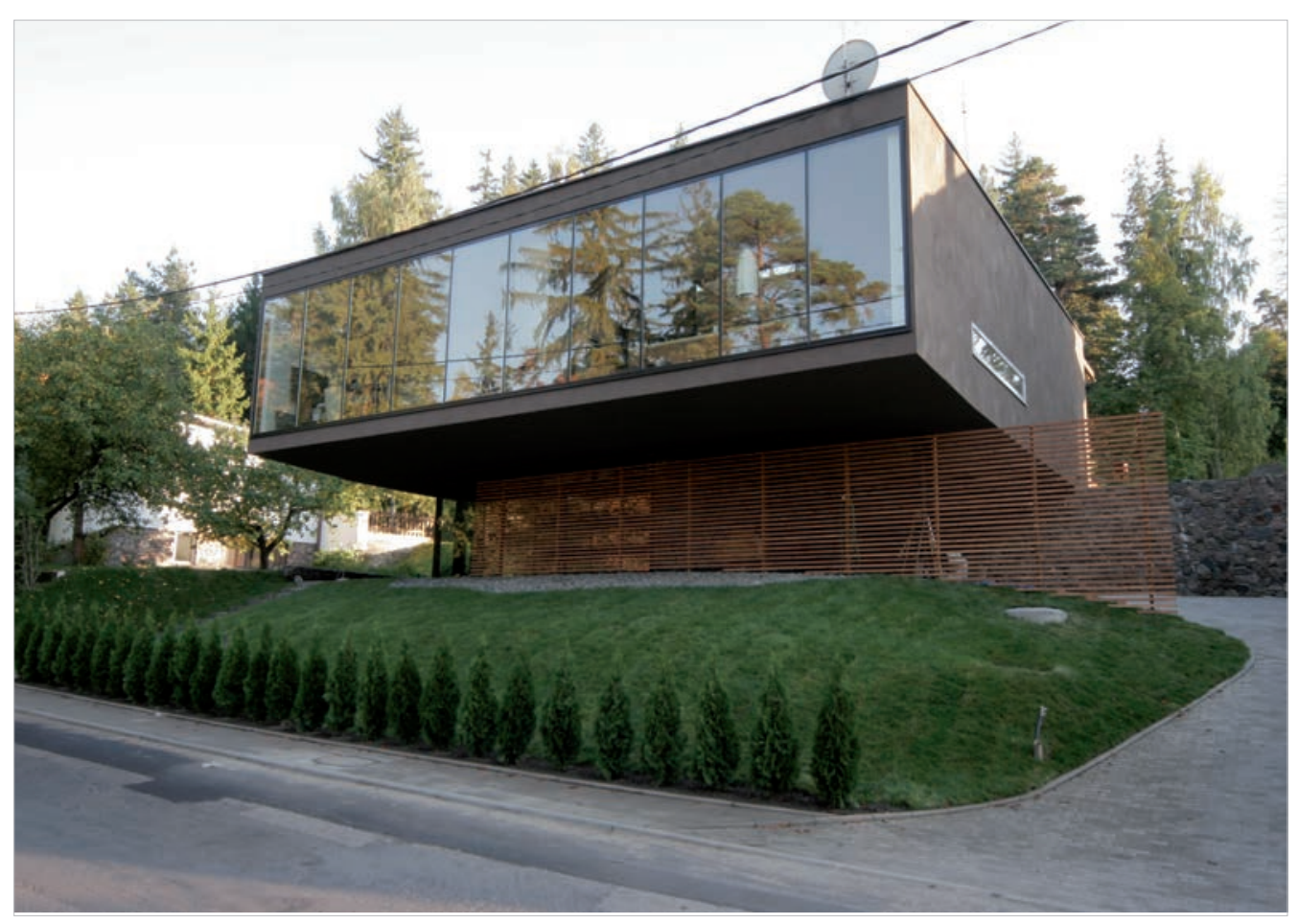

Doc. R. Palekas. Gyvenamasis namas Mildos g. Vilniuje 
Architektai A. AMBRASAS, K. LUPEIKIS

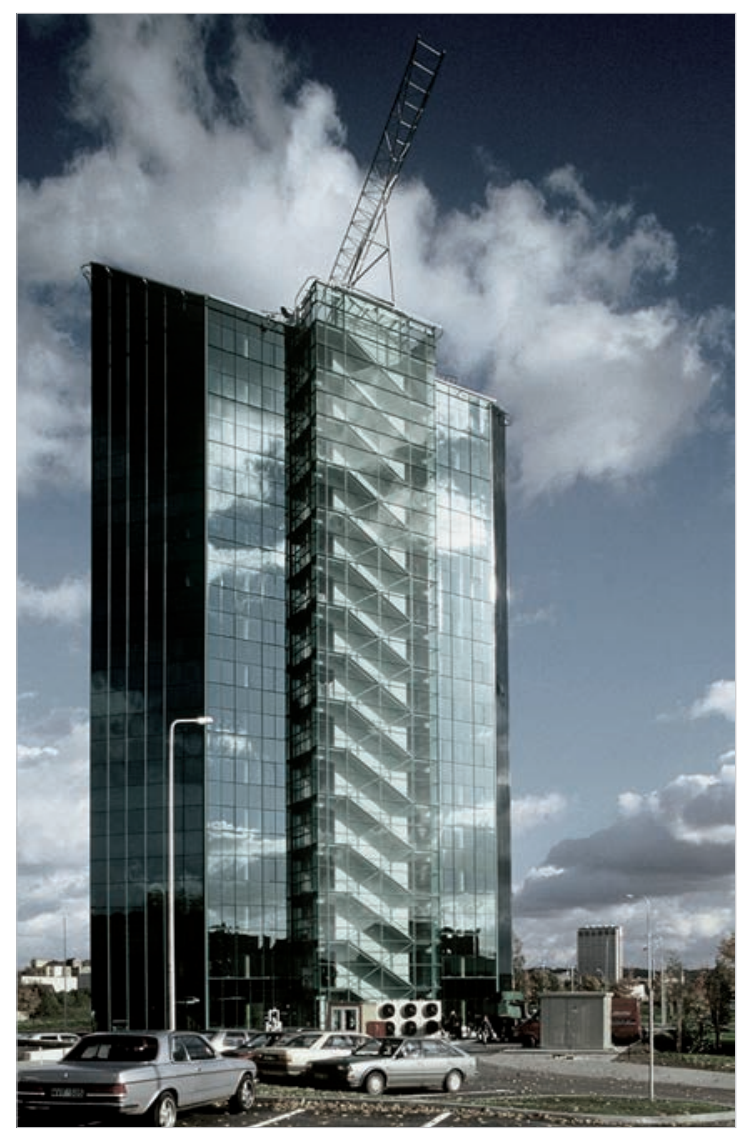

A. Ambrasas. "Hanner" pastatas Vilniuje

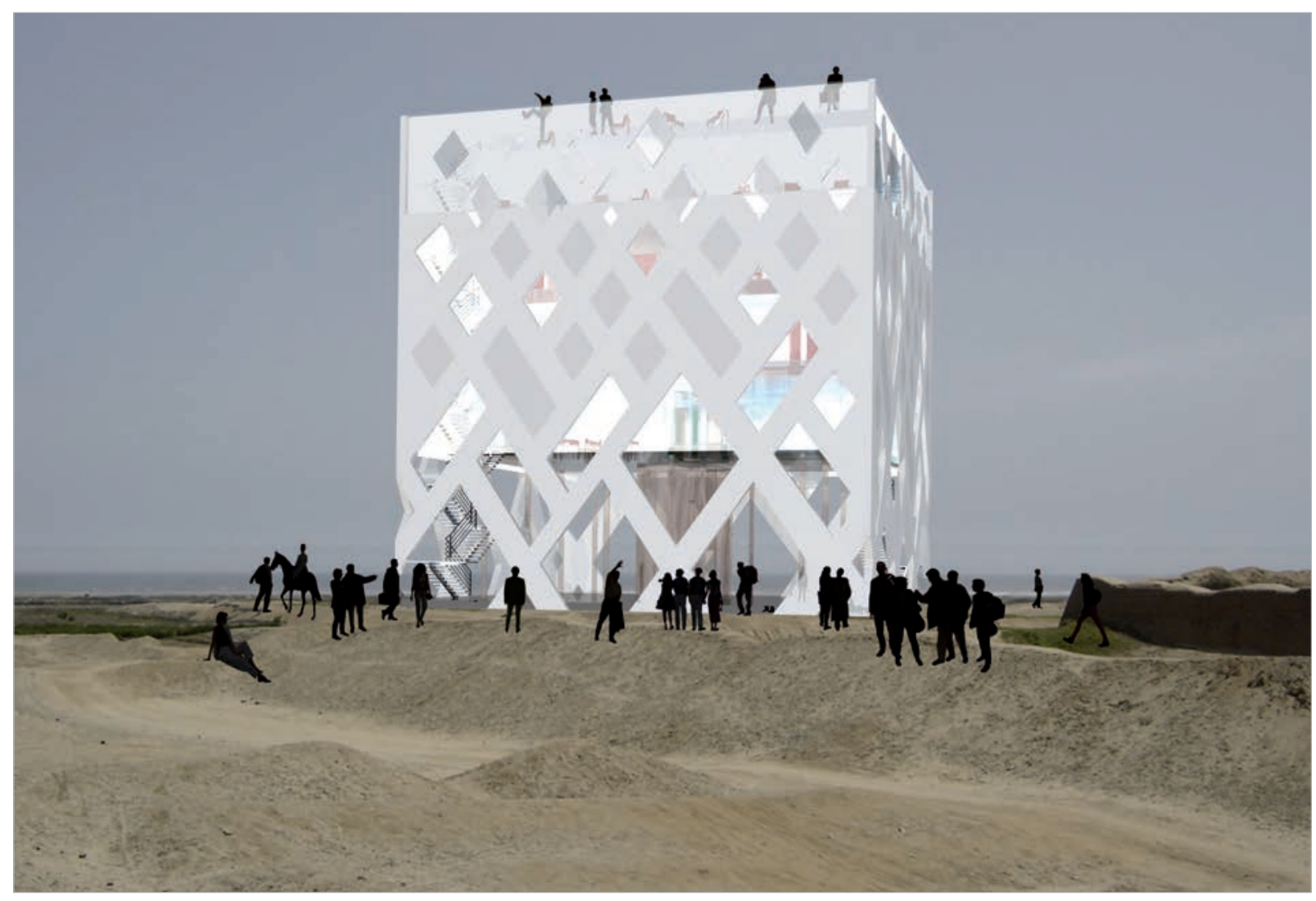

K. Lupeikis. Viešbutis CHAN CHAN Peru. Konkursinis projektas 

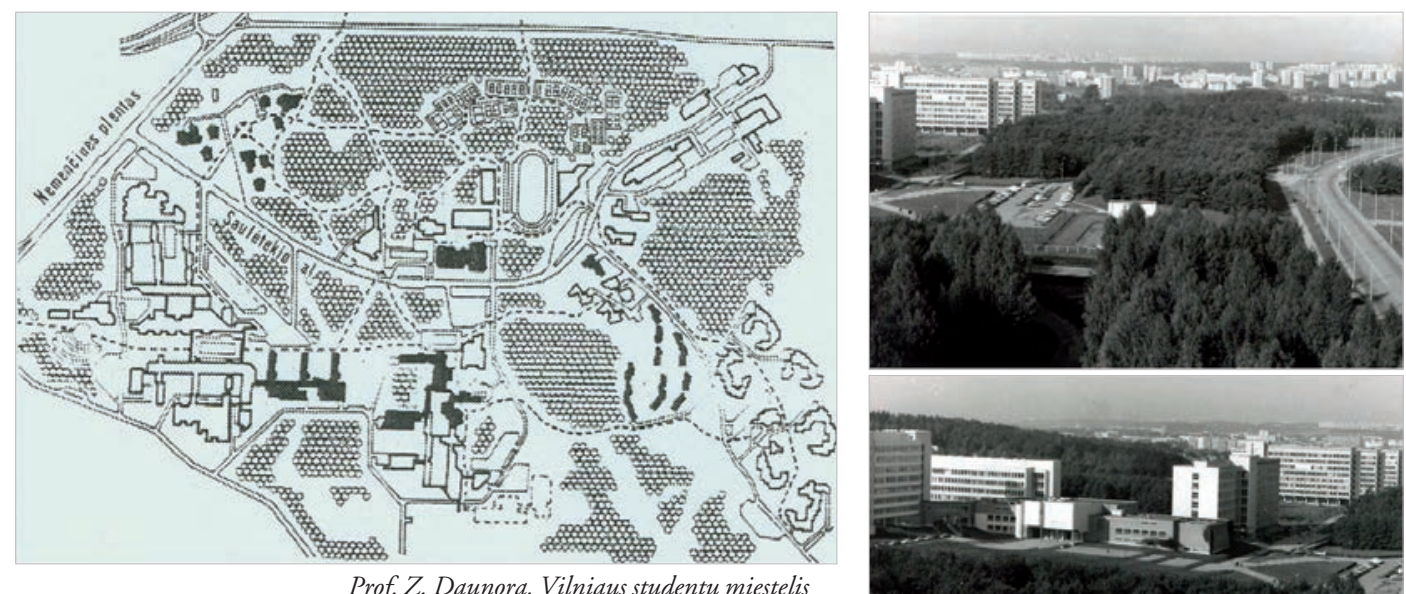

Prof. Z. Daunora. Vilniaus studenty miestelis
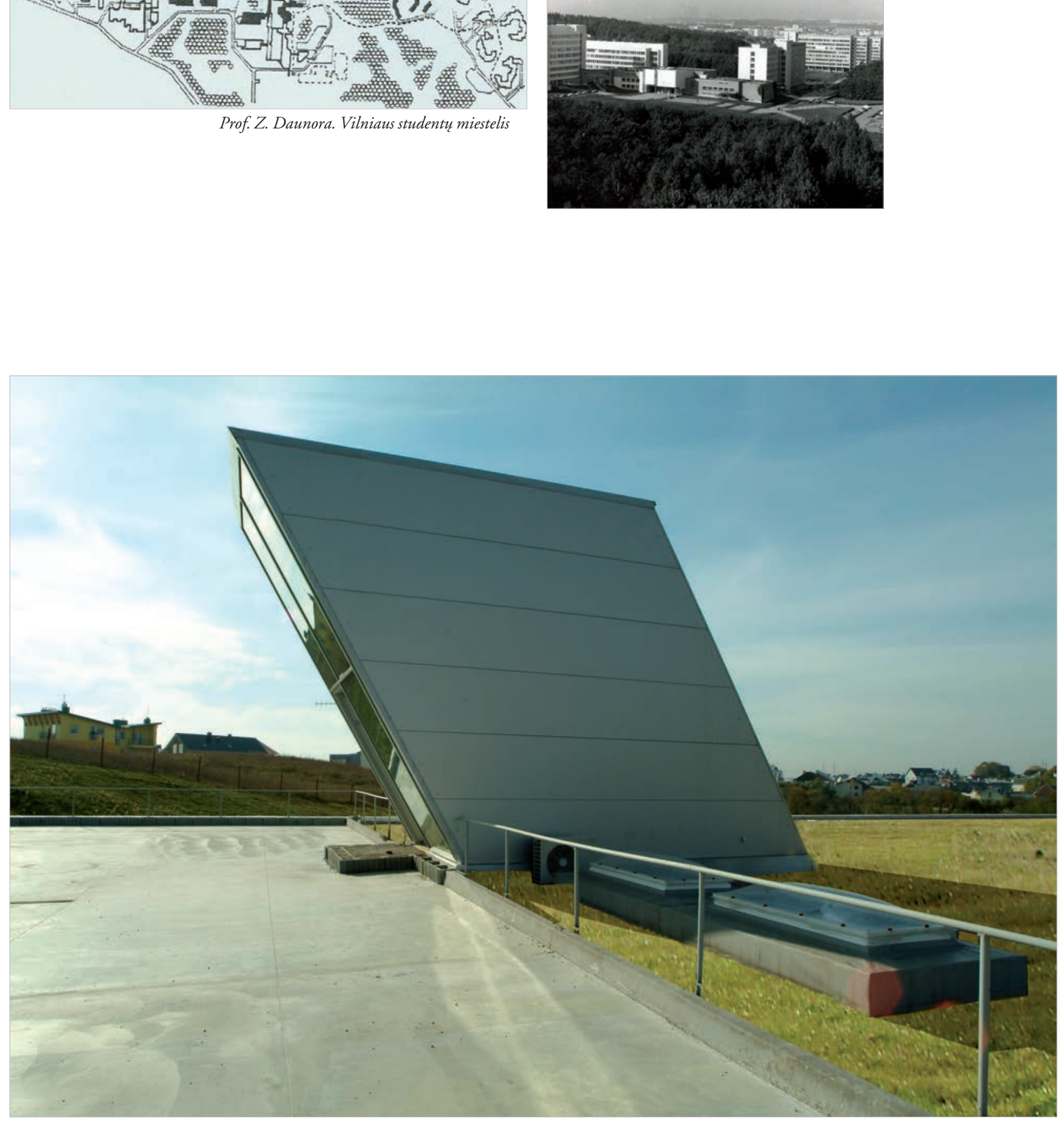

V. Gerdvilis. Spaustuves projektas 
Architektas A. VYŠNIŪNAS

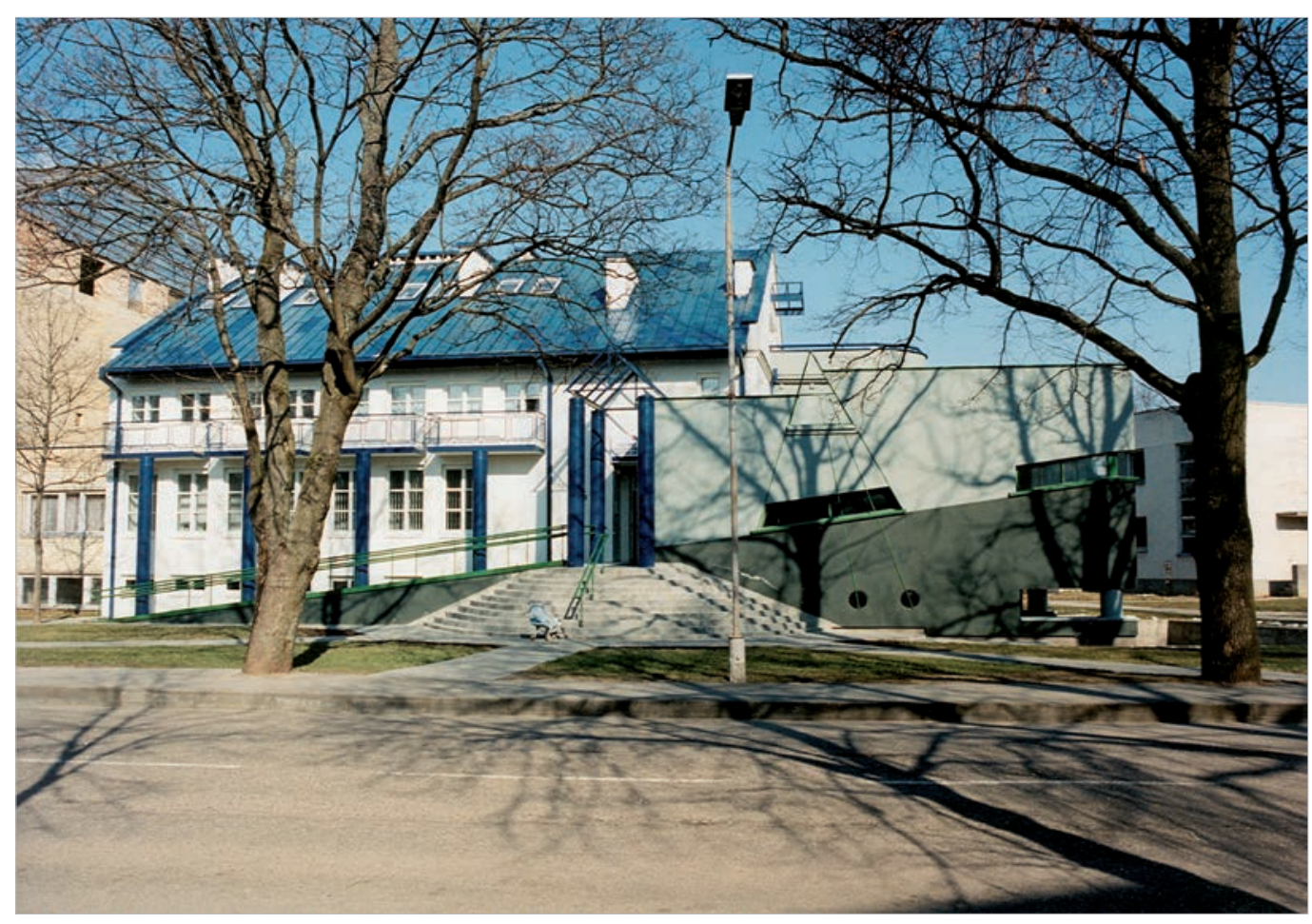

Doc. A. Vyšniūno darbai: Bištone ir Telšiuose

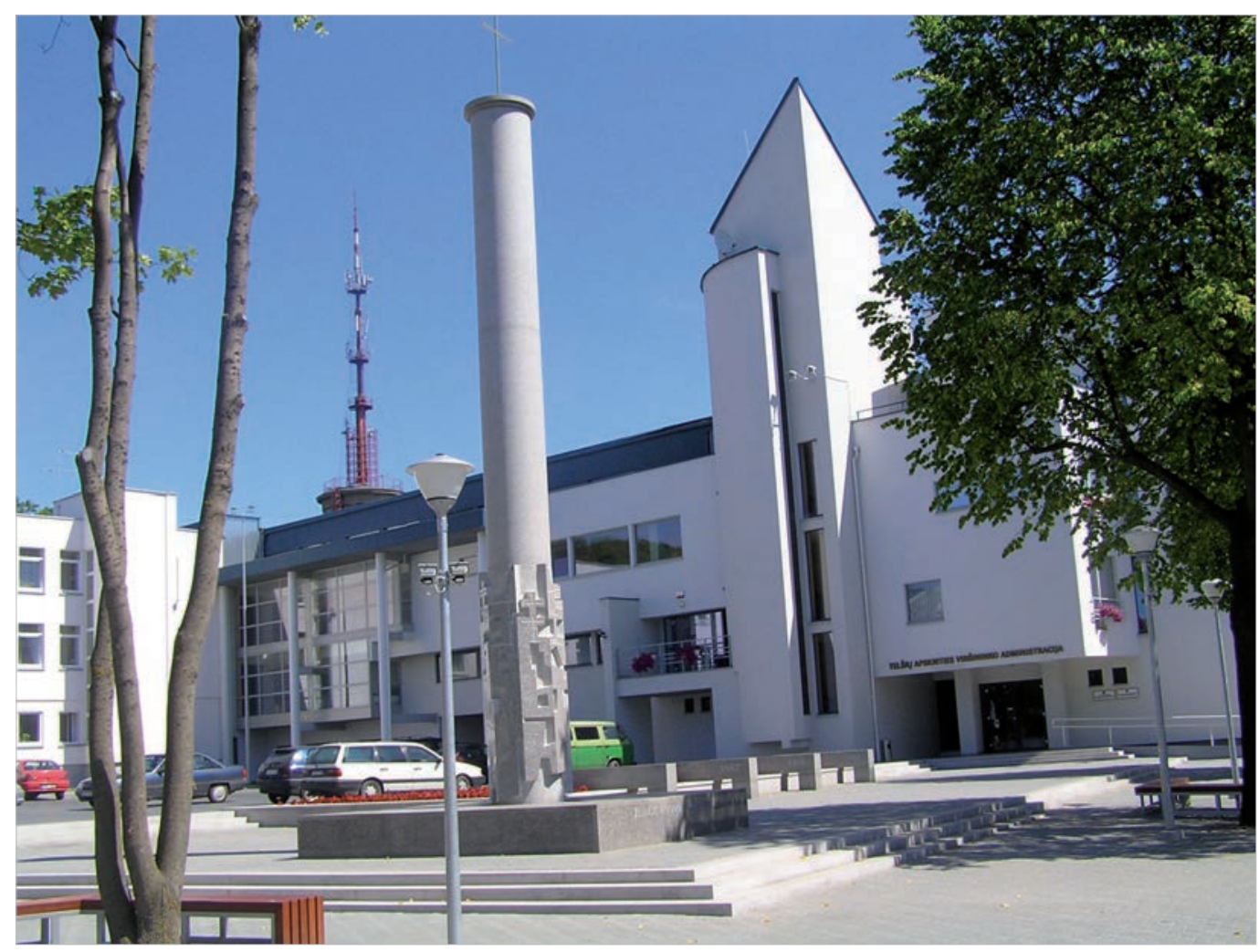




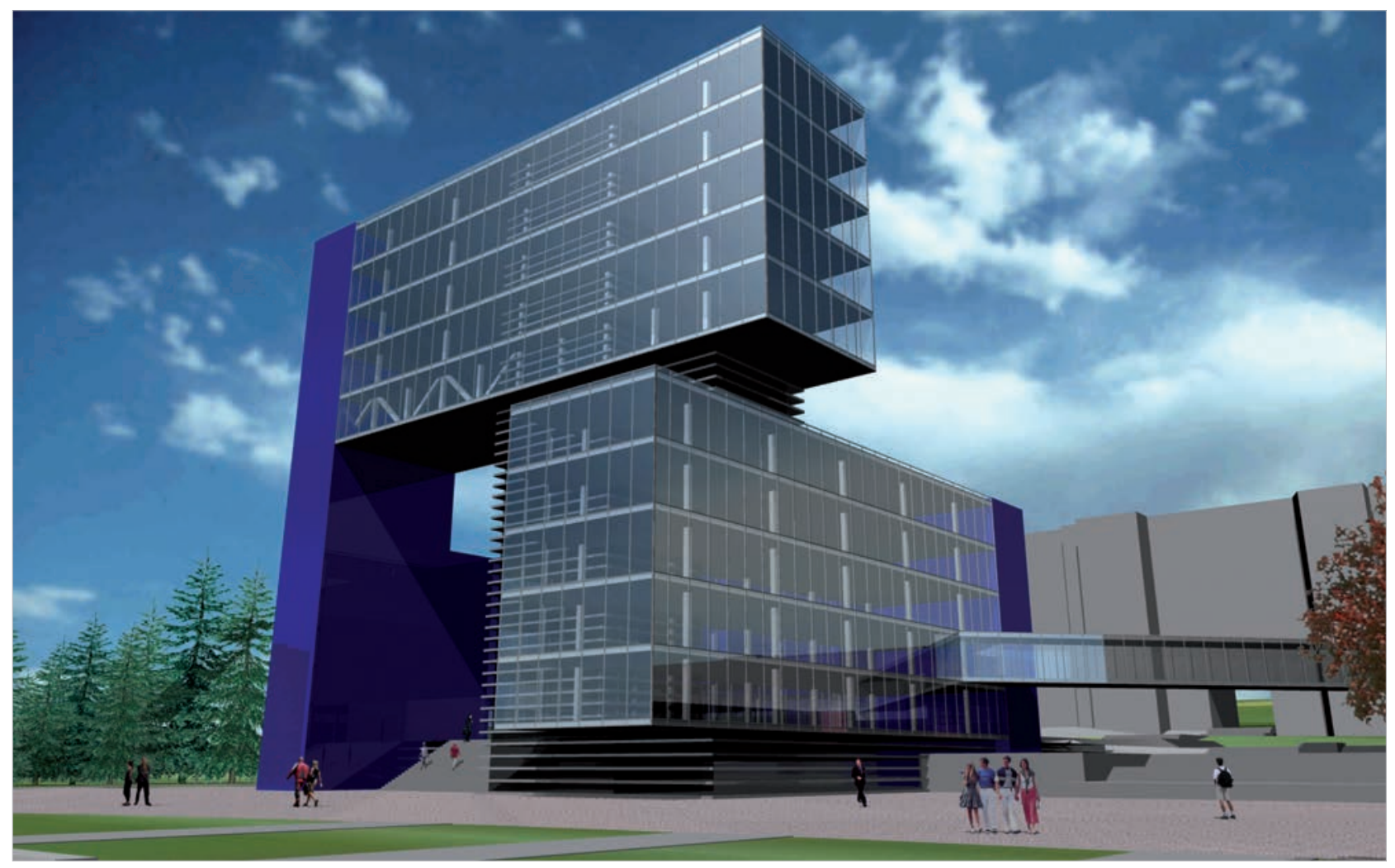

S. Kuncevičius. VGTU mokslo ir studiju centras Vilniuje
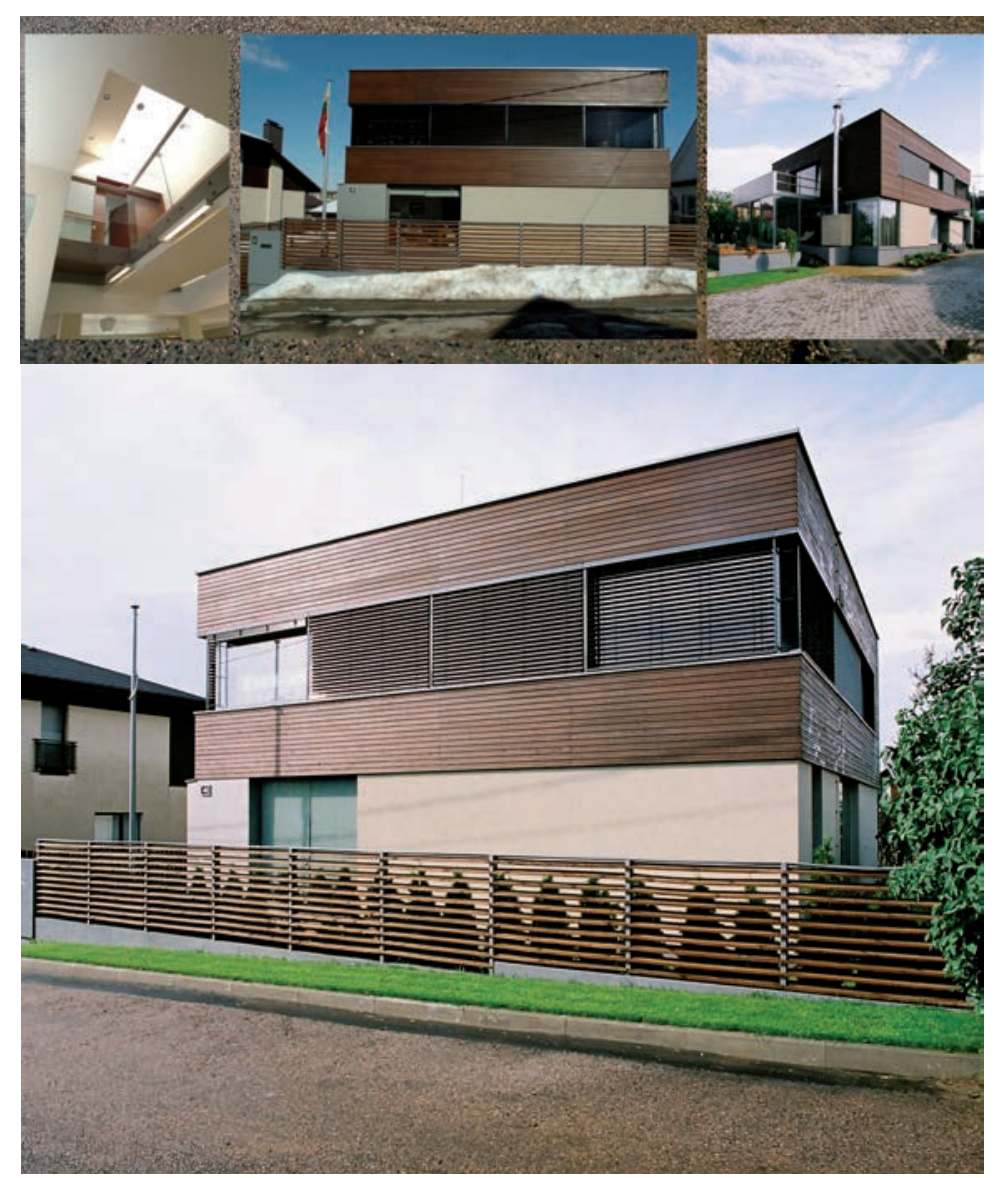

T. Grunskis. Medžiotoju namas 
Architektas E. NENIŠKIS

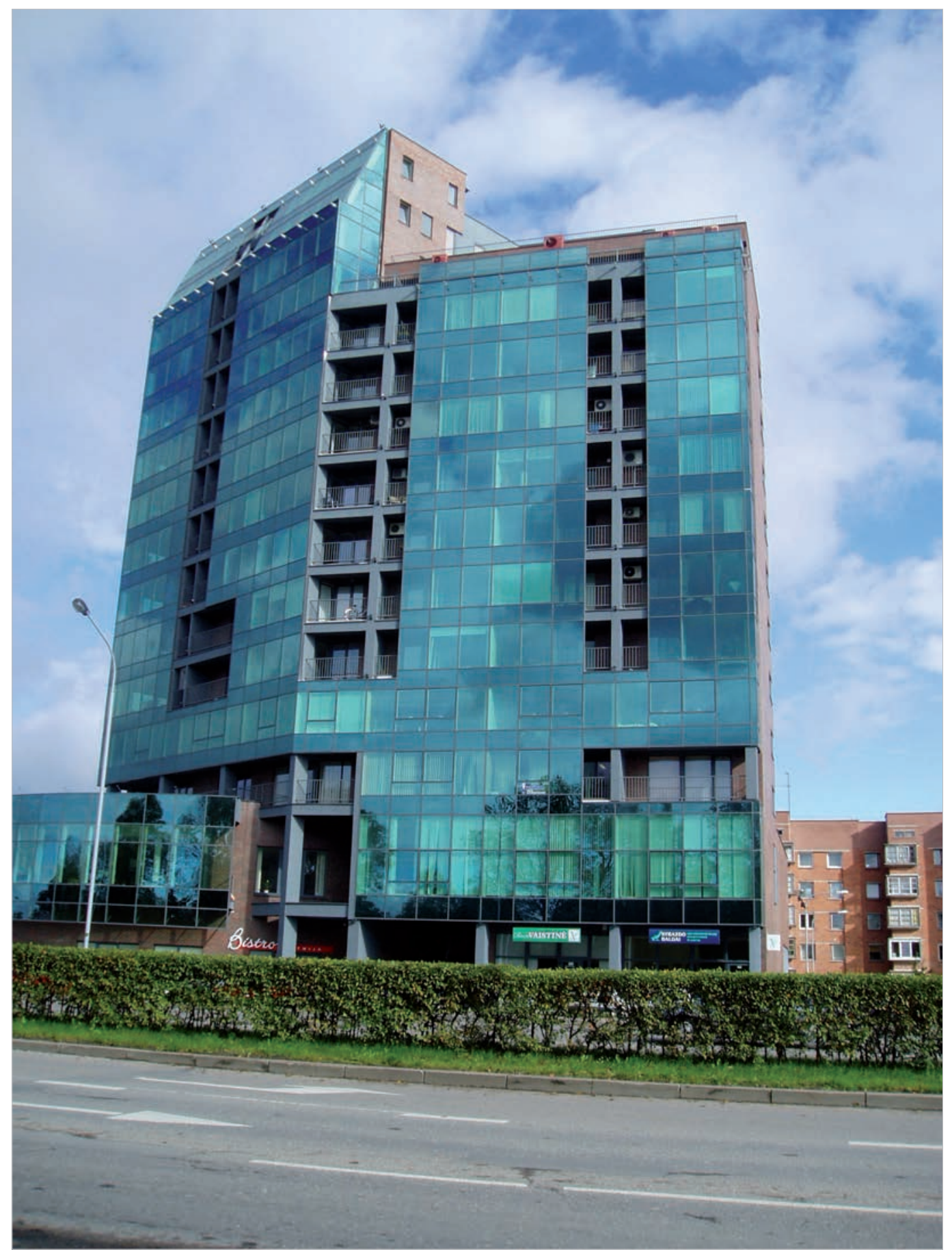

E. Neniškis. Civilinis pastatas Vilniuje 

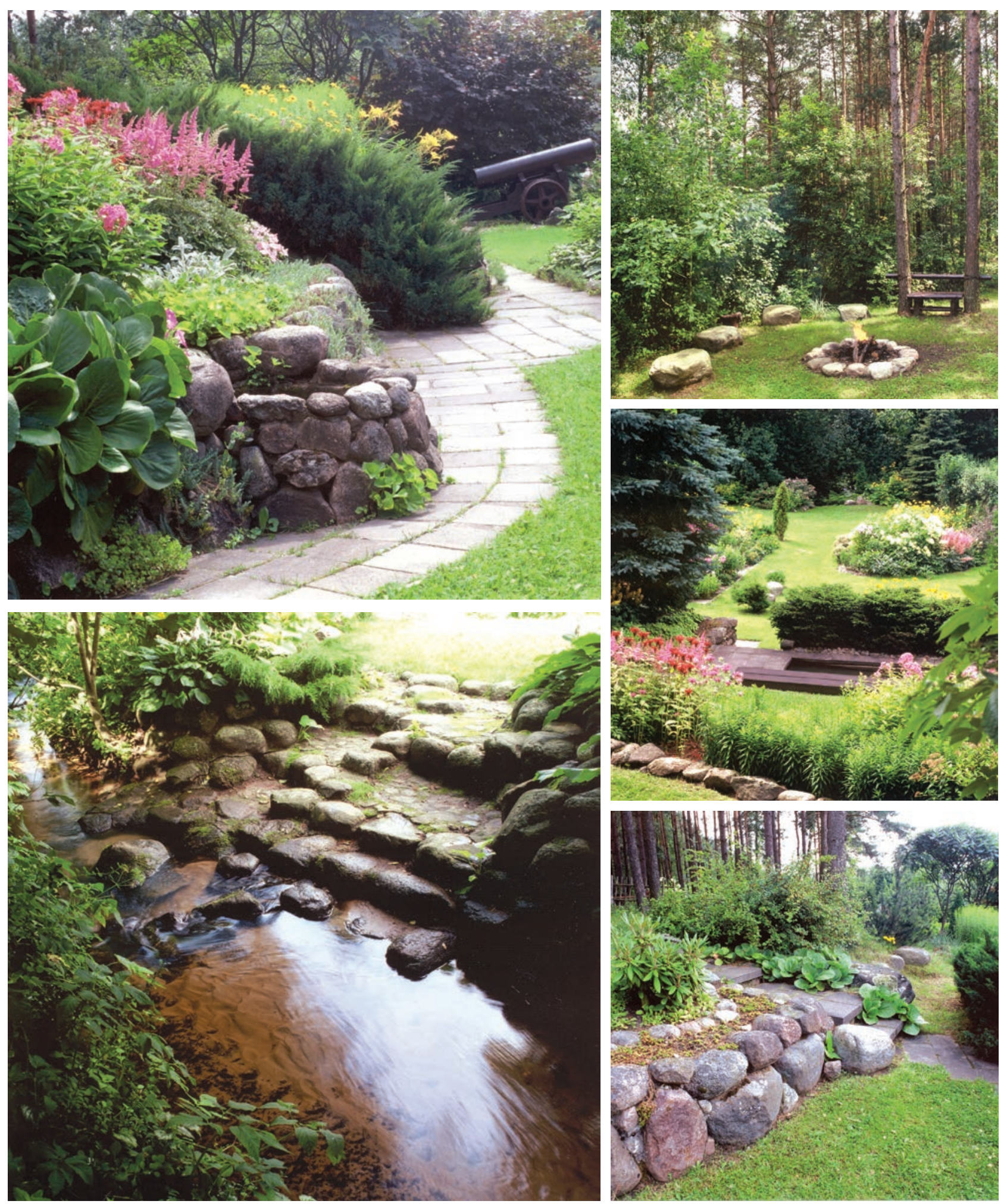

Prof. K. Jakovlevas-Mateckis. Užmiesčio vilos prie Vilniaus aplinkos projektas 


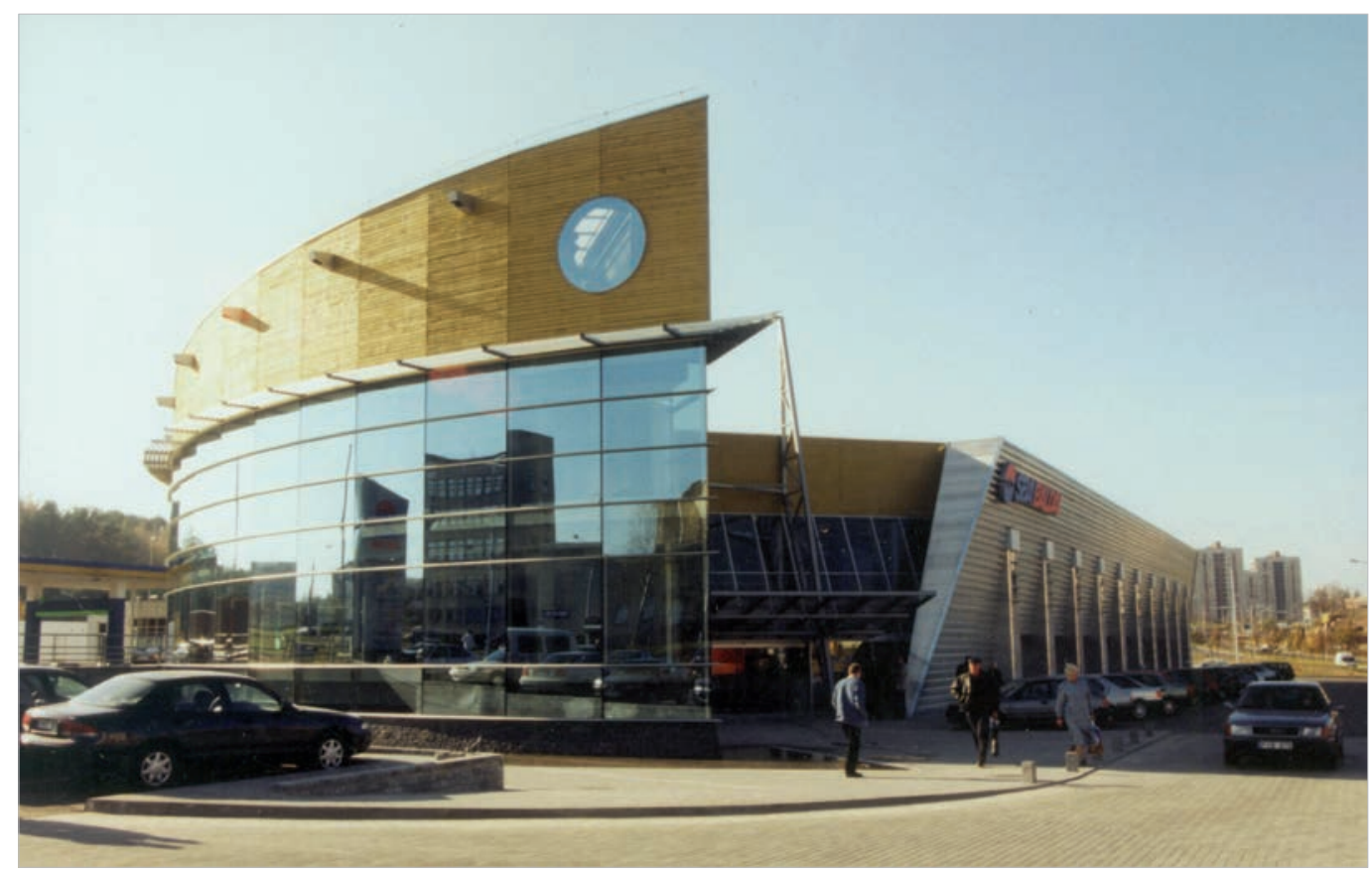

Doc. S. Kuncevičius, A. Jakutis. Baldu prekybos centras Vilniuje

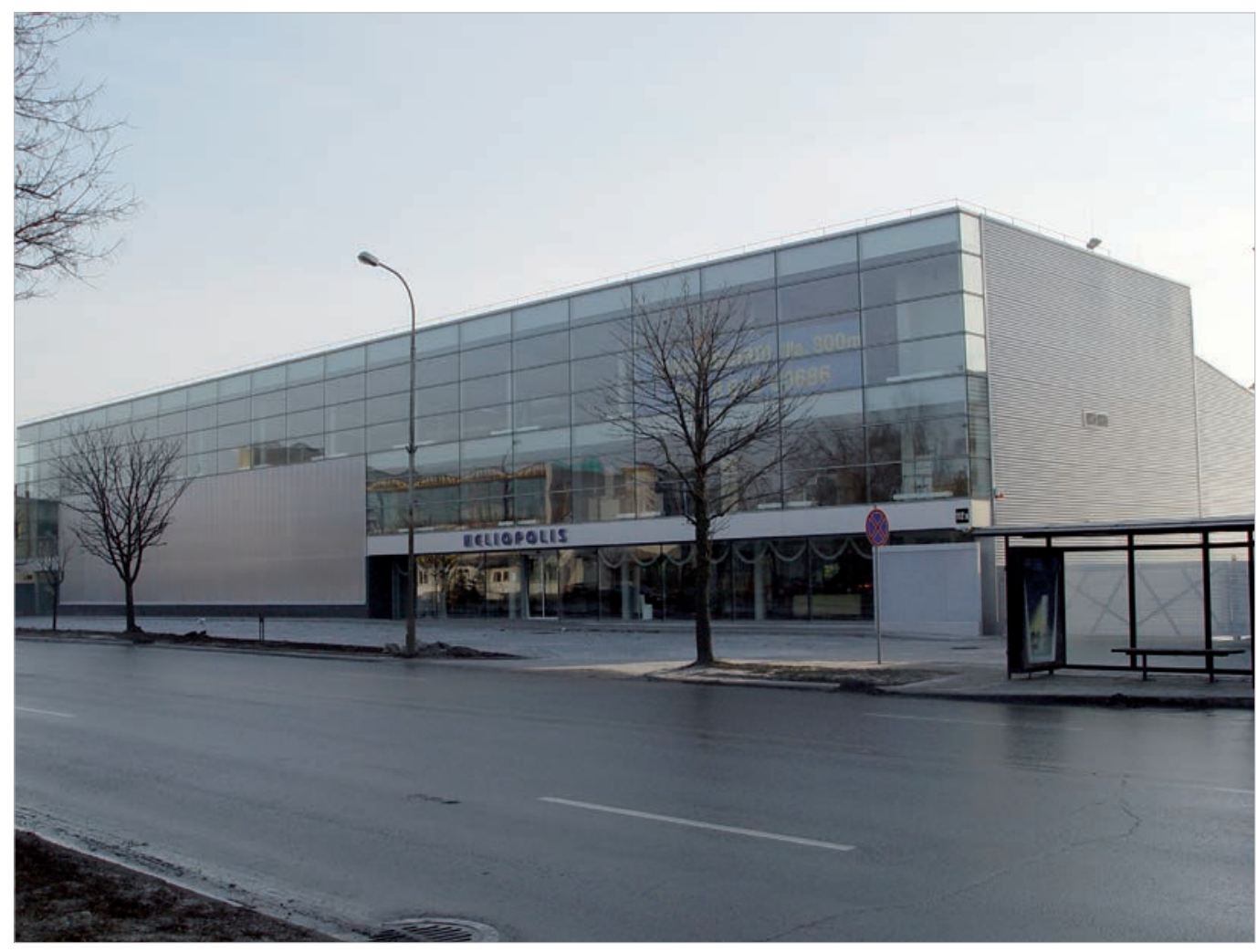

Doc. S. Kuncevičius. UAB „Heliopolis" Vilniuje 


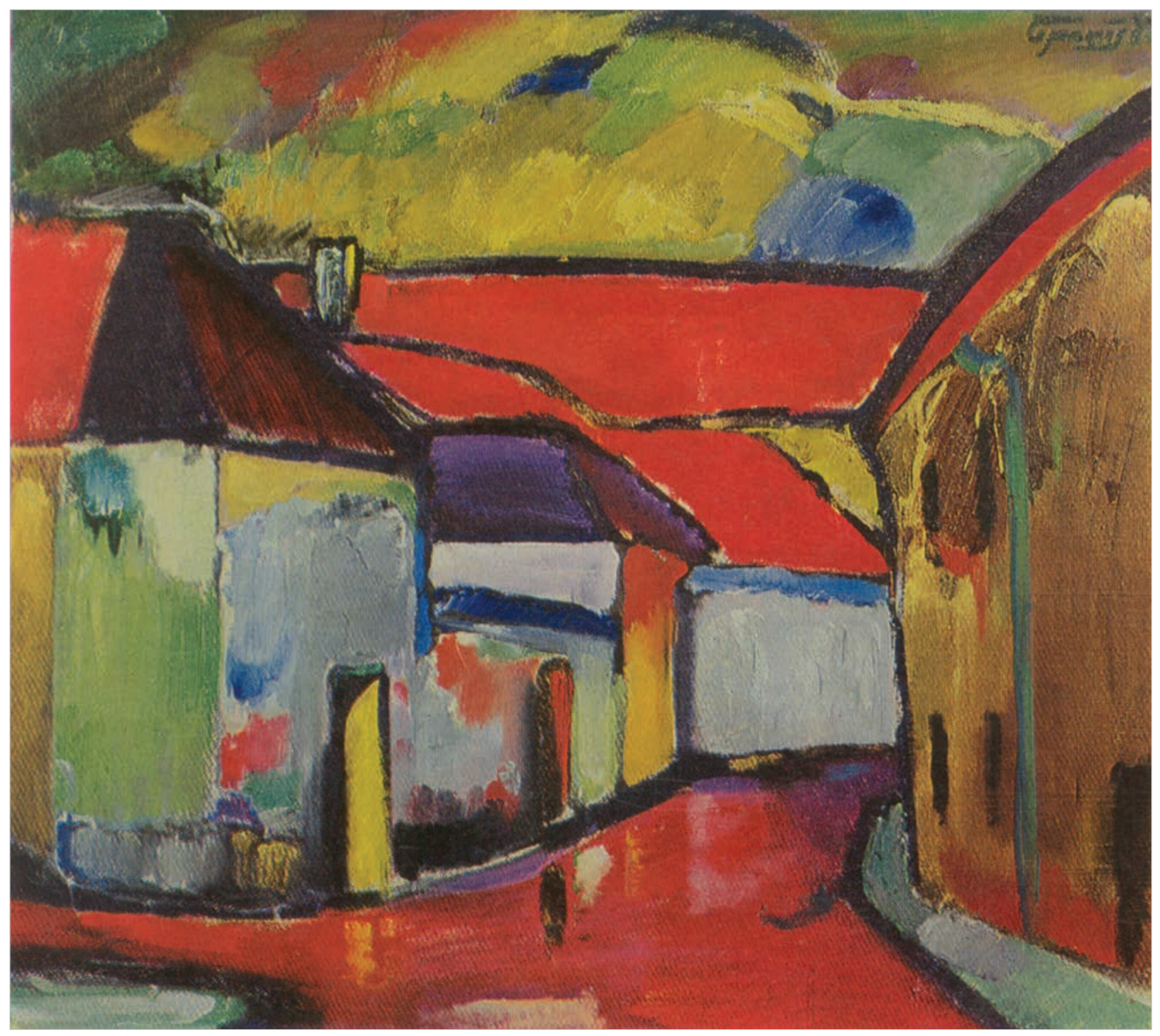

Doc. J. Čeponis. „Vilniaus senamiestyje“ 
Dailininkas A. ŠVE்GŽDA

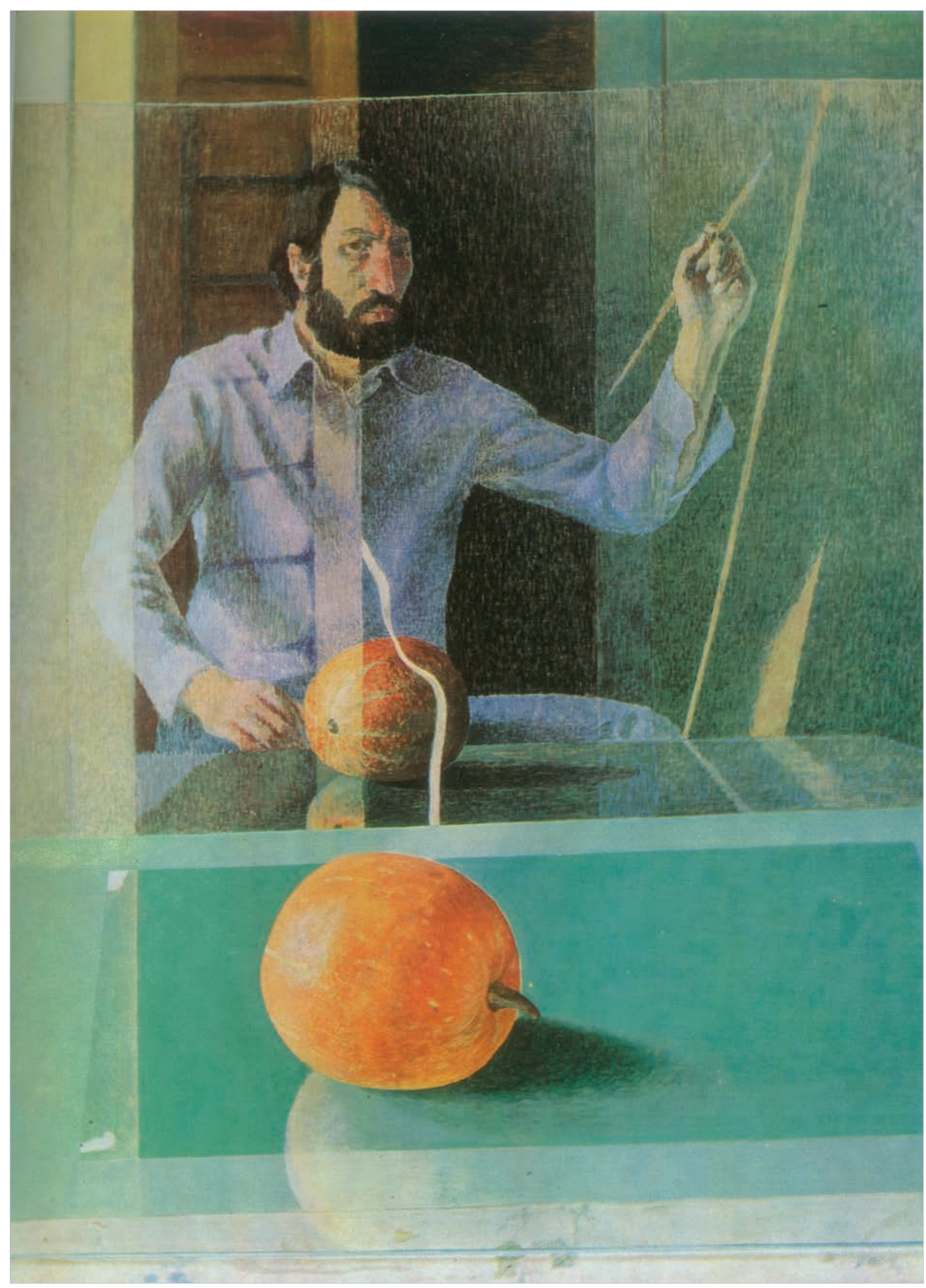

Dest. A. Švègžda. Autoportretas 


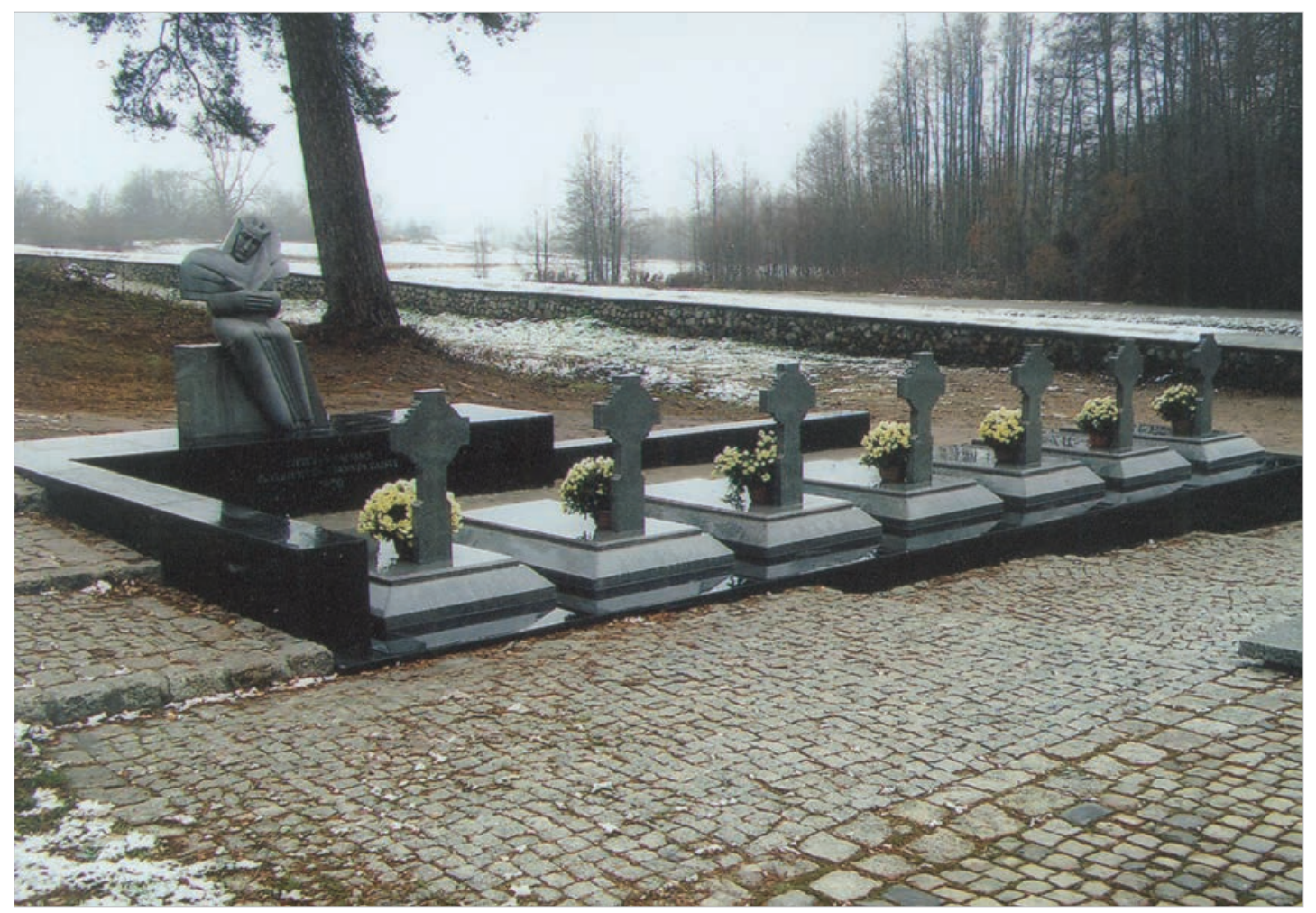

Skulpt. prof. D. Matulaite, VDA; prof.dr. R. Buivydas, VGTU; doc. J. Balkevičius, VDA. Lietuvos kariu kapai Bereznikuose, Lenkijoje

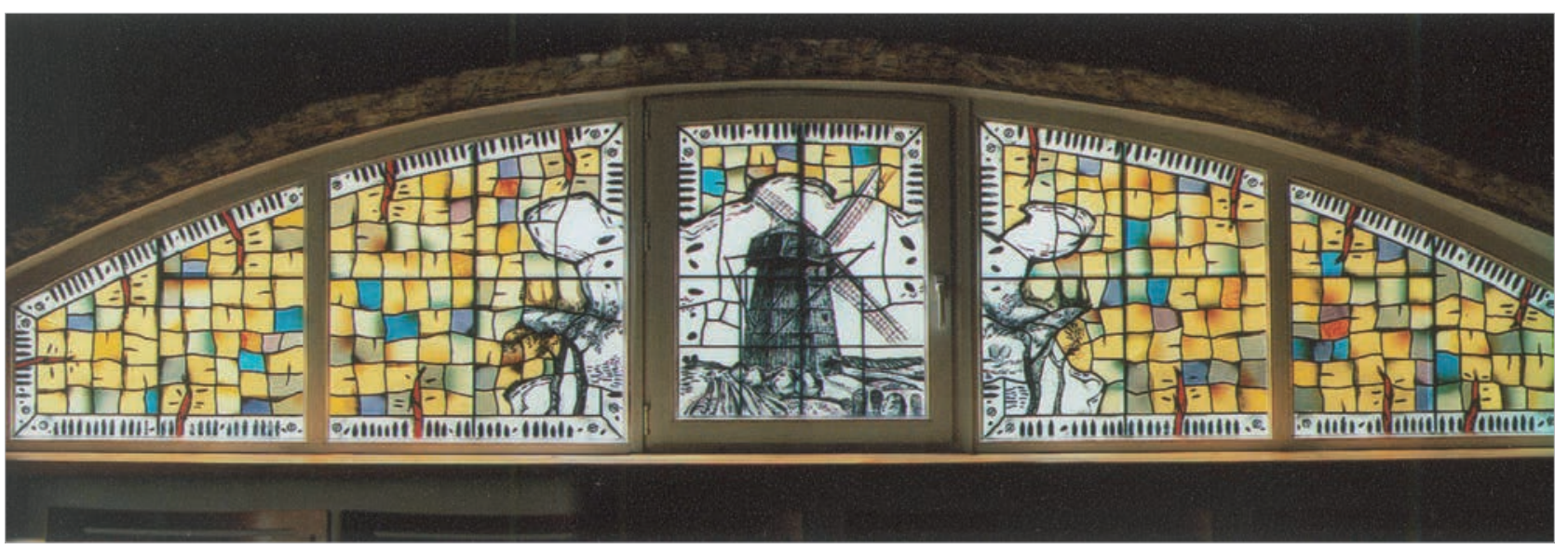

Desst. D. Žebenkienè. Vitražas „Malūnas“ 

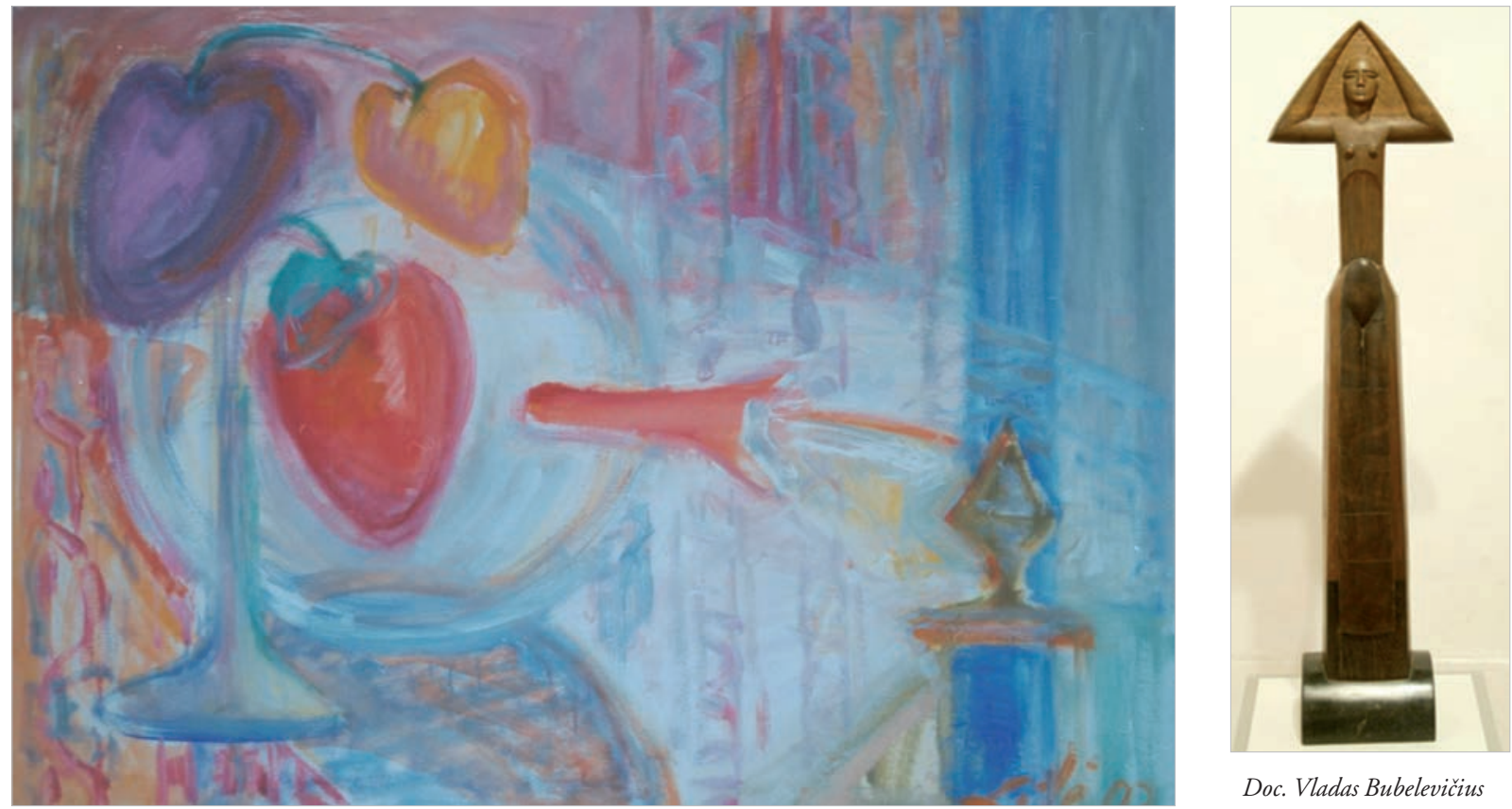

Doc. Vladas Bubelevičius

Asist. L. Puipiene. „Burbulai“

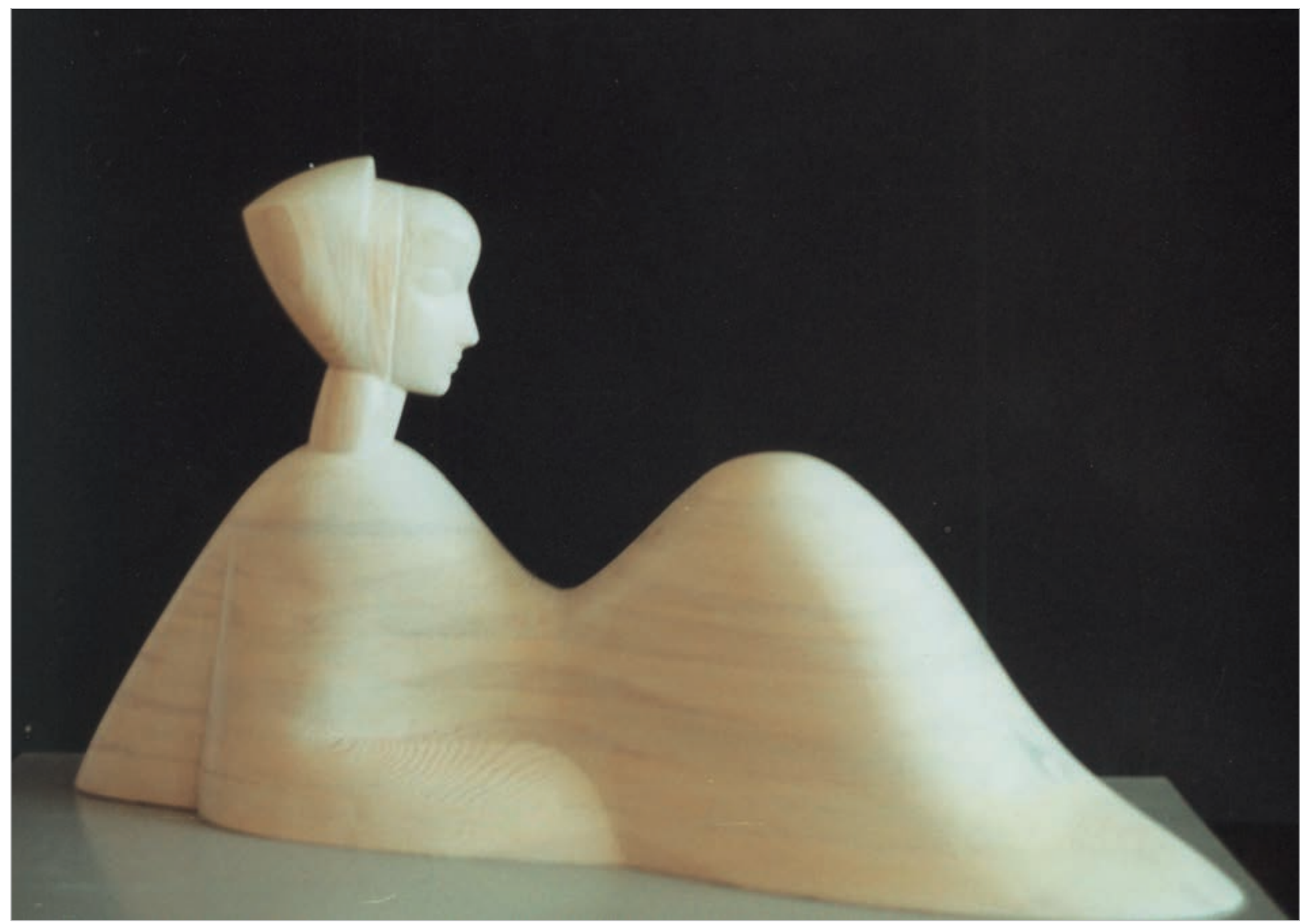

Doc. V. Gylikis. „Neringa“ 


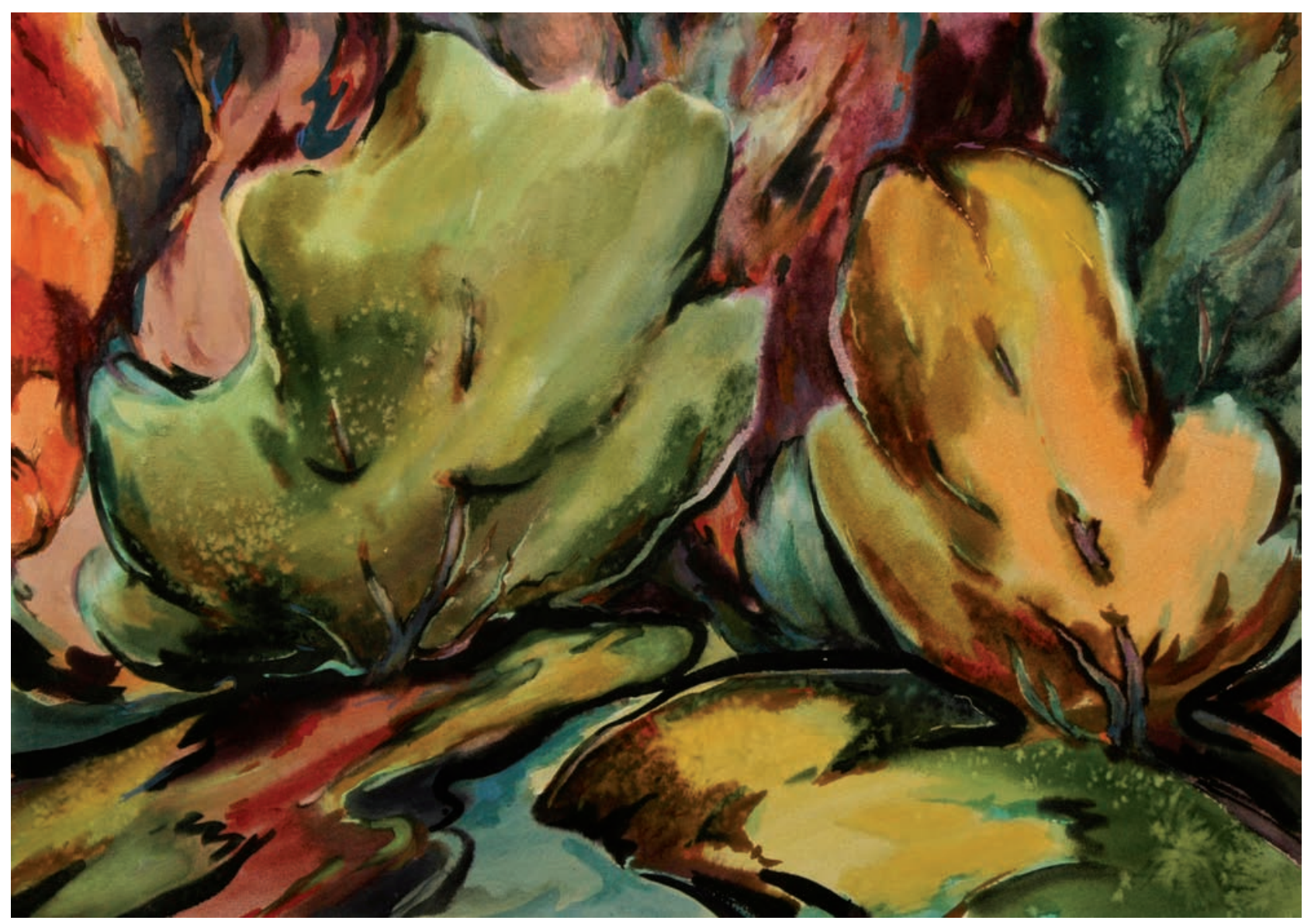

Doc. A. Keturka. „Prie Ūlos"

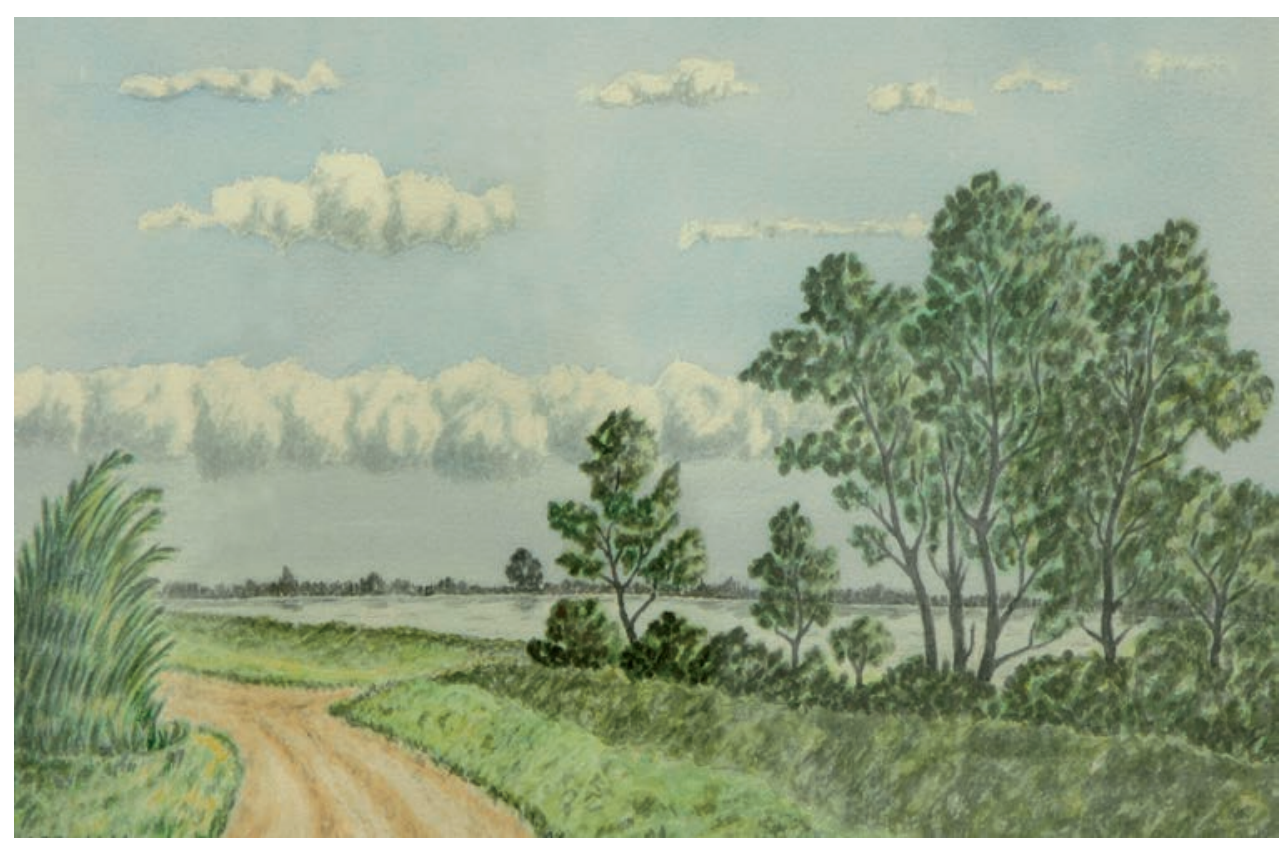

Prof. V. Kriščiūnas. „Rusnëje“ 


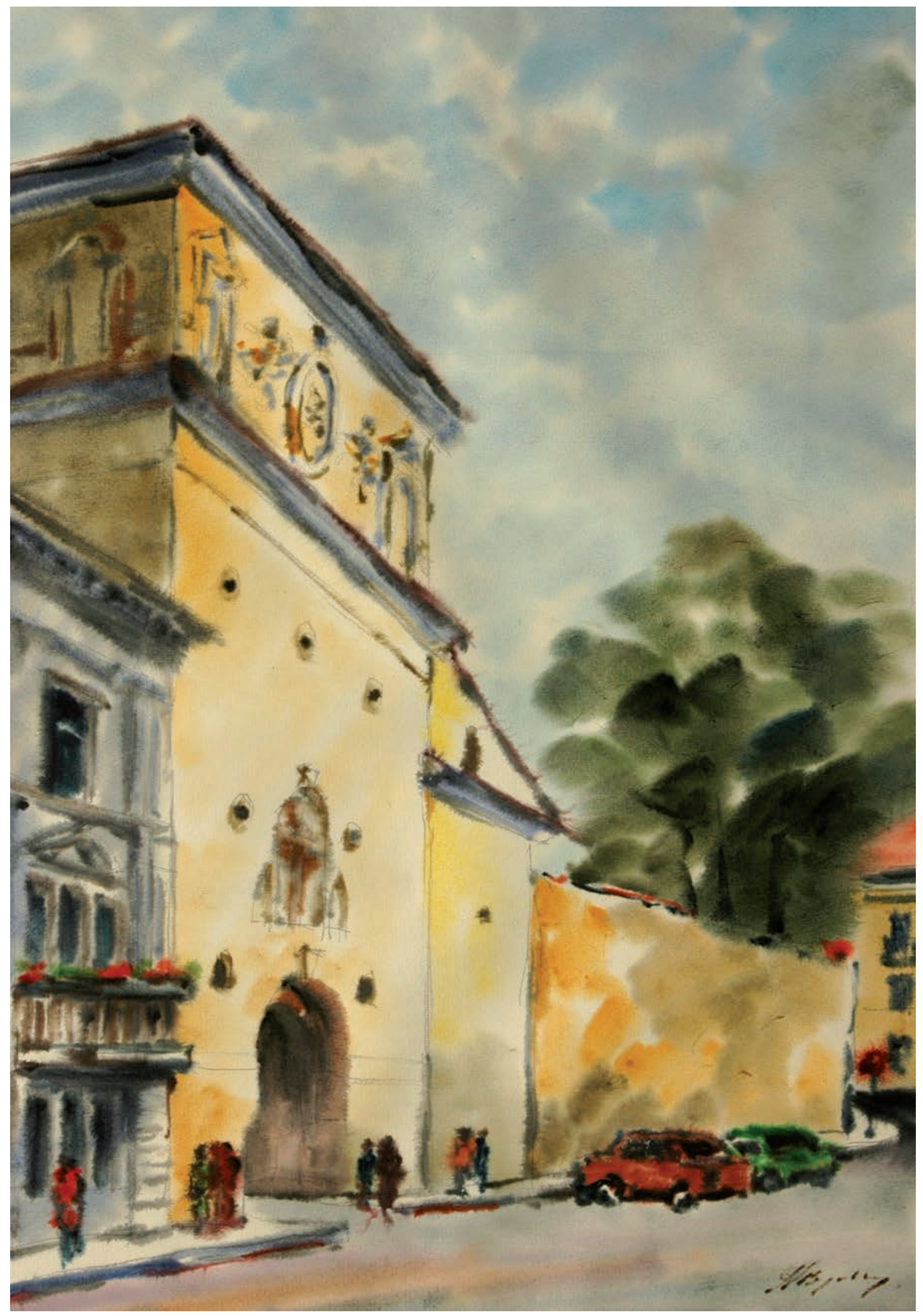

Doc. H. Bogdanas. „Medininku vartai“ 


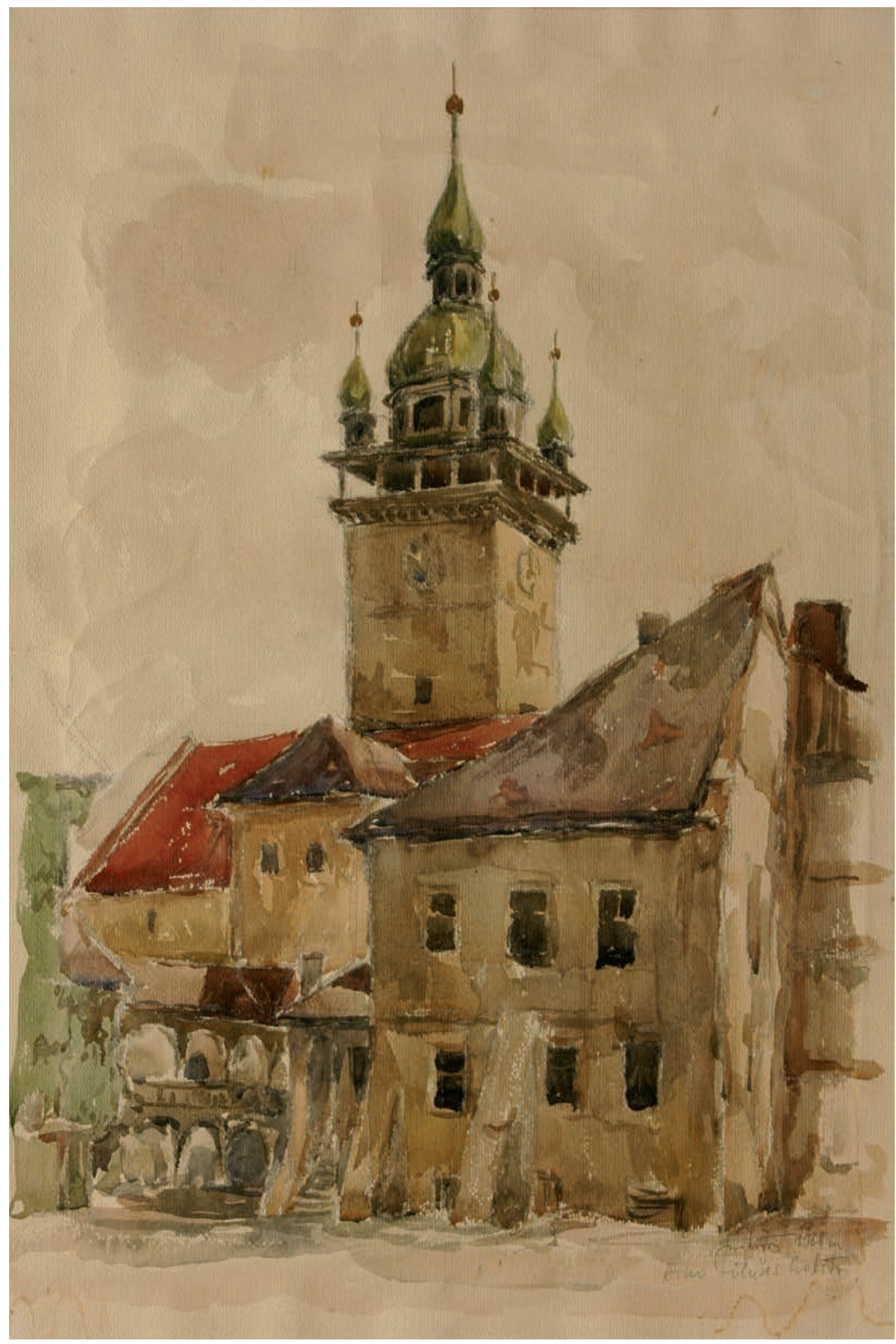

Doc. V. Jurkštas. „Brno rotušéc 


\section{Inžinierius G. VASIONIS, dailininke் J. ŠIUGŽDAITE்}

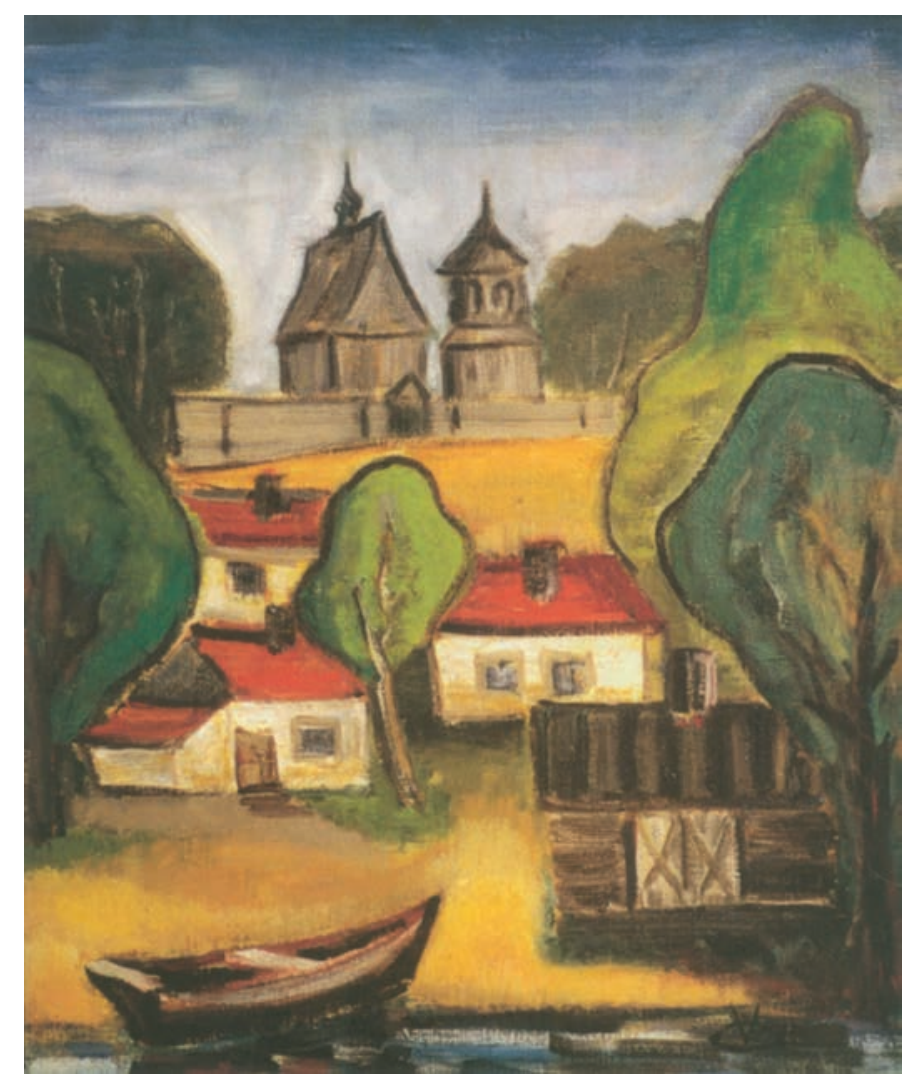

Inž. G. Vasionis. „Palūšé

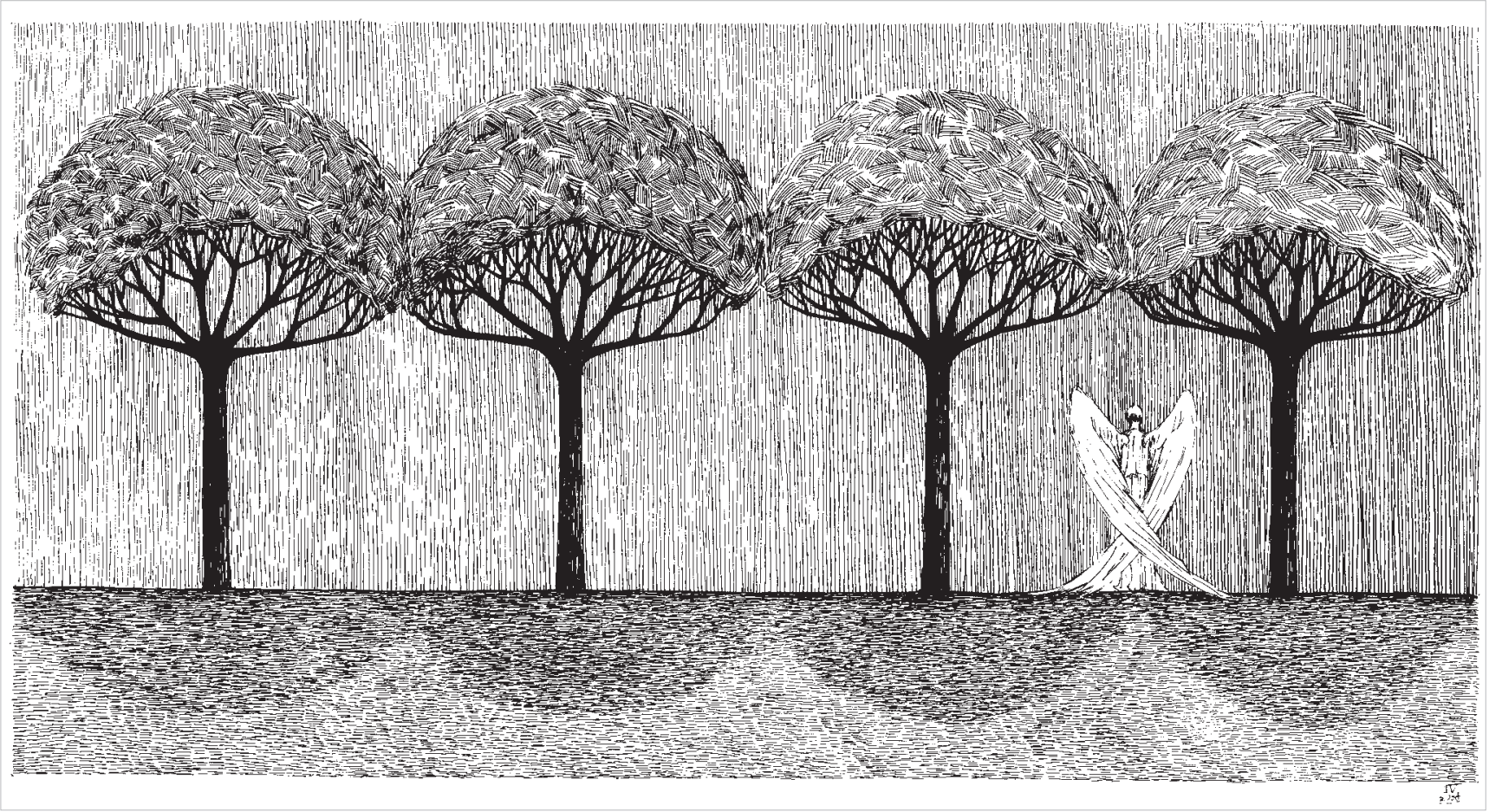

Dail. J. Šiugždaitè, „Medžiai“ 


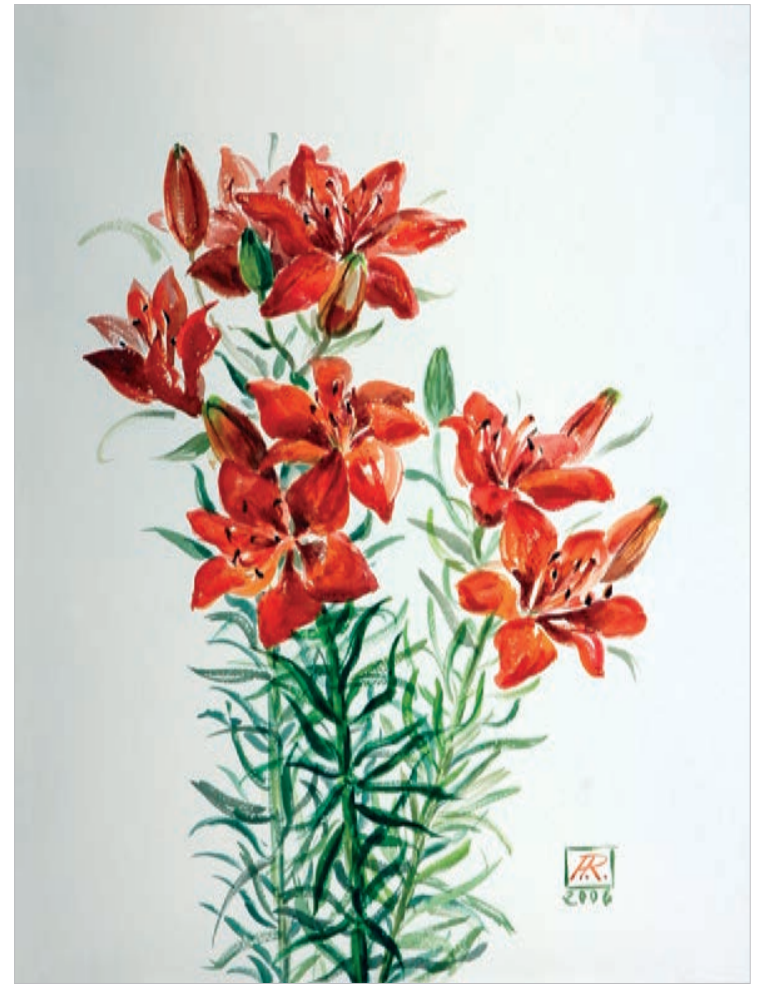

„Lelijos", akvarele

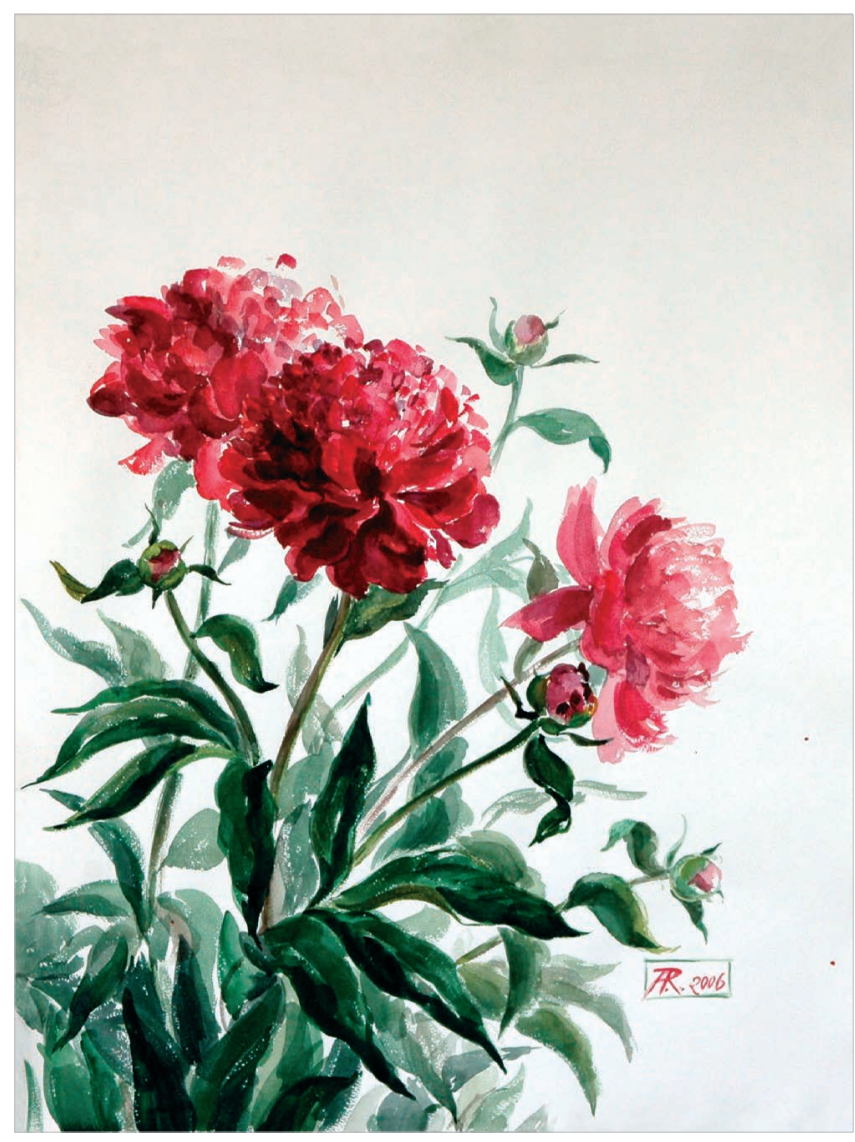

„Bijūnai", akvarelé

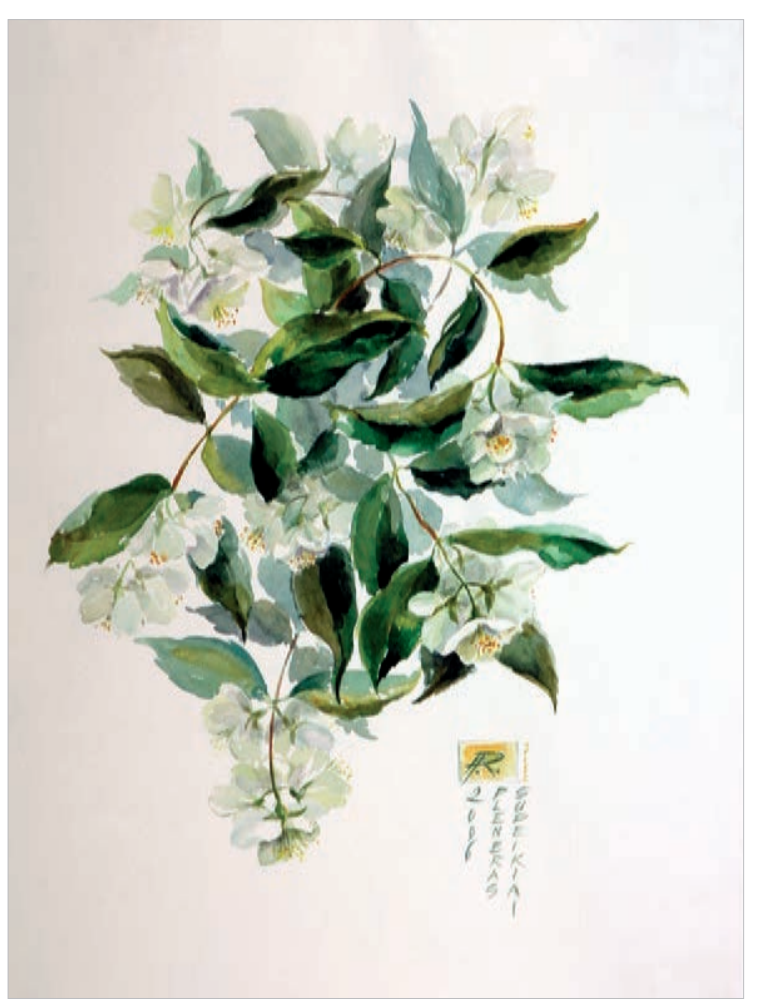

„Jazminai", akvarele

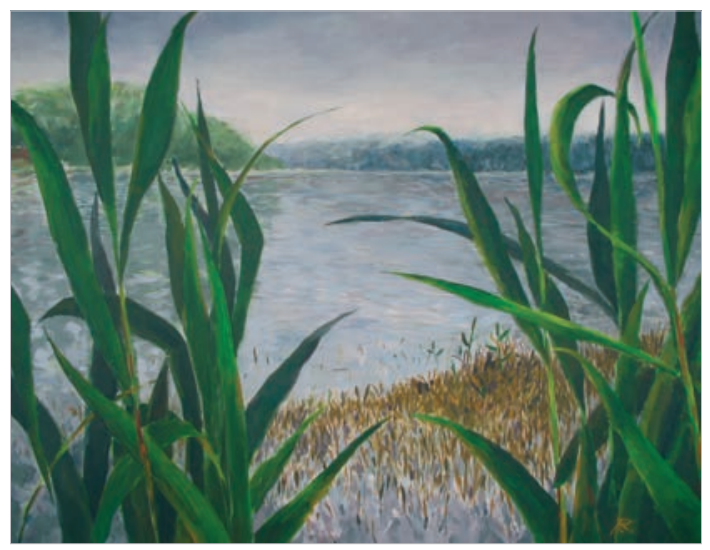

„Laukiu lizdas", drobe, akrilas; 2006 m.

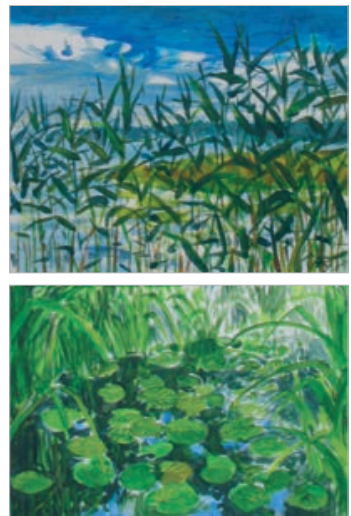

Etiudai

kartonas, akrilas 
Fotografai A. JAUNIUS ir G. URBANAVIČIUS

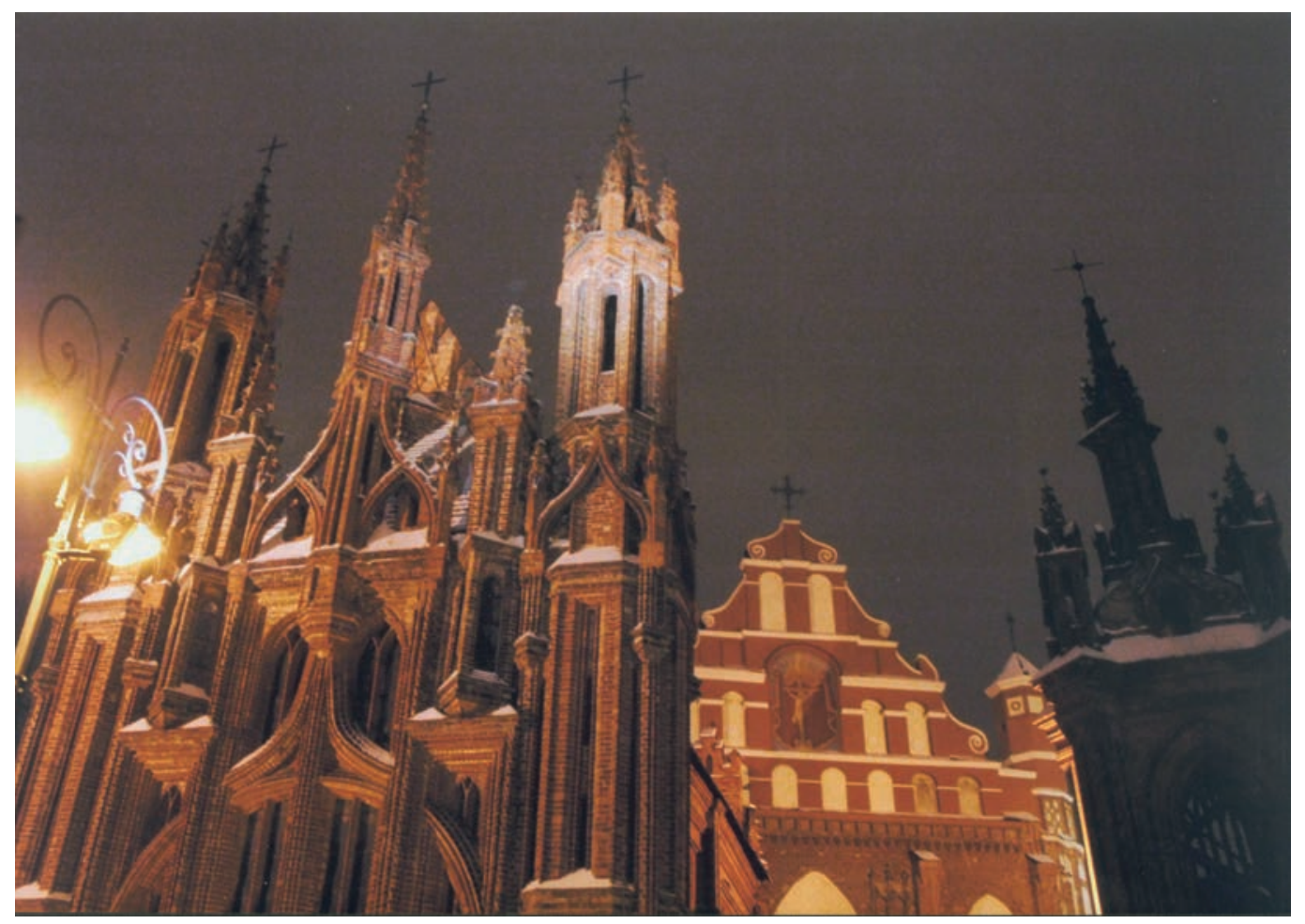

A. Jaunius, "Vilniaus kodas"

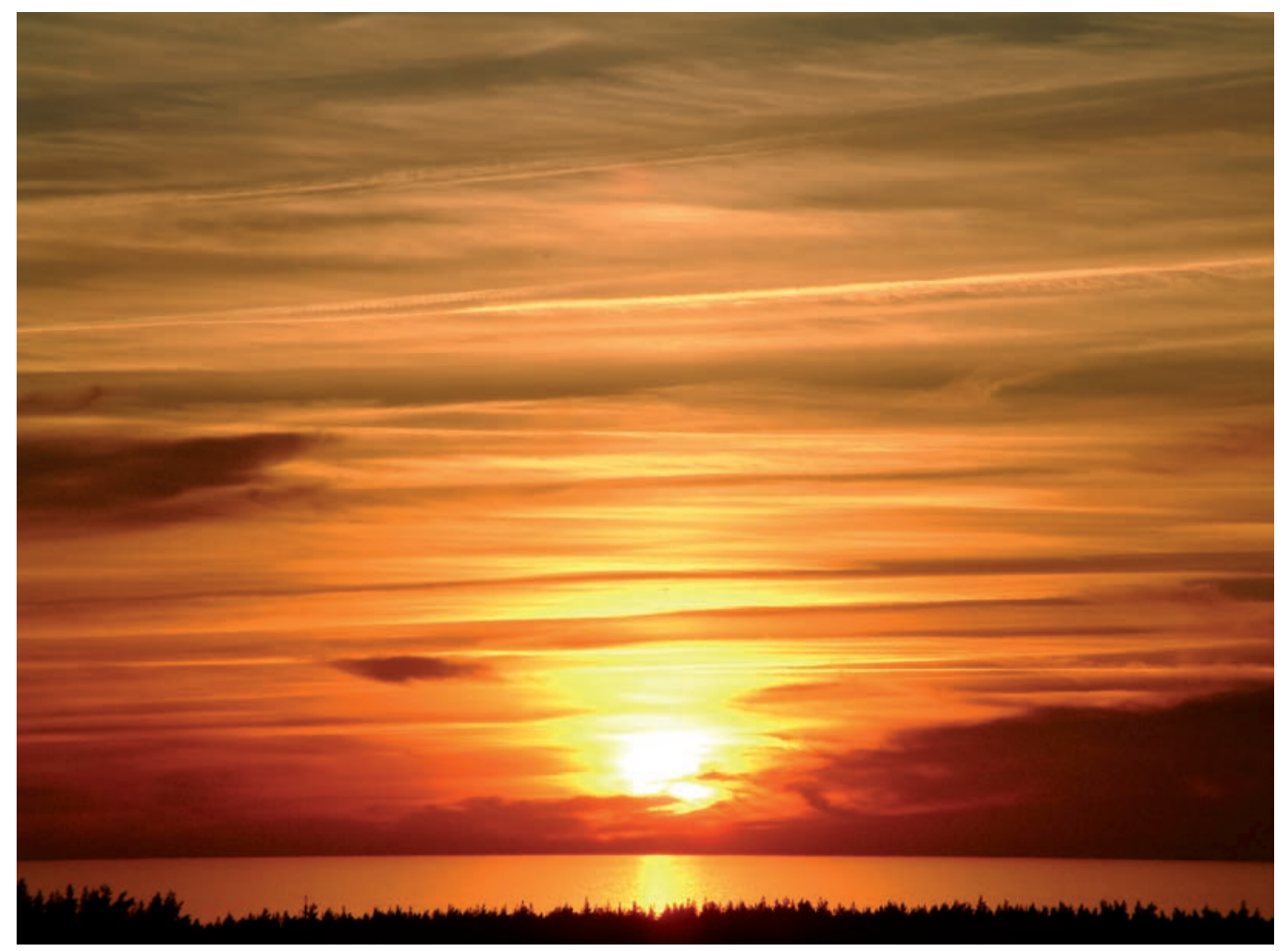

G. Urbanavičius. "Saulelydis" 


\section{Literatūra ir šaltiniai}

\section{I skyrius}

1.1. NIKŽENTAITIS, A. Gediminas. Vilnius, 1989.

1.2. ABRAMAUSKAS, S. Iš Lietuvos inžinerijos istorijos. Už tarybini moksla, Nr. 23(603). $1964 \mathrm{~m}$. birželio $11 \mathrm{~d}$.

1.3. ŠIDLAUSKAS, A. Lietuvos Didžiosios kunigaikštystès vyriausioji mokykla (1773-1803). Iš Vilniaus universiteto istorija, 1579-1994. Vilnius, 1994.

1.4. ČEPĖNAS, P. Naujuju laiku Lietuvos istorija. I tomas. Čikaga, 1977. Fotografuotinis leidinys. Vilnius, 1992.

1.5. Lietuvos istorija. Red. A. Šapoka. Kaunas, 1936. Fotografuotinis leidinys. Vilnius, 1989.

1.6. JEGELEVIČIUS, S. Universiteto atkūrimas (19181919). Iš Vilniaus universiteto istorija, 1579-1994. Vilnius, 1994.

1.7. Iniciatoriai. Universitetas Vilniuje. Vilniaus žinios, Nr. 290, 1905 m. gruodžio 20 d.

1.8. Universitetas ar Politechnika Vilniuje. Viltis, Nr. 31, 1907.

1.9. Universitetas ar Politechnika Vilniuje. Lietuvos $\bar{u} k i-$ ninkas, Nr. 18, 1908.

1.10. Lietuviy tauta. Lithuanian Nation. 1 knyga. Sud. A. Liekis. Vilnius, 1997.

1.11. GIMBUTAS, J. Jonas Šimoliūnas. Inžinierius, valstybininkas, profesorius. Chicago, Illinois, 1988.

1.12. MARČIUKAITIS, G. Lietuvos mokslininkų - techniniu draugiju vaidmuo vystant technikos mokslą. Iš Mokslo istoriku konferencijos "Technikos moksly raida Lietuvoje" pranešimai. Vilnius, 1996.

1.13. KLIMKA, L. Užmiršti XIX a. inžinierių iš Lietuvos darbai. Iš Mokslo istoriky konferencijos "Technikos moksly raida Lietuvoje" pranešimai. Vilnius, 1996.

1.14. ОРЛОВСКИЙ, Б. Шеренга великих инжинеров строителей и гидростроителей. Варшава, 1980

1.15. NAKAS, A.; PRUSKUS, V. Petras Vileišsis. Inžinierius. Kultūrininkas. Verslininkas. Vilnius, 2001.

1.16. NAKAS, A. Čechavičius Povilas. IšVisuotine lietuvin enciklopedija, IV tomas. Vilnius, 2003.

1.17. VIDUGIRIS, L. Mūsų profesūra. Iš Studiju ir polekiu metai. Vilnius, 2000.

1.18. NAKAS, A. Silvestras Grinkevičius. Mokslas ir technika, 1996, Nr. 2.

1.19. NAKAS, A. Pranciškus Markūnas - gelžbetonio patriarchas Lietuvoje. Iš Architektas inžinierius Vytautas Landsbergis-Žemkalnis ir jo darbu konstruktoriai. Vilnius, 1997.

1.20. Lietuviu enciklopedija, 19 t. Bostonas, 1959.

1.21. KOLUPAILA, S. Prof. Julius Graurogkas. Technikos žodis, Nr. 3, 1956.

1.22. Lietuviu enciklopedija, $4 \mathrm{t}$. Bostonas, 1954.

1.23. Lietuviu enciklopedija, 30 t. Bostonas. 1964.

1.24. ŠENAVIČIENĖ, I.; ŠENAVIČIUS, A. Universiteto organizavimo pradžia: Aukštieji (vakariniai) kursai. Iš Vytauto Didžiojo universitetas. Mokslas ir visuomene 1922-2002. Kaunas, 2002.

1.25. MANČINSKAS, Č. Aukštasis mokslas Lietuvoje 1918-1940 metais. Vilnius, 1996.

1.26. TERLECKAS, V. Pinigai Lietuvoje 1915-1944. Vilnius, 1992.

1.27. KTU. Nuo Aukštuju kursu Kaune iki Kauno technologijos universiteto. Kaunas, 1997.

1.28. BUDREIKA, E. Architektūros meno ir mokslo studijos Vilniuje. Iš Vilniaus architektūros mokykla XVIII-XX a. Vilnius, 1993.

1.29. VINTARTAS, V. Vilniaus universitetas per 400 metu. Technikos žodis, Nr. 4, 1979. Čikaga.

1.30. STRAŽNICKAS, J. Kazimieras Vasiliauskas. Mokslininkas. Pedagogas. Inžinierius. Kaunas, 1997.

1.31. GIMBUTAS, J. VDU Statybos fakultetas karo metu (1941-1944). Statybos aukštojo mokslo raidos Lietuvoje momentai. Vilnius, 1994.

1.32. MARTYNAITIS, M. Kauno Antano Sniečkaus politechnikos institutas. Vilnius, 1979.

1.33. TAMAŠAUSKAS. Is Kauno universiteto ir politechnikos instituto praeities. Komunistu partines organizacijos raidos ir veiklos apžvalga. Kaunas, 2000.
1.34. KTU. VGTU. Statybos mokslo ir studiju raida Lietuvos universitetuose. Kaunas, 2000.

1.35. VTU mokslo darbai. Geodezijos darbai, Nr. 18. Vilnius, 1993.

1.36. MAČIONIS, Z.; ČEPINSKIS, J. Profesorius Vincas Cepinskis. Vilnius, 1992.

1.37. JODELE, J.; KUBILIUS, J. et al. Profesorius Pranas Jodele (1871 02 13-1955 12 08). Vilnius, 1996.

38. GIMBUTAS, J.; DANYS, J. V. Steponas Kolupaila. Čikaga, 1974.

39. NAKAS, A. Profesorius Anatolijus Rozenbliumas. Vilnius, 2002

1.40. RUDOKAS, J. Istorija, kuria galime didžiuotis. Vilnius, 2002

1.41. GRIGAS, R. Tautos likimas. Vilnius, 1995.

1.42. RAILA, B. Kitokios Lietuvos ilgesys. Vilnius, 1993.

1.43. STRAŽNICKAS, J. Profesorius Kazimieras Baršauskas. Meilés galia. Kaunas, 2003.

\section{II skyrius}

2.1. MEŠKAUSKAS, K. et al. Lietuvos pramone ikisocialistiniu laikotarpiu. Vilnius, 1976.

2.2. MOTULAS, A. Vilniaus dabartis ir rytdiena. Vilnius, 1980

2.3. MERKYS, V. Lietuvos poligrafijos įmonès 17951915 m. Iš Lietuviu kultūros istorija, t. 7. Vilnius. 1972.

2.4. KAA. F. R-1260, Ap. 1, b.199.

2.5. KAA. F. R-1260, Ap. 1, b. 200.

2.6. KAA. F. R-1260, Ap. 1, b. 201

2.7. TAMAŠAUSKAS, A. Iš Kauno universiteto ir Politechnikos instituto praeities. Komunistu partines organizacijos raidos ir veiklos apžvalga. Kaunas, 2000.

2.8. STRAŽNICKAS, J. Profesorius Kazimieras Baršauskas. Meiles galia. Kaunas, 2003.

2.9. MATUKONIS, A. et al. Nuo Aukštuju kursu Kaune iki Kauno technologijos universiteto. 1920-1997. Kaunas, 1997.

2.10. KAA. F. R-1260, ap. 1, b. 197.

2.11. Vilniaus universiteto archyvas. Byla Nr. 146.

2.12. VGTU archyvas, ap. 03, bylos 1689, 3300, U822.

2.13. DANYS, J. V. Statybos inžinieriaus paruošimas mokykloje ir gyvenime. Technikos žodis, Nr. 2(80), 1963.

2.14. PŠIBILSKIS, V. Vilniaus valstybinis Vinco Kapsuko universitetas (1955-1990). Iš Vilniaus universiteto istorija. 1579-1994. Vilnius, 1994.

2.15. Vilniaus universiteto istorija. 1940-1979. Ats. red. A. Bendžius. Vilnius, 1979.

2.16. AŽUBALIS, A. Matematikos didaktika Lietuvos pedagoginëje periodikoje (1945-1990 m.): monografija. Vilnius, 2005.

2.17. VGTU archyvas. Ap. 02, b. 8. Marija Priluckaja.

2.18. Lietuviškoji tarybiné enciklopedija, t. 2. Vilnius, 1977.

2.19. Lietuvos architektai. Sud. A. Mačiulis. Vilnius, 2002.

2.20. KUDABA, J. Vilniaus vakariniame skyriuje. $U z ̌$ tarybini mokslą, $1959 \mathrm{~m}$. lapkričio $5 \mathrm{~d}$.

2.21. MAKARIŪNIENĖ, E.; KLIMKA, L. Lietuvos fiziky ir astronomy squadas. Vilnius, 2001

2.22. RUDOKAS, J. Istorija, kuria galime didžiuotis. Vilnius, 2002.

2.23. VGTU archyvas, Ap. 02, b. 166.

2.24. NAKAS, A.; LIKAS, G. Vytautas Kriščiūnas. Inžinierius. Pedagogas. Mokslininkas. Vilnius, 1999.

2.25. KRIŠČIŪNAS, B. Sužeista širdis. Profesoriaus Stasio Vabalevičiaus šimtmečiui. Statyba ir architektūra, Nr. 7-8, 2001.

2.26. KPI direkcijos posedžio protokolas Nr. 155 KAA F. R-1260, Ap. 1, b. 290

2.27. KPI direkcijos posèdžio protokolas Nr. 157 KAA F. R-1260, Ap. 1, b. 290.

2.28. KPI direkcijos posedžio protokolas Nr. 159 KAA F. R-1260, Ap. 1, b. 290. 
2.29. KPI Mokslinès tarybos posèdžio protokolas Nr. 103 KAA F. R-1260, Ap. 1, b. 291.

2.30. KPI direkcijos posèdžio protokolas Nr. 161. KAA F. R-1260, Ap. 1, b. 290.

2.31. KPI direkcijos posèdžio protokolas Nr. 162. KAA F. R-1260, Ap. 1, b. 264.

2.32. KPI direkcijos posèdžio protokolas Nr. 178. KAA F. R-1260, Ap. 1, b. 427.

2.33. KPI direkcijos posedžio protokolas Nr. 73. KAA.F. R-1260, Ap. 1, b. 242.

2.34. KPI tarybos posèdžio protokolas Nr. 107. KAA.F. R-1260, Ap. 1, b. 291.

2.35. Vilniaus architektūra. Šv. Trejybès cerkvès ir bažnyčios ir bazilijony vienuolyno pastaty ansamblis. Vilnius, 1985.

2.36. KPI Vilniaus vakarinio fakulteto posedžių protokolai. VGTU archyvas, Ap. 1, b. 479.

2.37. V. Valaičio asmens byla. VGTU archyvas, Ap. 1, b. 1643 .

2.38. KPI rektorato posedžio protokolas Nr. 183. KAA.F. R-1260, Ap. 1, b. 427.

2.39. KPI tarybos posedžio protokolas Nr. 107. KAA.F. R-1260, Ap. 1, b. 291.

2.40. KPI tarybos posèdžio protokolas Nr. 121. KAA.F. R-1260, Ap. 1, b. 428.

\section{III skyrius}

3.1. LTSR Ministrų Tarybos nutarimas Nr. 397.

3.2. Kauno apskrities archyvas. F.R.-1260, Ap. 1, B.425.

3.3. LIKAS, G. VGTU informacines sistemos raida. Iš Technikos mokslu raida Lietuvoje. Vilnius: Technika, 1999.

3.4. VGTU archyvas. Ap. 02, B.93.

3.5. VGTU archyvas. Ap. 1 b. 477.

3.6. KUDZYS, A. Dar arčiau gamybos. Už tarybini mokslą, Nr. 14(476), 1962 m. spalio $10 \mathrm{~d}$

3.7. VGTU archyvas. Ap. 1, B. 622.

3.8. JANUŠKA, R. Norai geri, tik trūksta paramos. $U z ̌$ tarybini moksla, Nr. 25(355), 1959.

3.9. ŽITNIKOVIENĖ, M. Naujos priemimo taisyklès. $U z ̌$ tarybini moksla, Nr. 25(355), 1959.

3.10. GLUOSNIS, A. Pirmoji pažintis. Už tarybinį mokslą, Nr.14 (476), 1962 m. spalio $10 \mathrm{~d}$.

3.11. BILVINAS, L. Atsisveikinimo su institutu išvakarèse. Už tarybini mokslą, Nr. 23 (353), 1959 m. gegužes $22 \mathrm{~d}$.

3.12. ČYRAS, A. Pirmoji diplomantų laida KPI Vilniaus filiale. Už tarybini moksla, Nr. 25-26 (487-488), 1962 m. birželio 19 d.

3.13. KOSTRAUSKAS, P. Aukštoji matematika - techninių disciplinu pagrindas. Už tarybini moksla, Nr. 28 (315), $1958 \mathrm{~m}$. rugsejo $12 \mathrm{~d}$.

3.14. VGTU archyvas. Ap. 16, b.4

3.15. VGTU archyvas. Ap. 1, b.548.

3.16. VGTU archyvas. Ap. 1, b.612.

3.17. KPI direkcijos 1961-03-13 posedžio protokolas Nr. 178. KAA F.R-1260, Ap. 1, b.427.

3.18. VGTU archyvas. Ap. 1, b.613.

3.19. VGTU archyvas. Ap. 1, b.709.

3.20. L. Syraus sudarytais duomenimis. VGTU istorijos muziejaus fondai, $1969 \mathrm{~m}$. birželio $1 \mathrm{~d}$

3.21. ATKOČIŪNAS, J.; ČIŽAS, A. Aleksandras Čyras ir optimizacija statybinëje mechanikoje. Vilnius: Technika, 2002.

3.22. MINKEVIČIUS, R. Pirmoji KPI Vilniaus filiale. Už tarybini moksla, Nr. 17(597), 1964 m. balandžio $30 \mathrm{~d}$

3.23. VGTU archyvas Ap.1, b.709.

3.24. MASČIUS, P. Studentiška vasara Aukštadvaryje. Už tarybini mokslą, Nr. 30(700), $1964 \mathrm{~m}$. rugsëjo $24 \mathrm{~d}$.

3.25. MARTYNAITIS, M. Kauno Antano Sniečkaus politechnikos institutas. Vilnius, 1979.

3.26. VGTU archyvas. Ap. 1, b.31.

3.27. VGTU archyvas. Ap. 1, b. 805.
3.28. PALECKIS, J. V.; SIMAŠKA, A. Non multa, sed multum. Už tarybini moksla, Nr. 6(630), $1965 \mathrm{~m}$. vasario $11 \mathrm{~d}$.

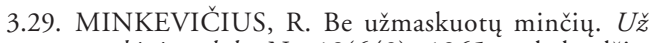
tarybini moksla, Nr. 18(642), 1965 m. balandžio $22 \mathrm{~d}$

3.30. JAKIMAVIČIUS, Č. Apie diskusiją. Už tarybinị moksla, Nr. 24(648), 1965 m. birželio $3 \mathrm{~d}$.

3.31. VYSKUPAITIS, A. Pirmieji choristų metai. $U z ̌$ tarybini moksla, Nr. 18(642), 1965 m. balandžio $22 \mathrm{~d}$.

3.32. VGTU archyvas. Ap. Nr. 1, B. 805.

3.33. Nauji mokslų daktarai. Aleksandras Čyras. Už tarybini moksla, Nr. 3(688), 1966 m. sausio $20 \mathrm{~d}$.

3.34. M. Martynaičio kalba LKP XV suvažiavime. Už tarybini moksla, Nr. 9(674), 1966 m. kovo $10 \mathrm{~d}$

3.35. VGTU archyvas. Ap. Nr. 1, B.909.

3.36. NAKAS, A. Kai kurie VISI kūrimo momentai (minint 30-meti). Iš Technikos mokslu raida Lietuvoje. Vilnius: Technika, 1999.

3.37. STRAŽNICKAS, J. Aleksandras Čyras. Gyvenimo spalvos. Vilnius, 2006.

3.38. ŠEPETYS, L. Neprarastoji karta. Siluetai ir spalvos. Vilnius, 2005.

3.39. MARČIUKAITIS, G. Nauji mokslu daktarai. A. Kudzys. Už tarybini mokslą, Nr. 7(716), $1967 \mathrm{~m}$. vasario $9 \mathrm{~d}$.

3.40. Kauno apskrities archyvas. F. R-1260. Ap.1, B835.

3.41. MATULIONIS, A. KPI Vilniaus filiale. Gražaus derliaus švente. Už tarybini mokslą, Nr. 12(721), $1967 \mathrm{~m}$. kovo $16 \mathrm{~d}$

3.42. RUDOKAS, J. Istorija, kuria galime didžiuotis. Vilnius, 2002.

3.44. ČIŽAS, A. 1968 metu KPI mokslinis derlius. Kodèl premijuotas? Už tarybini moksla, Nr. 6(803), $1968 \mathrm{~m}$. vasario $12 \mathrm{~d}$.

3.45. ČYRAS, A. Kelyje ì tautines mokyklos atgimimą ir pertvarką. Statyba ir architektūra, Nr. 8(364), 1989.

3.46. RAILA, B. Kitokios Lietuvos ilgesys. Vilnius, 1993.

\section{IV skyrius}

4.1. Mokslinès tarybos posèdžių protokolai. Ap. 1., b. 92, 1969.

4.2. Gero vejo, VISI! Komjaunimo tiesa, Nr. 175 (6271). $1969 \mathrm{~m}$. rugsejo $7 \mathrm{~d}$.

4.3. Nauja inžinierių laida. Komjaunimo tiesa, Nr. 174 (6270), 1969 m. rugsëjo $6 \mathrm{~d}$.

4.4. VGTU archyvas. VISI rektoriaus ịsakymai. Ap. 1., b. 91 .

4.5. NAKAS, A. Profesorius Anatolijus Rozenbliumas. Vilnius, 2002.

4.6. VGTU istorijos muziejaus fondai.

4.7. ŠERNAS, V. Profesine pedagogika. Vilnius, 1995

4.8. VGTU archyvas. VISI rektoriaus įsakymai. Ap. 1., b. 122 .

4.9. VGTU archyvas. VISI rektoriaus įsakymai. Ap. 1., b. 152.

4.10. VGTU archyvas. VISI tarybos posedžių protokolai. Ap. 1., b. 153.

4.11. DAMBRAUSKAS, L. Gyvenimo akimirkos. Antra knyga. Vilnius, 1990.

4.12. VGTU archyvas. VISI rektoriaus įsakymai. Ap. 02., b. 456 .

4.13. VGTU archyvas. VISI tarybos posedžiu protokolai. Ap. 1., b. 193.

4.14. VGTU archyvas. VISI tarybos posedžiu protokolai. Ap. 1., b. 182 .

4.15. STRAŽNICKAS, J. Akademikas Aleksandras Čyras. Gyvenimo spalvos. Vilnius, 2006.

4.16. LIKAS, G. VGTU informacinès sistemos raida. Iš Technikos moksly raida Lietuvoje. Vilnius, 1999.

4.17. Garbingas svečias. Inžinerija, Nr. 6 (17), 1974 m. vasario $13 \mathrm{~d}$.

4.18. Mūsų židinio ugnelè. Inžinerija, Nr. 4-5 (15-16), 1974 m. sausio 23-30 d.

4.19. CYRAS, A. Vieningai iškèlème draugo Leonido Brežnevo kandidatūrą. Inžinerija, Nr. 17 (28), 1974 m. balandžio $24 \mathrm{~d}$. 
4.20. VGTU archyvas. VISI tarybos posèdžiu protokolai. Ap. 1, b. 211.

4.21. ČYRAS, A. Nauji mokslo metai - nauji ir mūsu uždaviniai. Inžinerija, Nr. 30 (41), 1974 m. rugsèjo $11 \mathrm{~d}$.

4.22. Aukštojo ir specialiojo vidurinio mokslo ministro issakymas Nr. 389. 1974 m. spalio 14 d.

4.23. VGTU archyvas. VISI tarybos posèdžiu protokolai. Ap. 1., b. 245.

4.24. VGTU archyvas. VISI tarybos posèdžiu protokolai. Ap. 1., b. 286.

4.25. Inžinerija, Nr. 20 (122), 1976 m. gegužes 26 d.

4.26. Inžinerija, Nr. 6 (149), 1977 m. vasario 23 d.

4.27. PŠIBILSKIS, V. Akademinis jaunimas: priemimas, mokymas, idejjinis niveliavimas. Vilniaus universitetas, 1994-1990.

4.28. Sveikiname nugalètojus. Inžinerija, Nr. 8 (151), 1977 m. kovo 9 d.

4.29. Inžinerija, Nr. 28 (171), 1977 m. rugsejo $21 \mathrm{~d}$.

4.30. Inžinerija, Nr. 41 (184), 1977 m. gruodžio 28 d.

4.31. A. Kvedaro mokslinès stažuotès ataskaita, 1978.

4.32. Inžinerija, Nr. 6 (226), 1979 m. vasario 14 d.

4.33. Inžinerija, Nr. 20 (204), 1978 m. birželio 21 d.

4.34. Inžinerija, Nr. 23 (207), 1978 m. rugsëjo 5 d.

4.35. Inžinerija, Nr. 3-4 (223-224, 1979 m. sausio $24 \mathrm{~d}$.

4.36. KOBECKAITE், H. Universitetas vieši VISI. Tvirta draugyste. Inžinerija, Nr. 7 (227), 1979 m. vasario $28 \mathrm{~d}$.

4.37. VIRŽYTE், J. Kas lemia sèkmę. Inžinerija, Nr. 5 (225), $1979 \mathrm{~m}$. vasario $14 \mathrm{~d}$.

4.38. RADZEVIČIUS, L. Dar viena daktarinè. Inžinerija, Nr. 15 (235), 1979 m. balandžio $25 \mathrm{~d}$.

4.39. Inžinerija, Nr. 31 (251), 1979 m. spalio 17 d.

4.40. VGTU istorijos muziejaus fondai. VISI tarybos posèdžių protokolai. 1980.

4.41. ERLICKAS, J. Koks šiupinio skonis? Inžinerija, Nr. 8 (408), $1981 \mathrm{~m}$. kovo $13 \mathrm{~d}$.

4.42. ŽILINSKAITÉ, J. Išreikšti save. Inžinerija, Nr. 11 (411), $1981 \mathrm{~m}$. balandžio $3 \mathrm{~d}$.

4.43. GAIŽUTIS, A. Keturkos akvarelès. Inžinerija, Nr. 15 (415), 1981 m. gegužes $8 \mathrm{~d}$.

4.44. LIUTIKAS, V. Studento adaptacijos pedagoginès problemos. Inžinerija, Nr. 5 (485), $1982 \mathrm{~m}$. vasario $25 \mathrm{~d}$.

4.45. BŪDA, V. Širdies balso šaukiami. Inžinerija, Nr. 10 (450), $1982 \mathrm{~m}$. balandžio $6 \mathrm{~d}$.

4.46. ŽILINSKAITĖ, J. „Opusas“, 82 m. Inžinerija, Nr. 15 (455), $1982 \mathrm{~m}$. balandžio $30 \mathrm{~d}$.

4.47. Tiesa, Nr. 261 (12086), 1982 m. lapkričio $12 \mathrm{~d}$.

4.48. ŠMIGELSKIENĖ, V. Mūsų mokslininkams - LTSR valstybinè premija. Inžinerija, Nr. 39-40 (479-480), 1982 m. gruodžio $31 \mathrm{~d}$.

4.49. DIČIUS, V. Absolventu keliai. Inžinerija, Nr. 9-10 (489-490), $1983 \mathrm{~m}$. balandžio $1 \mathrm{~d}$.

4.50. VGTU istorijos muziejaus fondai. A. Čižo prisiminimai. 1996.

4.51. Išlydejome ị Tarybinę armiją. Inžinerija, Nr. 20-21 (500-501), $1983 \mathrm{~m}$. liepos $1 \mathrm{~d}$.

4.52. Taresi komjaunimo aktyvistai. Inžinerija, Nr. 1 (609), 1984 m. sausio $6 \mathrm{~d}$.

4.53. Sudaryta studentu komunistinio auklejimo taryba Inžinerija, Nr. 6 (614), 1984 m. vasario $20 \mathrm{~d}$.

4.54. KOBECKAITĖ, H. Kaimo statybos problemos. Inžinerija, Nr. 6 (614), 1984 m. vasario 20 d.

4.55. GAIŽUTIS, A. Sèkmę lemia vadovo asmenybè. Inžinerija, Nr. 20 (628), 1984 m. gegužès $28 \mathrm{~d}$

4.56. ABRAMAUSKAS, S. Istorija-faktai-datos. Inžinerija, Nr. 29 (675), 1985 m. spalio 3 d.

4.57. MATONIS, V. Susitikimas su kompozitoriumi. Inžinerija, Nr. 38 (645), 1984 m. gruodžio 10 d.

4.58. ŠERNAS, V. Mūsų veikla, planai ir rūpesčiai. Inžinerija, Nr. 2 (649), 1985 m. sausio $14 \mathrm{~d}$.

4.59. ŠEŠELGIS, K. Šalis, kurią mačiau. Inžinerija, Nr. 4 (651), $1985 \mathrm{~m}$. sausio $28 \mathrm{~d}$.

4.60. DRUNGILAITÉ, V. Politinès dainos festivalyje Inžinerija, Nr. 19 (665), 1985 m. gegužès 23 d.

4.61. TSRS Aukštujų mokyklų valstybinio inspektavimo aktas. Vilnius, 1985.
4.62. KAZANAVIČIUS, V. Neišsiųsti laiškai. Vilnius, 2005.

4.63. DINEIKA, A. Architektūrinis projektavimas. Inžinerija, Nr. 12-13 (698-699), 1986 m. balandžio $3 \mathrm{~d}$.

4.64. ŠERNAS, V. Epochos reikalavimas - persitvarkyti. Inžinerija, Nr. 30 (716), 1986 m. spalio 2 d.

4.65. JASAITIS, P. Stalo tenisininkai nugaletojai, arba treneris, subūręs komandą. Inžinerija, Nr. 30 (716), 1986 m. spalio 2 d.

4.66. POCIUS, R. Kaip ugdysime kūrybiškai mąstančius specialistus? Inžinerija, Nr. 35-36 (721-722), 1986

4.67. VISI rektorato posèdžių protokolai, $1986 \mathrm{~m}$. gruodžio $22 \mathrm{~d}$.

4.68. LIUTIKAS, V. Ju tikslas - aukštasis mokslas. Inžinerija, Nr. 3-4 (729-730), 1987 m. sausio 22 d.

4.69. DIČIUS, V. Profsajungos rūpesčiai ir darbo gairès. Inžinerija, Nr. 27-28 (753-754), 1987 m. rugsèjo $25 \mathrm{~d}$.

4.70. SRĖBALIUS, J. Bendraminčiu dialogo pradžia. Inžinerija, Nr. 29-30 (755-756), 1987 m. spalio $9 \mathrm{~d}$.

4.71. VISI rektorato posèdžių protokolai, $1988 \mathrm{~m}$. sausio $18 \mathrm{~d}$.

4.72. LIEKIS, A. LKP agonijos kronika. I. Vilnius, 1996.

4.73. VISI rektoriaus prof. A. Čyro ataskaita. Inžinerija Nr. 15-16 (781-782), $1988 \mathrm{~m}$. balandžio $22 \mathrm{~d}$.

4.74. SAKALAUSKAITĖ, V. Rugsëjo 1-oji - dvidešimtąji kartą. Inžinerija, Nr. 23-24 (789-790), $1988 \mathrm{~m}$. rugsëjo $8 \mathrm{~d}$.

4.75. KOBECKAITE், H. Sąūdis peržengè VISI slenkstị. Inžinerija, Nr. 25-26 (791-792), 1988 m. rugsejjo $22 \mathrm{~d}$.

4.76. ŠMIGELSKIENĖ, V.; SAKALAUSKAITE், V. Instituto partijos komiteto ataskaitinis rinkiminis susirinkimas. Inžinerija, Nr. 31-32 (797-798), 1988 m. lapkričio $3 \mathrm{~d}$.

4.77. MARČIUKAITIS, G. Norime tikro technikos šuolio. Tiesa, Nr. 5 (13924), 1989 m. sausio $6 \mathrm{~d}$.

4.78. Svarstymu valandos. Inžinerija, Nr. 3-4 (807-808), $1989 \mathrm{~m}$. vasario $2 \mathrm{~d}$

4.79. OLŠAUSKAS, K. TSKP LKP CK XVII plenumo nutarimas ir pertvarkos bei demokratizacijos uždaviniai institute. Inžinerija, Nr. 11-12 (815-816), 1989 m. balandžio $6 \mathrm{~d}$.

4.80. KUDZYS, A. Mokslininko pastabos dèl Kauno Vytauto Didžiojo universiteto atkūrimo. Inžinerija, Nr. 17-18 (821-822), 1989.

4.81. Vilniaus inžinerinio statybos instituto atviro komunistų susirinkimo pareiškimas. Inžinerija, Nr. 28-29 (829-830), 1989 m. lapkričio 2 d.

4.82. ZAVADSKAS, E. K. Lietuva be mokslo - Lietuva be ateities. Inžinerija, Nr. 30-31 (831-832), 1989 m. lapkričio $16 \mathrm{~d}$.

4.83. ŠMIGELSKIENÉ, V. ir kt. Svečias iš Maskvos Inžinerija, Nr. 1-2 (840-841), 1990 m. sausio $16 \mathrm{~d}$.

4.84. V. R. Lietuva reikalauja laisvès. Gimtasis kraštas, Nr. 3 (1192), $1990 \mathrm{~m}$. sausio 19-25 d.

4.85. V. R. Lietuva spaudos veidrodyje. Gimtasis kraštas, Nr. 4 (1193), 1990 m. sausio 26 d. - vasario $21 \mathrm{~d}$

4.86. Kandidatai ị rektoriaus pareigas. Inžinerija, Nr. 3 (842), $1990 \mathrm{~m}$. sausio $25 \mathrm{~d}$

4.87. Lietuva - LTSR. Lietuvos tokios NEBĖR! Atgimimas, Nr. 11 (72), 1990 m. kovo 4-21 d.

4.88. ZAVADSKAS, E. K. Talentingas žmogus - tai tautos turtas. Inžinerija, Nr. 8-9 (847-848), 1990 m. kovo $14 \mathrm{~d}$.

4.89. SIDARAVIČIUS, J. Kaip keisime statutạ? Inžinerija, Nr. 10-11 (849-850), 1990 m. kovo 26 d. 


\section{V skyrius}

5.1. ZAVADSKAS, E. K. Vilniaus technikos universiteto raidos bruožai. Rektoriaus veikos ataskaita (1990-1994). Vilnius, 1994.

5.2. ZAVADSKAS, E. K. Ar Lietuvoje igytas inžinieriaus diplomas taps konvertuojamu? Tévynés šviesa. Iš Vilniaus technikos universitetas. Praeitis, dabartis, ateitis. Vilnius, 1994.

5.3. SIAURUSEVIČIUS, A. Aš mačiau galvažudžiu akis, kai jie dauže žmonių galvas ir konservatorijos langus. Atgimimas, Nr.45 (106).

5.4. Su Naujaisiais, „Atgimimo“ skaitytojau! Atgimimas, Nr. 51 (112), 1990 m. gruodžio 26 d.-1991 m. sausio $2 \mathrm{~d}$.

5.5. Metai ir dienos. VGTU 1990-1993 m. Sudarytojai E. K. Zavadskas ir V. Lujaniené. Vilnius, 1999

5.6. JONAITIS, A. Déstytoju ir mokslininku profesine sąjunga. Ką ji man duos? Inžinerija, Nr. 30-31 (868-869), $1991 \mathrm{~m}$. birželio $6 \mathrm{~d}$.

5.7. ZAVADSKAS, E. K. Inžinieriai...Kokie jie? Kokiu reikia? Lietuvos aidas, O. Balčiūnienès interviu. Iš Vilniaus technikos universitetas: praeitis, dabartis, ateitis. Vilnius, 1994

5.8. ZAVADSKAS, E. K. Su naujaisiais mokslo metais! Kalba, pasakyta per mokslo metų atidarymą Šv. Kazimiero bažnyčioje 1992-09-16. Iš Vilniaus technikos universitetas: praeitis, dabartis, ateitis. Vilnius, 1994

5.9. Gyvename ir gyvensime Lietuvoje... Inžinerija, Nr. 17-18 (910-91), 1992 m. lapkričio 26 d.

5.10. ZAVADSKAS, E. K. Vardan kilnios vertingos ateities Inžinerija, Nr. 13 (926), 1993 m. rugsëjo $13 \mathrm{~d}$.

5.11. KRIAUNEVIČIUS, A. Naujojo skrydžio pradžia. Inžinerija, Nr. 14(927), 1993 m. rugséjo $30 \mathrm{~d}$.

5.12. ZAVADSKAS, E. K. Kam naudinga paniekinti Mokslo žmones? Tiesa, 1993-129. Iš Vilniaus technikos universitetas: praeitis, dabartis, ateitis. Vilnius, 1994

\section{VI skyrius}

6.1. ZAVADSKAS, E. K. Mieli destytojai, darbuotojai, studentai. Inžinerija, Nr. 13 (986), 1996 m. rugsëjo $3 \mathrm{~d}$.

6.2. BUIVYDIENÉ, D. Vilniuje turime tvirtą inžinierių branduolį. Inžinerija, Nr. 14 (987), 1996 m. rugsejo $17 \mathrm{~d}$.

6.3. BAZARAS, D. Studentas ir universitetas. Inžinerija, Nr. 7 (999), 1997 m. balandžio $18 \mathrm{~d}$.

6.4. ZAVADSKAS, E. K. Laukiamas, turiningas pašnekovas. Inžinerija, Nr. 8 (1000), 1997 m. gegužè 16 d.

6.5. A. Lubio prisiminimai. Inžinerija, Nr. 8 (1000), 1997 m. gegužès $16 \mathrm{~d}$.

6.6. ZAVADSKAS, E. K. Mokytis be nuolaidu sau. Inžinerija, Nr. 11 (1003), 1997 m. rugsëjo $1 \mathrm{~d}$.

6.7. Prof. habil. dr. Vytauto Landsbergio kalba. Inžinerija, Nr. 14 (1006), 1997 m. spalio 29 d.

6.8. G. Vagnoriaus kalba. Inžinerija, Nr. 15-16 (10071008), 1997 m. lapkričio $17 \mathrm{~d}$.

6.9. RAILA, B. Kodèl antraip? Vilnius, 1991

6.10. ZAVADSKAS, E. K. Svarbiausia-nuolatinis žinojimo alkis. Inžinerija, Nr. 7-8 (1016-1017), 1998 m. balandžio $7 \mathrm{~d}$.

6.11. NORKEVIČIUS, J. Varpo dūžiai laisvei prikelti. Inžinerija, Nr. 12 (1021), 1998 m. birželio 12 d.

6.12. SAULIS, L. Sausio 13-oji - neatskiriama širdies dalis. Inžinerija, Nr. 2 (1044), 1999 m. sausio $12 \mathrm{~d}$.

6.13. NORKEVIČIUS, J. Tegul skamba per amžius Lietuvos vardas. Inžinerija, Nr. 7 (1049), 1999 m. vasario $23 \mathrm{~d}$.

6.14. NORKEVIČIUS, J. Nepriklausomybe - atejimas i savo namus. Inžinerija, Nr. 10 (1052), 1999 m. kovo $16 \mathrm{~d}$.

6.15. ZAVADSKAS, E. K. Pagal savo žodžius būsi išteisintas. Inžinerija, Nr. 11 (1053), 1999 m. kovo 23 d.

6.16. NORKEVIČIUS, J. Ateities vardan įveikti permainų baimę. Inžinerija, Nr. 11 (1095), 2000 m. kovo $14 \mathrm{~d}$.
6.17. ZAVADSKAS, E. K. Žinių skrydžiui pakèlę sparnus. Inžinerija, Nr. 28 (1112), 2000 m. rugsëjo $1 \mathrm{~d}$.

6.18. Ministro K. Platelio sveikinimas. Inžinerija, Nr. 30 (1114), $2000 \mathrm{~m}$. rugsejo $12 \mathrm{~d}$.

6.19. NORKEVIČIUS, J. Universiteto modernios bibliotekos ịkurtuves. Inžinerija, Nr. 31 (1115), 2000 m. rugsëjo $19 \mathrm{~d}$.

6.20. NORKEVIČIUS, J. Paskutinis Senato forumo akordas. Inžinerija, Nr. 2 (1130), $2001 \mathrm{~m}$. sausio $16 \mathrm{~d}$.

6.21. NAKAS, A; NORKEVIČIUS, J. Bičiulystès puslapiai. Vilnius, 2002.

6.22. NAKAS, A. Dirbkim kiekvienas, veikim kartu! Inžinerija, Nr. 4 (1132), $2001 \mathrm{~m}$. sausio $30 \mathrm{~d}$.

6.23. ZAVADSKAS, E. K. Su pirmąja naujojo tūkstantmečio rugsëjo 1-ąja! Gedimino universitetas, Nr. 4 (21), 2001

6.24. KONTRIMAS, J. Teikianti optimizmo dinamiškai plètotei. Inžinerija, Nr. 7 (1176), $2002 \mathrm{~m}$. vasario $19 \mathrm{~d}$.

6.25. Universiteto rektoriaus rinkimams artejant. A. Nako interviu su E. K. Zavadsku. Gedimino universitetas, Nr. 2 (26), 2002.

6.26. NORKEVIČIUS, J. İkurtuvès Naugarduko rūmuose. Inžinerija, Nr. 27 (1196), $2002 \mathrm{~m}$. rugsëjo $10 \mathrm{~d}$.

6.27. KONTRIMAS, J. Darbais papuoštas dešimtmetis. Inžinerija, Nr. 1 (1212), 2003 m. sausio 7 d.

6.28. Išminties simfonija. Aforizmai ir posakiai. V. Voronkovo kompozicija. Kaunas, 1996.

6.29. ŠUKŠTA, M. Didžiausia vertè - Monsinjoro mintys. Inžinerija, Nr. 14 (1225), $2003 \mathrm{~m}$. balandžio $8 \mathrm{~d}$.

6.30. NORKEVIČIUS, J. Tèvynè gyva savo vaikų darbais. Inžinerija, Nr. 7 (1218), $2003 \mathrm{~m}$. vasario $18 \mathrm{~d}$.

6.31. DANIŪNAS, A. Kodèl verta pasirinkti studijas Vilniaus Gedimino technikos universitete. Inžinerija, Nr. 10 (1221), 2003 m. kovo 11.

6.32. NORKEVIČIUS, J. Gedimino dienose - nauji renginiai. Inžinerija, Nr. 23 (1276), 2004 m. spalio $5 \mathrm{~d}$.

6.33. ŠNIUKŠTINAITIS, A. Sukonkretintos bendradarbiavimo gairès. Inžinerija, Nr. 25 (1278), 2004 m. lapkričio $2 \mathrm{~d}$.

6.34. LAURINAVIČIUS, A. Akredituota automobiliu keliu mokslo laboratorija. Inžinerija, Nr. 27 (1280), 2004 m. lapkričio $30 \mathrm{~d}$.

6.35. KAČIANAUSKAS, R. İteisintas bendradarbiavimas. Inžinerija, Nr. 1 (1283), 2005 m. sausio $11 \mathrm{~d}$.

6.36. VGTU - 2005. Mokslinis informacinis leidinys, Nr. 1 (33), Vilnius, 2006.

6.37. I c prezidentus pretenduoja ir mūsiškis. Inžinerija, $\mathrm{Nr} .7$ (1289), $2005 \mathrm{~m}$. balandžio $5 \mathrm{~d}$.

6.38. JUČIŪTĖ, E. Didejjančios SOCRATES/ERASMUS galimybes. Inžinerija, Nr. 7 (1289), 2005 m. balandžio $5 \mathrm{~d}$.

6.39. MAŽEIKA, D. Pasiektas Lietuvos rekordas. Inžinerija, Nr. 16 (1298), 2005 m. spalio 11 d.

6.40. GINEVIČIUS, R. Pažintis su Kazachstano universitetais. Inžinerija, Nr. 20 (1302), 2005 m. gruodžio $6 \mathrm{~d}$.

6.41. GINEVIČIUS, R. Ką universiteto mokslininkai nuveike 2005-aisiais? Respublika, 2006 m. gegužè $31 \mathrm{~d}$.

6.42 RAMANAUSKAITĖ, V; KARKLAITIS, G. Studentai laukiami „Eikos“ įmonese. Inžinerija, Nr. 2 (1305), $2006 \mathrm{~m}$. sausio $24 \mathrm{~d}$.

6.43 NORKEVIČIUS, J. Lankytojai domëjosi vadoveliais. Inžinerija, Nr. 5 (1308), $2006 \mathrm{~m}$. kovo $7 \mathrm{~d}$.

6.44 NORKEVIČIUS, J. „Aukso paukšte“ - geriausia dovana. Inžinerija, Nr. 6 (1309), 2006 m. kovo $21 \mathrm{~d}$.

6.45 GINEVIČIUS, R. Rezultatai liudija apie reagavimą i rinką. Inžinerija, Nr. 8 (1311), 2006 m. balandžio $25 \mathrm{~d}$.

6.46 VILKAS, E. Universitetai su autonomija, bet be teisių. Veidas, $2006 \mathrm{~m}$. birželio $8 \mathrm{~d}$.

6.47 Atejo vilčiu išsipildymo metas. R. Ginevičiaus interviu. Langas, Mokslo Lietuva, Nr. 9 (299), 2004 m. gegužès $6 \mathrm{~d}$.

6.48 LR švietimo ir mokslo ministerija. Lietuvos aukštasis mokslas. Baltoji knyga. Vilnius, 1999. 

Pavardžių
rodyklè
A

Abelkis P. R. 183

Abramauskas S.

Abramauskas S. 26, 125, 145, 165, 183, 197, 219, 278

Abramčikienė R. 317, 324

Achverdovas I. 109

Adamkus V. 161, 162, 260, 261, 292, 300, 302, 303, 309, 311, 326, 331, 340

Adelina 88

Adomaitis R. 217

Adomavičius V. 148, 190, 202

Adomenas G. P. 228

Adomenas P. 303, 306

Adomenas P. G. 260, 303, 343

Adomeniené E. 88, 89

Ahner K. 183

Aidukas A. 156

Aksamitauskas Č. 339, 356, 357, 360

Aksomitas A. 78, 80, 89, 100, 141

Aksomitas G. 231, 314, 330

Akstinaite M. 277, 295

Alekna R. 214, 229

Aleksaite I. 148, 149, 160, 183, 190, 226

Aleksandras 26, 52

Aleksandras I 29

Aleliūnas M. 356

Alfonsas de Laatas 320, 321

Alikonis A. 124, 146, 175, 185, 214, 230

Alionis A. 156

Ališauskaitè J. 87

Alperyte I. 337.

Ambrasas A. 190, 351,471

Ambrazevičius V. 281

Ambraziejūnaitè I. 86

Amšiejus R. 300

An Jingxin 356

Ancevičius 63

Andras A. 27

Andriolis M. E. 26

Andriukaitis V. 314, 338

Andriušinas V. 167, 175, 185, 215

Andropovas J. 188, 194

Angarietis 245

Annus 27

Antanaityte V. 135, 137

Antanavičius J. 274

Antanavičius K. 117, 137, 146, 152, 163, 185, 186, 196, 213, 214, 217-219, 222-234, 236, 237, 290, 295, 302, 308

Antokolskis 187

Anuškevičienè D. 156

Anuškevičius J. 267

Aprijarskyte R. 55

Arbušauskas J. 276

Argyris J. 250, 251, 277

Arkauskas A. 175

Arlauskas S. 222, 226

Arliukas A. 231

Artiomenka S. 173

Astrauskas J. 315

Astrauskienè N. 229
Ašmenskas R. 260

Atkočiūnas J. 99, 181, 259, 260, 280, 303,

303, 306, 315, 336, 343, 368

Audzijonis P. 229, 255

Augustaitis V. 315

Augustaitis V. K. 260, 280

Augustinavičius R. 170

Auštrevičius P. 315

Avdejenkova V. 338, 339

Avyžius J. 222, 232

Avulis A. 339, 340, 351

Ažubalis A. 296

\section{B}

Babakas V. 345

Babilius V. 93

Babitas A. S. 88

Bacevičius J. 77, 88-90, 96, 105, 107,

$115,157+$

Bačènas V. 145, 146

Bačinskas D. 333

Bagdonas G. 329

Bagdonas P. 310

Bagdonas V. 146, 185, 214, 228

Bagdonavičius J. 30

Bagočiūnas V. 92, 108

Bahras J. 312

Bajoras B. 139

Balasevičius A. 280

Balčytis Z. 319

Baldauskas J. 356

Baliukonyte L. 303, 304

Baliulis A. 79, 127, 137

Balkevičius J. 480

Baltrenaite E. 343

Baltrenas P. 255, 256, 265, 267, 301, 303, 306, 308, 310, 314, 335, 341, 343, 347

Baltrušaitis J. 187

Baltušis K. 217

Balzakas H. 330

Balzakas O. 314

Baniene R. 87

Baniulis R. 329, 330

Bansevičius R. 307, 308

Baradokas A. 148

Baradokas P. 175

Baranauskiene M. 259

Baras J. 325

Barauskas J. 117

Barauskas R. 368

Baravykas G. 182

Barisas J.V. 229

Barisas V. 90, 93

Barkauskas A. 159

Barkauskas E. 157

Barkauskas V. 186

Barkauskiene Z. 88, 226

Baronas R. 117

Baršauskas J. 185, 192

Baršauskas K. 13, 44, 46, 48, 53-56, 59, 60, 63, 64, 68, 69, 71-73, 77, 78, 80, 81, 90, 92, $95,127,307,311,312$ 
Bartkus A. 268

Bartusevičius R. 169

Basanavičius J. 30, 288, 331

Baskutis P. 54, 55

Bastyte L. 87

Baškys K. 109, 110, 134, 136, 142, 148, 157, 162, 163, 166, 175, 281

Batoras S. 40, 41, 55, 56

Baublys A. 189, 214, 221, 228, 253, 255, 267, 275, 296, 303, 309, 310, 370

Baublys M. 40

Baublys P. 124, 147, 148, 214

Baušys R. 182, 312

Baužienè A. 229

Bazaras D. 261, 278, 281, 360

Bejder E. 273

Belenia J. I. 159

Belevičienè L. 297

Belevičius R. 229, 265, 303, 306, 307, 343, 368

Belozaras K. 186

Bendikas J. 146

Bendorius R. 255

Benke H. 197

Beregovojus G. 161, 162

Bergas O. J. 109

Berija L. 46

Berinas 191

Berūkštis V. 192, 198

Berunka V. 182

Bičkauskas V. 231

Bieliauskas F. 106

Bieliūnas K. 46, 96, 109, 137

Bilinskas K. 230

Bilkis T. 77, 86

Bilkyte A. 60, 61

Bimba D. 303

Birgeris U. 138

Birgiolas E. 278, 281, 303

Birieta V. 273

Birutis V. 136

Biržiška M. 41, 331

Biržiškis J. 216

Bistrickas A. 43, 44

Bivainis G. 170

Bivainis J. 228, 255, 260, 303

Bytautas 63

Blažiene A. 185, 226

Blažys K. 125, 149

Blinkevičius V. 186, 187

Blonskis K. 173

Bobelis K. 309

Bodunov D. 110

Bogdanas H. 190, 198, 213, 483

Bogdevičius M. 230, 306, 312, 341, 343

Bogoslovskis V. N. 159

Bogušauskas A. 55, 189

Bokša P. 27

Bolotinas V. 111, 160, 164, 179

Bombliauskas J. 182

Bore K. 343

Borkauskas A. 138, 142

Borkauskas E. 72, 166, 175
Borkovskij A. 315

Borovskis M. 321

Borre K. 256, 257, 277

Borisa B. 92

Boruta J. 254, 282, 283

Brandišauskas V. 218, 219, 226,

Braškys A. 98, 111, 119, 158

Brazauskas A. 111, 134, 217, 218, 223, 261, 264, 266, 267, 272, 273, 277, 282, 285, 290, 305, 308, 309, 326, 331

Brazauskas E. 208

Brazauskas Z. 80

Brazdžiūnas P. 61

Brazys R. 125

Breivè P. 77, 87

Bretfusas J. 27

Brežnevas L. 245

Brežnevas L. 96, 98, 106, 114, 115, 158,

170-172, 179, 180, 188,194

Briedis K. 231,236

Briedis S. 347

Brodovskiené D. 312

Brodovskis L. 312, . 325

Broga L. 187

Bručas V. 156

Bruzgelioniené A. 307

Bubliene R. 352

Bubnys V. 217

Bubelevičius V. 481

Buckus P. 55

Bučiūtè E. 208, 255, 304, 464

Bučyla R. 353

Buda M. 366

Būda V. 156, 185-187, 223, 234, 290

Budreika E. 60, 61

Budriūnas A. 203

Budrys 122

Budrys J. 281

Buivydas R. 275, 306, 335, 336, 480

Buivydienè D. 277

Bukauskas 119

Bukenaitè V. 326

Bulavas J. 237

Bulovas J. 55, 59, 60, 92, 217

Bulovas R. 139, 202

Bumbliauskas A. 26

Bumelis V.A. 274, 352, 353

Buožis S. 137

Burdulis D. 231

Burinskiené M. 228

Burinskienè M. 308

Burokevičius M. 98, 99, 134, 139, 152, 155, 157-160, 162, 164, 165, 167, 201, 222, 242, 245, 251, 255

Busila R. 339, 340

Busima R. 194

Butkevičius L. 177, 184

Butkus A. 109, 149, 203

Butkus G. 167, 175, 222

Butkus T. 306

Butrinavičius A. 231 
Caspersen S. 250, 256, 257, 277

Chadyšas V. 365

Chajamas O. 187

Charitas J. 77, 78, 80, 88, 89, 92, 93, 96, 110 , 112, 127, 134, 136, 142, 186

Charitienè E. 87

Chazanovas V. 158

Chein G. 343

Chlomauskas E. 80

Chomskis R. 92, 107, 110, 111

Chruščiovas N. 47, 58, 79, 85, 96, 194

Cibas A. 141

$\check{\mathrm{C}}$

Čaginas N. 104

Čaikauskas G. 190, 469

Čaplikas V. 176

Čaplinskas A. 368

Čarneckis V. 31

Čechavičius P. 34, 45

Čechavičius R. 215, 286, 287

Cechovas A. 181

Čeičys J. 45

Čekuolis A. 217

Čepaitis V. 217

Čepas R. 149

Čepinskis V. 37, 45

Čeponis J. 145, 478

Čeputis J. 160

Čereškevičius S. 146, 171

Černeckis A. 303

Černeckis D. 303

Černenka K. 194, 195, 196, 199

Černiauskas E. 309

Česnys A. 303, 306, 343

Česonis V. 80, 112, 134, 136, 139, 142, 146, 157

Čiegis R. 275, 306, 317, 346, 354, 357, 361, 366

Čirba S. 215, 230

Čiučelis A. 255, 261, 266, 279, 280, 290, 299, 303, 306, 316, 343

Čiupaila R. 256, 279

Čiuprunovas D. 135

Čiurlionis M. K. 56

Čiurlys J. 31, 34, 36, 37, 39, 40

Čiužas A. 109

Čižas A. 99, 136, 146, 149, 158, 160, 166, $175,180,185,190,191,200,202,215,218$, $219,253,281,290,303,308,315,328$

Čižas A. E. 221, 230, 231, 232, 235

Čygas D. 306, 317, 321, 326, 330, 341-343, $348,355,359,360,366,368$

Čyras A. 17, 62, 65, 68, 70-72, 77-80, 82-85, $87,89,90-97,99-117,121,125,127,132-$ 135, 137-141, 144, 146, 148, 149, 151-155, $157-159,161,162,164,166,167,172,173$, $175,176,179,180-182,185,186,189,190$, 199, 200, 204. 211, 213, 216, 219, 221 ,223, $226,227,230,239,259,260,264,274,301$, $302,366,367,376$
Čyras P. 215, 306, 315, 317, 329, 342, 357, 367

\section{D}

Dabrila J. 58

Dabulskis A. 169, 170

Dagienè E. 255, 364, 365, 369

Dailydka S. 274, 279

Dambrauskas A. 255, 370

Dambrauskas L. 150

Dambrauskas M. 141

Dambrava V. 255

Damušis A. 45, 58, 299

Danaitis K. St. 231

Daniūnas A. 230, 261, 268, 290, 302, 303, $307,319,329,332,343,350,352,359,372$, 375

Danys J. 265

Danys-Daniliauskas J. 58

Daraškevičiūtè V. 98

Darbetas E. 161

Darbutas 119

Dargis R. 364

Darius S. 278

Darkovas A. V. 138

Dasevičius B. 134

Daščioras P. 315, 316, 331

Daubaras E. 214

Daujotis V. 345

Daukantas F. 136

Daukša A. 217

Daunora Z. 100, 368, 472

Daunoras V. 217

Daunoravičius Z. 145

Davulis V. 141

Degutienè I. 287, 303

Degutienè I. 304

Degutis A. 125

Degutyte E. 86, 87

Deimantavičius S. 173

Dembčinskis J. 314

Dichovičnyj I. 160

Dičius R. 100

Dičius V. 91, 95, 145, 147, 148, 171, 184,

190, 212, 217, 255, 260, 290, 297, 300, 374, 468

Dičiuvienè N. 125, 145, 148, 149, 171, 219 , 221, 229

Didžiapetrienè P. 261

Diedonis J. 203

Dieninis J. 316, 319

Dietrich M. 272

Dilba J. 175, 185, 226, 281

Dilys P. 149, 175, 185

Dindaite-Kupliauskienè J. 222

Dineika A. 204, 214, 467

Dineika R. 176, 182, 229, 260, 281, 290

Ding Tao 356

Dirgèla K. 186

Dirmantas S. 37, 38, 40

Diržauskienè A. 329

Diržinskaitè L. 102, 117, 134 
Dyčmonas J. 220, 281

Dobkevičius F. 40

Domarkas V. 272, 273, 274

Dovydenas V. 315

Dowlingas P.J. 269, 274, 276, 277

Dragūnas G. 215

Drobelis V 230

Drobnys A. 106

Dubčekas A. 118

Dubickas J. 98

Dulmanas A. 117

Dulmanas I. 139, 140

Dulskis J. 308, 309

Dundzila A. 183

Duoba J. 214, 229, 236, 251, 252

Dzeržinskis F. 251

Džovanjolis 187

\section{E}

Eičaite S. 184

Eidrigevičius S. 31

Eidukas D. 305

Eidukevičius G. 109

Eileris L. 28

Eitminavičius V. 79

Eyre A. 297

Ekingeris M. 27

Erlickas J. 182

Ežerskis A. 185

\section{$\mathbf{F}$}

Federavičius A. 356

Ferensas A. 139, 140

Filatovas L. 160

Filinas A. P. 138

Fliotovienè R. 260

Frohner K. 368

Furmanavičius L. 125, 222, 290, 303, 341

\section{$\mathbf{G}$}

Gabartas J. 200

Gabrenas A. 226

Gabrys J. 40, 45

Gaidamavičienè I. 156, 295

Gailius A. 125, 157, 166, 167, 175, 185, 186, 228, 231, 303, 341

Gaisas R. K. 173

Gaižutis A. 149, 157, 158, 175, 183, 185, 190, $191,195,198,316$

Gajauskas B. 175

Gajauskas J. 214, 345

Gajosinskis B. 167

Galiorkinas A. 115

Galvanauskas V. 182

Gap̌̌ys A. 62, 77, 80, 88, 261

Garalevičius R. 281

Garberis M. 169, 170, 176, 191

Gasiūnas V. 280, 303

Gastila L.
Gastila L. 46, 125, 185, 277, 281

Gaule K. 192, 221

Gaušienè R. 229

Geda S. 217

Gedgaudas M. 148, 149, 175, 185, 214, 276

Gediminas 26

Gedvilas N. 219

Geigeris J. 13

Geleževičius R. 226, 229

Genzelis B. 217

Gerdvilis V. 472

Gerdžiūnas P. 229, 250

Gerekas E. 173, 193

Gerlachas M. 181

Gerliakas Č. 63

Geršas N. 125, 148

Gervè V. 190

Getkantas F. 28

Gibieža S. 93

Giedrys H. 231

Gilduninas B. 69

Gilys H. 281

Gilytè N. 364

Gylikis V. 481

Gimbutas J. 31, 37, 38, 40, 58,259, 265, 297, 300

Gineitis A. 84, 326

Ginevičius G. 9, 21, 122, 163, 164, 177 , 192, 252, 255, 258, 274, 275, 285, 290, 295, 296, 298, 301, 303, 307, 312, 314, 315, 316, 318-321, 325, 326, 329, 330, 331, 333, 335, $337,338,340,341,343,345,348,350,352$, 353, 355, 357, 359-364, 366, 368, 369, 371, 374-376

Giniotis V. 268, 275, 280, 296, 341

Girčienè B. 134, 149

Girčius 119

Girnius V. 357

Gylys H. 83, 92, 117, 134, 149, 157, 166

Glaubicas J. K. 104

Glebovas V. 230

Glebus S. 290

Glemžienè A. 77, 88, 96, 112, 134, 156, 157, 166, 167, 175

Glismejeris H. 197

Gloyova O. 215

Godbergas I. 208

Goldenblatas I. 99

Golokvoščius P. 55

Golšteinas E. G. 138

Gorbačiovas M. 199, 203, 204, 205, 234, 246, 250, 282

Gorbulskis B. 169, 170

Gorodeckis V. 35, 40

Grabys J. 189, 236, 237, 242, 274

Graičiūnas A. 321

Graičiūnas V.A. 295, 308

Graurogkas A. 34, 35, 37

Gražulevičius A. 149

Grèska J. 112, 134, 149, 157, 159, 166, 167 , 229

Griauzde K. 94, 98, 142, 158, 160

Grigaliūnas K. 280, 303 
Grigas A. J. 228

Grigas R. 47, 170

Grigorovičius J. 284, 288, 295, 299, 315

Grincevičius L. 308

Grinkevičius S. 34, 39, 40, 55, 308

Griškevičius M. 329, 330

Griškevičius P. 106, 158, 173, 179, 180

Griškūnaite E. 226

Grodzenskis A. 122

Gromyko T. 98

Gropiusas V. 197

Grotusas R. 265

Grotusas T. 29, 265

Grunskis T. 258, 259, 474

Gruzdys A. 169, 170

Gruzdys B. 125, 190, 229, 246, 247, 364

Gucevičius L. 28, 29, 60, 153

Gudaitis A. 187

Gudavičienè V. 206

Gudavičius E. 352

Gudavičius R. 185, 186, 194, 206

Gudvaišiene D. 231

Gulbinas 63

Gulbinas A. 189

Gulbinovičius H. 192, 198

Guliamas G. 187

Gumauskas J. 84

Gumauskas M. 95, 219

Guobys 119

Guokas L. 148

Gureckas A. 237

Gureckas J. 226

Gurklienè A. 364

Gurskis V. 29, 77, 86

Gustaitis A. 284, 308

Gutmanienè H. 69-71, 77, 87, 90

Guzaitis R. 146

Gužas D. 230

Gužauskas J. 124

Gvozdevas A. 122

\section{H}

Hafizas 187

Hahn U. 183

Hengguang G. 302

Hensonas K. O. 173

Hiksas D. H. 173

Hitleris 43, 251

Hitleris

Horacijus 250

Hozijus U. 27

Hukas R. 28

Husakas 118

Huseinas M. 187

I

Ignatavičius Č. 148, 156, 214, 221, 229, 341 Ignatavičius G. 341

Ilgūnas G. 331

Ilšinskis A. 160
Imbrasas J. 110

Imbrasas J. 299

Indriūnas A. 125

Indriūnas J. 43-45, 69

Ivanovas V. 226

Ivoška J. 316

Izbickas V. 58, 299, 306

Izraelis G.

Izraelis G. 80, 87, 89, 110, 139, 146, 148, 149

Y

Yang Xiuping 356

J

Jablonskis H. 173

Jackevičius H. 141, 217

Jackūnas Ž. 304

Jagèlo R. 360

Jagminas S. 267

Jagodinas G. 233, 234

Jakaite D. 150, 151

Jakas R. 150

Jakas S. 150, 151

Jakiene E. 150

Jakiene M. 151

Jakimavičius Č. 95, 97, 110, 135

Jakimavičius J. 204, J. 221, 229, 253, 255 ,

261, 290

Jakimavičius Z. 320

Jakovickis V. 45

Jakovlevas-Mateckis K. 214, 215, 229, 281,

354, 360, 476

Jaksebogaite R. 214

Jakštas A. 229, 315

Jakubauskas D. 214

Jakubenas 119

Jakutis A. 477

Janajevas G. 250

Jančiauskas E. 156

Jančiulytė D. 306

Janickis J. 113

Janickis J. 69, 73

Jankauskas Z. 229, 236

Jankauskas B. 164, 247

Jankauskas J. 40, 341

Jankauskas P. 37, 38, 40

Jankauskas R. 247, 267, 286, 307, 313, 330, 349, 364

Jankauskas Z. 146, 175, 185, 214, 255

Jankevičius J. 39, 40

Jankevičiūtè A. 309

Jankovskij V. 365

Jankus L. 256

Janulaitis A. 345

Janulevičius G. 185

Janulionis L. 69, 71, 77, 78, 86, 89, 134, 136, 149

Janulis A. 125, 145, 146, 157, 166, 175, 185, 214

Jarašiūnaitè Z. 77 
Jaruzelskis V. 193

Jasaitis P. 208

Jasilionis R. 136, 149, 157

Jasinavičius R. 93, 96, 111, 356

Jasinskis F. 32, 33

Jasiulionis R. 142

Jasmontas A. 226

Jasonis V. 368

Jasulaitis V. 124, 146, 214, 223, 238, 231,

236, 246, 247, 255, 258, 280, 290, 364

Jauniškis J. 195

Jaunius A. 23, 277, 487

Jazdauskas D. 347

Jekateriničevas F. 134

Jekelevičius V. 177

Jelcinas B. 251

Jeliutinas V. 68, 125, 179

Jemeljanovas V. 87, 105

Jermalavičius J. 247,

Jeršovas A. 156

Jeruslanov V. 226

Jodelè P. 31, 37, 38, 39, 40, 45

Jokūbaitis V. 144, 188, 189

Jokubovas O. 187

Jonaitis A. 192, 218, 219

Jonaitis A. 249, 250,

Jonaitis H. 55

Jonaitis J. 255

Jonas Paulius II 279

Jonikas 119

Jonys L. 276, 297

Jonušas A. 326, 331, 355-366

Jonušas J. 159, 164, 176, 190, 197, 231, 344

Jonušas R. 88, 89, 95-98, 101, 104, 105, 107,

109, 112, 115, 126, 127, 132-134, 136, 139,

$146,149,155,157,159,160,162,165,281$,

315

Jonušis A. 313

Jovaiša A. 109

Jovaišaitè J. 173

Jovarauskas A. 62

Jucevičius R. 348

Jucys A. 105, 355

Judinas A. 106

Jukna 90

Juocevičius A. 250

Juocevičius V. 171

Juodagalvis J. 226

Juodka B. 265, 291

Juonienè S. 166, 167, 175, 201

Juoniene S. 222

Juozaitis A. 217, A. 222, 223, 331

Juozaitis J. 230, 255

Jurele A. 72

Jurenas P. 77, 87

Jurevičius J. 211, 315

Jurgaitis J. 125

Jurgelionis J. 101, 102

Jurgilas V. 258

Jurgutis R. 164

Jurkonis E.

Jurkša A. 148, 181, 226, 230, 250

Jurkštas V. 125, 145, 171, 484
Juršènas A. 141

Juršenas Č. 340

Juškevičius P. 185, 202, 228, 237, 242, 246,

255,

Juzeliūnas J. 198, 217

Juzènas A. 185, 223, 228, 249, 216

\section{$\mathbf{K}$}

Kabulovas St. 231

Kačaunauskas R. 229

Kačeniauskas A. 309

Kačianauskas R 303,

Kačianauskas R. 153, 175, 176, 275, 280, 290, 303, 306, 307, 310, 315, 343, 346, 349, 368

Kačianovas L. 160

Kačkuvienè M. 230

Kagan V. 215

Kairienè Z. 176

Kairys J. 176, 334

Kairys K. 96, 100

Kairys S. 31, 186, 308, 331

Kairys V. 176

Kaklauskas A. 283, 306, 343, 352, 353, 360, 363, 369

Kaklauskas G. 182, 306, 312, 343, 368

Kalanta R. 150

Kalanta S. 215, 259, 260

Kalinauskas R. 309

Kamaitienè D. 174

Kamaitis I. Z. 231,236, 237, 242, 243, 248,

252, 258, 260, 267, 274, 275, 306, 308, 314,

343 ,

Kamaitis V. 174

Kamaitis Z. 138, 165, 185, 216

Kamaitis Z. I. 144

Kaminskas A. 181, 200, 290

Kaminskas K. A. 357, 364

Kaminskas V. 350

Kanapenas R. 315, 370

Kanapenas R. M. 358

Kantorovičius L. 115

Kapitonovas I. 158

Kaplinkski O. 272, 274, 276, 277

Kapsukas 245

Karablikovas A. 368

Karalius A. 190

Kareckas R. 308

Karkauskas R. 259, 260

Karkauskas V. 165

Karnilaite R. 23

Karosas J. 186

Karpickiene E. 371

Karulaitis A. 162

Karvelis R. 164, 168, 175, 183, 187, 287

Kaskievič O. 55

Kasputis V. 125, 145

Kastro F. 76

Katalynaite E. R. 230

Katinas F. 354

Katkauskas A. 214

Katkus D. 198

Kaulakis L. 111 
Kaulakys J. 255

Kaunas J. 69

Kaunelis J. 79

Kaušpèdas A. 146, 171, 190, 217

Kaveckas K. 186

Kaveckis M. 69, 72, 113

Kavolèlis A. 175, 182, 184-196, 315

Kavolelis A. P. 157, 163, 166, 202, 211

Kazakas G. 111

Kazakevičius S. 148, 149

Kaziela V. 261

Kazlauskienè (Montviliene) V. 187, 200

Kazlauskienè G. 157

Kazlauskienè V. 164

Kazragis A. 109, 139, 146, 255, 341

Keblas L. 230, 255

Keleras B. 234

Kelminskas S. 185

Kenedis D. 76

Kerbedis S. 32, 33, 308

Kerulis A. 280, 303

Kesminas O. 300, 355

Keturka A. 125, 145, 148, 170, 183, 198, 213,

266,482

Kieras K. 231

Kilimonyte D. 277

Kinderis V. 200

Kindzičius T. 28

Kirilevičius R. 214

Kirilinas 68

Kirjackis E. 265

Kirvaitiené S. 368

Kirvaitis R. 177, 178, 267, 277, 280, 290, 291, $306,307,315,316,318-320,324,343,345$, $348,355,366,370,372$

Kisielius K. 146, 190

Kiškinas J. 34, 43, 44, 46

Kišonaite V. 309

Kitkauskienè L. 187

Kivilša J. 125, 149, 153, 188, 189, 215, 255, 281,

Kiznis M. 261, 281

Kybartienè M. 88

Kleinas M. 125, 145

Kleiza J. 230

Klešaite 214

Kliauza J. 167, 231, 236, 246

Kličius V. 164

Klimašauskas V. 182

Klimavičius L. 87

Klimavičius V. 68, 71, 72, 77, 88, 92, 96, 134, 136,186

Klimka L. 185, 229

Kliučius A. 203

Kliukas R. 182, 277, 329

Kliukojtis S. 173

Knyva R. 231

Kobeckaite H. 183, 186, 187, 190, 218, 219, 222, 223, 227, 229, 282, 295

Kolis H. 251

Kolupaila S. 39, 40, 43, 45

Komka A. 290, 307, 319, 321, 343, 354, 371, 372,375
Končius I. 41

Kondratenko G. 193

Kondratovas K. 96

Kondrusevičius A. 183, 185

Kononenka V. 160

Kontrauskas V. 178, 339, 340

Kornilcevas V. 190

Korsakiene R. 343

Kosciukevičius D. 89

Kosčiauskas M. 281

Kosčiauskas M. 43, 124, 144

Kosyginas A. 125

Kostiukevičius D. 78, 141

Kovalevičius R. 360

Krasauskas M. 365

Krausas R. 265

Kriaunevičius A. 295

Krikščiukaitienè G. 356

Kriščiukaitis K. 40

Kriščiūnas V. 63, 69, 77, 78, 80, 83, 87, 89, $90,94,96,98,105,110,112,127,134,136$, 138, 142, 146, 148, 157, 175, 237, 482

Krištaponis B. 153

Kriukelis Č. V. 230

Kriukelis V. 144, 149, 368

Krygeris O. 27

Kryžanauskaite A. 88, 156, 165

Kruopys K. 94

Krušinskas V. 112, 113, 134, 136, 141, 142, $152,157,166,167,175,181,185$

Krutinis A. 148, 175, 185, 230, 259, 260

Kubilius A. 319

Kubilius J. 292, 367, 60, 48, 177

Kubilius R. 261

Kubilius V. 112, 192

Kubiliūtè M. 98

Kučinskas V. 277

Kučma L. 276, 277

Kudaba Č. 217

Kudaba J. 55, 56, 64, 127

Kudokas S. 137

Kudriavcevas P. 341

Kudzys A. 63, 69, 70, 77, 78, 80, 82, 83, $87,89,90,92,96,98,100,101,104-106$, $108-112,117,127,134,136,138,139,141$ $146,149,157,160,163,165,166,171,175$, $182,185,186,188,189,211,215,218,223$, 226, 230, 249, 281, 286, 287, 305, 315, 367

Kukys J. 156

Kulaitis Z. 149, 230

Kulakauskas J. 226

Kulakauskas V. 87, 90, 93, 94, 96, 112, 134, 157, 166

Kuliešienè J. 308

Kuliešius V. 230

Kulikauskas V. 175, 330

Kulys J. 317, 332, 345, 354

Kulvietis G. 189, 260, 315

Kumetaitis Z. 214, 228, 316

Kumpikas L. 46, 69, 110

Kuncevičius S. 474, 477

Kunčinas A. 185, 186, 218, 255, 305

Kundrotas V. 171

Kunigèlis J. 124 
Kunigèlis K. 82, 86

Kuodiene O. 230

Kuodis J. 45, 58, 336

Kupliauskas R. 164, 167

Kupliauskienė J. 223, 227

Kuprionis R. 170

Kurcevič R. 164

Kurpis G. 183

Kutas R. 354, 362

Kutas S. 349

Kuzmickas A. 62, 77, 80, 88, 149, 229, 233

Kuzmickas B. 217, 221

Kuzminskis V. 45, 85

Kvartūnas D. 147

Kvedaras A. 92, 104, 117, 134, 136, 165, 174 , $181,268,328,343$

Kvedaras K. 306

Kvedaras V. 221

Kvietkauskas V. 338

$\mathbf{L}$

Labutis S. 274

Landsbergis G. 290

Landsbergis V. 217, 223, 225, 245, 250, 267,

268, 283, 284, 290, 291, 297

Landsbergis-Žemkalnis V. 137, 283, 284, 285, 290,318

Lapè K. 156

Lapeika J. 173

Lapinskaite R. 192

Lašas G. 230

Latvenas D. 347

Laucevičius E. 63

Laucius D. 300

Laucius T. 231

Laukaitienè B. 88

Laurinavičius A. 182

Laurinavičius A. 317, 368

Lazarevičius H. 125, 137, 144

Lazutka S. 88

Lekaravičius A. 122

Lekevičius J. 290

Lekys R 231

Lemkè V. 146

Lengvinas K. 69

Leninas V. 115, 251

Leonavičius B. 217

Leonavičius G. 93

Leonavičius I. 333

Leonavičius M. 191

Leonavičius M. K. 306, 310, 343

Leonavičiūtè D. 290

Lepkovskis Č. 300

Levickas R. 229

Liaudis B. 69, 71, 77, 78, 80, 82, 83, 86,

$87,89,92,93,96,98,100,101,106,107$, $110,127,134,136,139,142,157,166,167$, 175,185 ,

Liaudis K. 221

Liaukonis A. 214

Liaukonis A. R. 229

Liekis A. 298, 302, 356, 357
Liesis I. 186

Likas G. 156, 75

Likienè V. 159, 167, 175, 185

Limba R. 170, 184

Lingaitis L. 236, 255, 307, 370

Lingaitis L. P. 343, 348

Linnert P. 256, 257, 277

Lipnevič M. 306

Lisauskas A. 200

Lisys R. 215

Liubimovas J. 160

Liubinaite R. 231

Liulčenko G. 69, 72

Liumpickas M. 303

Liutikas V. 164, 166, 185, 186, 208, 210, 215 , $219,222,223,227,230,233,255,285$

Liutkaite R. 198

Liutkaityte R. 192

Lygis D. 305

Lygnugariene G. 33, 340

Ločerytè V. 230

Lomaia A. 353

Lopas V. 170

Lubys A. 122, 136, 146, 165, 167, 282

Lubys B. 356, 357

Lujanienè V. 23, 256, 298, 299, 306, 348

Lukošaitis A. 157, 166, 171

Lukoševičiene O. 255

Lukoševičius A. 165, 214, 226

Lukoševičius K. 125, 143, 157, 166, 281

Lukoševičius K. L. 229

Lukošiūnas S. 120

Lukošius P. 137, 196, 227

Lukšienè M. 217

Lukšienè R. 87

Lumpickas M. 303

Lupeikis K. 471

Luošaitis A. 125, 145

Lurje A. 160

\section{M}

Maceika K. 251, 252

Macevičius J. 69

Maciulevičius D. 88, 89, 96, 108-110, 127,

134, 136-139, 145, 146, 149, 157, 158, 166,

$167,172,175,176,185,189,214,218,221$,

229, 281, 294, 308

Maciulevičius N. 221, 228

Maciūnas V. 40

Mackevičius A. 331

Mackevičius K. 91, 107, 116

Mackevičius S. 209

Mačiulaitis R. 260, 329

Mačys A. 93, 255, 258

Mačys A.

Maironis 218, 331

Makačinas T. 200

Makarevič V. 193

Makariūnas K. 299, 301, 326

Makarovas I. 203

Maksimavičius E. 87, 96, 98, 100, 105, 109,

112 
Maldonis A. 217

Maleckas S. 90

Malienè V. 339

Malikeniene 23

Malikenienè R. 366

Malinauskas P. 320

Mališauskas V. 364

Mamontovas A. 205

Maniušis J. 91, 105, 107, 108, 125, 127, 135,

$158,161,166$

Mao Dz. 114

Marašinskaite A. 256

Marašinskas B. 122

Marazas S. 69, 77, 78, 80, 82, 89, 92, 93, 96, 98, 100, 105, 109, 127

Marcelis A. 223, 229

Marcelis A. 77, 78, 88, 89, 96, 105, 112, 134, $137,166,167,175,185$

Marcinkevičius A. 177

Marcinkevičius A. H. 312

Marcinkevičius H. 230

Marcinkevičius J. 217, 253, 331,

Marcinkevičius S. 170

Marčènas V. 109, 149

Marčiukaitienė O. I. 229

Marčiukaitis G. 109, 125, 133, 134, 146, 149, 157-159, 162, 167, 175, 180, 185, 275

Marčiukaitis J. G. 221, 230

Mariūnas M. 214, 215, 230, 255, 274, 275, 306, 307, 315, 317, 328, 343

Markauskas K. 134, 136

Markelytė V. 146

Markevičius V. 312

Markūnas P. 34, 35, 40

Marma A. 331

Martavičius R. 290, 291, 296, 306, 343, 370

Martinaitis A. 80, 88, 90, 96, 98, 166, 112,

$127,134,139,141,146,301$

Martinaitis V. 203, 229, 248, 252, 255, 268,

303, 306, 343, 360

Martinaityte E. 229

Martinenas B. 146

Martynaitis M. 15, 63, 64, 68-73, 92, 95, 100, $105,108,110,111,113,123,124,135,179$

Martynaitis V. 108

Masaitis V. 93, 101

Masalskienè E. 226

Masilionis R. 255

Masilionyte R. 146

Mastiuginas A. 155

Mašanauskienè 77

Mašiotas J. 31, 37, 40

Matiliauskas A. 341

Matonis V. 197, 198, 217

Matukonis A. 46

Matulaite D. 480

Matulaitis S. 30

Matulionis A. 111, 112, 287

Matulionis J. 46, 54, 68, 186

Matulionis P. 30

Matulionis R. 273

Matusas A.312

Matuzevičius A. 255
Mauricas M. 352

Mauza E. 96, 100, 101,112, 127, 134, 136,

$137,142,146,149,157$

Mauzariene L. 230

Mazurovas K. 125

Mažeika D. 361

Mažeikis E. 316

Mažuolis S. 139

Mažvydas M. 349

Mečinskaite K. 306, 331, 343

Mečkovskis T. 365, 368

Medaikis V. 366

Medalinskas A. 217

Mekionis T. 347

Melko-Staniūnienè J. 175

Melnikas B. 255, 307, 343

Meslinas 119

Mickevičius A. 66

Mickevičius J. 28

Mickevičius-Kapsukas V. 40

Mickūnaitis V. 214

Mikaila K. 203

Mikalajūnas M. 309

Mikelionis S. 280

Mikenas R. 280, 303

Mikènas R. 303

Mikšys A. 122, 144

Mikšta P. 281, 368

Mikuckis J. 46, 69

Mikučianis V. 103

Mikuta A. 170

Milaknis T. 316

Milaknis T. 321

Milbern N. S. 173

Milenskis N. 44, 46, 54, 55, 69, 113

Milevskis A. 27

Miliukas A. 77

Miliūnas E. 146, 190

Miliušas A. 86, 87

Milneris D. H 306

Minkevičius J. 217

Misiukas-Misiūnas A. 61

Miškinis A. 265

Mištinas V. 341

Mitkowski E. 272

Mituzas J. 45

Mykolaitienè N. 229

Mykolaitis J. 84, 326

Mockevičius A. 214

Molotovas 41, 151, 215

Monkevičius A. 320, 326, 350

Monkevičius K. 226

Monkevičius T. 303

Moskvičius 139

Mošinskis V. 35, 42

Motiejūnas H. 162

Motuzas R. 350, 370

Mozeris A. 52

Mozūraite R. 309

Mroz M. 279

Muchtaras A. 187

Mugevičius R. 193

Mulakas A. 312 
Muliuolis J. 93

Mulokas J. 267

Mumgaudyte I. 215

Muntianas V. 164, 372

Muralienè R. 256, 277, 305

Muravjovas M. 30

Mureika J. 122, 134, 136, 146, 160, 166, 167 , 175, 185, 212, 213, 216, 229, 233

Mušinskas V. 34

\section{$\mathbf{N}$}

Nadolski R. 272

Nagevičius A. 216

Nagevičius J. 148, 181, 220, 259, 260, 367, 368

Naginevičiūtė I. 192

Naidionovas A. 96, 109, 139, 146, 158, 175, 178, 185, 202

Nainys D. 170

Nainys V. 358

Nakas A. 9, 23, 125, 148, 149, 166, 175, 183 , $185,216,256,261,274,277,285,288,299$, $306,308,314,315,318,330$

Nakas A.J. 229

Nakas H. 175, 185, 368

Nakiene V. 23

Naktinis V. 352

Narbutis B. 203

Narkevičius 191, 192, 231

Narmontas D. 282

Narūnas-Naronavičius (Naronskis) J. 28

Naruševičienè B. 87

Naruškevičius A. 165

Naruškevičius J. 163

Narutavičius S. 331

Nasvytis A. 182, 217, 218, 260, 290, 466

Nasvytis V. 466

Naudžiūnas V. 190

Naujokaitis A. 125, 134, 146, 151, 153, 154,

157, 158, 159, 166, 167, 175, 185, 214, 215

Naujokaitis R. 231

Naujokas R. 333

Naujokas R. 333

Nausèda Č. 331

Navickaite B. 159, 326

Navickas K. 62

Navickas N. 307

Navikauskas A. 182

Nazelskis E. 356

Nazimovas V. 29

Nekrašas J. 80

Nekrošius A. 127

Nemira J. 185

Nemira J. M. 88, 229

Nemira M. 214, 255

Neniškis E. 475

Nickus I. 62, 63, 77, 78, 82, 83, 87, 89, 90, 92, 96, 101, 108, 109, 112, 127, 134, 136, 139, 141, 157, 281

Nigel Wiliams 355

Nikitinas N. 223

Nikolajeva N. 60, 71, 77, 88
Nikžentaitis A. 26

Niutonas I. 28

Noreikienè S. 96

Norkevičius J. 23, 282, 295, 330, 349, 352

Norkus A. 203

Norkus K. 164

Norkus P. 166, 175, 185, 214, 228, 255, 260

Norvaiša P. 28

Norvaišiene J. 142

Norvilas H. 211

Novodvorskis A. 44, 46

Nugaras J. 361, 371

Nurpeisovas A. 187

\section{$\mathbf{O}$}

Obrazcovas I. 179

Olšauskas K. 214, 221,223, 226, 236

Olšauskas M. 343

Olšauskas V. 189

Orentas G. 255, 261, 274, 300, 305, 308, 309, 352

Ostaševičius V. 307

Owenas R. 339

Ozolas R. 217

Oželytè N. 298

\section{$\mathbf{P}$}

Pabedinskaite L. 361

Padagèlis R. 339, 340

Pajeda R. 228

Pakalnis R. 217

Paksas R. 294, 298, 305, 330, 338, 340

Palavinskas E. 146, 175

Palčiauskas V. 182

Paleckis J. V. 97, 219

Palekas R. 470

Paliulis N. 307, 343

Paliulis N.K. 260

Palšaitis E. 124, 146, 177, 281

Palšaitis R. 228, 232, 280, 307, 309, 343, 354

Palubeckis R. 170, 171

Panamariovas J. 182

Panavas J. 176

Panavas St. 230

Panoko J. 99

Panovko I. 138

Papajanov H. 110

Papinigis V. 167

Parasonis J. 339

Parasonis J. 360

Parčiauskas V. 215

Parulis N. 190

Paškevičienè 77

Paškevičius B. 88

Paškevičius K. 80, 88

Paškūnienè E. 94, 98

Paštukas A. 141

Patapavičius A. 230

Pauersas H. 76

Paukštyte D. 229 
Paulauskaitè S. 203

Paulauskas A. 111, 331, 342

Paulauskas C. 109

Paulauskas G. 329

Paulauskas J. 125

Paulauskas M. 82, 86, 89, 90, 96, 109, 112, 139

Pauža V. 144

Pavilionis D. 173

Paviržis G. 326

Pečiukaitis G. 156

Pečiulis S. 217

Pečiūra B. 72, 73

Peldschus F. 249, 273, 277, 345

Peleckas E. 168

Peltasonas D. 173

Pempé K. 146

Peras J. 125

Pesys R. 46, 72

Pesliakas J. H. 352

Petkevičius I. 360, 365

Petkevičius J. 156

Petkevičius K. 231

Petkevičius V. 217

Petkuvienè J. 23, 364

Petraškevičius O. 77, 88

Petrauskaite A. 267

Petrauskaite P. 182

Petropavlovskis A. 99

Petroškevičius P. 328, 368

Petrulievičius V. 329

Petrulis B. 44

Petrusevičius H. 65, 68, 71

Petrušinas A. 156

Petruškevičius P. 228

Petruškevičius R. 203

Pikčilingis J. 55

Pikelis 119

Pikūnas A. 142, 214, 229, 307, 312, 343

Pikutis R. 214

Pilenas S. 124, 152, 153

Piliauskas G. 214

Piliponis R. 320

Pilypaitis A. 115, 136, 145

Pilypaitis A. S. 110, 127

Pilsuckis J. 40, 42

Piskarskas A. 347

Plakys V. 231, 234, 256, 258

Platelis K. 304

Pliučius A. 266

Plunge S. 182

Pocius P. 93

Pocius Z. 290

Počiauskienè P. 255

Počobutas M. 28

Podagèlis R. 142, 181, 218, 277, 278, 316, 317, 347, 351

Podviezko V. 149

Polinkis-Pelka M. 29

Popilskis R. 136, 149

Popkova U. 230

Poselis E. 52

Pošiūnaitè N. 165
Poška A. 275, 280, 306, 343

Poviliūnas J. 125

Požèla J. 253

Pranaitis V. 63, 77, 87, 91, 93, 95, 105, 107, 109, 113, 116, 125, 127, 134, 281

Praniauskienè K. 349

Prapras V. 169

Preikšas K. 55

Prentkovskis O. 345

Prigorovskis N. 138

Prikšaitis M. 138, 146, 147, 148

Priluckaja M. 60, 77, 78, 87, 89, 96

Prunskiene K. 217, 246

Pruskus V. 307, 308, 343

Pugačiukas E. 200

Pugžlienè R. 277, 304, 310, 317, 324

Puipiene L. 481

Pūgžlys A. 176, 326

Pulinas V. 231

Pundzevičius P. 31

Pundžius E. 176

Puodžiukynas L. 125

Purenas A. 43

Puškinas A. 187

Puzakovas V. 136

$\mathbf{R}$

Rabinovičius A. 173

Rabinovičius I. 138

Rachlevičienè D. 125

Radovičius J. 172

Radvila 52

Radvila B. 28

Radzevičiene A. 337,364

Radzevičius A. 142

Radzevičius L. 178

Radzivonas A. 148, 214

Radžvilas V. 217

Ragauskas Ž. 231

Ragulskis K. 111, 138, 315, 339

Raibys M. 110

Raila B. 126, 127, 288

Rajeckas R. 217

Rakauskas G. 181, 185

Rakauskas J. 141

Rakauskienè L. 187

Rakauskienè O.G. 296

Rakštytè L. 343

Rakuckij T. 144

Ralys A. 47, 104

Ramanauskaite 119

Ramanauskas E. 55

Ramanauskas V. 280

Ramonas A. 316

Ramoniene R. 55

Ramonis A. 141

Ramutyte A. 146

Rasimavičius B. 162

Raslanas J. 175, 185

Ratautas M. 144

Raudeliūnas A. 60

Raudeliūnienè A. 77, 87, 213 
Raudonikis A. 186

Raudonikis V. 80

Raue E. 273

Raulinaitis J. 230

Razma J. 290

Razmienè R. 315

Ražaitis V. 72

Ražinskas A. 98, 134, 136, 139, 142, 144, 149 ,

157, 159, 166, 175, 190

Rečiūnas E. 339, 340

Reiganas R. 193, 203, 215216

Reilis D. 173

Rekašius T. 333

Remeikienè V. 371

Remišauskas M. 124, 147, 164

Rerichas N. 45

Ribentropas 41, 151, 215

Rigertas R. 309

Rilkè 187

Rimgaila F. 29

Rimkevičius A. 221, 231, 234, 268, 371

Rimkevičius J. 182,

Rimkevičius S. 258, 259

Rimkus A. 134

Rimkus G. 198

Rimkus L. 164, 171, 215, 354, 372, 373, 375

Rimkus Liudas 280

Rimkus Liudvikas 260

Rimša J. 164

Rinkevičienè R. 320, 324

Rybakovas N. 226

Ryder J. 337

Rokas S. 112, 124, 134, 136, 142, 146, 157, 158, 166, 202

Rosinas A. 138, 149, 219

Rozenbliumas A. 46, 92, 125, 134, 136, 137-139, 141, 144, 147, 149, 160, 317, 318

Rozenbliumas M. 108

Rudalevičius J. 188

Rudminaite A. 23, 244, 256, 277, 305, 315 , 486

Rudzikas Z. R. 355

Rudzkis R. 348

Ruikys A. 355

Rukšenas A. 148

Rukšenas K. 88, 185, 230, 234

Rultas B. 268

Rumša P. 55

Rumšas P. 60

Rusakevičiene A. 309

Rusakevičius D. 309

Ruseckas A. 107

Ruseckas D. 339, 340

Ruseckas O. 190

Rusteika A. 69-71, 77, 78, 80, 83, 87, 89

Rūtelionis L. 347

Rutkauskas A. 275. 275,

Rutkauskas A. V. 307, 319, 343

Ržanycinas A. 115, 122, 160

\section{S}

Sabaite N. 156
Sabaliauskas J. 192, 198

Sabonienè A. 77, 88

Sabonis A. 173

Sacharovas A. 311

Sadauskaite D. 208

Sadauskas T. 55

Sadeckis A. 213

Sakalas A. 237

Sakalauskaite R. 299

Sakalauskas K. 124, 146, 149, 167, 175, 185 ,

$161,195,214,228,368$

Sakalauskas R. 281, 345, 367, 368

Sakalauskas V. 184

Sakalys K. V. 229

Sakalys V. 93,185, 258

Samalavičius A. 349

Samofolovas M. 333

Samsonovas 85

Samulevičius A. 157, 166, 185, 214, 301

Santvaras S. 150

Sarčickas H. 141

Sartakovas V. 112

Sasnauskas K. 157, 185

Satkūnaite A. 182

Saugenienè R. 88

Saulis A. 255

Saulis L. 253, 272, 275, 279, 284, 287, 288, 295, 297, 301, 302, 303, 305, 306, 307, 321, 339, 343

Saulys L. 216

Saunomis V. 125

Sausenavičius H. 124, 208, 366

Saženyte E. 309

Schild J. 183

Sčesnulevičius J. 148, 149

Sčesnulevičius S. 44, 46, 54, 68, 72, 73

Seilius A. 80, 146, 185

Semenavičius K. 27, 28, 294, 308

Semprūnas Ch. 187

Senuta A. 125, 149

Sereikyte R. 60

Sermontis E. 192

Siaurusevičius A. 245,

Sidaravičius J. 231, 238

Sidauga B. 120, 124, 134, 136, 137, 142, 157,

164, 166, 167, 175, 185, 192, 230, 281

Sidauga P. 255

Silevičius V. 214

Simaška A. 97

Simonavičiūte A. 310

Sinikas L. 200

Sivilevičius H. 345

Skardžius A. 326

Skardžius J. 209

Skardžius P. 170

Skarga-Paveneckis P. 27

Skaržauskas V. 317, 260,362

Skeivalas J. 214, 125, 138, 228, 255, 275

Skidelis J. 27

Skirgaila A. 366

Skivalas J. 221

Skrebè J. 189

Skrinska A. 328 
Skrinska A. K. 280

Skrinskas S. 208, 229

Skripkus J. 31

Skučas A. 217

Skudutis J. 290, 291, 306, 343, 360

Slankauskienè D. 87

Slavina Z. 160

Slavinskas 122

Slavinskas S. 209

Slivinskas K. 315

Sližys B. 31

Sloanas B. 283

Smechovas V. 160

Smetona A. 30, 288

Smilgevičius A. 112, 113, 134, 136, 142, 148, 157, 166, 175, 260, 308

Smilgyte J. 146

Smirnovas A. 111

Smuika M. 214

Sniečkus A. 96, 99, 104-107, 125, 127, 154, $155,158,245$

Sniečkus V. 165

Snudaitienè L. 221

Solanas B. 333

Solominas J. 315

Songaila G. 217

Songaila M. 37, 38, 40

Spartakas 187

Speičys A. 61, 62, 80

Spelskis A. 145, 147, 157, 162, 166, 167, 175, 176, 183, 185, 211

Spiridavičius M. 40

Spruogis B. 182, 184, 185, 211, 214, 230,

296, 315, 341, 363, 369

Srèbalius J. 226, . 290

Sriubas A. 169

Srumskiene E. 229

Sruoga A. 31

Stacevičius R. 139

Stagys V. V. 343

Staleriūnas M. 290

Stalinas J. 42, 47, 61, 76, 194, 251

Stanaitis J. 101, 112, 134, 136, 142

Stančiauskas R. 365

Stanevičienè Z. 230

Stanevičius V. 173

Stanislovaitis A. 165

Stanislovaitis R. 159

Staniūnas E. 146, 153, 297

Stankevič L. 343

Stankevičius G. 170

Stankevičius H. 156

Stankevičius J. 86

Stankevičius M. 273

Stankūnas J. 196, 197, 209, 255, 259, 267,

268, 277, 280, 290, 291, 294, 307, 317, 343,

$354,355,360,365$

Stankūnienè V. 268

Stankus E. 157, 167, 175, 185

Stargys V. 306

Starikovičius V. 361

Starkus N. 303

Staškevičius A. J. 307, 343
Staškevičius J. A. 261, 267, 268, 274

Staškus E. 183

Statkus N. 280, 303

Statulevičius V. 305

Statulevičius V. J. 274, 293

Stauskis V. 255, 296, 332, 338,

Stauskis V. J. 358

Steikūnas J. 109

Steponavičius A. 125

Styra D. 204, 214, 277, 309

Stoletovas V. 55

Stonis K. 157, 162

Stonis M. 44

Stonys A. 310

Stonys J. 192, 230, 255

Stonyte R. 55, 60

Stragys V. 181

Stragys V. 276, 328, 331

Straupys 119

Stražnickas J. 54, 105, 155, 356, 366, 367

Strelčiukas N. 155

Strigūnas V. 125, 144, 148

Striogiene A. 329

Strumskienè E 214

Strumskyte J. 306, 313

Stukiene B. 226

Stulginskis S. 44, 45

Stulpinas 115, 140, 152

Stundžaitė R. 171

Subačius V. 231

Sudeikis A. 355

Sudžiūte M. 209

Surpinas V. 193

Survilaite A. 214

Suslavičius V. 329

Suslova G. 341

Sutt P. 279

Suveizdis V. 231

Swichartas J. 264

\section{$\check{S}$}

Šafiras Š. 356

Šakalys A. 278

Šakenis K. 31

Šaknys B. 256

Šalkauskas L. 313

Šalna J. 109, 110

Šaltenis A. 217

Šaltenis L. 187

Šaltenis S. 355

Šapalas A. 182

Šapalas K. 185

Šapira G. 160

Šarakauskas D. 182

Šatas A. 77, 87, 156

Šatas A. J. 229

Šatkus J. 141

Šaulys V. 266

Šeibokas J. 281, 465

Šeibokienè E. 148

Šemis N. 281

Šepetys L. 91, 106, 212, 213 
Šeputis A. 77, 86, 90, 96, 146

Šerenas R. 303

Šernaite Ž 355

Šernas 92

Šernas V. 144, 188, 198, 192, 208, 263, 277

Sernius G. 214

Šervenikas R. 310

Šešelgis K. 125, 145, 146, 149, 157, 162, 165,

166, 175, 199, 281, 285, 324, 358

Šeštakauskas A. 286, 290, 305, 308, 316, 319

Šeštokas V. 136, 138, 139, 144, 145, 147, 158, $162,164-166,172,175,185,186,192,197$, 202, 295, 296

Ševčenko 187

Šiaučiūnas R. 307

Šileika A. 278, 347

Śleika J. 80

Šilovas E. V. 160, 181

Šilževičius S. 144

Šimaitis R. 297, 318

Šimenas A. 214, 228, 246, 247, 248,

Šimkūnas V. 170

Šimkus J. 38, 40, 125, 142, 143, 149, 157,

165, 166, 175, 185, 215, 255, 281

Šimkus J. R. 276

Šimkus J. R. 368

Šimkus S. 195

Šimoliūnas J. 31, 36, 37, 38, 39, 40, 42, 43

Šimonis V. 88

Šiškus H. 111

Šiugždaitè J. 23, 485

Šiukšta M. 306

Šivickas J. 40

Šlajus A. 312

Šlajus A. 318, 334

Šleinotaite L. 281

Šlekiene A. 157, 167

Šlekienè A. 231

Šleževičius A. 260, 265

Šliogeris J. 36, 40, 255

Šmigelskienè R. 227

Šmigelskienè V. 256

Šnaras A. 169

Šneideris A. 360

Šneiderova M. 182

Šniukas D. 356

Šniukšta A. 108, 109, 255, 294

Šostakaitè J. 193

Špokas A. 93

Šreiberis A. 304, 305

Šreiberis A. K. 159

Šriupša A. 166, 175, 185

Štaras S. 177, 178, 255, 290, 291, 303, 303,

308

Šturos G. 164

Šubinas L. 155

Šukys R. 230

Šukys R. 328, 329, 358

Šukšta M. 153, 310, 330, 343

Šulcas T. 31, 34, 36, 37, 39, 40

Šulga V. 203, 281

Šulinskas A. 360, 365

Šumauskas M. 102, 106, 127, 134
Šurpikas V. 173

Šustavičius 63

Šutovas S. 182

Švedas V. 366

Šveiceris M. 317, 321

Švenčianas P. 92

Švėgžda A. 479

\section{$\mathbf{T}$}

Tabuns B. 192

Tamkevičius S. 150

Tamošaitis A. 230

Tamošauskas P. 255, 335, 343

Tamoševičius A. 120

Tamoševičius B. 31

Tamoševičius E. 467

Tamošiūnas A. 221, 231

Tamošiūnienè R. 307, 343

Tamulaitiene B. 182, 352, 359

Tamulevičiūtè G. 209

Tamulyte J. 192

Tamutis R. 160, 166, 167, 175, 176, 190, 301, 326, 355, 365, 366

Tamutis Z. 120, 124

Tarasevičius I. 184

Tartilas J. 265, 268, 358

Tarulis A. 297

Tarvydas A. 122, 316

Taunys S. 88

Tautvaišas N. 280, 303

Tečer M. 193

Teišerskas Č. 134, 136, 146, 157, 166, 167

Teišerskis Č. 101, 175, 186

Telksnys A. L. 87

Telksnys L. 347

Terleckas V. 37

Tilindis V. 175, 214, 229

Timofejevas M. 347

Tiškevičius 336

Toleikytè V. 86, 87

Tomkus V. 217

Topper R. 61

Trapeznkovas S. 231

Treigiene V. 226

Treinys V. 190

Treinyte A. 209

Trimonis A. 184

Triole E. 187

Trušinas I. 69

Tulevičius V. 69, 71, 77, 87, 109, 186, 214, 281

Tumas-Vaižgantas J. 30

Tuomas E. 203

Tupinis A. $125,146,198$

Turauskis V. 276

Turla S. 157

Turla V. 156, 164, 185, 188, 196, 209, 211, 214, 229,V. 315

Turoniene O. R. 230

Tutkus V. 149, 226

Tvaronavičienė M. 343 
Uljanovas A. 145, 149

Urbanavičius G. 487

Urbanavičius V. 209

Urbelis A. 166, 175, 186

Urbelis M. 100, 101, 110, 138, 148

Urbonas V. 228

Urbonavičienė S. 329

Urbonavičius M. 281

Uschopčikas V. 247

Usevičius M. 303

Usonine A. 339, 340, 347

Ustinovičius A. 353

Ustinovičius L. 345

Ušinskas S. 125, 145

Utarienè E. 301, 317

Uždavinys R. 86, 87, 89, 96, 127

Užkuraite S. 55

Užpolevičius B. 92, 108, 117, 163, 164, 221, 227, 238, 290

\section{V}

Vabalas-Gudaitis J. 37

Vabalevičius S. 44, 46, 54, 63, 69

Vabalienè I. 263, 285, 326

Vadlūga R. 87, 90, 108, 188, 189, 303 306, 307, 310, 343

Vagnorius G. 182, 247, 248, 279, 284, 285, 291

Vaičiulis R. 196

Vaičys P. 63, 69, 70, 77, 80, 82, 83, 86, 149

Vailionis T. 353

Vainauskas V. 124, 144, 255

Vaineikyte R. 289, 290

Vainiūnas E. 343

Vainiūnas P. 214, 215, 230, 255, 261, 274, 301, 302, 306, 315, 316, 333, 334, 360

Vainoris Z. 94, 96, 100, 101, 109, 110, 112,

$127,134,136,139,142,146,157,163,164$,

$166,175,177,178,186,196,255,281,290$,

291,321

Vaiškūnaite R. 360

Vaišvila Z. 217

Vaitelis E. 303, 306

Vaitiekus I. 226

Vaitys J. 55

Vaitys L. 290

Vaitkevičius S. 164

Vaitkevičius V. 108, 136, 215, 230

Vaitkus J. V. 347

Vaitkus V. 145, 149, 165

Vaivada A. 125

Vakrina E. 230

Valaitis V. 71, 87, 93, 280

Valančius A. 109

Valašimas K. 228, 236, 290

Valeckienè J. 277

Valenskaite N. 146

Valentinavičius A. 138, 144, 157, 166,

175,181

Valentukevičienè M. 341, 354
Valiukenas G. 214

Valiukenas J. 166

Valiukenas J. G. 229

Valiulienè I. 308

Valiulis A. V. 23, 111, 112, 221, 230, 237, 243, 246, 255, 261, 268, 285, 290, 296, 300, 303, 306-308, 310, 314, 317-319, 337, 341, $342,343,365$

Valiūnas B. 250

Valiuviene T. M. 277

Valivonis J. 182

Van de Velde H. 197

Vanagas G. 93, 111

Vanagas J. 125, 145, 149, 175, 176, 186, 214, $221,229,352,353,358$

Vapšys A. 325

Varanauskas R. 297

Varanauskas V. 354

Varniené R. 227, 230

Vasilecas O. 213, 346

Vasiliauskas K. 31, 37, 38, 40, 45, 186, 268, 272, 274, 286, 287, 288, 299, 304, 305, 308, 309, 311, 330, 341

Vasiljevas A. P. 109

Vasionis G. 60, 61, 281, 485

Vasys-Vasiliauskas J. 58

Vaškevičius J. 100, 249

Veisas E. 311

Vekteris V. 255, 275, 306, 343, 358

Vencevičius J. 54

Venckūnas R. 156

Vengrienè E. 61

Venskevičius J. 46

Verbickas V. 31

Verbickienè A. 23, 312

Verbickis V. 37, 38, 40, 125

Veršelis A. 170

Vežauskas G. 256, 326

Vidmantas J. 40, 44, 46, 111

Vidugiris L. 124, 281

Vidžiūnas A. 287, 338

Vika A. 303, 310, 317

Vileikienè G. 93

Vileikis A. 30, 161

Vileišis J. 30, 331

Vileišis P. 30, 31, 33, 34, 53, 288,

308, 309, 331

Vilkas E. 222, 223, 373

Vilkas S. 170

Vilkauskaite A. 215

Vilkyte A. 55

Vilkončius L. 182

Vinogradovas A. 122

Vinskute V. 281

Virbickaite L. 192, 198

Viršilas V. 125, 156, 281

Viskantaite R. 277, 333

Viskantas F. 160, 164, 176, 190, 195

Vislavičius K. 230, 264, 290

Viščiakas J. 55

Vitkauskaite R. 164

Vitkauskas V. 63

Vivian R. 273 
Vizbaras F. 137

Vyčinas E. 182, 195, 197, 199, 237

Vyskupaitis A. 111, 122

Vyšniūnas A. 258, 259, 349, 368, 473

Vladimirovienè I. 55, 60, 61

Vlasenko V. 134, 157, 166

Vleikis A. 218

Volanas J. 305

Voldemaras A. 31

Vorobjovas D. 200

Voronkovas B. 62

Vosylius A. 258, 259

Vosylius P. 87, 109

\section{W}

Wasilewski W. 272

Werner F. 273

\section{Z}

Zabarauskas M. 190

Zaborskaite V. 192

Zabotka B. 149, 214

Zabulis H. 48, 64, 91, 97, 102-105, 108, 111, $116,127,134,135,139,140,153-155,159$, $161,165,173,190,367$

Zaicevas A. 226

Zakarevičius A. 124, 149, 229, 306, 343

Zakarevičius V. 92

Zaleckaite R. 326, 355, 365, 366

Zaparackiene S. 79

Zaremba P. 331

Zaskevičiūtè S. 77

Zavadskas E. K. 19, 23, 156, 195, 202, 210, 215, 221,226,227,230, 232, 236, 237, 238, 242-244, 246-249, 251-256, 258-262, 264-268, 272-275, 277-280, 282-288, 290, 294, 297-299, 301-321, 330, 331, 333 335, 339-341, 343, 345, 347, 349, 352, 353, 360, $367,368,372,375,376$

Zaveckas S. 195

Zdanavičius A. 125

Zemlickas G. 356

Zenkevičius V. 173

Ziberkas L. 125, 145, 149, 217, 256, 284, 306, 343, 468

Zimkute J. 300

Zinkevičius P. 101

Zinkevičius Z. 290

Zolotuchinas V. 160

Zonas O. 171

Zubavičius L. 315

Zubrickas B. 94

Zulonas K. 300, 329, 330

Zuokas A. 319, 321, 336, 371

\section{$\check{\mathbf{Z}}$}

Žalenas G. 190

Žalys A. 216, 304

Žalnieriukas A. 124, 138, 149, 184
Žalnieriūnas A. 148, 149

Ždanovičius M. 214

Žebenkienè D. 480

Žebrauskas T. 28

Žebriūnas A. 217

Žegunis S. 167

Žekevičius A. J. 230

Žekevičius J. 124, 149, 164, 165, 183, 190, 223

Želigovskis L. 40

Želvys A. 55

Žemaitis P. 55

Žemaitis R. 280

Žemaitis T. 86

Žemaitis Z. 36, 37, 41, 259

Žemkalnis G. 289

Žemkienè R. 257, 361

Žemkus J. 79, 127, 132, 133, 157, 16

Žeromskas R. 125, 260, 261, 266, 267

Žigina T. 310, 317

Žilinskaite B. 176

Žilinskas A. 231

Žilinskas R. P. 307

Žilionis A. 185

Žiliukas A. 315

Žintelis B. 125, 148, 149

Žitkute A. 88, 277

Žitnikoviene M. 64

Žydelis Ž. 280

Žygimantas Augustas 52

Žmuidzinavičius A. 69

Žukas J. 260, 281

Žukas N. 178

Žukauskas A. 256, 257, 272, 274, 277, 282, 286

Žukauskas H. 146, 190

Žurauskas A. 352

Žvirblis S. 184

Žvirenas A. 92 


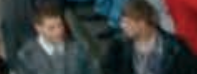

$\Gamma$

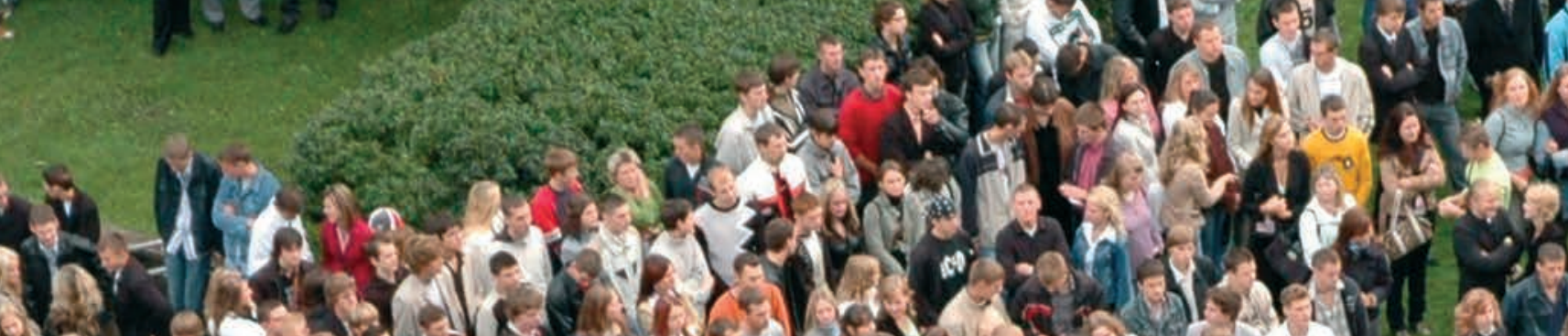

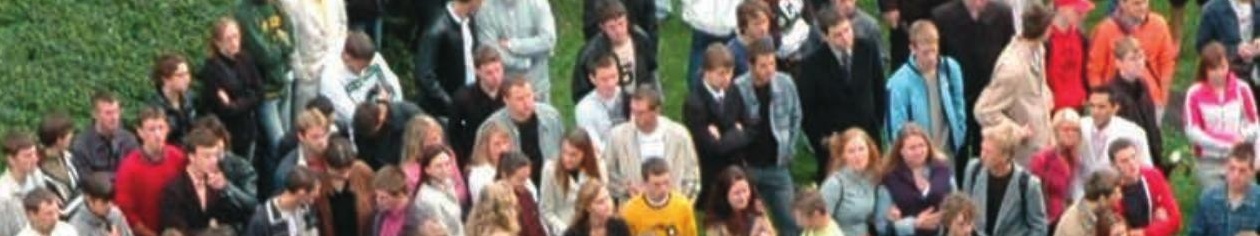

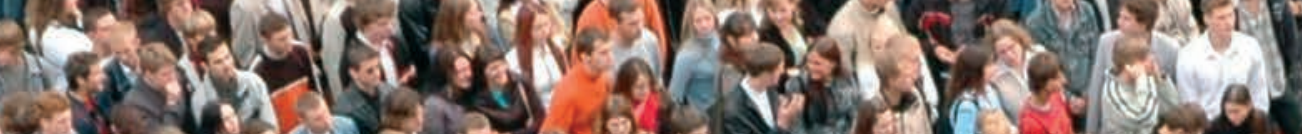

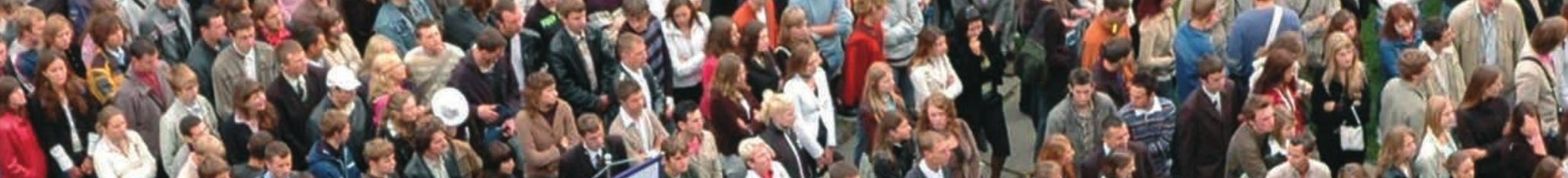

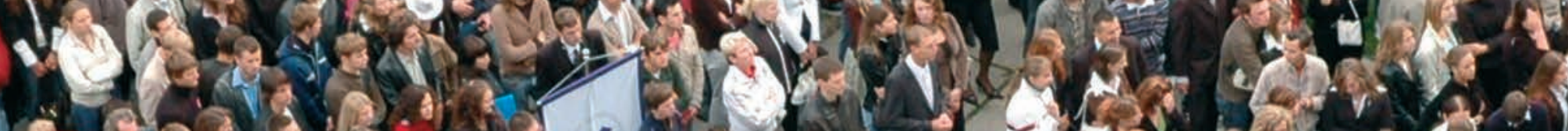
10.

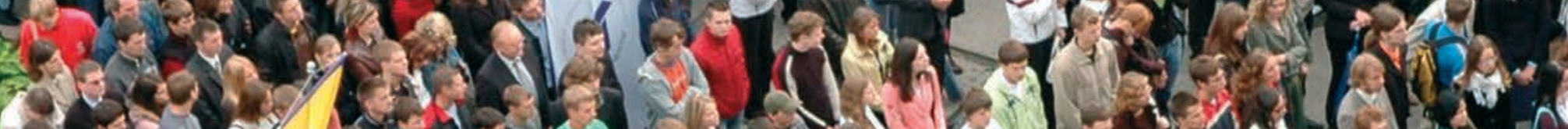

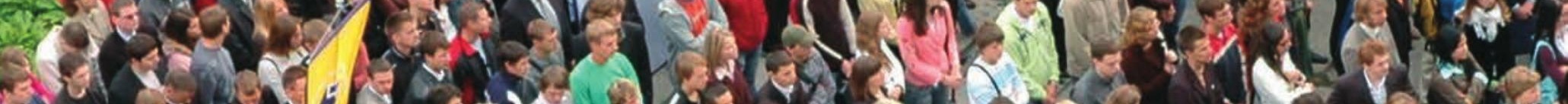
1.5.

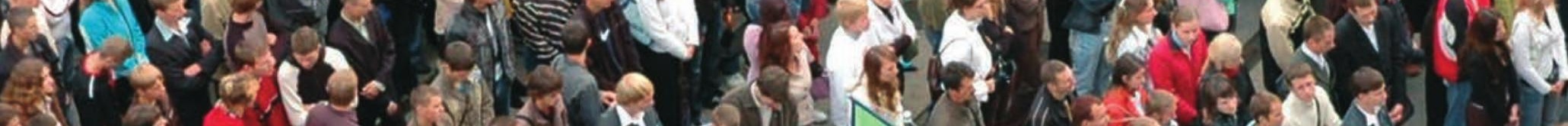
Lif 6 .

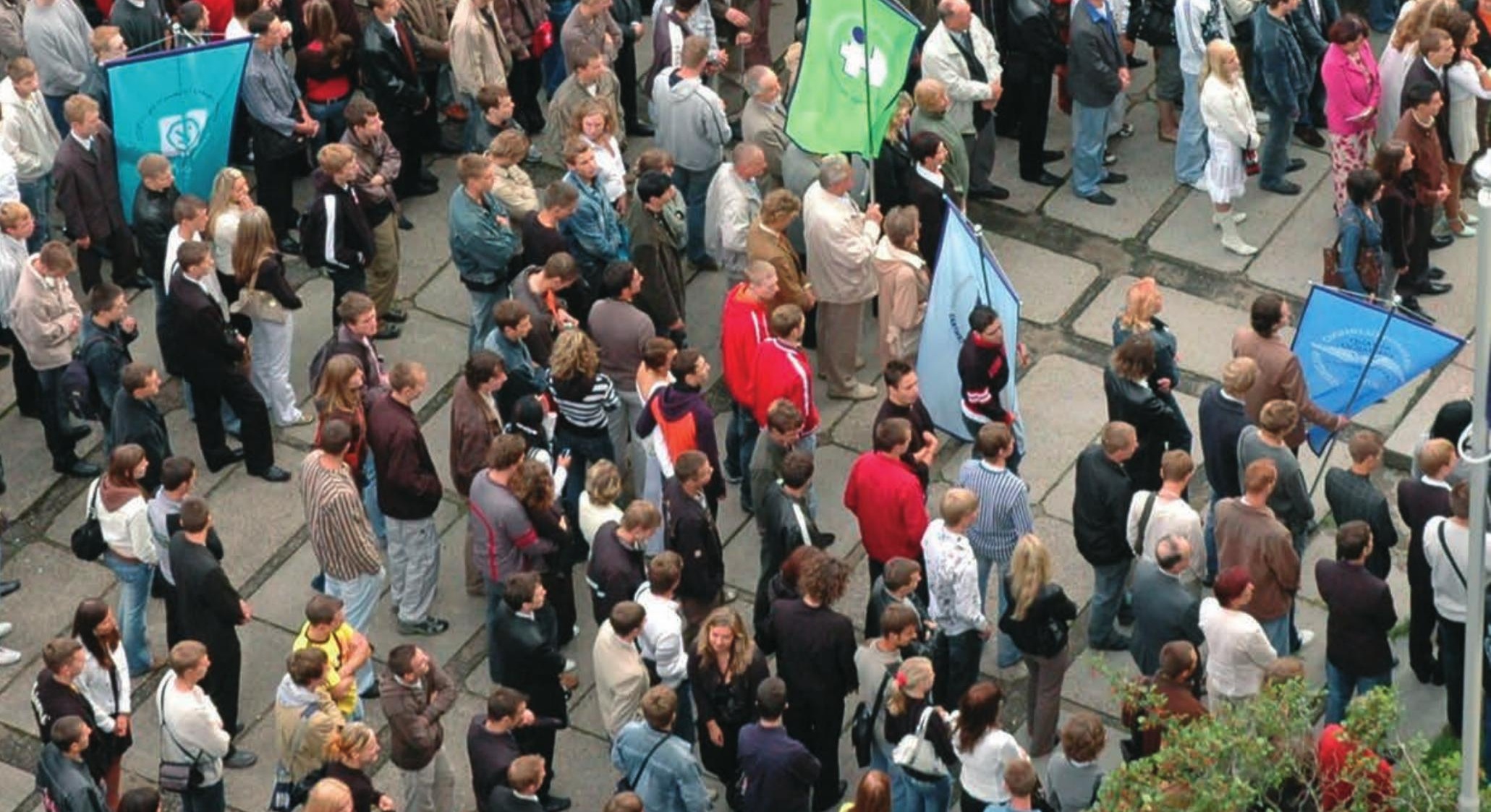


DEVELOPMENT

OF VILNIUS

GEDIMINAS

TECHNICAL

UNIVERSITY

IN 1956-2006
The monograph is meant to disclose the development of the higher technical school in Vilnius. The school was founded in the capital in 1956 as Vilnius Department of Kaunas Polytechnic Institute. Within four years it grew into the Faculty and in 1961 became the afiliated subdivision of Kaunas Polytechnic Institute.

In 1969 the subdivision was reformed into the independant school - Vilnius Civil Engineering Institute.

In 1990 after the restoration of independence of Lithuania Vilnius Civil Engineering Institute was reorganised into Vilnius Technical University and in 1996 it was awarded the name of Gediminas, the Grand Duke of Lithuania.

50000 high qualification engineers, architects, specialists in economics, business management, computer sciences, etc. have been trained at the university throughout the period of 50 years. The total number of students recently exceeds 15 000. It is the third biggest institution in Lithuania and its graduates are totally successful in the employment.

In the monograph the author describes and analyses the characteristic moments of the university development, changes in study plans, academic staff, structure of the institution, research activities, variations in profession and specializations, as well as increased variety in national composition of students, etc. The author also introduces the leaders of the institution and its subdivisions.

The monograph is meant for the interest of the academic communities and public society. 


\section{Algimantas Nakas}

\section{VILNIAUS GEDIMINO TECHNIKOS UNIVERSITETAS. 1956-2006.}

Mokslotyros centro leidinys

Redagavo Rita Malikeniene

Maketavo Jevgenija Petkuviene

Dailininkè Asta Rudminaitè

Dauguma nuotrauku Jono Grambos, Jono Česnavičiaus, Alekso Jauniaus

Dalis iliustraciju paimta iš Adolfo Bumblausko, Vlado Drèmos, Algimanto Mačiulio, Jono Rudoko ir kt. leidinių

Knygoje panaudoti VGTU, VGTU istorijos muziejaus ir

Kauno apskrities archyvų (KAA) dokumentai.

2006-09-04. 63,75 sp. 1. Tiražas 1000 egz.

Vilniaus Gedimino technikos universiteto

leidykla „Technika“, Sauletekio al. 11, 10223 Vilnius

Spausdino UAB „Draugų studija“,

S. Moniuškos g. 21-10, 08121 Vilnius 